EL ARTE RUPESTRE EN LOS MACIZOS DEL DESEADO Y SOMUNCURÁ:

LA PRODUCCIÓN DE GRABADOS Y PINTURAS ENTRE CAZADORES-RECOLECTORES DESDE EL HOLOCENO MEDIO

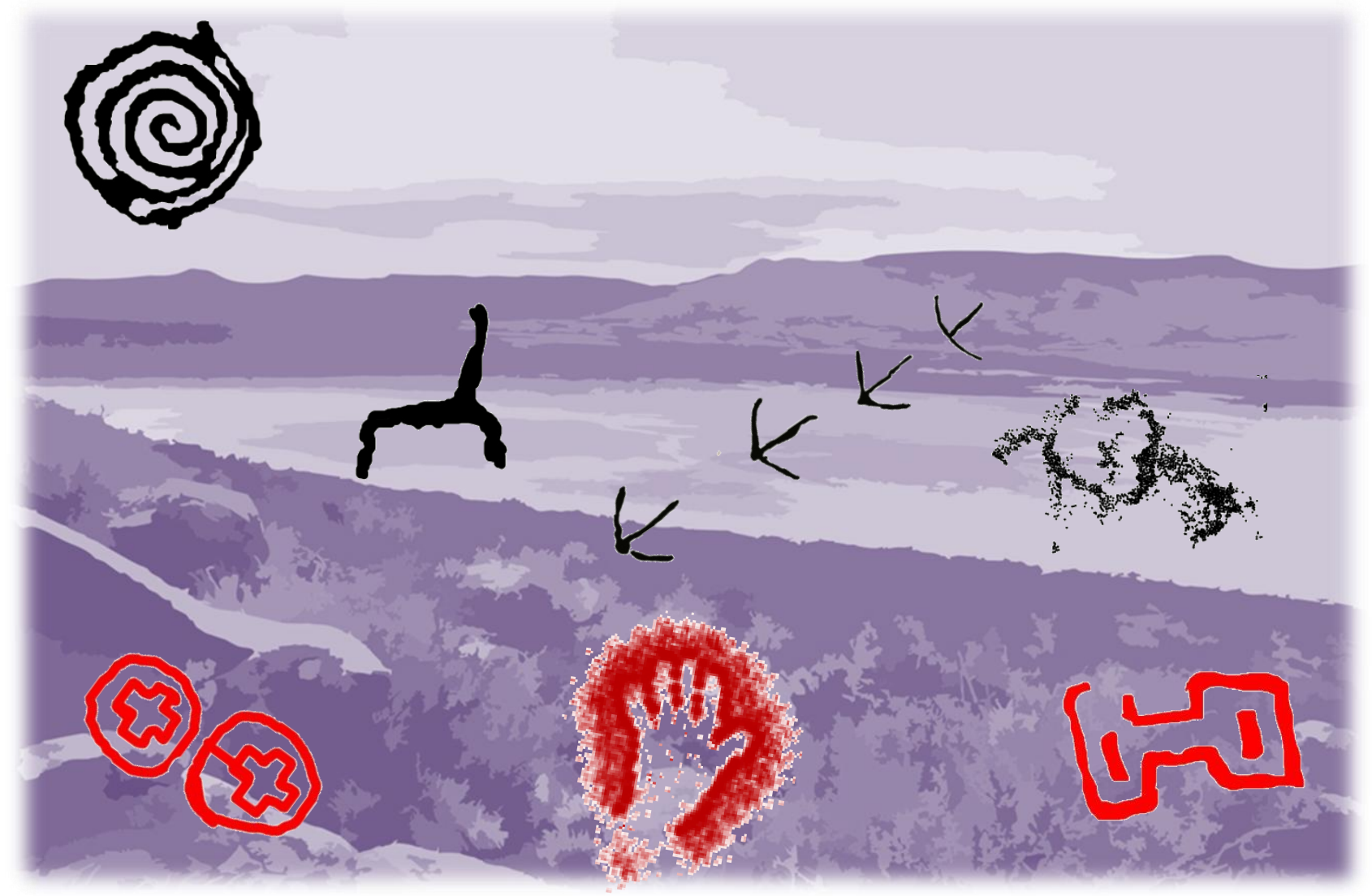

Tesis para optar para el título de Doctor en Ciencias Naturales

Doctorando: Lic. Rocío V. Blanco Directora: Dra. Laura L. Miotti Co-directora: Dra. Natalia Carden 


\title{
EL ARTE RUPESTRE EN LOS MACIZOS DEL DESEADO Y SOMUNCURÁ: LA PRODUCCIÓN DE GRABADOS Y PINTURAS ENTRE CAZADORES-RECOLECTORES DESDE EL HOLOCENO MEDIO
}

\author{
Lic. Rocío Vanesa Blanco \\ Tesis para optar al título de Doctor en Ciencias Naturales \\ Directora: Dra. Laura Lucía Miotti \\ Co-directora: Dra. Natalia MarinaCarden \\ Facultad de Ciencias Naturales y Museo \\ Universidad Nacional de La Plata
}



A Mamá,

por su apoyo y aliento constantes 



\section{Agradecimientos}

Esta tesis es el resultado del trabajo de seis años, tiempo en el cual recibí ayuda, consejos, críticas constructivas y aportes de numerosas personas. Justo en este momento, en el cierre y la edición del manuscrito, resulta un tanto injusto dar formalmente las gracias a cada una de las personas que en buena medida participaron en mi vida durante este tiempo porque es harto probable que me olvide de alguno, de unos o de unos cuantos. Sin embargo, haré el esfuerzo y trataré de seguir mi listado mental para recordar a quienes, poco a poco, fueron encaminándome y ayudándome a carretear en este lento andar.

Sin lugar a dudas, mis directoras son a quienes primero quiero agradecer: Laura Miotti y Natalia Carden. Laura me acompañó durante todo el proceso de la tesis, proceso en el que aprendí muchísimo de ella. No sólo en lo referido a lo arqueológico o académico, sino también en lo personal, que no es poca cosa: desarrollé niveles de paciencia que no pensé que existían en mí... Chiste, chiste! En realidad, le tengo que agradecer el aliento y confianza constante, los consejos, los ratos compartidos, las lecturas de los capítulos sin filtro, el cruce de trabajos que nos permitía a ambas crecer académicamente. Natalia también hizo numerosos aportes: constantemente me brindó consejos, leyó cada uno de los lastres que le envíe sin chistar, salvo cuando de la cita de su tesis se refería -chascarrillo-. Me alentó constantemente a que no parara, a que avanzara con lo pudiera: la idea era no perder el ritmo. Con ambas compartí buena parte de los relevamientos de los sitios con arte, por lo que las charlas en campo fueron un aporte invaluable de las dos a mi formación. En verdad, gracias a ambas esta tesis llegó a su final.

A mis compañeros de equipo, capaz que al principio les costó comprender mi humor y mis agudos silencios, aunque luego pudieron soportar mi compañía o, por lo menos, lo disimularon bastante bien. Empecemos por "los de Abajo". Darío Hermo fue un hacedor de carcajadas por diferentes medios, situación que valoro muchísimo; fue además a quién le envíe manuscritos de trabajos que leyó estoicamente y devolvió con valiosos aportes. Laura Marchionni constantemente me recordó que tenía que terminar este manuscrito, de quién recibí consejos y con quién compartí innumerables charlas sobre arqueología y otros tópicos, en el campo, en el laboratorio y en ámbitos sociales varios. Enrique Daniel Terranova 
(“Quique”) fue el infaltable en todas las campañas a Somuncurá, con quién hicimos las tesis "casi" a la par y discutimos datos e información para acordar ideas. Laurita y Quique, además, al comienzo de la etapa experimental colaboraron con anotaciones y fotografías. Bruno Mosquera ayudó con sus chistes, comentarios y abrazos en esos momentos en los que se me daba por bajar los brazos $u$ ofuscarme con alguna nimiedad. Eloisa García Aniño estuvo en la mayor parte de los momentos en los que Brunito hacía bromas, hablaba y me abrazaba; los tres compartimos mañanas durante un buen tiempo, entre trabajo, mates y chipás. Natalia G. Barreto merece una mención especial, ya que colaboró en buena parte de los trabajos experimentales: haciendo de "picapiedras" o realizando anotaciones, tomando fotografías o pintando; sin lugar a dudas, sin su aporte este manuscrito tampoco se habría terminado...

Sigo con las chicas "de Arriba o del Despacho": con Lucía Magnín, Virginia Lynch y Franca Griffiths compartí momentos de trabajo y de ocio que hicieron de esta etapa más llevadera. Particularmente, Lucía me ayudó con algunos mapas incluidos en aquí, y Virginia realizó el análisis funcional de algunas piezas usadas en los diseños experimentales, dos aportes importantísimos para la tesis. Asimismo, y sobre todo durante el último andar, Virginia ha sido una muy buena confidente de tesis. Todos ellos, además de ser compañeros de trabajo y de haber revisado algún que otro capítulo o realizado algo de la edición del manuscrito, forman parte de esta familia platense que fue adquiriendo miembros con el transcurso de los años. Mis sinceros agradecimientos a todos.

Tengo que recordar a otros compañeros del Museo: Rafael Paunero y Fabiana Skarbun brindaron oportunamente consejos y fueron una fuente constante de aliento para culminar el manuscrito. Federico Lotto y Sebastián Carreño realizaron aportes desde la antropología biológica, y desde la fotografía y la ayuda en el campo, respectivamente. Celeste Weitzel ofreció consejos y consuelo en los momentos que tenía libre, ambas cosas fueron muy bien recibidas por mi parte y estoy muy agradecida. Por alguna razón creo que merecen mención aquí Antonio Ceraso, Manuel Cueto, Mariano Del Papa y Ariel Frank. Con ellos compartí diferentes momentos a lo largo de estos años y han aportado alguna idea o buen consejo.

Estoy convencida de que la familia, además de involucrar lazos sanguíneos, está compuesta por afectos que son difíciles de describir con palabras y de manera breve (el que avisa no traiciona, dicen). Primero, la familia sanguínea. 
Esta tesis está dedicada a mi Mamá, a quién le voy a estar eternamente agradecida por acompañarme -a pesar de los $1.200 \mathrm{~km}$ que nos separan-, escucharme, alentarme y apoyarme en cada una de las etapas de mi vida y, fundamentalmente, en la "etapa de la tesis". Por intentar comprender este mundo arqueológico que elegí, sin jamás poner un "pero" o "no se puede" durante nuestras charlas. Por aguantar mis silencios en el teléfono, mis llantos y mis chistes (estas dos últimas sí que son cosas que hay que soportar!).... Sencillamente, ¡GRACIAS MAMÁ!

De igual manera, entran en este agradecimiento consanguíneo mis hermanos, la Abuela Lupe, los tíos, primos y sobrinos. Estos últimos son muchos, muchos y son unos soles. Todos ellos fueron un motor fundamental en mi vida, desde lejos con sus palabras de aliento y confianza ayudaron a que termine.

Ahora, la familia por adopción... Los "Nenes" (ya no tan nenes) y Gabriel, familia adoptiva platense, quienes supieron entender mis rayes y silencios y nunca dejaron de brindarme su apoyo. Las chicas de la Pensión de Berta, con muchas conviví y actualmente nos une una amistad que no entiende de distancias: Silvita Macario, Daniela Lezcano López, Alicia Ratto, Tamara Ponce y María de los Ángeles Rodríguez Álvarez. Mis amigos de la vida: Mauro Giacobbo (\& familia) y Florencia Angaut, por estar siempre presentes. Mis compañeros de la facultad: Yamil Suárez, Jorge Noel Bidaure, Giovanna Salazar Siciliano y Jimena Oría. A los dos primeros les estoy agradecida por escuchar de manera tranquila y sosegada todo el recorrido post-facultad; a Giova le agradezco haber estado por aquí y por allí a lo largo de la carrera -de grado y de posgrado-, compartiendo diferentes instancias, momentos y consejos; a Jimena por ser fuente de consejos desde que éramos jóvenes, siempre yo más joven que ella (Chiste!). A las chicas de ahora: Silvina Julieta León ("Pitu”), Ana Ratto, Agustina y Eugenia Madariaga, Nadia Arripe, Carolina Di Carlo, Lorena Carreño, María Cecilia Silva, Juan Manuel Moyano Latorre (no es chica, pero donde va Ceci, va él y ya no hay tapujos. Es una más!) por charlas, mates y cervecitas compartidas cuando se pudo, y por comprender mi ausencia cada vez que me pegaba el faltazo o me negaba asistir a alguna reunión. "Pitu" merece mención especial ya que vive conmigo y fue la que soportó a diario, desde la mañana hasta última hora, cada silencio, enojo y charla que tuve con cada uno de los archivos en los que trabajé; de verdad verdadera "Pitu", gracias! 
Para cerrar, los personajes más lindos que conocí en estos años, los que sacaron lo más bonito de mí, aún en esos momentos donde la peluca estaba para cualquier lado: los nenes de Fisu (Camilo, Martino y Salvador), las nenas de Natalia (Sofía y Helena); aquellos sobrinitos prestados: Lorenzo, Lola y Goyo, Julián, Las Mellis (Renata y Ema, hermosas y amorosas), Francisco, Dante, Tomás, Isabela y Juan Ignacio -las más recientes adquisiciones- y otros, muchos otros, por hacerme acordar de que no todo es tesis.

Por último, creo que dos personas merecen estar en estos agradecimientos. Emilia Napolitano, la profe del gimnasio y ahora amiga, fue una de las pocas personas que me hizo olvidar de la tesis durante los últimos dos años -esto mayoritariamente mientras hacía abdominales- y sacarme sonrisas con sus bailes o comentarios. María Griselda Arruabarrena, mi reikista, quien intentó que durante el último tiempo esté armoniosa para escribir y desarrollar de manera ordenada mis ideas.

Seguramente se me estén olvidando nombres, pero creo que todas las personas enunciadas previamente forman parte de mi familia y a quienes les agradezco profundamente el apoyo brindado a lo largo de estos seis años.

Institucionalmente también hay agradecimientos. Para poder llevar adelante esta investigación se contó con el apoyo de la UNLP (Becas de Iniciación y Perfeccionamiento en la Investigación) y del CONICET (Beca tipo II) así como de la Facultad de Ciencias Naturales y Museo de la UNLP. Subsidios de la ANPCyT, de la UNLP y de CONICET percibidos por las directoras de tesis conformaron el aporte monetario para la realización de las tareas de campo. De no haber contado con ellos este manuscrito no se habría terminado.

$\mathrm{Al}$ haber estudiado dos áreas en provincias distintas es necesario realizar los agradecimientos institucionales por separado. En Santa Cruz, la Secretaría de Cultura de Pico Truncado prestó valioso apoyo para los trabajos de campo. Agradezco especialmente a Sebastián Toledo, por su siempre amable recibimiento y constante atención. Las tareas en el campo resultaron posibles gracias a la invalorable hospitalidad y colaboración de las familias Quiroga (Ea. La Marianita) e Iribarne (Ea. Aguada del Cuero), y del Sr. Ramón Cano (“El Pampa”). A ellos agradezco su amena compañía y sus charlas que nos alejaban un poco de lo estrictamente arqueológico.

Por otro lado, en Río Negro recibimos el apoyo de la Agencia Cultura y del CODEMA. De esta última institución, me gustaría remarcar los aportes realizados 
por Atilio Namuncurá, harto conocedor de los caminos y secretos mesetarios, de quién recibimos valiosa información y muy buenos consejos para llegar a destino. Los habitantes de El Caín siempre nos han recibido cordialmente, ofreciéndonos diferentes instalaciones y su caluroso afecto en todos nuestros viajes. Marisa Huentenao y Gerardo Melivilo (guardas ambientales de Somuncurá) han compartido con nosotros labores de campo. Las familias Melivilo, Poblet, Cayupán, Carrasco y Cayú nos brindaron apoyo constante. El Sr. Ernesto Digenbauer así como el personal y alumnos de la escuela "Güemes" nos asistieron en todo momento.

Por afuera del Museo, pero cercanos a las labores realizadas, tengo que agradecerle a varias personas más. Miguel Giardina, quién cedió una de las materias primas para realizar las experiencias replicativas. Por otro lado, Juan José y Nelson Mazquiarán propietarios de Guenguel SRL -mediante la gestión de Sandra Rivera- facilitaron lana y pelo de guanaco usado en algunos ensayos. María Fernanda Rozas realizó algunas aclaraciones respecto a la composición química de las pinturas. Todos ellos en buena medida hicieron algún aporte, así que gracias.

Cualquier error $\mathrm{u}$ omisión que presente el manuscrito es enteramente responsabilidad mía.

La Plata, 18 de septiembre de 2014

(fecha de entrega del manuscrito) 


\section{Índice}

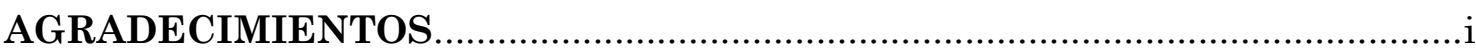

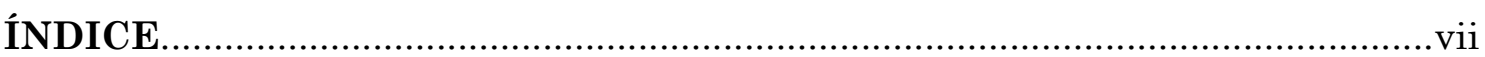

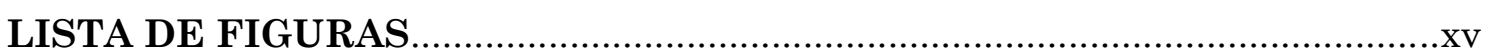

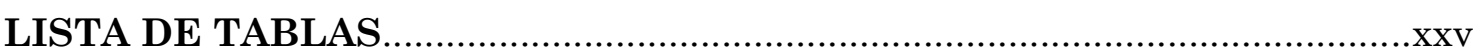

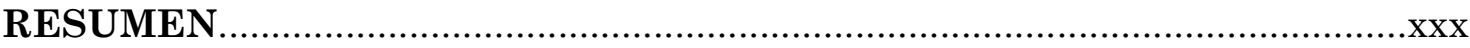

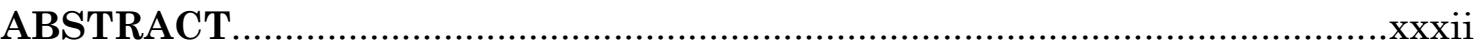

Capítulo 1. INTRODUCCIÓN..........................................................................

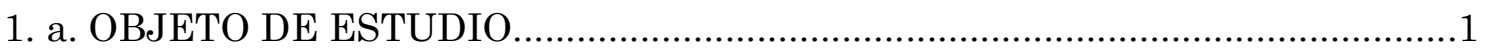

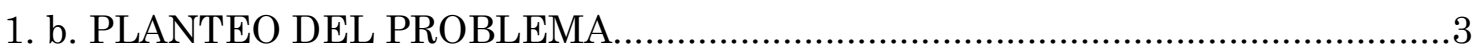

1. c. OBJETIVOS DE ESTA INVESTIGACIÓN...................................................

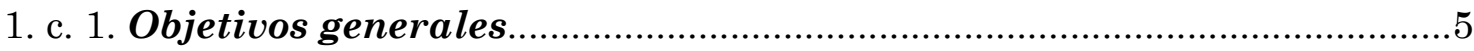

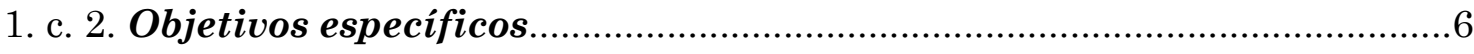

1. d. HIPÓTESIS DE TRABAJO_.........................................................................

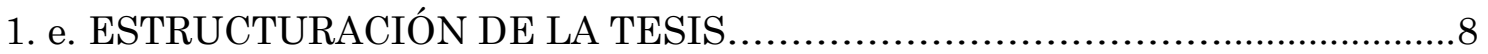

Capítulo 2. CONSIDERACIONES TEÓRICO-METODOLÓGICAS...................11

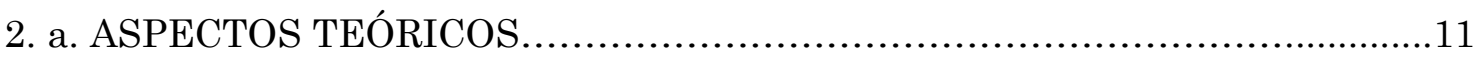

2. a. 1. Estudios sobre Cultura Material y Tecnología....................................13

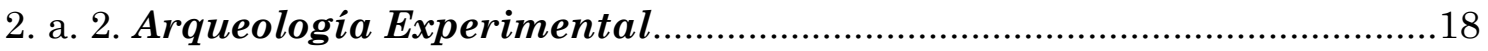

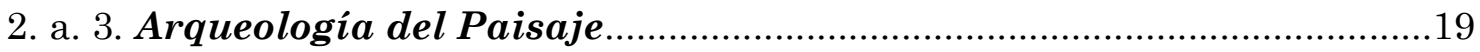

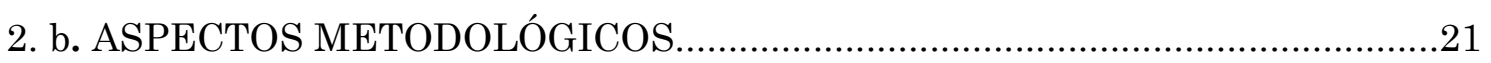

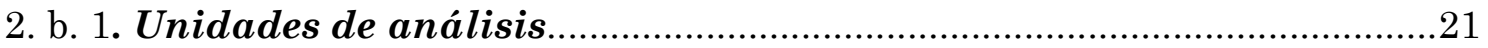

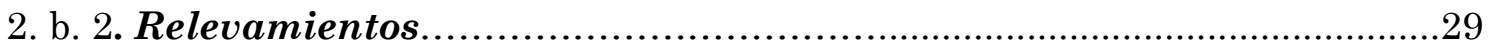

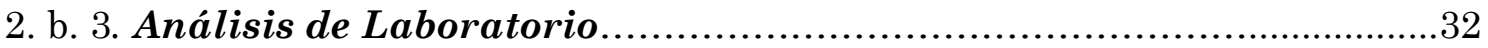

2. b. 3. 1. Ordenamiento de la información de campo...................................................33

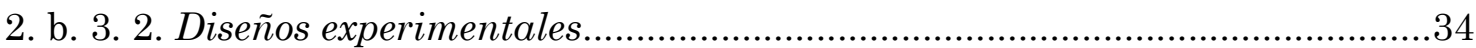

2. b. 3. 2. a. Protocolo para replicación de grabados......................................................35

2. b. 3. 2. b. Protocolo para replicación de motivos pintados.....................................36 
Capítulo 3. CARACTERIZACIÓN AMBIENTAL DE LAS REGIONES EN ESTUDIO.

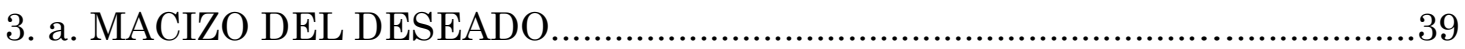

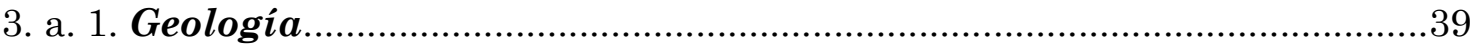

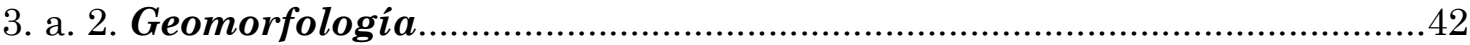

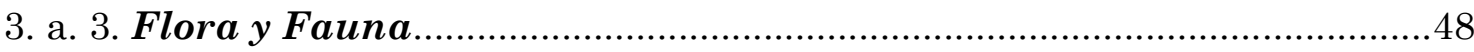

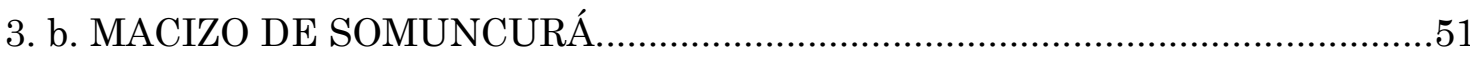

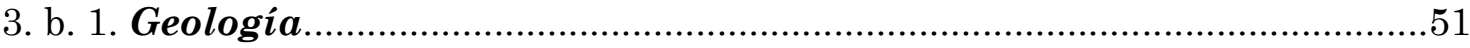

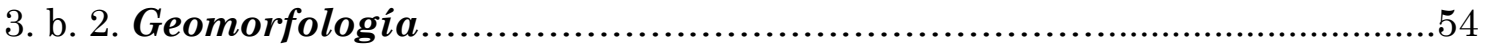

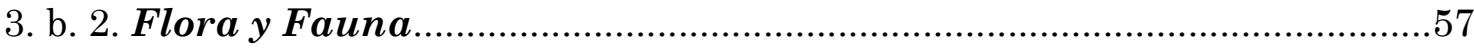

3. c. FACTORES COMUNES ENTRE AMBOS MACIZOS......................................60

Capítulo 4. ANTECEDENTES SOBRE LOS ESTUDIOS DEL ARTE

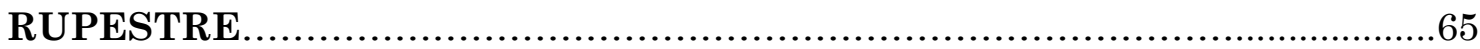

4. a. INVESTIGACIONES EN EL MACIZO DEL DESEADO ...............................66

4. a. 1. Investigaciones referidas al estudio tecnológico del arte rupestre...66

4. a. 2. El estudio de las técnicas en regiones aledañas.................................77

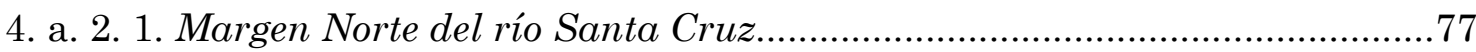

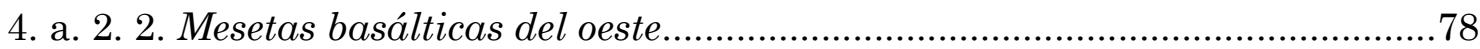

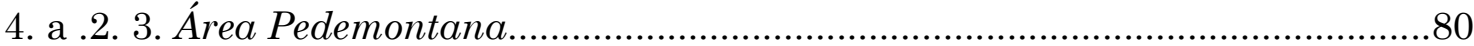

4. a. 3. Síntesis sobre el estudio de las técnicas de producción del arte rupestre en el Macizo del Deseado y en áreas aledañas...................................83

4. b. INVESTIGACIONES ARQUEOLÓGICAS EN EL MACIZO DE

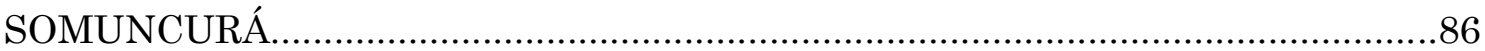

4. b. 1. Investigaciones arqueológicas referidas al estudio del arte rupestre

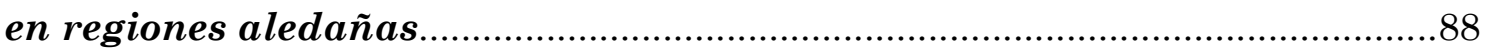

4. b. 1. 1. Los sitios con arte rupestre en el macizo de Somuncurá.............................89

4. b. 1. 2. Sitios con arte en el borde del macizo..........................................................91

4. b. 2. Investigaciones del arte rupestre en áreas aledañas a

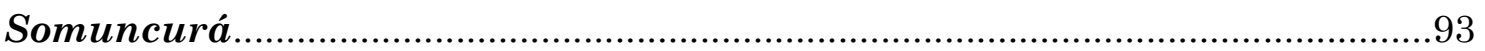

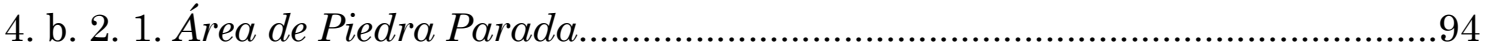

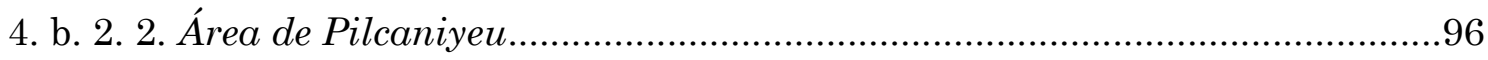

4. b. 2. 3. Cuenca media y superior del río Limay ....................................................99

4. b. 3. Integración de la información técnica para Somuncurá y áreas aledañas (Piedra Parada, Pilcaniyeu y cuenca del río Limay)..................102 


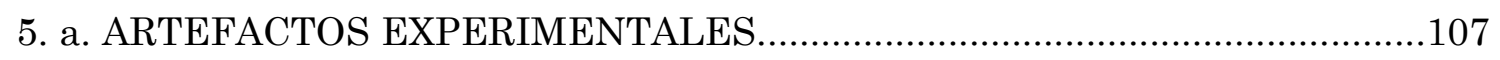

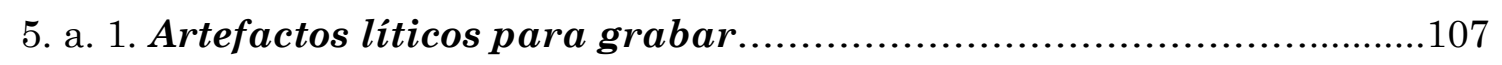

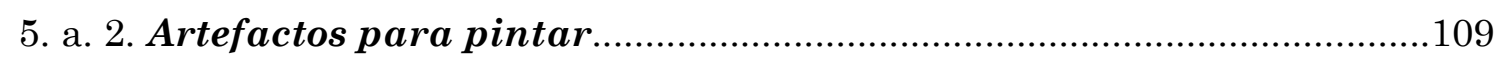

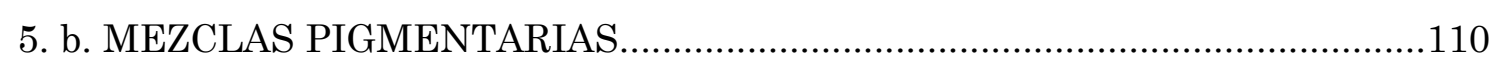

5. b. 1. Materias primas colorantes: procedencia y composición...................111

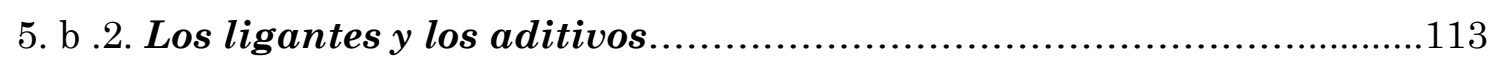

5. b. 3. Preparación y puesta a prueba de las mezclas pigmentarias...........115

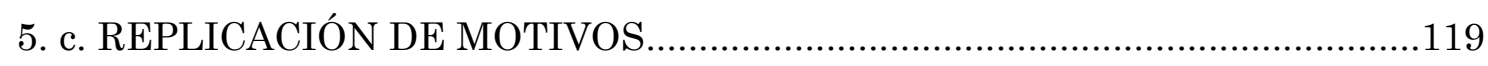

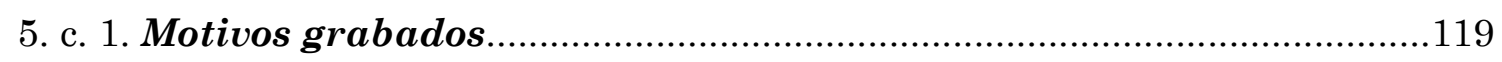

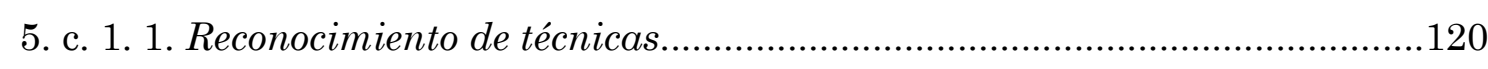

5. c. 1. 2. Replicación de grabados rupestres sobre diferentes soportes.....................127

5. c. 1. 2. a. Réplicas sobre bloque de arenisca coquinoide..............................127

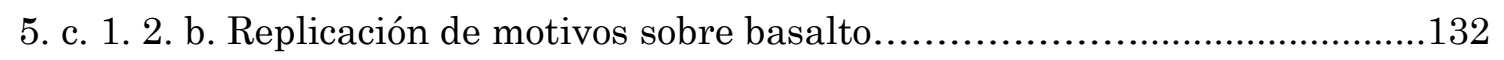

5. c. 1. 2. c. Comparación de réplicas grabadas sobre diferentes soportes...............137

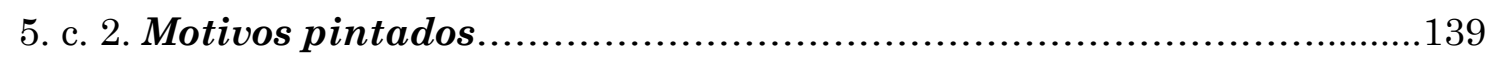

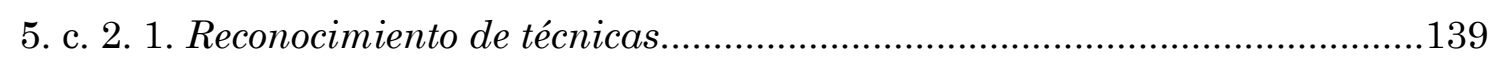

5. c. 2. 2. Réplicas de motivos pintados de la localidad La Primavera.................141

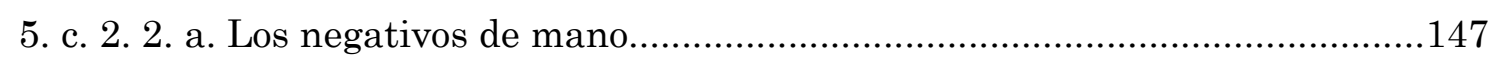

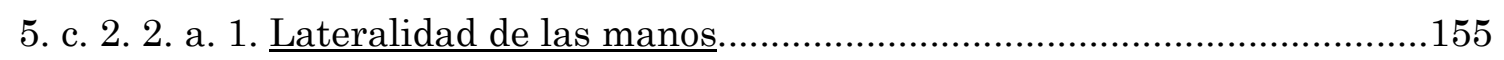

5. c. 2. 2. a. 2. Las réplicas de negativos de mano de Cueva Maripe........................160

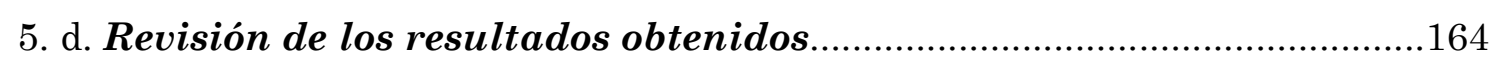

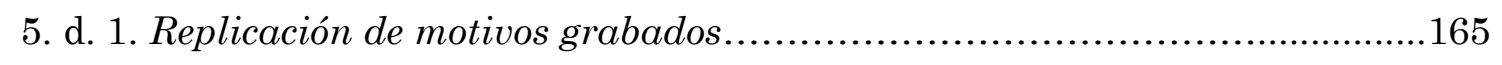

5. d. 2. Replicación de motivos pintados.................................................. 167

Capítulo 6. EL ARTE RUPESTRE DEL MACIZO DEL DESEADO................170

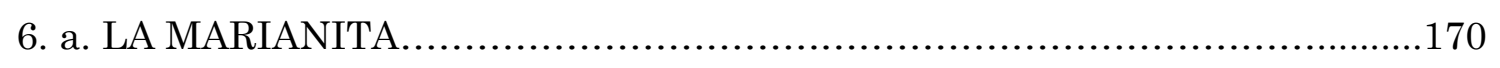

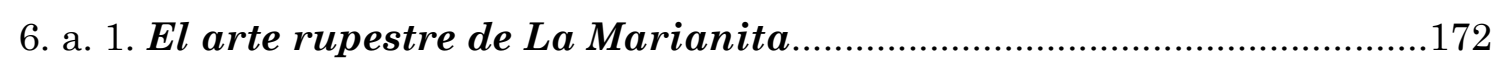

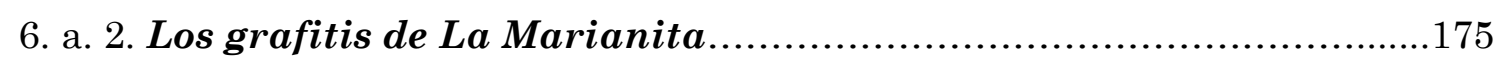

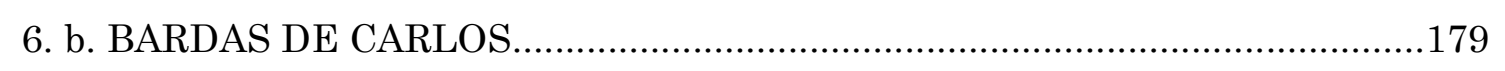

6. b. 1. Otros contextos arqueológicos de la localidad .....................................180

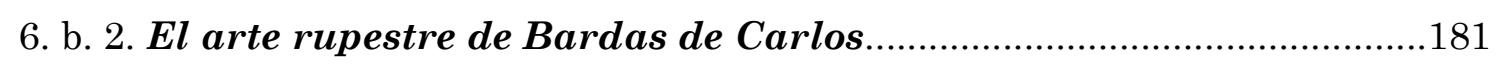

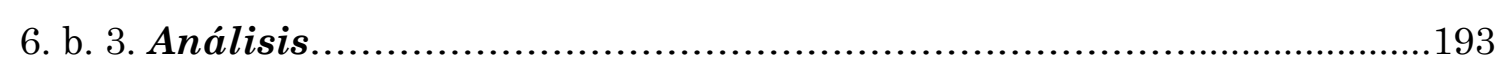

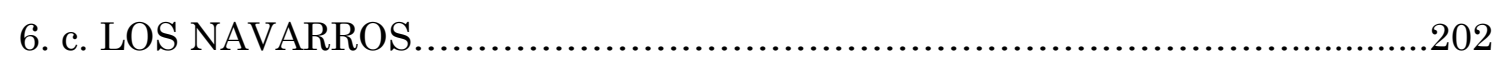

6. c. 1. Otros contextos arqueológicos de la localidad.....................................203 


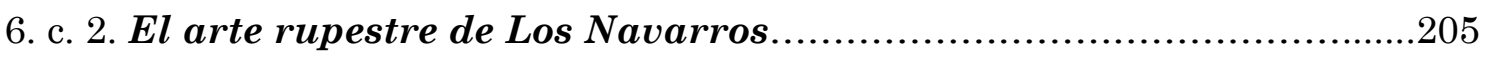

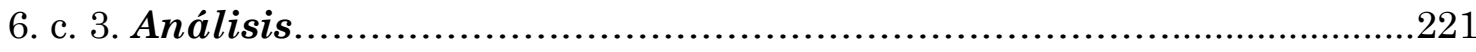

6. d. INTEGRACIÓN DE LA INFORMACIÓN..........................................2239

Capítulo 7. ARTE RUPESTRE EN EL MACIZO DE SOMUNCURÁ...............246

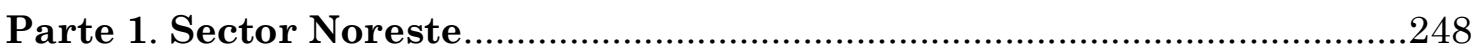

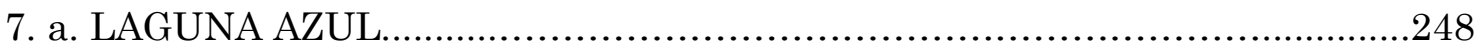

7. a. 1. Otros contextos arqueológicos en Laguna Azul..........................249

7. a. 2. El arte rupestre de Laguna Azul...........................................251

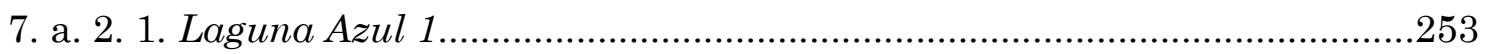

7. a. 2. 2. Laguna Azul 2..................................................................254

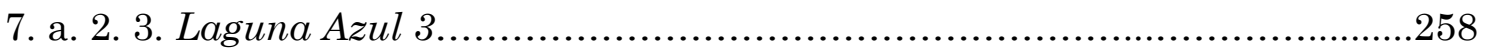

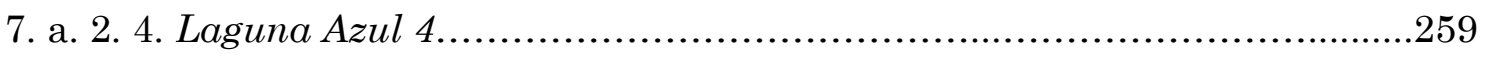

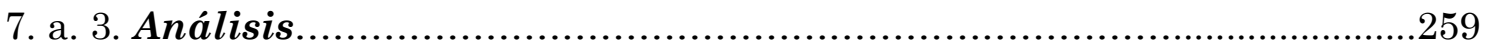

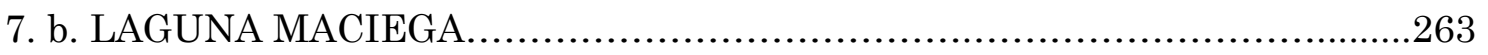

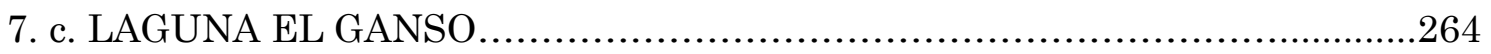

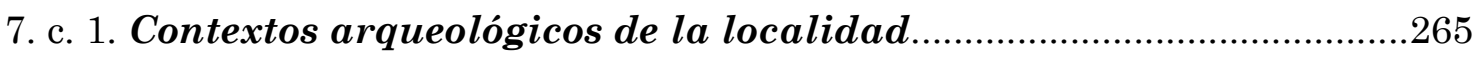

7. c. 2. El arte rupestre de Laguna El Ganso...........................................267

7. c. 2. 1. Sector 1...............................................................................2 270

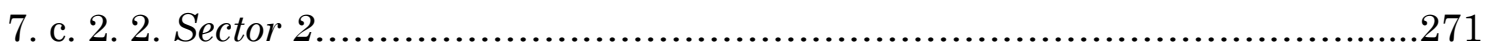

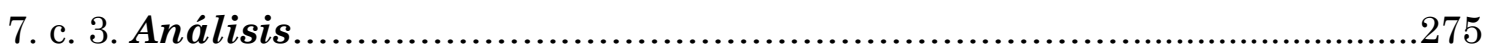

7. d. BARDAS DE ANTONIO ( LAGUNA LA MACIEGA)............................285

7. d. 1.Otros contextos arqueológicos de la localidad ............................286

7. d. 2. El arte rupestre de Bardas de Antonio.........................................287

7. d. 2. 1. Sector 1........................................................................290

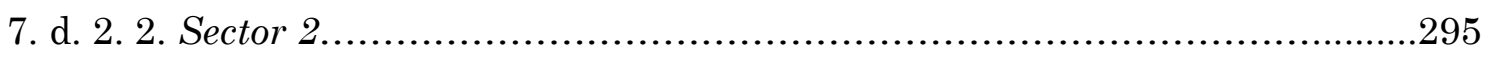

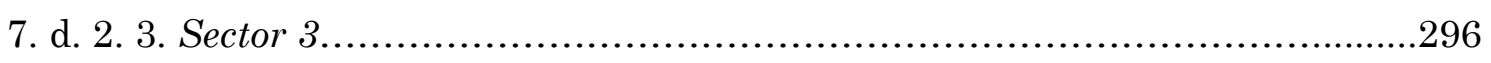

7. d. 2. 4. Sector 4..................................................................297

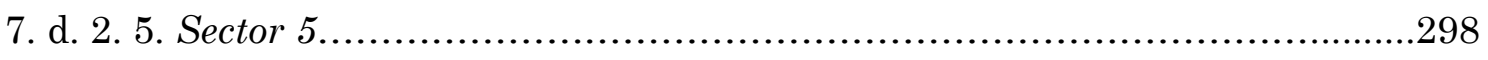

7. d. 2. 6. Sector 6 .................................................................................................298

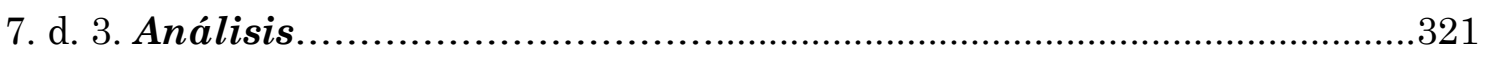

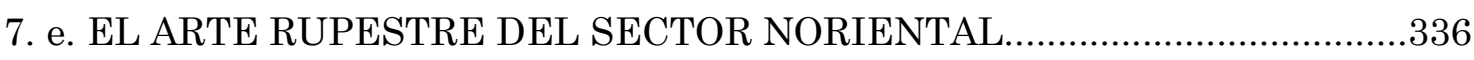

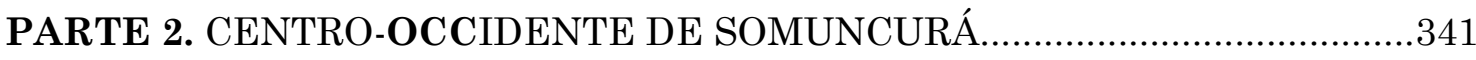

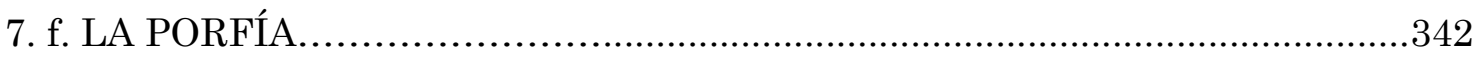

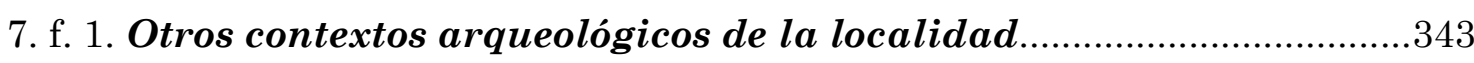




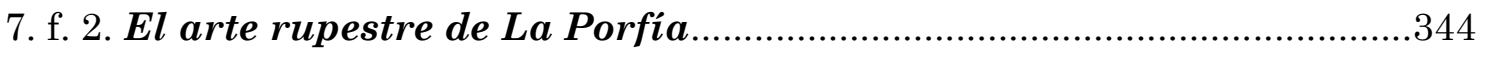

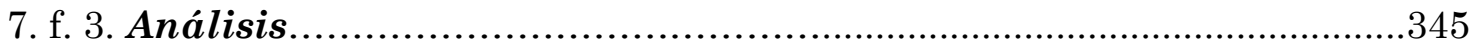

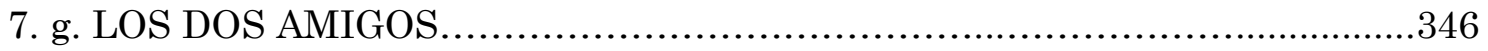

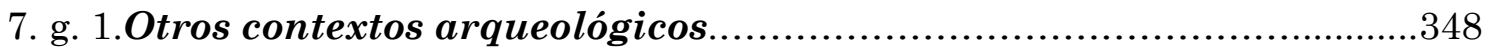

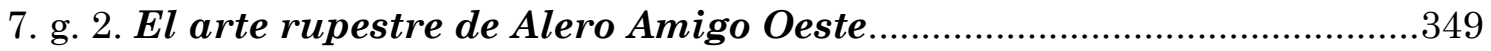

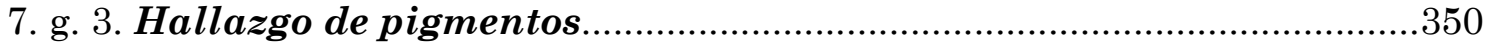

7. h. LOCALIDAD ARQUEOLOGICA TAPERA DE ISIDORO..............................352

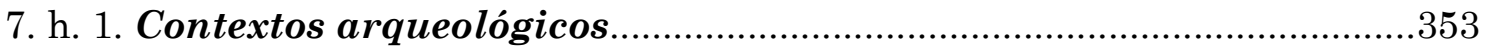

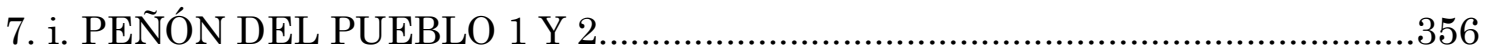

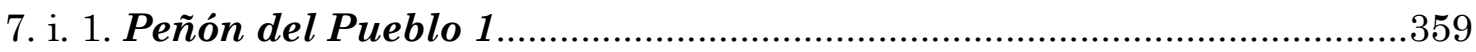

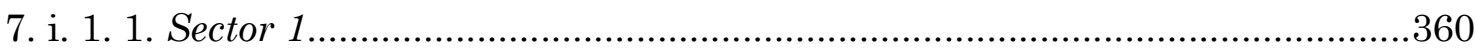

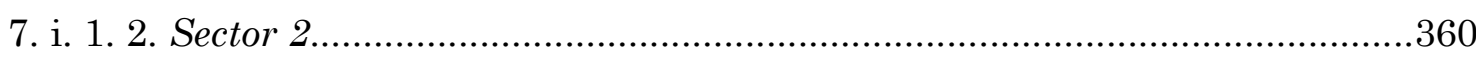

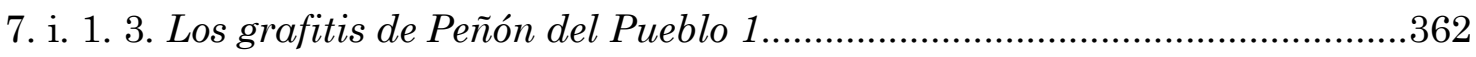

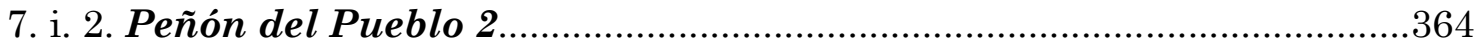

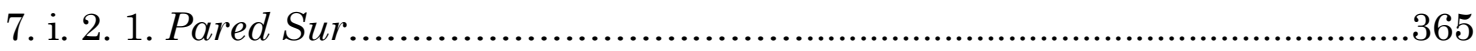

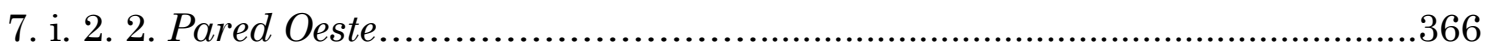

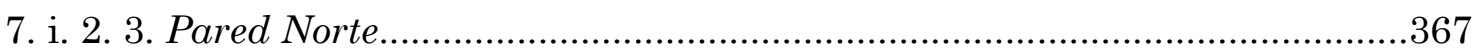

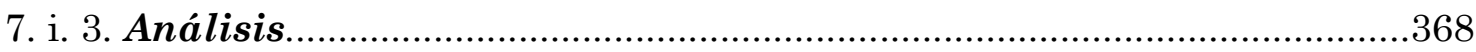

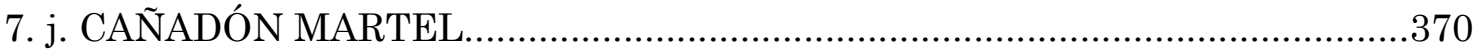

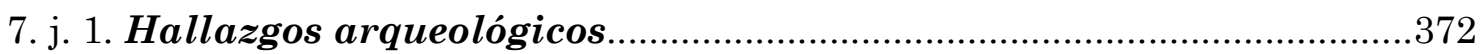

7. j. 2. El arte rupestre de Cueva Martel ...............................................................372

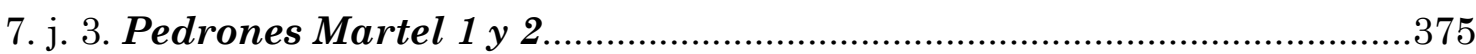

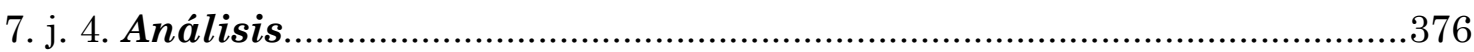

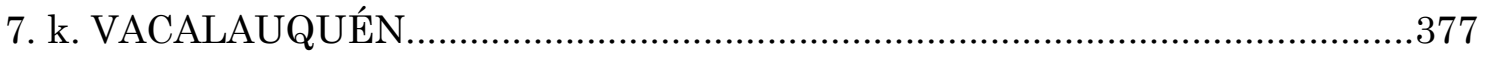

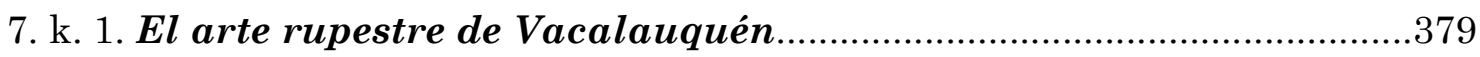

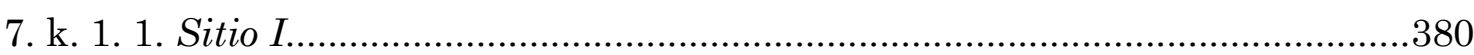

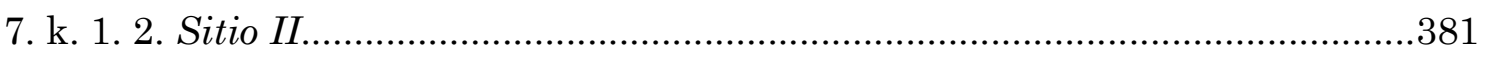

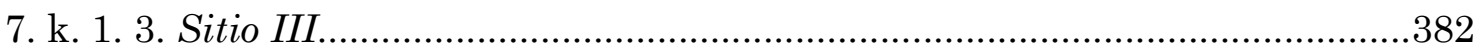

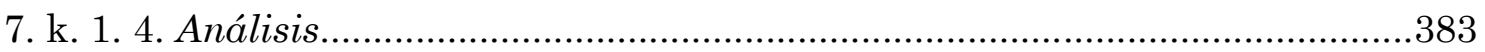

7. 1. EL ARTE RUPESTRE DEL CENTRO-OCCIDENTE DE SOMUNCURÁ....387

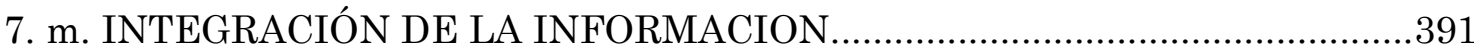

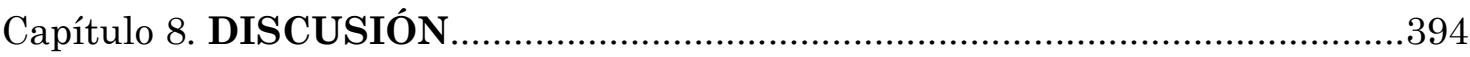

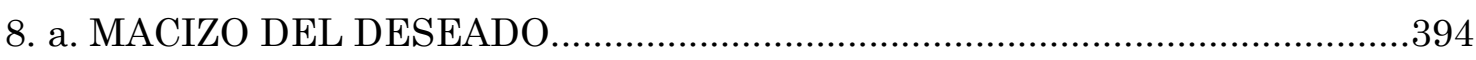

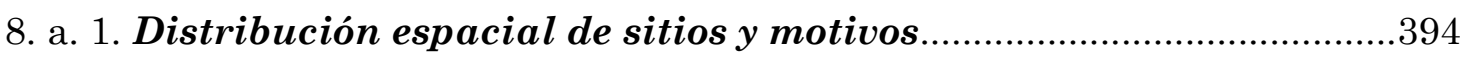




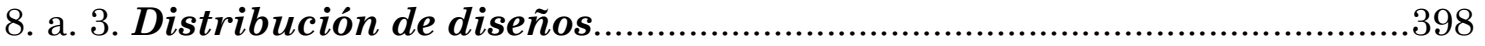

8. a. 4. Relación entre la distribución del diseño y la técnica .......................399

8. a. 5. Evaluación de posibles condicionantes tecnológicos..........................401

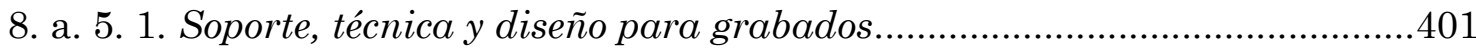

8. a. 5. 1. a. Re-evaluación de las técnicas de grabado en la localidad Piedra Museo .404

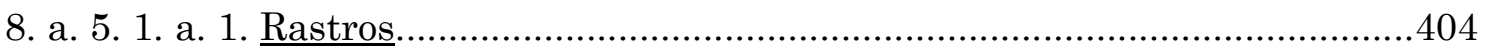

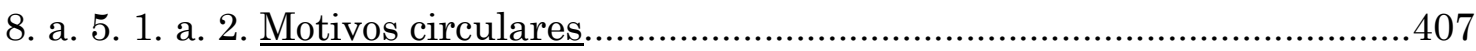

8. a. 5. 1. b. Re-evaluación de las técnicas de grabado en el sitio Laguna del Cerro Bonete. .408

8. a. 5. 1. c. Re-evaluación de técnicas para grabados.................................409

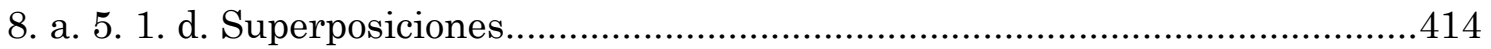

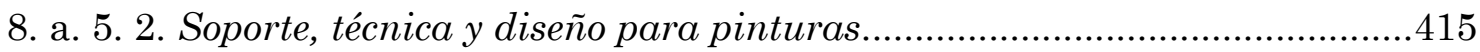

8. a. 5. 2. a. Evaluación de de técnicas para motivos figurativos...........................417

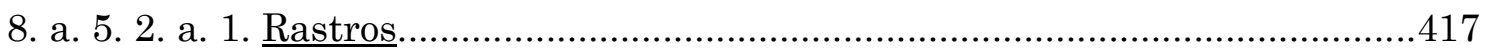

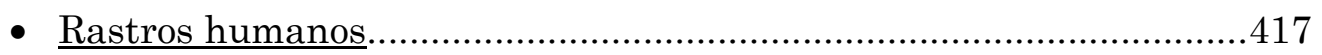

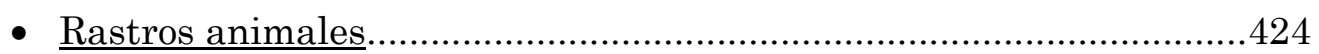

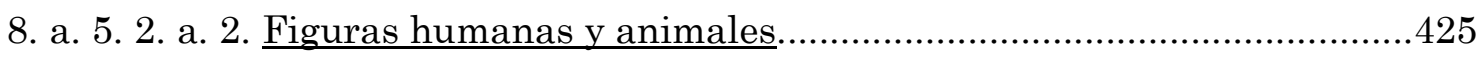

8. a. 5. 2. b. Evaluación de técnicas para motivos circulares....................................427

8. a. 5. 2. c. Evaluación de motivos ortogonales.........................................................430

8. a. 5. 2. d. Re-evaluación de técnicas de pintura.................................................430

8. a. 5. 2. e. Superposiciones..............................................................431

8. a. 6. Distribución temporal de los sitios con arte del macizo.....................431

8. a. 7. Distribución espacial de los sitios con arte .........................................432

8. a. 8. Relación entre soporte, técnicas y diseños en áreas aledañas.........433

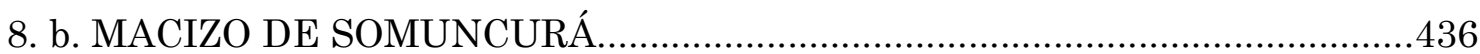

8. b. 1. Distribución espacial de sitios y motivos............................................437

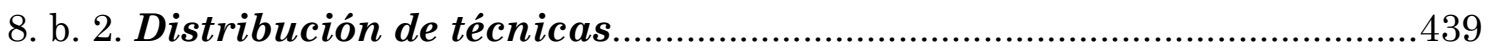

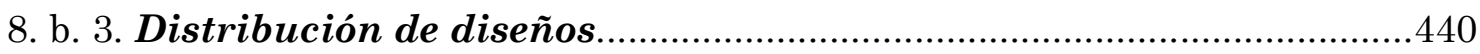

8. b. 4. Relación entre la distribución del diseño y la técnica.......................441

8. b. 5. Evaluación de posibles condicionantes tecnológicos...........................444

8. b. 5. 1. Soporte, técnica y diseño para grabados...................................................444

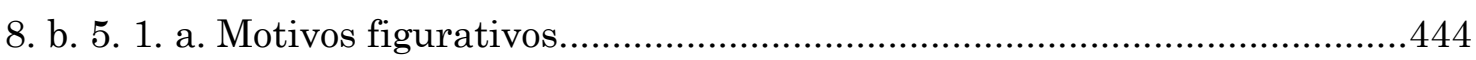

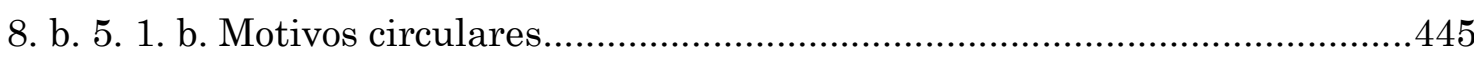




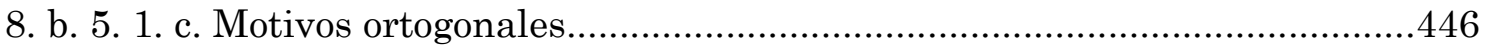

8. b. 5. 1. d. Evaluación de las técnicas de grabado................................................446

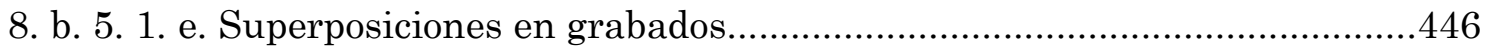

8. b. 5. 2. Soporte, técnica y diseño para pinturas...................................................447

8. b. 5. 2. a. Motivos figurativos..................................................... 448

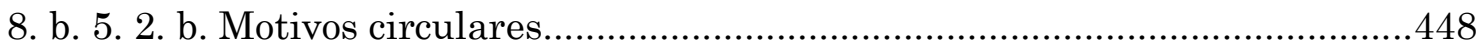

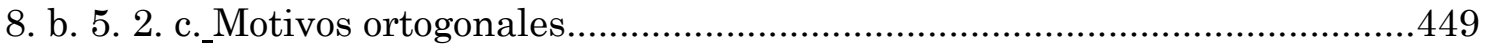

8. b. 5. 2. d. Evaluación de las técnicas de pintura................................................450

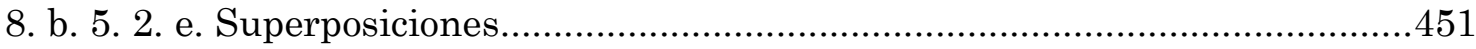

8. b. 5. 3. Soporte, técnica y diseño para pictograbados........................................451

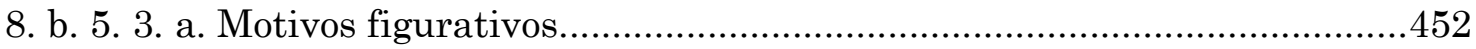

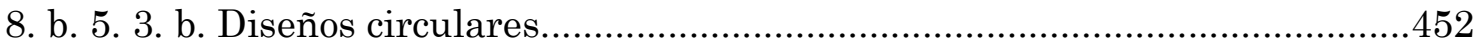

8. b. 5. 3. c. Evaluación de las técnicas de pictograbado.........................................452

8. b. 6. Distribución temporal de los sitios con arte ........................................453

8. b. 7. Relación entre soporte, técnicas y diseños en áreas aledañas..........455

8. b. 8. Relación entre soporte, técnicas y diseños en áreas aledañas..........459

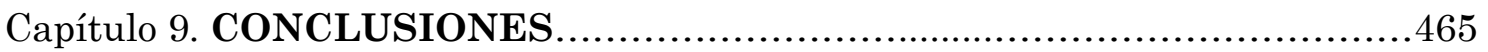

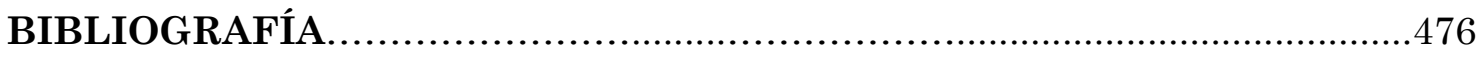

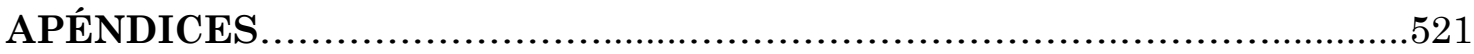

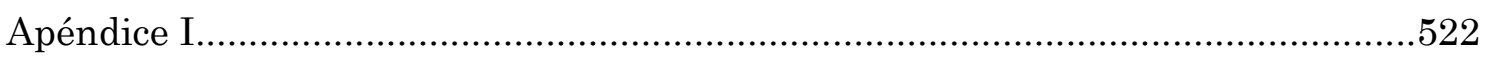

Apéndice I.1. Listado de motivos identificados.....................................................523

Apéndice I.2. Protocolo para la replicación experimental de grabados...................525

Apéndice I.3. Protocolo para la replicación experimental de pinturas....................527

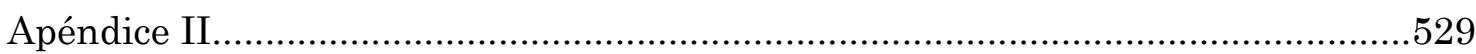

Apéndice II.1. a. Sitios arqueológicos tratados en antecedentes...........................530

Apéndice II.1.b. Motivos pintados, correlatos materiales y artefactos detectados en el macizo del Deseado.

Apéndice II.1.c. Motivos grabados, correlatos materiales y artefactos detectados en

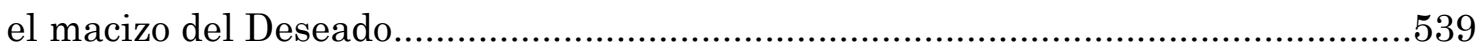

Apéndice II.2. a. Sitios arqueológicos de áreas aledañas....................................542 Apéndice II.2.b. Motivos pintados, correlatos materiales y artefactos detectados en áreas aledañas al macizo del Deseado .543

Apéndice II.2.c. Motivos grabados, correlatos materiales y artefactos detectados en áreas aledañas al macizo del Deseado. 
Apéndice II.3.a. Sitios y tipos de motivos del macizo de Somuncurá.

Apéndice II.3.b. Motivos pintados, técnicas inferidas y materiales asociados en estratigrafía en Somuncurá

Apéndice II.3.c. Motivos grabados, técnicas inferidas y materiales asociados en estratigrafía en Somuncurá

Apéndice II.4.a. Sitios y tipos de motivos de áreas aledañas a Somuncurá.

.549

Apéndice II.4.b. Motivos pintados, técnicas inferidas y materiales asociados en estratigrafía en áreas aledañas a Somuncurá

Apéndice II.4.c. Motivos grabados, técnicas inferidas y materiales asociados en estratigrafía para áreas aledañas a Somuncurá.

Apéndice III.

.561

Apéndice III.1. Ficha de registro de ANF experimentales.

.562

Apéndice III.2. Artefactos empleados durante las experiencias replicativas de motivos grabados.

Apéndice III.3. Proporciones de las mezclas pigmentarias usadas para realizar negativos de mano

Apéndice III.4. Proporciones de las mezclas usadas en la replicación de negativos de manos realizados apoyando el dorso de la extremidad derecha. .566

Apéndice IV. .567

Apéndice IV.1. Motivos rupestres documentados en Bardas de Carlos...... .568

Tabla IV.1.a. Distribución de motivos por sector. .568

Tablas IV.1.b. Categorías de motivos identificadas para los rectilíneos, los circulares lineales y los curvilíneos de Bardas de Carlos. .569

Apéndice IV.2. Arte rupestre de los Navarros .571

Tabla IV.2.a. Tipos de motivos registrados en Los Navarros. .571

Tabla IV.2.b. Categorías de motivos identificadas para los circulares lineales, los rectilíneos y los curvilíneos de Los Navarros. .573 Apéndice V. 


\section{LISTA DE FIGURAS}

\section{Capítulo 1}

Figura 1.1. Ubicación de las regiones en estudio. .1

\section{Capítulo 2}

Figura 2.1. Categorías reconocidas para los motivos rupestres.

Figura 2.2. Tipos de pisadas de animales para las clases pisadas de ave, de felino y de guanaco...... .24

Figura 2.3. Subgrupo de los puntiformes .25

Figura 2.4. Subgrupo de los rectilíneos. .25

Figura 2.5 Subgrupo de los circulares llenos. .25

Figura 2.6. Subgrupo de los circulares lineales. .26

Figura 2.7. Subgrupo de los curvilíneos .26

\section{Capítulo 3}

Figura 3.1. Paredones y cueva en formación Chon Aike............................................ 44

Figura 3.2. Afloramiento Laguna Palacios.................................................................4

Figura 3.3. Afloramiento Puesto del Museo................................................................45

Figura 3.4. Cuenca endorreica rodeada por Basalto Cerro del Doce..........................46

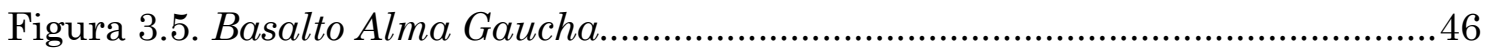

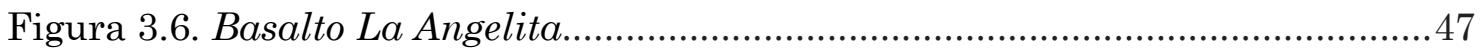

Figura 3.7. Clasificación cartográfica de provincias fitogeográficas argentinas......48

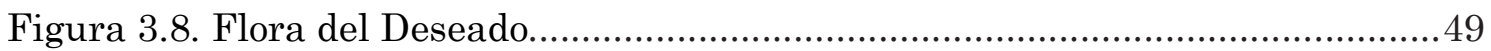

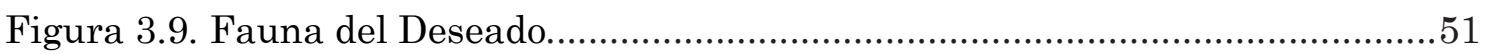

Figura 3.10. Formación Somun Curá...................................................................55

Figura 3.11. Relieve invertido: Sierra de Tromen Niyeu..........................................55

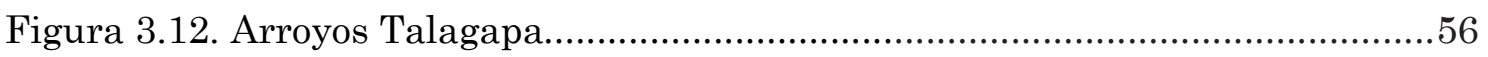

Figura 3.13. Bajo El Caín...................................................................................57

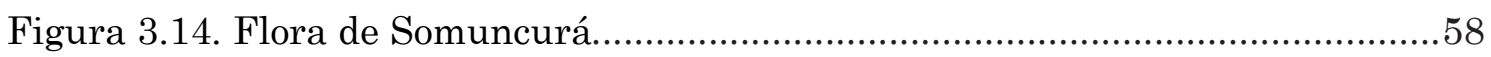

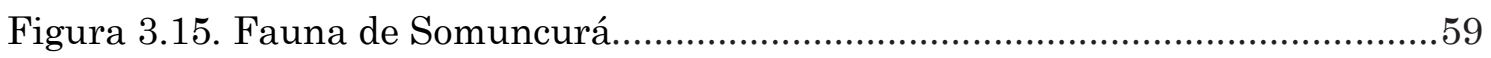

Figura 3.16. Sistema de cuencas residuales al sur del río Deseado..........................61

Figura 3.17. Sectores altitudinales reconocidos en Somuncurá...............................62 


\section{Capítulo 4}

Figura 4.1. Áreas consideradas en este capítulo. 66

Figura 4.2. Localidades y sitios con manifestaciones rupestres considerados para el macizo del Deseado. .68

Figura 4.3. Ubicación de los sitios considerados para el macizo de Somuncurá.......87 Figura 4.4. Sitios con arte rupestres de referencia para las áreas aledañas a Somuncurá.

\section{Capítulo 5}

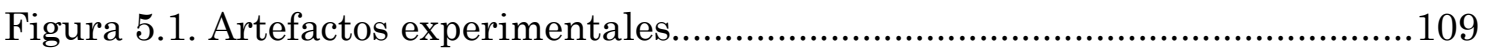

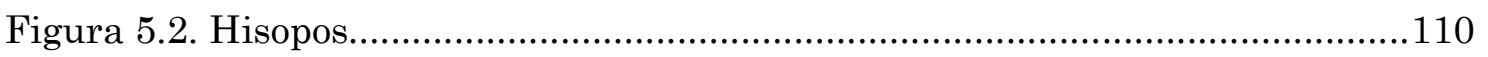

Figura 5.3. Localización en el Macizo del Deseado de las muestras pigmentarias

Figura 5.4. Materiales empleados en la puesta a prueba de las sustancias colorantes. 116

Figura 5.5. Puesta a prueba de diferentes mezclas pigmentarias. 117

Figura 5.6. Marcas grabadas mediante diferentes técnicas 121

Figura 5.7. Superficie homogeneizada mediante raspado. 124

Figura 5.8. Abradido de superficie utilizando agua y arena 125

Figura 5.9. Bloque de arenisca coquinoide con diversas fracturas luego del empleo de cinceles para grabarlo por percusión indirecta. 126

Figura 5.10. "Lado A" del bloque experimental de arenisca coquinoide Puesto del Museo. 128

Figura 5.11.Comparación entre tridígito experimental y arqueológico. 131

Figura 5.12. Tridígito experimental 3 realizado por percusión directa. 131

Figura 5.13. Circunferencia replicada experimentalmente. 132

Figura 5.14. Bloque basáltico de formación La Angelita, "Lado A"..... 133

Figura 5.15. Variantes en la posición de trabajo de los productores 135

Figura 5.16. Bloque con réplicas experimentales de los grabados de LCB. 135

Figura 5.17. Comparación entre grabado experimental y arqueológico. .136

Figura 5.18. Trazos experimentales pintados con hisopos y mediante la técnica digital. .140

Figura 5.19. Empleo de vellones y ramas para realizar marcas pintadas. .141

Figura 5.20. Réplicas de las pisadas de felino documentadas en LP2..... .142

Figura 5.21. Réplica de motivo de LP5. 144 
Figura 5.22. Réplicas de motivos del panel 7B de cueva Maripe. .145

Figura 5.23. Medidas de la mano tomadas sobre la palma izquierda. 148

Figura 5.24. Posturas y gestos durante la replicación de diferentes negativos de mano... 149

Figura 5.25. Comparación entre las medidas de la mano real y los negativos experimentales de una niña de 11 años. 150

Figura 5.26. Negativos realizados apoyando el dorso de mano derecha. 156

Figura 5.27. Movimientos de la mano y su relación con la muñeca. .158

Figura 5.28. Producción de negativos de mano izquierda apoyada sobre la palma y de mano derecha apoyada sobre el dorso.

Figura 5.29. Réplica experimental de una selección de motivos del panel 6B de Cueva Maripe. 160

Figura 5.30. Referentes arqueológicos de los motivos experimentales. .161

Figura 5.31. Trazos de pintura obtenidos a partir de la aplicación de pintura mediante pulverizado directo. .162

Figura 5.32. Replicación de negativos de manos cruzadas. .164

Figura 5.33. Referente arqueológico. .164

Figura 5.34. Réplicas experimentales del bloque de arenisca coquinoide. .167

\section{Capítulo 6}

Figura 6.1. Ubicación de los sitios estudiados en el Macizo del Deseado. 171

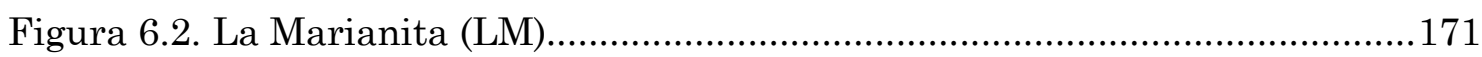

Figura 6.3. Calco del panel 1 con grabados de LM................................................. 173

Figura 6.4. Proporciones de grupos y subgrupos de motivos de LM.......................173

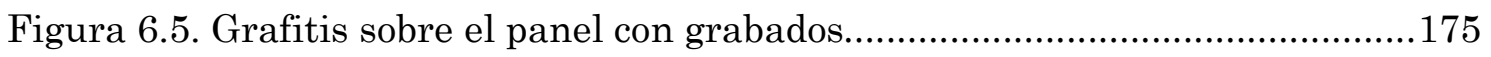

Figura 6.6. Distribución porcentual por tipos de grafitis en LM............................176

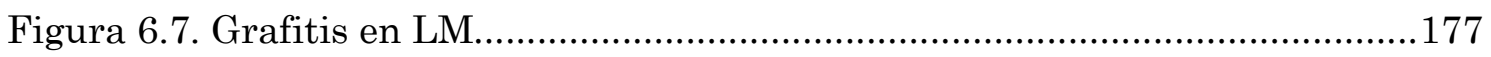

Figura 6.8. Afloramiento de basaltos y vista desde Bardas de Carlos.....................180

Figura 6.9. Croquis de sectorización de Bardas de Carlos...................................... 182

Figura 6.10. Materiales de superficie detectados en Bardas de Carlos...................182

Figura 6.11. Proporciones de motivos por sector en BC.......................................... 183

Figura 6.12. Proporciones de grupos y subgrupos de motivos identificados en

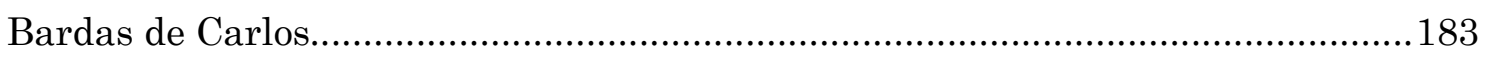

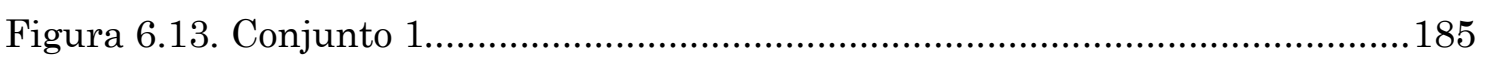




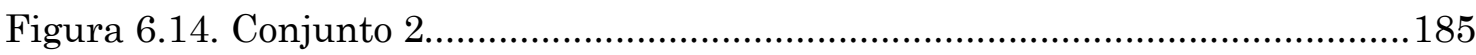

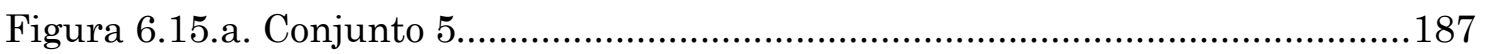

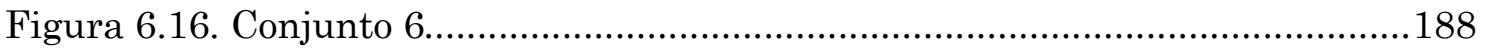

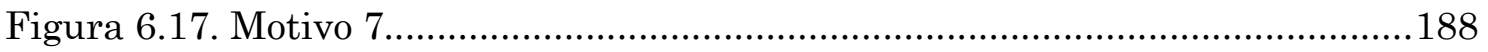

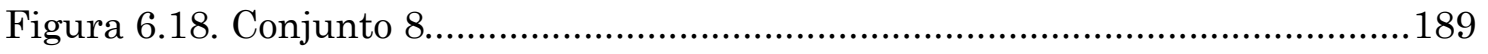

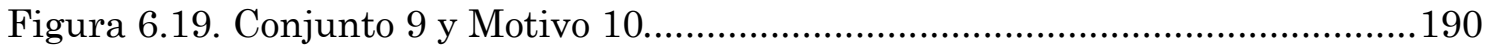

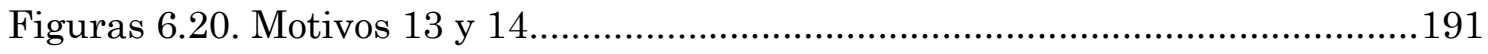

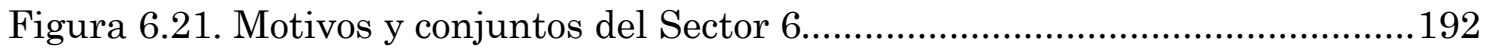

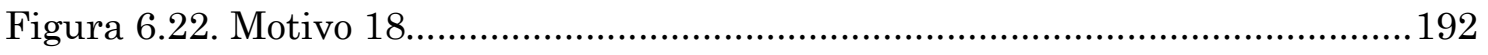

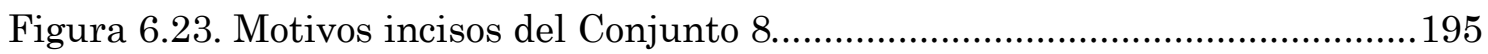

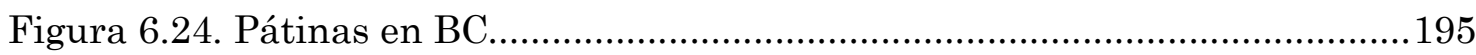

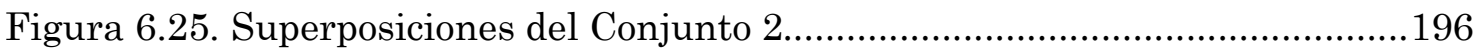

Figura 6. 26. Proporciones acumuladas y frecuencias de las categorías de motivos

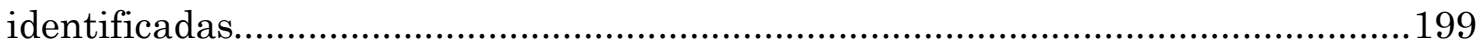

Figura 6.27. Distribución porcentual de los grados de pátina por clases de

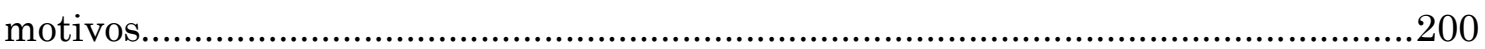

Figura 6.28. Motivos figurativos de Bardas de Carlos.............................................201

Figura 6.29. Laguna de Los Navarros vista desde el sector con grabados.............203

Figura 6.30. Ubicación de otros hallazgos arqueológicos.......................................204

Figura 6.31. Materiales líticos registrados en Los Navarros.................................204

Figura 6.32. Barda de los Navarros...................................................................205

Figura 6.33. Proporciones de motivos por sector.....................................................2.205

Figura 6.34. Proporciones de grupos y subgrupos de motivos...............................206

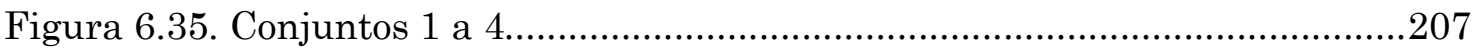

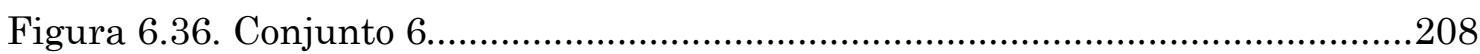

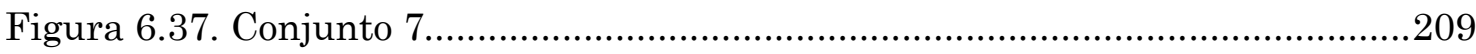

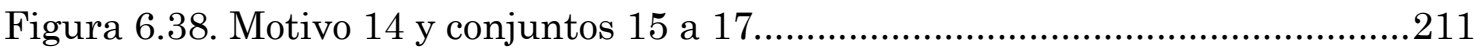

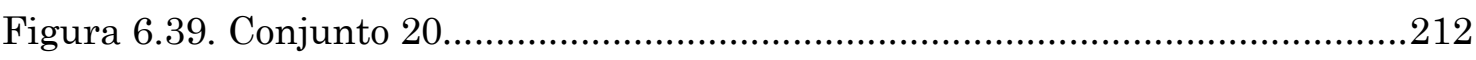

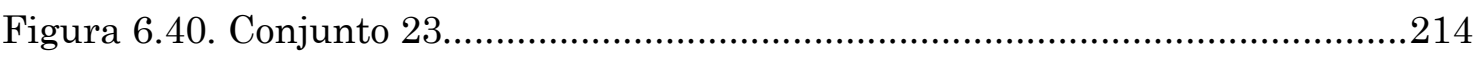

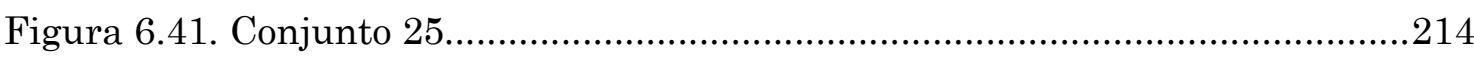

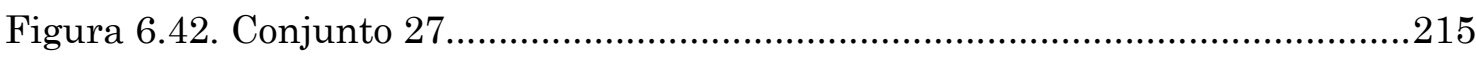

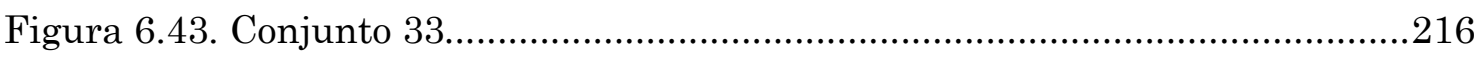

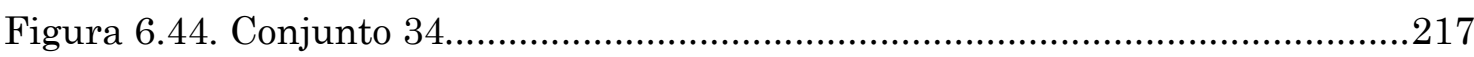

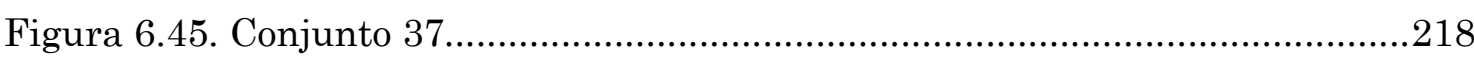

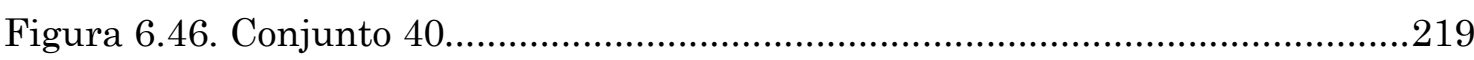


Figura 6.47. Conjuntos 42 y 45 .

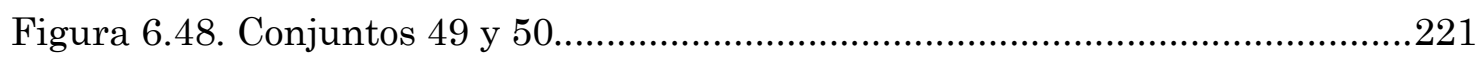

Figura 6.49. Visualización y posible continuidad entre los Conjuntos 4 y

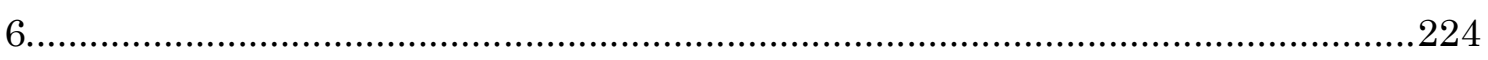

Figura 6.50. Proporciones y distribución por sector de los grados de pátina.........226

Figura 6.51. Proporciones y distribución por sector de los grados de pátina reconocidos en Los Navarros sin considerar aquellos con pátina no

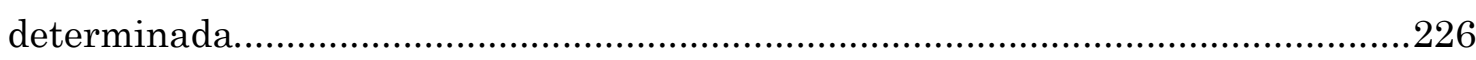

Figura 6.52. Superposiciones del Conjunto 6......................................................228

Figura 6.53. Distribución por sector de subgrupos y clases de motivos..................233

Figura 6.54. Distribución porcentual de categorías de motivos y tipo de pátina sin

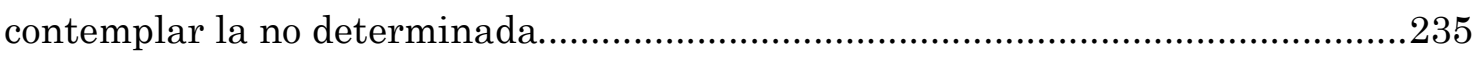

Figura 6.55. Distribución de los motivos figurativos en los diferentes

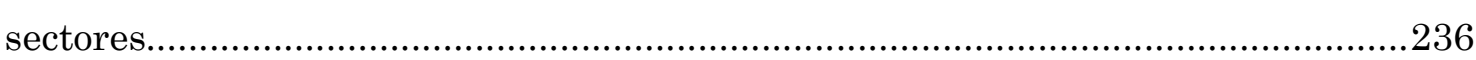

Figura 6.56. Tipos de pisadas de ave de Los Navarros.......................................223

Figura 6.57. Proporciones acumuladas de subgrupos de motivos reconocidos en los sitios.....

\section{Capítulo 7, Parte 1}

Figura 7.1. Sectores prospectados y sitios con arte rupestre en el macizo

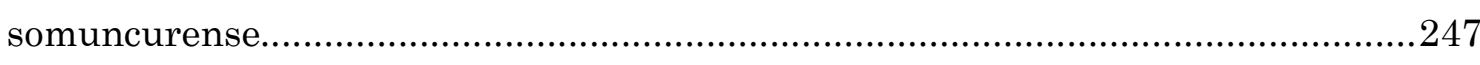

Figura 7.2. Ubicación de los sitios documentados en el NE de Somuncurá...........248

Figura 7.3. Vista de la Laguna Azul (LA) y riqueza avifaunística........................249

Figura 7.4. Distribución espacial de los sitios en LA...........................................250

Figura 7.5. Diferentes contextos arqueológicos en LA.........................................251

Figura 7.6. Proporciones de motivos por sitio en LA...............................................252

Figura 7.7. Proporciones de grupos y subgrupos de motivos en LA.......................252

Figura 7.8. Motivos de LA1................................................................................254

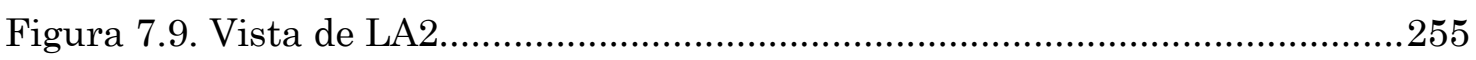

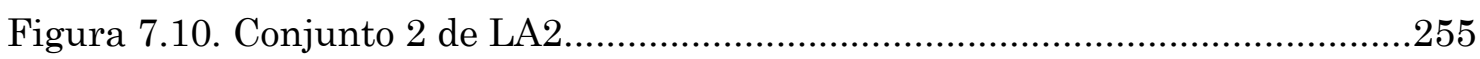

Figura 7.11. Conjunto 3 y Motivo 4 de LA2 ...........................................................256

Figura 7.12. Motivo 6 y Conjunto 7 de LA2 .......................................................257

Figura 7.13. Materiales registrados al interior de LA2 ...................................257

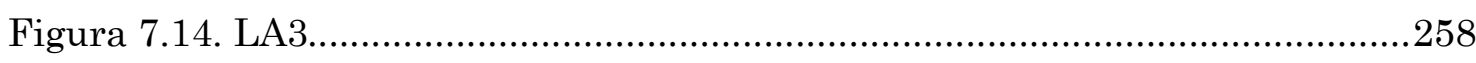




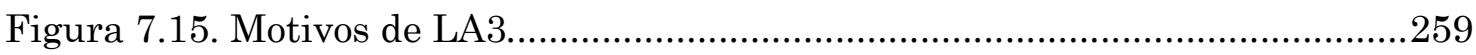

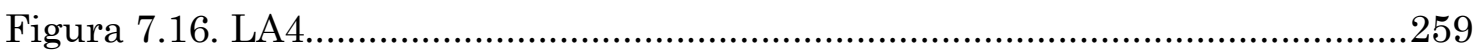

Figura 7.17. Distribución de motivos de LA..........................................................261

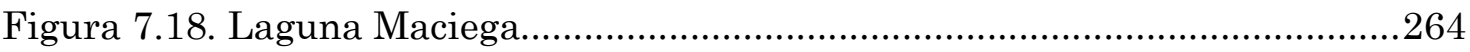

Figura 7.19. Laguna El Ganso (LEG) vista desde la margen sudoeste..................265

Figura 7.20. Hallazgos arqueológicos en la localidad..........................................267

Figura 7.21. Distribución de sectores con arte y estructuras en LEG....................268

Figura 7.22. Proporciones de motivos por sectores en LEG..................................269

Figura 7.23. Proporciones de grupos y subgrupos de motivos en LEG...................269

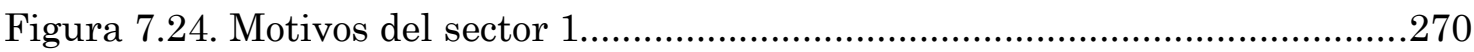

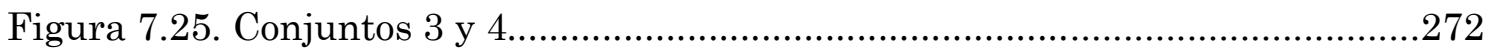

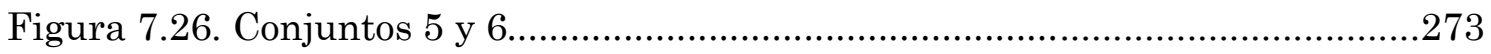

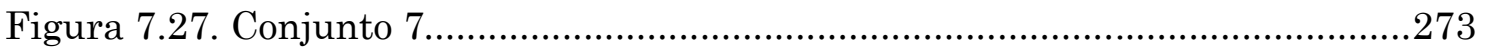

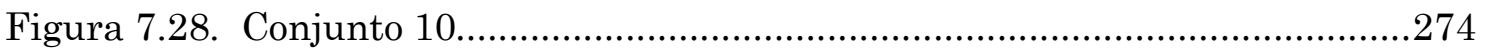

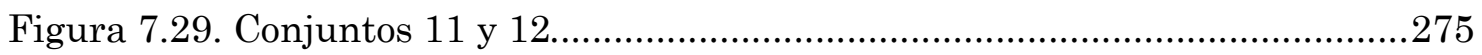

Figura 7.30. Técnicas documentadas en LEG y su distribución por sectores.........277

Figura 7.31. Reconocimiento macroscópico de técnicas..........................................2278

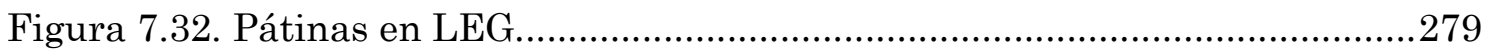

Figura 7.33. Distribución espacial de frecuencias de subgrupos y categorías de

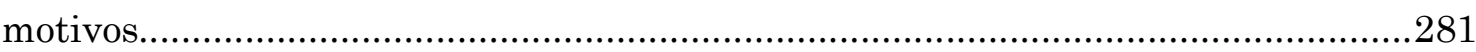

Figura 7.34. Distribución de grados de pátina por sector y por categorías de

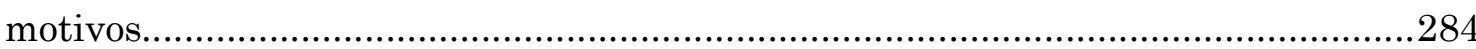

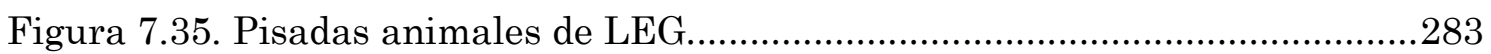

Figura 7.36. Vista de la laguna La Maciega y puntos de referencia......................286

Figura 7.37. Sectorización del sitio Bardas de Antonio.........................................228

Figura 7.38. Proporciones de motivos por sectores..............................................289

Figura 7.39. Proporciones de grupos y subgrupos de motivos en Bardas de

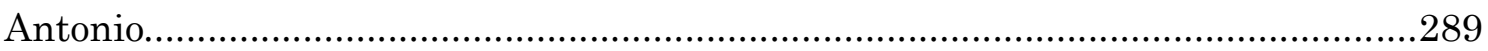

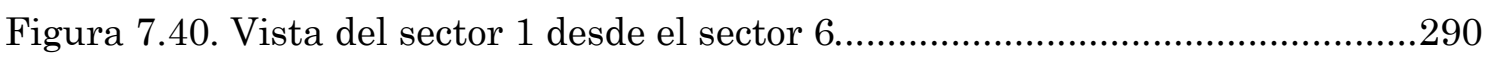

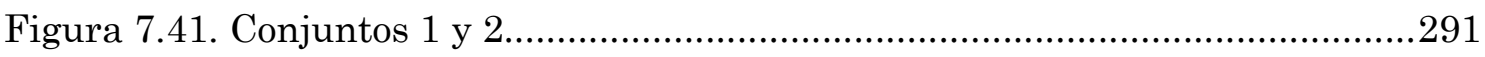

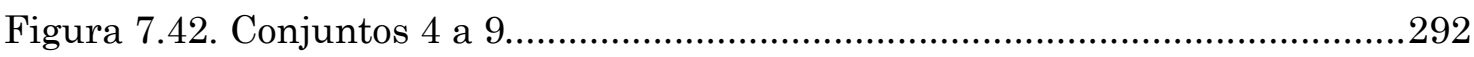

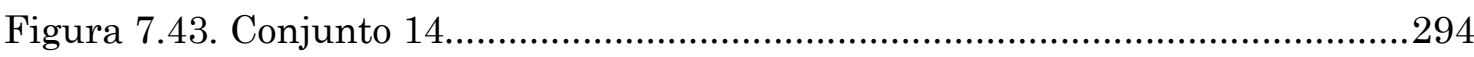

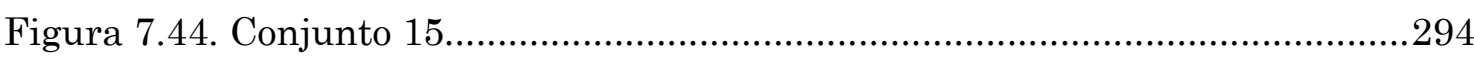

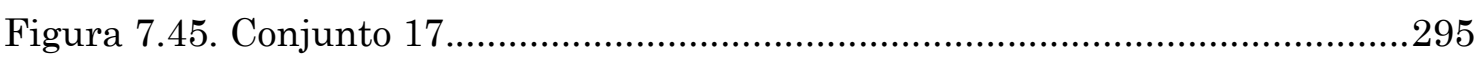

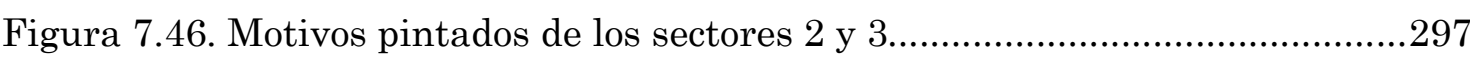




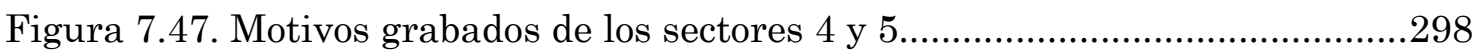

Figura 7.48. Vista del Sector 6 desde el Conjunto 14..........................................298

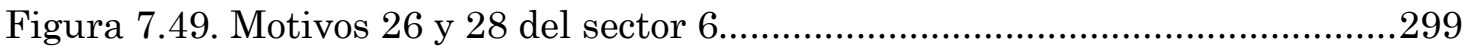

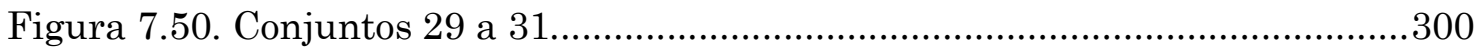

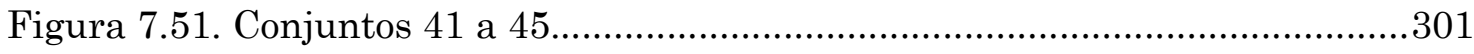

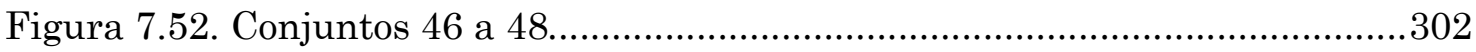

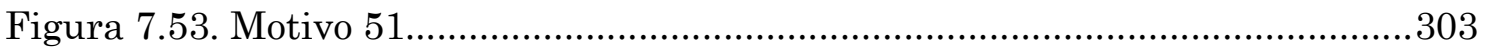

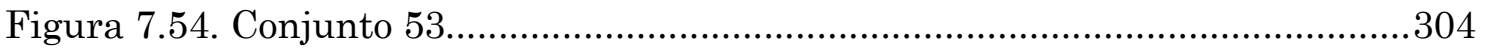

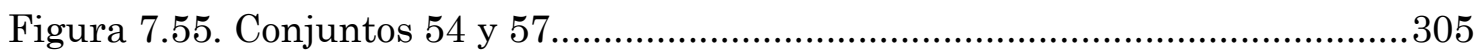

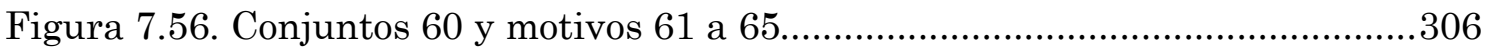

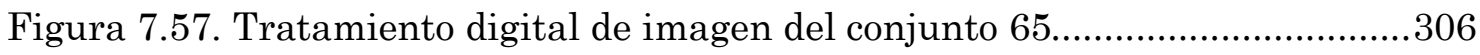

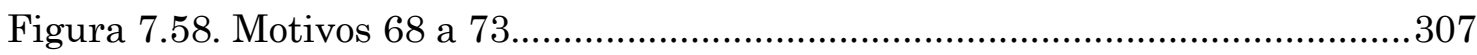

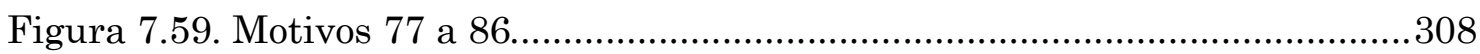

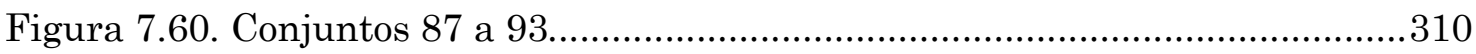

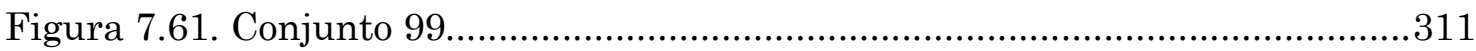

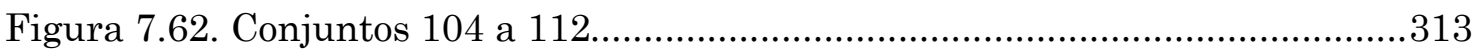

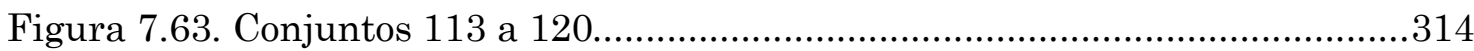

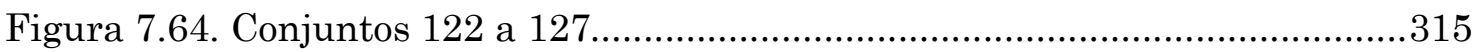

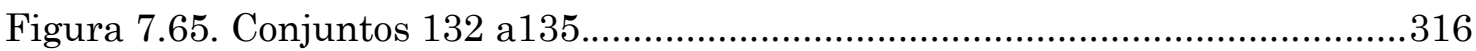

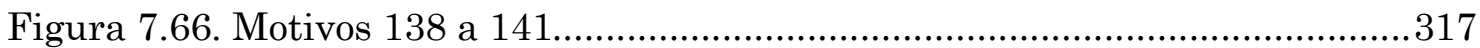

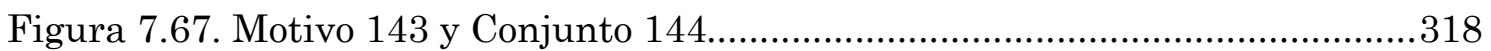

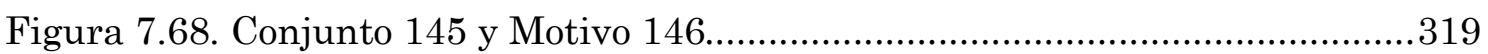

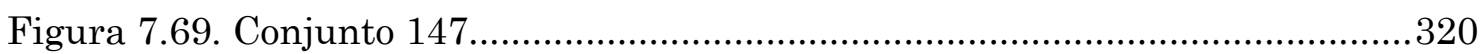

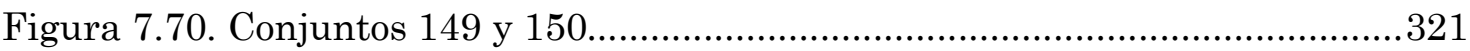

Figura 7.71. Proporciones y distribución de técnicas por sector en Bardas de

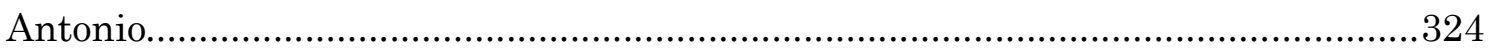

Figura 7.72. Proporciones y distribución por sector de técnicas de grabado...........324

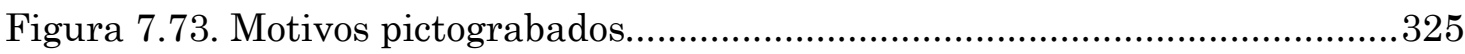

Figura 7.74. Proporciones de pátinas en BA y proporciones acumuladas por

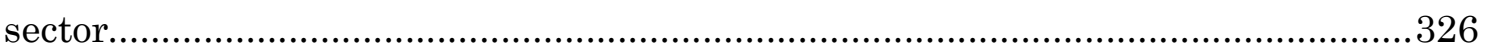

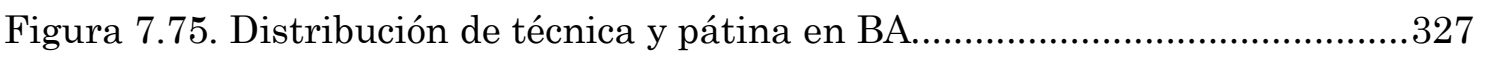

Figura 7.76. Proporciones acumuladas de subgrupos y categorías de motivos

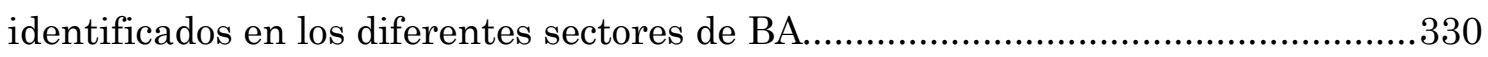

Figura 7.77. Distribución por sectores de las distintas clases de motivos y sus

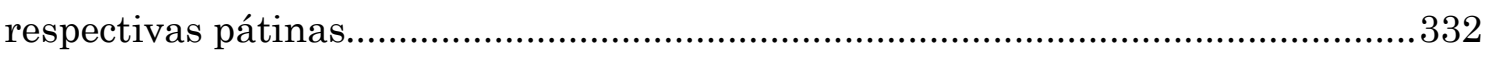


Figura 7.78. Tipos de pisadas de aves de Bardas de Antonio. .333

Figura 7.79. Proporciones acumuladas de subgrupos de motivos reconocidos en los sitios del sector noreste. .338

\section{Capítulo 7, Parte 2}

Figura 7.80. Ubicación de los sitios considerados.................................................. 341

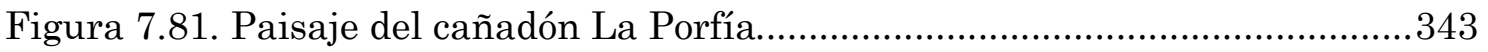

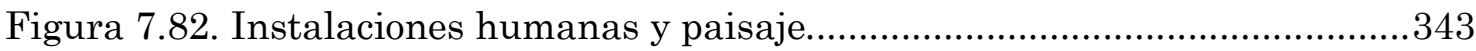

Figura 7.83. Acumulación de materia prima colorante al N de La Porfía...............344

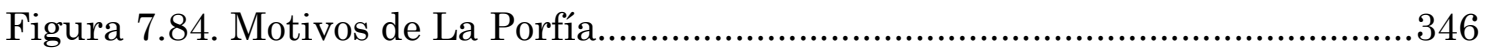

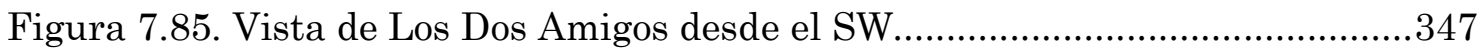

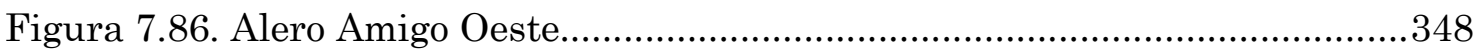

Figura 7.87. Materiales del Cerro Amigo Oeste y esferoide de ocre........................349

Figura 7.88. Motivo de Alero Amigo Oeste............................................................ 350

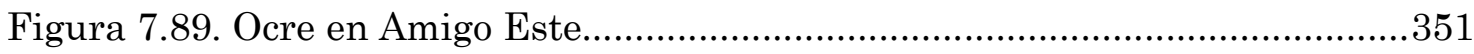

Figura 7.90. Potenciales fuentes de aprovisionamiento de materias primas

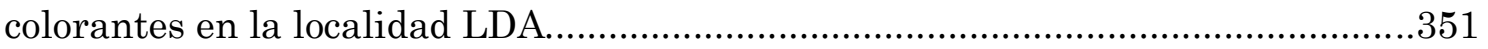

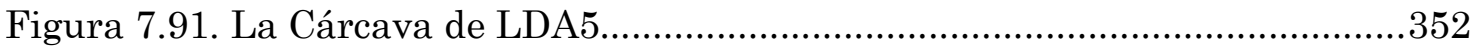

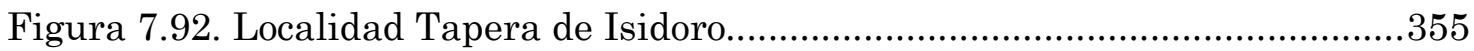

Figura 7.93. Paisaje y vista de los sitios de Peñón del Pueblo................................357

Figura 7.94. Proporciones de motivos por sitio de Peñón del Pueblo........................358

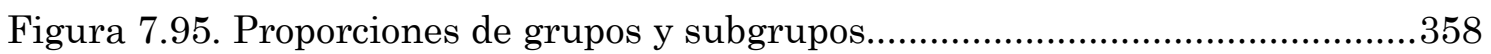

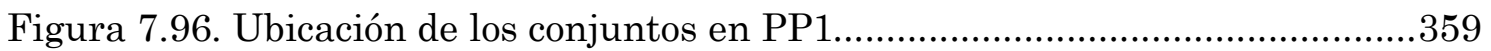

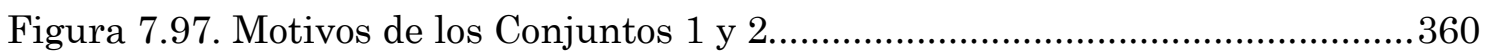

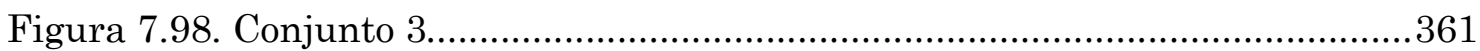

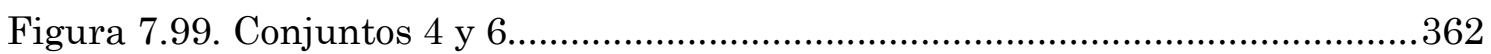

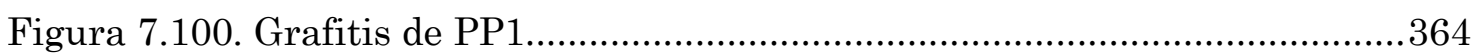

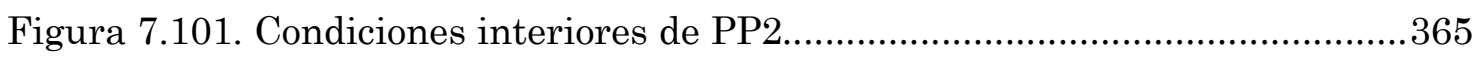

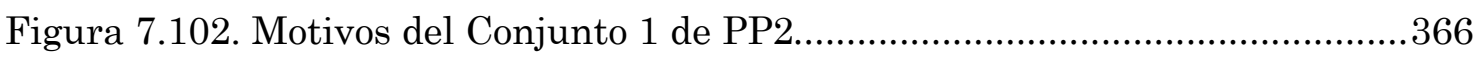

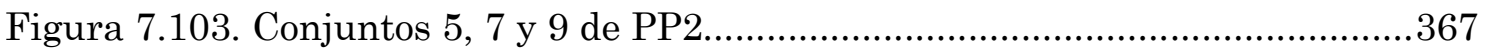

Figura 7.104. Técnicas de producción reconocidas en distintos motivos del Conjunto

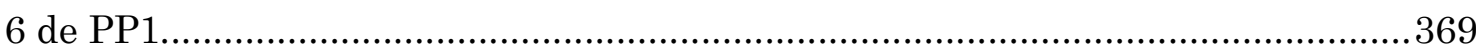

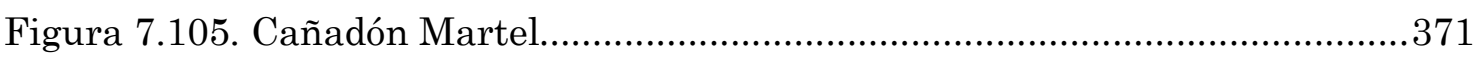

Figura 7.106. Rocas que conforman el Cañadón Martel.......................................... 371 
Figura 7.107. Cueva Martel y material en superficie al interior de la cueva 373

Figura 7.108. Localización del arte rupestre en Cueva Martel................................373

Figura 7.109. Grafiti y motivo 1 en Cueva Martel..................................................374

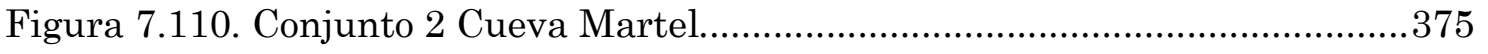

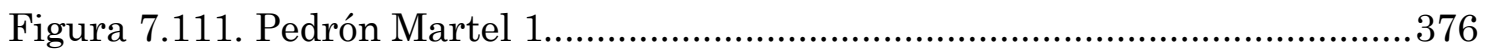

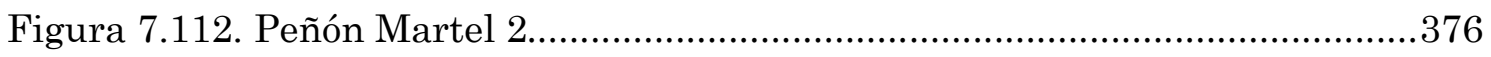

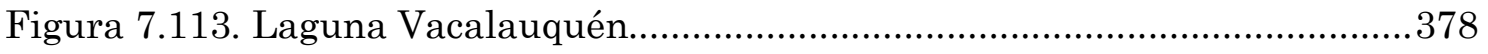

Figura 7.114. Materia prima colorante en Vacalauquén........................................378

Figura 7.115. Distribución de motivos en los sitios de Vacalauquén.......................379

Figura 7.116. Proporciones de grupos y subgrupos de motivos en Vacalauquén...380

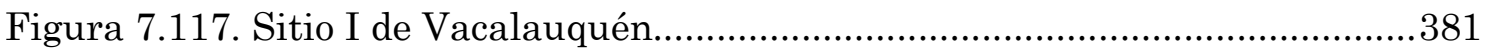

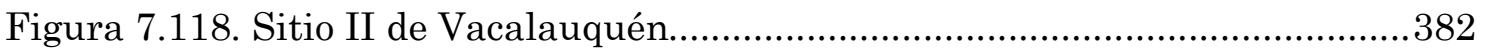

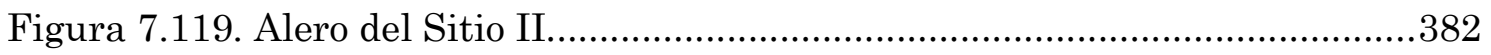

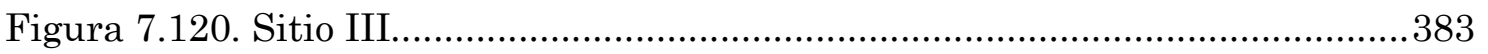

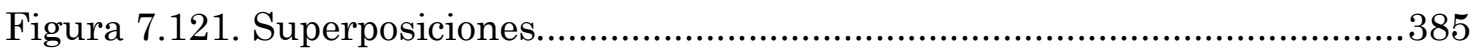

Figura 7.122. Proporciones acumuladas de subgrupos de motivos reconocidos en los sitios.

\section{Capítulo 8}

Figura 8.1. Ubicación de las localidades y sitios tratados en esta tesis en los diferentes sectores del macizo del Deseado.

Figura 8.2. Distribución porcentual y espacial de técnicas de producción de arte rupestre reconocidas en el NE del macizo del Deseado. 396

Figura 8.3. Distribución porcentual y espacial de las técnicas de producción reconocidas en el macizo del Deseado. .398

Figura 8.4. Proporciones de técnicas de producción para motivos figurativos y no figurativos

Figura 8.5. Distribución de técnicas y subgrupos de motivos no figurativos en los diferentes sectores reconocidos. .400

Figura 8.6. Distribución de técnicas y subgrupos de motivos figurativos en los diferentes sectores reconocidos. .400

Figura 8.7. Rastros de aves realizados mediante percusión directa e incisión en los sitios de la localidad Piedra Museo. .405

Figura 8.8. Pisadas de felino. .406 


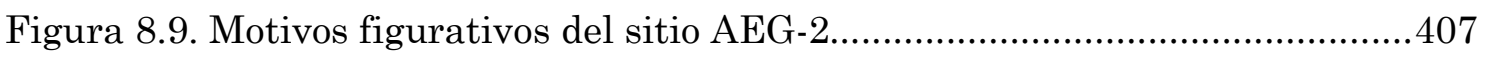

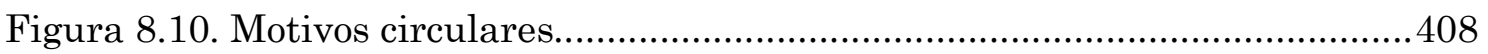

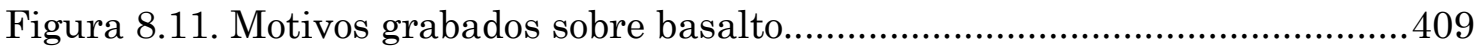

Figura 8.12. Manos negativas en Tito del Valle y Sierras Blancas.......................420

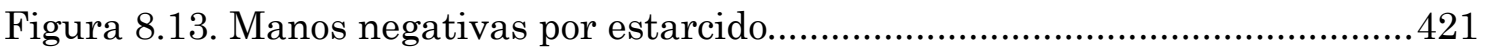

Figura 8.14. Técnicas adicionales reconocidas para la producción de manos.......422

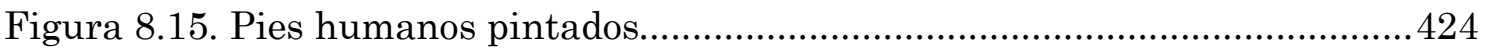

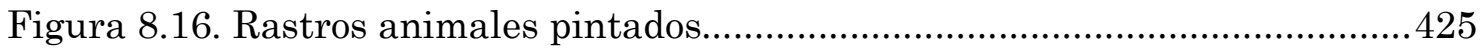

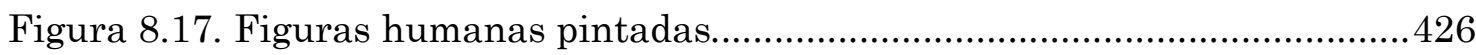

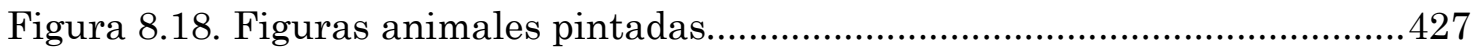

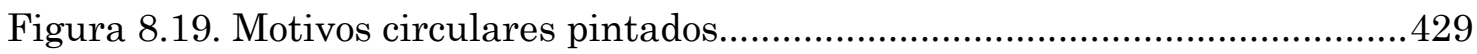

Figura 8.20. Una de las posibles maneras de acceder al soporte en CH..............429

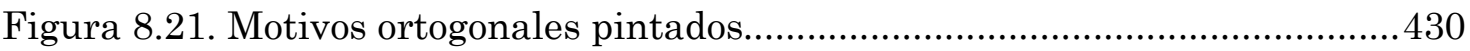

Figura 8.22. Sectores y sitios con arte rupestre del Macizo de Somuncurá y

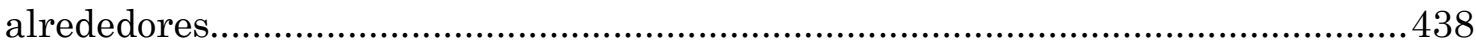

Figura 8.23. Distribución porcentual de sitios y motivos en el macizo de Somuncurá y alrededores. 438

Figura 8.24. Técnicas de producción reconocidas en el macizo de Somuncurá y alrededores. .440

Figura 8.25. Proporciones de motivos por técnicas de producción...........................442

Figura 8.26. Distribución de motivos no figurativos en Somuncurá........................443

Figura 8.27. Distribución de motivos figurativos en Somuncurá..............................443

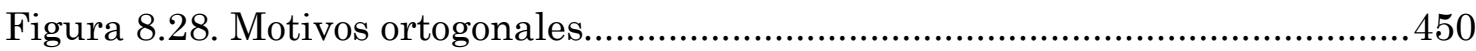

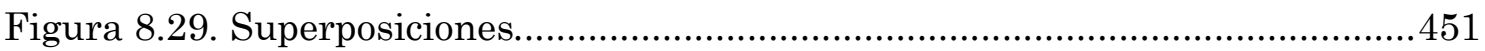

Figura 8.30. Distribución espacial de los sitios con arte rupestre según la secuencia cronológica propuesta. .455

Figura 8.31. Distribución de sitios, motivos y técnicas de producción en los diferentes sectores estudiados en Somuncurá .456

Figura 8.32. Dispersión de los grabados y los motivos geométricos en Patagonia 457

Figura 8.33. Distribución de sitios, motivos y técnicas de producción para Somuncurá y áreas aledañas. 460 
Capítulo 2

Tabla 2.1. Técnicas de pintura y grabado y su correlato material. .29

\section{Capítulo 3}

Tabla 3.1. Distribución de los sitios con arte rupestre de las áreas en estudio .63

\section{Capítulo 4}

Tabla 4.1. Técnicas reconocidas en los diferentes sitios en el macizo del

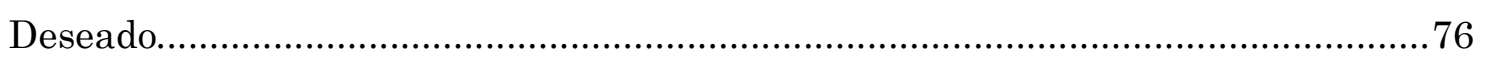

Tabla 4.2. Técnicas de pintura y grabado registradas en áreas aledañas al macizo

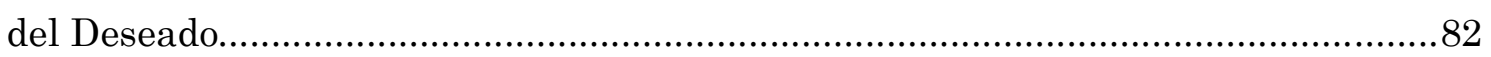

Tabla 4.3. Integración de la información disponible para el macizo de

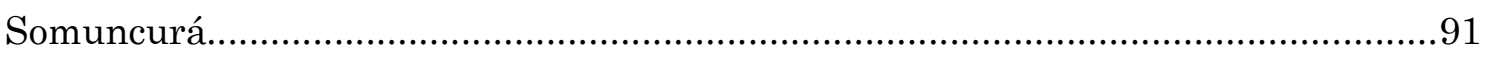

Tabla 4.4. Técnicas de producción reconocidas en áreas aledañas a

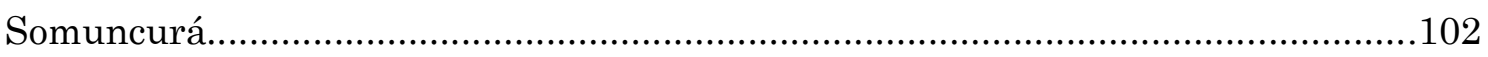

\section{Capítulo 5}

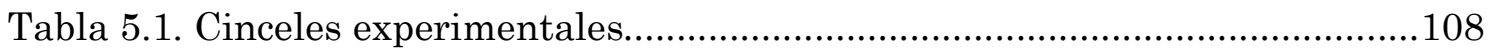

Tabla 5.2. Muestras empleadas en las diferentes experiencias realizadas............112

Tabla 5.3. Composición mineralógica de las muestras contempladas en esta etapa......

Tabla 5.4. Variantes contempladas en la preparación y aplicación de las distintas mezclas.

Tabla 5.5. Detalles de las experiencias respecto a las técnicas de producción........121

Tabla 5.6. Características de los bloques experimentales.....................................128

Tabla 5.7. Selección de motivos replicados de AEG-2 y CG....................................129

Tabla 5.8. Selección de motivos replicados de LCB.............................................136 
Tabla 5.9. Información referida a la selección de motivos replicados de la localidad La Primavera 146

Tabla 5.10. Datos experimentales de los negativos de mano..... 149

Tabla 5.11. Cálculo del coeficiente de variación .153

Tabla 5.12. Variaciones en el tamaño de los negativos realizados a partir de la misma mano.

Tabla 5.13. Mediciones de negativos realizados apoyando el dorso de la mano derecha en la roca. 156

Tabla 5.14. Evaluación en la participación de un pintor-modelo o de un pintor y un modelo en la producción de negativos.....

\section{Capítulo 6}

Tabla 6.1. Frecuencia de motivos en La Marianita........................................174

Tabla 6.2. Grafitis de La Marianita..................................................................... 178

Tabla 6.3. Frecuencia de grupos de motivos por sector...........................................184

Tabla 6.4. Condiciones de emplazamiento y movilidad en Bardas de Carlos..........193

Tabla 6.5. Superposición de técnicas por sector y conjunto.....................................197

Tabla 6.6. Frecuencias de los tipos de pátina para las diferentes clases de motivos reconocidas en Bardas de Carlos............................................................................20

Tabla 6.7. Frecuencia de conjuntos y motivos aislados por sector en Los

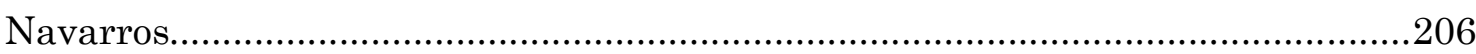

Tabla 6.8. Condiciones de emplazamiento y visibilidad en LN............................223

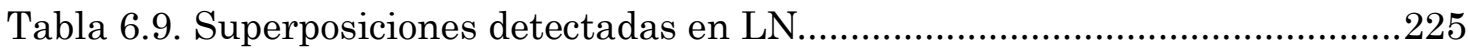

Tabla 6.10. Frecuencias de tipos de pátina por sector de Los Navarros................225

Tabla 6.11. Motivos involucrados en las superposiciones de LN...........................229

Tabla 6.12. Pátinas involucradas en las superposiciones de LN..........................2230

Tabla 6.13. Categorías de motivos y grado de pátina presentes en las

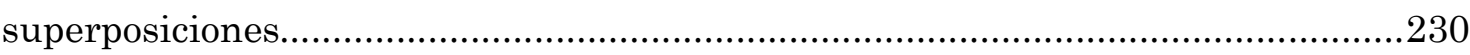

Tabla 6.14. Presencia de los diferentes grados de pátinas y superposiciones por

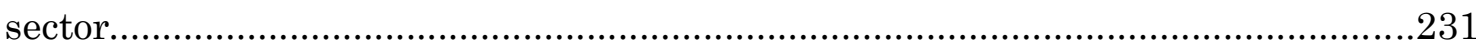

Tabla 6.15. Distribución de pátinas por clases de motivos....................................224

Tabla 6.16. Distribución y frecuencias de los tipos de pisadas de ave de Los

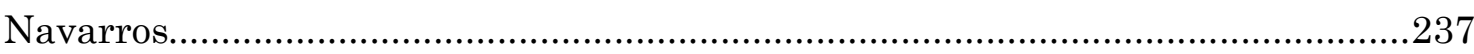


Tabla 6.17. Distribución y frecuencias de los tipos de pisadas de felino en Los

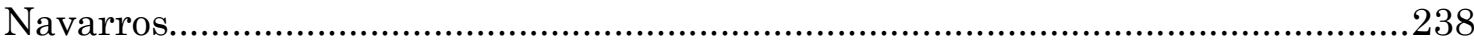

Tabla 6.18. Frecuencias y proporciones de motivos reconocidos en los sitios.........241

Tabla 6.19. Comparación de los sitios considerados en este capítulo. 243

\section{Capítulo 7, Parte 1}

Tabla 7.1. Frecuencia de subgrupos de motivos en Laguna Azul .253

Tabla 7.2. Visibilidad y emplazamiento de los motivos en Laguna Azul...... .260

Tabla 7.3. Frecuencia de subgrupos de motivos en Laguna El Ganso...... .269

Tabla 7.4. Visibilidad y emplazamiento de los sectores de LEG. .276

Tabla 7.5. Pátinas y categorías de motivos en LEG. .282

Tabla 7.6.Frecuencia de pisadas animales reconocidas en LEG. .283

Tabla 7.7. Frecuencia de grupos y subgrupos de motivos en Bardas de Antonio...289

Tabla 7.8. Visibilidad y emplazamiento de los sectores de Bardas de Antonio......323

Tabla 7.9. Frecuencias de técnicas reconocidas en los distintos sectores de Bardas de Antonio

Tabla 7.10. Frecuencias y proporciones de pátinas en los distintos sectores .326

Tabla 7.11. Distribución por sector de las técnicas de grabado reconocidas y el grado de pátina asociado.

Tabla 7.12. Frecuencias de categorías de motivos y pátina. .331

Tabla 7.13. Frecuencia de los tipos de pisadas de ave en Bardas de Antonio. .333

Tabla 7.14. Frecuencias y proporciones de motivos reconocidos en los sitios. .337

Tabla 7.15. Comparación de los sitios considerados en el E de Somuncurá .339

\section{Capítulo 7, Parte 2}

Tabla 7.16. Emplazamiento y visibilidad de los sitios con arte rupestre del centrooccidente de Somuncurá. .356

Tabla 7.17. Grupos y subgrupos de motivos de Peñón del Pueblo. 358

Tabla 7.18. Frecuencia de motivos para los sitios Vacalauquén (VL) 1 a 3............380 Tabla 7.19. Frecuencias y proporciones de motivos reconocidos en los sitios. .387

Tabla 7.20. Comparación de los sitios del centro-occidente de Somuncurá. .390 


\section{Capítulo 8}

Tabla 8.1. Distribución de sitios con arte rupestre en el NE del macizo del Deseado. .396

Tabla 8.2. Frecuencias y proporciones de técnicas de producción reconocidas en el macizo del Deseado.

Tabla 8.3. Frecuencias y proporciones de grupos y subgrupos de motivos reconocidos

Tabla 8.4. Distribución de motivos y técnicas de producción en los diferentes sectores reconocidos.

Tabla 8.5. Distribución de los subgrupos de motivos grabados más frecuentes en diferentes soportes. 403

Tabla 8.6. Re-evaluación de las técnicas de producción de grabado para motivos figurativos y los circulares del NE del macizo del Deseado.

Tabla 8.7. Distribución de los subgrupos de motivos pintados más frecuentes en diferentes soportes. 416

Tabla 8.8. Distribución de sitios y motivos en el macizo de Somuncurá 439

Tabla 8.9. Técnicas reconocidas en las diferentes localidades del macizo de Somuncurá

Tabla 8.10. Frecuencia y proporciones de grupos y subgrupos de motivos reconocidos en esta tesis y por otros autores.

Tabla 8.11. Distribución espacial de técnicas y subgrupos de motivos en Somuncurá.

Tabla 8.12. Secuencia estilística del arte rupestre de Somuncurá. .454

Tabla 8.13. Distribución de sitios y motivos considerados en la comparación entre Somuncurá y áreas aledañas 461

\section{Capítulo 9}

Tabla 9.1. Comparación entre macizos referida a aspectos de emplazamiento, tecnológicos, cronológicos y de diseño. 471 


\section{RESUMEN}

En esta investigación se aborda el arte rupestre desde dos perspectivas complementarias: 1) el análisis cualitativo-distribucional de motivos a nivel intra e inter regional, los cuales fueron registrados en el macizo del Deseado (Santa Cruz, Argentina) y en la porción rionegrina del macizo de Somuncurá; y 2) el estudio experimental de los procesos de producción del arte rupestre documentado por otros investigadores en la primer región. Se considera válida la primera comparación debido a que ambas regiones mesetarias son ambiental y geomorfológicamente similares, resultantes de procesos volcánicos y erosivos que modelaron el paisaje. En tanto que el segundo abordaje resulta novedoso por haber evidenciado poco desarrollo, hasta el momento, en los estudios realizados en nuestro país.

Los grabados estudiados en el macizo del Deseado se ajustan a las tendencias observadas en trabajos previos (Carden 2008a), aunque la principal diferencia se observa en el sitio La Marianita, en el que se empleó un soporte tobáceo ubicado en una planicie de inundación de un arroyo temporario. Por otro lado, el desarrollo y la implementación de protocolos experimentales para la replicación de motivos grabados y pintados permitieron el control minucioso de variables referidas al soporte y a los artefactos empleados, así como al trabajo y los motivos realizados. Se coincide con otras propuestas en las que se considera que, en la producción de grabados, el soporte seleccionado condiciona la técnica y los artefactos a emplear así como el diseño del motivo a realizar. La puesta a prueba de materias primas colorantes recolectadas en el macizo del Deseado permitió comprobar sus cualidades para pintar, lo que constituye una de las primeras etapas de la cadena operativa. Además, la fabricación de los primeros artefactos para pintar (v.g., hisopos) permitió reconocer su trazo y diferenciarlo de aquellos trazos realizados con las yemas de los dedos. Al ser los motivos más abundantes en la región en estudio del macizo del Deseado, los negativos de mano recibieron especial atención durante las experiencias replicativas. Los resultados obtenidos permitieron reconocer que las variaciones en los gestos técnicos influyen en el largo del negativo obtenido, si éste es comparado con el largo real de la mano. 
El estudio minucioso de doce sitios con manifestaciones rupestres en el macizo de Somuncurá permite profundizar el conocimiento respecto del arte en esa región. La integración de esta información a la obtenida en estudios previos permite reconocer cierto patrón en la localización de los sitios con arte rupestre: se encuentran en espacios reparados, aprovechando superficies verticales $u$ horizontales de bardas o aleros (entre las primeras predominan los grabados y entre los segundos las pinturas); se encuentran cercanos a lagunas o fuentes de agua temporarias, que en el pasado podrían haber funcionado como atractores de recursos y de personas convirtiéndolos en nodos o puntos de encuentro en el paisaje. Hasta el momento en el occidente de Somuncurá no se han documentado sitios con grabados, lo cual no indica que éste tipo de manifestaciones se restrinja sólo al oriente somuncurense. Asimismo, se observó una alta disponibilidad de materias primas colorantes y de soportes aunque los sitios con arte rupestre pintado en el sector occidental del macizo no son abundantes o presentan baja frecuencia de motivos. Esta situación podría ser explicada por numerosas cuestiones, entre ellas se puede mencionar: 1) el arte pintado no era común siendo pasible que pintaran otras superficies, 2) la falta de empleo de materias colorantes disponibles, 3) cuestiones tafonómicas de preservación.

De la comparación inter-regional se observa que en ambos macizos se documentaron motivos pintados y grabados sobre los diferentes soportes rocosos disponibles. Los pictograbados parecen ser recurrentes en Nordpatagonia, y algunos casos fueron documentados en Somuncurá. Por otro lado, el macizo del Deseado presenta mayor variabilidad en cuanto a las técnicas tanto de grabados como de pintura, principalmente por el desarrollo de los estudios del arte rupestre desde hace cuatro décadas. En síntesis, cada uno de los macizos presenta un conjunto de características que los hace distintivos a pesar de las semejanzas ambientales y geomorfológicas. Las similitudes en el arte rupestre de ambos macizos parecen acentuarse hacia el Holoceno tardío, por la presencia de motivos correspondientes al "estilo de grecas" y del "estilo de pisadas". 


\section{ABSTRACT}

In this $\mathrm{Ph} . \mathrm{D}$., rock art is approached through two complementary perspectives: 1) at intra and inter-regional level by qualitative-distributional motifs analysis, which were recorded in the Deseado Massif (Santa Cruz, Argentina) and in Somuncurá Massif (Rio Negro); and 2) experimental study of the rock art production using data registered by other researchers in the first region. The first comparison is possible because both plateaux regions are similar environmental and geomorphologically, resulting from volcanic and erosional processes that shaped the landscape. While the second approach is original for having shown little development in studies developed in our country so far.

The engravings studied in the Deseado Massif fit the trends observed in previous studies, although the main difference is observed in La Marianita site which is in a tuffaceous support located in a flood plain. Furthermore, the development of experimental protocols for replication engravings and paintings allowed careful control of variables related with support and the devices used, as well as tasks performed and motifs replicated. We agree with other proposals which considered that rock support selected conditioned technique, artifacts and design of engraving motifs to be carried out. Testing coloring raw materials collected in Deseado Massif allowed to know their qualities for paintings, which is one of the first stages of the operational chain. In addition, the manufacture of artifacts to apply paint (e.g., swabs) enable to recognize its strokes -outline- and differentiate it of those made with the fingertips. Hand stencils are the most abundant motifs in the study region of Deseado Massif (Carden 2009a, 2013), and for this reason, they received special attention during the replicative experiences. The results allowed to recognize that variations in technical gestures influence the measurement of hand stencil, if these is compared with the actual length of the hand.

Detailed study of twelve rock art sites in Somuncurá allows deepening our knowledge of this topic in the region. Through the integration of this data to that obtained in previous studies, certain patterns in the location of rock art sites can be recognize: they are in repaired areas, with motifs on vertical or horizontal surfaces of rock-shelters or rock-walls (paintings for the first one and engravings for the second one); they are near springs or temporary water sources, which in the past 
could functioned like attractors of resources and people, making them nodes or meeting points in the landscape. Up to now, in western of Somuncurá have not been documented engravings sites which do not indicate that this kind of manifestation is restricted to the eastern of Somuncurá. A high availability of coloring raw materials and rock-support were also observed, although painting sites in the western of Somuncurá are not abundant or have low frequency of motifs. This could be explained by a number of issues: 1) paintings were not common being liable to paint other surfaces, 2) lack of use of available coloring raw materials, 3) taphonomic preservation issues.

Inter-regional comparison shows that in both massifs there are paintings and engravings on different rocky substrates. Painting-engravings motifs are recurrent at Nordpatagonia and some cases were registered in Somuncurá. On the other hand, Deseado Massif has a greater variability in painting and engraving techniques, mainly by the development of rock art studies for four decades. In summary, each massif has distinguishing features despite environmental and geomorphological similarities. Similarities in rock art of both massifs seem to be more significant towards the late Holocene, by the presence of "footprints style" and "Grecas style" motifs. 


\section{Capítulo 1}

\section{INTRODUCCIÓN}

\section{1. a. OBJETO DE ESTUDIO}

Esta tesis doctoral se centra en el estudio comparativo del arte rupestre, contemplando la producción de los motivos -técnicas y artefactos utilizadosy la distribución espacial de los motivos en dos regiones mesetarias que son ambiental y geomorfológicamente similares: las cuencas residuales al sur del río Deseado, en el nordeste del macizo del Deseado, y las cuencas lagunares del macizo de Somuncurá en la provincia de Río Negro (Figura 1.1). La investigación se inserta dentro de un proyecto marco, de carácter regional, orientado a conocer la dinámica poblacional de las sociedades cazadoras-recolectoras que habitaron la Patagonia desde finales del Pleistoceno, dirigido por la Dra. Laura Miotti.

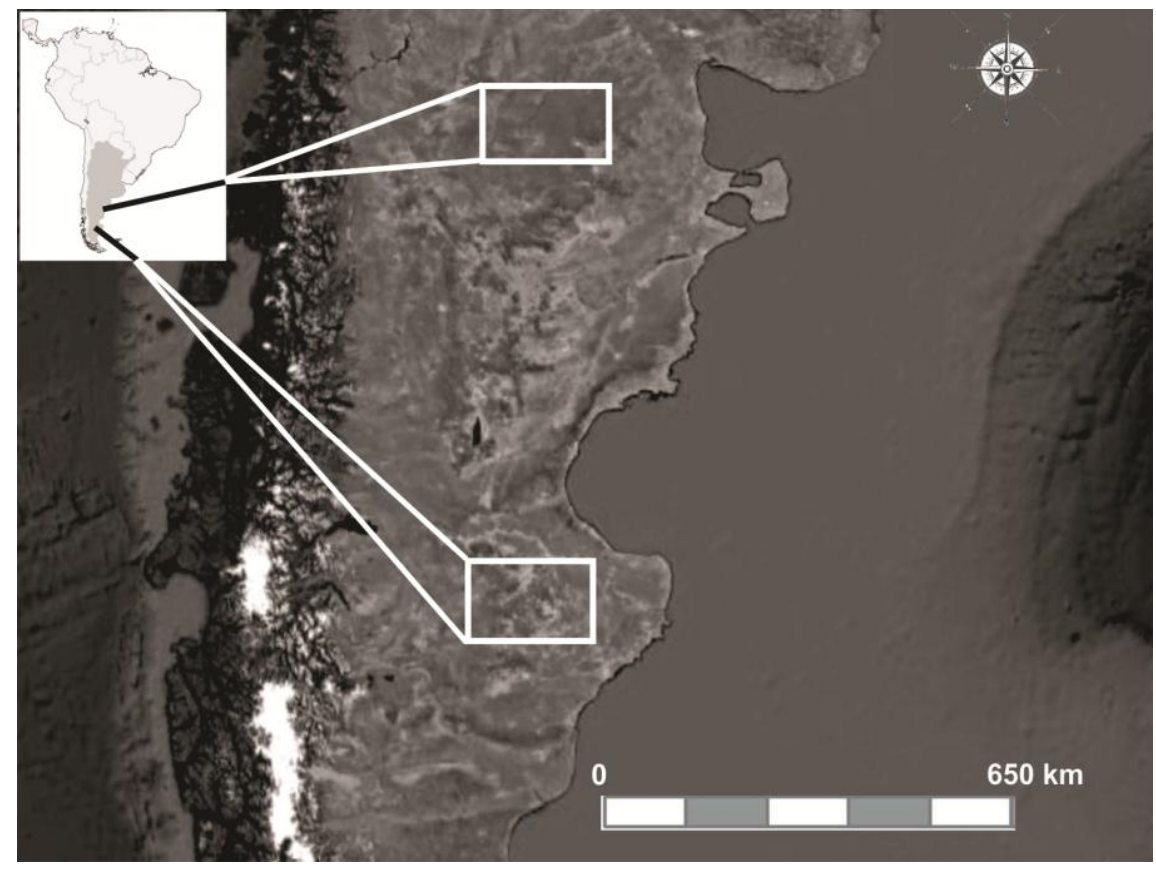

Figura 1.1. Ubicación de los dos macizos considerados. 
En el macizo del Deseado el arte rupestre ha sido investigado desde principios de la década de 1930 (de Aparicio 1933-35), de manera intermitente al principio (Menghin 1952, 1957; Vignati 1950), y a partir de fines de la década de 1970 los estudios fueron cobrando mayor frecuencia (Arrigoni 1996; Cardich 1979; Durán 1983-85; Gradin y Aguerre 1983; Miotti 1991, 1996; Miotti et al. 1999a; Paunero 1992, 1994); hasta contar en la actualidad con un corpus importante de datos (Carden 2008a, 2009a; Carden et al. 2009; Miotti et al. 2007b, 2007c, 2009d; Paunero et al. 2005; Podestá et al. 2005). Estas investigaciones han seguido diferentes lineamientos teóricos para el análisis: las primeras se focalizaron en la definición de estilos y la construcción de una cronología del arte a partir de los mismos; mientras que las últimas han redirigido la investigación, integrando al arte con la información arqueológica disponible para los sitios considerados desde una perspectiva que contempla al paisaje como un constructo social (Carden 2004, 2008a, 2009a, 2013; Carden et al. 2009; Miotti 2006, 2008; Miotti y Carden 2007; Miotti et al. 1999a, 2005, 2007b).

En el macizo de Somuncurá la historia de las investigaciones sobre el arte rupestre es mucho más fragmentaria que en el macizo del Deseado. En tal sentido, los trabajos desarrollados han tenido un carácter exploratorio y comparativo (ver Albornoz 2003; Gradin 2003a, 2003b y bibliografía allí citada). Un antecedente relevante en lo que respecta a esta investigación es el estudio realizado por Gradin (1971) de los sitios Laguna Azul, La Maciega y El Ganso, continuados en parte por García y Pérez de Micou (1980). Si bien Gradin caracteriza las estructuras de piedra al borde de dichas lagunas, no menciona la presencia de arte rupestre. Al respecto, es importante señalar que en las campañas realizadas por el equipo de investigación en 2008 y 2009, estos sitios fueron relocalizados, detectándose la presencia de grabados y pinturas rupestres sobre bardas basálticas, que podrían ser vinculados a los momentos en los que los parapetos fueron ocupados o a momentos previos.

Con respecto a los procesos de producción del arte rupestre, se han realizado estudios que refieren a la obtención de las materias primas para la 
confección de pintura (Aschero 1983-85; Iñiguez y Gradin 1977; Barbosa y Rial 1983-85), a diferentes etapas en la producción de los motivos (Álvarez y Fiore 1995; Álvarez et al. 1999, 2001; Fiore 1996-98, 1999, 2007, 2009; Paunero 1992, 1994), y al reconocimiento de artefactos recuperados en el registro arqueológico que potencialmente podrían haber sido empleados en la producción de motivos (Aschero 1985; Fiore 1996-98, 2007; Marchione y Bellelli 2013; Onetto 1986-87; Scheinsohn 2010).

Sobre la base de estos antecedentes, esta tesis contribuirá a profundizar dos aspectos del arte rupestre. En primer lugar, aspectos analíticos de los procesos de producción y uso del arte rupestre por parte de las sociedades cazadoras-recolectoras que habitaron ambas regiones. En segundo lugar, la vinculación de dichos procesos con la apropiación y transformación social y simbólica del paisaje, tema que se ha abordado intensamente dentro del equipo de investigación para una de las áreas propuestas (Carden 2008a, 2009a; Miotti 2006, 2008). Cabe aclarar que las dos grandes temáticas que se abordarán no constituyen vías analíticas separadas, sino que están imbricadas en el estudio del arte rupestre, conformando diferentes etapas dentro de una misma investigación.

\section{1. b. PLANTEO DEL PROBLEMA}

En líneas generales, las preguntas planteadas en esta tesis refieren a los procesos de producción de las imágenes, al emplazamiento de los sitios con arte rupestre y a la distribución espacial y temporal de los tipos de motivos en ambos bloques mesetarios.

Las propuestas disponibles acerca de las técnicas de producción del arte rupestre de Patagonia se han basado en la observación macroscópica de los trazos pintados o de los surcos grabados. El estudio experimental de dichas técnicas permite reconocerlas con mayor agudeza en el campo, así como reevaluar las técnicas previamente inferidas. La experimentación contempla la materialidad de los soportes, los artefactos y los pigmentos que forman 
parte de los procesos de producción del arte; esto implica considerar las formas, texturas y fracturas de las superficies rocosas como significativas en la conformación de imágenes (Aschero 1988; Bednarik 2007a). En este sentido, existen propuestas previas que plantean que las propiedades materiales de los soportes condicionan los artefactos y las técnicas a emplear en la realización de ciertos motivos (Belardi y Goñi 2002; Fiore 2007). Por lo anterior, parte de la investigación está orientada a indagar las relaciones entre soporte, técnica y diseño de las manifestaciones rupestres.

La distribución espacial y el emplazamiento de los sitios con arte rupestre están en relación a la disponibilidad de soportes en primera instancia, y a la accesibilidad de materias primas necesarias para su producción. Por lo tanto, se relaciona con características geomorfológicas particulares de los macizos en los que se utilizaron bardas, aleros o cuevas, ¿pueden haber sido éstos rasgos considerados como hitos geográficos (sensu Santos Granero 2001); que permitieran de alguna manera "escribir la historia" de las sociedades cazadoras-recolectoras que ocuparon esos espacios?; ¿qué rasgos geomorfológicos, propios o aledaños, presentan para poder ser valorados de tal manera?, ¿la presencia de agua o de algún otro recurso crítico -actual o pasado- puede haber condicionado la recurrencia de la ocupación de dicho sitio? ¿Explicarían las situaciones anteriores la convergencia de estilos en un mismo sitio?

Por otro lado, si se contempla la distribución espacial y temporal de los diferentes grupos estilísticos del arte rupestre (Gradin 1978) que se han informado en ambas regiones, se podría comprobar que la distribución temporal del "estilo de grecas" (Menghin 1957) se restringe a los últimos 1.500-500 años AP (Belardi 2004; Fernández 2006; Fernández et al. 2013; Gradin 2003b; Gradin et al. 1979) y es posible reconocerlo en sitios del macizo somuncurense que presentan motivos pintados de carácter geométrico, algunos de los cuales han sido reconocidos comúnmente como pertenecientes al estilo. Mientras que los motivos correspondientes al "estilo de pisadas" (Menghin 1957), caracterizado por pisadas de animales y motivos circulares mayoritariamente grabados, podría retrotraerse a los 
últimos 3.500 años AP (Carden 2009a; Gradin et al. 1976, 1979; Re 2011) y pueden ser reconocidos en las dos regiones estudiadas. En función de estas consideraciones y de los antecedentes que se presentarán en el Capítulo 4, se observará si es posible hablar de un arte característico de Nordpatagonia y de otro de la región meridional de la Patagonia.

\section{1. c. OBJETIVOS DE ESTA INVESTIGACIÓN}

Los objetivos que se pretenden alcanzar son:

\section{1. c. 1. Objetivos generales}

A. Analizar la distribución espacial de sitios con grabados y pinturas rupestres en la porción rionegrina del macizo de Somuncurá para evaluar qué tipos de espacios fueron seleccionados para la representación plástica con diferentes técnicas por parte de las sociedades cazadoras-recolectoras que lo ocuparon en el pasado. Esta información se considera novedosa tratándose de una región que no ha sido investigada intensamente.

B. Profundizar la información existente sobre la producción y la variabilidad de las manifestaciones rupestres en el macizo del Deseado.

C. De los anteriores objetivos se pretende lograr un balance documental que permita realizar el análisis comparativo del arte rupestre registrado en ambos macizos, considerando los atributos de diseño y tecnológicos, así como la distribución espacial. Esto a fin de evaluar si existen patrones en las relaciones entre dichos atributos que puedan estar informando respecto de la utilización y aprovechamiento de los soportes disponibles por parte de las sociedades que ocuparon esos espacios. Las semejanzas y las diferencias que se detecten mediante esta comparación permitirán profundizar el estudio de los paisajes sociales de cazadores-recolectores en ambientes mesetarios, mediante un énfasis en la esfera tecnológica, focalizada en la producción de manifestaciones rupestres. 


\section{1. c. 2. Objetivos específicos}

A. Conocer las técnicas empleadas en la producción del arte rupestre de las regiones en estudio para observar si existen diferencias inter-regionales que puedan estar señalando comportamientos y selecciones humanas distintas en ambientes similares.

B. Dentro de los procesos de producción, inferir mediante la experimentación qué artefactos pudieron haber sido utilizados para realizar los grabados y las pinturas, considerando que la secuencia de producción del arte rupestre implica cadenas operativas que trascienden la confección de las imágenes (Aschero 1988; Fiore 2007). De este modo, y sobre todo considerando el escaso número de artefactos vinculados con la producción de las manifestaciones rupestres en el registro arqueológico de los sitios estudiados, la experimentación permitirá ampliar el conocimiento de los recursos empleados en dichos procesos de producción y, a su vez, contribuir a la discusión sobre esta ausencia, que no sólo se registró en los sitios estudiados aquí sino también en otras áreas de la región patagónica y del mundo (Bednarik 2007a).

C. Evaluar si los soportes y los emplazamientos seleccionados para plasmar imágenes fueron condicionantes tecnológicos en la producción del arte rupestre.

D. Los objetivos anteriores apuntan a profundizar el conocimiento de los procesos tecnológicos implicados en la producción de imágenes desde el registro arqueológico y la arqueología experimental tanto en macizo del Deseado como en el macizo de Somuncurá. En la primera región se pretenden contrastar desde la vía experimental, las inferencias formuladas para los sitios del macizo santacruceño sobre la base de la observación macroscópica de los motivos (Carden 2008a). En la segunda región se pretende obtener información novedosa respecto a esta temática.

E. Registrar los afloramientos de pigmentos, de yeso y arcilla que pueden haber sido utilizados en la confección de las pinturas a través de 
prospecciones sistemáticas, para profundizar el conocimiento acerca de las primeras etapas de la cadena de producción de los motivos rupestres pintados.

\section{1. d. HIPÓTESIS DE TRABAJO}

Las hipótesis que se contrastarán se refieren a los objetivos antes mencionados, pero pueden reunirse en dos grandes grupos. En cuanto a la comparación extra-regional, se plantean tres hipótesis:

I. Dado que los macizos de Somuncurá y del Deseado son dos áreas geomorfológica y ambientalmente similares, se propone que la relación de los grupos humanos con los respectivos entornos fue similar, lo cual se reflejará en la selección de los enclaves para realizar el arte rupestre. En tal sentido, sería esperable encontrar patrones de emplazamiento similares de los sitios con arte (i.e., cercanos a cursos de agua, con presencia de recursos faunísticos, florísticos y de materias primas, vinculados a zonas de tránsito). II. Si bien es posible que la distribución de motivos atribuibles a diferentes grupos estilísticos sea similar en ambas regiones, es esperable que la frecuencia de tales motivos difiera a escala extra-regional (comparando ambos macizos), lo cual podría estar vinculado con la escala de la movilidad de los grupos cazadores-recolectores y con el alcance de la circulación de información (Aschero 1996).

III. Con respecto a las técnicas implicadas en el caso de los grabados se espera encontrar mayores semejanzas en soportes de litología similar. La contrastación de esta hipótesis permitirá evaluar si diseños y técnicas operaron a partir de dinámicas propias (Fiore 2009).

Con respecto al diseño experimental, las hipótesis que se plantean son:

IV. La variabilidad de las técnicas y los diseños de los motivos depende de las características del soporte (dureza, posición, exposición). De este modo, 
en los distintos tipos de soportes deberían observarse diferencias en los motivos y las técnicas empleadas para confeccionarlos.

V. La materia prima sobre la cual están elaborados los artefactos para la producción de grabados está condicionada por el tipo de soporte a grabar. Por esto se espera que artefactos confeccionados en materias primas más duras hayan sido utilizados para grabar rocas más duras (v.g., soportes basálticos) mientras que los soportes más blandos (tobáceos) habrían sido grabados con artefactos elaborados con materias primas silíceas o incluso óseas (Álvarez y Fiore 1995; Fiore 2007).

\section{1. e. ESTRUCTURACIÓN DE LA TESIS}

Habiéndose planteado los objetivos e hipótesis de la tesis en este capítulo, en el Capítulo 2 se presentan los fundamentos teórico-metodológicos sobre los cuales se basa esta investigación. Entre los aspectos teóricos se desarrolla la importancia que tienen los estudios de la cultura material y de la tecnología para el análisis del arte rupestre, así como la perspectiva de la arqueología del paisaje y los estudios experimentales; entre los aspectos metodológicos se da cuenta de las unidades de análisis empleadas en esta tesis y las líneas de trabajo seguidas en campo y en laboratorio.

En el Capítulo 3 se presentan las características ambientales de ambos macizos, principalmente en cuanto a su geología y geomorfología así como de la flora y la fauna. Esta información sustenta las comparaciones que se realizan a lo largo de la tesis.

El Capítulo 4 da cuenta de los antecedentes en las investigaciones sobre el arte rupestre de ambas regiones. Se hace especial énfasis en la información referida a las técnicas o procesos de producción del arte rupestre, considerando ambos macizos y los sectores aledaños, dando cuenta también de las cronologías disponibles para los sitios con arte rupestre.

Los estudios experimentales desarrollados en laboratorio son presentados en el Capítulo 5. Tales estudios dan cuenta de la replicación de motivos 
pintados y grabados utilizando soportes iguales o similares a aquellos documentados en los sitios arqueológicos.

En el Capítulo 6 se presentan y analizan los tres sitios con grabados relevados en el macizo del Deseado, mientras que en el Capítulo 7 se da cuenta de los 12 sitios con arte rupestre relevados y los afloramientos de materias primas colorantes detectados en el macizo de Somuncurá.

En el Capítulo 8 se integra la información proveniente del análisis de ambos macizos presentada en esta tesis, sea resultado de estudios propios como de la revisión de los antecedentes, referidos a los aspectos presentados en este capítulo (planteo del problema e hipótesis). En el Capítulo 9 se exponen las conclusiones alcanzadas a partir del análisis comparativo. 


\section{Capítulo 2}

\section{CONSIDERACIONES TEÓRICO- METODOLÓGICAS}

En este capítulo se presentan los aspectos teórico-metodológicos que guían los análisis realizados. Las cuestiones teóricas se vinculan al estudio de la cultura material y la tecnología, y su relación con las cadenas operativas que componen el proceso de producción del arte rupestre; la importancia de la arqueología experimental en ese abordaje y el estudio del paisaje arqueológico. Los aspectos metodológicos se relacionan con las unidades de análisis empleadas en el estudio del arte rupestre, con los procedimientos realizados durante los relevamientos de los sitios y aquellos vinculados a las tareas de laboratorio: el procesamiento de la información de campo y los diseños experimentales.

\section{2. a. ASPECTOS TEÓRICOS}

La arqueología estudia las sociedades del pasado a partir de los restos materiales que produjeron durante el transcurso de su existencia (Álvarez y Fiore 1993; Bate 1981; Childe 1955; Leroi Gourhan 1976; Lumbreras 1984, entre otros). Lo que la particulariza y diferencia de las restantes ciencias sociales es la manera en que se aproxima a su objeto de estudio

“... ya que, en un primer término, el conocimiento de las sociedades pasadas se logra a partir de una determinada clase de evidencia empírica diferente a otras ciencias; se trata de elementos actuales que fueron resultado de actividades 
pasadas y que a la vez han participado en interacciones complejas desde el contexto de su producción hasta el momento de su hallazgo" (Bate 1981: 22).

En este sentido, se considera que la disciplina arqueológica puede y debe hacer uso de la analogía para poder buscar plausibles respuestas a los interrogantes de investigación planteados. De este modo, si bien la analogía etnográfica ha pasado por diferentes estadios de aceptación en la disciplina (Gándara 2006), se entiende que el uso de analogías permite realizar un procedimiento lógico inferencial de abducción, el cual es válido y es usado en la mayoría de las disciplinas de carácter histórico. Es decir, la analogía es constitutiva de la inferencia arqueológica (Gándara 1990).

"En ausencia de una máquina del tiempo que permitiera la "observación directa" (si tal cosa existiera) de los seres humanos del pasado utilizando sus artefactos, la inferencia misma de que una raedera o un percutor son en efecto tales, se deriva de una analogía con los percutores y raederas observados en el registro etnográfico o en el examen de huellas de uso obtenidas experimentalmente en el presente, y que, al ser comparadas con las de los artefactos prehistóricos, permiten apoyar la inferencia de que estos últimos cumplían una función similar" (Gándara 2006: 14).

De este modo, la analogía sería un primer momento de un proceso que implica, al momento siguiente, someter a prueba las hipótesis planteadas. Estos lineamientos pueden ayudar en la consecución del fin de la disciplina: comprender los sistemas sociales del pasado a partir del registro material que evidencia las actividades realizadas por los actores sociales que formaban tales sistemas.

Por un lado, los aspectos teóricos que se detallan más adelante permiten comprender desde dónde se le hacen preguntas al registro material que se estudia -arte rupestre-, con qué fin y a partir de qué se estudia. Por otro lado, la analogía etnográfica permite plantear hipótesis acerca de cómo puede haber sido el comportamiento humano en el pasado. El análisis de la evidencia arqueológica 
y actualística permitirá contrastar o refutar las hipótesis planteadas en el Capítulo 1.

Dada la definición de arqueología presentada en el comienzo de este capítulo se considera relevante comenzar con la definición de los estudios de cultura material y el abordaje tecnológico de la misma, continuar con la importancia de los estudios experimentales y terminar el desarrollo teórico con los planteos referidos a la arqueología del paisaje.

\section{2. a. 1. Estudios sobre Cultura Material y Tecnologia}

Los estudios sobre cultura material resultan en un conjunto de estudios eclécticos que están interesados desde la materialidad de las cosas -entre ellas el arte rupestre- hasta la relación entre las cosas y el cuerpo humano (Hicks y Beaudry 2010; Hollenback y Schiffer 2010; Tilley et al. 2008). La definición en sentido amplio de los estudios de cultura material refiere a "la investigación de la relación entre las personas y las cosas, en todo tiempo y espacio, sea la perspectiva adoptada local o global, o que esté preocupada por el pasado o el presente, o la mediación entre ambos” (Miller y Tilley 1996: 5; traducción propia). Esta definición permite vincular interpretativamente a los restos arqueológicos con las personas que los originaron, y también con los procesos que los afectaron hasta que son recuperados por los arqueólogos (Schiffer 1972).

Dentro de los estudios de cultura material pueden incluirse los análisis tecnológicos. El concepto de tecnología propuesto por Lemonnier resulta útil, ya que en sus términos la tecnología “... abarca todos los aspectos del proceso de acción sobre la materia (...). Las tecnologías son producción social en si mismas" (Lemonnier 1992: 1-2; traducción propia). Tomando como base los trabajos de Mauss sobre la técnica y el cuerpo, Lemonnier (1992) plantea que una técnica ${ }^{1}$ tendría cinco componentes:

1) materia, incluyendo el propio cuerpo;

\footnotetext{
${ }^{1}$ Lemonnier toma como sinónimos tecnología y técnicas, lo que no coincide con los postulados de otros autores (v.g., Ingold 1990).
} 
2) energía, que abarca las fuerzas que mueven los objetos y transforman la materia;

3) objetos, engloba los artefactos, las herramientas o los medios de trabajo;

4) gestos, que mueven los objetos involucrados en una acción tecnológica, y están organizados en secuencia; y

5) conocimiento específico, formado por el "saber cómo" o las habilidades manuales.

Dichos elementos interactúan entre sí para darle forma a la acción tecnológica, la cual es el resultado final de todas las posibilidades y elecciones hechas en un nivel individual o social. Para comprender una tecnología es necesario contemplar las interacciones antes mencionadas así como el modo en que una tecnología particular se relaciona con otra/s tecnología/s y la manera en que tales tecnologías se vinculan a diferentes fenómenos sociales. Lemonnier denomina representaciones sociales a las diferentes posibilidades de elección, y serían el canal a través del cual los fenómenos sociales influyen a los sistemas tecnológicos. Asimismo, en los estudios tecnológicos deben considerarse las diferentes opciones que brinda el ambiente, porque esto permitiría comprender los elementos que emplea dicha sociedad y aquellos que tiene a su alcance y no utiliza (Lemonnier 1992).

Dobres y Hoffman (1994) también subrayan que las tecnologías están insertas dentro de un contexto social, por lo que es necesario considerarlas desde la teoría social. Para estos autores, los arqueólogos por lo general reconstruyen secuencias de manufactura, cuando en realidad

“... los actos tecnológicos (...) son un medio fundamental a través del cual son expresadas y definidas relaciones sociales, estructuras de poder, visiones de mundo y la producción y reproducción social. La tecnología es una parte integral y activa del cambio y la reproducción social" (Dobres y Hoffman 1994: 212; traducción propia).

La materialidad de la tecnología y las reglas técnicas de modificación subyacentes identificadas a través de estudios empíricos de grano fino -en 
nuestro caso sería posible mediante la implementación de estudios experimentales- forman la base para el entendimiento de la dinámica social de la producción material en el pasado (Dobres y Hoffman 1994). Este tipo de visión destaca las actividades, interrelaciones y tensiones sociales involucradas en la modificación continua de recursos naturales en productos culturales, por lo que la tecnología es material pero concretada dentro de contextos de interacción social dinámicos y hacedores de significados, cultural e históricamente específicos. Planteos similares pueden observarse en Dobres (1999), Falskenström (2006), Knutsson (2006), entre otros autores.

Reunir todos esos planteamientos permite considerar que la tecnología involucra todos aquellos aspectos mediante los cuales se transforma la materia: la materia propiamente dicha, la energía, los objetos, los gestos y el conocimiento específico necesarios para dicha transformación, que son sociales e individuales al mismo tiempo. Sociales porque las decisiones para ejecutar esa transformación son resultado de representaciones colectivas, de un conocimiento compartido (Dobres 1999; Dobres y Hoffman 1994; Falkeström 2006; Knutsson 2006; Lemonnier 1992), e individuales porque resultan de la interacción (la "urdimbre") entre un actor y la materia mediante diferentes gestos, conocimiento, usando energía y objetos ("trama”) (Ingold 2000). De este modo, la tecnología incluye los actos dinámicos de transformación social y material, es el medio por el cual las relaciones sociales y la concepciones de mundo son expresadas y mediadas, se materializan y hacen concretas las actitudes de las personas acerca de los modos correctos (y erróneos) de hacer y usar cosas (Dobres 1999). En tal sentido, los arqueólogos deben explorar la tecnología como un acto de transformación material y social en paralelo.

Una manera de encarar los estudios tecnológicos es mediante el concepto de cadena operativa, el cual fue cambiando de acepción a lo largo del tiempo. La primera definición la efectuó Leroi-Gourhan (1964, 1965), la cual involucra la naturaleza secuencial de la acción corporal y los movimientos que se realizan en las actividades tecnológicas repetitivas de la vida diaria. Luego, se definió como "una serie de operaciones que van desde una materia prima en estado natural hasta el estado fabricado" (Cresswell 1976: 6 en García Roselló 2009). 
Actualmente, el concepto de "cadena operativa", aplicado al estudio de la tecnología lítica, es un concepto que designa "los procesos o secuencias de obtención de materias primas, elaboración, técnicas, tecnología, utilización y desecho que tiene un determinado instrumento, pero también la transmisión de conocimiento de talla y el tratamiento del material lítico" (Vicente Santos 2011: 15-16). En este sentido, comprende cuestiones relacionadas con la historia de vida de los artefactos o, dicho en otros términos, con los contextos sistémicos en los que se insertan (Aschero 1988; Hollenback y Schiffer 2010; Totesvin 2011).

En relación con lo expresado anteriormente, el arte rupestre comprende el proceso de creación de imágenes (pintadas, dibujadas o grabadas); por lo tanto, este aspecto también puede ser abordado desde el concepto de cadena operativa en el marco de los estudios de cultura material y tecnología, ya que es el resultado de una serie de actividades secuenciales, conocimientos y elementos materiales producidos por los seres humanos en determinado momento de su historia (Álvarez y Fiore 1995; Bednarik 2007a; Lemonnier 1992; Schlanger 2005).

El abordaje de la producción del arte rupestre se caracteriza por discernir las cadenas operativas que la componen, vinculadas a la producción de artefactos, a la producción de mezclas pigmentarias y a la producción de imágenes (Fiore 2007). Además, cada cadena abarca dos o más estadios que pueden incluir una o más operaciones, las cuales pueden repetirse o realizarse sólo una vez (Fiore 2007: 150). Los diferentes estadios que se reconocen en las cadenas operativas son: la obtención de materias primas, la manufactura de productos, su mantenimiento y/o su reciclaje (Aschero 1988: Figura 5; Fiore 2007: cuadro 1). Las operaciones de los estadios involucran la manipulación física de los objetos y la construcción mental de las nociones que se relacionan a dicha manipulación (Fiore 2007: 151). Es decir, en las operaciones participan de modo simultáneo conocimiento teórico y práctico, los cuales se materializan en los gestos técnicos.

El proceso de conocimiento en torno a lo tecnológico ha sido abordado desde diferentes perspectivas (para una revisión ver Tehrani y Riede 2008). Apel (2000) distingue el conocimiento teórico del práctico, que se homologan, respectivamente, al conocimiento (connaisance) y saber-hacer (savoir-faire) 
planteado por Pelegrin (1990) en el estudio de las cadenas operativas líticas. Según Apel (2000) lo que distingue a ambos tipos de conocimiento son sus características: el conocimiento teórico es explícito y declarativo, mientras que el conocimiento práctico es inconsciente e intuitivo. En el primer caso, puede corresponderse con la instrucción verbal, la imitación, las demostraciones prácticas, y el auto-aprendizaje por ensayo y error, en tanto que el conocimiento práctico puede ser alcanzado solamente mediante la experiencia propia. Ambas maneras de adquirir conocimiento son necesarias para elaborar cualquier artefacto u objeto.

Con respecto a las maneras de reconocer arqueológicamente a ambas formas de adquirir conocimiento, Bleed (2011) propone que los diferentes niveles de maestría/habilidad pueden estar reflejados en las diferencias entre los objetos que se producen. En este sentido, dichos objetos pueden ser producidos por un sujeto experimentado y/o habilidoso, o bien por un practicante a través de diferentes ensayos. Relacionados a la actividad tecnológica, los ensayos son el medio para adoptar o aprender a largo plazo los pasos de un procedimiento, y para desarrollar las actividades motoras que están asociadas a los mismos (Bleed 2011). El resultado del ensayo puede o no ser empleado, o centrarse en partes de una actividad tecnológica que ofrece dificultad o demanda atención especial como parte de una práctica de aprendizaje (Bleed 2011: 301). Según propone este autor, dado que la producción en sí misma y los ensayos tienen diferentes metas, se podrían distinguir arqueológicamente ya que éstos últimos evidenciarían una habilidad menor a la de la producción.

Diferentes ideas fenomenológicas han influenciado los estudios sobre la cultura material, y lo tecnológico puntualmente, aunque su aporte no siempre ha sido explícito (Thomas 2006). Los estudios fenomenológicos tuvieron su auge en la década de 1990 en la arqueología postprocesual (Bradley 2000; Fowler y Cummings 2003; Tilley 1994), dándole importancia a la totalidad de la experiencia sensorial con el mundo para poder así comprender el pasado (Renfrew y Bahn 2008). Así, por ejemplo en el trabajo de Howes (2006) se discute la importancia del olor, el sonido y la intersensorialidad en los estudios de cultura material de artefactos líticos. Particularmente, en los estudios sobre el arte 
rupestre dentro de esta línea de análisis se destacan los trabajos de Whaller (2002, 2003) y Ouzman (2001).

Whaller (2002, 2003) propone que las pinturas dentro de las cuevas paleolíticas estarían ubicadas en sectores que habrían tenido un rol de "guías de circulación", ya que se encuentran en lugares en los que la sonoridad dentro de las cuevas, obtenida mediante la percusión, serviría para llegar a rincones más profundos, aún cuando se carece de iluminación artificial. Entre los San de Sudáfrica, la producción de grabados rupestres no se basa solamente en lograr una imagen, sino que esa producción comporta una carga sensorial (visión, tacto, olfato, audición) y simbólica-ideológica que combina el cuerpo, el paisaje y la cosmovisión de quién la produce (Ouzman 2001). Esta información resulta útil para poner la atención en otros aspectos de la producción del arte rupestre que trascienden lo visual.

Sin lugar a dudas, los lineamientos enunciados permiten poner en relación cuestiones como el cuerpo de quien produce el arte, la percepción de distintos ruidos y olores durante la producción de las imágenes, la percepción de las imágenes por diferentes observadores, etc.; cuestiones que están en estrecha relación con el accionar tecnológico y que forman parte del conocimiento específico sobre el que se basan tales acciones.

\section{2. a. 2. Arqueología experimental}

La experimentación constituye una herramienta de gran importancia heurística para la construcción de inferencias sobre actores, agentes y procesos del pasado. Dentro de la actividad arqueológica permite la elaboración, el desarrollo y la contrastación de hipótesis, así como el manejo controlado de variables. Resulta en una vía actualística útil para el reconocimiento de las cadenas operativas y/o de la tecnología de producción del arte, información que es complementada con aquella proveniente del análisis observacional y documental del arte rupestre (Fiore 2009) y la consulta de fuentes etnográficas y etnohistóricas cuando están disponibles (Bednarik 2007b). 
La línea experimental aplicada al estudio del arte rupestre tienen una extensa trayectoria en Europa y Australia (ver para mayor detalle Bahn y Vertut 1997; Bednarik 2007b; Clottes et al. 1990a, 1990b; Groenen 1988; Lorblanchet 1980, 1990, 1991 en Bahn y Vertut 1997; Rowe 2001; Whitley 2005). Sin embargo, los mismos han tenido historias mucho más breves en otros países. Particularmente, en Latinoamérica han alcanzado mayor desarrollo en los últimos tiempos, aunque se observan casos en los que se han implementado de modo innovador desde hace más de dos décadas (para una revisión bibliográfica ver Álvarez y Fiore 1995; Fiore y Podestá 2006; Méndez 2008; Paunero 1992; Vasini y Tropea 2009; Vergara Murúa 2009).

La mayor dificultad a la que se enfrentan los estudios experimentales aplicados al arte rupestre es reconocer al agente productor, sus conocimientos y habilidades, si recibió ayuda de terceros; esto genera cierto sesgo para el control de variables. Puede suceder que quien desarrolle la experiencia replicativa actual sea un varón experimentado mientras que en el pasado la actividad fue realizada por un adulto sin experiencia, una mujer, un adolescente o un niño, o pueden darse, también, las situaciones inversas. Lo anterior es razón suficiente para volver a esgrimir el uso que se puede hacer de la analogía en los estudios arqueológicos, en el que el trabajo experimental abre posibilidades para el planteamiento de hipótesis respecto a cuestiones vinculadas a cómo y a quién realizó las actividades; hipótesis que pueden ser contrastadas mediante el minucioso análisis del registro arqueológico.

\section{2. a. 3. Arqueología del paisaje}

Dado que el arte rupestre está anclado en el espacio por su materialidad, en esta tesis se entiende a ese espacio desde la arqueología del paisaje. Esta última denominación comporta gran variedad de significados (Anschuetz et al. 2001; Darvill 2008; David y Thomas 2008, entre otros). Un paisaje no es sólo un recurso ecológico, sino que también está construido a partir de las prácticas sociales y simbólicas como una intrincada trama de relaciones entre los humanos y su 
entorno. Criado Boado (1991) señala tres perspectivas para abordar al paisaje: a) la empiricista, para la cual el paisaje aparece como una realidad ya dada; b) la sociológica, en la que se explica al paisaje como medio y producto de los procesos sociales; y c) la culturalista, que interpreta al paisaje como la objetivación de las prácticas sociales, tanto de carácter material como imaginario.

Siguiendo a Criado Boado, la Arqueología del Paisaje serviría

“... para entender el pasado de los seres humanos en el mundo (ya que una parte de esta historia es el modo cómo el ser está en el mundo y esto implica ante todo determinar cómo se adapta a, modifica, utiliza, organiza y comprende el espacio)" (Criado Boado 1999: 1).

A partir de esta definición, el paisaje es visto como un "producto socio-cultural creado por la objetivación, sobre el medio y en términos espaciales, de la acción social tanto de carácter material como imaginario" (Criado Boado 1999: 5; ver también Anschuetz et al. 2001; Atkinson et al. 2005; Crumley et al. 2005; Ingold 1993). Es decir, el paisaje está compuesto por tres dimensiones: la física como matriz medio ambiental (dominio ecológico), la social como entorno construido por el ser humano (dominio sociológico) y la ideacional (dominio simbólico). Cada una de estas dimensiones puede ser aprehendida de diferente manera a partir del estudio de un espacio particular, incluyendo al registro arqueológico como integrante de este. La dimensión física de un paisaje puede ser estudiada a partir del relevamiento topográfico, geomorfológico, geológico, ecológico y palinológico de dicho espacio. Por otro lado, la dimensión social de ese espacio puede y debe ser estudiada a partir del registro arqueológico, ya que evidencia las actividades humanas pasadas. La dimensión ideacional es plausible de ser estudiada a partir de la relación y de las conexiones que pueden plantearse en la evidencia registrada entre los dominios anteriores y a través de la interpretación y de los enfoques fenomenológicos.

El arte rupestre puede ser caracterizado como la demarcación de lugares mediante signos, siendo igualmente importante la integración de la información proveniente de los análisis de la topografía de los signos ya que la vinculación de 
ambos es muy estrecha: los motivos grabados o pintados están fijos en un punto particular del paisaje (Bradley 2000). También hay que contemplar la audiencia a la que esas imágenes estaban dirigidas: tanto la cantidad de personas como el acceso que tenían a las mismas (Aschero 1996; Bradley 2000; Carden 2008a).

\section{2. b. ASPECTOS METODOLÓGICOS}

En este apartado se detallan los procedimientos empleados para abordar el estudio del arte rupestre en las áreas consideradas en esta tesis. Primero se reseñan los elementos necesarios para realizar la descripción formal de las manifestaciones rupestres, luego los procedimientos metodológicos empleados para abordar esa información e integrarla a su contexto. En tercer lugar se da cuenta de los aspectos considerados en el estudio experimental sobre las técnicas de producción del arte rupestre.

\section{2. b. 1. Unidades de análisis}

Al momento de comenzar cualquier investigación tiene que estar en claro qué se va estudiar y cuáles serán las unidades de análisis (Eco 2002). Distintos especialistas en arte rupestre señalan la necesidad de definir desde un principio qué se considera como motivo, cuáles son los criterios que permiten identificarlo como tal para luego poder asignarlo a un grupo o tipo dentro de una clasificación (Bednarik 2007a; Fiore 2009; Whitley 2005). En tal sentido, Bednarik señala que el registro del arte rupestre es una cuestión multifacética cuya diversidad es el resultado del desarrollo histórico de las investigaciones, las diferencias en las prácticas regionales y las preferencias individuales (Bednarik 2007a). Sin embargo, Fiore (2009: 137) advierte que “... más allá de la irremediable subjetividad implícita en la definición de los tipos de motivos, resulta fundamental mantener una fuerte coherencia en el uso de estos criterios, que arrojen resultados fidedignos porque están basados en datos consistentes". 
Desde las primeras propuestas para las secuencias estilísticas del arte rupestre patagónico la unidad de análisis ha sido el motivo rupestre, aunque éste no haya sido caracterizado explícitamente (Gradin 1962, 1973; Gradin et al. 1976; Menghin 1957). El motivo fue definido por Gradin (1978: 121) como una unidad de ejecución y motivación. Un motivo puede ser simple cuando se lo realiza mediante un trazo unitario que confluye en una entidad, o compuesto, cuando está constituido por varios elementos por razones morfológicas o de contenido. Ambos casos corresponden a un acto unitario de realización. Un conjunto refiere a una distribución de motivos en un espacio relativamente reducido, delimitado por accidentes naturales de las rocas, que fueron realizados mediante una técnica similar y presentan un estado de conservación semejante (sea de pátina o en cuanto al desvanecimiento/exfoliación), lo que permite considerar una sincronía relativa de ejecución (Gradin 1978).

Estos son los conceptos clave que serán utilizados en esta tesis y en los que se han basado distintos estudios sobre el arte rupestre patagónico (Carden 2008a; Gradin et al. 1979; Fiore 1999; Fiore y Ocampo 2009; Fiore et al. 2012; Franco et al. 2013; Guichón 2012; Paunero et al. 2005; Podestá et al. 2005; Podestá et al. 2008; Re 2011, entre otros).

En el análisis formal de los motivos rupestres se reconocen tres grandes grupos: figurativos, no figurativos y no determinados. Los dos primeros se distinguen según su grado de vinculación formal con los referentes del mundo real: los figurativos presentan analogías con dichos referentes mientras que los segundos no (Aschero 1983-85, 1988; Gradin 1984, 1987; Fiore 2011; Hernández Llosas 1985). Las manchas de pintura o las marcas grabadas sin una forma discernible, en algunos casos por su estado de conservación, corresponden a motivos no determinados. A su vez, estos grupos se subdividen en distintos subgrupos. Entre los no figurativos se reconocen motivos puntiformes, rectilíneos, circulares llenos, circulares lineales y curvilíneos; mientras que entre los motivos figurativos se reconocen antropomorfos, zoomorfos y representaciones de objetos (Figura 2.1). De la misma manera, estos subgrupos están integrados por clases, subclases y tipos de motivos. Por ejemplo, entre los zoomorfos pueden reconocerse representaciones de cuerpo entero o pisadas; en estas últimas se reconocen las 
pisadas de felino, de guanaco y de ave (subclase), cada con diferentes tipos (Figuras 2.1 y 2.2).

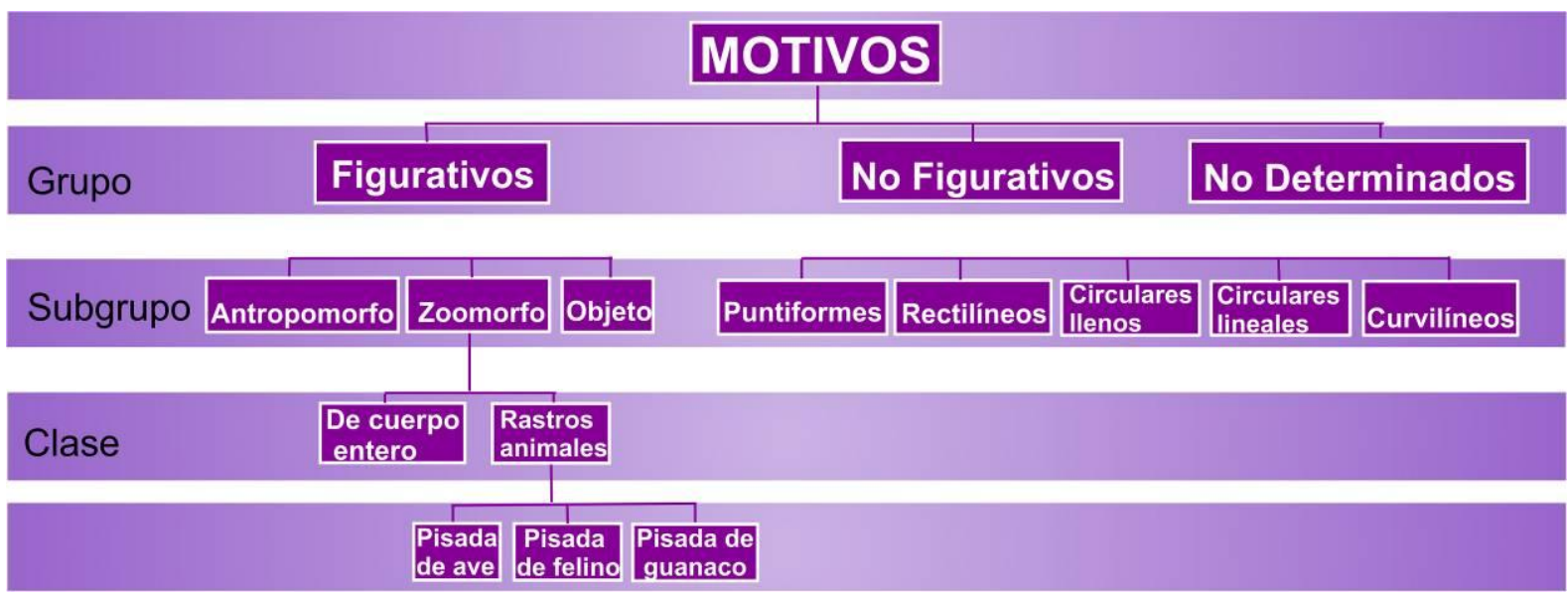

Figura 2.1. Categorías reconocidas para los motivos rupestres. Grupos, subgrupos y algunos ejemplos de clases.

La clasificación de las pisadas de animales efectuada por Carden para la localidades de Aguada del Cuero y Piedra Museo (Carden 2008a) fue tomada para realizar la clasificación de las pisadas reconocidas en esta tesis. En dicha clasificación se distinguen seis tipos de pisadas de ave (A-F) para cada una de las localidades, considerando la robustez de los dedos, el ángulo de separación interdigital y su contorno. En esta tesis se reconocen siete tipos: pisadas con dedos a $45^{\circ}$, con dedos delgados o robustos (tipos A y B, respectivamente); pisadas que presentan una separación interdigital de $45^{\circ}$ y presentan el dedo 1 -o trasero(tipo C); con ángulo de separación interdigital $>45^{\circ}$ y $<90^{\circ}$ (tipo D). Asimismo, se reconocen pisadas en las que el dedo medio está a $90^{\circ}$ (tipo E), aquellas con contorno en "U" (tipo F), y por último, aquellos que presentan el dedo medio curvo (tipo G) (Figura 2.2).

Los tipos A-D podrían corresponder a aves corredoras (i.e., rheidos o tinámidos), el tipo $\mathrm{E}$ a aves vadeadores de ambientes acuáticos (i.e., ardeiformes), mientras que los tipos F-G no podrían ser asignadas a ningún taxón (para mayor detalle ver Carden 2008a: 260-262 y 327-328).

En la clasificación de las pisadas de felino se distinguen cinco tipos: A, la más realista, con cuatro dedos; B a D, con 3, 5 y 6 dedos respectivamente (Figura 2.2). Estos tipos presentan mayor o menor cantidad de dedos, existiendo cierto vínculo 
formal con el modelo natural (Carden 2008a: 330). El tipo E se corresponde con las "rosetas" (círculo central rodeado por círculos de tamaño más pequeño) (Figura 2.2). Si bien este motivo fue clasificado como abstracto por Gradin (1978, 2001), este autor señala que resultó del proceso de abstracción de la pisada del puma a la que se le agregaron más dedos. De este modo, el motivo posee una conexión formal con las pisadas más realistas (Carden 2008a). Por último, en las pisadas de guanaco se reconocen dos tipos: A, de forma ovalada, y B, de forma rectilínea (Carden 2008a: Figura 9.41) (Figura 2.2).

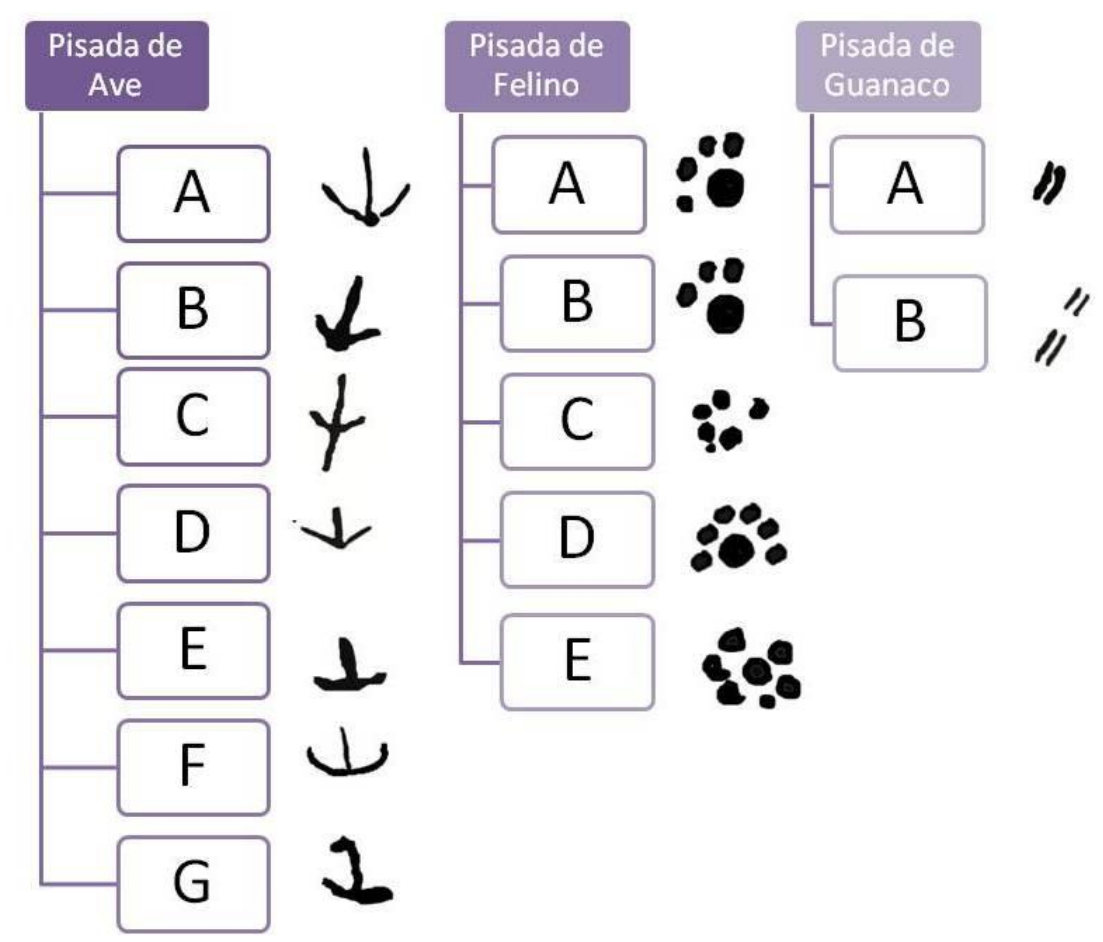

Figura 2.2. Tipos de pisadas de animales para las clases pisadas de ave, de felino y de guanaco (Tomado y modificado de Carden 2008a).

Con respecto a los subgrupos de motivos no figurativos, entre los puntiformes se reconocieron puntos aislados, línea simple de puntos o líneas de puntos en series paralelas (con diferente orientación), conjuntos de puntos así como círculos y circunferencias de puntos (Figura 2.3). Los motivos rectilíneos incluyen una amplia variedad, entre los que se destacan líneas rectas simples, en series paralelas, en serie paralelas y perpendiculares (con diferente orientación y que pueden estar asociadas a líneas de puntos, conjuntos de puntos o circunferencias); líneas quebradas (simples o combinadas), ortogonales o figuras 
rectangulares (simples o con trazos internos) (Figura 2.4). El subgrupo de los circulares llenos presenta menor variabilidad, habiéndose registrado círculos llenos simples, con apéndice (recto, curvo, o radiado), así como circulares llenos con apéndice asociados a líneas (Figura 2.5).

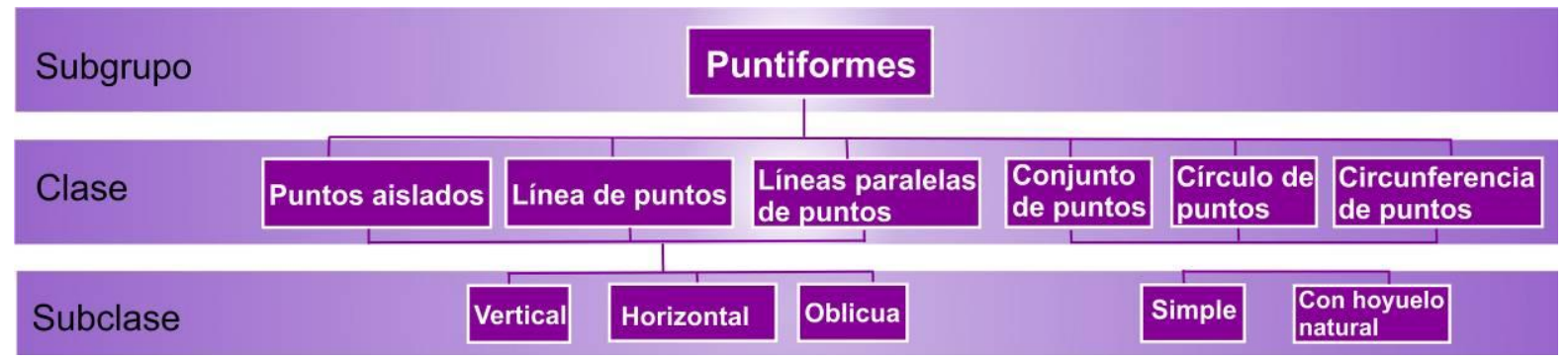

Figura 2.3. Subgrupo de los puntiformes.

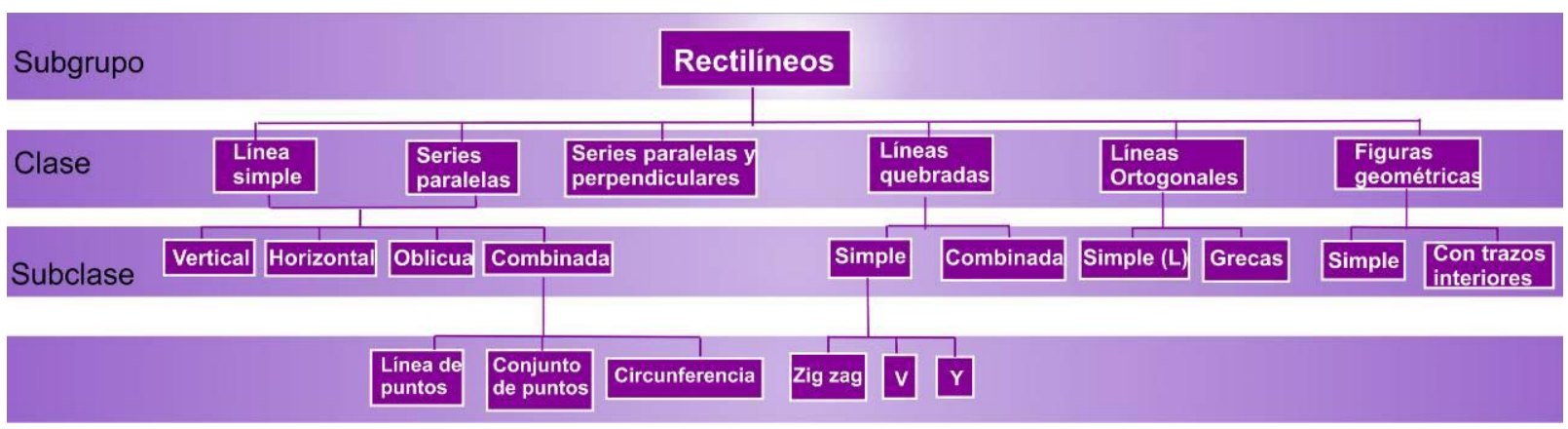

Figura 2.4. Subgrupo de los rectilíneos.

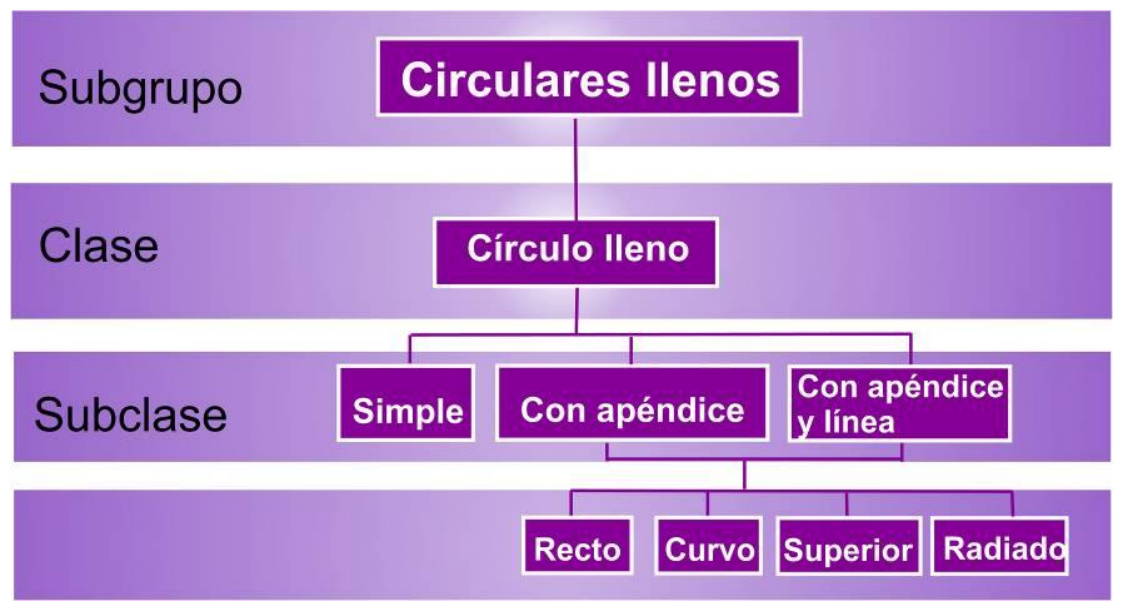

Figura 2.5. Subgrupo de los circulares llenos.

Entre los motivos circulares lineales se distinguen las semicircunferencias, circunferencias, espirales y óvalos, que pueden ser simples, concéntricos, presentar punto u hoyuelo central, apéndices -simples, de número variables o radiados-, apéndices y hoyuelo o punto central (Figura 2.6). Por último, entre los 
motivos curvilíneos se reconocieron líneas curvas (simples o en series paralelas con diferente orientación), combinadas con líneas rectas, circunferencias o apéndices; "media U" y "U" (simple o invertida) que presentan apéndice/s, punto central, trazo/s interno/s, y serpentiformes (Figura 2.7). Para un mayor detalle de los tipos de motivos reconocidos ver el Apéndice I.1.

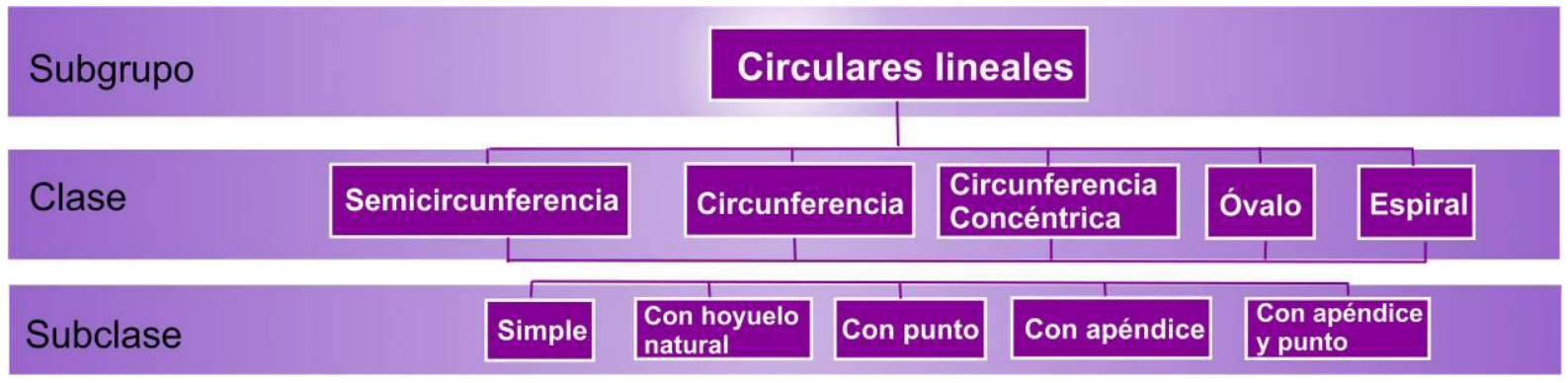

Figura 2.6. Subgrupo de los circulares lineales.

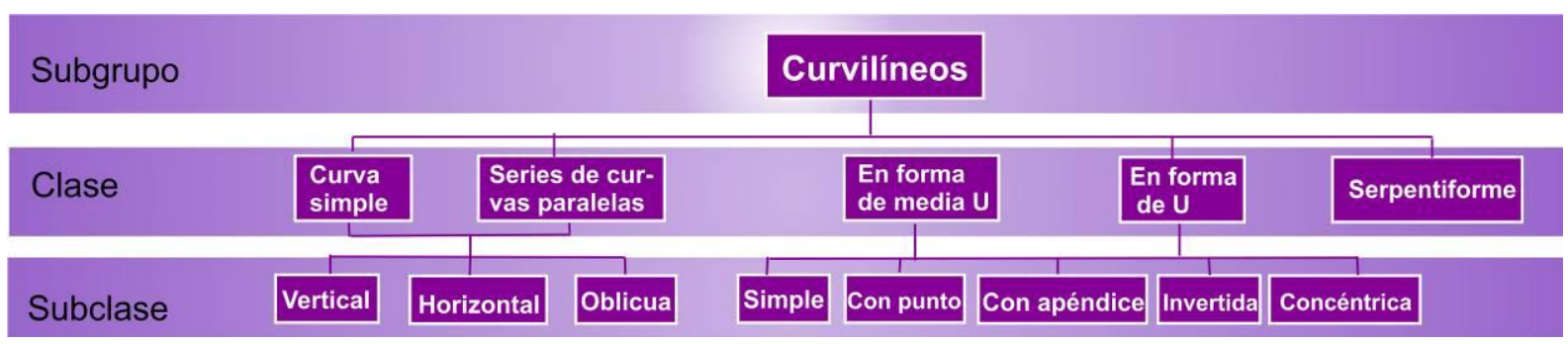

Figura 2.7. Subgrupo de los curvilíneos.

Entre las técnicas de producción se distinguen la pintura, el grabado y la combinación de ambas. En el primer caso, los motivos pueden haber sido pintados de manera directa o indirecta (Tabla 2.1). La aplicación de pintura de manera directa pudo ser mediante la técnica digital, que implica la aplicación de pintura con la punta o la yema de los dedos (Bahn y Vertut 1997: 117; Bednarik 2007: 4748; Whitley 2005: 6), o mediante la pulverización directa de pintura con la boca, también denominada estarcido directo (Groenen 1988; Lorblanchet 1980, 1990 en Bahn y Vertut 1997; Paunero et al. 2005). En esta última técnica entran en juego varios factores relacionados con los gestos técnicos. Al colocar la pintura directamente en la boca, se le adiciona saliva y calor, con lo que aquella se vuelve más viscosa; asimismo, durante la aplicación se deben controlar la presión de los labios y las respiraciones (Bahn y Vertut 1997: 118; Paunero 1992). Esta técnica puede ser utilizada para la aplicación de pintura sin forma discernible o para la 
realización de negativos de manos u objetos. En este último caso, el ángulo y la distancia de aplicación de la pintura se relacionan con el tamaño del negativo obtenido (para un ejemplo de replicación de negativos de mano ver Paunero 1992).

Por otro lado, la pintura puede ser aplicada sobre el soporte rocoso de manera indirecta, empleando artefactos. Entre estos se distinguen:

a) Hisopos, realizados con pequeñas porciones de madera o algún elemento aguzado, con por lo menos un extremo cubierto con algún material que pueda impregnarse en pintura, que puede ser pelo o fibras vegetales por ejemplo (Aschero 1983-1985, 1988; Aschero et al. 2005; Bednarik 2007a; Marchionne y Bellelli 2013; Onetto 1987, 1991; Reigadas 2002; Whitley 2005);

b) Pinceles: similares a los anteriores, pero con fibras más largas (Bednarik 2007a; Scheinsohn 2010);

c) Estampas: fibras vegetales, pelos o retazos de cueros de animales embebidos con pintura, que luego apoyados o arrojados contra el soporte rocoso (Gradin et al. 1976; Aschero 2012a).

d) Canutillos: pueden corresponder a huesos de tipo neumático, o fragmentos de los mismos, o pequeñas porciones de caña utilizados como intermediarios para la aplicación de la pintura por pulverizado. Estos canutillos podrían haber sido usados para contener pintura y aplicarla sobre la roca; o usados en combinación con un contenedor de pintura, a modo de aerógrafo ${ }^{2}$.

Las técnicas de producción de los motivos grabados fueron identificadas a partir de los lineamientos de Álvarez y Fiore (1995: 218-219) y Fiore (2007: 156). Se pueden distinguir (Tabla 2.1):

- Incisión: implica el corte o hendidura del soporte mediante el movimiento unio bidireccional del artefacto, cuyo filo se desplaza en forma paralela a la dirección de la utilización.

\footnotetext{
${ }^{2}$ El aerógrafo implica el uso de un contenedor de pintura y de dos canutillos. Uno de estos canutillos se coloca en posición vertical inmerso en la pintura mientras que el segundo canutillo se coloca en posición transversal al anterior, con un extremo libre al que se acerca la boca. Así, los orificios de ambos canutillos quedan perpendiculares y separados por pocos milímetros. Para poder aplicar la pintura se sopla enérgicamente y se produce la pulverización (Bahn y Vertut 1997; Groenen 1988).
} 
- Raspado: se trata de la abrasión del soporte mediante el movimiento bidireccional del artefacto, cuyo filo se desplaza en forma perpendicular a la dirección de utilización.

- Horadación: implica la inserción gradual de un artefacto en el soporte mediante movimientos de rotación en sentido horario y anti-horario

- Percusión: se trata del golpeteo del soporte, que puede ser directa al utilizar un artefacto o un guijarro, o ser indirecta ya que se usan dos artefactos (un cincel y un percutor). Esta última versión de la percusión fue denominada picado (Álvarez y Fiore 1995). Se cree que la percusión indirecta usualmente ofrece mayor control de impacto, y por lo tanto del diseño del motivo (Álvarez y Fiore 1995; Carden 2008a; Re 2011), aunque Bednarik (2007a) propone que el reconocimiento entre la percusión directa o indirecta es imposible de hacer a partir de la observación macroscópica de los surcos grabados. La percusión deja sobre el soporte pequeños hoyuelos superficiales de forma levemente cóncava.

- Abrasión involucra el movimiento repetitivo -uni o bidireccionalmente- de un artefacto -guijarro- sobre una superficie rocosa (Maynard 1977), y puede involucrar el uso de abrasivos como arena (Tabla 2.1).

Estas técnicas pueden aparecer combinadas en los motivos rupestres (Carden 2008a; Fiore 2007, 2009; Re 2011). Además, se distinguen motivos pictograbados, en los que parte del motivo grabado presenta trazos de pintura por encima, y motivos pintados y grabados, en los que trazos o surcos realizados con ambas técnicas se combinan aunque no se superponen.

Para la evaluación de las técnicas de producción que figuran en el Capítulo 4, se utilizarán como sinónimos: picado, piqueteado y percusión indirecta, en tanto que para la percusión directa se reconocerán como sinónimo el machacado. Por último, para el raspado se reconocerán como sinónimos fricción, frotación y alisado. 


\begin{tabular}{|c|c|c|c|c|}
\hline Técnica & \multicolumn{2}{|c|}{ Tipo } & Correlato material & Fuente \\
\hline \multirow{5}{*}{ Pintura } & Digital & Directa & Trazo ancho & Bednarik 2007b \\
\hline & Hisopo/ Pincel & Indirecta & $\begin{array}{l}\text { Trazo angosto o ancho; } \\
\text { puede ser continuo o } \\
\text { discontinuo. }\end{array}$ & $\begin{array}{l}\text { Onetto 1987, 1991; } \\
\text { Paunero et al. } 2005\end{array}$ \\
\hline & "Estampas" & Indirecta & Trazo de ancho variable & $\begin{array}{c}\text { Aschero 1988, } \\
\text { 2012a; Aguerre y } \\
\text { Gradin 2003; } \\
\text { Gradin et al. } 1979\end{array}$ \\
\hline & \multirow[b]{2}{*}{ Pulverizado } & Directa & \multirow{2}{*}{$\begin{array}{c}\text { Cobertura de superficie y } \\
\text { salpicaduras }\end{array}$} & \multirow{2}{*}{$\begin{array}{c}\text { Bednarik 2007, } \\
\text { 2008; Lorblanchet } \\
\text { 1991; Paunero } 1992\end{array}$} \\
\hline & & $\begin{array}{c}\text { Indirecta con } \\
\text { canutillos }\end{array}$ & & \\
\hline \multirow{6}{*}{ Grabado } & \multicolumn{2}{|c|}{ Incisión } & Surco en V & \multirow{6}{*}{$\begin{array}{c}\text { Álvarez y Fiore } \\
\text { (1995); Fiore 2007; } \\
\text { Gradin 1976; } \\
\text { Maynard 1977 }\end{array}$} \\
\hline & $\mathrm{Ra}$ & & & \\
\hline & Abr & & & \\
\hline & Hora & & superficial & \\
\hline & \multirow{2}{*}{ Percusión } & Directa & & \\
\hline & & $\begin{array}{c}\text { Indirecta } \\
\text { (picado) }\end{array}$ & & \\
\hline
\end{tabular}

Tabla 2.1. Técnicas de pintura y grabado y su correlato material.

\section{2. b. 2. Relevamientos}

El relevamiento de los sitios presentados en esta tesis fue efectuado por la autora en colaboración con miembros del equipo de investigación. Se completaron fichas prediseñadas en las que se consignaron datos referidos a distintos aspectos formales de los motivos rupestres, su altura respecto del suelo, la técnica inferida en su realización, la distribución de los motivos en paneles y/o sectores, su estado de conservación, entre otros (Carden 2008a; Hernández Llosas 1985). Asimismo, se tomaron fotografías digitales y se efectuaron croquis a mano alzada de la distribución de motivos en todos los paneles. En algunos casos se realizaron calcos sobre nylon de 200 micrones, usando marcadores indelebles de diferentes colores para distinguir entre la microtopografía del soporte, el trazo del motivo rupestre y grafitis en caso de registrarse cerca o sobre los motivos. Estos calcos fueron digitalizados, utilizando el negro para los motivos grabados, el gris para la roca, el marrón para la microtopografía y el azul para los grafitis.

En los sitios, la designación de los sectores, conjuntos y motivos se realizó con un orden de izquierda a derecha del observador de frente a los motivos, y de arriba hacia abajo. Los sectores se definieron tomando como límites a los 
accidentes topográficos más conspicuos, como derrumbes de rocas o cambios de orientación de las paredes en las bardas, a lo que se suma la ausencia de motivos a lo largo de 6,5 m de soporte. Dentro de los sectores, los conjuntos se definieron a partir de la presencia de motivos delimitados por fallas, grietas o discontinuidades en el soporte rocoso. Las distancias fueron calculadas usando cinta métrica y mediante el geoposicionamiento de los paneles.

En cuanto a su ubicación, los motivos pueden encontrarse sobre superficies verticales u oblicuas de aleros o bardas, o bien sobre diferentes superficies de bloques desprendidos y alejados de las mismas. Además, respecto de los conjuntos, se contempló la orientación hacia los puntos cardinales, la orientación y distancia a fuentes de agua y a puntos sobresalientes del paisaje (v.g., cerros) (Carden 2008a).

A este análisis se le adicionó información referida a la ubicación de los sitios en el paisaje, en las unidades topográficas en las que se encuentran (cañadón, cuenca endorreica, planicie de inundación), y a las condiciones de visibilidad. Con respecto a estas últimas, se distinguieron cuatro alternativas (Carden 2008a; Lenssen-Erz 2004):

a) paneles con visibilidad alta: con amplio campo visual, que reciben buenas condiciones de iluminación natural y pueden ser visualizados desde $15 \mathrm{~m}$ de distancia;

b) paneles con visibilidad intermedia: pueden ser observados desde los $7 \mathrm{~m}$. Esto puede deberse a la microtopografía del soporte empleado, al tamaño pequeño de los motivos o a la baja cantidad de los mismos en los soportes;

c) paneles con visibilidad baja: motivos con campo visual bajo o en lugares resguardados. La distancia máxima desde la que se los puede visualizar es de 3 $\mathrm{m}$;

d) paneles con visibilidad muy baja: se corresponden con un campo visual muy bajo ya que las posiciones que se requiere adoptar para observarlos son limitadas. Es posible observarlos desde menos de $1 \mathrm{~m}$ de distancia máxima.

Los paneles con un alto campo visual y con un amplio espacio circundante (visibilidad alta e intermedia) pueden haber sido observados simultáneamente por muchas personas. Los paneles con baja visibilidad coinciden con espacios 
circundantes menores, lo que podría involucrar un número menor de personas en su producción y uso. Los paneles con muy baja visibilidad sugieren relaciones más individuales con el arte rupestre (Carden 2009a).

Asimismo, durante los relevamientos se registraron pátinas y superposiciones de los motivos. Dicho registro ha sido de utilidad para plantear secuencias relativas de producción de motivos (Keyser 2001). En casos de estudios en Patagonia las referencias son amplias (Aschero 1988, 1997; Carden 2008a; Cardich 1979; Gradin 1959-60a, 1959-60b, 1976, 1996; Gradin et al. 1976, 1979; Guichón 2012; Re 2011).

La pátina es una delgada película que recubre la superficie rocosa, la cual resulta de la acción a lo largo del tiempo de diferentes procesos fisico-químicos que alteran esta superficie (Bednarik 2007b), característica de climas áridossemiáridos (Keyser 2001). Los motivos grabados, al ser el resultado de técnicas extractivas (Álvarez y Fiore 1995; Fiore 1996-98), dejan al descubierto la superficie original de la roca, eliminando la pátina y la corteza del soporte, lo cual genera un contraste visual y de relieve que permite distinguir los grabados. Con el transcurso del tiempo, el re-patinado de la roca puede alcanzar tal grado que lleve a confundir el surco grabado con la corteza de la roca.

A partir de los lineamientos de Gradin (1959-60a, 1976), Re (2011) y Re et al. (2006-07), se distinguieron tres grados de pátina: oscura, intermedia y clara. La primera sería más antigua, implicando que la superficie rocosa habría estado expuesta por mayor tiempo, confundiéndose surco y soporte. Por otro lado, la pátina intermedia implica un menor desarrollo, mientras que en la pátina clara el surco y el soporte se distinguen nítidamente. En el campo, la determinación de grado de pátina fue realizada a nivel macroscópico.

Cabe aclarar que en la determinación de los grados de pátina se perciben algunas dificultades, vinculadas con el accionar de diferentes observadores, los tipos de soportes rocosos, la incidencia de la luz sobre la superficie, las técnicas empleadas así como cuestiones tafonómicas (Bednarik 2007a). Sin embargo, en conjunto con otra información, el análisis de pátinas puede resultar sumamente útil, como se enuncia a continuación y se desarrolla con mayor profundidad en los Capítulos 6 y 7 . 
El análisis de las superposiciones de motivos es otro método que permite plantear dataciones relativas del arte rupestre (Keyser 2001). Las superposiciones también pueden involucrar mantenimiento, reciclado y comportamiento destructivo de distintos motivos (Aschero 1988; Martel et al. 2012; Pastor 2012; Re 2012; Troncoso 2005).

A partir de la información procedente del análisis conjunto de los tipos de motivos, las técnicas de producción, las pátinas y superposiciones se puede plantear una secuencia cronológica -relativa- de producción de motivos a nivel intra e inter-sitio (Gradin et al. 1976, 1979; Guichón 2012; Re 2011).

En paralelo al relevamiento de las manifestaciones rupestres, se prospectaron los sectores inmediatos y aledaños a los sitios para el registro de otras evidencias arqueológicas que informen acerca del uso de los lugares en los que se emplaza el arte. Cuando se consideró necesario se efectuaron recolecciones de materiales arqueológicos superficiales o se practicaron pequeños sondeos (ver Capítulos 6 y 7). Durante esas prospecciones, se efectuó el relevamiento y geoposicionamiento de afloramientos de sustancias colorantes a fin de incluir esa información en la base de datos regional. Se recolectaron muestras para analizar por difracción de rayos X (DRX) y comparar dichos resultados con los análisis efectuados previamente en el marco de la investigación regional (Carden et al. 2011, 2014). Asimismo, se tomaron muestras adicionales que forman parte de la colección de materias primas empleadas para la confección de las pinturas experimentales (Capítulo 5).

\section{2. b. 3. Análisis de Laboratorio}

El trabajo de gabinete estuvo centrado en dos tareas fundamentales: el ordenamiento de la información recolectada en campo y las tareas relacionadas a la actividad experimental. 


\section{2. b. 3. 1. Ordenamiento de la información de campo}

Las imágenes obtenidas en las labores de campo (fotografías, croquis y calcos) fueron digitalizadas en los últimos dos casos, ordenadas por región, por sitio y por conjunto, para confeccionar un archivo digital de los relevamientos. Las fotografías fueron procesadas con Adobe Photoshop $\$ e ImageJC (complemento Decorrelation Stretch - D-Stretch) para mejorar la visualización de los motivos y realizar calcos digitales. En el caso de los motivos pintados, la utilización de $D$ Stretch permitió definir la forma de motivos clasificados en campo como no determinados (Capítulos 6 y 7).

D-Stretch funciona como complemento del programa ImageJ(C). Permite resaltar los colores presentes en una imagen digital mejorando su contraste, creando una imagen de colores falsos mediante un algoritmo de decorrelación (Harman 2008, 2011). Este complemento opera en numerosos espacios de color, los cuales tienen una capacidad de representación distinta con respecto a la gama de colores que pueden mostrar. Por ejemplo, los espacios de color YDS, LYE e YYE resaltan los colores amarillos, en tanto que los espacios YRE y LRE resaltan los rojos (Harman 2011). Así, sin modificar la imagen original, se genera un nuevo archivo en el que se produce un cambio de color por la manipulación de espacios de color determinados. La intensidad de la transformación o el resalte se corresponden con valores predeterminados, comprendidos entre 2,5 y 50 puntos, aunque también se puede trabajar con el modo experto y manejar las modificaciones manualmente (Harman 2011).

En Argentina, la aplicación del complemento D-Stretch a imágenes obtenidas en relevamientos en el sur del macizo del Deseado así como en la margen norte del río Santa Cruz ha permitido resaltar motivos desvaídos -casi imperceptibles mediante la observación macroscópica-, destacar superposiciones, identificar motivos no percibidos durante el relevamiento o erróneamente registrados, e indudablemente lograr una mejor caracterización del repertorio de motivos de esas regiones (Acevedo y Franco 2012). Si bien existen antecedentes en los que el Adobe Photoshop $($ fuera utilizado para el tratamiento digital de las imágenes (ver Gerónimo y Hocsman 2011 y bibliografía allí citada; Mark y Billo 2009), D- 
Stretch es un complemento creado para el estudio del arte rupestre, de ahí la preferencia de este último frente al uso del primero, ejemplificado en el Capítulo 7.

La información recabada fue cargada en planillas de cálculo de Microsoft Office Excel 2007C), siguiendo los lineamientos de las fichas de relevamiento para posteriormente poder efectuar el análisis cuantitativo de las distintas variables relevadas en cada uno de los sitios y la comparación inter-sitio por región.

\section{2. b. 3. 2. Diseños experimentales}

La colección experimental, tanto para pinturas como para grabados, se confeccionó considerando la mayor semejanza posible con los materiales arqueológicos (Bard y Busby 1974; Bednarik 2007b; Keyser 2007; Keyser y Rabiega 1999; Whittacker et al. 1999). Para la realización de pinturas y grabados se trabajaron, por lo tanto, superficies rocosas de diferente litología. Esta selección se diferencia de otros trabajos, donde la pintura fue aplicada sobre hojas de papel (Gunn 2006) o sobre superficies de cartón preparadas con yeso (Groenen 1988).

La producción de motivos rupestres está compuesta por tres cadenas operativas imbricadas, relacionas a la producción de artefactos, de pinturas y de motivos rupestres (Fiore 2007). Las variables contempladas en los diseños experimentales que se relacionan con dichas cadenas refieren a:

- el soporte: constitución de la superficie rocosa (formación geológica, composición mineralógica, dureza), topografía y microtopografía del mismo, preparación, color de la pátina, altura, posición y ángulo;

- los artefactos: materia prima, características dimensionales, tipo de artefacto, técnica de manufactura, cantidad de veces que fue utilizado;

- el trabajo: posición y lateralidad del ejecutante, campo manual, técnica de producción, dirección y sentido en la manufactura del motivo, ángulo de trabajo, modo de prensión del artefacto, posición del filo respecto de la superficie, tiempo invertido en la manufactura del motivo; 
- el motivo: tipo de motivo; tratamiento de la superficie, ancho y profundidad del trazo/surco, forma del surco, tamaño del motivo, trabajo con o sin dibujo previo (tomado y modificado de Álvarez y Fiore 1995: 221).

2. b. 3. 2. a. Protocolo para replicación de grabados

El registro de las experiencias replicativas de motivos grabados fue realizado contemplando diferentes variables. Se trabajaron soportes basálticos y de areniscas coquinoides pertenecientes a las formaciones rocosas en las que se encuentran los sitios tomados como referentes en la provincia de Santa Cruz (Capítulos 3 y 5).

Los artefactos empleados para grabar fueron seleccionados luego de analizar los materiales presentes en los contextos arqueológicos y de una exhaustiva revisión bibliográfica, a partir de la cual se identificaron los instrumentos inferidos como potencialmente utilizables en la producción de grabados (Fiore 1996-98; para mayor detalle ver Capítulo 4). Las materias primas líticas utilizadas fueron recolectadas en diferentes campañas arqueológicas realizadas en el macizo del Deseado; corresponden a materiales silíceos y guijarros de diferente litología. Estos materiales fueron medidos, dibujados y fotografiados previamente a su utilización.

Una vez seleccionado el motivo a replicar se registró la información relevante en el protocolo experimental (Apéndice I.2), considerando la altura respecto del suelo, la ubicación del panel, el tipo de motivo, las dimensiones, la técnica inferida, etc. Tales condiciones fueron replicadas en el laboratorio. En la misma ficha se registraron los artefactos usados.

2. b. 3. 2. b. Protocolo para replicación de motivos pintados

Este protocolo involucra la cadena operativa de preparación de pintura, del motivo y, si la técnica usada es indirecta, la cadena operativa en la que se confecciona el artefacto. 
En la preparación de las mezclas se utilizaron diferentes tipos de pigmentos, diluyentes y aditivos (Aschero 1988). Los pigmentos utilizados son minerales (Capítulo 5), y fueron seleccionados a partir de la revisión bibliográfica (Capítulo 4). Como diluyentes (aglutinantes o ligantes) se utilizaron agua, grasas de diferentes animales y clara de huevo. El aditivo o mordiente usado fue el yeso hemihidratado. Para una justificación detallada de esta selección ver Capítulos 4 y 5 .

En el protocolo de los motivos pintados se registró el tipo y color del pigmento empleado, su procedencia, si fue molido y de qué manera, la cantidad usada así como las cantidades de ligante, agua y aditivo empleadas. Dichas cantidades fueron medidas en gramos para los sólidos y en mililitros para los líquidos. Asimismo, se consideraron el soporte, el trabajo y los artefactos usados (Apéndice I.3). En el caso de estos últimos, además, se detallaron los materiales con los que se confeccionaron. 


\section{Capítulo 3}

\section{CARACTERIZACIÓN AMBIENTAL DE LAS REGIONES EN ESTUDIO}

Las regiones en estudio se encuentran en el ámbito patagónico. El límite geológico del norte de Patagonia argentina se estableció a lo largo de la dorsal Huincul (Ramos et al. 2004: 785-786), en tanto que su límite oriental está dado por la costa atlántica y el occidental por la Cordillera de los Andes. Desde el punto de vista geográfico, el norte de la Patagonia argentina abarcaría el tercio austral de Neuquén, el territorio de Río Negro, y las porciones más australes de las provincias de La Pampa y Buenos Aires incluyendo, además, los territorios de las actuales provincias de Chubut, Santa Cruz y Tierra del Fuego, Antártida e Islas del Atlántico Sur. Las regiones consideradas son el macizo del Deseado, que se encuentra en el NE de Santa Cruz, y el macizo de Somuncurá, en la porción central de las provincias de Río Negro y Chubut (Figura 1.1). A continuación se presentan las características geológicas, geomorfológicas, climáticas y ambientales de ambas, ya que constituyen la matriz física en la que se desenvuelven las actividades humanas y que conforman la dimensión física del paisaje, tal como es entendido en esta tesis.

Existe un desbalance en cuanto a las investigaciones geológicas de ambas áreas, siendo más numerosas y detalladas para el macizo del Deseado, probablemente debido al mayor desarrollo minero y petrolero sucedido en la provincia de Santa Cruz. 


\section{3. a. MACIZO DEL DESEADO}

\section{3. a. 1. Geología}

El macizo (Leanza 1958) o Nesocratón del Deseado (Harrington 1962) es una provincia geológica de aproximadamente $60.000 \mathrm{~km}^{2}$, situada en la porción central de la provincia de Santa Cruz. Se extiende entre el río Deseado (límite septentrional) y el río Chico (límite meridional) y, desde la costa atlántica en el oriente hasta la llamada Dorsal de Río Mayo en el oeste (Moreira et al. 2005: 49; Ruiz 2012). Esta unidad se caracteriza por el predominio de un extenso plateau de ignimbritas riolíticas de edad jurásica y amplias zonas cubiertas por coladas de basaltos del Terciario y Cuaternario, con pequeños asomos aislados de rocas prejurásicas (Moreira et al. 2005). Recibe la denominación de macizo por su comportamiento positivo y rígido a través del tiempo, cuya evolución y estructura son el resultado de una serie de ciclos diastróficos de intensidad variable ocurridos durante buena parte del Fanerozoico (Panza 2001). Los rasgos estructurales están íntimamente ligados al desarrollo de la Cordillera Patagónica Austral, conjuntamente con la evolución de la dorsal meso-atlántica durante gran parte del Mesozoico y Cenozoico (Panza 2001: 4).

Las rocas más antiguas corresponden a unidades prejurásicas, de escaso desarrollo y pobre distribución. La secuencia geológica del macizo del Deseado ha sido ampliamente desarrollada en trabajos efectuados por especialistas (Moreira 2005; Moreira et al. 2005, 2010; Panza 2001; Panza y Marin 1998; Ruiz 2012). Esta unidad también ha sido tratada en estudios arqueológicos como meseta central o altiplanicie central santacruceña (Aguerre 1987; Aguerre y Gradin 2003; Carden 2008a, 2009a; Cattáneo 2002; Durán 1983-85; Frank 2011; Gradin y Aguerre 1983; Hermo 2008; Magnín 2010; Marchionni 2013; Miotti 1998, 2008; Miotti et al. 2007c; Skarbun 2009, entre otros). Aguerre (1987) reconoce que en trabajos previos la división entre la porción septentrional y meridional de la altiplanicie se había fijado arbitrariamente en el paralelo $48^{\circ} \mathrm{S}$, división que fue retomada 
en otros trabajos y que estuvo basada parcialmente en la localización de los sitios con ocupaciones tempranas (Los Toldos y el área del Río Pinturas).

Los sitios arqueológicos documentados en la porción NE del macizo del Deseado aquí tratada corresponden a diferentes ocupaciones, y se encuentran asociados a distintas formaciones. Por ejemplo, Los Toldos (Cardich 1987; Cardich et al. 1973; Miotti 1998) y Cueva Maripe (Hermo 2008; Marchionni 2013; Miotti 2008; Miotti et al. 2007c) se emplazan en la formación Chön Aike, mientras que algunos sitios de la localidad arqueológica Piedra Museo se encuentran en las areniscas coquinoides de la formación Puesto del Museo (Carden 2008a; Miotti 1992, 1996; Miotti et al. 1999a, 1999b). En estos sitios se recuperaron evidencias de diferentes momentos ocupacionales, algunos de los cuales se corresponden a la ocupación inicial de este espacio (Miotti y Salemme 2004). Los sitios con arte rupestre estudiados en la localidad arqueológica Aguada del Cuero se encuentran en formaciones distintas: Laguna del Cerro Bonete y La Leonera, ambos con arte rupestre y en los que se detectaron materiales arqueológicos en superficie, se encuentran sobre las bardas del Basalto La Angelita; los grabados de Bardas del Doce se emplazan en las bardas del basalto homónimo mientras que Cueva Moreno y Cueva de La Hacienda están insertas en oquedades de la formación Baqueró (Carden 2008a). Los sitios de superficie se corresponden a los sedimentos y depósitos lacustres, aluviales y eólicos que cubren las distintas unidades (Hermo 2008; Magnín 2010).

En este apartado se caracterizan las formaciones sobre las que se ubican los sitios con arte rupestre presentados en esta tesis. Estas son Laguna Palacios, Alma Gaucha y La Angelita, así como una abreviada caracterización de las formaciones Chön Aike, Puesto del Museo y del Basalto de Cerro del Doce. Estas últimas fueron presentadas en profundidad en trabajos previos (Carden 2008a, 2008b, 2009a; Hermo 2008; Magnín 2010; Marchionni 2013; Miotti et al. 2007c), y son relevantes en esta tesis para el desarrollo del diseño experimental presentado más adelante (Capítulo 5). 
La formación Laguna Palacios integra el Grupo Chubut, que está constituida por tobas, cineritas y tufitas subordinadas (Panza 2001). En todo su desarrollo areal y vertical dicha unidad es litológicamente uniforme, existiendo unas pocas variaciones que se dan principalmente por ligeras diferencias en la tonalidad de los estratos o en la dureza relativa de los mismos (Panza 2001).

La formación Basalto Alma Gaucha está integrada por vulcanitas que se presentan principalmente como mantos tabulares o relictos de los mismos (chimeneas volcánicas y diques), que pueden constituir rasgos positivos del paisaje por presentar mayor resistencia a los agentes erosivos. Esta característica da lugar a un relieve de planicies estructurales, cuya superficie es irregular y se encuentra salpicada por pequeños bajos y lagunas, o bien son disectadas por profundos cañadones de paredes escarpadas y con mallines en parte de su recorrido. Los bordes de tales planicies estructurales conforman bardas elevadas, abruptas y subverticales, donde son muy comunes los fenómenos de remoción en masa. La gran dureza de los basaltos ha dado en consecuencia notorios ejemplos de inversión de relieve en prácticamente todos los afloramientos (Panza 2001).

El Basalto La Angelita es olivínico y constituye un campo lávico de grandes dimensiones, de superficie áspera, cubierta de grandes bloques y losas de aristas redondeadas. La sección superficial de las coladas es muy vesicular, de color negro y casi siempre fresco, aunque en partes esta sección suele hacerse escoriácea, siendo entonces mayor su grado de alteración y tinción por óxidos de hierro. El contacto basal se ve en muy pocos casos, pero cuando es visible se advierte que el metamorfismo de las rocas infrayacentes (casi siempre sedimentarias) se reduce a un espesor de 10 a $15 \mathrm{~cm}$ donde éstas se endurecen y toman un color ligeramente rojo (Panza 2001: 79), lugar dónde se pueden reconocer y recolectar materias primas colorantes.

La formación Chön Aike integra el Grupo Bahía Laura. Está formada predominantemente por ignimbritas de composición riolítica, asociadas con espesos bancos de aglomerados volcánicos gruesos y con escasas tobas, lapillitas y tufitas (Panza 2001). Esos mantos de ignimbritas riolíticas son 
compactos y espesos constituyendo grandes paredones y crestas muy abruptas, que pueden presentar marcada disyunción columnar y, ocasionalmente, ser interrumpidos por grandes cavernas y oquedades.

Bajo la denominación Puesto del Museo se reconoce a sedimentitas marinas de edad eocena (Panza 2001). La formación aflora en dos sectores específicos del macizo, uno de las cuales se encuentra en el puesto "El Museo" en la estancia San Miguel (Miotti 1992, 1996; Miotti et al. 1999b). Se trata de una sucesión de unos 15 a 20 m de espesor de areniscas coquinoides friables de color variable gris-castaño rojizas. Están formadas por fragmentos de conchillas de hasta $3 \mathrm{~mm}$, unidos por cemento ferruginoso y muy escasa matriz arcillosa, donde se han reconocido foraminíferos eocenos (Panza et al. 1996).

El Basalto Cerro del Doce constituye un conjunto de superficies mesetiformes, o bien pequeños asomos de dichas superficies, remanentes de coladas lávicas actualmente muy afectados por erosión. En los bordes de dichas superficies ocasionalmente se observan bardas subverticales de poca altura. Casi siempre forma, por el contrario, lomadas redondeadas con pequeños afloramientos dispersos y gran cantidad de lajas y bloques que cubren el terreno. La roca tipo es un basalto olivínico, de grano más bien grueso, de aspecto siempre muy alterado y con una costra de meteorización (Panza 2001).

\section{3. a. 2. Geomorfología}

Las geoformas son principalmente el resultado de la acción fluvial aunque la acción eólica o los fenómenos de remoción en masa han jugado un rol importante en el modelado del paisaje (Panza 2001). Asimismo, la actividad volcánica ha sido un factor importantísimo en la morfología local.

Según Panza (2001), en el macizo del Deseado pueden reconocerse dos paisajes distintos: el mesetiforme y el de relieve irregular de cerros y picos 
aislados que alternan con zonas bajas. En estas últimas se advierten grupos de lomadas o escoriales basálticos.

Las planicies mesetiformes pueden observarse como relictos aislados, o bien pueden estar disectadas por depresiones sin salida de dimensiones variadas. En líneas generales, las planicies más elevadas están coronadas con mantos basálticos que protegen a las unidades sedimentarias inferiores, observándose en sus márgenes paredones abruptos. El resto de la comarca se caracteriza por una morfología muy recortada e irregular, con un paisaje en el que se destacan cerros y conos volcánicos aislados, alternando con lomadas redondeadas y mesetas de reducidas dimensiones. En este paisaje se encuentran gran cantidad de bajos endorreicos, cuya parte central está ocupada por guadales y lagunas temporarias (Mazzoni 2001).

En el área son numerosos los cañadones y zanjones de reducidas dimensiones que vierten aguas en depresiones sin desagüe, por ejemplo en las lagunas Grande (o de Madre e Hija) y La Porfiada (Panza 2001). Todos los cauces son de régimen efímero y llevan agua con posterioridad a las precipitaciones, durante la primavera. Las cuencas centrípetas, en su mayoría desconectadas entre sí, tienen un escurrimiento pobremente desarrollado.

De acuerdo a los procesos dominantes en cada sector, Panza (2001) distingue el tipo de relieve y las formas resultantes que genera cada uno de ellos. Ellos son:

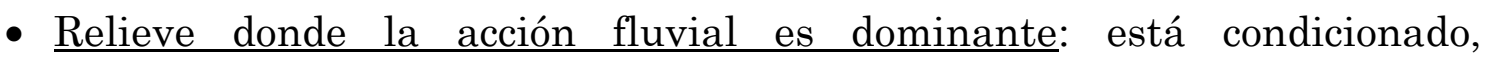
principalmente, por la resistencia a la erosión que presentan las distintas rocas. Por ejemplo, las ignimbritas de la formación Chön Aike constituyen el paisaje más abrupto y quebrado de la comarca, ya que los potentes mantos resaltan en el relieve a manera de altos paredones de 10 a $20 \mathrm{~m}$ de altura (Figura 3.1). No obstante, en algunos lugares forman pequeñas bardas de escasa altura (2 a $4 \mathrm{~m}$ ) o lomadas bajas con asomos redondeados apenas aflorantes en el terreno. Otro rasgo característico de este paisaje es la presencia de innumerables cavidades y cuevas, algunas de gran tamaño (Figura 3.1). La red de drenaje está condicionada por el control estructural. 
Estos arroyos, mayoritariamente temporarios, no desarrollan un valle ancho, con lo que se puede originar una estrecha garganta de paredes verticales abruptas y elevadas.

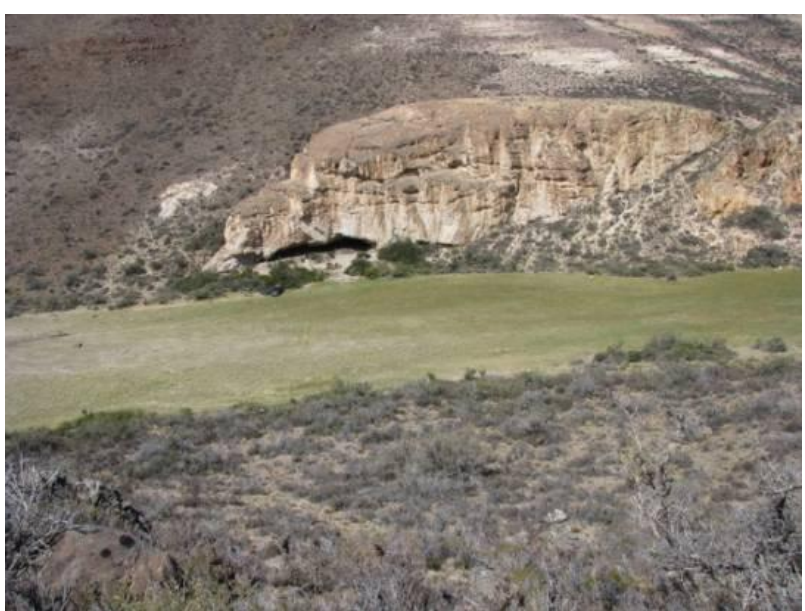

Figura 3.1. Paredones y cueva en formación Chön Aike.

En las bardas altas de las Formaciones Bajo Grande, Baqueró o Laguna Palacios, es típica la erosión en forma de "tubos de órgano" (Figura 3.2.a), así como la erosión diferencial que remarca notablemente la alternancia de estratos cineríticos friables con otros tobáceos más consolidados que se destacan como pequeñas cornisas. Los cursos de agua son de régimen efímero, de hábito anastomosado con planicies aluviales generalmente bastante anchas (Figura 3.2.b). Los principales arroyos son afluentes de los zanjones del Pescado, Pescado Chico y Graneros.

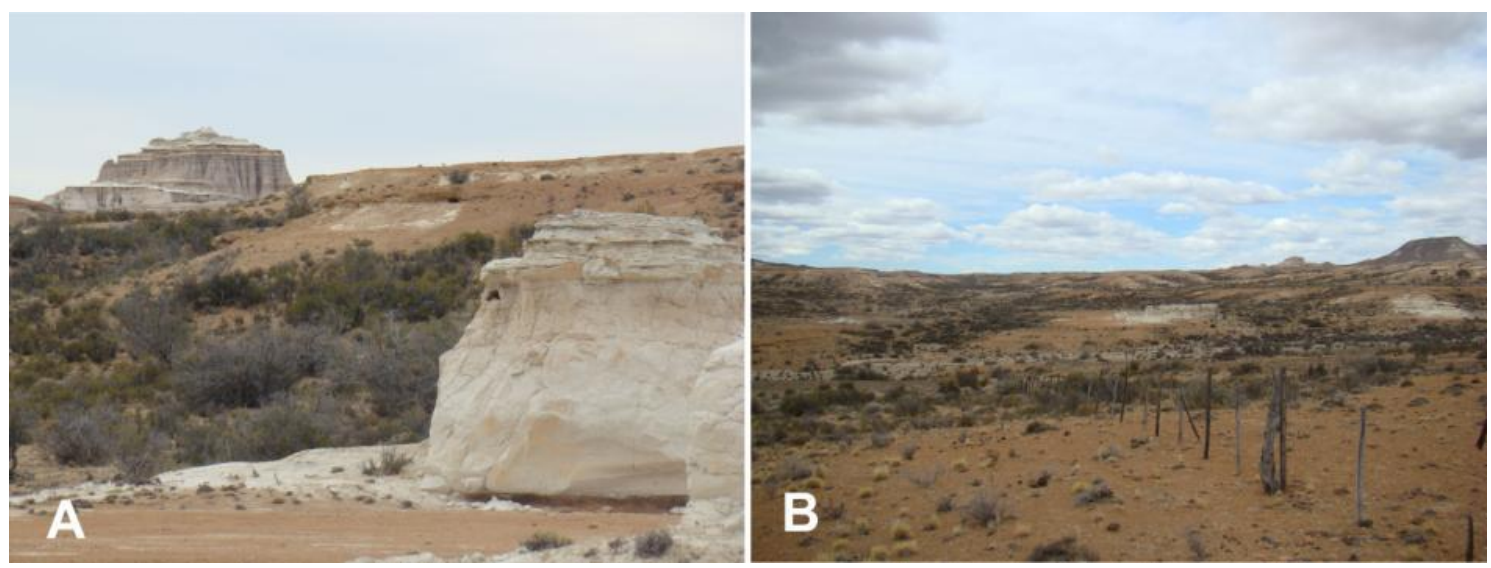

Figura 3.2. Afloramiento Laguna Palacios: a. Vista desde relicto con arte rupestre, al fondo afloramiento que presenta erosión en forma de "tubos de órgano"; b. Relicto de la formación en inmediaciones arroyo temporario. 
Los asomos de las sedimentitas paleógenas (v.g., Puesto del Museo) son reducidos y discontinuos, de muy poco espesor, aunque por la consolidación de las rocas y su posición se disponen como pequeñas mesetas o cornisas de bordes verticales (Figura 3.3). El frente de los afloramientos es una escarpa de erosión en activo retroceso por el proceso de remoción en masa, principalmente por caída de bloques.

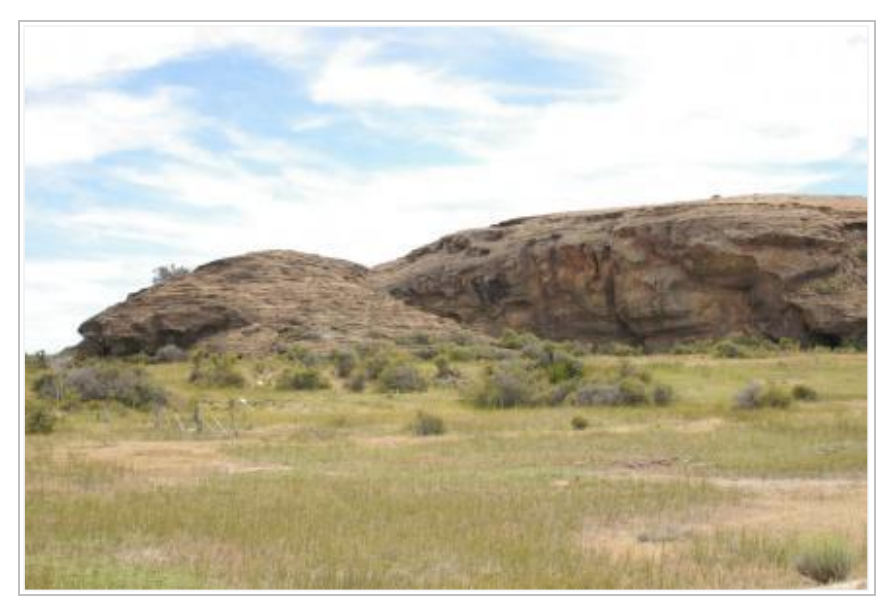

Figura 3.3. Afloramiento Puesto del Museo.

- Relieve volcánico: el vulcanismo basáltico es uno de los procesos más importantes que han intervenido en el desarrollo de la geomorfología, ya que las principales elevaciones de la comarca corresponden a formas originadas por dicha actividad, las cuales luego fueron degradadas por acción subaérea con formación de extensas planicies estructurales lávicas (Panza 2001).

Dependiendo del tipo y edad de las coladas se observan diferencias. Por ejemplo, el Basalto Cerro del Doce se presenta formando parte de remanentes de coladas lávicas que constituyen planicies estructurales en la actualidad muy desmembradas, sea por acción fluvial o por procesos de remoción en masa. Se trata de lomadas redondeadas casi sin preservación de bardas o bien con escarpas de reducida altura (Figura 3.4). En muchos casos son dominantes las mesillas, montes testigo, que se conservan como testimonio de la mayor extensión anterior de las planicies. 


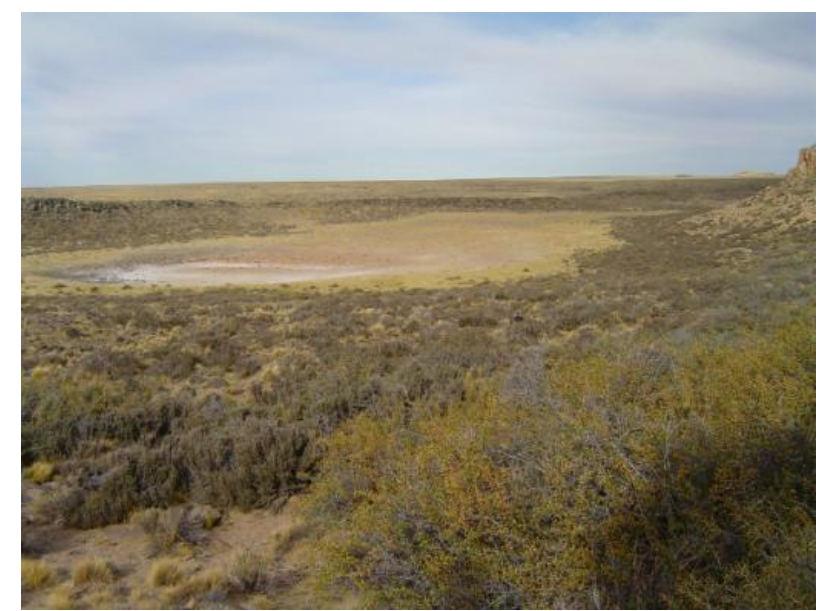

Figura 3.4. Cuenca endorreica rodeada por Basalto Cerro del Doce.

En cuanto al Basalto Alma Gaucha, en general se trata de formas mesetiformes típicamente tabulares, subhorizontales, cuya superficie es esencialmente plana y de gran extensión (Figura 3.5.a). Pueden conformar planicies estructurales dispuestas en forma escalonada, o bien, tratarse de remanentes de una planicie estructural de la cual solo quedan numerosas mesillas. El frente de las planicies estructurales es una barda elevada, subvertical (Figura 3.5.b), que constituye una abrupta escarpa de erosión en activo retroceso por procesos de remoción en masa (deslizamientos y caída de rocas). La superficie de las mesetas es irregular, tapizada de numerosas depresiones sin salida, de forma en planta generalmente subcircular o elongada y con diámetros entre 200 y 800 m, pero que pueden superar el kilómetro (Panza 2001: 92).
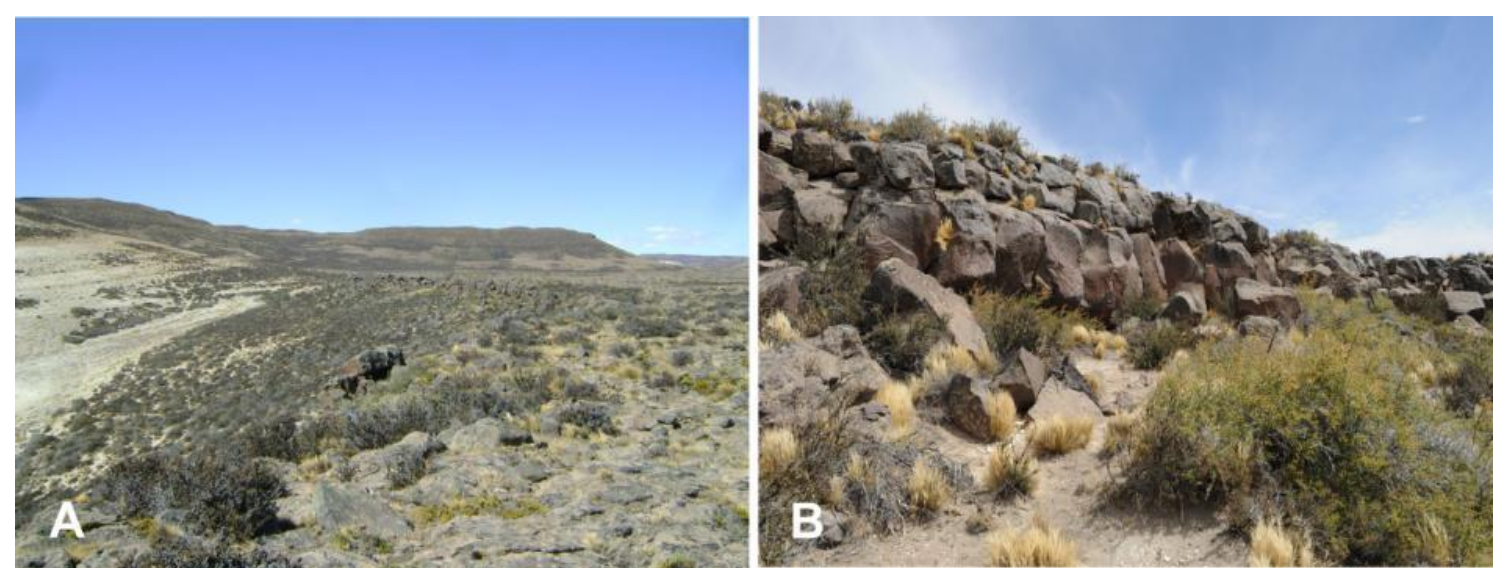

Figura 3.5. Basalto Alma Gaucha: a. Superficie mesetiforme; b. Frente de la formación conformando una barda. 
El Basalto La Angelita constituye extensos mantos basálticos de poco espesor (2 a $5 \mathrm{~m}$ ) que han sido apenas modificados por la acción subaérea posterior (Figura 3.6). Se registran varios ejemplos de inversión de relieve, principalmente por la erosión de las rocas infrayacentes más friables. En estos sectores se han formado abruptas bardas subverticales. El relieve superficial es algo áspero, compuesto por bloques y lajas sueltas, algunos de grandes dimensiones, pero las caras de los fragmentos son lisas y pulidas.

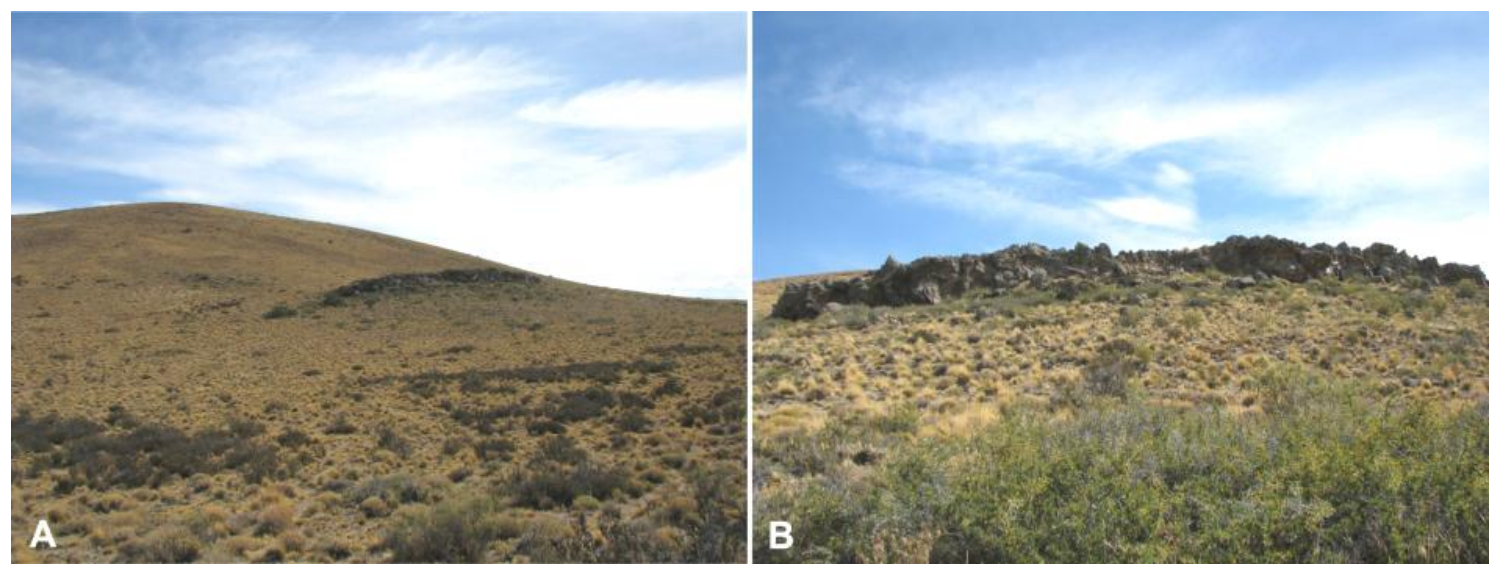

Figura 3.6. Basalto La Angelita: a. Vista del afloramiento basáltico al pie de una lomada; b. Vista de frente.

- Relieve de depresiones endorreicas: innumerables cuencas sin desagüe se encuentran diseminadas por toda la comarca, que en sus sectores más profundos presentan barreales o lagunas temporarias. Estas depresiones constituyen el nivel de base local de erosión, y su forma en planta es por lo general elíptica o subcircular, si bien en los casos de mayor tamaño es muy irregular. Su diámetro oscila entre algún centenar de metros hasta 2 ó $3 \mathrm{~km}$, con profundidades variables ( $\geq 25 \mathrm{~m}$ ), con los cuerpos de agua generalmente recostados sobre uno de los bordes de la cuenca

- Valles del río Deseado y del zanjón del Pescado: otros depósitos de terrazas fluviales, generalmente arenosos con abundantes rodados dispersos, se encuentran en los tramos medios e inferiores de los zanjones Blanco, Rojo y del Zorro, al sur del Bosque Petrificado. 


\section{3. a. 3. Flora y Fauna}

Las condiciones climáticas en el macizo corresponden a clima riguroso, frío y semidesértico, de escasa pluviosidad (en promedio $200 \mathrm{~mm}$ por año). Fitogeográficamente corresponde a la Región Neotropical, y dentro de esta última, al Dominio Andino-Patagónico: Provincia Patagónica (Cabrera 1971). Esta provincia está subdividida en seis distritos (Cabrera 1971), de acuerdo con esta subdivisión, el macizo del Deseado corresponde al distrito Patagónico Central, que comprende la zona más árida de la Patagonia (Figura 3.7.a). Las formaciones vegetales que caracterizan este dominio son altamente xerófilas con arbustos bajos y achaparrados, plantas en cojín o en forma de placas adheridas al suelo, con hojas pequeñas y espinosas.

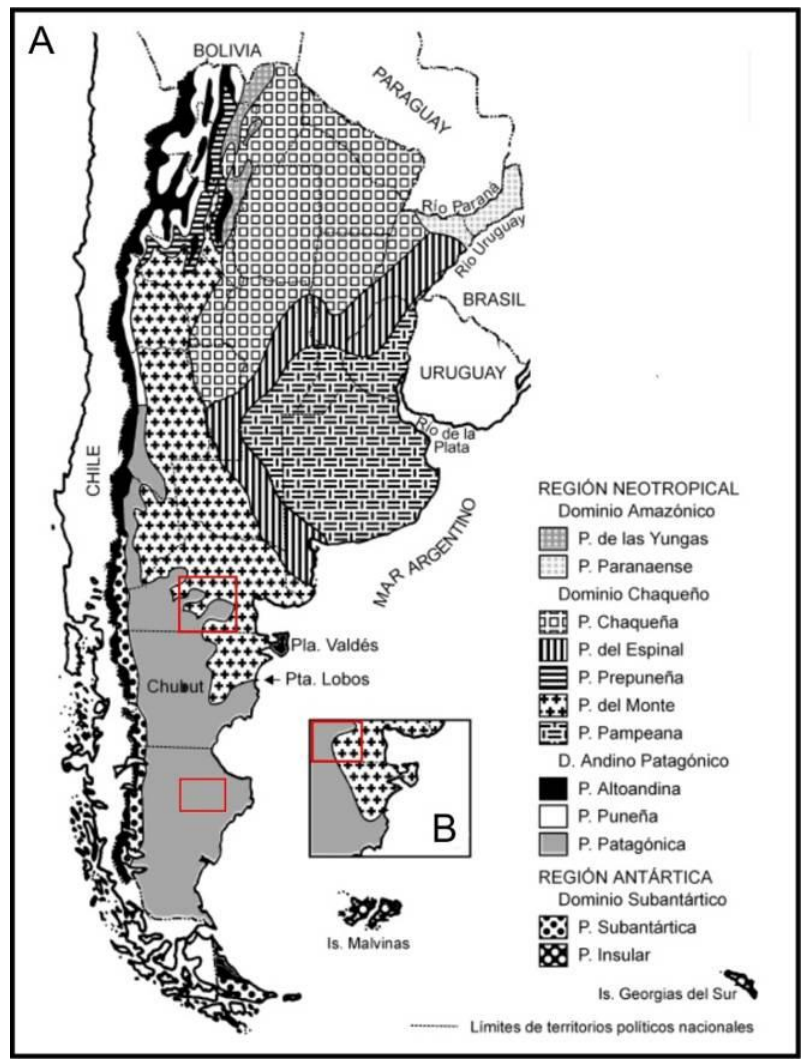

Figura 3.7. Clasificación cartográfica de provincias fitogeográficas argentinas: a. Dominios y provincias según Cabrera (1976). Los recuadros rojos indican indican las regiones en estudio en esta tesis en el ámbito de la Provincia Patagónica; b. el sector SE y transicional entre la Provincia Patagónica y la del Monte. Tomado y modificado de Ribichich 2002: Figura 1. 
La vegetación de la provincia patagónica está adaptada a suelos pedregosos o arenosos pobres en materia orgánica, principalmente debido a la fuerte erosión eólica y a la escasez de agua. En las mesetas y pampas altas predominan las especies graminosas que determinan una estepa herbácea, dominadas por los coirones (Stipa sp.) mientras que las hondonadas y los cañadones más abrigados que conservan más humedad se caracterizan por una mayor presencia de arbustos más altos (Figura 3.8.a). Otro tipo de microambiente está formado por las vegas de ciperáceas y gramíneas (mallines), que a pesar de ser frecuentes ocupan una escasa superficie, asociadas a los valles y a las vertientes con agua permanente (Cabrera 1971; León et al. 1998) (Figura 3.8.b).

Entre los arbustos, predomina la mata negra (Junellia tridens) y Schinus $s p$ (molles). Otras comunidades vegetales importantes son Naussauvia glomerulosa (cola de piche) y Stipa speciosa (coirón amargo). En los cañadones aparecen arbustos como Anarthrophyllum rigidum (mata guanaco), Berberis sp. (calafate) y Senecio sp. (mata mora).

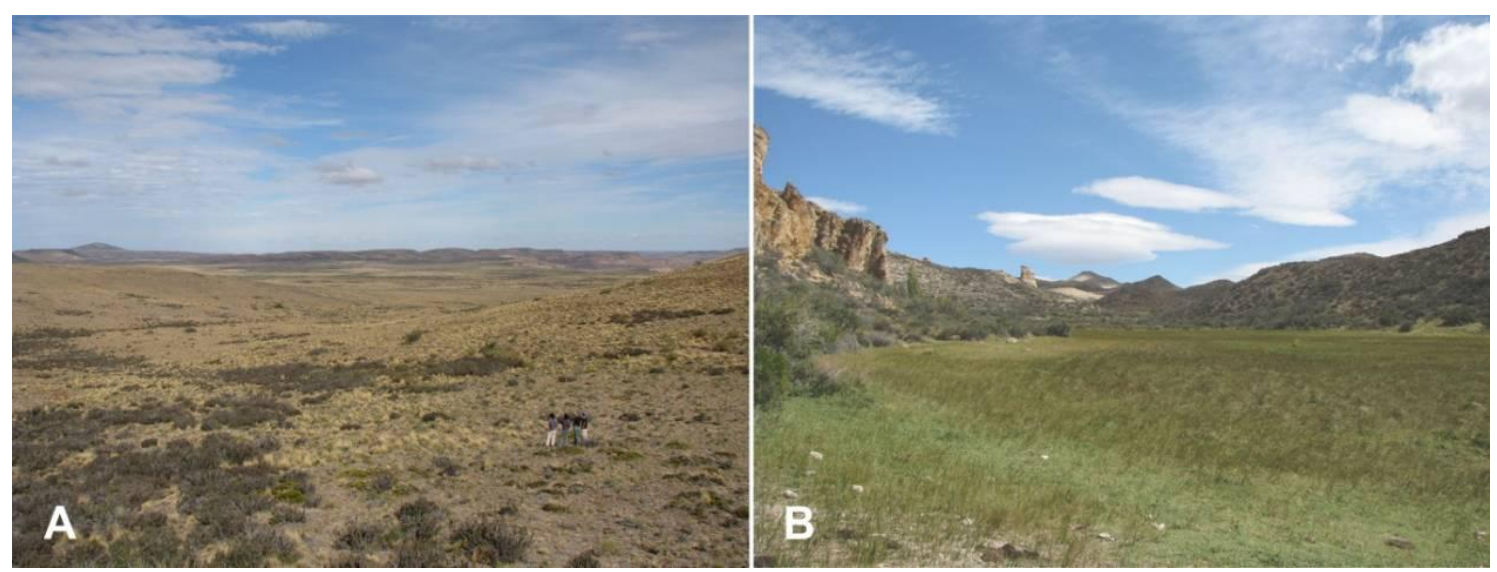

Figura 3.8. Flora: a. En hondonadas, donde predominan Stipa sp. y arbustos; b. Vegas ciperáceas y gramíneas en zonas reparadas, de cañadones.

La porción extra-andina de la provincia de Santa Cruz corresponde zoogeográficamente a la Subregión Patagónica (Provincia Patagónica) de la Región Neotropical (Cabrera y Yepes 1940). Los géneros y especies faunísticas de este distrito están adaptadas a la vida al resguardo de las plantas achaparradas, en general debido al constante viento, a la escasez de 
agua y a los marcados cambios de temperatura diurna, nocturna y estacional.

El guanaco (Lama guanicoe) es el mamífero de mayor tamaño que actualmente habita la región (Figura 3.9.a). Entre las especies más comunes de mamíferos de menor tamaño se pueden mencionar: la comadreja overa (Didelphis), lestodelfo patagónico (Lestodelphis), la mara o liebre patagónica (Dolichotis patagonum) y la vizcacha de la sierra (Lagidium). Los tuco-tucos (Ctenomys) y los Cricetidae son muy abundantes. Los armadillos o edentados están representados por dos especies: el piche (Zaedyus pichiy) y el peludo (Chaetophractus villosus). En el área se encuentran diferentes carnívoros: el puma (Puma concolor) -es el de mayor porte-, el zorro colorado (Canis (Pseudalopex) culpaeus), el zorro gris (Canis (Pseudalopex) griseus), el gato montés (Oncifelis geoffroyi), el zorrino (Conepatus humboldtii) y el huroncito patagónico (Lyncodon), estos últimos de menor tamaño.

La riqueza avifaunística del área es variada. Entre las diferentes especies se pueden citar: el ñandú petiso o choique (Pterocnemia pennata) (Figura 3.9.b), patos (Anas, Oxyura, Merganeta) y macaes, cauquenes o avutardas (Chloephaga), cisnes de cuello negro (Cygnus), flamencos (Phoenicopteridae) y martinetas (Eudromia elegans). Entre las aves rapaces más frecuentes se encuentran el águila escudada o mora (Geranoaetus melanoleucus), el carancho (Polyborus), el chimango (Milvago chimango) y la lechuza del campanario (Tyto alba) (Figura 3.9.c). Además, varias especies de iguánidos (géneros Liolaemus y Diplolaemus) integran la fauna de esta región (Figura 3.9.d). 

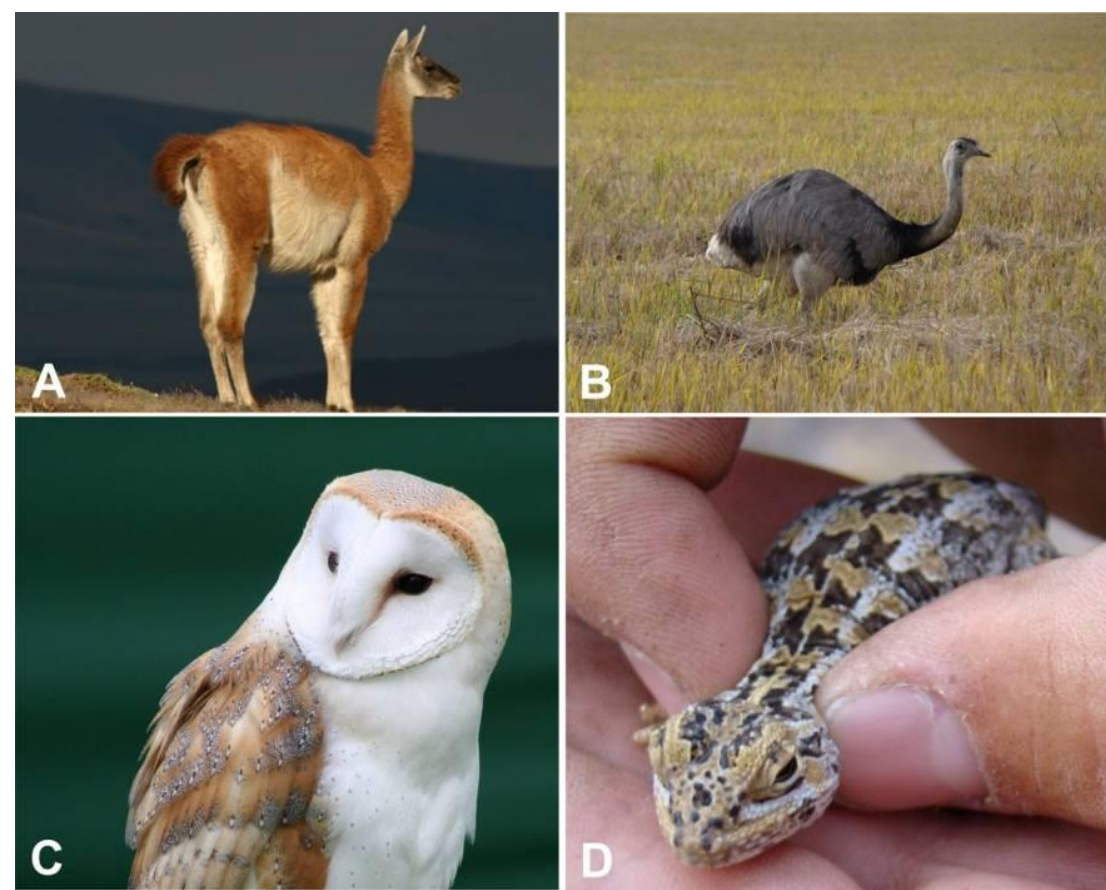

Figura 3.9. Fauna: a. Guanaco; b. Choique; c. Lechuza del campanario; d. Iguánido.

\section{3. b. MACIZO DE SOMUNCURÁ}

\section{3. b. 1. Geologia}

El macizo de Somuncurá cubre una superficie de $55.000 \mathrm{~km}^{2}$ sobre los actuales territorios de Río Negro y Chubut, en la Patagonia extra-andina (Maro y Remesal 2012). Se considera macizo porque representa un segmento de corteza terrestre compuesto por rocas precámbricas y tectónicamente estables respecto de cinturones móviles adyacentes (Brune 1969 en Aguilera 2005: 4). Las rocas que lo constituyen afloran desde la región andina hasta la margen atlántica de manera discontinua, por lo que resulta difícil fijar sus límites (Aguilera 2005; Corbella 1984; Kay et al. 2007; Remesal et al. 2001, entre otros). El magmatismo que le dio origen consistió en un vulcanismo de intraplaca que sucedió en el Terciario, cuyas mayores acumulaciones están constituidas principalmente por basaltos olivínicos de la formación Somun Curá y cuerpos volcánicos que resultaron del desarrollo 
de complejos volcánicos post-plateau (Kay et al. 2004; Maro y Remesal 2012; Remesal et al. 2001, 2012).

El desarrollo de esta altiplanicie se dio sobre una superficie gondwánica de características graníticas que fue afectada por diversos procesos (Aguilera y Rabassa 2010; Llambías et al. 1984; Remesal et al. 2001). Dicha superficie comenzó a desarrollarse en tiempos del Pérmico-Triásico temprano, culminando en el Jurásico tardío-Cretácico medio (Aguilera y Rabassa 2010; Aragón et al. 2010).

Los sitios arqueológicos documentados en el macizo de Somuncurá corresponden a diferentes ocupaciones humanas, asociados a distintas formaciones geológicas. Haciendo énfasis en la porción rionegrina de este macizo, algunos enclaves arqueológicos fueron estudiados puntual y parcialmente entre 1970 y 1980 (García y Pérez de Micou 1980; Gradin 1971, 2003b), otros fueron documentados a finales de 1990 (Albornoz 2003; Albornoz y Pereda 2010). Estos sitios se encuentran sobre la formación Somun Curá. En la misma formación se encuentran los sitios con arte rupestre estudiados en el oriente del macizo (Laguna Azul 1-4; Laguna El Ganso y Bardas de Antonio) y tratados con mayor profundidad en el Capítulo 7 de esta tesis.

Por otro lado, los sitios identificados en los trabajos desarrollados por el equipo de Miotti se encuentran en diferentes formaciones. Por ejemplo, el sitio Amigo Oeste (Terranova 2013) se emplaza en la Superunidad Quiñelaf, en la formación Complejo Volcánico Barril Niyeu. En este sitio se recuperó evidencia correspondiente a diferentes ocupaciones, algunas de las cuales corresponden a la ocupación inicial de este espacio (Miotti y Terranova 2014; Miotti et al. 2011a). En tanto que los sitios con arte rupestre Cueva Martel, Peñón Martel 1 así como los sitios Peñón del Pueblo 1 y 2 se emplazan sobre la formación Complejo Volcánico Barril Niyeu, mientras que el sitio La Porfía se encuentra en la formación Cerro Cortado (ver Capítulo 7). Los afloramientos de ocre detectados se encuentran subyacentes a coladas basálticas de diferentes unidades y corresponden a los sectores superiores del Grupo Sarmiento (Remesal et al. 2001). 
A continuación se caracterizan las formaciones sobre las que se ubican los sitios con arte rupestre presentados en esta tesis. Gran parte de la superficie de este macizo se encuentra cubierta por basaltos olivínicos de la formación Somun Curá (Kay et al. 2004; Maro y Remesal 2012; Remesal et al. 2001, 2012), de color gris y con estructura vesicular o amigdaloide. Los derrames de esta formación "dan origen a una extensa estructura mesetiforme que respondería a la coalescencia de coladas muy fluidas" (Remesal et al. 2011: 26). Los mantos basálticos suelen tener espesor variables y pueden suprayacer a rocas sedimentarias y estar cubiertos por efusiones más jóvenes correspondientes a las Vulcanitas Corona Chico y lavas del Complejo Volcánico Barril Niyeu (Remesal et al. 2001).

La Superunidad Quiñelaf está conformada por diferentes complejos volcánicos post-plateau: Talagapa, Apas, Barril Niyeu, Agua de la Piedra y Pire Mahuida. Cada uno presenta características litológicas propias y podrían considerarse en gran medida contemporáneos entre sí (Remesal et al. 2001). Los dos primeros complejos están ubicados en las sierras homónimas, mientras que el Complejo Volcánico Barril Niyeu tiene su centro de efusión en la porción central de las Sierras de Chatchauñieu, con una amplia extensión, llegando a cubrir basaltos de la formación Somun Curá en la Sierra de Tromen Niyeu y desde Pilquiniyeu hasta Rucu Luan (Remesal et al. 2012).

El Grupo Sarmiento reúne diferentes depósitos piroclásticos, generalmente desvinculados espacial y temporalmente. Son rocas masivas de colores blanquecinos y amarillentos, que cuando se encuentran cubiertos por basaltos, tornan a tonalidades rojizas y rosadas debido a la disipación del calor procedente de dichas coladas. "La abundancia de materias piroclásticas permite vincular su génesis con eventos efusivos significativos y muy probablemente de origen local, relacionados con el emplazamiento del vulcanismo de los Complejos Volcánicos Apas, Talagapa, Agua de Piedra y Barril Niyeu" (Remesal et al. 2001: 24-25). Son estas porciones aflorantes donde se registran materias primas colorantes. 
En el Pleistoceno ocurrieron depositaciones fluviales de flujos densos, cenoglomerados y diatomitas, y la formación Talcahuala caracterizada por la presencia de conglomerados y areniscas aglomeradas (Remesal et al. 2001). Por su parte, en el Holoceno se produjeron depósitos de abanicos aluviales, principalmente cerca de la red de drenaje actual, así como depósitos aluviales, coluviales de bajos y lagunas, y depósitos resultantes de remoción en masa.

\section{3. b. 2. Geomorfologia}

El reconocimiento de las principales geoformas realizado por Aguilera (2005), Remesal et al. (2001) y los trabajos subsiguientes, se basan en el estudio integral del territorio rionegrino efectuado por González Díaz y Malagnino (1984). Entre los rasgos geomorfológicos más conspicuos se encuentran las planicies estructurales lávicas, entre ellas la de Somun Curá (Remesal et al. 2001: 54). Se caracterizan por ser superficies llanas o suavemente onduladas, elevadas respecto de su entorno, con aparatos volcánicos sobrepuestos (Figura 3.10.a) y bajos endorreicos en su superficie (Figura 3.10.b), coladas encauzadas y abanicos aluviales. Su origen se debe al derrame y apilamiento en una superficie de gran extensión, parcialmente llana, de grandes volúmenes de lavas básicas fluidales. La acción diferencial de los agentes erosivos sobre las distintas rocas determinó que las áreas cubiertas por los basaltos se erosionaran mucho menos que su entorno de sedimentitas. En algunos sectores, a las planicies estructurales se han sobreimpuesto aparatos volcánicos de magnitud, por ejemplo, conformando las sierras de Apas y Chatchauñieu.

Los bajos que salpican la superficie de las planicies son de pequeñas dimensiones, no mayores de 2 a $3 \mathrm{~km}^{2}$. Suelen estar ocupados por lagunas efímeras, que cuando se secan dejan al descubierto playas salitrosas o limosas (Figura 3.10.b). Algunos se originaron como ventanas lávicas, ya que las coladas basálticas rodearon lomadas de rocas sedimentarias que 
luego, por erosión diferencial, quedaron convertidas en áreas deprimidas. La posterior ampliación del bajo ocurre por una sumatoria de fenómenos como el sub-lavado, la deflación y la remoción en masa (Croce 1963; Methol 1967).

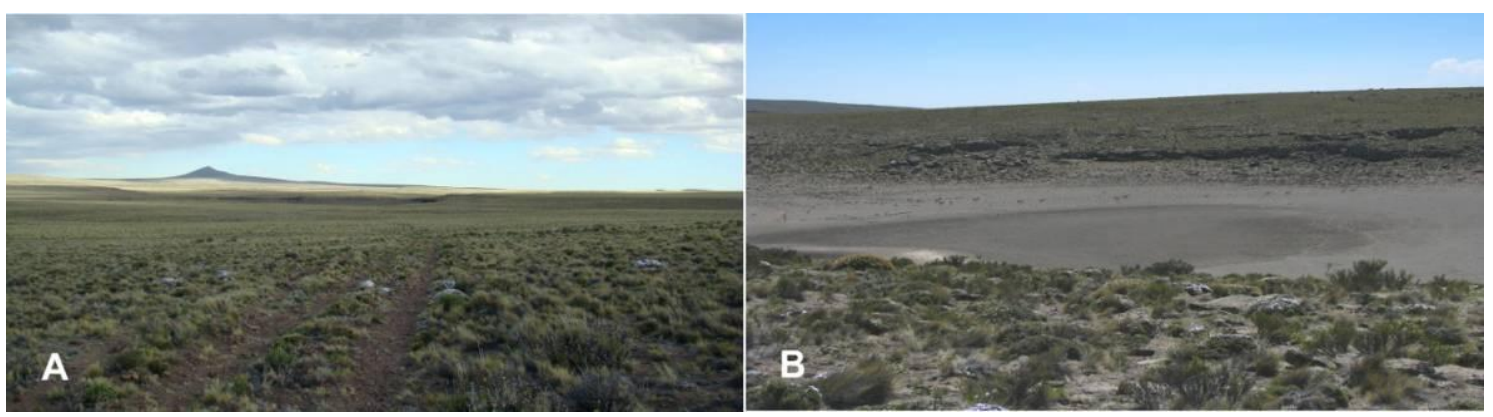

Figura 3.10. Formación Somun Curá: a. Planicie estructural lávica con aparatos volcánicos sobreimpuestos; b. Bajos sin salida que cortan la planicie estructural (Laguna El Ganso).

Otra geoforma característica en algunos sectores de las planicies de la región corresponde a antiguas coladas encauzadas, que, por inversión de relieve, sobresalen a modo de largas y angostas elevaciones: la sierra de Tromen Niyeu, cercana a la localidad de El Caín, es un claro ejemplo (Figura 3.11). Se generó a partir de acumulaciones lávicas que cubrieron depósitos de sedimentitas friables ubicados por encima de coladas basálticas antiguas: las acumulaciones recientes se encauzaron en los cursos labrados en las piroclastitas. Cuando cesaron los procesos volcánicos y comenzaron a actuar los erosivos, se removieron fácilmente las rocas tobáceas más friables, quedando elevadas aquellas áreas cubiertas por las lavas (Remesal et al. 2001: 54-55).

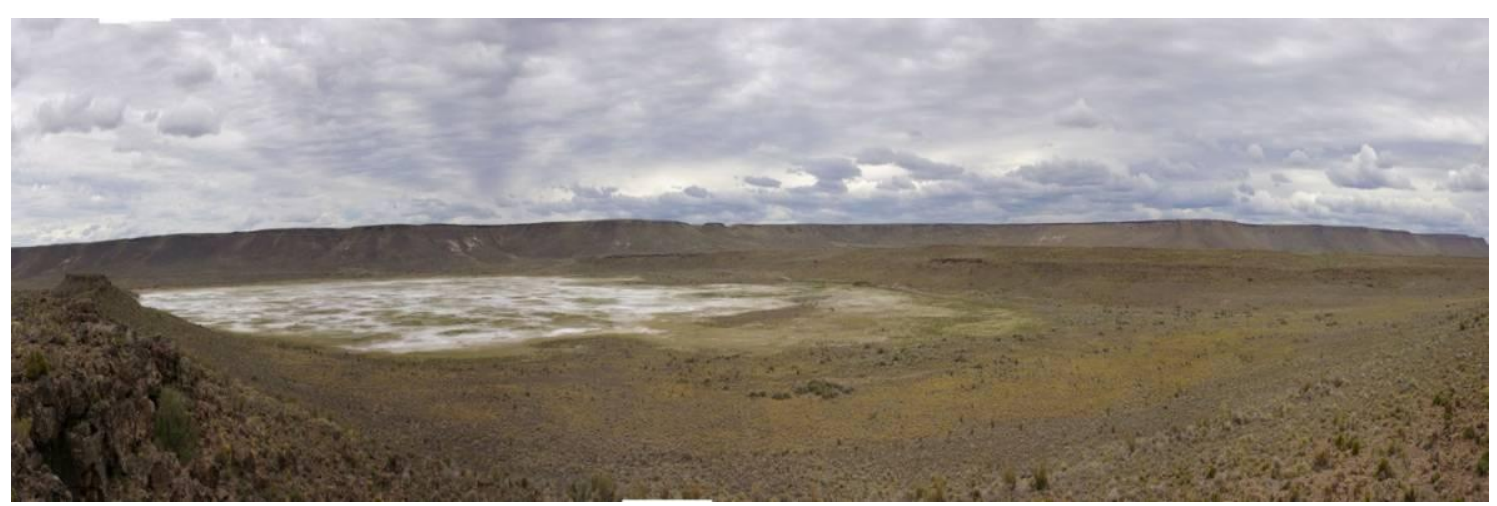

Figura 3.11. Relieve invertido: Sierra de Tromen Niyeu. 
Sobre las planicies estructurales lávicas se hallan depósitos de abanicos aluviales. Entre los ejemplos se mencionan aquellos situados al NW de la sierra de Apas y rodeando a la sierra de Tromen Niyeu, generados a partir de elevaciones que sobresalen del nivel topográfico general de Somun Curá. En el primer caso, el origen corresponde a cursos efímeros que drenan hacia el NW de la sierra de Apas, en tanto que en el segundo caso se trata de cursos efímeros y semipermanentes, como el arroyo Talagapa (Figuras 3.12.a y 3.12.b). Estos cursos efímeros sirven de colectores de las aguas que escurren hacia el norte desde la sierra de Talagapa (en Chubut). En ambos casos se han formado planicies aluviales que cubren las lavas paleógenas de la formación Somun Curá con un delgado, aunque continuo y homogéneo tapiz sedimentario que confiere regularidad al paisaje local (Remesal et al. 2001).

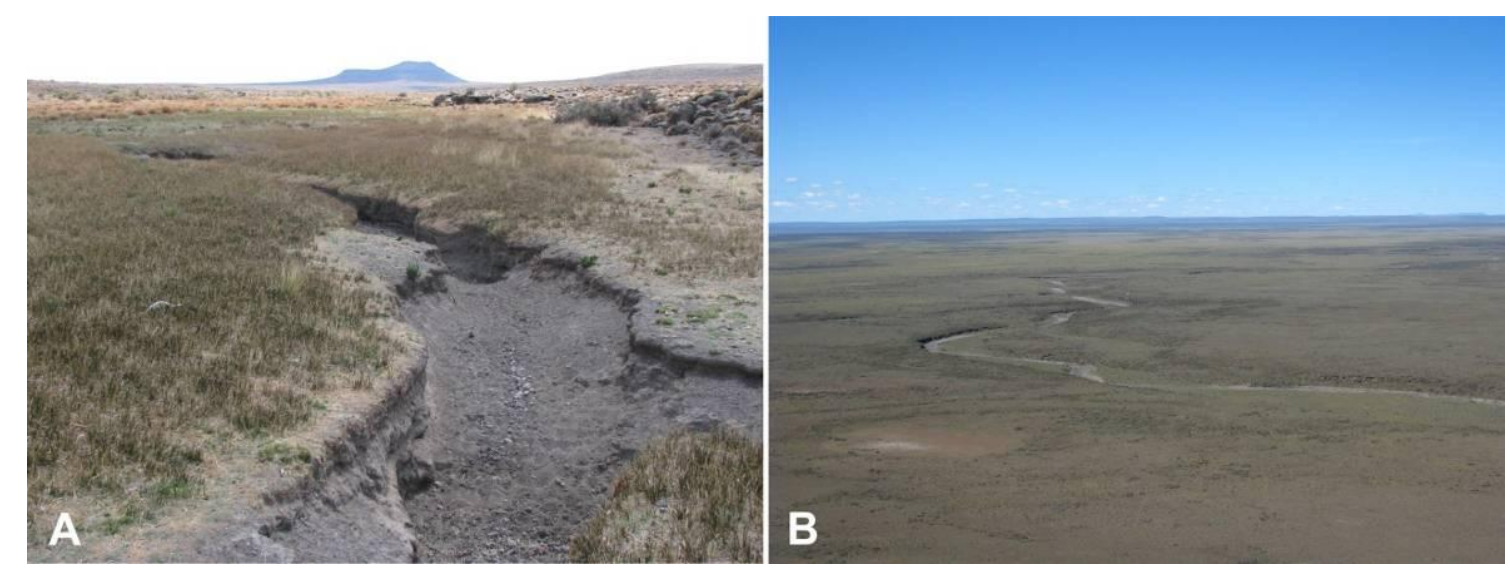

Figura 3.12. Arroyo Talagapa: a. Detalle de su cauce efímero; b. Planicie de inundación sobre la cuenca media del arroyo.

Una geoforma particular es la del bajo de El Caín (Figura 3.13). Es ésta una gran depresión, de unos $30 \mathrm{~km}$ por $15 \mathrm{~km}$. Gran parte del borde norte del bajo está orlado por una faja de deslizamientos, en tanto que en el interior afloran varios cuerpos subvolcánicos de la formación Cerro Cortado. Inicialmente, la profusión de dichos cuerpos debe haber generado un domamiento general en las capas sedimentarias, formándose una estructura positiva que no fue cubierta por las coladas basálticas, aunque tampoco por los flujos piroclásticos derivados de los aparatos volcánicos de la 
Superunidad Quiñelaf. Luego, la erosión diferencial removió la cubierta sedimentaria, iniciándose la elaboración del bajo.

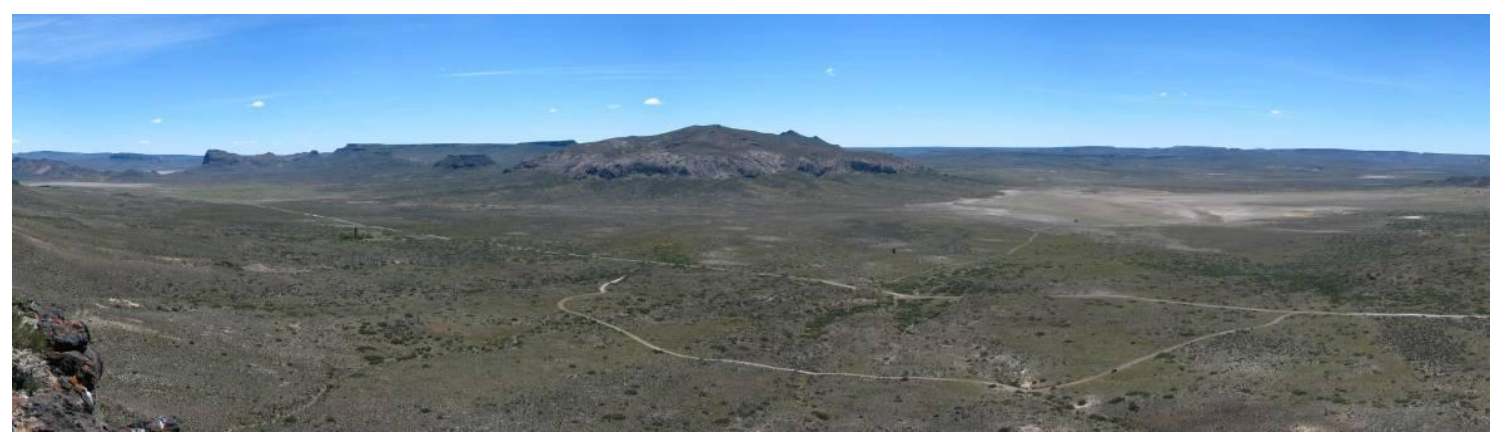

Figura 3.13. Bajo El Caín desde Chorroy Ruca.

Otras geoformas se han desarrollado a partir de la remoción en masa, principalmente en los bordes de las planicies estructurales lávicas, o bien son remanentes aislados de la masa principal, originados por procesos de erosión que dan como resultados mesas y mesillas.

\section{3. b. 3. Flora y Fauna}

El macizo de Somuncurá, al igual que el del Deseado, pertenece a la Región Neotropical, en la que se observa la confluencia de dos dominios: el Chaqueño, representado por la Provincia de Monte, y el dominio AndinoPatagónico representado por la Provincia Patagónica (ver Figura 3.7.b).

El Dominio Chaqueño se caracteriza por presentar un clima variado aunque, en general, predomina el de tipo continental, con lluvias entre moderadas y escasas, inviernos suaves y veranos cálidos. La Provincia del Monte ocupa una gran extensión de las regiones más áridas de la Argentina, desde el paralelo 27 al 44 aproximadamente, desde la provincia de Salta hasta el NE de Chubut (ver Figura 3.7.b). El clima en la porción sur de esta provincia fitogeográfica es árido y fresco, con temperaturas medias alrededor de los $13,4{ }^{\circ} \mathrm{C}$ en el sur. Las máximas y mínimas absolutas alcanzan a los $43,8^{\circ} \mathrm{C}$ y los $-13{ }^{\circ} \mathrm{C}$, respectivamente. Es notable la diferencia entre la temperatura máxima y mínima en el mismo día, como consecuencia 
de la continentalidad y la extrema aridez. Las precipitaciones no superan los $300 \mathrm{~mm}$ anuales, por lo se registra un marcado déficit hídrico en todas las temporadas y en toda la región.

La comunidad vegetal de este distrito es la estepa arbustiva de jarillas y retamo, llamada localmente "jarillar". Las especies dominantes son especies del género Larrea (llamadas comúnmente jarillas) y Chuquiraga sp. (quilembai), las gramíneas como las Poa y Stipa, árboles pequeños como Geoffroea decorticans (chañar), y Schinus fasciculatus (molle), varios algarrobos arbustivos como Prosopis strombulifera (retortuño), Bulnesia retama (retamo), Cassia aphylla (retamilla), Ephedra breana (tramontana), Cercidium australe (retama amarilla); cactáceas como Monttea aphylla (la mata sebo), compuestas como Grindelia chiloensis (botón de oro), Oenothera odorata, Glandularia platense (verbena blanca), Oxalis viscosisima, Petunia axillaris, etc. Se desarrollan, además, estepas de Chuquiraga avellanadae (quilembai), de Naussavia glomerulosa (cola-piche) o de Junellia tridens (mata negra) (Cabrera y Willink 1980). En el fondo de los cañadones se desarrolla vegetación hidrófila.

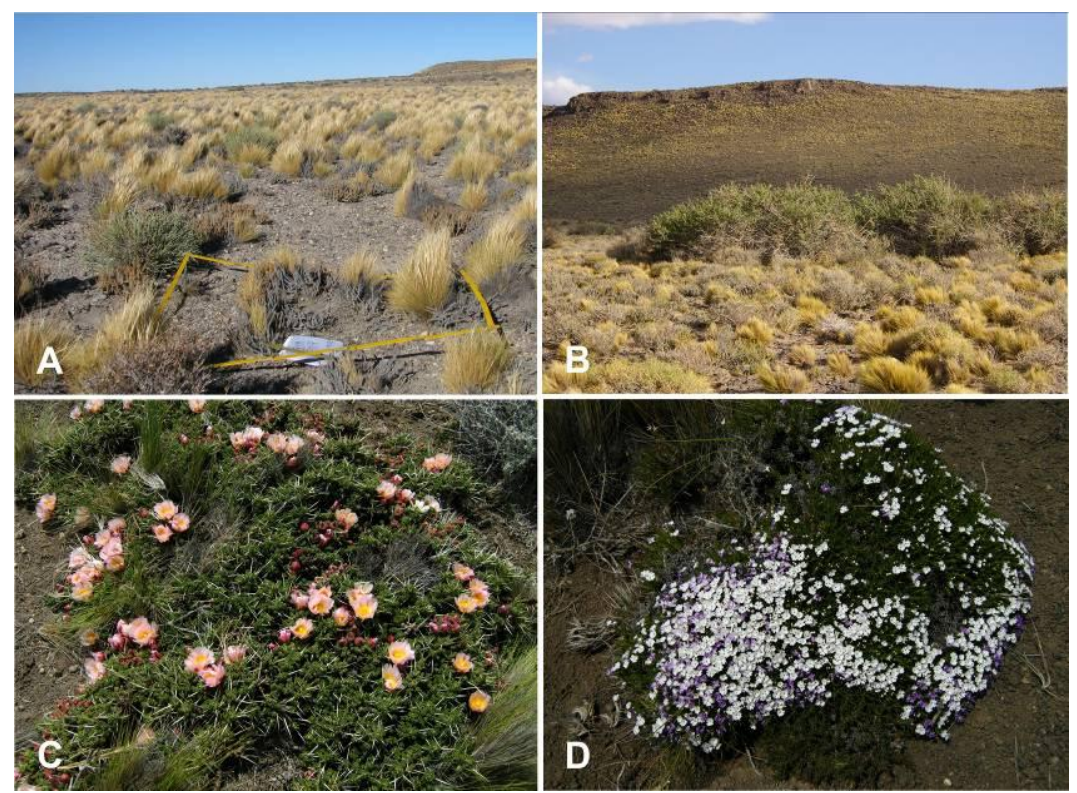

Figura 3.14. Flora de Somuncurá: a. Estepa herbácea; b. Vegetación herbácea y arbustiva; c. Cactácea; d. Glandularia platense (verbena blanca).

La fauna de Somuncurá se corresponde a aquella de la Región Neotropical - Dominio Patagónico, que fue detallado en el Apartado 3. a. 3, 
aunque en el macizo somuncurense existen varias especies endémicas (Vinci 1998). Entre ellas, el pilquín de Somuncurá (Lagidium viscacia somuncurensis), diferentes especies de lagartijas (Liolaemus ruizleali; L. kingi somuncurae; L. elongatus petrophylus), el lagarto cola de piche patagónico (Centaura (Phymaturus) patagonicus somuncurensis), distintos anuros como la rana de Somuncurá (Pleurodema somuncurense) y, entre los peces, la mojarra desnuda (Gymnocharacinus bergei) (Figura 3.15). La presencia de estas especies endémicas le otorga al macizo de Somuncurá importancia por ser un área de biodiversidad sobresaliente en la estepa patagónica y, por lo tanto, de alto valor de conservación (Vinci 1998). En tal sentido, desde 2003 el gobierno de la provincia de Río Negro estuvo trabajando en el desarrollo del plan de manejo del Área Natural Protegida de Somuncurá, el cual entró en implementación efectivamente hace unos años (Plan de Manejo Área Natural Protegida Meseta de Somuncurá Provincia de Río Negro 2007). Dicho plan incluye la normativa necesaria para preservar el medio ambiente de este espacio.

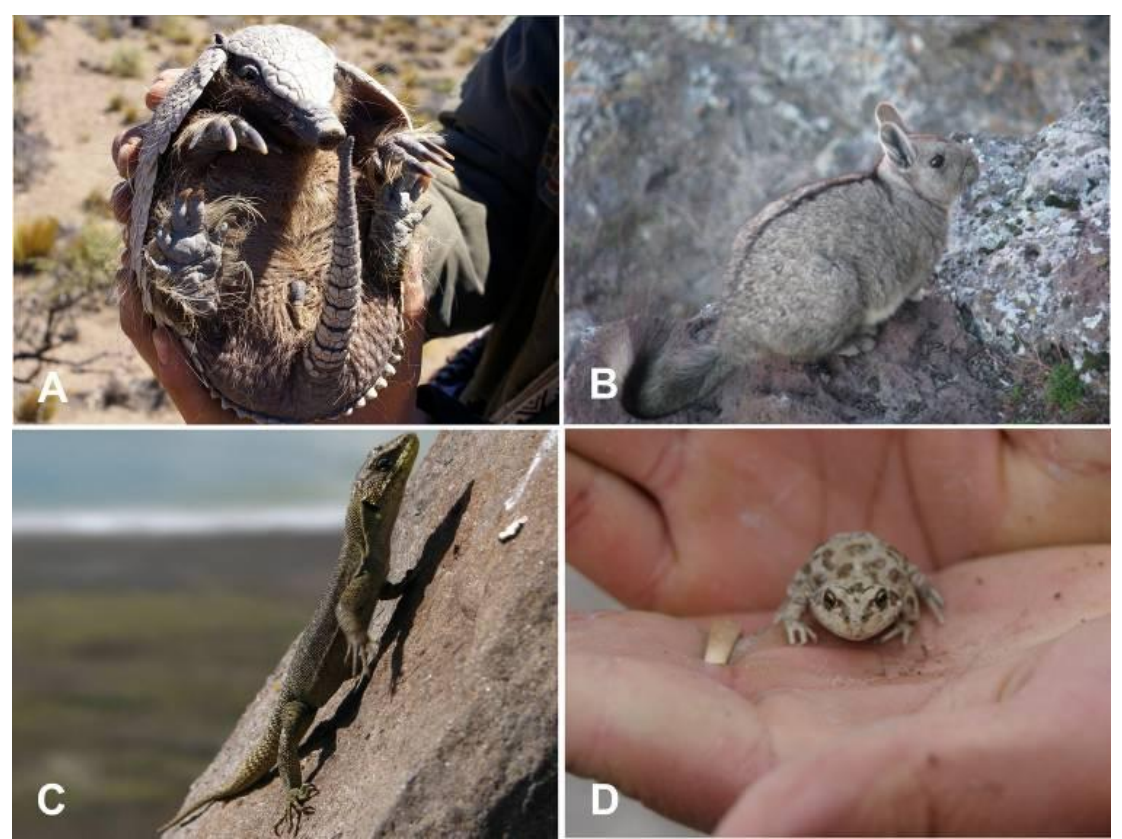

Figura 3.15. Fauna de Somuncurá: a. Piche; b. Pilquín; c. Iguánido; d. Rana de Somuncurá. 


\section{3. c. 1. FACTORES COMUNES ENTRE AMBOS MACIZOS}

Las superficies cubiertas por ambos macizos son relativamente similares; en los dos se observa que las formaciones más importantes son de origen volcánico, aunque también existen formaciones de origen marino y fluviales (Panza 2001; Remesal et al. 2001). Los principales agentes modeladores del paisaje están vinculados a la acción de procesos fluviales y eólicos, y a diferentes procesos volcánicos.

Las geoformas de características mesetiformes predominan en las dos regiones, y también se distinguen sectores con relieve irregular de cerros y picos aislados (Panza 2001; Remesal et al. 2001). Se pueden reconocer como comunes los bajos, los cañadones, los valles o planicies de inundación desarrollados por cursos temporarios y aparatos volcánicos sobreimpuestos.

Respecto a la vegetación, ambos macizos presentan especímenes de la Provincia fitogeográfica Patagónica, a la que en el macizo de Somuncurá se le adicionan especies de la Provincia de Monte. En cuanto a la fauna, ambos se corresponden con la Subregión Patagónica, Dominio Patagónico (Cabrera y Willink 1980).

Las técnicas de producción del arte rupestre registradas en los sitios presentados en esta tesis son recurrentes y, además, muestran soportes similares encontrándose en geoformas parecidas (Tabla 3.1). En el macizo del Deseado los sitios estudiados son La Marianita, Bardas de Carlos y Los Navarros, emplazados en distintos sectores, diferentes formaciones rocosas y con geoformas asociadas que también difieren entre sí. La Marianita se encuentra en la cuenca media del zanjón del Pescado (Figura 3.16), sobre un relicto de sedimentitas en la planicie de inundación de un arroyo temporario. Bardas de Carlos se encuentra en la cabecera norte del Zanjón Blanco $^{1}$, sobre superficies basálticas ubicadas al pie de una lomada, cerca de

\footnotetext{
${ }^{1}$ Esta sectorización se corresponde con los secciones de cabeceras, cuenca media e inferior propuesta por Carden (2008a: 11-12), en la que también se contempla la altitud sobre el nivel del mar de dichas secciones.
} 
una hoyada de deflación, mientras que Los Navarros, ubicado en la cabecera sur del Zanjón Blanco, corresponde a parte de las bardas basálticas que rodean a una laguna temporaria. Si bien las formaciones rocosas en las que se emplazan estos dos últimos sitios son diferentes, todos los motivos registrados corresponden a grabados.

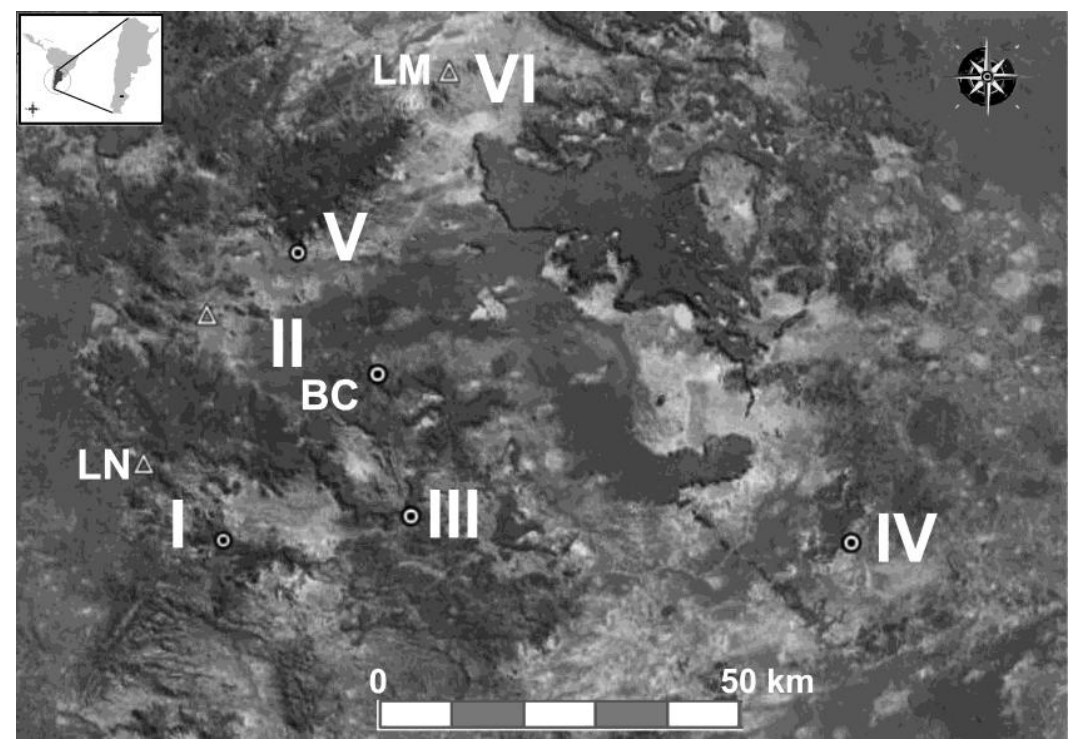

Figura 3.16. Sistemas de cuencas residuales al sur del río Deseado.

Referencias: I) sur de las cabeceras del zanjón Blanco, II) norte de las cabeceras del zanjón Blanco, III) curso medio del zanjón Blanco, IV) curso inferior del zanjón Rojo, V) cabeceras del zanjón del Pescado, VI) curso medio del zanjón del Pescado.

LM: La Marianita; BC: Bardas de Carlos; LN: Los Navarros.

En el macizo de Somuncurá se estudiaron dos espacios distintos: el sector oriental y el centro de la porción rionegrina de dicho macizo. Sin embargo, con la inclusión de los sitios estudiados por otros investigadores se reconocen varias secciones con diferencias altitudinales. Entre ellos podemos mencionar el borde septentrional del macizo, porción NE (sector I) con alturas que oscilan entre 1.000 y 1.250 m.s.n.m., la sierra de Pailemán (sector II) con alturas cercanas a los 400 m.s.n.m (Figura 3.17). El borde centro oriental del macizo (sector III) se encuentra a alrededor de 780 m.s.n.m, en el centro del macizo (sector IV) incluye sitios que se encuentran entre 1.000 y 1.300 m.s.n.m siendo las Sierras de Apas uno de los puntos más altos (Figura 3.17). El borde centro-occidental del macizo (sector V), en las inmediaciones de cerro Castillo, las cotas rondan los 1.250-1.300 
m.s.n.m. Por último, en el NW del macizo (sector VI) las cotas alcanzan 9001.000 m.s.n.m. (Figura 3.17).

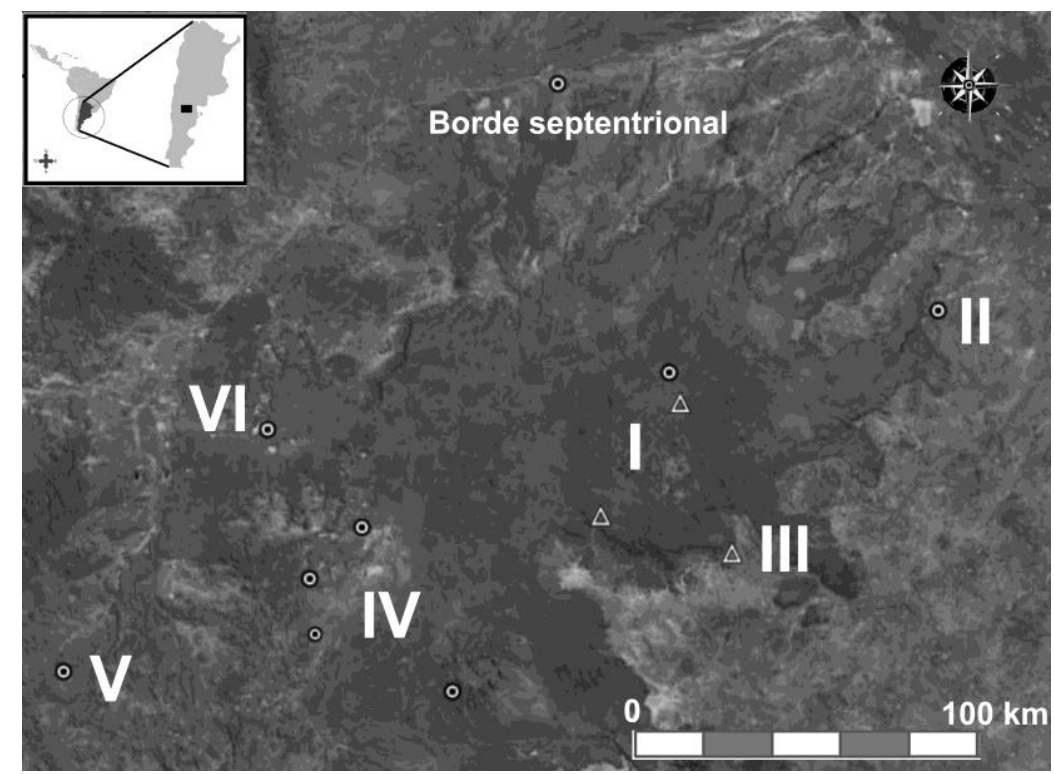

Figura 3.17. Sectores altitudinales reconocidos en Somuncurá

Referencias: I: sector NE; II: sector de Sierras de Pailemán; III: Borde Centrooriental; IV: sector central; V: Borde centro-occidental; VI: sector NW.

Los sitios de la porción oriental presentados en esta tesis (Laguna Azul 14, Laguna El Ganso y Bardas de Antonio) se encuentran el sector I del macizo, en la formación Somun Curá, donde se aprovecharon aleros y/o superficies en espacios reparados para la realización de distintas manifestaciones rupestres. Todos los sitios se encuentran al interior de bajos sin salida y presentan motivos pintados, grabados o pictograbados. Por otro lado, los sitios estudiados en la porción central del macizo (sector IV) presentan motivos pintados y se encuentran asociados a diferentes geoformas: cañadones (La Porfía, Martel), relictos de meseta (Alero Amigo Oeste), arroyos temporarios (Peñón del Pueblo 1 y 2) y bajos sin salida (Vacalauquén) (Tabla 3.1). En los dos macizos la aparición de materias primas colorantes se produce en el contacto entre las rocas basálticas y las sedimentarias subyacentes. 


\begin{tabular}{|c|c|c|c|c|c|}
\hline Macizo & Localidad/Sitio & $\begin{array}{l}\mathrm{n}^{0} \text { de } \\
\text { sitios }\end{array}$ & Afloramientos & Paisaje & Técnica \\
\hline \multirow{3}{*}{ Deseado } & $\begin{array}{l}\text { Bardas de } \\
\text { Carlos }\end{array}$ & 1 & $\begin{array}{c}\text { La Angelita: } \\
\text { basaltos olivínicos }\end{array}$ & $\begin{array}{l}\text { Pequeña barda al } \\
\text { pie de lomada, } \\
\text { cercana a hoyada. }\end{array}$ & Grabado \\
\hline & Los Navarros & 1 & $\begin{array}{c}\text { Alma Gaucha: } \\
\text { basaltos olivínicos }\end{array}$ & $\begin{array}{c}\text { Barda rodeando } \\
\text { laguna. }\end{array}$ & Grabado \\
\hline & La Marianita & 1 & $\begin{array}{l}\text { Laguna Palacios: } \\
\text { relictos de tobas y } \\
\text { tufitas. }\end{array}$ & $\begin{array}{l}\text { Afloramiento al } \\
\text { borde de arroyo } \\
\text { temporario }\end{array}$ & Grabado \\
\hline \multirow{8}{*}{ Somuncurá } & Laguna Azul & 4 & \multirow{3}{*}{$\begin{array}{c}\text { Somun Curá: } \\
\text { basaltos olivínicos }\end{array}$} & $\begin{array}{c}\text { Aleros en borde } \\
\text { de laguna }\end{array}$ & Pintura \\
\hline & El Ganso & 1 & & $\begin{array}{c}\text { Bardas en borde } \\
\text { de laguna }\end{array}$ & Grabados \\
\hline & $\begin{array}{l}\text { Bardas de } \\
\text { Antonio }\end{array}$ & 1 & & $\begin{array}{l}\text { Bardas y alero en } \\
\text { borde de laguna }\end{array}$ & $\begin{array}{c}\text { Grabados, } \\
\text { pintura y } \\
\text { pictograbados } \\
\end{array}$ \\
\hline & La Porfía & 1 & $\begin{array}{l}\text { Cerro Cortado: } \\
\text { basalto }\end{array}$ & $\begin{array}{l}\text { Barda en pequeño } \\
\text { cañadón }\end{array}$ & Pinturas \\
\hline & $\begin{array}{l}\text { Alero Amigo } \\
\text { Oeste }\end{array}$ & 1 & \multirow{3}{*}{$\begin{array}{c}\text { Complejo Volcánico } \\
\text { Barril Niyeu: } \\
\text { basaltos y } \\
\text { traquibasaltos }\end{array}$} & $\begin{array}{c}\text { Alero en relicto de } \\
\text { meseta; cercano a } \\
\text { laguna }\end{array}$ & Pinturas \\
\hline & $\begin{array}{l}\text { Peñón del } \\
\text { Pueblo }\end{array}$ & 2 & & $\begin{array}{l}\text { Alero y cueva en } \\
\text { borde de arroyo } \\
\text { temporario }\end{array}$ & Pinturas \\
\hline & $\begin{array}{l}\text { Cañadón } \\
\text { Martel }\end{array}$ & 2 & & $\begin{array}{l}\text { Cueva y pedrón } \\
\text { reparado en nivel } \\
\text { de base de } \\
\text { cañadón }\end{array}$ & Pinturas \\
\hline & Vacalauquén & 3 & $\begin{array}{c}\text { Complejo Los } \\
\text { Menucos: basaltos }\end{array}$ & $\begin{array}{l}\text { Aleros y paneles } \\
\text { al aire libre, } \\
\text { cercanos a laguna }\end{array}$ & Pinturas \\
\hline
\end{tabular}

Tabla 3.1. Distribución de los sitios con arte rupestre de las áreas en estudio. Referencia: s/d: sin datos. 


\section{Capítulo 4}

\section{ANTECEDENTES SOBRE LOS ESTUDIOS DEL ARTE RUPESTRE}

En este capítulo se sintetizan las investigaciones sobre el arte rupestre de las áreas bajo estudio y de las áreas aledañas a las mismas, así como los estudios actualísticos realizados en Patagonia y aplicados al arte rupestre. La información será presentada, en primer lugar, para el macizo del Deseado y regiones aledañas: la margen norte del río Santa Cruz, las mesetas altas del oeste de la provincia de Santa Cruz, y el sector pedemontano santacruceño (Figura 4.1). El énfasis de la revisión estará puesto en las técnicas de producción y en los correlatos materiales presentes en el arte rupestre o en contextos estratigráficos que permiten evaluar las posibles cadenas operativas vinculadas en su producción (en el sentido de Fiore 2007). Dos tesis doctorales recientes caracterizan la historia de las investigaciones en estas áreas (Carden 2008a; Re 2011), haciendo énfasis en las cronologías y en la descripción y contextualización arqueológica del arte rupestre. Por lo tanto, se remite a los mencionados trabajos para una profundización de dichos temas.

En la segunda parte del capítulo se presenta la información referida a la arqueología del macizo de Somuncurá, la cual no tiene tanta profundidad de estudios como la que se considera en primera instancia; sin embargo, en los últimos años se ha obtenido valiosa información referente a las ocupaciones de este espacio. La evaluación de los antecedentes hace espacial énfasis en la determinación de las técnicas empleadas en la producción del arte 
rupestre $\mathrm{y}$ en los correlatos materiales asociados a dicha actividad en Somuncurá. Luego, se expone la información de tres regiones aledañas: el área de Piedra Parada en la cuenca media del río Chubut, al sur de Somuncurá, el área de Pilcaniyeu e influencias (arroyos Comallo y Pichileufú) y la cuenca superior y media del río Limay, ambas al oeste de Somuncurá (Figura 4.1).

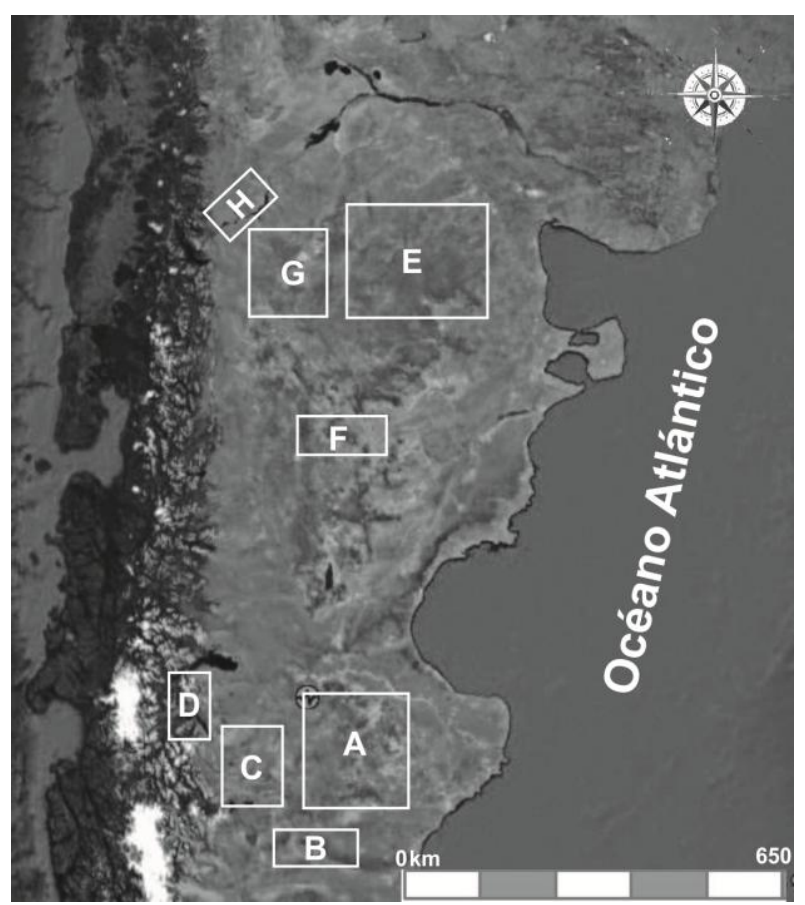

Figura 4.1. Áreas consideradas en este capítulo.

Referencias: A. Macizo del Deseado; B. Margen norte del río Santa Cruz; C.

Mesetas del centro-oeste; D. Piedemonte santacruceño; E. Macizo de Somuncurá; F. Área Piedra Parada (cuenca media Río Chubut); G. Área Pilcaniyeu e influencias; H. Cuenca media y superior del río Limay.

4. a. INVESTIGACIONES ARQUEOLÓGICAS EN EL MACIZO DEL DESEADO

4. a. 1. Investigaciones referidas al estudio tecnológico del arte rupestre

Los sitios tratados en este apartado son resumidos en el Apéndice II.1.a. En el Apéndice II.1.b se presentan los tipos de motivos pintados, los procesos 
de trabajo inferidos a partir de los mismos y sus correlatos materiales, tanto en los motivos rupestres como en contextos estratigráficos. Las mismas variables se consideran para los motivos grabados (Apéndice II.1.c).

A comienzos de la década de 1930 De Aparicio realiza la primera referencia respecto de la presencia de arte rupestre en el macizo del Deseado, dando cuenta de la presencia de pinturas y grabados en el Puesto del Museo (de Aparicio 1933-35). Esta referencia fue retomada por Menghin $(1952,1957)$ para la definición de los estilos de arte rupestre de Patagonia. El esquema planteado por Menghin se basó en sus observaciones acerca del arte rupestre de diferentes estancias del macizo del Deseado (v.g., La Primavera, Los Toldos, La Virginia, La Martita), algunas de las cuales fueron estudiadas posteriormente por otros investigadores.

Respecto de la producción de manos negativas y a partir de su tamaño, Menghin (1952) propone que fueron realizadas por hombres adultos incluso individuos juveniles, aunque posiblemente también participaron mujeres. Años más tarde, plantea que los “... negativos de manos izquierdas [fueron] producidos por la imposición de la mano sobre la pared, salpicando todo el contorno con color" (Menghin 1957: 61). Los grabados del estilo de pisadas “... muestran trazos groseros, elaborados mediante golpes de una burda piedra angular o puntiaguda" (Menghin 1957: 68).

Durante de la década de 1970, Cardich y su equipo comienzan las investigaciones en el Cañadón de Las Cuevas de la estancia Los Toldos (Figura 4.2) (Cardich 1977, 1979; Cardich y Flegenheimer 1978; Cardich y Miotti 1983; Cardich et al. 1973, 1993-94; Miotti 1998, entre otros). En los trabajos inéditos de Cardich et al. 1987 (en Carden 2008a) se reconocen cuali-cuantitativamente los motivos rupestres documentados en la Cueva 2, y se comparan con otros motivos registrados en diferentes cuevas y abrigos de la localidad. Con respecto a las técnicas de producción, se reconoció el estarcido para los negativos de mano, algunos de los cuales se habrían realizado sobre fondos preparados, formando de este modo policromías. Entre las formas negativas también se registró un pie y una pata de 
guanaco aunque no se les adscribe un modo de aplicación de la pintura (Carden 2008a) (Tabla 4.1; Apéndice II.1.b).

A la par de las investigaciones anteriores, Cardich y colaboradores comienzan los relevamientos en la estancia El Ceibo, ubicada $100 \mathrm{~km}$ al sur de Los Toldos (Figura 4.2). Producto de las diferentes excavaciones realizadas en dicha estancia se recuperaron materias primas colorantes en estratigrafía (Apéndice II.1.b). En la estancia La Reconquista (Figura 4.2), a poco más de $50 \mathrm{~km}$ hacia el NW de la anterior, Arrigoni (1996) aporta información sobre la "Cueva de Los Yaguaretés" reconociendo a la pintura como única técnica de producción de los motivos, en los que se combinan uno o más colores. La autora menciona que la pintura fue aplicada con la yema de los dedos sobre fondos preparados y menciona, además, la presencia de negativos de mano aunque no propone una técnica específica de producción (Tabla 4.1).

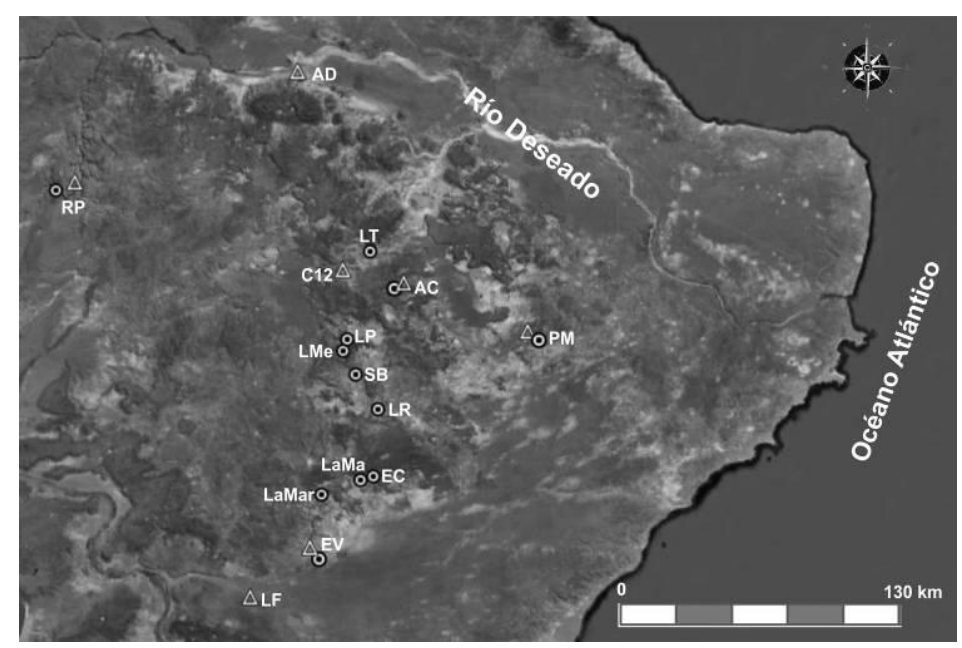

Figura 4.2. Localidades y sitios con manifestaciones rupestres tratados en este apartado. Referencias: AD: Angostura del Deseado; LT: Los Toldos; C12: Cerro del Doce; AC: Aguada del Cuero; PM: Piedra Museo; LP: La Primavera; LMe: Las Mercedes; SB: Sierras Blancas; LR: La Reconquista; LaMa: La María; EC: El Ceibo; LaMar: La Martita; EV: El Verano; EF: Estancia La Flecha; ARP: Área Río Pinturas. Referencias: triángulo: grabados; círculos: pinturas.

Contemporáneamente a los trabajos de Cardich en el norte y sureste de la región, Gradin y equipo realizan trabajos sistemáticos en el límite noroccidental del macizo, en el Área del Río Pinturas (Aguerre 1977; Aguerre y Gradin 2003; Barbosa y Gradin 1986-87; Gradin 1977, 1980, 1981-82, 1983; Gradin y Aguerre 1994; Gradin et al. 1976, 1979; Mengoni 
Goñalons y Silveira 1976; Silveira 1979, entre otros). Sobre la base de la integración de estos diferentes tópicos se planteó una secuencia de ocupación humana para el Área del río Pinturas, caracterizada por diferentes niveles culturales (Gradin et al. 1979).

Con respecto a las técnicas de producción del arte rupestre reconocidas en el sitio Cueva de las Manos, para los motivos circulares de cuerpo lleno ubicados entre $10 \mathrm{~m}$ de distancia al suelo, Gradin (1984) y Aschero (2012a) proponen la utilización de bolas arrojadizas cubiertas con cuero, o algún material que pueda ser embebido en pintura. Éstas eran arrojadas contra el techo dejando la impronta de pintura (Tabla 4.1; Apéndice II.1.b). Esta misma técnica se habría empleado en diferentes sitios de La Magdalena y en Cerro de los Indios (Aguerre y Gradin 2003; Gradin 1984; Apéndice II.1.b). Por otro lado, Gradin y colaboradores proponen que la técnica del negativo fue utilizada para pintar manos y pies humanos, patas de ñandú y objetos de forma circular, reconociendo que algunos negativos de mano fueron realizados sobre fondos preparados con una base de pintura (Apéndice II.1.b). Como técnica de producción para los negativos de mano también distinguen el "fileteado" o delineado del contorno de la mano con pintura (Gradin 1984; Gradin et al. 1976, 1979) (Tabla 4.1). Los diferentes tamaños de los negativos de mano relevados en la Cueva Grande del Arroyo Feo permitieron reconocer la participación de individuos de diferentes edades niños y adultos- en la producción de dichos motivos (Gradin 1981-82). Estas estimaciones fueron empleadas en otros sitios de Patagonia (Aguerre y Gradin 2003; Carden 2008a; Carden y Blanco 2013; Paunero et al. 2005). Aguerre y Gradin (2003) proponen que algunos motivos del Alero Hugo pudieron haber sido realizados con pincel debido a la finura de su trazo (Apéndice II.1.b).

Los estudios mineralógicos realizados dan cuenta de los componentes de las materias primas colorantes, de los aditivos añadidos a las mezclas y de la preparación de los soportes. Este tipo de análisis fue efectuado en diferentes sitios del río Pinturas y permitió reconocer los minerales utilizados en las mezclas, el uso de yeso entre los componentes de las 
mezclas así como en la preparación del soporte (Barbosa y Gradin 1986-87; Gradin 1984; Gradin et al. 1979; Iñíguez y Gradin 1977).

En la cuenca del río Pinturas, los sitios que presentan motivos grabados son escasos. Entre ellos se mencionan Alero Rosamel y Alero Parado. En el primer sitio se reconocieron la pintura, el grabado y la combinación de ambas como técnicas principales utilizadas en la producción de motivos rupestres. Los grabados de Alero Rosamel corresponden a motivos realizados por picado relativamente profundo así como de trazos finos y sinuosos (Aguerre y Gradin 2003). Para el sitio Alero Parado se propone que los grabados fueron realizados con puntas burilantes de obsidiana, inferencia que se basa en la presencia de más de 40 ejemplares de dichos instrumentos en el talud del alero (Aschero 2012b) (Apéndice II.1.c).

Los relevamientos efectuados en los sitios con arte rupestre del área de La Martita fueron realizados a finales de la década de 1970 y publicados años más tarde (Durán 1983-85; Gradin y Aguerre 1983). Gradin y Aguerre (1983) presentan la información sobre 30 sitios con motivos mayoritariamente pintados. En el sitio Cañadón Viuda Quenzana 4 -sector E- se documentaron los únicos motivos grabados subyacentes a puntiformes polícromos, que podrían haber sido realizados por raspado (frotación en términos de Gradin y Aguerre 1983). Estos autores reconocen la aplicación de la pintura usando la yema de los dedos para La Evelina, Los Guanaquitos 1, Viuda Quenzana 9; mientras que para los negativos de mano reconocen dos manos fileteadas en Viuda Quenzana 4A (Apéndice II.1.b). Durante los últimos años, La Gruta y Viuda Quenzana fueron revisitados por Franco et al. (2013), quienes reconocieron motivos adicionales a aquellos reconocidos previamente por Gradin y Aguerre.

A $140 \mathrm{~km}$ al sur de Los Toldos se encuentra la localidad arqueológica El Verano (Figura 4.2), donde se relevaron 14 cuevas y aleros con manifestaciones rupestres (Durán 1983-85). Los sitios con motivos grabados son cinco, siendo La Cantera 6 el único que cuenta con grabados de modo exclusivo. Los restantes sitios con arte rupestre presentan motivos pintados (Tabla 4.1; Apéndices II.1.a y II.1.b). Para los sitios con grabados, el autor 
reconoce a la percusión con surco en "U" como técnica de producción, excepto para La Cantera 4 donde adicionalmente reconoce la incisión fina (con surco en "V") en la realización de un reticulado y líneas paralelas (Durán 1983-85). Entre las técnicas que comportan la aplicación de pintura reconoce la realización de negativos mediante el "salpicado" y el pincelado o "fileteado" del contorno de la mano (Apéndice II.1.b). Lamentablemente, Durán no define qué entiende por salpicado, el cual podría corresponderse con el uso de algún implemento embebido en pintura o la aplicación de ésta directamente con la boca y/o utilizando algún intermediario. Menciona, igualmente, la preparación del soporte previamente a la aplicación de pintura, mediante abrasión de la superficie en el sitio El Verano Cueva 1 (Apéndice II.1.b)

Inferencias con respecto a las técnicas de producción de motivos rupestres son realizadas por Gradin (2003c) para el sitio La Flecha, ubicado a $160 \mathrm{~km}$ al SW de Los Toldos (Figura 4.2), integrado por grabados, pinturas y pictograbados. Si bien este autor no refiere explícitamente a las técnicas de producción, algunas de ellas pueden reconocerse en los diagramas e imágenes presentados. Por ejemplo, para la Hoja 1 menciona la presencia de puntos picados así como trazos rectos incisos y finos, mientras que para la Hoja 2 da cuenta de dos tipos de motivos que son de trazo fino, uno de ellos realizado mediante incisión y un tercero realizado por picado grueso (Gradin 2003c: 136). Además, en la Hoja 12 presenta un motivo con picado fuerte, planteando la posibilidad de su ejecución con un punzón (Gradin 2003c: 124). A partir de estas observaciones, y ajustándolas a las definiciones presentadas en el Capítulo 2 de esta tesis, es posible inferir que Gradin plantea a la percusión directa como principal técnica de grabado, reconociendo además el empleo de la incisión y de la percusión indirecta (con intermediario, en este caso punzón) (Apéndice II.1.c). Además, menciona la presencia de un motivo conformado por trazos verticales pintados y grabados intercalados (Tabla 4.1; Apéndice II.1.b).

Con la salvedad de la visita a la localidad efectuada por De Aparicio, las investigaciones arqueológicas en Piedra Museo comenzaron a finales de 
1980, extendiéndose durante la década de 1990 y los años siguientes (Cattáneo 2002; Giardina et al. 2000; Marchionni 2013; Miotti 1992, 1996, 2000, 2008, 2012; Miotti y Cattáneo 1997, 2003; Miotti y Salemme 2003, 2005; Miotti et al. 1999b).

En la localidad se registraron dos sitios con pinturas y grabados en el interior de espacios reparados (Carden 2007, 2008a, 2009b; Miotti 1991; Miotti y Carden 2007; Miotti et al. 1999a). Respecto de la técnica de producción de los grabados, de Aparicio (1933-35) menciona que "Es importante advertir el procedimiento seguido para grabar las líneas mediante una sucesión de puntos que luego han unido entre sí. Las líneas punteadas que aparecen no son, posiblemente, sino lineas en un primer estadio de grabación” (de Aparicio 1933-35: 85). A partir de esta descripción puede pensarse que los grabados fueron realizados por hoyuelos producto de la horadación o de la percusión, y que luego fueron unidos entre sí con alguna otra técnica.

El estudio in situ sobre el arte rupestre de la localidad fue continuado por Miotti (1991), quien propone a partir de la observación macroscópica de los surcos grabados la utilización de tres técnicas de producción: el piqueteado, el raspado y la incisión. Por la información brindada por Miotti (1991) no se puede estimar si el piqueteado fue directo o indirecto para esa autora. El estudio pormenorizado de las frecuencias y tipos de motivos, sus asociaciones espaciales al interior de los paneles y entre los sitios fue realizado por Carden (2007, 2008a, 2009a). Esta autora propone, también a partir de la observación macroscópica de los surcos, el empleo de cuatro técnicas para la confección de los distintos motivos grabados: el picado (i.e., percusión usando un intermediario), la horadación, la incisión y el "alisado", este último término considerado como sinónimo de raspado y que habría sido empleado para la terminación de algunos motivos. Estas técnicas pudieron haber sido usadas de manera individual o combinada para la confección de diferentes motivos (Carden 2008a: 319-323) (Tabla 4.1; Apéndice II.1.c).

Con respecto a las pinturas, Carden (2008a: 216) considera que en Piedra Museo la técnica más común fue el negativo, aunque también reconoce al 
"fileteado" o delineado del contorno de la mano y al enmarcado de manos en círculos u óvalos, empleando en este último caso dos o más colores (Tabla 4.1; Apéndice II.1.b).

Blanco y Lynch (2011) realizan el primer acercamiento experimental a las técnicas de producción inferidas para los sitios de Piedra Museo. Mediante la utilización de bloques experimentales de arenisca coquinoide y de artefactos de diferentes materias primas, formatizados y no formatizados, realizan 42 marcas grabadas que les permiten reconocer macro- y microscópicamente las técnicas de incisión, horadación y raspado.

Las localidades arqueológicas de Aguada del Cuero y Cerro del Doce se encuentran a $20 \mathrm{~km}$ al SE y 10 al $\mathrm{SW}$ de Los Toldos, respectivamente (Figura 4.2). Ambas localidades comenzaron a ser estudiadas hacia finales de 1990 por Miotti y colaboradores (Miotti et al. 1999a; Miotti et al. 2005). A partir de estas investigaciones se conocieron los momentos iniciales de ocupación -correspondientes al Holoceno tardío- en los sitios Cueva Moreno y Cueva de la Hacienda. Además, se efectuó un análisis preliminar de la tecnología lítica y de las manifestaciones rupestres pintadas de ambos abrigos (Miotti et al. 2005). Posteriormente, estos sitios fueron incluidos en el análisis de Carden (2008a, 2009a). Esta autora considera que debido a la altura respecto del suelo a la que se encuentran los motivos circulares del sector 1 en Cueva de la Hacienda (en la actualidad superior a 2 metros), su realización habría implicado la colaboración de dos o más personas, mientras que para el sector 2 del mismo sitio observa que un negativo de mano presenta estarcido de pintura por debajo de la muñeca (Apéndice II.1.b). Si bien señala que este último motivo es llamativo, no plantea alternativas en cuanto a las técnicas de ejecución (Carden 2008a).

Contemporáneamente a estos trabajos se estudiaron los grabados de los sitios Laguna Cerro del Bonete, La Leonera y Bardas del Doce. Los dos primeros se encuentran en la localidad Aguada del Cuero y el tercero en la localidad Cerro del Doce (Carden 2004, 2008a, 2008b, 2013; Miotti et al. 1999a). Carden (2008a) realiza una serie de inferencias sobre las técnicas de producción empleadas en cada uno de los sitios a partir de la observación 
macroscópica de los surcos grabados, los cuales son discontinuos. Por ejemplo, para Laguna Cerro del Bonete infiere que la mayor parte de los motivos fueron realizados por percusión, siendo que para los motivos más complejos se habrían utilizado dos artefactos -i.e., percusión indirecta o picado- a fin de lograr trazos dirigidos y precisos, aunque observa casos en los que se utilizó la incisión o el raspado para grabar las superficies basálticas (Apéndice II.1.c). Los motivos de La Leonera y Bardas del Doce presentan surcos superficiales, por lo que Carden (2008a: 245) considera que fueron realizados por percusión indirecta. En el primer sitio, a algunos motivos se le superponen incisiones finas y otros motivos por raspado (Tabla 4.1; Apéndice II.1.c).

Las investigaciones en la localidad La Primavera comenzaron en los albores del nuevo siglo, y son continuadas en la actualidad con una profundización del conocimiento que se tiene de la misma (Carden 2008a; Hermo 2008; Hermo y Magnín 2012; Magnín 2010; Marchionni 2013; Marchionni et al. 2010, 2012; Miotti 2010a, 2012; Miotti y Marchionni 2009, 2011; Miotti et al. 2007b, 2007c, 2009d, 2011b). Asimismo, se encuentran bajo estudio las localidades aledañas de Las Mercedes, Sierras Blancas y Los Ventisqueros. Se registraron 18 sitios con pinturas, entre las cuales los motivos más abundantes son los negativos de mano (Carden 2008a, 2013), que en algunos casos fueron realizados sobre un fondo preparado con pintura. Carden infiere que los negativos fueron realizados mediante el estarcido de pintura, técnica que también fue utilizada para realizar manchas de contorno circular en La Primavera 2 (Carden 2008a) (Apéndice II.1.b). En los sitios La Primavera 5 y Sierras Blancas 2 algunos motivos pudieron haber sido realizados aplicando la pintura directamente con los dedos; en términos de la autora, líneas de dígitos o arrastres de dedos (Carden 2008a) (Tabla 4.1; Apéndice II.1.b).

Las investigaciones en La María comenzaron en la década de 1980 (Cardich et al. 1981-82), con el estudio de materiales de superficie y del arte rupestre (Cardich 1987; Franchomme 1987). Durante la década de 1990 y años posteriores los estudios fueron continuados por Paunero y su equipo de 
trabajo, al inicio poniendo el énfasis en el reconocimiento y distribución de sitios (Paunero 2000a, 2000b, 2000c; Paunero et al. 2005), para luego comenzar con las excavaciones (Paunero 2003a, 2003b; Paunero et al. 2005; Frank 2011; Skarbun 2009). Entre los trabajos iniciales respecto del arte rupestre se pueden mencionar las tareas experimentales de replicación de negativos de mano realizadas por Paunero $(1992,1994)$, en los que presenta la manera de preparar las mezclas pigmentarias y donde sostiene que la distancia y el ángulo de aplicación de la pintura son importantes para obtener un tamaño similar entre el negativo y la mano usada como plantilla.

Paunero y colaboradores efectúan una caracterización inicial del arte rupestre de La María, señalando la presencia de 65 sitios con arte rupestre, de posibles canteras de aprovisionamiento de materias primas colorantes, además de mencionar brevemente las técnicas reconocidas en la producción de los motivos pintados. Entre estas últimas distinguen entre aquellas en las que se emplea un artefacto para aplicar la mezcla pigmentaria de las que no. Entre las primeras, denominadas técnicas indirectas o instrumentales, la pintura se aplica mediante el uso de pinceles o hisopos (medianos o gruesos) y de elementos finos o muy finos, siendo un ejemplo de este último el delineado. Entre las técnicas en las que se coloca la pintura directamente sobre los soportes rocosos reconocen el estarcido (soplando la pintura con la boca), la digital y la palmar (Paunero et al. 2005: 158). Infieren, además, la participación de dos o más actores en la realización de negativos, siendo los ejemplos más evidentes los de los negativos de manos de bebé y de niños (Paunero et al. 2005: Lámina 2e). Aunque los autores no mencionan cuáles son los motivos realizados mediante las diferentes técnicas, a partir de una de las figuras presentadas se observan negativos de mano realizados por estarcido directo, un motivo tricolor radial presumiblemente realizado mediante la técnica digital y un abstracto bilateral realizado mediante un pincel o hisopo (Paunero et al. 2005: figura 6) (Tabla 4.1; Apéndice II.1.b). 


\begin{tabular}{|c|c|c|c|c|c|c|c|c|c|c|c|c|c|c|c|c|c|c|}
\hline \multirow{3}{*}{ Ubicación } & \multirow{3}{*}{ Localidad } & \multicolumn{15}{|c|}{ TÉCNICAS } & \multirow{3}{*}{$\begin{array}{c}\text { Materiales en } \\
\text { estratigrafía } \\
\text { vinculados a } \\
\text { producción de pinturas }\end{array}$} & \multirow{3}{*}{ Autor } \\
\hline & & \multicolumn{9}{|c|}{ Pintura } & \multicolumn{5}{|c|}{ Grabado } & \multirow{2}{*}{\begin{tabular}{|l} 
Comb \\
P y G \\
\end{tabular}} & & \\
\hline & & Neg & $\mathrm{F}$ & $\mathrm{E}$ & $\mathrm{S}$ & $\mathrm{PP}$ & Dig & Mon & Bicr & Policr & $\mathrm{Pe}$ & Pind & $\mathrm{I}$ & $\mathrm{R}$ & $\mathrm{H}$ & & & \\
\hline \multirow{9}{*}{$\begin{array}{l}\text { Macizo del } \\
\text { Deseado } \\
\text { Norte }\end{array}$} & Los Toldos & $\mathrm{X}$ & $\mathrm{X}$ & - & - & $\mathrm{X}$ & - & $\mathrm{X}$ & $\mathrm{X}$ & $\mathrm{X}$ & - & - & - & - & - & - & 2 & $\begin{array}{c}\text { Cardich et al 1987; } \\
\text { Carden 2008a }\end{array}$ \\
\hline & Piedra Museo & $\mathrm{X}$ & $\mathrm{X}$ & - & - & - & - & $\mathrm{X}$ & $\mathrm{X}$ & - & & $\mathrm{X}$ & $\mathrm{X}$ & $\mathrm{X}$ & $\mathrm{X}$ & - & $\mathrm{X}$ & $\begin{array}{c}\text { Carden 2008a; Miotti } \\
1991\end{array}$ \\
\hline & A del C & $\mathrm{X}$ & - & - & - & $\mathrm{X}$ & - & $\mathrm{X}$ & - & - & - & - & - & - & - & & - & \multirow{7}{*}{ Carden 2008a } \\
\hline & Bajo Pantano & $\mathrm{X}$ & - & - & - & - & - & $\mathrm{X}$ & $\mathrm{X}$ & & - & - & - & - & - & - & - & \\
\hline & La Primavera & $\mathrm{X}$ & - & $\mathrm{X}$ & - & $\mathrm{X}$ & $\mathrm{X}$ & $\mathrm{X}$ & $\mathrm{X}$ & $\mathrm{X}$ & - & - & - & - & - & - & $\mathrm{X}$ & \\
\hline & $\begin{array}{c}\text { Los } \\
\text { Ventisqueros }\end{array}$ & $\mathrm{X}$ & - & $\mathrm{X}$ & - & $\mathrm{X}$ & - & $\mathrm{X}$ & - & - & - & - & - & - & - & - & - & \\
\hline & $\begin{array}{c}\text { Cañadón de la } \\
\text { Víbora }\end{array}$ & $\mathrm{X}$ & - & - & - & $\mathrm{X}$ & & $\mathrm{X}$ & - & - & - & - & - & - & - & - & - & \\
\hline & $\begin{array}{l}\text { Sierras } \\
\text { Blancas }\end{array}$ & $\mathrm{X}$ & - & - & - & $\mathrm{X}$ & $\mathrm{X}$ & $\mathrm{X}$ & - & - & - & - & - & - & - & - & - & \\
\hline & Las Mercedes & $\mathrm{X}$ & - & - & - & $\mathrm{X}$ & - & $\mathrm{X}$ & - & - & - & - & - & - & - & - & - & \\
\hline \multirow{6}{*}{$\begin{array}{c}\text { Macizo del } \\
\text { Deseado Sur }\end{array}$} & La María & $\mathrm{X}$ & $\mathrm{X}$ & $\mathrm{X}$ & - & $\mathrm{X}$ & $\mathrm{X}$ & $\mathrm{X}$ & $\mathrm{X}$ & $\mathrm{X}$ & - & - & - & - & - & - & $\mathrm{X}$ & Paunero et al. 2005 \\
\hline & El Ceibo & $\mathrm{X}$ & - & - & - & $\mathrm{X}$ & - & $\mathrm{X}$ & $\mathrm{X}$ & $\mathrm{X}$ & - & - & - & - & - & - & $\mathrm{X}$ & $\begin{array}{c}\text { Cardich 1979; } \\
\text { Franchomme 1987 }\end{array}$ \\
\hline & $\begin{array}{c}\text { La } \\
\text { Reconquista }\end{array}$ & $\mathrm{X}$ & - & - & - & $\mathrm{X}$ & $\mathrm{X}$ & $\mathrm{X}$ & $\mathrm{X}$ & $\mathrm{X}$ & & - & - & - & - & - & - & $\begin{array}{c}\text { Arrigoni 1996; } \\
\text { Franchomme 1987 }\end{array}$ \\
\hline & La Martita & $\mathrm{X}$ & $\mathrm{X}$ & $\mathrm{X}$ & $\mathrm{X}$ & $\mathrm{X}$ & $\mathrm{X}$ & $\mathrm{X}$ & - & $\mathrm{X}$ & - & - & - & $\mathrm{X}$ & - & - & - & $\begin{array}{c}\text { Gradin y Aguerre } \\
1983 \\
\end{array}$ \\
\hline & El Verano & $\mathrm{X}$ & $\mathrm{X}$ & $\mathrm{X}$ & $\mathrm{X}$ & $\mathrm{X}$ & $\mathrm{X}$ & $\mathrm{X}$ & - & - & $\mathrm{X}$ & & $\mathrm{X}$ & & & & $\mathrm{X}$ & Durán 1983-85 \\
\hline & La Flecha & $\mathrm{X}$ & - & - & - & $\mathrm{X}$ & - & $\mathrm{X}$ & - & - & 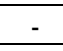 & $\mathrm{X}$ & $\mathrm{X}$ & - & - & $\mathrm{X}$ & - & Gradin 2003c \\
\hline \multirow{2}{*}{$\begin{array}{l}\text { NW Macizo } \\
\text { del Deseado }\end{array}$} & $\mathrm{ARP}$ & $\mathrm{X}$ & $\mathrm{X}$ & $\mathrm{X}$ & $\mathrm{X}$ & $\mathrm{X}$ & $\mathrm{X}$ & $\mathrm{X}$ & - & $\mathrm{X}$ & - & $\mathrm{X}$ & - & $\mathrm{X}$ & - & - & $\mathrm{X}$ & $\begin{array}{c}\text { Gradin 1977, 1981- } \\
\text { 82, 1984; Gradin et } \\
\text { al. } 1976,1979 \\
\end{array}$ \\
\hline & $\begin{array}{c}\text { Angostura del } \\
\text { Deseado }\end{array}$ & - & - & - & - & - & - & - & - & - & $\mathrm{X}$ & - & $\mathrm{X}$ & $\mathrm{X}$ & - & - & - & Gradin 1979 \\
\hline
\end{tabular}

Tabla 4.1. Técnicas reconocidas en los diferentes sitios en el macizo del Deseado. A del C: Aguada del Cuero; ARP: Área Río Pinturas.

Pintura. Neg: negativo; F: fileteado; Estarcido; S: Salpicado; PP: pintura plana o positiva; Dig: Dígitos. Mon: monocromías; Bicr: bicromías; Policr: policromías. Grabado. Pe: percusión; Pind: Percusión indirecta; I: incisión; R: Raspado; H: Horadación. P y G: combinación de trazos grabados y pintados. X: presencia; -: ausencia. 
4. a. 2. El estudio de las técnicas de producción del arte rupestre en regiones aledañas al Macizo del Deseado

A continuación se sintetiza la información generada para la margen norte del río Santa Cruz y las mesetas del oeste santacruceño que, a pesar de sus distancias variables al macizo del Deseado, se consideran como regiones aledañas.

\section{4. a. 2. 1. Margen norte del río Santa Cruz}

Los estudios arqueológicos sistemáticos en esta área comenzaron hacia mediados de la década de 2000 (Franco 2008; Franco et al. 2007a, 2007b), aunque menciones sobre el arte rupestre de la región fueron realizadas previamente por Burmeister (1892), Molina (1971, 1972 en Fiore y Ocampo 2009) y Gradin (1976, 1985).

Franco y colaboradores dan cuenta de motivos rupestres pintados y grabados detectados en el Cañadón El Lechuza, señalando la presencia de positivos y negativos de manos pintados, mientras que entre los grabados reconocen la presencia de surcos tanto superficiales como profundos, observando la técnica del piqueteado así como un "grabado fino" para motivos abstractos (Franco et al. 2007a).

Con posterioridad, se dan a conocer los resultados de las primeras prospecciones sistemáticas dirigidas al estudio del arte rupestre en la región (Acevedo et al. 2010; Fiore y Ocampo 2009; Fiore et al. 2012). Estos últimos trabajos contemplan la distribución de motivos, su frecuencia y variabilidad, sus asociaciones espaciales y distribuciones topográficas así como las técnicas de producción. Los sitios de la margen norte del río Santa Cruz presentan extensiones variables, con motivos pintados y grabados. Entre los primeros se reconocieron pinturas en positivo y en negativo, mientras que entre los grabados se reconocieron tres tipos de técnicas: el piqueteado, la incisión y el raspado 
(Acevedo et al. 2010; Fiore y Ocampo 2009; Fiore et al. 2012) (Tabla 4.2; Apéndices II.2.a y II.2.b).

\section{4. a. 2. 2. Mesetas basálticas del oeste}

A comienzos de la década de 1960, Gradin (1959-60a, 1959-60b) da cuenta de diferentes hallazgos arqueológicos realizados en la meseta del lago Strobel. Tales hallazgos estaban constituidos por grandes extensiones de materiales líticos en superficie ("picaderos"), estructuras de piedra (parapetos) y arte rupestre. En relación a este último, Gradin (1959-60a) menciona los potenciales artefactos empleados en la realización de los grabados: habrían sido buriles o punzones para las técnicas de picado e incisión, respectivamente, y habrían resultado en surcos grabados con distintas características (Apéndice II.2.c). Además, con respecto a los negativos de mano del sitio Laguna de los Negros, el autor propone que éstos habrían sido realizados “... mediante el procedimiento de salpicar con pintura una superficie rocosa alrededor de una mano apoyada sobre ella..." (Gradin 1959-60b: 145) (Tabla 4.2; Apéndice II.2.b). Sin embargo, Gradin no distingue la forma de aplicar la pintura; es decir, si se hizo mediante el empleo de algún implemento o directamente a través de la boca.

Los grabados documentados en la meseta del Lago Bueno Aires son presentados durante la década de 1970 cuando se prospecta la porción norte de dicha altiplanicie, mientras que a comienzos de 1990 se efectúan los relevamientos en la porción meridional (Gradin 1976, 1996). En la primera recorrida, Gradin da cuenta de los grabados registrados en Puesto Filin González; Puesto Blanco Slick y Bardas Bajas, refiriéndose parcialmente a las posibles técnicas de producción. Para Puesto Filín González distingue el picado y el grabado fino o inciso, donde el picado presenta diferentes variantes por los surcos grabados: irregular, ancho, superficial o profundo (Tabla 4.2; Apéndice II.2.c). En Puesto Blanco Slick menciona el picado -que puede ser superficial o profundo- y el grabado fino o inciso; mientras que para Bardas Bajas distingue el grabado fino o inciso y el picado (Apéndice II.2.c). Durante la segunda recorrida, el autor 
documenta 11 sitios, y reconoce a la percusión como técnica predominante en la ejecución de los motivos (Gradin 1996) (Tabla 4.2; Apéndice II.2.c).

En el lago Cardiel se registraron motivos pintados en los cañadones y en las mesetas bajas, mientras que los grabados se registraron tanto en las mesetas bajas como en la meseta alta (Belardi y Goñi 2002). La pintura corresponde a trazos o motivos en negativo y en positivo, mientras que para el grabado se reconocieron el raspado, la incisión (o rayado en términos de los autores) y el picado como técnicas de producción (Belardi y Goñi 2002) (Tabla 4.2). Con respecto a la distribución espacial así como a los tipos de motivos y técnicas en los sectores altos y bajos del Cardiel, los autores proponen que el arte rupestre en la zona está condicionado por la variabilidad natural de los soportes y por la funcionalidad de las mesetas altas y los cañadones bajos en los circuitos de movilidad estacional (Belardi y Goñi 2002, 2006).

Los estudios realizados del arte rupestre de las mesetas de los lagos Strobel, Cardiel Chico, Guitarra y de San Adolfo tuvieron mayor desarrollo en la última década (Belardi et al. 2003; Ferraro y Molinari 2006, 2010; Goñi 2010; Goñi et al. 2004, 2007; Guichón 2012; Re 2011; Re y Guichón 2009; Re et al. 2005, 2006-07, 2009, 2010a, 2010b). En la meseta del Strobel se reconocieron motivos pintados y grabados (Tabla 4.2), correspondiendo casi la totalidad de la muestra a los segundos -ca. 99\%- (Re 2011). Entre las técnicas de pintura se observa al estarcido indirecto como la única empleada para la realización de negativos de mano en las lagunas de Los Negros, Don Edmundo y de Las Novias. Sin embargo, Re (2011) no menciona el correlato material que le permite proponer al estarcido indirecto cómo técnica implementada en la realización de negativos de mano (Apéndice 4.2.b). Para los grabados se reconocen como técnicas el picado -con un amplio predominio de utilización-, la incisión y el raspado, observándose también combinaciones entre las mismas (ver Apéndice II.2.c para las técnicas reconocidas por tipos de motivos). No obstante, no se mencionan superposiciones o combinaciones entre pinturas y grabados.

En las mesetas de San Adolfo y del Cardiel Chico se documentaron motivos grabados exclusivamente (Tabla 4.2), siendo las técnicas de producción inferidas el picado, la incisión y, en menor medida, el raspado, observándose combinaciones 
de raspado e incisión y picado e incisión (Re 2011) (Apéndice II.2.c). Por último, en la meseta del Lago Guitarra las representaciones rupestres se ejecutaron mediante distintas variantes de grabado, entre las que se identificó el picado, la incisión, el raspado y las distintas combinaciones de aquellas (Re 2011) (Tabla 4.2; Apéndice II.2.c). El análisis en conjunto de las técnicas de producción, de las superposiciones y de las pátinas de los motivos le permitió a $\operatorname{Re}$ (2011) vislumbrar, de modo relativo, un empleo diferente de las técnicas a través del tiempo.

\section{4. a. 2. 3. Área pedemontana}

Hasta el momento se han documentado 19 sitios con arte rupestre en el área comprendida entre los lagos Pueyrredón y Burmeister (Aschero 1996; Aschero et al. 1999, 2005, 2009). Todos ellos presentan motivos pintados, excepto Cerro de los Indios 1 que, además, presenta motivos grabados. La revisión bibliográfica permite distinguir entre el negativo, el positivo e "impactos de objetos circulares" como técnicas de producción de los motivos pintados (Aschero et al. 1999) (Tabla 4.2; Apéndice II.2.b). Torres (2000) realiza algunas propuestas respecto a las técnicas de producción en Alero Destacamento Guardaparques y Alero Gorra de Vasco. Por ejemplo, los motivos zoomorfos y una figura humana podrían haber sido realizados mediante el empleo de algún artefacto; en los trazos paralelos verticales la pintura se habría aplicado mediante la técnica digital, y los negativos de mano podrían haber sido realizados mediante el "rociado bucal" (estarcido directo) o mediante el uso de algún otro elemento, como por ejemplo pincel o hisopos (Torres 2000). Para los restantes sitios se mencionan representaciones realizadas con pintura plana y lineal (Aschero et al. 2009).

En cuanto a los hallazgos en estratigrafía de diferentes materiales o artefactos asociados con la producción del arte rupestre, para el sitio Cerro Casa de Piedra 5 (CCP-5) se describen diferentes sustancias colorantes en las capas 2 a 4 , próximos a los fogones o dentro de los mismos (Aschero 1981-82, 1983-85, 1985). En la capa 3 se recuperaron vellones teñidos de rojo, mientras que en la capa 2 se 
recuperó un fragmento de escápula con restos de pintura roja, la cual Aschero (1981-82) sostiene que podría haber sido utilizada como paleta de pintor (Apéndice II.2.b). Los resultados del análisis de difracción de rayos $\mathrm{X}$ de una muestra de pintura extraída de la escápula y de restos de pintura de la pared señalaron que ambos son similares en su composición mineralógica (Barbosa y Rial 1983-85; Rial y Barbosa 1985) y permitieron corroborar la hipótesis de Aschero respecto a su uso como paleta de pintor. Scheinsohn (2010: Figura 7) muestra una imagen del pincel recuperado en los niveles inferiores del sitio CCP7, tratándose de una astilla ósea que en un extremo presenta un vellón de lana teñido de rojo (Apéndice II.2.b). Este instrumento se vincula con la producción de las pinturas de guanacos más antiguas registradas en el sitio (Scheinsohn 2010: $4)$.

En el Área de Excavación 2 de Cerro de Los Indios 1 se recuperaron pequeños fragmentos vegetales ("palitos"), trozos de cuero y vellones teñidos o pintados, así como una moleta con restos de pintura (Aschero et al. 1999). Estos materiales podrían vincularse con las diferentes cadenas de producción de pintura (Apéndice II.2.b). Asimismo, Gradin y colaboradores (1979) informan el hallazgo en la capa $1 \mathrm{~b}$ de percutores-cinceles sobre guijarros, los cuales podrían estar vinculados a la realización de los grabados (Tabla 4.2; Apéndice II.2.c).

En un sondeo de Cueva del Milodón Norte 1 se recuperaron restos de pigmentos minerales, fragmentos de pigmentos preparados así como vellones de pelo y valvas impregnados con pintura. Estos podrían estar relacionados a la producción de pinturas (Aschero et al. 2009). 


\begin{tabular}{|c|c|c|c|c|c|c|c|c|c|c|c|c|c|c|c|}
\hline \multirow{3}{*}{ Ubicación } & \multirow{3}{*}{\multicolumn{2}{|c|}{ Localidad/Área }} & \multicolumn{11}{|c|}{ TÉCNICAS } & \multirow{3}{*}{$\begin{array}{c}\text { Materiales } \\
\text { asociados en } \\
\text { estratigrafía }\end{array}$} & \multirow{3}{*}{ Fuentes } \\
\hline & & & \multicolumn{7}{|c|}{ Pintura } & \multicolumn{4}{|c|}{$\mathrm{G}$} & & \\
\hline & & & $\mathrm{Neg}$ & $\mathrm{S}$ & $\mathrm{PP}$ & Dig & Mon & Bicr & Polic & $\mathrm{Pe}$ & Pind & $\mathrm{I}$ & $\mathrm{R}$ & & \\
\hline \multirow{5}{*}{ MNRSC } & \multicolumn{2}{|c|}{ Sitio El Rincón } & & - & - & - & - & - & & - & $\mathrm{X}$ & $\mathrm{X}$ & $\mathrm{X}$ & - & \multirow{5}{*}{$\begin{array}{c}\text { Acevedo et al. 2010; Fiore y } \\
\text { Ocampo 2009; } \\
\text { Franco et al. } 2007 \mathrm{a}\end{array}$} \\
\hline & \multicolumn{2}{|c|}{$\begin{array}{l}\text { Cañadón El Lechuza y } \\
\text { Moro }\end{array}$} & $\mathrm{X}$ & - & - & - & - & - & - & - & $\mathrm{X}$ & $\mathrm{X}$ & $\mathrm{X}$ & - & \\
\hline & \multicolumn{2}{|c|}{ Bajada del Dibujo } & $\mathrm{X}$ & - & $\mathrm{X}^{*}$ & - & $\mathrm{X}$ & - & - & - & $\mathrm{X}$ & $\mathrm{X}$ & $\mathrm{X}$ & - & \\
\hline & \multicolumn{2}{|c|}{ Yaten Guajen } & - & - & $\mathrm{X}^{*}$ & - & $\mathrm{X}$ & - & - & - & $\mathrm{X}$ & - & & - & \\
\hline & \multicolumn{2}{|c|}{ Cañadón Mercerá } & $\mathrm{X}$ & - & - & - & $\mathrm{X}$ & - & - & - & $\mathrm{X}$ & - & - & - & \\
\hline \multirow{7}{*}{$\begin{array}{l}\text { Mesetas del } \\
\text { Oeste } \\
\text { santacruceño }\end{array}$} & \multicolumn{2}{|c|}{ MLBA } & - & - & - & - & - & - & - & $\mathrm{X}$ & $\mathrm{X}$ & $\mathrm{X}$ & $\mathrm{X}$ & - & Gradin 1976, 1983, 1996 \\
\hline & \multirow{3}{*}{$\mathrm{LC}$} & Cañadones & $\mathrm{X}$ & - & $\mathrm{X}$ & - & $\mathrm{X}$ & - & - & - & - & - & - & - & \multirow{3}{*}{$\begin{array}{c}\text { Belardi y Goñi 2002; Molinari } \\
\text { y Ferraro } 2006\end{array}$} \\
\hline & & $\begin{array}{c}\text { Mesetas } \\
\text { bajas }\end{array}$ & $\mathrm{X}$ & - & $\mathrm{X}$ & & - & - & - & - & $\mathrm{X}$ & - & - & - & \\
\hline & & $\begin{array}{c}\text { Mesetas } \\
\text { altas }\end{array}$ & - & - & - & - & - & - & - & - & $\mathrm{X}$ & $\mathrm{X}$ & - & - & \\
\hline & & MLS & $\mathrm{X}$ & - & - & & $\mathrm{X}$ & - & - & - & $\mathrm{X}$ & $\mathrm{X}$ & $\mathrm{X}$ & - & Re 2011, Guichón 2012 \\
\hline & & MLG & - & - & - & - & - & - & - & - & $\mathrm{X}$ & $\mathrm{X}$ & $\mathrm{X}$ & - & $\operatorname{Re} 2012$ \\
\hline & & $\mathrm{A} \mathrm{y} \mathrm{Cch}$ & - & & - & - & - & - & - & - & $\mathrm{X}$ & $\mathrm{X}$ & $\mathrm{X}$ & - & $\operatorname{Re} 2011$ \\
\hline \multirow{4}{*}{$\begin{array}{c}\text { Área } \\
\text { Pedemontana }\end{array}$} & Lag & $\begin{array}{l}\text { ueyrredón- } \\
\text { chrane }\end{array}$ & $\mathrm{X}$ & - & $\mathrm{X}$ & - & $\mathrm{X}$ & - & - & - & - & - & - & $\mathrm{X}$ & Aschero et al. 2009 \\
\hline & & Posadas & $\mathrm{X}$ & - & $\mathrm{X}$ & - & $\mathrm{X}$ & - & $\mathrm{X}$ & $\mathrm{X}^{\#}$ & & & & $\mathrm{X}$ & $\begin{array}{c}\text { Aschero 1996a; Aschero et al. } \\
\text { 1999; Gradin et al. } 1979\end{array}$ \\
\hline & & Belgrano & $\mathrm{X}$ & $\mathrm{X}$ & - & $\mathrm{X}$ & $\mathrm{X}$ & - & - & - & - & - & - & - & Torres 2000 \\
\hline & Lag & Burmeister & $\mathrm{X}$ & & $\mathrm{X}$ & $\mathrm{X}$ & $\mathrm{X}$ & & & - & - & - & - & $\mathrm{X}$ & $\begin{array}{c}\text { Aschero 1983-85; Barbosa y } \\
\text { Rial 1983-85; Aschero et al. } \\
2005\end{array}$ \\
\hline
\end{tabular}

Tabla 4.2. Técnicas de pintura y grabado registradas en áreas aledañas al macizo del Deseado.

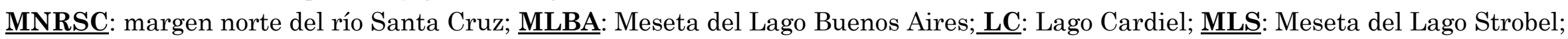
MLG: Meseta del Lago Guitarra; MSA y CCh: Meseta de San Adolfo y Cardiel Chico.

Área pedemontana: incluye el área del Río Belgrano, Lago Pueyrredón-Posadas y el Parque Nacional Perito Moreno.

Pintura. Neg: negativo; F: fileteado; Estarcido; S: Salpicado; PP: pintura plana o positiva; Dig: Dígitos. Mon: monocromías; Bicr: bicromías; Policr: policromías. Grabado. Pe: percusión; Pind: Percusión indirecta; I: incisión; R: Raspado; H: Horadación. X: presencia; -: ausencia.

*: manos positivas.

\#: inferida por la presencia de percutor-cincel. 


\section{4. a. 3. Síntesis sobre el estudio de las técnicas de producción del arte}

rupestre en el macizo del Deseado y en áreas aledañas

A partir de la información considerada en los apartados previos se observa que en los distintos sitios y localidades estudiados se han distinguido dos grandes grupos de técnicas: la pintura y el grabado. Para el primer grupo, pueden diferenciarse el negativo y el positivo, tratándose, en el caso del negativo, de colocar pintura alrededor del objeto que se desea plasmar sobre la pared (mano, pie, pata de algún animal o algún objeto). Esta acción permite lograr una imagen de contorno del objeto usado como plantilla. La aplicación de pintura en positivo puede ser directa, si se realiza con el cuerpo, o indirecta, si se utiliza para tal acción un artefacto como intermediario.

Al considerar la información presentada para el macizo del Deseado y regiones aledañas según las tres cadenas operativas propuestas por Fiore (2007), relacionadas con la producción de artefactos, la preparación de mezclas pigmentarias y la realización de motivos, se observa que:

1) Las referencias a los artefactos empleados o potencialmente empleados en la producción de motivos no son abundantes, lo cual concuerda con una propuesta previa (ver Fiore 1996-98). Los artefactos hallados en estratigrafía y vinculados con la producción de motivos pintados se limitan a un pincel en el sitio CCP-7 (Scheinsohn 2010), a vellones de pelo de guanaco y restos vegetales teñidos con pintura en Cerro de los Indios 1, y a una escápula teñida con pintura en CCP-5 (Aschero et al. 1999, 2005).

Entre los artefactos potencialmente utilizados para la producción de grabados se mencionan puntas burilantes de obsidiana (Aschero 2012b), punzones o buriles (Gradin 1959-60a), rocas con extremo puntiagudo (Menghin 1957), o se propone el uso de intermediarios sin plantear una morfología potencial para los mismos (Carden 2008a). En Cerro de los Indios 1 se recuperaron en estratigrafía percutores-cinceles aunque no se vinculan a la producción de ningún motivo grabado en particular (Gradin et al. 1979). 
La relación entre los tipos de motivos grabados y los artefactos potenciales inferidos por Gradin (1959-60a), permite proponer que los punzones habrían sido empleados para la incisión y los buriles para la percusión, aunque el autor no aclara si la percusión fue directa o indirecta. Esta última situación puede plantearse, además, para el empleo de percutores-cinceles, sin poder afirmar su utilización de modo directo o si funcionaron como intermediarios.

2) La cadena de producción de pinturas comprende varias etapas: aprovisionamiento de materia prima colorante, de yeso o de ligantes, la manufactura, uso y almacenamiento de la mezcla (Aschero 1988; Fiore 2007). Entre las evidencias materiales de esta cadena se pueden mencionar la presencia de fragmentos de yeso, pigmentos minerales o mezclas de pigmentos y sustancias grasas ("crayones") en diferentes sitios. Los materiales correspondientes a manos de molienda, teñidos o con restos de pigmentos, también pueden ser mencionados aquí (Apéndice II.2.b). Aunque los pigmentos suelen formar parte del registro arqueológico no siempre se establece una relación con el arte rupestre, podría haber servido para la fabricación de pinturas corporales o para otros fines. Los análisis mineralógicos y físicoquímicos permitieron reconocer la utilización de algunos de los fragmentos recuperados en estratigrafía (Apéndice II.2.b).

3) En cuanto a la producción de imágenes, se pueden distinguir varios puntos:

a) Las técnicas de producción suelen inferirse a partir de la observación macroscópica de los trazos pintados o de los surcos grabados. Así, se reconocieron motivos realizados por estarcido directo y mediante la técnica digital. Con respecto al uso de intermediarios para la aplicación de pintura, se propusieron hisopos, pinceles de distinto grosor para delinear o pintar, o cueros embebidos en pintura (Apéndices II.1.b y II.2.b). Para el caso del estarcido indirecto, en un sitio se recuperó un hueso neumático de ave con restos de pintura roja en su interior y se lo consideró como potencial intermediario en la 
aplicación de pintura. Sin embargo, no se han realizados pruebas para testear su efectividad.

En la mayoría de los trabajos se detalla la cantidad de colores empleados en la producción de los motivos y el tratamiento de las superficies pintadas. Es decir, aquellos pueden ser mono-, bi- o policromáticos con tratamiento puntiforme, lineal o plano, aunque no suele hacerse ningún tipo de inferencia respecto del artefacto utilizado en su producción.

La experimentación realizada por Paunero $(1992,1994)$ le ha permitido proponer al autor que el estarcido directo habría sido utilizado para realizar los negativos de mano debido al parecido entre las réplicas experimentales realizadas con esa técnica y los referentes arqueológicos.

b) Con respecto a las técnicas de grabado no existe consenso terminológico, aunque se observa una mayor homogenización en los trabajos recientes. La mayoría de los autores se refiere al piqueteado como sinónimo de picado o percusión indirecta, a la incisión, y al raspado como sinónimo de abradido o fricción. Percusión indirecta, incisión y raspado son las técnicas mayormente propuestas (Apéndices II.1.c y II.2.c), aunque no siempre se explicita el correlato material que permitió definirlas. Inversamente, existen menciones acerca de la morfología de los surcos grabados sin hacer referencia al empleo de alguna técnica particular (Durán 1983-85).

El trabajo experimental realizado por Blanco y Lynch (2011) permitió reconocer macroscópicamente tres técnicas de grabado sobre el soporte de Piedra Museo y microscópicamente sobre los artefactos empleados. Este es el primer trabajo sobre replicación de grabados realizado con materiales del macizo del Deseado, que permitió sentar las bases para trabajos posteriores.

c) Respecto al proceso de trabajo, se ha planteado el uso de medios de elevación o ayuda de terceros para la realización de motivos que se encuentran a alturas elevadas respecto del suelo (Apéndice II.1.b). Otro medio propuesto para alcanzar espacios altos ha sido la utilización de bolas arrojadizas cubiertas con algún material embebido en pintura. Se menciona la preparación 
del soporte mediante raspado previo a la realización de los motivos pintados (Durán 1983-85) así como por la aplicación de pintura previamente a la producción de negativos de mano (Carden 2008a, 2013; Cardich 1979; Cardich et al. 1973).

A partir de lo anterior, se plantea que para el macizo del Deseado y las regiones aledañas se han realizado inferencias sobre los procesos de producción del arte rupestre, aunque éstas se refieren parcialmente a algunas cadenas operativas. Estos antecedentes implican que el estudio de los procesos de producción del arte rupestre no fue tratado en forma sistemática porque no constituyó un objetivo central de las investigaciones, con excepción de trabajos recientes (Blanco y Lynch 2011; Fiore et al. 2012).

\section{4. b. INVESTIGACIONES ARQUEOLÓGICAS EN EL MACIZO DE SOMUNCURÁ}

Los primeros estudios en Somuncurá, de índole naturalista, fueron realizados hacia finales del siglo XIX (Claraz 1988; Moreno s/f). Con posterioridad se realizaron trabajos arqueológicos aislados (Casamiquela 1960). En los bordes de Laguna Azul y El Ganso, en el NE del macizo, se reconocieron diferentes estructuras de piedra (Gradin 1971) (Figura 4.3). Este autor efectuó sondeos en dichas estructuras recuperando material en estratigrafía, lo que en conjunto con el análisis de la morfología de las mismas le permitió efectuar proposiciones respecto de su funcionalidad.

Durante la década de 2000, las investigaciones en Somuncurá se tornan más asiduas. En sus inicios se registran diferentes sitios en la Estancia Los Manantiales, al NE de Cona Niyeu (Figura 4.3), algunos con arte rupestre (Albornoz 2003; Albornoz y Pereda 2010).

Las investigaciones realizadas por Miotti y colaboradores en el centro y en el oriente del macizo permitieron conocer las características del arte rupestre 
regional (Blanco 2010; Blanco et al. 2010a, 2010b, 2013), las ocupaciones tempranas de la región (Miotti 2010b; Miotti et al. 2011a; Terranova y Marchionni 2010), la estructura de los recursos líticos y los distintos tipos de espacios ocupados (Hermo y Terranova 2012; Hermo et al. 2013a; Miotti et al. 2004, 2007a, 2009c, 2011a, 2012d; Terranova 2012, 2013), así como abordar la movilidad de los grupos del macizo hacia la cordillera (Miotti 2010b) y otros espacios (Miotti y Terranova 2010, 2014).

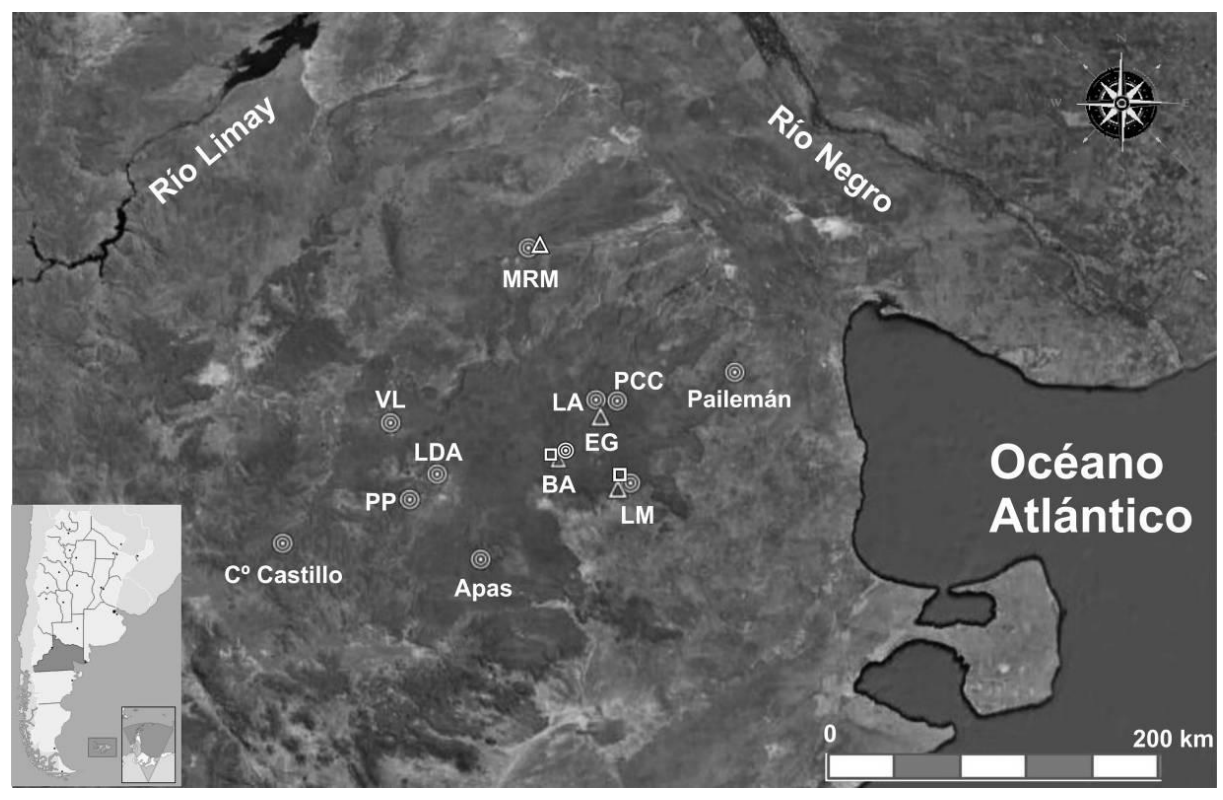

Figura 4.3. Ubicación de los sitios considerados en este apartado. Referencias: MRM: Manantial Ramos Mexía; Pailemán: Sierra de Pailemán; PCC: Pintada de Corral Curá; LA: Laguna Azul; EG: Laguna El Ganso; BA: Bardas de Antonio; LM: Los Manantiales; Apas: Sierra de Apas; $\mathrm{C}^{\circ}$ Castillo: Cerro Castillo; PP: Peñón del Pueblo; LDA: Los Dos Amigos; VL: Vacalauquén. Referencias: círculos: pinturas; triángulos: grabados; cuadrados: pictograbados.

4. b. 1. Investigaciones arqueológicas referidas al estudio del arte rupestre en Somuncurá

Los estudios referidos al arte rupestre de Nordpatagonia son abundantes y tienen una extensa trayectoria de investigación, que se inicia a comienzos de siglo XX (Bruch 1902, 1904) y se intensifica a lo largo de dicho siglo (ver 
síntesis en Fiore y Hernández Llosas 2007). En la mayoría de los trabajos consultados, los motivos rupestres de Nordpatagonia han sido clasificados siguiendo la sistematización estilística propuesta por Menghin (1957). De este modo, se han identificado motivos asignables al "estilo de pisadas" (Boschin 2009; Llamazares 1980, 1989), al "estilo de paralelas" (Schobinger 1956) y al "estilo de grecas" (Gradin 2003a). Sobre la base de los estilos definidos por Menghin (1957), Gradin (1999) define la "Tendencia Abstracta Geométrica Compleja" (TAGC), la cual se habría desarrollado durante el Holoceno tardío (con posterioridad a los 1.300 años AP) con una amplia distribución espacial, tanto en los contrafuertes cordilleranos como en la estepa colindante, llegando hasta los $47^{\circ}$ de latitud S. Los motivos que conforman dicha tendencia y fueron reconocidos para el "estilo de grecas" corresponden a trazos escalonados conformando triángulos opuestos por el vértice, cruciformes, enmarcados, laberintiformes realizados mediante líneas quebradas, grecas, etc., pintados en diferentes tonalidades de rojo, a veces combinados con otros colores (amarillo, blanco, negro y verde) (Albornoz 2003; Gradin 2003a). Albornoz y Cúneo (2000) reconocen una variante de dicha tendencia, la modalidad del Ámbito Lacustre Boscoso del noroeste de Patagonia, restringida al corredor de lagos y ríos del bosque andino patagónico, ubicado entre el sur neuquino y el noroeste chubutense (ver también Podestá y Albornoz 2007; Podestá et al. 2008 y bibliografía allí citada; Scheinsohn et al. 2009, 2011).

\section{4. b. 1. 1. Los sitios con arte rupestre en el macizo de Somuncurá}

Los sitios registrados hasta el momento son 16 (Apéndice II.3.a). Los

primeros relevamientos de sitios con arte rupestre fueron efectuados por Casamiquela (1960) en las Sierras de Apas, y por Gradin (2003b) en los sitios La Pintada de Corral Curá y Vacalauquén (Figura 4.3). En Sierras de Apas, los 
cuatro sitios documentados presentan motivos con pintura plana (Casamiquela 1960).

La Pintada de Corral Curá se encuentra muy próxima a las lagunas Azul y El Ganso, alrededor de unos $10 \mathrm{~km}$ al NE (Figura 4.3). En este sitio se registraron motivos geométricos y manchas de pintura, todos ellos en distintas tonalidades de rojo, en los que la única referencia técnica es la mención del tratamiento de los motivos (puntiforme o plano) (Gradin 2003b). Vacalauquén se ubica aproximadamente a unos $120 \mathrm{~km}$ hacia el oeste de lagunas Azul y El Ganso (Figura 4.3), y presenta motivos geométricos y escalonados asignados al estilo de grecas, principalmente en tonalidades rojizas, y unos pocos casos en los que se combina el rojo y el amarillo (Gradin 2003b). Con respecto a las técnicas de este sitio, Gradin menciona la presencia de dígitos e impresiones de dedos, así como la pintura plana (monocroma y en bicromía).

Laguna Azul 1-4, Laguna El Ganso y Bardas de Antonio son sitios ubicados sobre el NE de Somuncurá (Figura 4.3). En ellos se registraron motivos pintados, grabados y motivos pintados, grabados y pictograbados respectivamente (Blanco et al. 2010a, 2010b, 2013). Los sitios Peñón del Pueblo 1 y 2 presentan motivos pintados, algunos de los cuales fueron realizados mediante técnica digital (Blanco 2010). Todos estos sitios fueron presentados de modo preliminar con anterioridad y son tratados con mayor profundidad en el Capítulo 7.

\section{4. b. 1. 2. Sitios con arte en el borde del macizo}

Entre los sitios relevados al pie de la meseta de Somuncurá ascienden a 15. Se pueden mencionar las pinturas del Manantial Ramos Mexía hacia el norte, en las inmediaciones del pueblo homónimo, las pinturas de la Rinconada Catriel y Cueva Galpón en la Sierra de Pailemán (Figura 4.3). En Manantial Ramos Mexía y Rinconada Catriel se registraron pinturas geométricas 
rectilíneas en color rojo que fueron asociadas al "estilo de grecas" (Albornoz 2003; Gradin 2003b). Entre las técnicas de producción en Manantial Ramos Mexía se reconoce la pintura plana, bicromías y un motivo pictograbado de surco profundo (Gradin 2003b) (Tabla 4.3; Apéndices II.3.a y II.3.c).

En Cueva Galpón se recuperaron restos mortuorios asociados a otros materiales, entre los que se mencionan pigmentos (Prates et al. 2011). En este sitio se documentaron motivos rojos, negros y blancos, así como casos de bicromía entre el rojo y el negro, sobre las paredes de la cueva (Apéndice II.3.a).

En Estancia Manantiales se relevaron tres sitios con arte rupestre (Albornoz 2003; Albornoz y Pereda 2010). Los Manantiales 1 presenta motivos grabados, pintados y pictograbados. Entre los motivos pintados, se reconocen monocromías y bicromías (Tabla 4.3; Apéndice II.3.b). Entre los grabados, el raspado fue empleado en la producción de motivos lineales rectos y circulares planos que presentan surcos superficiales o profundos de ancho variable. La incisión se utilizó para los reticulados con surco fino y superficial. Entre los motivos curvilíneos y circulares se distingue la morfología de los surcos aunque no se le atribuye ninguna técnica particular (Albornoz y Pereda 2010). Algunos motivos grabados, además, presentan trazos pintados sobrepuestos (Apéndices II.3.b y II.3.c). En Los Manantiales 5 se registraron motivos grabados, rectilíneos y curvilíneos realizados por raspado (Apéndice II.3.c). En Los Manantiales 12 se identificaron motivos pintados en color rojo, entre los que predominan los puntiformes y los motivos lineales, algunos podrían haber sido realizados con los dedos (Albornoz y Pereda 2010) (Tabla 4.3; Apéndice II.3.b).

A la evidencia mencionada se suman las cuevas y aleros registrados por Belardi (1996) en el área de Cerro Castillo (Figura 4.3), en el borde centrooccidental del macizo, en el límite actual entre los territorios de Río Negro y Chubut. Todos los motivos pintados fueron adscriptos por el autor al "estilo de grecas", registrándose también motivos puntiformes. 


\begin{tabular}{|c|c|c|c|c|c|c|c|c|}
\hline \multirow{3}{*}{ Ubicación } & \multirow{3}{*}{$\begin{array}{l}\text { Localidades- } \\
\text { Sitios }\end{array}$} & \multicolumn{5}{|c|}{ TÉCNICAS } & \multirow{3}{*}{$\begin{array}{c}\text { Otras } \\
\text { asociaciones }\end{array}$} & \multirow{3}{*}{ Fuentes } \\
\hline & & \multicolumn{3}{|c|}{ Pintura } & \multirow{2}{*}{ Grabado } & \multirow{2}{*}{ Comb } & & \\
\hline & & Mon & Bicr & Policr & & & & \\
\hline $\begin{array}{c}\text { Borde } \\
\text { Septentrional }\end{array}$ & $\begin{array}{c}\text { Manantial } \\
\text { Ramos Mexía }\end{array}$ & $\mathrm{X}$ & - & - & $\mathrm{s} / \mathrm{d}$ & $\mathrm{P} / \mathrm{G}$ & $\mathrm{X}$ & Gradin $2003 \mathrm{~b}$ \\
\hline \multirow{4}{*}{ NE Somuncurá } & $\begin{array}{c}\text { Pintada de } \\
\text { Corral Curá }\end{array}$ & $\mathrm{X}$ & $\mathrm{X}$ & - & - & - & $\mathrm{s} / \mathrm{d}$ & $\begin{array}{c}\text { Gradin } 1971, \\
2003 \mathrm{a}\end{array}$ \\
\hline & Laguna Azul & $\mathrm{X}$ & - & - & - & - & $\mathrm{X}$ & \multirow{3}{*}{$\begin{array}{c}\text { Blanco et al. 2010a, } \\
\text { 2010b, } 2013\end{array}$} \\
\hline & $\begin{array}{c}\text { Laguna El } \\
\text { Ganso }\end{array}$ & - & - & - & $\begin{array}{c}\text { I, Pe, } \\
\text { Pind y R }\end{array}$ & $\mathrm{X}$ & - & \\
\hline & $\begin{array}{c}\text { Bardas de } \\
\text { Antonio }\end{array}$ & $\mathrm{X}$ & - & - & $\mathrm{Pe}$ & $\mathrm{X}$ & $\mathrm{X}$ & \\
\hline \multirow{2}{*}{$\begin{array}{l}\text { Sierra de } \\
\text { Pailemán }\end{array}$} & Cueva Galpón & $\mathrm{X}$ & $\mathrm{X}$ & - & - & - & $\mathrm{X}$ & Prates et al. 2011 \\
\hline & $\begin{array}{c}\text { Rinconada } \\
\text { Catriel }\end{array}$ & $\mathrm{X}$ & $\mathrm{X}$ & - & - & - & $\mathrm{s} / \mathrm{d}$ & Gradin $2003 b$ \\
\hline $\begin{array}{l}\text { Borde Centro- } \\
\text { oriental }\end{array}$ & $\begin{array}{c}\text { Los } \\
\text { Manantiales }\end{array}$ & $\mathrm{X}$ & $\mathrm{X}$ & - & $\mathrm{R}$ e I & $\mathrm{P} / \mathrm{G}$ & $\mathrm{X}$ & $\begin{array}{c}\text { Albornoz 2003; } \\
\text { Albornoz y Pereda } \\
2010\end{array}$ \\
\hline \multirow{2}{*}{$\begin{array}{l}\text { Centro de } \\
\text { Somuncurá }\end{array}$} & Apas & $\mathrm{X}$ & $\mathrm{X}$ & $\mathrm{X}$ & - & - & $\mathrm{s} / \mathrm{d}$ & Casamiquela 1960 \\
\hline & $\begin{array}{c}\text { Peñón del } \\
\text { Pueblo } 1 \text { y } 2\end{array}$ & $\mathrm{X}$ & - & - & - & - & $\mathrm{X}$ & Blanco 2010 \\
\hline $\begin{array}{c}\text { Borde Centro- } \\
\text { occidental }\end{array}$ & Cerro Castillo & $\mathrm{X}$ & - & - & - & - & $\mathrm{X}$ & Belardi 1996 \\
\hline NW Somuncurá & Vacalauquén & $\mathrm{X}$ & $\mathrm{X}$ & - & - & - & $\mathrm{X}$ & Gradin $2003 \mathrm{~b}$ \\
\hline
\end{tabular}

Tabla. 4.3. Integración de la información disponible para Somuncurá.

Técnicas. Mon: monocromías; Bicr: bicromías; Policr: policromías; Grabado: Pe: percusión; Pind: percusión indirecta; R: raspado; I: Incisión. P/G: pictograbado. X: presencia; -: ausencia; s/d: sin datos.

Las dataciones radiocarbónicas obtenidas en sitios sobre la meseta y en sus inmediaciones permiten esbozar una cronología para las ocupaciones humanas de esta región. En Cueva La Rural se registró arte rupestre y las ocupaciones rondan los ca. 3.740 y 1.740 años AP (Belardi 1996; Stern et al. 2000) aunque no existe asociación estratigráfica entre los fechados y las manifestaciones. Las dataciones de Alero 2 del sitio Los Cuatro Aleros indican ocupaciones entre ca. 2.000 y 950 años AP; sin embargo, este abrigo no presenta arte rupestre (Miotti 2010b; Terranova y Marchionni 2010). Los fechados obtenidos en los contextos mortuorios de Cueva Galpón en la Sierra de Pailemán rondan los ca. 3.200 años AP (Prates et al. 2011). Es decir, para Somuncurá tenemos ocupaciones desde hace por lo menos 3.000 años AP aunque no se puede establecer una asociación contextual con las manifestaciones rupestres. 
4. b. 2. Investigaciones sobre el arte rupestre en áreas aledañas a Somuncurá

En este apartado se consideran los estudios sobre el arte rupestre de las áreas de Piedra Parada, Pilcaniyeu y la cuenca superior y media del río Limay (Figura 4.1). Estas áreas se encuentran al suroeste y al oeste del macizo de Somuncurá, y distan del mismo, $190 \mathrm{~km}$ al SW, $230 \mathrm{~km}$ al W y $250 \mathrm{~km}$ NNW respectivamente, tomando como punto de referencia la localidad Los Dos Amigos (Figura 4.4).

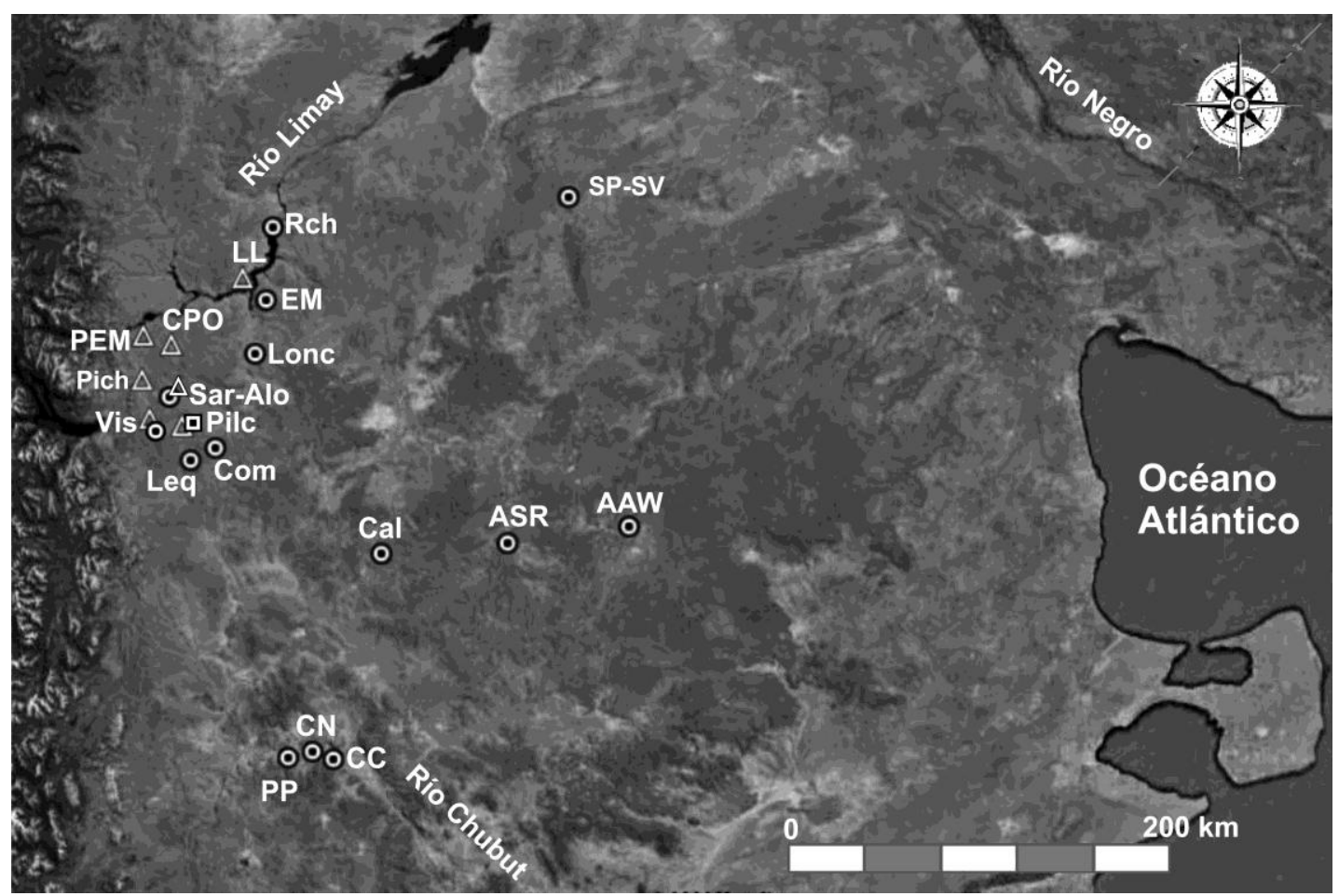

Figura 4.4. Sitios con arte rupestres de referencia para las áreas aledañas a

Somuncurá. Referencias: LDA: Los Dos Amigos; CC: Campo Crettón; CN: Campo Nassif; PP: Piedra Parada; ASR: Alero Santo Rosario; Cal: Calcatreo I; Com: Comallo; Leq: Cuadro Leleque; Pilc: Pilcaniyeu; Vis: Cueva Visconti; Pich: Cueva Pichileufú; Sar-Alo: Sarita-Alonso; Lonc: Cueva Loncomán; CPO: Casa de Piedra de Ortega; PEM: Pintada El Manzanito; LL: Epullán Grande; EM: El Monito; Rch: Rincón Chico 2/87; SP-SV: Supayniyeu- Santa Victoria. Círculos: pinturas; triángulos: grabados; cuadrados: pictograbados. 


\section{4. b. 2. 1. Área de Piedra Parada}

Se encuentra en la cuenca media del río Chubut (Figura 4.4), desde la confluencia con el río Gualjaina hasta Paso del Sapo, incluyendo, además de la ribera, las zonas interiores y las pampas altas (Onetto 1991; Aschero et al. 1983). Las investigaciones comenzaron a finales de 1970, y permitieron la profundización de diferentes tópicos (Aschero et al. 1983b; Bellelli 1987, 1994, 2000-02, 2005; Bellelli y Pereyra 2002; Bellelli et al. 2007; Gómez Otero y Stern 2005; Onetto 1981-82, 1987, 1990, 1991; Pérez de Micou 1979-82, 1987; Pérez de Micou y Castro 2005; Pérez de Micou et al. 1992; Stern et al. 2000).

Veinticuatros sitios corresponden a aleros o cuevas que presentan arte rupestre, sea pintado o grabado (Onetto 1991), y sólo se cuenta con datos cualicuantitativos para siete. El análisis de las superposiciones, las series tonales, los tipos de motivos y las técnicas, le permitieron a Aschero (1983a, 1983e) y Onetto $(1987,1990)$ reconocer grupos estilísticos que, si bien se adecúan a las características reconocidas para los grupos estilísticos de Patagonia meridional (Gradin et al. 1979), presentan variaciones de orden local.

La técnica de producción predominante es la pintura, habiéndose registrado de manera positiva motivos monocromos, bicromos o polícromos (Tabla 4.4; Apéndice II.4.b). Asimismo, en algunos sitios la pintura fue aplicada directamente con la yema de los dedos, a modo de "dígitos" (Aschero 1983c, 1983d; Onetto 1987). En Piedra Parada 1 podría haberse utilizado un hisopo o un pincel para la realización de los motivos puntiformes y lineales (Aschero 1983a). Las miniaturas registradas en Campo Nassif 1 permiten pensar en la utilización de algún artefacto delgado ya que presentan un trazo inferior a 2 mm (Aschero 1983b) (Tabla 4.4). Por último, en el sitio Aguada del Potrillo 1 se registraron motivos pintados de patrón escalonado de trazo fino $(2$ a $5 \mathrm{~mm}$ ) y de tamaño reducido, los cuales podrían haber sido realizados con algún implemento de escaso grosor. Con respecto a este mismo sitio, se propuso, debido a las variaciones registradas en la intensidad de la pintura, la 
posibilidad de que un motivo escalonado haya sido repintado o completado en diferentes momentos (Aschero 1983d) (Apéndice 4.4.b).

En los diferentes contextos estratigráficos excavados se obtuvieron materiales que permiten suponer su utilización como artefactos vinculados a la secuencia de producción de las manifestaciones rupestres (Apéndice II.4.b). En Campo Nassif 1 se recuperaron cuatro hisopos de pequeñas dimensiones (tres de ellos alrededor de $6 \mathrm{~mm}$ de largo por $2 \mathrm{~mm}$ de ancho, y el cuarto de $18 \mathrm{~mm}$ de largo por $8 \mathrm{~mm}$ de ancho), de forma aguzada y completamente teñidos de color rojo (Onetto 1986-87, 1991; Pérez de Micou 1987). Según esta última autora, los hisopos pudieron haber sido realizados con fibras vegetales ovilladas y una cubierta de pelo, posiblemente de camélido. Además, en este sitio se recuperaron otros artefactos e implementos que pudieron haber sido empleados en la producción de pinturas: una mano de moler y lascas teñidas de rojo, fragmentos de cuero, varios ovillos de fibra vegetal y un pequeño tallo leñoso que también presentaba restos de pintura (Onetto 1986-87).

En todos los niveles del sitio Campo Moncada 2 se recuperaron fragmentos preparados y no preparados de pigmentos de diferentes tonalidades. Dichos pigmentos pudieron haber sido utilizados para la preparación o decoración de cueros o pieles, en la pintura corporal o en pinturas rupestres de otros sitios, ya que Campo Moncada 2 carece de manifestaciones rupestres (Pérez de Micou et al. 1992). Además, se recuperaron instrumentos con restos de pigmentos adheridos, entre ellos fragmentos de cuero y vellones en forma de hisopo (Marchione y Bellelli 2013) y fragmentos de yeso. Este último pudo haber sido empleado en la confección de mezclas pigmentarias (Pérez de Micou et al. 1992) (Apéndice II.4.b).

Los motivos grabados fueron registrados en cinco sitios (Apéndice II.4.c). Según Onetto (1983c) las técnicas implementadas para grabar en Campo Cretton 1 fueron la incisión (de surco profundo y de surco fino) y el picado continuo (superficial o profundo), distinguiendo un tercer tipo que denomina "grabado surco en V". La definición realizada por dicha autora resulta confusa 
al ser observada con los parámetros propuestos en el Capítulo 2, debido a que la técnica de incisión tiene como correlato material motivos con surcos en forma de "V" (Álvarez y Fiore 1995).

La evidencia indica que este espacio fue ocupado durante el Holoceno medio y tardío. Las primeras ocupaciones del área se registraron en Campo Moncada 2, entre ca. 5.080 y 3.350 años AP (Onetto 1991; Pérez de Micou et al. 1992). En Campo Cerda 1 las ocupaciones iniciales comenzaron hace ca. 2.850 años AP mientras que en Piedra Parada 1 la ocupación del alero comenzó hacia $c a$. 1.330 años AP. Los fechados radiocarbónicos obtenidos en otros sitios ubican las ocupaciones tardías entre ca. 580 y 450 años AP (Onetto 1987; Pérez de Micou 1983; Pérez de Micou y Castro 2005).

\section{4. b. 2. 2. Área de Pilcaniyeu}

Con centro en la localidad homónima, se encuentra al SW de la provincia de Río Negro, y se extiende en un radio aproximado de $40 \mathrm{~km}$. Su borde septentrional es Paso Corralito, al sur la localidad de Las Bayas, Bariloche por el W y la localidad de Comallo al E (Boschin 1986). Los sitios con manifestaciones rupestres son abundantes en esta área. Éstos están siendo estudiados desde comienzos la década de 1980 (Arrigoni et al. 2010; Boschin 1986, 2009; Boschin y Nacuzzi 1980; Fiore 1999; Llamazares 1980, 1989, Massaferro et al. 2012), aunque existen menciones previas de algunos sitios (Casamiquela 1960, 1968; para mayor detalle ver Boschin 1986 y bibliografía allí citada). Asimismo, se estudiaron las cuencas de los arroyos Pilcaniyeu, Pichileufú y Comallo, a los que se adicionan algunos sitios de la cuenca del arroyo Maquinchao (Boschin 1986, 2009).

Los sitios con arte rupestre del área de Pilcaniyeu son 33. Entre éstos, se dispone de información completa sobre 24 (Apéndice II.4.a). Si bien la mayor parte de los sitios ha sido atribuida como perteneciente al "estilo de grecas" o al 
"estilo de pisadas" (Menghin 1957), también se han propuesto estilos locales. Por ejemplo, Llamazares (1980) plantea la existencia de dos grupos estilísticos en base a las diferencias técnicas observadas en la realización de los motivos en el Abrigo Pilcaniyeu. A partir de una postura interpretativa del arte rupestre, Boschin (2009) identifica ciertas representaciones como símbolos de linaje, y distingue varios estilos que reúne en ciclos artísticos de valor cronológico.

En cuanto a las técnicas de pintura, en los trabajos consultados se mencionan motivos monocromos, bicromos y polícromos, o bien una combinación o superposición de la pintura con el grabado. Además, se considera el tratamiento de la superficie pintada (puntiforme, lineal, plana o combinada) aunque no se proponen modos de aplicación de las mezclas, como el uso de la yema de los dedos o de artefactos.

A partir de diferentes sondeos y excavaciones se recuperaron materias primas colorantes (Boschin 2009; Ceballos y Peronja 1983; Llamazares 1980), que en algunos casos fueron vinculadas a la preparación de pinturas (Boschin 2009; Boschin et al. 2003, 2004, 2011; Maier et al. 2006, 2007; Massaferro et al. 2012) (Tabla 4.4; Apéndice II.4.b)

Son pocos los trabajos en los que se explicitan detalladamente las técnicas de producción de los grabados. En la mayoría de los sitios del área, Boschin (2009) reconoce la presencia de grabados de surco profundo y grueso mientras que en Sarita I y III reconoce al picado, y en Paredón Alonso y Paredón Loncomán identifica la incisión y la horadación. En Paredón Loncomán ambas técnicas habrían sido combinadas para la realización de algunos motivos. De igual manera, reconoce el raspado como técnica adicional en Paredón Alonso y en Cueva 1 del río Pichileufú (Apéndice II.4.c).

Por otro lado, las técnicas de grabado de Abrigo Pilcaniyeu y Cueva Visconti se definieron con mayor detalle a partir de la observación macroscópica de los surcos. En este sentido, Llamazares (1980) distingue el picado, la incisión, la horadación y el raspado para el primer sitio, mientras que Ceballos y Peronja 
(1983) para Cueva Visconti reconocen el raspado y tres variantes de percusión (en bajo relieve -plana o lineal- y en alto relieve delineado) (Apéndice II.4.c).

Con respecto a los potenciales artefactos empleados para grabar, Llamazares (1980: 117) vincula un percutor-cincel obtenido en estratigrafía en Abrigo Pilcaniyeu con la producción de los grabados, que fue definido previamente como un cincel (Boschin y Nacuzzi 1980: 126) (Apéndice II.4.c). Para los sitios Calcatreo 1 y Cueva Pichileufú se plantearon hipótesis relacionadas con las posturas de los productores en función de la altura con respecto al suelo de los motivos (Boschin 2009; Casamiquela 1968).

En el área de Pilcaniyeu se desarrollaron estudios experimentales vinculados a la producción de motivos grabados. En estos trabajos se analizaron distintas variables relacionadas con la producción del arte, como los soportes, los artefactos, las técnicas y el diseño (Álvarez y Fiore 1995). Además, se reconocieron los micro-rastros de uso en los filos de los artefactos empleados en la confección de motivos experimentales mediante las técnicas de incisión, horadación y raspado (Álvarez et al. 1999, 2001). Los resultados obtenidos a partir de la experimentación permitieron proponer que es posible realizar grabados con artefactos no formatizados (Álvarez y Fiore 1995). Esta conclusión explicaría el escaso número de artefactos potencialmente utilizables para grabar que se recuperan en el registro arqueológico (Fiore 1996-98).

Las ocupaciones del área corresponden al Holoceno tardío, entre ca. 2.7001.000 años AP, siendo que las más tardías se encuentran entre ca. 600-400 años AP (Boschin 1986, 2009; Ceballos y Peronja 1983; Nacuzzi 1987). Sin embargo, son numerosos los sitios con arte rupestre que no presentan anclaje cronológico. 


\section{4. b. 2. 3. Cuenca media y superior del río Limay}

El río Limay discurre en sentido SW-NE en el límite actual de las provincias de Neuquén y Río Negro. Desde finales del siglo XIX se han efectuado investigaciones sobre todo su curso (Moreno s/f, Bruch 1904, Vignati 1944). A partir de 1980 se iniciaron las investigaciones arqueológicas en la cuenca media del río (Arias et al. 2012; Crivelli Montero et al. 1991, 1996; Crivelli y Fernández 2003; Fernández y Crivelli 2004; Sanguinetti de Bórmida 1996). La sectorización de la cuenca que se presenta está basada en la propuesta de Crivelli Montero (2006: Tabla 2), quien distingue cuatro subáreas de norte a sur: Piedra del Águila, Quemquemtreu, Paso Limay-Paso Flores, y Alicurá. En ellas se estudiaron sitios con arte rupestre (Apéndice II.4.a) que presentan motivos grabados, pintados y pictograbados (Apéndices II.4.b y II.4.c). Los motivos identificados han sido asignados a los estilos "de pisadas" y "de grecas", coincidentes con la propuesta de Menghin (1957), mientras que regionalmente se han identificado sitios con grabados basales (Crivelli Montero 1988, 2006; Fernández 2006).

La técnica más abundante en esta porción de la cuenca del Limay es el grabado, seguido por la pintura. Ésta última es monocroma en seis sitios, aunque se han registrado sitios con motivos bicromáticos (Apéndices II.4.b). En los sitios Rincón Chico 2/87, La Marcelina 1 y Vaca Mala se recuperaron restos de pigmentos en capa y artefactos teñidos con pintura. Los materiales con restos de pintura de La Marcelina 1 podrían corresponder a tareas de preparación de pintura utilizada para otros fines diferentes, no relacionados con la producción de motivos rupestres ya que en el sitio se registraron motivos grabados (Sanguinetti de Bórmida y Curzio 1985 en Boschin 2009) (Apéndice II.4.b).

En la bibliografía consultada para el área no se observa un tratamiento exhaustivo de las técnicas de producción. Sólo para tres sitios se reconoce alguna técnica de grabado (Apéndice II.4.c). Por ejemplo, los grabados basales 
incisos de Epullán Grande (Crivelli Montero et al. 1991) o la incisión mediante grabado profundo y fino de Mata Molle (Plautz de Frenchi et al. 1975). Asimismo, en Casa de Piedra de Ortega se identificó la abrasión (de surco ancho), la horadación y el grabado fino (Crivelli Montero 1987). De acuerdo con la terminología empleada en esta tesis, la abrasión correspondería al raspado, y los grabados finos a la incisión.

La cronología de los grabados fue estimada de manera relativa sobre la base de la edad de los niveles arqueológicos que cubrían a los motivos (sellos arqueológicos). De este modo, se propusieron edades muy dispares para los grabados basales (principalmente líneas incisas) de Epullán Grande - ca. 10.000 años AP- (Arias et al. 2012; Crivelli y Fernández 1996, 2003; Crivelli et al. 1991, 1996) y de Casa de Piedra de Ortega - ca. 2.800 años AP - (Crivelli 1988, 2006). La disparidad entre ambas fechas no necesariamente implica una diacronía profunda en la producción de dichos grabados, ya que se trata de edades mínimas o ante quem (Crivelli Montero 2006; Crivelli y Fernández 2003). Por otro lado, los grabados de Epullán Grande ubicados sobre las paredes del sitio, correspondientes al "estilo de pisadas", fueron interpretados como anteriores a 2.800 años AP (Crivelli Montero et al. 1991; Crivelli Montero y Fernández 2003) mientras que en Epullán Chica el fechado radiocarbónico de ca. 2.200 años AP indica que la realización de los grabados es anterior a esa fecha (Crivelli Montero 2006; Crivelli Montero et al. 1996). Las grecas grabadas del sitio La Oquedad fueron interpretadas como cercanas a la conquista debido a sus semejanzas formales con los diseños de un enterratorio hallado en la cueva Epullán Grande, también vinculado con este momento (Crivelli Montero et al. 1991). La presencia de caballos grabados en Paredón Sur condujo a una estimación cronológica similar, vinculada con el contacto hispano-indígena (Crivelli Montero 2006).

En cuanto a la cronología de los motivos pintados, Fernández (2006) asigna a las grecas pintadas $c a$. 700 años de antigüedad, a partir de la semejanza estilística formal y la asociación con fechados radiocarbónicos de artefactos 
recuperados en estratigrafía y el arte rupestre de diferentes sitios. El planteo de Crivelli Montero (2006) coincide con el anterior para la asignación cronológica del estilo de grecas.

A partir de esta información se observa que, con excepción de Epullán Grande, los sitios de la cuenca media y superior del río Limay que presentan asociaciones entre el arte rupestre y los contextos estratigráficos se vinculan con el Holoceno tardío.

Aproximadamente $165 \mathrm{~km}$ al NNE de Epullán Grande, en los cañadones Supayniyeu y Santa Victoria (Figura 4.4), Gradin (1972) y Gradin y Aguerre (2003) informan cuatro sitios con arte rupestre pintado (Apéndice II.4.b; Tabla 4.4). En cañadón Supayniyeu reconocen tres sitios: Puesto Martínez 1 y 2, y Puesto Painemán. El sitio Santa Victoria 6 se encuentra en el cañadón homónimo (Apéndice II.3.a). Las consideraciones técnicas realizadas para estos sitios refieren a que se trata de motivos monocromos rojos (Gradin y Aguerre 2003).

\section{4. b. 3. Integración de la información técnica para Somuncurá y áreas} aledañas (Piedra Parada, Pilcaniyeu y cuenca del río Limay)

A partir de la información presentada en los apartados previos se observa que en los distintos sitios y localidades estudiados se han distinguido dos grandes grupos de técnicas: la pintura y el grabado, aunque no se registró en la bibliografía un tratamiento exhaustivo de dichas técnicas de producción.

Si esta información se contempla según la propuesta de Fiore (2007), en la que la secuencia de producción del arte rupestre está integrada por tres cadenas operativas (producción de artefactos, producción de mezclas pigmentarias y producción de motivos), se observa que:

1) Las referencias a los artefactos empleados o potencialmente empleados en la producción de motivos son sumamente puntuales. Para el macizo de 
Somuncurá no hay referencias, en tanto que para el área de Piedra Parada se infiere la utilización de hisopos o pinceles por la finura de los trazos pintados en el sitio Piedra Parada 1 (Aschero 1983a), que coincide con el grosor de las pequeñas ramas halladas en Campo Nassif 1 y de los hisopos teñidos con pintura recuperados en Campo Moncada 2 (Marchione y Bellelli 2013). Este último sitio no presenta arte rupestre, por lo que se infirió que tales artefactos pudieron haber sido usados en otros sitios o para pintar otras superficies (Pérez de Micou et al. 1992). En la cuenca media y superior del río Limay, Fernández (2003-05) infiere la utilización de dos artefactos diferentes para explicar la diferencia en el ancho de los trazos rojos y amarillos del sitio Rincón Chico 2/87. A pesar de realizar la distinción, Fernández (2003-05) no menciona ningún tipo de artefacto en particular. Entre los artefactos potencialmente utilizados para la producción de grabados sólo se ha recuperado un percutor-cincel en Abrigo Pilcaniyeu (Boschin y Nacuzzi1980; Llamazares 1980).

2) Se han recuperado restos de pigmentos en estratigrafía en diferentes sitios. Aquellos fueron sometidos a análisis en los que se intentaba conocer la composición mineralógica y química de las muestras. También fueron analizadas muestras de motivos rupestres de diferentes sitios y sustancias colorantes recolectadas en superficie (Boschin et al. 2003, 2011; Maier et al. 2006, 2007; Massaferro et al. 2012). Se observa que si bien las muestras fueron obtenidas en el momento de la excavación de los sitios, los análisis no se realizaron hasta momentos en que el equipo interdisciplinario estuvo conformado (Boschin et al. 2011).

3) En cuanto a cadena de producción de imágenes, se pueden distinguir varios puntos:

a) Las técnicas de producción suelen inferirse a partir de la observación macroscópica de los trazos pintados o de los surcos grabados. En el área de Piedra Parada se reconocieron motivos realizados mediante la técnica digital y mediante el uso de intermediarios como hisopos o pinceles (Aschero et al. 1983). 


\begin{tabular}{|c|c|c|c|c|c|c|c|c|c|c|c|c|c|c|c|c|}
\hline \multirow{3}{*}{ Área } & \multirow{3}{*}{ Sub-área } & \multicolumn{13}{|c|}{ TÉCNICAS } & \multirow{3}{*}{$\begin{array}{l}\text { Materiales } \\
\text { asociados }\end{array}$} & \multirow{3}{*}{ Fuentes } \\
\hline & & \multicolumn{7}{|c|}{ Pintura } & \multicolumn{5}{|c|}{ Grabado } & \multirow[t]{2}{*}{ Comb } & & \\
\hline & & Neg & $\mathrm{S}$ & $\mathrm{PP}$ & Dig & Mon & Bicr & Polic & $\mathrm{Pe}$ & Pind & I & $\mathrm{R}$ & $\mathrm{H}$ & & & \\
\hline Piedra Parada & - & $\mathrm{X}$ & $\mathrm{X}$ & $\mathrm{X}$ & $\mathrm{X}$ & $\mathrm{X}$ & $\mathrm{X}$ & - & $\mathrm{X}$ & & & - & - & $\mathrm{P} / \mathrm{G}$ & $\mathrm{X}$ & $\begin{array}{c}\text { Aschero et al 1983, } \\
\text { Onetto } 1987,1990, \\
1991\end{array}$ \\
\hline \multirow{4}{*}{ Pilcaniyeu } & Arroyo Pilcaniyeu & - & & - & - & $\mathrm{X}$ & $\mathrm{X}$ & $\mathrm{X}$ & - & $\mathrm{X}$ & $\mathrm{X}$ & $\mathrm{X}$ & - & $\begin{array}{l}\mathrm{P} / \mathrm{G} \\
\mathrm{P}+\mathrm{G}\end{array}$ & $\mathrm{X}$ & \multirow{4}{*}{$\begin{array}{l}\text { Boschin } 1986, \\
\text { 2009; Fiore } 1999\end{array}$} \\
\hline & Arroyo Pichileufú & $\mathrm{X}$ & - & - & & $\mathrm{X}$ & $\mathrm{X}$ & $\mathrm{X}$ & $\mathrm{X}$ & $\mathrm{X}$ & $\mathrm{X}$ & $\mathrm{X}$ & $\mathrm{X}$ & $\mathrm{P} / \mathrm{G}$ & $\mathrm{X}$ & \\
\hline & Arroyo Comallo & - & - & - & - & $\mathrm{X}$ & $\mathrm{X}$ & $\mathrm{X}$ & - & & $\mathrm{X}$ & $\mathrm{X}$ & $\mathrm{X}$ & - & $\mathrm{X}$ & \\
\hline & Arroyo Maquinchao & - & - & - & - & $\mathrm{X}$ & $\mathrm{X}$ & $\mathrm{X}$ & - & - & - & - & - & & - & \\
\hline \multirow{7}{*}{$\begin{array}{l}\text { Cuenca media y } \\
\text { superior del } \\
\text { Limay }\end{array}$} & Piedra del Águila & - & - & - & - & $\mathrm{X}$ & - & - & - & - & $\mathrm{X}$ & - & - & $\mathrm{P} / \mathrm{G}$ & $\mathrm{X}$ & $\begin{array}{c}\text { Crivelli Montero } \\
\text { 2006; Crivelli et al. } \\
\text { 1991, } 1996\end{array}$ \\
\hline & Quemquemtreu & - & - & - & - & $\mathrm{X}$ & - & - & - & - & $\mathrm{X}$ & - & - & $\mathrm{P} / \mathrm{G}$ & & $\begin{array}{c}\text { Crivelli Montero } \\
1988,2006\end{array}$ \\
\hline & $\begin{array}{c}\text { Paso Limay- Paso } \\
\text { Flores } \\
\end{array}$ & - & - & - & - & $\mathrm{X}$ & - & - & - & $\mathrm{X}$ & - & - & - & - & $\mathrm{X}$ & $\begin{array}{c}\text { Crivelli Montero } \\
2006 \\
\end{array}$ \\
\hline & Corralito & - & - & - & - & $\mathrm{X}$ & - & - & - & - & $\mathrm{X}$ & $\mathrm{X}$ & $\mathrm{X}$ & - & - & $\begin{array}{c}\text { Crivelli Montero } \\
1988 \\
\end{array}$ \\
\hline & Alicurá & - & - & - & - & $\mathrm{X}$ & $\mathrm{X}$ & - & - & - & - & - & & $\begin{array}{c}\mathrm{P}+\mathrm{G} \\
\mathrm{P} / \mathrm{G}\end{array}$ & $\mathrm{X}$ & $\begin{array}{c}\text { Bruch 1902; } \\
\text { Crivelli Montero } \\
1988\end{array}$ \\
\hline & Supainiyeu & \multirow[t]{2}{*}{-} & \multirow[t]{2}{*}{-} & \multirow{2}{*}{$\mathrm{X}$} & \multirow{2}{*}{$\mathrm{X}$} & \multirow{2}{*}{$\mathrm{X}$} & \multirow[t]{2}{*}{-} & \multirow{2}{*}{-} & \multirow{2}{*}{-} & \multirow{2}{*}{-} & \multirow{2}{*}{-} & \multirow{2}{*}{-} & - & \multirow{2}{*}{-} & \multirow{2}{*}{$\mathrm{X}$} & \multirow{2}{*}{$\begin{array}{c}\text { Gradin y Aguerre } \\
2003\end{array}$} \\
\hline & Santa Victoria & & & & & & & & & & & & & & & \\
\hline
\end{tabular}

Tabla 4.4. Técnicas reconocidas en áreas aledañas a Somuncurá.

Pintura. Neg: negativo; S: Salpicado; PP: pintura plana o positiva; Dig: Dígitos. Mon: monocromías; Bicr: bicromías; Policr: policromías. Grabado. Pe: percusión; Pind: Percusión indirecta; I: incisión; R: Raspado; H: Horadación; Comb: Combinación de técnicas. P/G: Pintura sobre grabado; P+G: Pintura y grabado sin superponerse conforman el mismo motivo; X: presencia; -: ausencia. 
Tanto en Somuncurá como en las áreas aledañas, la mayor distinción realizada con respecto a la técnica de pintura se refiere a la cantidad de colores empleados (motivos mono-, bi- o policromáticos) y al tratamiento de la superficie pintada (puntiforme, lineal, plano o combinado).

b) En cuanto a las técnicas de producción de grabados, no existe consenso en los términos empleados y su reconocimiento no es similar en todos los casos: no siempre se explicita el correlato material que permitió definirlas o, a la inversa, se describe la morfología del surco grabado sin reconocer la técnica. De este modo, los ejemplos donde se mencionan conjuntamente el tipo de motivo, la morfología del surco y las técnicas inferidas son escasos. Asimismo, para diferentes sitios se describen motivos pictograbados, donde hay trazos pintados sobrepuestos a surcos grabados, y motivos pintados y grabados, donde trazos de cada técnica sin superponerse conforman un motivo.

c) Respecto al proceso de trabajo, solo para dos sitios se plantean hipótesis relacionadas con las posturas de los productores (Cueva Pichileufú y Calcatreo 1), planteadas en función de la altura respecto del suelo a la que se encuentran los motivos.

d) La experimentación realizada por Álvarez y Fiore (1995) y Álvarez et al. (2001) ha permitido inferir que los grabados sobre toba pueden ser realizados con artefactos formatizados (percutores cinceles) y no formatizados (lascas), así como con guijarros.

La información respecto a la secuencia de producción del arte rupestre es dispar. Los estudios más detallados corresponden a las áreas de Piedra Parada y de Pilcaniyeu, en esta última el tema se abordó experimentalmente. El desarrollo de este tópico en la cuenca media y superior del río Limay es menos intenso, y sumamente puntual en el macizo de Somuncurá. Como en el caso del macizo del Deseado, estos antecedentes indican que los procesos de producción del arte rupestre fueron considerados, aunque no en forma sistemática.

Esta situación de disparidad en relación a diferentes análisis del arte rupestre entre las diferentes áreas nordpatagónicas podría vincularse a la 
profundidad temporal de los estudios, a los objetivos de los proyectos de investigación, y a la presencia de especialistas en arte rupestre dentro de los equipos. 


\section{Capítulo 5}

\section{LOS ESTUDIOS EXPERIMENTALES}

En los apartados siguientes se presenta el desarrollo de los diseños experimentales referidos a la producción de motivos rupestres realizados en esta tesis. La experimentación permitirá ampliar el conocimiento de los recursos empleados en producción de las manifestaciones rupestres, debido al escaso número de artefactos vinculados con la misma en el registro arqueológico de diferentes sitios de Patagonia (Fiore 1996-98; para mayor detalle ver Capítulo 4). A su vez, el abordaje experimental permitirá evaluar las propuestas realizadas acerca de las técnicas de producción en algunos sitios a partir de la observación macroscópica de los motivos y su comparación formal con motivos similares.

El diseño experimental contempla partes de las cadenas operativas que integran la secuencia de producción del arte rupestre: la producción de artefactos, la producción de pintura y la producción de motivos rupestres (grabados y pinturas) (Fiore 2007). En este capítulo se describen los artefactos que forman parte de la colección experimental, se desarrollan aspectos sobre la preparación y puesta a prueba de distintas mezclas de pintura y, en tercer lugar, se presentan los resultados de la replicación experimental de una selección de motivos grabados y pintados. La exposición separada de las diferentes cadenas operativas es sólo analítica, ya que éstas se encuentran imbricadas en la secuencia de producción del arte rupestre (Fiore 2007) y en el desarrollo experimental llevado a cabo en esta tesis. 


\section{5. a. ARTEFACTOS EXPERIMENTALES}

La colección experimental considerada en los diseños involucra artefactos formatizados, no formatizados y ecofactos (Aschero y Hocsman 2004; Hermo 2008), que fueron empleados en alguna etapa y/u operación de las cadenas operativas de la producción de arte rupestre.

En los antecedentes, entre los artefactos empleados para grabar se mencionan artefactos formatizados (v.g., cinceles o buriles), no formatizados (v.g., lascas) y ecofactos (guijarros de diferentes tamaños y materias primas usados como percutores). Algo similar sucede con los artefactos empleados para pintar, entre los que se enumeran artefactos formatizados (v.g., pinceles o hisopos) y ecofactos (vellones de pelo de guanaco y pequeñas ramas con restos de pintura). Estos artefactos fueron seleccionados debido a su presencia en diferentes sitios arqueológicos (para mayor detalle ver Capítulo 4) y fueron replicados en laboratorio, formando parte de la colección experimental.

\section{5. a. 1. Artefactos empleados para grabar}

La colección lítica experimental fue confeccionada con muestras de rocas silíceas de grano fino y coloración variada, recolectadas en el macizo del Deseado. Materias primas similares fueron registradas en los conjuntos líticos de los sitios arqueológicos estudiados (Blanco y Lynch 2011; Hermo 2008). La colección está integrada por 15 percutores sobre rodados, 90 artefactos no formatizados (ANF) de diferente tamaño (Figura 5.1.a) y tres cinceles (Figura 5.1.b).

Los percutores fueron seleccionados por materia prima y por tamaño. En relación a este último, tenían que ser lo suficientemente grandes para caber en la mano de quien iba a realizar las réplicas experimentales, ya que iban a ser utilizados sin enmangue. A partir de la revisión de fuentes etnohistóricas y observaciones etnoarqueológicas realizadas en Australia, 
Bednarik (2007b: 40-41) informa las características generales de artefactos similares, utilizados como percutores sin enmangue para diferentes actividades de grabado, reconocidos como mur-e por las poblaciones australianas.

Los artefactos fueron tallados por percusión directa con un percutor duro por el Dr. Darío Hermo y el Lic. Bruno Mosquera. Los ANF fueron rotulados, fotografiados, medidos y dibujados previamente al registro de los atributos (Hermo 2008). Las grillas de registro se detallan en el Apéndice III.1 Si bien en el proceso de talla se obtuvieron diferentes ANF (Figura 5.1.a), para replicar los motivos grabados se seleccionaron aquellos que presentaban tamaño mediano a muy grande (Aschero 1975) debido a que la prensión de los mismos iba a ser directa. Este tamaño permite un mayor contacto del filo de la pieza con el soporte y un manejo más cómodo. La nomenclatura de los mismos se corresponde con las experiencias replicativas realizadas y la colección experimental (E\# RVB de uno en fondo)

La formatización final de los cinceles fue realizada con un percutor blando (hueso). Estos artefactos fueron empleados para realizar marcas mediante la técnica de percusión indirecta (Figura 5.1.b). Las dimensiones de los mismos se presentan en la Tabla 5.1.

\begin{tabular}{|c|c|c|c|}
\hline Id & $\begin{array}{c}\text { Largo } \\
(\mathrm{mm})\end{array}$ & $\begin{array}{c}\text { Ancho } \\
(\mathrm{mm})\end{array}$ & $\begin{array}{c}\text { Espesor } \\
(\mathrm{mm})\end{array}$ \\
\hline E1 RVB C1 & 64,1 & 32,6 & 19,4 \\
\hline E1 RVB C2 & 73,3 & 36,6 & 22,5 \\
\hline E1 RVB C3 & 109,5 & 43,8 & 24,1 \\
\hline
\end{tabular}

Tabla 5.1. Cinceles experimentales.

Referencias: El siglado corresponde a E\# (número de experiencia); RVB (colección lítica para grabar) $\mathrm{C}$ (Cincel). 

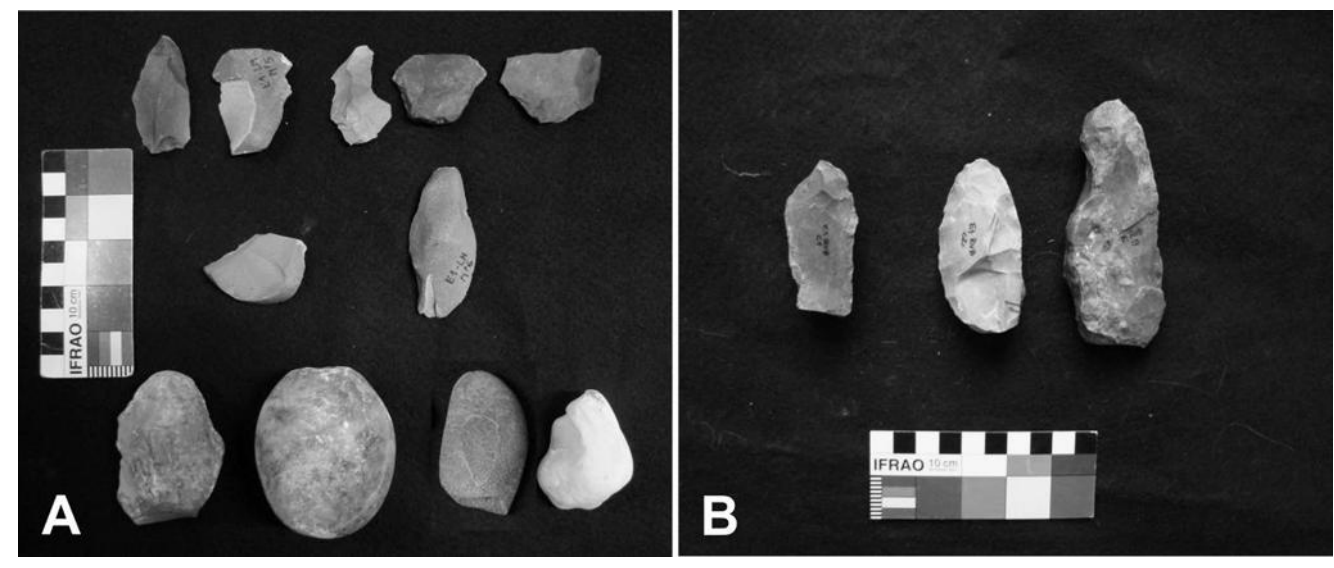

Figura 5.1. Artefactos experimentales: a. ANF (filas superiores) y percutores (fila inferior) de la colección experimental; b. Cinceles.

En una primera instancia, parte de esta colección fue empleada para probar las técnicas de grabado en las que se ejerce presión (incisión, horadación y raspado, como se detalla más adelante) y, en una segunda instancia, algunos de los ANF que la integran fueron empleados para la producción de motivos.

\section{5. a. 2. Artefactos para pintar}

En el registro arqueológico del macizo del Deseado los artefactos recuperados que permiten inferir su utilización para pintar son escasos (ver Capítulo 4). Sin embargo, la mayor parte de los motivos registrados son pintados y se infiere el empleo de artefactos en la realización de los mismos (Gradin et al. 1976, 1979; Paunero et al. 2005). En base a la escasa evidencia disponible, se plantea como posible la utilización de hisopos para aplicar mezclas pigmentarias: ya que si bien existen sitios arqueológicos en Patagonia donde se recuperaron pinceles (Scheinsohn 2010), los hisopos resultaron ser más abundantes en el registro (Onetto 1986-87; Marchione y Bellelli 2013: Figura 3.a; Reigadas 2007).

A partir de la información conocida, los hisopos de la colección experimental fueron confeccionados usando pequeñas hebras de pelo de guanaco (Lama guanicoe), generalmente menores a $1 \mathrm{~g}$, y ramas pequeñas de árboles de largo variable (entre 10 y $30 \mathrm{~cm}$ ) (Figura 5.2.a). En la 
elaboración de estos artefactos, un extremo de la rama fue cubierto con pelo y atado con una pequeña hebra adicional (Figura 5.2.b), siendo el producto formatizado experimental muy similar al arqueológico (Figura 5.2.c). Estos artefactos fueron empleados en la realización de puntos y líneas paralelas, ya que se tenía como primer objetivo reconocer el tipo de trazo que dejan. Adicionalmente, se emplearon vellones de pelo de guanaco embebidos en pintura.

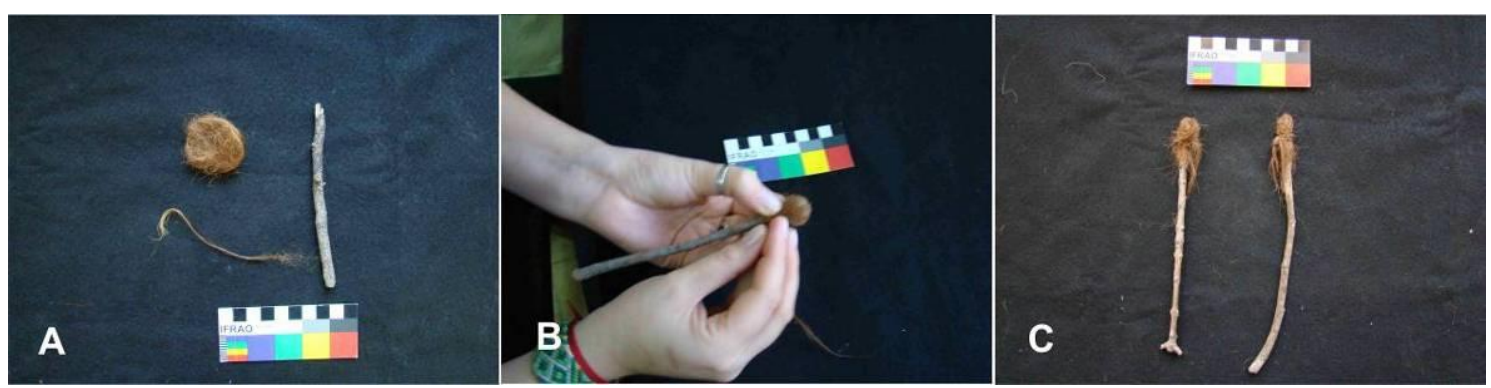

Figura 5.2. Hisopos: a. Materia prima empleada en la realización; b. cobertura con pelo de un extremo de la rama; c. Artefactos terminados.

\section{5. b. MEZCLAS PIGMENTARIAS}

Las mezclas pigmentarias o pinturas están compuestas por tres elementos: pigmento, ligante y aditivo (Aschero 1988; Attard Montalto 2010; Boschin et al. 2011; Chalmin et al. 2003). El pigmento es la materia que le da color a las mezclas, y puede ser de origen vegetal, animal o mineral. En el caso del arte rupestre, a partir de los estudios realizados en distintas regiones de Patagonia se han identificado pigmentos de origen mineral (Aschero 1983-85; Barbosa y Gradin 1986-87; Boschin et al. 2003, 2011; Iñíguez y Gradin 1977; Maier et al. 2006; Massaferro et al. 2012; Rial y Barbosa 1983-85; Sepúlveda 2011; Wainwright et al. 2000), que se utilizaban molidos en forma de polvo. El ligante (aglutinante o diluyente) es un solvente orgánico (aceites o grasas) o inorgánico (agua) que le otorga consistencia fluida a la pintura. Estos componentes son más difíciles de identificar arqueológicamente debido a sus menores chances de preservación. Sin embargo, existen estudios en los que se ha logrado identificar la presencia de grasas $u$ otros materiales de origen animal 
(Boschin et al. 2011; Maier et al. 2006, 2007). A estos componentes se le suma el aditivo o mordiente, que se vincula con la adherencia y la densidad de la mezcla (Aschero 1988; Attard Montalto 2010; Chalmin et al. 2003). En las pinturas rupestres el aditivo podría ser yeso (Aschero 1988; Barbosa y Gradin 1986-87; Iñíguez y Gradin 1977; Ledesma 2005, entre otros). A continuación se presentan las materias primas empleadas para la confección de las mezclas experimentales y las condiciones bajo las que se sometieron a prueba.

\section{5. b. 1. Materias primas colorantes: procedencia y composición}

Las materias empleadas en estas experiencias proceden, casi en su totalidad, de recolecciones efectuadas en las inmediaciones del Parque Nacional Bosque Petrificado de Jaramillo y en las localidades arqueológicas Aguada del Cuero, Piedra Museo y La Primavera, todos ellos en el macizo del Deseado (Carden 2008a; Carden et al. 2011, 2014; Magnín 2010; Miotti 2008) (Figura 5.3; Tabla 5.2).

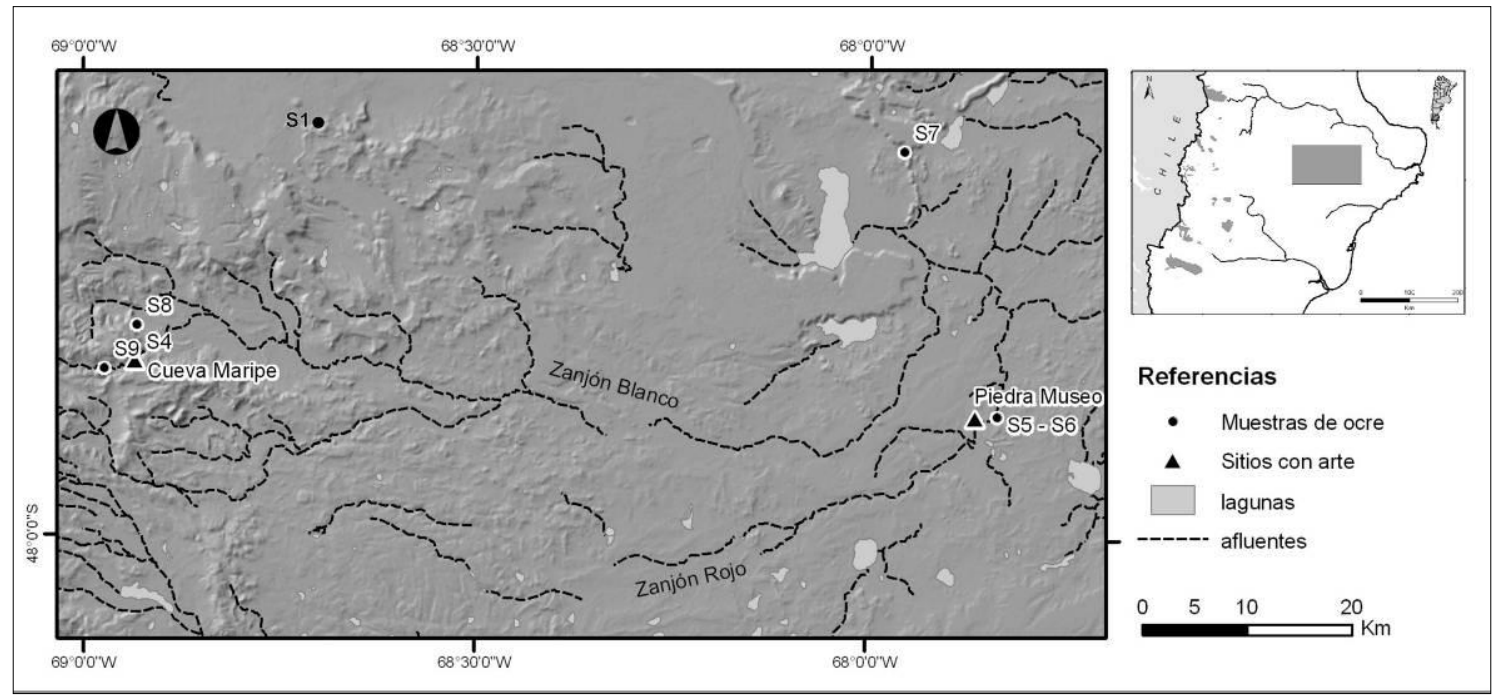

Figura 5.3. Localización de las muestras pigmentarias en el Macizo del Deseado: localidades de Piedra Museo y La Primavera. Tomada de Carden et al. 2011. Referencias en Tabla 5.2 


\begin{tabular}{|c|c|c|c|c|}
\hline Muestra & Localidad & Formación geológica & Código de color & Forma \\
\hline $\mathrm{S} 1$ & $\begin{array}{l}\text { Aguada del Cuero } \\
\text { (Cerro Bonete) }\end{array}$ & La Angelita/Baqueró* & $2.5 \mathrm{Y} 8 / 2$ pale yellow & Clastos angulares \\
\hline $\mathrm{S} 4 \mathrm{~A}$ & \multirow[t]{2}{*}{ La Primavera } & Chön Aike & $2.5 \mathrm{Y} 7 / 8$ yellow & Clastos angulares \\
\hline S4B & & Chön Aike & 10R 5/8 red & Clastos vesiculares \\
\hline S5A & \multirow{3}{*}{ Piedra Museo } & Bajo Pobre & $10 \mathrm{R} 5 / 8 \mathrm{red}$ & $\begin{array}{l}\text { Clastos angulares } \\
\text { ("ladrillos") }\end{array}$ \\
\hline S5B & & Bajo Pobre & $\begin{array}{l}\text { 5YR3/4 dark reddish } \\
\text { brown }\end{array}$ & guijarros \\
\hline S6 & & Bajo Pobre & $\begin{array}{l}2.5 \mathrm{YR} 7 / 4 \text { light } \\
\text { reddish brown }\end{array}$ & $\begin{array}{c}\text { Clastos angulares } \\
\text { ("ladrillos") }\end{array}$ \\
\hline S7 A & \multirow{2}{*}{$\begin{array}{c}\text { PNBP } \\
\text { (El Arenal) }\end{array}$} & Baqueró/La Matilde & $7.5 \mathrm{R} 5 / 2$ weak red & \multirow{2}{*}{$\begin{array}{l}\text { Clastos angulares } \\
\text { ("ladrillos") }\end{array}$} \\
\hline S7 B & & Baqueró/La Matilde & $7.5 \mathrm{R} \mathrm{4/2}$ weak red & \\
\hline S8 & \multirow[t]{3}{*}{ La Primavera } & Baqueró/Chön Aike & $7.5 \mathrm{R} 5 / 6 \mathrm{red}$ & $\begin{array}{c}\text { Clastos de aspecto } \\
\text { vesicular }\end{array}$ \\
\hline S9 A & & Chön Aike & \multirow{2}{*}{$10 \mathrm{R} 3 / 6$ dark red } & \multirow{2}{*}{$\begin{array}{l}\text { Clastos angulares } \\
\text { ("ladrillos") }\end{array}$} \\
\hline S9 B & & Chön Aike & & \\
\hline
\end{tabular}

Tabla 5.2. Muestras empleadas en las diferentes experiencias realizadas. Código de color: Earth Soil Chart. Referencias: PNBP: Parque Nacional Bosque Petrificado de Jaramillo; entre paréntesis se indica el sitio; * Aparecen en la disyunción entre ambas formaciones.

La composición mineralógica de las muestras utilizadas se conoce a partir del análisis de difracción de rayos $\mathrm{X}$ (DRX), realizado en el Centro de Investigaciones Geológicas de La Plata (CIG-CONICET) por el equipo del Dr. Daniel Poiré (Carden et al. 2011, 2014). Algunas muestras de color rojo contienen óxidos de hierro, principalmente hematita, en las amarillas no se ha identificado el pigmento mientras que las muestras rosadas y violáceas contienen un alto porcentaje de esmectita, por lo que se interpretaron como no útiles para pintar (Carden et al. 2014) (Tabla 5.3).

A las muestras anteriores se adiciona una muestra recolectada en 2012 a $7,5 \mathrm{~km}$ hacia el NE de Cueva Maripe (Figura 5.3). Ésta fue empleada como pigmento blanco (10YR 8/1; Earth Soil Chart) en la mayor parte de las experiencias. No obstante, los estudios sobre composición mineralógica aun están en procesamiento. 


\begin{tabular}{|c|c|c|c|c|c|c|c|c|c|c|c|c|c|c|c|c|c|c|c|c|c|}
\hline \multirow{4}{*}{$\frac{5}{\frac{5}{2}}$} & \multirow{4}{*}{ 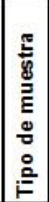 } & \multicolumn{8}{|c|}{ Roca Total } & \multicolumn{12}{|c|}{ Fracción Arcillas } \\
\hline & & \multirow{2}{*}{\multicolumn{2}{|c|}{ Feld }} & \multirow{2}{*}{\multicolumn{2}{|c|}{ Carbonatos }} & \multirow{2}{*}{ Ceolitas } & \multirow{3}{*}{ 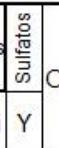 } & \multirow{3}{*}{\multicolumn{2}{|c|}{$\mathrm{pp} H \mathrm{Ht}$}} & & \multirow{2}{*}{\multicolumn{2}{|c|}{$\begin{array}{ll}\text { nectita } & \text { Clorita }\end{array}$}} & \multicolumn{5}{|c|}{ Interestratificados } & \multirow{2}{*}{ Illita } & \multirow{2}{*}{\multicolumn{2}{|c|}{ Caolinita }} & \multirow{3}{*}{ Impurezas } \\
\hline & & & & & & & & & & L Esm & & & \multicolumn{3}{|c|}{ is } & \multicolumn{2}{|c|}{ cs } & & & & \\
\hline & & & $\mathrm{K} \mid \mathrm{PI}$ & $: \mathrm{Ca}$ & D & A & & & & Abu & $\mathrm{Cr}$ & Abu C & $\mathrm{Cr}$ Abu & $\mathrm{Cr}$ & CE A & $\mathrm{Abu} C$ & $\mathrm{Cr} C$ & $A$ Abu & Cr Abu & $\mathrm{Cr}$ & \\
\hline B12 & \begin{tabular}{l|}
$\frac{\pi}{0}$ \\
$\frac{8}{8}$ \\
$\frac{8}{8}$
\end{tabular} & A & Mo & & E & Mo & & $\mathrm{E}$ & & $\operatorname{Tr}$ & & & Tr & & & & & & MA & $R$ & Ab: Clivesc: $Q-F$ \\
\hline $\mathrm{P} 8$ & & $E$ & $\mathrm{E}$ & $\mathrm{E}$ & & E & MA & & \begin{tabular}{l|l} 
Mo & $E$ \\
\end{tabular} & $\mathrm{E}$ & & $\operatorname{Tr}$ & $\mathrm{E}$ & $\mathrm{M}$ & NC & & & $\mathrm{Tr}$ & MA & $B$ & Esc: We-Cli-Y \\
\hline P9 & 0 & $\mathrm{E}$ & E N & ME & $\operatorname{Tr}$ & $\mathrm{E}$ & MA & Mo 1 & Mo & & & & $\mathrm{Tr}$ & & & & & MA 1 & \begin{tabular}{l|l} 
M & $A$ \\
\end{tabular} & $\mathrm{M}$ & Ab: Clivesc: Y-Op-Q-F-We \\
\hline P14 & $\frac{\pi}{\pi}$ & $\mathrm{A}$ & $\mathrm{A} N \mathrm{~N}$ & ME & $\operatorname{Tr}$ & Mo & A & Mo & $\mathrm{E} \mid \mathrm{M}$ & ME & & & $\mathrm{Tr}$ & & & & & \begin{tabular}{l|l} 
Mo & 1 \\
1
\end{tabular} & M $\quad$ MA & $\mathrm{R}$ & Ab: Clivsc: Op-Q-F-We \\
\hline $\mathrm{P} 15$ & & Mo E & $\begin{array}{l}\text { MAIN } \\
\end{array}$ & ME & & $E$ & $A$ & $\mathrm{E}$ & $\mathrm{E}$ & & & & Mo & $M$ & NC & & & Tr & \begin{tabular}{l|l} 
MA \\
\end{tabular} & $M$ & Ab: Clivesc: Op-Q-F-We \\
\hline $\mathrm{P} 16$ & & \begin{tabular}{|l|l|l}
$A$ & $M$ \\
\end{tabular} & $\mathrm{ME} E \mathrm{E}$ & ME & $\mathrm{Tr}$ & $\mathrm{E}$ & Mo & Mo & $E$ & & & & $\mathrm{Tr}$ & & & & & $E$ & \begin{tabular}{l|l|}
$M$ & $M A$ \\
\end{tabular} & $\mathrm{R}$ & Ab: Cli-We/Esc: Q-F \\
\hline E19 & $\approx$ & MA & & $\mathrm{E}$ & & & & & Mo & & & & $\mathrm{Tr}$ & & & & & & MA & $\mathrm{MB}$ & Esc: Q \\
\hline E28 & 离 & MEM & MEIME & $\operatorname{Tr}$ & & ME & MA & $E$ & & & & $\operatorname{Tr}$ & $\operatorname{Tr}$ & & & & & & & & Ab:Y-CluEsc: Q-F \\
\hline E29 & 㽭 & Mo & $|\mathrm{Mo}| \mathrm{N}$ & ME & & \begin{tabular}{l|l|}
$E$ & Mo \\
\end{tabular} & A & Mo & & & & $\mathrm{Tr}$ & $\operatorname{Tr}$ & & & & & & & & Ab: Clivesc: $Y-O p-Q-F$ \\
\hline E33 & 点 & MA T & 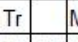 & ME & & & & & $\mathrm{ME}$ & & & & & & & & & $\operatorname{Tr}$ & MA & MB & Ab: Q/Esc: $\mathrm{Ha}$ \\
\hline E35 & & Mo $\mathrm{E}$ & \begin{tabular}{l|l|l}
$E$ & $E$ \\
\end{tabular} & E & & & & MAl & ME & & & & $\mathrm{E}$ & $M$ & $\mathrm{NC}$ & & & $\operatorname{Tr}$ & MA & $\mathrm{B}$ & Ab: Clivesc: Op-Q-F \\
\hline S4A & & \begin{tabular}{|l|l}
$E$ & $T$ \\
\end{tabular} & Tr MAln & ME ME & ME & $\operatorname{Tr}$ & & A & & MA & $M$ & & $\mathrm{Tr}$ & & & & & & ME & $M$ & Esc: Q-CT-F-Cli \\
\hline S5 & & $\mathrm{A} \mid \mathrm{M}$ & Mo|MEN & Mo & $E$ & & & & $\mathrm{ME}$ & MA & $\mathrm{MB}$ & & & & & & & & & & Esc: Q-F \\
\hline S6 & $\underline{\underline{w}}$ & \begin{tabular}{l|l}
$\mathrm{A}$ & $\mathrm{A}$ \\
$\mathrm{A}$
\end{tabular} & \begin{tabular}{l|l|l}
$A$ & $E$ \\
\end{tabular} & $\mathrm{E}$ & & $E$ & & & $\mathrm{ME}$ & MA & MB & & & & & & & & & & Ab: Q-F/Esc: Cli \\
\hline S7A & $\stackrel{0}{t}$ & $\mathrm{Tr}$ & MAN & ME & & Mo & & & $\mathrm{E}$ & MA & $R$ & & $\operatorname{Tr}$ & & & & & & & & Ab: F/Esc: Cli \\
\hline S7B & 일 & E & $E$ & ME & & MA & & & $E$ & MA & $R$ & & $\operatorname{Tr}$ & & & & & & Mo & $\mathrm{M}$ & Ab: Cli-Q/Esc: F \\
\hline S8 & $\infty$ & $E$ & $\mid$ maln & Mo & & $\mathrm{Tr}$ & & & $\operatorname{Tr}$ & MA & $R$ & & & & & & & & & & Esc: Q-F \\
\hline S9A & & \begin{tabular}{|l|l}
$E$ & $T$ \\
\end{tabular} & $\operatorname{Tr}|\mathrm{MA}|$ & & & $\operatorname{Tr}$ & & & Mo & Esc & asisim & na arcill & \begin{tabular}{ll|l} 
lla & $\mathrm{Tr}$ \\
\end{tabular} & & & & & & $\operatorname{Tr}$ & & Ab: F/Esc: Cli-Q \\
\hline S9B & & \begin{tabular}{|l|l}
$A$ & $A$ \\
\end{tabular} & \begin{tabular}{l|l|l}
$\mathrm{A}$ & $\mathrm{A}$ & $\mathrm{N}$ \\
$\mathrm{N}$
\end{tabular} & & & $\mathrm{Tr}$ & $\mathrm{Tr}$ & & $E$ & $\mathrm{Tr}$ & $\mathrm{Tr}$ & & $\mid \mathrm{MA}$ & $M$ & $\mathrm{NC}$ & & & & & & Esc: Q-F-Cli \\
\hline & $\begin{array}{l}\text { Q: c } \\
\text { Feld } \\
\text { Pl: p } \\
\text { Y: y } \\
\text { Ca: } \\
\text { D: d } \\
\text { Cli: } \\
\end{array}$ & $\begin{array}{l}\text { Uarzo } \\
\text { K: fel } \\
\text { plagioc } \\
\text { eso } \\
\text { calcita } \\
\text { tolomit } \\
\text { clinopt }\end{array}$ & $\begin{array}{l}\text { o } \\
\text { eldespat } \\
\text { oclasa } \\
\text { ta } \\
\text { tata } \\
\text { ptilolita } \\
\end{array}$ & $\begin{array}{l}\text { A: analc } \\
\text { to potásic } \\
\text { We: wed } \\
\text { Lep: lepic }\end{array}$ & $\begin{array}{l}\text { Sellita } \\
\text { locrocita }\end{array}$ & $\begin{array}{l}\text { Op: } \\
\text { Ht: } \\
\text { IS: il } \\
\text { CS: } \\
\text { Abu: } \\
\text { ta Cr: } \\
\text { CE: } \\
\end{array}$ & $\begin{array}{l}\text { ópal } \\
\text { hem } \\
\text { illita/ } \\
\text { clor } \\
\text { u: abu } \\
\text { crist } \\
\text { cap }\end{array}$ & & $\begin{array}{l}\text { T } \\
\text { a } \\
\text { nectita } \\
\text { esmec } \\
\text { ancla } \\
\text { idad } \\
\text { expans }\end{array}$ & astita & & $\begin{array}{l}\text { Esc: } e \\
\text { Ab: ab } \\
\text { MB: } m \\
\text { B: bue } \\
\text { R: regu } \\
\text { M: mal } \\
\text { NC: no }\end{array}$ & $\begin{array}{l}\text { escaso } \\
\text { oundant } \\
\text { nuy bue } \\
\text { ena } \\
\text { ular } \\
\text { ala } \\
\text { o cuanti }\end{array}$ & $\begin{array}{l}\text { te } \\
\text { ena }\end{array}$ & & & $\begin{array}{l}\text { IA: mu } \\
\text { : abun } \\
\text { lo: mo } \\
\text { iesca } \\
\text { IE: mu } \\
\text { r: traze }\end{array}$ & $\begin{array}{l}\text { uy abur } \\
\text { ndante } \\
\text { oderado } \\
\text { aso (ent } \\
\text { uy esca } \\
\text { zas }\left(<1^{\circ}\right.\end{array}$ & $\begin{array}{l}\text { Undante ( } \\
\text { ? (entre } 3 \\
\text { lo (entre } \\
\text { ntre } 5 \text { y } \\
\text { caso (ent } \\
1 \% \text { ) }\end{array}$ & $\begin{array}{l}>50 \% \\
30 \text { y } \\
15 \mathrm{y} \\
15 \% \\
\text { tre } 1 \text {. }\end{array}$ & $\begin{array}{l}\%) \\
50 \%) \\
30 \%) \\
y 5 \%)\end{array}$ \\
\hline
\end{tabular}

Tabla 5.3. Composición mineralógica de las muestras contempladas en esta etapa (tomado y modificado de Carden et al. 2014).

\section{5. b. 2. Los ligantes y los aditivos}

Existen fuentes etnográficas que informan sobre el empleo de recursos vegetales, minerales y animales para elaborar las mezclas pigmentarias por parte de las poblaciones que habitaron la Patagonia argentina (Aguerre 2000; Bórmida y Casamiquela 1958-59; Miotti 1998; Pérez de Micou 2010; Prates 2009). Esta información fue el punto de partida para considerar componentes análogos en la conformación de las mezclas pigmentarias experimentales.

En las diferentes etapas de trabajo se emplearon distintos ligantes, todos ellos de origen animal: dos procedentes de bóvidos (grasa del lomo y de la médula ósea de vaca -Bos taurus-), grasa de pollo (Gallus gallus domesticus), grasa de choique (Pterocnemia pennata), unto sin sal de porcino (Sus scrofa) y clara de huevo de gallina, a los que se le adicionó agua. 
Estas sustancias fueron obtenidas mediante diferentes procedimientos. La grasa del lomo vacuno se obtuvo derritiendo trozos de dicha materia prima. Un procedimiento similar fue seguido para la obtención de la grasa de pollo y de choique. La médula ósea vacuna se obtuvo a partir del hervido de un trozo de hueso largo. Por su parte, el unto sin sal corresponde a la materia grasa extraída del epiplón del cerdo ${ }^{1}$; una vez obtenido el tejido adiposo se lo dispone en un contenedor y se lo deja orear hasta que cambia su consistencia. La clara se extrajo de un huevo de gallina.

En un primer momento, las grasas vacunas, porcina y de gallina fueron utilizadas como ligantes. La grasa de choique se obtuvo con posterioridad y, a partir de ese momento, fue el principal ligante empleado en las experiencias replicativas ya que se pretendía utilizar materiales análogos a aquellos que podrían haber empleado las poblaciones que ocuparon este espacio en el pasado.

El aditivo empleado en la experimentación fue el yeso hemihidratado. Si bien en el macizo del Deseado hasta el momento no se han reconocido fuentes naturales de yeso, según Panza (2001) este aparece en forma natural en la formación Salamanca y en el Grupo Sarmiento (ver capítulo 3). Si se considera a Cueva Maripe como punto de referencia (Figura 5.3) asomos de la formación Salamanca se encuentran alrededor de $70-85 \mathrm{~km}$ al NE en las Mesetas de Mojón o Álvarez; mientras que asomos del Grupo Sarmiento pueden estar alrededor de 70 o $30 \mathrm{~km}$ al NE (en las Mesetas del Mojón o La Levadura, y en Cerro Alto), o tan solo a 10-15 km hacia el sur en la estancia La Dorita (Panza 2001).

Estudios previos realizados en el área del río Pinturas y en el área pedemontana de Santa Cruz proponen que a partir de la alteración térmica de la basanita -yeso natural- se puede obtener yeso hemihidratado, que presenta mayor capacidad de fragüe que la versión natural (Barbosa y Gradin 1986-87; Iñiguez y Gradin 1977; Rial y Barbosa 1983-85). En los difractogramas de rayos $\mathrm{X}$ es posible reconocer este componente (yeso)

\footnotetext{
${ }^{1}$ El epiplón es el tejido adiposo que se ubica al interior del tejido conectivo que recubre el vientre del cerdo. En algunas zonas rurales de Patagonia esta preparación se emplea para hacer curaciones o para ablandar implementos de cuero.
} 
aunque resulta imposible saber si el componente original de la mezcla fue su versión natural o la hemihidratada, debido a que con el aditamento de agua la mezcla recupera las moléculas perdidas (Barbosa y Gradin 1986-87; Gradin 1983; Ma. Fernanda Rozas, comunicación personal 2012). En síntesis, la decisión de emplear yeso hemihidratado como aditivo fue tomada en función de estos antecedentes, que proponen una mayor capacidad de fragüe. El yeso utilizado fue la versión comercial del mismo que puede obtenerse en ferreterías y corralones.

\section{5. b. 3. Preparación y puesta a prueba de las mezclas pigmentarias}

En esta etapa de análisis, la experimentación involucró la puesta a prueba de las sustancias que conforman las mezclas empleadas para la replicación de los motivos rupestres. Se utilizaron siete muestras de pigmentos de distintos colores y composición mineralógica (Tablas 5.3 y 5.4). Aquellos pigmentos recolectados bajo la forma de guijas o guijarros fueron molidos con rodados a fin de obtener la fracción pulverulenta necesaria (Aschero 1988; Carrasco 2003) (Figura 5.4.a). A ese polvo se le adicionaron diferentes ligantes y yeso hemihidratado. Siguiendo los lineamientos de Paunero (1992), las proporciones empleadas fueron de 5 a 1: es decir, por cada $5 \mathrm{~g}$ de pigmento o sustancia colorante se adiciona $1 \mathrm{~g}$ de ligante, 1,5 g de yeso y la cantidad necesaria de agua, la cual varía en función de la consistencia que se desea para la mezcla. Las cantidades de pigmento, yeso y grasa fueron pesadas en una balanza digital de precisión (0,1-500 g), mientras que el agua fue medida con una pipeta de $1 \mathrm{ml}$ de precisión. 


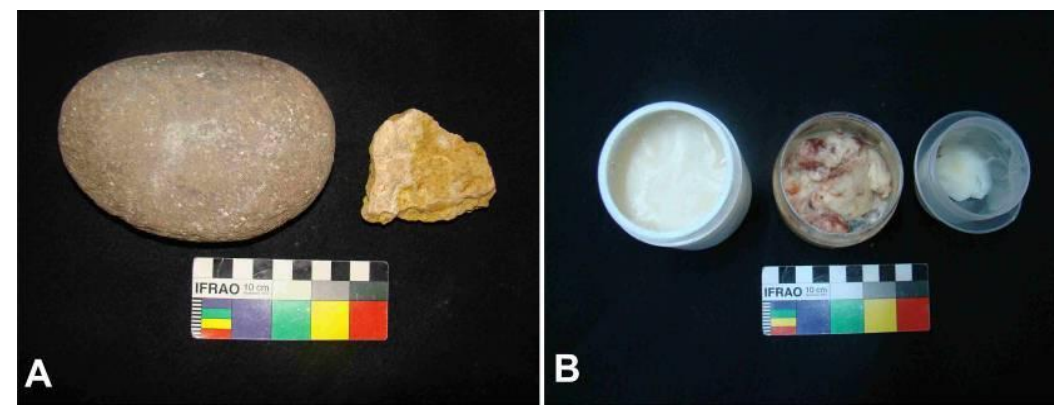

Figura 5.4. Materiales empleados en la puesta a prueba de las sustancias colorantes: a. Percutor para moler y pigmento S4A; b. Ligantes, de izquierda a derecha: grasa vacuna (del lomo y de la médula ósea), unto sin sal porcino.

Una vez lograda la integración de los componentes, las mezclas fueron dejadas en reposo por el lapso de 60 minutos para su correcta hidratación; en algunos casos fue necesario adicionar agua para lograr la consistencia deseada. Luego, las mezclas fueron aplicadas sobre dos bloques rocosos experimentales empleando dos técnicas distintas: el pulverizado directo y la técnica digital (Tabla 5.4).

Los bloques utilizados en esta instancia corresponden a lajas de ignimbrita procedentes de las inmediaciones de San Carlos de Bariloche, adquiridas en comercios del ramo de la construcción que, si bien son de un sector diferente de Patagonia al considerado en esta tesis, permiten observar la adherencia de las pinturas a un soporte rocoso de litología similar al arqueológico. Existen investigaciones que han aplicado las mezclas directamente sobre planchas de cartón recubiertas con yeso (Groenen 1988) u hojas de papel (Gunn 2006). El análisis de esos trabajos permite sugerir que los bloques rocosos se comportan de manera más similar entre sí en cuanto a la absorción de las mezclas que si se comparan rocas con cartón recubierto con yeso o con hojas de papel. Por lo anterior, para las expectativas analógicas de este estudio, la roca continúa siendo el mejor análogo experimental.

En el caso de la técnica del pulverizado directo, y para evitar que se superpongan las variantes de las mezclas aplicadas sobre el mismo bloque, se procedió a separar cada estarcido mediante recuadros de $3 \mathrm{~cm} \mathrm{x} 3 \mathrm{~cm}$ en un papel (Figura 5.5.a). Al realizar la siguiente aplicación, los recuadros ya 
pintados eran cubiertos con otro papel para que no mezclaran entre sí (Figura 5.5.b). En el caso de la técnica digital no fue necesario esperar el secado entre las aplicaciones de pintura (Figura 5.5.c; Tabla 5.4).

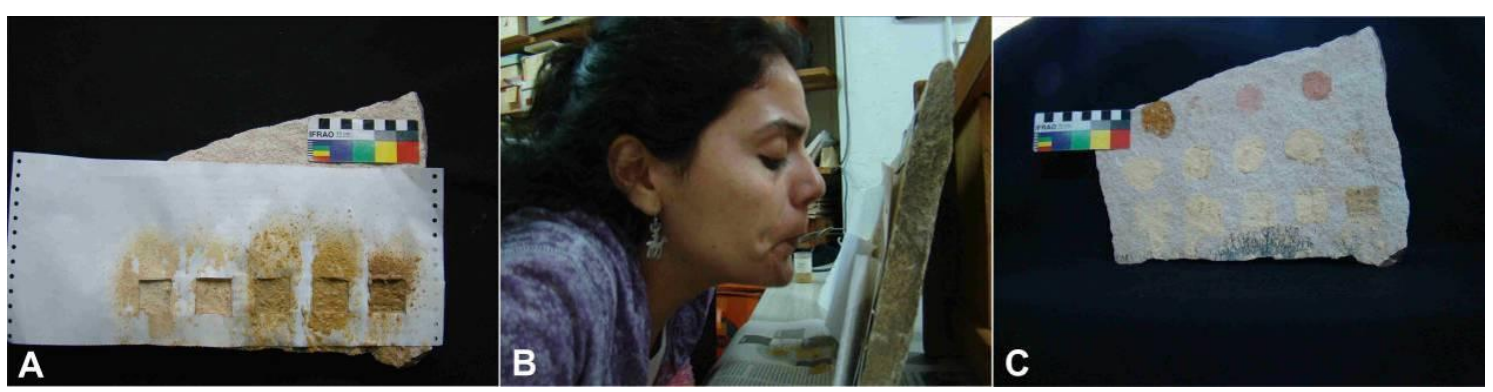

Figura 5.5. Puesta a prueba de diferentes mezclas pigmentarias mediante dos técnicas: a. Separación de las distintas mezclas con rectángulos de $3 \mathrm{~cm}^{2} ; \mathrm{b}$. pulverizado directo de la pintura; c. Bloque 2 en el que se aplicó pintura por medio del pulverizado directo y de la técnica digital.

Si bien en la preparación de las mezclas se mantuvieron las proporciones, existe un caso donde las mismas fueron modificadas para observar cambios en la consistencia, integración y adherencia de la mezcla al sustrato rocoso (Tabla 5.4). Todos los pigmentos empleados pintaron el sustrato rocoso. Si se consideran las propiedades físico-químicas de los pigmentos y los ligantes (Attard Montalto 2010; Bednarik 2007b; Sepúlveda 2011), cuatro características de las mezclas pigmentarias influyen sobre su permanencia en el soporte rocoso: la heterogeneidad, la integración, la consistencia y la adherencia (Aschero 1988; Chalmin et al. 2003).

El grado de heterogeneidad de la pintura está dado por la fracción pulverulenta de la sustancia pigmentaria, dependiendo del grado de molienda que presenta y de la composición química de la misma (Cole y Watchman 1996; Sepúlveda 2011). La integración de los componentes se relaciona con los ligantes empleados, mientras que la consistencia se vincula con la cantidad de agua agregada. Todas estas variables afectan la adherencia de la pintura al sustrato rocoso. Por ejemplo, a mayor granulometría del polvo de pigmento aumentan las probabilidades de que la pintura, luego de ser aplicada, se desprenda del soporte.

Las mezclas preparadas con grasa de pella y médula ósea bovina, así como con unto sin sal, se integraron óptimamente. Por el contrario, las 
mezclas confeccionadas con clara de huevo no lograron integrarse de manera adecuada, ni durante el estacionamiento ni en la boca ${ }^{2}$. Además, en el caso de esta última mezcla, luego de que la pintura se secara sobre el soporte, comenzó a exfoliarse independientemente de la técnica usada para aplicarla (pulverizado o digital). En cuanto al empleo de la grasa de pollo como ligante, esta mezcla se comportó en un punto intermedio entre las grasas vacunas y porcinas, por un lado, y la clara de huevo, por otro. Estas observaciones se basan en el seguimiento de las mezclas a través del tiempo. El uso de grasa de choique como ligante favoreció la integración de las mezclas, siendo el mejor ligante comparado con los casos enunciados previamente. Con respecto a la preparación en la que se empleó mayor cantidad de ligante y aditivo (Tabla 5.4, sombreado) no se observaron diferencias con aquella preparada respetando las proporciones propuestas por Paunero (1992).

En cuanto a la consistencia (Aschero 1988), la mezcla que se aplica por pulverizado directo necesita menos agregado de agua, ya que al colocarla en la boca se le adiciona saliva y se aumenta su temperatura, volviéndola aún más líquida. Por otro lado, la mezcla que se aplica con algún artefacto o mediante la técnica digital tiene que ser relativamente espesa para que llegue a la pared sin chorrearse. Estrechamente relacionada a las características anteriores se observa la capacidad de actuar del aditivo. Si la mezcla presenta una alta proporción de fracción pulverulenta de gran tamaño o mala integración de los componentes, de nada sirve adicionar un elemento con buena capacidad de fragüe ya que la mezcla tendrá de todos modos poca adherencia.

\footnotetext{
2 Mientras se estacionaba la mezcla, los componentes (clara de huevo, agua y pigmento molido) no lograron unirse completamente debido a la decantación de la clara en el fondo del recipiente. En la boca también se percibía la separación entre la fase terrosa y la líquida.
} 


\begin{tabular}{|c|c|c|c|c|c|c|c|}
\hline \multirow[b]{2}{*}{ Bloque } & \multicolumn{2}{|c|}{ Pigmento } & \multicolumn{4}{|c|}{ Proporciones } & \multirow[b]{2}{*}{ Técnica } \\
\hline & Muestra & Color & $\begin{array}{c}\text { Pigmento } \\
(\mathrm{g})\end{array}$ & $\begin{array}{c}\text { Yeso } \\
(\mathrm{g})\end{array}$ & $\begin{array}{c}\text { Ligante } \\
(\mathrm{g})\end{array}$ & $\begin{array}{c}\text { Agua } \\
(\mathrm{ml})\end{array}$ & \\
\hline \multirow{8}{*}{$\begin{array}{c}\text { Bloque } \\
1\end{array}$} & $\mathrm{~S} 1$ & $\begin{array}{c}2.5 \mathrm{Y} 8 / 2 \\
\text { pale yellow }\end{array}$ & 0,50 & 0,15 & $\begin{array}{c}0,10 \text { grasa de } \\
\text { pella }\end{array}$ & 1 & Digital \\
\hline & \multirow{5}{*}{$\mathrm{S} 4 \mathrm{~A}$} & \multirow{5}{*}{$\begin{array}{c}2.5 \mathrm{Y} 7 / 8 \\
\text { yellow }\end{array}$} & 5 & 1,50 & 1 unto sin sal & 9 & \multirow{5}{*}{$\begin{array}{c}\text { Pulverizado } \\
\text { y Digital }\end{array}$} \\
\hline & & & 5 & 1,50 & $\begin{array}{c}1 \text { grasa de } \\
\text { pella }\end{array}$ & 12 & \\
\hline & & & 5 & 1,50 & $\begin{array}{c}1 \text { médula ósea } \\
\text { bovina }\end{array}$ & 12 & \\
\hline & & & 5 & 1,50 & $\begin{array}{c}1 \text { grada de } \\
\text { pollo }\end{array}$ & 12 & \\
\hline & & & 5 & 1,50 & $\begin{array}{c}1 \text { clara de } \\
\text { huevo }\end{array}$ & 12 & \\
\hline & S5 A & $\begin{array}{c}10 \mathrm{R} 5 / 8 \\
\text { red }\end{array}$ & 0,50 & 0,15 & $\begin{array}{c}0,10 \text { grasa de } \\
\text { pella }\end{array}$ & 1 & \multirow{2}{*}{ Digital } \\
\hline & $\mathrm{S} 8$ & $\begin{array}{c}7.5 \mathrm{R} 5 / 6 \\
\text { red }\end{array}$ & 0,50 & 0,15 & $\begin{array}{c}0,10 \text { grasa de } \\
\text { pella }\end{array}$ & 1 & \\
\hline \multirow{6}{*}{$\begin{array}{c}\text { Bloque } \\
2\end{array}$} & \multirow{3}{*}{$\mathrm{S} 4 \mathrm{~B}$} & \multirow{3}{*}{$\begin{array}{c}10 \mathrm{R} 5 / 8 \\
\text { red }\end{array}$} & 5 & 1,50 & $\begin{array}{c}1 \text { grasa de } \\
\text { pella }\end{array}$ & 9 & \multirow{3}{*}{$\begin{array}{c}\text { Pulverizado } \\
\text { y Digital }\end{array}$} \\
\hline & & & 5 & 1,50 & $\begin{array}{c}1 \text { médula ósea } \\
\text { bovina }\end{array}$ & 9 & \\
\hline & & & 5 & 1,50 & $\begin{array}{c}1 \text { clara de } \\
\text { huevo }\end{array}$ & 9 & \\
\hline & \multirow{2}{*}{ S7A } & \multirow{2}{*}{$\begin{array}{l}7.5 \mathrm{R} 5 / 2 \\
\text { weak red }\end{array}$} & 0,50 & 0,15 & $\begin{array}{c}0,10 \text { grasa de } \\
\text { pella }\end{array}$ & 2 & \multirow{3}{*}{ Digital } \\
\hline & & & 0,60 & 0,20 & $\begin{array}{c}0,30 \text { grasa de } \\
\text { pella }\end{array}$ & 3 & \\
\hline & S7B & $\begin{array}{l}7.5 \mathrm{R} 4 / 2 \\
\text { weak red }\end{array}$ & 0,50 & 0,15 & $\begin{array}{c}0,10 \text { grasa de } \\
\text { pella }\end{array}$ & 3 & \\
\hline
\end{tabular}

Tabla 5.4. Variantes contempladas en la preparación mezclas y técnicas de aplicación. Sombreada la mezcla en la que se variaron las proporciones utilizadas.

Código de color: Earth Soil Chart.

\section{5. c. REPLICACIÓN DE MOTIVOS}

\section{5. c. 1. Motivos grabados}

El estudio de la cadena operativa de la producción de imágenes implica la identificación de las diferentes operaciones y etapas que la componen (Fiore 2007). Para lograr un mejor entendimiento de las mismas, la descripción será presentada de acuerdo al desarrollo del protocolo experimental: primero el reconocimiento de las distintas técnicas de grabado y luego la replicación de motivos sobre diferentes soportes. 


\section{5. c. 1. 1. Reconocimiento de técnicas}

Las técnicas de grabados se distinguen por el tipo de mecánica ejercida, en función del movimiento realizado y del artefacto utilizado. Por lo anterior, se agrupan en aquellas que requieren presión y aquellas en las que se percute la superficie rocosa a fin de extraer una porción del soporte y lograr un surco grabado (Álvarez y Fiore 1995). Entre las primeras se distinguen la incisión, el raspado y la horadación mientras que la percusión puede ser directa o indirecta, empleando en este último caso un intermediario (definidas en el Capítulo 2). Álvarez y Fiore proponen que la observación macroscópica de los surcos dejados sobre el soporte por la implementación de cada una de esas técnicas ayuda en su distinción, por lo que "puede decirse que las técnicas de picado, raspado, machacado y horadación dejarian un surco en forma de "U», mientras que la incisión dejaría un surco en forma de "V»" (Álvarez y Fiore 1995: 220 y bibliografía allí citada).

Las primeras tareas, vinculadas al reconocimiento de las técnicas antes mencionadas, fueron realizadas en laboratorio sobre tres bloques pertenecientes a la formación Puesto del Museo (Panza 2001) que, por su composición mineralógica, consistencia y baja dureza, ofrecen poca resistencia ante la realización de marcas o diseños sobre su superficie. Las marcas se efectuaron con diferentes ANF y tres cinceles de la colección lítica experimental.

Para aprovechar mejor la superficie de los bloques se emplearon ambas caras disponibles, que fueron denominadas "Lado A" y "Lado B", presentando una superficie homogénea e irregular, respectivamente. Los bloques experimentales se colocaron sobre el suelo, en posición horizontal. Las marcas fueron realizadas por dos mujeres diestras, sentadas en el suelo con un campo manual hacia el interior (en el sentido de Álvarez y Fiore 1995). La prensión de los artefactos fue directa, sin enmangue.

Se efectuaron 42 marcas, utilizando las técnicas de horadación, raspado e incisión (Figura 5.6; Tabla 5.5). Los ANF empleados corresponden a 15 
lascas de filo natural, que fueron empleadas por períodos de cinco, 15, 30, 45 y 60 minutos para cada técnica. Dichos lapsos temporales fueron no aditivos; es decir, para cada técnica y cada período se utilizó un ANF (Tabla 5.5). Las piezas usadas presentaban, por lo menos, un filo potencialmente utilizable mayor a $30 \mathrm{~mm}$, lo que permitió utilizarlas sin enmangue y un mayor contacto del filo con el soporte.

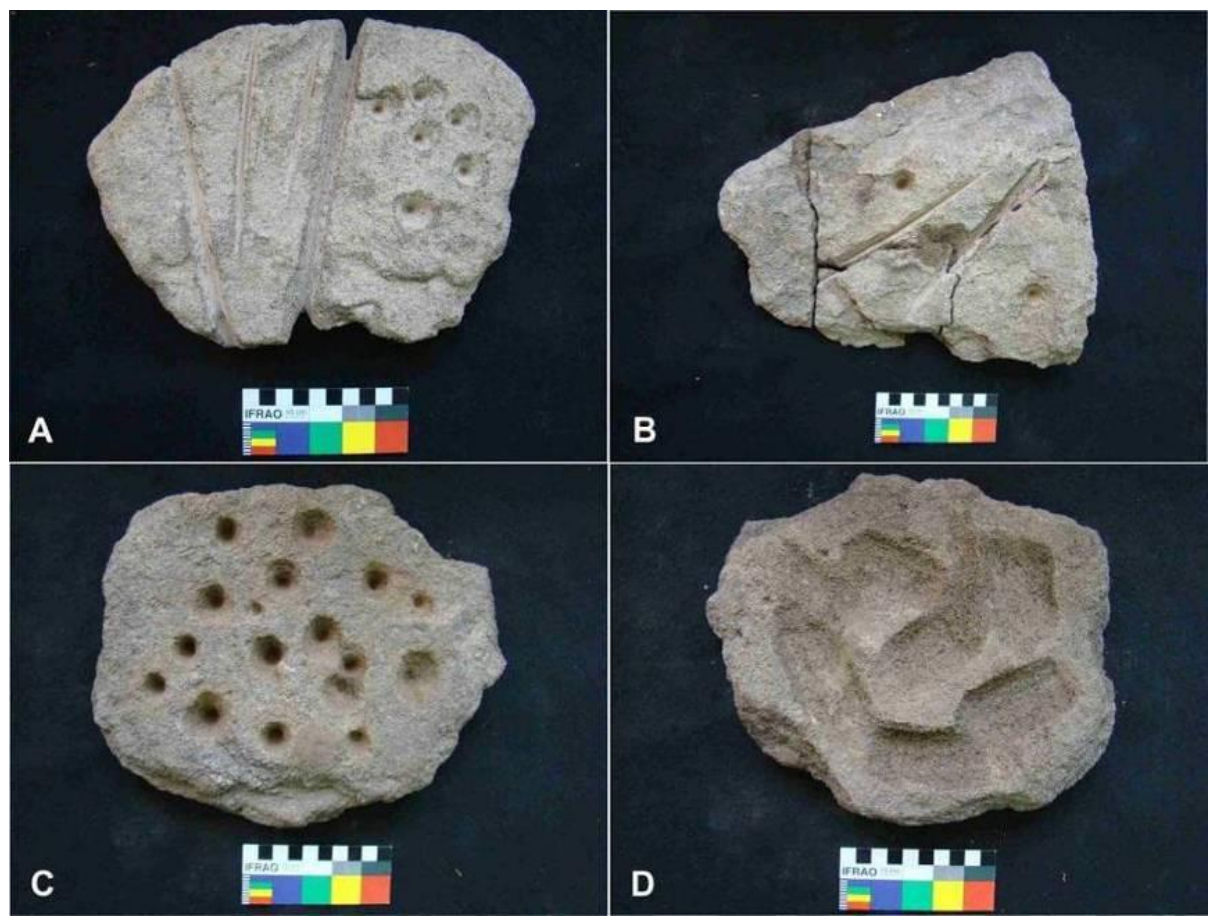

Figura 5.6. Marcas grabadas mediante diferentes técnicas: a. Bloque Experimental (BE) 1 Lado A: incisión y horadación; b. BE 2 Lado A: incisión y horadación; c. BE 3 Lado A: horadación; d. BE 3 Lado B: raspado.

\begin{tabular}{|c|c|c|c|c|c|c|c|}
\hline Técnica & Tiempo & $\begin{array}{c}\text { Bloque } \\
\text { experimental }\end{array}$ & Lado & $\mathrm{ANF}^{*}$ & $\begin{array}{l}\text { Delineación del } \\
\text { filo }\end{array}$ & $\begin{array}{l}\text { Ángulo } \\
\text { del filo }\end{array}$ & $\begin{array}{c}\text { Cantidad de } \\
\text { marcas }\end{array}$ \\
\hline \multirow{5}{*}{ Incisión } & 5 & \multirow{3}{*}{ BE 1} & \multirow{3}{*}{ Lado A } & E1 RVB 14 & Convexo & 35 & 1 \\
\hline & 15 & & & E1 LM 13 & Convexo & 15 & 2 \\
\hline & 30 & & & E1 RVB 44 & Rectilíneo & 50 & 1 \\
\hline & 45 & \multirow{2}{*}{ BE 2} & \multirow{2}{*}{ Lado A } & E1 RVB 42 & Rectilíneo & 60 & 1 \\
\hline & 60 & & & E1 RVB 48 & Convexo & 30 & 1 \\
\hline \multirow{5}{*}{ Raspado } & 5 & BE 2 & Lado B & E1 RVB 24 & Convexo & 15 & 1 \\
\hline & 15 & BE 3 & Lado B & E1 RVB 29 & Convexo & 25 & 6 \\
\hline & 30 & BE 2 & Lado B & E1 LM 17 & Convexo & 25 & 1 \\
\hline & 45 & \multirow{2}{*}{ BE 1} & \multirow{2}{*}{ Lado B } & E1 RVB 43 & Rectilíneo & 50 & \multirow{2}{*}{1} \\
\hline & 60 & & & E1 RVB 41 & Rectilíneo & 35 & \\
\hline \multirow{5}{*}{ Horadación } & 5 & BE 2 & Lado B & E1 RVB 60 & - & - & 1 \\
\hline & 15 & \multirow{2}{*}{ BE 3} & \multirow{2}{*}{ Lado A } & E1 RVB 11 & - & - & 9 \\
\hline & 30 & & & E1 RVB 17 & - & - & 9 \\
\hline & 45 & BE 1 & Lado A & E1 RVB 45 & - & - & 6 \\
\hline & 60 & BE 2 & Lado A & E1 RVB 47 & - & - & 2 \\
\hline
\end{tabular}

Tabla 5.5. Detalles de las experiencias respecto a las técnicas de producción. Referencias: BE: Bloque experimental. ANF: Artefacto no formatizado. *El siglado de los ANF respeta la numeración correspondiente a la colección experimental, por lo tanto es no continuo. Tomado y modificado de Blanco y Lynch (2011). 
La posición del filo con respecto a la superficie, la dirección del movimiento y el ángulo de trabajo están determinados por la técnica empleada. En el caso de la incisión, la posición del filo fue paralela respecto al movimiento del instrumento sobre la superficie trabajada, el movimiento unidireccional interior y el ángulo de trabajo de $90^{\circ}$. En el raspado, la posición del filo fue perpendicular respecto al movimiento del instrumento sobre la superficie trabajada, el movimiento bidireccional y el ángulo de trabajo de $90^{\circ}$. La horadación merece una mención especial, ya que si bien la posición del artefacto es perpendicular a la superficie trabajada, el movimiento de rotación genera que entren en contacto el vértice y los filos laterales del artefacto. Con respecto al ángulo de trabajo la posición inicial del vértice fue de $90^{\circ}$, pero a medida que la marca se profundiza dicho ángulo varía.

La morfología de los surcos obtenidos en el transcurso de las experiencias fue en "V" para la incisión y en forma de "U" para el raspado y la horadación, coincidente con la ya informada por Álvarez y Fiore (1995) (Figura 5.6) aunque, como se detalla más adelante, existen excepciones.

Las piezas empleadas fueron sometidas al análisis funcional de bajos y altos aumentos por la Dra. Virginia Lynch (Blanco y Lynch 2011: 14-17). A partir de los estudios microscópicos se observaron micropulidos, estrías, esquirlamientos y redondeamientos sobre los filos de los ANF que estuvieron en contacto con el soporte rocoso. A continuación se reseñan los resultados de ese análisis:

1) Los motivos arqueológicos y las marcas grabadas pudieron haber sido ejecutados utilizando ANF, los cuales son asibles de manera directa, lo que facilita la realización del trabajo. El filo potencialmente utilizable de dichos artefactos, mayor a $30 \mathrm{~mm}$, fue de gran ayuda para dejar marcas sobre el soporte, facilitando su manejo y aumentando la superficie de contacto con aquel.

2) A partir del análisis de los rastros de uso de las piezas experimentales se pudo determinar que desde los cinco minutos de comenzado el trabajo 
comienzan a aparecer las etapas iniciales de modificación sobre las superficies de los filos.

2.a) En las piezas empleadas para las técnicas de incisión y raspado se produjo contacto con el material trabajado en ambas caras del filo, por lo que el desarrollo del micropulido implicó tanto la cara dorsal como la ventral.

2.b) En la incisión, la orientación de los micropulidos y las estrías (paralela al filo) permitió identificar la cinemática efectuada. Los micropulidos -con morfología particular-, comenzaron a desarrollarse a partir de los cinco minutos de trabajo, mientras que los esquirlamientos fueron más abundantes durante los primeros minutos de la actividad siendo medianos a escasos y discontinuos una vez estabilizado el movimiento. Se observó el redondeamiento del filo en las piezas que fueron trabajadas por 15 minutos o durante más tiempo.

2.c) En el caso del raspado, los micropulidos presentan una orientación transversal al filo y características diagnósticas luego de 15 minutos de trabajo. Los esquirlamientos son abundantes al principio y escasos con posterioridad a 15 minutos de trabajo. Las estrías exhiben una orientación transversal o perpendicular al filo y morfología variable.

2.d) En la horadación, las piezas empleadas contactaban con el soporte en el punto de apoyo y en la porción medial de los filos por lo que la distribución y características de las estrías y los micropulidos desarrollados en esos puntos permitieron reconocer dos tipos de movimientos: i) un movimiento transversal o transversal-oblicuo, en especial en la porción medial del filo, evidenciado por estrías de longitud y morfología variable que presentaban una orientación transversal-oblicua al filo; y ii) movimientos rotatorios en la arista distal del instrumento (punto de apoyo). Además, el desarrollo de micropulidos fue notorio luego de 15 minutos de trabajo, los esquirlamientos son abundantes durante los primeros minutos de actividad y escasos y discontinuos con posterioridad. Buena parte de las piezas trabajadas con esta técnica presentan redondeamiento de filos (Blanco y Lynch 2011).

Con respecto a los surcos grabados en los bloques experimentales de la formación Puesto del Museo, se observó lo siguiente: 
1) los surcos realizados por incisión presentan surco en forma de "V" (Figuras 5.6.a y 5.6.b);

2) los surcos realizados por horadación presentan mayoritariamente forma en "U", la cual está supeditada a la morfología y tamaño del ANF empleado por lo que puede resultar en hoyuelos profundos, cóncavos y en forma de cono (Figura 5.6.b y 5.6.c);

3) los surcos del raspado pueden presentar dos morfologías: a) en forma de "U", coincidente con lo planteado por otros autores (Álvarez y Fiore 1995), donde el surco obtenido es el resultado de movimientos uni- o bidireccionales restringidos, que pueden reflejar parcialmente la forma del filo y el tamaño del artefacto usado (Figura 5.6.d), o b) como superficies amplias y lisas, sin forma ni tamaño definido, sobre todo si los movimientos se aplican arealmente (Figura 5.7).

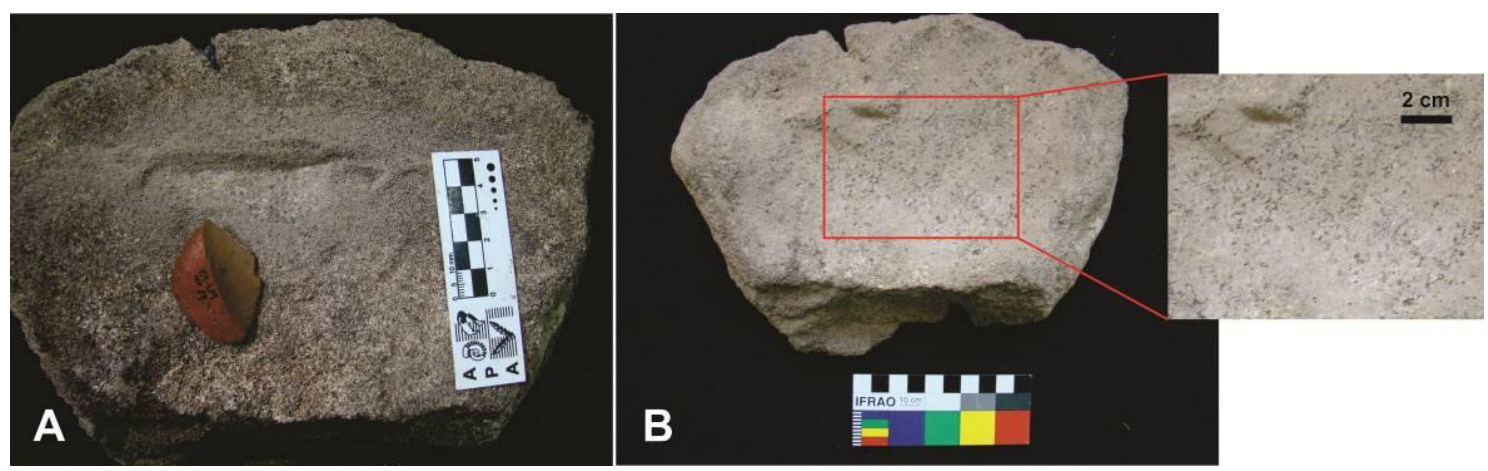

Figura 5.7. Superficie homogeneizada mediante raspado: a. ejemplo de en el que se observa la forma del inicio de esta tarea; b. superficie homogeneizada luego del uso de diferentes artefactos con detalle ampliado.

Frente a este último caso, se planteó el problema de discernir entre raspado y abradido, este último término entendido en el sentido de Maynard (1977). A fin de resolverlo, se empleó un cuarto bloque de arenisca coquinoide y se trabajó parte de su superficie por 70 minutos durante los cuales se realizaron movimientos circulares con un guijarro, utilizando agua y arena como abrasivos (Figura 5.8). En este soporte, el abradido permite obtener una superficie homogénea, sin rebordes o irregularidades producto de la presencia de restos de conchilla. Esta técnica podría haber sido empleada para la finalización de motivos de gran superficie en la localidad Piedra Museo. Esta última consideración será tratada con mayor detalle en 
la discusión cuando se revisen las técnicas propuestas para la realización de los motivos de esa localidad.

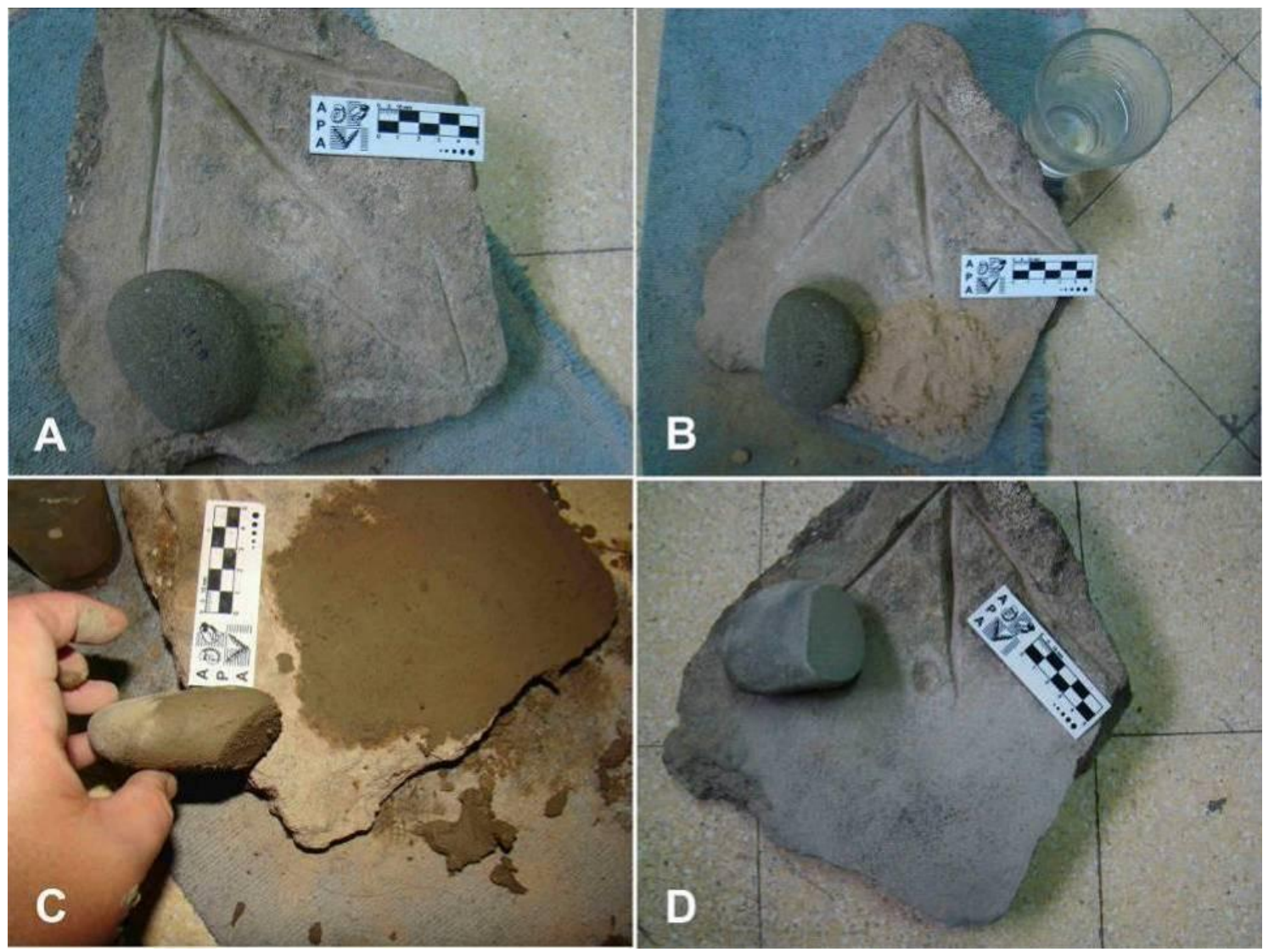

Figura 5.8. Abradido de superficie utilizando agua y arena. Se puede observar como desaparecen las incisiones que conformaban un tridígito.

Las técnicas de percusión -directa e indirecta- fueron implementadas en un bloque de la formación Puesto del Museo, utilizando tres cinceles. El primer cincel fue utilizado como percutor en la técnica de percusión directa, mientras que los dos siguientes se usaron como intermediarios en la técnica de percusión indirecta. A partir de estas acciones se observó:

1) la fractura del ápice del primer cincel (E1 RVB C1), causada por los impactos contra el bloque y por la delgadez del extremo del artefacto;

2) la fractura del soporte utilizado, causada por el contacto en forma de cuña del segundo cincel (E1 RVB C2), cuyo extremo presenta un bisel asimétrico doble. Esta situación provocó un debilitamiento en la arenisca que, al recibir percusiones indirectas adicionales con el extremo romo del tercer cincel (E1 RVB C3), se fracturó nuevamente (Figura 5.9). 


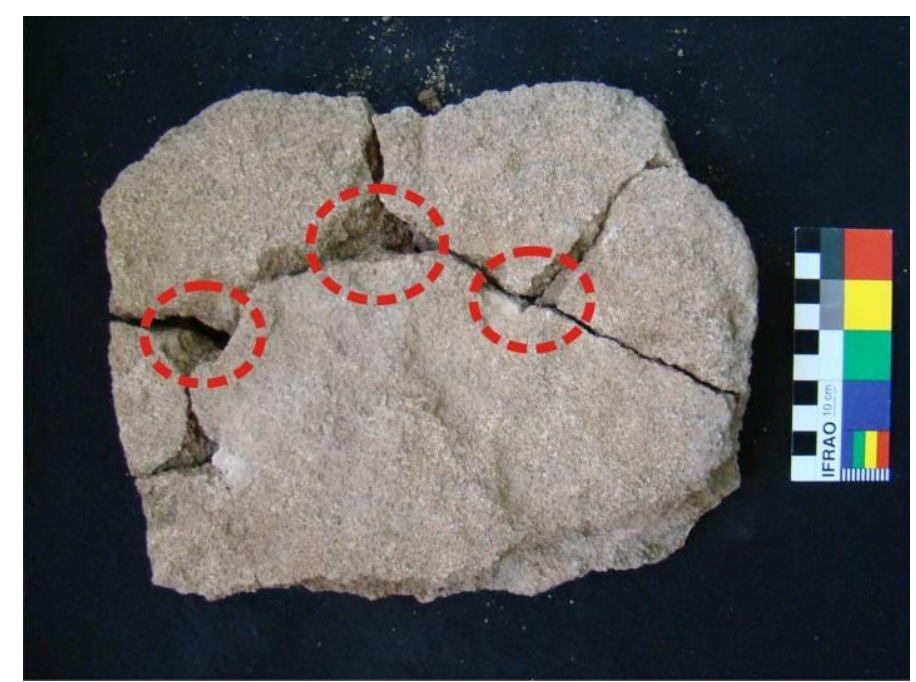

Figura 5.9. Bloque de arenisca coquinoide con diversas fracturas luego del empleo de cinceles para grabarlo por percusión indirecta.

La utilización de cinceles para grabar bloques experimentales mediante percusión - directa o indirecta- fue improductiva, resultando en la fractura del bloque experimental o bien en la rotura del artefacto. Las dimensiones de los bloques experimentales utilizados son más pequeñas que las de los bloques arqueológicos (Carden 2008a), lo que probablemente haya resultado en una menor absorción de la fuerza resultante de los golpes $\mathrm{y}$, por consiguiente, en la fractura del bloque experimental y de los artefactos utilizados. Otra causa que puede haber coadyuvado a la fractura del bloque es que la experiencia se realizó directamente sobre el piso de mosaico. Este material es más resistente que la arenisca, por lo tanto, puede haber actuado como un percutor durmiente generando dos series de ondas: las del cincel y las del rebote del mosaico.

Esta experiencia deberá ser repetida utilizando, en primer lugar, bloques de delgado espesor variando el sustrato de apoyo por tierra, tierra con pasto y arena, para indagar en cada caso la reacción del bloque experimental. En una segunda etapa se deberán usar bloques de dimensiones similares a las de los soportes arqueológicos. 
5. c. 1. 2. a. Réplicas sobre bloque de arenisca coquinoide

El referente arqueológico corresponde a la localidad Piedra Museo, donde los motivos registrados y las técnicas de producción inferidas para estos últimos han sido objeto de trabajos previos (Carden 2008a, 2009a, 2009b; Miotti 1991). En la localidad se registraron dos sitios con arte rupestre: Alero El Galpón 2 y Cueva Grande, ambos con pinturas y grabados (AEG-2 y CG de aquí en adelante). En AEG-2 se registraron pinturas en el techo y las paredes del alero, así como un bloque grabado de grandes dimensiones, del total de motivos identificados el 70\% corresponde a motivos figurativos (Carden 2008a). Los motivos de CG, también al interior de un alero, están distribuidos en 13 bloques desprendidos del techo; el 31\% de los motivos registrados son figurativos. En ambos sitios, para la realización de los motivos se aprovecharon las superficies horizontales disponibles en los bloques, a una altura cercana a $1 \mathrm{~m}$ respecto del suelo actual (Carden 2008 a, 2009 a). Se infirieron tres técnicas de producción de los motivos: picado (percusión indirecta), incisión y horadación, las cuales habrían sido empleadas de manera individual o combinada (Carden 2009a: 218). Por ejemplo, se propuso que la base de algunos tridígitos se realizó por horadación, mientras que las partes restantes de dichos motivos se habrían realizado mediante la incisión o el picado (Carden 2009a: 219). Además, se planteó que en CG las figuras circulares y los motivos curvilíneos podrían haber sido hechos por picado, utilizando un intermediario para manejar mejor las acciones y lograr trazos más controlados (Carden 2009a: 219).

Las replicaciones de los motivos registrados en esta localidad se efectuaron en un bloque de arenisca coquinoide de tamaño pequeño (Figura 5.10, Tabla 5.6), del que se emplearon ambas caras disponibles para la realización de seis motivos. El "Lado A" de este bloque presentaba una pátina con escaso desarrollo -alrededor de $5 \mathrm{~mm}$ - mientras que el "Lado B" 
presentaba una superficie irregular y fresca (negativo de desprendimiento). Durante estas replicaciones, el bloque estuvo en posición horizontal colocado sobre el piso del laboratorio. Se utilizaron tres percutores y diferentes ANF de la colección experimental (Apéndice III.2).

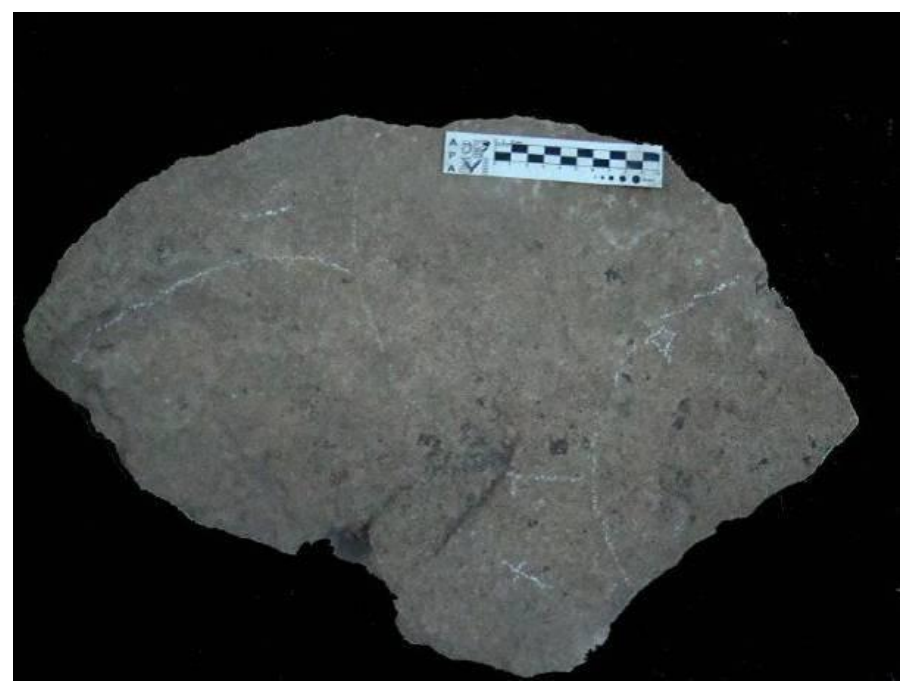

Figura 5.10. "Lado A" del bloque experimental de arenisca coquinoide Puesto del Museo.

\begin{tabular}{|c|c|c|c|c|c|c|c|}
\hline Bloque & Características & $\begin{array}{c}\text { Ancho } \\
\mathrm{cm}\end{array}$ & $\begin{array}{c}\text { Alto } \\
\mathrm{cm}\end{array}$ & $\begin{array}{c}\text { Espesor } \\
\text { máximo cm }\end{array}$ & $\begin{array}{c}\text { Accidentes } \\
\text { naturales }\end{array}$ & $\begin{array}{c}\text { Dureza } \\
\text { (Mohs) }\end{array}$ & Pátina \\
\hline PM & $\begin{array}{c}\text { Arenisca } \\
\text { Coquinoide }\end{array}$ & 52 & 34 & 6 & $\begin{array}{c}\text { Escalón/desnivel } \\
\text { en lado A }\end{array}$ & $3-4$ & Gris \\
\hline LCB & $\begin{array}{c}\text { Basalto de } \\
\text { grano fino }\end{array}$ & 50 & 35 & 7,5 & $\begin{array}{c}\text { Presencia de } \\
\text { hoyuelos } \\
\text { naturales en } \\
\text { lado A }\end{array}$ & 5 & Rojiza \\
\hline
\end{tabular}

Tabla 5.6. Características de los bloques experimentales empleados para grabar motivos. PM: Piedra Museo; LCB: Laguna del Cerro Bonete.

Es necesario aclarar que los bloques de arenisca coquinoide empleados en las diferentes experiencias replicativas fueron recolectados del afloramiento pre-jurásico (Panza 2001). Dichos bloques son de pequeñas dimensiones y fácilmente transportables, para poder realizar las experiencias replicativas en laboratorio y no afectar los sitios. Piedra Museo es un referente arqueológico importante para el estudio del poblamiento americano: las características paisajísticas, científicas e históricas identificadas allí son únicas siendo considerada patrimonio cultural de gran importancia (Miotti et al. 2009c). Los motivos fueron realizados por una mujer diestra, sentada 
en el suelo con un campo manual hacia el interior (sensu Álvarez y Fiore 1995). La prensión de los artefactos fue directa, sin enmangue. Previo a su replicación, los motivos fueron dibujados sobre la superficie rocosa con un lápiz, respetando los tamaños documentados en los sitios arqueológicos. Los motivos replicados mediante diferentes técnicas corresponden a cuatro tridígitos con diferente diseño y tamaño, una roseta y una circunferencia (Tabla 5.7).

Los motivos se replicaron de acuerdo a las técnicas que se infirieron a partir de la observación de los surcos. Éstas difieren, en algunos casos, de las propuestas en trabajos previos (Tabla 5.7). Por ejemplo, Carden (2008a) infiere la percusión indirecta (picado, usando un intermediario) como técnica de producción en algunos de los motivos seleccionados a replicar. La observación de los mismos en campo, permitió pensar que podría haberse aplicado otra técnica en la producción de esos motivos; por lo tanto, en la experimentación en primera instancia se empleó la percusión directa, y luego se emplearon otras técnicas como el raspado y la incisión. Hay que considerar en esta selección de técnicas, además, los intentos fallidos para implementar la percusión indirecta señalados en el apartado previo. Se puede destacar que en las excavaciones de Piedra Museo no fueron registrados cinceles (Cattáneo 2002; Hermo 2008).

\begin{tabular}{|l|c|c|c|c|c|c|}
\hline \multicolumn{1}{|c|}{ Motivo } & $\begin{array}{c}\text { Tamaño } \\
(\mathrm{cm})\end{array}$ & $\begin{array}{c}\text { Forma } \\
\text { del } \\
\text { surco }\end{array}$ & $\begin{array}{c}\text { Técnica de } \\
\text { replicación }\end{array}$ & $\begin{array}{c}\text { Tiempo } \\
\text { invertido } \\
(\text { min. })\end{array}$ & $\begin{array}{c}\text { Técnicas inferidas } \\
\text { previamente } \\
\text { (Carden 2008a) }\end{array}$ & $\begin{array}{c}\text { Ubicación de } \\
\text { los motivos }\end{array}$ \\
\hline Tridígito 1 & $7,5 \times 6,8$ & $\mathrm{U}+\mathrm{V}$ & $\mathrm{R}$ & 50 & Pind + H & $\begin{array}{c}\text { AEG-2 Bloque } \\
\text { grande }\end{array}$ \\
\hline Tridígito 2 & $7,5 \times 6,8$ & $\mathrm{U}+\mathrm{V}$ & $\mathrm{R}$ & 155 & $\mathrm{I}+\mathrm{H}$ & $\begin{array}{c}\text { AEG-2 Bloque } \\
\text { grande }\end{array}$ \\
\hline Tridígito 3 & $7,5 \times 6,8$ & $\mathrm{U}$ & $\mathrm{Pe}$ & 25 & Pind & CG Bloque 5 \\
\hline Tridígito 4 & $10 \times 17$ & $\mathrm{~V}$ & $\mathrm{I}$ & 145 & $\mathrm{I}$ & CG Bloque 12 \\
\hline Roseta & $10 \times 6$ & $\mathrm{U}$ & $\mathrm{Pe}$ & 35 & Pind & $\begin{array}{c}\text { AEG-2 Bloque } \\
\text { grande }\end{array}$ \\
\hline Circunferencia & $10 \times 11$ & $\mathrm{U}$ & $\mathrm{R}+\mathrm{Pe}$ & 60 & Pind & CG Bloque 2 \\
\hline
\end{tabular}

Tabla 5.7. Selección de motivos replicados de AEG-2 y CG. Pind: Percusión indirecta; H: horadación; I: Incisión; R: raspado; Pe: percusión.

La composición del soporte facilitó, al mismo tiempo que impidió, el desarrollo de la acción realizada. La cementación diferencial que presenta facilitó el grabado debido a la presencia de poros y una matriz fina de arena, 
en tanto que la fracción conchil que lo compone jugó un rol importante en la resistencia al proceso de grabado, principalmente por la presencia de fragmentos de valvas de diferente tamaño que se disponen de manera heterogénea en la matriz arenosa. Por otra parte, la pátina en el "Lado A" del bloque implicó una mayor inversión de trabajo: luego de que el surco grabado atravesara su espesor, la acción de grabar resultó más fácil, independientemente de la técnica utilizada. La fracción conchil y la pátina de la roca afectaron los filos utilizados, en los que se produjeron abundantes esquirlamientos durante los primeros minutos de trabajo.

Los tridígitos experimentales 1 y 2 presentan una sucesión de hoyuelos que parecen horadados en tanto que en la base del surco presentan una línea incisa; sin embargo ambos fueron producidos mediante raspado con la punta de un ANF. La presencia de hoyuelos en el surco se debe, en este caso, a la fracción conchil que compone el soporte, la cual se va desprendiendo de modo diferencial a medida que se trabaja, en tanto que el trazo inciso en la base del surco grabado podría ser explicado por la morfología de los ANF utilizados. Los tridígitos 1 y 2 tienen el mismo tamaño; sin embargo, comportaron tiempos de replicación diferentes. (Tabla 5.7). En el tridígito 1, que presenta mayor similitud con el motivo arqueológico y se replicó en el lado carente de pátina, se invirtieron 50 minutos (Figura 5.11). Por su parte, el tridígito 2 resultó más fácil de grabar luego de superar la pátina del Lado A del bloque, y triplicó el tiempo invertido en su reproducción (Tabla 5.7). Debido a la similitud entre la réplica y el motivo arqueológico, se plantea la posibilidad de que algunos tridígitos de Piedra Museo hayan sido ejecutados mediante el raspado con la punta de un ANF. Esta cuestión será retomada en el Capítulo 8. 

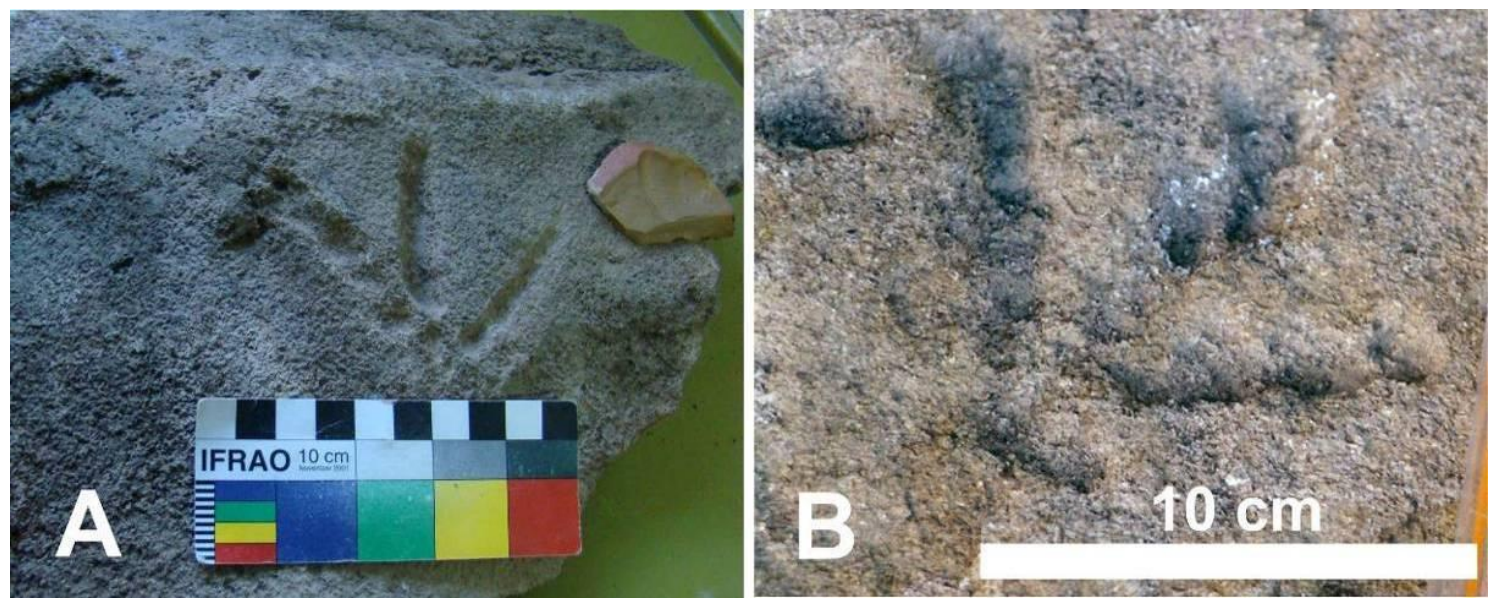

Figura 5.11. Comparación entre un tridígito experimental y el motivo arqueológico: a. Tridígito 1 en bloque experimental; b. Referente arqueológico de AEG-2.

El perfil del surco del tridígito 3 presenta forma de "U”, característica de la percusión directa, habiéndose invertido en su producción 25 minutos (Figura 5.12). Debido a la friabilidad del soporte y a pequeños desprendimientos producto de la percusión no se logró alcanzar mayor profundidad del surco grabado. Por último, el tridígito 4 fue realizado por incisión, insumiendo 135 minutos en los que no pudo profundizarse el surco debido a la presencia de pátina.
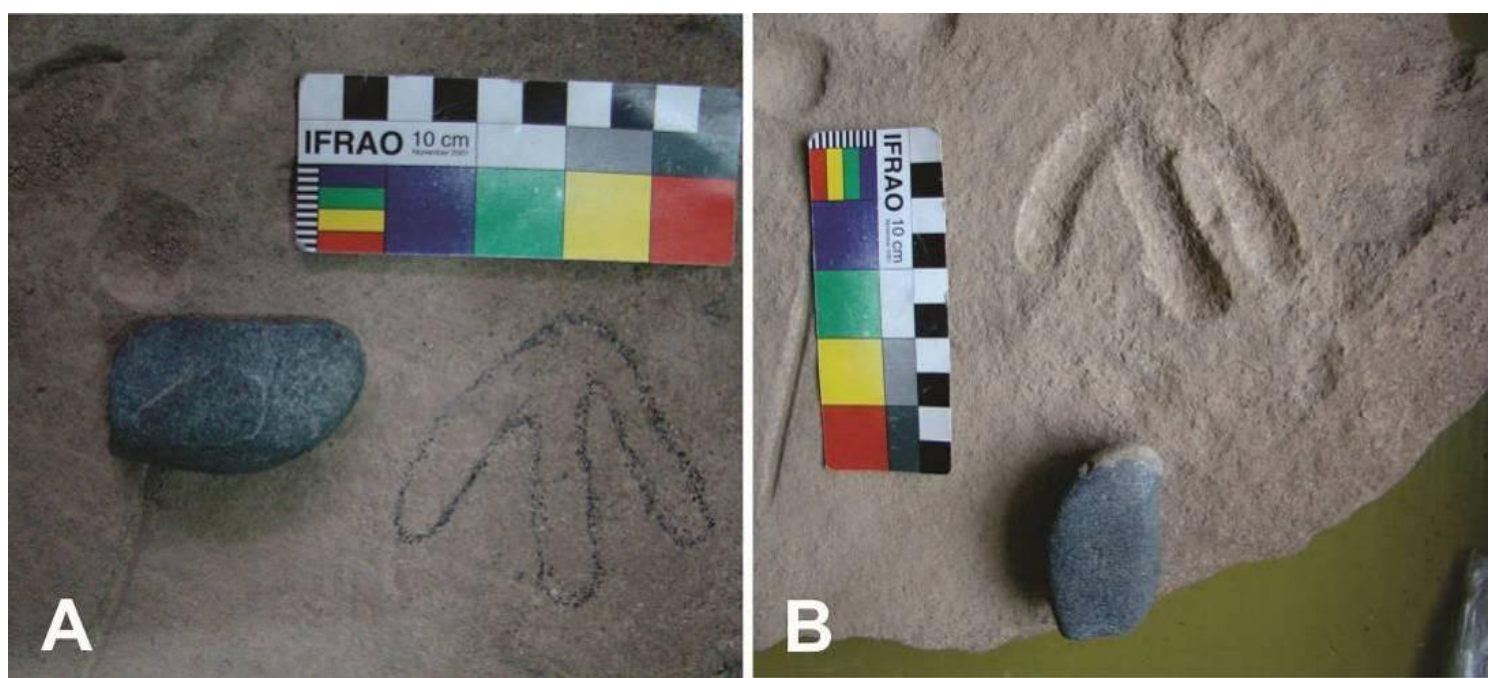

Figura 5.12. Tridígito 3 experimental realizado por percusión directa: a. dibujo del motivo sobre el soporte experimental; b. réplica experimental. Sobre el borde del percutor se observan restos de sedimento adheridos resultado de la percusión directa.

La roseta fue replicada mediante percusión directa. En este caso, la porción seleccionada del bloque presentaba un pequeño escalón que hizo que 
la réplica experimental difiriera del motivo arqueológico. Por otro lado, la circunferencia fue realizada mediante raspado y percusión directa; cada técnica fue empleada durante 30 minutos. Mediante el raspado logró definirse y mantenerse la forma original del motivo, aunque la profundización del surco fue mínima. Con la implementación de la percusión directa se logró profundizar el surco, manteniendo la forma delineada previamente (Figura 5.13).

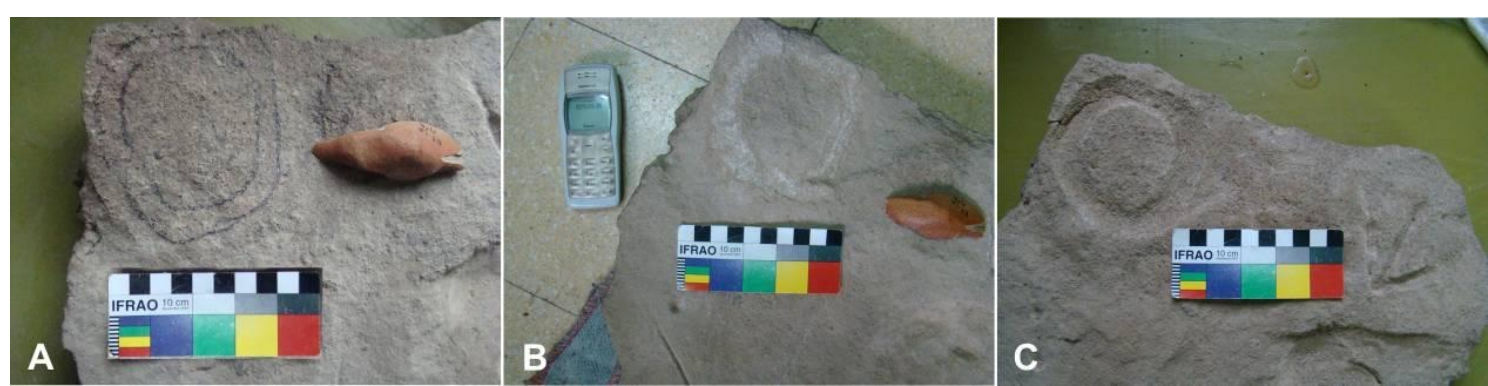

Figura 5.13. Circunferencia replicada experimentalmente: a. delineado con lápiz previo al proceso de grabado; b. circunferencia realizada por raspado durante 30 minutos; c. Circunferencia final, con la aplicación de 30 minutos adicionales de percusión directa.

Por la escasa dureza del soporte se observa, producto de la percusión directa, un surco homogéneo y con perfil en "U" (ver Figura 5.12), en el cual no se perciben a ojo desnudo los puntos de impacto como en otro tipo de soporte (basalto por ejemplo, ver más adelante). Por lo anterior, sumado a la presencia de restos de conchilla, la presencia de puntos $u$ hoyuelos no necesariamente se deba a golpes de percusión sino que podría corresponder a otras técnicas, como el raspado, tal como se planteó anteriormente (ver Figura 5.11), o la horadación.

5. c. 1. 2. b. Replicación de motivos sobre basalto

Este soporte fue utilizado con el fin de replicar motivos registrados en el sitio Laguna del Cerro Bonete (LCB), en el cual se registraron grabados y un motivo pintado a lo largo de la barda basáltica que rodea a la laguna homónima (Carden 2008a). Los basaltos columnares, pertenecientes a la 
formación La Angelita, son de grano fino y superficies homogéneas, con un color castaño oscuro que presenta una pátina rojiza (Panza 2001). El 92\% de los motivos son no figurativos; los pocos motivos figurativos corresponden a pisadas animales, a excepción de un negativo de mano. Entre los motivos no figurativos predominan los circulares, seguidos en cantidad por los curvilíneos, y luego por los rectilíneos y los puntiformes. A partir de la observación macroscópica de los surcos, que son discontinuos, Carden (2008a) infiere que la mayor parte de los motivos fueron realizados por percusión. En el caso de los motivos más complejos, en los que se observaron trazos más dirigidos y precisos, la autora propone que la técnica utilizada fue el picado (utilizando un percutor y un intermediario), aunque no da cuenta del artefacto que podría haber sido utilizado como intermediario.

La percusión directa fue la técnica empleada en la producción de las réplicas (Tabla 5.8), la cual es similar a la inferida para la realización de los motivos de LCB. Asimismo, se implementó esta técnica ya que los potenciales intermediarios no fueron reconocidos en el registro arqueológico del sitio.

A fin de contrastar las técnicas propuestas por Carden, se empleó un bloque basáltico de la formación La Angelita (Figura 5.14; ver Tabla 5.6), que presentaba una cara de superficie regular y uniforme ("Lado A") y otra irregular ("Lado B"). Se seleccionó la superficie homogénea para la realización de cinco motivos mediante el empleo de dos percutores (Apéndice III.2).

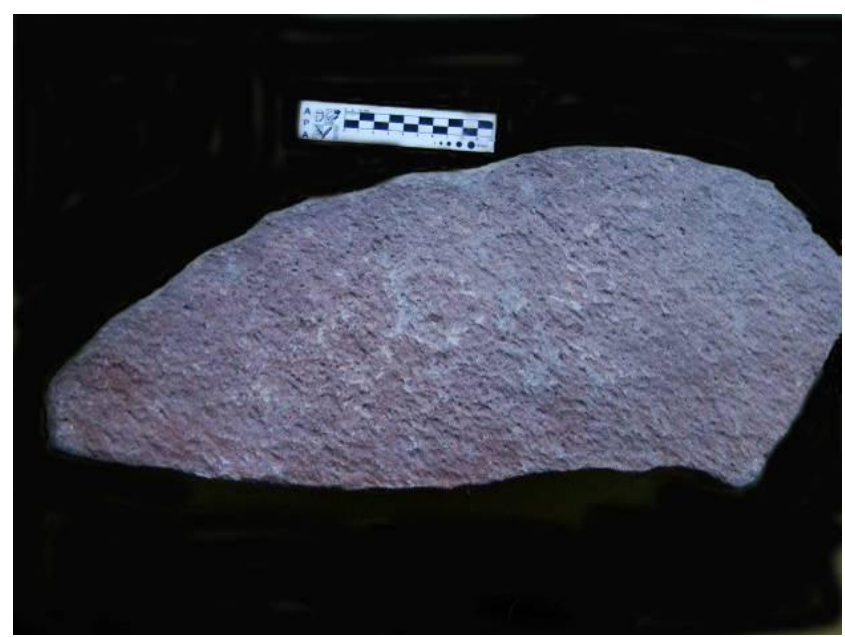

Figura 5.14. Bloque basáltico de formación La Angelita, lado A. 
Los motivos fueron realizados por dos mujeres diestras cuya posición varió, aunque en todos los casos su campo manual fue hacia el interior (sensu Álvarez y Fiore 1995). La prensión de los percutores fue directa, sin enmangue. Previo a su replicación, los motivos fueron dibujados sobre la superficie rocosa con un lápiz, respetando los tamaños de los motivos documentados en el sitio. El bloque se encontraba en posición vertical, a diferentes alturas respecto del suelo.

Los motivos replicados fueron cinco: dos tridígitos, un conjunto de puntos, un motivo circular con curvilíneo asociado y una circunferencia concéntrica doble con apéndice, registrados en diferentes sectores de LCB (Tabla 5.8; Carden 2008a). Esta selección se vincula con la representatividad de estos motivos en el sitio de referencia.

Si bien el soporte basáltico presenta una dureza cercana a 5 en la escala de Mohs, al presentar una pátina diferente al color de la roca, lograr un contraste entre surco del grabado y soporte no comporta mucha inversión de trabajo. Por otro lado, el golpeteo con un percutor lítico produce un ruido metálico en la roca, situación que influyó en el desarrollo del trabajo ya que se requirieron pausas de descanso para evitar la molestia que genera el sonido constante resultado del golpeteo.

Durante los primeros momentos de trabajo el extremo de los percutores que impactaba contra el basalto sufrió pequeños esquirlamientos, que fueron menores luego de que la plataforma de impacto se estabilizaba. Es importante señalar que si se adecúan en calidad y tamaño, los percutores pueden ser empleados para más de un motivo, tal como sucedió en los casos aquí presentados.

Respecto al proceso de trabajo pueden realizarse diferentes consideraciones. La superficie basáltica puede ser golpeada estando en cuclillas, de rodillas o acostado (Figura 5.15). En tales posiciones resulta posible asir los percutores y realizar los golpes de manera continua por diferentes períodos de tiempo. 


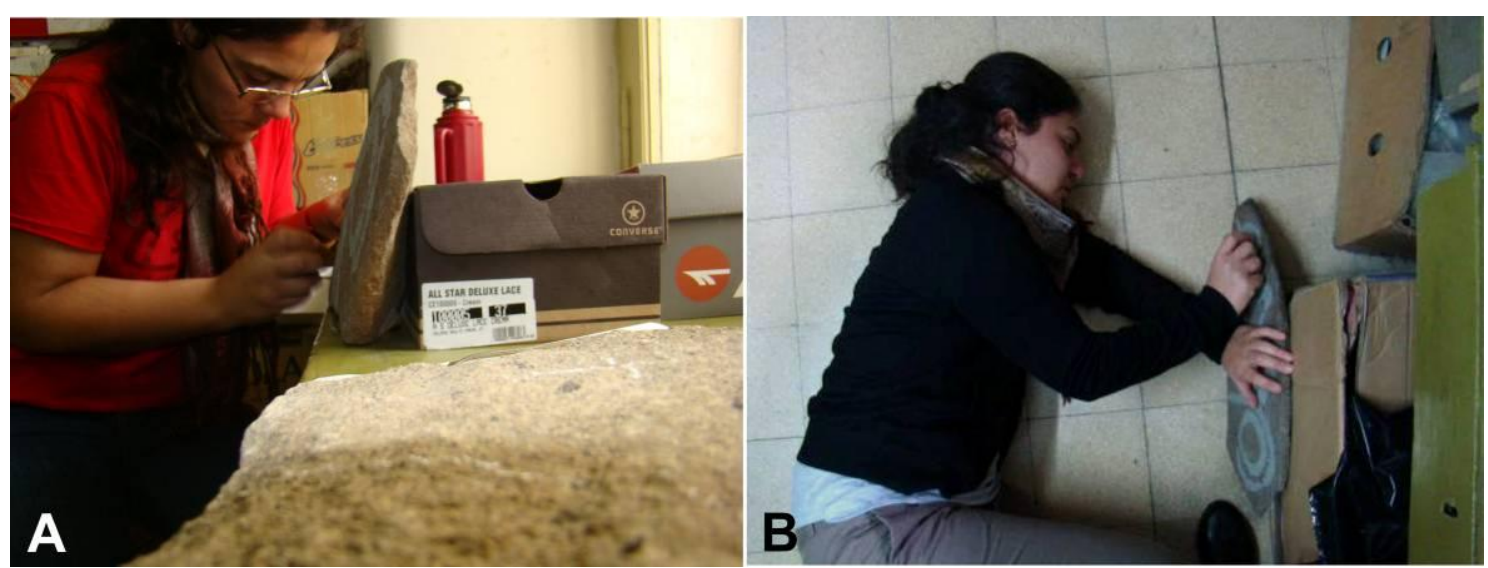

Figura 5.15. Variantes en la posición de trabajo de los productores.

En cuanto al diseño de los motivos, los tridígitos fueron realizados con la misma técnica, aunque se observaron diferencias en el tiempo invertido en su realización, vinculadas principalmente con su tamaño. Por ejemplo, el tridígito 1 implicó el doble de tiempo que el tridígito 2, siendo que el primero duplica el tamaño del segundo (Tabla 5.8, Figura 5.16). El motivo circular asociado a un curvilíneo insumió 95 minutos de trabajo, 35 de los cuales corresponden a la circunferencia y 60 al curvilíneo externo (Tabla 5.8, Figura 5.17). Esta diferencia podría ser explicada por el tamaño de ambos elementos y por la presencia de pequeños hoyuelos en la superficie, los cuales tuvieron que ser golpeados por más tiempo para lograr un surco homogéneo. Esta réplica es similar al motivo arqueológico (Figura 5.17), probablemente porque se trabajó con dibujo previo.

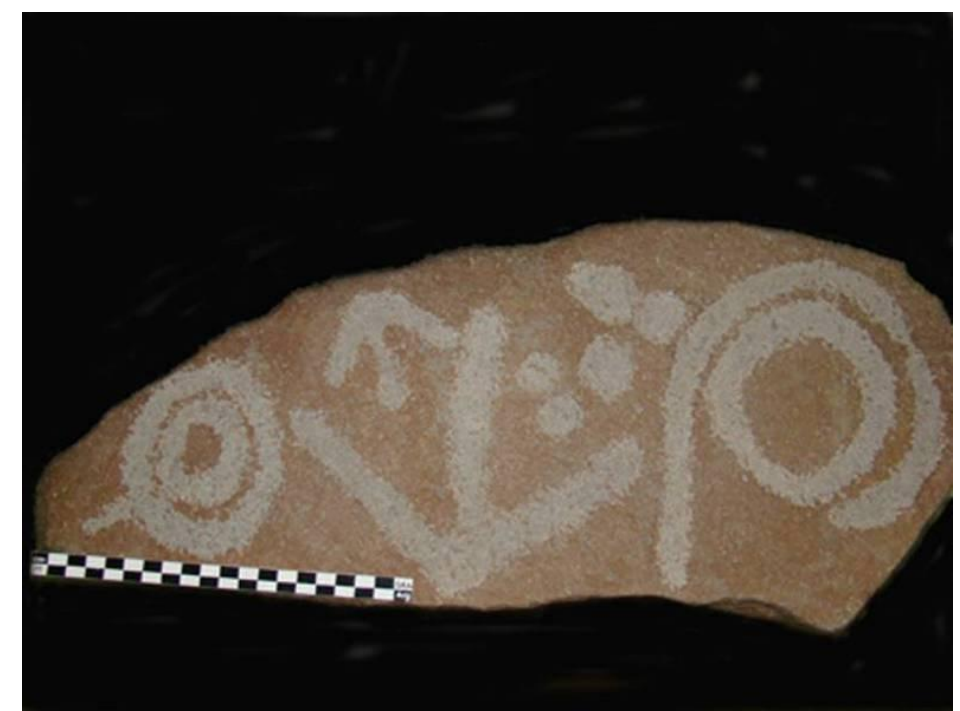

Figura 5.16. Bloque con réplicas experimentales de los grabados de LCB. 


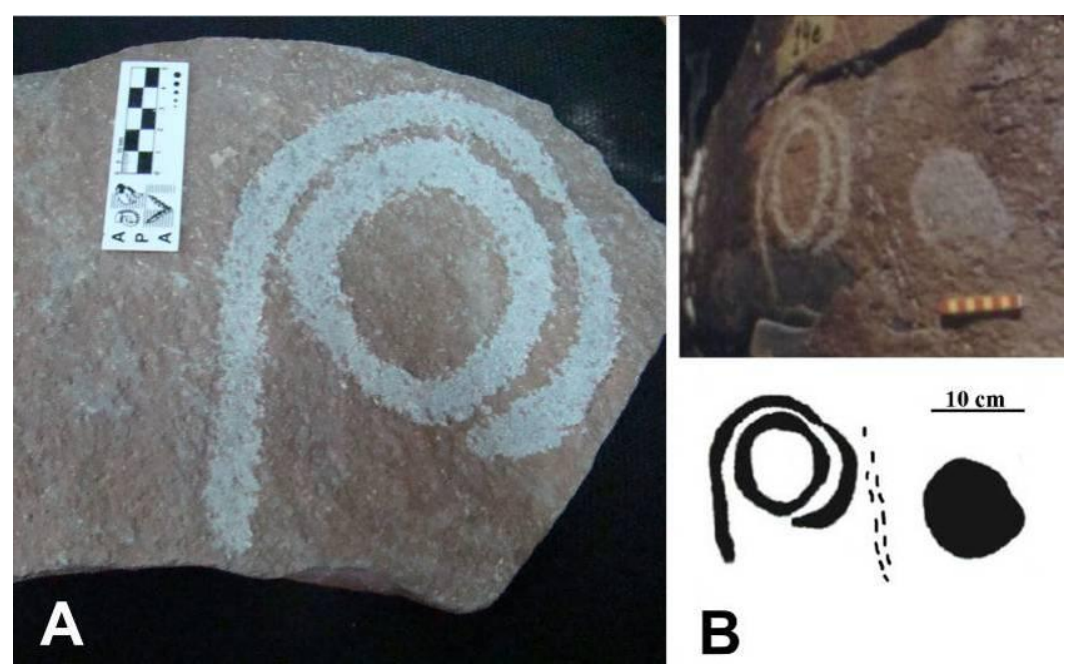

Figura 5.17. Comparación entre grabado experimental y arqueológico: a. Réplica experimental; b. Motivo arqueológico de LCB (Tomado y modificado de Carden 2008a).

En el motivo circular doble con apéndice se invirtieron 60 minutos, la circunferencia interna comportó 20 minutos de trabajo y durante los restantes 40 minutos se percutió la superficie para lograr la circunferencia externa con apéndice (Tabla 5.8; ver Figura 5.16).

Los surcos logrados sobre este bloque basáltico son superficiales, en los que se deja expuesta una superficie de color gris claro que contrasta con el color de la pátina del bloque (ver Figura 5.16). Se puede observar que los surcos experimentales son continuos, con ciertas irregularidades producto de la microtopografía de la superficie basáltica.

\begin{tabular}{|c|c|c|c|c|c|c|}
\hline Motivo & $\begin{array}{l}\text { Tamaño } \\
\text { (cm) }\end{array}$ & $\begin{array}{l}\text { Forma del } \\
\quad \text { surco }\end{array}$ & $\begin{array}{l}\text { Técnica de } \\
\text { replicación }\end{array}$ & $\begin{array}{c}\text { Tiempo } \\
\text { invertido } \\
\text { (min.) }\end{array}$ & $\begin{array}{c}\text { Técnicas } \\
\text { inferidas } \\
\text { (Carden } \\
\text { 2008a) }\end{array}$ & $\begin{array}{c}\text { Ubicación } \\
\text { de los } \\
\text { motivos }\end{array}$ \\
\hline Tridígito 1 & $18 \times 15,5$ & Superficial & $\mathrm{Pe}$ & 55 & Pind & \multirow[t]{2}{*}{ Conjunto 18} \\
\hline Tridígito 2 & $7,5 \times 7$ & Superficial & $\mathrm{Pe}$ & 25 & Pind & \\
\hline $\begin{array}{l}\text { Circunferencia } \\
\text { con curvilíneo }\end{array}$ & $15,5 \times 21,5$ & Superficial & $\mathrm{Pe}$ & 95 & Pind & $\begin{array}{c}\text { Conjunto } \\
14 \mathrm{e}\end{array}$ \\
\hline $\begin{array}{l}\text { Conjunto de } \\
\text { puntos }\end{array}$ & $10 \times 7$ & Superficial & $\mathrm{Pe}$ & 50 & Pind & \multirow{2}{*}{ Conjunto $2 \mathrm{~b}$} \\
\hline $\begin{array}{l}\text { Circunferencia } \\
\text { doble con apéndice }\end{array}$ & $9 \times 10,5$ & Superficial & $\mathrm{Pe}$ & 60 & Pind & \\
\hline
\end{tabular}

Tabla 5.8. Selección de motivos replicados de LCB. Pe: percusión directa; Pind: percusión indirecta. 
5. c. 1. 2. c. Comparación de réplicas grabadas sobre diferentes soportes

Los resultados obtenidos a partir de este trabajo refieren a las cuatro variables consideradas en las experiencias replicativas:

1) La constitución del soporte, su composición mineralógica y dureza, así como las características de su microtopografía y pátina, influyen en el proceso de trabajo. En el bloque de arenisca coquinoide se observó que la composición de la roca favoreció diferencialmente el proceso de grabado, ya que la fracción conchil ofrece una resistencia mayor al trabajo realizado, mientras que la matriz arenosa, facilita la apertura del surco; la cementación heterogénea condiciona la fragmentación del soporte por la existencia de porosidades. Asimismo, la presencia de pátina ofreció resistencia para la realización de grabados.

La superficie seleccionada para realizar las réplicas en el bloque de basalto presenta pátina rojiza, por lo que la aplicación de golpes permitió dejar surcos grabados superficiales que contrastan con dicha pátina. Además, una porción de este bloque es irregular y rugosa, trabajarla implicó mayor inversión de tiempo a fin de lograr un surco homogéneo.

2) El empleo de cantos rodados o guijarros como percutores, asibles con una mano, permitió realizar motivos grabados. Las observaciones etnoarqueológicas, la escasa frecuencia de artefactos potencialmente utilizables para producir grabados, sumadas a trabajos experimentales previos (Álvarez y Fiore 1995; Bednarik 2007b; Fiore 1996-98; Méndez 2008; Vergara Murúa 2009) y los presentados en apartados anteriores permiten considerar a los cantos rodados como potenciales percutores. Estos pueden ser abundantes en las inmediaciones de los sitios con grabados, aunque no se les ha prestado suficiente atención.

Luego del trabajo realizado, los percutores sufrieron una leve reducción en su tamaño (Apéndice III.2), la cual resultó del contacto con el soporte y es evidente en los extremos con marcas de impacto o machacados.

3) La pericia de los ejecutantes hizo que la aplicación de las técnicas seleccionadas sea llevada a cabo sin inconvenientes, adaptándose a 
posiciones variadas para realizarlas, dadas principalmente por el ángulo de trabajo cuando se emulaban las condiciones en las que fueron relevados los motivos grabados en los distintos sitios.

A pesar de la mayor dureza del bloque basáltico de LCB con respecto a la arenisca coquinoide de PM, la inversión de tiempo en la realización de motivos con tamaños y diseños semejantes fue similar en ambos soportes (i.e., tridígito 2 de LCB y tridígito 3 de PM). La diferencia radica en la obtención de una imagen por contraste en LCB y en una imagen de bajo relieve en PM.

El sonido resultante de las percusiones no fue contemplado como una variable en el diseño experimental, aunque durante las experiencias este factor condicionó la continuidad del trabajo debido a la molestia del sonido metálico generado. Esta es, entonces, una vía analítica a explorar en el futuro. Si bien las experiencias replicativas fueron realizadas en laboratorio y sobre bloques aislados y de tamaño pequeño, los sitios con grabados sobre superficies basálticas son espacios abiertos o semi-abiertos, con grandes paredes. Este tipo de roca genera sonidos metálicos al ser golpeada, por lo que se pueden plantear interrogantes respecto al rol que habría tenido el sonido de la percusión en la producción de los grabados, y cómo habría sido dicho sonido de haber sido realizado por uno o más productores al mismo tiempo (Ouzman 2001).

4) La similitud entre las réplicas experimentales y los motivos arqueológicos fue notable, posiblemente debido al trabajo con dibujo previo, aunque se observaron casos donde la microtopografía y la composición del soporte dificultaron lograr réplicas similares a los referentes arqueológicos. La friabilidad y menor dureza de la arenisca coquinoide condiciona la técnica a emplear y con ello, el mantenimiento del diseño y profundidad del motivo. Esta situación coincide con planteos previos que proponen que los soportes condicionaron las técnicas empleadas para grabar (Álvarez y Fiore 1995; Bednarik 2007b; Belardi y Goñi 2002, 2006; Fiore 2007, 2009). 


\section{5. c. 2. Motivos pintados}

\section{5. c. 2. 1. Reconocimiento de técnicas}

En las pinturas también se ha utilizado el reconocimiento de técnicas de producción a partir de la observación macroscópica de los trazos, y los artefactos o implementos utilizados para aplicar la mezcla pigmentaria son escasos en el registro arqueológico (Apartado 4. a. 1). Al comenzar estas experiencias, el interés rondaba en distinguir la técnica digital (aplicación directa de la pintura con la yema de los dedos) de aquella que comporta la aplicación de pintura con algún tipo de implemento (indirecta). En tal sentido, se realizaron dos líneas de puntos y dos series de trazos verticales paralelos aplicando la pintura con la yema de los dedos y con hisopos, respectivamente. Éstos últimos se confeccionaron de la manera que fue presentada en el Apartado 5. a. 2, en tanto que las mezclas pigmentarias respetan las proporciones planteadas en el Apartado 5. b. 1.

Los trazos paralelos realizados mediante la técnica digital son anchos y presentan acumulación de pintura en la parte externa, en tanto que hacia el centro son tenues. Los puntos, en cambio, presentan acumulación de pintura en el sector donde el extremo del dedo apoyó último (Figura 5.18). Los trazos realizados con hisopos son planos y homogéneos, en los que el ancho del trazo depende mayoritariamente del tamaño del instrumento utilizado. 


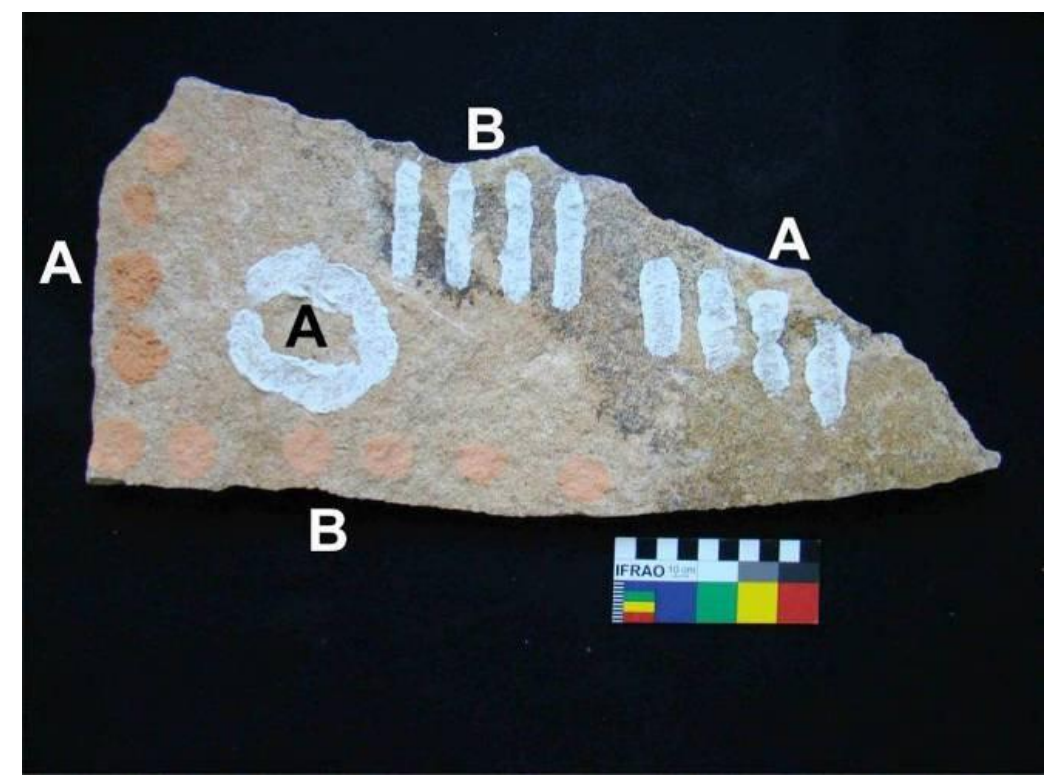

Figura 5.18. Trazos experimentales pintados con hisopos y mediante la técnica digital. A: digital, B: con hisopo.

Trazos adicionales fueron realizados con vellones de pelo de guanaco embebidos en pintura y con el extremo de una pequeña rama. Se separaron vellones de $1 \mathrm{~g}$, a los que se les dio forma de esfera o aguzada (Figuras 5.19.a y 5.19.b). Luego, los vellones fueron embebidos con mezcla pigmentaria y se realizaron círculos planos y líneas verticales (Figura 5.19.c). Durante el trabajo los vellones se fueron deformando (Figura 5.19.d). Los trazos resultantes del vellón con forma de esfera ( $\mathrm{n}^{\circ} 1$ en Figura 5.19.c) son similares a aquellos realizados con el vellón con forma aguzada ( $\mathrm{n}^{0} 2$ en Figura 5.19.c). Ambos presentan una superficie relativamente homogénea cuyas dimensiones están relacionadas a la forma y tamaño del vellón en el momento del trabajo. Los trazos realizados con una rama embebida en pintura $\left(\mathrm{n}^{0} 3\right.$ en Figura 5.19.c) también presentan una superficie relativamente homogénea y su tamaño está estrechamente relacionado a las dimensiones del fragmento vegetal utilizado. Se realizó, además, un círculo lleno mediante la técnica digital $\left(\mathrm{n}^{\circ} 4\right.$ en Figura 5.19.c) que presenta un perímetro más definido si se lo compara con los restantes círculos realizados sobre el bloque con técnicas indirectas de aplicación de la pintura. La observación de los diferentes trazos permite distinguirlos en cuanto a la definición del perímetro, y se relaciona con la deformación que sufren los vellones de pelo durante la aplicación de la pintura (Figura 5.19.d). 


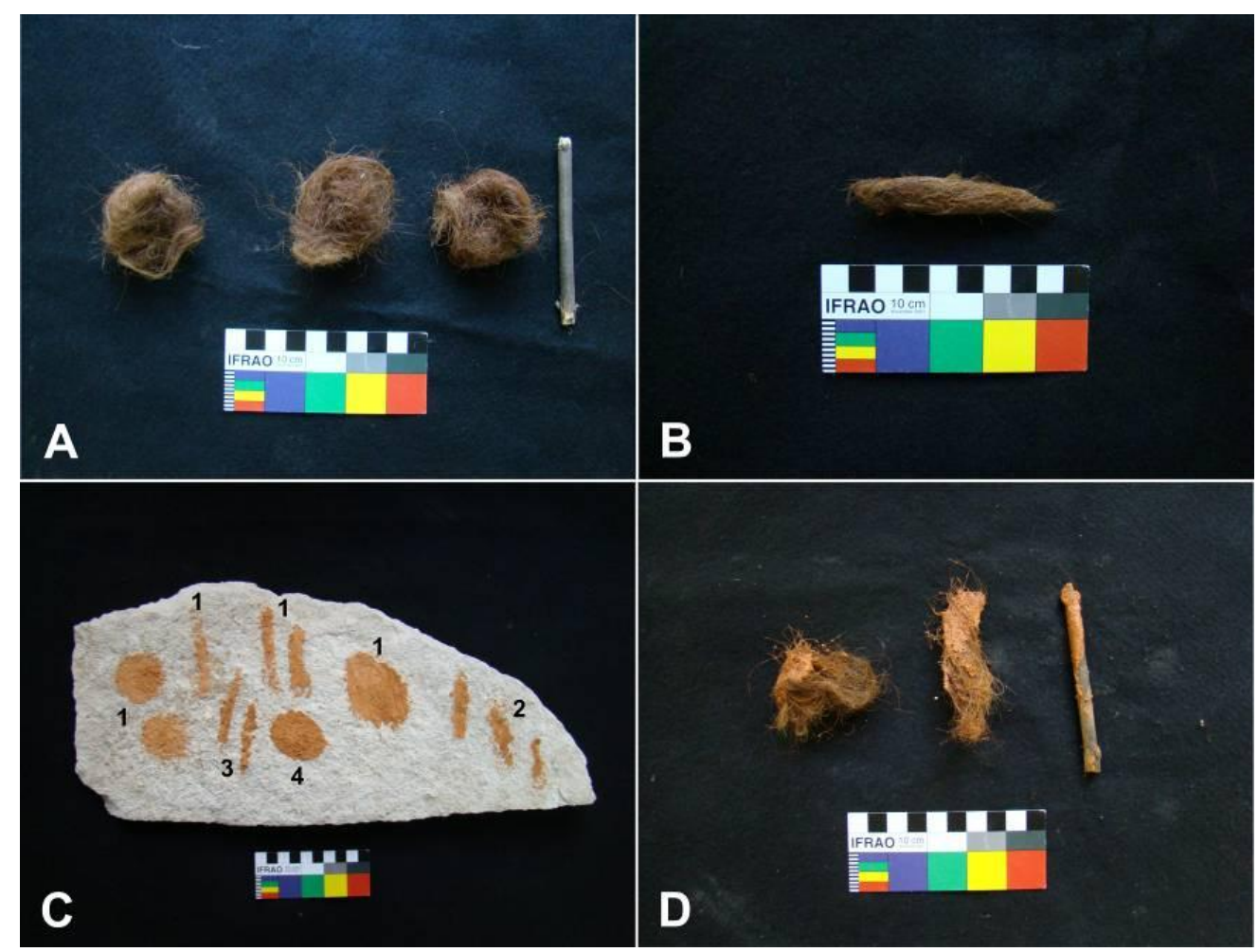

Figura 5.19. Empleo de vellones y ramas para realizar marcas pintadas: a. Vellones de pelo de guanaco de $1 \mathrm{~g}$, fragmento vegetal utilizado para aplicar pintura; $b$. vellón de pelo de guanaco de forma aguzada; c. trazos realizados con vellón con forma de esfera (1), con vellón en forma aguzada (2); con fragmento vegetal (3); con técnica digital (4); d. Vellones y fragmento vegetal luego de ser utilizados.

\section{5. c. 2. 2. Réplicas de motivos pintados de la localidad La Primavera}

La localidad La Primavera se encuentra en el sector NE del macizo del Deseado (ver Figura 5.3). Está integrada por numerosos sitios arqueológicos, de los cuales siete presentan arte rupestre (Carden 2008a). Estos sitios se encuentran al interior de espacios reparados (aleros o cuevas), donde se observan motivos pintados entre los que predominan los negativos de mano (Carden 2013). A continuación se presentan los motivos seleccionados para replicar de esta localidad, entre los que se incluyen una pisada de felino, un motivo circular complejo, un zoomorfo asociado a puntiformes y negativos de mano.

La pisada de felino de color blanco fue relevada en el sector $1 \mathrm{~B}$ de La Primavera 2 (LP-2). Se trata de una pequeña cueva, ubicada a $60 \mathrm{~m}$ sobre el nivel de base del cañadón, que presenta motivos adicionales distribuidos 
diferentes sectores. Se pueden mencionar, además, negativos de mano y conjuntos de manchas. Este motivo fue replicado tres veces sobre un bloque experimental ubicado a $1,45 \mathrm{~m}$ del suelo con $78^{\circ}$ de inclinación (Tabla 5.9). Las réplicas fueron realizadas por dos mujeres diestras, que trabajaron de pie frente al bloque. Dos réplicas fueron hechas mediante el uso de hisopos, y en la tercera la pintura fue aplicada mediante la técnica digital. La mezcla pigmentaria se corresponde con las proporciones empleadas con anterioridad (Apartado 5. b. 1), conformada por pigmento blanco, yeso, grasa de choique y agua (Tabla 5.9).

En los motivos experimentales en los que se utilizaron hisopos para aplicar la pintura se observan diferencias: en la réplica 1 se aplicó demasiada fuerza al momento de realizar el trazo de pintura $\left(n^{\circ} 1\right.$ en Figura 5.20.a), en tanto que en la réplica 2 se observa que el hisopo estuvo sobrecargado con pintura $\left(\mathrm{n}^{\circ} 2\right.$ en Figura 5.20.a). La tercera réplica fue realizada mediante la técnica digital $\left(\mathrm{n}^{\circ} 3\right.$ en Figura 5.20.a). A pesar de haber empleado dos técnicas distintas, las réplicas 2 y 3 son similares al motivo arqueológico (Figura 5.20.b), lo cual señala un caso de equifinalidad.

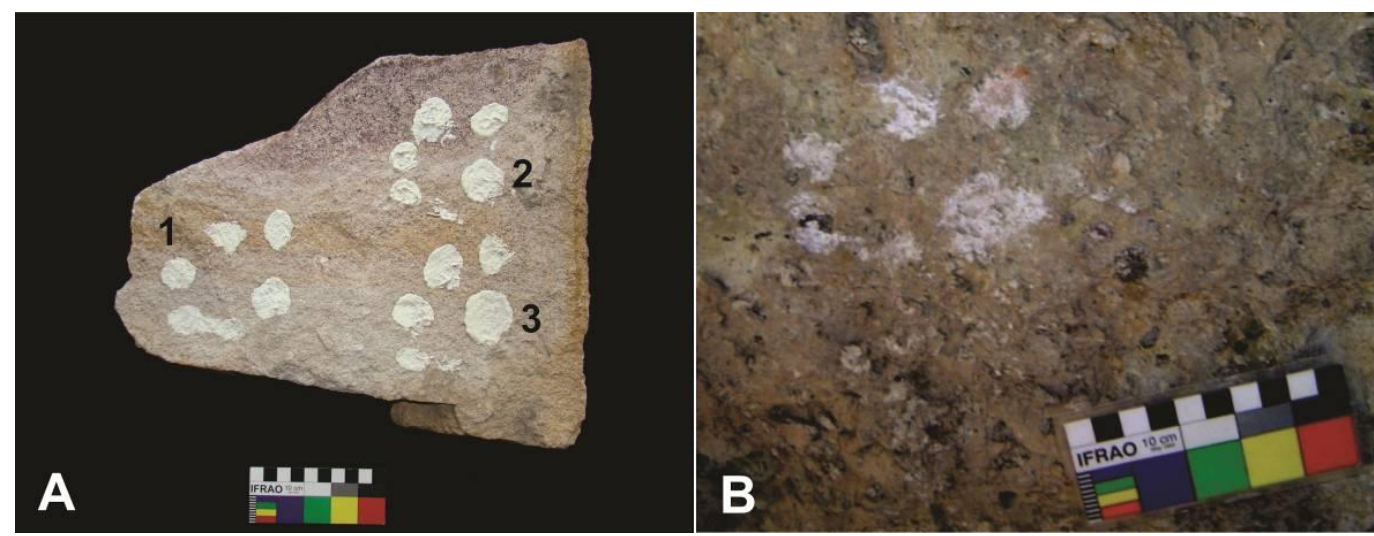

Figura 5.20. Réplicas de las pisadas de felino documentadas en LP-2: a. réplicas experimentales: 1. realizada utilizando un hisopo, 2. réplica que realizó otra pintora usando un hisopo diferente, 3. réplica ejecutada mediante técnica digital; $b$. referente arqueológico.

Otro motivo seleccionado para la replicación está conformado por un conjunto de circunferencias en policromía documentado en el sitio La Primavera 5 (LP-5). Este se encuentra a $2 \mathrm{~km}$ de LP-1 y LP-2, y corresponde a un alero de pequeñas dimensiones $(10 \mathrm{~m}$ frente por $3 \mathrm{~m}$ de profundidad máxima) en el que se relevaron, además, negativos de mano, líneas 
puntiformes negras, líneas de dígitos (Carden 2008a, 2013). El motivo seleccionado está ubicado sobre un plano horizontal a $0,50 \mathrm{~m}$ del suelo actual. Las condiciones de replicación fueron similares a las del registro (Tabla 5.9; Figura 5.21.a). El conjunto se realizó con tres mezclas pigmentarias, dos de ellas resultado de la combinación de pigmentos con yeso, grasa y agua, en tanto que la tercera fue el resultado de la fusión de pigmento blanco, carbón vegetal, yeso, agua y grasa (Tabla 5.9). La pintura se aplicó con hisopos (Figura 5.21.b).

Respecto de la técnica utilizada, si comparamos los trazos de la réplica con los de su referente arqueológico se detectaron similitudes (Figura 5.21.c y 5.21.d), por lo que el hisopo podría haber sido el artefacto empleado para aplicar la pintura; aunque se tiene que hacer una salvedad para los trazos paralelos blancos superiores. En la réplica estos trazos son relativamente homogéneos (Figura 5.21.c), en tanto que en el referente arqueológico son más anchos, desvaídos y superficiales (Figura 5.21.d). Esto último no estaría vinculado a cuestiones de conservación, ya que el panel no recibe insolación directa de ningún tipo. Es posible, por lo tanto, que dicha diferencia se vincule con la técnica utilizada para aplicar la pintura blanca, que probablemente haya sido digital.

Las tonalidades de las mezclas experimentales rojas y negras son diferentes a las registradas en el motivo arqueológico. Esto sugiere diferencias técnicas en su preparación que deberán ser resueltas con futuros análisis composicionales de las pinturas experimentales y arqueológicas. 

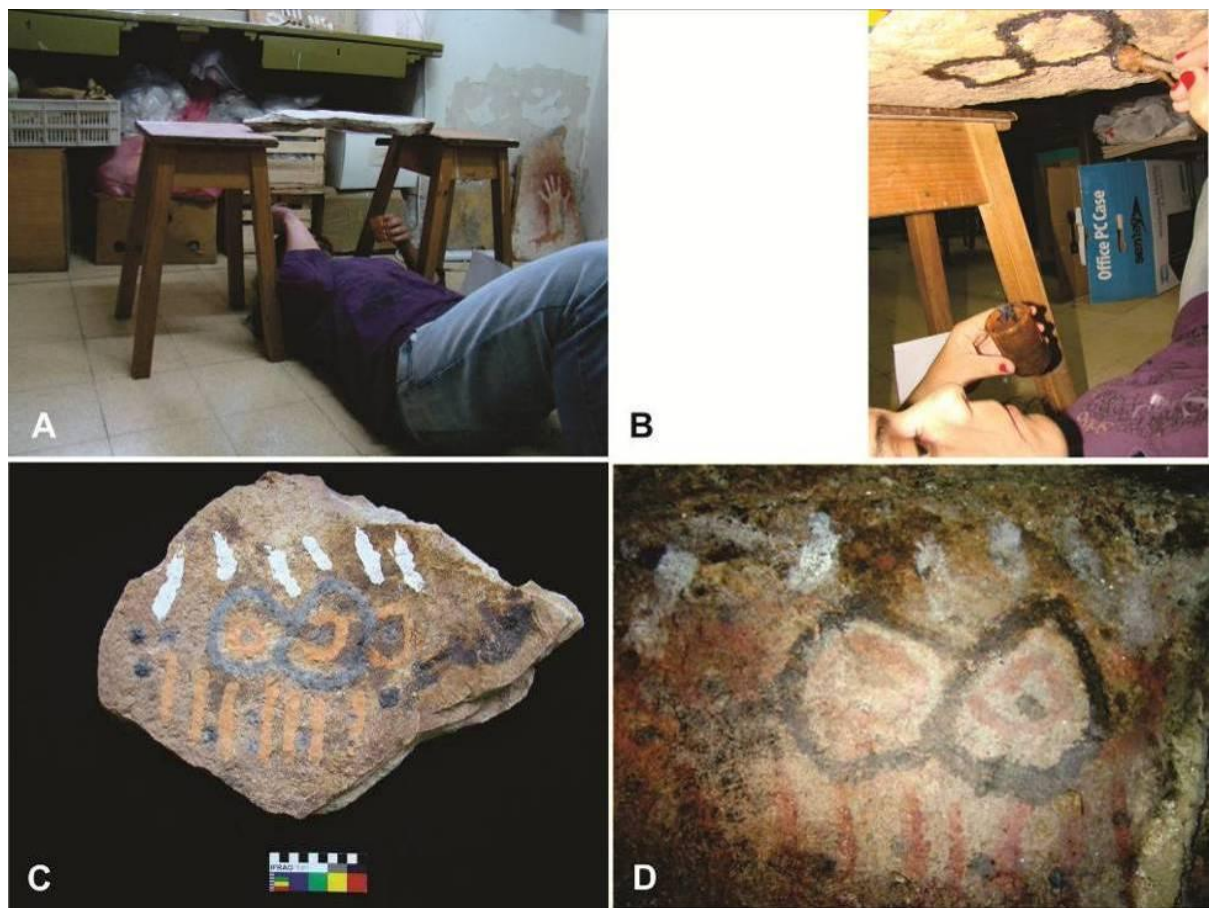

Figura 5.21. Réplica de motivos de LP-5: a. posición del pintora y relación con el soporte; b. Empleo de hisopo y mezcla negra; c. réplica; d. referencia arqueológica.

Del sitio Cueva Maripe se seleccionaron tres motivos (Tabla 5.9). En esta cueva de grandes dimensiones se registraron principalmente negativos de mano de varios colores, escasos zoomorfos, motivos puntiformes y lineales (Carden 2008a). Debido a la abundancia de los negativos, estos serán tratados en el apartado siguiente.

De los motivos replicados, se seleccionó parte de un conjunto documentado en el sector 7B de Cueva Maripe (Figura 5.22.a). En el laboratorio, el bloque experimental fue ubicado a $1 \mathrm{~m}$ del suelo con una inclinación de $105^{\circ}$; la pintura fue aplicada con hisopos, vellones de pelo de guanaco embebidos con pintura y con la yema de los dedos (Tabla 5.9). Durante esta experiencia replicativa el artefacto empleado se desarmó posteriormente a la realización del círculo. La pintura utilizada en este motivo tenía una consistencia líquida que dio como resultado que el motivo terminara con una chorreadura luego de levantar el hisopo (Figura 5.22). El zoomorfo fue realizado enteramente con un vellón de pelo embebido en pintura, lográndose dos tipos de trazos: una superficie amplia de pintura y trazos planos finos. Se realizaron dos líneas de puntos: la superior mediante la técnica digital y la inferior usando un vellón de pelo (Figura 5.22). 


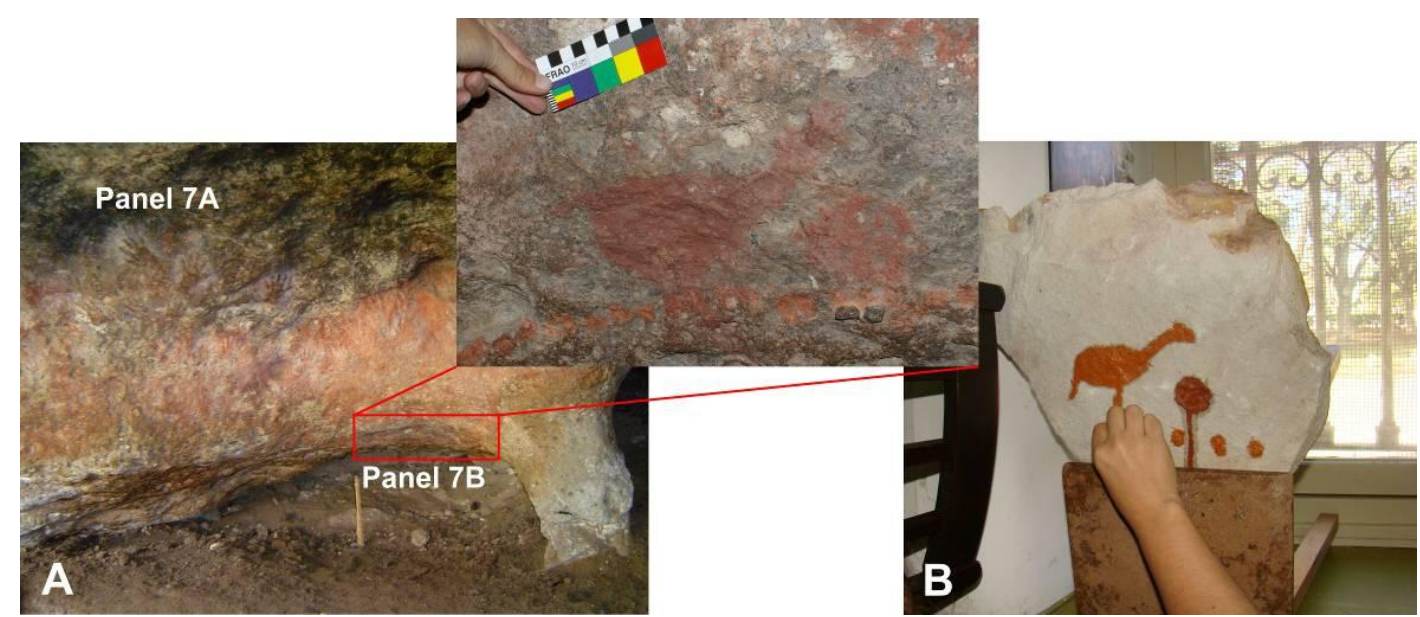

Figura 5.22. Réplica de motivos de panel 7B: a. ubicación del panel 7B en el interior de cueva Maripe y detalle de los motivos a replicar; b. Producción de línea inferior de puntos utilizando vellón de pelo de guanaco embebido con pintura.

Entre las observaciones referidas a los gestos técnicos se puede mencionar que la consistencia de la pintura y la cantidad que se carga sobre el artefacto utilizado puede dar como resultado chorreaduras. Por otro lado, si el artefacto -en este caso un hisopo- se desarma, es factible obtener trazos planos y homogéneos con un vellón embebido en pintura. Esta situación, en conjunto con la presentada en el apartado previo, permite plantear que simples vellones de pelo de guanaco embebidos con mezclas pigmentarias son suficientes para pintar y lograr trazos o superficies planas de pintura. Por esta razón no sería necesaria la confección de artefactos formatizados para pintar. Lo anterior podría explicar la escasez de este tipo de artefactos en el registro arqueológico Patagonia, ya que se trata de objetos orgánicos altamente perecibles. 


\begin{tabular}{|c|c|c|c|c|c|c|c|c|c|c|}
\hline \multirow{2}{*}{ Sitio } & \multirow{2}{*}{ Sector } & \multirow{2}{*}{ Motivo } & \multirow{2}{*}{ Altura } & \multirow{2}{*}{$\begin{array}{c}\text { Técnica } \\
\text { Experimental }\end{array}$} & \multirow{2}{*}{$\begin{array}{c}\mathrm{BE} \\
\text { (altura y ángulo) }\end{array}$} & \multicolumn{5}{|c|}{ Mezcla pigmentaria } \\
\hline & & & & & & Pigmento & $\begin{array}{c}\text { Cant. } \\
\text { pigmento }\end{array}$ & Yeso & Ligante & Agua \\
\hline La Primavera 2 & 1 & Pisada de felino & $1,45 \mathrm{~m}$ & $\begin{array}{l}\text { Digital y aplicación con } \\
\text { hisopo. }\end{array}$ & $\begin{array}{l}1,45 \mathrm{~m} \text { del suelo } \\
\text { y } 78^{\circ}\end{array}$ & $10 Y R$ 8/1 & $10 \mathrm{~g}$ & $3 \mathrm{~g}$ & $2 \mathrm{~g}$ & $18 \mathrm{ml}$ \\
\hline La Primavera 5 & 1B & $\begin{array}{l}1 \text { circular complejo } \\
\text { polícromo }\end{array}$ & $0,50 \mathrm{~m}$ & $\begin{array}{l}\text { Digital trazo lineal con } \\
\text { hisopo }\end{array}$ & $\begin{array}{l}0,50 \mathrm{~m} \text { del suelo, } \\
\text { horizontal } \\
\text { paralelo al } \\
\text { suelo. }\end{array}$ & $\begin{array}{l}\text { Mezcla I: } 10 \mathrm{YR} \\
8 / 1 \\
\text { Mezcla II: } 10 \text { R } 3 / 6 \\
\text { Mezcla III: Carbón } \\
\text { y Blanco }\end{array}$ & $\begin{array}{l}5 \mathrm{~g}, \\
5 \mathrm{~g} \\
5 \mathrm{~g} \\
5 \mathrm{~g}\end{array}$ & $\begin{array}{l}1,5 \mathrm{~g} \\
1,5 \mathrm{~g} \\
5 \mathrm{~g}\end{array}$ & $\begin{array}{l}1 \mathrm{~g} \\
1 \mathrm{~g} \\
2 \mathrm{~g}\end{array}$ & $\begin{array}{l}6 \mathrm{ml} \\
6 \mathrm{ml} \\
15 \mathrm{ml}\end{array}$ \\
\hline \multirow{4}{*}{ Cueva Maripe } & 7B & $\begin{array}{l}1 \text { zoomorfo y } \\
\text { puntiformes }\end{array}$ & $1,00 \mathrm{~m}$ & $\begin{array}{l}\text { Zoomorfo y puntos } \\
\text { superiores con hisopo y } \\
\text { vellones de guanaco } \\
\text { embebido en pintura. } \\
\text { Puntos inferiores con } \\
\text { técnica digital }\end{array}$ & $1,00 \mathrm{~m} \mathrm{y} 105^{\circ}$ & $\begin{array}{l}\text { Mezcla I: } 7.5 \text { R 5/2 } \\
\text { Mezcla II: } 10 \text { R 3/6 }\end{array}$ & $\begin{array}{l}6 \mathrm{~g} \\
1,75 \mathrm{~g}\end{array}$ & $\begin{array}{l}2 \mathrm{~g} \\
0,6 \mathrm{~g}\end{array}$ & $\begin{array}{l}1,2 \mathrm{~g} \\
0,4 \mathrm{~g}\end{array}$ & $\begin{array}{l}8 \mathrm{ml} \\
2 \mathrm{ml}\end{array}$ \\
\hline & $6 \mathrm{~B}$ & $\begin{array}{l}\text { Manos negativas } \\
\text { blancas sobre fondo } \\
\text { preparado }\end{array}$ & $1,00 \mathrm{~m}$ & Pulverizado directo & $\begin{array}{l}1,00 \mathrm{~m} \text { del suelo } \\
\text { y } 72^{\circ}\end{array}$ & $\begin{array}{l}\text { Fondo: } 10 \mathrm{R} 5 / 8 \\
\text { Negativo de mano: } \\
10 \mathrm{YR} 8 / 1\end{array}$ & $\begin{array}{l}20 \mathrm{~g} \\
10 \mathrm{~g}\end{array}$ & $\begin{array}{l}6 \mathrm{~g} \\
3 \mathrm{~g}\end{array}$ & $\begin{array}{l}4 \mathrm{~g} \\
2 \mathrm{~g}\end{array}$ & $\begin{array}{l}21 \mathrm{ml} \\
18 \mathrm{ml}\end{array}$ \\
\hline & & & & & & $\begin{array}{l}\text { Pintura } \\
\text { pulverizada: } 2.5 \mathrm{Y} \\
7 / 8\end{array}$ & $5 \mathrm{~g}$ & $1,5 \mathrm{~g}$ & $1 \mathrm{~g}$ & $10,5 \mathrm{ml}$ \\
\hline & $7 \mathrm{~A}$ & $\begin{array}{l}\text { Manos negativas } \\
\text { blancas }\end{array}$ & $1,80 \mathrm{~m}$ & Pulverizado directo & $1,60 \mathrm{~m} \mathrm{y} 82^{\circ}$ & 10YR 8/1 & $30 \mathrm{~g}$ & $9 \mathrm{~g}$ & $6 \mathrm{~g}$ & $40 \mathrm{ml}$ \\
\hline
\end{tabular}

Tabla 5.9. Información referida a la selección de motivos replicados de la localidad La Primavera. Referencias: S: sector del sitio; BE: bloque experimental; Cant. pigmento: cantidad de pigmento. 
5. c. 2. 2. a. Los negativos de mano

Estos motivos son abundantes en la porción centro-norte del macizo del Deseado, siendo predominantes en las localidades La Primavera y Los Toldos (Carden 2008a, 2013). Debido a su alta representatividad y por tratarse de una de las improntas más directas de los grupos humanos que habitaron este sector del macizo, la replicación de manos negativas fue tratada como un caso aparte. Considerando su tamaño y la altura respecto del suelo a la que se encuentran en los sitios, los negativos de mano permitirían inferir los actores sociales que participaron en su producción y la utilización medios de elevación para acceder a los soportes. El reconocimiento de grupos etarios y/o sexo de las personas que participaron en su producción también ha sido objeto de estudio (Bednarik 2008; Carden 2008a; Casamiquela 1980; Gradin 1981-82; Gunn 2006; Manhire 1998; McDonald 1995; Snow 2006, entre otros).

Entre las personas involucradas en la producción de negativos de manos, Gradin (1981-82) denominó "propietario" a quien impuso su mano para ser pintada y "pintor" a quien aplicó la pintura, dejando en claro que tales designaciones pueden corresponder a la misma persona si el pintor aplica pintura sobre su propia mano o a dos personas diferentes si participa un asistente. Una propuesta similar fue realizada por Bednarik (2008: 177), en la que se denomina "artista" a quien pintó negativos de manos de niños. En esta tesis se usa el término "modelo"3 para quien apoya su mano sobre la superficie rocosa mientras que pintor es quien aplica la pintura.

Previamente a la replicación de los negativos de mano, se efectuó el registro de la edad, el sexo y la estatura de cada modelo. Adicionalmente, se tomaron medidas en las manos izquierdas de acuerdo a lo establecido en trabajos previos (Gradin 1981-82; Gunn 2006). Tales medidas incluyen el largo y el ancho de la mano, así como los largos del dedo medio, del meñique y del pulgar (Figura 5.23). El largo de la mano va desde el extremo del dedo

\footnotetext{
${ }^{3}$ Modelo (del italiano modello), según la RAE, en pintura y escultura corresponde a la persona u objeto que copia el artista.
} 
mayor hasta el pliegue interno de la muñeca, mientras que el ancho de la mano va de la base del dedo índice a la base del dedo meñique.

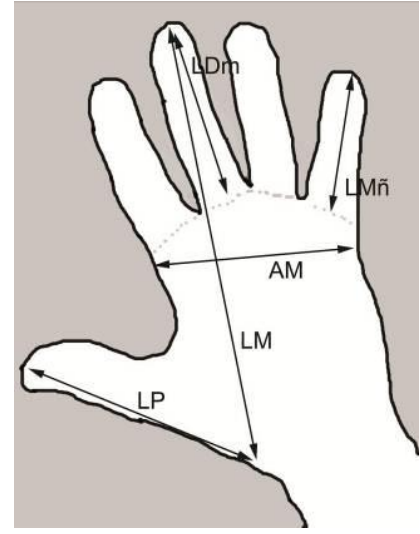

Figura 5.23. Medidas de la mano tomadas sobre la palma izquierda. Referencias: LM: Largo de la mano; AM: ancho de la mano; LDm: largo del dedo medio; LMñ: largo del dedo meñique; LP: largo del dedo pulgar.

En las experiencias participaron 21 individuos: 10 varones, de los cuales cuatro son niños entre 3 y 11 años; y 11 mujeres, entre ellas cinco son niñas entre 5 y 11 años. Se obtuvieron, en total, 54 negativos de la mano izquierda. Las mezclas pigmentarias fueron preparadas respetando las proporciones consideradas para otros motivos pintados (Apéndice III.3). La pintura fue aplicada por dos mujeres, por pulverizado directo.

Todos los negativos se realizaron sobre bloques en posición vertical a 1,30 del suelo, con ángulos variables entre $68^{\circ}$ y $80^{\circ}$ (Apéndice III.3). Los modelos apoyaron la palma de su mano sobre el bloque experimental en posición de pie, junto a la pintora (Figura 5.24.a), con excepción de tres casos donde los modelos (niños pequeños) debieron ser levantados por la pintora mientras se pulverizaba la pintura debido a su baja estatura (Figura 5.24.b). En treinta y cinco réplicas, el pintor y el modelo corresponden a la misma persona: una pintora-modelo realizó 34 negativos (Figura 5.24.c), mientras que una segunda pintora-modelo realizó el negativo restante (sombreados en Tabla 5.10). Las demás réplicas corresponden a la participación de un modelo y una pintora. 


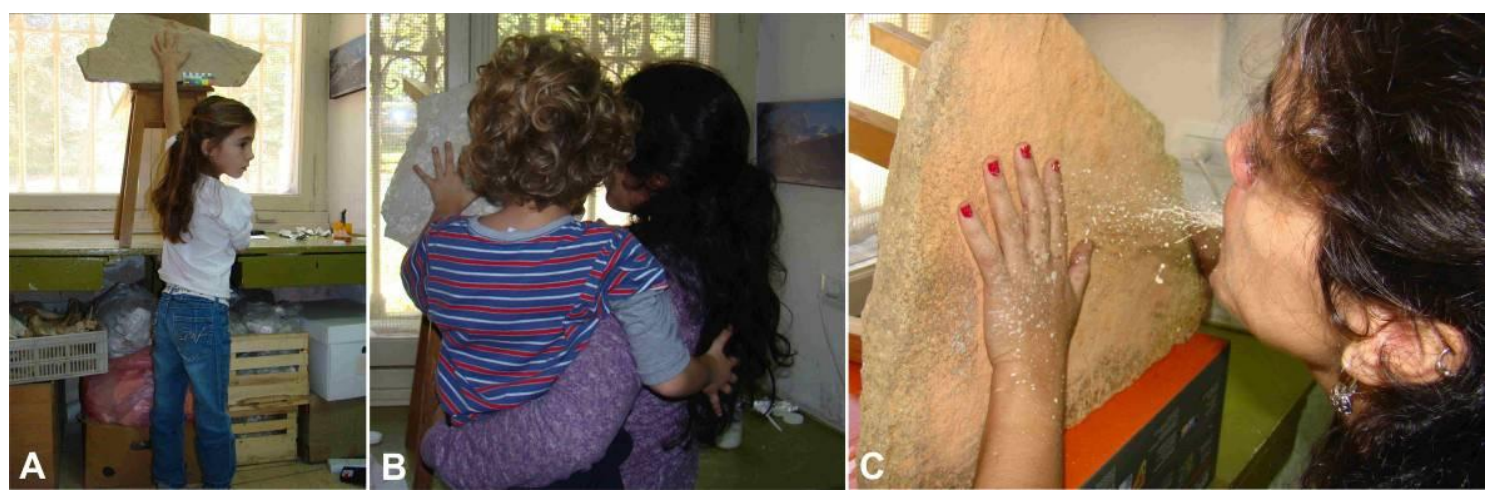

Figura 5.24. Posturas y gestos durante la replicación de diferentes negativos de mano: a. Modelo de 8 años parada frente al bloque experimental previo a la realización de su negativo de mano; b. Pintora sosteniendo en brazos a un modelo de 5 años de edad; c. Pintora pulverizando pintura sobre su propia mano.

\begin{tabular}{|c|c|c|c|c|c|c|c|c|}
\hline $\begin{array}{l}\text { Rango } \\
\text { etario }\end{array}$ & Edad & Sexo & $\mathrm{N}$ réplicas & $\mathrm{LM}$ & $\mathrm{AM}$ & $\mathrm{LDm}$ & LMñ & LP \\
\hline \multirow{4}{*}{$3-5$} & 3 & M & 1 & 106,95 & 55,4 & 46,39 & 37,42 & 62,28 \\
\hline & 5 & M & 2 & 129,36 & 63,46 & 58,2 & 46,61 & 74,89 \\
\hline & 5 & $\mathrm{~F}$ & 1 & 120,59 & 65,06 & 56,23 & 40,76 & 73,19 \\
\hline & 5 & $\mathrm{~F}$ & 1 & 117,74 & 55,64 & 46,8 & 37,3 & 71,01 \\
\hline \multirow{5}{*}{ 8-11 } & 8 & $\mathrm{M}$ & 1 & 129,83 & 62,41 & 56,3 & 41,1 & 73 \\
\hline & 8 & $\mathrm{~F}$ & 1 & 126,87 & 61,1 & 57,87 & 39,29 & 78,03 \\
\hline & 8 & $\mathrm{~F}$ & 1 & 140,81 & 68,4 & 65,57 & 45,69 & 88,43 \\
\hline & 10 & $\mathrm{~F}$ & 3 & 152,78 & 76,28 & 72,22 & 56,08 & 94,28 \\
\hline & 11 & M & 1 & 142,84 & 69,23 & 60,42 & 40,72 & 81,61 \\
\hline \multirow{12}{*}{$\geq 13$} & 13 & M & 1 & 171 & 73,33 & 73,1 & 57,82 & 51,52 \\
\hline & 15 & M & 1 & 181 & 80,03 & 76,09 & 56,15 & 102,26 \\
\hline & 17 & M & 1 & 186 & 80,59 & 76,44 & 61,1 & 101,27 \\
\hline & 23 & $\mathrm{~F}$ & 1 & 166 & 65,32 & 72,94 & 52,41 & 92,36 \\
\hline & 23 & $\mathrm{~F}$ & 1 & 175 & 74,19 & 74,28 & 57,63 & 114,98 \\
\hline & 24 & M & 1 & 194 & 83,31 & 85,45 & 66,44 & 112,21 \\
\hline & 29 & $\mathrm{~F}$ & 34 & 170 & 72,34 & 72,75 & 60,39 & 98,64 \\
\hline & 31 & $\mathrm{~F}$ & 1 & 160 & 73,7 & 72,61 & 46,7 & 95,49 \\
\hline & 32 & $\mathrm{~F}$ & 1 & 176 & 74,43 & 71,77 & 53,29 & 91,82 \\
\hline & 33 & $\mathrm{M}$ & 1 & 203 & 85,36 & 86,28 & 67,96 & 108,63 \\
\hline & 34 & $\mathrm{M}$ & 1 & 180 & 88,97 & 82,51 & 61,62 & 103,72 \\
\hline & 38 & $\mathrm{M}$ & 1 & 192 & 80,28 & 77,22 & 62,38 & 105,6 \\
\hline
\end{tabular}

Tabla 5.10. Datos experimentales de los negativos de mano: medidas en mm de las manos de los diferentes modelos. Referencias: M: masculino; F: femenino. N réplicas: cantidad de réplicas. LM: Largo de la mano; AM: ancho de la mano; LDM: largo del dedo medio; LMñ: largo del dedo meñique; LP: largo del dedo pulgar. Los casos sombreados corresponden a pintora-modelo. 
$\mathrm{Al}$ considerar un ejemplo donde el pintor y el modelo corresponden a dos personas, se observan variaciones en el largo de tres negativos de mano obtenidos a partir de una misma mano (Figura 5.25). Estas diferencias podrían explicarse a partir de cambios en la posición de ambos. Cuando el modelo se ubicó hacia la derecha de la pintora se obtuvieron réplicas más largas o más cortas que el largo real de la mano porque el campo manual de la pintora -y con ello el ángulo de aplicación de la pintura- se vio restringido por la posición del modelo. Cuando el modelo se ubicó a la izquierda de la pintora, esta última tuvo más acceso al soporte lo cual permitió una mejor aplicación de la pintura, obteniéndose un negativo con largo y ancho similares a los de la mano real (Figura 5.25). Además, en las dos primeras experiencias de replicación se varió la distancia de aplicación de la pintura, a más de $15 \mathrm{~cm}$ (NE 1) y entre 7 y $10 \mathrm{~cm}$ (NE 2), obteniendo una mano más larga o más pequeña que la mano real, respectivamente (Figura 5.25).

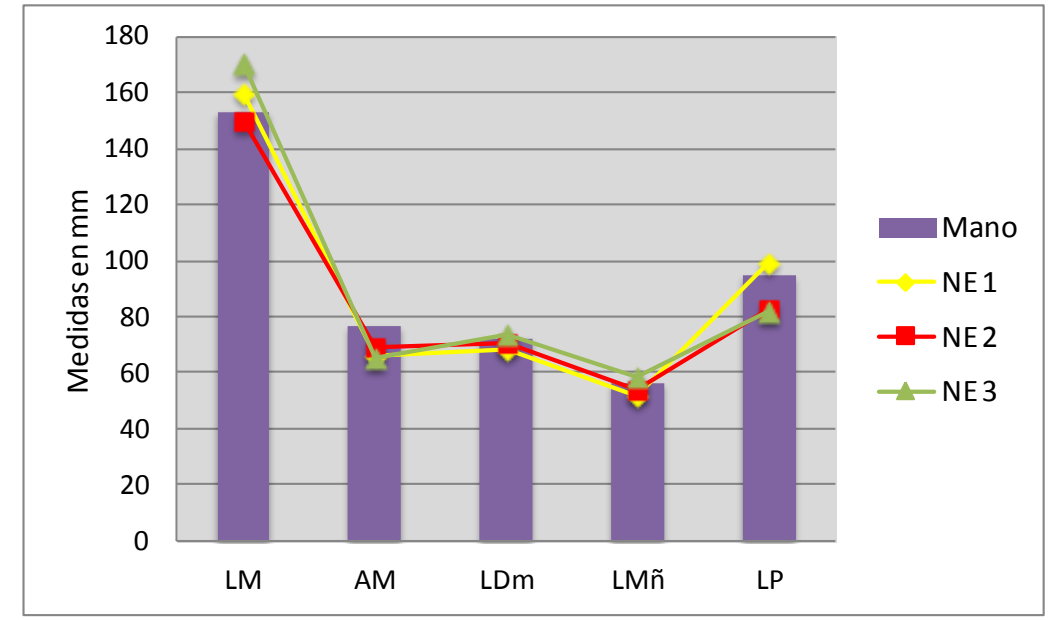

Figura 5.25. Comparación entre las medidas de la mano real y los negativos experimentales de una niña de 11 años. Referencias: NE: Negativo experimental; LM: largo de la mano; AM: ancho de la mano; LDm: largo del dedo medio, LMñ: largo del dedo meñique; LP: largo del pulgar.

Asimismo, la estatura de la pintora y la altura respecto del suelo en la que se encuentran las manos a estarcir son factores que influyen en el tamaño de los negativos. Por ejemplo, teniendo en cuenta que una de las pintoras mide 1,60 m de estatura, los bloques experimentales y las manos replicadas se colocaron a una altura que osciló entre 1,30-1,45 m respecto del suelo, que resultó ser la altura óptima para trabajar de pie. De este 
modo, se obtuvo una horizontalidad relativa entre la boca de la pintora y la mano sobre la que se pulverizó pintura. Dicha horizontalidad permitió mantener la pintura dentro de la boca sin tragarla y, al mismo tiempo, controlar las respiraciones para poder cubrir con una sola carga de mezcla toda la mano. De igual manera, esta horizontalidad influye en la distancia y el ángulo de aplicación de la pintura.

Si bien la distancia de aplicación fue considerada previamente, se puede remarcar que la pintura aplicada entre 7-10 $\mathrm{cm}$ de distancia da como resultado negativos similares en cuanto al tamaño a la mano real. Sin embargo, el tamaño del negativo obtenido también está en relación al ángulo de aplicación de la pintura. Este último es definido a partir de la dirección desde la cual se pulveriza la pintura en relación a un plano horizontal (Paunero 1992).

De acuerdo con estos parámetros, es posible plantear que si participaron un modelo y un pintor en la experiencia de producción de los negativos, la posición y la distancia entre ambos influye sobre el ángulo y la distancia de aplicación de la pintura. Si la distancia de aplicación de la pintura es superior a 15-20 cm, y el ángulo de aplicación es amplio, se obtiene un negativo más ancho y más largo que la mano real. Si la distancia de aplicación es menor a $15 \mathrm{~cm}$ y el ángulo de aplicación de la pintura es agudo, el negativo de mano obtenido puede ser igual o más pequeño que la mano real. Por otro lado, al ubicarse el modelo hacia la izquierda del pintor se obtuvieron tamaños similares entre la mano y el negativo.

Por lo anterior, se puede plantear que más allá de la posición adoptada (de pie, en cuclillas o arrodillado), la horizontalidad relativa entre la mano usada como plantilla y la boca del pintor es clave para aplicar óptimamente la pintura y lograr manos negativas de tamaños similares a las manos reales.

Si bien puede resultar difícil reconocer la participación de dos actores, se puede pensar que los negativos de mano de tamaño pequeño, correspondientes a un modelo de corta edad, ubicados a más de 1,25 m respecto del suelo pudieron haber sido realizados mediante estarcido por un 
pintor de mayor edad. Para los casos arqueológicos, además de los tamaños de los negativos, se tienen que considerar las condiciones de sedimentación presentes en los sitios con este tipo de motivo rupestre.

Para observar el grado de variación en el tamaño de los negativos de mano y la mano real se realizaron dos tipos de análisis. Por un lado, se consideraron solamente todas las medidas de los negativos de mano obtenidos por una modelo-pintora a fin de observar qué medida era la que presentaba menor variación, mediante el cálculo del coeficiente de variación (Gunn 2006). Por otro lado, y a partir de los resultados anteriores, se consideraron las variaciones en el largo de todos los negativos experimentales y el largo real de las manos de los modelos. A partir de esto se propuso un factor de corrección, el cual, aplicado a las medidas obtenidas en los negativos arqueológicos, permite estimar grupos de edad.

Los datos obtenidos a partir de la realización de 31 negativos de la mano izquierda del mismo modelo-pintor fueron empleados para evaluar la relación entre el tamaño de los negativos y los gestos técnicos. Durante estas experiencias se mantuvieron constantes las condiciones de replicación. De este modo, los bloques experimentales se encontraban a 1,30 m respecto del suelo, con una inclinación entre 65 y $80^{\circ}$, y las mezclas pigmentarias fueron preparadas manteniendo las proporciones presentadas en apartados previos (Apéndice III.3).

Luego, se tomaron las diferentes medidas de los negativos experimentales y se calculó su coeficiente de variación (CV) (sensu Gunn 2006). La fórmula $(C V=[D S /$ media $] x 100)$ fue aplicada a todas las medidas tomadas. La medida que menos varió fue el largo de la mano $(\mathrm{CV}=2,82)$, seguida por el largo del dedo medio $(\mathrm{CV}=4,10)$, el ancho de la mano $(\mathrm{CV}=4,82)$ y el largo del dedo meñique $(\mathrm{CV}=6,28)$ (Tabla 5.11). Las medidas obtenidas para el pulgar no fueron consideradas ya que en algunos negativos no pudo tomarse con certeza su largo, en algunos casos debido a la falta de pintura. Los resultados obtenidos señalan, por lo tanto, que el largo de la mano es la medida más confiable para considerar en las estimaciones de edad a partir del tamaño de las manos negativas. 


\begin{tabular}{|c|c|c|c|c|}
\hline Medidas & $\mathrm{LM}$ & $\mathrm{AM}$ & $\mathrm{LDm}$ & LMñ \\
\hline Mano real & 170 & 72 & 73 & 60 \\
\hline Neg. 1 & 175 & 73 & 79 & 71 \\
\hline Neg. 2 & 172 & 73 & 75 & 60 \\
\hline Neg. 3 & 170 & 80 & 80 & 56 \\
\hline Neg. 4 & 173 & 81 & 68 & 56 \\
\hline Neg. 5 & 170 & 79 & 74 & 54 \\
\hline Neg. 6 & 160 & 91 & 77 & 63 \\
\hline Neg. 7 & 185 & 80 & 73 & 56 \\
\hline Neg. 8 & 180 & 77 & 71 & 63 \\
\hline Neg. 9 & 169 & 82 & 76 & 59 \\
\hline Neg. 10 & 173 & 82 & 76 & 64 \\
\hline Neg. 11 & 172 & 78 & 77 & 63 \\
\hline Neg. 12 & 172 & 80 & 78 & 66 \\
\hline Neg. 13 & 173 & 80 & 79 & 64 \\
\hline Neg. 14 & 176 & 82 & 81 & 61 \\
\hline Neg. 15 & 176 & 81 & 79 & 61 \\
\hline Neg. 16 & 176 & 81 & 75 & 55 \\
\hline Neg. 17 & 175 & 81 & 79 & 58 \\
\hline Neg. 18 & 182 & 80 & 78 & 56 \\
\hline Neg. 19 & 173 & 79 & 79 & 61 \\
\hline Neg. 20 & 179 & 77 & 80 & 59 \\
\hline Neg. 21 & 167 & 84 & 81 & 57 \\
\hline Neg. 22 & 171 & 74 & 79 & 66 \\
\hline Neg. 23 & 177 & 78 & 78 & 61 \\
\hline Neg. 24 & 170 & 80 & 77 & 61 \\
\hline Neg. 25 & 172 & 80 & 77 & 59 \\
\hline Neg. 26 & 169 & 82 & 82 & 57 \\
\hline Neg. 27 & 173 & 77 & 76 & 64 \\
\hline Neg. 28 & 180 & 76 & 82 & 62 \\
\hline Neg. 29 & 177 & 85 & 81 & 64 \\
\hline Neg. 30 & 171 & 82 & 79 & 65 \\
\hline Neg. 31 & 180 & 85 & 78 & 61 \\
\hline DS & 4,90 & 3,85 & 3,17 & 3,82 \\
\hline Media & 173,69 & 79,75 & 77,41 & 60,72 \\
\hline CV & 2,82 & 4,82 & 4,10 & 6,28 \\
\hline
\end{tabular}

Tabla 5.11. Cálculo del coeficiente de variación a partir de las medidas obtenidas a partir de 31 negativos experimentales. Referencias: Neg.: negativo; LM: Largo total de la mano; AM: ancho de la mano; LDm: largo del dedo medio; LMñ: largo dedo meñique; DS: Desvío estándar; CV: coeficiente de variación (Tomado de Carden y Blanco 2013).

Considerando el largo de las manos negativas en la totalidad de la muestra experimental ( $\mathrm{N}=54$ negativos), en 51 casos se observaron variaciones con respecto al largo de las manos reales, registrándose casos de mayor y de menor tamaño (Tabla 5.12). Las diferencias positivas y negativas fueron contempladas por separado, obteniéndose dos valores medios: 6,5 mm para los negativos de mayor tamaño que la mano real, y -5,5 mm para los negativos más pequeños que el largo real de la mano. En base a estas diferencias medias, se propuso un valor de corrección de $7 \mathrm{~mm}$ para las medidas de los largos de los negativos arqueológicos. Este valor fue 
agregado y restado a los largos de las manos negativas obtenidos en campo, estableciendo, de este modo, un rango de posibilidades de $14 \mathrm{~mm}$ y no una medida absoluta.

\begin{tabular}{|c|c|c|c|c|}
\hline $\begin{array}{c}\text { Cantidad } \\
\text { réplicas }\end{array}$ & LM real & LM neg. & Dif $(+)$ & Dif (-) \\
\hline 1 & 152,78 & 170 & 17,22 & - \\
\hline 1 & 106,95 & 123,64 & 16,7 & - \\
\hline 1 & 203 & 187 & - & -16 \\
\hline 1 & 170 & 185 & 15 & - \\
\hline 1 & 129,36 & 142,61 & 13,25 & - \\
\hline 1 & 120,59 & 133,33 & 12,74 & - \\
\hline 1 & 142,84 & 155,08 & 12,24 & - \\
\hline 1 & 129,83 & 141,77 & 11,94 & - \\
\hline 2 & 129,36 & 140,44 & 11,08 & - \\
\hline 2 & 170 & 180 & 10 & - \\
\hline 1 & 166 & 176 & 10 & - \\
\hline 1 & 180 & 190 & 10 & - \\
\hline 1 & 160 & 170 & 10 & - \\
\hline 8 & 170 & 160 & - & -10 \\
\hline 1 & 171 & 180 & 9 & - \\
\hline 1 & 126,87 & 134,2 & 7,33 & - \\
\hline 2 & 152,78 & 160 & 7,22 & - \\
\hline 1 & 194 & 199 & 5 & - \\
\hline 3 & 170 & 175 & 5 & - \\
\hline 1 & 181 & 176 & - & -5 \\
\hline 1 & 186 & 181 & - & -5 \\
\hline 1 & 192 & 196 & 4 & - \\
\hline 1 & 140,81 & 144,79 & 3,98 & - \\
\hline 1 & 117,74 & 121 & 3,26 & - \\
\hline 1 & 175 & 178,18 & 3,18 & - \\
\hline 4 & 170 & 173 & 3 & - \\
\hline 3 & 152,78 & 150 & - & $-2,78$ \\
\hline 5 & 170 & 172 & 2 & - \\
\hline 6 & 170 & 170 & 0 & - \\
\hline 7 & 170 & 170 & 0 & - \\
\hline 1 & 176 & 176 & 0 & - \\
\hline \multicolumn{3}{|c|}{$\begin{array}{c}\text { Promedio de las } \\
\text { diferencias }\end{array}$} & $6,5 \mathrm{~mm}$ & $-5,5 \mathrm{~mm}$ \\
\hline
\end{tabular}

Tabla 5.12. Variaciones en el tamaño de los negativos realizados a partir de la misma mano (medidas en $\mathrm{mm}$ ). Referencias: LMreal: Largo total de la mano real; LMneg: largo de la mano negativa; Dif (+): diferencia positiva entre las medidas anteriores; LM (-) diferencia negativa entre las medidas anteriores.

(Tomado de Carden y Blanco 2013).

El coeficiente de variación y el factor de corrección permitieron re-evaluar las medidas de negativos arqueológicos para estimar rangos de edad de los individuos que participaron en la producción de negativos de manos en el NE del macizo del Deseado (Carden y Blanco 2013). 


\section{5. c. 2. 2. a. 1. Lateralidad de las manos}

Con respecto a la lateralidad de las manos negativas, el registro arqueológico de diferentes continentes muestra un amplio predominio de las manos izquierdas frente a las derechas (Gradin 1981-82; Gradin et al. 1976, 1979; Gunn 2006, 2007). En el caso patagónico, diferentes autores plantean la posibilidad de que los negativos se realizaran sobre manos derechas apoyadas sobre el dorso (Aschero et al. 2005; Casamiquela 1960). Al considerar esta alternativa, Gradin (2001) propuso que de haber sido realizados sobre manos derechas apoyadas sobre el dorso, los negativos presentarían chorreaduras o no se encontrarían completamente cubiertos con pintura. Para someter a prueba esta ideas se realizaron cuatro negativos a partir de una misma mano derecha (que corresponde a la pintora) apoyada sobre el dorso (Figura 5.26.a). Los bloques experimentales fueron ubicados a 1,30 m respecto del suelo, con inclinaciones que oscilaban entre 70 y $85^{\circ}$. Las mezclas pigmentarias empleadas mantuvieron las proporciones de componentes usadas previamente (Apéndice III.4).

Los negativos sobre dorso de la mano derecha fueron realizados sin que se produzcan chorreaduras (Figura 5.26.b), aunque en dos casos se observa escasa cobertura con pintura del dedo meñique. En todos ellos se observa una curvatura pronunciada del dedo pulgar, ausente en los negativos realizados sobre la mano izquierda (Figuras 5.26.c y 5.27.b-c). Este podría ser, por lo tanto, un factor relevante para la distinción de manos negativas realizadas apoyando el dorso sobre la roca. 


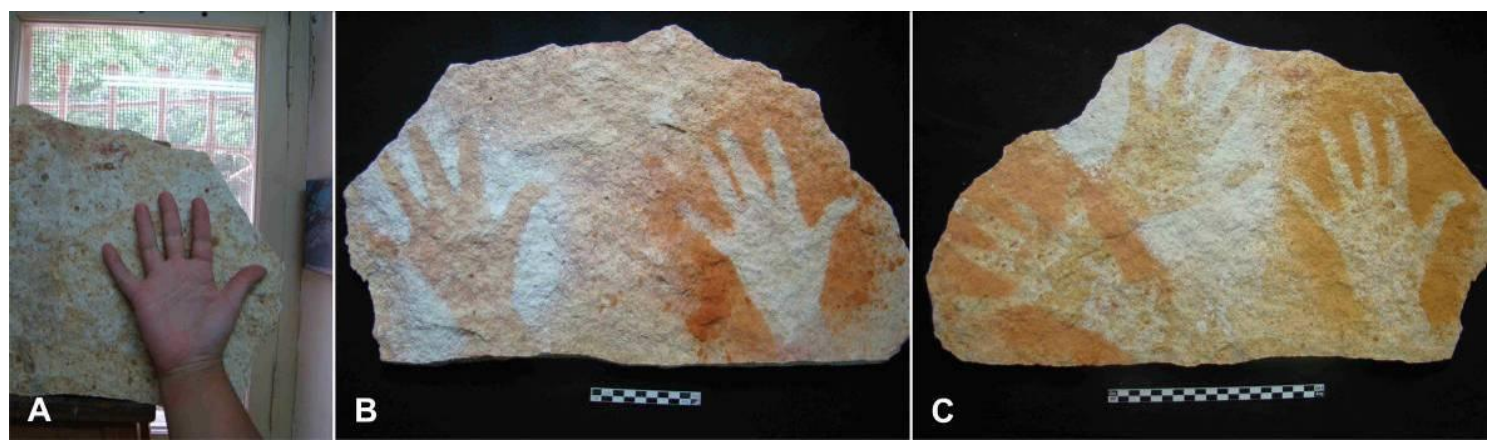

Figura 5.26. Negativos realizados apoyando el dorso de mano derecha: a. modo en que se colocó la mano; b. dos negativos sobre dorso de mano derecha; c. dos negativos sobre dorso de mano derecha apoyado en la roca y, en color blanco, negativo de mano izquierda.

Si bien se registraron diferencias entre el tamaño de la mano derecha y sus negativos (Tabla 5.13), la muestra es demasiado pequeña para calcular el coeficiente de variación. Sin embargo, la mayor parte de las medidas obtenidas en los negativos sobre dorso son mayores que las de la mano real, principalmente para el largo y ancho de la mano así como para el dedo pulgar.

\begin{tabular}{|l|c|c|c|c|c|c|}
\hline \multicolumn{1}{|c|}{ Mano } & Pigmento* & LM & AM & LDm & LMñ & LP \\
\hline Derecha & - & 171 & 74 & 73 & 61 & 102 \\
\hline NE 1 & 10YR 8/1 & 175 & 84 & 77 & 64 & 100 \\
\hline NE 2 & $10 R ~ 5 / 8$ & 180 & 85 & 72 & 60 & 105 \\
\hline NE 3 & $10 R ~ 3 / 6$ & 174 & 80 & 75 & 60 & 104 \\
\hline NE 4 & 2.5 Y 7/8 & 183 & 86 & 72 & 55 & 110 \\
\hline Izquierda & - & 170 & 72,34 & 72,75 & 60,39 & 98,64 \\
\hline NE 5 & 10YR 8/1 & 169 & 82 & 76 & 59 & 110 \\
\hline
\end{tabular}

Tabla 5.13. Mediciones de negativos realizados apoyando el dorso de la mano derecha en la roca. Referencias: LM: Largo total de la mano; AM: ancho de la mano; LDm: largo del dedo medio; LMñ: largo dedo meñique. NE: negativo experimental. Medidas en mm. * Código de color: Earth Soil Chart.

Estas experiencias permiten plantear que es posible la realización de negativos de mano sobre el dorso sin producir chorreaduras. En el caso particular presentado, el negativo sobre dorso presenta una curvatura en el dedo pulgar que lo hace característico. Si bien es necesario aumentar la muestra, resulta un buen comienzo por donde indagar la lateralidad de los negativos arqueológicos.

Existen otros indicadores que permiten realizar propuestas respecto a la lateralidad de las manos negativas. Dichos indicadores se relacionan con la 
anatomía del brazo, e involucran la posición de la mano y el ángulo entre la mano y el antebrazo. En este sentido, la muñeca permite que la mano se mueva en relación al antebrazo en torno a un plano frontal (movimientos de flexo-extensión) y a un plano sagital (movimientos de abducción y aducción) (Huaroto Rosa-Pérez 2000). Los movimientos de abducción y aducción serán opuestos si la mano se encuentra en posición prona (apoyada sobre la palma) o en posición supina (sobre dorso). En el primer caso, tanto la mano izquierda como la derecha estarán en posición de abducción si se presentan inclinadas hacia afuera y abajo y en aducción si están inclinadas hacia adentro y hacia abajo. En tanto que si se encuentran en posición supina estarán en abducción si están inclinadas para hacia adentro y abajo y en aducción si está inclinada hacia afuera y abajo.

Por otro lado, el ángulo que se forma entre la mano y el antebrazo, en el caso que los negativos presenten parte de este último, puede ayudar a reconocer la lateralidad de la mano. Durante el trabajo de un modelo-pintor se observó que un negativo realizado sobre mano izquierda en posición prona (apoyando la palma) presentará el antebrazo hacia la izquierda (Figura 5.27.b), mientras que el negativo realizado sobre la mano derecha en posición supina presentará, además de la curvatura del dedo pulgar, el antebrazo hacia la derecha (Figura 5.27.c). En este sentido, y al conjugar la posición e inclinación de la mano (abducción, aducción), la posición del antebrazo se podría reconocer la participación de uno o dos actores en la producción de negativos de mano. 

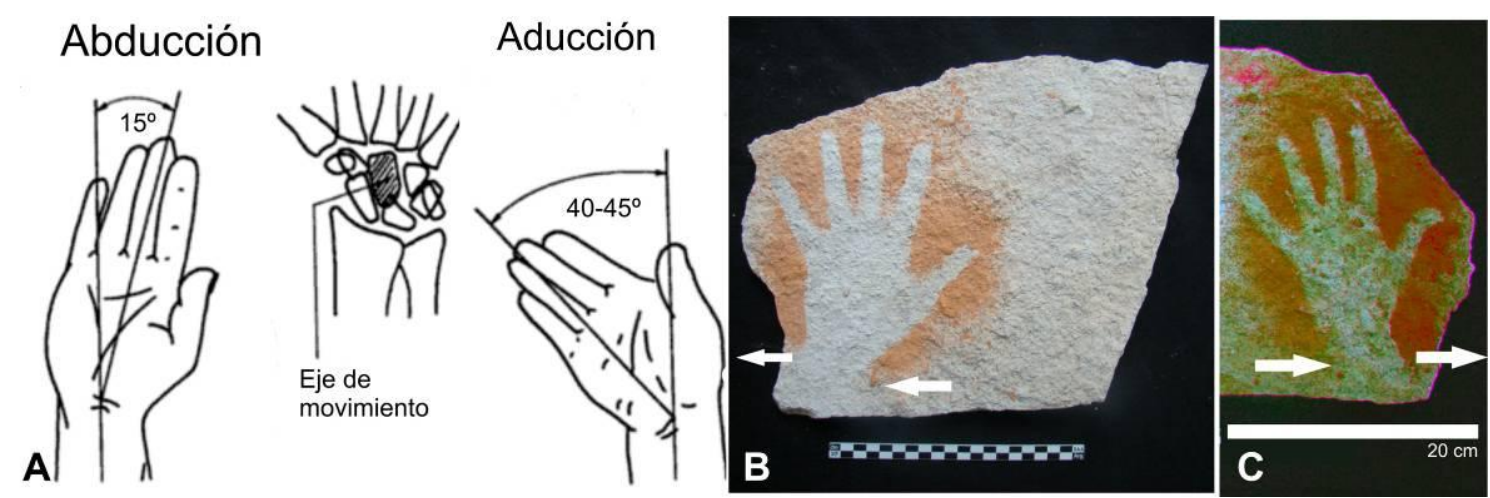

Figura 5.27. Movimientos de la mano y su relación con la muñeca: a. Movimientos de la muñeca (tomado y modificado de Palastanga et al. 2000: Figura 3.106); b.

Negativo experimental sobre mano izquierda apoyada sobre la palma, en abducción; c. Negativo experimental sobre mano derecha apoyada sobre el dorso, en abducción. Las flechas blancas indican hacia donde se esperaría encontrar el antebrazo si hubiera sido incluido en el negativo.

Si el productor de los negativos es uno solo (modelo-pintor), los ángulos de trabajo se restringen. Si se considera un eje vertical imaginario entre el antebrazo, la mano y la boca, el modelo-pintor tiene que apoyar la palma izquierda sobre el soporte en ángulo menor o igual a $90^{\circ}$, trabajando hacia el interior y manteniendo la horizontalidad entre boca y mano (Figura 5.28.a, flecha violeta). Si decide replicar en forma negativa la mano derecha sobre el dorso puede aplicar adecuadamente la pintura si esta se encuentra -sobre el eje vertical imaginario- a más de $90^{\circ}$ y hacia la izquierda (Figura 5.28.a, flecha azul). La mano puede estar en abducción o en aducción en conjunto con la posición del antebrazo, dependiendo de la intervención de dos actores o de uno solo (Tabla 5.14). 


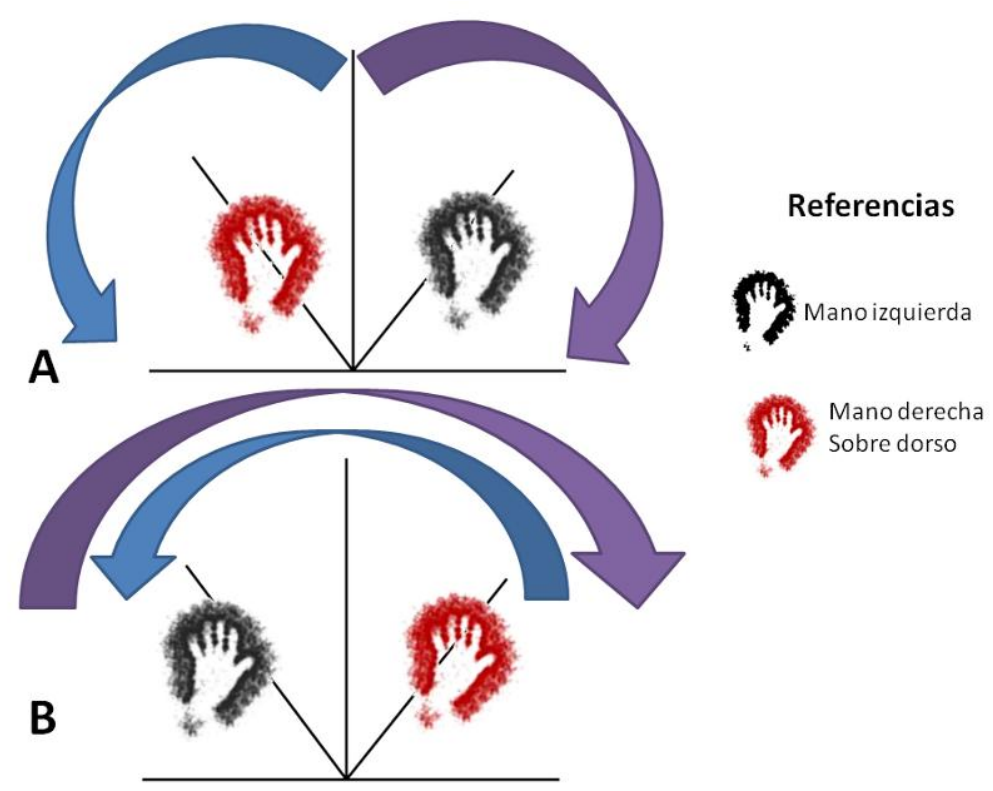

Figura 5.28. Producción de negativos de mano de mano izquierda apoyada sobre la palma y derecha apoyada sobre el dorso: a. acceso restringido al soporte si trabaja solamente un modelo-pintor; b. Amplio acceso al soporte si intervienen un pintor y un modelo. La flecha azul indica la dirección de aplicación de pintura sobre la mano derecha sobre dorso (supina), la flecha violeta la dirección de aplicación de la pintura sobre la mano izquierda en posición prona.

\begin{tabular}{|c|c|c|c|c|}
\hline Mano & Posición & Antebrazo & Participantes & Potencialidad \\
\hline \multirow{3}{*}{$\begin{array}{l}\text { Izquierda } \\
\text { Prona }\end{array}$} & \multirow{2}{*}{$\begin{array}{c}\text { Abducción } \\
\text { (hacia adentro y abajo) }\end{array}$} & & \multirow{2}{*}{ Pintor-modelo } & SI \\
\hline & & & & $\mathrm{NO}$ \\
\hline & $\begin{array}{c}\text { Aducción } \\
\text { (hacia afuera y abajo) }\end{array}$ & & $\begin{array}{l}\text { Pintory } \\
\text { modelo }\end{array}$ & SI \\
\hline \multirow[t]{3}{*}{$\begin{array}{l}\text { Derecha } \\
\text { Supina }\end{array}$} & \multirow{2}{*}{$\begin{array}{c}\text { Abducción } \\
\text { (hacia afuera y abajo) }\end{array}$} & & \multirow{2}{*}{ Pintor-modelo } & SI \\
\hline & & & & $\mathrm{NO}$ \\
\hline & $\begin{array}{c}\text { Aducción } \\
\text { (hacia adentro y abajo) }\end{array}$ & & $\begin{array}{l}\text { Pintory } \\
\text { modelo }\end{array}$ & $\mathrm{SI}$ \\
\hline
\end{tabular}

Tabla 5.14. Evaluación en la participación de un pintor-modelo o de un pintor y un modelo en la producción de negativos. Antebrazo: indica la inclinación que puede alcanzar el antebrazo según los participantes. 
Al ser el motivo más abundante en la localidad La Primavera, se seleccionaron para replicar un grupo de negativos presentes en el sitio Cueva Maripe debido a que presentan características que pueden aportar información respecto a algunas de las etapas que componen su cadena operativa de producción. Los referentes arqueológicos se encuentran en los paneles 6B y 7A (Tabla 5.12; ver Figura 5.22.a).

Del panel 6B se replicaron negativos blancos sobre un fondo preparado con pintura roja. Para conseguir dicho fondo, la pintura fue aplicada por estarcido directo sobre el bloque ubicado a $1 \mathrm{~m}$ del respecto del suelo, con una inclinación de $72^{\circ}$. Con posterioridad, se realizaron dos negativos blancos por estarcido directo y se aplicó pintura amarilla en el sector superior del bloque empleando la misma técnica, a fin de observar si las gotas de color amarillo fueron realizadas mediante esta técnica.

Entre la aplicación de pintura roja del fondo preparado y la realización de los negativos de manos fue necesario un período para que las pinturas no se mezclaran. El pulverizado de pintura amarilla para realizar las "gotas" resultó en una superficie homogénea (Figura 5.29).

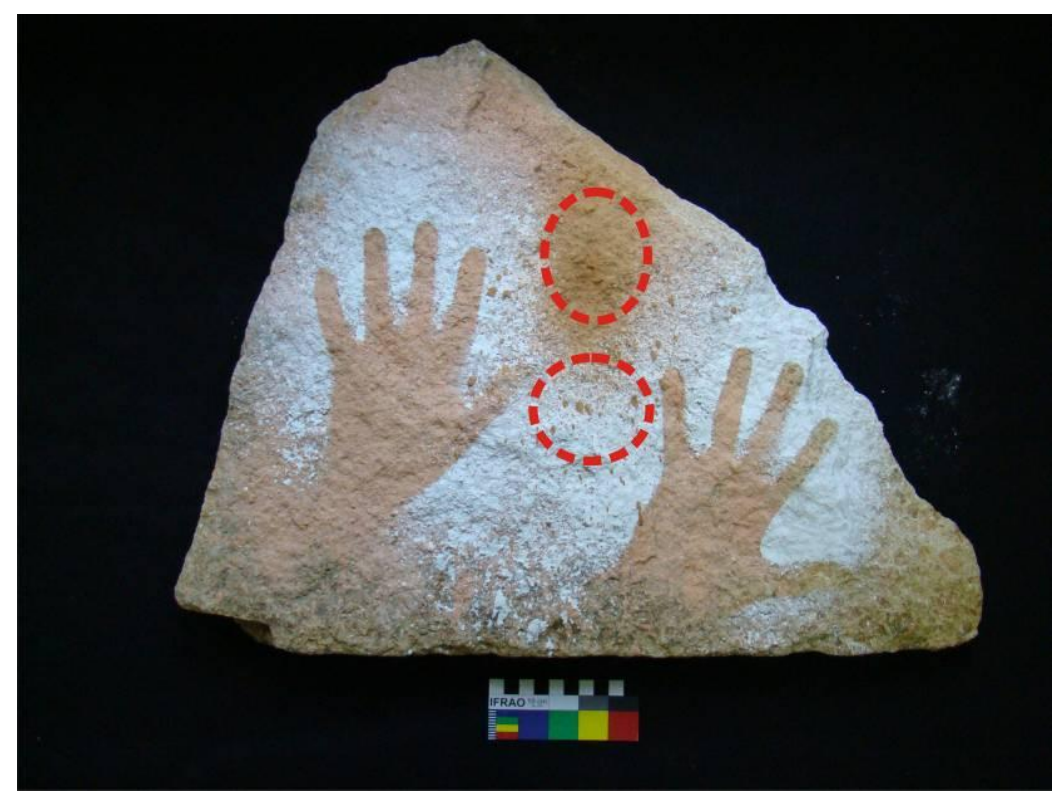

Figura 5.29. Réplica experimental selección de motivos del panel 6B de Cueva Maripe. 
La observación de diferentes fotografías del panel 6B de Cueva Maripe y el tratamiento digital de las mismas, así como la información procedente de otros sitios de la localidad -como LP-2- (Figura 5.30) permitió reconocer que en el arte rupestre de la localidad podrían observarse etapas de aprendizaje o ensayos. Si bien la intención de aplicar pintura sobre la pared es clara, esta podría ser el resultado de pulverizaciones aleatorias o fortuitas en el panel $6 \mathrm{~B}$, tanto para la pintura amarilla como para la pintura blanca (Figuras 5.30.a-b y 5.30.c-d) y de pulverizaciones precisas en el caso de LP-2 (Figura 5.30.e-f). En el primer caso, las pinturas amarilla y blanca están distribuidas heterogéneamente y podrían corresponder a un ensayo; en el caso de los motivos de LP-2 se observa un grado de control relativo en la aplicación de la pintura para cubrir ampliamente la superficie. Estos casos arqueológicos permitirían considerar la propuesta de Bleed (2011), con respecto a la diferencia entre ensayos y la producción en sí misma, exhibiendo los primeros una habilidad menor.

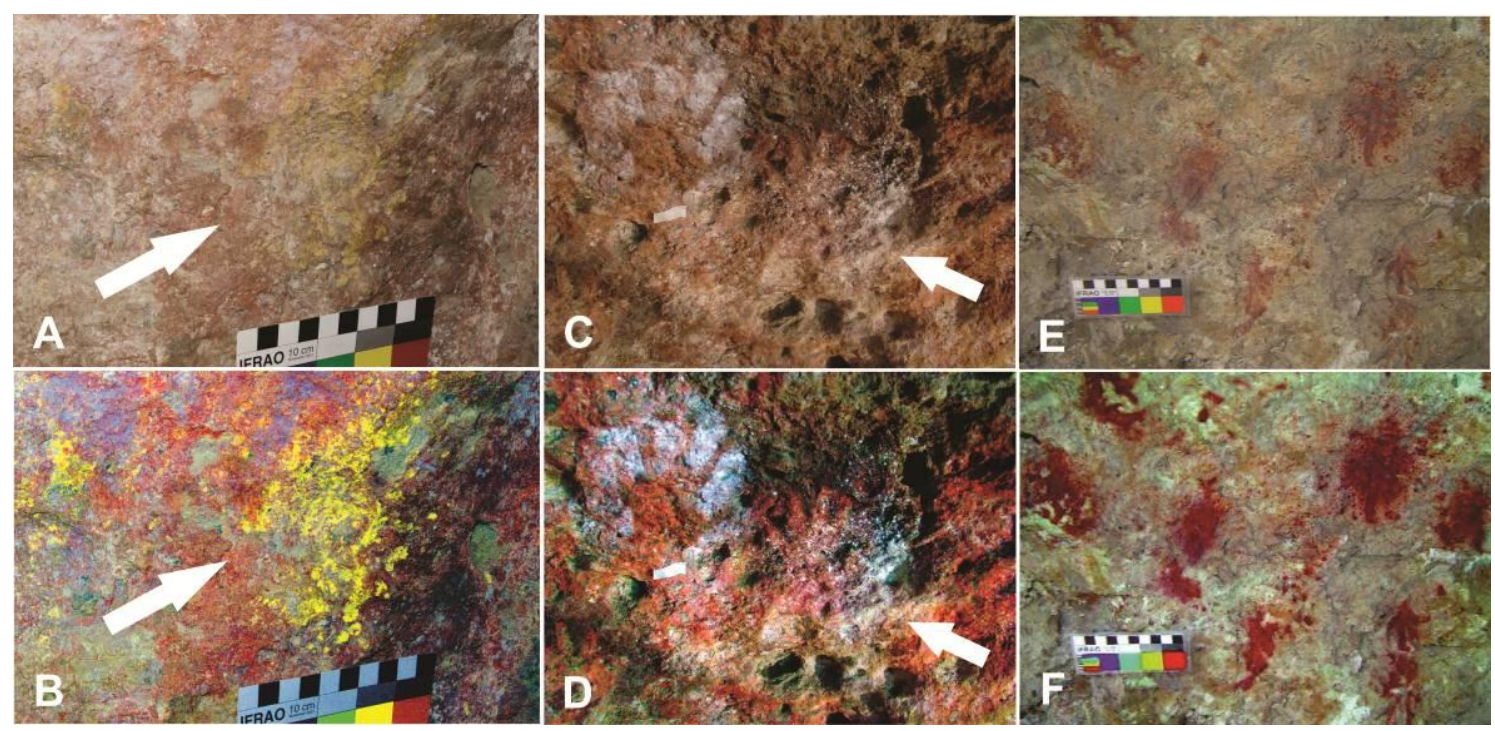

Figura 5.30. Referentes arqueológicos de los motivos experimentales: a. Panel 6B de Cueva Maripe con restos de pintura amarilla; b. Imagen tratada digitalmente (D-Stretch lds 12,5); c. Panel 6 B donde se observan una mano negativa y restos de pintura blanca; d. Imagen tratada digitalmente (D-Stretch lab 15); e. Pulverizaciones controladas en LP-2; f. Imagen tratada digitalmente (D-Stretch lrd 15).

Patrones similares al detectado en la pintura amarilla del panel 6B han sido observados en los talleres "Análisis experimentales en arte rupestre: métodos y técnicas para la resolución de problemas arqueológicos". Estos 
talleres fueron dictados conjuntamente con el lic. Rafael Paunero en la FCNyM-UNLP (2011-2013). Los pintores-aprendices fueron alumnos avanzados de la licenciatura en Antropología quienes, durante sus primeros intentos de pulverizar pintura, lograron superficies estarcidas heterogéneas conformadas por conjuntos de puntos y manchas de pintura (Figura 5.31).
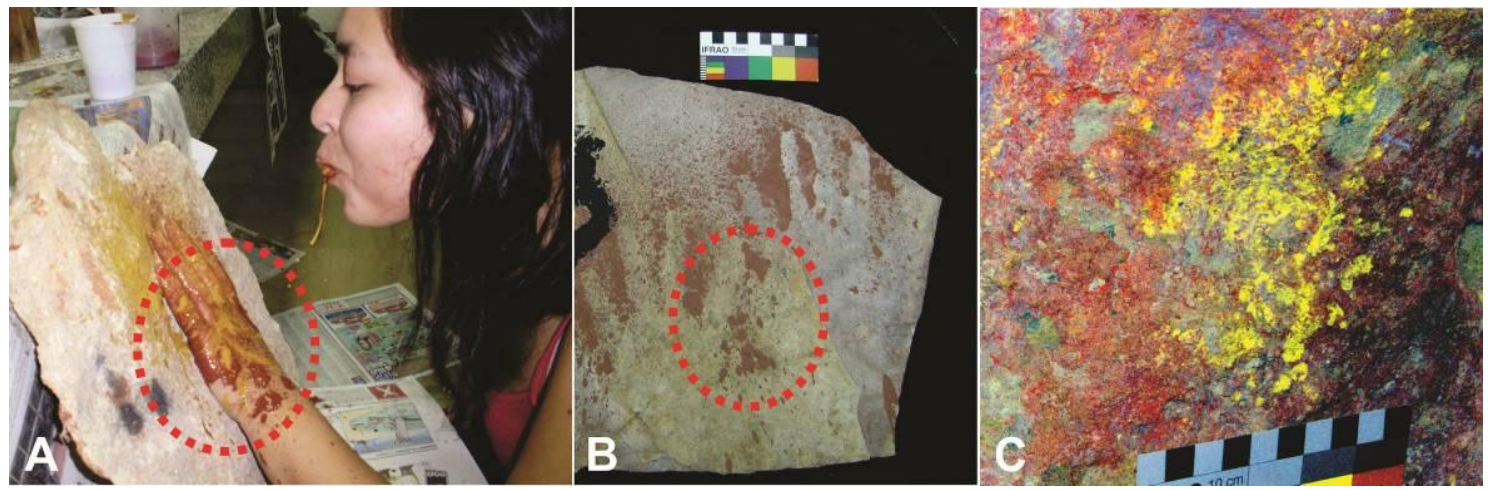

Figura 5.31. Trazos de pintura obtenidos a partir de aplicación de pintura mediante pulverizado directo: a. momento de pulverización de pintura; b: negativos de mano realizados por un aprendiz (pintor-modelo). Los círculos punteados enmarcan manchas de pintura; c. referente arqueológico del panel 6B de Cueva Maripe.

Se replicaron, además, dos negativos de mano blancos que se encuentran en el panel 7A, a 1,80 m respecto del suelo actual (ver Tabla 5.9; Figura 5.22.a). Carden (2008a: 144-145) considera que podría tratarse de manos cruzadas entre sí, siendo una izquierda y otra derecha, y que presentan parte del antebrazo. Este motivo fue replicado dos veces para evaluar si en su realización participaron dos personas o una sola, además de contemplar en cada caso la altura respecto del suelo a la que se encuentran las manos a estarcir, la cual podría ser equivalente a la estatura del pintor o menor. Las limitantes para reproducir las condiciones de registro fueron la altura respecto del suelo y el tamaño de los bloques utilizados, la estatura de la pintora -1,60 m-, y, en un caso, la pintura utilizada.

En el caso de la réplica 1 participaron una pintora y un modelo. El bloque experimental fue colocado a $1,60 \mathrm{~m}$ del suelo con una inclinación de $82^{\circ}$. Se pretendía evaluar que sucedía si los negativos se produjeron a una altura equivalente a la estatura del pintor. En esta réplica, el acercamiento de la pintora a la superficie rocosa estuvo limitado por la presencia del modelo y 
por la altura a la que se encontraba el soporte (Figura 5.32.a). El bloque quedaba por encima de la altura de la boca, con lo que la pintora tuvo que ponerse en puntas de pie y estirarse para acercarse a la roca. Esta situación no permitió controlar las respiraciones entre pulverización de pintura. La participación de un modelo y una pintora, la altura a la que se encontraba el bloque, similar a la estatura de la pintora- y la distancia a la que se estarcía pintura hicieron que se obtuvieran negativos anchos, en parte superpuestos y carentes de algunos dedos debido a chorreaduras de pintura (Figura 5.32.b).

En la réplica 2 participó una sola persona, modelo-pintora. El bloque se colocó a una altura menor a la estatura del pintor -1,45 m-, hecho que permitió generar cierta horizontalidad entre las manos a estarcir y la boca. Al no presentar impedimentos para acercarse al soporte, la distancia de aplicación de la pintura no superó los 15-20 cm (Figura 5.32.c). Esta segunda réplica fue realizada con la mano derecha sobre la izquierda: la posición inversa resultó incómoda para acceder al soporte (Figura 5.32.d).

Si bien las réplicas son diferentes al referente (comparar Figuras 5.32.b, 5.32.d y 5.33) se observa un parecido relativo entre éste y la réplica 2. Esta razón, quizás, permitiría pensar que las manos negativas del panel 7A de Cueva Maripe podrían haber sido realizadas por un modelo-pintor de talla muy alta, cercana a los $2 \mathrm{~m}$, ya que dado el requerimiento de horizontalidad para la aplicación de pintura la boca del modelo-pintor tendría que haber quedado a 1,80 m. Sin embargo, podría tratarse de un modelo-pintor de menor estatura ya que si se consideran las condiciones de sedimentación presentes al pie del panel -alrededor de $20-30 \mathrm{~cm}$ - podría pensarse que ese modelo-pintor habría elevado su altura respecto del suelo, por ejemplo mediante alguna piedra de gran tamaño usada como escalón. Cabe la posibilidad de que el motivo haya sido realizado mediante la participación de un modelo y un pintor, los cuales podrían haber empleado escalones para acceder a los sectores superiores de la cueva. Sin embargo, al considerar esta posibilidad también hay que contemplar que el acceso al soporte por 
parte del pintor se restringe aún más con el empleo de algún medio de elevación, lo que le resta movilidad alrededor del modelo.

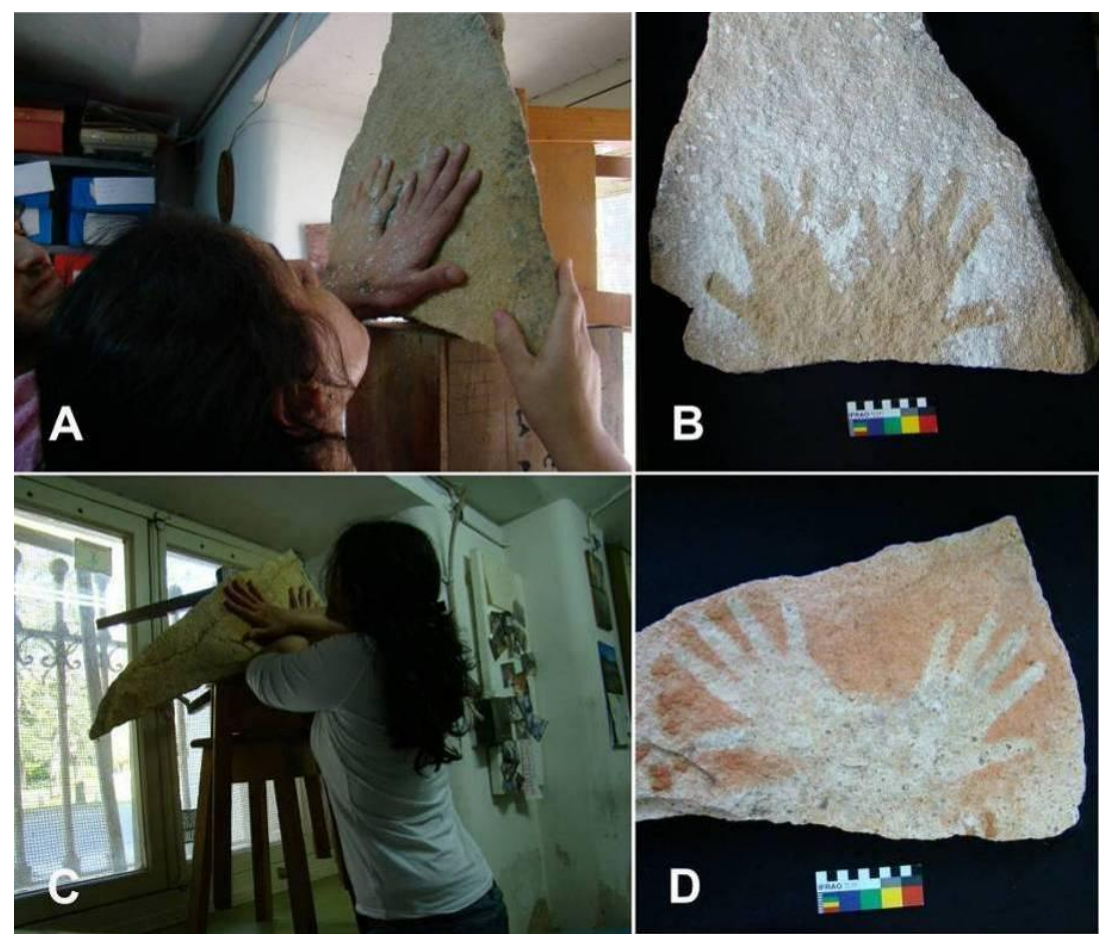

Figura 5.32. Replicación de negativos de manos cruzadas: a. relación entre modelo y pintora; b. replicas experimentales; c. modelo-pintora realizando sus manos negativos de mano; d. réplica experimental del motivo.

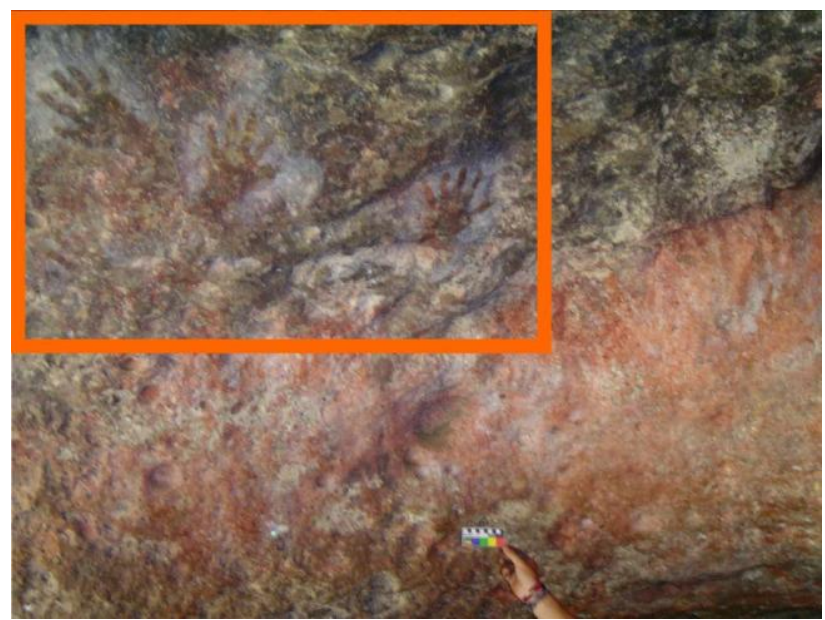

Figura 5.33. Referente arqueológico panel 7A.

\section{5. d. Revisión de los resultados obtenidos}

En los apartados anteriores se presentó la información correspondiente a las distintas experiencias replicativas diseñadas tomando como eje las 
cadenas de producción del arte rupestre. Dichas experiencias involucraron la realización de motivos grabados y pintados, considerando variables relacionadas a los soportes, a los artefactos, a las mezclas pigmentarias, a los actores intervinientes y los gestos técnicos, al trabajo realizado y al diseño de los motivos (Álvarez y Fiore 1995).

En el caso de las réplicas grabadas se evaluó el desempeño de las materias primas de los artefactos líticos en la tarea de grabado y la relación entre el soporte, la técnica y el tipo de artefacto empleado para llevarla a cabo. Para las réplicas pintadas se comenzaron a vislumbrar las posibles etapas y operaciones en la producción de algunos motivos pintados y la utilización de artefactos, además de evaluar parcialmente la cadena de producción de la pintura.

\section{5. d. 1. Replicación de motivos grabados}

Los estudios experimentales han resultado de utilidad para evaluar las relaciones entre los soportes, los artefactos usados, los procesos de trabajo y los diseños de los motivos (Álvarez y Fiore 1995; Bednarik 2007; Méndez 2008; Vergara Murúa 2009). Estas variables están imbricadas en la secuencia de producción del arte rupestre.

1) Soportes. Álvarez y Fiore (1995) así como Belardi y Goñi (2002, 2006) proponen que las propiedades físicas de los soportes, así como la textura y la microtopografía, influyen en la realización de un motivo. El trabajo realizado sobre los diferentes bloques de arenisca coquinoide permitió observar que la presencia de ciertas irregularidades condiciona la inversión de trabajo. En este sentido, la fracción conchil de la arenisca opuso resistencia a la acción de grabar, mientras que la cementación diferencial y los poros de aire en la roca facilitaron dicha tarea.

Por otro lado, la pátina puede facilitar o dificultar el proceso de grabado, dependiendo de la superficie a trabajar. Por ejemplo, en el basalto se logró un contraste entre el surco grabado y la superficie con pátina mientras que 
en el caso de la arenisca coquinoide, a pesar de su menor dureza con respecto al basalto, fue necesaria una mayor inversión de trabajo para lograr un surco profundo. Las experiencias indican, por lo tanto, que si bien las rocas blandas permiten motivos de surcos más profundos que las rocas duras, este hecho no implica que no presenten dificultades para grabarlas.

2) En cuanto a los artefactos utilizados, Álvarez y Fiore (1995) proponen que si bien es posible grabar superficies con cincel, también pueden grabarse con lascas y con guijarros sin modificación. Propuestas similares fueron efectuadas en Australia (Bednarik 2007b) y Chile (Méndez 2008; Vergara Murúa 2009). En las experiencias replicativas desarrolladas en el marco de esta tesis se utilizaron filos naturales de ANF, cinceles y guijarros sin modificación; estos últimos para grabar arenisca coquinoide y basalto. En los filos o extremos que entraron en contacto con los bloques se observaron restos minerales del soporte $\mathrm{y}$, en los ANF utilizados, diferentes rastros complementarios que dependen del tipo de materia prima de los artefactos y el tiempo de uso (Álvarez y Fiore 1995; Blanco y Lynch 2011). En algunos casos, la morfología y el tamaño del artefacto pueden inferirse a partir del surco grabado, condicionando su forma y dimensiones.

3) El proceso de trabajo comprende la técnica utilizada y el tiempo insumido. Se evaluaron las técnicas de producción de grabados sobre bloques de arenisca coquinoide y basalto. En el primer tipo de soporte, las técnicas usadas fueron la incisión, el raspado, la horadación, la percusión -directa e indirecta- y la abrasión. Las tres primeras técnicas se realizaron mediante el uso de ANF, en tanto que la percusión y la abrasión se llevaron a cabo con guijarros. Sobre el soporte basáltico se implementó la técnica de percusión directa con guijarros.

La medición del tiempo permite relacionar el soporte -dureza y textura-, el artefacto, la técnica de ejecución, la morfología y el tratamiento de la superficie del motivo (Álvarez y Fiore 1995). La experimentación aquí realizada amplía el espectro de interpretaciones respecto de los puntos anteriores ya que, por ejemplo, el tiempo invertido en la producción del mismo motivo con distintas técnicas y en distintos soportes no es siempre 
proporcional a la dureza del soporte o al tamaño del motivo. Esto se fundamenta en lo explicitado para el caso del tridígito 3 sobre arenisca coquinoide (ver página 131 de este capítulo).

4) El diseño de los motivos se relaciona con la técnica empleada y el tipo de soporte a grabar (Álvarez y Fiore 1995; Belardi y Goñi 2002). Por ejemplo, un mismo diseño (tridígito) fue hecho mediante tres técnicas diferentes en el mismo soporte. Las diferencias observadas (Figura 5.34) se relacionan con la técnica de producción y, además, con el grado de pátina y la texturamicrotopografía del soporte.

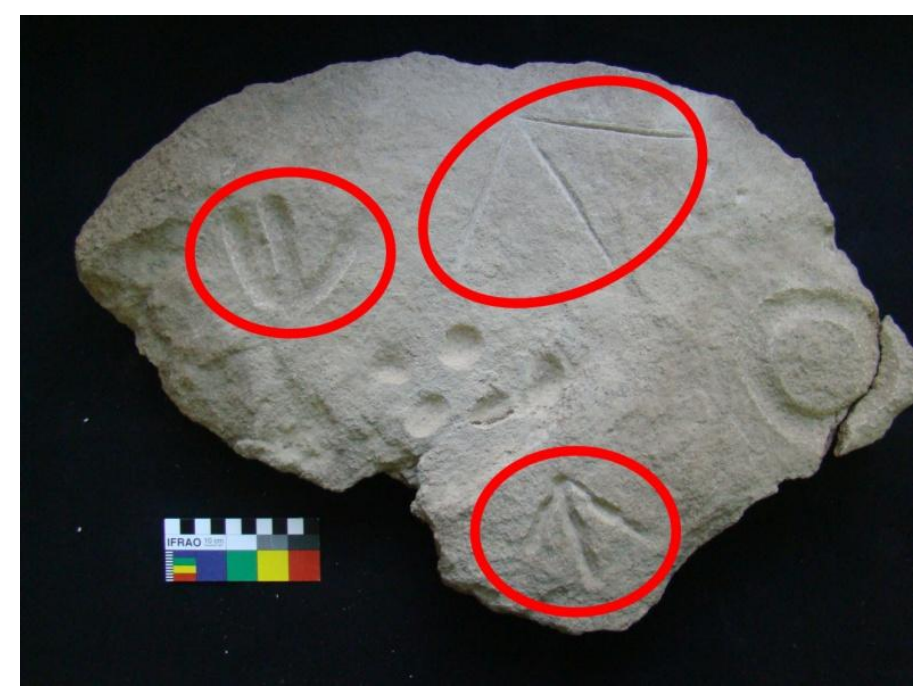

Figura 5.34. Réplicas experimentales del bloque de arenisca coquinoide, las circunferencias rojas marcan tres diseños de tridígitos.

\section{5. d. 2. Replicación de motivos pintados}

El reconocimiento de técnicas de aplicación de pintura permitió distinguir los trazos realizados mediante técnica digital de los realizados utilizando vellones de pelo de guanaco o hisopos. Dicha distinción se corresponde a trazos homogéneos que, dependiendo de la dirección de aplicación de la pintura, pueden presentar pequeñas acumulaciones en la técnica digital, mientras que los trazos resultantes del uso de algún implemento presentan bordes irregulares, relacionados con la deformación que sufren los vellones de lana al contacto con la superficie rocosa. La técnica empleada para la producción de los negativos de mano fue el estarcido o pulverización directa 
de pintura con la boca. Si bien se reconoce la existencia de otras técnicas para la realización de negativos, fue la pulverización directa la que permitió obtener negativos de mano experimentales similares a los arqueológicos.

La replicación de manos negativas ha permitido ampliar el espectro de inferencias manejadas hasta ahora en los sitios de Patagonia ya que:

1) se puede inferir la participación de al menos dos actores a partir del largo de la mano y su altura respecto del suelo (en el caso de niños pequeños);

2) se puede hacer un negativo sosteniendo a un niño en brazos;

3) la distancia y la posición-relación entre el pintor y el modelo facilita, o no, el acceso del primero al soporte para aplicar la pintura;

4) la altura a la que se va a realizar el negativo por estarcido está en estrecha relación a la estatura del pintor, siendo necesaria cierta horizontalidad entre la boca y la mano (para no tragar pintura y para acceder bien al soporte). En este sentido, es válido suponer el uso de algún medio de elevación en el caso de manos ubicadas en sectores altos.

5) Existen factores vinculados con los gestos técnicos que se relacionan con variaciones en el tamaño de las manos, evaluados aquí a partir de las diferencias entre el largo real de la mano y el de sus réplicas experimentales.

6) Realizar experiencias replicativas con materias primas análogas a las empleadas en los sitios arqueológicos facilita la realización de inferencias relacionadas con los gestos técnicos involucrados en la producción de los motivos rupestres.

7) Es posible discernir negativos de manos realizados sobre manos izquierdas apoyando la palma y sobre manos derechas apoyando el dorso. Asimismo, se puede distinguir, en algunos casos, el trabajo de un pintormodelo a partir de la posición, orientación y ángulos de abducción y aducción de la muñeca, siempre y cuando los negativos presenten antebrazo.

Estos puntos serán tratados en el Capítulo 8, en el que se integran y revisan los antecedentes y la información presentada a lo largo de esta tesis. 


\section{Capítulo 6}

\section{EL ARTE RUPESTRE DEL MACIZO DEL DESEADO}

En este capítulo se analizan tres sitios con grabados rupestres: La Marianita, Bardas de Carlos y Los Navarros. Estos sitios fueron dados a conocer por pobladores locales durante las tareas de campo de 2010 y 2012 . Como se detallará más adelante, esta información complementa la obtenida en estudios previos, referida a cuatro sitios con grabados (Carden 2008a).

\section{6. a. LA MARIANITA}

Este sitio con grabados se encuentra en la estancia homónima, a la que puede accederse por la ruta provincial $\mathrm{n}^{0} 12$ en las inmediaciones del destacamento policial de Sierras Blancas. Sus coordenadas geográficas son $47^{\circ} 16^{\prime} 59.5^{\prime \prime} \mathrm{S}$ y $68^{\circ} 28^{\prime} 12.2^{\prime \prime} \mathrm{W}$ (Figura 6.1), por lo que se ubica en la cuenca media del zanjón del Pescado, en el sector VI del área (Capítulo 3). Accedimos al sitio gracias a las indicaciones del señor Enrique Quiroga, dueño de la estancia. 


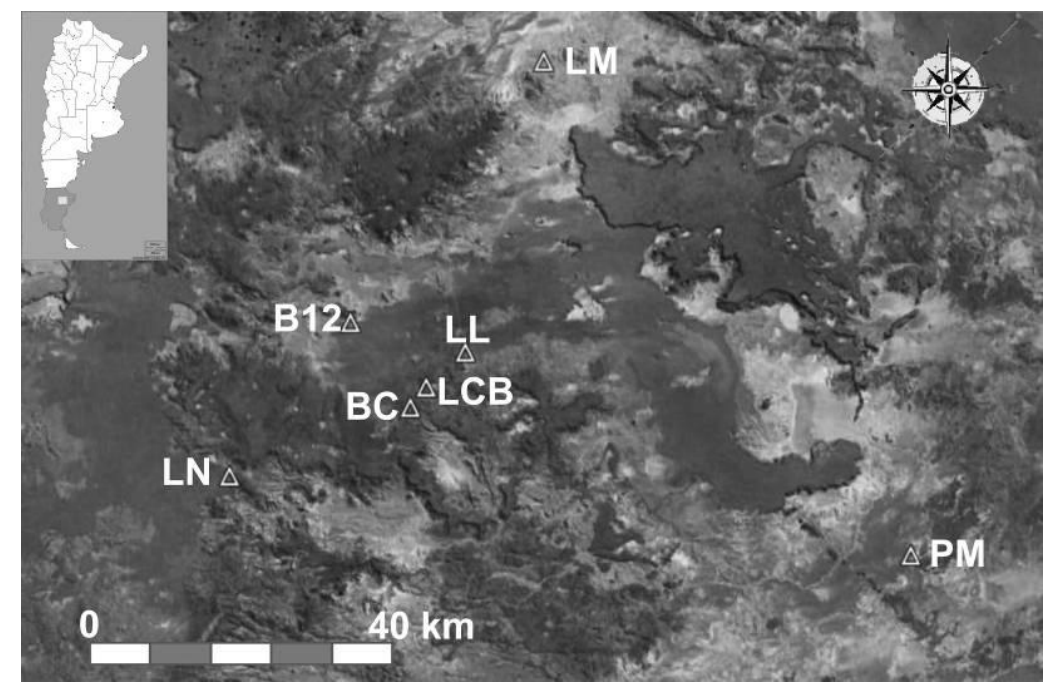

Figura 6.1. Ubicación de los sitios tratados en este capítulo. Referencias: LM: La Marianita; BC: Bardas de Carlos; LN: Los Navarro presentados en este capítulo. Sitios con grabados estudiados por Carden (2008a): B12: Bardas del Doce; LL: La Leonera; LCB: Laguna del Cerro Bonete; PM: Piedra Museo.

El afloramiento en el que se encuentran los grabados corresponde a un relicto de $6.768 \mathrm{~m}^{2}$ (Figura 6.2.a) de la formación Laguna Palacios, que integra el Grupo Chubut (Panza 2001: 43-47). Alrededor de 150-200 m del afloramiento se encuentran dos afluentes temporarios e innominados del zanjón del Pescado. Si bien en las inmediaciones de dicho relicto la cubierta vegetal es escasa, se registraron diferentes arbustos y coirones (Figura 6.2.a).

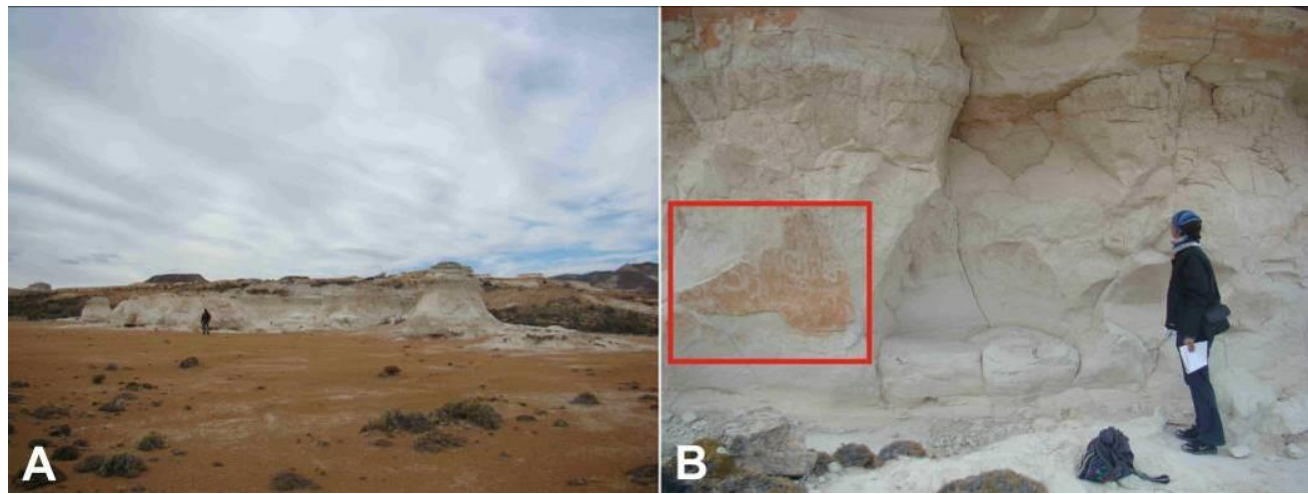

Figura 6.2. La Marianita: a. Afloramiento con grabados; b. Panel con arte rupestre y detalle del afloramiento.

Debido a la escasa cobertura vegetal y por la ausencia de relictos adicionales hacia el occidente, desde este afloramiento se tiene un amplio dominio visual. Las mismas razones pueden esgrimirse para afirmar que su 
visibilidad también es alta, con el componente adicional de que algunas de las superficies de este afloramiento, con pátina naranja, presentan grabados (Figura 6.2.b) o grafitis. Asimismo, algunos de éstos últimos se han documentado sobre la superficie blanca de la toba y tienen asociadas fechas que permiten proponer el momento de su realización.

Debido a la baja dureza de la roca (3 en la escala de Mohs) se registra sobre todo el afloramiento un alto índice de desprendimientos $\mathrm{y}$ exfoliaciones. Además, éste es afectado de manera constante por el viento del oeste, y por la acción del agua durante las precipitaciones. Es posible que estos factores, sumados a la litología del soporte y a la insolación directa que recibe, hayan influido en el proceso de exfoliación que se observa actualmente.

\section{6. a. 1. El arte rupestre de La Marianita}

Para la realización de grabados, en La Marianita se utilizó la superficie vertical de color naranja más grande del afloramiento, la cual se encuentra orientada al NW y recibe insolación directa por las tardes (Figura 6.2.b). Los motivos se encuentran entre 1 y $1,50 \mathrm{~m}$ sobre el suelo actual.

Este panel tiene forma trapezoidal y se encuentra dividido por tres fisuras verticales oblicuas (Figura 6.3); mide 1,52 $\mathrm{m}$ de ancho y tiene alturas variables respecto del suelo, entre 1,03 m y 0,91 m para el borde inferior. En esta superficie se registraron 18 motivos, entre los que predominan los no figurativos (Figura 6.4.a; Tabla 6.1) mientras que entre los figurativos se reconoció un solo elemento, correspondiente a una roseta, asociada formalmente a la pisada de felino (Gradin 1978, 2001; ver Capítulo 2 para una mayor profundización). Abundan los motivos circulares lineales (simples, con o sin apéndices) que llegan al 59\%, seguidos por los rectilíneos y los puntiformes (Figura 6.4.b; Tabla 6.1).

Como se trata de un soporte muy friable, es posible que hayan existido otros paneles con arte rupestre en el pasado, sin haberse preservado a 
través del tiempo (Bednarik 2007b). De hecho, el 22,22\% (n=4) de los motivos exhibe alguna porción faltante.

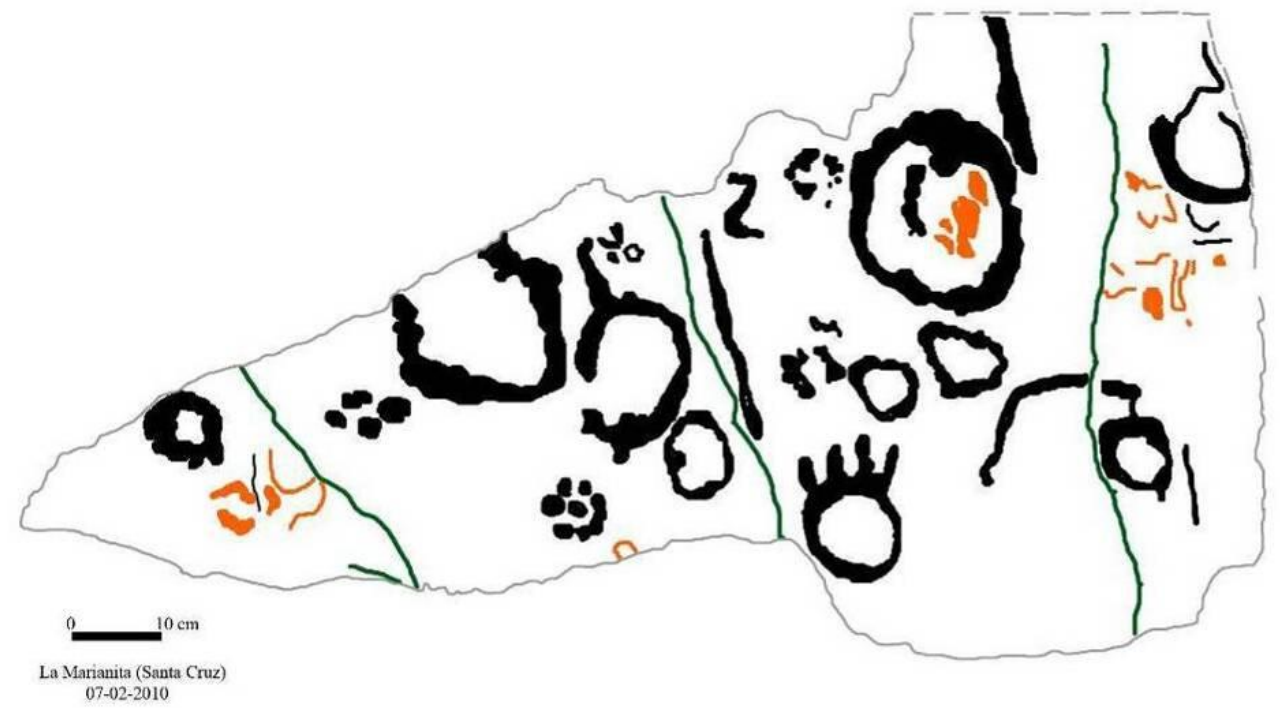

Figura 6.3. Panel 1 con grabados en La Marianita. En verde grietas del soporte; en rojo: exfoliaciones del soporte; en negro surcos grabados.

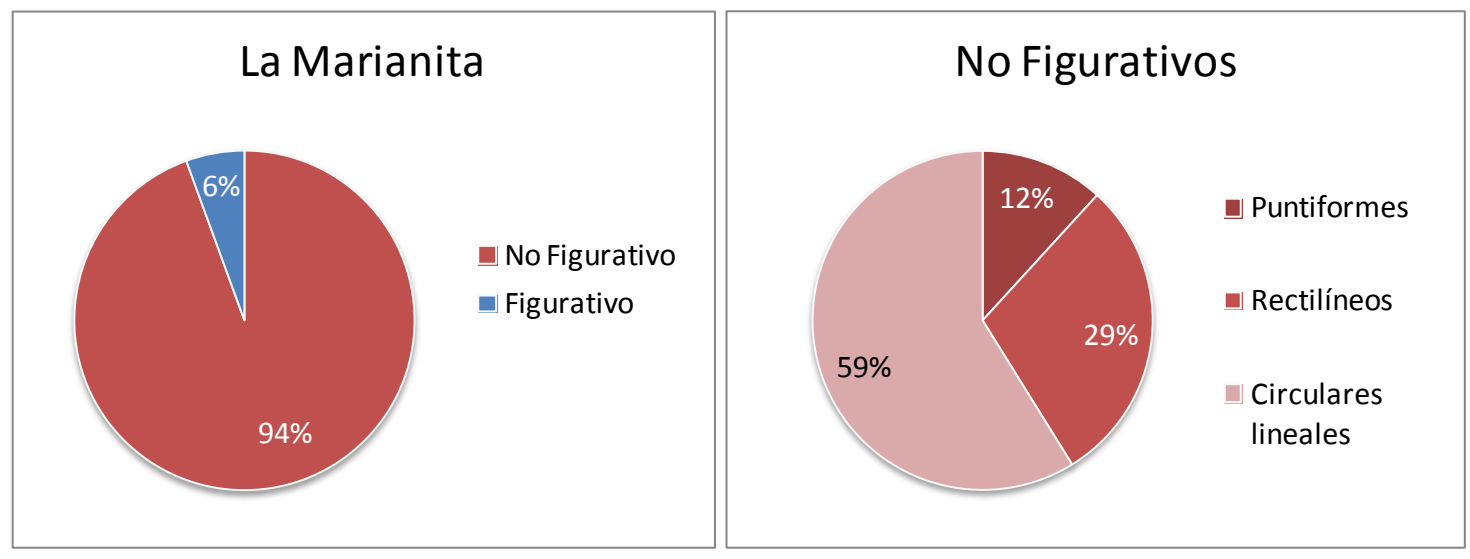

Figura 6.4.a. Proporciones de grupos de motivos en La Marianita. b.

Proporciones de los subgrupos de motivos no figurativos reconocidos en el sitio. 


\begin{tabular}{|l|c|}
\hline Motivos & Total \\
\hline Conjunto de puntos & 1 \\
\hline Circunferencia de puntos & 1 \\
\hline Subtotal Puntiformes & 2 \\
\hline Línea recta vertical & 3 \\
\hline Línea quebrada & 1 \\
\hline Figura cuadrangular & 1 \\
\hline Subtotal Rectilíneos & 5 \\
\hline Semicircunferencia con apéndice recto & 1 \\
\hline Circunferencia & 5 \\
\hline Circunferencia con línea recta interior & 1 \\
\hline Circunferencia con apéndice recto & 1 \\
\hline Circunferencia con apéndice curvo & 1 \\
\hline Circunferencia con trazos superiores & 1 \\
\hline Subtotal Circulares Lineales & 10 \\
\hline No Figurativos & 17 \\
\hline Roseta & 1 \\
\hline Figurativos & 1 \\
\hline & 18 \\
\hline
\end{tabular}

Tabla 6.1. Frecuencias de tipos de motivos en La Marianita.

Se registraron grafitis dispuestos en diferentes porciones y sectores del afloramiento. Entre ellos se incluyen palabras, nombres y fechas, así como diferentes trazos que pueden a llegar a conformar figuras. Particularmente, sobre el panel con grabados se registraron cuatro grafitis: un par de líneas horizontales paralelas intersecadas por dos líneas verticales paralelas (Figura 6.5.a); los nombres "francisco" (Figura 6.5.b), "Cata" (Figura 6.5.c) y “Gino Rocha '42” (Figura 6.5.d). Los restantes grafitis relevados en el sitio serán presentados en el apartado siguiente. 


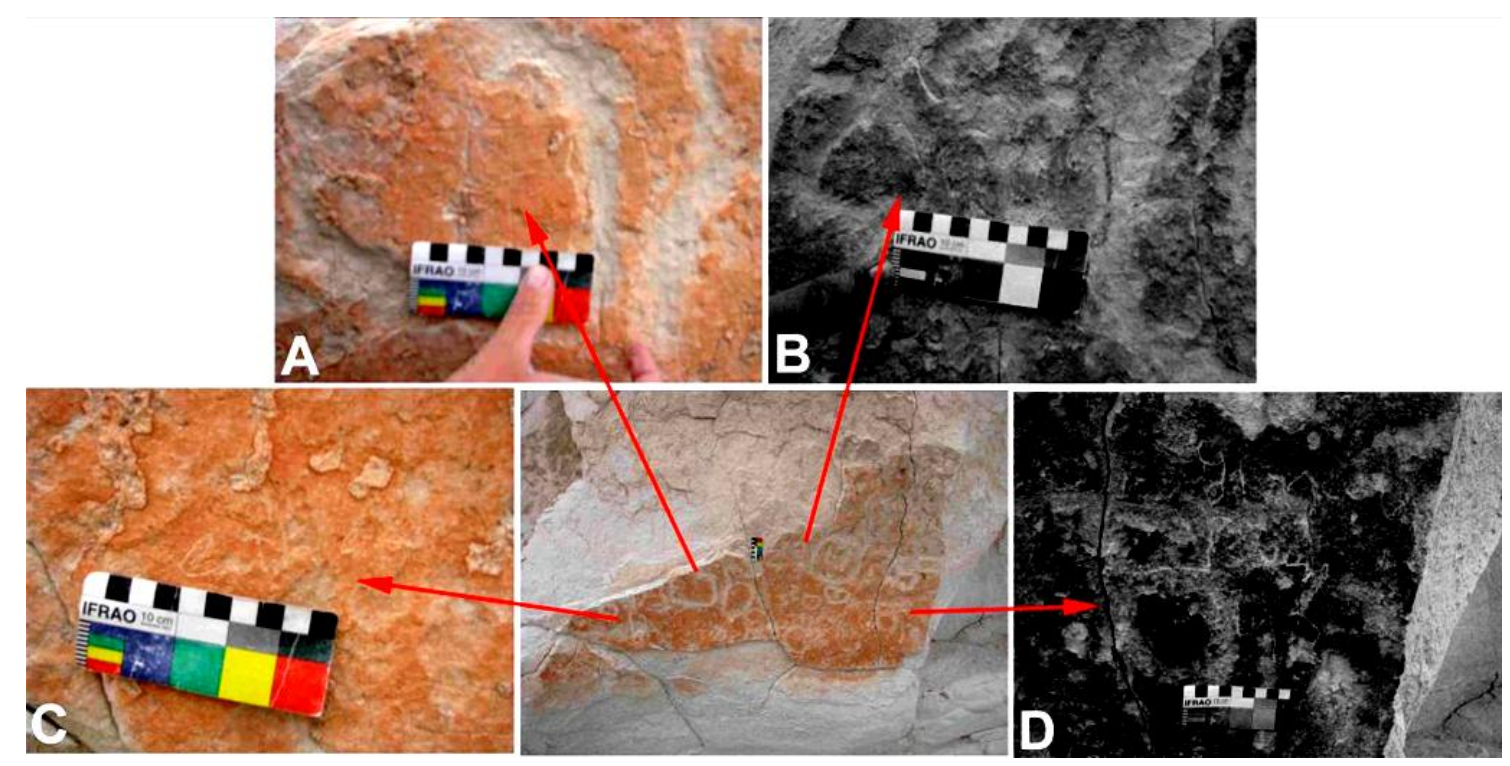

Figura 6.5. Grafitis del panel con grabados: a. líneas paralelas verticales y horizontales intersectadas (\#); b. "francisco"; c. "Cata"; d. "Gino Rocha".

A partir de la observación macroscópica de los surcos grabados pudo reconocerse que predomina la percusión, dado que los motivos presentan un perfil de surco en "U". Sin embargo, se observa que la línea recta vertical en el sector superior del panel fue realizada por incisión: si bien presenta cierto grado de redondeamiento del surco, éste presenta un perfil en "V".

\section{6. a. 2. Los grafitis de La Marianita}

El relevamiento de las diferentes inscripciones detectadas en el afloramiento se efectuó en sentido horario, de arriba abajo, tomando como punto de partida su punto más oriental. Se determinaron diferentes conjuntos y grafitis aislados principalmente siguiendo el criterio empleado para el relevamiento de otros sitios: las distintas inscripciones registradas a más de $6 \mathrm{~m}$ de distancia fueron consideradas como conjuntos o grafitis diferentes; mientras que aquellas encontradas a una distancia menor fueron integradas en el mismo conjunto. La mayoría de estos corresponde a iniciales $(n=41)$, nombres y apellidos $(n=20)$, líneas $(n=4)$ mientras que se registraron dos figuras (un automóvil y un rostro), un símbolo compuesto y una sola frase, a los que se le suman los cuatro grafitis documentados sobre 
el conjunto de grabados rupestres arqueológicos (Figura 6.6; Tabla 6.2). El total de grafitis del sitio asciende a 69, de los cuales sólo 18 están asociados a fechas. Esta última situación permite proponer el momento en el que algunas poblaciones ejecutaron dichas manifestaciones.

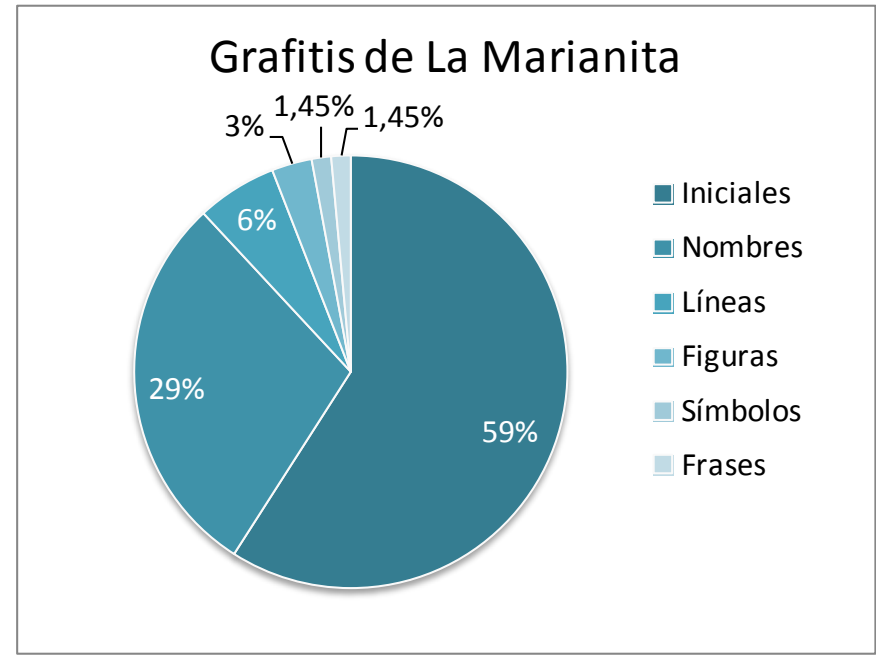

Figura 6.6. Distribución porcentual por tipos de grafitis en LM.

La mayoría de las inscripciones $(72,46 \%)$ se realizaron sobre superficies tobáceas blancas (Figuras 6.7.a, 6.7.b y 6.7.f), aunque se observan 27,54\% de los grafitis sobre superficies con pátina naranja (Figuras 6.7.c, 6.7.e y 6.7.g; Tabla 6.2). Dieciséis de los conjuntos se encuentran hacia el este (hacia la derecha) del panel con grabados (Figura 6.6), mientras que los restantes ocho se encuentran hacia el norte (a la izquierda).

El Conjunto 7 es el que presenta las figuras (automóvil y rostro) mencionadas previamente. En este caso, las ruedas del automóvil son circulares y del mismo tamaño, razón que permite pensar que podrían haber sido realizadas con el mismo artefacto de contorno circular. En las inmediaciones del Conjunto 12 se encontró un fragmento de caño de hierro que encastra perfectamente en las ruedas, por lo se infiere que correspondería al instrumento utilizado para su realización (Figuras 6.7.d y 6.7.e). Por otro lado, los puntos que acompañan las iniciales inferiores del Conjunto 12 están rodeados por circunferencias, que coinciden en tamaño y forma con las ruedas del vehículo, por lo que también esas circunferencias podrían haber sido realizadas con ese mismo instrumento. 
En el Conjunto 10 algunas de las iniciales presentan la particularidad de haber sido realizadas con tipografía de cedilla (Figura 6.7.f), con surco profundo en forma de "V". Para lograr un mayor control del surco se considera que podría haberse empleado un artefacto filoso y puntiagudo.

Entre las dieciocho fechas documentadas, observamos que las más antiguas remiten a las décadas de 1930 y $1940(\mathrm{n}=6)$, el segundo grupo refiere a diferentes inscripciones que pueden situarse entre 1950 y $1970(\mathrm{n}=$ 11), mientras sólo una podría referir a una inscripción reciente (02-09-01 $F Q O$ ), posiblemente realizada en 2001.

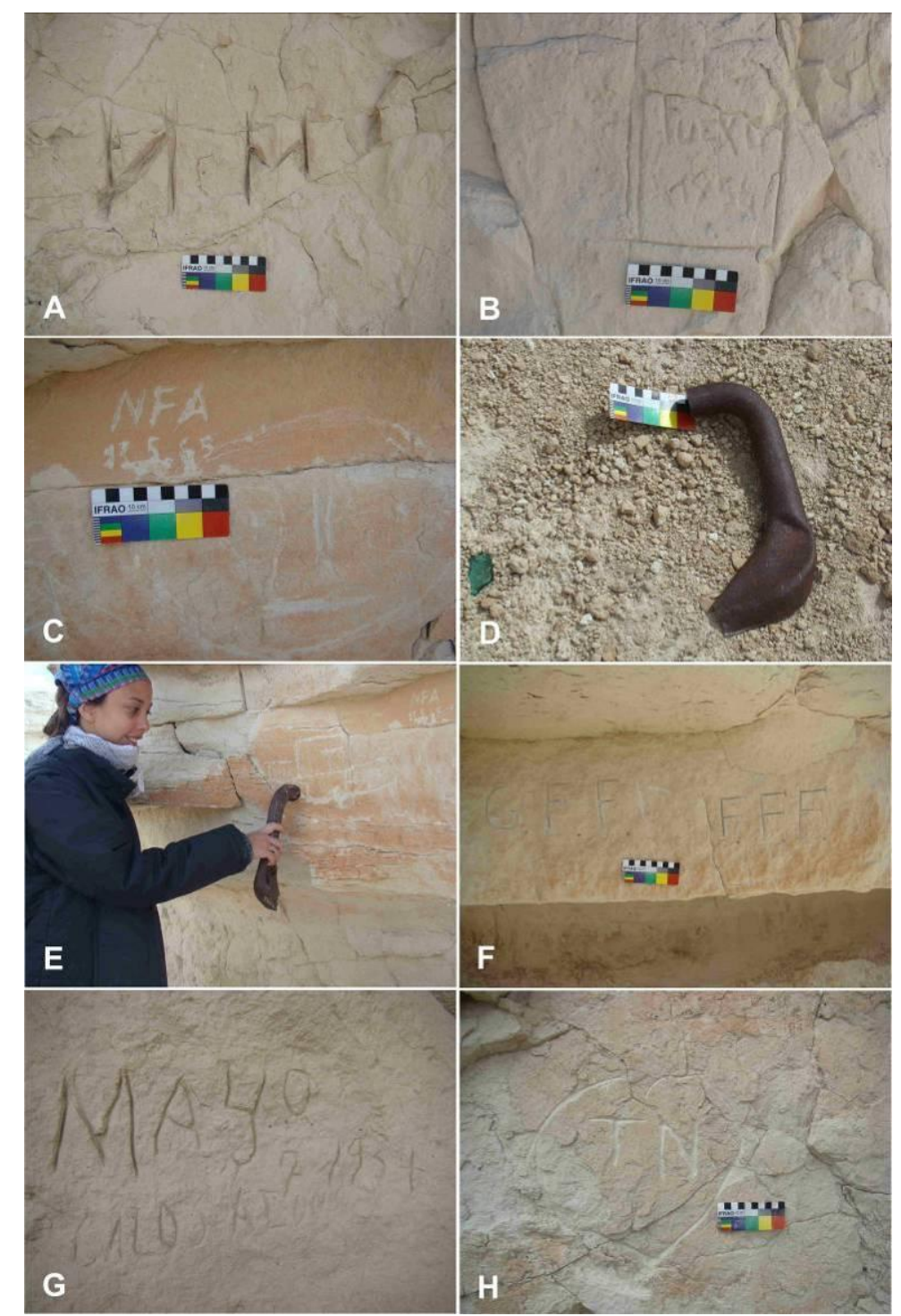

Figura 6.7. Grafitis en La Marianita: a. Conjunto 1; b. Conjunto 3; c. Conjunto 7; d. Fragmento cilíndrico de hierro encontrado cercano a Conjunto 12; e. Calce de caño de hierro en ruedas del automóvil que conforma el conjunto 7; f. Conjunto 10; g.

Parte del Conjunto 12; h. Conjunto 24. 


\begin{tabular}{|c|c|c|c|c|}
\hline Conjunto/Grafiti & Inscripciones & $\mathrm{N}$ & $\begin{array}{c}\mathrm{N} \\
\text { fechas }\end{array}$ & Observaciones \\
\hline 1 & MG; ANA & 2 & 0 & - \\
\hline 2 & NNM & 1 & 0 & Incisiones profundas \\
\hline 3 & HDI; I; 1956 FUEYO & 3 & 1 & $\begin{array}{l}\text { Sobre pátina color naranja; I al interior de pequeño oquedad. } 1956 \text { Fueyo } \\
\text { enmarcado por recuadro. }\end{array}$ \\
\hline 4 & Titi Morales & 1 & 0 & A más de $1,60 \mathrm{~m}$. Surco superficial. \\
\hline 5 & А; 9 МАЛІА, Dos líneas paralelas verticales incisas. & 3 & 0 & $\begin{array}{l}\text { Las primeras sobre superficie con pátina naranja; las líneas sobre superficie } \\
\text { blanca. }\end{array}$ \\
\hline 6 & $\begin{array}{l}\text { D JUNI 195(2); E. Quiroga 14/01/60; C.A.; Pasará una } \\
\text { sola vez... Acosta } 11 / 7 / 56\end{array}$ & 5 & 3 & $\begin{array}{l}\text { Al interior de alero; C.A con surco profundo e inciso. La frase no se pudo discernir } \\
\text { cómo terminaba. }\end{array}$ \\
\hline 7 & Automóvil; 13.5 .65 N.F.A.; Rostro; P. M. G I.; DKI & 5 & 1 & $\begin{array}{l}\text { Sobre pátina naranja. Entre las figuras se encuentra la fecha y las iniciales. } \\
\text { Ruedas del automóvil realizadas con mismo artefacto. }\end{array}$ \\
\hline 8 & M.A.; MAT & 2 & 0 & Sobre pátina naranja \\
\hline 9 & $M K D 10 / 8 / \ldots 7 ; \Omega \Lambda$ & 2 & 1 & $\begin{array}{l}\text { Sobre pátina naranja; mientras que los símbolos se encuentran sobre superficie } \\
\text { blanca. }\end{array}$ \\
\hline 10 & $\begin{array}{l}\text { MAF; C.A.; S.A.C.; A.F.; SP 9/12/46, STC 31/1/53 (5?); } \\
\text { G.F.F.; F.F.F }\end{array}$ & 8 & 2 & $\begin{array}{l}\text { Las letras en tipografía con cedilla. El último grupo de iniciales se encuentra } \\
\text { hacia la derecha. }\end{array}$ \\
\hline 11 & RDH; CAP & 2 & 0 & Sobre pátina naranja \\
\hline 12 & $\begin{array}{l}\text { ASUNCION 11/1940; Otubre; CAF; } 7 \text { mayo } 1934 \\
\text { Calos Alonso; MINA; ENERO } 13 \text { 1936; VBENERO; } \\
\text { Fela; F.F.F. A.B.L. 15/10/63 }\end{array}$ & 6 & 2 & $\begin{array}{l}\text { Al interior de alero, sobre superficie blanca. Tres grupos de inscripciones. Los } \\
\text { puntos que acompañan a las iniciales inferiores están rodeados por una } \\
\text { circunferencia. }\end{array}$ \\
\hline 13 & HAP; dos líneas paralelas verticales & 2 & 0 & 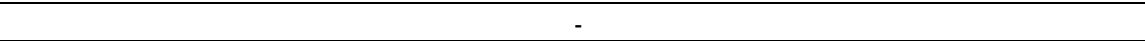 \\
\hline 14 & $\begin{array}{l}\text { Año } 1952 \text { J A; Jacinta; 9-7-1930; } \\
\text { M. V. De SURETA }\end{array}$ & 3 & 2 & Jacinta y MV Sureta en el mismo nivel. \\
\hline 15 & ASFEF; SURETA 1962; RD; ACD; AD; C.F. & 6 & 1 & - \\
\hline 16 & JMH 24-XII-44 & 1 & 1 & - \\
\hline 17 & $M N ; R O G E L I O, B A$. & 3 & 0 & 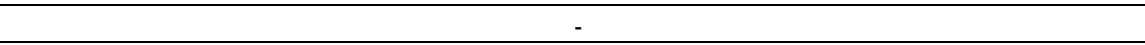 \\
\hline Grabados & \#; Cata; francisco; Gino Rocha ‘42 & 4 & 1 & Sobre superficie con pátina naranja, algunos se superponen a motivos grabados. \\
\hline 18 & $A M$ & 1 & 0 & 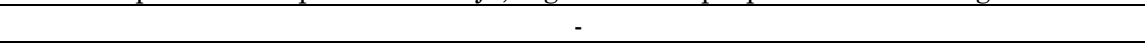 \\
\hline 19 & $\begin{array}{l}\text { Cacho; tres líneas verticales junto a dos líneas verticales } \\
\text { paralelas intersectadas por una línea transversal }\end{array}$ & 2 & 0 & - \\
\hline 20 & $M M$ & 1 & 0 & - \\
\hline 21 & MAXIMO 1969 & 1 & 1 & - \\
\hline 22 & $02-09-01 F Q O$ & 1 & 1 & - \\
\hline 23 & $J A F ; 21-7-63 M P$ & 2 & 1 & La letra A se encuentra desvaída. \\
\hline 24 & Mary; TN (al interior de un corazón) & 2 & 0 & e \\
\hline \multicolumn{2}{|r|}{ (2) } & 69 & 18 & \\
\hline
\end{tabular}

Tabla 6.2. Grafitis de La Marianita. En la columna de las inscripciones los puntos y coma separan diferentes grafitis. 
La inscripción "1956 FUEYO" coincide con el período en el cual los hermanos Fueyo fueron propietarios de la estancia, de acuerdo con la información provista por la señora Silvia Cameron de Iribarne, propietaria de la vecina Estancia Aguada del Cuero. Probablemente, aquellas iniciales que terminan en "F" correspondan a alguno de estos dueños. La inscripción "Quiroga 1960", si bien coincide con el apellido del dueño de la estancia La Marianita desde 1980, hace referencia a un período previo.

Tal como mencionamos anteriormente, la toba en la que se encuentran estos grabados y grafitis es blanda por lo que no es necesario utilizar un artefacto muy filoso o ejercer demasiada presión para dejar alguna marca sobre su superficie. Con respecto a los demás artefactos usados para realizar las inscripciones, podría tratarse de artefactos carentes de filos en los grabados con surco en forma de "U" o de artefactos con filos pronunciados en los grabados con surco en forma de "V".

\section{6. b. BARDAS DE CARLOS}

Este sitio con grabados rupestres se encuentra en la localidad arqueológica Aguada del Cuero, cercano a los sitios con grabados Laguna del Cerro Bonete y La Leonera (Figura 6.1) (Carden 2008a, 2009a; Miotti et al. 2005). Sus coordenadas geográficas son $47^{\circ} 41^{\prime} 29.1^{\prime}$ S, $68^{\circ} 44^{\prime} 22.9^{\prime \prime} \mathrm{W}$, y se encuentra en la cabecera norte del zanjón Blanco (sector II). Accedimos al sitio gracias a las indicaciones recibidas del señor Carlos Iribarne, dueño de la estancia Aguada del Cuero, a quién debe su denominación.

Los grabados se encuentran sobre un paredón de basaltos de la Formación La Angelita (Panza 2001) (Figura 6.8.a). Estos son de color marrón o gris, con pátina rojiza. Pueden presentar fractura irregular, además de líquenes y un grado variable de meteorización. Este afloramiento mide aproximadamente $130 \mathrm{~m}$ de extensión y presenta una orientación NWSE (Figura 6.8.b). Desde diferentes puntos del mismo se tiene amplio dominio visual del terreno circundante, y como puntos de referencia se 
observan los cerros Bonete (Figura 6.8.c) y de la Comisión hacia el noreste. Frente a este afloramiento se distingue una pequeña hondonada, de 0,17 km de ancho por 0,37 $\mathrm{km}$ de largo, la cual actualmente carece de agua y se presenta cubierta por coirones y matas negras (Figura 6.8.c).

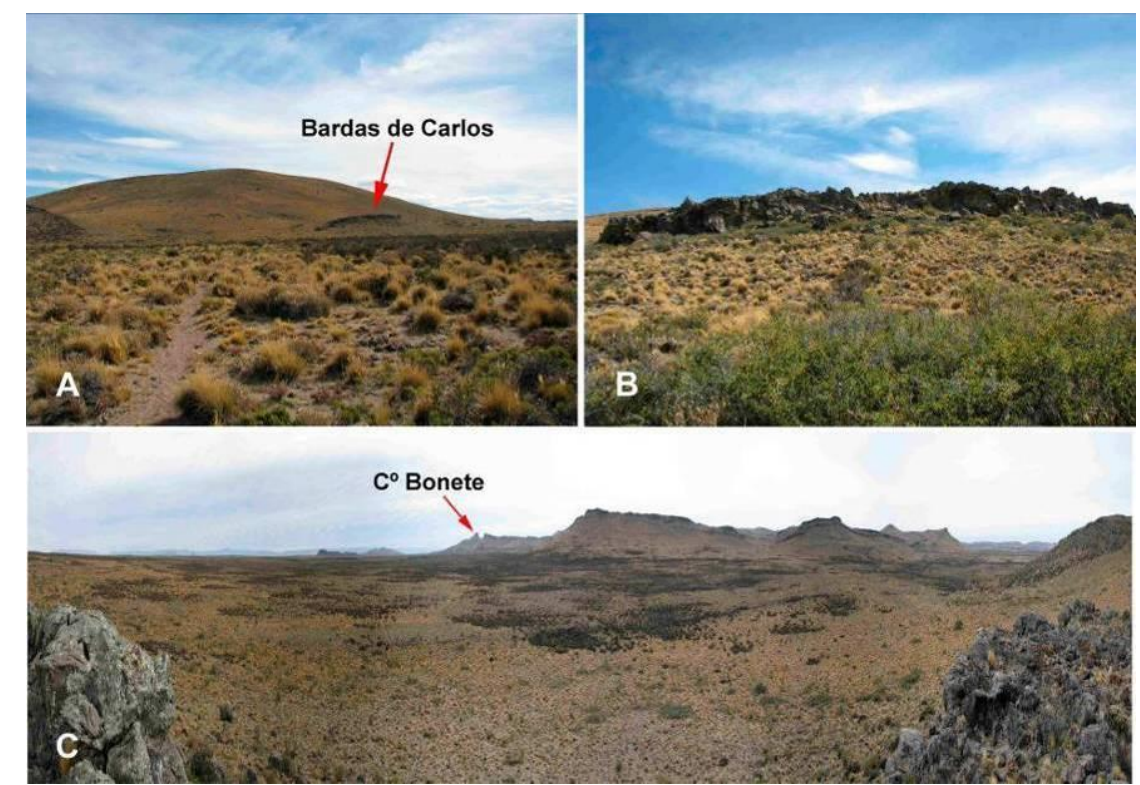

Figura 6.8. Bardas de Carlos: a. Vista del sitio; b. Afloramiento de basalto; c. Vista al cerro Bonete.

\section{6. b. 1. Otros contextos arqueológicos de la localidad}

Aguada del Cuero es una localidad arqueológica que cuenta con trabajos previos relacionados al estudio del arte rupestre (Carden 2008a, 2008b, 2009a; Miotti et al. 2005), al registro de sitios en estratigrafía y asociaciones de materiales en superficie (Miotti et al. 2005). Hasta el presente trabajo, en Aguada del Cuero se habían relevado cuatro sitios con arte rupestre: Cueva de la Hacienda y Cueva Moreno distan 7,60 y 2,90 km, respectivamente, hacia el E de Bardas de Carlos y presentan pinturas. La Leonera y Laguna del Cerro Bonete se encuentran a 3,25 y $10 \mathrm{~km}$, hacia el NE y NNE del mencionado sitio, respectivamente, y presentan motivos grabados (Figura 6.1) (Carden 2008a, 2008b). En Laguna del Cerro Bonete (LCB) se relevaron motivos grabados sobre basaltos columnares de la misma formación que en Bardas de Carlos. El emplazamiento de LCB corresponde a una barda que 
rodea una laguna somera ubicada en una hondonada (Carden 2008a). El arte rupestre corresponde mayoritariamente a motivos no figurativos, entre los que predominan los circulares, seguidos por los curvilíneos, los rectilíneos y los puntiformes. Si bien escasos, entre los motivos figurativos se identificaron rastros animales grabados -pisadas de aves y de felino- y una mano negativa pintada. La evidencia recuperada y registrada en el sitio, que incluye artefactos de superficie, permite proponer que allí se realizaron actividades domésticas (Carden 2008a).

Por último, en La Leonera se documentaron motivos grabados sobre superficies verticales en un pequeño sector de la barda. El sitio se encuentra frente a una vega y a una pampa abierta, lo que permite el amplio dominio visual de puntos topográficos que pudieron haber funcionado como puntos de orientación. El arte rupestre está conformado por motivos no figurativos, principalmente rectilíneos, seguidos por curvilíneos y circulares; los dos motivos figurativos del sitio fueron identificados como pisadas de aves (Carden 2009a).

\section{6. b. 2. El arte rupestre de Bardas de Carlos}

En el sitio se distinguieron seis sectores, en los que se distribuyen de manera heterogénea 12 conjuntos y seis motivos aislados (Figura 6.9). La definición de sectores se corresponde con los accidentes más conspicuos de la barda, como derrumbes de rocas o cambios de orientación de las paredes y de la presencia de superficies de $6 \mathrm{~m}$ o más de largo, carentes de motivos. 


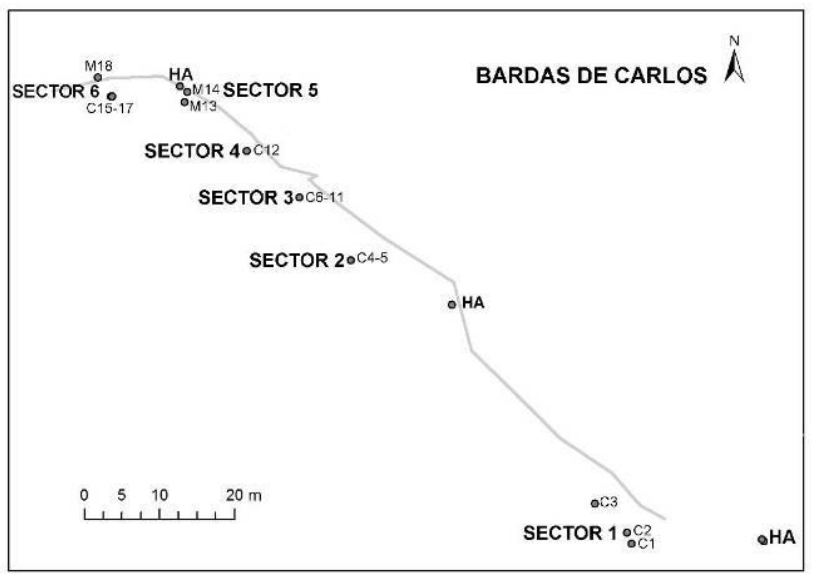

6.9. Croquis de sectorización de Bardas de Carlos.

Referencias: C: Conjunto; M: motivo; HA: hallazgos arqueológicos.

Los materiales arqueológicos detectados en superficie en el sitio se encuentran en las proximidades del Conjunto 1 con arte rupestre y corresponden a una concentración de artefactos líticos (Figuras 6.9 y 6.10). Asimismo, se realizaron hallazgos aislados cercanos a los sectores 2 y 5 . Dichos materiales se corresponden a artefactos formatizados y no formatizados de diferentes materias primas (Miotti et al. 2012b).
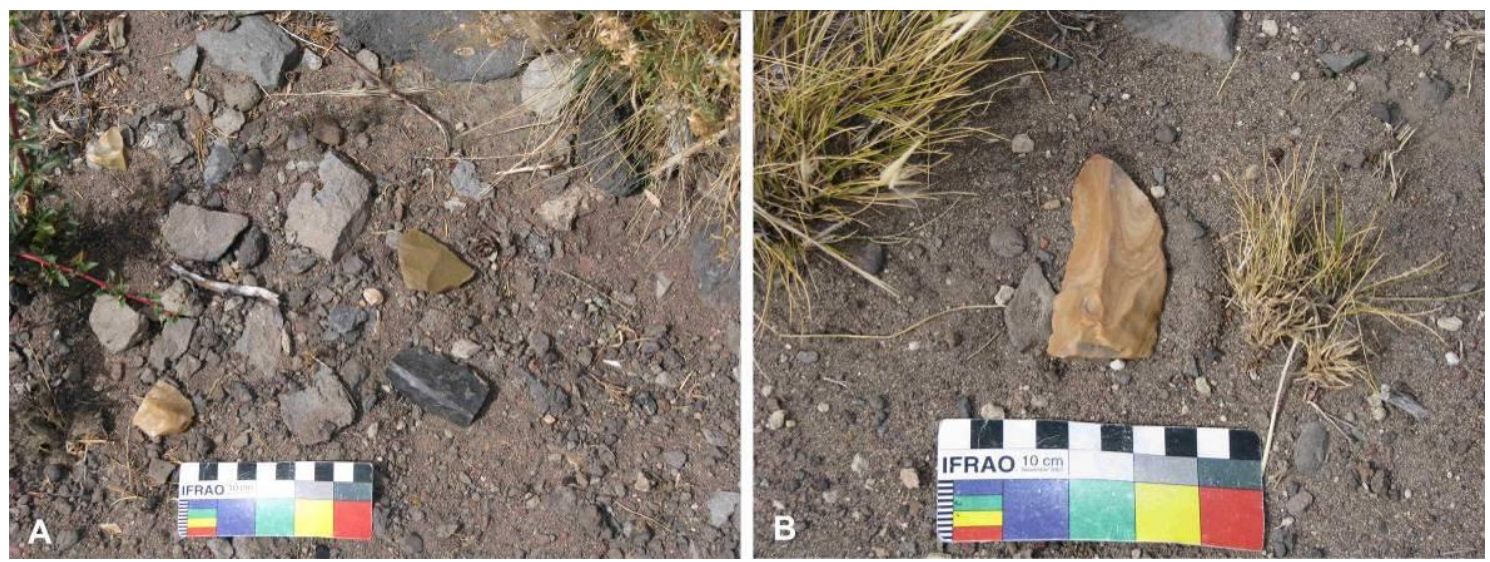

Figura 6.10. Materiales de superficie detectados en Bardas de Carlos.

Si se considera la distribución espacial de los motivos, los sectores 1 y 3 presentan la mayor frecuencia de motivos del sitio (77\% entre los dos), seguidos por los sectores 6 y $2(20 \%)$ mientras que los sectores 4 y 5 suman el 3\% de los motivos (Figura 6.11). 


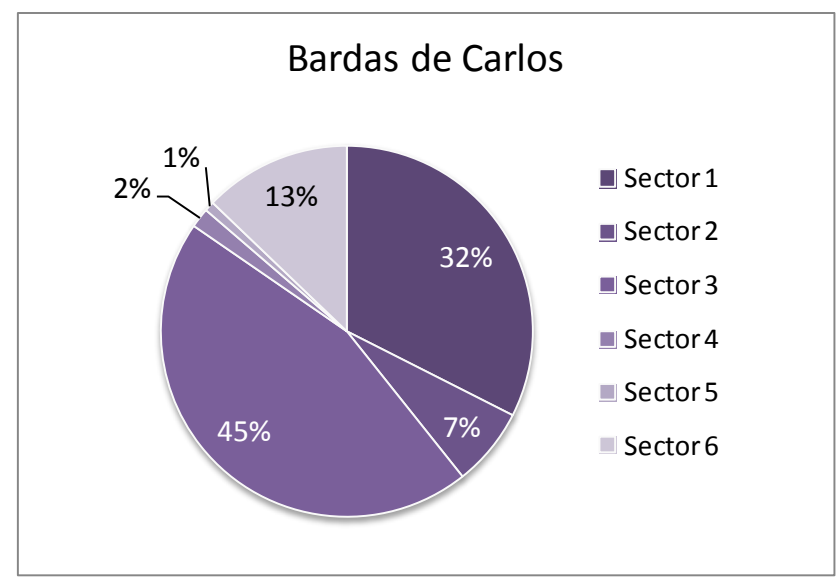

Figura 6.11. Proporciones de motivos por sector en Bardas de Carlos.

Los motivos registrados ascienden a 118, el 85\% de los cuales corresponde a motivos no figurativos y el $2 \%$ a motivos figurativos, mientras que la proporción restante corresponde a motivos no determinados (Figura 6.12.a). Dentro del primer grupo predominan los motivos rectilíneos, seguidos por los curvilíneos, los circulares lineales y los puntiformes (Figuras 6.12.b). Los dos motivos definidos como figurativos corresponden a un zoomorfo esquemático en el sector 2 y a un tridígito en el sector 3. La frecuencia de subgrupos de motivos por sector es presentada en la Tabla 6.3 (ver en el Apéndice IV.1 los tipos de motivos reconocidos en el sitio).

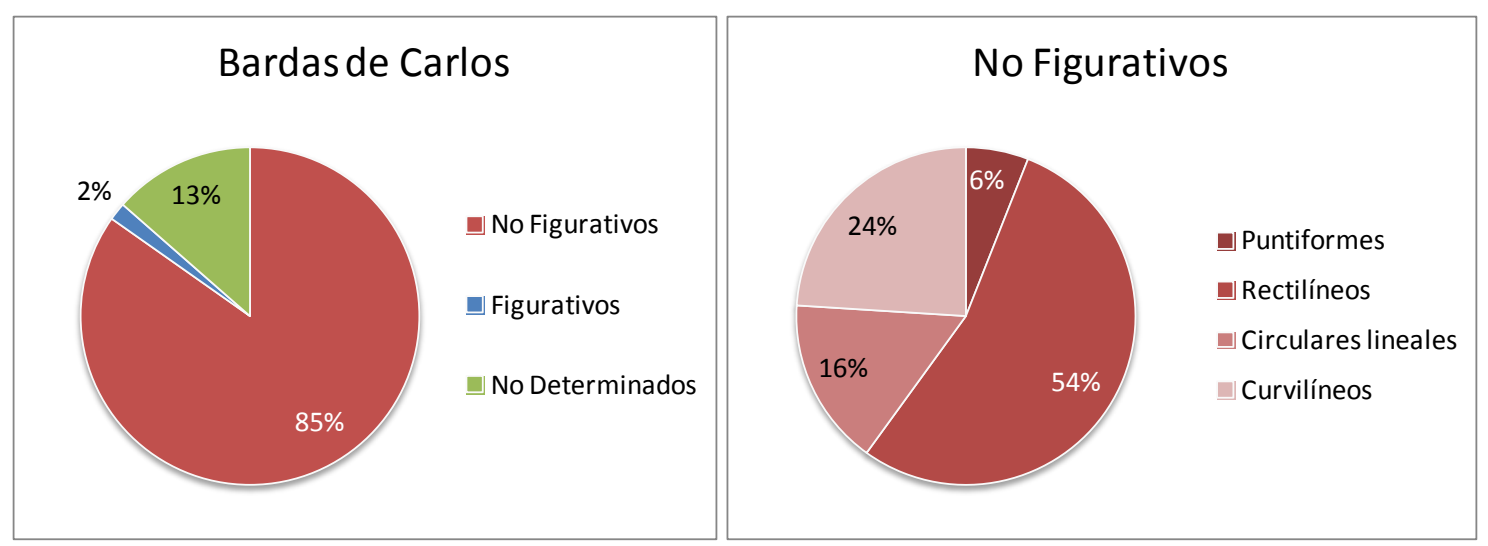

Figura 6.12.a. Proporciones de grupos de motivos reconocidos en Bardas de Carlos. b. Proporciones de subgrupos. 


\begin{tabular}{|c|c|c|c|c|c|c|c|}
\hline \multirow[b]{2}{*}{ Motivos } & \multicolumn{6}{|c|}{ Sector } & \multirow[b]{2}{*}{ Subtotal } \\
\hline & 1 & 2 & 3 & 4 & 5 & 6 & \\
\hline Puntiformes & 1 & 1 & 3 & - & - & 1 & 6 \\
\hline Rectilíneos & 23 & 1 & 20 & 1 & 1 & 7 & 53 \\
\hline Circulares lineales & 3 & 3 & 7 & - & - & 3 & 16 \\
\hline Curvilíneos & 7 & 2 & 16 & - & - & - & 25 \\
\hline No Figurativos & 34 & 7 & 46 & 1 & 1 & 11 & 100 \\
\hline Zoomorfos & - & 1 & - & - & - & - & 1 \\
\hline Pisadas de animales & - & 0 & 1 & - & - & - & 1 \\
\hline Figurativos & - & 1 & 1 & - & - & - & 2 \\
\hline No Determinados & 4 & 0 & 6 & 1 & 1 & 4 & 16 \\
\hline Total & 38 & 8 & 53 & 2 & 2 & 15 & 118 \\
\hline
\end{tabular}

Tabla 6.3. Frecuencia de grupos y subgrupos de motivos por sector en Bardas de Carlos.

El primer sector está conformado por los conjuntos 1 a 3 . Incluye los primeros 7,5 m de la barda. Se trata de superficies verticales de coloración marrón rojiza, afectadas por la presencia de líquenes y la acción del agua. Se observan bloques desprendidos y alejados unos metros delante de la barda. El conjunto 2 se localiza sobre uno de dichos bloques. La técnica de producción de estos motivos es la percusión, habiéndose observado además motivos incisos finos.

Conjunto 1. Sobre una superficie irregular de color rojiza, orientada al NNW. Los dieciocho motivos del conjunto se encuentran a $1,15 \mathrm{~m}$ del suelo actual, entre los que se pueden mencionar un conjunto de puntos, líneas rectas y curvas simples -verticales u oblicuas-, una línea sinuosa que termina en círculo lleno, motivos circulares lineales de trazo irregular y superficies grabadas no determinadas (Figuras 6.13). Tres motivos corresponden a incisiones caóticas (en el sentido de Re 2011). 


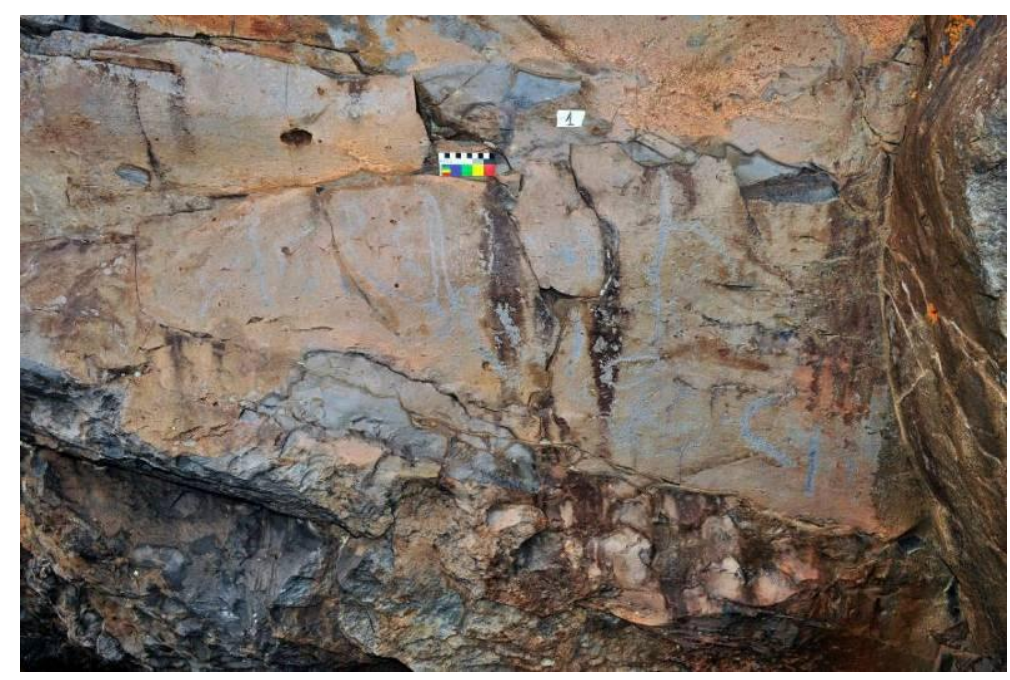

Figura 6.13. Conjunto 1.

Conjunto 2. Se encuentra sobre un bloque desprendido de la barda, por delante del conjunto anterior (Figura 6.14), del que se utilizó una superficie vertical. El conjunto está conformado por 15 motivos, de los cuales el inferior se encuentra a $0,30 \mathrm{~m}$ del suelo actual. Se registraron líneas verticales simples, algunas con apéndices perpendiculares, series de líneas paralelas; una circunferencia con apéndice recto; líneas curvas conectadas por un apéndice lateral, y superficies grabadas sin forma determinable. Se observan incisiones caóticas -superpuestas y subyacentes- a los motivos grabados. Las mismas serán tratadas más adelante.

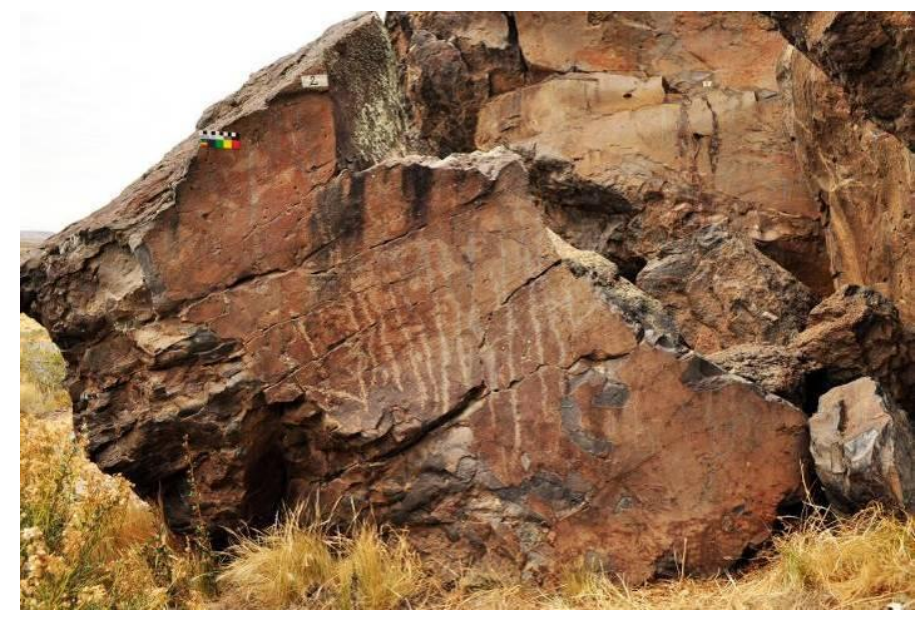

Figura 6.14. Conjunto 2.

Conjunto 3. Se encuentra sobre una superficie de la barda, orientada al $\mathrm{N}$ y subdividida por grietas y fallas. En este sector del afloramiento, el basalto presenta una coloración variable, entre rojiza y grisácea y de 
superficie irregular. Este conjunto está integrado por seis motivos, entre los que se incluyen líneas rectas verticales simples, series de líneas rectas y curvas paralelas. La altura respecto del suelo a la que se encuentran los motivos varía entre 0,70 y $1,65 \mathrm{~m}$.

El sector 2 se encuentra a $46 \mathrm{~m}$ de distancia del anterior y está conformado por el motivo $4 \mathrm{y}$ el conjunto 5. Estos se ubican en superficies verticales de la barda, orientadas al $\mathrm{E}$, a alturas superiores a $1 \mathrm{~m}$ respecto del suelo actual.

Motivo 4. Sobre una superficie rugosa e irregular de color rojo, a 1,39 m del suelo actual, se registró una circunferencia que presenta adosadas dos rectas: una superior y otra inferior. El surco de este motivo contrasta con la coloración rojiza del soporte.

Conjunto 5. Se encuentra sobre superficies verticales de la barda, separadas entre sí por grietas. Una porción de estas superficies está parcialmente cubierta por un bloque (Figura 6.15.a). Este hecho sólo posibilita una visión cercana del conjunto, ubicado entre 1 a 1,5 m respecto el suelo. El conjunto está constituido por siete motivos: en una de las superficies se registraron un motivo en forma de "media U" y una circunferencia con apéndice superior; este último motivo presenta dos tipos de trazo: discontinuo en la parte superior y continuo en su porción inferior. Hacia la derecha, en la superficie contigua, se relevaron los motivos restantes: un punto, una línea en ángulo recto, dos líneas curvas -una de ella “en forma de U”- y el único motivo zoomorfo del sitio, de carácter esquemático (Figura 6.15.b). 


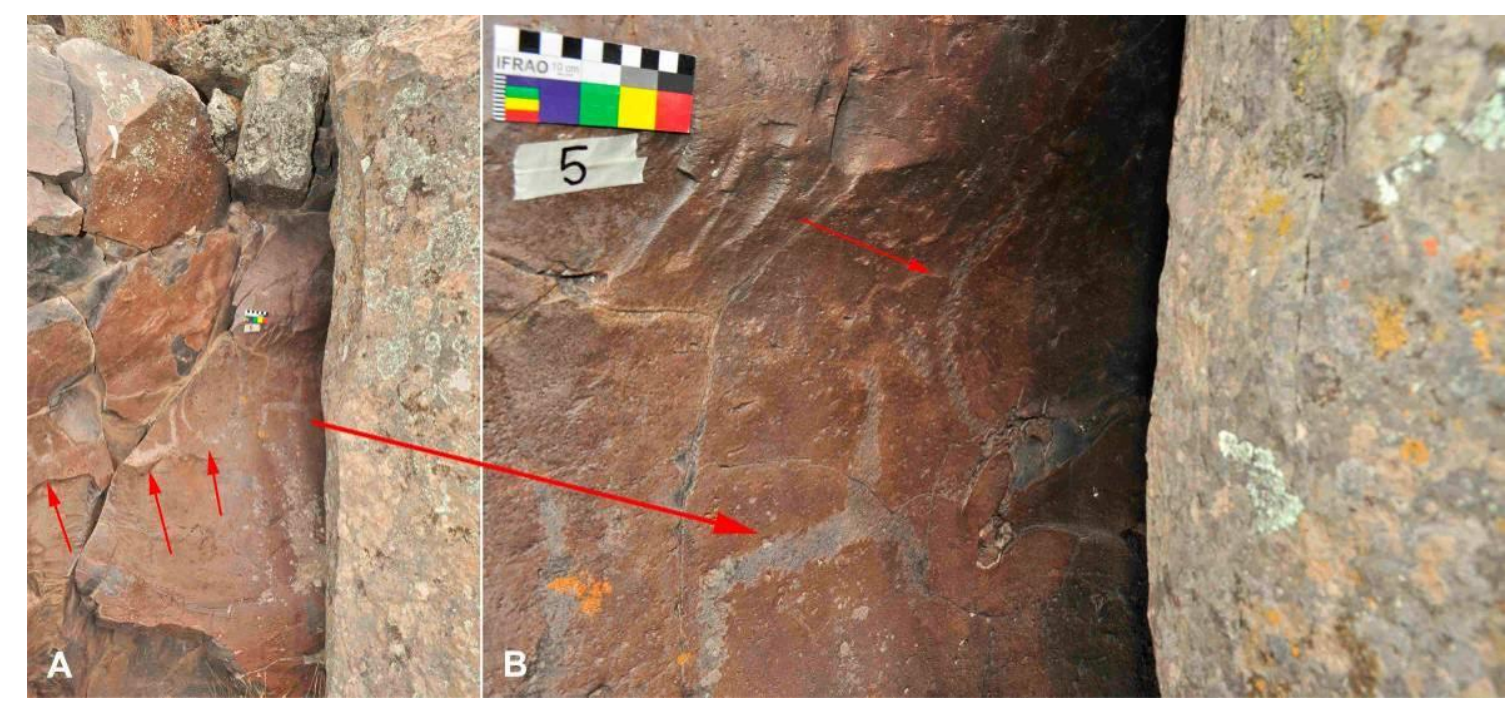

Figura 6.15. Conjunto 5: a. Vista del conjunto; b. Zoomorfo esquemático y semicircunferencia.

El sector 3 está conformado por los conjuntos 6 a 11. Está separado del anterior por 10,8 m de basalto sin ningún tipo de manifestación. Presenta bloques cuya orientación es hacia el E o el NNE, de los cuales se utilizaron superficies verticales de color rojizo, mayoritariamente irregulares. Los motivos se encuentran entre 0,55 y $1,75 \mathrm{~m}$ respecto del suelo actual, y pueden estar enmarcados por grietas o fallas naturales del soporte.

Conjunto 6. Está integrado por 14 motivos que se encuentran a $0,55 \mathrm{~m}$ del suelo actual. Se trata de motivos puntiformes, líneas rectas con diferente orientación, algunas pueden presentar apéndices; circunferencias y semicircunferencias; motivos "en forma de "U" o "media U" y un motivo combinado en el que se integran dos líneas curvas -una de ellas con apéndice corto transversal-, una circunferencia y una recta (Figura 6.16.a). Algunas de las exfoliaciones registradas interrumpen los surcos grabados, aunque también se empleó el borde y la superficie de exfoliación para la realización de algunos motivos curvilíneos mencionados anteriormente (Figura 6.16.b). 

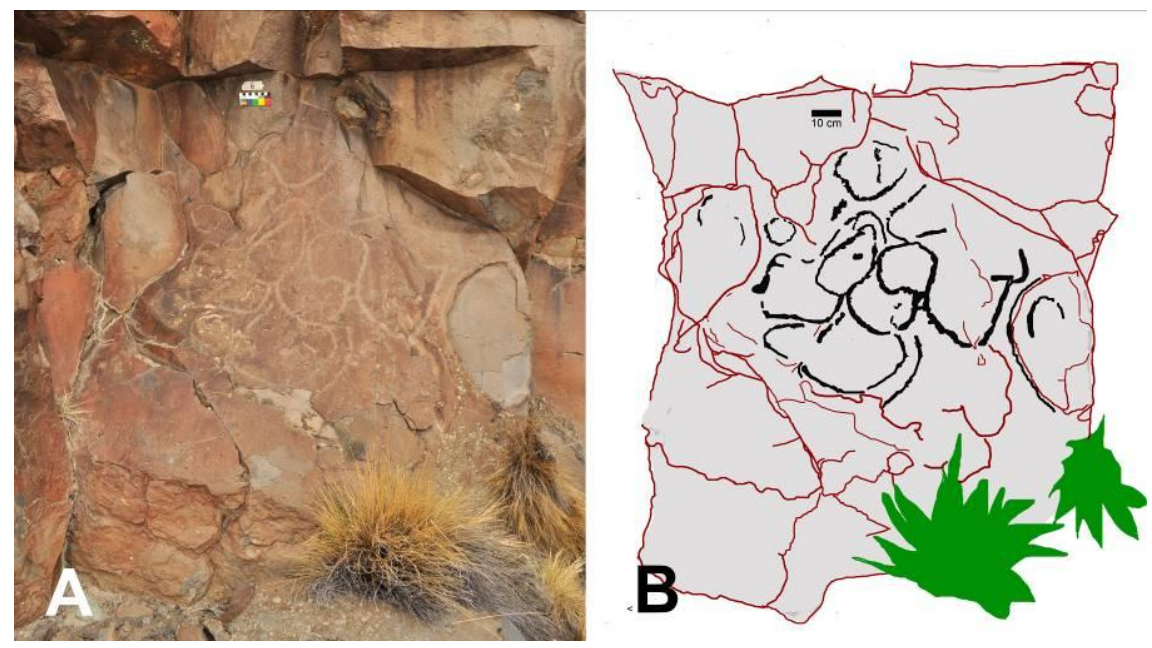

Figura 6.16. Conjunto 6: a. Fotografía del conjunto; b. Calco digital.

Motivo 7. Una circunferencia con apéndice rodeada por dos semicircunferencias concéntricas que se encuentra a 1,05 m del suelo actual. La semicircunferencia más externa está apenas esbozada por percusión superficial (Figura 6.17).

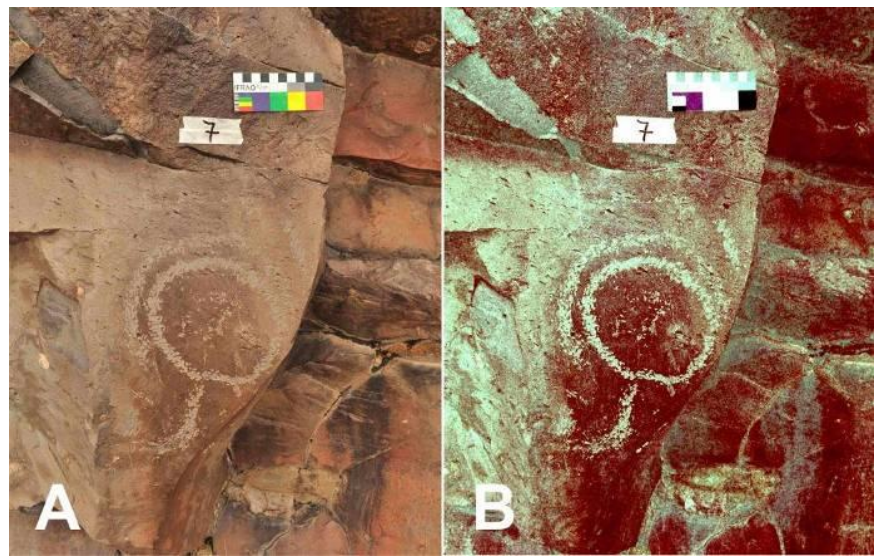

Figura 6.17. Motivo 7: a. Fotografía del motivo; b. Imagen tratada digitalmente (DStretch yre 30).

Conjunto 8. Está conformado por 21 motivos que se encuentran entre 0,59 y 1,30 m del suelo, entre los que se documentaron: puntos, líneas rectas con diferente orientación; una línea en ángulo recto invertida; líneas curvas con o sin apéndices, y un óvalo con una línea vertical en su interior. Dos motivos corresponden a superficies grabadas no determinadas (Figura 6.18.a). Los grabados incisos corresponden a rombos adosados verticalmente y a incisiones caóticas, algunas de las cuales se superponen a algunos de los motivos grabados por percusión (Figura 6.18.b). El motivo figurativo 
corresponde a una pisada de ave, cuyo eje central es largo y curvo. Las superposiciones y el motivo figurativo serán tratados más adelante.
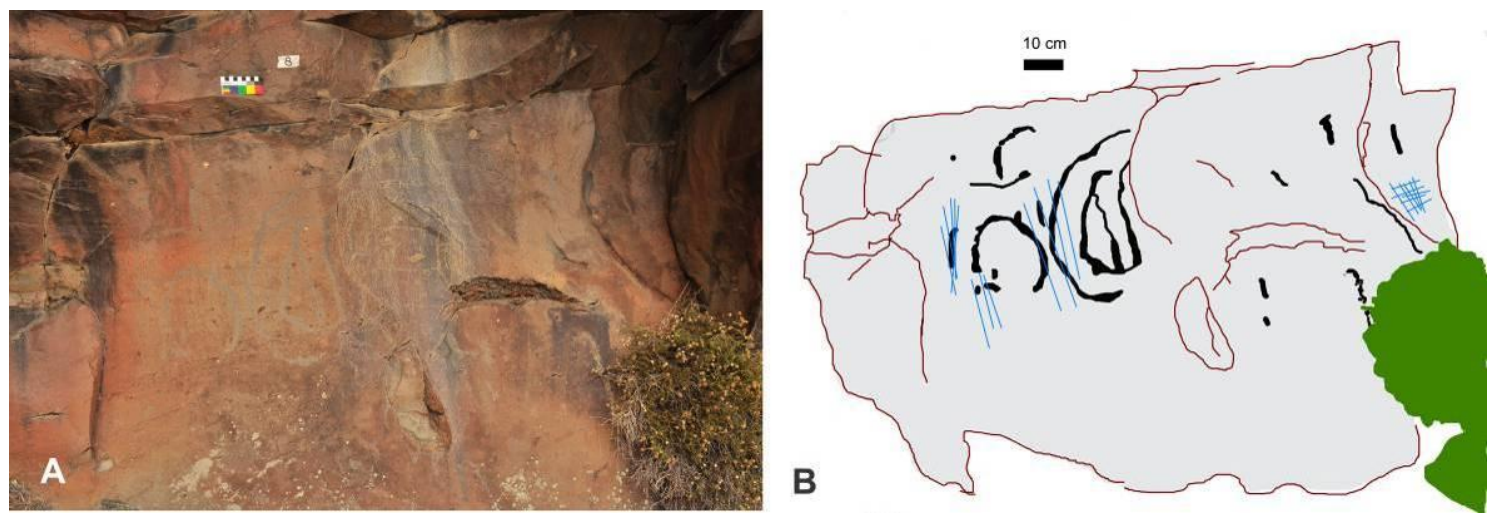

Figura 6.18. Conjunto 8: a. Fotografía del conjunto; b. Calco digital realizado a partir de la fotografía. En azul se indica la ubicación de los motivos incisos.

Conjunto 9. Se encuentra sobre dos superficies con diferente orientación dentro de un mismo bloque: una hacia el $\mathrm{N}$ y la otra hacia el E. Las alturas respecto del suelo a las que fueron registrados los motivos varían entre 0,66 m y $1,75 \mathrm{~m}$. Tres de esos motivos corresponden a superficies grabadas no determinadas, mientras que los restantes son líneas rectas o curvas verticales con dimensiones variables, un motivo en forma de "U invertida", y un motivo "en forma de U" adosadas de $88 \mathrm{~cm}$ de ancho, en el que se utilizó la convexidad existente entre ambas superficies del bloque (Figura 6.19).

Conjunto 10. Se encuentra a continuación del conjunto anterior, sobre la superficie vertical orientada al $\mathrm{N}$ y dista $0,30 \mathrm{~m}$ del suelo actual. Se trata de una circunferencia con un apéndice en ángulo recto, que presenta asociadas tres líneas rectas (Figuras 6.19). Este motivo mide $51 \mathrm{~cm}$ de ancho por 126 $\mathrm{cm}$ alto. En diferentes porciones de este motivo se superponen incisiones caóticas. 

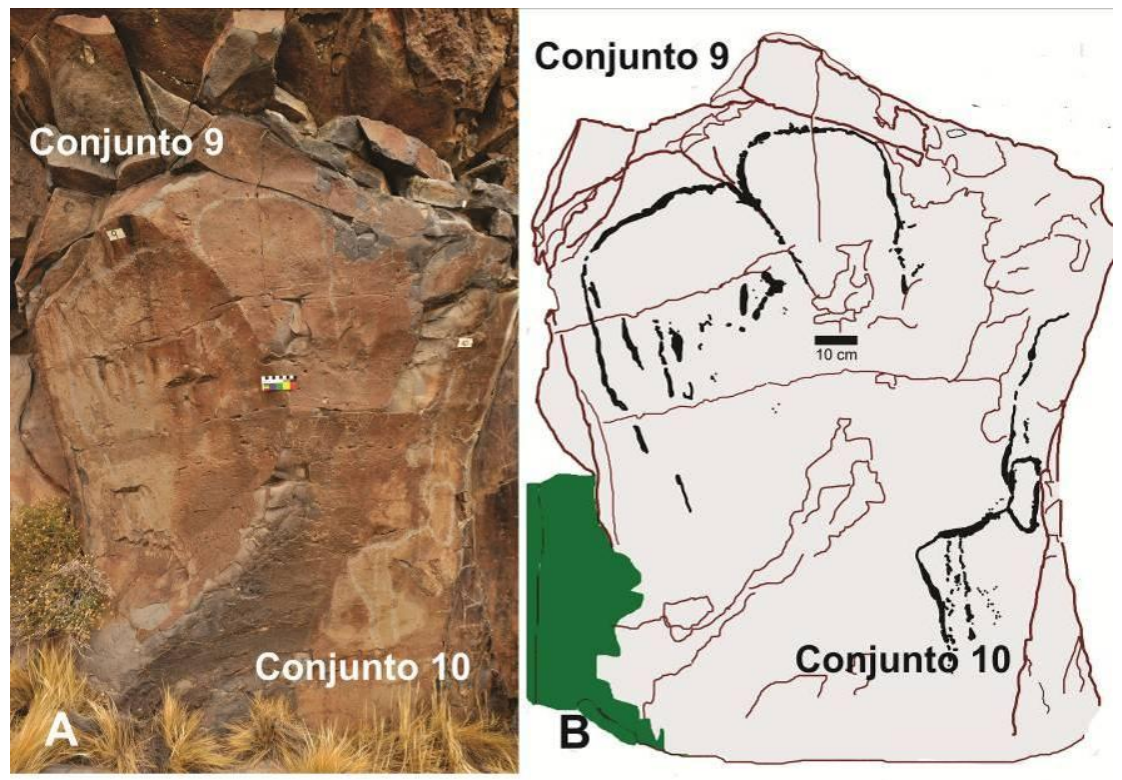

Figura 6.19. Conjuntos 9 y 10 de Bardas de Carlos: a. Fotografía de los conjuntos; b. Calco digital.

Conjunto 11. Se encuentra en una superficie irregular, a 1,35 m sobre el suelo. Está integrado por cinco motivos: una circunferencia con apéndice, un curvilíneo, dos líneas oblicuas y una pequeña superficie grabada no determinada.

En el sector 4 se relevó el Conjunto 12. Se encuentra a 9,5 m de distancia del sector 3 y se utilizó una superficie vertical orientada al N. Este conjunto está conformado por dos motivos realizados sobre una superficie irregular. A 1,40 m del suelo, en el sector central del panel, se observa una marca grabada superficial y, a menor altura, una línea zigzagueante.

El sector 5 está integrado por los motivos 13 y 14 (Figura 6.20.a). Dista $9,7 \mathrm{~m}$ del sector anterior y se utilizaron superficies verticales de tonalidad rojiza, orientadas al $\mathrm{N}$ y al $\mathrm{E}$, respectivamente.

Motivo 13. Se corresponde con incisiones finas superficiales (Figura 6.20.b).

Motivo 14. Se trata de una superficie grabada a $0,82 \mathrm{~m}$ del suelo actual, que está "enmarcada" por un desprendimiento del soporte (Figuras 6.20.c). 


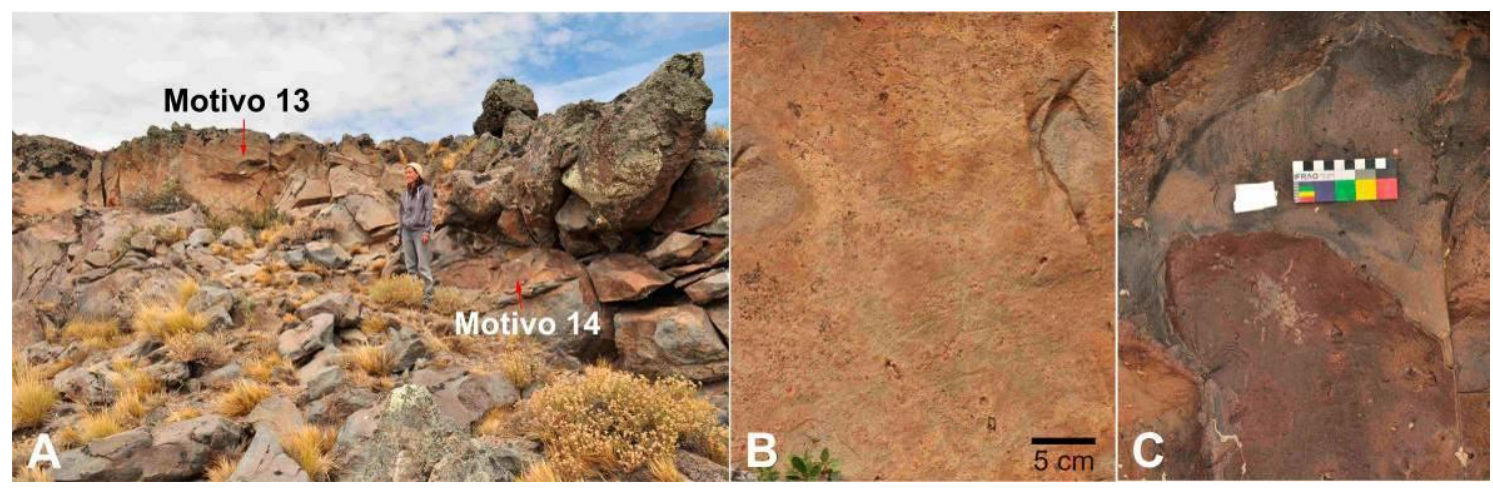

Figuras 6.20. Sector 4: a. Motivos documentados en el sector; b. Motivo 13; c. Motivo 14.

El sector 6 dista $10 \mathrm{~m}$ del sector anterior, e incluye los motivos 15 y 18 y los conjuntos 16 y 17 (Figura 6.21.a). Este sector corresponde a la finalización de la barda, donde se emplearon superficies con diferente orientación y altura respecto al suelo para la realización de los motivos

Motivo 15. Se encuentra a 1,15 m del suelo, sobre una superficie vertical. Se trata de incisiones caóticas.

Conjunto 16. Está ubicado sobre una superficie vertical, de coloración rojiza e irregular, orientada al NNW. El sector derecho del panel presenta un pequeño desprendimiento. A 0,12-0,30 m del suelo se registraron ocho motivos: tres líneas rectas (con diferente orientación), un óvalo con apéndice curvo y tres superficies grabadas no determinadas (Figura 6.21.b). Sobre todos los motivos del conjunto se observaron incisiones caóticas.

Conjunto 17. Se encuentra en el lugar donde termina el afloramiento, a 0,50 m del suelo sobre un bloque al pie de la barda. Está integrado por cinco motivos: un punto, una circunferencia, una línea recta y una superficie grabada no determinada (Figura 6.21.c). Sobre la circunferencia se observaron incisiones caóticas. 


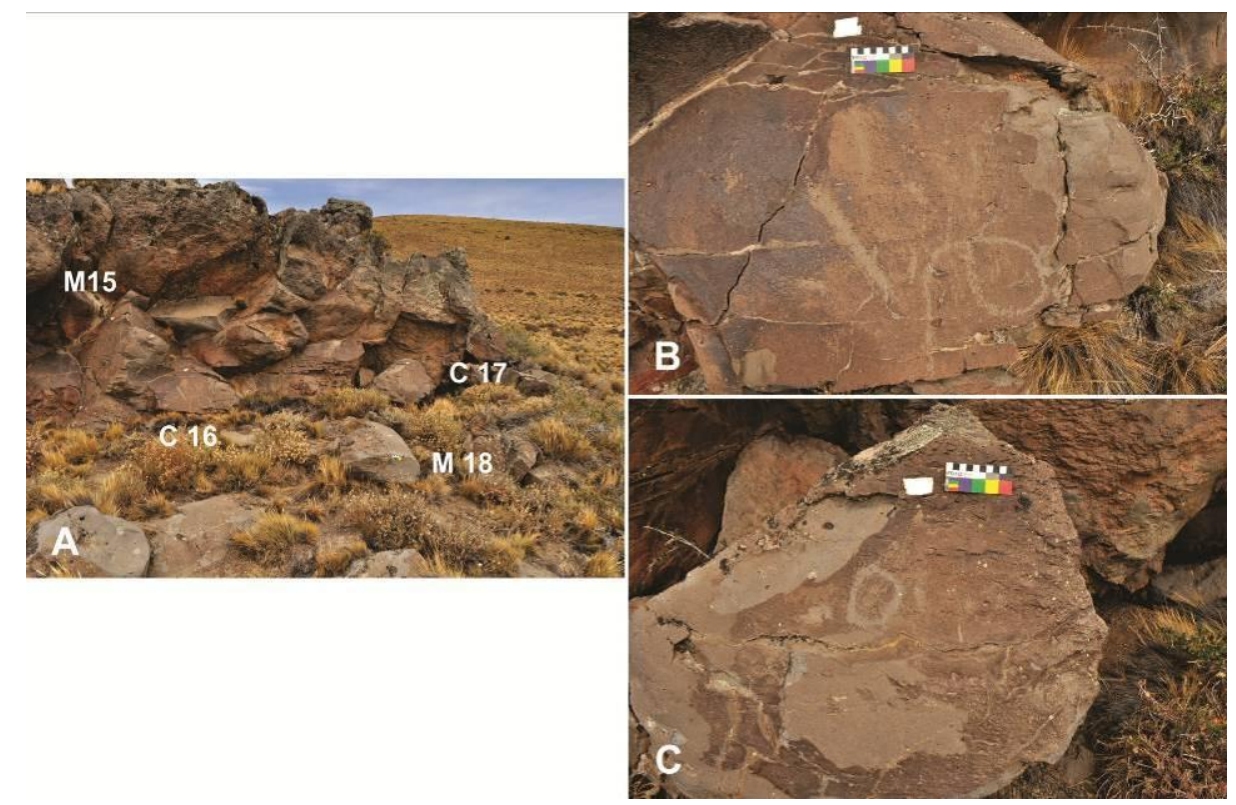

Figura 6.21. Motivos y conjuntos del sector 6: a. Detalle de la barda; b. Conjunto 16; c. Conjunto 17. Referencias. C: conjunto; M: Motivo.

Motivo 18. Frente al conjunto 17, sobre la superficie horizontal orientada al $\mathrm{N}$ de un bloque ubicado a 1,40 $\mathrm{m}$ de la barda. Esta superficie es de color gris (diferente al resto de lo observado en el sitio) y se encuentra a $0,45 \mathrm{~m}$ del suelo actual. El motivo está conformado por dos circunferencias adosadas: una de ellas presenta una línea interna y la otra tiene un pequeño apéndice en ángulo recto (Figura 6.22).

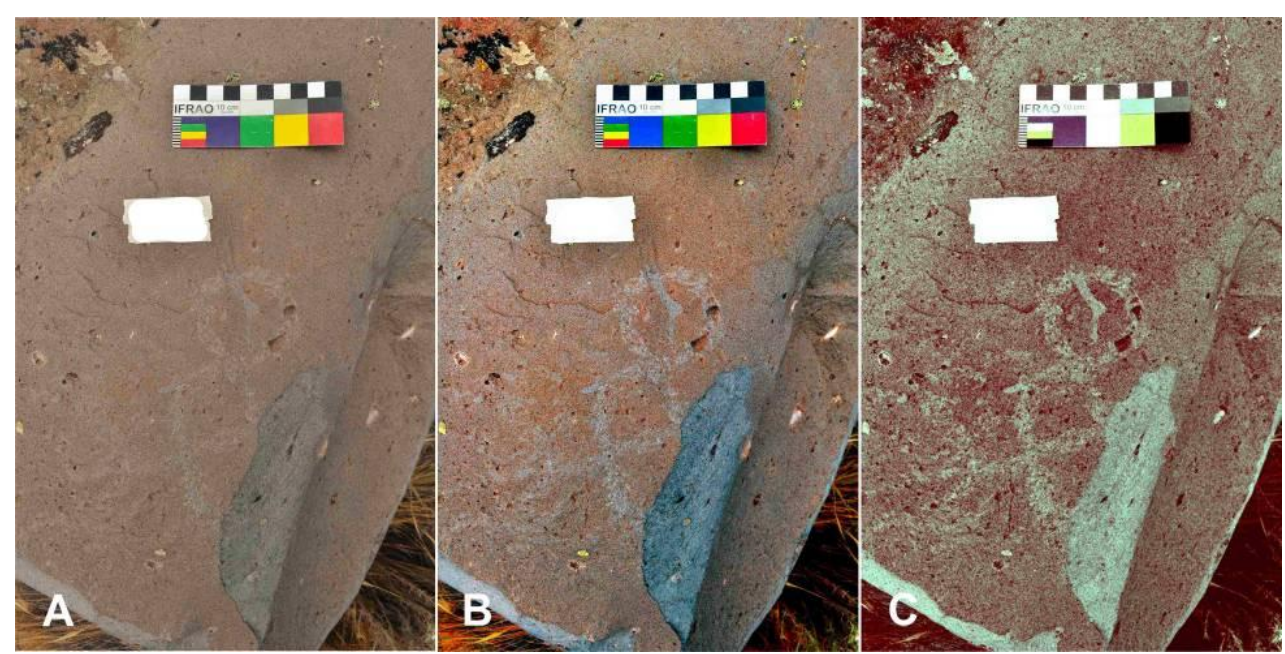

Figura 6.22. Motivo 18: a. fotografía sin modificar; b. Imagen tratada digitalmente (D-Stretch lab 15); c. Imagen tratada digitalmente (D-Stretch yre 30). 


\section{6. b. 3. Análisis}

Por las condiciones de emplazamiento y visibilidad que presentan (Tabla 6.4), los motivos de Bardas de Carlos se encuentran sobre diferentes superficies generalmente en posición vertical u oblicua, excepto en dos casos donde se utilizaron superficies de bloques desprendidos y alejados de la barda. En el Conjunto 2 se utilizó una superficie vertical mientras que para el Conjunto 18 la superficie del bloque empleada estaba horizontal. Por otro lado, la distancia entre los sectores 1 y 2 es de alrededor de $46 \mathrm{~m}$ mientras que los restantes sectores del sitio se encuentran equidistantes a $10 \mathrm{~m}$ aproximadamente.

\begin{tabular}{|c|c|c|c|c|c|c|c|}
\hline \multirow{2}{*}{\multicolumn{2}{|c|}{ Variables }} & \multicolumn{6}{|c|}{ Sectores } \\
\hline & & 1 & 2 & 3 & 4 & 5 & 6 \\
\hline Emplazamiento & $\begin{array}{l}\text { pared } \\
\text { bloque }\end{array}$ & $\begin{array}{l}X \\
X\end{array}$ & $\mathrm{X}$ & $\mathrm{X}$ & $\mathrm{X}$ & $\mathrm{X}$ & $\begin{array}{l}X \\
X\end{array}$ \\
\hline Posición & $\begin{array}{l}\mathrm{H} \\
\mathrm{V} \\
\mathrm{O}\end{array}$ & $\begin{array}{l}X \\
X\end{array}$ & $\begin{array}{l}X \\
X\end{array}$ & $\begin{array}{l}X \\
X\end{array}$ & $\mathrm{X}$ & $\mathrm{X}$ & $\begin{array}{l}\mathrm{X} \\
\mathrm{X}\end{array}$ \\
\hline Orientación & $\begin{array}{l}\mathrm{N} \\
\mathrm{S} \\
\mathrm{E} \\
\mathrm{W}\end{array}$ & $\begin{array}{l}\mathrm{X} \\
\mathrm{X} \\
\mathrm{X}\end{array}$ & $\mathrm{X}$ & $\mathrm{X}$ & $\mathrm{X}$ & $\mathrm{X}$ & $\mathrm{X}$ \\
\hline $\begin{array}{l}\text { Distancia al } \\
\text { suelo } \\
\text { en } \mathrm{m}\end{array}$ & $\begin{array}{l}>2 \\
2-1,6 \\
1,5-1 \\
<1\end{array}$ & $\begin{array}{l}X \\
X\end{array}$ & $\mathrm{X}$ & $\begin{array}{l}X \\
X \\
X\end{array}$ & $\begin{array}{l}X \\
X\end{array}$ & $\mathrm{X}$ & $\mathrm{X}$ \\
\hline $\begin{array}{l}\text { Campo visual } \\
\text { máximo en } \mathrm{m}\end{array}$ & $\begin{array}{l}1 \\
3 \\
7 \\
15\end{array}$ & $\begin{array}{l}\mathrm{X} \\
\mathrm{X}\end{array}$ & $\mathrm{X}$ & $\begin{array}{l}\mathrm{X} \\
\mathrm{X}\end{array}$ & $\mathrm{X}$ & $\mathrm{X}$ & $\begin{array}{l}\mathrm{X} \\
\mathrm{X}\end{array}$ \\
\hline Iluminación & $\begin{array}{l}\text { luz tarde } \\
\text { luz mañana }\end{array}$ & $\mathrm{X}$ & $\mathrm{X}$ & $\mathrm{X}$ & $\mathrm{X}$ & $\mathrm{X}$ & $\begin{array}{l}\mathrm{X} \\
\mathrm{X}\end{array}$ \\
\hline Visibilidad & $\begin{array}{l}\text { 1) alta } \\
\text { 2) intermedia } \\
\text { 3) baja } \\
\text { 4) muy baja }\end{array}$ & $\begin{array}{l}X \\
X\end{array}$ & $\begin{array}{l}\mathrm{X} \\
\mathrm{X}\end{array}$ & $\begin{array}{l}\mathrm{X} \\
\mathrm{X}\end{array}$ & $\mathrm{X}$ & $\mathrm{X}$ & $\begin{array}{l}\mathrm{X} \\
\mathrm{X} \\
\mathrm{X}\end{array}$ \\
\hline Motivos & $\begin{array}{l}\text { Puntiformes } \\
\text { Rectilíneos } \\
\text { Incisiones caóticas } \\
\text { Circulares lineales } \\
\text { Curvilíneos } \\
\text { ND } \\
\text { Guanaco } \\
\text { esquemático } \\
\text { Pisada de ave }\end{array}$ & $\begin{array}{l}\mathrm{X} \\
\mathrm{X} \\
\mathrm{X} \\
\mathrm{X} \\
\mathrm{X} \\
\mathrm{X}\end{array}$ & $\begin{array}{l}X \\
X\end{array}$ & $\begin{array}{l}\mathrm{X} \\
\mathrm{X} \\
\mathrm{X} \\
\mathrm{X} \\
\mathrm{X} \\
\mathrm{X} \\
\mathrm{X}\end{array}$ & $\mathrm{X}$ & $\mathrm{X}$ & $\begin{array}{l}\mathrm{X} \\
\mathrm{X} \\
\mathrm{X} \\
\mathrm{X}\end{array}$ \\
\hline
\end{tabular}

Tabla 6.4. Condiciones de emplazamiento y visibilidad en Bardas de Carlos. 
En los sectores 1 y 3 se documentaron motivos a alturas superiores a 1,50 $\mathrm{m}$, en tanto que para los restantes sectores las alturas son inferiores a 1,50 m. Entre los motivos y los conjuntos definidos en el sitio, el $80 \%$ posee una visibilidad baja, ya que pueden ser observados desde una distancia cercana a los $3 \mathrm{~m}$. Entre los factores que limitan su campo visual se pueden mencionar la superficie irregular de la barda y el escaso contraste entre el surco grabado y el soporte rocoso. Esta situación estaría señalando un factor tafonómico de visibilidad ya que posiblemente al momento de su producción los surcos grabados habrían sido más visibles. En el sector 2, el Conjunto 5 presenta muy baja visibilidad dado que, si bien los motivos se encuentran sobre superficies libre de líquenes, están sobre la barda, "protegidos" o "tapados" parcialmente por bloques, de modo tal que el conjunto no se puede observar completamente a una distancia superior a $1 \mathrm{~m}$ (ver Figura 6.15.a). De igual modo, el motivo romboidal documentado en el conjunto 8 así como las incisiones caóticas que lo acompañan presentan baja visibilidad por el escaso contraste entre el surco grabado y la pátina del soporte. Los Conjuntos 9 y 10 del sector 3 presentan una visibilidad intermedia debido al contraste entre el surco grabado y el soporte, además de las dimensiones de los motivos (ver Figura 6.19).

La técnica empleada para la ejecución del 89\% de los motivos fue percusión. Por el momento, resulta sumamente difícil discernir si fue directa o indirecta. Se ha reconocido como técnica complementaria la incisión, principalmente para la ejecución de líneas finas caóticas de los sectores 1, 3, 5 y 6. Tales incisiones pueden encontrarse por encima o por debajo de motivos realizados por percusión (como se detalla más adelante), o pueden haber sido realizadas sobre superficies libres de motivos. En los Motivos 13 y 15 así como el Conjunto 8 (Figura 6.23) corresponden a líneas caóticas registradas en superficies libres de otro tipo de motivos. Los rombos adosados verticalmente del Conjunto 8 (Figura 6.23.b) fueron realizados con un instrumento filoso, el cual permitió mantener el tamaño y la forma del surco inciso durante el proceso de trabajo, ya que no se observan trazos incisos superpuestos o sobrepasados. 


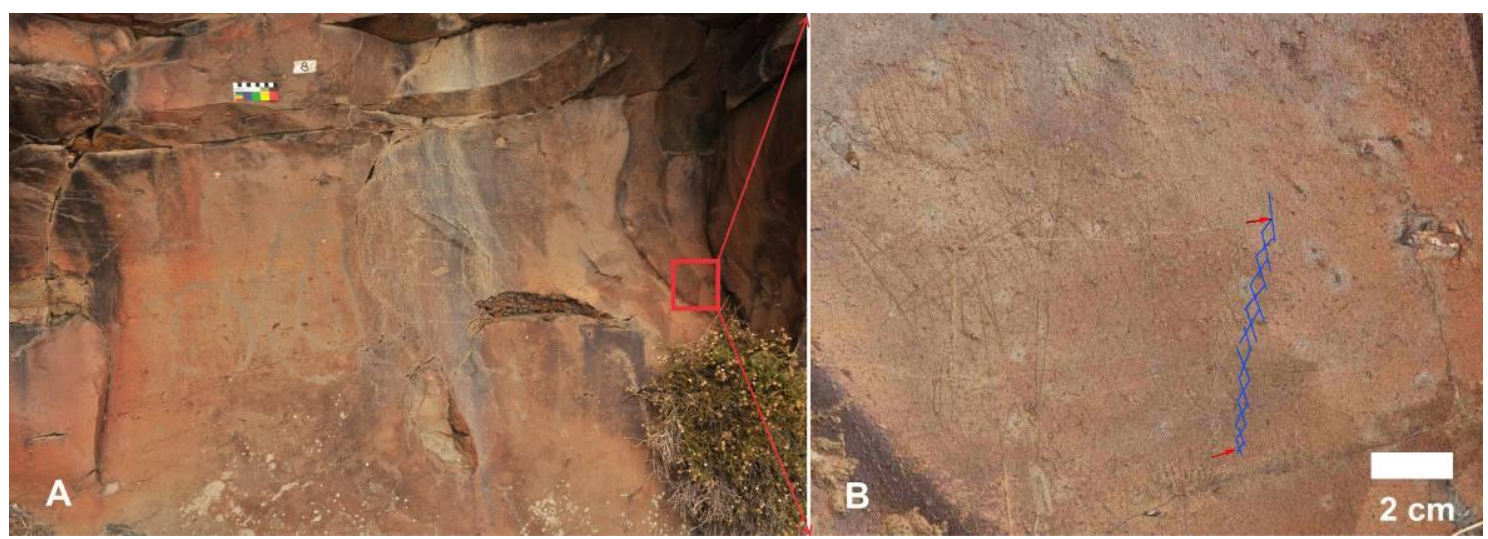

Figura 6.23. Motivos incisos del Conjunto 8: a. Ubicación de los motivos incisos dentro del conjunto; b. Detalle de las incisiones, obsérvese los rombos adosados hacia la porción media imagen (dibujado al costado en azul).

En relación a la pátina de los motivos, en Bardas de Carlos se registraron los tres grados definidos en el Capítulo 2: clara, intermedia y oscura (Figura 6.24). Asimismo, el motivo 14 (ver Figura 6.20.c) es el único motivo del sitio que presenta pátina clara-intermedia vinculada, probablemente, con la profundidad del surco y la superficie sobre la que se encuentra. En líneas generales, se observó un amplio predominio de motivos con pátina clara, presentes en casi todos los sectores (Figura 6.24), mientras que aquellos motivos con pátina intermedia se registraron en los sectores 2 y 3 . Los motivos con pátina oscura se corresponden con la mayoría de las incisiones caóticas y se encuentran en los sectores 1, 3 y 5. Los dos motivos registrados en los que no se pudo determinar la pátina se encuentran en el sector 2 , cuyo surco se encontraba parcialmente obliterado por restos de líquenes.

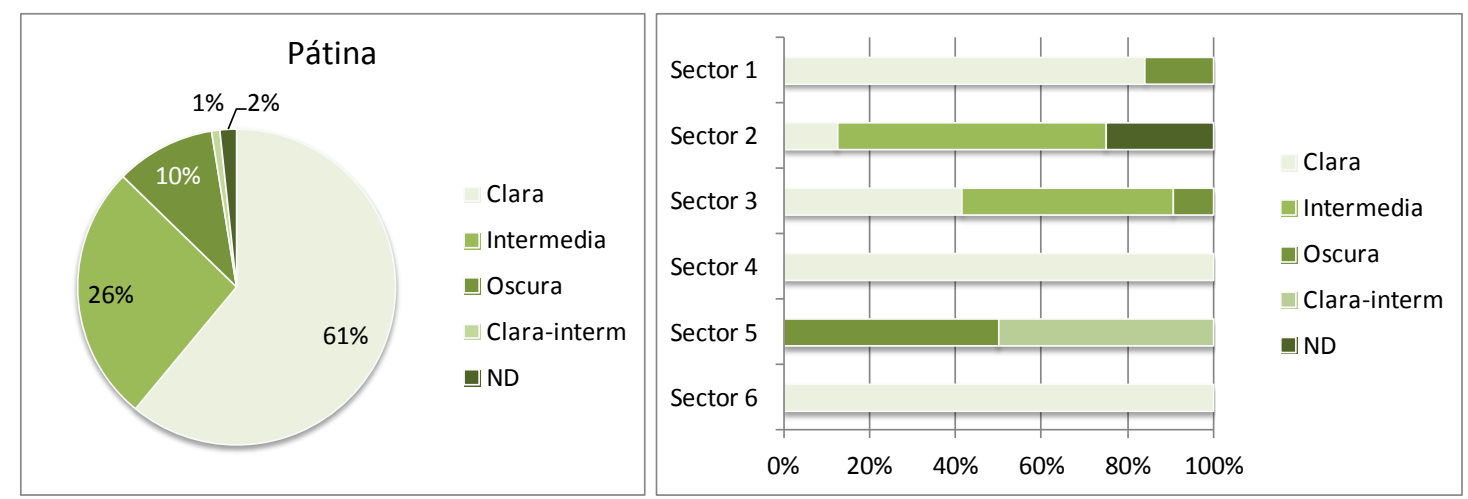

Figura 6.24. Pátinas en Bardas de Carlos: a. Proporciones de los tipos de pátina; b. Proporciones acumuladas por tipos de pátina por sector. Clara-interm: Claraintermedia; ND: no determinada. 
Haciendo un análisis de las catorce superposiciones registradas en el sitio, se observa que en el $78,57 \%$ de los casos las incisiones caóticas presentan pátina más oscura que los motivos subyacentes (Tabla 6.5; Figura 6.25), mientras que el $14,28 \%$ de las superposiciones presenta motivos inferiores y superiores con pátina clara. Sólo en una de las superposiciones $(7,14 \%)$ se registraron líneas incisas con pátina oscura por debajo de un motivo con pátina intermedia (Figura 6.25). La primera situación resulta llamativa ya que la expectativa es la contraria: que los motivos superiores presenten pátina similar o más clara que los inferiores. En la meseta del Lago Strobel son escasas las superposiciones que presentan características parecidas:

"donde la pátina menos desarrollada se encuentra en posición inferior a una más fuerte, los motivos superiores se habian ejecutado mediante inciso y los inferiores por picado, entendiéndose, por lo tanto, que las diferencias de pátinas observadas en esos ejemplos se relacionan con la técnica de ejecución” (Re 2011: 152).

Probablemente, el/los artefacto/s empleado/s para la realización de las incisiones no lograron atravesar la pátina del soporte, razón por la cual los surcos incisos superiores presentan una coloración oscura en relación a los motivos inferiores. Será ésta una cuestión en la que se deberá ahondar con trabajos experimentales adicionales.

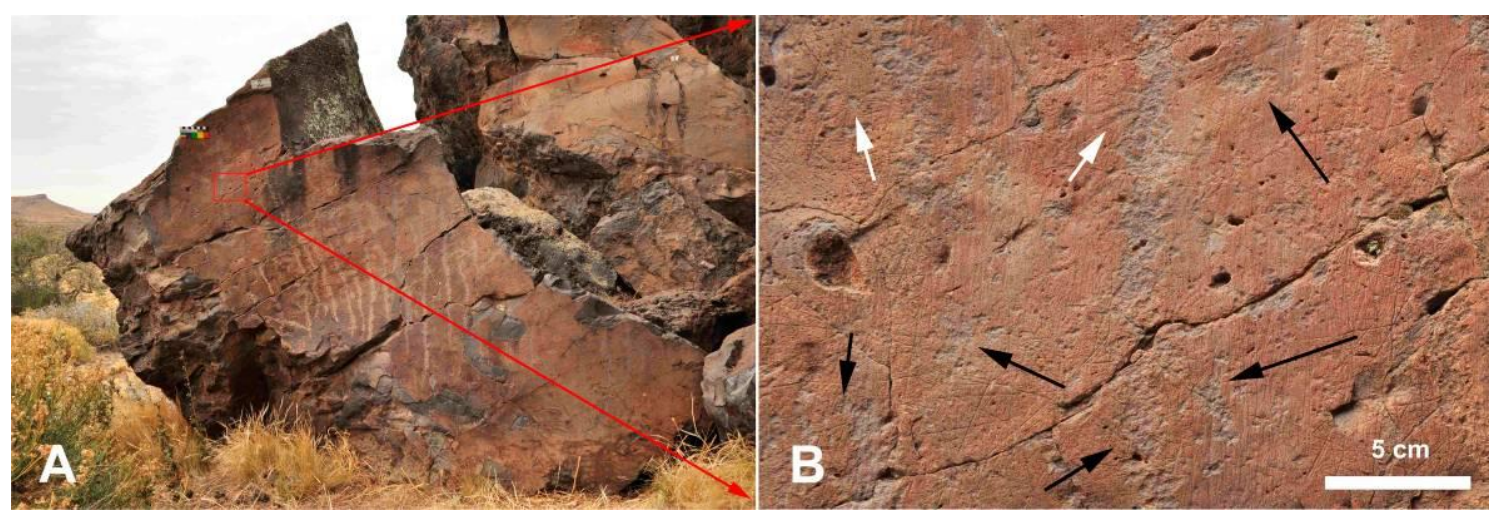

Figura 6.25. Superposición del conjunto 2: incisiones caóticas por encima (flecha blanca) y por debajo (flecha negra) de línea vertical realizada por percusión. 


\begin{tabular}{|c|c|c|c|c|c|}
\hline \multirow{2}{*}{ Sector } & \multirow{2}{*}{ Conjunto } & \multicolumn{4}{|c|}{ Motivo } \\
\hline & & Inferior & Pátina & Superior & Pátina \\
\hline \multirow{8}{*}{1} & \multirow[t]{4}{*}{1} & $\begin{array}{l}\text { Línea sinuosa que termina } \\
\text { en circulo lleno }\end{array}$ & Clara & \multirow{6}{*}{$\begin{array}{l}\text { Líneas } \\
\text { caóticas }\end{array}$} & Oscura \\
\hline & & Óvalo con punto central & Clara & & Oscura \\
\hline & & Óvalo & Clara & & Oscura \\
\hline & & Línea curva & Clara & & Oscura \\
\hline & \multirow[t]{4}{*}{2} & Grabado no determinado & Intermedia & & Oscura \\
\hline & & Línea vertical larga & Intermedia & & Oscura \\
\hline & & Líneas caóticas & Oscura & Línea vertical larga & Intermedia \\
\hline & & $\begin{array}{l}\text { Circunferencia con apéndice } \\
\text { recto }\end{array}$ & Clara & \multirow[t]{7}{*}{$\begin{array}{c}\text { Líneas } \\
\text { caóticas }\end{array}$} & Oscura \\
\hline \multirow{4}{*}{3} & \multirow[t]{3}{*}{8} & Línea vertical corta & Clara & & Oscura \\
\hline & & Tridígito & Clara & & Oscura \\
\hline & & "media U"+ óvalo & Clara & & Oscura \\
\hline & 10 & Circunferencia con apéndice & Clara & & Clara \\
\hline \multirow[t]{2}{*}{6} & 16 & $\begin{array}{l}\text { Línea recta, óvalo con } \\
\text { apéndice, grabado ND }\end{array}$ & Clara & & Clara \\
\hline & 17 & Circunferencia & Clara & & Clara \\
\hline
\end{tabular}

Tabla 6.5. Superposición de motivos por sector y conjunto. Los motivos subyacentes se realizaron por percusión y los superpuestos se realizaron por incisión, salvo el caso sombreado.

Si se analiza cada uno de los sectores es posible observar diferencias con respecto a la cantidad y diversidad de motivos que presentan. Particularmente, se observa que el $84 \%$ de los motivos se concentra en los tres primeros sectores y presentan todos los subgrupos de motivos no figurativos (Figura 6.26). En los sectores 1 y 3 predominan los rectilíneos seguidos por los curvilíneos (Figura 6.26). En el sector 2 predominan los motivos circulares lineales y se registró el único motivo zoomorfo del sitio. Los sectores 4 y 5 presentan motivos rectilíneos y grabados no determinados, en el sector 6 son frecuentes los motivos rectilíneos. La mayor cantidad de motivos rupestres se encuentra en el sector 3, a lo largo de 7,5 $\mathrm{m}$ y el que presenta todos los subgrupos de motivos analizados. Esta distribución resulta llamativa si se considera la extensión total de la barda (130 m).

Se puede analizar la distribución espacial de los subgrupos de motivos predominantes (rectilíneos, circulares lineales y curvilíneos), que aúnan $79,67 \%$ del total del sitio $(n=94)$. Estos subgrupos, a su vez, están divididos en clases, lo que permite reducir la variabilidad documentada en los tipos de motivos y observar alguna tendencia. Los rectilíneos fueron divididos según su complejidad en rectas simples (incluyen líneas rectas con diferente 
orientación), rectas con apéndices (oblicuos o transversales), series de líneas paralelas, líneas caóticas y líneas combinadas. En Bardas de Carlos, estas últimas se corresponden con el motivo de rombos unidos por el vértice del Conjunto 8 y aquel en forma de "U invertidas" adosadas del Conjunto 9, las cuales se identificaron en el sector 3 de manera exclusiva.

Los motivos rectilíneos están presentes en todos los sectores. Los circulares lineales se encuentran en los sectores 1 a 3 y 6 , la variabilidad observada consta de siete categorías. En los motivos curvilíneos las categorías identificadas son cinco (Figura 6.26), y fueron registrados en los tres primeros sectores.

La información anterior señala que en Bardas de Carlos, si bien los motivos fueron registrados en mayor número y con mayor variabilidad en el sector 3, la distribución espacial por clases indicaría la selección de los tres primeros sectores para plasmar cierto tipo de motivos. 


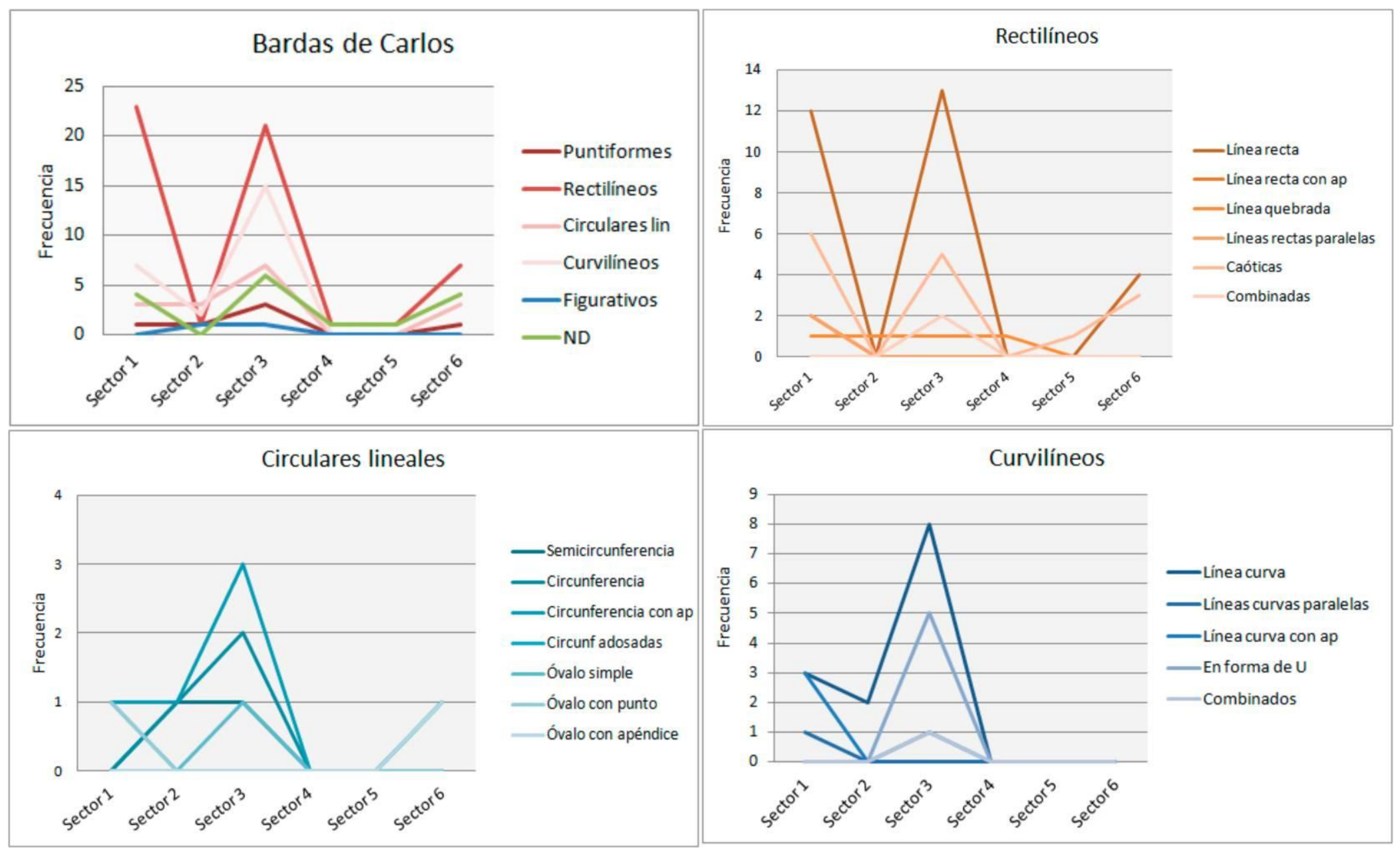

Figura 6.26. Proporciones acumuladas y frecuencias de las clases de motivos identificadas en Bardas de Carlos. Referencias: Circulares lin: circulares lineales; ND: no determinado; línea recta con ap: línea recta con apéndice; circunferencia con ap: circunferencia con apéndice; circunf adosadas: circunferencias adosadas; línea curva con ap: línea curva con apéndice. 
Al cruzar la información respecto de las clases de motivos con el tipo de pátina reconocida se observa que predominan los motivos con pátina clara e intermedia, coincidente con el patrón observado en el sitio (Tabla 6.6). Las categorías contempladas presentan pátina clara e intermedia en proporciones variables, en tanto que la mayoría de las líneas caóticas y una baja proporción de "otros rectilíneos" presentan pátina oscura (Figura 6.27).

\begin{tabular}{|l|c|c|c|c|c|c|c|c|c|c|}
\cline { 2 - 12 } \multicolumn{1}{c|}{} & \multicolumn{10}{c|}{ Pátina } \\
\hline \multicolumn{1}{|c}{ Clases de motivos } & C & $\%$ & I & $\%$ & O & $\%$ & ND & $\%$ & Subtotal & $\%$ \\
\hline Línea recta & 23 & 24,47 & 6 & 6,38 & 0 & 0 & 0 & 0 & 29 & 30,85 \\
\hline Línea quebrada & 2 & 2,12 & 1 & 1,06 & 0 & 0 & 1 & 1,06 & 4 & 4,24 \\
\hline Líneas caóticas & 4 & 4,24 & 0 & 0 & 11 & 11,66 & 0 & 0 & 15 & 15,9 \\
\hline Otros rectilíneos & 5 & 5,30 & 0 & 0 & 1 & 1,06 & 0 & 0 & 6 & 6,38 \\
\hline Semicircunferencia & 0 & 0 & 1 & 1,06 & 0 & 0 & 1 & 1,06 & 2 & 2,12 \\
\hline Circunferencia & 1 & 1,06 & 3 & 3,18 & 0 & 0 & 0 & 0 & 4 & 4,24 \\
\hline Circunferencia con apéndice & 4 & 4,24 & 1 & 1,06 & 0 & 0 & 0 & 0 & 5 & 5,30 \\
\hline Otros circulares lineales & 4 & 4,24 & 1 & 1,06 & 0 & 0 & 0 & 0 & 5 & 5,30 \\
\hline Línea curva & 7 & 7,42 & 6 & 6,38 & 0 & 0 & 0 & 0 & 13 & 13,78 \\
\hline Línea curva con apéndice & 3 & 3,18 & 1 & 1,06 & 0 & 0 & 0 & 0 & 4 & 4,24 \\
\hline "En forma de U" & 2 & 2,12 & 3 & 3,18 & 0 & 0 & 0 & 0 & 5 & 5,30 \\
\hline Otros curvilíneos & 2 & 2,12 & 0 & 0 & 0 & 0 & 0 & 0 & 2 & 2,12 \\
\hline \multicolumn{1}{|c|}{ Total } & 57 & 60,63 & 23 & 24,47 & 12 & 12,72 & 2 & 2,12 & 94 & 100 \\
\hline
\end{tabular}

Tabla. 6.6. Frecuencias de los tipos de pátina para las diferentes clases de motivos reconocidas en Bardas de Carlos. Referencias: C: Clara; I: intermedia; O: Oscura; ND: no determinada

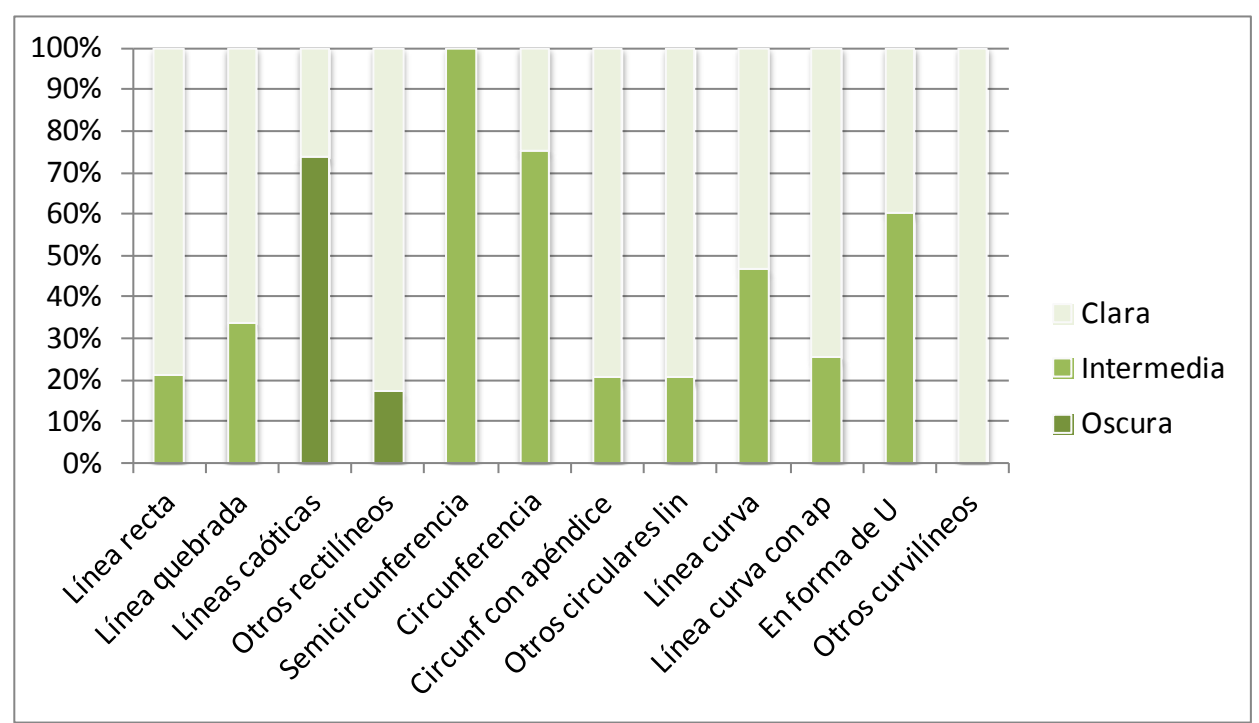

Figura 6.27. Distribución porcentual de los grados de pátina por clases de motivos, sin contemplar aquellos con pátina no determinada. Referencias: Circunf con apéndice: Circunferencia con apéndice; Otros circulares lin: otros circulares lineales; línea curva con ap: línea curva con apéndice. 
Respecto de los motivos figurativos, en Bardas de Carlos este grupo de está representado por un zoomorfo esquemático y una pisada de ave, o tridígito, cuyo dedo medio es largo y curvo (Figura 6.28). Este tridígito se asemeja al registrado en el sitio Laguna del Cerro Bonete, a 3,3 km de distancia. Además de las semejanzas formales entre ambos tridígitos, llama la atención la asociación con motivos similares, como líneas "en forma de U" y óvalos con líneas verticales en su interior (ver Carden 2008a: 232).

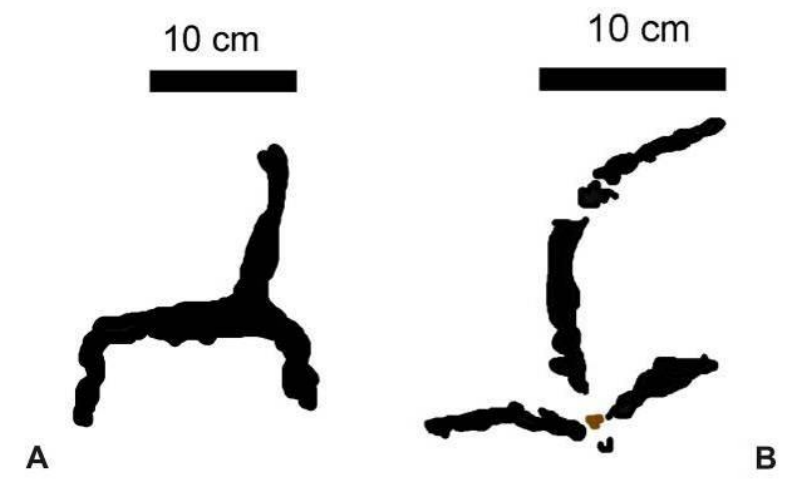

Figura 6.28. Motivos figurativos de Bardas de Carlos: a. Zoomorfo esquemático; b. Tridígito con dedo medio largo y curvo.

Los grabados de Bardas de Carlos presentan las siguientes características:

1) la técnica más utilizada fue la percusión, siendo la incisión menos abundante que la anterior;

2) en cuanto a su diseño, si bien se detectó variabilidad, la mayor parte de los grabados son rectilíneos (53\%) y curvilíneos (25\%);

3) en líneas generales, los motivos presentan una pátina clara o intermedia que apenas contrasta con la superficie de color castaño oscuro-rojiza del soporte conformado por los basaltos;

4) se detectaron escasas superposiciones, principalmente en los sectores 1, 3 y 6, donde se observan motivos incisos finos sobre motivos realizados por percusión. Los primeros fueron reconocidos exclusivamente a partir de la observación cercana, ya que en su mayoría presentan pátina oscura. Es posible, entonces, que las superposiciones estén implicando una situación de diacronía. Son necesarios mayores estudios para poder reconocer el instrumento con el que fueron realizadas las incisiones caóticas. 
5) Por último, resulta llamativa la ubicación y la coloración de la superficie sobre la que se encuentra el motivo 18 (ver Figura 6.21), que es diferente a la del resto del sitio. Se encuentra sobre una superficie horizontal de color gris, de un bloque alejado y enfrentado de la barda, se trata de circunferencias adosadas con trazos internos y externos, motivo que no se ha repetido en el sitio. Quizás esta situación implique, adicionalmente, un momento de producción diacrónico en relación al resto del sitio ya que se observan superficies disponibles sobre la barda, libres de líquenes que no fueron seleccionadas.

A partir de esos factores (técnica, diseño, pátina y escasas superposiciones) se podría pensar que la mayor parte de los grabados de Bardas de Carlos fueron realizados con una sincronía relativa, a excepción de las incisiones caóticas -de pátina oscura- y del motivo 18 -sobre superficie horizontal-. Esta idea implica distintos eventos de producción de los grabados por gente que compartía cánones similares de representación de las imágenes: para los motivos grabados por percusión se escogieron diseños rectilíneos y curvilíneos mayoritariamente, mientras que las incisiones se corresponden con diseños rectilíneos exclusivamente.

\section{6. c. LOS NAVARROS}

Este sitio se ubica en la porción sudoriental de una laguna actualmente seca, aunque en el pasado tuvo varias cotas de nivel de agua (Figura 6.29). En las márgenes $\mathrm{N}$ y $\mathrm{NE}$ del bajo se observan pequeños manantiales y surgentes. Los grabados se disponen a lo largo de $166 \mathrm{~m}$ de la barda basáltica que constituye la margen SW del bajo. Sus coordenadas geográficas son $47^{\circ} 45^{\prime} 20,56^{\prime \prime} \mathrm{S}$ y $69^{\circ} 4^{\prime} 4,31^{\prime \prime} \mathrm{W}$, por lo que se encuentra en la cabecera sur del Zanjón Blanco (sector I). Este sitio fue localizado por el Sr. Ramón Cano, quien nos brindó la información necesaria para acceder al mismo en 2008 y 2012. 


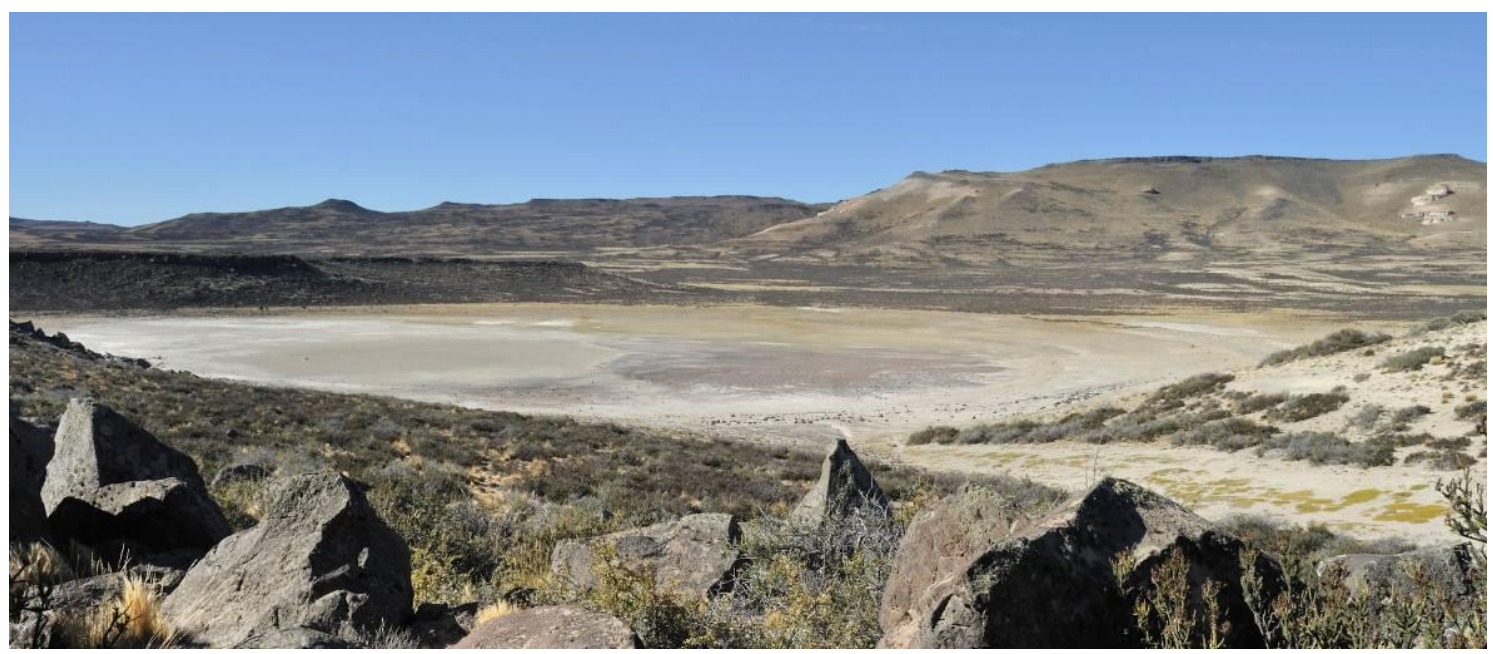

Figura 6.29. Laguna de Los Navarros vista desde el sector con arte rupestre.

El límite oriental del bajo está marcado por una serranía mientras que su margen meridional está dada por la meseta de Los Navarros, con la barda y los bloques desprendidos de ella, en la que se registraron los grabados. Los basaltos corresponden a la formación Basalto Alma Gaucha (Panza 2001), que en este sector del macizo presenta coloración variada, en diferentes gamas del gris, rojo y marrón, y cuyas superficies pueden presentar fracturas de tipo recta angular. El grado de meteorización de los basaltos es heterogéneo, dado principalmente por el grado de insolación diferencial que reciben las rocas, el escurrimiento superficial de agua y la presencia de líquenes.

La orientación de la barda en la que se encuentran los grabados es SENW, razón por la cual la mayoría de los conjuntos y motivos recibe insolación directa hasta las 14 horas (en verano). Existen casos en los que la insolación es mayor debido a la orientación que presentan los paneles y a la presencia o ausencia de reparo en el resto de la barda.

\section{6. c. 1. Hallazgos arqueológicos en la localidad}

Aproximadamente a $100 \mathrm{~m}$ del último conjunto de grabados que conforma el sitio se observa la disyunción entre la corona basáltica y las rocas sedimentarias subyacentes. Esta disyunción se corresponde con la presencia 
de diferentes materias primas colorantes, principalmente de color rosado y de grano grueso (Figura 6.30.a). Asimismo, en el extremo occidental de la barda se registró una estructura de piedra (Figura 6.30.b) (Miotti et al. 2012).

En diferentes sectores de la barda y en los distintos niveles de paleoplayas de la laguna se observaron concentraciones de artefactos líticos, formatizados y no formatizados, así como materias primas (Figura 6.31.a). Al pie del conjunto 6 con arte rupestre se observó una concentración de artefactos de diferentes materias primas: sílices, calcedonias, xilópalos y materias primas termoalteradas (Figura 6.31.b). En este sector se practicó un sondeo de $1 \times$ x 0,50 m que arrojó materiales en estratigrafía y carbones, los que se enviaron para fechar por AMS.

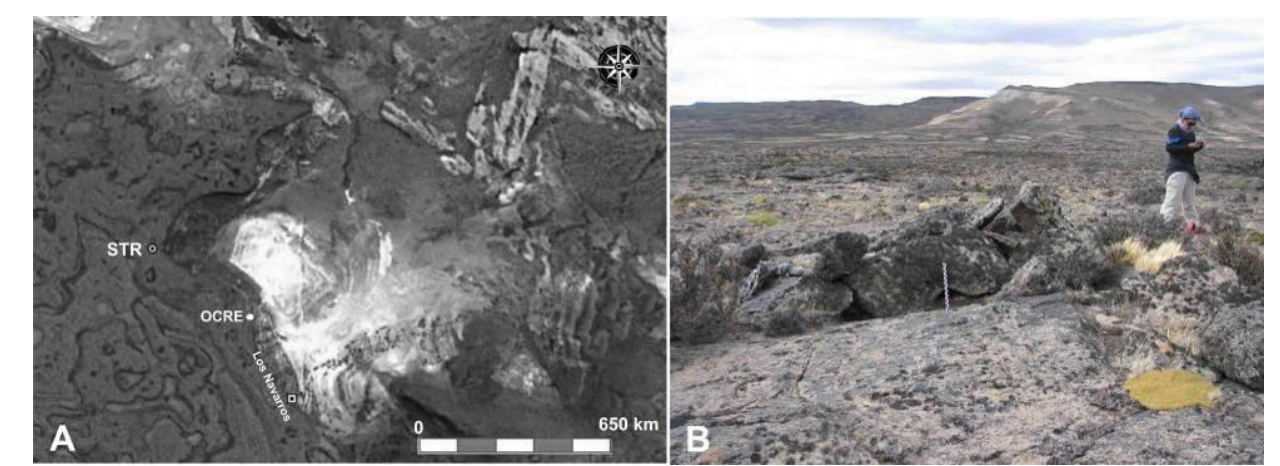

Figura 6.30. Ubicación de otros hallazgos arqueológicos: a. Ubicación de la estructura (STR) y materias colorantes (OCRE) en relación al arte rupestre (Los Navarros); b. aspecto de la estructura.

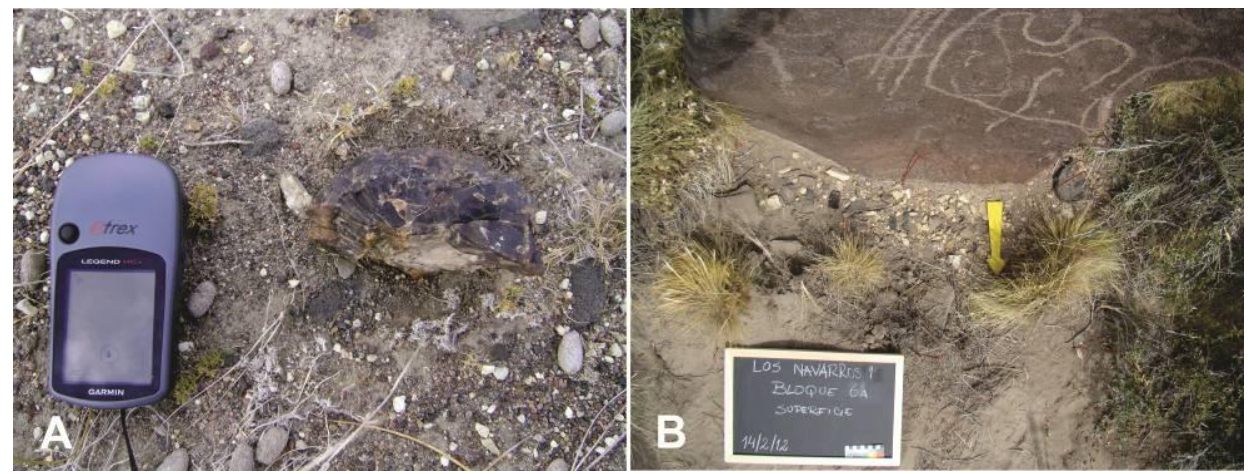

Figura 6.31. Materiales líticos registrados en Los Navarros: a. Materias primas documentadas en un nivel de paleoplaya de la laguna; b. Materiales en superficie al pie de Conjunto 6. 


\section{6. c. 2. El arte rupestre de Los Navarros}

En el sitio se documentaron 286 motivos distribuidos en nueve sectores (Figura 6.32). La sectorización se corresponde a fracturas, cambios de ángulo u orientación de la barda y de la observación de superficies rocosas de 6 m o más de extensión sin manifestaciones rupestres.
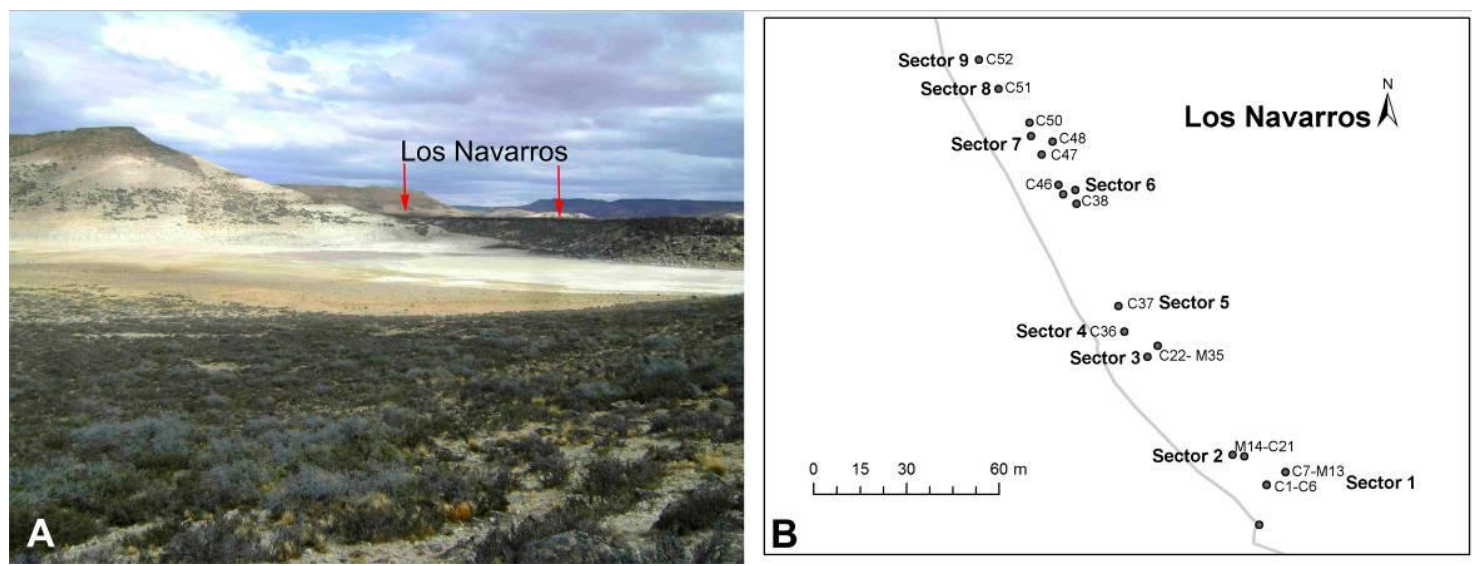

Figura 6.32. Barda de los Navarros: a. vista desde la margen NW de la laguna; b.

Sectorización del sitio.

De los nueve sectores reconocidos, el sector 1 agrupa el 37\% de los motivos, los sectores 2 y 3 juntos agrupan la misma proporción mientras que los restantes cuatro sectores agrupan el 26\% (Figura 6.33).

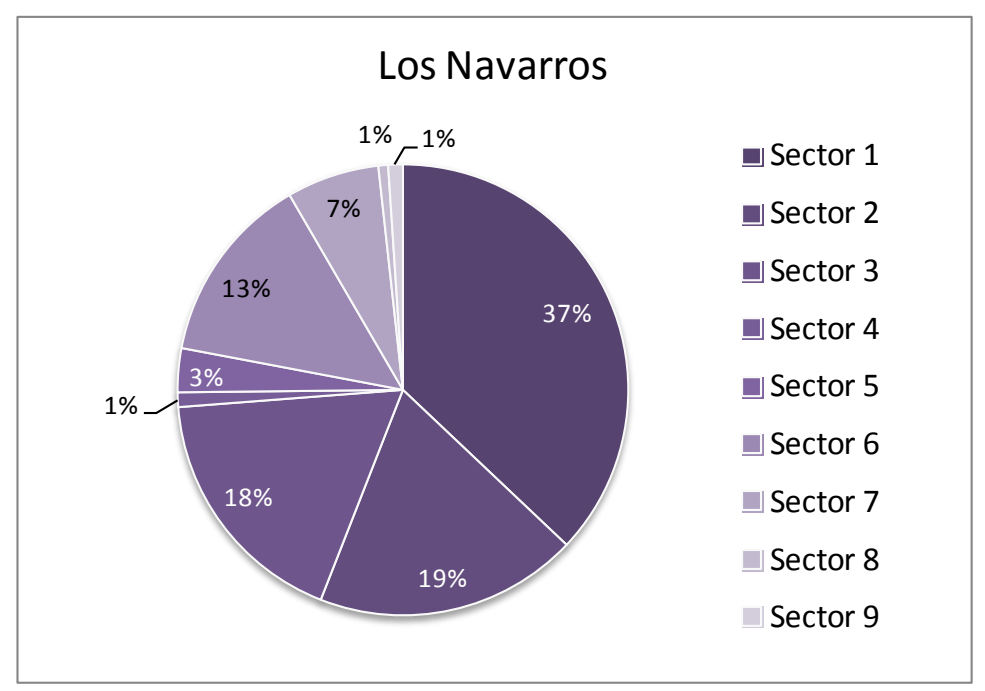

Figura 6.33. Proporciones de motivos por sector.

Los motivos documentados en Los Navarros se encuentran a lo largo de $166 \mathrm{~m}$, y se corresponden mayoritariamente al grupo de los no figurativos (84\%) seguidos por los figurativos y no determinados (Figura 6.34.a). Entre 
los motivos no figurativos predominan los circulares lineales, seguidos por los rectilíneos y los curvilíneos (Figura 6.34.b), los puntiformes alcanzan el $4,5 \%$ mientras que los circulares llenos están representados por un solo motivo. Las frecuencias de subgrupos de motivos identificados por sector se presentan en la Tabla 6.7.

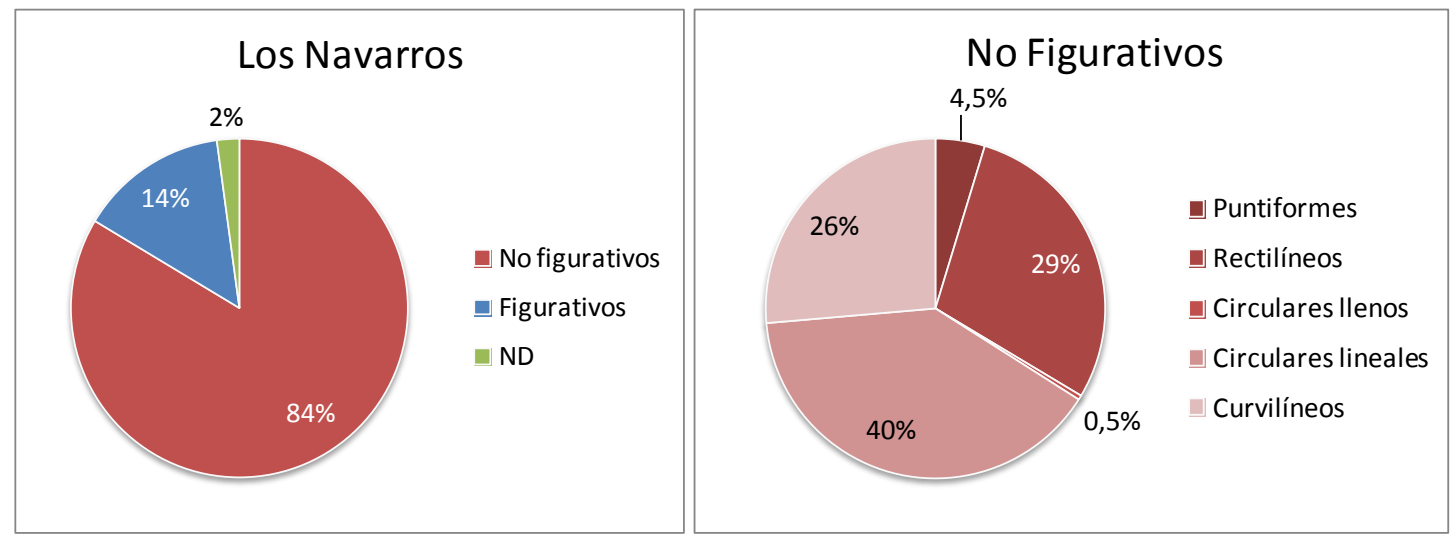

Figura 6.34.a. Grupos de motivos identificados en Los Navarros. b. Proporciones de los subgrupos identificados entre los motivos no figurativos.

\begin{tabular}{|c|c|c|c|c|c|c|c|c|c|c|}
\hline \multirow{3}{*}{ Motivos } & \multirow{2}{*}{\multicolumn{9}{|c|}{ Sectores }} & \multirow[b]{3}{*}{ Subtotal } \\
\hline & & & & & & & & & & \\
\hline & 1 & 2 & 3 & 4 & 5 & 6 & 7 & 8 & 9 & \\
\hline Puntiformes & 3 & 3 & 2 & 0 & 0 & 3 & 0 & 0 & 0 & 11 \\
\hline Rectilíneos & 33 & 14 & 10 & 0 & 4 & 5 & 4 & 0 & 0 & 70 \\
\hline Circulares llenos & 0 & 1 & 0 & 0 & 0 & 0 & 0 & 0 & 0 & 1 \\
\hline Circulares lineales & 17 & 18 & 19 & 3 & 4 & 27 & 6 & 1 & 1 & 96 \\
\hline Curvilíneos & 29 & 9 & 14 & 0 & 1 & 4 & 4 & 1 & 0 & 62 \\
\hline No Figurativos & 82 & 45 & 45 & 3 & 9 & 39 & 14 & 2 & 1 & 240 \\
\hline Zoomorfo & 1 & 0 & 0 & 0 & 0 & 0 & 0 & 0 & 0 & 1 \\
\hline Pisadas animales & 22 & 6 & 5 & 0 & 0 & 0 & 5 & 0 & 1 & 39 \\
\hline Figurativos & 23 & 6 & 5 & 0 & 0 & 0 & 5 & 0 & 1 & 40 \\
\hline No Determinados & 1 & 3 & 1 & 0 & 0 & 0 & 0 & 0 & 1 & 6 \\
\hline Total & 106 & 54 & 51 & 3 & 9 & 39 & 19 & 2 & 3 & 286 \\
\hline
\end{tabular}

Tabla 6.7. Frecuencias de subgrupos de motivos por sector.

El sector 1 abarca los Conjuntos 2 a 12, y los Motivos 1 , 8 y 13 . Se extiende a lo largo de $9 \mathrm{~m}$ (Figura 6.32) y dista aproximadamente $12 \mathrm{~m}$ del comienzo de la barda. La mayoría de las superficies verticales utilizadas encuentran sobre la barda, excepto el Conjunto 6 donde se emplearon dos superficies de un bloque desprendido de aquella y alejado 1,75 m. La coloración de esas superficies es rojiza o marrón y, generalmente, se 
encuentran orientadas al NE. Algunos conjuntos se encuentran en superficies afectadas por líquenes. Las tablas con el detalle de los motivos de este sitio se encuentran en el Apéndice IV.2.

Motivo 1. Se trata de una línea en ángulo recto ubicada en una superficie rugosa e irregular orientada al W, a $1 \mathrm{~m}$ del suelo actual (Figura 6.35.a).

Conjunto 2. Se encuentra sobre una superficie oblicua vertical protegida por una pequeña visera resultante del desprendimiento de otros bloques. El conjunto está conformado por dos motivos curvilíneos que se encuentran a $1,80 \mathrm{~m}$ respecto del suelo actual. El color de los grabados y el soporte tienden a confundirse debido al efecto de la luz que reciben.

Conjunto 3. Está ubicado sobre una superficie regular parcialmente cubierta por líquenes, a 1,20 m del suelo actual. El conjunto está compuesto por una semicircunferencia, dos motivos en forma de "media U" y una línea recta (Figura 6.35.a).

Conjunto 4. Está ubicado a alturas entre 0,35 y 1,95 m respecto del suelo. La superficie sobre la que se encuentra recibe insolación directa entre las 10 y 13 horas. En este conjunto se contabilizaron 17 motivos: circunferencias simples, con o sin apéndices, o bien con trazos interiores; curvilíneos "en forma de U”, con o sin apéndices, líneas rectas, y entre los figurativos una roseta y tres tridígitos (Figura 6.35.b). Sobre estos motivos se superponen pequeñas superficies grabadas sin formas determinadas, resultantes de percusiones aleatorias. Asimismo, líquenes cubrieron algunos de los grabados por lo que su estado de conservación es regular a malo.

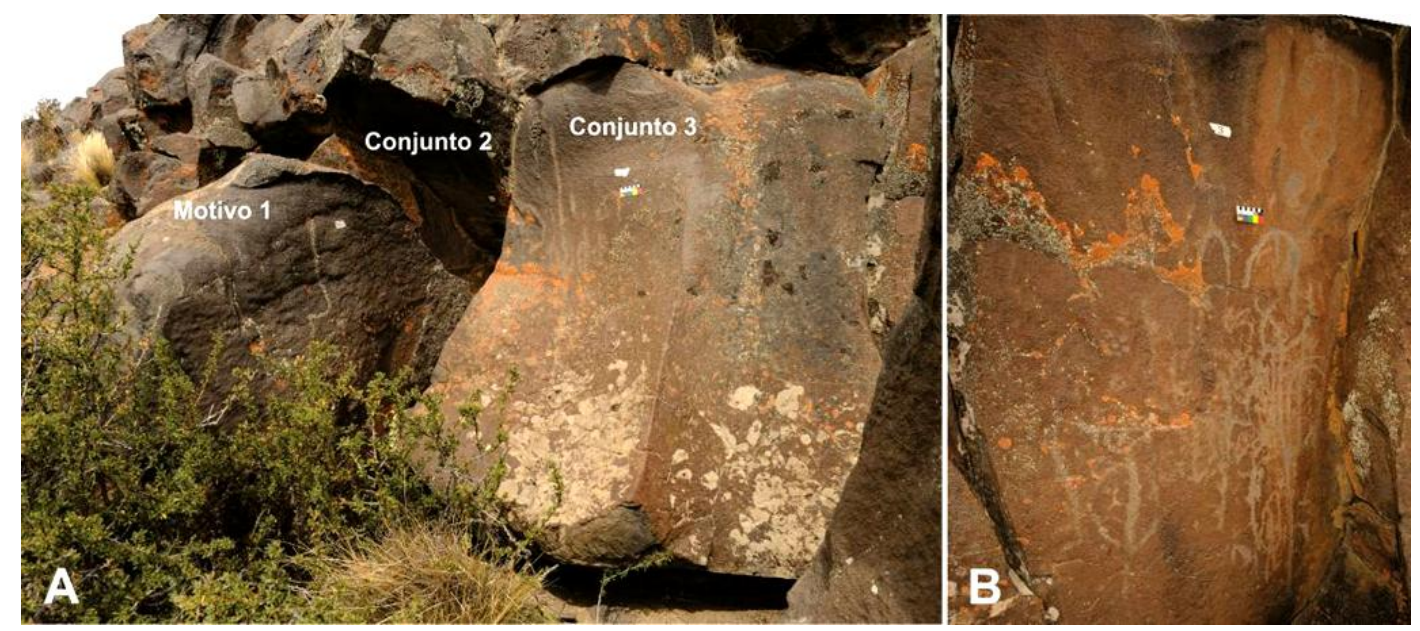

Figura 6.35. Conjuntos 1 a 4: a. Conjuntos 1 a 3; b. Conjunto 4. 
Conjunto 5. Se encuentra sobre una superficie vertical de color oscuro, a 1,87 $\mathrm{m}$ respecto del suelo. Se trata de una línea vertical y una pisada de guanaco.

Conjunto 6. Por delante de los conjuntos 4 y 5, un bloque separado 1,75 $\mathrm{m}$ de la barda. Este conjunto presenta la mayor cantidad y variedad de motivos del sitio. De este bloque se utilizaron dos superficies para la ejecución de manifestaciones: una orientada hacia el $\mathrm{N}$ y la otra orientada hacia el W. Esta última presenta motivos que en gran medida son una continuación de aquellos que se encuentran sobre la otra cara.

La superficie basáltica es homogénea y de color oscuro, aunque se observaron algunas grietas y fallas (Figuras 6.36.a). El grado de insolación que recibe este bloque varía dependiendo de la superficie considerada: aquella orientada al $\mathrm{N}$ recibe luz durante toda la mañana, y hacia las 15.45 horas sólo recibe luz solar la mitad superior. La superficie orientada al W recibe luz durante el mediodía.
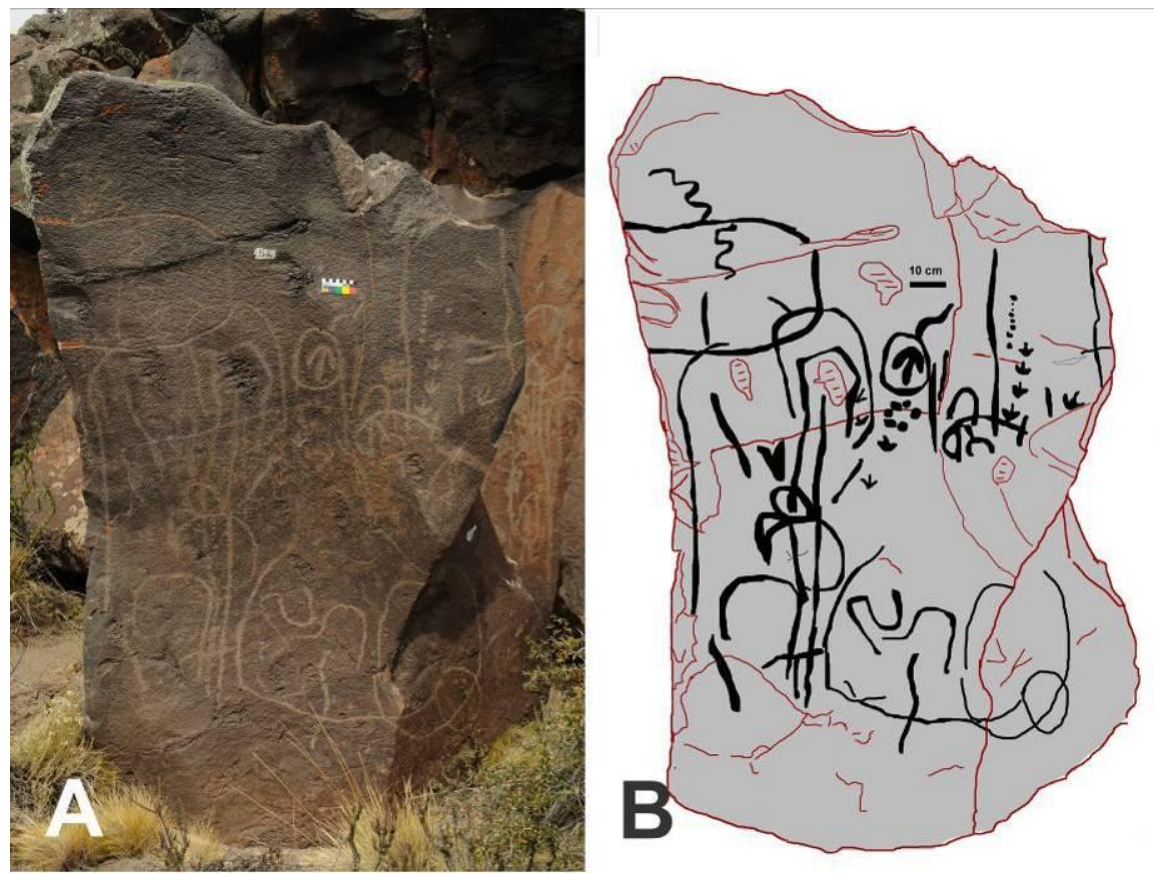

Figura 6.36. Conjunto 6: a. Fotografía; b. Calco digital a partir de la imagen.

Los motivos registrados en este bloque son 45 , se encuentran a alturas que oscilan entre 0,25 y 1,87 m respecto del suelo. Se pueden mencionar, líneas rectas verticales u oblicuas simples, con diferentes tipos de apéndice o bien atravesadas con otras rectas, y una línea "en forma de V" abierta. 
Asimismo, se observaron circunferencias con o sin apéndices, con líneas o tridígitos en su interior, y un óvalo con dos apéndices; líneas curvas simples, con o sin apéndice, un serpentiforme. Entre los motivos figurativos se observan dos rastros de tridígitos alineados (uno de estos rastros está asociado a un motivo puntiforme), dos tridígitos y dos pisadas de felino. Se observaron 15 superposiciones que serán tratadas más adelante.

Conjunto 7. Se encuentra a $0,75 \mathrm{~m}$ del suelo, sobre la barda basáltica, en una superficie oscura y vertical orientada al NW. Está compuesto por siete motivos, entre los que se destacan líneas rectas o curvas con diferente orientación, una circunferencia y un motivo en forma de "media U". Entre los figurativos se incluyen pisadas de guanaco y un matuasto, siendo este último único en todo el sitio (Figura 6.37).
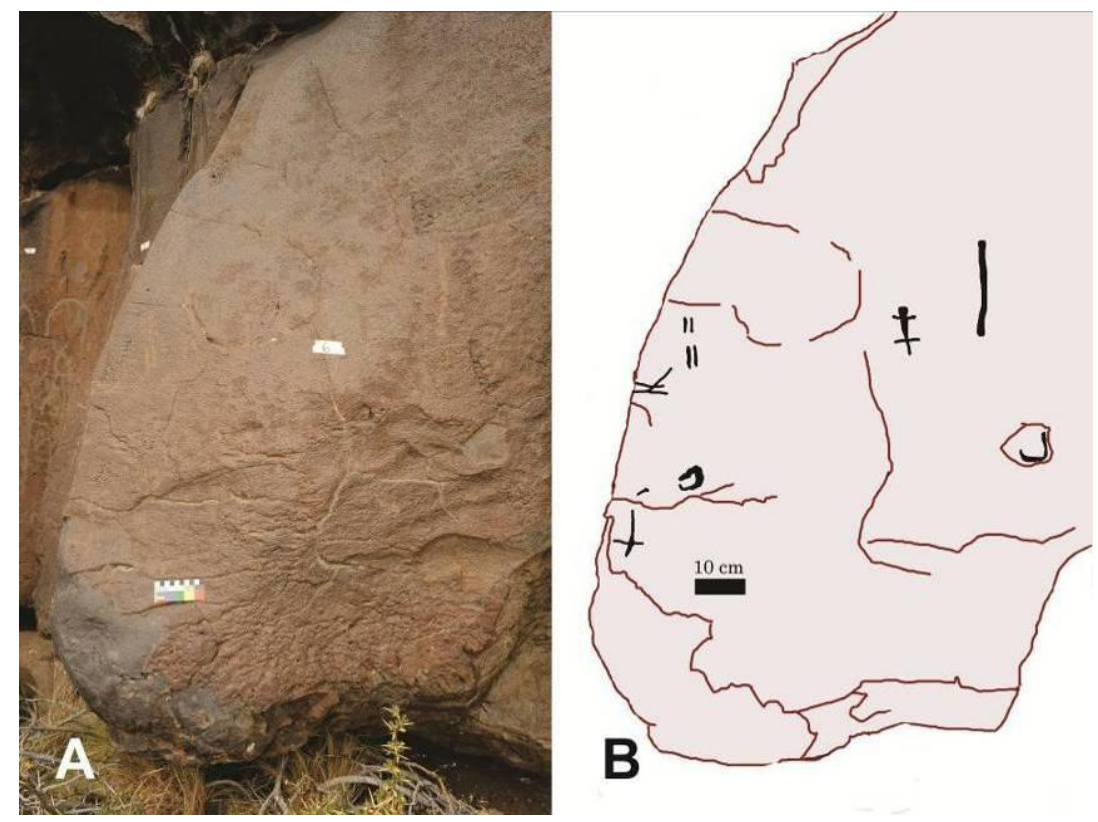

Figura 6.37. Conjunto 7: a. Panel como se observa en campo; b. Calco digital a partir de fotografía.

Motivo 8. Se trata de un tridígito ubicado a 1,48 m del suelo actual, sobre una superficie vertical.

Conjunto 9. Está ubicado en una superficie vertical. Los diecisiete motivos que lo conforman se encuentran a diferentes alturas sobre el suelo, siendo la inferior $0,50 \mathrm{~m}$. Se observan líneas de puntos y líneas rectas o curvas con diferente orientación; líneas quebradas, motivos en forma de "U invertida" y de "media U”, una circunferencia con tres puntos y una línea en 
su interior. Entre los motivos figurativos se reconocieron un tridígito y una pisada de felino.

Conjunto 10. Está ubicado sobre una superficie rugosa y con fisuras, orientada al $\mathrm{N}$ y a $1 \mathrm{~m}$ del suelo. Se trata de un tridígito, cuyo dedo medio es curvo, y una línea curva oblicua.

Conjuntos 11 y 12. Se encuentran sobre superficies muy deterioradas: irregulares, rugosas y exfoliadas por la acción de líquenes, que presentan diferente orientación. Los motivos se encuentran a alturas que oscilan entre 1,30 y 0,80 m. Corresponden a una figura geométrica con trazos interiores, una circunferencia simple y una línea curva horizontal atravesada por una línea oblicua (Conjunto 11), mientras que el segundo conjunto está integrado por una línea recta oblicua, una circunferencia simple, una línea curva horizontal que termina en una circunferencia y un motivo en forma de " $U$ invertida".

Motivo 13. Sobre una convexidad natural de la barda orientada al NW, a 1,40 $\mathrm{m}$ respecto del suelo. Se trata de una circunferencia doble concéntrica, muy exfoliada y afectada por la colonización de líquenes.

El sector 2 está conformado por los conjuntos 15 a 21 y el motivo 14. Se encuentra a 13,20 m del sector anterior. Mayoritariamente, se utilizaron superficies verticales de la barda, de coloración rojiza. El conjunto 19 es el único del sector que se ubica en un bloque desprendido y alejado de la barda. Estas superficies se encuentran orientadas principalmente hacia el $\mathrm{N}$, a excepción de los conjuntos 18 y 19, orientados al NNW, y del conjunto 21 donde se emplearon dos superficies con diferente orientación. El motivo 14 y los conjuntos 15 a 17 se encuentran asociados espacialmente (Figura 6.38.a).

Motivo 14. Ubicado a $1,15 \mathrm{~m}$ del suelo, se trata de una circunferencia doble concéntrica (sobre una superficie cóncava) adosada a una circunferencia (sobre una superficie convexa). Esta última aprovecha parte del surco de la primera (Figura 6.38.b).

Conjunto 15. Está integrado por cinco motivos que se encuentran a alturas variables (entre 1,50 y 1,10 m) respecto del suelo actual. Se trata de tres circunferencias concéntricas rodeadas por una semicircunferencia, un 
tridígito, dos líneas curvas paralelas verticales, una línea recta vertical y "U" dobles concéntricas e invertidas (Figura 6.38). En el borde inferior del panel se observa un desprendimiento de parte de la roca lo cual permitiría pensar que algunos de estos motivos se encuentran incompletos.

Conjunto 16. Está compuesto por 13 motivos, el inferior se encuentra a 0,80 m del suelo. Entre los no figurativos se observan puntiformes, líneas rectas con diferente orientación, una semicircunferencia y dos circunferencias, una de ellas con apéndice. Los motivos figurativos incluyen cuatro tridígitos que parecen configurar una rastrillada ya que, vistos en conjunto, disminuyen sus dimensiones hacia el sector superior del panel (Figura 6.38). Asimismo, se identificó una superficie grabada sin poder determinar su forma.

Conjunto 17. Se encuentra por debajo de los anteriores, en el interior de un pequeño reparo en la barda, donde se registraron dos circunferencias, a $0,62 \mathrm{~m}$ y a $0,26 \mathrm{~m}$ respecto del suelo actual.

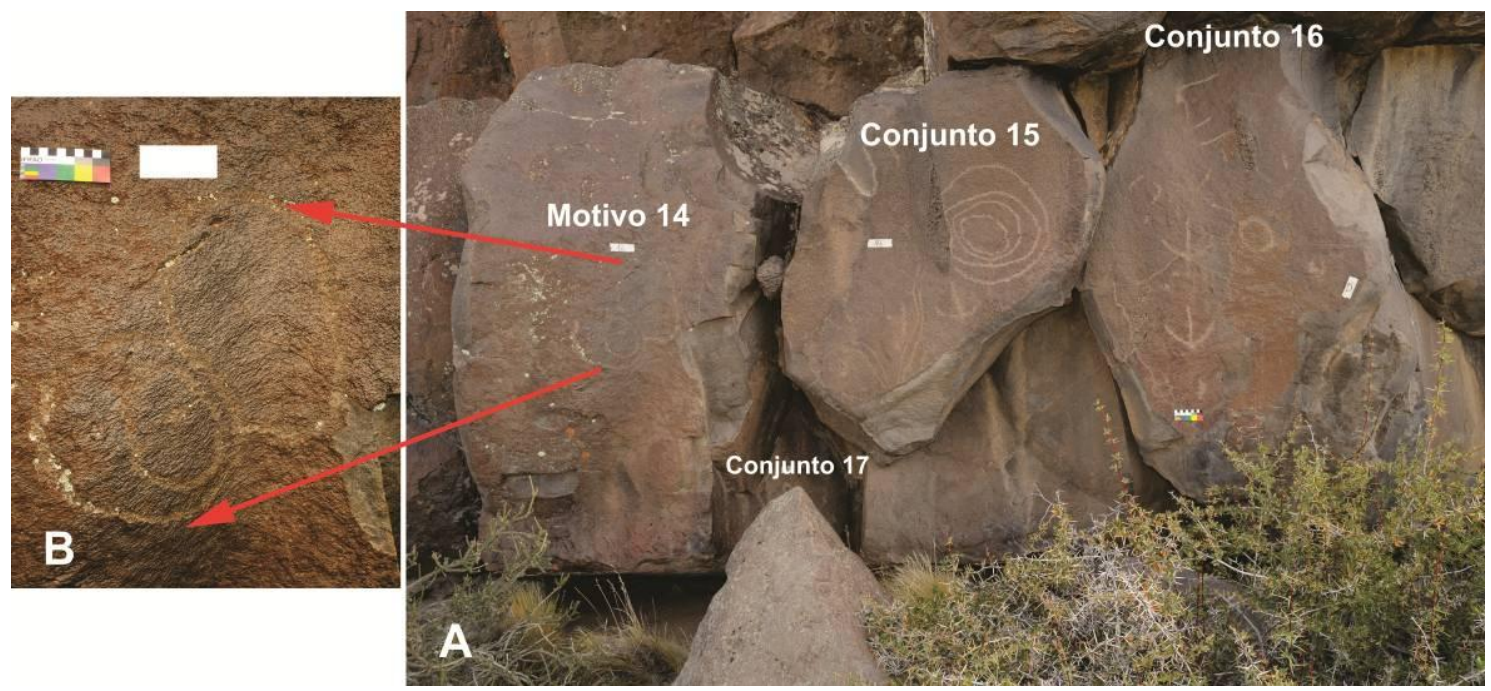

Figura 6.38. Motivo 14 y conjuntos 15 a 17: a. Relación espacial de los paneles; b.

Motivo 14.

Conjunto 18. Está sobre una superficie rugosa e irregular, en la que se observan marcas de filtración de agua y sectores con exfoliaciones. A 1,38 m del suelo se registraron 10 motivos: un punto, líneas rectas y curvas con diferente orientación, circunferencias, motivos en "forma de U", un óvalo con apéndice curvo y una superficie grabada de forma no determinada. En este 
conjunto se registró una superposición entre un óvalo con apéndice curvo y una línea recta, la cual que será tratada más adelante.

Conjunto 19. Sobre la superficie de un bloque desprendido de la barda, alejado $4 \mathrm{~m}$ de ésta. Se trata de una circunferencia simple y circunferencias concéntricas a $0,60 \mathrm{~m}$ del suelo.

Conjunto 20. Se encuentra sobre la barda, en un panel de superficie homogénea. En su porción superior se observan marcas de percolación de agua; sin embargo, los motivos están bien conservados (Figura 6.39.a). Se registraron 13 motivos a alturas entre 1,80 y $0,65 \mathrm{~m}$ respecto del suelo actual. Se trata de un motivo laberintiforme con tres apéndices rectos en su parte inferior; una línea recta quebrada, una línea recta vertical con línea vertical perpendicular; un serpentiforme, un motivo en forma de "media U" invertida y otro "en forma de U”; un círculo lleno, una semicircunferencia, una circunferencia, y circunferencias concéntricas alrededor de un hoyuelo natural. Estas últimas carecen de la porción izquierda, debido a un desprendimiento del soporte. Se registró, además, un único motivo figurativo que corresponde a una pisada de ave. Las dos superposiciones registradas en este conjunto serán consideradas en el próximo apartado (Figura 6.39.b). Este conjunto se destaca debido a la complejidad del motivo laberintiforme; además, evidencia una reactivación de algunos surcos grabados. La pátina más clara de la porción inferior en las líneas rectas del laberinto sugiere la existencia de un caso de reciclaje de la figura.

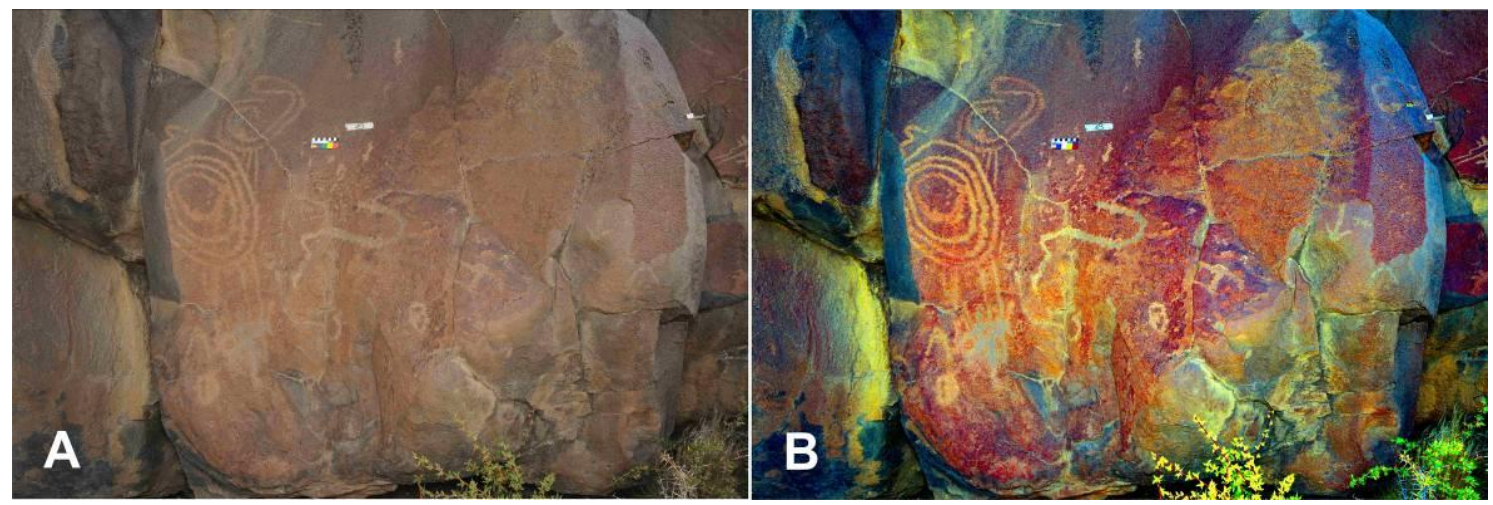

Figura 6.39. Conjunto 20: a. fotografía del conjunto; b. Imagen tratada digitalmente (D-Stretch lds 15). 
Conjunto 21. Está integrado por ocho motivos que se realizaron sobre dos superficies de la barda que presentan diferente orientación. En la superficie orientada al $\mathrm{W}$, a alturas variables respecto del suelo (entre 1,50$0,70 \mathrm{~m}$ ), se registraron un motivo no determinado, dos circunferencias (una con apéndice) y una semicircunferencia. Sobre la superficie orientada al $\mathrm{N} \mathrm{y}$ a diferentes alturas respecto del suelo (entre 1,50 y $2 \mathrm{~m}$ ) se registraron líneas oblicuas simples y paralelas, un motivo en "forma de U" y una línea recta horizontal atravesada por dos rectas cortas perpendiculares. Al igual que los restantes motivos del conjunto, se encuentran separados entre sí por grietas. La particularidad de este conjunto está dada por su altura respecto del suelo actual (cercana a $2 \mathrm{~m}$ ), la cual sugiere el uso de algún dispositivo o ayuda adicional para su realización.

El sector 3 está separado del anterior por $7 \mathrm{~m}$. Está integrado por los conjuntos 22 a 35 . Se emplearon superficies verticales de la barda, mientras que para los conjuntos 25, 26 y 33 y los motivos 31 y 32 se emplearon superficies de bloques desprendidos de la barda. Dichas superficies se orientan mayoritariamente al $\mathrm{N}$, excepto los conjuntos 22 y 29 que se orientan al E, y los motivos 25 y 35 que miran al W.

Conjunto 22. Sobre una superficie que se ubica a $0,50 \mathrm{~m}$ del suelo, se registraron dos motivos: una línea recta vertical y una superficie grabada no determinada.

Conjunto 23. Se encuentra sobre una superficie vertical de color rojizo que presenta porciones exfoliadas e irregulares o parcialmente cubiertas por líquenes. El conjunto está compuesto por siete motivos: un escutiforme incompleto, motivos "en forma de U" que pueden ser sinuosas o presentar apéndices, dos líneas verticales oblicuas y un tridígito con el vértice hacia arriba, superpuesto a los motivos curvilíneos (Figura 6.40). El motivo escutiforme está incompleto debido a desprendimientos en la porción izquierda del panel. Algunos de los motivos en "forma de U" pueden medir 90-95 cm de alto. 


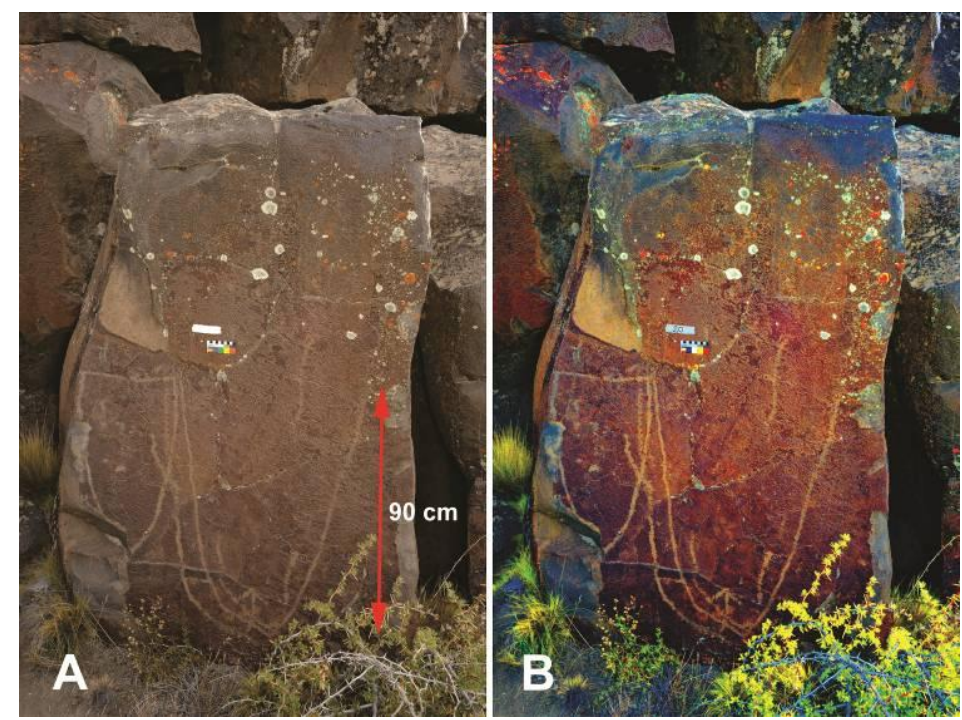

Figura 6.40. Conjunto 23: a. Imagen sin tratar; b. imagen tratada digitalmente (DStretch lds 15).

Conjunto 24. Se encuentra sobre una superficie cóncava de la barda, muy exfoliada, irregular y actualmente colonizada por líquenes. Está conformado por tres motivos que se ubican a 1,12 m del suelo actual: una línea recta vertical, una circunferencia y una línea curva.

Conjunto 25. Está ubicado sobre la superficie de un bloque desprendido de la barda, alejado alrededor de 2,5 m y apoyado sobre otros bloques. Dicha superficie, aunque sumamente exfoliada, presenta restos de la pátina en el centro del panel. A 0,65 m del suelo se registraron cinco motivos: un par líneas curvas paralelas horizontales asociadas a una circunferencia, una circunferencia concéntrica doble, dos circunferencias simples y una semicircunferencia (Figura 6.41). En el sector inferior del panel se observa un desprendimiento que afecta a uno de los motivos.

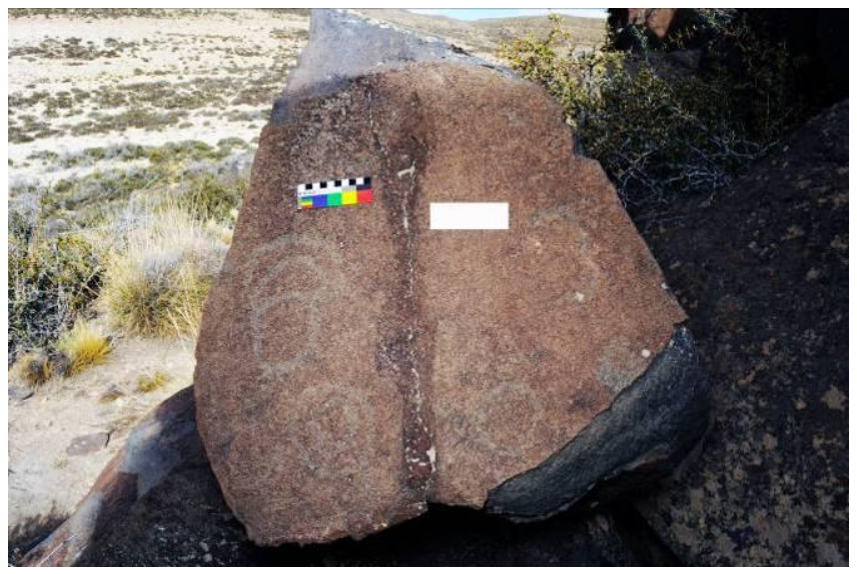

Figura 6.41. Conjunto 25. 
Motivo 26. Se encuentra a $0,77 \mathrm{~m}$ del suelo, sobre un bloque alejado de la barda cuya superficie se encuentra altamente exfoliada y parcialmente colonizada por líquenes. Se trata de una línea en ángulo recto.

Conjunto 27. Ubicado sobre la barda basáltica, en una superficie irregular, está conformado por 12 motivos a 0,91 m del suelo actual. Entre ellos, cuatro circunferencias, una de las cuales posee un tridígito en su interior, una línea de puntos oblicua, una circunferencia de puntos, un motivo "en forma de V", líneas curvas en forma de "media U" o de "U invertida”, y un motivo serpentiforme (Figura 6.42). Se observaron dos superposiciones: una línea de puntos subyace parcialmente a la circunferencia con tridígito interior y a una circunferencia de tratamiento puntiforme y lineal. La incidencia de la luz juega un rol fundamental en la distinción de los motivos, ya que el color de los surcos grabados se confunde con la coloración del soporte (Figura 6.42.a) siendo mejor su observación a la sombra.

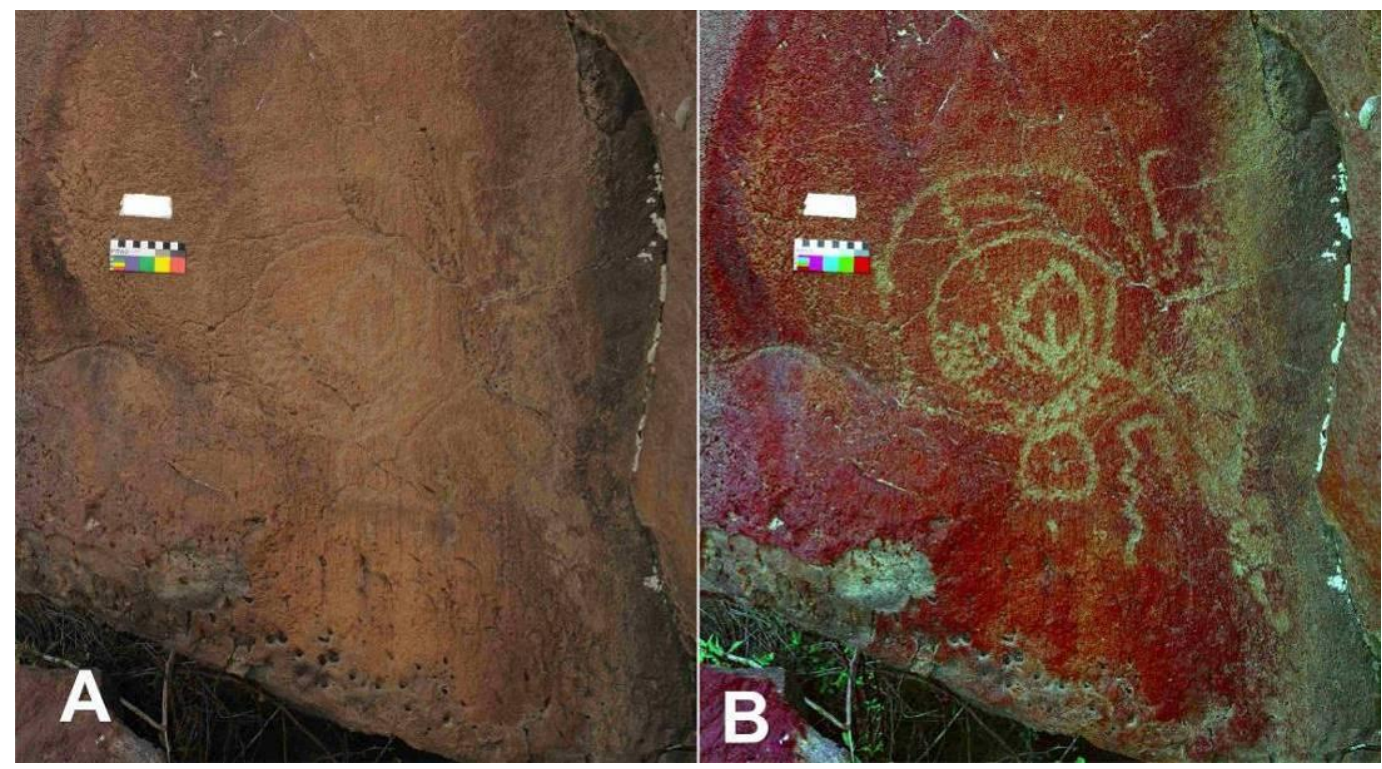

Figura 6.42. Conjunto 27: a. Motivo fotografiado al mediodía; b. imagen tratada digitalmente (D-Stretch yrd 15).

Conjunto 28. Los motivos se encuentran a 1,02 m del suelo actual, sobre una superficie rugosa, irregular y altamente exfoliada por la acción de los líquenes. Se trata de un óvalo y una circunferencia con apéndices.

Motivo 29. Se registró sobre una superficie sumamente rugosa y colonizada por líquenes. Este motivo se encuentra a 0,97 m del suelo y se 
trata de una circunferencia con apéndice curvo del que se desprenden, a su vez, dos líneas rectas oblicuas.

Conjunto 30. Se encuentra sobre una superficie irregular y muy exfoliada de la barda, en la que se detectaron desprendimientos y diferentes líquenes. Está conformado por un motivo en forma de "V" y una circunferencia concéntrica doble con punto central, ambos a 1,20 m del suelo actual.

Motivos 31 y 32. Sobre distintos bloques desprendidos de la barda, a 0,92 y $0,25 \mathrm{~m}$ del suelo, respectivamente. Corresponden a dos circunferencias simples.

Conjunto 33. En un bloque desprendido de la barda, sobre una superficie irregular y exfoliada, se registraron dos motivos. Se trata de dos circunferencias con apéndices que se ubican aproximadamente a 0,72 $\mathrm{m}$ del suelo actual (Figura 6.43).

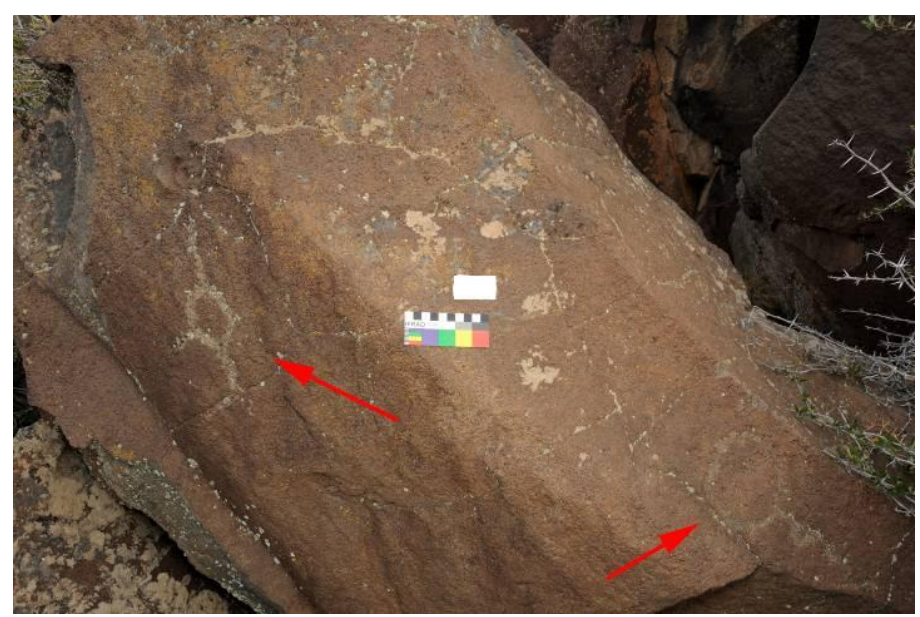

Figura 6.43. Conjunto 33.

Conjunto 34. Sobre una superficie de la barda, rugosa se registraron 11 motivos, a alturas que oscilan entre 0,65 y 1,00 m respecto del suelo actual. Se distinguieron líneas rectas y curvas con diferente orientación, líneas con apéndices rectos, una circunferencia con apéndice tripartito superior, un óvalo con apéndice curvo. Además, se observan dos tridígitos, una pisada de felino y una pisada de guanaco (Figura 6.44). La pátina de la roseta, de la pisada de guanaco y de uno de los tridígitos es oscura, razón por la cual estos motivos se confunden con el soporte (Figura 6.44.a). 


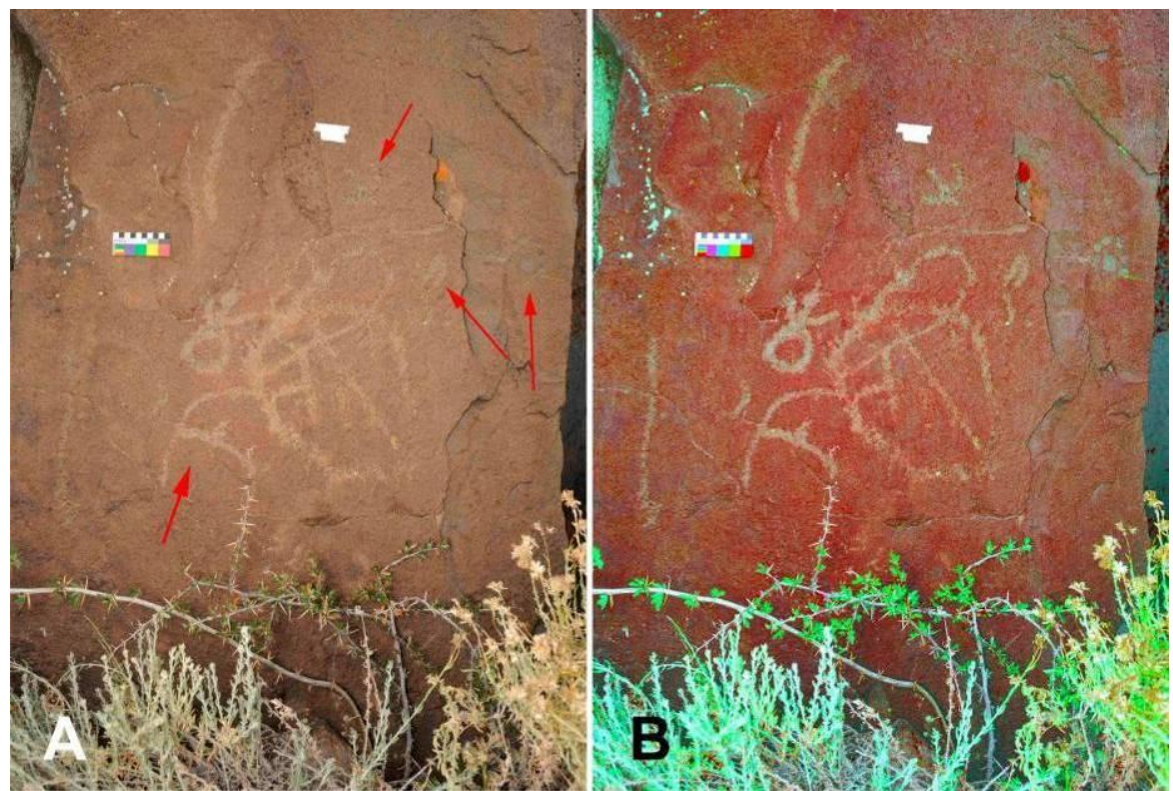

Figura 6.44. Conjunto 34: a. los motivos figurativos se señalan con flechas; b. Imagen tratada digitalmente (D-Stretch yrd 15).

Motivo 35. A 0,41 $\mathrm{m}$ del suelo se observa una "U invertida" con un tridígito en un extremo. Registrado sobre un bloque alejado 4,5 $\mathrm{m}$ de la barda. Se encuentra en una superficie vertical, rugosa y exfoliada de coloración rojiza, orientada al W.

El sector 4 se corresponde con el Conjunto 36, que dista del sector anterior 6,5 m. Este conjunto se encuentra sobre una superficie rugosa y exfoliada de la barda, orientada al N. El panel presenta coloración rojiza y se encuentra protegido por una pequeña visera formada por otros bloques; el sector inferior posee desprendimientos. Este conjunto está conformado por tres circunferencias simples que se encuentran a $0,83 \mathrm{~m}$ del suelo.

El sector 5 está conformado por el Conjunto 37 y se encuentra $10 \mathrm{~m}$ del anterior. Está ubicado sobre una superficie vertical de la barda orientada al $\mathrm{E}$, irregular y fuertemente afectada por líquenes. A 0,62 m del suelo se registraron nueve motivos: líneas rectas con o sin apéndice, una línea en ángulo recto, una figura cuadrangular con una línea recta en su borde inferior, circunferencias (con o sin apéndice o concéntricas dobles), una circunferencia dividida por una línea recta larga y una línea curva (Figura $6.45)$. 


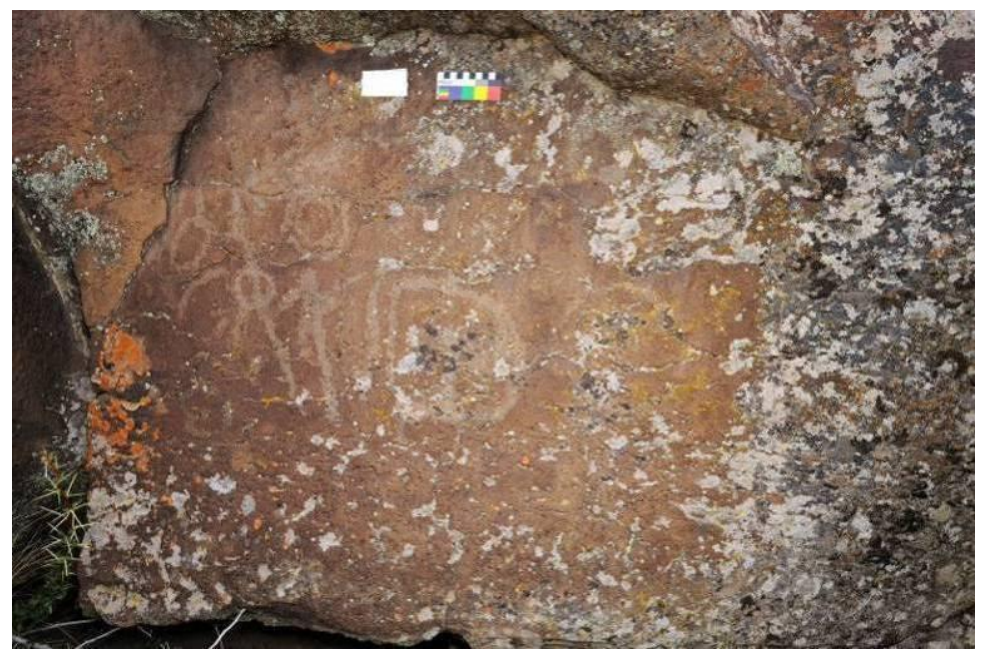

Figura 6.45. Conjunto 37.

El sector 6 está conformado por los conjuntos 38 a 46 y el motivo 43, y dista $48 \mathrm{~m}$ del sector anterior. Se emplearon superficies verticales de la barda, de coloración rojiza, mayoritariamente orientadas al E a excepción de los conjuntos 42 y 44 que miran al NE, y los conjuntos 45 y 46 que orientan al $\mathrm{N}$.

Conjunto 38. Se encuentra sobre una superficie con diferente grado de exfoliación y parcialmente afectada por la acción del agua. A 1,0 m del suelo se registraron dos circunferencias, una de ellas con dos apéndices.

Conjunto 39. Se ubica a $0,70 \mathrm{~m}$ del suelo sobre una superficie rugosa y exfoliada. El conjunto está integrado por cinco motivos: puntos formando un triángulo, una semicircunferencia con apéndice curvo, dos circunferencias simples y una circunferencia concéntrica doble. Estos motivos tienden a confundirse con el soporte debido al grado de exfoliación que presenta.

Conjunto 40. Sobre una superficie libre de líquenes que se torna más oscura hacia la base. Está conformado por 17 motivos a alturas variables, siendo 1,23 $\mathrm{m}$ respecto del suelo la distancia inferior. Entre estos motivos se observa un amplio predominio de motivos circulares lineales y puntiformes (Figura 6.46). Se observa, además, un motivo complejo conformado por un óvalo -subdividido por trazos internos- con una circunferencia adosada y un apéndice. La superposición detectada entre un óvalo complejo y una circunferencia será tratada más adelante. 


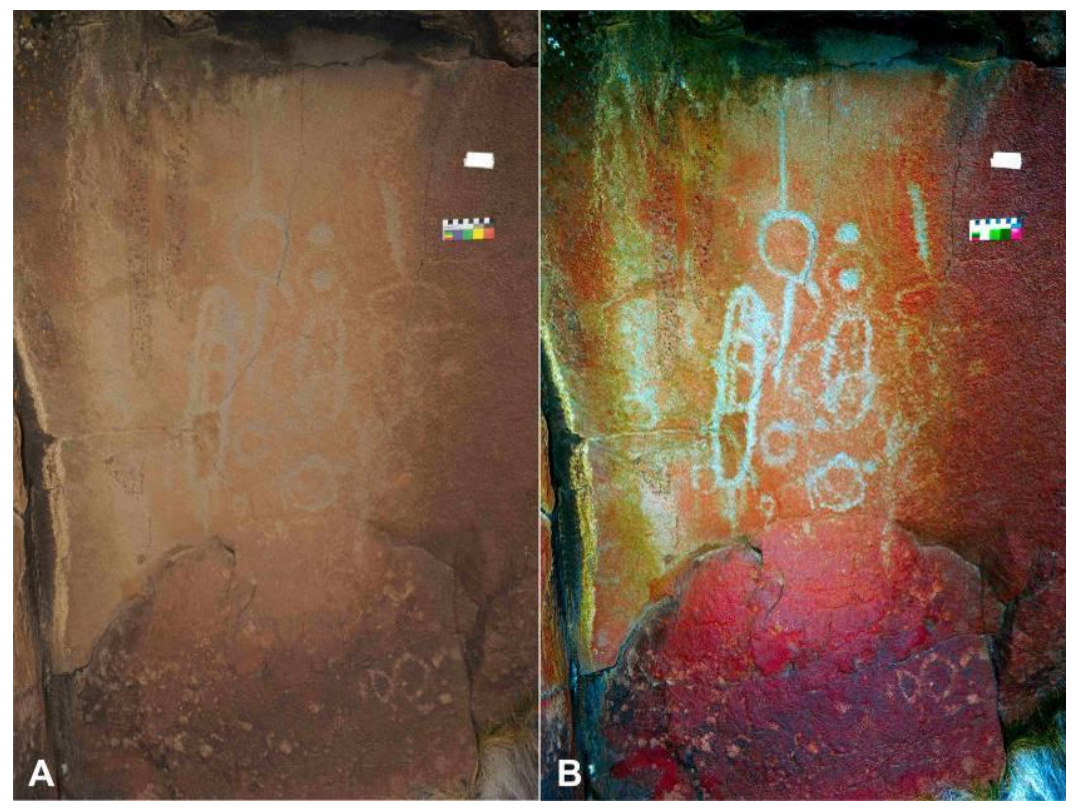

Figura 6.46. Conjunto 40: a. Fotografía del conjunto; b. Imagen tratada digitalmente (D-Stretch lab 15).

Conjunto 41. A 0,65 m sobre el suelo actual, un motivo en "forma de U" y una línea vertical. Ambos son de surco irregular y superficial.

Conjunto 42. Se ubica a $0,85 \mathrm{~m}$ del suelo, sobre una superficie muy exfoliada y agrietada, con líquenes cubriendo en la mayor parte de la misma. El conjunto está integrado por tres motivos: uno en forma de " $U$ invertida", una circunferencia y una circunferencia con un tridígito invertido en su interior (Figura 6.47.a).

Motivo 43. Se encuentra sobre una superficie vertical-cóncava, rugosa y exfoliada. Se trata de una línea recta vertical ubicada a $1,14 \mathrm{~m}$ del suelo actual, afectada por la exfoliación que actuó sobre la roca y, debido a este factor, es visible dependiendo del grado de insolación que recibe.

Conjuntos 44 y 45 . Se encuentran sobre diferentes superficies verticales, irregulares y con líquenes, a $1,35 \mathrm{~m}$ y $1,15 \mathrm{~m}$ del suelo respectivamente. Corresponden a una circunferencia y dos líneas rectas con diferente orientación (conjunto 44) y circunferencias, simple o concéntricas (Conjunto 45) (Figura 6.48.b). 

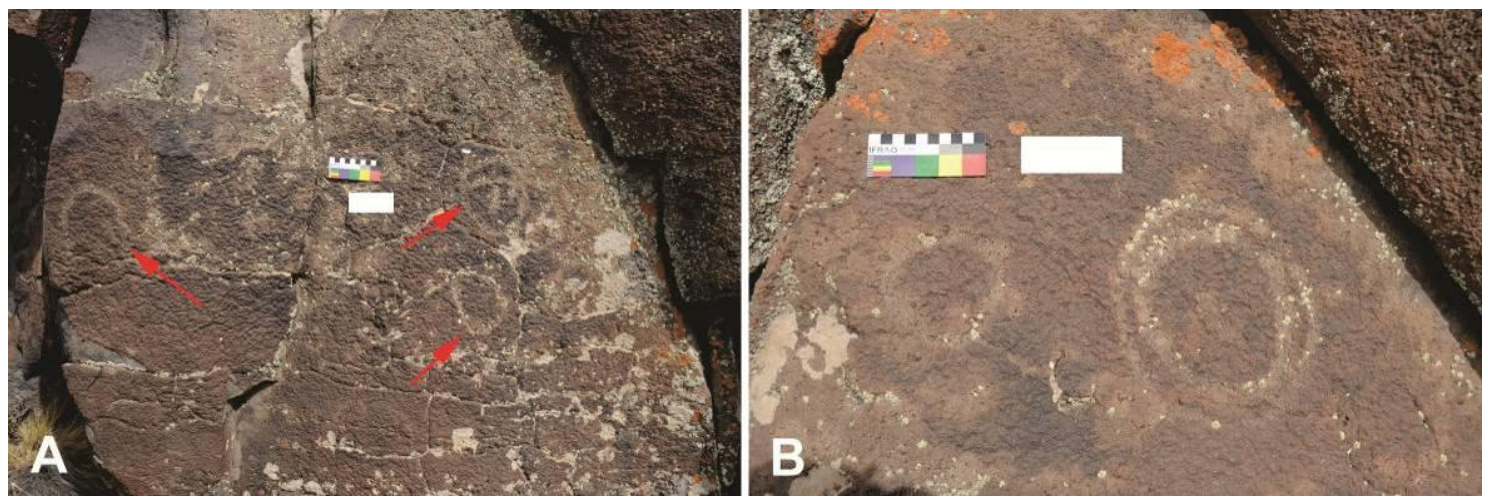

Figura 6.47. Conjuntos 42 y 45: a. Conjunto 42; b. Conjunto 45.

Conjunto 46. Está integrado por cuatro motivos que se ubican en dos superficies con distinta orientación, a alturas que oscilan entre 1,10 y 1,25 $\mathrm{m}$ del suelo actual. Se trata de una circunferencia, una línea curva, una semicircunferencia y un óvalo. El estado de conservación de los motivos es malo por la exfoliación que presentan las superficies en las que se encuentran.

El sector 7 está integrado por dos conjuntos (Conjuntos 47 y 50) y dos motivos aislados (Motivos 48 y 49). Dista 11,20 m del sector anterior. El conjunto 47 y el motivo 49 se encuentran en bloques separados de la barda sobre superficies orientadas al NE, mientras que para el motivo 48 y el conjunto 50 se utilizaron superficies de la barda orientadas al N. En todos los casos se trata de superficies verticales, irregulares y rugosas. La mayor parte de dichas superficies se encuentran cubiertas de líquenes.

Conjunto 47. Se ubica sobre la barda a 0,62 $\mathrm{m}$ del suelo, donde se documentaron cuatro motivos: una línea recta vertical, una semicircunferencia, un motivo en forma de "media U" y una circunferencia (Figura 6.48.a). Tres de estos motivos se encuentran superpuestos y presentan el mismo grado de pátina.

Motivo 48. Sobre la superficie vertical de un bloque que dista $4 \mathrm{~m}$ de la barda, se registró una circunferencia a 0,73 m del suelo.

Motivo 49. A $1,15 \mathrm{~m}$ del suelo actual, sobre una superficie de la barda libre de líquenes, se observa una circunferencia.

Conjunto 50. Si bien el bloque utilizado posee sus cuatro caras disponibles sólo se empleó la que se encuentra orientada al $\mathrm{N}$, que presenta 
algunos desprendimientos y coloraciones diferentes (Figura 6.48.b). Los trece motivos que integran el conjunto se encuentran a diferentes alturas respecto del suelo actual, siendo la inferior $0,75 \mathrm{~m}$. Se trata de una circunferencia con punto central y dos apéndices rectos, circunferencias concéntricas asociadas a una línea curva; una línea recta oblicua; cinco tridígitos; dos motivos en "V" y tres motivos curvilíneos, dos de ellos serpentiformes.
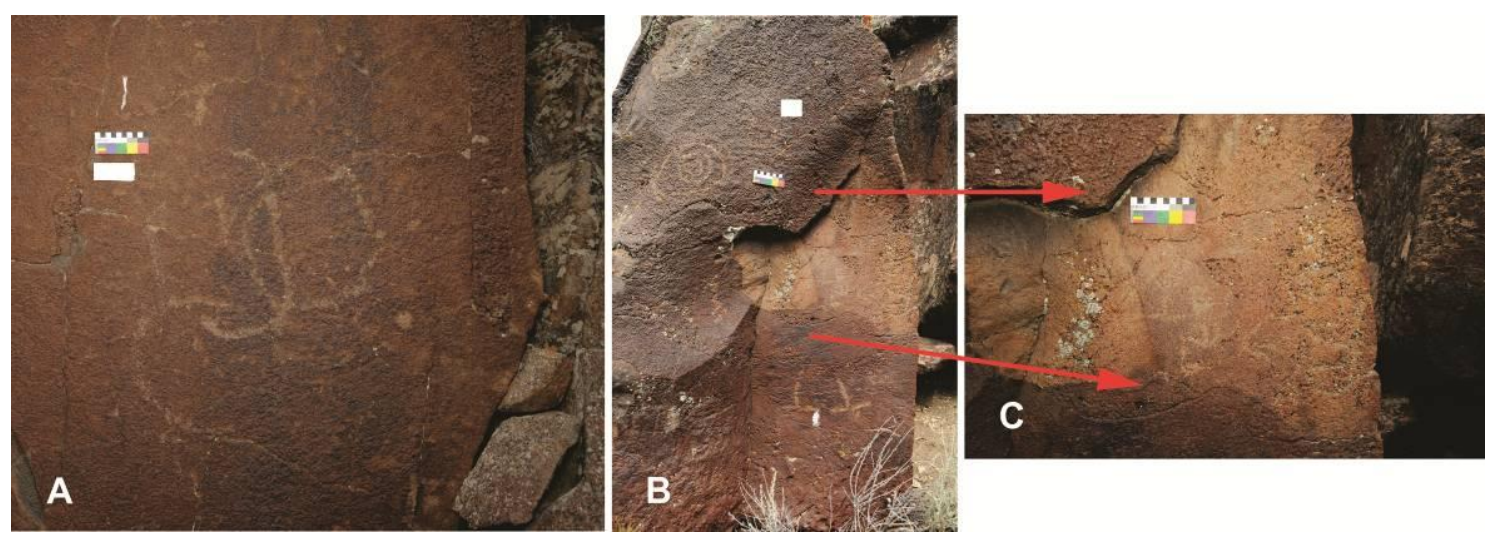

Figura 6.48. Conjuntos 47 y 50: a. Conjunto 47; b. Conjunto 50; c. detalle del Conjunto 50.

El sector 8 está constituido por el Conjunto 51, separado del sector anterior por $15 \mathrm{~m}$. Este conjunto se encuentra sobre la barda, en una superficie irregular y de color gris, orientada al N. A 1,24 m del suelo se documentaron una circunferencia y una línea curva intersecada por una línea recta oblicua.

Por último, el sector 9 dista del anterior 11,40 m. Está conformado por el Conjunto 52, que también se encuentra sobre la barda. Sobre una superficie vertical, rojiza e irregular orientada al NE y a 0,54 m del suelo actual, se registraron un tridígito, una circunferencia y una superficie grabada no determinada.

\section{6. c. 3. Análisis}

Considerando sus condiciones de emplazamiento y visibilidad (Tabla 6.8), todos los motivos de Los Navarros se encuentran sobre superficies verticales 
y, en algunos casos de los sectores 1,3 y 7 se utilizaron, además, bloques alejados de la barda basáltica. En todos los sectores se documentaron superficies con grabados orientadas al $\mathrm{N}$.

Respecto de su visibilidad, a nivel del sitio los motivos o conjuntos altamente visibles se encuentran sobre superficies libres de líquenes en las que los surcos grabados contrastan fuertemente con el soporte (ver Figuras 6.38.a y 6.40). El tamaño de los motivos también jugó un rol importante para su visibilidad. Los conjuntos y motivos con baja visibilidad se encuentran sobre superficies exfoliadas o colonizadas por líquenes, en los que se observa falta de contraste entre el surco grabado y el soporte (ver Figuras 6.38.b y 6.45), es decir que la baja visibilidad de estos conjuntos se vincula con factores tafonómicos, mientras que en otros casos la visibilidad de los conjuntos está sujeta e a la incidencia de la luz sobre el soporte en el momento del registro.

Al considerar la altura sobre el nivel del suelo, en la mayoría de los sectores los motivos se encuentran dispuestos hasta 1,50 m mientras que en los sectores 1 y 2 se documentaron motivos por encima de 1,50 m (Tabla 6.8). Los Conjuntos 5 y 20, en el sector 1 y 2 respectivamente, presentan motivos ubicados alrededor de $2 \mathrm{~m}$ sobre el suelo. Para dichos motivos se puede inferir algún tipo de soporte o ayuda de terceros en su realización. Esta idea se refuerza con la sedimentación que se registra al pie de dichos paneles (alrededor de 20-25 cm de profundidad), a partir de la cual se infiere que la altura respecto del suelo en el pasado debe haber sido mayor. En cuanto a la distribución espacial de los motivos, se observa que la distancia entre los sectores generalmente oscila entre 10 y $15 \mathrm{~m}$, siendo mínima $(6,5 \mathrm{~m})$ entre los sectores 3 y 4, y máxima (46 m) para los sectores 5 y 6 . 


\begin{tabular}{|c|c|c|c|c|c|c|c|c|c|c|}
\hline \multirow{2}{*}{\multicolumn{2}{|c|}{ Variables }} & \multicolumn{9}{|c|}{ Sectores } \\
\hline & & 1 & 2 & 3 & 4 & 5 & 6 & 7 & 8 & 9 \\
\hline Emplazamiento & $\begin{array}{l}\text { pared } \\
\text { bloque }\end{array}$ & $\begin{array}{l}\mathrm{X} \\
\mathrm{X}\end{array}$ & $\mathrm{X}$ & $\begin{array}{l}\mathrm{X} \\
\mathrm{X}\end{array}$ & $\mathrm{X}$ & $\mathrm{X}$ & $\mathrm{X}$ & $\begin{array}{l}\mathrm{X} \\
\mathrm{X}\end{array}$ & $\mathrm{X}$ & $\mathrm{X}$ \\
\hline Posición & $\begin{array}{l}\mathrm{V} \\
\mathrm{O}\end{array}$ & $\begin{array}{l}\mathrm{X} \\
\mathrm{X}\end{array}$ & $\mathrm{X}$ & $\mathrm{X}$ & $\mathrm{X}$ & $\mathrm{X}$ & $\begin{array}{l}X \\
X\end{array}$ & $\mathrm{X}$ & $\mathrm{X}$ & $\mathrm{X}$ \\
\hline Orientación & $\begin{array}{l}\mathrm{N} \\
\mathrm{S} \\
\mathrm{E} \\
\mathrm{W}\end{array}$ & $\begin{array}{l}X \\
X\end{array}$ & $\begin{array}{l}\mathrm{X} \\
\mathrm{X} \\
\end{array}$ & $\begin{array}{l}\mathrm{X} \\
\mathrm{X}\end{array}$ & $\mathrm{X}$ & $\mathrm{X}$ & $\mathrm{X}$ & $\mathrm{X}$ & $\mathrm{X}$ & $\begin{array}{l}\mathrm{X} \\
\mathrm{X}\end{array}$ \\
\hline $\begin{array}{l}\text { Distancia al } \\
\text { suelo } \\
\text { en } \mathrm{m}\end{array}$ & $\begin{array}{l}2 \\
2-1,6 \\
1,5-1 \\
<1\end{array}$ & $\begin{array}{l}X \\
X \\
X\end{array}$ & $\begin{array}{l}\mathrm{X} \\
\mathrm{X} \\
\mathrm{X} \\
\mathrm{X}\end{array}$ & $\begin{array}{l}X \\
X\end{array}$ & X & $\mathrm{X}$ & $\begin{array}{l}X \\
X\end{array}$ & $\begin{array}{l}X \\
X\end{array}$ & $\mathrm{X}$ & $\mathrm{X}$ \\
\hline $\begin{array}{l}\text { Campo visual } \\
\text { máximo en m }\end{array}$ & $\begin{array}{l}1 \\
3 \\
7 \\
15 \\
\end{array}$ & $\begin{array}{l}X \\
X \\
X \\
X \\
\end{array}$ & $\begin{array}{l}X \\
X \\
X\end{array}$ & $\begin{array}{l}X \\
X\end{array}$ & $\mathrm{X}$ & $\mathrm{X}$ & $\begin{array}{l}X \\
X \\
X \\
X\end{array}$ & $\begin{array}{l}\mathrm{X} \\
\mathrm{X} \\
\mathrm{X}\end{array}$ & $\mathrm{X}$ & $\mathrm{X}$ \\
\hline Iluminación & $\begin{array}{l}\text { luz tarde } \\
\text { luz mañana }\end{array}$ & $\begin{array}{l}\mathrm{X} \\
\mathrm{X} \\
\end{array}$ & $\begin{array}{l}\mathrm{X} \\
\mathrm{X} \\
\end{array}$ & $\mathrm{X}$ & $\mathrm{X}$ & $\mathrm{X}$ & $\mathrm{X}$ & $\begin{array}{l}\mathrm{X} \\
\mathrm{X}\end{array}$ & $\begin{array}{l}\mathrm{X} \\
\mathrm{X}\end{array}$ & $\begin{array}{l}\mathrm{X} \\
\mathrm{X}\end{array}$ \\
\hline Visibilidad & $\begin{array}{l}\text { 1) alta } \\
\text { 2) intermedia } \\
\text { 3) baja } \\
\text { 4) muy baja }\end{array}$ & $\begin{array}{l}X \\
X \\
X \\
X\end{array}$ & $\begin{array}{l}\mathrm{X} \\
\mathrm{X} \\
\mathrm{X}\end{array}$ & $\begin{array}{l}X \\
X\end{array}$ & $\mathrm{X}$ & $\mathrm{X}$ & $\begin{array}{l}\mathrm{X} \\
\mathrm{X} \\
\mathrm{X}\end{array}$ & $\begin{array}{l}\mathrm{X} \\
\mathrm{X} \\
\mathrm{X}\end{array}$ & $\mathrm{X}$ & $\mathrm{X}$ \\
\hline Motivos & $\begin{array}{l}\text { Puntiformes } \\
\text { Rectilíneos } \\
\text { Circular lleno } \\
\text { Circular lineal } \\
\text { Curvilíneos } \\
\text { Tridígito } \\
\text { Pisada guanaco } \\
\text { Pisadas felino } \\
\text { Matuasto } \\
\text { ND }\end{array}$ & $\begin{array}{l}\mathrm{X} \\
\mathrm{X} \\
\mathrm{X} \\
\mathrm{X} \\
\mathrm{X} \\
\mathrm{X} \\
\mathrm{X} \\
\mathrm{X} \\
\mathrm{X}\end{array}$ & $\begin{array}{l}\mathrm{X} \\
\mathrm{X} \\
\mathrm{X} \\
\mathrm{X} \\
\mathrm{X} \\
\mathrm{X}\end{array}$ & $\begin{array}{l}\mathrm{X} \\
\mathrm{X} \\
\mathrm{X} \\
\mathrm{X} \\
\mathrm{X}\end{array}$ & $\mathrm{X}$ & $\begin{array}{l}X \\
X\end{array}$ & $\begin{array}{l}X \\
X\end{array}$ & $\begin{array}{l}\mathrm{X} \\
\mathrm{X} \\
\mathrm{X}\end{array}$ & $\begin{array}{l}X \\
X\end{array}$ & $\begin{array}{l}\mathrm{X} \\
\mathrm{X}\end{array}$ \\
\hline
\end{tabular}

Tabla 6.8. Condiciones de emplazamiento y visibilidad en Los Navarros.

Si se considera la visualización del Conjunto 6, que presenta la mayor cantidad de motivos del sitio, se pueden observar algunas cuestiones interesantes. Dependiendo de la distancia de observación, este conjunto se asocia parcialmente (Figura 6.49.a) o completamente al Conjunto 4 (Figura 6.49.b). Si bien las superficies sobre las que se encuentran presentan diferente coloración, es posible pensar en la continuidad de motivos en ambos conjuntos por la presencia de una línea grabada en el conjunto 6 que parece prolongarse en una grieta cubierta con líquenes presente en la barda -donde se encuentra el conjunto 4- y remata en un motivo en forma de "U invertida" (Figura 6.49.a flecha naranja). Si se amplía la distancia de 
observación, en la que se observan mejor los motivos que conforman ambos conjuntos, se podría pensar que los rasgos naturales del soporte los integran (Figura 6.49.b). Es decir, en los extremos izquierdo y derecho se observan mayoritariamente líneas verticales grabadas (Figura 6.49.b, flechas blancas) que enmarcan los motivos figurativos -pisadas animales- de ambos conjuntos (Figura 6.49.b; zona sombreada), con líneas grabadas y rasgos naturales del soporte parecen unirlos (Figura 6.49.b; blancas centrales y flechas naranjas). A partir de lo anterior, puede plantearse que en el sector 1 podrían haber existido varias instancias de observación de los motivos.

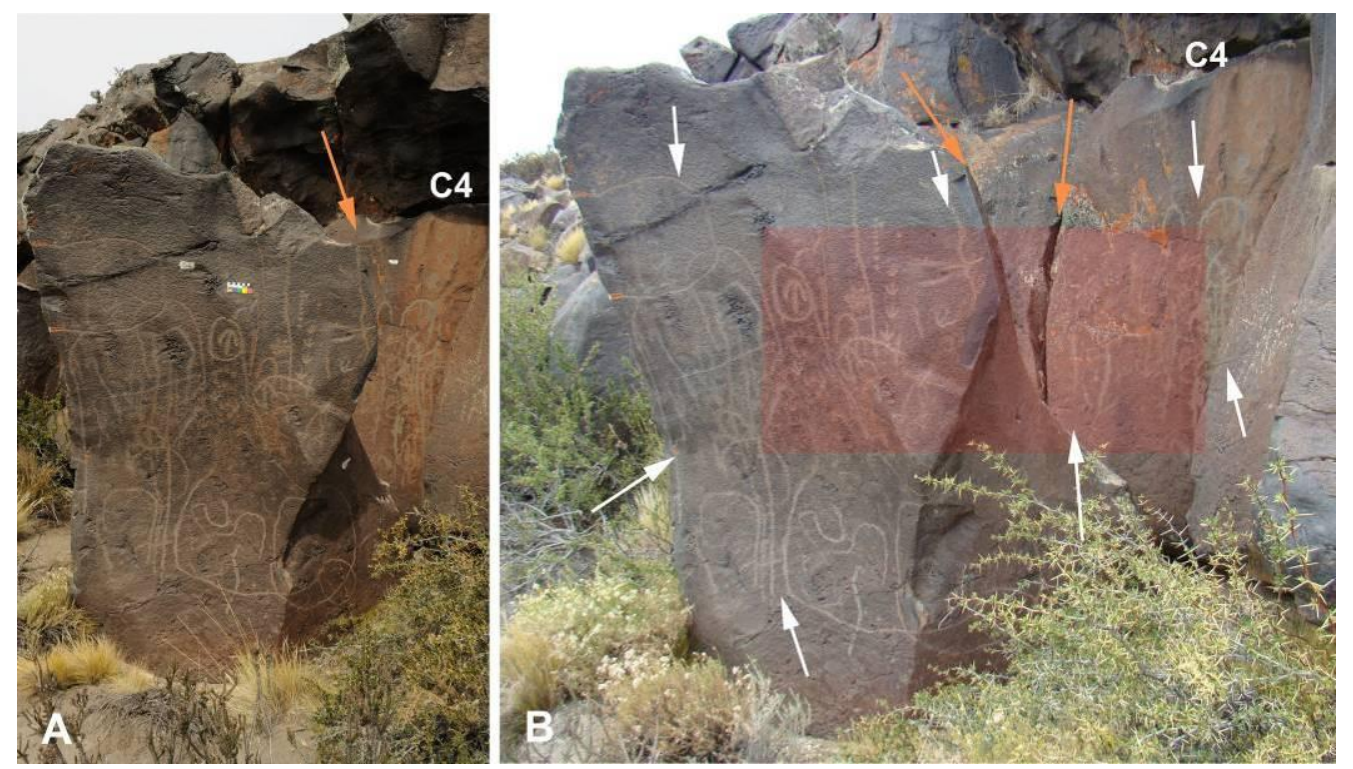

Figura 6.49. Visualización y posible continuidad entre los conjuntos 4 y 6: a. integración parcial con el conjunto 4; b. integración y continuidad con la mayor parte del conjunto 4 .

Para inferir que hubo una planificación previa en la integración de los conjuntos 4 y 6 deberían observarse dos situaciones: 1) que los conjuntos presenten motivos similares, y 2) que esos motivos presenten pátina similar, lo que indicaría una sincronía relativa en su producción. Si bien la cantidad de motivos que integra cada conjunto es diferente, en ambos se observaron líneas rectas y curvas verticales, motivos circulares lineales y pisadas de animales, que en el Conjunto 4 presentan pátina clara e intermedia en tanto que en el Conjunto 6 presentan tres tipos de pátina (Tabla 6.9). Estas semejanzas permitirían pensar que existió cierto grado de planificación en la realización de estos conjuntos. 


\begin{tabular}{|l|l|l|c|}
\hline \multicolumn{2}{|c|}{ Conjunto 4 } & \multicolumn{1}{c|}{ Conjunto 6 } \\
\hline \multicolumn{1}{|c|}{ Motivos } & Pátina & \multicolumn{1}{c|}{ Motivos } & Pátina \\
\hline $\begin{array}{l}\text { "En forma de U" y "U invertida" } \\
\text { con apéndice, líneas rectas y } \\
\text { curvas, circunferencias y } \\
\text { semicircunferencias, no } \\
\text { determinados. }\end{array}$ & Clara & $\begin{array}{l}\text { Tridígitos, líneas rectas y } \\
\text { curvas, líneas quebradas, } \\
\text { circunferencias }\end{array}$ & Clara \\
\hline $\begin{array}{l}\text { Tridígitos, pisada felino, "U } \\
\text { invertida" }\end{array}$ & Intermedia & $\begin{array}{l}\text { Semicircunferencias, línea de } \\
\text { puntos, pisada felino, líneas } \\
\text { curvas, líneas rectas, óvalo } \\
\text { con apéndice }\end{array}$ & Intermedia \\
\hline- & Oscura & $\begin{array}{l}\text { "U invertida" con apéndice, } \\
\text { tridígitos, circunferencia con } \\
\text { apéndice, líneas curvas }\end{array}$ & Oscura \\
\hline
\end{tabular}

Tabla 6.9. Tipos de motivos y pátinas de los conjuntos 4 y 6 , vinculados espacialmente mediante su visualización a diferentes distancias.

La técnica empleada para la realización de los motivos fue la percusión. Por el momento, resulta sumamente difícil discernir si fue directa o indirecta

Los motivos de Los Navarros presentan tres grados de pátina: clara, intermedia y oscura. En líneas generales, se observó un predominio de motivos con pátina clara, presente en los sectores 1 a 3 y 5 a 7 , seguidos por motivos con pátina intermedia (Figura 6.50; Tabla 6.10). Motivos con pátina oscura fueron documentados en los sectores 1 a 4, y 6, 7 y 9. Los motivos en los que no se pudo determinar el grado de pátina corresponden a aquellos casos en los que el surco grabado se encontraba parcial o totalmente obliterado por líquenes, y se encuentran en los sectores 1 a 3, 5, 6 y 9.

\begin{tabular}{|l|c|c|c|c|c|c|c|c|c|c|}
\cline { 2 - 13 } \multicolumn{1}{c|}{} & \multicolumn{10}{c|}{ Sectores } \\
\hline Pátina & 1 & 2 & 3 & 4 & 5 & 6 & 7 & 8 & 9 & Subtotal \\
\hline Clara & 52 & 30 & 16 & 0 & 8 & 5 & 1 & 0 & 0 & 112 \\
\hline Intermedia & 32 & 18 & 14 & 1 & 0 & 16 & 3 & 2 & 1 & 87 \\
\hline Oscura & 14 & 4 & 16 & 2 & 0 & 11 & 15 & 0 & 1 & 63 \\
\hline ND & 8 & 2 & 5 & 0 & 1 & 7 & 0 & 0 & 1 & 24 \\
\hline Total & 106 & 54 & 51 & 3 & 9 & 39 & 19 & 2 & 3 & 286 \\
\hline
\end{tabular}

Tabla 6.10. Frecuencias de tipos de pátina por sector de Los Navarros. Referencias: ND: no determinada. 


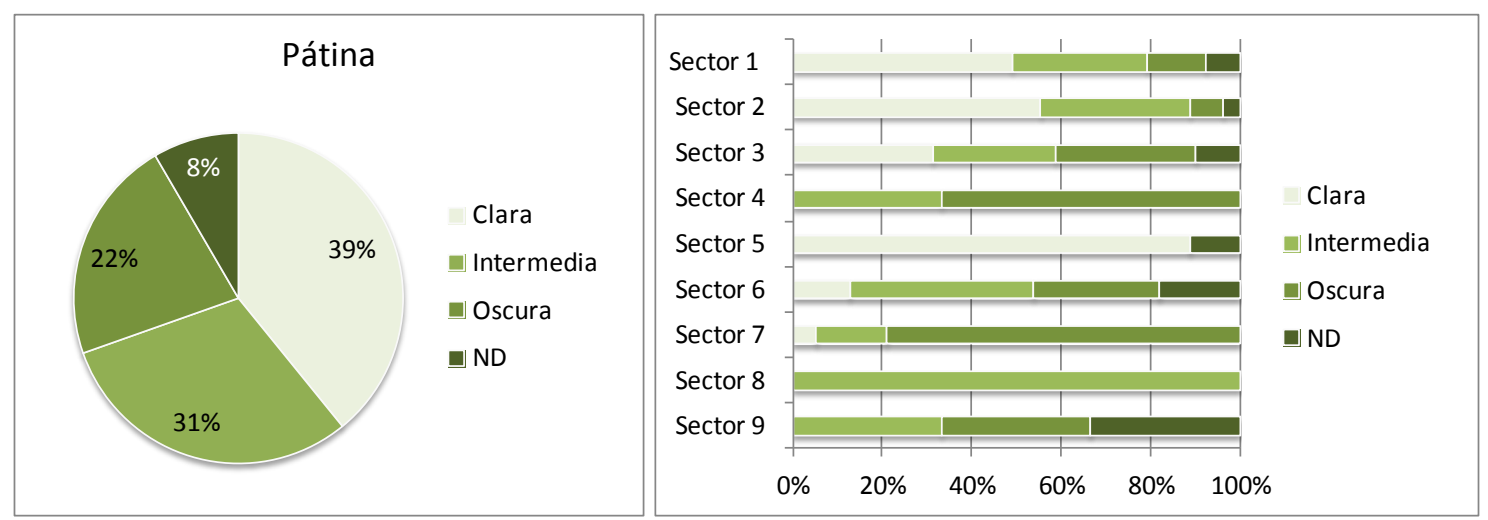

Figura 6.50. Proporciones y distribución por sector de los grados de pátina reconocidos en Los Navarros. ND: no determinada.

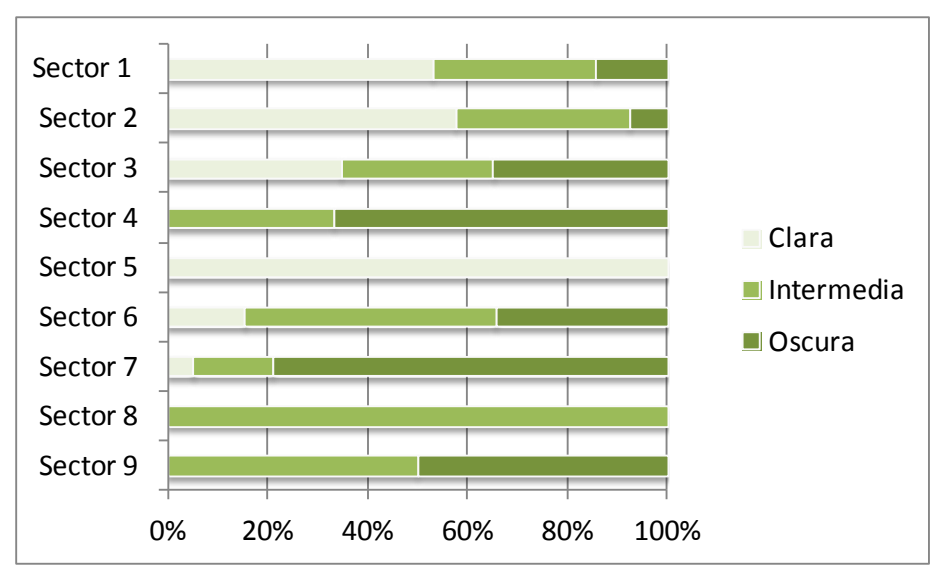

Figura 6.51. Proporciones y distribución por sector de los grados de pátina reconocidos en Los Navarros sin considerar aquellos con pátina no determinada.

Se observan 29 superposiciones en nueve conjuntos del sitio (Tabla 6.11). En el sector 1 dichas superposiciones fueron registradas en los Conjuntos 4 y 6. El primer conjunto se encuentra muy afectado por la acción de líquenes (ver Figura 6.30.b), por lo que fue difícil establecer con certeza todas las superposiciones presentes, aunque pudieron establecerse con precisión dos. En el Conjunto 6 se distinguieron 15 superposiciones involucrando 20 motivos (Figura 6.52). En el sector 2 se observaron tres superposiciones: una en el Conjunto 18 y las restantes en el Conjunto 20 (ver Figura 6.39). En este último, el tramo final del surco grabado de las rectas que conforman el laberinto -ubicado en posición inferior- parece haber sido reactivado con cierta contemporaneidad a la semicircunferencia (ver Figura 6.39.b), ya que ambos presentan pátina clara en ese sector del soporte. Para el Conjunto 23 se observaron tres superposiciones (Tabla 6.11). 
En el sector 3 se detectaron cuatro superposiciones: dos en el Conjunto 27 y dos en el Conjunto 34 (ver Figuras 6.42 y 6.44 respectivamente). En el sector 6 se observa una superposición entre dos motivos circulares lineales del Conjunto 40: el complejo por encima del simple (ver Figura 6.46). Por último, en el sector 7 dos motivos del Conjunto 47 se encuentran superpuestos (ver Figura 6.48.a).

En la mayoría de las superposiciones se observan motivos inferiores con pátina en algún grado más oscura que en los motivos superiores, aunque también se observan casos donde ambos motivos presentan el mismo tipo de pátina (Tabla 6.11). La única salvedad debería notarse para las superposiciones 9 a 12 del Conjunto 6 donde el motivo inferior presenta tres tipos de pátina, y los motivos superiores también presentan pátina de diferente tipo: oscura e intermedia para las superposiciones 9 y 10, mientras que las superposiciones 11 y 12 evidencian pátina de clara tanto para los motivos inferiores como superiores (Figura 6.52: referencias 11 y 12). 


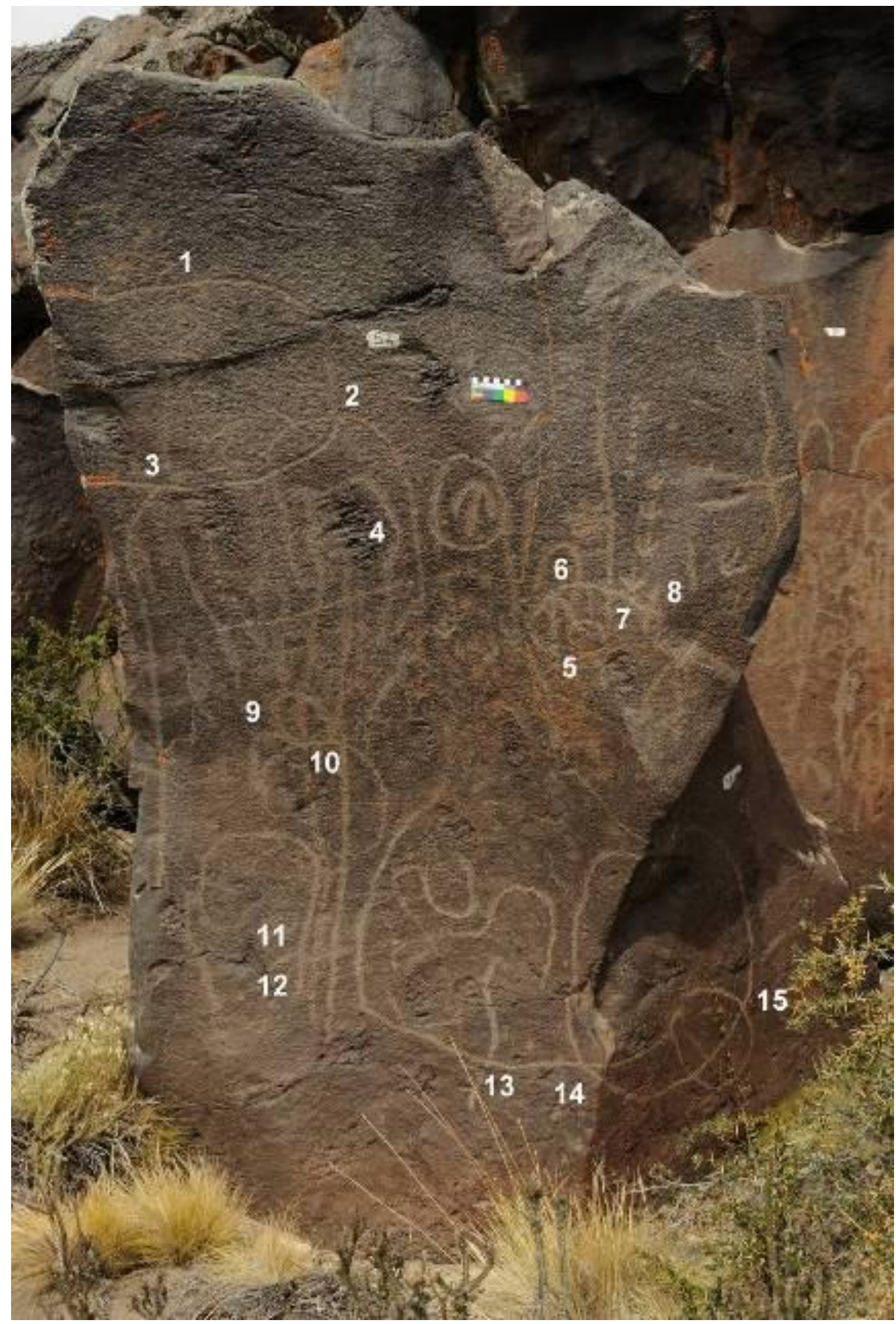

Figura 6.52. Superposiciones del Conjunto 6. Los números refieren a las mismas, indicadas en Tabla 6.8. 


\begin{tabular}{|c|c|c|c|c|c|c|}
\hline Sector & Conj. & Nro. & Motivo inferior & Pátina & Motivo superior & Pátina \\
\hline \multirow{17}{*}{1} & \multirow{2}{*}{4} & 1 & "En forma de U" & Clara & Líneas rectas vertical larga & Clara \\
\hline & & 2 & Óvalo con apéndice & Clara & Línea curva & Clara \\
\hline & \multirow{15}{*}{6} & 1 & Serpentiforme & \multirow[b]{2}{*}{ Oscura } & \multirow{2}{*}{ Semicircunferencia } & \multirow{2}{*}{ Intermedia } \\
\hline & & 2 & "U invertida" con apéndice & & & \\
\hline & & 3 & Semicircunferencia & Intermedia & Línea recta vertical con apéndice & Clara \\
\hline & & 4 & Tridígito superior de rastro & Oscura & "U invertida" & Clara \\
\hline & & 5 & Tridígito & Intermedia & Óvalo con dos apéndices & Intermedia \\
\hline & & 6 & U invertida & Oscura & Apéndice horizontal de óvalo & Clara \\
\hline & & 7 & \multirow{2}{*}{ Apéndice horizontal de óvalo } & \multirow{2}{*}{ Clara } & Línea recta vertical larga & Clara \\
\hline & & 8 & & & Línea vertical corta & Clara \\
\hline & & 9 & \multirow{3}{*}{ Líneas rectas paralelas } & Oscura & Circunferencia con apéndice curvo & Oscura \\
\hline & & 10 & & Intermedia & Semicircunferencia & Intermedia \\
\hline & & 11 & & Clara & Línea curva & Clara \\
\hline & & 12 & "U invertida" & Clara & Línea curva & Clara \\
\hline & & 13 & Línea en ángulo recto (L) & Clara & Línea recta vertical oblicua & Clara \\
\hline & & 14 & Circunforoncis ambos caras & Clara & Línea en ángulo recto (L) & Clara \\
\hline & & 15 & Circunterencia ambas caras & Clara & Circunferencia en cara oeste & Clara \\
\hline \multirow{6}{*}{2} & 18 & 1 & Óvalo con apéndice curvo & Intermedia & Línea recta vertical & Intermedia \\
\hline & \multirow{2}{*}{20} & 1 & Estela de laberintiforme & Oscura & Circunferencias concéntricas & Intermedia \\
\hline & & 2 & Líneas rectas & Intermedia & Semicircunferencia & Clara \\
\hline & \multirow{3}{*}{23} & 1 & Línea curva & \multirow{3}{*}{ Intermedia } & Tridígito invertido & \multirow{3}{*}{ Intermedia } \\
\hline & & 2 & Facutiformo & & Línea curva & \\
\hline & & 3 & Escutiforme & & Línea recta vertical & \\
\hline \multirow{4}{*}{3} & \multirow{2}{*}{27} & 1 & \multirow{2}{*}{ Línea de puntos } & \multirow{2}{*}{ Oscura } & Circunferencia con tridígito interior & \multirow{2}{*}{ Intermedia } \\
\hline & & 2 & & & Circunferencia de de trazo combinado & \\
\hline & \multirow{2}{*}{34} & 1 & \multirow{2}{*}{ Óvalo con apéndice curvo } & \multirow{2}{*}{ Intermedia } & Línea recta +curva & \multirow{2}{*}{ Clara } \\
\hline & & 2 & & & Línea recta con apéndice & \\
\hline 6 & 40 & 1 & Circunferencia simple & Oscura & Óvalo complejo & Intermedia \\
\hline Total & 47 & 1 & Circunferencia simple & Oscura & "Media U" & Oscura \\
\hline
\end{tabular}

Tabla 6.11. Motivos involucrados en las superposiciones detectadas en LN. Referencias: Conj: Conjunto; Nro: número de superposición 
En las superposiciones registradas en Los Navarros, se evidencia que generalmente los motivos en posición superior presentan pátina similar o menos desarrollada que los inferiores (Tabla 6.12), siendo abundantes los casos en los que los motivos con pátina clara se encuentran en posición superior $(51,7 \%)$ en tanto que en posición inferior se observan proporciones similares de motivos con pátina intermedia y oscura $(34,5 \%)$, y pátina clara $(31 \%)$.

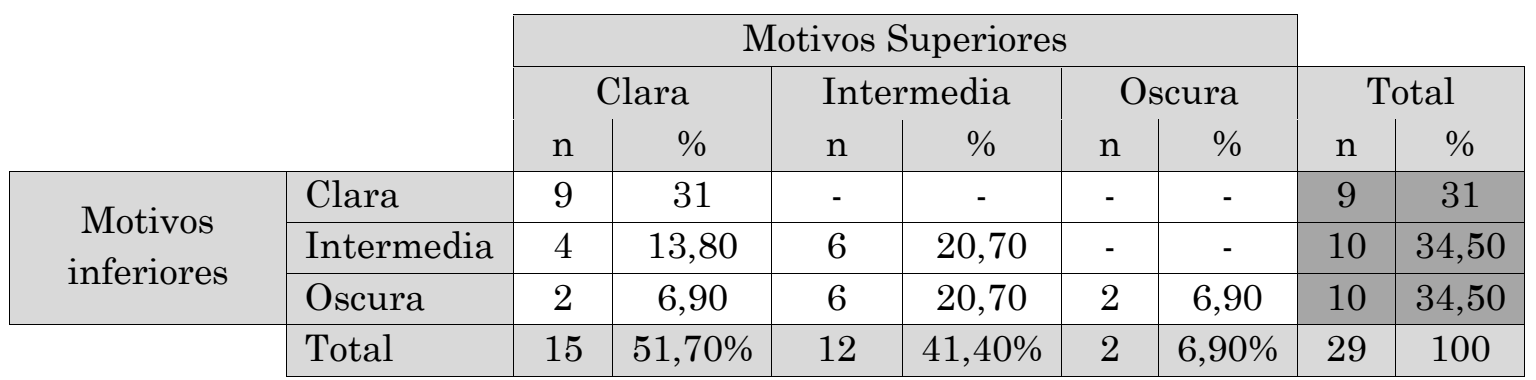

Tabla 6.12.Pátinas involucradas en las superposiciones de LN.

En cuanto a los motivos que integran estas superposiciones, se trata de motivos figurativos y no figurativos. Entre los primeros, solo se observaron tridígitos con pátina intermedia y oscura, que se encuentran en posición inferior o superior a motivos no figurativos. Entre estos últimos, la variabilidad observada es mayor, pudiendo encontrarse en posición inferior o superior y con los tres tipos de pátina reconocidos (Tabla 6.13).

\begin{tabular}{|l|l|l|}
\hline Pátina & \multicolumn{1}{|c|}{ Motivo Inferior } & \multicolumn{1}{|c|}{ Motivo Superior } \\
\hline Clara & $\begin{array}{l}\text { Líneas rectas (simples o paralelas), } \\
\text { línea en ángulo recto, "en forma de } \\
\text { U", apéndice de óvalo; "U invertida" } \\
\text { con apéndice, circunferencia }\end{array}$ & $\begin{array}{l}\text { Líneas rectas y líneas curvas (simples y } \\
\text { con apéndice), línea en ángulo recto, "U } \\
\text { invertida", circunferencia simple }\end{array}$ \\
\hline Intermedia & $\begin{array}{l}\text { Semicircunferencia, tridígito, líneas } \\
\text { rectas; líneas curvas, escutiforme, } \\
\text { óvalo con apéndice }\end{array}$ & $\begin{array}{l}\text { Semicircunferencias, óvalo con apéndice, } \\
\text { líneas rectas (simples y paralelas), } \\
\text { circunferencias concéntricas, línea curva, } \\
\text { tridígito invertido, tridígito en el interior } \\
\text { de circunferencia, circunferencia de trazo } \\
\text { combinado, óvalo complejo }\end{array}$ \\
\hline Oscura & $\begin{array}{l}\text { Serpentiforme, "U invertida" con } \\
\text { apéndice, tridígito, "U invertida", } \\
\text { líneas paralelas, línea de puntos, } \\
\text { circunferencia simple }\end{array}$ & Circunferencia con apéndice, "media U" \\
\hline
\end{tabular}

Tabla 6.13. Categorías de motivos y grado de pátina presentes en las superposiciones.

Estas superposiciones junto con los distintos grados de pátina reconocidos son las que permiten proponer cronologías relativas en cuanto a la 
realización de los motivos. Los sectores 1 a 3,6 y 7 son los que presentan motivos con tres grados de pátina y en los que además se registraron superposiciones (Tabla 6.14), por lo que se puede proponer un uso diacrónico y continuado de los mismos. Si bien los sectores 4 y 9 exhiben motivos con pátinas intermedias y oscuras, esto podría estar relacionado a la exfoliación y a la acción de líquenes sobre las superficies rocosas. Por último, los motivos del sector 5 y 8 presentan pátina intermedia.

\begin{tabular}{|c|c|c|c|c|}
\hline \multirow{2}{*}{ Sector } & \multicolumn{3}{|c|}{ Pátina } & Superposiciones \\
\cline { 2 - 5 } & Clara & Intermedia & Oscura & X \\
\hline 1 & $\mathrm{X}$ & $\mathrm{X}$ & $\mathrm{X}$ & $\mathrm{X}$ \\
\hline 2 & $\mathrm{X}$ & $\mathrm{X}$ & $\mathrm{X}$ & $\mathrm{X}$ \\
\hline 3 & $\mathrm{X}$ & $\mathrm{X}$ & $\mathrm{X}$ & - \\
\hline 4 & - & $\mathrm{X}$ & $\mathrm{X}$ & - \\
\hline 5 & - & $\mathrm{X}$ & - & $\mathrm{X}$ \\
\hline 6 & $\mathrm{X}$ & $\mathrm{X}$ & $\mathrm{X}$ & $\mathrm{X}$ \\
\hline 7 & $\mathrm{X}$ & $\mathrm{X}$ & $\mathrm{X}$ & - \\
\hline 8 & - & $\mathrm{X}$ & - & - \\
\hline 9 & - & $\mathrm{X}$ & $\mathrm{X}$ & $\mathrm{y}$ \\
\hline
\end{tabular}

Tabla 6.14. Presencia de los diferentes grados de pátinas y superposiciones por sector. Referencias: X: presencia; -: ausencia.

Si se analiza cada uno de los sectores es posible observar diferencias con respecto a la diversidad y cantidad de motivos que presenta. En Los Navarros predominan los motivos circulares lineales, presentes en todos los sectores mientras que los motivos rectilíneos y curvilíneos están presentes en los sectores 1 a 3 y 5 a 7 (Figura 6.53); estos últimos también están presentes en el sector 8. Los circulares llenos están representados exclusivamente en el sector 1 por un sólo motivo.

La variabilidad a nivel intrasitio puede observarse a través de la distribución espacial de los subgrupos de motivos más abundantes, considerando diferentes clases. Los motivos rectilíneos, circulares lineales y curvilíneos son los más abundantes $(n=228)$. Los rectilíneos fueron divididos según su complejidad en simples, con apéndices, línea quebrada, series de líneas paralelas y figura geométrica con trazos internos (Figura 6.53). Las líneas rectas simples son las que predominan y se encuentran en los sectores 1 a 3 y 5 a 7. 
Los motivos circulares lineales se encuentran en todos los sectores. La variabilidad observada consta de 12 clases de motivos (Figura 6.53), 11 de las cuales están presentes en el sector 6. Predominan las circunferencias simples, presentes en todos los sectores; le siguen las circunferencias con apéndices registradas en los sectores 1 a 3,5 y 6 . Las circunferencias concéntricas se encuentran presentes en los sectores 1 a 7 . Para los motivos curvilíneos, las clases identificadas son 11 (Figura 6.53). Este subgrupo de motivos fue registrado en los sectores 1 a 3 y 5 a 8 , siendo los tres primeros los que presentan mayor variabilidad. La categoría predominante es la de las líneas curvas, seguida por aquellas "en forma de U".

Los tres primeros sectores presentan la mayor frecuencia $(n=211$; 73,77\%) y variabilidad de motivos del sitio: la totalidad de las clases reconocidas en los rectilíneos y los curvilíneos, y 66,66\% de las clases reconocidas en los circulares lineales. El sector 6 presenta el 13,36\% de motivos del sitio y es el que presenta mayor cantidad de motivos circulares lineales, con una alta variabilidad en las clases reconocidas para ese subgrupo de motivos. Es decir, que se observa cierta asociación espacial para la realización de motivos circulares lineales.

Referencias Figura 6.53. Circulares lin: circulares lineales; Línea recta con ap: línea recta con apéndice; Fig con trazo internos: figura con trazos internos; semicircunf con ap: semicircunferencia con apéndice; Circunf con caract int: circunferencia con características internas; circunf con ap + caract int: circunferencia con apéndice y características internas; En forma de U tap: en forma de "U" con apéndice. 


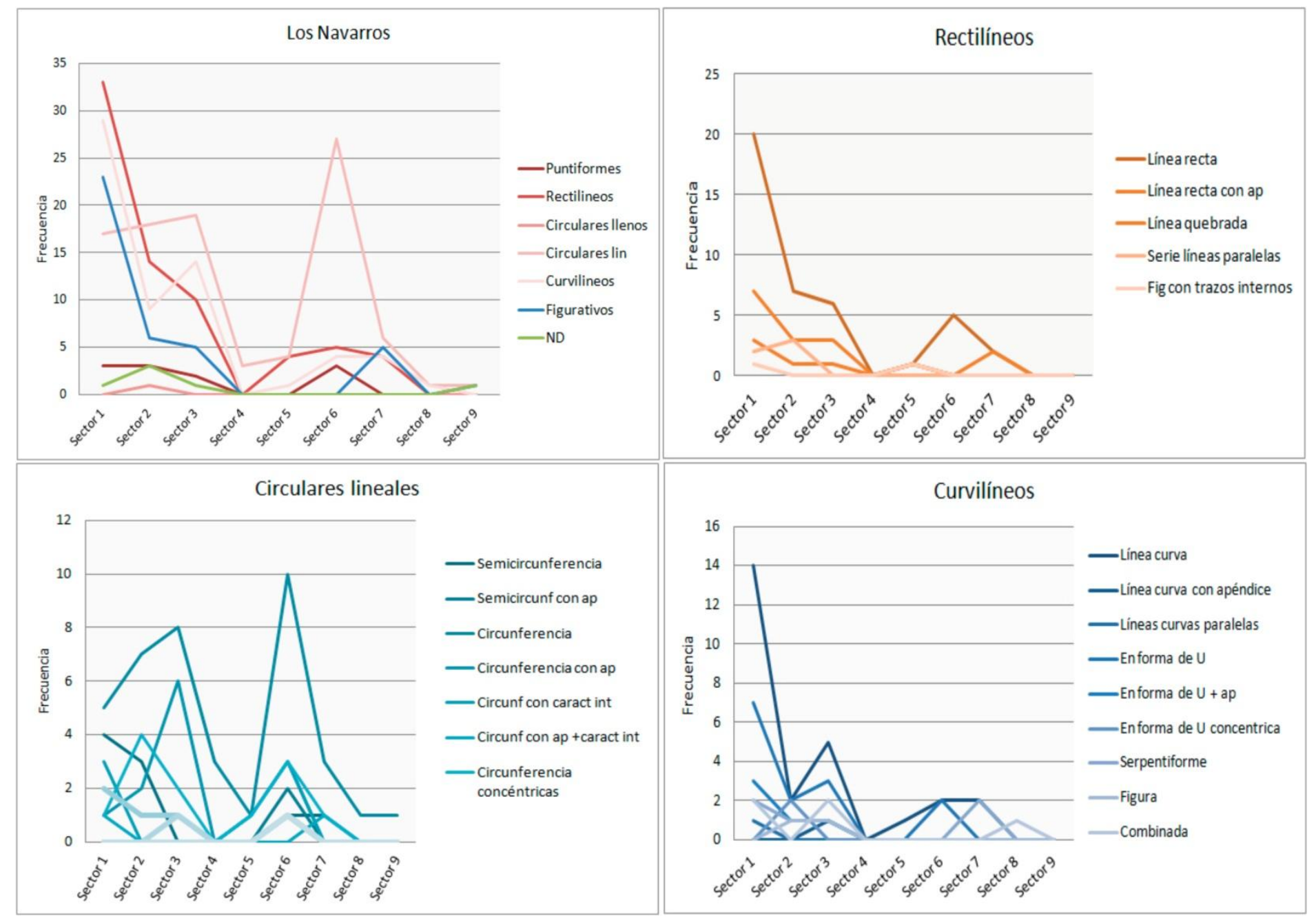

Figura 6.53. Distribución por sector de subgrupos y clases de motivos. 
$\mathrm{Al}$ cruzar esta información con el tipo de pátina reconocida se observa que predominan los motivos con pátina clara e intermedia, coincidente con el patrón observado en el sitio. La mayoría de las clases presentan los distintos tipos de pátina reconocidos (Tabla 6.15), aunque las líneas rectas con apéndice y otros rectilíneos no presentan pátinas oscuras (Figuras 6.54). Esta situación, en conjunto con aquella indicada por las superposiciones, en las que algunas rectas se encuentran en posición superior y con pátina clara, o bien en posiciones inferior con pátina intermedia o clara, indicaría que las mismas serían de factura más reciente que los restantes motivos.

\begin{tabular}{|c|c|c|c|c|c|c|c|c|c|c|}
\hline \multirow{2}{*}{ Clase de motivo } & \multicolumn{9}{|c|}{ Pátina } & \multicolumn{3}{c|}{ Total } \\
\cline { 2 - 11 } & Clara & $\%$ & Intermedia & $\%$ & Oscura & $\%$ & ND & $\%$ & N & $\%$ \\
\hline Línea recta & 31 & 13,60 & 6 & 2,63 & 4 & 1,75 & 0 & - & 41 & 17,98 \\
\hline Línea con apéndice & 6 & 2,19 & 0 & - & 0 & - & 0 & - & 6 & 2,19 \\
\hline Línea recta quebrada & 6 & 2,63 & 5 & 2,19 & 2 & 0,88 & 3 & 1,31 & 16 & 7,01 \\
\hline Otros rectilíneos & 4 & 1,75 & 2 & 0,88 & 0 & - & 1 & 0,44 & 7 & 3,07 \\
\hline Semicircunferencia & 5 & 2,19 & 2 & 0,88 & 2 & 0,88 & 0 & - & 9 & 3,95 \\
\hline Circunferencia & 7 & 3,07 & 10 & 4,38 & 14 & 6,13 & 8 & 3,51 & 39 & 17,10 \\
\hline Circunf con apéndice & 4 & 1,75 & 4 & 1,75 & 3 & 1,32 & 3 & 1,32 & 14 & 6,14 \\
\hline Circunf concéntrica & 4 & 1,75 & 3 & 1,32 & 2 & 0,87 & 3 & 1,32 & 12 & 5,26 \\
\hline Otros circulares lin & 6 & 2,63 & 9 & 3,94 & 3 & 1,32 & 4 & 1,75 & 22 & 9,64 \\
\hline Línea curva & 12 & 5,26 & 8 & 3,51 & 6 & 2,63 & 0 & - & 26 & 11,40 \\
\hline "En forma de U” & 4 & 1,75 & 4 & 1,75 & 5 & 2,19 & 1 & 0,44 & 14 & 6,14 \\
\hline Serpentiforme & 2 & 0,88 & 1 & 0,44 & 3 & 1,32 & 0 & - & 6 & 2,19 \\
\hline Otros curvilíneos & 6 & 2,63 & 7 & 3,07 & 3 & 1,32 & 0 & - & 16 & 7,01 \\
\hline Total & 97 & 42,54 & 61 & 26,75 & 47 & 20,61 & 23 & 10,08 & 228 & $100 \%$ \\
\hline
\end{tabular}

Tabla 6.15. Distribución de pátinas por clases de motivos en Los Navarros.

Referencias: Circunf con apéndice: Circunferencia con apéndice; Otros circulares lin: otros circulares lineales; línea curva con ap: línea curva con apéndice; Pátina ND: no determinada. 


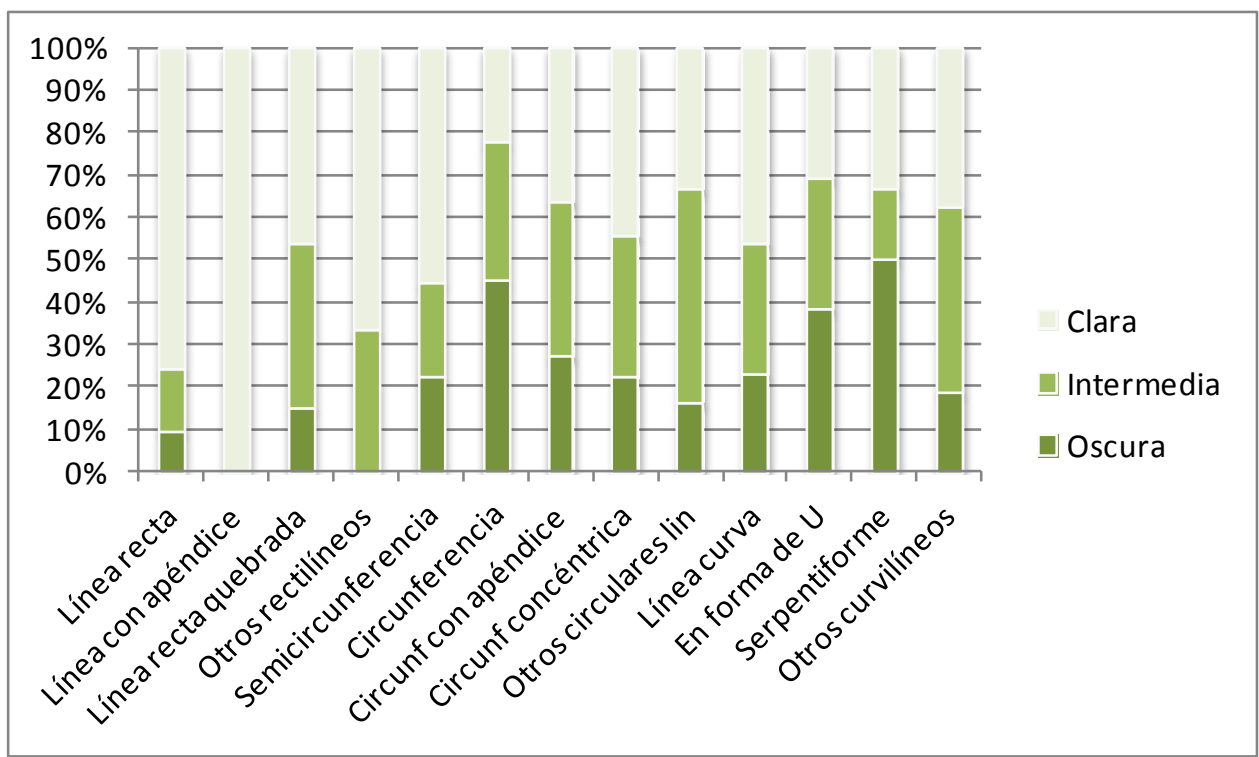

Figura 6.54. Distribución porcentual de categorías de motivos y tipo de pátina sin contemplar la no determinada. Referencias: Circunf con apéndice: Circunferencia con apéndice; Otros circulares lin: otros circulares lineales; línea curva con ap: línea curva con apéndice.

Respecto de los motivos figurativos, este grupo está representado por un único zoomorfo y por 39 pisadas de animales, documentados en los sectores 1 a 3, 7 y 9 (Figura 6.55). El zoomorfo corresponde a un matuasto y se encuentra en el sector 1; este motivo es muy poco frecuente en el área, habiéndose registrado un sólo caso en el sitio LCB (Carden 2013). Las figuras de matuastos se concentran en las mesetas altas del oeste de Santa Cruz (Carden et al. 2009; Gradin 1996; Guichón 2012; Re 2011). Respecto a los rastros animales, se reconocieron tres clases: las pisadas de ave o tridígitos, las de guanaco y las de felino. Predominan los tridígitos, que están presentes en todos los sectores mencionados previamente, mientras que las pisadas de guanaco y de felino se encuentran exclusivamente en los sectores 1 y 3 (Figura 6.55). 


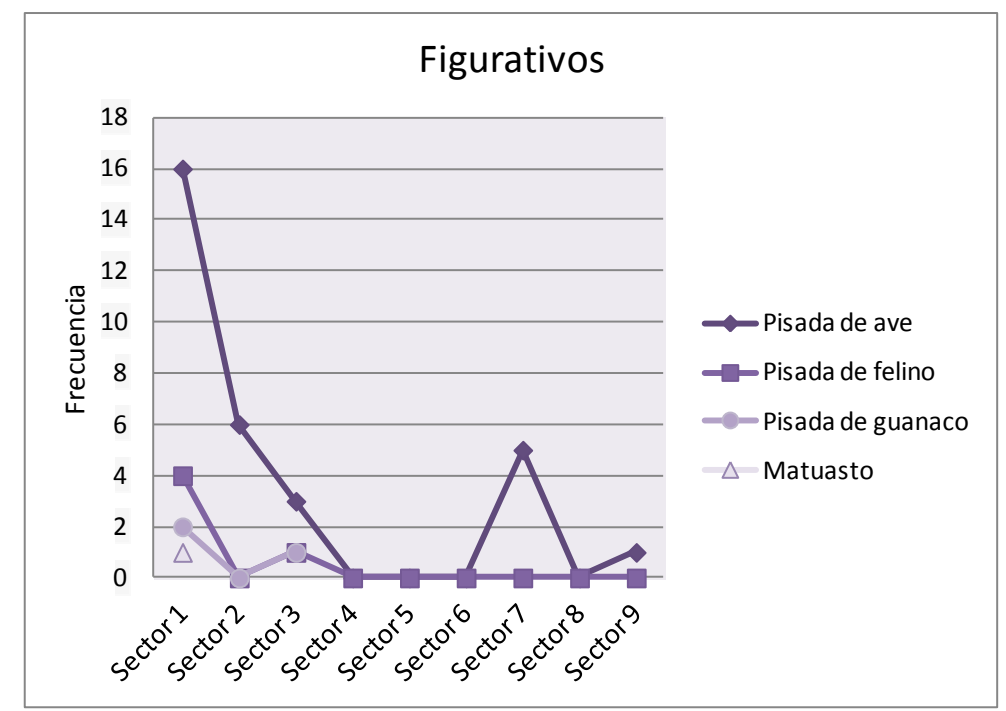

Figura 6.55. Distribución de los motivos figurativos en los diferentes sectores.

En el Capítulo 2 se desarrolló de manera más extensa la clasificación de pisadas animales empleada en esta tesis, cuyo fundamento es la propuesta realizada por Carden (2008a) para las localidades de Aguada del Cuero y Piedra Museo. Entre las pisadas de ave, en esta tesis se reconocen siete tipos considerando la robustez de los dedos, el ángulo de separación interdigital y su contorno. El tipo A conformado por tres trazos finos convergentes a $45^{\circ}$, el B es similar aunque de características robustas. En el tipo $\mathrm{C}$, los trazos convergen a $45^{\circ}$ con presencia del dedo trasero mientras que en el tipo $\mathrm{D}$ el ángulo entre los trazos es mayor a $45^{\circ}$ y menor a $90^{\circ}$. En el tipo E, el dedo medio se encuentra a $90^{\circ}$, para el tipo $\mathrm{F}$ el contorno de la pisada es en forma de U, y el tipo G presenta el eje medio largo y curvado.

En los Navarros se observaron 31 pisadas de ave (Tabla 6.16), de las cuales el 29\% corresponde al tipo A, el 38,71\% corresponde al tipo B. Los tipos D y E suman 19,40\% (Figura 6.56). Los tipos C, F y G están representados por pocos motivos, reuniendo el 12,90\% (Tabla 6.16). 


\begin{tabular}{|c|c|c|c|c|c|}
\hline Tipo & Sector & Conjunto & $\mathrm{N}$ & Total & $\%$ \\
\hline \multirow{5}{*}{ A } & \multirow{3}{*}{1} & 4 & 1 & \multirow{5}{*}{9} & \multirow{5}{*}{29} \\
\hline & & 6 & 3 & & \\
\hline & & 9 & 1 & & \\
\hline & 2 & 16 & 3 & & \\
\hline & 3 & 34 & 1 & & \\
\hline \multirow{6}{*}{ B } & \multirow{2}{*}{1} & 4 & 1 & \multirow{6}{*}{12} & \multirow{6}{*}{38,71} \\
\hline & & 6 & 7 & & \\
\hline & 2 & 20 & 1 & & \\
\hline & 3 & 23 & 1 & & \\
\hline & 7 & 50 & 1 & & \\
\hline & 8 & 52 & 1 & & \\
\hline $\mathrm{C}$ & 1 & 4 & 1 & 1 & 3,22 \\
\hline \multirow{2}{*}{ D } & 2 & 15 & 1 & \multirow{2}{*}{3} & \multirow{2}{*}{9,70} \\
\hline & 7 & 50 & 2 & & \\
\hline \multirow{2}{*}{$\mathrm{E}$} & 1 & 8 & 1 & \multirow{2}{*}{3} & \multirow{2}{*}{9,70} \\
\hline & 7 & 50 & 2 & & \\
\hline \multirow{2}{*}{$\mathrm{F}$} & 1 & 16 & 1 & \multirow{2}{*}{2} & \multirow{2}{*}{6,45} \\
\hline & 3 & 34 & 1 & & \\
\hline G & 1 & 10 & 1 & 1 & 3,22 \\
\hline \multicolumn{4}{|c|}{ Total } & 31 & $100 \%$ \\
\hline
\end{tabular}

Tabla 6.16. Distribución y frecuencias de los tipos de pisadas de ave de Los Navarros.

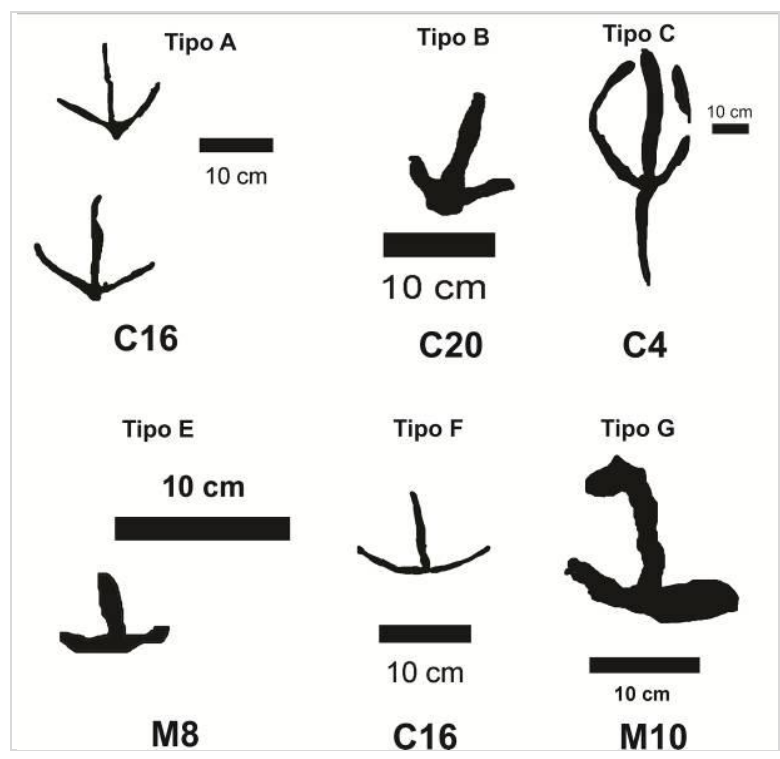

Figura 6.56. Tipos de pisadas de ave de Los Navarros. Referencias: C: conjunto; M: motivo.

Para las pisadas de felinos, siguiendo los lineamientos propuestos por Carden (2008a) se distinguen seis tipos, entre los cuales el tipo A sería más realista, mientras para los tipos B-D varía la cantidad de dedos (3, 5 y 6 dedos respectivamente); el tipo E correspondería a las rosetas. En Los Navarros, las pisadas de felino reconocidas son 5. Una del tipo A, en el 
conjunto 9; del tipo C se observaron dos motivos (ver Figuras 6.36 y 6.44). El tercer tipo reconocido en el sitio es el E, se trata de un punto central rodeado por 6 dedos, registrado en los conjuntos 4 y 6 (Tabla 6.17; ver Figura 6.36).

\begin{tabular}{|c|c|c|c|}
\hline Tipo & Sector & Conjunto & $\mathrm{n}$ \\
\hline $\mathrm{A}$ & 1 & 9 & 1 \\
\hline \multirow{2}{*}{$\mathrm{C}$} & 1 & 6 & 1 \\
\cline { 2 - 4 } & 3 & 34 & 1 \\
\hline \multirow{2}{*}{$\mathrm{E}$} & \multirow{2}{*}{1} & 4 & 1 \\
\cline { 2 - 4 } & & 6 & 1 \\
\hline \multicolumn{2}{|c}{} & \multicolumn{3}{|c}{ Total } & 5 \\
\hline
\end{tabular}

Tabla 6.17. Distribución y frecuencias de los tipos de pisadas de felino en Los Navarros.

En cuanto a las pisadas de guanaco, los dos tipos propuestos por Carden (2008a) fueron reconocidos en Los Navarros: una correspondiente al tipo A en el sector 3 -de forma más ovalada- (ver Figura 6.44), y dos correspondientes al tipo $\mathrm{B}$, de forma más recta, en el sector 1 (ver Figura $6.37)$.

Los grabados Los Navarros presentan las siguientes características:

1) la técnica empleada con exclusividad para la producción de los motivos fue la percusión;

2) en cuanto a su diseño, si bien se detectó variabilidad, la mayor parte de los grabados son circulares lineales (40\%), curvilíneos (26\%) y rectilíneos $(19 \%)$;

3) en líneas generales, los motivos presentan una pátina intermedia o clara que contrasta con las superficies de color castaño oscuras-rojizas del soporte. Una particularidad se observa en el Conjunto 34, ya que la mayoría de los motivos figurativos presentan pátina oscura mientras que los restantes presentan pátina clara, lo cual podría estar indicando un momento más temprano de ejecución de los motivos figurativos de ese conjunto (ver Figura $6.46)$;

4) el estado de conservación de los motivos es bueno a regular. En el sector 1 se observan conjuntos fuertemente afectados por la acción de líquenes, lo que no ha permitido el reconocimiento de las técnicas de producción (Conjuntos 3, 11 y 12) o de superposiciones (Conjunto 4). En el sector 2, el Conjunto 19 es el único que presenta líquenes sobre uno de sus motivos 
mientras que en los sectores 3,5 a 7 y 9 el soporte presenta un grado de exfoliación alto por lo que los conjuntos se encuentran en mal estado de conservación. El Conjunto 40 se encuentra en el sector 6, y constituye una excepción para lo anterior, ya que se encuentra sobre una superficie libre de líquenes y en la que en el caso de los motivos no figurativos se observa un claro contraste con el surco grabado. En el sector 8 el soporte se encuentra exfoliado aunque la conservación de los motivos que lo integran es buena.

5) se detectaron veintinueve superposiciones, principalmente en los sectores 1 a 3 , donde se observan motivos superiores con pátinas similares o más claras que los motivos inferiores. En todos los casos, se trató de motivos ejecutados por percusión. Es posible que estas superposiciones estén implicando una situación de posible diacronía, aunque son necesarios mayores estudios para confirmar esta suposición. Estos permitirían conocer, por ejemplo, si los tres grados de pátinas registrados en el mismo motivo se relacionan con diferentes momentos de producción o bien con las características petrológicas del soporte (ver superposiciones 9 a 12 del conjunto 6; Tabla 6.10). La observación a ojo desnudo de los surcos grabados no permitió discernir, por el momento, el uso de diferentes artefactos, de actividades de mantenimiento-reciclado o alguna otra causa que explique la presencia en un mismo motivo de distintos grados de pátina.

Estos factores (técnica, diseño, pátina y superposiciones) permitirían pensar que la mayor parte de los grabados de Los Navarros fueron realizados con una diacronía relativa, utilizando los sectores 1 a 3 , en una primera instancia por la presencia de pátinas oscuras e intermedias y de superposiciones, y con posterioridad se empleaaron otras superficies disponibles de la barda. Lo anterior comportaría distintos eventos de producción por gente que compartía cánones de representación de las imágenes similares, y en el caso del sector 1, con códigos de interpretación compartidos ya que la visualización del mismo podría estar señalando la integración de los motivos pertenecientes a diferentes conjuntos. Sin embargo, esta interpretación debe ser evaluada con mayor profundidad. 


\section{6. d. INTEGRACIÓN DE LA INFORMACIÓN}

Los sitios presentados en este Capítulo se encuentran en distintos sectores de las cuencas relictuales del macizo del Deseado, sobre relictos de afloramientos tobáceos y en bardas basálticas, que presentan o presentaron algún tipo de fuente de agua cercana. Estos son arroyos temporarios en el caso de La Marianita, una pequeña depresión en Bardas de Carlos y una laguna en el caso de Los Navarros.

Si bien dos de los soportes coinciden en ser basálticos, corresponden a dos formaciones geológicas diferentes. En función de los antecedentes presentados en el Capítulo 4 resulta novedoso el soporte tobáceo utilizado en La Marianita, ya que hasta ahora sólo en Angostura del Deseado, en la cuenca del río homónimo, se registraron motivos grabados sobre toba (Gradin 1979). Se han registrado, además, manifestaciones sobre soportes ignimbríticos, de areniscas coquinoides o basálticos (Carden 2008a).

En los tres sitios presentados se realizaron diferentes hallazgos arqueológicos que permiten considerar a las manifestaciones rupestres como formando parte de un paisaje pensado, construido a partir de las prácticas sociales y simbólicas como una intrincada trama de relaciones entre los humanos y su entorno (Alberti 2011; Bradley et al. 1994; Criado Boado 1999; Curtoni 2011; Tilley 1994).

Se recuperaron y registraron materiales líticos en superficie, indicando cierta recurrencia ocupacional de los paisajes en los que se encuentran los sitios con manifestaciones rupestres. Además, Miotti y colaboradores (2007d, 2012b) documentaron estructuras de piedra en la estancia La Marianita y en Los Navarros, entre 1,5 y 0,8 km de distancia de las manifestaciones rupestres. Es decir, que ciertas prácticas sociales - acumulación de piedras, confección de artefactos líticos, aprovisionamiento de materias primas- se realizaron cercanas a los sitios con arte, el cual no tienen que haber pasado desapercibido. Es decir, que las sociedades que ocuparon estos espacios analizaron y construyeron ese paisaje a través de la demarcación de diferentes sectores y/o elementos del mismo, en función de 
creencias simbólicas y del aprovechamiento de ciertos recursos fundamentales para sobrevivir en ese espacio.

El sitio que presenta mayor cantidad de motivos es Los Navarros, seguido por Bardas de Carlos y La Marianita (Tabla 6.18). En éste último sitio predominan los motivos lineales circulares seguidos por los rectilíneos, al igual que en Los Navarros. Si bien estas proporciones son similares, no implica que los tipos de motivos lo sean. En Bardas de Carlos predominan los motivos rectilíneos, seguidos por los curvilíneos y los lineales circulares (Figura 6.59). Las marcas grabadas de Bardas de Carlos identificadas como no determinadas son $13,79 \%$ del total de motivos, resultantes de percusión sobre la roca. Estas marcas no fueron registradas en Los Navarros o en La Marianita. Proponer algún tipo de posible causa de dichas marcas sería rondar el ámbito de las conjeturas, ya que se desconoce si son el resultado del accionar de productores expertos o sin experiencia, cuya intención era dejar una marca sobre el basalto. De los tres sitios, Los Navarros es el que presenta mayor porcentaje de motivos figurativos con mayor variabilidad en sus diseños.

\begin{tabular}{|l|c|c|c|c|c|c|}
\hline \multicolumn{1}{|c|}{ Motivos/Sitio } & LM & $\%$ & B de C & $\%$ & LN & $\%$ \\
\hline $\mathrm{n}$ & 18 & 100 & 118 & 100 & 286 & 100 \\
\hline Puntiformes & 2 & 11,11 & 6 & 5,17 & 11 & 3,83 \\
\hline Rectilíneos & 5 & 25,5 & 54 & 44,83 & 70 & 24,40 \\
\hline Circulares llenos & 0 & 0 & 0 & 0 & 1 & 0,34 \\
\hline Circulares lineales & 10 & 55,55 & 16 & 13,79 & 96 & 33,45 \\
\hline Curvilíneos & 0 & 0 & 24 & 20,69 & 62 & 21,60 \\
\hline Figurativos & 1 & 5,55 & 2 & 1,72 & 40 & 14,28 \\
\hline No Determinados & 0 & 0 & 16 & 13,79 & 6 & 2,09 \\
\hline
\end{tabular}

Tabla 6.18. Frecuencias y proporciones de motivos reconocidos en los sitios. Referencias: LM: La Marianita; B de C: Bardas de Carlos; LN: Los Navarros. 


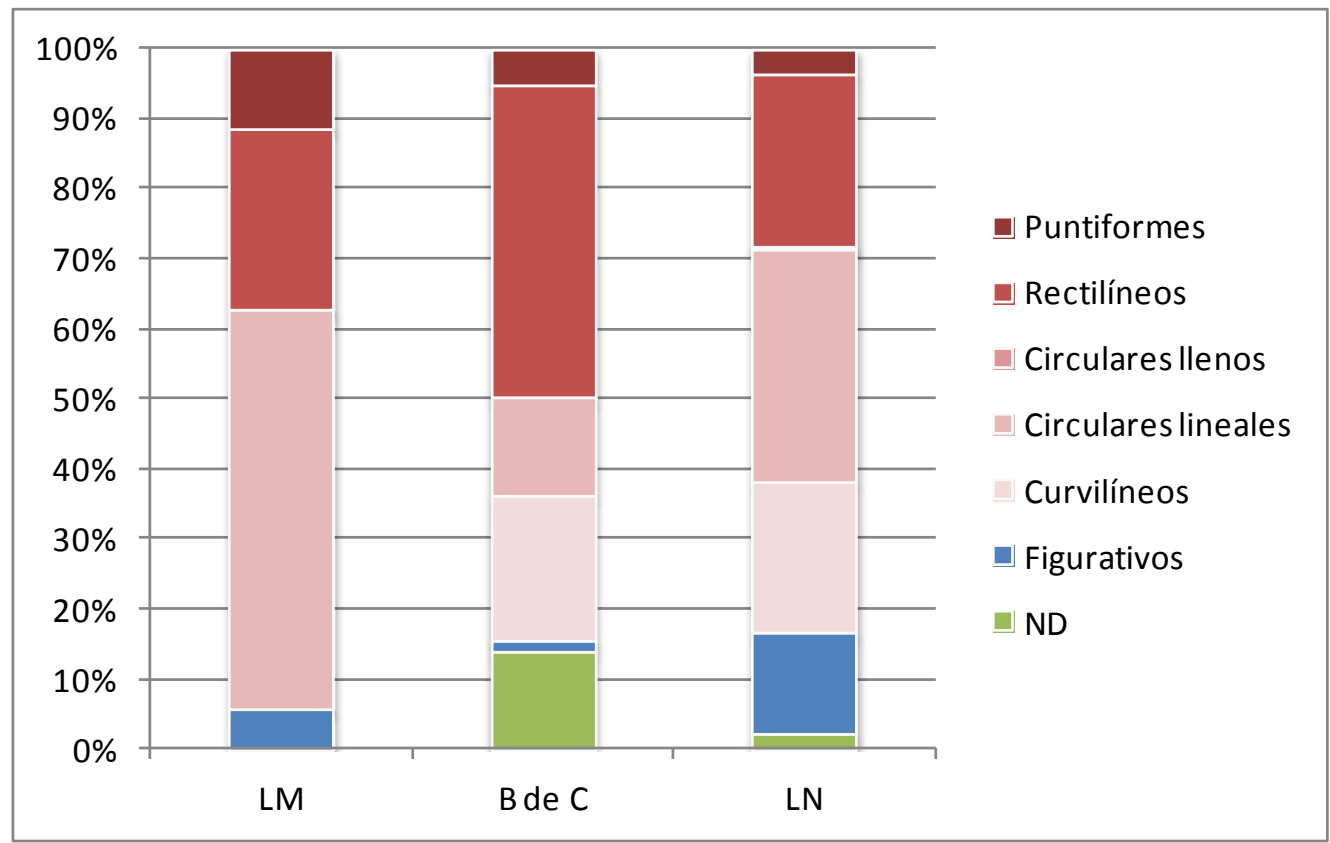

Figura 6.57. Proporciones acumuladas de subgrupos de motivos reconocidos en los sitios. Referencias: LM: La Marianita; B de C: Bardas de Carlos; LN: Los Navarros; ND: no determinados.

Asimismo, al considerar en conjunto los atributos presentados a lo largo de este Capítulo se pueden vislumbrar diferencias y similitudes entre los sitios (Tabla 6.19). En cuanto a la distribución de los motivos en cada uno de los afloramientos, vemos que en La Marianita los motivos se ubican sobre la superficie que presenta la mayor proporción de pátina original del afloramiento tobáceo. Las restantes superficies (con o sin pátina) fueron empleadas para la realización de diferentes grafitis, algunos de los cuales fueron ejecutados durante la década de 1930, cuando comienza la explotación ganadera extensiva en la región. Estos grafitis señalan el uso de ese afloramiento para la producción de manifestaciones hasta momentos recientes. Una situación semejante fue documentada en el sitio Cueva Grande de la localidad Piedra Museo, donde se reconocieron iniciales y fechas (Carden 2008a). Para La Marianita debe destacarse que el camino de acceso al casco de la estancia pasa al lado del afloramiento, hecho que debe haber contribuido a la producción de grafitis en el lugar.

En Bardas de Carlos se utilizaron superficies para la realización de grabados a lo largo de todo el afloramiento $(130 \mathrm{~m})$, aunque existen espacios con superficies rocosas que carecen de motivos. En el caso de Los Navarros, 
la barda basáltica circunda la laguna en su margen occidental: los grabados se localizan en el sector más meridional de la misma. Probablemente esto responda al tipo de soporte rocoso en ese sector: con menor cantidad de líquenes, de tonalidad más oscura y rojiza, presentando irregularidades aunque careciendo de exfoliaciones, las cuales fueron observadas otras porciones de la barda.

$\mathrm{Al}$ considerar la altura respecto del suelo, en La Marianita los motivos no superan 1,50 m mientras que en Bardas de Carlos las alturas varían en los distintos sectores: desde el ras del suelo actual hasta a más de 1,50 m. En Los Navarros ocurre algo similar, con la excepción de los sectores 1 y 2 que presenta motivos que se encuentran actualmente alrededor de los $2 \mathrm{~m}$ del suelo.

\begin{tabular}{|c|c|c|c|}
\hline Atributos/Sitios & La Marianita & Bardas de Carlos & Los Navarros \\
\hline $\begin{array}{lll}\text { Figurativos } & \text { vs. } & \text { No } \\
\text { figurativos } & & \end{array}$ & $\begin{array}{l}\text { Predominio no } \\
\text { figurativos y sólo } 1 \\
\text { figurativo }\end{array}$ & $\begin{array}{l}\text { Predominio no } \\
\text { figurativos, sólo } 2 \\
\text { figurativos }\end{array}$ & $\begin{array}{l}\text { Predominio de no } \\
\text { figurativos, } \\
\text { figurativos } 16 \%\end{array}$ \\
\hline Diseño & $\begin{array}{l}\text { Abundancia de } \\
\text { motivos circulares } \\
\text { lineales y } \\
\text { rectilíneos }\end{array}$ & $\begin{array}{l}\text { Predominio de motivos } \\
\text { rectilíneos, abundancia } \\
\text { de curvilíneos y ND. }\end{array}$ & $\begin{array}{l}\text { Abundancia de } \\
\text { motivos circulares } \\
\text { lineales y } \\
\text { rectilíneos. }\end{array}$ \\
\hline Técnica & $\begin{array}{l}\text { Percusión e } \\
\text { incisión }\end{array}$ & Percusión e incisión & Percusión \\
\hline Pátina & Clara & $\begin{array}{l}\text { Clara, intermedia y } \\
\text { oscura }\end{array}$ & $\begin{array}{l}\text { Clara, intermedia } \\
\text { y oscura }\end{array}$ \\
\hline Superposiciones & $\begin{array}{l}\text { Mínimas, grafitis } \\
\text { sobre motivos } \\
\text { grabados }\end{array}$ & $\begin{array}{l}\text { Mínimas, incisiones } \\
\text { caóticas sobre motivos } \\
\text { por percusión. } \\
\text { Registradas en todo el } \\
\text { afloramiento }\end{array}$ & $\begin{array}{l}\text { Mínimas, siempre } \\
\text { percusión sobre } \\
\text { percusión. } \\
\text { Registradas } 4 \\
\text { sectores }\end{array}$ \\
\hline Emplazamiento & $\begin{array}{l}\text { Afloramiento en } \\
\text { borde de planicie } \\
\text { de inundación, } \\
\text { superficies } \\
\text { verticales }\end{array}$ & $\begin{array}{l}\text { Al pie de una lomada, } \\
\text { paredón basáltico del } \\
\text { que se utilizaron } \\
\text { superficies verticales }\end{array}$ & $\begin{array}{l}\text { Sobre barda } \\
\text { basáltica que } \\
\text { rodea un bajo, se } \\
\text { emplearon } \\
\text { principalmente } \\
\text { superficies } \\
\text { verticales }\end{array}$ \\
\hline Formación & $\begin{array}{l}\text { Toba Laguna } \\
\text { Palacios }\end{array}$ & $\begin{array}{l}\text { Basalto } \\
\text { La Angelita }\end{array}$ & $\begin{array}{l}\text { Basalto Alma } \\
\text { Gaucha }\end{array}$ \\
\hline Orientación & NW & $\mathrm{NE}^{*}$ & $\mathrm{NE}^{*}$ \\
\hline $\begin{array}{lll}\text { Visibilidad } & \text { de } & \text { los } \\
\text { conjuntos }\end{array}$ & Intermedia & Alta- intermedia y baja & $\begin{array}{l}\text { Alta- intermedia y } \\
\text { baja }\end{array}$ \\
\hline $\begin{array}{l}\text { Altura de los motivos } \\
\text { respecto del suelo }\end{array}$ & $<\mathrm{a} 1,50 \mathrm{~m}$ & $\geq 1,50 \mathrm{~m}$ & $0 \mathrm{a} \geq 2 \mathrm{~m}$ \\
\hline
\end{tabular}

Tabla 6.19. Comparación de los sitios considerados en este capítulo. * Para la mayoría de las superficies.

Los patrones aquí observados son coincidentes con los presentados para los sitios con grabados documentados previamente (Carden 2008a), los 
cuales se encuentran en bardas de basaltos (LCB y LL en Aguada del Cuero, y B12 en Cerro del Doce) o en bloques al interior de espacios reparados (AEP-1 y CG en Piedra Museo), en relieves deprimidos que bordean lagunas o rodean mallines que pueden estar asociados a lagunas secas. Es decir, se encuentran asociados a fuentes de agua que habrían sido atractores de fauna y de las poblaciones humanas en el pasado.

En cuanto a los tipos de motivos documentados, en Piedra Museo hay una alta presencia de pisadas animales, en Aguada del Cuero hay un predominio de motivos no figurativos y en Bardas del Doce se observan motivos no figurativos, principalmente de forma circular. Entre las técnicas de producción de grabados, en estos sitios habrían sido la percusión indirecta (o picado, utilizando un intermediario, el cual permitiría mayor precisión en el surco obtenido) y en menores proporciones, la incisión, el raspado y la horadación así como la combinación de tales técnicas (Carden 2008a). Estas observaciones difieren con las técnicas registradas en los sitios presentados en este Capítulo, donde se documentó la percusión (sin poder reconocer el uso de intermediario) y la incisión. La comparación de todos los sitios con grabados en el macizo del Deseado será desarrollada en el Capítulo 8. 


\section{Capítulo 7}

\section{ARTE RUPESTRE EN EL MACIZO DE SOMUNCURÁ}

En este Capítulo se presentan los sitios estudiados en la porción rionegrina del macizo somuncurense (Figura 7.1). El primer sector relevado - expuesto en la primera parte del capítulo- se ubica hacia el NE del macizo, en las inmediaciones de las Sierras de Somuncurá, donde se detectaron siete sitios con arte rupestre: Laguna Azul 1 a 4, Laguna El Ganso y Bardas de Antonio.

En el sector central del macizo, en las inmediaciones de la localidad de El Caín, se relevaron los sitios La Porfía, Alero Amigo Oeste, Cueva Martel, Peñón Martel 1 y los sitios Peñón del Pueblo 1 y 2. Además, se efectuaron registros superficiales de materias primas colorantes en La Porfía y Cañadón Martel, y se relevaron los afloramientos de materias primas colorantes en las localidades Los Dos Amigos y Tapera de Isidoro. Estos sitios serán presentados en la segunda parte del capítulo. 


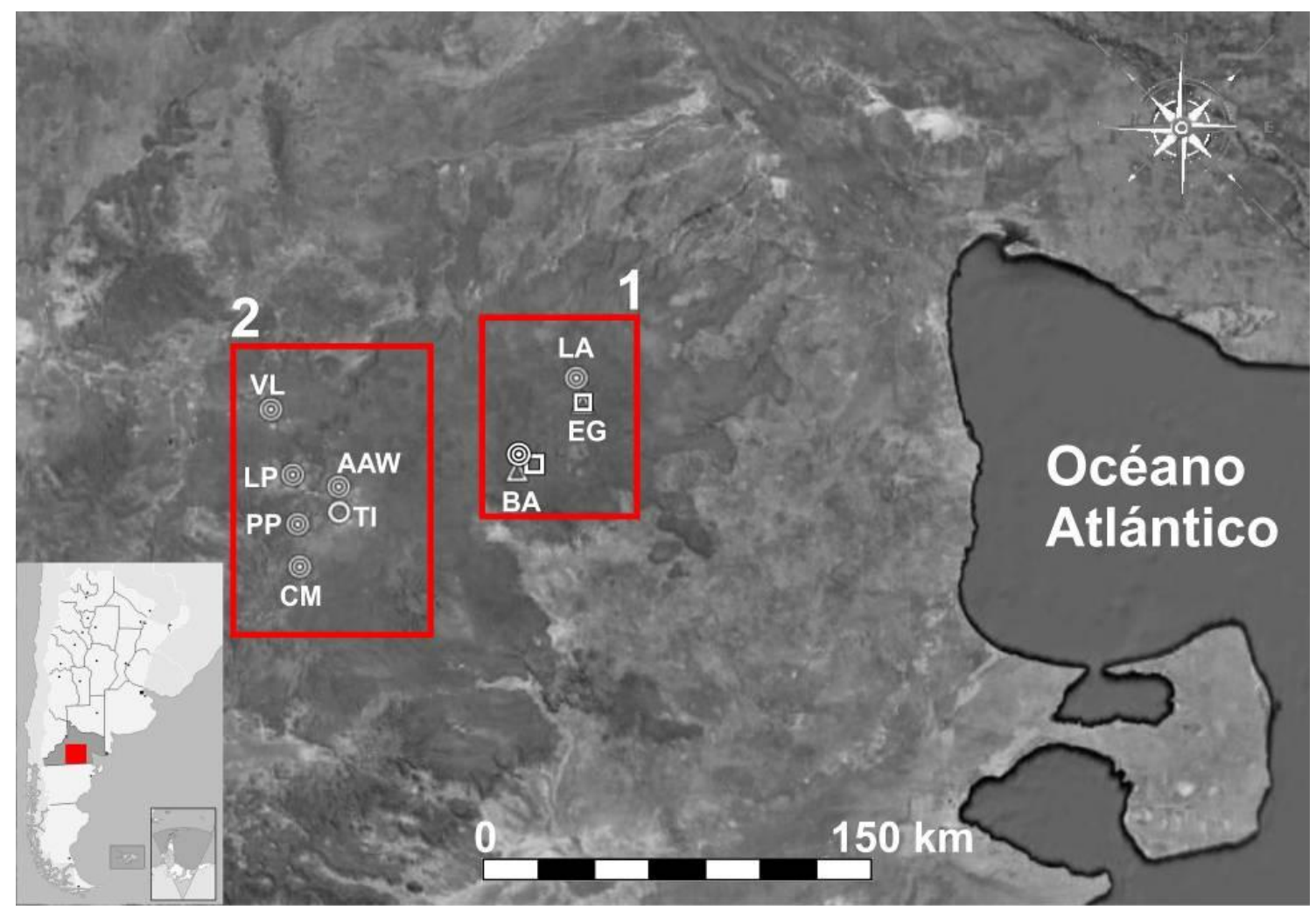

Figura 7.1. Sectores prospectados y sitios con arte rupestre estudiados en el macizo de Somuncurá: 1 sector noreste, 2: sector centro-occidental. Referencias. LA:

Laguna Azul; EG: Laguna El Ganso; BA: Bardas de Antonio; VL: Vacalauquén; LP: La Porfía; AAW: Alero Amigo Oeste; TI: Tapera de Isidoro; CM: Cañadón Martel; PP: Peñón del Pueblo. Círculos: pinturas; triángulos: grabados; cuadrados: pictograbados. 


\section{Parte 1. Sector Noreste}

\section{7. a. LAGUNA AZUL}

Laguna Azul se encuentra a los $41^{\circ} 17^{\prime} \mathrm{S}$ y $66^{\circ} 50^{\prime} \mathrm{W}$. Es una localidad arqueológica ubicada a unos $90 \mathrm{~km}$ al SW de Valcheta y $30 \mathrm{~km}$ al norte de las sierras de Somuncurá (Figura 7.2). Esta cuenca fue visitada por Gradin a comienzos de la década de 1970, cuando realizó el relevamiento de diferentes estructuras de piedra y algunos sondeos (Gradin 1971).

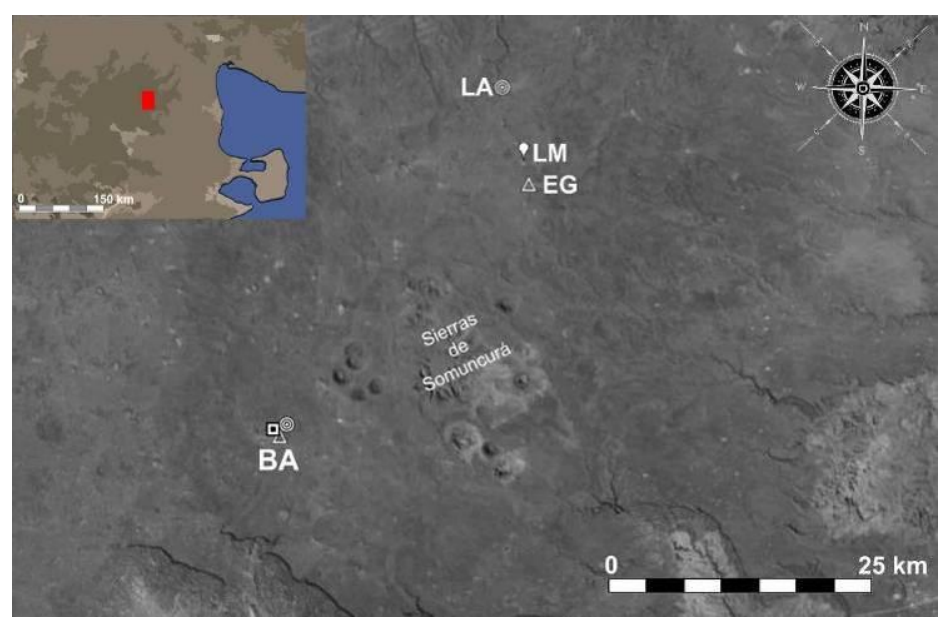

Figura 7.2. Ubicación de los sitios documentados en el NE de Somuncurá. Referencias: LA: Laguna Azul; LM: Laguna Maciega; EG: El Ganso; BA: Bardas de Antonio.

Círculos: pinturas; triángulos: grabados; cuadrados: pictograbados.

Se trata de una cuenca endorreica rodeada con altos paredones basálticos, la cual presentó agua en dos de las instancias en que fue visitada (Figura 7.3.a). Los farallones pertenecen a la Formación Somun Curá (Ravazzoli 1982; Remesal et al. 2001), que se caracteriza por la presencia de basaltos de color gris oscuro a negro, de composición olivínica, que pueden exhibir vesículas y estar alterados por la acción del viento y del sol. Esta laguna mide 1,24 km de ancho por 0,69 $\mathrm{km}$ de largo, coincidente con el tamaño estimado para otros bajos del macizo (Methol 1967). 
Debido a que el bajo interrumpe la planicie estructural lávica, desde su margen el dominio de panorámica visual es amplio, pudiéndose observar pequeñas lomadas, otros bajos, y diferentes conos sobreimpuestos a la planicie. Estos últimos sirven como puntos de referencia en el paisaje, siendo un claro ejemplo en Laguna Azul los cerros Puntudo y Corona (Figura 7.3.a). Principalmente debido a la presencia de agua, la abundancia y riqueza avifaunística observada es grande, incluyendo diferentes aves (flamencos, cisnes, patos negros y loros; Figuras 7.3.b-d) y mamíferos (guanacos y pilquines) (Figura 7.3.e).

Los sitios con manifestaciones rupestres, denominados Laguna Azul 1 a 4, fueron detectados gracias a las indicaciones del Sr. Atilio Namuncurá y la Srta. Nancy Pazos, y relevados durante 2008.

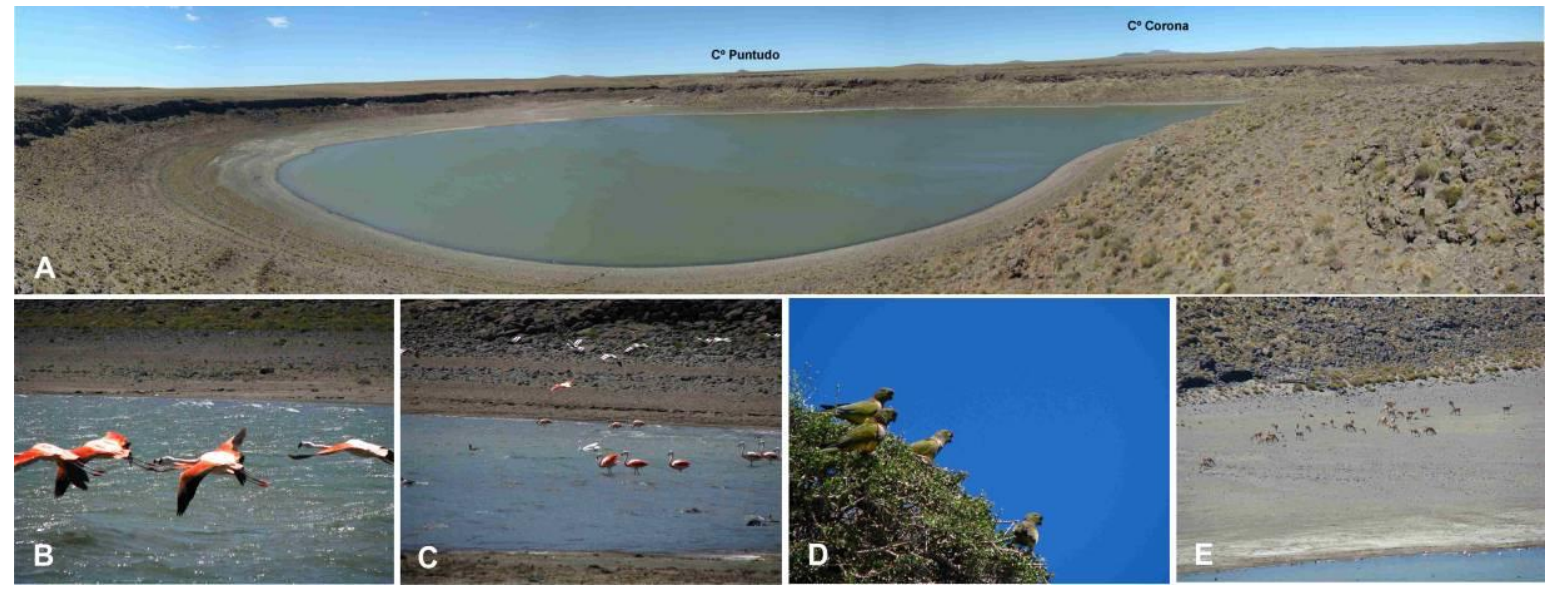

Figura 7.3. Laguna Azul: a. vista desde el NW, hacia el fondo se ven los cerros Puntudo y Corona; b-d. Riqueza avifaunística; e. guanacos observados en el borde de la cuenca.

\section{7. a. 1. Otros contextos arqueológicos de la localidad}

Entre las evidencias arqueológicas de esta cuenca se han informado un grupo de parapetos en la margen norte de la laguna (Figura 7.4), los cuales fueron sondeados por Gradin a comienzos de la década de 1970 (Gradin 1971) y los materiales recuperados fueron analizados por García y Pérez de Micou 
(1980). Estos parapetos fueron re-ubicados durante la campaña de 2011 (Figura 7.5.a). Alrededor de $150 \mathrm{~m}$ al norte de estas estructuras se localizó una densa acumulación de materiales líticos en superficie (Figura 7.4, Miotti et al. 2011c). El estudio de estas evidencias forma parte las próximas tareas de campo en este sector de Somuncurá.

Durante la campaña 2008 se localizó una estructura de piedra en la corona basáltica de la margen sur de la laguna (Figura 7.4). En el muestreo se obtuvieron diferentes artefactos líticos (Figura 7.5.b). Cercana a esta estructura, en la disyunción entre la corona basáltica y las rocas subyacentes, se observó una vena de materia prima colorante de la que se extrajeron muestras que están en proceso de análisis (Figura 7.5.c). Por último, durante las distintas prospecciones en los bordes de la laguna, así como en diferentes sectores cercanos al puesto actual, se registraron artefactos líticos formatizados y no formatizados en superficie (Figura 7.5.d).

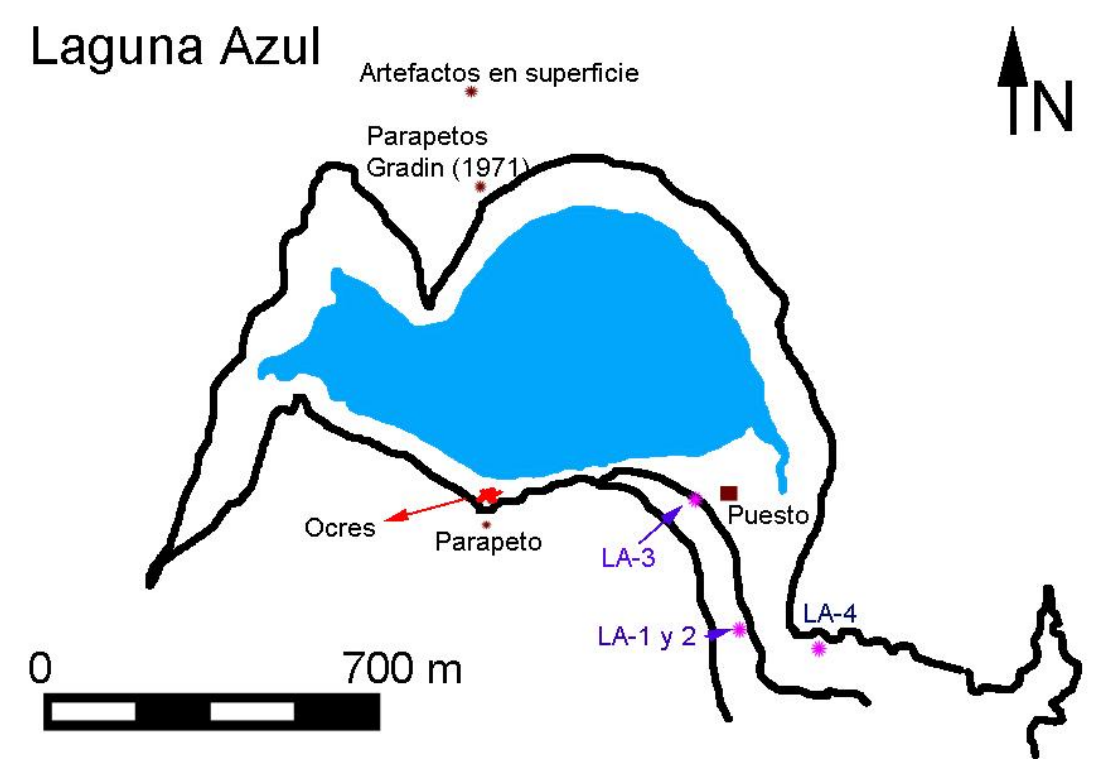

Figura 7.4. Distribución espacial de los sitios en Laguna Azul. 


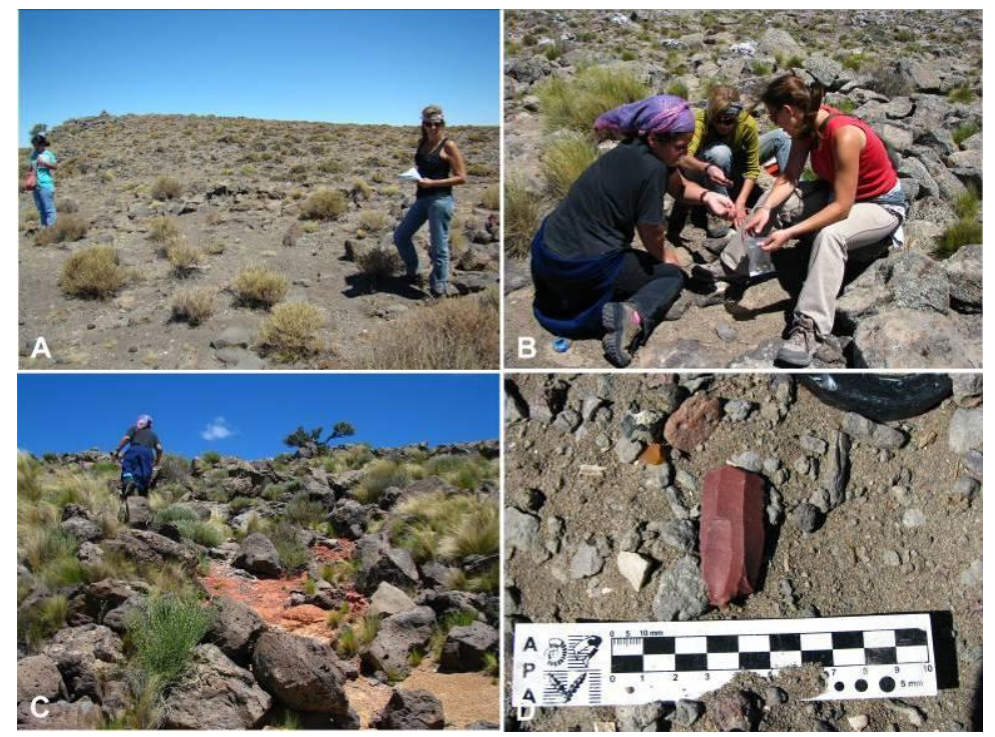

Figura 7.5. Diferentes contextos arqueológicos en Laguna Azul: a. Parapetos estudiados por Gradin (1971); b. Recolección de materiales líticos en estructura de piedra localizada en la margen sur; c. Vena de materia prima colorante en margen sur; d. Materiales en superficie cerca del borde lagunar.

\section{7. a. 2. El arte rupestre de Laguna Azul}

Los sitios con arte se encuentran al interior de aleros ubicados en la porción SE de la laguna, en las márgenes del cañadón de acceso al bajo, donde se encuentra el puesto actual. Las superficies utilizadas corresponden a basaltos de tipo alveolar de tonalidad predominantemente grisácea, con pátina rojiza. Todos los motivos fueron realizados mediante pintura, en diferentes tonalidades de rojo.

Laguna Azul (LA) 1 a 3 se ubican sobre la margen izquierda del cañadón mencionado anteriormente, en tanto que LA4 se localiza sobre la margen opuesta (ver Figura 7.4).

En la localidad se registraron 32 motivos, la mayoría de los cuales se encuentra en LA2, mientras que en LA1 se registró el 22\% y en LA3 el 9\%. Un único motivo fue registrado en LA4 (Figura 7.6). Entre las manifestaciones registradas predominan los motivos no figurativos, seguidos por los no 
determinados y los figurativos (Figura 7.7.a). Dentro del primer grupo, son mayoría los motivos rectilíneos, seguidos por los puntiformes, los circulares lineales y los curvilíneos en proporciones similares (Figura 7.7.b). En LA2 se encuentra el único motivo figurativo de la localidad y un motivo circular lleno. La frecuencia de subgrupos de motivos de cada sector se presenta en la Tabla 7.1, mientras que las frecuencias de los tipos motivos reconocidos se presenta en el Apéndice V.1.

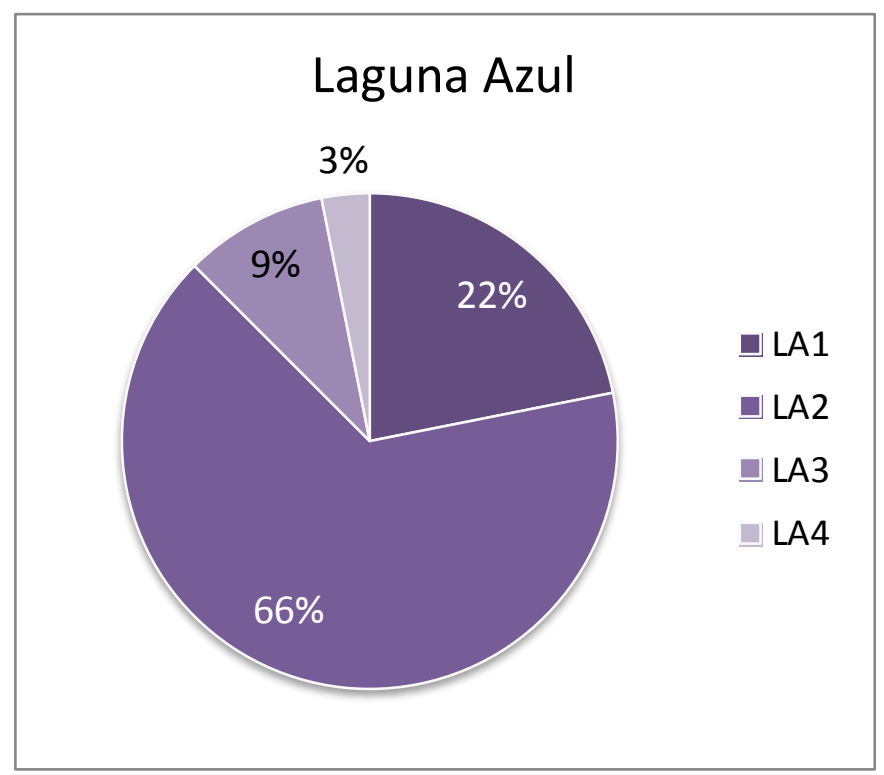

7.6. Proporciones de motivos por sitio en Laguna Azul.

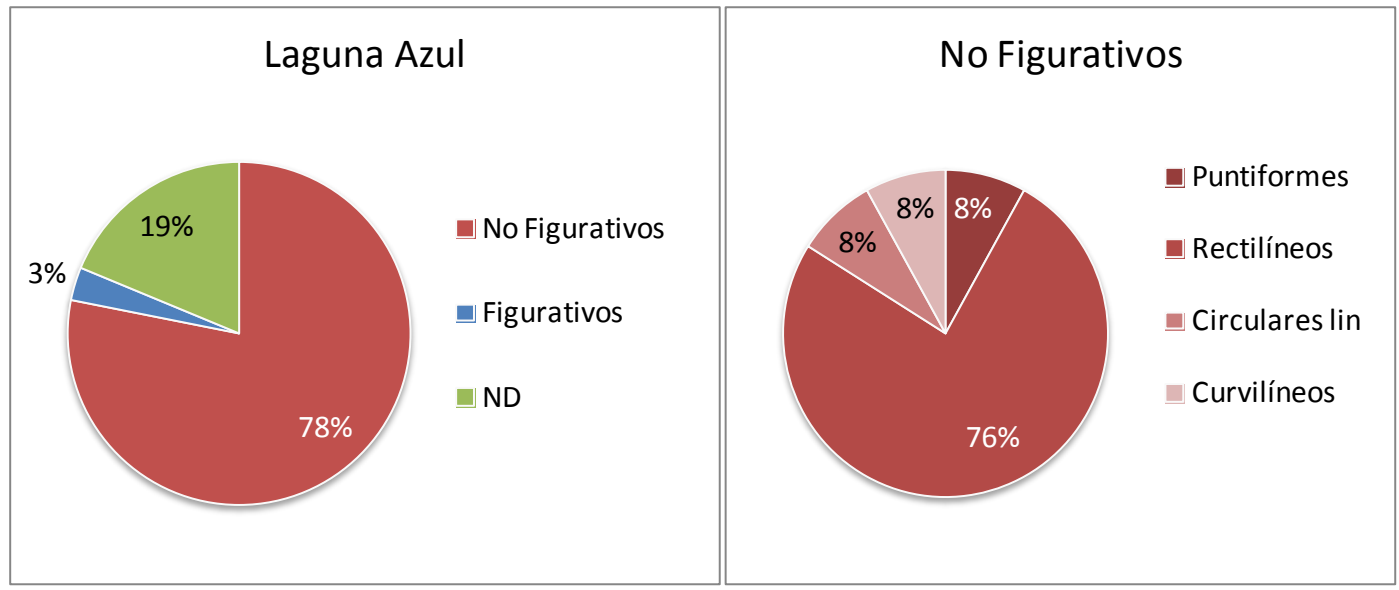

Figura 7.7. Proporciones de grupos y subgrupos de motivos en Laguna Azul. Referencia. Circulares lin: circulares lineales; ND: no determinados. 


\begin{tabular}{|c|c|c|c|c|c|}
\hline & \multicolumn{4}{|c|}{ Sitio } & \\
\hline Motivos & LA1 & $\mathrm{LA} 2$ & LA3 & LA4 & Subtotal \\
\hline Puntiformes & - & 1 & 1 & - & 2 \\
\hline Rectilíneos & 4 & 14 & - & 1 & 19 \\
\hline Circulares lineales & - & 2 & - & - & 2 \\
\hline Curvilíneos & - & 2 & - & - & 2 \\
\hline No Figurativos & 4 & 19 & 1 & 1 & 25 \\
\hline "Hacha en 8" & - & 1 & - & - & 1 \\
\hline Figurativos & - & 1 & - & - & 1 \\
\hline No Determinados & 3 & 1 & 2 & - & 6 \\
\hline Total & 7 & 21 & 3 & 1 & 32 \\
\hline
\end{tabular}

Tabla 7.1. Frecuencia de subgrupos de motivos en Laguna Azul.

\section{7. a. 2. 1. Laguna Azul 1 (LA1)}

Este sitio corresponde a un alero ubicado en la porción meridional de la margen sur del cañadón de acceso a la laguna (Figura 7.4). Mide 4,20 m de ancho por 3,30 m de profundidad y tiene una altura promedio de $2,80 \mathrm{~m}$. Las superficies empleadas son grises, mayoritariamente alveolares aunque también se utilizaron superficies rugosas con pátina rojiza.

Conjunto 1. Se encuentra sobre el techo del alero, a 2,80 $\mathrm{m}$ del suelo actual. El soporte está afectado por líquenes y por el escurrimiento de agua. Los motivos son tres grecas de color rojo: dos de ellas hacia la izquierda de una grieta que divide el panel, mientras que la tercera se ubica hacia la derecha de dicha grieta. Éste último motivo se encuentra muy desvaído y fue realizado utilizando una porción convexa del soporte (Figura 7.8.a). El tratamiento digital de la fotografía del conjunto permite distinguirlos con mayor claridad (Figura 7.8.b)

Conjunto 2. A 1,41 m del suelo actual se observaron trazos irregulares y desvaídos de pintura roja. A partir del tratamiento digital de la fotografía se observa una cruz, trazos rectilíneos y restos de pintura roja (Figura 7.8.c).

Motivo 3. Se ubica a 1,02 m del suelo actual, sobre una superficie que sufre un importante proceso de exfoliación. Se trata de restos de pintura desvaída por la incidencia directa del sol y probablemente haya sido afectada por el 
escurrimiento de agua. A esta última situación se debe además la presencia de concreciones de carbonato en los bordes del soporte.

Motivo 4. Se encuentra a $1,09 \mathrm{~m}$ del suelo actual, en el interior de una concavidad (Figura 7.8.e). Se trata restos de pintura roja atravesados transversalmente por una grieta (Figura 7.8.f).

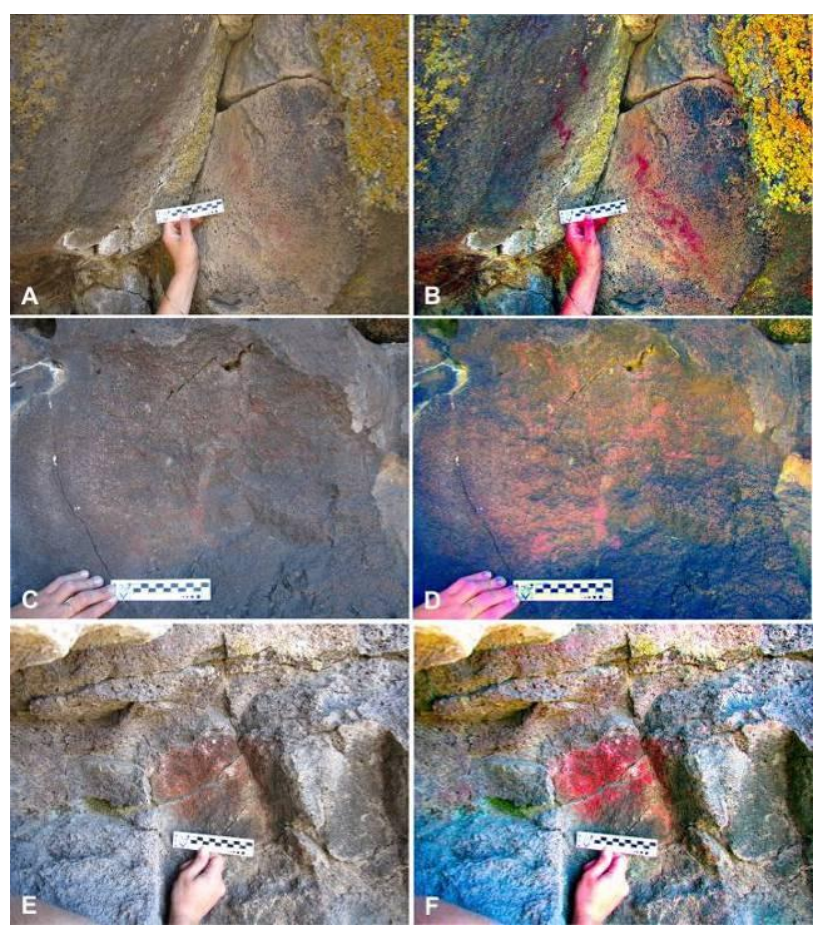

Figura 7.8. Motivos de LA1: a. Conjunto $1 ; \mathrm{b}$. Imagen tratada digitalmente ( $D$ Stretch lds 15); c. Conjunto 2; d. Imagen tratada digitalmente (D-Stretch ybk 15); e. Motivo 4; f. Imagen tratada digitalmente (D-Stretch lab 15).

7. a. 2. 2. Laguna Azul 2(LA2)

Corresponde a lo que los actuales pobladores identifican como el antiguo "Puesto de Félix". Este es un alero de 7,90 m de ancho, entre $2 \mathrm{~m}$ y 3,90 m de profundidad, cuya altura máxima es de 2,40 m (Figura 7.9). Los motivos documentados en el sitio ascienden a 21 (Tabla 7.1), siendo el que presenta la mayor variabilidad y densidad de motivos en la localidad. 


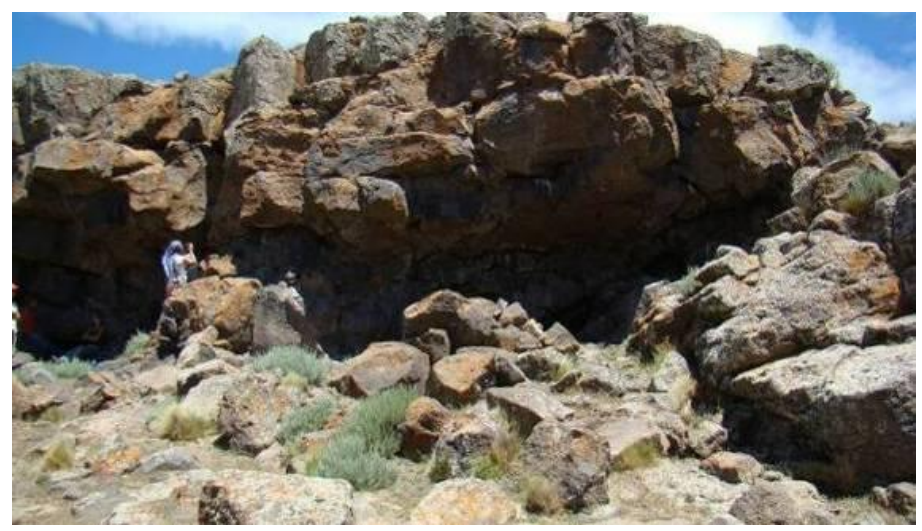

Figura 7.9. Vista de LA2.

Motivo 1. Se ubica a $1,78 \mathrm{~m}$ del suelo actual y se trata de una greca pintada de color rojo.

Conjunto 2. Se encuentra a $1,80 \mathrm{~m}$ del suelo actual. Este conjunto está integrado por 10 motivos: una "U", dos semicircunferencias, una figura poligonal, una línea quebrada, un segmentado y tres grecas, dos de las cuales presentan un trazo desvaído y difuso (Figura 7.10.a y b). El motivo figurativo del sitio corresponde a una figura semejante a un "hacha en 8" que presenta dos trazos internos (Figura 7.10.c).

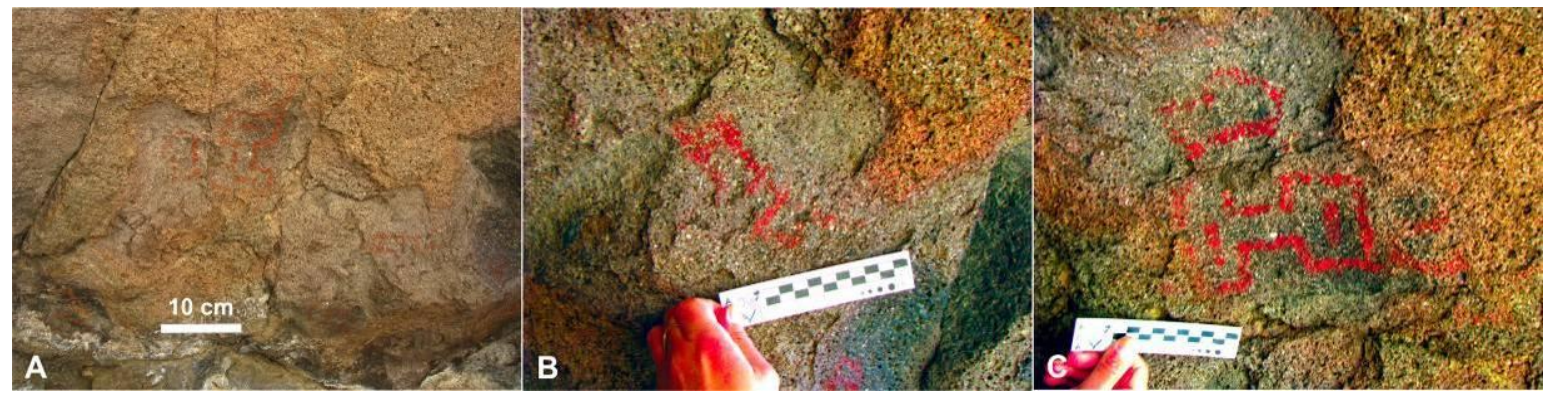

Figura 7.10. Conjunto 2 de LA2: a. vista del conjunto; b. segmentado (Imagen tratada digitalmente $D$-Stretch lab 15); c. Motivo figurativo, figura poligonal y motivo "en forma de U” (Imagen tratada digitalmente D-Stretch lab 15).

Conjunto 3. Se encuentra en el techo del alero, a 2,38 $\mathrm{m}$ del suelo. Está integrado por cuatro motivos pintados en rojo: una greca, una línea quebrada, un segmentado y una semicircunferencia (Figuras 7.11.a y b).

Motivo 4. Está compuesto por una línea escalonada y un punto que se encuentran en un estado muy desvaído, y se ubican a 0,65 m del suelo, sobre una superficie vertical e irregular (Figuras 7.11.c y d). 

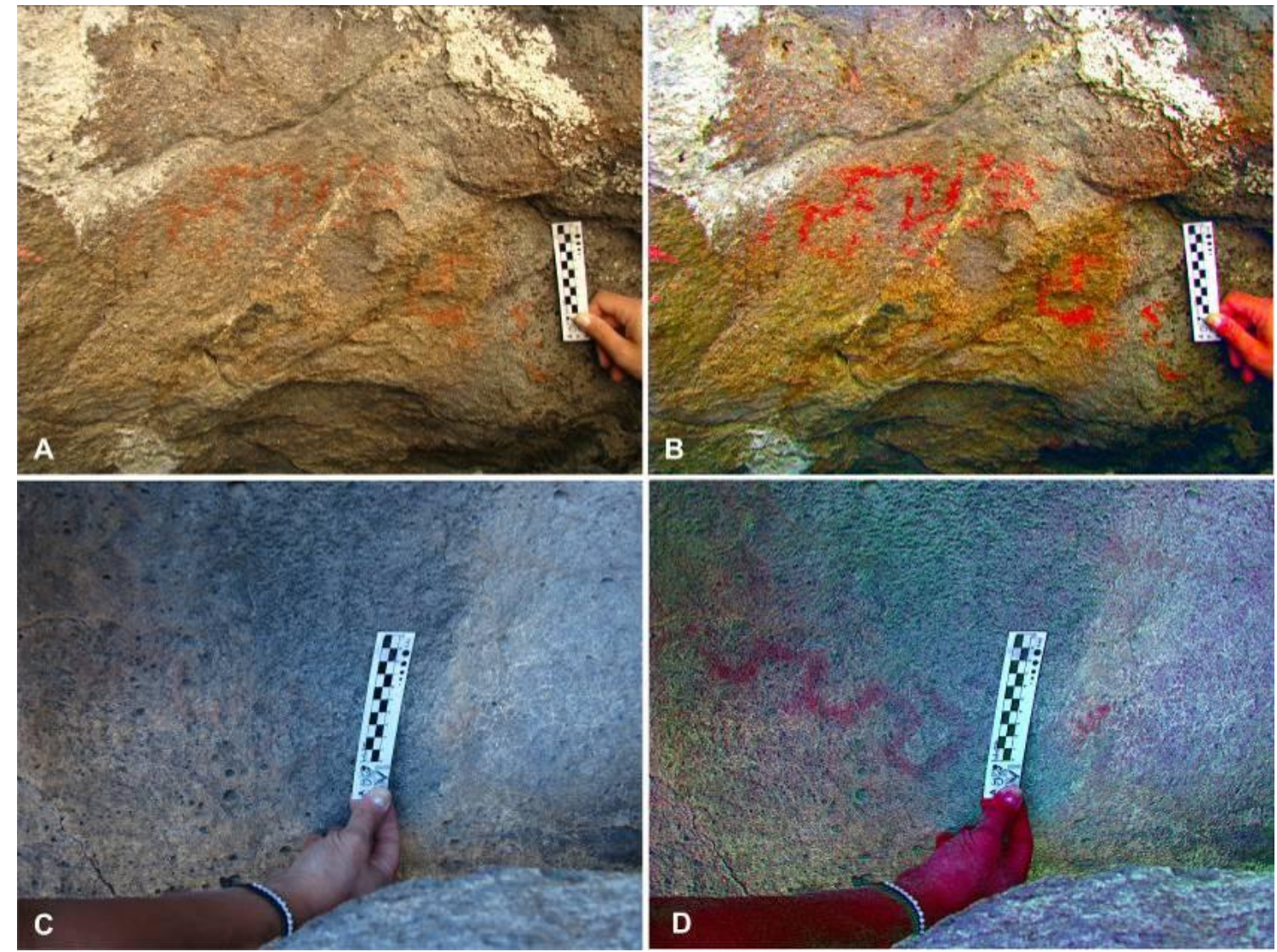

Figura 7.11. Conjunto 3 y Motivo 4 de LA2: a. Conjunto 3; b. imagen tratada digitalmente (D-Stretch lab 15); c. Motivo 4; d. imagen tratada digitalmente ( $D$-Stretch yrd 15)

Motivo 5. A $1,03 \mathrm{~m}$ del suelo, se observa un motivo "en forma de U" invertida, de trazo ancho y desvaído.

Motivo 6. Se encuentra a 1,06 $\mathrm{m}$ del suelo actual. Se trata de un motivo en color rojo claro, en forma de "B" rectilínea con trazos rectilíneos asociados, parcialmente cubierto por deyecciones de aves (Figuras 7.12.a y 7.12.b).

Conjunto 7. Se ubica a 1,26 m del suelo actual. Está integrado por cuatro motivos: una greca, un motivo "en forma de V" invertida, una línea vertical de puntos de color rosa pálido y restos de pintura de color rosa (Figura 7.12.c y d). 


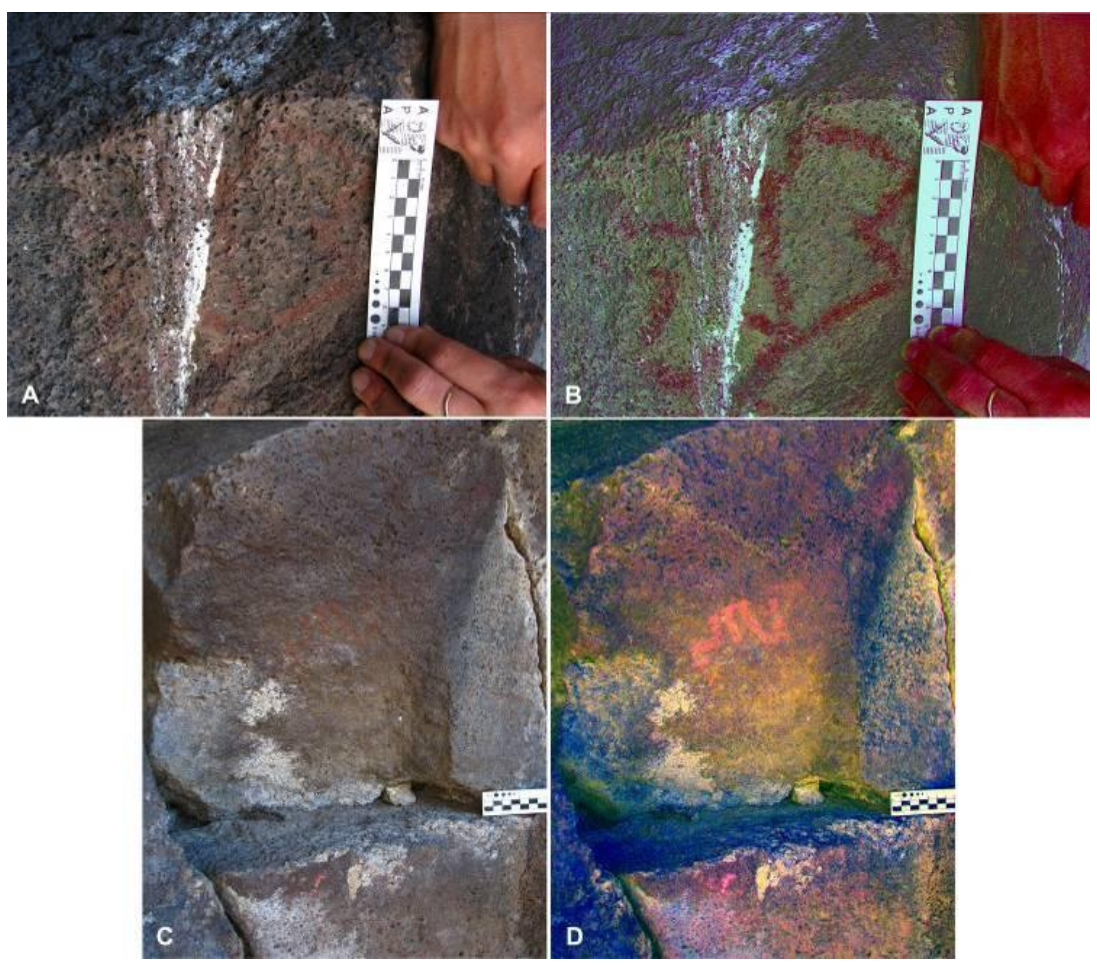

Figura 7.12. Motivo 6 y Conjunto 7 de LA2: a. motivo 6; b. imagen tratada digitalmente ( $D$-Stretch yrd 15); c. parte del conjunto 7; d. imagen tratada digitalmente (D-Stretch ybk 15).

$\mathrm{Al}$ interior de este alero, además, se hallaron piedras que podrían considerarse discoidales (Hermo et al. 2013b) o manos de moler, ya que una de ellas cuales presenta sustancia colorante adherida en una de sus caras (Figura 7.13.a). Asimismo se observó un fragmento de bola arrojadiza con surco perimetral (Figura 7.13.b).
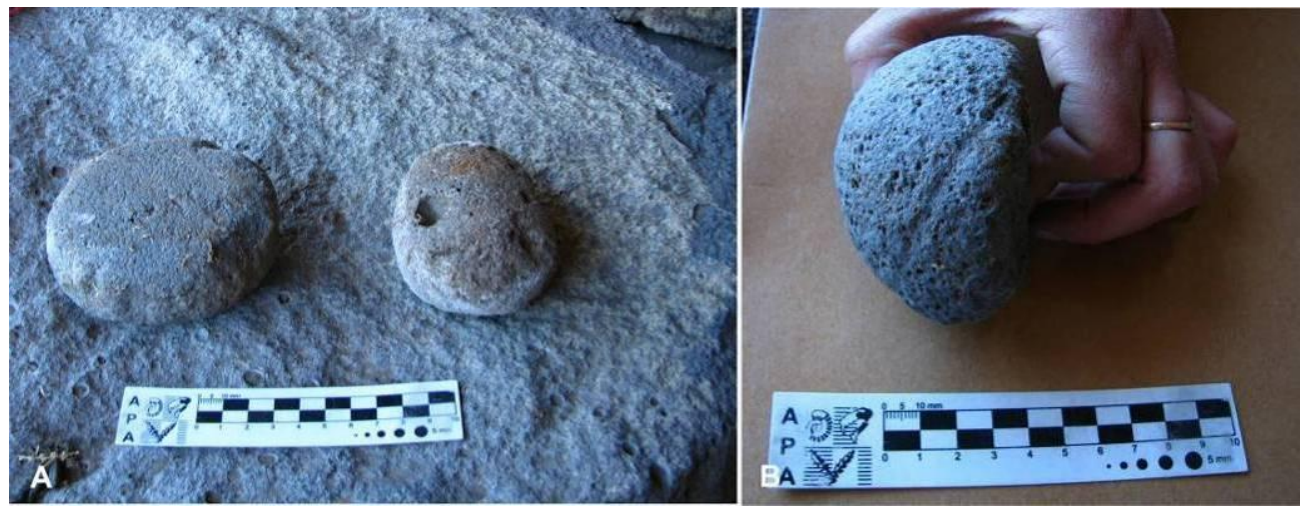

Figura 7.13. Materiales registrados al interior de LA2: a. Manos de moler o discoidales de Laguna Azul; b. Fragmento de bola arrojadiza con surco perimetral. 
Hacia el NW del puesto de la familia Pazos, se encuentra un gran corral de piedras que sirve para encerrar el ganado caprino (Figura 7.14.a). Este corral abarca un sector de la barda basáltica, por lo que incluye un pequeño alero que sirve de sombra a los animales (Figura 7.14.b). Al interior de dicho alero se registraron motivos pintados.

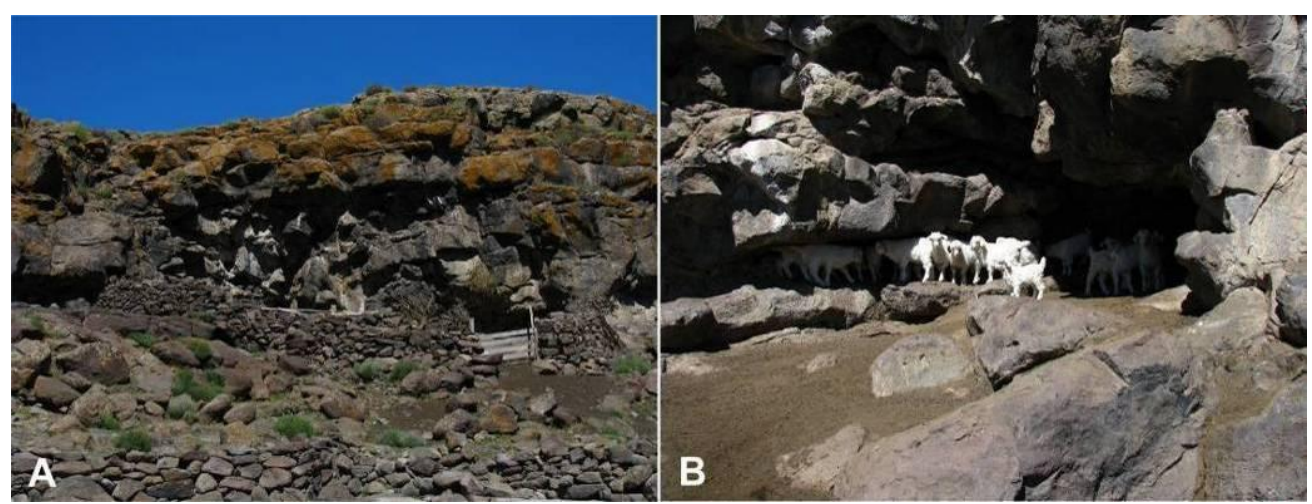

Figura 7.14. LA3: a. Vista del corral de chivas delante del sitio; b. Alero al interior del corral, con manifestaciones.

Conjunto 1. Se encuentra en una superficie vertical, a 1,35 m del suelo. Está integrado por dos motivos: restos de pintura en color rojo, parcialmente exfoliada, y pequeños puntos en color rojo por encima y alrededor de un hoyuelo natural (Figuras 7.15.a y 7.15.b).

Motivo 2. En otro sector del alero, a $0,75 \mathrm{~m}$ del suelo, se registró una mancha de pintura de color rosa pálido (Figuras 7.15.c y 7.15.d). 


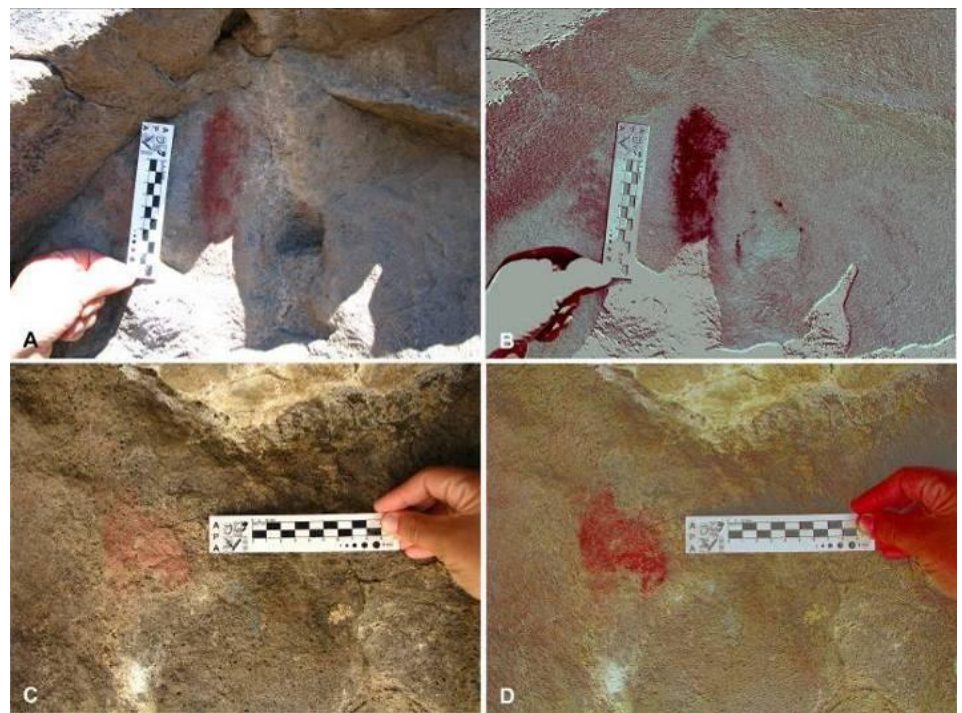

Figura 7.15. Motivos de LA3: a. Conjunto 1; b. Imagen tratada digitalmente $(D$ Stretch yre 15); c. Motivo 2; d. Imagen tratada digitalmente (D-Stretch yrd 10).

\section{7. a. 2. 4. Laguna Azul 4 (LA4)}

Es un pequeño alero de 2,50 $\mathrm{m}$ de ancho por $1,15 \mathrm{~m}$ de alto, y $1,21 \mathrm{~m}$ profundidad, que carece de sedimento por ser su base un bloque en posición oblicua (Figura 7.16.a). En el interior y sobre el techo se registró un motivo en forma de "B" rectilínea asociado a un par de puntos (Figuras 7.16.b y 7.16.c).

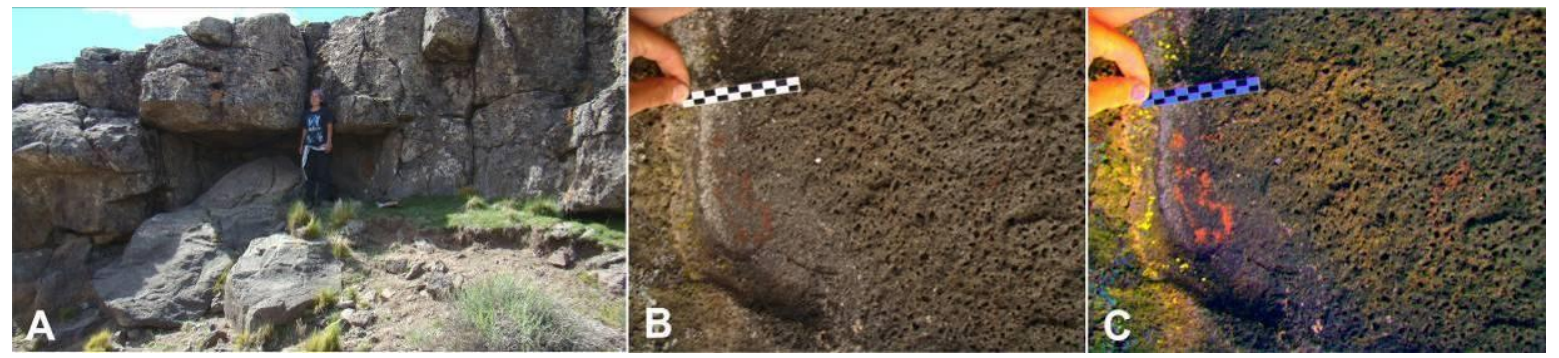

Figura 7.16. LA4: a. Vista del alero; b. Motivo; c. Imagen tratada digitalmente ( $D$ Stretch ybk 15).

\section{7. a. 3. Análisis}

En cuanto a las condiciones de emplazamiento y visibilidad (Tabla 7.2), se observa que en los sitios LA1 a LA3 se emplearon las paredes al interior de los 
aleros para realizar motivos pintados, en LA2 y LA4 se utilizó la superficie del techo. En líneas generales, los motivos se encuentran entre 1 y 1,5 m respecto del suelo, excepto en LA2 donde algunos motivos están por debajo de esa altura y a más $2 \mathrm{~m}$ respecto del suelo. Al encontrarse al interior de aleros, el campo visual está restringido a la extensión de los mismos. En todos los sitios es necesario estar a 1-3 $\mathrm{m}$ de distancia de los paneles para poder observar los motivos: en algunos casos se debe a la ubicación de los mismos (v.g., techo), en otros se debe a su estado de conservación (Motivo 4 de LA2).

\begin{tabular}{|c|c|c|c|c|c|}
\hline \multirow{2}{*}{\multicolumn{2}{|c|}{ Variables }} & \multicolumn{4}{|c|}{ Sitio } \\
\hline & & LA1 & LA2 & LA3 & LA4 \\
\hline Emplazamiento & $\begin{array}{l}\text { pared } \\
\text { techo }\end{array}$ & $\mathrm{X}$ & $\begin{array}{l}\mathrm{X} \\
\mathrm{X}\end{array}$ & $\mathrm{X}$ & $\mathrm{X}$ \\
\hline Posición & $\begin{array}{l}\mathrm{H} \\
\mathrm{V}\end{array}$ & $\mathrm{X}$ & $\begin{array}{l}\mathrm{X} \\
\mathrm{X}\end{array}$ & $\mathrm{X}$ & $\mathrm{X}$ \\
\hline Orientación & $\begin{array}{l}\mathrm{N} \\
\mathrm{S} \\
\mathrm{E} \\
\mathrm{W}\end{array}$ & $\begin{array}{l}\mathrm{X} \\
\mathrm{X}\end{array}$ & $\begin{array}{l}X \\
X\end{array}$ & $\begin{array}{l}\mathrm{X} \\
\mathrm{X}\end{array}$ & $\begin{array}{l}\mathrm{X} \\
\mathrm{X}\end{array}$ \\
\hline $\begin{array}{l}\text { Distancia al } \\
\text { suelo } \\
\text { en } \mathrm{m}\end{array}$ & $\begin{array}{l}>2 \\
2-1,6 \\
1,5-1 \\
<1\end{array}$ & $\begin{array}{l}X \\
X\end{array}$ & $\begin{array}{l}\mathrm{X} \\
\mathrm{X}\end{array}$ & $\mathrm{X}$ & $\mathrm{X}$ \\
\hline $\begin{array}{l}\text { Campo visual } \\
\text { máximo en } \mathrm{m}\end{array}$ & $\begin{array}{l}1 \\
3 \\
7 \\
15 \\
\end{array}$ & $\mathrm{X}$ & $\begin{array}{l}\mathrm{X} \\
\mathrm{X}\end{array}$ & $\mathrm{X}$ & $\mathrm{X}$ \\
\hline Iluminación & $\begin{array}{l}\text { luz tarde } \\
\text { luz mañana } \\
\text { penumbra } \\
\text { contraluz }\end{array}$ & $\mathrm{X}$ & $\mathrm{X}$ & $\mathrm{X}$ & $\mathrm{X}$ \\
\hline Visibilidad & $\begin{array}{l}\text { 1) alta } \\
\text { 2) intermedia } \\
\text { 3) baja } \\
\text { 4) muy baja }\end{array}$ & $\mathrm{X}$ & $\begin{array}{l}X \\
X\end{array}$ & $\mathrm{X}$ & $\mathrm{X}$ \\
\hline Motivos & $\begin{array}{l}\text { Puntiformes } \\
\text { Rectilíneos } \\
\text { Circulares llenos } \\
\text { Circulares lineales } \\
\text { Curvilíneos } \\
\text { Figurativos } \\
\text { ND }\end{array}$ & $\mathrm{X}$ & $\begin{array}{l}X \\
X \\
X \\
X \\
X \\
X \\
X\end{array}$ & $\mathrm{X}$ & $\mathrm{X}$ \\
\hline
\end{tabular}

Tabla 7.2. Emplazamiento y visibilidad de los sitios de Laguna Azul. 
En cuanto a las técnicas empleadas para la producción de los motivos pintados de Laguna Azul, se infiere la utilización de artefactos como hisopos o pinceles finos para la aplicación de las pinturas rojas, ya que el trazo de los motivos no supera los $1,50 \mathrm{~cm}$. Si bien todos los motivos son pintados, se observan variaciones en cuanto a la tonalidad de los mismos. Probablemente esta situación se vincule a la utilización de diferentes sustancias colorantes y al estado de conservación de los motivos. En relación a esto último, algunos motivos presentan un estado de conservación malo debido a la incidencia directa del sol (v.g., Conjunto 2 y Motivo 3 de LA1), al escurrimiento de agua sobre la superficie que se encuentran (Conjunto 1 LA1), al grado de exfoliación que presenta la pintura (Motivo 1 de LA4); mientras que pueden haber sido afectados por deyecciones de aves (Motivo 6 en LA2).

Al considerar la distribución espacial de los motivos, se observa la mayor variabilidad y densidad en LA2 (Figura 7.17), con todos los subgrupos reconocidos presentes. En tanto que LA1 y LA3 presentan motivos no determinados así como rectilíneos y puntiformes respectivamente. Los motivos rectilíneos son los más frecuentes del sitio. Se distinguieron tres clases: línea quebrada, línea ortogonal y figura poligonal. Dentro de las líneas ortogonales se incluyen escalonados, grecas, segmentados y cruciformes. Todas estas clases están presentes en LA2 mientras que LA1 y LA4 presentan sólo una clase (Figura 7.17.b).

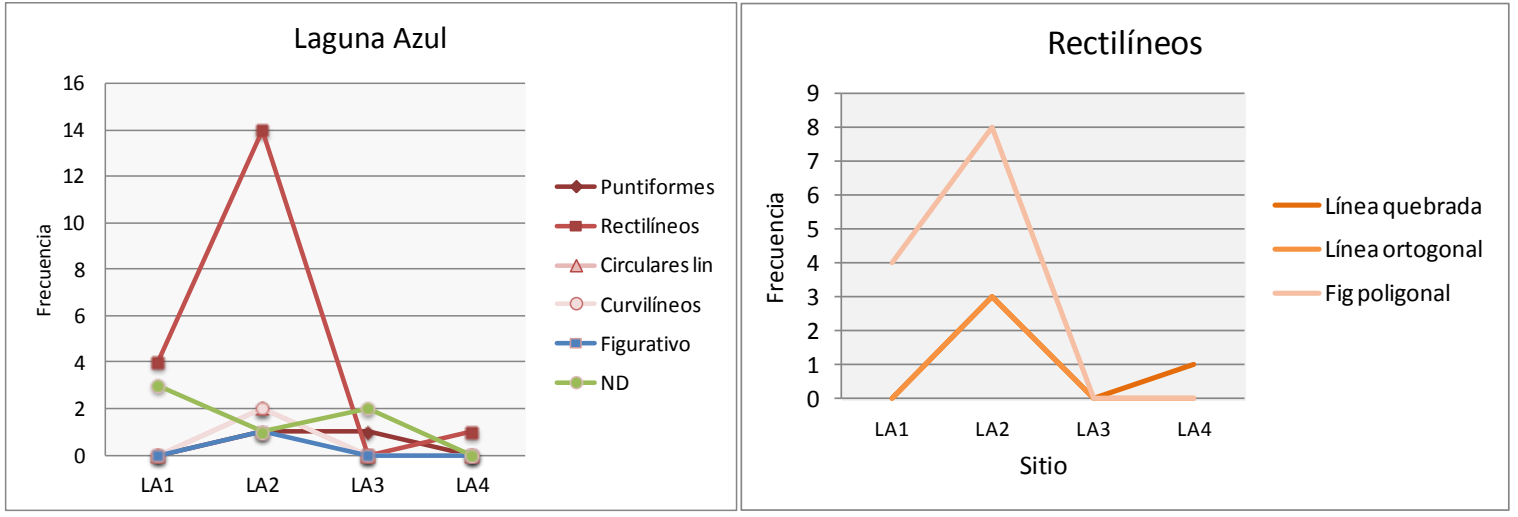

Figura 7.17. Distribución de motivos en LA: a. Frecuencias acumuladas de subgrupos de motivos reconocidos en los sitios; b. Clases de motivos rectilíneos reconocidos. Referencias: Circulares lin: circulares lineales; Fig poligonal: figura poligonal. 
El registro arqueológico observado y recuperado en Laguna Azul refiere a locus de actividades específicas -posiblemente a un taller en el caso de los materiales líticos en superficie y a la observación de personas y animales en el caso del parapeto de la margen sur- (Miotti et al. 2011c), y a lugares de actividades múltiples o campamentos en el caso de los parapetos de la margen norte (Gradin 1971). En Laguna Azul los motivos son pintados, de diseño predominantemente rectilíneo. El estado de conservación general de los mismos es regular a malo y, además, se observan diferentes tonalidades de rojo que podrían ser explicadas por la utilización de diferentes materias primas o bien por los procesos atmosféricos que los han afectado.

En esta localidad no se han observado superposiciones de motivos. La variabilidad observada indica que este arte rupestre puede ser atribuido a la Tendencia Abstracto-Geométrica Simple (TAGS) y Tendencia AbstractoGeométrica Compleja (TAGC) (Gradin 1987, 2001). La primera está representada por motivos puntiformes, curvilíneos y rectilíneos, en tanto que la segunda estaría representada por escalonados, cruciformes y motivos ornamentales. La cronología propuesta para la TAGS podría remontarse a 1.950 años AP, mientras que la TAGC habría aparecido con posterioridad (1.250 años AP). Ambas tendencias habrían perdurado hasta la época del contacto hispano-indígena (Gradin 2003a). Una cronología más reciente fue propuesta para sitios de la cuenca media y superior del río Limay, donde los diferentes motivos pintados del "estilo de grecas" -asociados a la TAGC- tienen alrededor de 750 años AP (Crivelli Montero 2006; Fernández 2006). En base a estas caracterizaciones se infiere que el arte rupestre de Laguna Azul correspondería a momentos relativamente recientes del Holoceno tardío. 


\section{7. b. LAGUNA MACIEGA}

Esta laguna fue visitada por Gradin en la década de 1970, donde relevó y sondeó parapetos en su margen septentrional (Gradin 1971). Lindera al trazado de la ruta provincial 60 , se localiza en los $41^{\circ} 21^{\prime}$ ' S y $66^{\circ} 49^{\prime}$ de $\mathrm{W}$ a 6,5 km al sureste de Laguna Azul (ver Figura 7.2). Como parte de los objetivos de esta tesis, durante 2011 se relevó el 70\% de la barda y de la cornisa basáltica.

Esta cuenca actualmente no presenta agua y está deshabitada (Figura 7.18.a). La prospección estuvo dirigida a re-ubicar los parapetos sondeados por Gradin y a localizar sitios o sectores con arte rupestre en las bardas basálticas que la rodean. La densa cobertura vegetal y los bloques desprendidos de la barda obstaculizan la observación directa de la superficie, lo que dificulta la detección de material arqueológico.

Luego del reconocimiento efectuado, se puede sostener que si bien a lo largo de las bardas existe soporte que pudo ser potencialmente empleado en la producción de arte rupestre, no se observan manifestaciones grabadas o pintadas. Asimismo, se observaron sectores cubiertos de líquenes (Figura 7.18.b). En la margen norte de la laguna se registró un parapeto de grandes dimensiones (Figura 7.18.c), que probablemente corresponda al que sondeó Gradin durante su visita. En superficie y en las inmediaciones del mismo se observaron materiales líticos asociados.

Aún resta prospectar el 25\% de la laguna, la porción de la cornisa y el pie de la barda basáltica que se encuentra detrás de un puesto abandonado, para descartar la producción de arte rupestre en esta cuenca. 

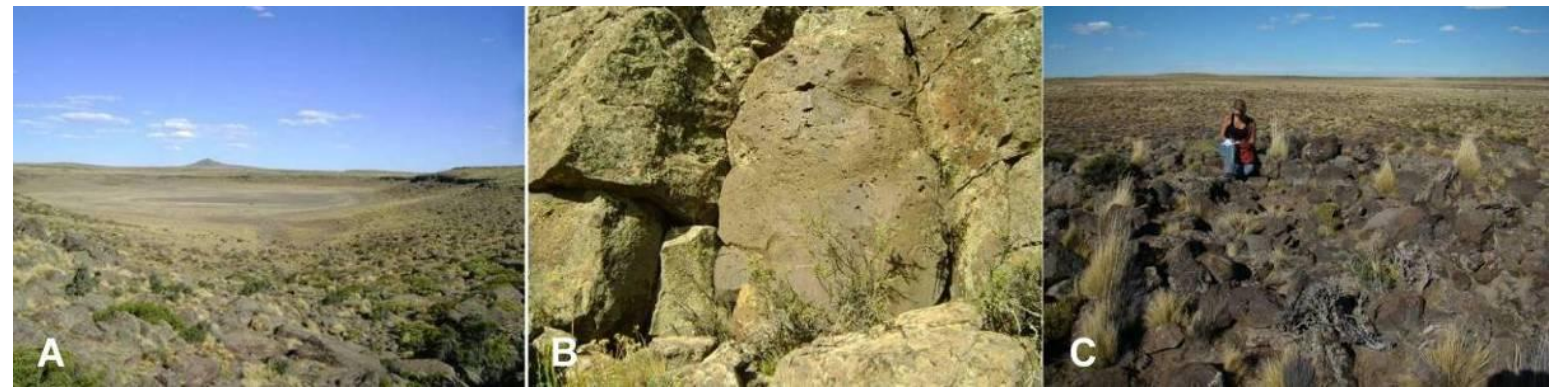

Figura 7.18. Laguna Maciega: a. vista desde el extremo NW (2011), con el cerro Puntudo al fondo; b. Apariencia de las bardas basálticas que rodean la laguna. Obsérvese los bloques cubiertos con líquenes y aquellos que no los presentan; c. Parapeto en margen norte de laguna.

\section{7. c. LAGUNA EL GANSO}

Como en el caso de las cuencas anteriores, la laguna El Ganso fue visitada por Gradin a comienzos de la década de 1970, cuando relevó y sondeó diferentes estructuras en la margen septentrional de la misma. Ubicada $9 \mathrm{~km}$ al sur de Laguna Azul y $15 \mathrm{~km}$ al NE de las Sierras de Somuncurá, sus coordenadas geográficas son $41^{\circ} 22^{\prime} \mathrm{S}$ y $66^{\circ} 47^{\prime} \mathrm{W}$ (Figura 7.2). Esta cuenca fue visitada en 2008 para el relevamiento del arte rupestre gracias a la información recibida del Sr. Atilio Namuncurá. Asimismo, parte de los objetivos de las tareas de campo incluyeron la relocalización y el estudio de las estructuras de piedra informadas previamente.

Con alturas inferiores a 2,5 m, basaltos de la Formación Somun Curá (Ravazzoli 1982; Remesal et al. 2001) rodean las márgenes norte, sur y oeste de la laguna. Se trata de bardas bajas, con superficies homogéneas de grano fino, de color gris a gris oscuro, que presentan áreas reparadas.

Durante las dos instancias en que fue visitada (2008 y 2011), esta cuenca no presentaba agua en superficie, aunque pudieron observarse pequeñas surgentes en su fondo que funcionaban como abrevaderos de guanacos (Figura 7.19). 


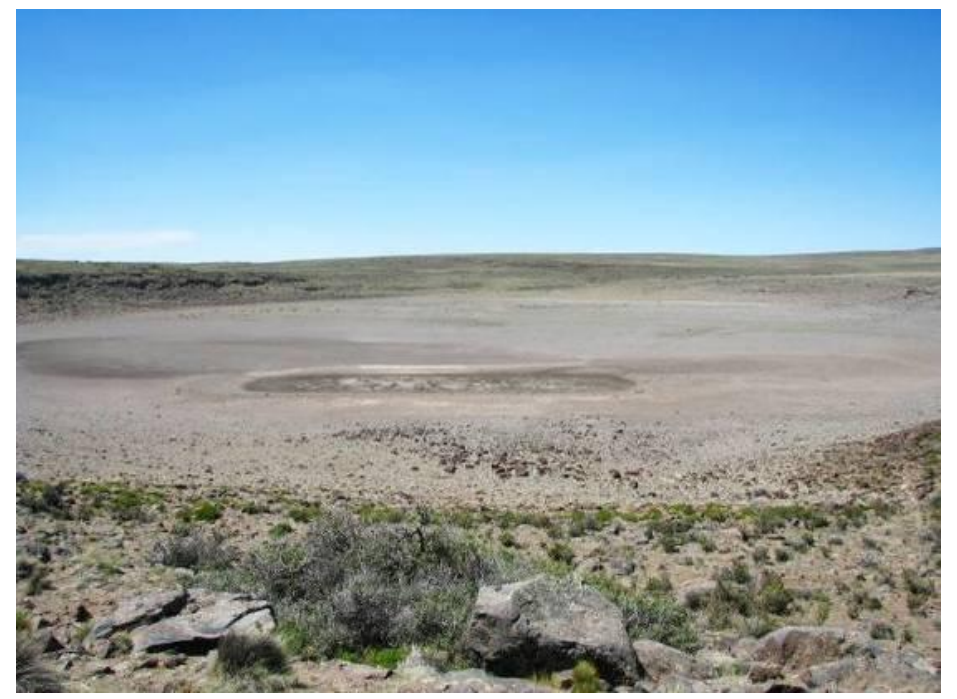

Figura 7.19. Laguna El Ganso vista desde la margen sudoeste.

\section{7. c. 1. Contextos arqueológicos de la localidad}

Gradin (1971) relevó y sondeó parapetos y estructuras de piedra similares a aquellas estudiadas en Laguna Azul y Maciega. Durante las tareas de 2008, las prospecciones en el borde lagunar fueron realizadas en dos grupos de trabajo. Los resultados fueron diferentes en los sectores explorados. En las márgenes norte y oeste de la laguna se reconocieron diferentes estructuras de piedra. En la corona basáltica septentrional se identificaron un conjunto de estructuras semicirculares sobre el pedimento y un posible "vichadero" de alrededor de $4 \mathrm{~m}$ de diámetro (Figuras 7.20.a y 7.20.b). Este último se encuentra en una pequeña lomada sobre la meseta basáltica, desde donde se pueden observar los bordes de las lagunas Maciega y El Ganso, siendo un punto estratégico de observación. Una propuesta similar fue efectuada por Hajduk et al. (2007) respecto de ciertas estructuras de piedra que se encontraban en un punto estratégico de observación del paisaje circundante.

Probablemente las estructuras sobre el pedimento basáltico se correspondan con aquellas relevadas y estudiadas por Gradin en esta laguna, ya que estas acumulaciones de piedras no superan los $0,50 \mathrm{~m}$ respecto del suelo, 
coincidentes en orientación y dimensiones con lo informado por aquel autor (Gradin 1971). Asimismo, sobre la corona basáltica, en el borde occidental, se registró una estructura adicional de 7 por $5 \mathrm{~m}$ (Miotti et al. 2008).

$\mathrm{Al}$ pie de la corona, en el borde de la laguna se observaron y geoposicionaron estructuras adicionales, que fueron ocupadas en épocas recientes: al menos tres corralitos (uno circular y dos rectangulares), que presentan ollas, materiales de hierro y nylon, probablemente empleados por los cazadores actuales de guanacos (Figura 7.20.c).

La altura y extensión que alcanza la barda en la margen norte pudo haber sido apta para la realización de arte rupestre. No obstante, las superficies basálticas actualmente se encuentran cubiertas por líquenes (Figura 7.20.d). A pesar de la observación minuciosa de la misma, sobre ellas no se detectó ningún tipo de manifestación rupestre.

En superficie se observaron diferentes artefactos no formatizados, principalmente de calcedonia y un fragmento de bola arrojadiza (Figura 7.20.e). Este último se encontró en el interior de una pequeña cárcava.

En la margen meridional se relevaron 15 estructuras de piedra con diferentes características. Dos de ellas, por su extensión y morfología, podrían corresponder a parapetos (Figura 7.20.f), en tanto que las restantes son estructuras circulares, pequeñas y cerradas, cuya altura oscila entre 0,25-0,50 m (Miotti et al. 2008). 

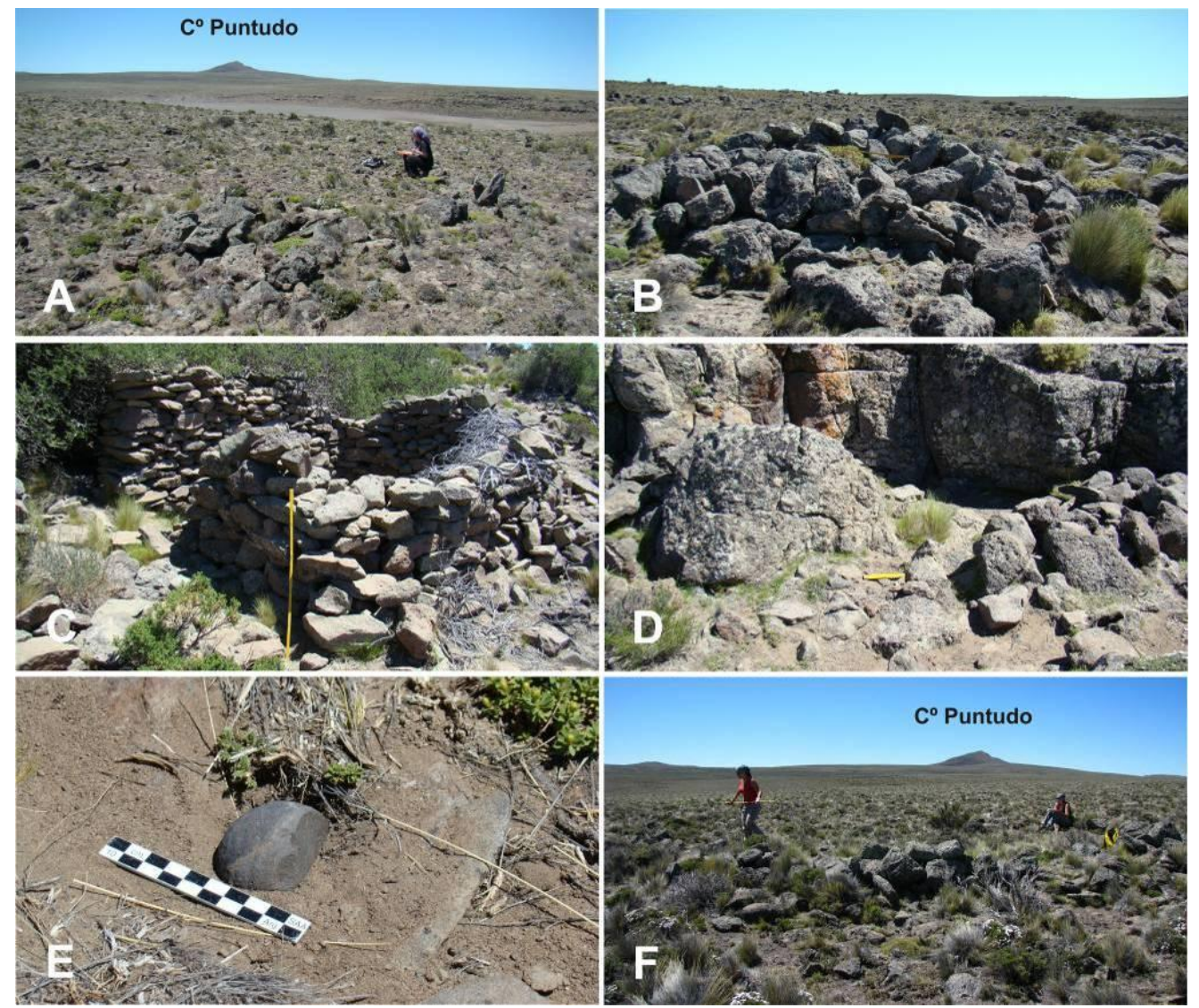

Figura 7.20. Hallazgos arqueológicos en la localidad: a. Estructura de piedra sobre pavimento de margen norte; b. "vichadero" al norte de Laguna El Ganso; c. Estructura rectangular de piedra en la margen occidental; $d$. Basaltos de la margen norte cubiertos de líquenes; e. Fragmento bola en cárcava; f. Parapeto de la margen sur.

\section{7. c. 2. El arte rupestre de Laguna El Ganso}

En Laguna El Ganso se identificaron dos sectores que incluyen un total de 92 motivos grabados distribuidos en 14 paneles: uno de ellos en el sector 1 sobre la barda sur de la laguna (Figuras 7.21.a y 7.21.b), los restantes en el sector 2, en la margen suroccidental de la laguna (Figura 7.21.c). 


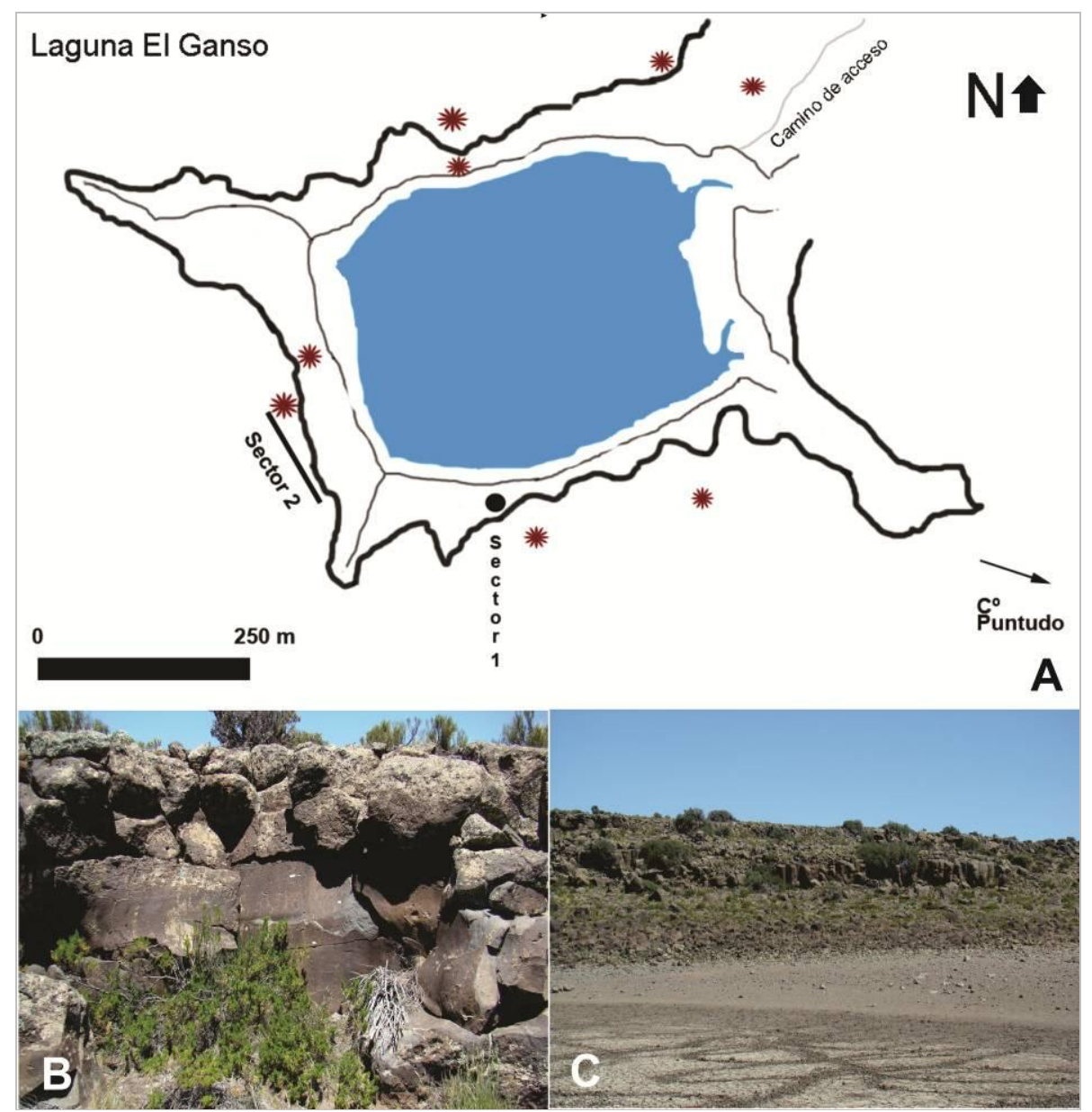

Figura 7.21. Distribución de sectores con arte y estructuras en Laguna El Ganso: a. Croquis con ubicación de las estructuras de piedra detectadas (asteriscos marrones) y de los sectores con arte rupestre; b. Vista al sector 1; c. Vista al sector 2 desde el este.

El sector 2 incluye el $80 \%$ de los motivos del sitio (Figura 7.22), probablemente por la extensión y altura que alcanza la barda en esa porción de la laguna. A nivel del sitio abundan los motivos no figurativos, seguidos por los figurativos y no determinados en proporciones similares (Figura 7.23.a). En el primer grupo, el $42 \%$ corresponde a motivos rectilíneos, seguidos por curvilíneos y puntiformes, mientras que los motivos circulares (llenos y lineales) abarcan el 12\% restante (Figuras 7.23.b). En la Tabla 7.3 se presenta la frecuencia de subgrupos de motivos identificados en Laguna Azul, y un detalle de los mismos se encuentra en el Apéndice V.1. 


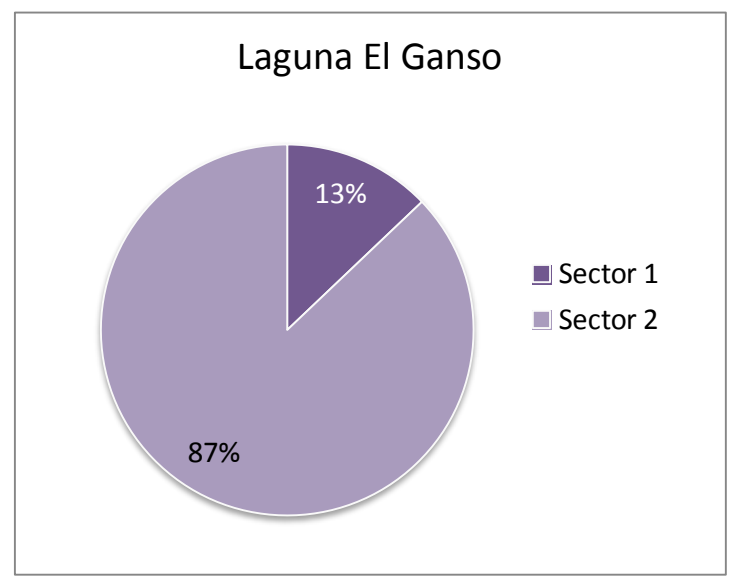

Figura 7.22. Proporciones de motivos por sectores en El Ganso.

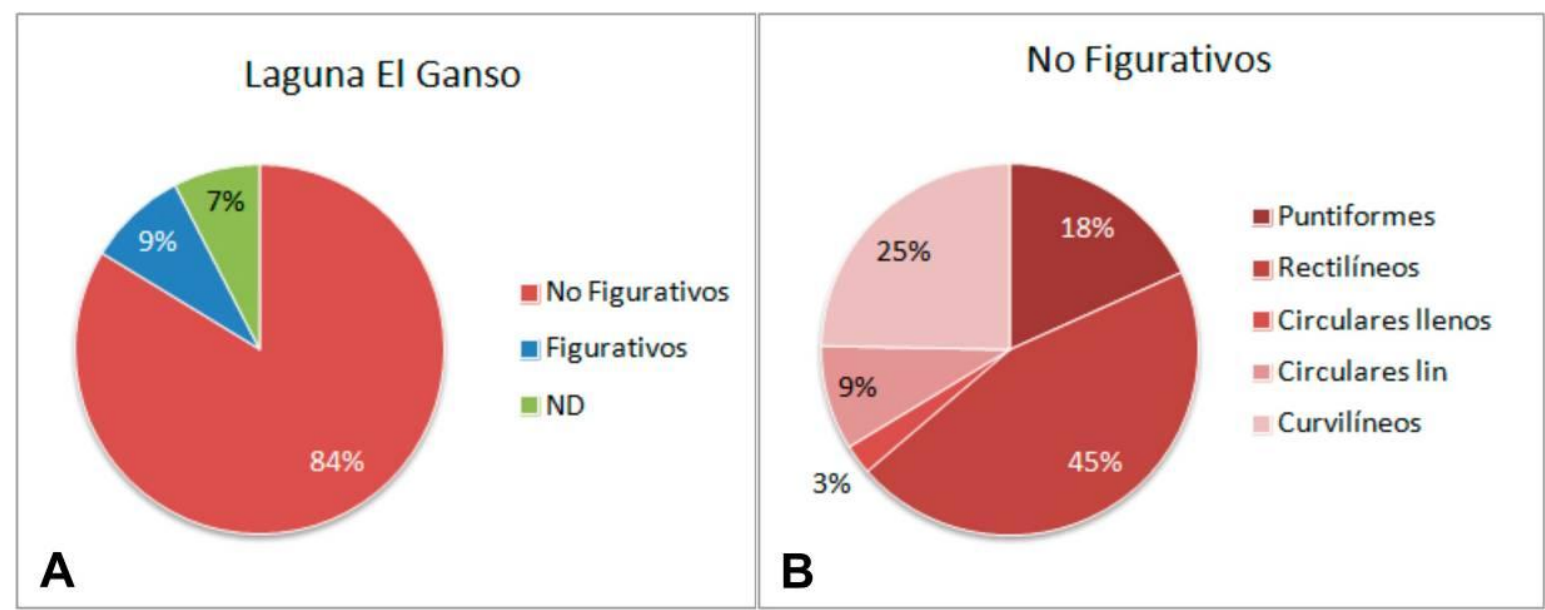

Figura 7.23. Proporciones de motivos en Laguna El Ganso: a proporciones de grupos de motivos; b. Proporciones de subgrupos de motivos no figurativos. Referencias: ND: no determinados; circulares lin: circulares lineales.

\begin{tabular}{|l|c|c|c|}
\cline { 2 - 4 } \multicolumn{1}{c|}{} & \multicolumn{2}{c|}{ Sector } & \multicolumn{1}{c|}{} \\
\hline Motivos & 1 & 2 & Subtotal \\
\hline Puntiformes & - & 14 & 14 \\
\hline Rectilíneos & 8 & 27 & 35 \\
\hline Circulares llenos & - & 2 & 2 \\
\hline Circulares lineales & - & 7 & 7 \\
\hline Curvilíneos & 3 & 16 & 19 \\
\hline No figurativos & 11 & 66 & 77 \\
\hline Zoomorfo & 1 & - & 1 \\
\hline Pisadas de Animales & - & 7 & 7 \\
\hline Figurativos & 1 & 7 & 8 \\
\hline No determinados & - & 7 & 7 \\
\hline \multicolumn{1}{|c|}{ Total } & 12 & 80 & 92 \\
\hline
\end{tabular}

Tabla 7.3. Frecuencias de subgrupos de motivos en Laguna El Ganso. 


\section{7. c. 2. 1. Sector 1}

Se encuentra en la margen sur, en la porción de la barda basáltica que alcanza mayor desarrollo y altura. Está parcialmente limitado por un gran pircado de piedra, al que se suma vegetación arbustiva (ver Figura 7.21.a). Si bien la superficie vertical disponible es amplia de coloración gris rojiza, para la realización de los grabados se utilizaron los sectores más homogéneos libres de líquenes, orientados al $\mathrm{N}$.

Conjunto 1. Se encuentra a alturas que oscilan entre 1,10 y $0,64 \mathrm{~m}$ respecto del suelo actual. Está integrado por 12 motivos, que presentan surcos de color gris o marrón dependiendo de su profundidad (Figura 6.24.a). El motivo figurativo del sector se corresponde a un zoomorfo, mientras que entre los no figurativos se reconocieron grecas, dos figuras poligonales, una circunferencia y dos serpentiformes (Figura 7.24.b, c y d). Asimismo, se documentaron un motivo enmarcado (rectángulo con escalonado en su interior), una línea curva, y una línea recta con apéndice corto a $90^{\circ}$. Sobre los motivos grabados, así como en superficies carentes de ellos, se registraron líneas incisas superficiales (Figura 7.24.c).

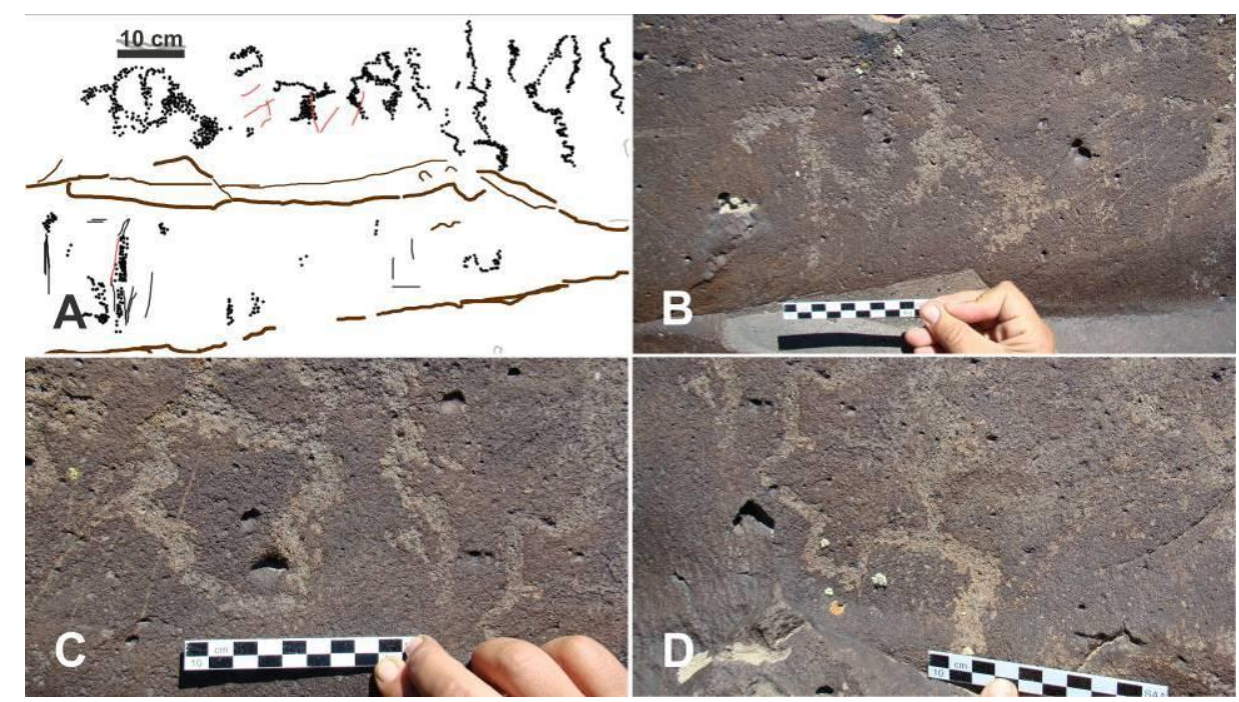

Figura 7.24. Motivos del sector 1: a. Calco del Conjunto 1 realizado a partir de fotografía digital; b. Motivo zoomorfo; c. Figura poligonal 3, nótese las incisiones superficiales en la porción inferior derecha del motivo; d. Poligonal con apéndice rectilíneo. 


\section{7. c. 2. 2. Sector 2}

Este sector se describe siguiendo el orden del relevamiento, desde la margen sur hacia la norte. La mayoría de las superficies utilizadas se encuentran en posición vertical, orientadas al E y presentan una coloración dispar: entre marrón claro y marrón oscuro rojizo.

Conjunto 2. Se encuentra en un sector reparado de la barda, a $0,14 \mathrm{~m}$ del suelo. Está conformado por tres motivos: tres líneas rectas verticales paralelas de largo variable, una línea horizontal de puntos muy pequeños sobre una convexidad de la roca y un motivo no determinado. Éste último está separado de los restantes por grietas naturales. En el espacio intermedio entre las líneas media y derecha del primer motivo se registraron, superpuestas, líneas incisas finas y superficiales.

Conjunto 3. A diferentes alturas, que oscilan entre $0,55 \mathrm{~m}$ y el ras del suelo, se registraron 11 motivos: puntiformes, rectilíneos (líneas simples, quebradas o series de líneas paralelas), círculos llenos; circulares lineales (circunferencias simples o con trazos internos), curvilíneos y un motivo complejo (Figura 7.25.a). Este último está integrado por semicircunferencias, circunferencias simples y concéntricas así como líneas rectas, simples o con apéndices. Entre los figurativos se reconoció una roseta. Los motivos fueron realizados por percusión o por incisión. Este tema se desarrolla más adelante en el capítulo.

Conjunto 4. Se encuentra al ras del suelo, al interior de un pequeño espacio reparado de la barda: al momento del relevamiento estaba parcialmente cubierto por sedimento. Este conjunto está integrado por tres motivos: una serie de líneas rectas paralelas verticales (las dos centrales están asociadas a una semicircunferencia), un motivo "en forma de U" invertida y un conjunto de puntos (Figura 7.25.b). Las líneas paralelas acrecientan su tamaño hacia el centro y, al igual que la semicircunferencia, son de trazo muy superficial. 


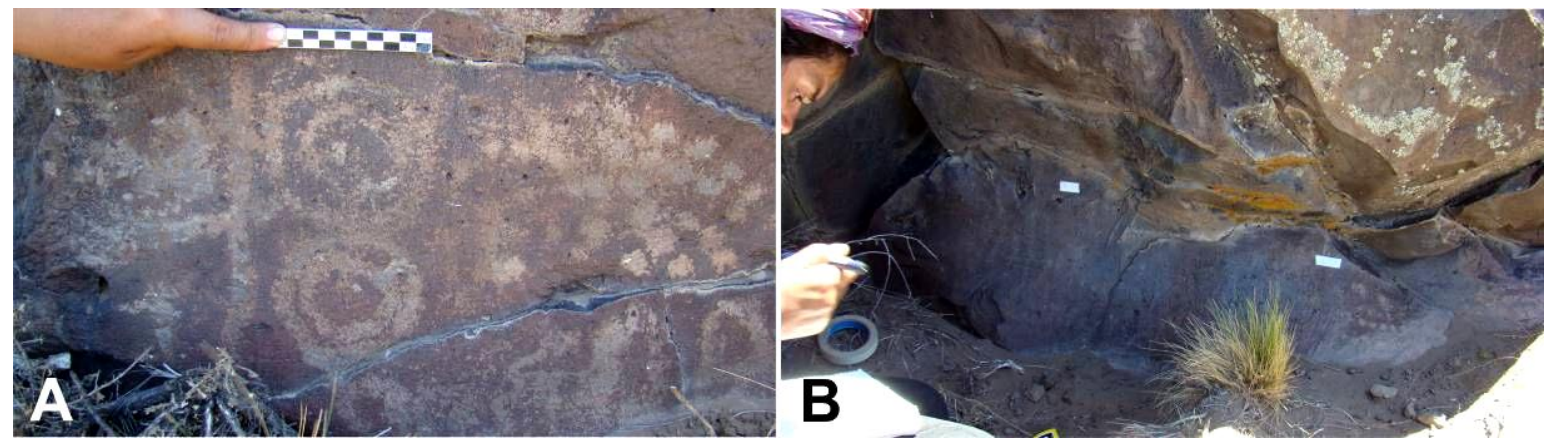

Figura 7.25. Conjuntos 3 y 4 de LEG: a. motivo combinado del Conjunto 3; Motivos del Conjunto 4.

Conjunto 5. Se encuentra en el sector más reparado de la barda y corresponde a un alero de pequeñas dimensiones, cuya altura es inferior a 1,50 m (Figura 7.26.a). Este conjunto está conformado por 15 motivos, a alturas variables respecto del suelo (entre $1,10 \mathrm{~m}$ y $0,30 \mathrm{~m}$ ). Los motivos identificados son dos líneas de puntos, tres conjuntos de puntos, una línea recta con apéndice oblicuo, una línea curva horizontal, una serie de líneas curvas paralelas horizontales y dos superficies grabadas no determinadas. Entre los figurativos se reconocieron tres pisadas de ave y dos pisadas de felinos.

Conjunto 6. A nivel del suelo y detrás del pircado que se encuentra al interior del espacio reparado en la barda (Figura 7.26.a), se registró este conjunto integrado por cuatro motivos: una superficie grabada no determinada a 0,30 m del suelo, una circunferencia concéntrica doble, un círculo de puntos (Figura 7.26.c) y un motivo líneas curvas invertidas y concéntricas atravesadas por dos líneas oblicuas y una grieta natural (Figura 7.26.d). Este último motivo se encontraba parcialmente cubierto con sedimento. Se infiere la incisión, la percusión con intermediario y el raspado como las técnicas de producción de estos motivos. Este tema será retomado más adelante. 


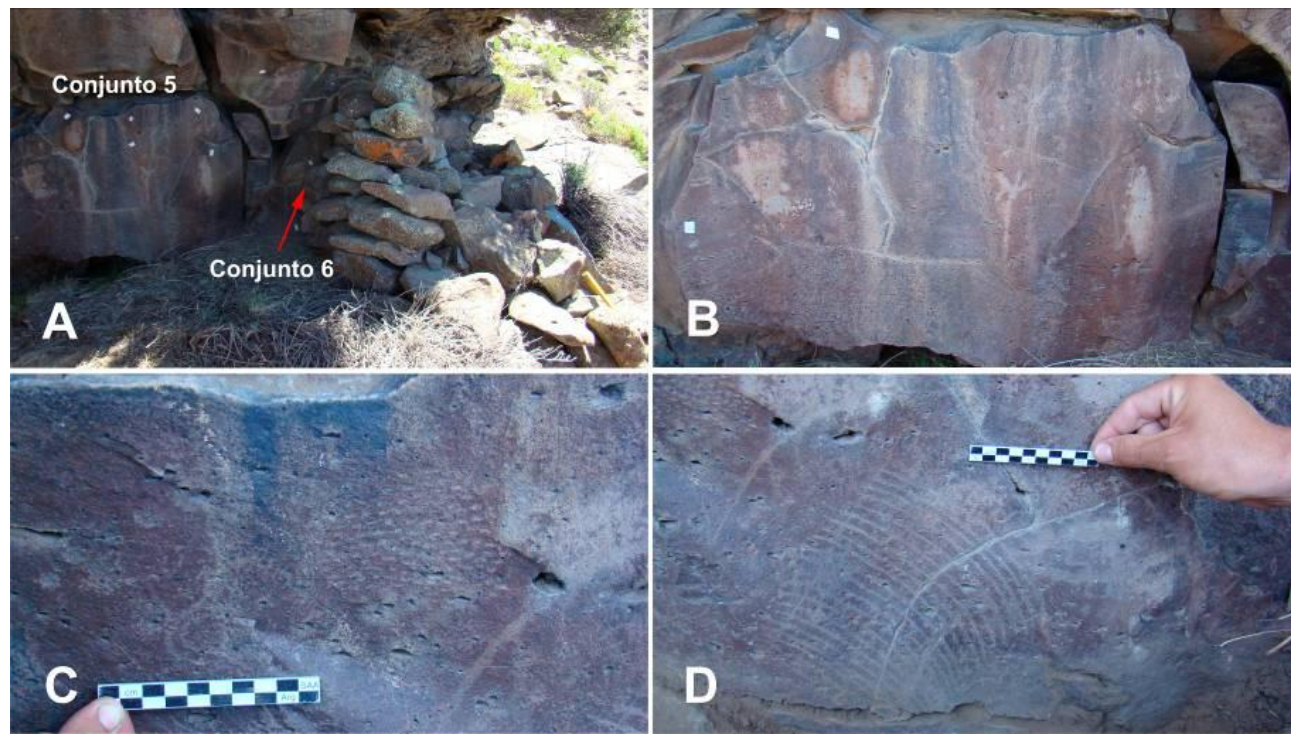

Figura 7.26. Conjuntos 5 y 6: a. Espacio reparado de la barda en el que se encuentran los conjuntos 5 y 6; b. Paneo del conjunto 5; c. Circunferencia concéntrica doble y circunferencia de puntos del conjunto 6; d. Serie de líneas curvas invertidas y concéntricas, atravesadas por líneas oblicuas y grieta natural.

Conjunto 7. Corresponde a una superficie en posición oblicua, también debajo del alero, aunque orientada al NE (Figura 7.27.a). Está integrado por ocho motivos, de los cuales el inferior se ubica a 0,50 $\mathrm{m}$ del suelo actual. Se identificaron líneas de puntos, líneas rectas y curvas simples con diferente orientación, un rectángulo con una superficie picada en su interior, un serpentiforme y un motivo no determinado (Figura 7.27.b).
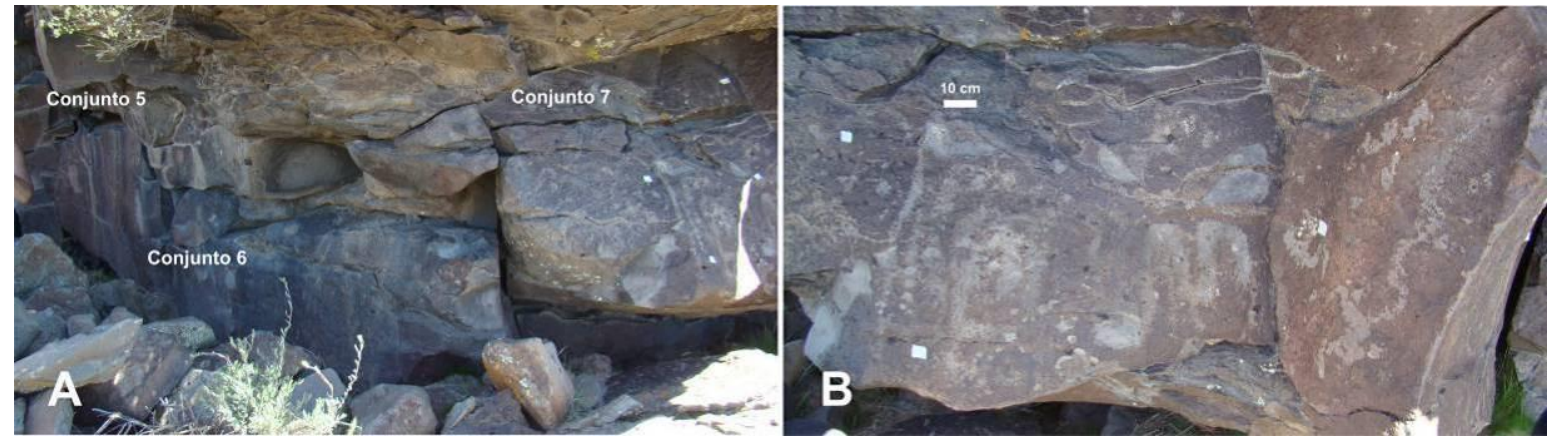

Figura 7.27. Conjunto 7: a. En relación a los Conjuntos 5 y 6; b. Detalle de los motivos.

Motivo 8. Se encuentra en posición oblicua en relación al panel anterior. Se corresponde con una superficie irregular que presenta varias facetas, algunas 
de las cuales carecen pequeñas porciones del soporte principalmente por la acción de líquenes. Se trata de un serpentiforme con un apéndice curvo.

Conjunto 9. También se encuentra debajo del espacio reparado, aunque orientado al $\mathrm{N}$ y a 0,46 m del suelo. Está integrado por ocho motivos: un conjunto de puntos, dos líneas rectas con diferente orientación, una semicircunferencia, una circunferencia con un apéndice curvo, dos circunferencias adosadas con un apéndice en forma de hoz, una "U" invertida y un serpentiforme paralelo al borde de la roca.

Conjunto 10. A alturas variables respecto del suelo, entre 0,33 y $0,10 \mathrm{~m}$, sobre dos superficies enfrentadas de la barda, se registraron tres motivos. Sobre una superficie horizontal oblicua se observa una línea curva asociada a un punto. Enfrentada a la anterior, sobre una superficie vertical, una serie de líneas rectas verticales de largo variable, entrecruzadas con dos líneas horizontales (Figura 7.28.c). El tercer motivo del conjunto corresponde a un grabado no determinado. Sobre la serie de líneas rectas se superponen líneas incisas y marcas de picado aleatorio (Figuras 7.28. b y c).
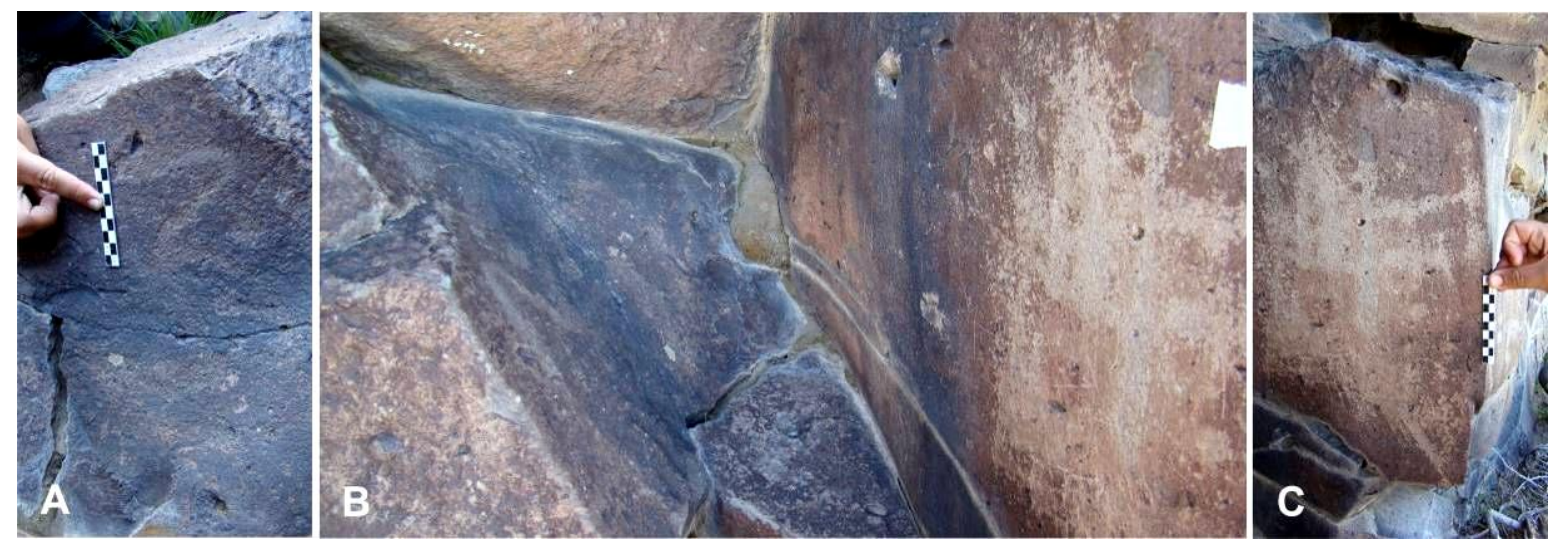

Figura 7.28. Conjunto 10: a. Serpentiforme; b. Superficies enfrentadas en las que se encuentran los motivos; c. Líneas entrecruzadas, más incisiones superpuestas.

Conjunto 11. A diferentes alturas respecto del suelo actual, siendo la inferior $0,33 \mathrm{~m}$, sobre una superficie vertical se registraron 12 motivos. Entre estos se reconocieron cuatro líneas rectas (con diferente orientación), dos motivos en zigzag (uno de ellos doble), una circunferencia, una línea curva 
atravesada por dos líneas verticales oblicuas (de largos variables), una "U" invertida, una pisada de felino y una superficie grabada no determinada (Figura 7.29.a).

Conjunto 12. Sobre una superficie vertical orientada al E, a $0,40 \mathrm{~m}$ del suelo actual, se relevaron los dos motivos que integran este conjunto: dos líneas paralelas verticales y una "V" invertida (Figura 7.29.b).
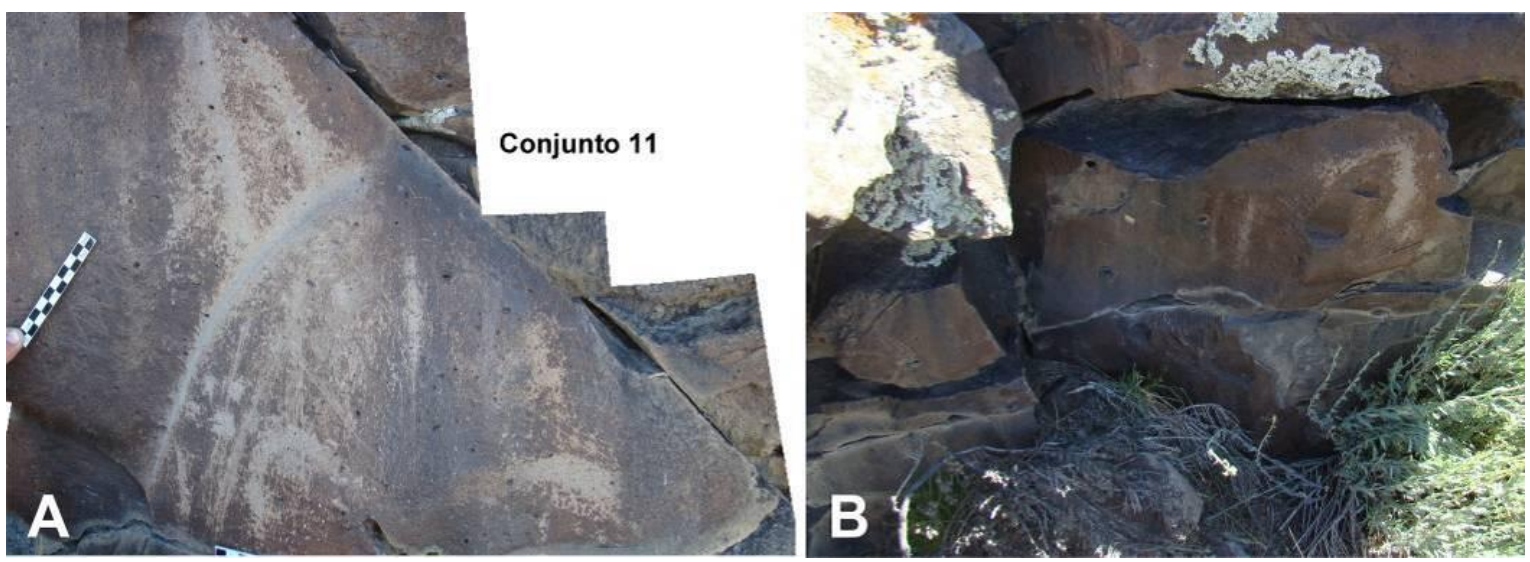

Figura 7.29. Conjuntos 11 y 12: a. Conjunto 11; b. Conjunto 12.

Conjunto 13. Se encuentra a 1,36 m del suelo actual, sobre una superficie vertical. Está integrado por dos motivos: dos líneas de puntos paralelas horizontales y un serpentiforme asociado a un par de puntos.

Conjunto 14. Se encuentra por debajo del conjunto anterior, a escasos centímetros del suelo y al interior de una concavidad. Los motivos que lo integran fueron realizados sobre dos superficies enfrentadas: un par de puntos y una superficie incisa de forma no determinada se encuentran en posición vertical; mientras que sobre una superficie horizontal, se registró un motivo en forma de "media U" invertida.

\section{7. c. 3. Análisis}

Se observan similitudes y diferencias en cuanto a sus condiciones de emplazamiento y visibilidad de los dos sectores que conforman el sitio (Tabla 
7.4). Se emplearon las superficies verticales de las bardas que circundan la laguna, siendo que en el sector 2 la mayoría de los motivos se encuentra en espacios reparados (pequeños aleros). En este último sector se utilizaron, además, algunas superficies horizontales. La altura a la que se encuentran los motivos no supera $1,50 \mathrm{~m}$ respecto del suelo actual. La visibilidad de los mismos está en relación a la altura sobre el suelo a la que se encuentran así como también la superficie sobre la que se ubican y el contraste entre el surco grabado y el soporte, siendo intermedia-baja.

\begin{tabular}{|c|c|c|c|}
\hline \multirow{2}{*}{\multicolumn{2}{|c|}{ Variables }} & \multicolumn{2}{|c|}{ Sectores } \\
\hline & & 1 & 2 \\
\hline Emplazamiento & $\begin{array}{l}\text { pared } \\
\text { techo }\end{array}$ & $\mathrm{X}$ & $\mathrm{X}$ \\
\hline Posición & $\begin{array}{l}\mathrm{H} \\
\mathrm{V}\end{array}$ & $\mathrm{X}$ & $\begin{array}{l}\mathrm{X} \\
\mathrm{X}\end{array}$ \\
\hline Orientación & $\begin{array}{l}\mathrm{N} \\
\mathrm{S} \\
\mathrm{E} \\
\mathrm{W}\end{array}$ & $\mathrm{X}$ & $\begin{array}{l}X \\
X \\
X\end{array}$ \\
\hline $\begin{array}{l}\text { Distancia al } \\
\text { suelo en m }\end{array}$ & $\begin{array}{l}>2 \\
2-1,51 \\
1,5-1 \\
<1\end{array}$ & $\begin{array}{l}X \\
X\end{array}$ & $\begin{array}{l}X \\
X\end{array}$ \\
\hline $\begin{array}{l}\text { Campo visual } \\
\text { máximo en } \mathrm{m}\end{array}$ & $\begin{array}{l}1 \\
3 \\
7 \\
15\end{array}$ & $\mathrm{X}$ & $\begin{array}{l}X \\
X\end{array}$ \\
\hline Iluminación & $\begin{array}{l}\text { luz tarde } \\
\text { luz mañana } \\
\text { penumbra } \\
\text { contraluz }\end{array}$ & $\begin{array}{l}X \\
X\end{array}$ & $\mathrm{X}$ \\
\hline Visibilidad & $\begin{array}{l}\text { 1) alta } \\
\text { 2) intermedia } \\
\text { 3) baja } \\
\text { 4) muy baja }\end{array}$ & $\mathrm{X}$ & $\begin{array}{l}\mathrm{X} \\
\mathrm{X}\end{array}$ \\
\hline Motivos & $\begin{array}{l}\text { Puntiformes } \\
\text { Rectilíneos } \\
\text { Circulares llenos } \\
\text { Circulares lineales } \\
\text { Curvilíneos } \\
\text { Pisada felino } \\
\text { Tridígito } \\
\text { Zoomorfo } \\
\text { ND }\end{array}$ & $\mathrm{X}$ & $\begin{array}{l}X \\
X \\
X \\
X \\
X \\
X \\
X \\
X\end{array}$ \\
\hline
\end{tabular}

Tabla 7.4. Visibilidad y emplazamiento en Laguna El Ganso 
Los motivos fueron realizados mayoritariamente por percusión, siendo técnicas complementarias la incisión y la combinación de ambas (percusión e incisión) (Figura 7.30). Los escasos casos en los que no pudo determinarse la técnica se deben principalmente a la presencia de restos de líquenes sobre los surcos grabados. La mayor variabilidad de técnicas se observa en el sector 2 (Figura 7.30).

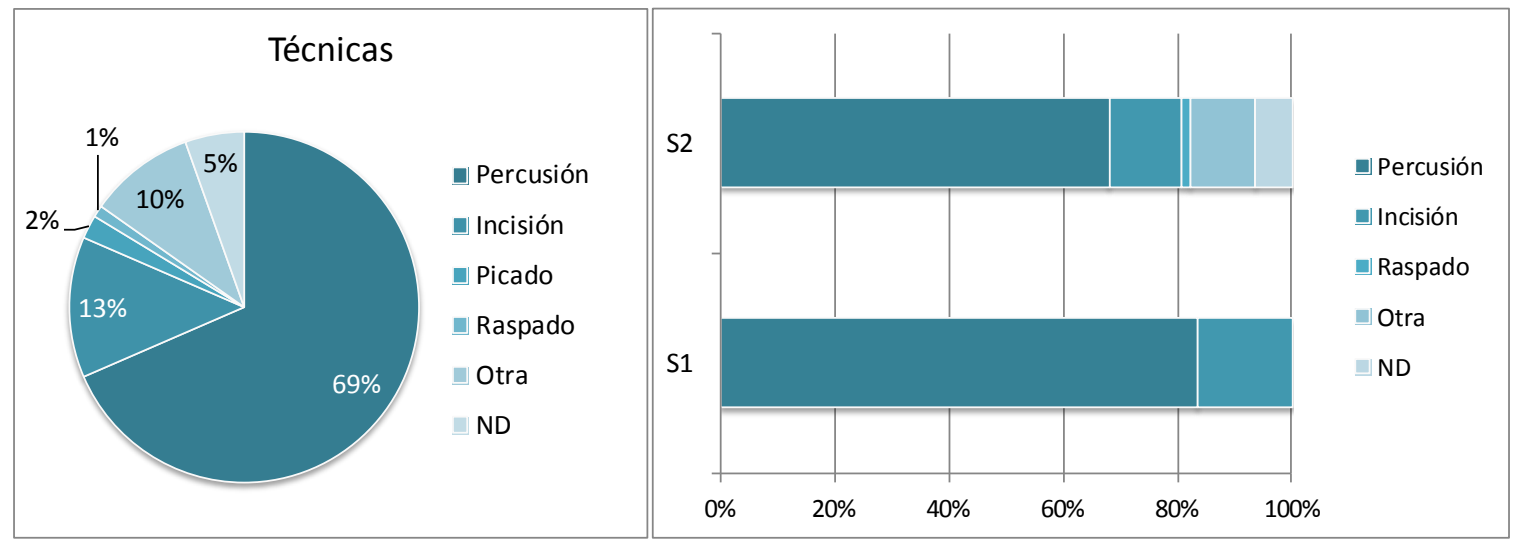

Figura 7.30. Técnicas documentadas en LEG y su distribución por sectores. ND: no determinada.

La determinación de las técnicas fue realizada a partir de la observación macroscópica de los surcos. En la percusión, se observaron puntos de impacto sobre las superficies basálticas. Si bien son de tamaño pequeño, en general no puede determinarse si dichos puntos de impacto fueron realizados directamente con un percutor con punta aguzada o de manera indirecta, a través de un intermediario. No obstante, para los motivos del Conjunto 6 sí puede plantearse el uso de un intermediario, debido al tamaño pequeño y a la profundidad de los surcos (Figura 7.31.a). La incisión fue empleada para la realización de algunos motivos así como para la producción de líneas que presentan surco fino y superficial (Figura 7.31.b). Esta segunda situación presenta dos variantes: las líneas incisas se superponen a motivos realizados por percusión (Figuras 7.31.c y 7.31.d) o bien pueden haber sido empleadas para remarcar algún surco picado, manteniendo la morfología del motivo (Figura 7.31.c). Sin embargo, en el Conjunto 3 una circunferencia con líneas 
rectas interiores fue producida con ambas técnicas: la circunferencia y una de las líneas internas fueron realizadas por percusión, en tanto que para la línea restante se empleó la incisión (Figura 7.31.e). El raspado se registró en un motivo no determinado del conjunto 6 , siendo su surco homogéneo y liso (Figura 7.31.e).
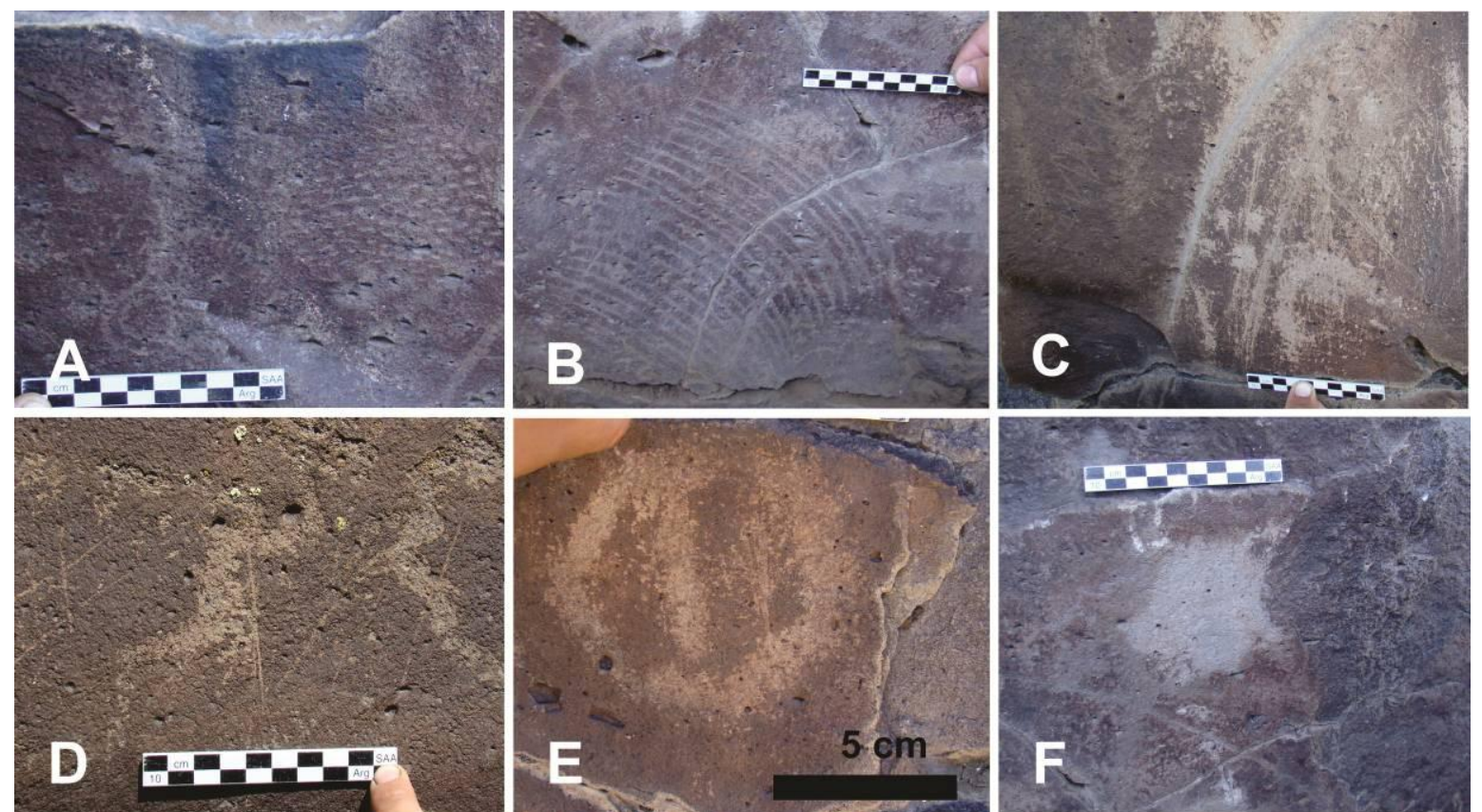

Figura 7.31.Reconocimiento macroscópico de técnicas: a. Conjunto 6 motivos por picado (percusión indirecta); b. Serie de líneas curvas paralelas del Conjunto 6 realizadas por incisión; c. Líneas incisas del Conjunto 7 superpuestas a motivos realizados por percusión; d. Líneas incisas superficiales del Conjunto 1 superpuestas a motivos realizados por percusión o en superficies libres de motivos; e. Circunferencia por picado con trazos internos incisos del conjunto 3; f. Motivo no determinado del conjunto 6 realizado por raspado.

Al considerar la pátina de los motivos, se observa un predominio de pátina clara seguido por la pátina intermedia, mientras que la pátina oscura y la no determinada están presentes en bajas proporciones (Figura 7.32). En el sector 2 se registró la mayor variabilidad (Figura 7.32). 


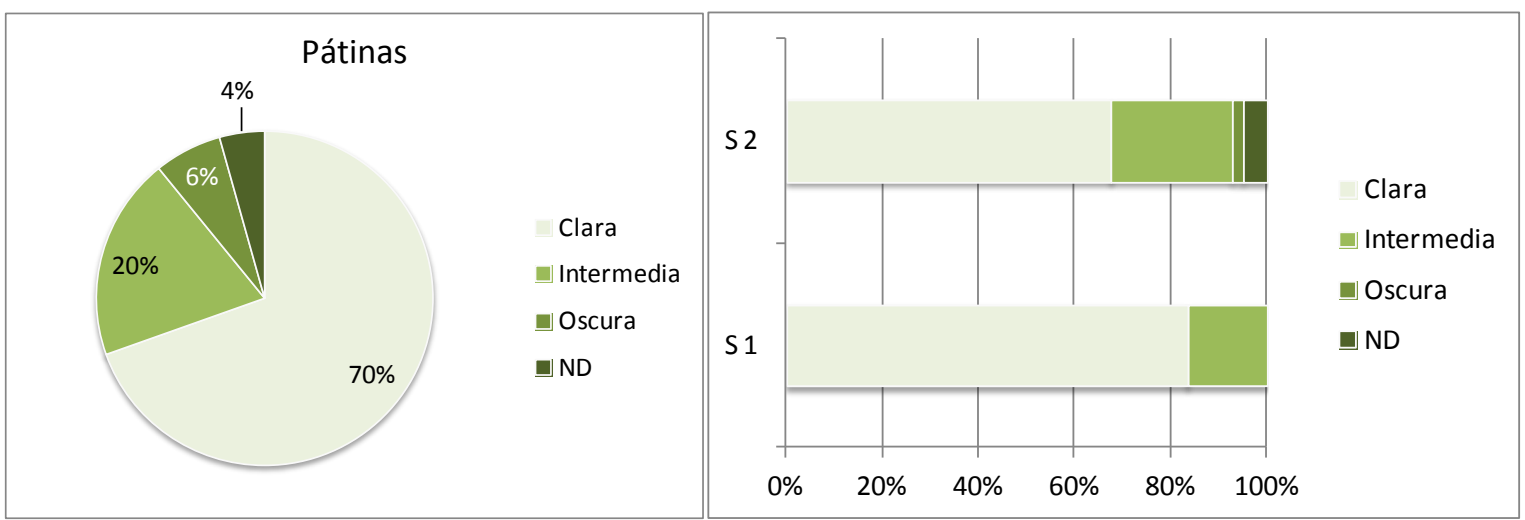

Figura 7.32. Pátinas en Laguna El Ganso: proporciones en el sitio y proporciones acumuladas por sector. ND: no determinada.

Se registraron siete casos de superposiciones, una en el sector 1 y las restantes en el sector 2. En la mayoría de los casos se trata de líneas caóticas incisas sobre motivos grabados por percusión (ver Figuras 7.31.c y 7.31.d). Utilizando la propuesta de Pastor (2012), podría plantearse la supresión de motivos ya que algunas incisiones evidenciarían cierta intencionalidad en destruir el diseño subyacente. Estas incluyen las incisiones caóticas documentadas en el sector 1, las de los Conjuntos 3, 5 y 11 del sector 2. En el caso del Conjunto 6, el motivo no determinado grabado por raspado podría corresponderse a otro ejemplo de esa situación ya que por debajo se observa de manera tenue una pisada de felino siendo más evidente la eficacia para suprimir parcialmente este motivo.

Al considerar la distribución espacial de los motivos, se observa la mayor variabilidad y densidad en el sector 2, que presenta todos los subgrupos reconocidos, mientras que el sector 1 presenta motivos rectilíneos, curvilíneos y el único zoomorfo esquemático del sitio (Figura 7.33). La mayor densidad de motivos en el sector 2 podría vincularse con que presenta el mayor desarrollo de la barda de la laguna, y la mayor superficie libre de líquenes disponible en esa porción de la laguna.

Los subgrupos de motivos más frecuentes son los rectilíneos, los circulares lineales y los puntiformes que ascienden a 68 (Figura 7.33). La distribución espacial de motivos será considera por clases. Para los puntiformes se 
reconocieron cuatro clases: líneas de puntos simples y líneas paralelas de puntos, conjunto y círculo de puntos. Entre los rectilíneos se reconocieron siete clases: líneas simples, líneas con apéndice, líneas quebradas, líneas ortogonales (que abarcan las grecas), series de líneas paralelas y figuras poligonales (Figura 7.33). Por último, entre los curvilíneos se reconocieron cuatro categorías: líneas curvas simples, "en forma de U", serpentiformes y series de líneas curvas paralelas.

Los puntiformes sólo se encuentran en el sector 2, siendo más frecuentes las líneas y conjuntos de puntos. Los motivos rectilíneos se encuentran en ambos sectores: en el sector 1 se reconocieron cuatro categorías, mientras que los conjuntos del sector 2 predominan las series de líneas paralelas, seguidas por líneas rectas simples y las líneas quebradas. Los curvilíneos se encuentran en ambos sectores, predominan los serpentiformes y las líneas curvas simples, presentes en los dos sectores, seguidos por líneas "en forma de U” y líneas paralelas curvas registrados en el sector 2. Se observa una mayor variabilidad de clases de motivos en el sector 2 , probablemente vinculada a la mayor frecuencia de motivos. 


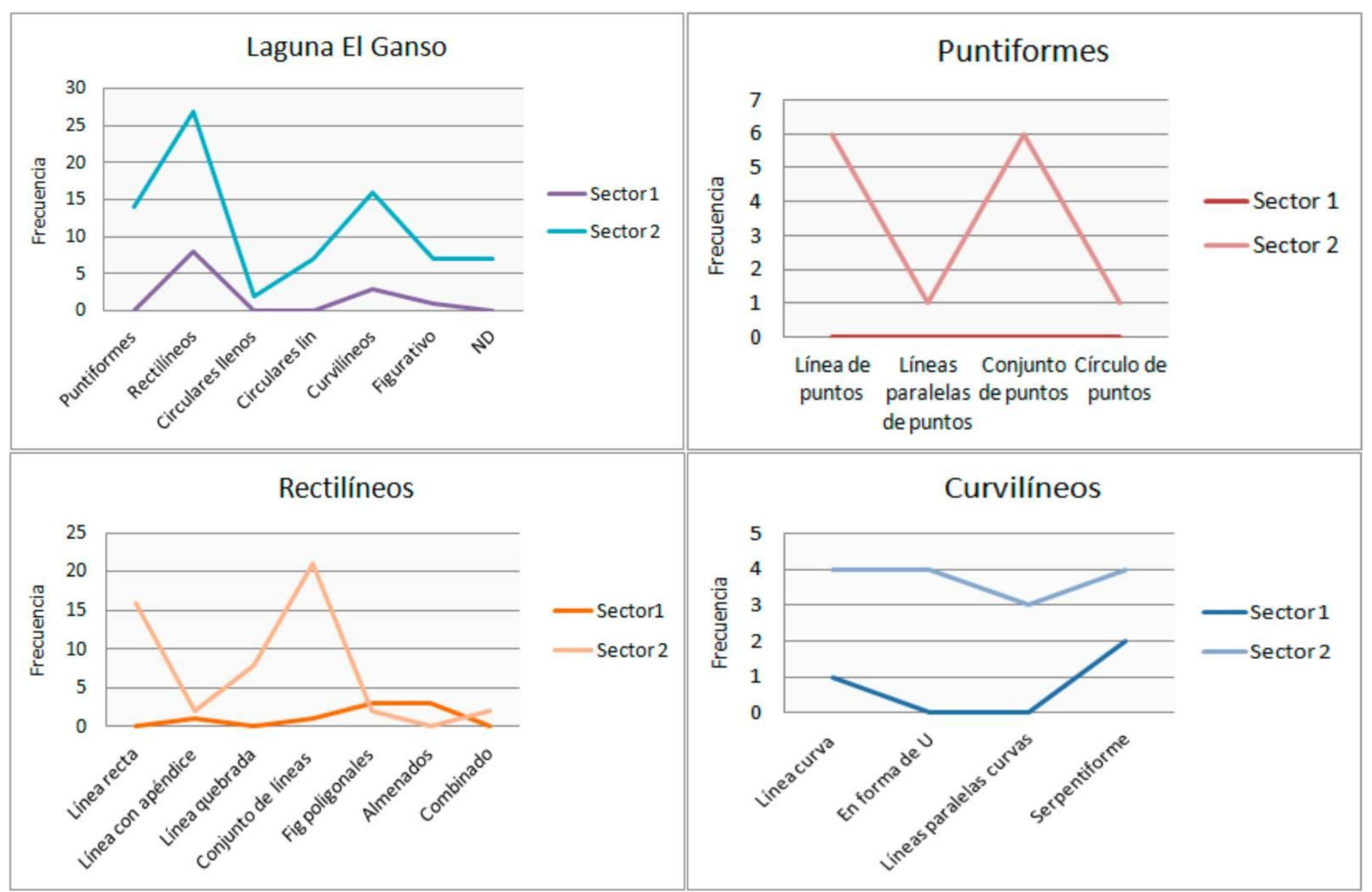

Figura 7.33. Distribución espacial de frecuencias de subgrupos y categorías de motivos. Proporciones acumuladas de clases de motivo por sector. Referencias: Circulares lin: circulares lineales; Fig poligonales: figuras poligonales 
Si se contempla la pátina por categoría de motivo y por sector, se observan que los motivos rectilíneos del sector 1 presentan pátina clara y los curvilíneos intermedia (Tabla 7.5). En el sector 2 los puntiformes y curvilíneos presentan los tres tipos de pátina, mientras que los rectilíneos presentan pátina clara, intermedia o no determinada. Presentan pátina oscura, líneas rectas simples y en series paralelas (Tabla 7.5).

\begin{tabular}{|c|c|c|c|c|c|c|c|}
\hline \multirow{2}{*}{ Motivos/Pátinas } & \multicolumn{2}{|c|}{ Sector 1} & \multicolumn{4}{|c|}{ Sector 2} & \multirow{2}{*}{ Total } \\
\hline & $\mathrm{C}$ & I & $\mathrm{C}$ & I & $\mathrm{O}$ & ND & \\
\hline Línea de puntos & - & - & 5 & - & 1 & - & 6 \\
\hline Conjunto de puntos & - & - & 4 & 2 & - & - & 6 \\
\hline Otros puntiformes & - & - & 1 & & 1 & - & 2 \\
\hline Línea recta & - & - & 5 & 1 & - & 2 & 8 \\
\hline Línea quebrada & - & - & 2 & 1 & 1 & - & 4 \\
\hline Conjunto de líneas & 1 & - & 9 & 1 & 1 & 1 & 13 \\
\hline Figura poligonal & 3 & - & 1 & - & - & - & 4 \\
\hline Otros rectilíneos & 4 & - & - & 2 & - & - & 6 \\
\hline Línea curva & - & 1 & 3 & 1 & - & - & 5 \\
\hline "En forma de U" & - & - & 2 & 1 & 1 & - & 4 \\
\hline Líneas paralelas curvas & - & - & 1 & 1 & 1 & - & 3 \\
\hline Serpentiforme & 1 & 1 & 4 & & - & - & 6 \\
\hline Total & 9 & 2 & 37 & 10 & 6 & 3 & 64 \\
\hline
\end{tabular}

Tabla 7.5. Distribución por sector de las categorías de motivos y los tipos de pátina de Laguna El Ganso. Referencias: C: clara; I: intermedia; O: Oscura; ND: no determinada.

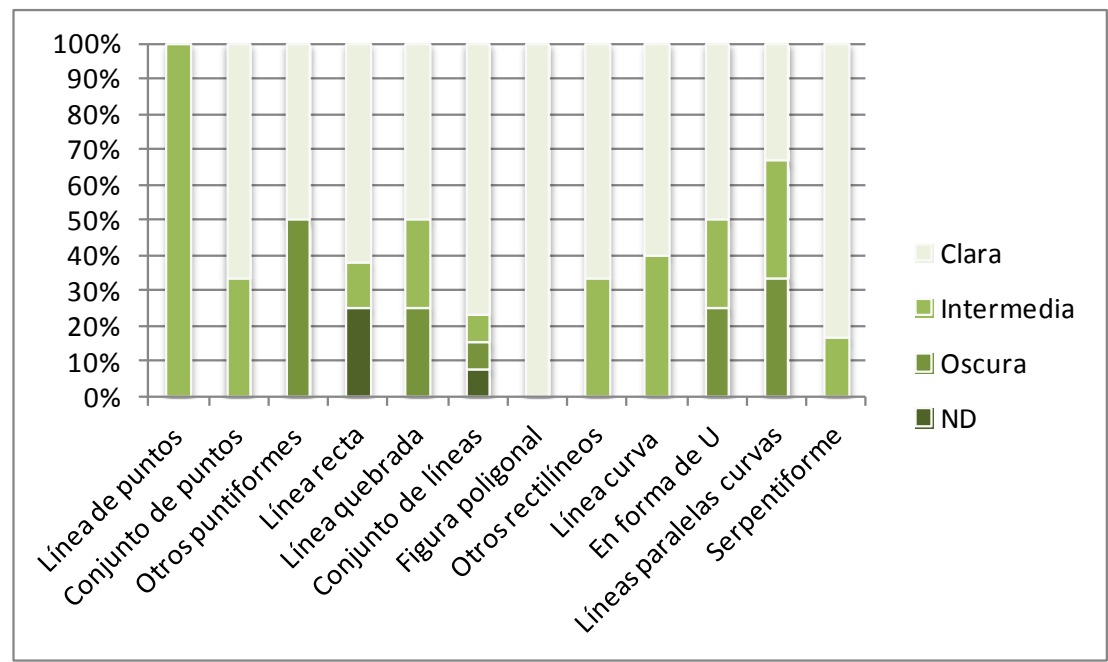

Figura 7.34. Distribución de grados de pátina por sector y por categorías de motivos. Referencias: ND: no determinada.

Respecto a los motivos figurativos, en Laguna El Ganso este grupo de está representado por un único zoomorfo esquemático y por siete pisadas de animales, presentes en los sectores 1 y 2 respectivamente (Figura 7.35). Las 
pisadas de animales se corresponden con pisadas de felino y aves. Considerando la clasificación de pisadas animales presentada en el Capítulo 2, las pisadas de ave con los tipos A (dedo medio a $45^{\circ}$ ) y $\mathrm{C}$ (con dedo medio trasero) mientras que las pisadas de felino se corresponden con los tipos A (4 dedos) y E (roseta) (Figura 7.35; Tabla 7.6). Todas las pisadas animales se encuentran en el sector 2.
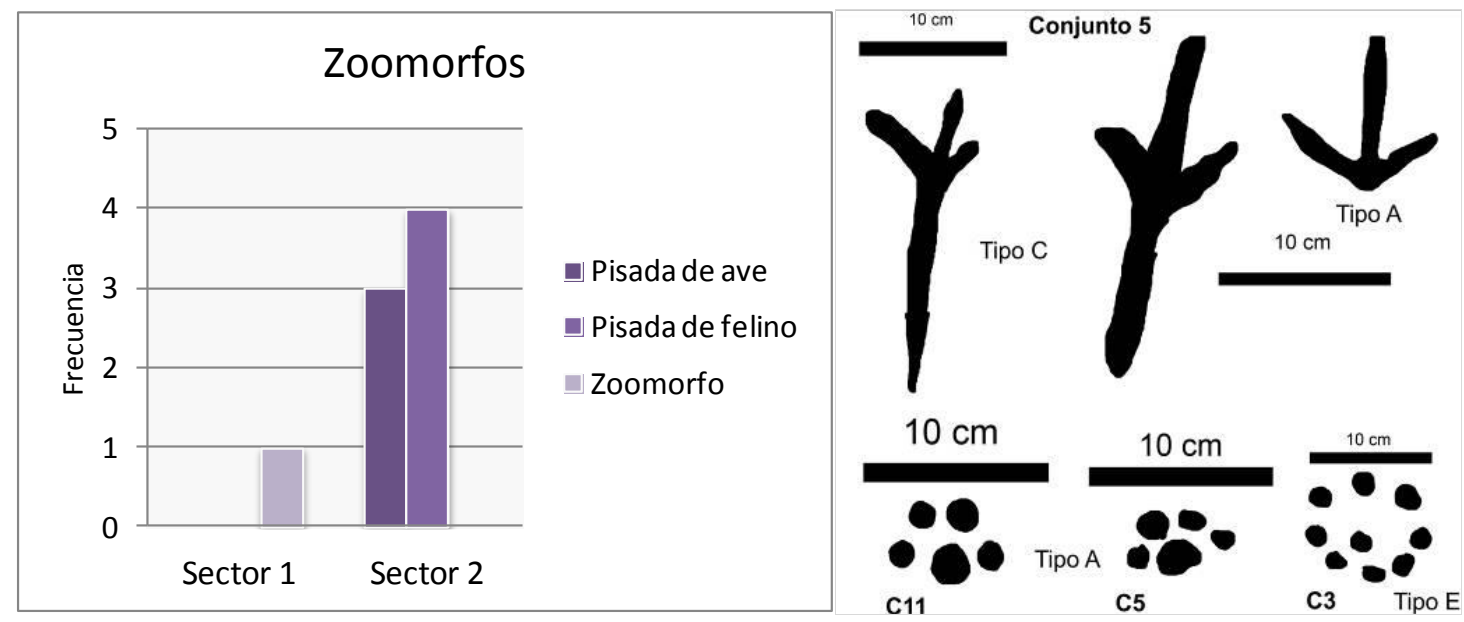

Figura 7.35. Pisadas animales: a. Distribución de motivos figurativos en LEG; b. tipos de pisadas animales registradas. Referencia: C: conjunto.

\begin{tabular}{|c|l|l|c|}
\hline Pisada & Tipo & $\mathrm{N}$ & Subtotal \\
\hline \multirow{2}{*}{ Ave } & $\mathrm{A}$ & 1 & \multirow{2}{*}{3} \\
\cline { 2 - 3 } & $\mathrm{C}$ & 2 & \multirow{2}{*}{} \\
\hline \multirow{2}{*}{ Felino } & $\mathrm{A}$ & 3 & \multirow{2}{*}{4} \\
\cline { 2 - 3 } & $\mathrm{E}$ & 1 & \\
\hline \multicolumn{3}{|c|}{ Total } & \multicolumn{2}{|c}{7} \\
\hline
\end{tabular}

Tabla 7.6.Frecuencia de pisadas animales reconocidas en LEG.

Los grabados Laguna El Ganso manifiestan las siguientes características: 1) la técnica empleada con mayor frecuencia fue la percusión, seguida por la incisión, la percusión con intermediario (indirecta) y la combinación de ambas. Son pocos los casos en los que no se pudo determinar la técnica;

2) en cuanto a su diseño, la mayor parte de los grabados son rectilíneos (38\%), seguidos en proporciones menores por curvilíneos (21\%) y puntiformes (15\%);

3) en líneas generales, los motivos presentan una pátina clara o intermedia, que contrasta con las superficies de color castaño oscuras del basalto; 
4) El estado de conservación de los motivos es bueno a regular;

5) En cuanto a las superposiciones, se trata en la mayoría de los casos de motivos incisos, generalmente caóticos, que se encuentran por encima de motivos realizados por percusión, también con pátina clara. La excepción la constituyen las líneas incisas del Conjunto 11, que presentan pátina oscura, hecho que probablemente se deba a que la profundidad del surco inciso no atravesó la pátina del soporte. Estas incisiones superpuestas corresponderían a otro evento de producción, ya que en algunos casos se encuentran sobre diseños diferentes (v.g., grecas y figuras poligonales en Conjunto 1, pisadas y curvilíneos en el Conjunto 11). Ésta situación se correspondería a un caso de supresión en el sentido de Pastor (2012).

Si se consideran todas las variables analizadas (técnica, diseño, pátina y superposiciones) es posible plantear que la mayor parte de los grabados de Laguna El Ganso fueron realizados con una sincronía relativa, implicando sucesivos eventos de retorno al sitio por gente que compartía los mismos códigos para interpretar las imágenes.

Asimismo, contemplando los contextos arqueológicos de la localidad, se puede pensar que el arte rupestre fue realizado por grupos que ocupaban las inmediaciones de la laguna, tanto al norte (Gradin 1971; García y Pérez de Micou 1980) y al sur de la laguna (Miotti et al. 2008), que en la actualidad presentan escasos materiales asociados. Además, esta laguna ha sido ocupada en épocas recientes como locus de cacería o "chulengueadas", uso que posiblemente también habría ocurrido en el pasado, y que estaría evidenciado por el fragmento de bola partida recuperado.

Por las características enunciadas previamente, el arte rupestre de Laguna El Ganso puede ser atribuido a la Tendencia Representativa Esquemática (Gradin 1987), tendencia que, en palabras de Gradin, se corresponde con el "estilo de pisadas" de Menghin (1957), ya que se observan improntas de animales así como motivos circulares lineales y curvilíneos. Las cronologías relativas propuestas para el arte rupestre en áreas aledañas indican que esta tendencia se desarrolló a partir de ca. 2.800 años AP, durante el Holoceno tardío (Ceballos y Peronja 1984; Crivelli Montero 2006; 
Crivelli Montero et al. 1996; Fiore 2006, ver para mayor detalle Capítulo 4). Es decir, en Laguna El Ganso la presencia de pisadas de animales grabadas similares a las de áreas aledañas podría mostrar una mayor profundidad temporal que Laguna Azul, aunque la presencia de grecas grabadas permitiría pensar en la recurrencia ocupacional de la Laguna El Ganso en momentos posteriores.

\section{7. d. BARDAS DE ANTONIO (LAGUNA LA MACIEGA)}

El sitio se encuentra a $15 \mathrm{~km}$ al SW de las Sierras de Somuncurá, al sur de las lagunas tratadas en los apartados previos (ver Figura 7.2). Sus coordenadas geográficas son $41^{\circ} 35^{\prime} \mathrm{S}$ y $67^{\circ} 06^{\prime} \mathrm{W}$. Esta cuenca endorreica, denominada laguna La Maciega, actualmente carece de agua (Figura 7.36.a), aunque en el sector medio de la misma se encuentra una surgente. La laguna mide aproximadamente $1 \mathrm{~km}$ de ancho por $1,5 \mathrm{~km}$ de largo, y tiene dos cursos temporales tributarios, uno al NW y otro al SE.

Este bajo se abre entre los basaltos olivínicos de la Formación Somun Curá (Ravazzolli 1982; Remesal et al. 2001). La barda circundante se caracteriza por ser de color gris o marrón, presentando a veces coloración rojiza. Las superficies pueden ser homogéneas o bien irregulares, principalmente resultado la acción del agua, la arena y/o los líquenes.

Respecto del dominio visual, desde el bajo no puede observarse la planicie circundante aunque desde la corona basáltica pueden tomarse como puntos de referencia en el paisaje parte de las Sierras de Somuncurá: los Cuatro Cerros, el Cerro Somuncurá Grande y el Peñón de los Cóndores hacia el NE (Figura 7.36.b). 


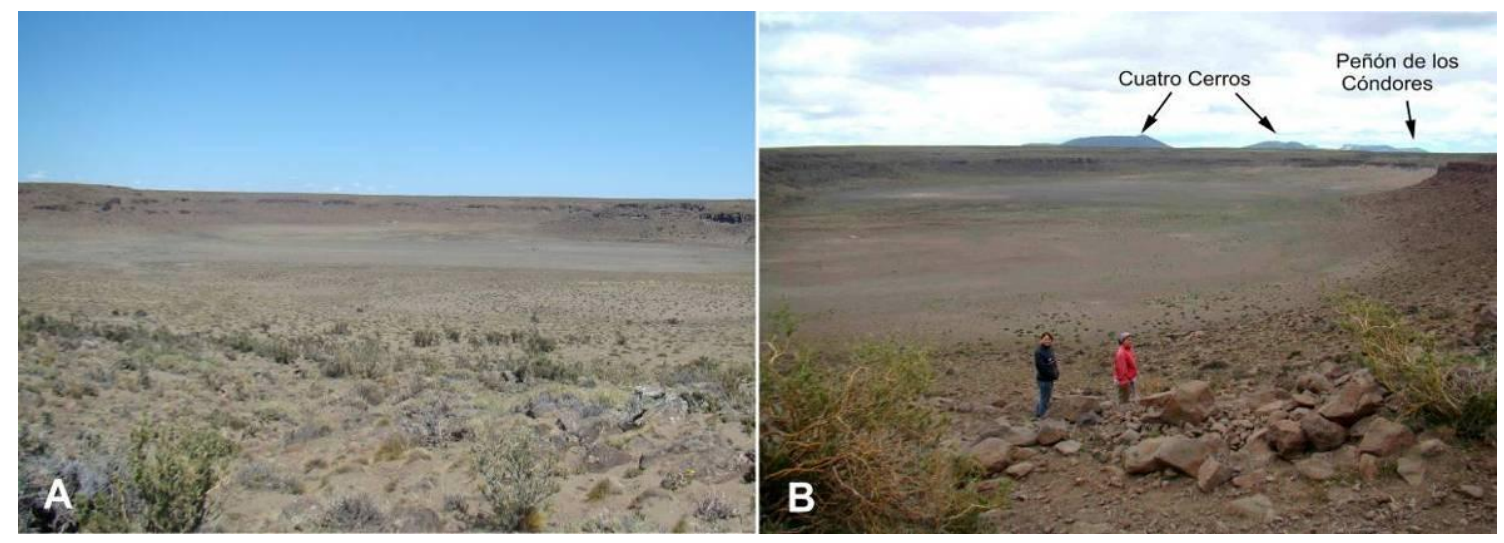

Figura 7.36. Laguna La Maciega: a. Vista desde margen SE; b. Vista desde el camino de acceso al puesto de don Antonio, desde donde las Sierras de Somuncurá pueden tomarse como punto de referencia.

La primera noticia sobre el arte rupestre de esta laguna la recibimos del Sr. Atilio Namuncurá, mientras que las indicaciones respecto de su ubicación exacta fueron brindadas por don Pablo Antonio, actual ocupante. La denominación del sitio no condice con el nombre de la cuenca para evitar la confusión con el sitio Laguna Maciega, registrado por Gradin durante la década de 1970 y ubicado $30 \mathrm{~km}$ al norte (Apartado 7.b). El nombre Bardas de Antonio hace homenaje al actual puestero de la estancia, quien nos brindó su hospitalidad e información acerca del paraje.

\section{7. d. 1. Otros contextos arqueológicos de la localidad}

Los trabajos realizados por el equipo de investigación han permito realizar diferentes registros en esta laguna, que hasta entonces permaneció fuera de la conocimiento. Tales trabajos se relacionan principalmente a prospecciones sistemáticas que involucraron el relevamiento de estructuras de piedra, de restos óseos humanos (Miotti et al. 2008, 2009b; Terranova 2012) y del arte rupestre (Blanco et al. 2013).

Sobre la cornisa basáltica de la margen sur de la laguna, en las inmediaciones del sitio con arte rupestre, se relevó una estructura de piedra considerada como "vichadero" ya que corresponde a un punto estratégico de observación hacia la planicie basáltica circundante y hacia el bajo 
(Terranova 2012). En ese lugar, así como en distintas porciones del talud de la barda, se realizaron recolecciones sistemáticas de materiales líticos. El análisis de esos materiales permitió proponer que en el sector suroriental de la laguna se realizaron actividades de laboreo de cueros (Terranova 2012).

Por otra parte, en el borde septentrional de la cuenca se registró un grupo de estructuras de piedras sobre el pavimento basáltico, denominado Alta Maciega (Terranova 2012: Figura 4)-. Tanto las estructuras como la superficie sobre la que se encuentran carecen de materiales arqueológicos. Esta falta de evidencia sería resultado de ocupaciones cortas en ese sector de la laguna (Terranova 2012).

\section{7. d. 2. El arte rupestre de Bardas de Antonio}

Las manifestaciones rupestres se encuentran a lo largo del cañadón tributario ubicado al sureste de la laguna, que presenta una orientación NW-SE y en el cual discurre uno de los afluentes temporarios mencionados previamente. El sitio está conformado por seis sectores, uno de ellos en la margen norte y cinco en la margen sur (Figura 7.37). La delimitación de los sectores estuvo basada en la continuidad de motivos en las distintas unidades topográficas de la barda así como por cambios de orientación o la presencia de grietas: cuando esa discontinuidad, o la superficie sin registro de manifestaciones rupestres, superaba los $6 \mathrm{~m}$ se reconoció un nuevo sector. 


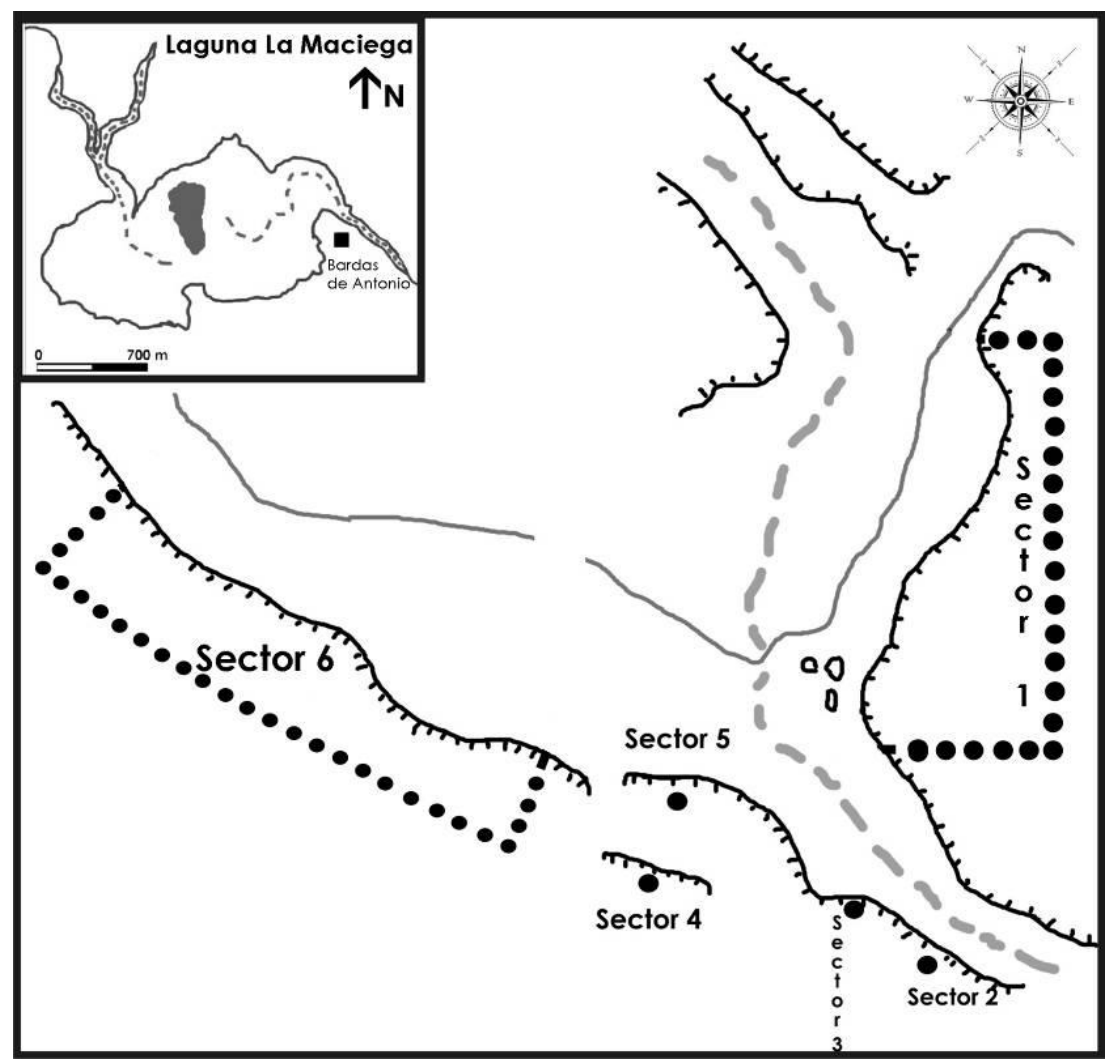

Figura 7.37. Sectorización de Bardas de Antonio. Croquis sin escala

Bardas de Antonio presenta 383 motivos, distribuidos heterogéneamente en los distintos sectores, con una alta proporción en el sector 6 (Figura 7.38). Entre las manifestaciones predominan los motivos no figurativos, seguidos en proporciones similares por los figurativos y no determinados (Figura 7.39.a). Dentro del primer grupo predominan los circulares lineales, seguidos por los rectilíneos y los puntiformes, mientras que curvilíneos y circulares llenos alcanzan el 6\% conjuntamente (Figura 7.39.b). La frecuencia de grupos y subgrupos de motivos por sector se presenta en la Tabla 7.7, en tanto que en el Apéndice V.1 se presenta un detalle de los motivos reconocidos. 


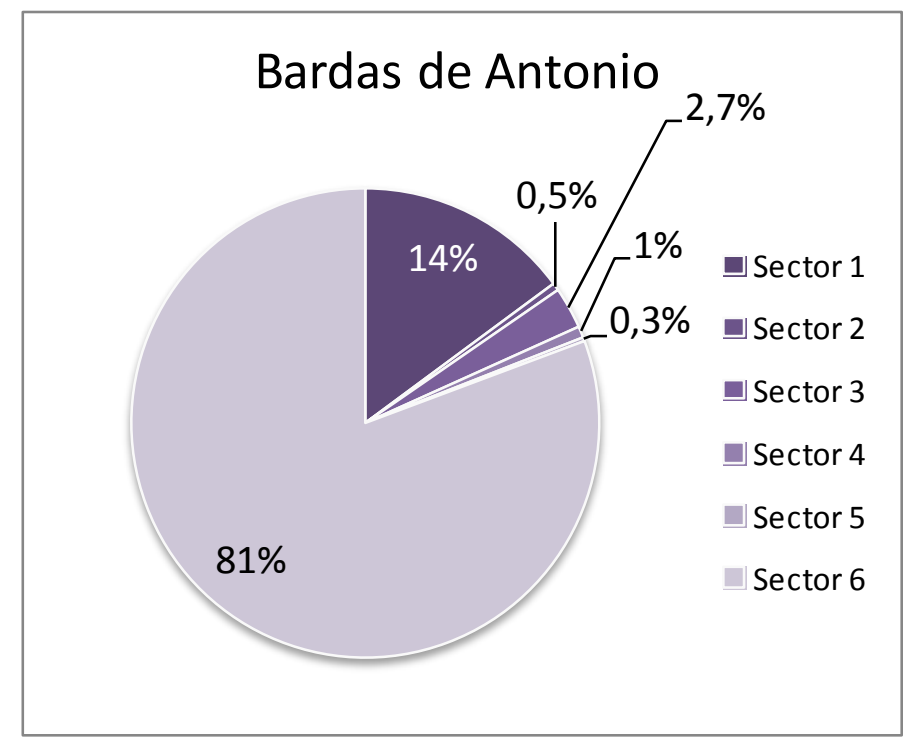

Figura 7.38. Proporciones de motivos por sectores en Bardas de Antonio.

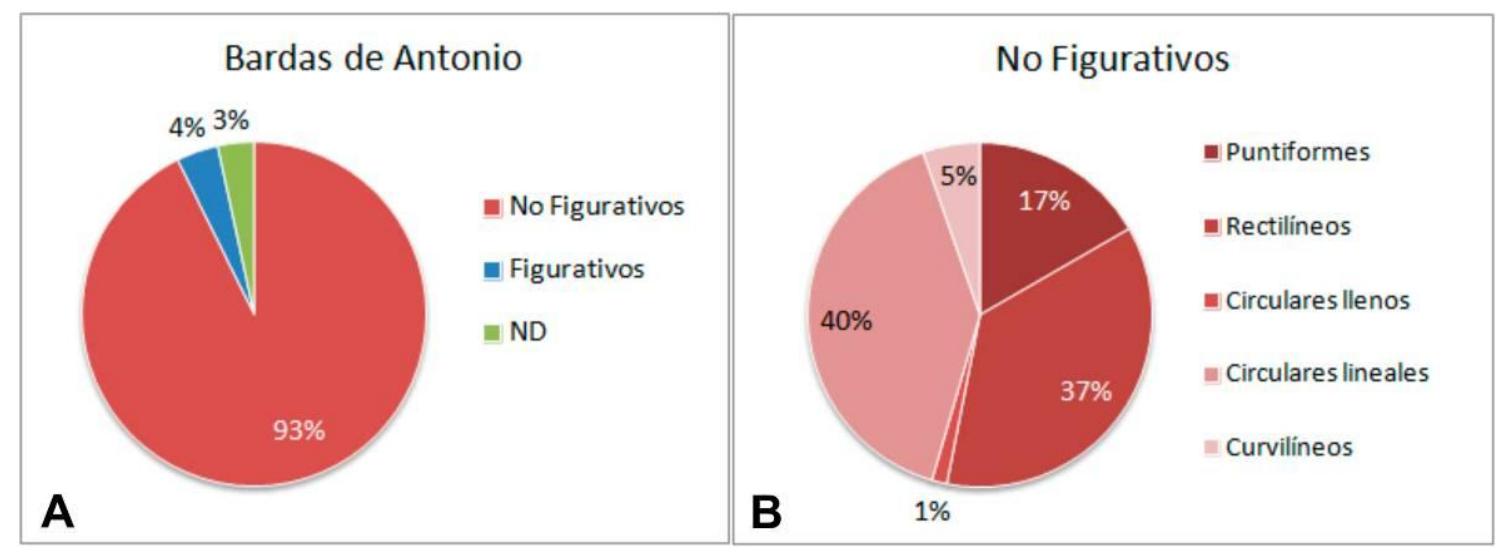

Figura 7.39. Proporciones de grupos y subgrupos de motivos en Bardas de Antonio.

\begin{tabular}{|l|c|c|c|c|c|c|c|}
\cline { 2 - 7 } \multicolumn{1}{c|}{} & \multicolumn{7}{c|}{ Sector } \\
\hline Motivos & 1 & 2 & 3 & 4 & 5 & 6 & Total \\
\hline Puntiformes & 6 & - & 1 & 1 & - & 51 & 59 \\
\hline Rectilíneos & 16 & 1 & 9 & 1 & - & 102 & 129 \\
\hline Circulares llenos & 1 & - & - & - & - & 4 & 5 \\
\hline Circulares lineales & 33 & - & - & 1 & 1 & 107 & 142 \\
\hline Curvilíneos & 1 & - & 1 & - & - & 17 & 19 \\
\hline No Figurativos & 57 & 1 & 11 & 3 & 1 & 208 & 354 \\
\hline Pisada ave & - & - & - & - & - & 10 & 10 \\
\hline Pisada felino & - & - & - & - & - & 5 & - \\
\hline Figurativos & - & - & - & - & - & 15 & 15 \\
\hline No determinados & - & 1 & 1 & - & - & 12 & 14 \\
\hline \multicolumn{1}{|r}{ Total } & 57 & 2 & 12 & 3 & 1 & 308 & 383 \\
\hline
\end{tabular}

Tabla 7.7. Frecuencias de grupos y subgrupos de motivos en Bardas de Antonio. 


\section{7. d. 2. 1. Sector 1}

Se encuentra sobre la margen NE del cañadón tributario (Figura 7.40). En líneas generales, se emplearon superficies verticales de la barda basáltica, de color castaño rojizo, aunque se observan motivos y conjuntos sobre bloques desprendidos de la misma. La mayor parte de los motivos está orientada al W (o al WNW), a excepción de los conjuntos 1, 14 y 15. Los motivos se encuentran a alturas variables respecto del suelo: que oscilan entre el ras del suelo y $2 \mathrm{~m}$. Algunos conjuntos se encuentran fuertemente afectados por la acción de líquenes.

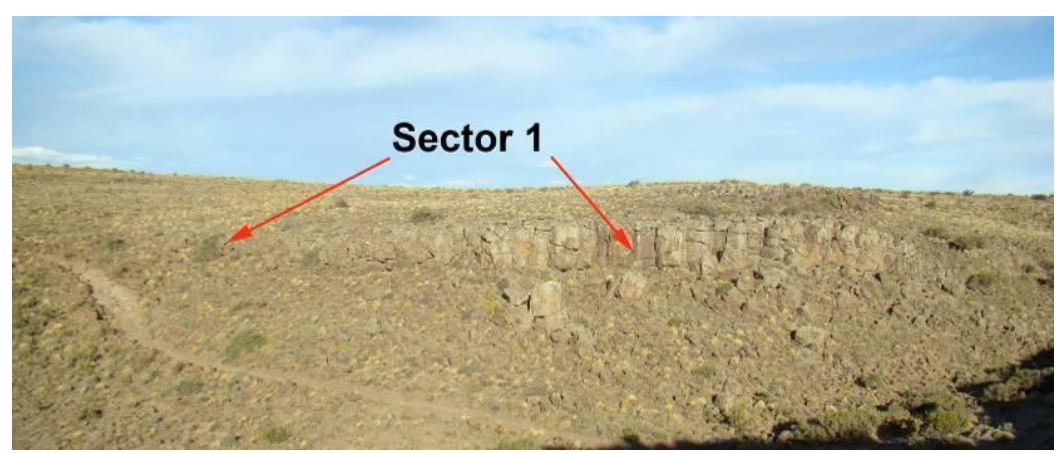

Figura 7.40. Vista del Sector 1 desde el sector 6.

Conjunto 1. Se encuentra en un bloque desprendido de la barda, sobre una superficie orientada al SE, a alturas respecto del suelo que oscilan entre 0,30 y 0,56 m. Está integrado por dos motivos: una línea vertical de puntos y una espiral (Figura 7.41.a).

Conjunto 2. Se registró sobre la barda basáltica, en dos superficies distintas y a alturas que oscilan entre 0,95 y 0,77 m. Está conformado por una serie de líneas paralelas (Figura 7.41.b), un motivo "en forma de U" invertida (Figura 7.41.c); una circunferencia con puntos en su interior, un óvalo, y un trapezoide con dos líneas paralelas horizontales en su interior (Figura 7.41.d). Estos motivos se encuentran en mal estado de conservación, principalmente debido a la acción de líquenes aunque también se observan exfoliaciones y desprendimientos del soporte. 

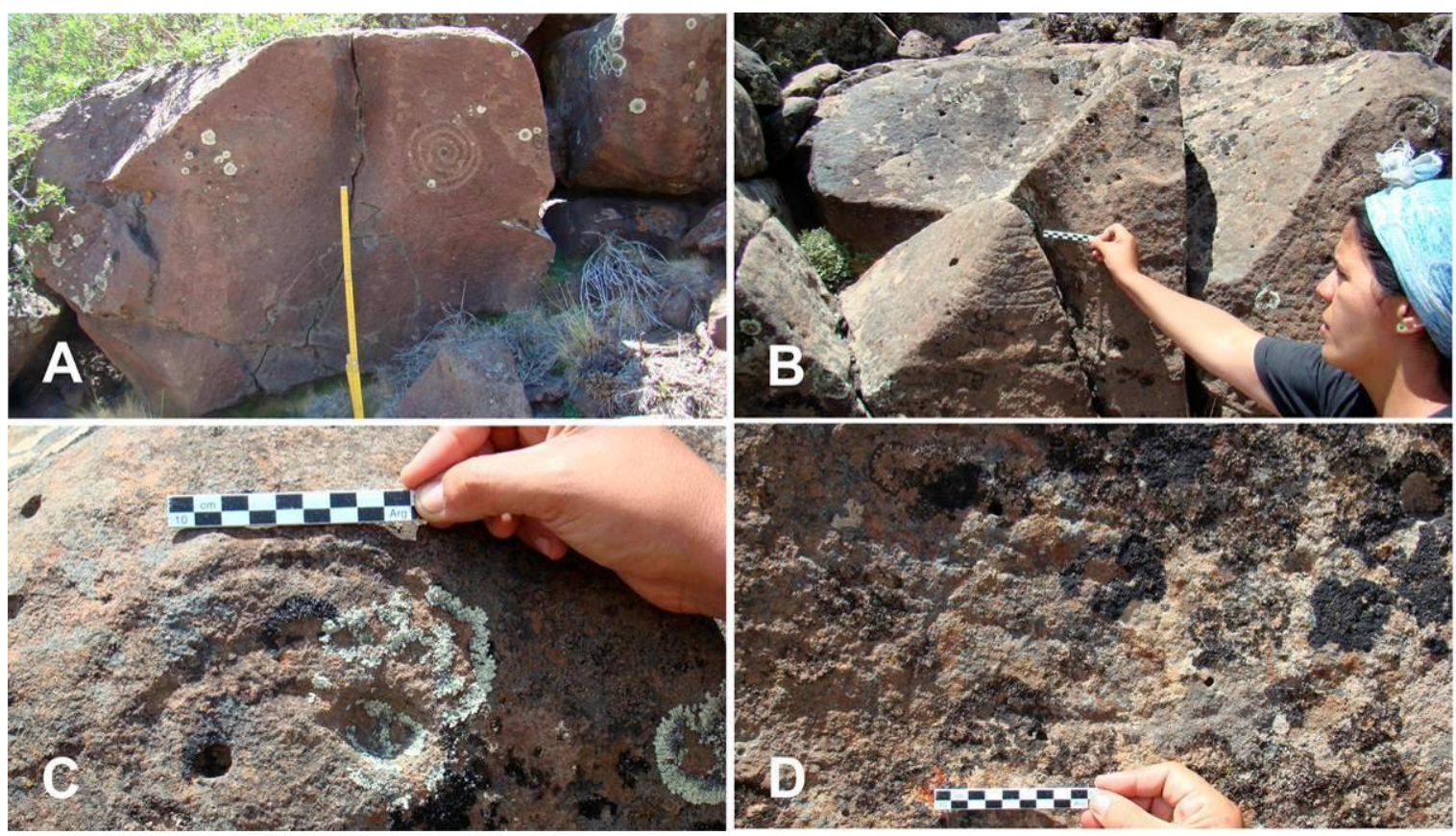

Figura 7.41. Conjuntos 1 y 2: a. Conjunto 1 ; b, c y d. Conjunto 2

Motivo 3. Se encuentra a $0,77 \mathrm{~m}$ del suelo actual, sobre una superficie oblicua de la barda. Se trata de un conjunto de puntos afectado por la acción de líquenes.

Conjunto 4. Se ubica sobre una superficie oblicua vertical de un bloque desprendido de la barda, a 0,67 m del suelo. Está integrado por ocho motivos: un conjunto de puntos, cinco circunferencias simples, una circunferencia alrededor de un punto central y una circunferencia con dos puntos interiores (Figura 7.42.a).

Motivo 5. Se encuentra en una superficie vertical de coloración rojiza, a 0,38 $\mathrm{m}$ del suelo. Para la realización de este motivo peiniforme se empleó el marco natural del soporte delimitado por grietas (Figura 7.42.b).

Conjunto 6. Sobre una superficie vertical de la barda, a diferentes alturas respecto del suelo (entre 0,54 y $1,57 \mathrm{~m}$ ), se registraron dos circunferencias concéntricas separadas entre sí por grietas naturales del soporte.

Motivo 7. Fue registrado a $0,16 \mathrm{~m}$ del suelo, sobre una superficie vertical. Se trata de una serie de líneas paralelas que presentan intercaladas tres líneas de puntos verticales. El motivo se encuentra cubierto por líquenes, salvo en su sector medio (Figura 7.42.c). 
Motivo 8. A 0,56 m del suelo, en una superficie vertical, se registró una línea recta vertical atravesada por cinco líneas rectas transversales (Figura 7.42.d). De éstas últimas, las líneas inferiores presentan líquenes.

Conjunto 9. Se encuentra sobre la barda, en una superficie vertical que presenta distintas grietas y fallas. Está integrado por tres circunferencias concéntricas y un conjunto de líneas verticales paralelas. Las últimas se encuentran a 0,92 $\mathrm{m}$ del suelo actual (Figura 7.42.e). Las circunferencias concéntricas se encuentran separadas por grietas y fallas naturales del soporte, y son apenas visibles ya que se encuentran cubiertas - parcial o totalmente- por líquenes (Figura 6.42.e).

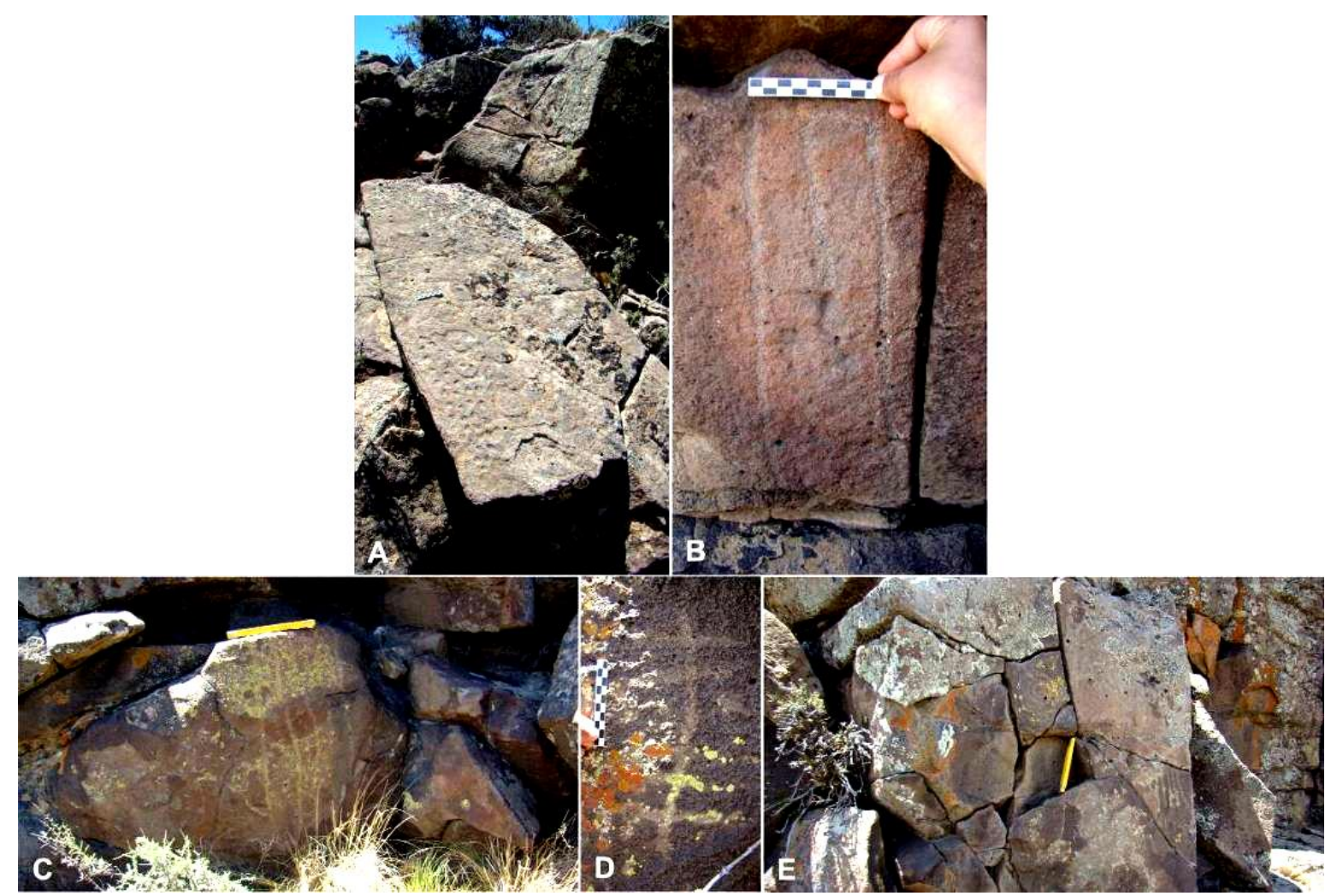

Figura 7.42. Conjuntos 4 a 9: a. Conjunto 4; b. Motivo 5; c. Motivo 7; d. Motivo 8; e. Conjunto 9.

Conjunto 10. A $0,90 \mathrm{~m}$ del suelo actual, sobre una superficie vertical de la barda se registraron dos motivos: un círculo con apéndices radiados y una circunferencia concéntrica.

Conjunto 11. Se encuentra a $0,98 \mathrm{~m}$ del suelo, sobre una superficie vertical orientada al SW. Este conjunto está conformado por un motivo circular no determinado y un conjunto de puntos en la porción inferior del 
panel. El primer motivo es apenas visible ya que su surco es poco profundo y está cubierto de líquenes. Podría tratarse de circunferencias concéntricas o una espiral.

Motivos 12 y 13. Sobre una superficie vertical de la barda, orientada al SW y a alturas que oscilan entre 1,30 y $1,10 \mathrm{~m}$ del suelo, se observó un conjunto de puntos y tres líneas de puntos paralelas verticales, respectivamente.

Conjunto 14. Este conjunto es el que Don Antonio nos indicó como la "Piedra de las Escarapelas", y por el cual accedimos al sitio. Sobre la superficie vertical de un bloque separado de la barda, a alturas que oscilan entre 1,20 y $2,15 \mathrm{~m}$ respecto del suelo se registraron los seis motivos que lo integran (Figura 7.43). Se trata de una serie de líneas paralelas -verticales y oblicuas-, cuatro circunferencias concéntricas y un espiral con apéndices rectos; este último ubicado en la porción central del bloque. En las circunferencias concéntricas del sector inferior derecho del bloque apenas pueden distinguirse los surcos grabados debido a la acción de los líquenes (Figura 7.43).

Conjunto 15. Se encuentra sobre la superficie vertical de un bloque separado de la barda, a alturas que oscilan entre 0,60 y $1,50 \mathrm{~m}$ respecto del suelo actual (Figura 7.44.a). Está compuesto por cinco motivos: dos circunferencias concéntricas (Figura 7.44.b), líneas paralelas horizontales (Figura 7.44.c), una circunferencia con apéndice curvo y un peiniforme (Figura 7.44.d). Algunos de estos motivos se encuentran exfoliados y afectados por la acción de líquenes. 


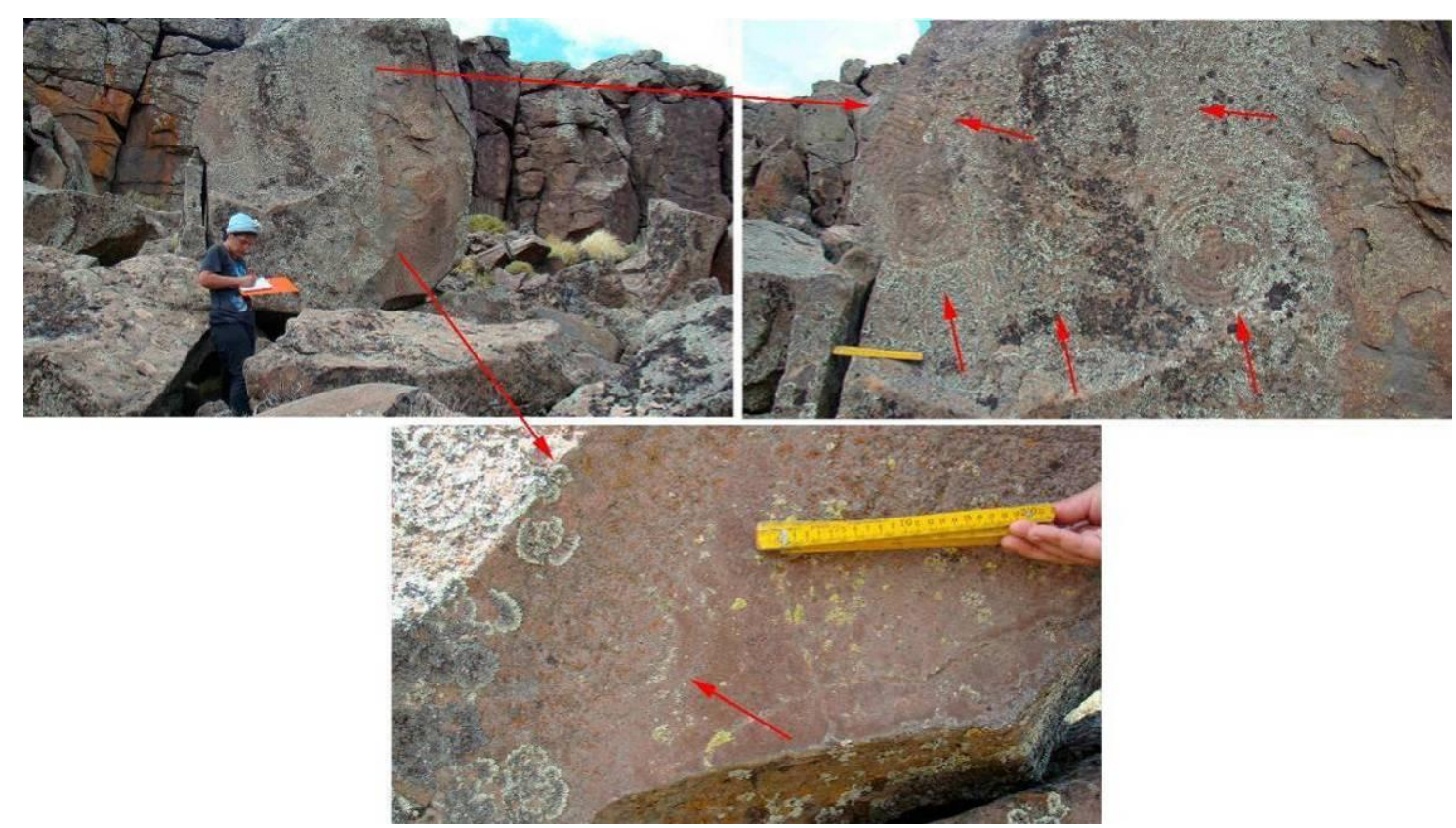

Figura 7.43. Conjunto 14. Las flechas rojas indican los motivos descriptos en texto.

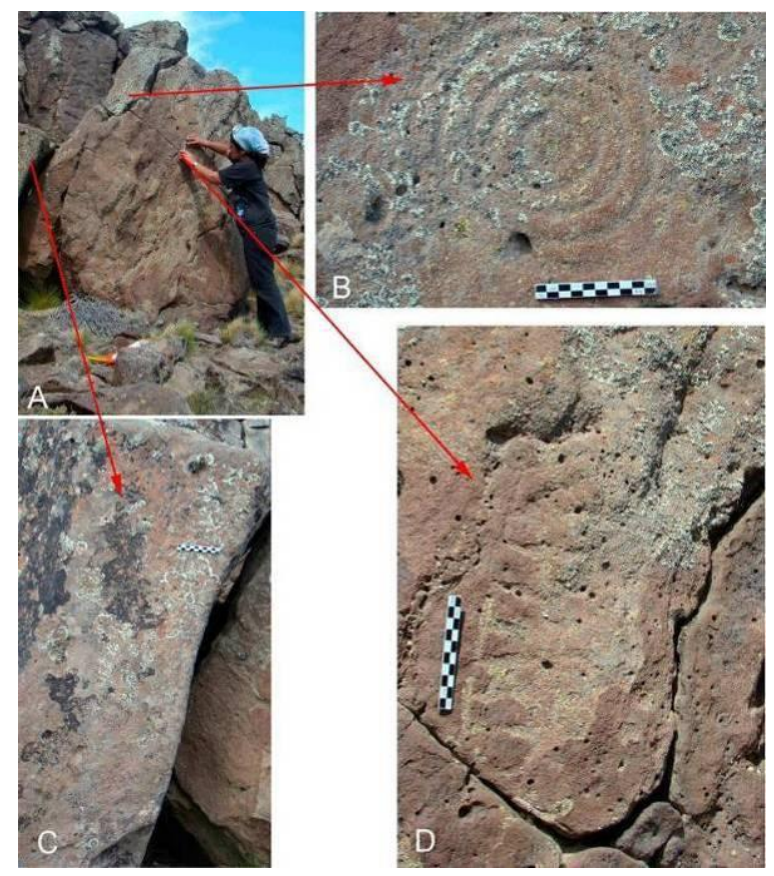

Figura 7.44. Conjunto 15.

Conjunto 16. Se registró en bloques orientados al oeste, alejados de la barda y separados entre sí por $1 \mathrm{~m}$. Este conjunto está integrado por dos motivos: circunferencias concéntricas ubicadas a 1,03 m del suelo, en una superficie muy alterada por presencia de líquenes, y una serie de líneas 
paralelas que se encuentran a 0,32 $\mathrm{m}$ del suelo sobre otro bloque, algunas de las cuales están parcialmente cubiertas por líquenes.

Conjunto 17. Se encuentra a $1 \mathrm{~m}$ del suelo actual, sobre una superficie oblicua. Está integrado por 13 motivos: cinco circunferencias concéntricas, tres de ellas con apéndices (en un caso son radiados); dos circunferencias simples, una circunferencia adosada a una línea vertical, cuatro líneas verticales simples y un conjunto de líneas entrecruzadas (Figura 7.45).
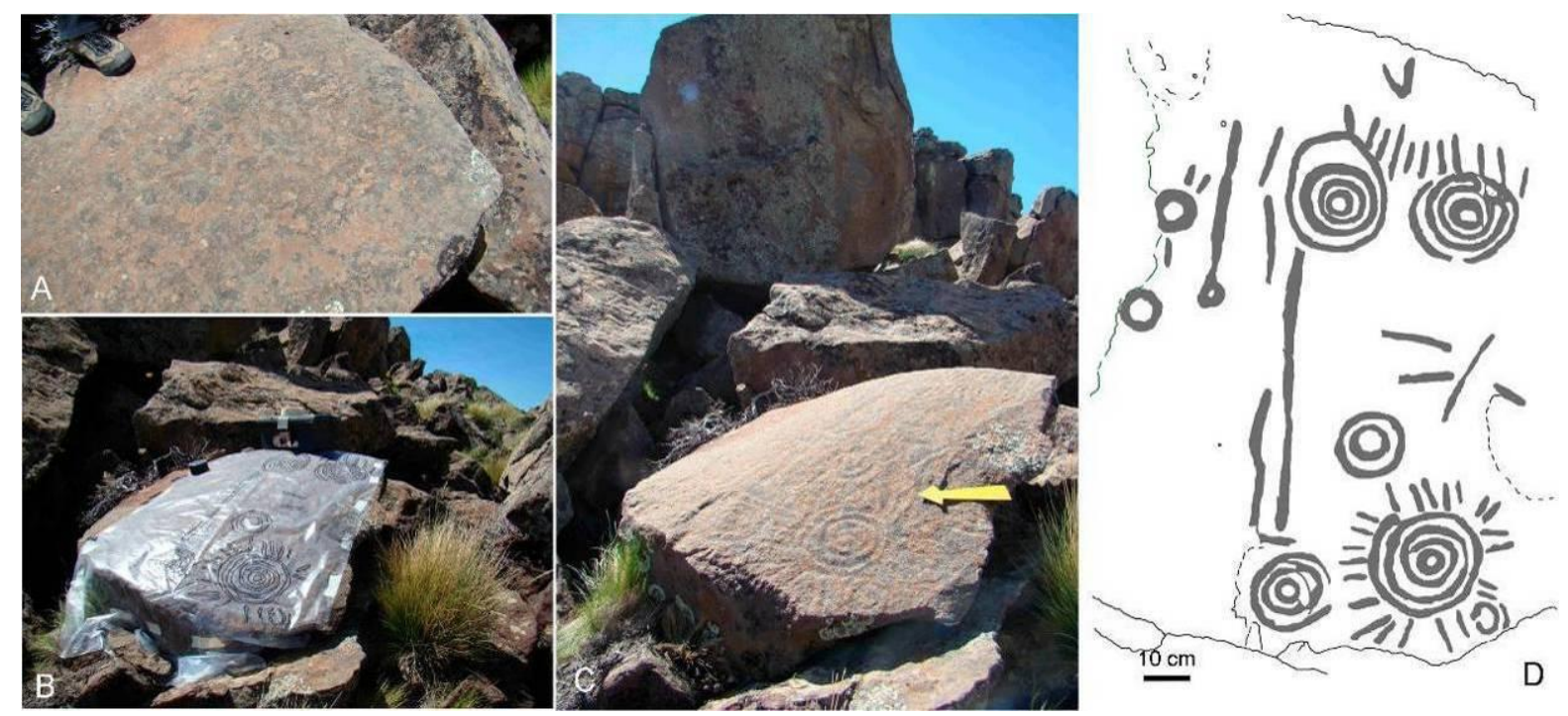

Figura 7.45. Conjunto 17: a. Vista del bloque en 2008; b. Realización del calco; c. Vista del conjunto en 2009; d. Calco.

7. d. 2. 2. Sector 2

Sobre la margen sur del cañadón se registró un panel con pinturas de color rojo muy desvaído, a unos $0,13 \mathrm{~m}$ del suelo. Se trata del único conjunto que compone este sector.

Conjunto 18. Está integrado por una greca hacia la izquierda y motivo pintado no determinado hacia la derecha (Figura 7.46.a). Se podría pensar que el mal estado de conservación de estos motivos se corresponde con la incidencia directa de factores atmosféricos (agua, sol y nieve). 
Se corresponde a un alero, orientado al este, de $8 \mathrm{~m}$ de boca con una profundidad variable (entre 0,55 y 1,80 m), cuya altura interior es inferior a 1,25 m. En las paredes de este alero se registraron motivos grabados y pintados. En este sector se relevaron los conjuntos 19 a 23.

Conjunto 19. Sobre una superficie vertical, a $0,58 \mathrm{~m}$ respecto del suelo, se encuentran cuatro motivos grabados: una línea recta, dos líneas curvas superpuestas en la porción media, un conjunto de puntos y un par de líneas paralelas verticales. Los surcos grabados contrastan con la coloración del soporte.

Conjunto 20. Se encuentra a $0,66 \mathrm{~m}$ respecto del suelo actual, sobre una superficie vertical. Está integrado por tres motivos pintados: un cruciforme de color rojo y dos grecas (Figura 7.46.b).

Los motivos 21 y 22 corresponden a grecas en color rojo, que se encuentran a alturas inferiores a 4,40 m respecto del suelo actual (Figura 7.46.c).

Conjunto 23. Se encuentra sobre una angulosidad del soporte, a 0,35 m del suelo. Se trata de dos grecas separadas por una grieta horizontal. No se observó contigüidad entre ambos motivos (Figura 7.46.d). 

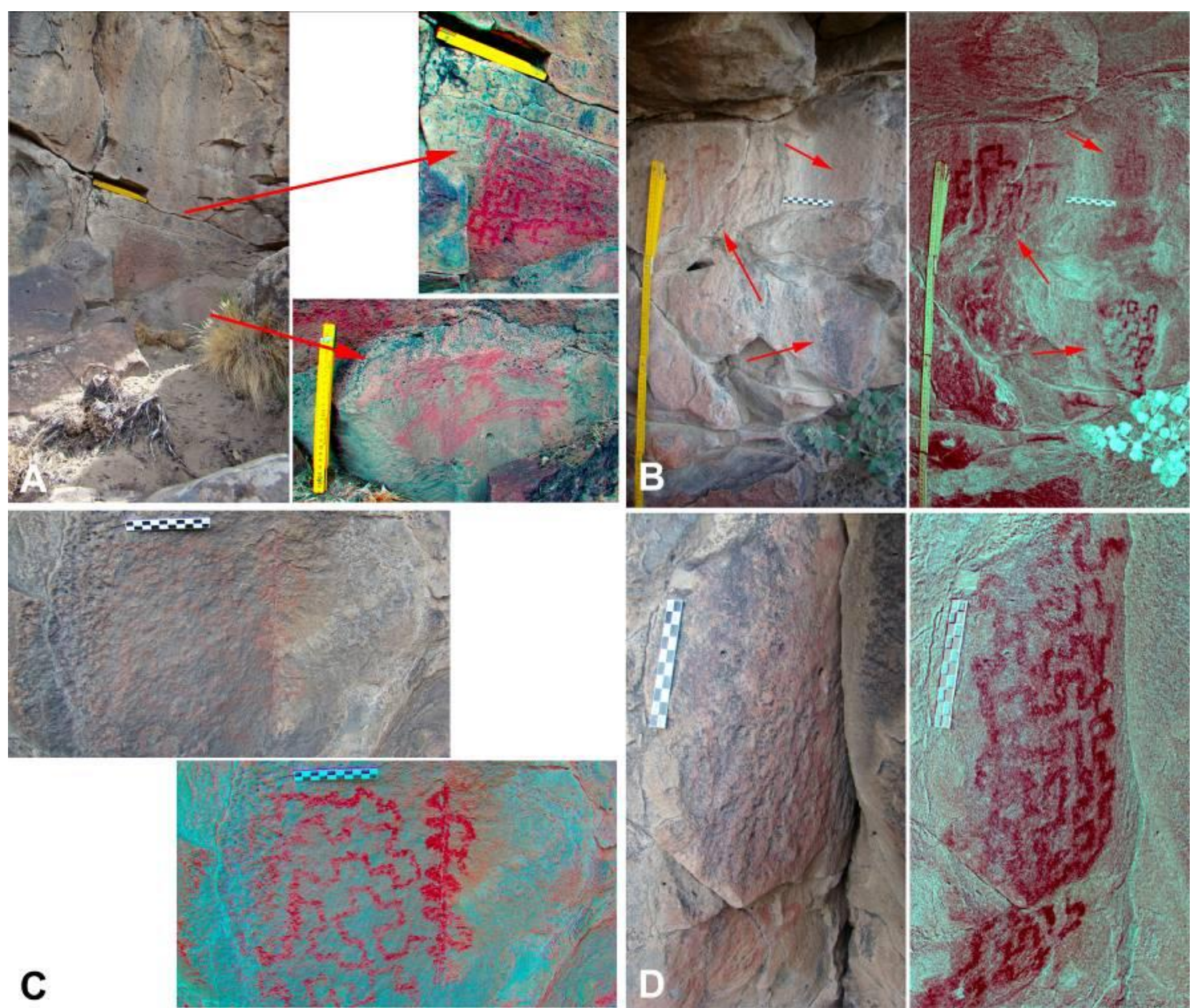

C

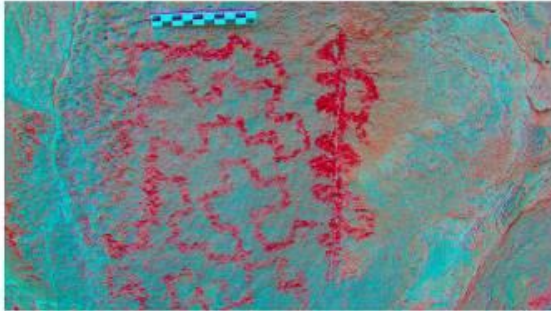

Figura 7.46. Motivos pintados de los sectores 2 y 3: a. Motivos del Conjunto 18 (Tratamiento digital $D$-Stretch lds 15); b. Conjunto 20 (Tratamiento digital $D$ Stretch yre 15); c. Motivo 22 (Tratamiento digital D-Stretch lre 15); d. Conjunto 23 (Tratamiento digital $D$-Stretch lre 15).

7. d. 2. 4. Sector 4

Sobre el borde de la cornisa basáltica, a 0,34 $\mathrm{m}$ del suelo, en una superficie vertical de color marrón rojiza orientada al este se registró el único conjunto de este sector.

Conjunto 24. Se trata de una línea curva, una circunferencia y un par de puntos (Figura 7.47.a). El sector izquierdo del panel presenta restos de líquenes. 


\section{7. d. 2. 5. Sector 5}

Este sector se encuentra cerca del cauce temporal que corta el cañadón. Está constituido por un motivo realizado sobre la superficie oblicua de un bloque desprendido de la barda, que orienta al SW.

Motivo 25. Se encuentra al ras del suelo, y está conformado por un conjunto de siete circunferencias simples, las cuales se encontraban parcialmente cubiertas por sedimentos (Figura 7.47. b).
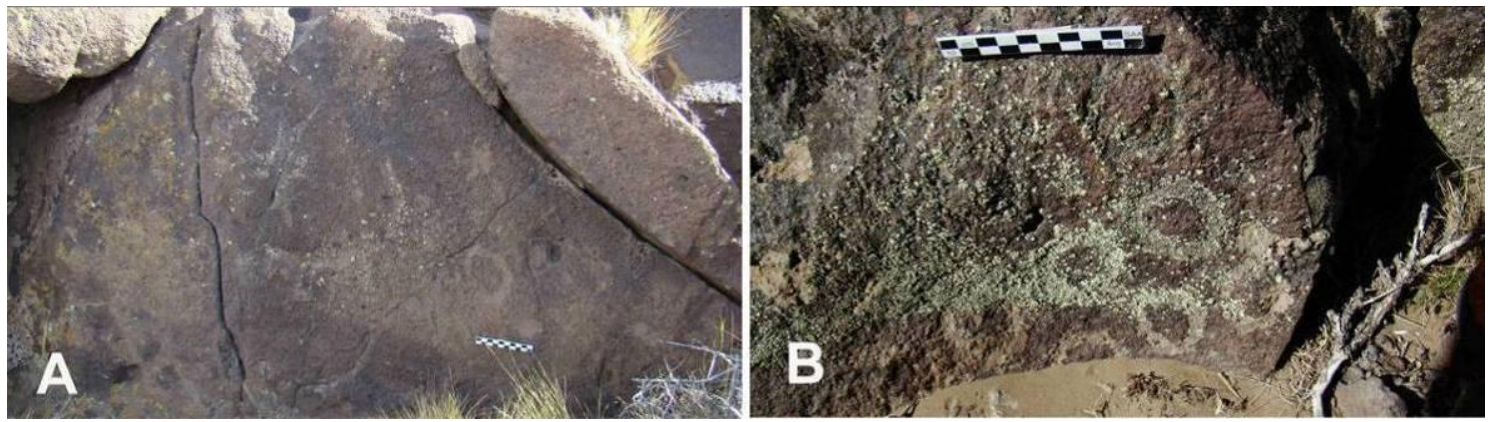

Figura 7.47. Motivos grabados de los sectores 4 y 5: a. Conjunto 24; b. Motivo 25.

\section{7. d. 2. 6. Sector 6}

Se encuentra en una porción de la barda meridional del cañadón en la que, a lo largo de $60 \mathrm{~m}$, se registraron distintos motivos y conjuntos pintados, grabados y pictograbados (Figura 7.48). Se efectuó un primer relevamiento de este sector en noviembre de 2008, en tanto que en la campaña de noviembre de 2009 fue relevado completamente.

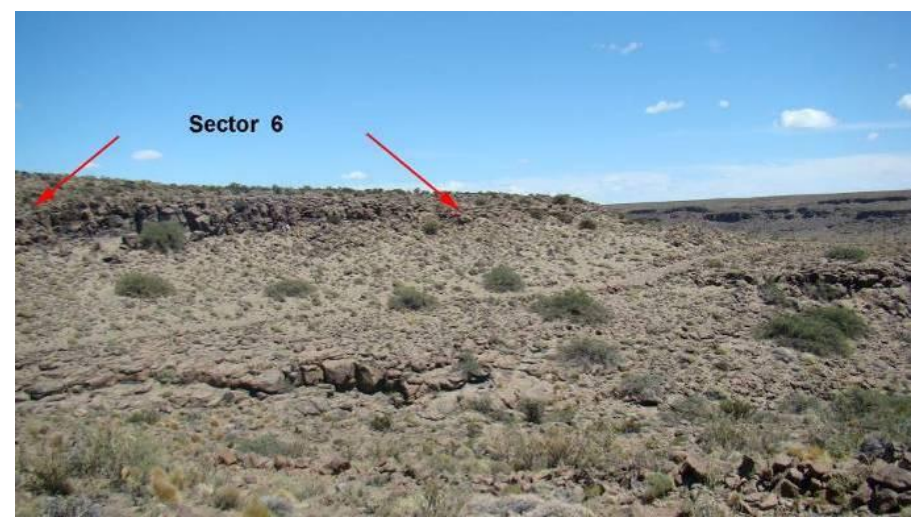

7.48. Vista del Sector 6 desde Conjunto 14.

Se registraron motivos sobre la barda, en bloques desprendidos y/o alejados de la misma, mayoritariamente sobre superficies verticales, de 
distinta coloración y a alturas variables respecto del suelo actual. La orientación de dichas superficies es, generalmente, hacia el NE. El estado de conservación de las manifestaciones es variable, vinculado principalmente a la acción de líquenes, del agua o bien al grado de exfoliación de la superficie en la que se encuentran. En el caso de las pinturas, la conservación también se vio afectada por la incidencia directa del sol.

Los Motivos 26 a 28 se encuentran sobre diferentes superficies verticales de la barda, a alturas que oscilan entre 0,52 y 1,70 m respecto del suelo. Se trata de una circunferencia simple (Motivo 26) y circunferencias concéntricas alrededor de un hoyuelo natural (Motivos 27 y 28). Estas últimas se encuentran exfoliadas (Figura 7.49).
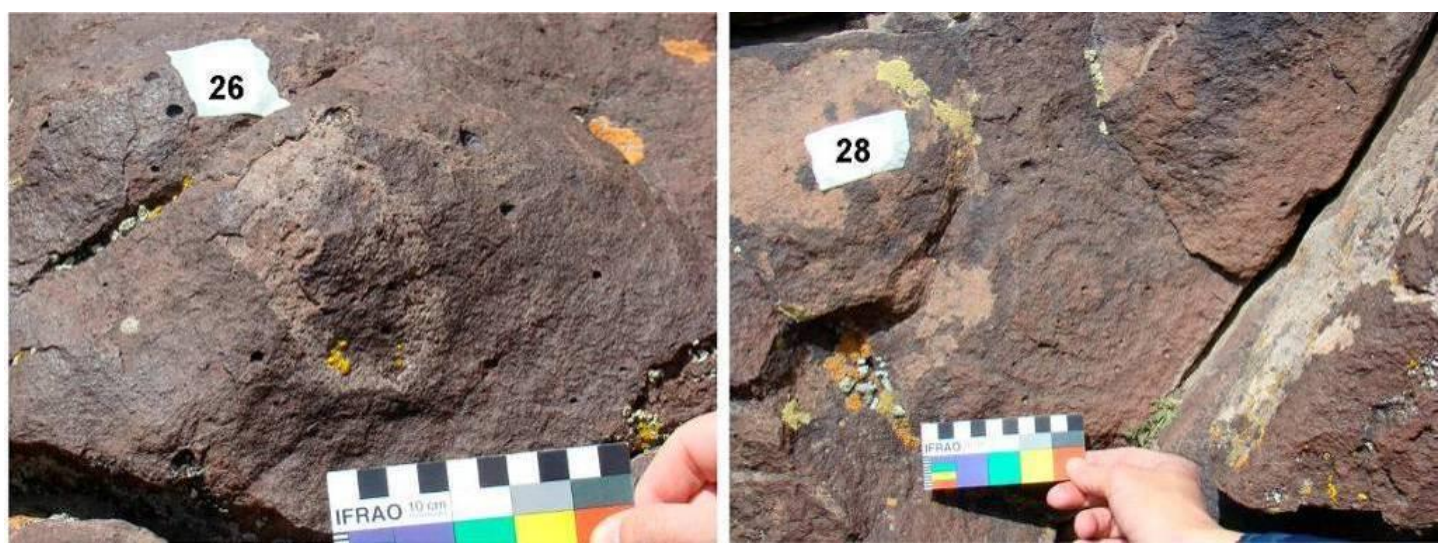

Figura 7.49. Motivos 26 y 28: a. Motivo 26; b. Motivo 28.

Motivos 29 y 30. Se encuentran sobre la cornisa basáltica, a más de 2,70 $\mathrm{m}$ del suelo, sobre una superficie vertical. Se trata de series de líneas paralelas (verticales y horizontales respectivamente) asociadas a un conjunto de puntos. La superficie está afectada por la acción de líquenes (Figura 7.50.a).

Conjunto 31. Se encuentra sobre el borde de la cornisa basáltica, a $3 \mathrm{~m}$ del suelo. Está integrado por un conjunto de puntos, una línea vertical simple; una serie de líneas rectas paralelas verticales y un óvalo (Figura 7.50.b). Las líneas paralelas verticales se encuentran parcialmente cubiertas por líquenes. 

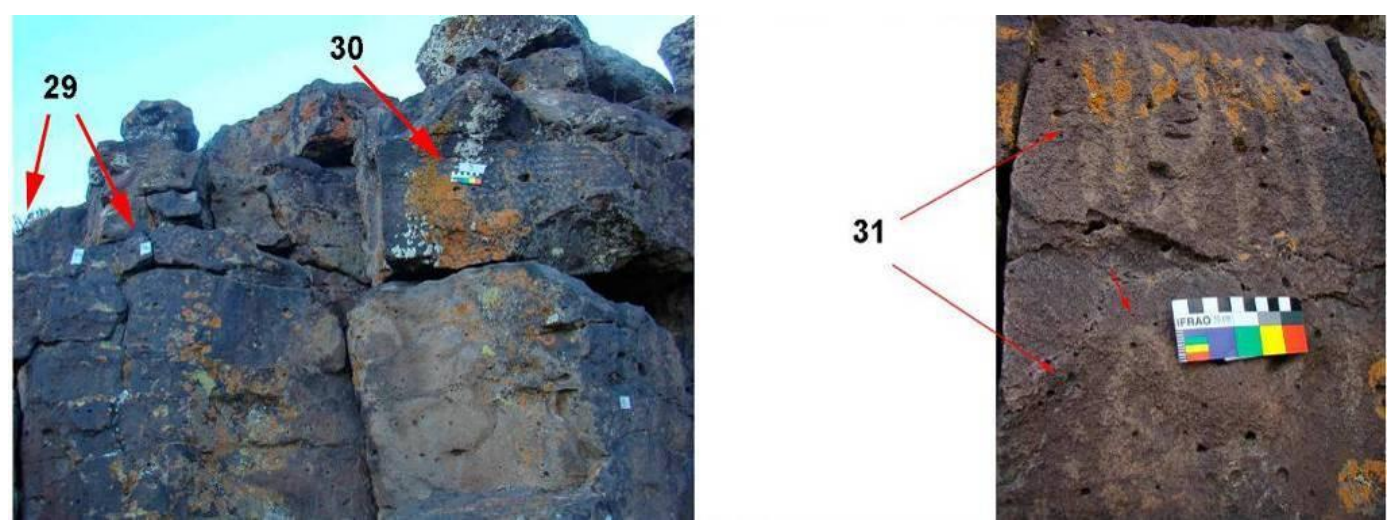

Figura 7.50. Conjuntos 29 a 31: a. Conjunto 29 y Motivo 30; b. Conjunto 31.

Motivos 32 y 34 y el Conjunto 33 se encuentran sobre superficies verticales orientadas al $\mathrm{N}$, a alturas que oscilan entre 1,20 y $1,95 \mathrm{~m}$ respecto del suelo. Se trata de una circunferencia simple (Motivo 32) y un conjunto de puntos (Motivo 34). El Conjunto 33 está integrado por puntiformes (una línea de puntos, dos conjuntos de puntos) y una circunferencia. Uno de los conjunto de puntos se observa actualmente cubierto por una colonia de líquenes.

Motivo 34. Conjunto de puntos sobre una superficie vertical orientada al $\mathrm{N}$, a 1,95 m del suelo. Dicha superficie está afectada por la acción de líquenes.

Conjuntos 35 y 36. Se documentaron sobre diferentes superficies, a 0,95 $\mathrm{m}$ del suelo actual. El primer conjunto se encuentra sobre una superficie levemente cóncava y vertical, está integrado por una serie de líneas paralelas verticales, dos circunferencias simples y una roseta. Mientras que el segundo conjunto corresponde con dos circunferencias. Los motivos circulares lineales se encuentran en mal estado de conservación.

Motivo 37. Circunferencia simple sobre una superficie levemente oblicua y orientada al E, a 0,90 m del suelo.

Conjuntos 38 y 39. Se encuentran sobre superficies verticales de la barda, entre 1,20-1,35 m respecto del suelo. Corresponden a dos conjuntos de puntos separados por una fractura natural del basalto (Conjunto 38) y a un par líneas paralelas verticales atravesadas por líneas horizontales y una circunferencia (Conjunto 39). Dos grietas naturales del soporte atraviesan 
las líneas paralelas, lo que tiene que haber influido en su estado de conservación malo.

Motivo 40. Dos líneas de puntos paralelas horizontales a 1,06 m del suelo, por debajo del conjunto anterior.

Conjunto 41. Dos series de líneas rectas (con diferente orientación) sobre una superficie vertical orientada al E, a 1,50 m del suelo.

Motivo 42 y 43. Se encuentran sobre una superficie vertical orientada al $\mathrm{E}$, a alturas respecto del suelo que varían entre 0,65 y 0,30 respecto del suelo. Se trata de un conjunto de puntos (Motivo 42) y una serie de líneas verticales que, luego de una fractura natural del soporte, son continuadas por líneas verticales de puntos y una línea simple (Motivo 43) (Figura 7.51.b).

Conjunto 44. Se encuentra sobre una superficie vertical orientada al E, los 10 motivos que lo integran se encuentran entre 1,50 y $2,05 \mathrm{~m}$ respecto del suelo. Se trata de líneas curvas, circunferencias, líneas y conjuntos de puntos (Figura 7.51.c)

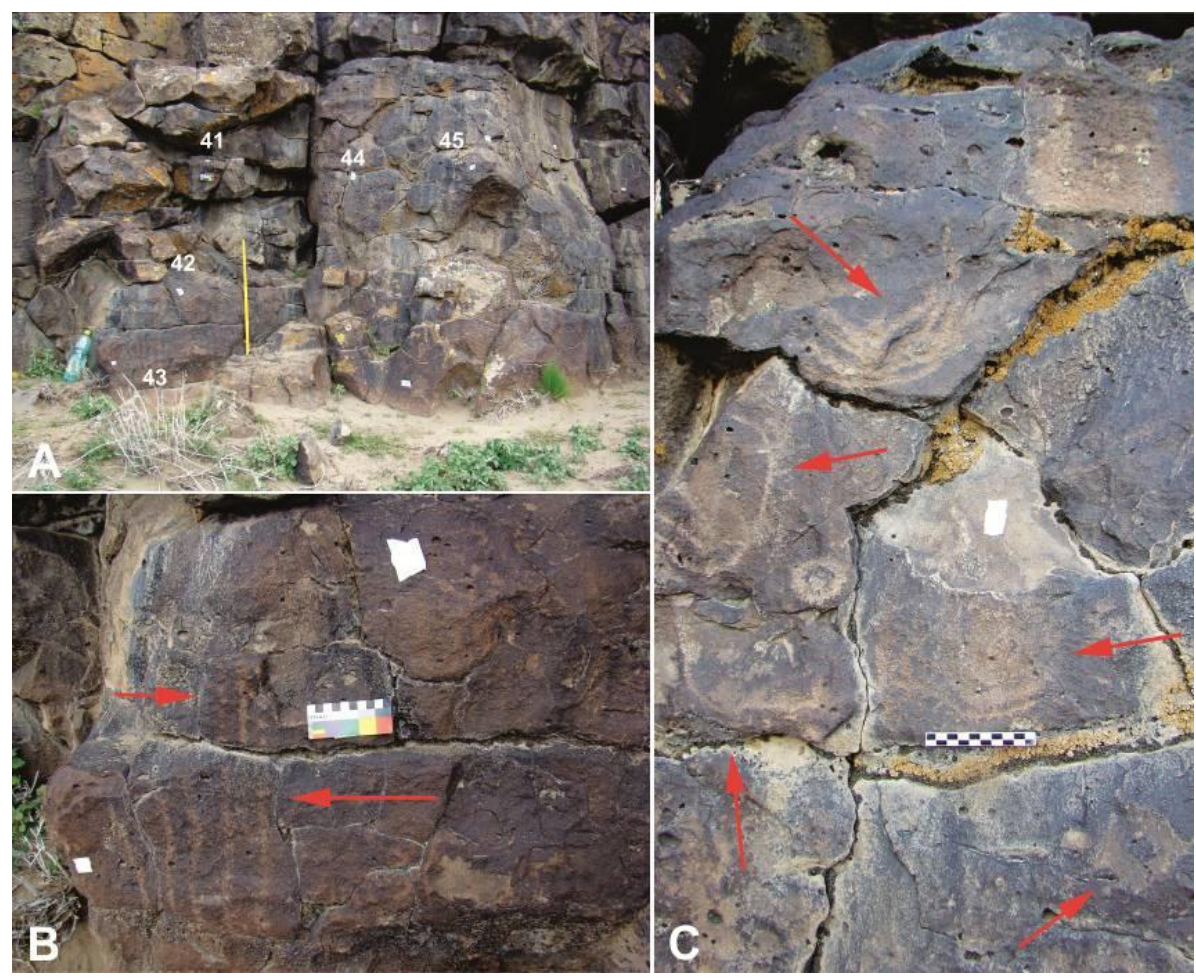

Figura 7.51. Conjunto 41 a 45: a. Ubicación sobre la barda; b. detalle de Conjuntos 42 y 43; c. Detalle subconjuntos del conjunto 44. 
Conjuntos 45 a 48. Se encuentran sobre superficies verticales de la barda orientadas al E, a alturas entre 0,87 y $2 \mathrm{~m}$ respecto del suelo. Se trata de series de líneas paralelas horizontales, conjuntos de puntos, circunferencias simples o concéntricas y circunferencias adosadas (Figura $7.52)$.

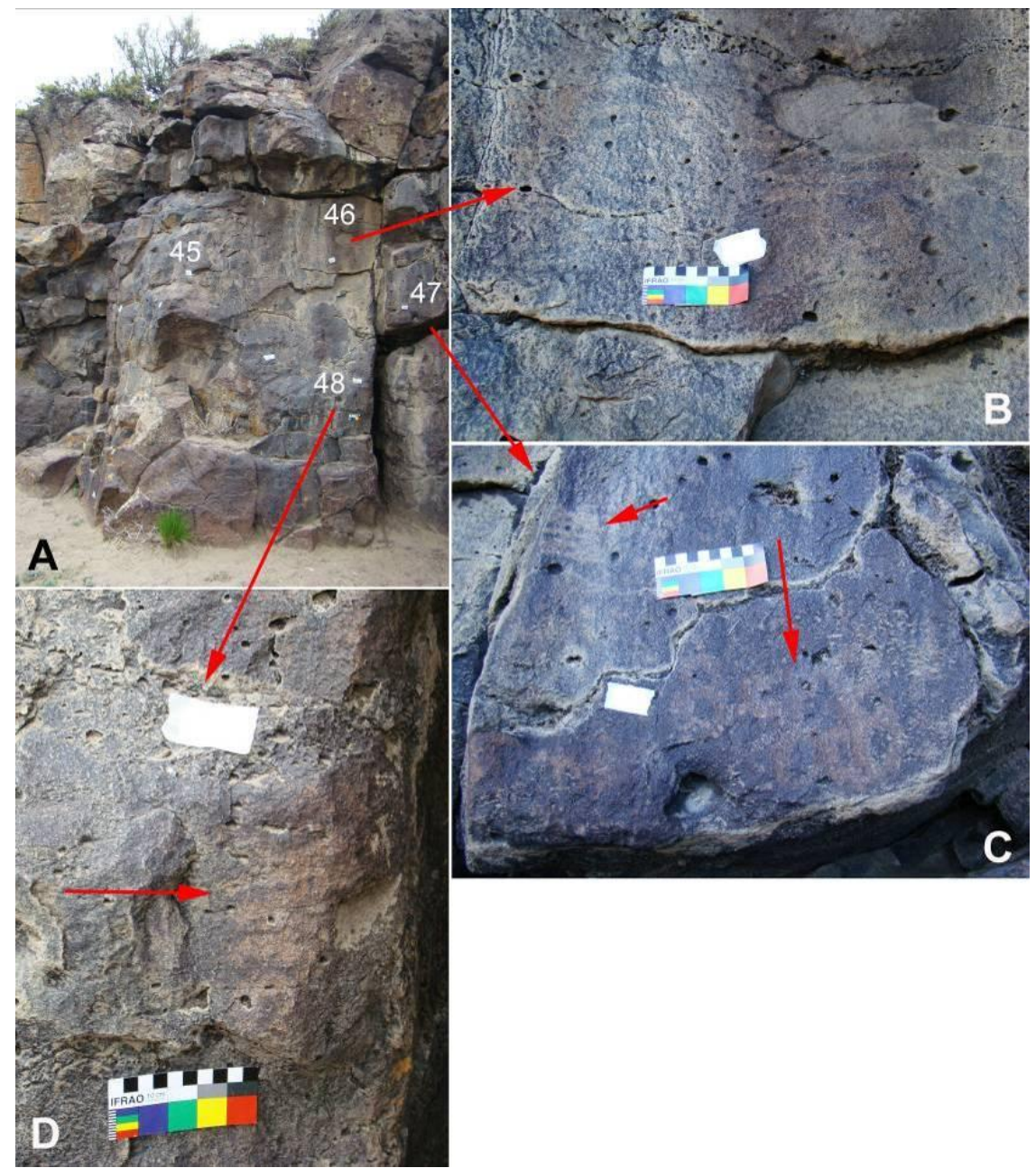

Figura 7.52. Conjuntos 45 a 48: a. Ubicación de los conjuntos sobre la barda; b. conjunot 46; c. Conjunto 47; d. Conjunto 48.

Motivo 49. Sobre una superficie vertical, a 2,30 $\mathrm{m}$ respecto del suelo, se registró una serie de líneas rectas paralelas verticales que son continuadas, luego de fractura horizontal, por líneas oblicuas paralelas.

Conjunto 50. Se encuentra a $1,33 \mathrm{~m}$ respecto del suelo actual, sobre una superficie vertical. Está integrado por tres motivos grabados: una circunferencia, una serie de líneas verticales y un círculo. Los motivos circulares se encuentran exfoliados. 
Conjunto 51. Se ubica en una superficie en posición vertical, orientada al $\mathrm{SE}$ y a 0,30 m del suelo. Se trata de motivos o restos de pintura de coloración rojiza, entre los que se puede mencionar un almenado, un motivo combinado (tres clepsidras unidas por trazos rectos), líneas simples, quebradas o en ángulo recto (Figura 7.53). La porción inferior del conjunto se encuentra exfoliada.

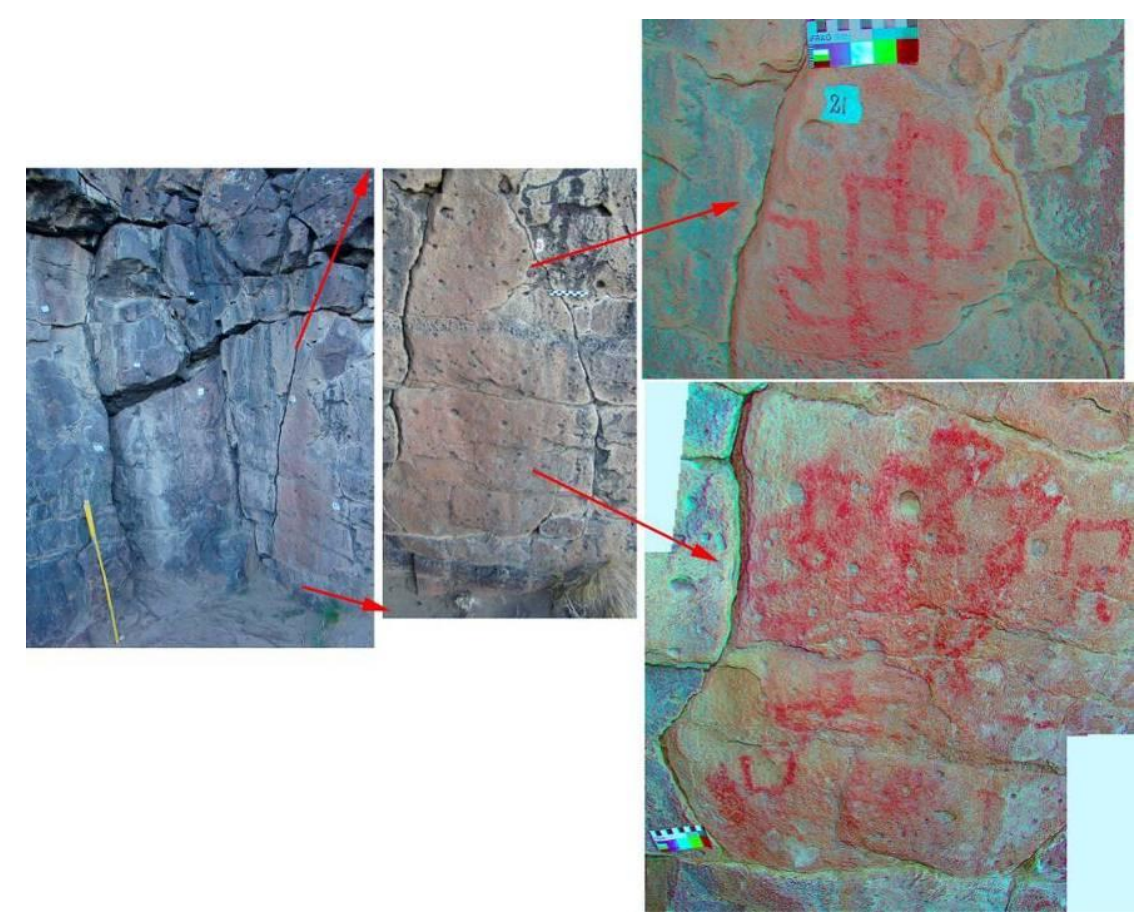

Figura 7.53. Motivo 51: Registro en campo y tratamiento digital de las imágenes (D-Stretch yrd 15).

Conjunto 52. Se encuentra sobre una superficie vertical entre 0 y $0,37 \mathrm{~m}$ respecto del suelo. Está integrado por un conjunto de puntos, circunferencias adosadas, una roseta y un tridígito. Este último presenta pátina más oscura que los anteriores por lo que puede confundirse con el soporte.

Conjunto 53. Sobre una superficie vertical, a alturas que varían entre 1,33 y 1,20 m respecto del suelo, se registraron tres motivos: un círculo y una circunferencia con apéndices radiados, y una circunferencia concéntrica alrededor de un hoyuelo natural (Figura 7.54). Estos motivos presentan pátina oscura por lo que pueden confundirse con el soporte. 


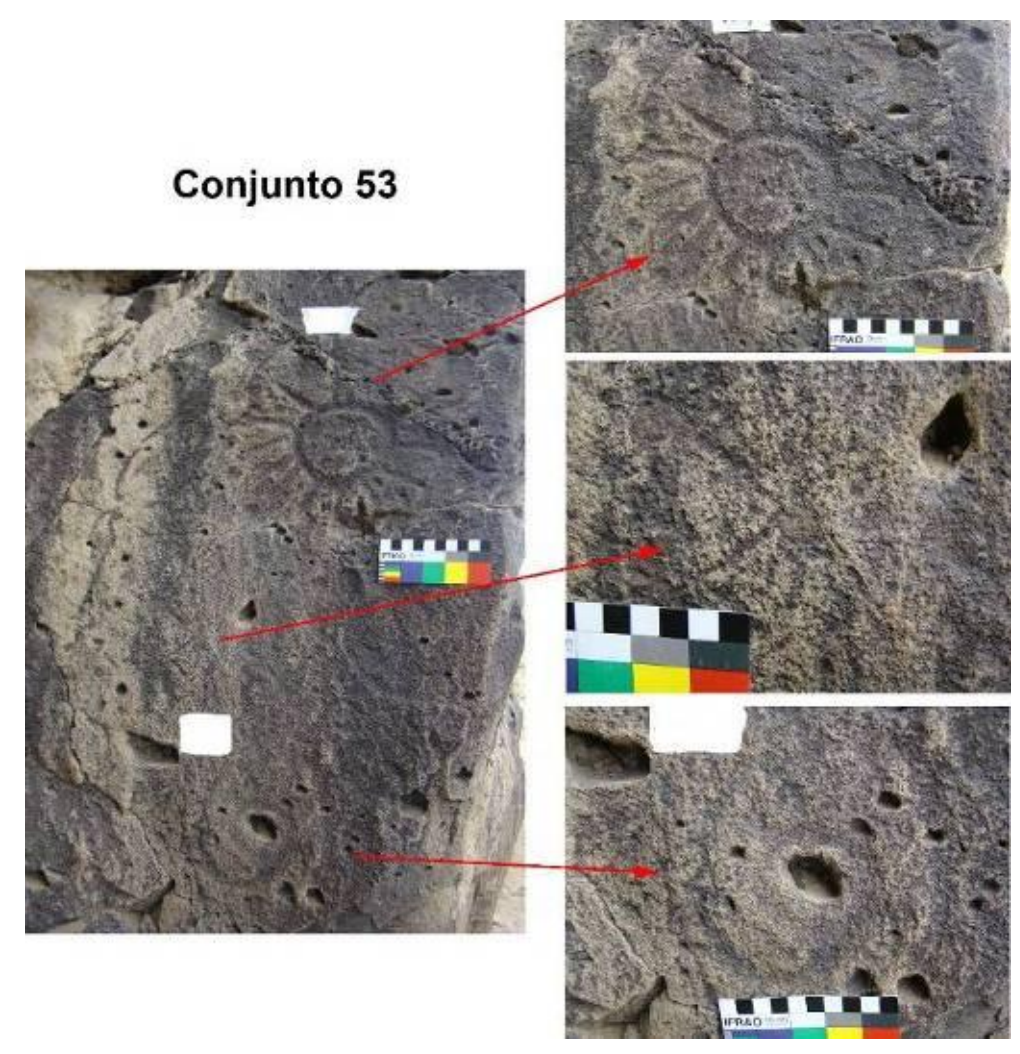

Figura 7.54. Conjunto 53.

Conjunto 54. A alturas que varían entre 0,42 y el ras del suelo, sobre dos superficies de la barda con distinta orientación, se registraron cuatro motivos. Tres de ellos grabados: dos líneas paralelas horizontales de las cuales la inferior tiene adosadas dos líneas paralelas verticales $(\bar{\eta})$, un par líneas rectas paralelas verticales y una circunferencia concéntrica alrededor de un hoyuelo natural. En tanto que el cuarto motivo se corresponde con dos líneas paralelas verticales pintadas de rojo, actualmente muy desvaídas (Figura 7.55.a).

Motivos 55 y 56. Se encuentran sobre superficies verticales orientadas al $\mathrm{NE}$, a 2,15 $\mathrm{m}$ del suelo. Se trata de un circular no determinado y líneas paralelas verticales, respectivamente. El estado de conservación del motivo circular es malo, bien podría tratarse de circunferencias concéntricas.

Conjunto 57. A alturas variables respecto del suelo actual (entre 1,65$1,05 \mathrm{~m}$ ), sobre una superficie vertical se registraron 11 motivos (Figura 7.55.b): un conjunto de puntos, tres semicircunferencias, cinco circunferencias simples (una alrededor de hoyuelos naturales) y circunferencias concéntricas. 


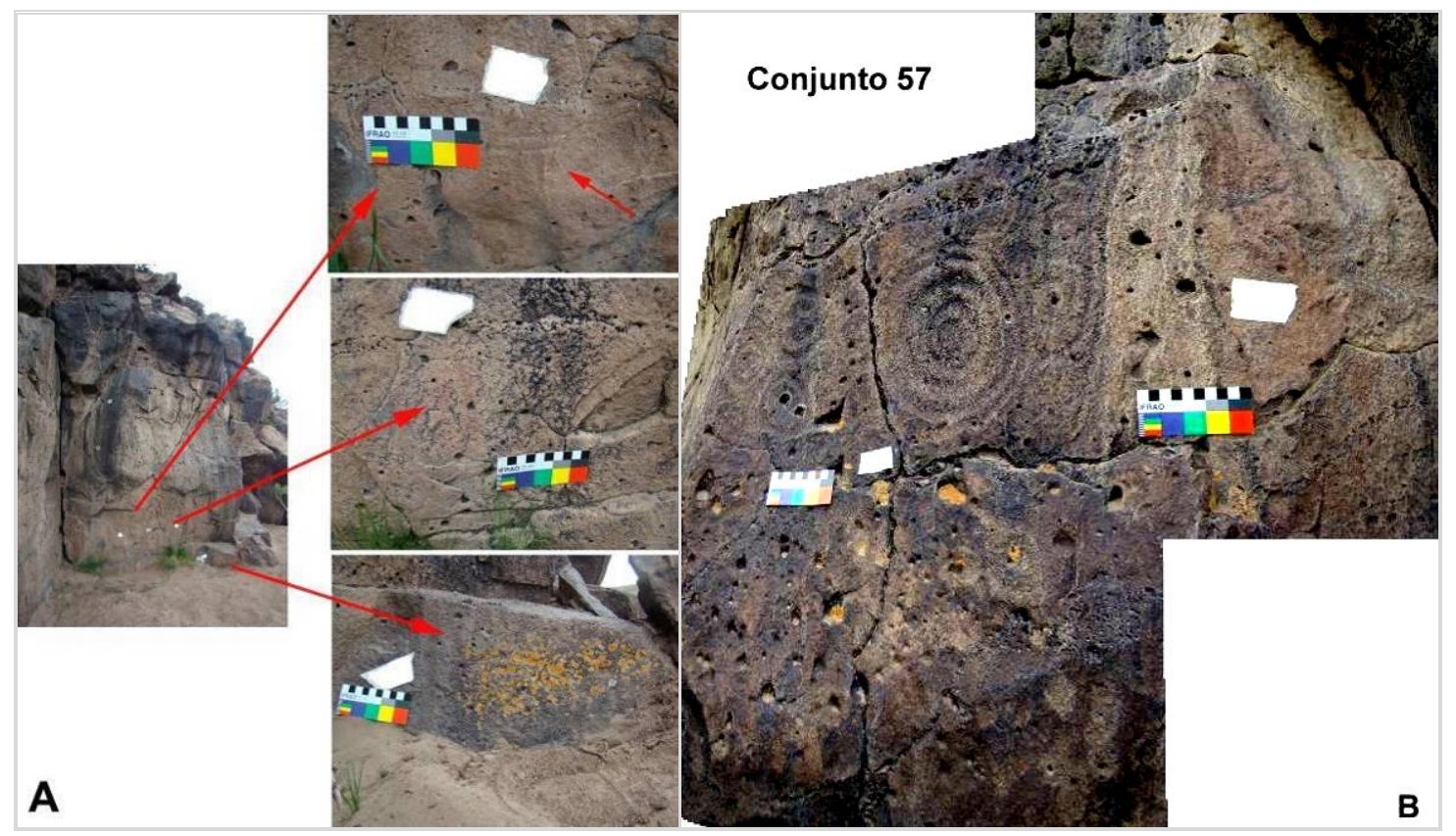

Figura 7.55. Conjuntos 54 y 57: a. Conjunto 54; b. Conjunto 57.

Motivo 58. Se encuentra a 1,65 m del suelo, sobre una superficie vertical orientada al SE. Se trata de un rombo, que se confunde con el soporte por la pátina que presenta.

Conjunto 59. Se encuentra sobre un ángulo de la roca que presenta una superficie horizontal y otra vertical, con distintas orientaciones. A alturas que oscilan entre $0,30 \mathrm{~m}$ y el ras del suelo se registraron tres motivos: una roseta ubicada sobre la superficie horizontal, y un motivo grabado no determinado y una línea recta sobre la superficie vertical.

Conjunto 60. A 1,70-1,65 m del suelo, sobre una superficie vertical muy exfoliada, con orientación al este y al NE, se registraron dos motivos: un motivo circular no determinado (este) y una circunferencia concéntrica alrededor de un hoyuelo natural (NE) (Figura 7.56). El primer motivo se encuentra sobre una superficie altamente exfoliada y parcialmente cubierto por concreciones amarillentas y líquenes, podría corresponder a circunferencias concéntricas o bien a una espiral.

Motivos 61 a 64. Corresponden a restos de pintura roja en mal estado de conservación, que se encuentran a alturas que oscilan entre 0,10 y 0,75 m respecto del suelo (Figura 7.56). 
Conjunto 65. Se encuentra al ras del suelo, sobre una superficie vertical y orientada al sur y está conformado por tres motivos: una greca y un almenado, ambos pintados en rojo y, mediante grabado sobrepintado, un óvalo con apéndice curvo y una línea "en forma de U" en su interior. La pintura se encuentran muy desvaída (Figuras 7.56.e y 7.57).

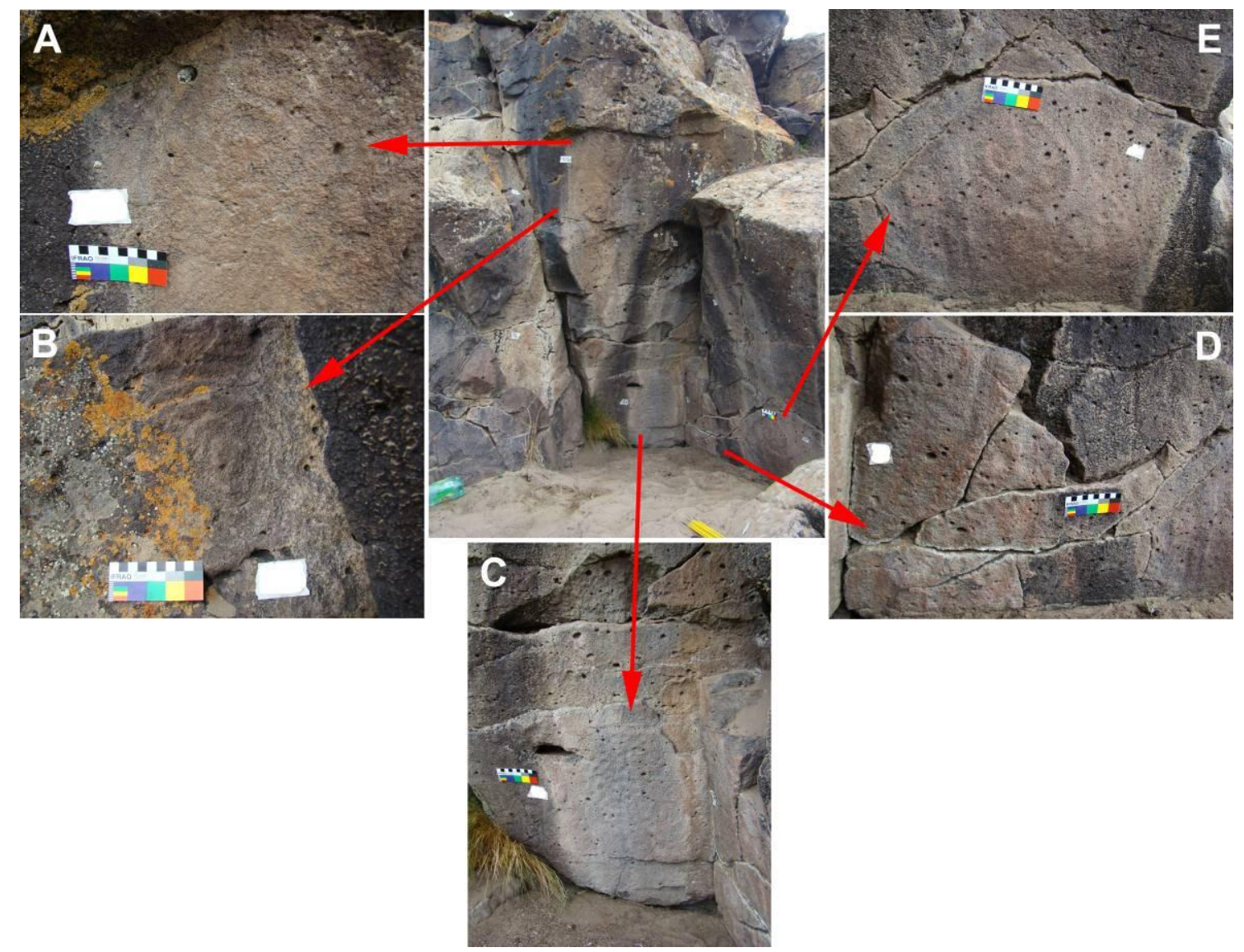

Figura 7.56. Conjuntos 60 a 65: a. circular no determinado del conjunto 60; b. circunferencias concéntricas del conjunto 60; c. motivo 62; d. Motivo 64; e. Conjunto 65 .

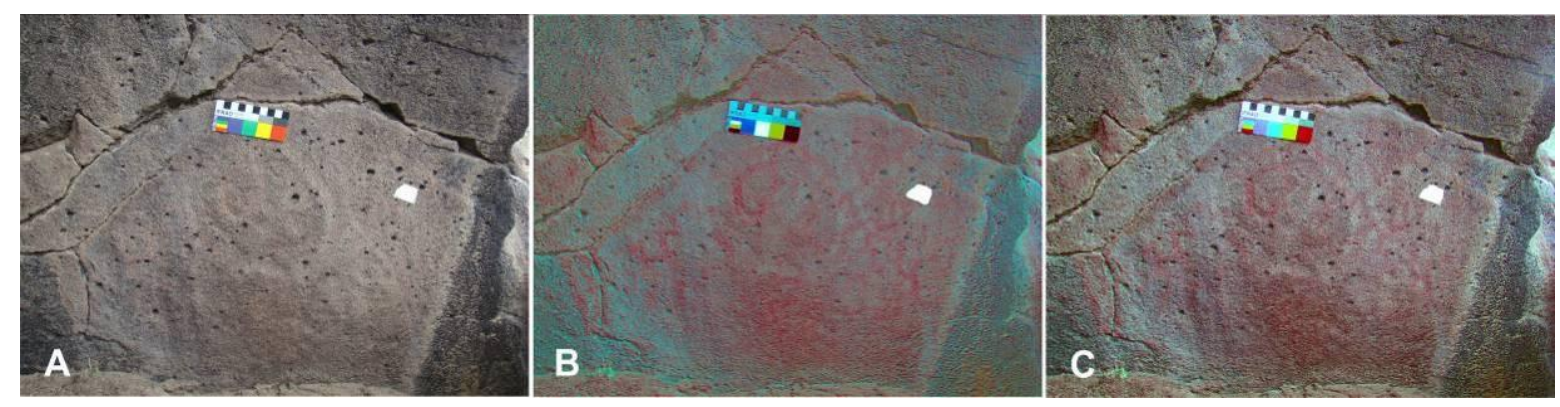

Figura 7.57. Conjunto 65: fotografía de campo; b y c. Imagen tratada digitalmente (D-Stretch lre 15 e yrd 15). 
Motivos 66 a 69. Se encuentra sobre superficies verticales, con diferente orientación y a alturas que oscilan entre 0,75-1 m respecto del suelo actual. Corresponden a series de líneas rectas verticales paralelas, circunferencias concéntricas y un motivo cuadrangular alrededor de un hoyuelo natural. Algunos de estos motivos se encuentran exfoliados y las superficies están afectadas por la acción de líquenes (Figuras 7.58 a y b).

Conjunto 70. A alturas que oscilan entre 0,55 y $0,30 \mathrm{~m}$ respecto del suelo, sobre una superficie vertical se registraron dos motivos: circunferencias concéntricas alrededor de un hoyuelo natural y una circunferencia simple.

Motivos 71, 72 y 73. Sobre diferentes superficies (de la barda y de bloques desprendidos de aquella), a alturas que oscilan entre el ras del suelo y $0,75 \mathrm{~cm}$ y con distinta orientación, se documentaron dos motivos circulares no determinados y una línea vertical atravesada por seis líneas rectas horizontales (Figura 7.58.c-e). Las superficies empleadas, así como los motivos registrados, se encuentran afectados por la acción de líquenes.

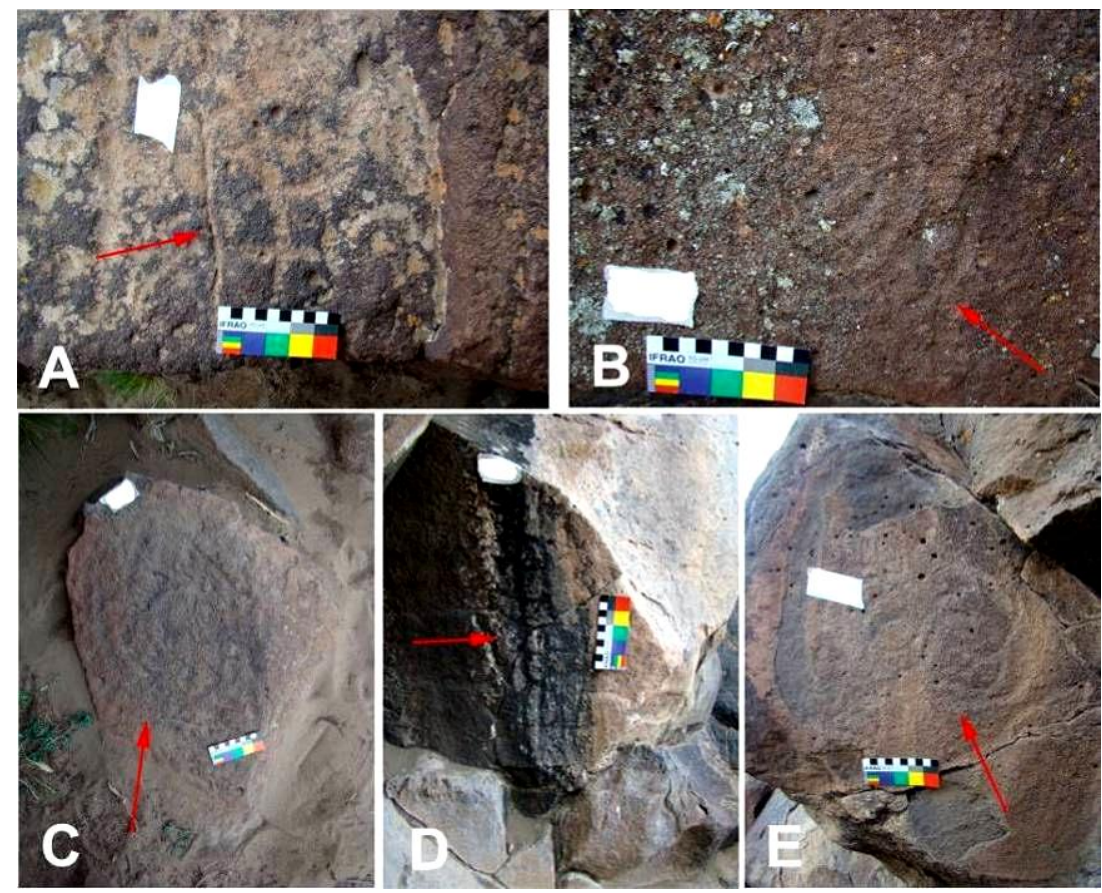

Figura 7.58. Motivos 68 a 73: a. Motivo 68; b. Motivo 69; c. Motivo 71; d. Motivo 72; e. Motivo 73.

Motivo 74. Serie de líneas rectas horizontales parcialmente cubiertas por líquenes sobre una superficie vertical a 2,25 $\mathrm{m}$ del suelo. 
Conjunto 75. Sobre distintas superficies verticales, a alturas que oscilan entre 1,70 y 0,77 m respecto del suelo, se registraron nueve motivos. Entre los que se puede mencionar: una circunferencia de puntos, dos conjunto de puntos, dos series de líneas rectas, una línea quebrada (en forma de "V" invertida), circunferencias (simples, con apéndice y trazo interno) y un motivo circular no no determinado. Algunos de estos motivos se encuentran separados por grietas y fallas naturales del soporte; además, pueden presentar líquenes superpuestos.

Motivos 76 a 84 y los conjuntos 85 y 86 se encuentran a alturas que van del ras del suelo a $2,93 \mathrm{~m}$, sobre superficies verticales de la barda con distinta orientación. Se trata de conjuntos de puntos (Motivos 78, 81, 83 y 84), series de líneas rectas paralelas verticales (Motivos 79 y 80) u horizontales (Motivo 82), circunferencias simples (Motivo 76), una línea recta vertical atravesada por nueve líneas horizontales (Motivo 77). El conjunto 85 está integrado por circunferencias adosadas verticalmente y un reticulado, en tanto que el Conjunto 86 por dos líneas rectas con diferente orientación, un tridígito y un punto (Figura 7.59).

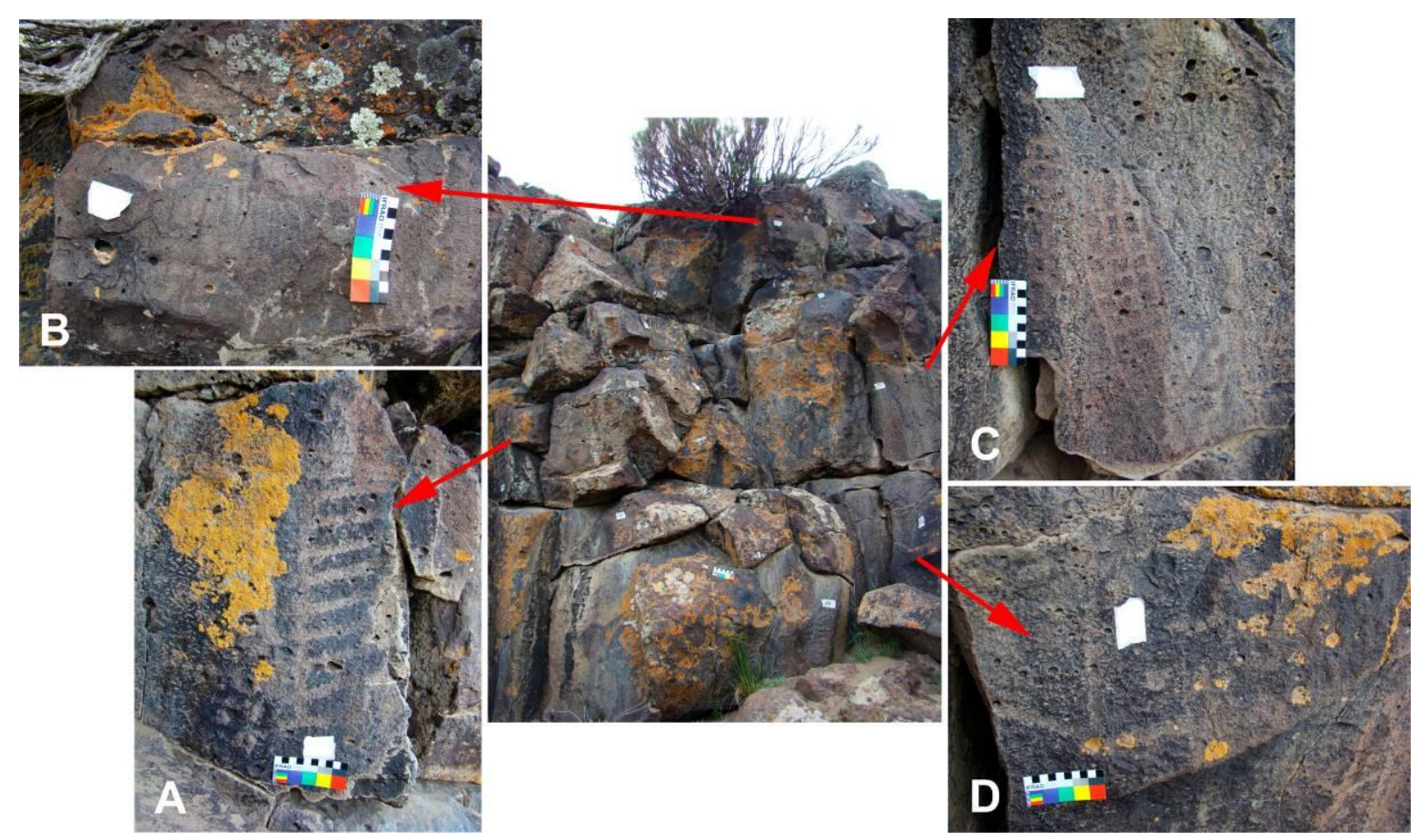

Figura 7.59. Motivos 77 a 86: a. Motivo 77; b. Motivo 80; c. Conjunto 85; d. Conjunto 86. 
Conjunto 87. Se encuentra a alturas que oscilan entre los $0,43 \mathrm{~m}$ y el ras del suelo actual. Está integrado por 11 motivos, entre los que se mencionan puntos simples, líneas rectas verticales simples, series de líneas verticales paralelas, circunferencias (simple o con apéndice) y tridígitos (Figura 7.60.a). Parte del panel se encuentra afectado por acción de líquenes.

Los Motivos 88 y 89 corresponden a series líneas paralelas verticales, que se encuentran en superficies verticales con diferente orientación, a 3,33 m y al ras del suelo, respectivamente (Figura 7.60.b). Algunas líneas están parcialmente cubiertas por líquenes

Conjunto 90. Se encuentra a $2,30 \mathrm{~m}$ del suelo, sobre una superficie vertical orientada al norte. Está integrado por cuatro motivos separados por grietas: una circunferencia concéntrica, una serie de líneas rectas paralelas verticales, un círculo con apéndices radiados asociado a una línea recta vertical y un motivo grabado no determinado (Figura 7.60.c). Los motivos circulares se encuentran cubiertos parcial o totalmente por líquenes, mientras que parte de las serie de líneas rectas verticales se observan incompletas debido a un desprendimiento del soporte.

Motivo 91. Sobre una superficie vertical, orientada al ENE y a 2,65 m del suelo, se encuentra un motivo circular no determinado, que podría corresponder a un espiral o a circunferencias concéntricas (Figura 7.60.d). Este motivo se encuentra fuertemente afectado por la acción de líquenes.

Conjunto 92 y 93. Se encuentran sobre superficies con distinta orientación, a más de 2,25 m respecto del suelo. El primer conjunto está conformado por tres motivos - una circunferencia concéntrica, una línea recta vertical y un conjunto de puntos- (Figura 7.60.e), en tanto que el segundo conjunto está integrado por dos motivos -una espiral y una circunferencia concéntrica- (Figura 7.60.e). Sobre los motivos circulares de estos conjuntos se observan restos de pintura roja. Esta técnica de producción diferente a la documentada en este sitio será tratada con mayor profundidad más adelante. 


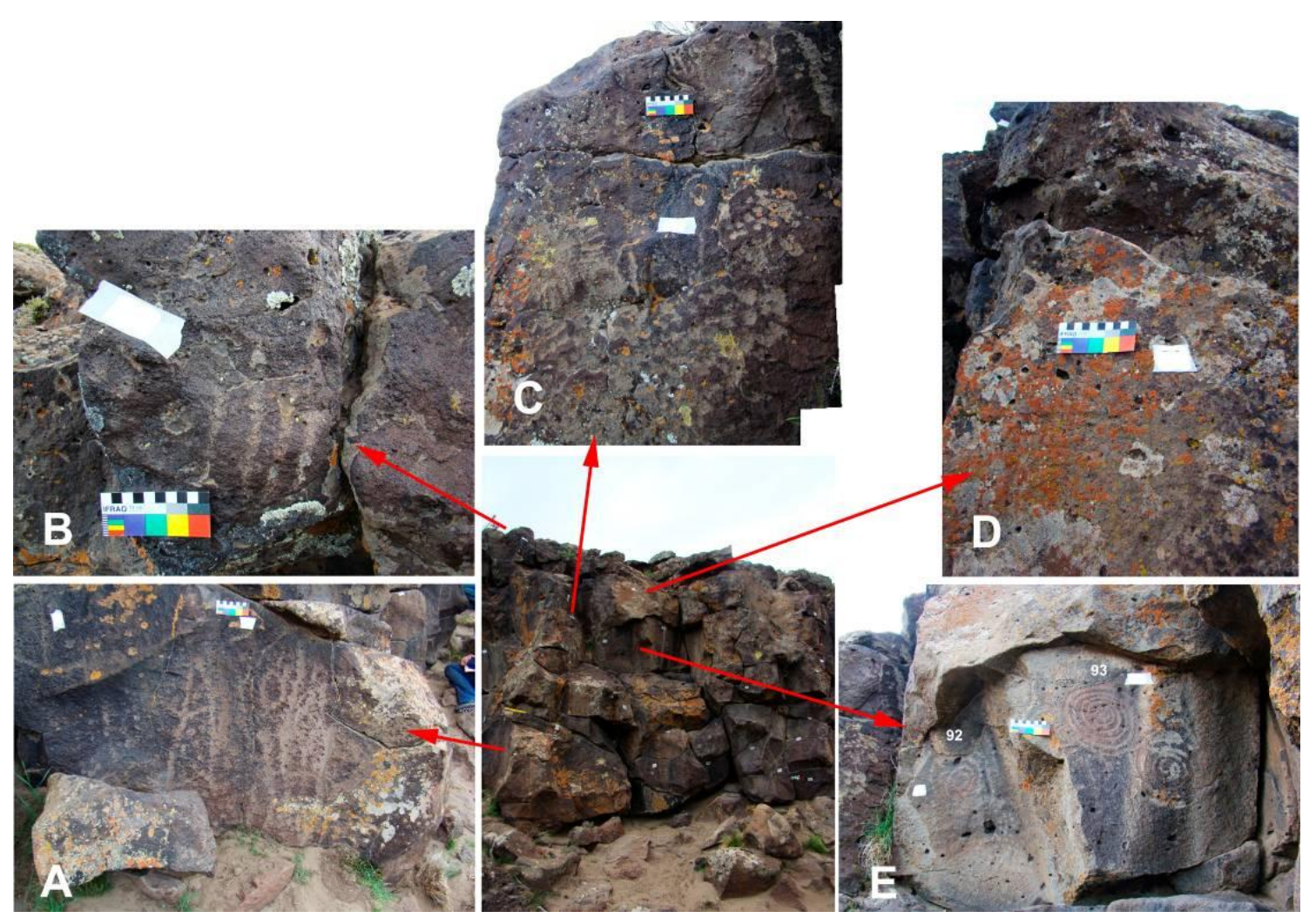

Figura 7.60. Conjuntos 87 a 93: a. Conjunto 87; b. Motivo 88; c. Conjunto 90; d. motivo 91; e. Conjuntos 92 y 93.

Motivo 94. Se encuentra a 1,05 m del suelo, sobre dos superficies de un bloque. Se trata de una serie de líneas rectas paralelas verticales, las tres primeras se continúan unos centímetros sobre la cara horizontal del bloque. Esta situación no pudo ser determinada en las restantes del conjunto por la fuerte colonización de líquenes observada.

Conjuntos 95 a 97. Sobre superficies verticales con diferente orientación y a alturas respecto del suelo que oscilan entre 0,23 y $1,40 \mathrm{~m}$. Se trata de series de líneas rectas paralelas verticales, líneas paralelas con líneas transversales, circunferencias concéntricas, un motivo circular no determinado, un serpentiforme que termina en óvalo y una pisada de felino.

Conjunto 98. Se encuentra sobre diferentes superficies verticales, orientadas al este y al NE, separadas por grietas y angulosidades naturales. A alturas que varían entre 0,70 y 0 m respecto del suelo actual, se registraron 10 motivos: circunferencias (de puntos, simple y con apéndice curvo), una línea recta, una línea curva con dos circunferencias adosadas en 
un extremo y un motivo serpentiforme. Entre los figurativos se reconocieron tres tridígitos (dos con el vértice hacia arriba) y una pisada de felino.

Conjunto 99. Se encuentra sobre diferentes superficies verticales orientadas al norte, cuyas alturas respecto del suelo oscilan entre 2,10 y 1,45 m. Este conjunto está integrado por 12 motivos: conjuntos de puntos, series de líneas paralelas (con diferente orientación) y circunferencias (simple alrededor de un hoyuelo natural o concéntricas) (Figura 7.61). Algunos de estos motivos se encuentran separados o enmarcados por grietas.

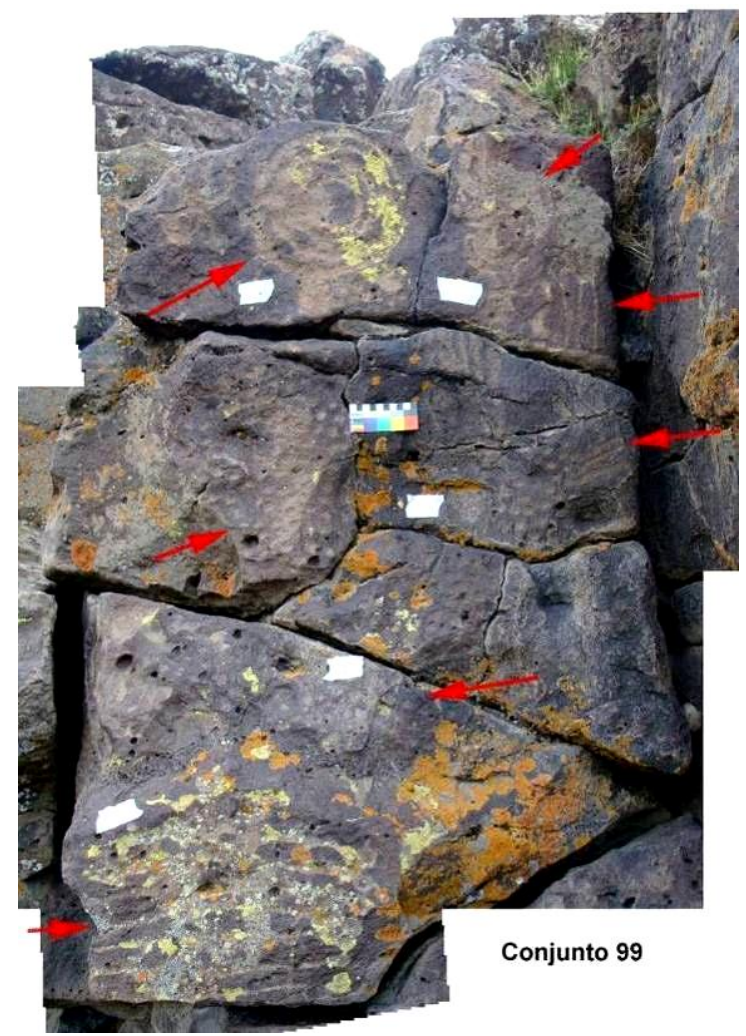

Figura 7.61. Conjunto 99.

Conjuntos 100 y 101. Se encuentran sobre superficies verticales, orientadas al norte, a alturas que oscilan entre 0,53 y $1,62 \mathrm{~m}$ respecto del suelo. Se trata de líneas y conjuntos de puntos, líneas verticales paralelas unidas por líneas transversales y un grabado no determinado.

Motivo 102 y Conjunto 103. Se encuentran sobre superficies verticales con distinta orientación y a diferentes alturas respecto del suelo (entre 0,66 y $0,80 \mathrm{~m})$. Se trata de una circunferencia alrededor de hoyuelo natural (motivo 102), una serie de líneas paralelas verticales y un conjunto de puntos (Conjunto 103). 
Motivos 104 a 107. Sobre superficies verticales con diferente orientación, a alturas que varían entre 1,35 m y 2,20 m. Se corresponde con un conjunto de puntos (Motivo 105), circunferencias concéntricas alrededor de un hoyuelo natural (Motivo 106) y un par de líneas paralelas (con diferente orientación; Motivos 104 y 107) (Figura 7.62).

Conjunto 108. Una "U" con apéndice curvo y un conjunto de puntos al interior de un recoveco, sobre una superficie oblicua, a 1,16 m del suelo

Motivos 109 y 110. A alturas que varían entre el ras del suelo y $0,71 \mathrm{~m}$, sobre superficies verticales fueron registrados un grabado no determinado y una línea recta oblicua, respectivamente.

Conjunto 111. Sobre una superficie vertical orientada al NE y a alturas inferiores a $0,50 \mathrm{~m}$ respecto del suelo, se encuentran los seis motivos que integran este conjunto. Se trata de dos líneas curvas verticales, una serie de líneas rectas paralelas verticales, una circunferencia simple, una circunferencia con cuatro apéndices rectilíneos superiores y un motivo grabado no determinado (Figura 7.62).

Conjunto 112. Se encuentra a alturas que varían entre 1,50 y $0,37 \mathrm{~m}$ respecto del suelo, sobre distintas superficies verticales separadas por grietas del soporte. Se trata, principalmente, de series de líneas verticales paralelas separadas por grietas naturales. También se reconocieron circunferencias simples y concéntricas, conjuntos de puntos, un grabado no determinado y un motivo combinado. Todo el sector de la barda se encuentra afectado por la acción de líquenes (Figura 7.62). 


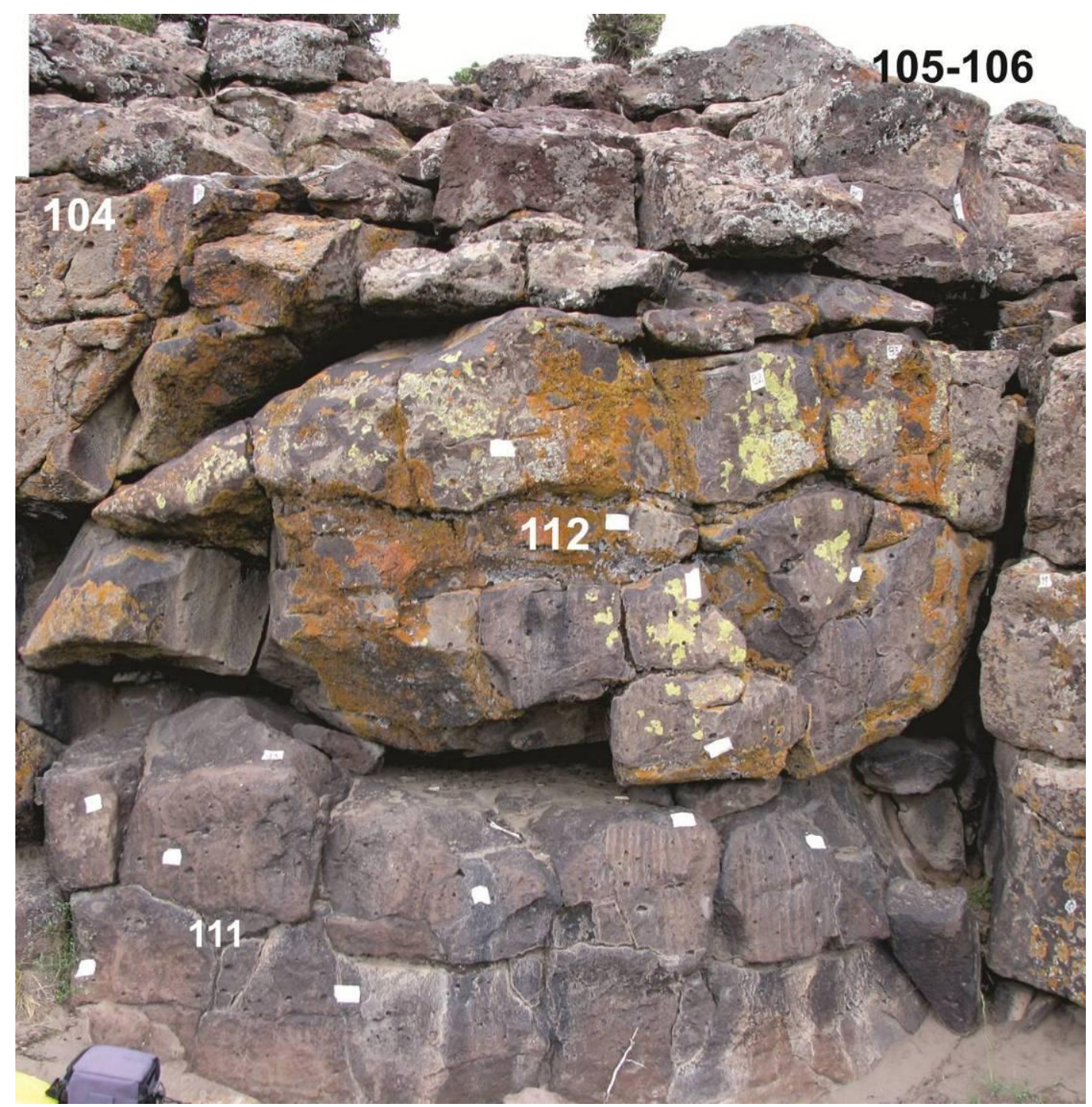

Figura 7.62. Conjuntos 104-112.

Motivo 113. Se encuentra sobre una superficie vertical orientada al este, a $0,81 \mathrm{~m}$ del suelo. Corresponde a una línea recta vertical cubierta enteramente por líquenes (Figura 7.63.a).

Conjunto 114. A $0,68 \mathrm{~m}$ del suelo, sobre una superficie vertical resultante de un desprendimiento se observan un conjunto de puntos y circunferencias concéntricas (Figura 7.63.b).

Motivos 115 y 116. Corresponden a circunferencias concéntricas y un motivo circular no determinado. Se encuentran en superficies verticales fuertemente afectadas por la acción de líquenes, a 1,16 m y a 0,65 m del suelo, respectivamente (Figuras 7.63.c y 7.63.d).

Conjunto 117. Sobre una superficie oblicua orientada al norte, a 0,16 m respecto del suelo actual. Se trata de una circunferencia con apéndice curvo 
y "media U" invertida (Figura 7.63.e). Entre estos dos motivos se registra una de las pocas superposiciones documentadas en el sitio, la cual será tratada más adelante.

Motivos 118 y 119. Se encuentran sobre superficies verticales, a 1 y 0,65 $\mathrm{m}$ del suelo. Se trata de un motivo circular no determinado y series de líneas rectas paralelas horizontales asociadas a dos líneas curvas paralelas, respectivamente (Figuras 7.63.f y 7.63.g).

Motivo 120. Sobre una superficie vertical, orientada al SE y a 0,72 $\mathrm{m}$ del suelo actual, se observa una circunferencia cuyo sector superior se encuentra incompleto por un desprendimiento del basalto (Figura 7.63.h).
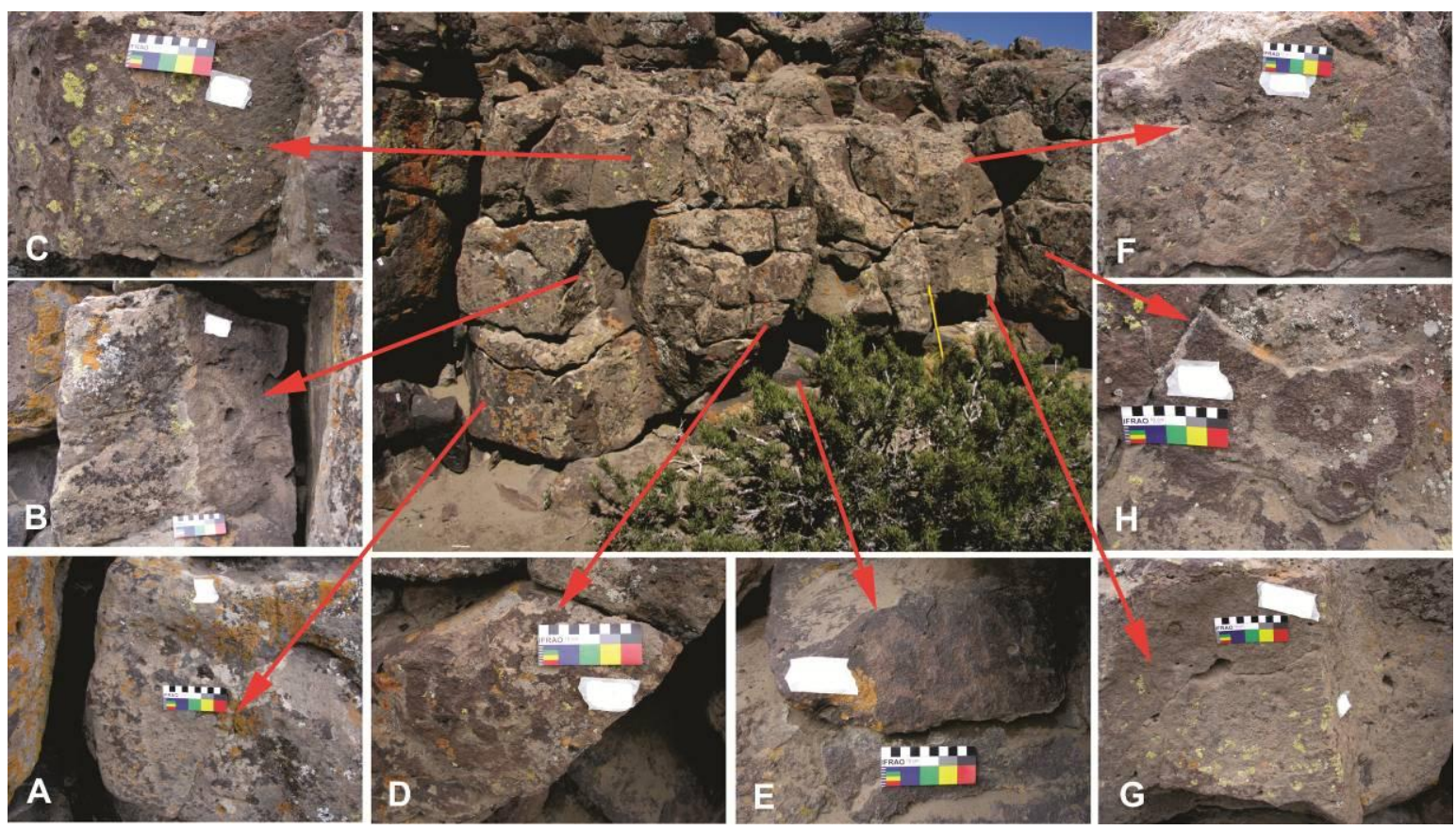

Figura 7.63. Conjuntos 113 a 120: a. Motivo 113; b. Conjunto 114; c. Motivo 115; d. Motivo 116; e. Conjunto 117; f. Motivo 118; g. Motivo 119; h. Motivo120

Motivo 121. Se encuentra a 2,50 $\mathrm{m}$ del suelo, en una superficie oblicua y orientada al N. Se trata de una circunferencia concéntrica que, al igual que la superficie sobre la que se encuentra, ha sido afectada por la acción de líquenes.

Conjunto 122 y Motivo 123. Se encuentran a alturas que varían entre 1,30 y $0,67 \mathrm{~m}$ sobre superficies verticales. Corresponden a circunferencias concéntricas y una espiral (Figura 7.64.a) y a un motivo circular no determinado alrededor de un hoyuelo natural (Motivo 123). 
Conjunto 124. Sobre superficies verticales, a alturas que oscilan entre 1,30 y $0,85 \mathrm{~m}$ respecto del suelo actual, se registraron ocho motivos separados por grietas y fallas del soporte: se trata predominantemente de motivos circulares (circunferencias simples, con trazos interiores y/o apéndices, circunferencias concéntricas, con y sin apéndices, circunferencias adosadas), series de líneas paralelas verticales y un tridígito (Figuras 7.64.a-e). Las superficies basálticas se encuentran cubiertas u obliteradas por líquenes.

Motivo 125. Conjunto de puntos a $0,31 \mathrm{~cm}$ del suelo, sobre una superficie vertical de un pequeño nicho de la barda.

Conjunto 126. Serie de líneas rectas paralelas verticales y una línea curva sobre una superficie oblicua de un bloque desprendido de la barda (Figura 7.64.f).

Motivo 127. Líneas rectas paralelas verticales muy exfoliadas a $0,25 \mathrm{~m}$ del suelo, sobre una superficie oblicua (Figura 7.64.g).

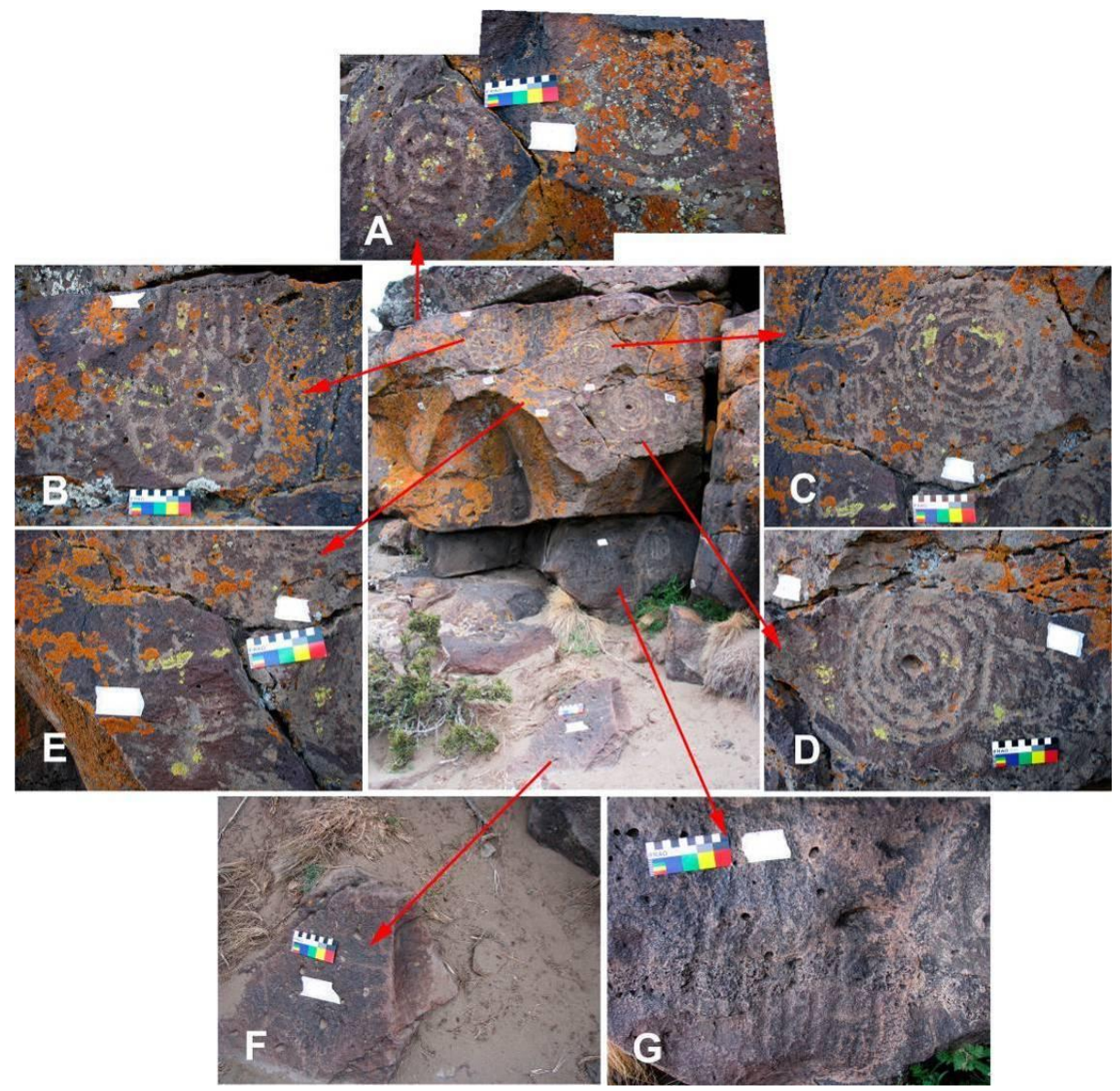

Figura 7.64. Conjuntos 122 a 127: a. Conjunto 122; b. Conjunto 124A; c. Conjunto 124C; d. Conjunto 124D; e. Conjunto 124E; f. Conjunto 126; g. Motivo 127. 
Conjunto 128. Grabado no determinado y una circunferencia simple a 0,41 $\mathrm{m}$ del suelo, sobre una superficie vertical orientada al SE.

Conjuntos 129 y 130. Sobre superficies verticales, orientadas al ENE, a alturas que varían entre 1,30 y $0,30 \mathrm{~m}$ del suelo. Corresponden a circunferencias concéntricas, líneas rectas verticales (Conjunto 129), a un conjunto de puntos separado y una serie de líneas paralelas verticales asociadas a un conjunto de puntos (Conjunto 130).

Motivo 131. Serie de líneas rectas paralelas verticales a $0,15 \mathrm{~cm}$ del suelo, sobre una superficie oblicua orientada al NW de un bloque desprendido de la barda (1,63 m por delante del conjunto anterior).

Conjunto 132. Sobre una superficie vertical, a alturas que varían entre 1,74 y $1,28 \mathrm{~m}$, se registraron tres series de líneas rectas paralelas verticales (Figura 7.65.a).

Motivos 133 a 135. Se encuentran sobre superficies verticales con diferente orientación, a alturas que varían entre 0,34 y 1,56 m respecto del suelo. Corresponden a un conjunto de puntos, una serie de líneas rectas paralelas verticales asociadas a un conjunto de puntos, y a un par de líneas paralelas verticales con líneas transversales internas, con tres líneas paralelas oblicuas en su porción media, respectivamente (Figuras 7.65.b y 7.65.c).
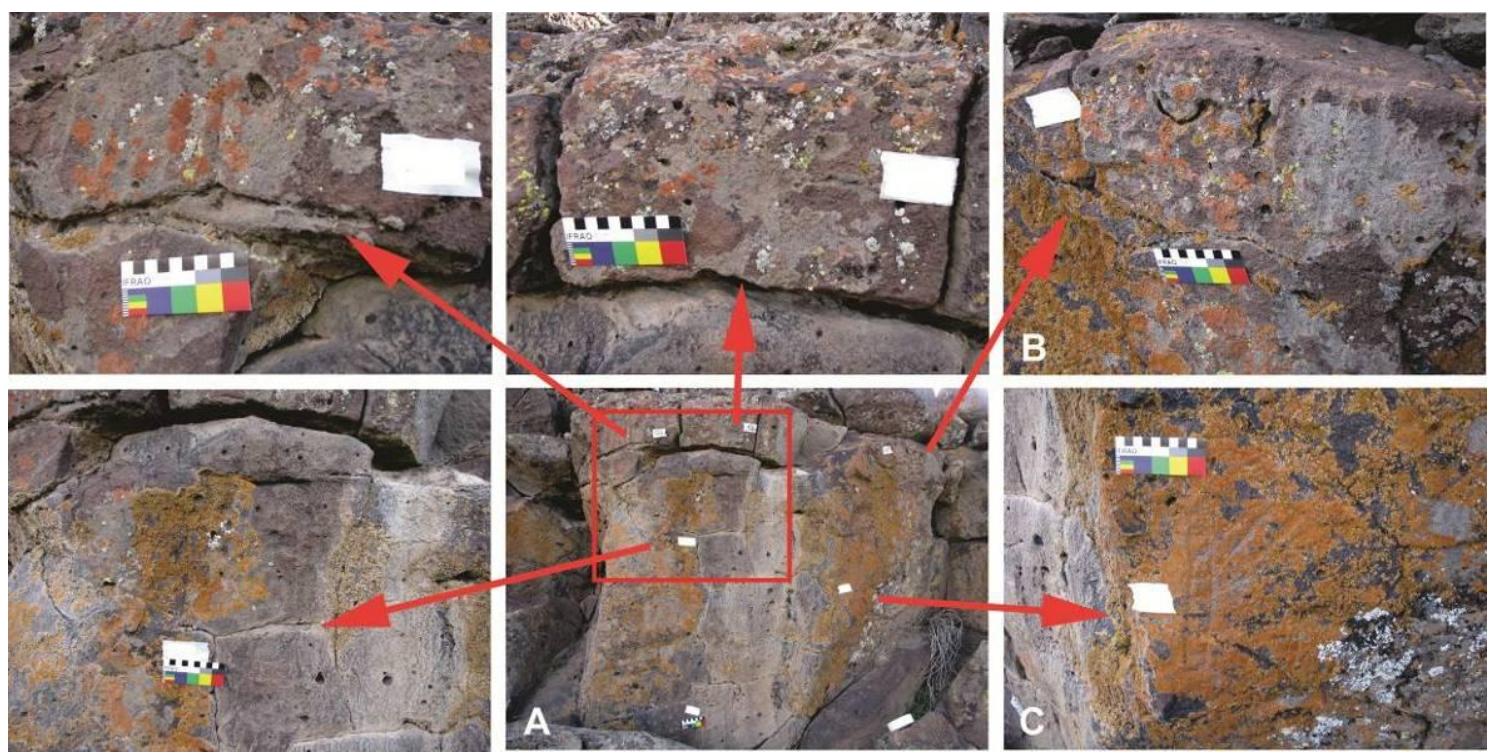

Figura 7.65. Conjuntos 132 a 135: a. Conjunto 132; b. Motivo 134; c. Motivo 135. 
Motivo 136. Serie de líneas rectas paralelas verticales sobre una superficie vertical orientada al $\mathrm{E}$, a 1,36 m respecto del suelo.

Motivo 137. Se trata de una circunferencia alrededor de un hoyuelo natural con apéndices rectilíneos superiores. Está ubicada al ras del suelo sobre una superficie oblicua de un bloque separado de la barda, $2 \mathrm{~m}$ por delante del motivo anterior. Este motivo se encontraba parcialmente cubierto por sedimento.

Motivos 138 y 139. Se encuentran sobre superficies verticales de la barda basáltica, con diferente orientación y a alturas que oscilan entre 0,28 m y 2,88 m respecto del suelo. Se trata de una serie de líneas rectas paralelas verticales y un conjunto de puntos, respectivamente (Figuras 7.66.a y 7.66.b).

Conjunto 140. Se encuentra sobre una superficie vertical, orientada al NW y a alturas que oscilan entre 0,59 y $0,10 \mathrm{~m}$ respecto del suelo. Está conformado por una circunferencia rodeada por dos líneas curvas paralelas y una serie de líneas paralelas horizontales y verticales (Figura 7.66.c).

Conjunto 141. Se encuentra sobre diferentes superficies verticales de la barda, con distinta orientación y a alturas menores a 0,56 m del suelo. Está integrado por un motivo "en forma de U", una circunferencia y una serie de líneas rectas paralelas verticales (Figura 7.66.d).
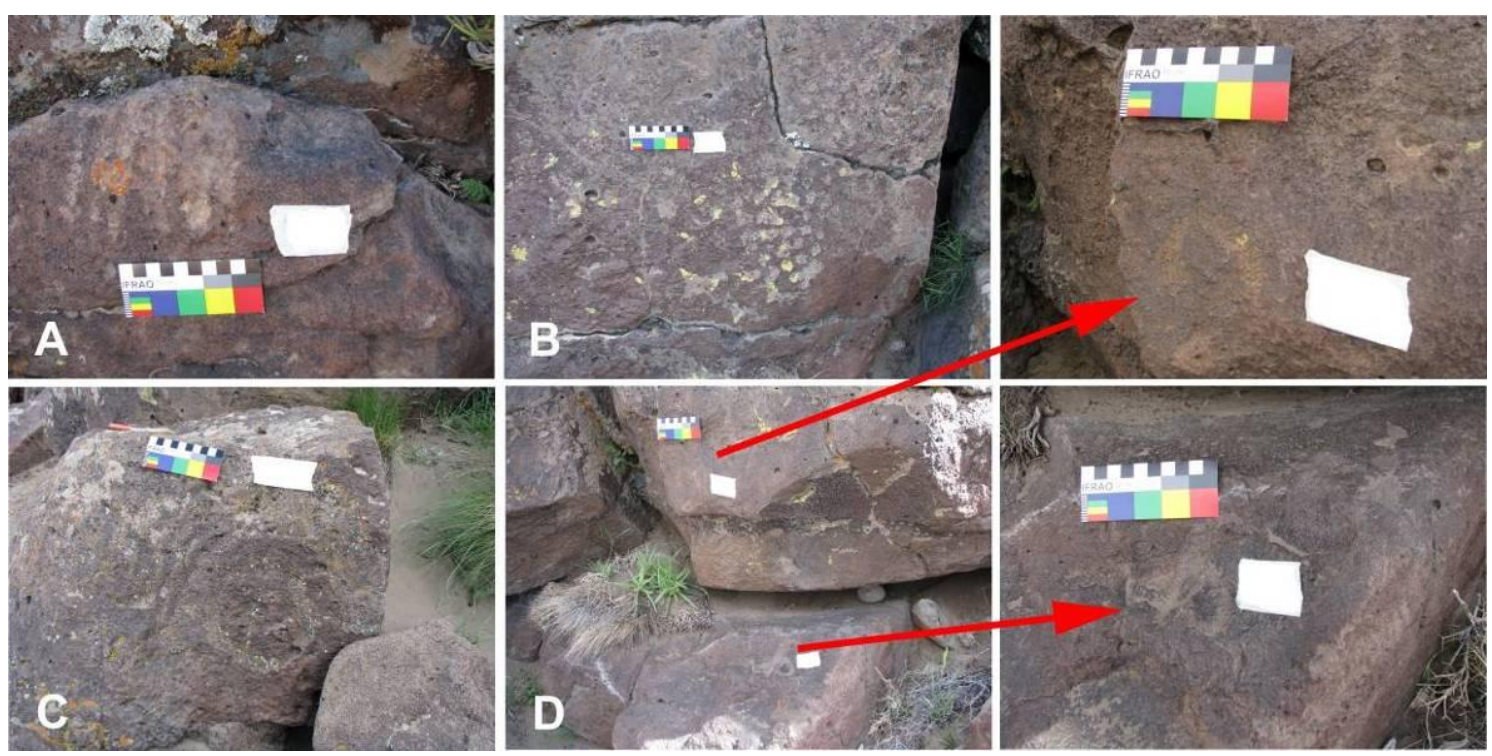

Figura 7.66. Conjuntos 138 a 141: a. Motivo 138; b. Motivo 139; c. Motivo 140; d.

Conjunto 141. 
Conjunto 142. Sobre superficies verticales, a alturas que varían entre 1,66 y $0,58 \mathrm{~m}$ respecto del suelo. Corresponden a una circunferencia simple, una línea recta vertical, una línea recta con una línea oblicua en ángulo y tres circunferencias concéntricas, respectivamente. Las líneas en ángulo se encuentran parcialmente libres de líquenes.

Conjunto 143. Sobre una superficie vertical orientada al este y a alturas que oscilan entre 1 y $0,30 \mathrm{~m}$ respecto del suelo, se observan cinco motivos: un conjunto de puntos, una línea vertical superpuesta a los anteriores, una serie de líneas rectas paralelas verticales, dos circunferencias adosadas verticalmente y una circunferencia concéntrica (Figura 7.67). Estos motivos se encuentran separados y enmarcados por grietas verticales y horizontales.

Motivo 144. Una línea en zigzag asociada a un conjunto de puntos, ubicada al ras del suelo, sobre la superficie vertical de un bloque desprendido de la barda, orientada al ENE. La superficie es de coloración rojiza, que contrasta fuertemente con el color marrón del surco. Por tratarse de un bloque desprendido de la barda, resulta llamativo que se encuentre libre de líquenes y sin haber sufrido ningún grado de exfoliación (Figura 7.67). Este motivo cierra el registro de conjuntos sobre la barda basáltica.

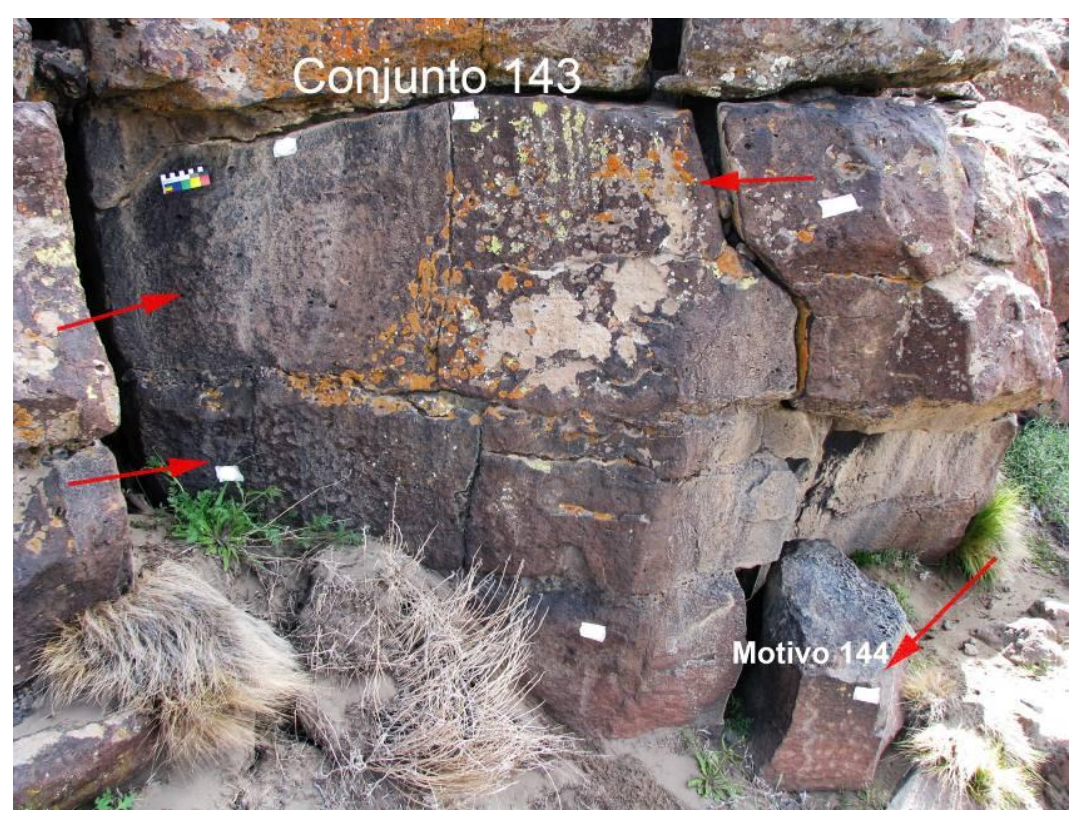

Figura 7.67. Conjunto 143 y Motivo 144.

Los motivos y conjuntos que se detallan a continuación se encuentran una cota inferior, en bloques separados entre 5 y $6 \mathrm{~m}$ de la barda. Dichos bloques 
presentan diferente grado de exfoliación y pueden estar afectados por la acción de líquenes.

Conjunto 145. Se encuentra por delante de los motivos 43 a 52 , en un bloque parcialmente cubierto por un molle (Figura 7.68). De dicho bloque se utilizaron diferentes superficies orientadas al NE-NNE; los motivos se encuentran a alturas que oscilan entre 0,86 y $0,36 \mathrm{~m}$ respecto del suelo actual. Este conjunto está integrado por un círculo, una circunferencia y un motivo circular no determinado que podría corresponder a circunferencias concéntricas (Figura 7.68).

Conjunto 146. Se encuentra debajo del reparo del follaje del molle, sobre una superficie vertical orientada al NNW y a alturas que oscilan entre 0,90 y 0,27 m respecto del suelo. Está conformado por ocho motivos: un conjunto de puntos, una serie de líneas rectas paralelas horizontales asociadas a líneas paralelas verticales, una serie de líneas rectas paralelas verticales, una circunferencia alrededor de un punto central, dos circunferencias concéntricas y dos tridígitos (Figura 7.68).

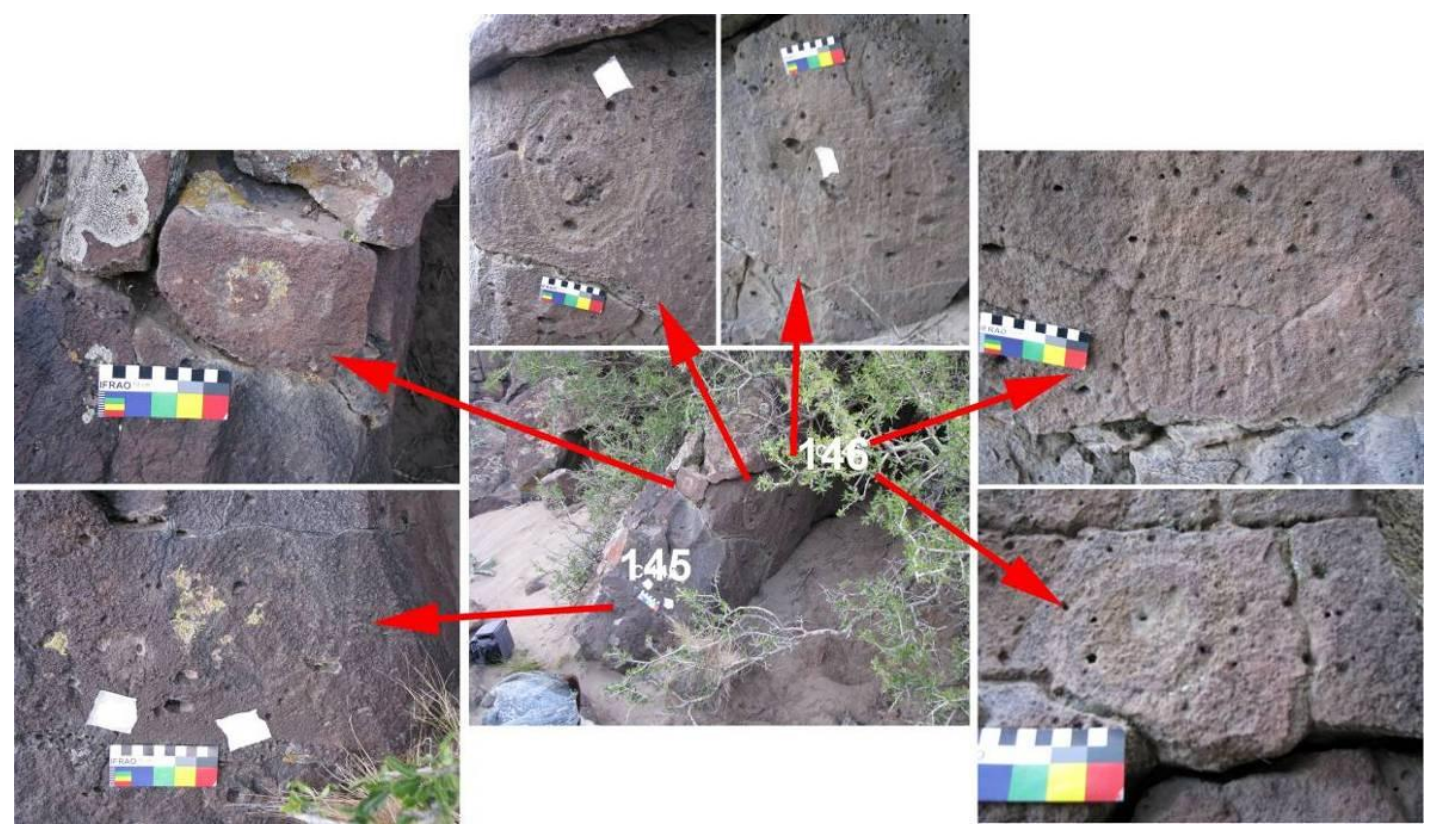

Figura 7.68. Conjuntos 145 y 146.

Conjunto 147. Se encuentra sobre una superficie vertical de un bloque derrumbado, orientada al NNW, a $0,20 \mathrm{~m}$ respecto del suelo. Está conformado por una circunferencia concéntrica, una línea curva y una serie 
de líneas paralelas verticales asociadas líneas paralelas horizontales (Figura 7.69).

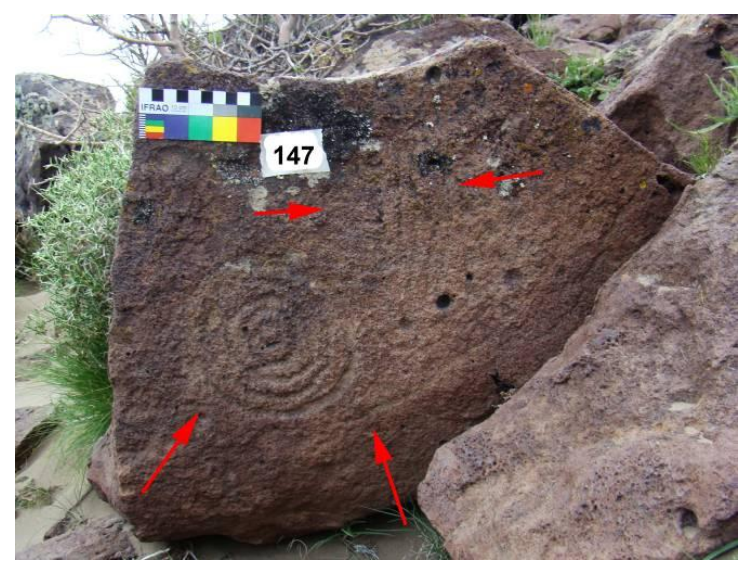

Figura 7.69. Conjunto 147.

Motivo 148. Se encuentra sobre la superficie vertical, orientada al SE, de un bloque parcialmente enterrado. Se trata de una circunferencia concéntrica.

Conjunto 149. Se encuentra por delante del Motivo 85, en un bloque desprendido de la barda. Está integrado por siete motivos sobre superficies con distintas orientaciones y a diferentes alturas respecto del suelo.

A: sobre una superficie oblicua, orientada al NW y a 1,55 m del suelo, se observan circunferencias concéntricas (Figura 7.70.a).

B: a 1,20 m del suelo, sobre una superficie vertical orientada al E, se observa un conjunto de puntos, un motivo combinado conformado por líneas rectas y curvas, una serie de líneas curvas concéntricas con apéndice que termina "en forma de U" invertida y cerrada, una serie líneas rectas paralelas verticales (Figura 7.70.b).

C: dos líneas oblicuas paralelas sobre una cara vertical orientada al NW, a $0,86 \mathrm{~m}$ del suelo.

D: una serie de líneas paralelas verticales a $0,85 \mathrm{~m}$ del suelo, sobre el borde superior de un bloque desprendido de los anteriores, orientado al $\mathrm{E}$ (Figura 7.70.c). Estas están cubiertas completamente por líquenes, lo que dificulta su visualización.

Motivo 150. Un conjunto de puntos separado por grietas a $0,78 \mathrm{~m}$ del suelo, sobre una superficie vertical orientada al WNW (Figura 7.70.d). 
Motivo 151. Se encuentra sobre un bloque alejado de la barda, apoyado sobre otros bloques derrumbados y parcialmente cubierto con arena, por delante del motivo 115. En una superficie vertical, orientada al NE y a $1 \mathrm{~m}$ del suelo, se observan circunferencias concéntricas alrededor de un hoyuelo natural.
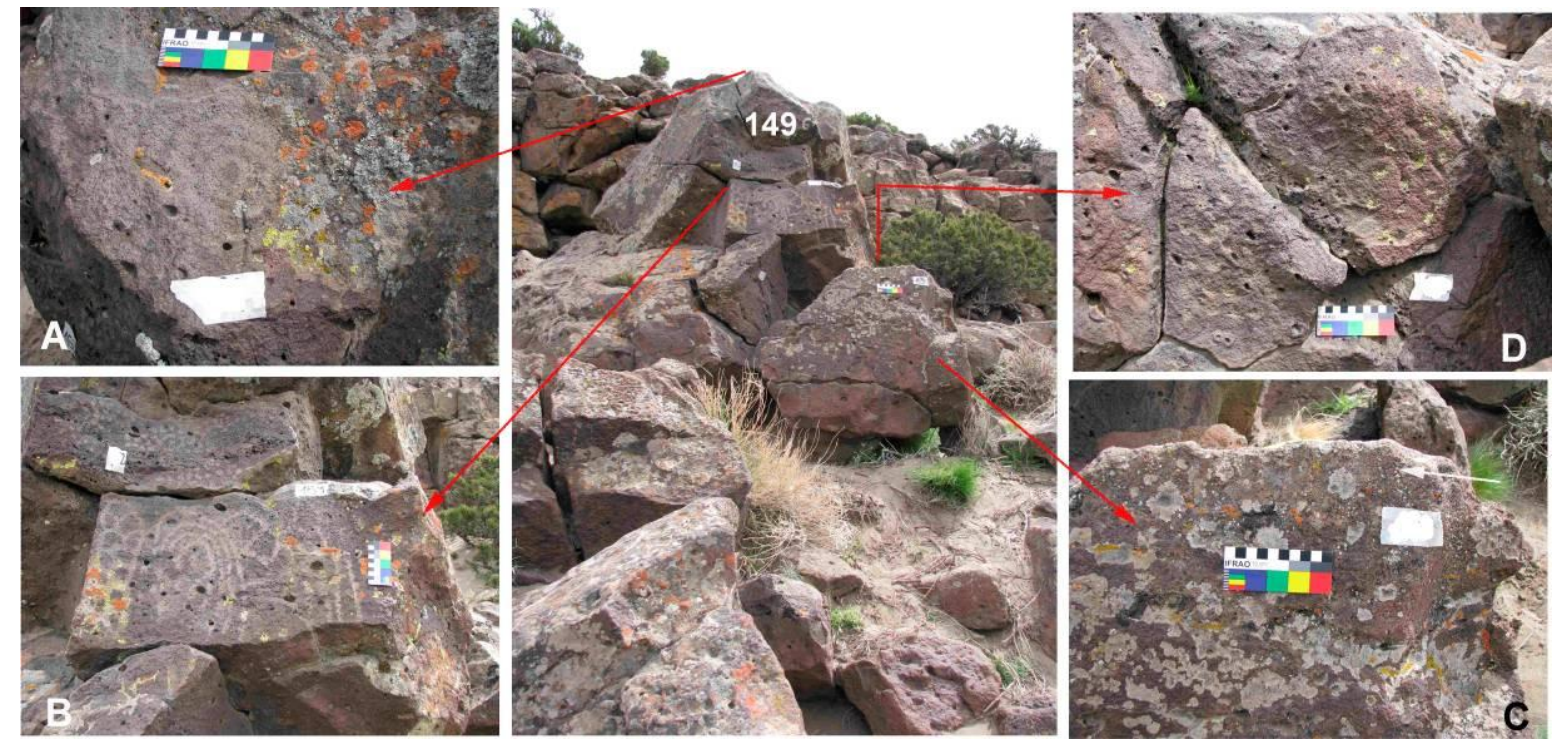

Figura 7.70. Conjuntos 149 y 150: a. conjunto 149a; b. Conjunto 149B; c. Conjunto 149D; d. Conjunto 150.

\section{7. c. 3. Análisis}

Con respecto a las condiciones de emplazamiento y visibilidad de los motivos rupestres de Bardas de Antonio, se observa que éstos se encuentran mayoritariamente sobre superficies verticales de la barda basáltica, a las que en los sectores 1 y 6 se le adiciona la utilización de superficies de bloques desprendidos o alejados de la barda (Tabla 7.8). Respecto a la altura sobre el suelo a la que se encuentran, en los sectores 1 y 6 los motivos se ubican desde el ras del suelo a alturas que superan los $2 \mathrm{~m}$, mientras que en los restantes sectores la altura respecto del suelo no supera $1,50 \mathrm{~m}$. La mayor variabilidad en cuanto al emplazamiento (altura respecto del suelo y/o bloques separados de la barda) se observa en los sectores que presentan mayor frecuencia y diversidad de motivos, lo cual podría estar indicando una selección preferencial de dichos sectores. 
Respecto a la visibilidad de los motivos, ésta se encuentra estrechamente relacionada con el grado de conservación de los mismos. Puede suceder que la superficie sobre la que se ubican está siendo afectada por la acción de líquenes o del agua, a las que se suma la incidencia del sol. Esta última afectó fuertemente la preservación de los motivos pintados. Los Conjuntos 14 y 17 corresponden a dos ejemplos de la acción de los líquenes y del agua sobre las superficies basálticas (ver Figuras 7.43 y 7.45). Los motivos pintados del Conjunto 18 (ver Figura 7.46.a) son un ejemplo de la incidencia del agua, mientras que el Conjunto 51 representa un caso de incidencia de diferentes factores sobre la pintura (i.e., agua y sol) (Figura 7.53).

Por otro lado, los motivos circulares de gran tamaño que se encuentran en bloques separados de la barda, actualmente cubiertos con líquenes, pueden haber presentado en el pasado una visibilidad intermedia-alta. De igual manera, los motivos pictograbados, que se corresponden con motivos circulares lineales, también podrían haber sido altamente visibles si se considera el contraste de de la pintura roja sobre las superficies basálticas. A partir de lo anterior, se observa que la baja visibilidad de ciertos motivos se corresponde con factores tafonómicos, posteriores a su producción, en tanto que la alta visibilidad de los motivos circulares lineales podría vincularse con una intencionalidad de los productores para hacerlos notorios, sea por su tamaño o por la aplicación de pintura sobre los surcos grabados. 


\begin{tabular}{|c|c|c|c|c|c|c|c|}
\hline \multirow{2}{*}{\multicolumn{2}{|c|}{ Variables }} & \multicolumn{6}{|c|}{ Sectores } \\
\hline & & \multirow{2}{*}{\begin{tabular}{|l|}
1 \\
$X$ \\
$X$
\end{tabular}} & \multirow{2}{*}{$\begin{array}{l}2 \\
X\end{array}$} & \multirow{2}{*}{\begin{tabular}{|l|}
3 \\
$X$
\end{tabular}} & \multirow{2}{*}{$\begin{array}{l}4 \\
X\end{array}$} & \multirow{2}{*}{$\begin{array}{l}5 \\
X\end{array}$} & \multirow{2}{*}{\begin{tabular}{|l}
6 \\
$X$ \\
$X$
\end{tabular}} \\
\hline Emplazamiento & $\begin{array}{l}\text { pared } \\
\text { bloques desprendidos }\end{array}$ & & & & & & \\
\hline Posición & $\begin{array}{l}\mathrm{H} \\
\mathrm{V}\end{array}$ & $\begin{array}{l}\mathrm{X} \\
\mathrm{X}\end{array}$ & $\mathrm{X}$ & $\mathrm{X}$ & $\mathrm{X}$ & $\mathrm{X}$ & $\mathrm{X}$ \\
\hline Orientación & $\begin{array}{l}\mathrm{N} \\
\mathrm{S} \\
\mathrm{E} \\
\mathrm{W}\end{array}$ & $\begin{array}{l}\mathrm{X} \\
\mathrm{X} \\
\mathrm{X}\end{array}$ & $\mathrm{X}$ & $\begin{array}{l}\mathrm{X} \\
\mathrm{X}\end{array}$ & $\mathrm{X}$ & $\begin{array}{l}X \\
X\end{array}$ & $\begin{array}{l}\mathrm{X} \\
\mathrm{X} \\
\mathrm{X} \\
\mathrm{X}\end{array}$ \\
\hline $\begin{array}{l}\text { Distancia al } \\
\quad \text { suelo } \\
\text { en } \mathrm{m}\end{array}$ & $\begin{array}{l}>2 \\
2-1,51 \\
1,50-1 \\
<1\end{array}$ & $\begin{array}{l}X \\
X \\
X \\
X\end{array}$ & $\mathrm{X}$ & $\mathrm{X}$ & $\mathrm{X}$ & $\mathrm{X}$ & $\begin{array}{l}\mathrm{X} \\
\mathrm{X} \\
\mathrm{X} \\
\mathrm{X}\end{array}$ \\
\hline $\begin{array}{l}\text { Campo visual } \\
\text { máximo en } \mathrm{m}\end{array}$ & $\begin{array}{l}1 \\
3 \\
7 \\
15\end{array}$ & $\begin{array}{l}X \\
X \\
X\end{array}$ & $\mathrm{X}$ & $\begin{array}{l}X \\
X\end{array}$ & $\mathrm{X}$ & $\mathrm{X}$ & $\begin{array}{l}\mathrm{X} \\
\mathrm{X} \\
\mathrm{X}\end{array}$ \\
\hline Iluminación & $\begin{array}{l}\text { luz tarde } \\
\text { luz mañana } \\
\text { penumbra }\end{array}$ & $\mathrm{X}$ & $\mathrm{X}$ & $\mathrm{X}$ & $\begin{array}{l}\mathrm{X} \\
\mathrm{X}\end{array}$ & $\begin{array}{l}\mathrm{X} \\
\mathrm{X}\end{array}$ & $\begin{array}{l}\mathrm{X} \\
\mathrm{X}\end{array}$ \\
\hline Visibilidad & $\begin{array}{l}\text { 1) alta } \\
\text { 2) intermedia } \\
\text { 3) baja } \\
\text { 4) muy baja }\end{array}$ & $\begin{array}{l}\mathrm{X} \\
\mathrm{X} \\
\mathrm{X}\end{array}$ & $\mathrm{X}$ & $\mathrm{X}$ & $\mathrm{X}$ & $\mathrm{X}$ & $\begin{array}{l}\mathrm{X} \\
\mathrm{X} \\
\mathrm{X} \\
\mathrm{X}\end{array}$ \\
\hline Motivos & $\begin{array}{l}\text { Puntiformes } \\
\text { Rectilíneos } \\
\text { Circulares llenos } \\
\text { Circulares lineales } \\
\text { Curvilíneos } \\
\text { Tridígito } \\
\text { Pisada de felino } \\
\text { Pintura ND } \\
\text { Grabado ND }\end{array}$ & $\begin{array}{l}\mathrm{X} \\
\mathrm{X} \\
\mathrm{X} \\
\mathrm{X} \\
\mathrm{X}\end{array}$ & $\mathrm{X}$ & $\begin{array}{l}X \\
X\end{array}$ & $\begin{array}{l}X \\
X\end{array}$ & $\mathrm{X}$ & $\begin{array}{l}X \\
X \\
X \\
X \\
X \\
X \\
X \\
X \\
X\end{array}$ \\
\hline
\end{tabular}

Tabla 7.8. Visibilidad y emplazamiento de los sectores de Bardas de Antonio.

En cuanto a la técnica de producción de los motivos, se observa un amplio predominio del grabado (94\%), con pocos motivos pintados y pictograbados (Figura 7.71). Al considerar su distribución espacial, en el sector 6 se registraron las tres técnicas de producción: pintura, grabado y pictograbado, mientras que en el sector 3 se documentaron pinturas y grabados. En el sector 2 solamente se registraron motivos pintados, en tanto que los sectores 1, 4 y 5 presentan exclusivamente motivos grabados (Tabla 7.9; Figura 7.71). 


\begin{tabular}{|c|c|c|c|c|c|c|c|}
\hline & \multicolumn{6}{|c|}{ Sector } & \\
\hline Técnica & 1 & 2 & 3 & 4 & 5 & 6 & Total \\
\hline Grabado & 57 & - & 4 & 1 & 3 & 291 & 356 \\
\hline Pintura & - & 2 & 7 & - & - & 15 & 24 \\
\hline Pictograbado & - & - & - & - & - & 3 & 3 \\
\hline Total & 57 & 2 & 11 & 1 & 3 & 309 & 383 \\
\hline
\end{tabular}

Tabla 7.9. Distribución espacial de reconocidas en los distintos sectores de Bardas de Antonio.

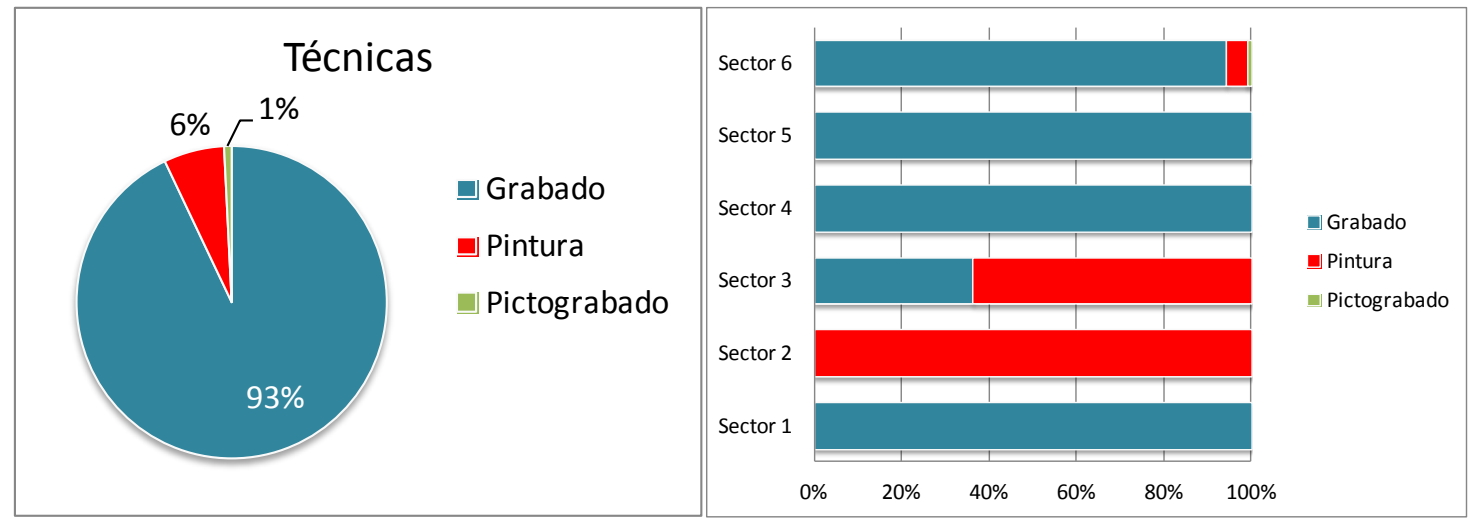

Figura 7.71. Proporciones de técnicas en Bardas de Antonio y su distribución por sector.

Entre las técnicas de grabado predomina ampliamente la percusión. En el $31 \%$ de los grabados no pudo observarse o definirse con exactitud la técnica de producción, principalmente debido al grado de exfoliación que presenta el motivo. Le siguen en proporciones menores la incisión, el raspado y otras técnicas combinadas (Figura 7.72). Respecto a su distribución en los distintos sectores, se observa mayor variabilidad en el sector 6 , en tanto que la percusión fue registrada en los restantes sectores que presentan grabados (Figura 7.72).

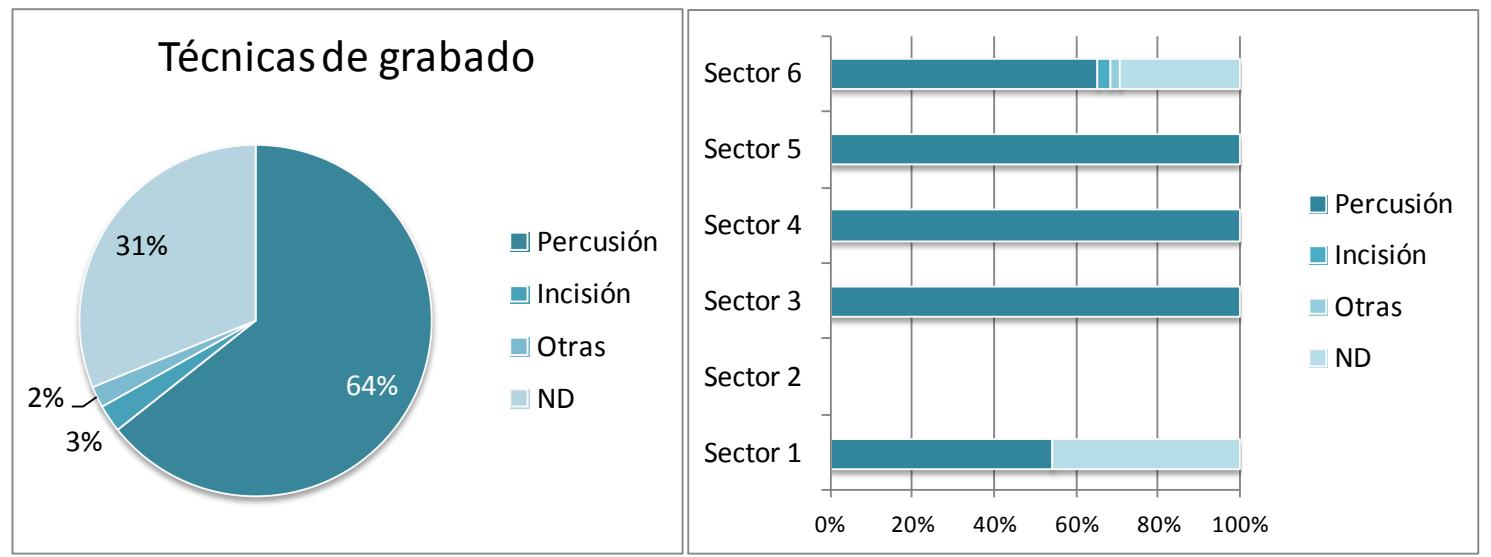

Figura 7.72. Proporciones de técnicas de grabado y distribución por sector. ND: no determinadas. 
Si bien se documentaron motivos pintados, la conservación de los mismos es mala como para inferir algún tipo de técnica de producción (ver Figura 7.46). Los motivos pictograbados se encuentran en el sector 6. Se trata de motivos circulares que se encuentran en los Motivos 65 y los Conjuntos 92 y 93. Si bien la observación en campo permitió discernir la presencia de pintura en las circunferencias concéntricas del Conjunto 92 (Figura 7.73.a), las imágenes obtenidas del relevamiento de los restantes motivos fueron sometidas a tratamiento digital. Los restos de pintura son claros luego de aplicar este procedimiento (Figuras 7.57, 7.73.b y 7.73d). En todos los casos se infirió que la técnica de grabado empleada en su producción fue la percusión, debido a que el Motivo 65 y el Conjunto 93 presentan surco en forma de "U" en tanto que las circunferencias concéntricas del Conjunto 92 presentan surco superficial y puntos de impacto.

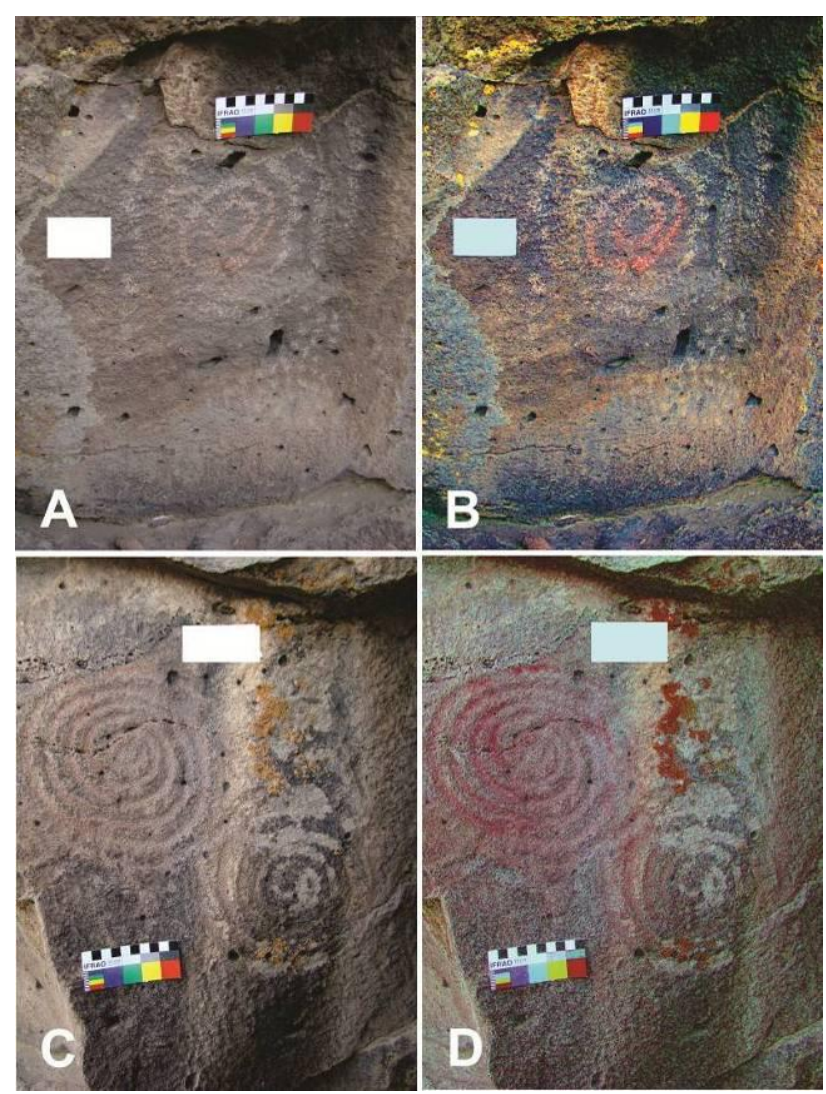

Figura 7.73. Motivos pictograbados: a. Conjunto 92; b. Tratamiento digital de la imagen ( $D$-Stretch yrd 15$)$; c. Conjunto 93 ; d. Tratamiento digital ( $D$-Stretch yrd $15)$.

Con respecto a las pátinas, a nivel del sitio predomina la no determinada seguida por la oscura y la intermedia (Figura 7.74). En los sectores 1 y 6 los 
grabados exhiben los tres grados: oscura, intermedia y clara. En el sector 1 la mayoría de los motivos presenta una pátina no determinada, seguidos por aquellos que presentan pátina oscura mientras que la proporción restante incluye motivos con pátina clara e intermedia. La preponderancia de motivos con pátina no determinada se relaciona con el estado de conservación de los mismos (Tabla 7.10). Los sectores 3, 4 y 5 presentan grabados con pátina clara, intermedia y no determinada respectivamente. En el sector 6 predominan los motivos con pátina intermedia, seguidos por aquellos con pátina no determinada y oscura (Tabla 7.10).

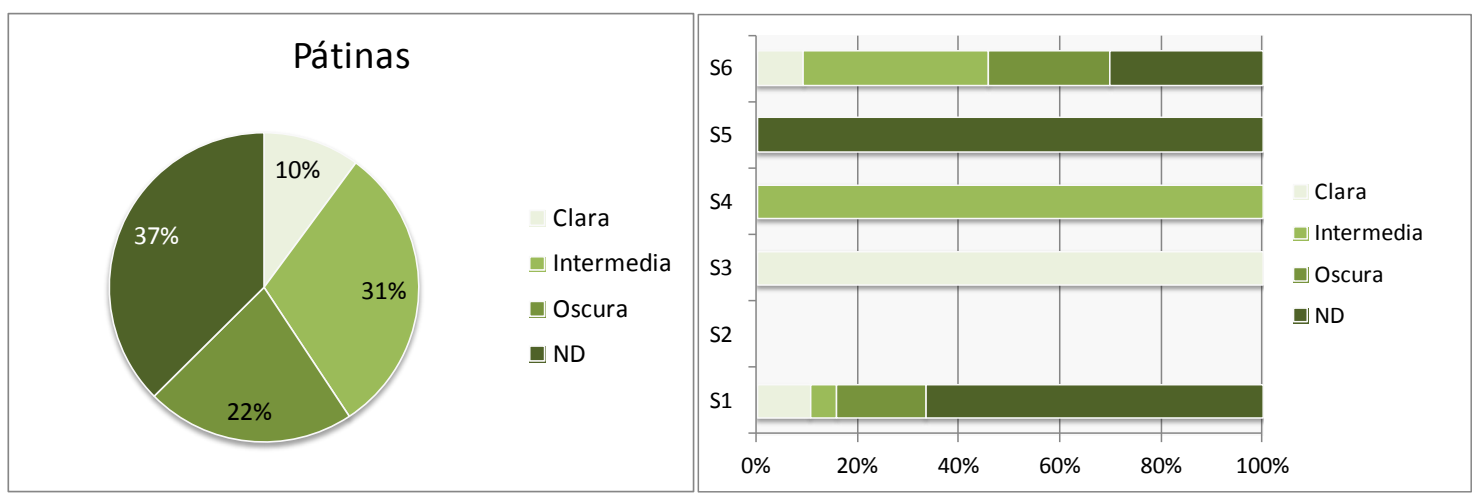

Figura 7.74. Proporciones de pátinas en Bardas de Antonio y proporciones acumuladas por sector. ND: no determinada

\begin{tabular}{|c|c|c|c|c|c|c|c|c|c|c|}
\hline \multirow{2}{*}{ Pátina } & \multicolumn{2}{|c|}{ Clara } & \multicolumn{2}{c|}{ Intermedia } & \multicolumn{2}{c|}{ Oscura } & \multicolumn{2}{c|}{ ND } & \multicolumn{2}{c|}{ Total } \\
\cline { 2 - 12 } Sector & $\mathrm{n}$ & $\%$ & $\mathrm{n}$ & $\%$ & $\mathrm{n}$ & $\%$ & $\mathrm{n}$ & $\%$ & $\mathrm{n}$ & $\%$ \\
\hline 1 & 6 & 1,68 & 3 & 0,84 & 10 & 2,80 & 38 & 10,67 & 57 & 16 \\
\hline 2 & - & - & - & - & - & - & - & - & - & - \\
\hline 3 & 4 & 1,12 & - & - & - & - & - & - & 4 & 1,12 \\
\hline 4 & - & - & 3 & 0,84 & - & - & - & - & 3 & 0,84 \\
\hline 5 & - & - & - & - & - & - & 1 & 0,28 & 1 & 0,28 \\
\hline 6 & 27 & 7,58 & 106 & 29,78 & 70 & 19,66 & 88 & 24,72 & 291 & 81,75 \\
\hline Subtotales & 37 & 10,38 & 112 & 31,46 & 80 & 22,47 & 127 & 35,67 & 356 & 100 \\
\hline
\end{tabular}

Tabla 7.10 Frecuencias y proporciones de pátinas en los distintos sectores de BA. Referencias: ND: No determinado.

A nivel de sitio, se observa que entre los motivos realizados por percusión predominan las pátinas intermedias y oscuras, seguidas por las pátinas claras y no determinadas (Tabla 7.11; Figura 7.75). Las frecuencias registradas para otras técnicas son menores a 5. Por último, entre los motivos en los que no se pudo determinar la técnica se observa que predominan aquellos en los que tampoco pudo determinarse un grado de 
pátina (Tabla 7.11). Si bien estas tendencias se observan en los sectores $1 \mathrm{y}$ 6, que presentan la mayor frecuencia de motivos, en el sector 1 la mayoría de los motivos realizados por percusión presentan pátina no determinada, seguidos por la pátina oscura y clara. En el sector 6, sin embargo, entre los motivos realizados por percusión prevalecen la pátina intermedia y oscura (Tabla 7.11).

\begin{tabular}{|c|c|c|c|c|c|c|c|c|c|c|c|c|c|c|c|c|c|}
\hline Técnica & \multicolumn{4}{|c|}{ Percusión } & \multicolumn{3}{|c|}{ Incisión } & \multicolumn{2}{|c|}{$\mathrm{R}$} & \multicolumn{2}{|c|}{$\mathrm{Pe}+\mathrm{Inc}$} & $\mathrm{Pe}+\mathrm{R}$ & Inc+R & \multicolumn{3}{|c|}{ ND } & \multirow[b]{2}{*}{ Total } \\
\hline Pátina & $\mathrm{C}$ & I & $\mathrm{O}$ & ND & I & $\mathrm{O}$ & ND & I & $\mathrm{O}$ & $\mathrm{C}$ & $\mathrm{O}$ & I & $\mathrm{O}$ & $\mathrm{I}$ & $\mathrm{O}$ & ND & \\
\hline Sector 1 & 6 & 3 & 7 & 15 & - & - & - & - & - & - & - & - & - & - & 3 & 23 & 57 \\
\hline Sector 2 & - & - & - & - & - & - & - & - & - & - & - & - & - & - & - & - & - \\
\hline Sector 3 & 4 & - & - & - & - & - & - & - & - & - & - & - & - & - & - & - & 4 \\
\hline Sector 4 & - & 3 & - & - & - & - & - & - & - & - & - & - & - & - & - & - & 3 \\
\hline Sector 5 & - & - & - & 1 & - & - & - & - & - & - & - & - & - & - & - & - & 1 \\
\hline Sector 6 & 26 & 99 & 49 & 16 & 3 & 2 & 4 & 1 & 2 & 1 & 1 & 1 & 1 & 2 & 15 & 68 & 291 \\
\hline Subtotal & 36 & 105 & 56 & 32 & 3 & 2 & 4 & 1 & 2 & 1 & 1 & 1 & 1 & 2 & 18 & 91 & 356 \\
\hline
\end{tabular}

Tabla 7.11. Distribución por sector de las técnicas de grabado reconocidas y el grado de pátina asociado. Referencias: R: raspado; Pe: percusión; Inc: incisión; ND: no determinado; C: Clara; I: intermedia; O: Oscura.

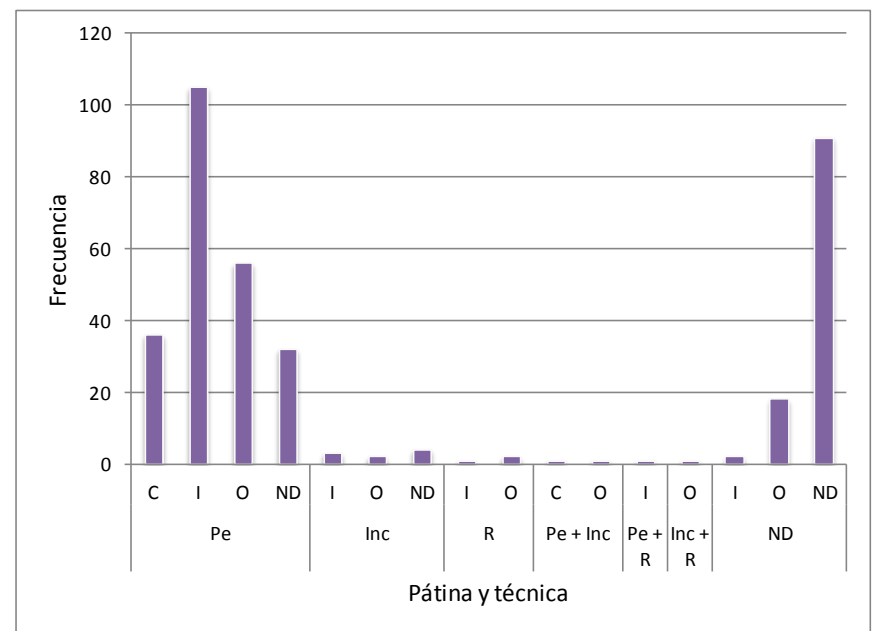

Figura 7.75. Distribución de técnica y pátina en BA. Referencias: R: raspado; P: percusión; Inc: incisión; ND: no determinado; C: Clara; I: intermedia; O: Oscura.

Sólo se observó una superposición en el Conjunto 117 del sector 6 (ver Figura 7.63.e). Se trata de una circunferencia con apéndice superpuesta a "media U invertida". Como ambos presentan pátina intermedia y la misma técnica de producción (percusión), es probable que su produccion haya sido sincrónica, o que no haya una diferencia temporal profunda entre los mismos. 
Al considerar el diseño de los motivos, en el sitio se registró un predominio de los circulares, seguidos por los rectilíneos y los puntiformes, con bajo número de motivos figurativos y no determinados. Al observar la distribución de motivos, se observa que los sectores 2 y 5 presentan motivos rectilíneos y circulares lineales respectivamente, mientras que el sector 4 presenta, además, manifestaciones puntiformes (Figura 7.76). En los sectores 1, 3 y 6 se relevaron motivos puntiformes, rectilíneos y curvilíneos, siendo que los sectores 1 y 6 además presentan motivos circulares llenos y circulares lineales. Los motivos figurativos del sitio fueron documentados solamente en el sector 6, y corresponden a pisadas de ave y felino (Figura 7.76).

Si se realiza un análisis más exhaustivo de la distribución espacial de esos subgrupos de motivos considerando diferentes clases y subclases (ver capítulo 2) se puede observar la variabilidad a nivel intrasitio. Considerando los puntiformes, rectilíneos y circulares lineales, los motivos analizados ascienden a 331. Se consideran 59 puntiformes, 130 rectilíneos y 142 circulares lineales, tanto grabados como pintados (ver Apéndice V.2.b).

Entre los motivos circulares lineales la variabilidad observada consta de 10 subclases de motivos, 9 de las cuales están presentes en el sector 6 (Figura 7.76). A nivel de sitio predominan las circunferencias concéntricas, seguidas por las circunferencias simples y los circulares no determinados, presentes en los sectores 1 y 6 . Las circunferencias agrupadas se encuentran en los sectores 5 y 6 , mientras que las circunferencias simples con punto central o con apéndice se encuentran en los sectores 1 y 6 . Las restantes categorías se observan en los diferentes sectores, presentes en cantidades inferiores a 5 motivos.

Para los motivos rectilíneos se reconocieron 11 clases. Las series de líneas rectas paralelas son las que predominan, seguidas por las líneas simples y las líneas paralelas asociadas puntiformes (Figura 7.76). Estas categorías más abundantes se distribuyen de manera similar en los sectores 1 y 6 mientras que en los sectores 2 y 3 predominan los almenados (Figura 7.76). 
Entre los motivos puntiformes se reconocieron seis clases, entre las que son abundantes los conjuntos de puntos, seguidos por los puntos y las líneas simples de puntos (Figura 7.76). En el sector 6 se reconocieron todas las categorías y se observan las tendencias generales del sitio; si bien en el sector 1 son abundantes los conjuntos de puntos, éstos son secundados por otras clases de puntiformes (Figura 7.76). Si bien pueden presentar diferente cantidad de elementos y orientación, se observa en el sitio una tendencia a la presencia de elementos simples o bien a su repetición para la conformación de conjuntos.

Referencias Figura 7.76. Línea quebr+conj de ptos: línea quebrada más línea de puntos; Líneas paralelas +puntif: serie de líneas paralelas más puntiforme; Semicircunf: semicircunferencia; circunf con pto: circunferencia con punto interior; Circunferencia+ap: circunferencia con apéndice; Circunf + trazos int + ap: Circunferencia con trazos interiores y apéndice; Circunferencias agrup: circunferencias simples agrupadas; Circunferencias conc: circunferencias concéntricas; Circunf conc + ap: circunferencia concéntrica con apéndice; Óvalo+trazos int+ap: óvalo con trazos interiores y apéndice; Espiral +ap: espiral con apéndice; Circular comb: circular lineal combinado; Circular ND: circular no determinado; Línea de ptos: línea de puntos; Líneas paralelas ptos: líneas paralelas de puntos; Circunf de ptos: circunferencia de puntos; Círculo de ptos: círculo de puntos; Conjunto de ptos: conjunto de puntos. 


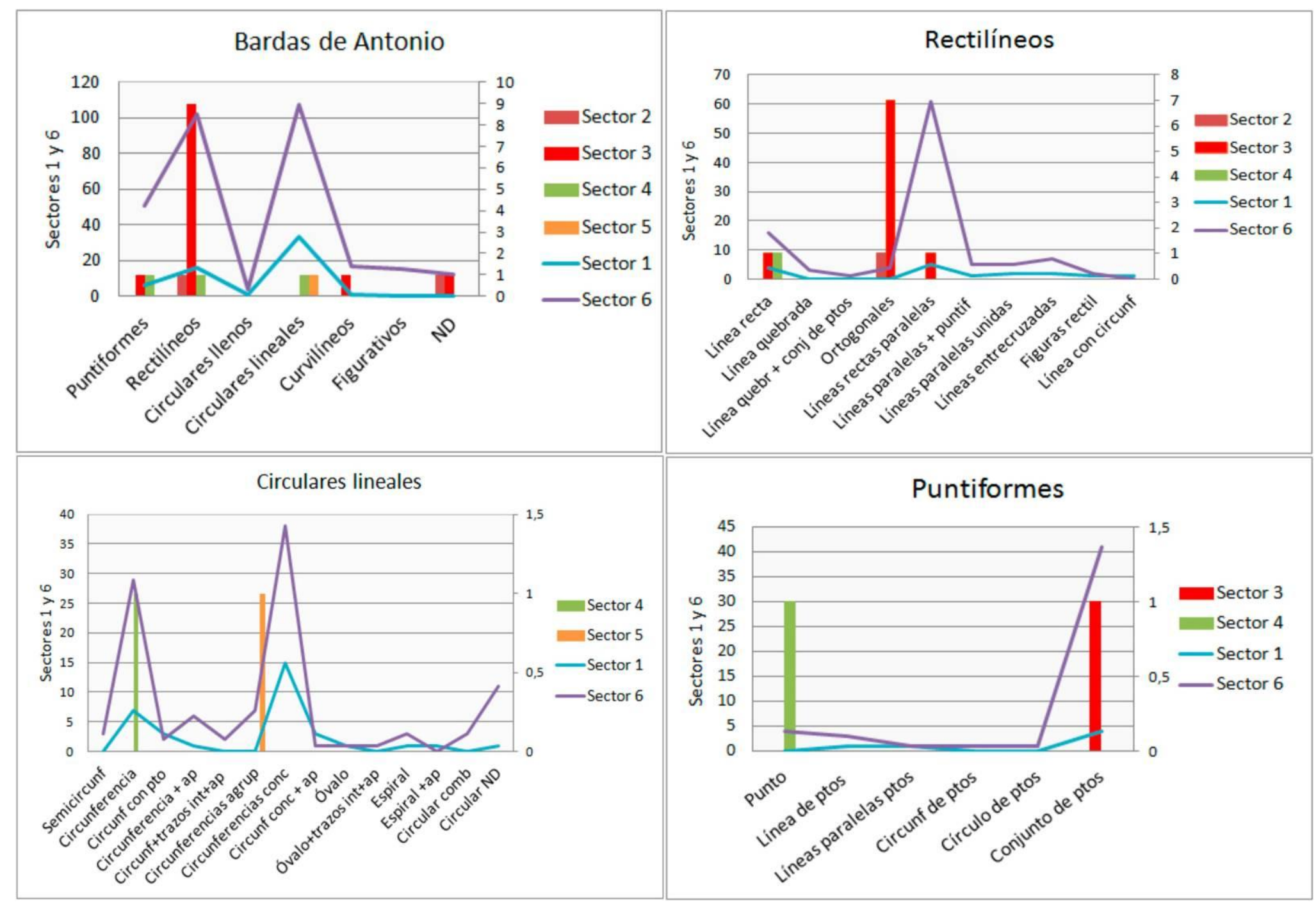

Figura 7.76. Proporciones acumuladas de subgrupos de motivos por sector en BA. 
$\mathrm{Al}$ relacionar los grados de pátina para las clases de motivos analizadas previamente para los motivos grabados, las frecuencias consideradas por clases de motivos se reducen a 309, distribuidas heterogéneamente en los sectores del sitio (Tabla 7.12). En Bardas de Antonio se observa que en las clases consideradas se registraron los tres grados de pátina, excepto para las líneas de puntos, las circunferencias con punto interior y con apéndice, las que presentan pátinas claras e intermedias. Entre los motivos circulares no determinados, que podrían corresponder a espirales o bien a circunferencias concéntricas, no se observaron motivos con pátina intermedia (Figura 7.77).

\begin{tabular}{|c|c|c|c|c|c|c|c|c|c|c|c|c|}
\hline & \multirow{2}{*}{\multicolumn{11}{|c|}{ Sector }} & \multirow{4}{*}{ Total } \\
\hline \multirow{3}{*}{ Clase de motivo/ Pátina } & & & & & & & & & & & & \\
\hline & \multicolumn{4}{|c|}{1} & \multirow{2}{*}{\multicolumn{2}{|c|}{\begin{tabular}{|c|} 
Sec \\
4 \\
I
\end{tabular}}} & \multirow{2}{*}{$\begin{array}{c}5 \\
\text { ND }\end{array}$} & \multicolumn{4}{|c|}{6} & \\
\hline & $\mathrm{C}$ & I & $\mathrm{O}$ & ND & & & & $\mathrm{C}$ & I & $\mathrm{O}$ & ND & \\
\hline Línea de puntos & 1 & - & - & - & - & - & - & 1 & 1 & - & 1 & 4 \\
\hline Conjunto de puntos & 1 & - & 2 & 1 & 1 & - & - & 7 & 20 & 7 & 7 & 46 \\
\hline Otros puntiformes & 1 & - & - & - & - & 1 & - & 1 & 4 & 2 & - & 9 \\
\hline Línea recta & - & - & - & 4 & 1 & - & - & 2 & 8 & 2 & 2 & 19 \\
\hline Líneas paralelas & - & 1 & 1 & 3 & - & - & - & 2 & 22 & 9 & 27 & 65 \\
\hline Otros rectilíneos & 1 & 2 & - & 4 & - & - & - & 3 & 4 & 8 & 4 & 26 \\
\hline Circunferencia simple & - & - & - & 7 & - & 1 & - & 3 & 8 & 13 & 5 & 37 \\
\hline Circunferencia con punto & - & - & - & 3 & - & - & - & 1 & 1 & - & - & 5 \\
\hline Circunferencia con apéndice & 1 & - & - & - & - & - & - & - & 5 & - & 1 & 7 \\
\hline Circunferencias agrupadas & - & - & - & - & - & - & 1 & - & 3 & 1 & 3 & 8 \\
\hline Circunferencias concéntricas & - & - & 6 & 9 & - & - & - & 1 & 5 & 12 & 19 & 52 \\
\hline Circular ND & - & - & - & 1 & - & - & - & 1 & - & 1- & - & 12 \\
\hline Otros circulares lineales & 1 & - & 5 & - & - & - & - & - & 4 & 3 & 4 & 17 \\
\hline Subtotales & 6 & 3 & 14 & 32 & 2 & 2 & 1 & 22 & 85 & 67 & 73 & 307 \\
\hline Totales por sector & & & 55 & & 2 & 2 & 1 & & & 47 & & 307 \\
\hline
\end{tabular}

Tabla 7.12. Frecuencias de categorías de motivos y pátina por sector. Referencias: C: clara; I: intermedia; O: oscura; ND: no determinada. 


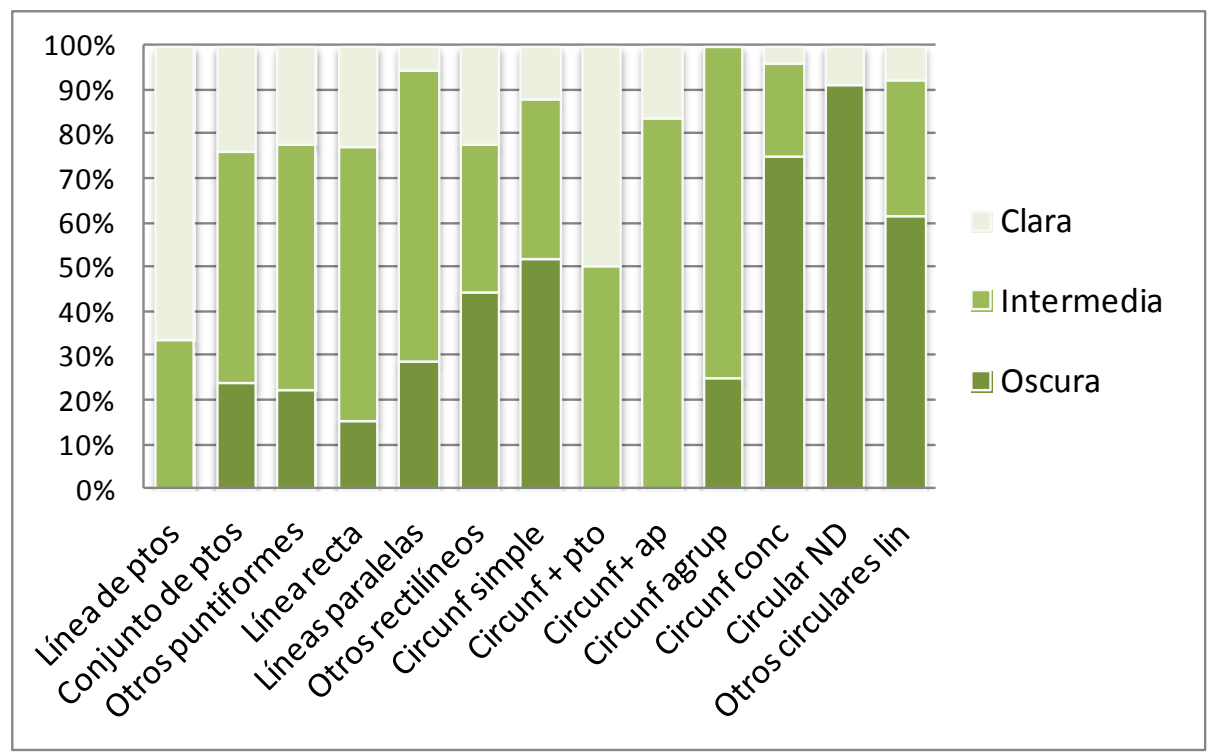

Figura 7.77. Distribución por sectores de las distintas clases de motivos y sus respectivas pátinas, sin considerar las pátinas no determinadas. Referencias: Circunf simple: circunfencia simple; circunf+pto: circunferencia con punto interior; Circunf+ap: circunferencia con apéndice; Circunf agrup: circunferencia agrupada; Circunf conc: circunferencia concéntrica; Circular ND: circular no determinado; Otros circulares lin: otros circulares lineales.

A partir de lo anterior, podría pensarse que los motivos puntiformes, rectilíneos y circulares lineales fueron realizados en diferentes momentos ya que hay clases que presentan los tres grados de pátina. Asimismo, las líneas de puntos, las circunferencias con punto interior y con apéndice serían de factura más reciente ya que no presentan pátina oscura. Esta secuencia implica una continuidad temporal en la producción de algunos motivos y un aumento en la frecuencia de producción de imágenes grabadas, que continuaron realizándose a lo largo del tiempo, con excepción de los motivos circulares planos, de los cuales no hay ejemplares de pátina clara.

Respecto de los motivos figurativos, en Bardas de Antonio este grupo está representado por 15 pisadas de animales, todas ellas documentadas en el sector 6. Se trata de pisadas de felino y de ave. Las pisadas de felino ascienden a cinco, tres de ellas presentan cuatro dedos alrededor del punto central (tipo A), mientras que las restantes presentan seis dedos (tipo E) (Figura 7.78). Teniendo presentes los planteos efectuados en los Capítulos 2 y 6, se puede 
observar que en Bardas de Antonio, las pisadas de ave más frecuentes corresponden a los tipos B y E (Tabla 7.13; Figura 7.78).

\begin{tabular}{|c|c|c|c|c|}
\hline Tipo & Conjunto & $\mathrm{N}$ & Total & $\%$ \\
\hline A & 86 & 1 & 1 & 10 \\
\hline \multirow{3}{*}{ B } & 52 & 1 & \multirow{3}{*}{3} & \multirow{3}{*}{30} \\
\hline & 87 & 1 & & \\
\hline & 98 & 1 & & \\
\hline $\mathrm{C}$ & 87 & 1 & 1 & 10 \\
\hline \multirow{2}{*}{ D } & 98 & 1 & \multirow{2}{*}{2} & \multirow{2}{*}{20} \\
\hline & $124 \mathrm{E}$ & 1 & & \\
\hline \multirow{2}{*}{$\mathrm{E}$} & 98 & 1 & \multirow{2}{*}{3} & \multirow{2}{*}{30} \\
\hline & 146 & 2 & & \\
\hline & Total & & 10 & $100 \%$ \\
\hline
\end{tabular}

Tabla 7.13. Frecuencia de los tipos de pisadas de ave en Bardas de Antonio.

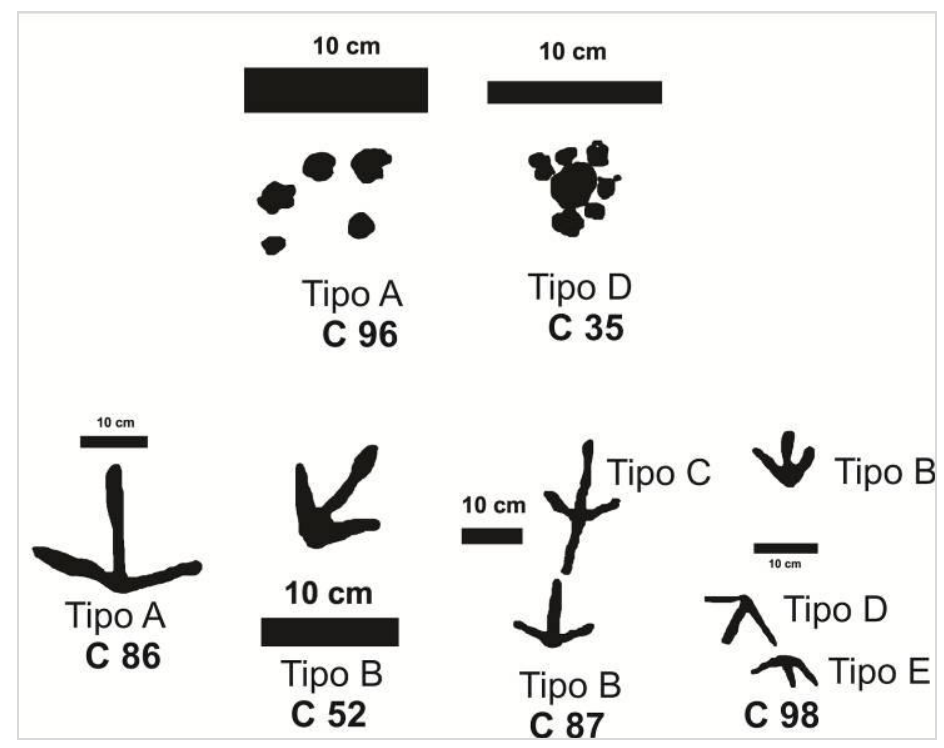

Figura 7.78. Tipos de pisadas de aves de Bardas de Antonio.C: conjunto.

Los motivos rupestres de Bardas de Antonio manifiestan las siguientes características:

1) se realizaron mediante las técnicas de pintura, grabado y pictograbado. $\mathrm{Si}$ bien en escasa proporción, los motivos pintados se corresponden principalmente a diseños rectilíneos. Entre los grabados, la técnica empleada con mayor frecuencia es la percusión, aunque se identificaron en bajo número motivos incisos, raspados y realizados mediante la combinación de dichas técnicas. Un punto a destacar es que Bardas de Antonio es el único sitio presentado en esta tesis con motivos pictograbados. 
2) en cuanto a su diseño, los motivos más abundantes son los circulares lineales (37\%), seguidos por los rectilíneos (35\%) y los puntiformes (15\%). Entre los circulares lineales son abundantes las circunferencias concéntricas y simples, en tanto que entre los rectilíneos predominan las series de líneas rectas paralelas y las líneas simples. Algo similar ocurre entre los puntiformes, donde predominan los conjuntos de puntos seguidos en frecuencia por los puntos simples. Si bien pueden presentar diferente cantidad de elementos y orientación, se observa en el sitio una tendencia a la presencia de elementos simples o bien a su repetición para la conformación de conjuntos.

3) la formación de la pátina es producto, entre otros factores, del tiempo transcurrido desde la producción del motivo (Keyser 2001; Re 2011), por lo que la presencia en Bardas de Antonio de motivos con diferente grado de pátina podría estar señalando diferentes momentos de producción de los grabados, y un uso recurrente a lo largo del tiempo del sitio. Hacia momentos tardíos la frecuencia de producción de grabados sería menor ya que los motivos con pátina clara ascienden al 10\%, mientras que aquellos que presentan pátina intermedia y oscura alcanzan el 50\%. Sin embargo, hay que tener presente que los motivos con pátina no determinada llegan al 35\% aproximadamente. Esta situación está en estrecha relación con los factores tafonómicos que afectan a los motivos.

Si a lo anterior se suma el diseño de los motivos, se reconocería un primer momento en el que los motivos circulares lineales y rectilíneos (con pátina oscura) habrían sido los más abundantes. A un segundo momento corresponde la misma variabilidad de motivos, representada por grabados de pátina intermedia, con un aumento en la producción de los rectilíneos y una disminución en la producción de los circulares lineales (Blanco et al. 2013). Esta secuencia implica una continuidad temporal en la producción de algunos motivos y un aumento en la frecuencia de producción de imágenes grabadas, que continuaron realizándose a lo largo del tiempo, con excepción de los motivos circulares planos, de los cuales no hay ejemplares de pátina clara. 
4) entre los motivos grabados se detectó una sola superposición, en el conjunto 117. Probablemente corresponda a un único momento de producción ya que los motivos reconocidos presentan pátina y técnica de producción similar.

5) En cuanto al estado de conservación de los motivos, algunos se encuentran cubiertos total o parcialmente por líquenes (ver Figuras 7.43 y 7.50) o bien sobre superficies altamente exfoliadas (Figuras 7.45 y 7.59 ) en los sectores 1 y 6.

Considerando esos factores (técnica, pátina y superposiciones), se podría pensar en diferentes momentos de producción de los motivos grabados en Bardas de Antonio, particularmente a partir de los diferentes grados de pátina reconocidos, ya que sólo se registró una superposición. Los grabados habrían sido producidos en diferentes momentos por gente que compartía los mismos códigos de representación de las imágenes (concordancia de diseño). Esta situación se observa de modo más claro en los sectores 1 y 6 , que presentan una alta frecuencia y variabilidad de motivos, donde se repiten los circulares lineales y las líneas. Por otro lado, los motivos pintados de los sectores 2,3 y 6 podrían haber sido realizados más recientemente debido a la menor resistencia de la pintura a las condiciones climáticas. Es decir, que habría una diacronía entre la producción de motivos rupestres mediante diferentes técnicas (grabado, pintura), ya que cada una involucra diferentes tipos de motivos.

En cuanto al contexto arqueológico de la localidad, el arte rupestre de Bardas de Antonio se relaciona con loci de actividades limitadas -laboreo de cuero y observación de personas y animales (Terranova 2012)-. Las prospecciones realizadas no permitieron el anclaje cronológico del arte rupestre de Bardas de Antonio, ya que no se realizaron sondeos ni se recuperaron otros elementos que permitan anclarlo. Por lo anterior, la profundidad cronológica del mismo puede plantearse empleando las propuestas efectuadas para otros sitios de Patagonia.

En Bardas de Antonio se observan motivos pintados que podrían ser incluidos dentro del repertorio del "estilo de grecas" (Menghin 1957) o de la 
Tendencia Abstracto-Geométrica Compleja (Gradin 1987). Los motivos grabados se atribuyen la Tendencia Representativa Esquemática -estilo de pisadas" de Menghin (1957)-, ya que se observan motivos circulares lineales, curvilíneos y rectilíneos asociados a rastros de animales. Por lo anterior, y contemplando las propuestas para áreas vecinas (ver Capítulo 4), la cronología para el arte rupestre de Bardas de Antonio se remontaría al Holoceno tardío (ca. 2.800 años AP) siendo que los motivos pintados podrían haber sido realizados a partir de 1.250 años AP (Fernández et al. 2013; Gradin 2003b).

\section{7. e. EL ARTE RUPESTRE DEL SECTOR NORIENTAL}

Los sitios presentados en esta parte del capítulo se encuentran en el oriente del macizo somuncurense, sobre bardas basálticas de la Formación Somun Curá que rodean a distintas cuencas lagunares. Dichas lagunas pueden presentar agua actualmente o bien pequeñas surgentes que funcionan como atractores de la fauna local (ver Figuras 7.2 y 7.19).

Los contextos arqueológicos asociados a los sitios con arte rupestre permiten ver a las manifestaciones rupestres como parte de un paisaje pensado, como un constructo social, en el que se emplearon recursos ecológicos disponibles en estos ambientes lagunares y en los que, además, se desarrollaron prácticas sociales y simbólicas, tejiendo así un entramado de significados para las poblaciones que los ocuparon (Anschuetz et al. 2001; Criado Boado 1999; Curtoni 2011). El uso y la ocupación del paisaje contribuyó jerarquizar determinados lugares en detrimento de otros (Alberti 2001; Curtoni 2011).

En el caso de Laguna Azul, las primeras informaciones dan cuenta de diferentes estructuras de piedra en la margen septentrional (Gradin 1971), a las que hay que adicionar un gran sitio de superficie con secuencias de talla alrededor de 150-200 m al norte de los parapetos antes mencionados, mientras que en la margen meridional se observaron estructuras de piedra adicionales, 
una vena de ocre y diferentes hallazgos arqueológicos en superficie. Por otro lado, en Laguna El Ganso se detectó evidencia similar a la Laguna Azul, aunque el material en superficie es escaso (Miotti et al. 2008, 2011b). Por último, en Laguna La Maciega, donde se encuentra el sitio Bardas de Antonio, sucede algo similar: se registraron parapetos y materiales en superficie a lo que se adicionan el hallazgo de restos óseos humanos en el cañadón tributario septentrional (Terranova 2012). Quizás sea esta recurrencia -lagunas, arte rupestre, parapetos, grandes sitios de superficie- esté señalando la manera en que las sociedades cazadoras-recolectoras que ocuparon el NE de Somuncurá le dieron significación a los espacios, transformándolos en paisajes pensados.

Si se comparan los sitios documentados, se observa que Bardas de Antonio presenta la mayor cantidad de motivos, seguido por Laguna El Ganso y los sitios de Laguna Azul (Tabla 7.14). En estos últimos predominan los motivos rectilíneos al igual que en Laguna El Ganso mientras que en el sitio Bardas de Antonio predominan los motivos circulares lineales (Figura 7.79).

\begin{tabular}{|l|c|c|c|c|c|c|}
\cline { 2 - 8 } \multicolumn{1}{c|}{} & \multicolumn{7}{c|}{ Sitios } \\
\hline \multicolumn{1}{c|}{ Motivos } & LA 1-4 & $\%$ & LEG & $\%$ & BA & $\%$ \\
\hline $\mathrm{n}$ & 32 & 100 & 92 & 100 & 383 & 100 \\
\hline Puntiformes & 2 & 6,25 & 14 & 15,21 & 59 & 15,40 \\
\hline Rectilíneos & 19 & 59,37 & 35 & 38,04 & 129 & 33,68 \\
\hline Circulares llenos & - & - & 2 & 2,17 & 5 & 1,30 \\
\hline Circulares lineales & 2 & 6,25 & 7 & 7,61 & 142 & 37,07 \\
\hline Curvilíneos & 2 & 6,25 & 19 & 20,65 & 19 & 4,96 \\
\hline Figurativos & 1 & 3,12 & 8 & 8,69 & 15 & 3,91 \\
\hline ND & 6 & 18,75 & 7 & 7,61 & 14 & 3,66 \\
\hline
\end{tabular}

Tabla 7.14. Frecuencias y proporciones de motivos reconocidos en los sitios. Referencias: LA: Laguna Azul; LEG: Laguna El Ganso; BA: Bardas de Antonio. 


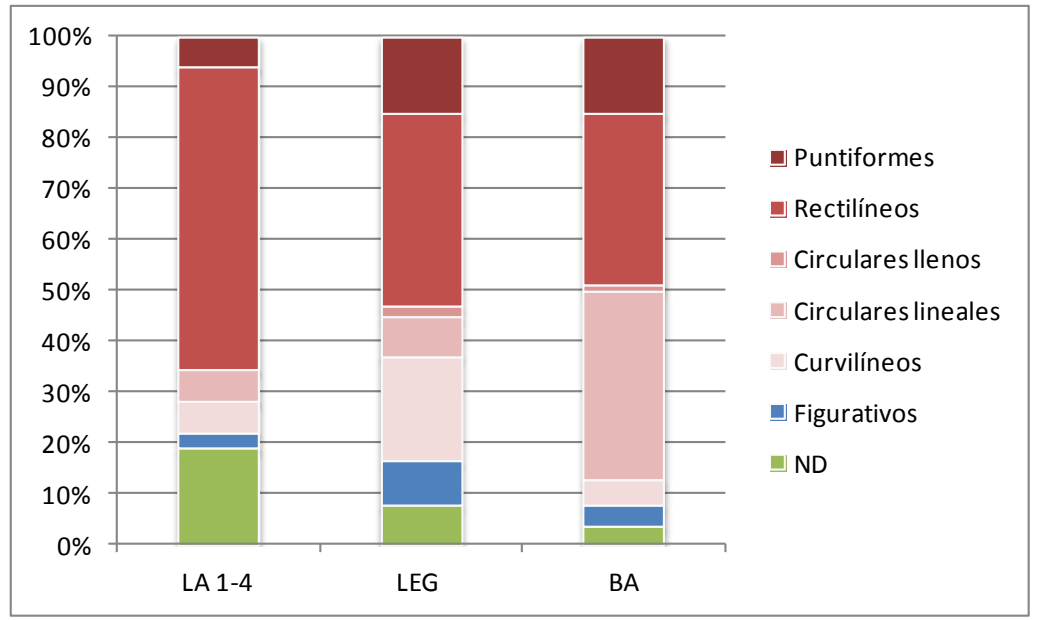

Figura 7.79. Proporciones acumuladas de subgrupos de motivos reconocidos en los sitios del sector noreste. Referencias: LA: Laguna Azul 1-4; LEG: Laguna El Ganso;

BA: Bardas de Antonio.

Asimismo, al considerar en conjunto los atributos presentados a lo largo de este capítulo, se pueden vislumbrar las diferencias y las similitudes entre los sitios del oriente de Somuncurá (Tabla 7.15). En todos los sitios predominan los motivos no figurativos, los figurativos se documentaron es bajas proporciones, siendo que Laguna Azul corresponde a un artefacto, en Laguna El Ganso a un zoomorfo esquemático y a pisadas de animales; mientras que en Bardas de Antonio solamente se observaron pisadas de animales. En cuanto al diseño, en Laguna Azul y El Ganso predominan los motivos rectilíneos y en Bardas de Antonio los circulares lineales. Respecto de las técnicas Laguna Azul presenta motivos pintados, Laguna El Ganso grabados, en tanto que Bardas de Antonio presenta motivos grabados, pintados y pictograbados. En este último sitio es el que presenta los tres grados de pátina reconocidos aunque tienen predominio los motivos con pátina no determinada, en tanto que Laguna El Ganso presenta motivos con pátina clara e intermedia. Esta información permite pensar en una mayor profundidad temporal para Bardas de Antonio y de su uso recurrente en el pasado, por lo que estaría señalando su importancia en relación a los otros sitios.

Las condiciones de emplazamiento y visibilidad son similares: los motivos se encuentran sobre superficies basálticas, en algunos casos reparadas y al 
interior de pequeños aleros, que pueden estar afectadas por la acción de líquenes o de agua. La visibilidad de los motivos es intermedia o baja, lo que se relaciona con su estado actual de conservación. Probablemente, en el pasado algunos motivos circulares de gran tamaño fueran altamente visibles en Bardas de Antonio.

\begin{tabular}{|c|c|c|c|}
\hline & \multicolumn{3}{|c|}{ Sitios } \\
\hline Atributos & LA $1-4$ & LEG & BA \\
\hline Fig vs. No fig. & $\begin{array}{l}\text { Predominio no } \\
\text { figurativos y sólo } 1 \\
\text { figurativo } \\
\text { (artefacto). }\end{array}$ & $\begin{array}{l}\text { Predominio no } \\
\text { figurativos, } 9 \% \\
\text { figurativos ( } 1 \\
\text { zoomorfo } \\
\text { esquemático y } 8 \\
\text { pisadas de animales) }\end{array}$ & $\begin{array}{l}\text { Predominio de no } \\
\text { figurativos, figurativos } \\
5 \% \text { que corresponden } \\
\text { a pisadas de animales }\end{array}$ \\
\hline Diseño & $\begin{array}{l}\text { Predominio de } \\
\text { motivos rectilíneos }\end{array}$ & $\begin{array}{l}\text { Predominio de } \\
\text { motivos rectilíneos, } \\
\text { abundancia de } \\
\text { curvilíneos y } \\
\text { puntiformes. }\end{array}$ & $\begin{array}{l}\text { Abundancia de } \\
\text { motivos circulares } \\
\text { lineales, abundancia } \\
\text { de rectilíneos y } \\
\text { puntiformes. }\end{array}$ \\
\hline Técnica & Pintura & $\begin{array}{l}\text { Grabado (percusión, } \\
\text { incisión y raspado) }\end{array}$ & $\begin{array}{l}\text { Pintura, grabado } \\
\text { (percusión, incisión y } \\
\text { raspado) y } \\
\text { pictograbado }\end{array}$ \\
\hline Pátina & - & $\begin{array}{l}\text { Predominio de pátina } \\
\text { clara e intermedia }\end{array}$ & $\begin{array}{l}\text { Tres grados de pátina, } \\
\text { aunque predominan } \\
\text { motivos con pátina } \\
\text { ND. }\end{array}$ \\
\hline Superposiciones & No hay. & $\begin{array}{l}\text { Mínimas, incisiones } \\
\text { caóticas sobre } \\
\text { motivos por } \\
\text { percusión. }\end{array}$ & Sólo 1. \\
\hline Emplazamiento & $\begin{array}{l}\text { En el cañadón de } \\
\text { acceso a la laguna, } \\
\text { al interior de } \\
\text { espacios reparados } \\
\text { de la barda } \\
\text { basáltica. }\end{array}$ & $\begin{array}{l}\text { En paredones } \\
\text { basálticos que rodean } \\
\text { a laguna, en algunos } \\
\text { casos en espacios } \\
\text { reparados. }\end{array}$ & $\begin{array}{l}\text { En cañadón tributario } \\
\text { de laguna, sobre barda } \\
\text { basáltica, en algunos } \\
\text { casos en espacios } \\
\text { reparados. }\end{array}$ \\
\hline Formación & & Somun Curá & \\
\hline Orientación & NE, N y SW & $\mathrm{Ny} \mathrm{E}^{*}$ & SW y NE * \\
\hline $\begin{array}{l}\text { Visibilidad de los } \\
\text { conjuntos }\end{array}$ & Intermedia a baja & Intermedia y baja & $\begin{array}{c}\text { Alta, intermedia y } \\
\text { baja }\end{array}$ \\
\hline $\begin{array}{l}\text { Altura de los } \\
\text { motivos respecto } \\
\text { del suelo }\end{array}$ & $0-\geq 2 \mathrm{~m}$ & $<1,50 \mathrm{~m}$ & $0-\geq 2 \mathrm{~m}$ \\
\hline
\end{tabular}

Tabla 7.15. Comparación de los sitios considerados en el noreste de Somuncurá. * Para la mayoría de las superficies. 


\section{Capítulo 7}

\section{Parte 2. Centro-occidente de Somuncurá}

En esta sección se presentan los sitios con arte rupestre y los registros de materias primas colorantes realizados en los sectores IV y VI del macizo de Somuncurá, lo que corresponde con su porción Centro-occidental (Figuras 7.1 y 7.80). En los sitios Cueva Martel, Peñón del Pueblo 1 y 2 , Alero Amigo Oeste, La Porfía y Vacalauquén se documentaron motivos pintados, mientras que en Cañadón Martel y las localidades arqueológicas Los Dos Amigos, Tapera de Isidoro, La Porfía y Vacalauquén se registraron materias primas colorantes en diferentes formas de presentación.

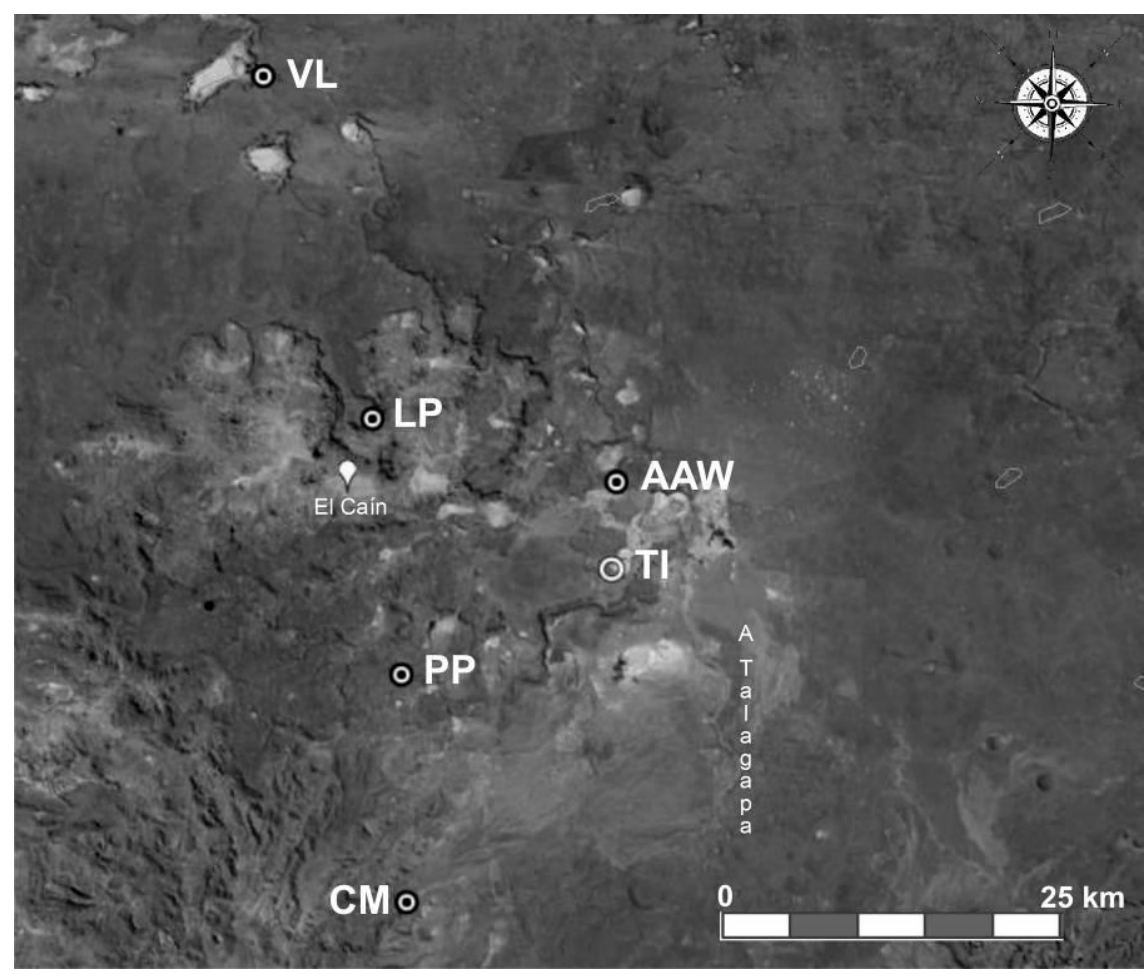

Figura 7.80. Ubicación de los sitios considerados en esta sección.

Referencias: LP. La Porfía; AAW: Alero Amigo Oeste; TI: Tapera de Isidoro; CM:

Cañadón Martel; PP: Peñón del Pueblo; VL: Vacalauquén; A Talagapa: arroyo Talagapa. 


\section{7. f. LA PORFÍA}

Durante los trabajos de campo de febrero de 2011 recibimos información de los pobladores de El Caín sobre la presencia de pinturas rupestres en la estancia Quiri Hue. El sitio La Porfía se encuentra en $41^{\circ} 37^{\prime}$ 'S y $68^{\circ} 8^{\prime} \mathrm{W}$, alrededor de $6 \mathrm{~km}$ al NW de la localidad El Caín. Está ubicado en el fondo de un pequeño cañadón al margen de un camino rural subsidiario a la ruta provincial $\mathrm{N}^{\circ} 5$. Dicho camino recorre la meseta y se une a la ruta provincial $\mathrm{N}^{\circ}$, que conduce a Los Menucos a través de Prahuaniyeu.

Este cañadón tiene una orientación NW-SE y es de escasa extensión, abarcando aproximadamente unos $250 \mathrm{~m}$ (Figura 7.81.a). Las rocas que lo conforman pertenecen a la formación Cerro Cortado (Remesal et al. 2001). Son basaltos de color gris fuertemente colonizados por líquenes, relacionado esto último a una percolación de agua y una surgente existente hacia el fondo y al pie de las paredes del cañadón (Figura 7.81.b). Las superficies basálticas presentan un grado avanzado de exfoliación (Figura 7.81.c). En la entrada del cañadón se observa un pequeño curso de escurrimiento temporario, varios ejemplares de sauce (Salix sp) y los restos de antiguas viviendas (Figuras 7.82.a y 7.82.b). Desde donde se encuentran los motivos rupestres sólo pueden observarse los árboles, aunque si consideramos que los mismos crecieron en tiempos relativamente recientes, es posible que desde el fondo del cañadón haya podido divisarse buena parte del Cerro Anekén, el que se observa actualmente desde el borde de la arboleda (Figura 7.82.c). En las inmediaciones de este cerro se han registrado materiales líticos y venas de materias primas que permitieron definir una cantera (Terranova 2009, 2013; Miotti et al. 2004). 

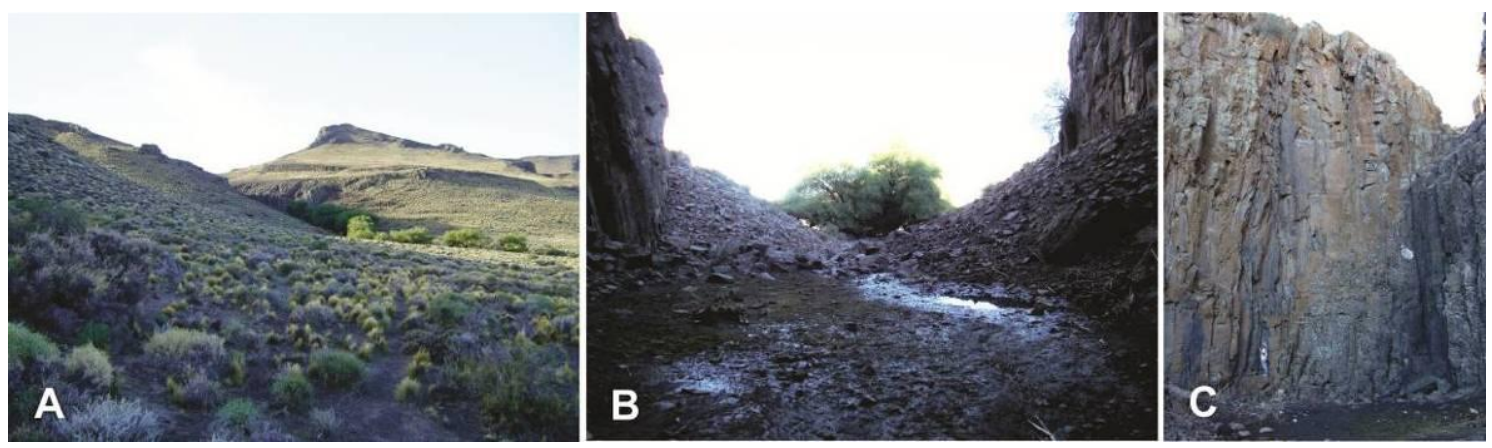

Figura 7.81. Paisaje del cañadón La Porfía: a. Cañadón al costado de camino rural;

b. Surgente del fondo del cañadón; c. Paredones colonizados por líquenes.
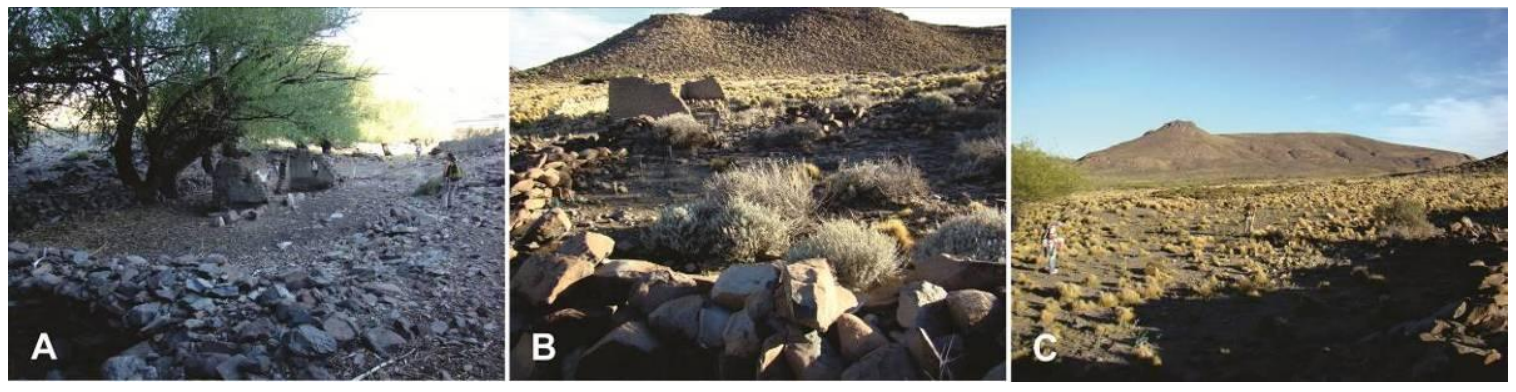

Figura 7.82. Instalaciones humanas y paisaje: a y b. Restos de viviendas (tapera) y estructuras de piedra; c. vista del cerro Anekén desde el borde de la arboleda.

\section{7. f. 1. Otros contextos arqueológicos}

Sumado a la presencia de los restos de vivienda se observan dos estructuras de piedra que pudieron haber sido usadas como corrales para ganado (Figura 7.82.b). De igual manera, se realizaron hallazgos de materias primas colorantes en superficie, distribuidos en dos sectores. Hacia el norte de la entrada al cañadón, sobre una pequeña cárcava de escorrentía superficial se observaron fragmentos de de ocre rosado, distinto tamaño (Figura 7.83), y hacia el sur se recuperó un fragmento de materia prima colorante de color amarillo. 


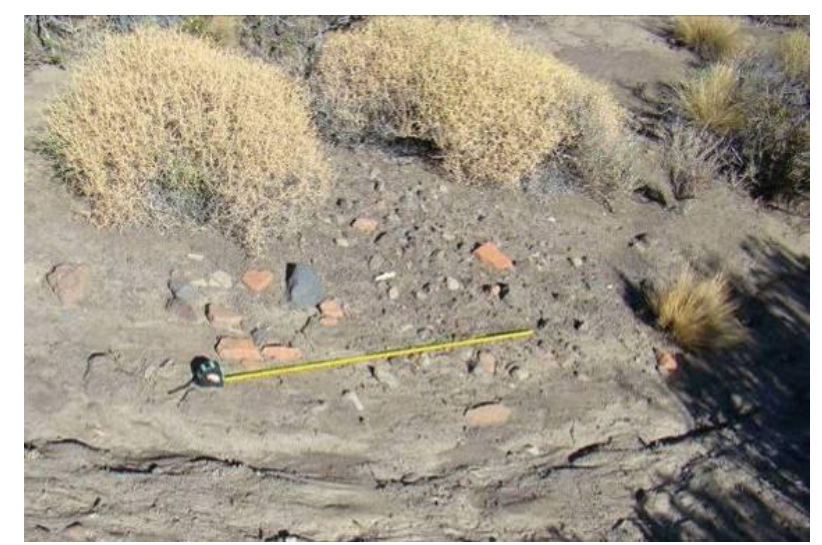

Figura 7.83. Acumulación de materia prima colorante al norte de Cañadón La Porfía.

\section{7. f. 2. El arte rupestre de La Porfía}

Los motivos pintados en color rojo se encuentran sobre la superficie libre de líquenes de la pared SW. Dada la cobertura de líquenes observada en el cañadón, resulta imposible saber si, a excepción del sector con manifestaciones, se emplearon otras superficies adicionales para plasmar motivos. Éstos se encuentran a alturas variables respecto del suelo: a aquellos registrados por encima de los $2 \mathrm{~m}$ se accede mediante un escalón natural de la roca (ver Figura 7.81.c).

Conjunto 1. Se encuentra en el punto meridional de la pared, a alturas que oscilan entre 1,23 y $1,40 \mathrm{~m}$ respecto del suelo actual, sobre una superficie vertical orientada al NNE. Está conformado por dos motivos: trazos rectilíneos asociados a una circunferencia con trazos cortos rectos en su interior y un motivo no determinado (Figuras 7.84.a-b). Ambos motivos se encuentran muy desvaídos. La parte inferior del motivo identificado está cubierta por líquenes.

Motivo 2. Se encuentra sobre una superficie vertical orientada al NNE, a 2,39 m respecto del suelo. El motivo en color rojo, está conformado por dos circunferencias simples unidas por un pequeño trazo, que presentan cruces en su interior (Figuras 7.84.c-d). Éstas presentan tamaño similar aunque no son idénticas: la diferencia entre ambas se debe a que la inferior presenta un pequeño trazo recto que une la circunferencia y la cruz interior. El estado 
de conservación de este motivo es malo, principalmente debido al proceso de exfoliación que lo afecta.

Conjunto 3. Se encuentra a 3,18 m respecto del suelo actual, sobre una superficie vertical orientada al este, separada de la anterior por una gran grieta. Está integrado por una pequeña línea recta vertical asociada a un escalonado y grecas (Figuras 7.84.e-f). Este conjunto se encuentra parcialmente afectado por la presencia de líquenes.

\section{7. f. 3. Análisis}

La visibilidad de estos motivos es muy baja por su estado de conservación, la falta de contraste entre la pintura y el soporte, a lo que se le suma la colonización de líquenes: es necesario estar frente a ellos -1 m de distanciapara poder distinguirlos (Figura 7.84). Entre los subgrupos de motivos reconocidos en La Porfía se mencionan los rectilíneos, los circulares lineales asociados a rectilíneos y motivos no determinados (Tabla 7.16). Resultan novedosas las circunferencias con cruces internas, motivo que no había sido registrado en el macizo hasta el momento. En cambio, las grecas o almenados son más frecuentes (ver Capítulo 4). Todos estos motivos, incluidos los trazos rectos paralelos (dígitos) podrían corresponderse a la Tendencia Abstracto-Geométrica Compleja (Gradin 1987, 1999), que tiene sus comienzos hacia los 1.250-750 años AP.

La técnica de producción de estos motivos podría corresponderse a la técnica digital para los trazos rectos asociados a la circunferencia (Conjunto 1), mientras que para las circunferencias con cruces interiores podría haberse empleado algún tipo de artefacto, sin poder proponer, por el momento, algún tipo artefactual particular (Figura 7.84). Por el grado de cobertura de líquenes que presenta los motivos ortogonales, no se pudo inferir una técnica de producción. 


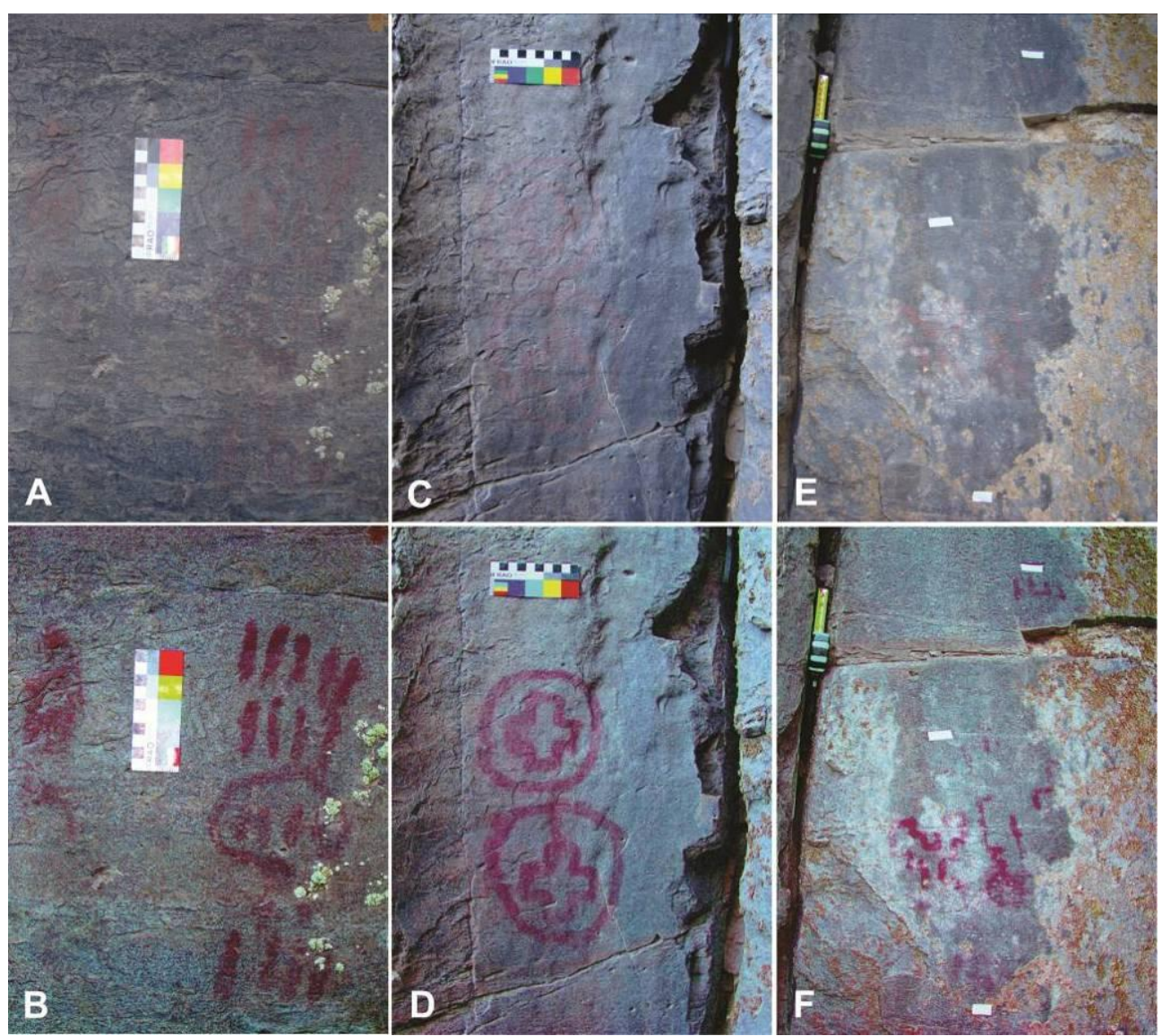

7.84. Motivos de La Porfía: a. Conjunto 1; b. imagen tratada digitalmente (DStretch yrd 15); c. Motivo 2; d. imagen tratada digitalmente (D-Stretch yrd 15); e. Conjunto 3; f. imagen tratada digitalmente (D-Stretch yrd 15).

\section{7. g. ALERO AMIGO OESTE}

Este sitio se encuentra a los $41^{\circ} 39^{\prime} \mathrm{S}$ y $67^{\circ} 55^{\prime} \mathrm{W}$, a $20 \mathrm{~km}$ al ENE de la comuna rural El Caín, dentro de lo que fuera definido como localidad arqueológica Los Dos Amigos (Miotti 2010b; Miotti et al. 2004, 2011a). Dicha localidad recibe su denominación por la geoforma homónima en la que se emplaza, constituida por dos cerros testigos: Amigo Oeste (AW de aquí en adelante) y Amigo Este (Figura 7.85). 


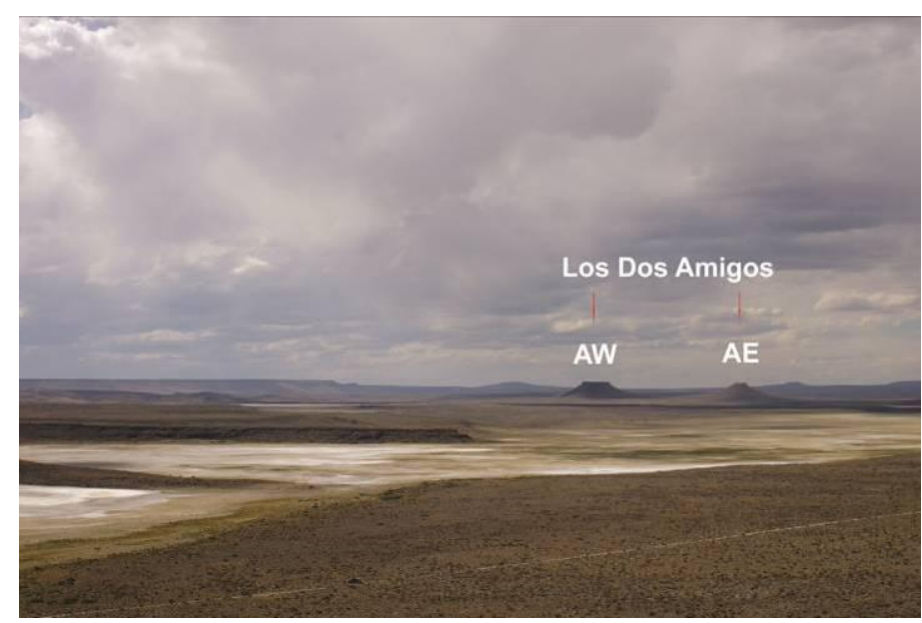

7.85. Vista de Los Dos Amigos desde el SW.

Referencias: AW: Amigo Oeste; AE: Amigo Este.

La corona basáltica de estos cerros testigos está conformada por basaltos olivínicos de la formación Complejo Volcánico Barril Niyeu (CVBN), que pueden presentar superficies regulares o bien tener aspecto vesicular, de color gris a marrón oscuro. Subyaciendo a los basaltos se encuentran rocas sedimentarias del Grupo Sarmiento (Remesal et al. 2001). Estas fueron afectadas térmicamente por el emplazamiento de la colada basáltica, por lo que el techo de las últimas corresponde a sedimentitas de coloración rojiza a rosada (7.87.a). El Cerro AW presenta un alero y un espacio reparado al pie de su corona basáltica: el primero orientado al este -donde se documentó un motivo rupestre- (Figura 7.86.a), el segundo orientado hacia el SSW.

El dominio visual que se tiene desde Los Dos Amigos es de $360^{\circ}$ : se pueden observar las planicies y mesetas del norte (Figura 7.86.b); la laguna de Las Vacas, el campo de caza histórico o Yamnagoo que se encuentra al S de dicha laguna (Boschin y del Castillo Bernal 2005; Claraz 1988; Miotti et al. 2004), parte de la sierra del Tromen Niyeu, los Dos Hermanos y las estribaciones occidentales de las Sierras de Apas hacia el S (Figura 7.86.c). Hacia el este, el borde de la "Meseta Alta", y hacia el oeste la Sierra del Tromen Niyeu y algunas de las estribaciones septentrionales de las Sierras de Chatchauñieu. Algunos de esos puntos altos pueden ser tomados como hitos de referencia en el paisaje. Ese dominio visual no es sólo del paisaje, también incluye la observación de personas y animales, hecho que llevó a interpretarlo como un punto de avistaje y de importancia para la caza 
durante la transición Pleistoceno final/Holoceno temprano (Miotti y Terranova 2010, 2014).

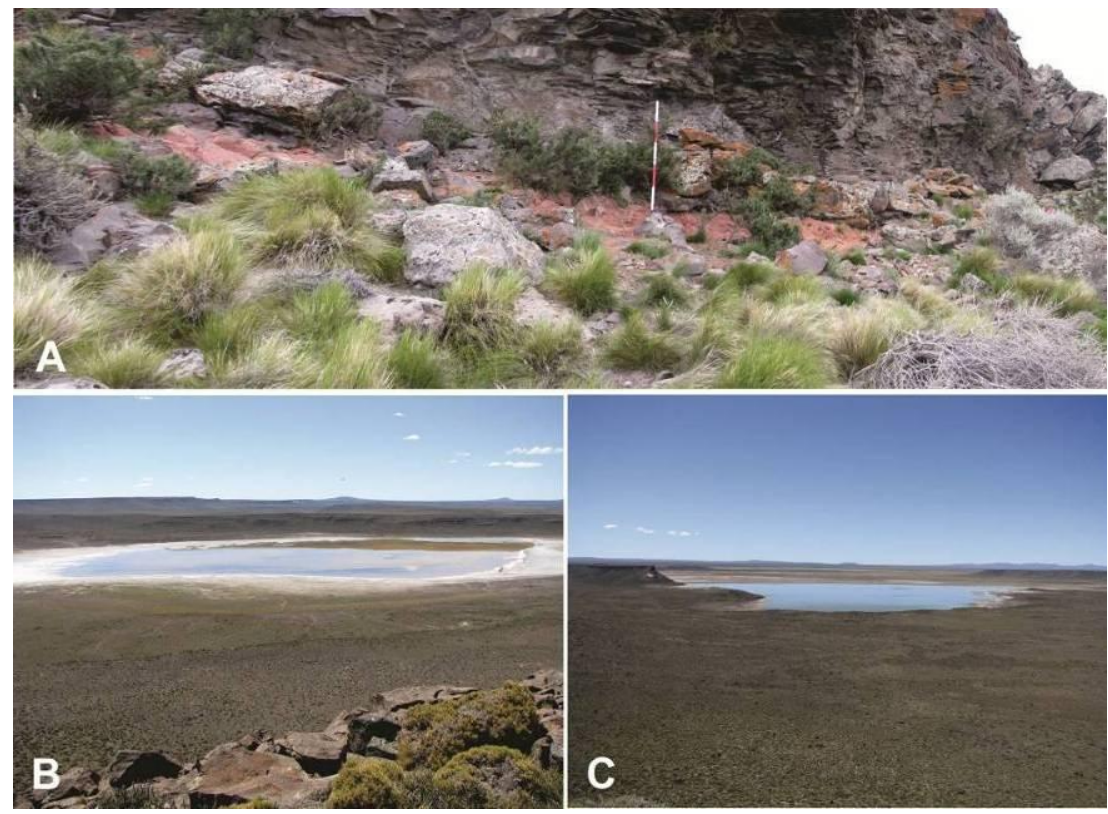

Figura 7.86. Alero Amigo Oeste: a. vena de materia prima colorante sobre la que se emplaza el alero; b. Vista al norte desde la cima de AW; c. Vista hacia el ESE

desde la cima de AW. Hacia el fondo de la imagen pueden observarse las estribaciones de la Sierra de Apas.

\section{7. g. 1. Otros contextos arqueológicos}

En AW se recuperaron evidencias de las ocupaciones humanas más tempranas de la región, que incluyen artefactos líticos formatizados y no formatizados (Hermo y Terranova 2012; Miotti 2010b; Miotti y Terranova 2010, 2014; Miotti et al. 2011a; Terranova 2013). Entre los primeros, cabezales líticos conocidos como Puntas Cola de Pescado (PCP), raspadores y bifaces (Figura 7.87.a) (Hermo y Terranova 2012; Terranova 2013). Si bien la mayor parte de los materiales se encuentra en la cima del cerro testigo, también se recuperaron en las laderas del AW, en el abra entre los cerros y en sitios cercanos (v.g., Los Dos Amigos 5) (Miotti et al. 2007a, 2009c, 2011a; Terranova 2013).

A fin de contextualizar estratigráficamente los diferentes hallazgos realizados en la cima, se efectuó un pequeño sondeo en el espacio reparado 
que del sector SSW del cerro. Dicho sondeo, lamentablemente, resultó estéril para los objetivos propuestos (Terranova 2013).

Resulta interesante el hallazgo en la cima de AW de un pequeño esferoide de arcilla que presenta una tonalidad rojiza (Figura 7.87.b), ya que en el sitio abundan los materiales líticos, siendo la materia prima del esferoide muy diferente. Por el momento, y dado el contexto superficial del sitio, no podemos asignarle una funcionalidad específica a este artefacto.
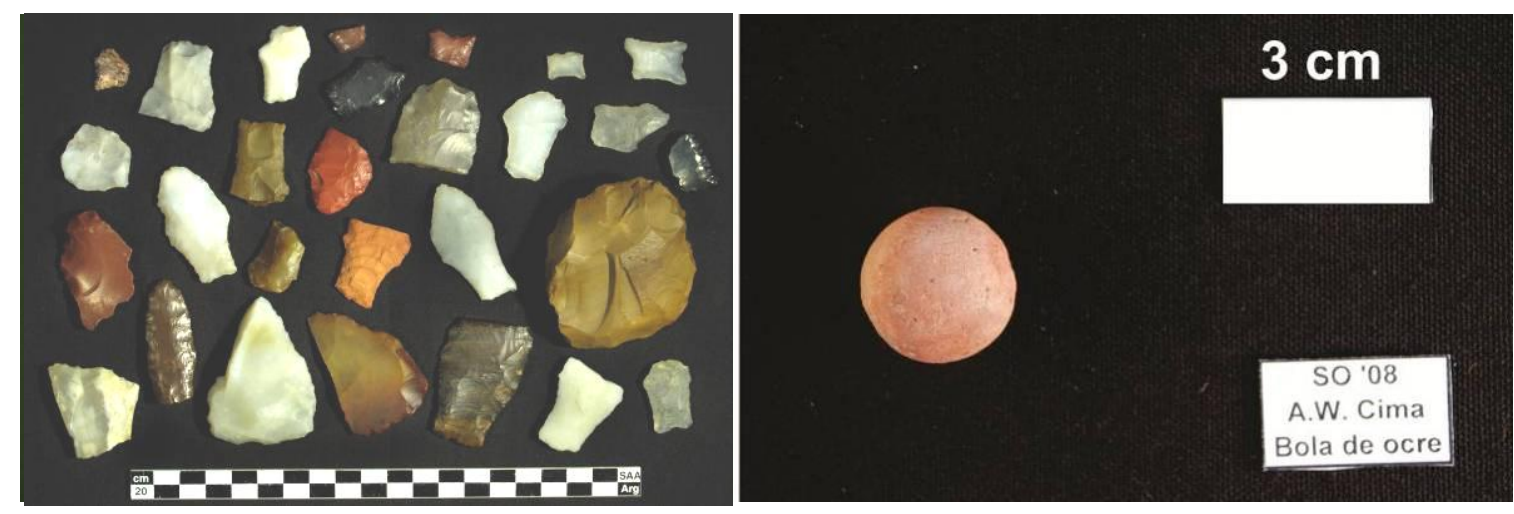

Figura 7.87. Materiales recuperados en Amigo Oeste Cima: a. Parcialidad de los materiales líticos; b. Esferoide con ocre

\section{7. g. 2. El arte rupestre de Alero Amigo Oeste}

Este alero se encuentra orientado al este. Está conformado por un basalto angular e irregular, encima de una vena de sedimentitas de color rosado y naranja, potencialmente utilizable como materia prima colorante (ver Figura 7.86.a). En dicho alero, sobre la superficie horizontal del techo, a 1,45 $\mathrm{m}$ del suelo se registró el único motivo rupestre de la localidad. Este motivo corresponde a una letra " $R$ " mayúscula, y fue realizado con pintura de color rosado (Figuras 7.88.a y 7.88.b). Las dimensiones del mismo son 11,50 cm de ancho, $20 \mathrm{~cm}$ de alto y presentan un trazo de 1,50- $2 \mathrm{~cm}$ de ancho. Este motivo no recibe luz solar directa de ningún tipo durante el día debido a su ubicación en el techo del alero (Tabla 7.16). De igual manera, su visibilidad es muy baja ya que resulta imposible observarlo, excepto estando acostado debajo del mismo. El campo visual desde el alero es amplio, ya que desde allí 
se observa sin inconvenientes el abra entre cerros, el Amigo Este, la laguna de Las Vacas y la planicie hacia el sur.

Probablemente este motivo sea de factura reciente, vinculable a las marcas de la hacienda lanar: sin lugar a dudas, el reconocimiento de dicho motivo plantea una tarea a futuro, que consiste en revisar el registro las diferentes marcas de hacienda de la región, o bien consultar el registro catrastal para observar coincidencias entre esta "inicial" y los diferentes dueños de parcelas que ocuparon las inmediaciones de la localidad Los Dos Amigos.

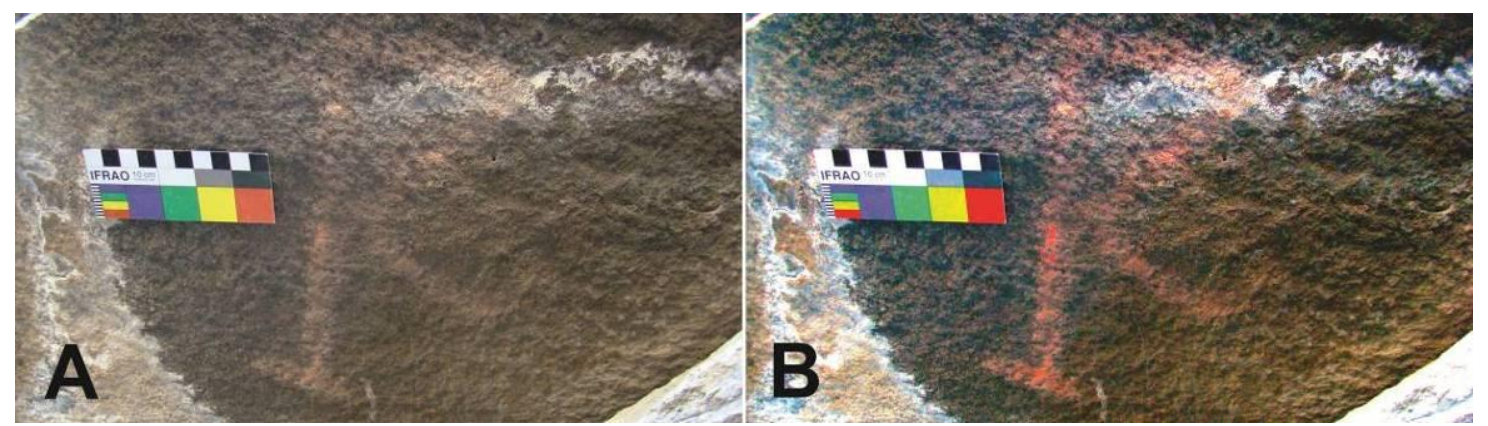

Figura 7.88. Motivo rupestre de AAW: a. registro fotográfico; b. Tratamiento digital de la imagen (D-Stretch lab 15).

\section{7. g. 3. Hallazgo de pigmentos}

Durante las prospecciones en esta localidad se detectaron potenciales fuentes de aprovisionamiento de materias primas colorantes. Una, mencionada anteriormente, en la disyunción entre la corona basáltica y las rocas subyacentes en el Alero AW. La misma forma de presentación se observó en el cerro Amigo Este (Figura 7.89). 


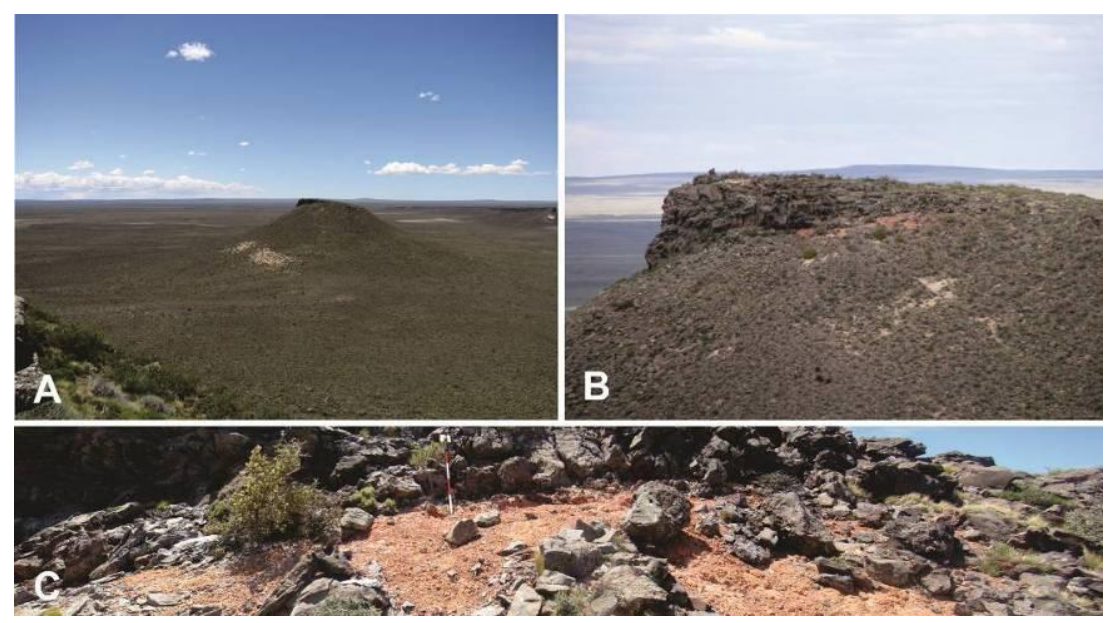

Figura 7.89. Amigo Este (AE): a-b. Vista del AE desde la cima del AW; c. forma de presentación de la vena de materia prima colorante.

Hacia el norte de Los Dos Amigos, en la cuenca de una pequeña cascada (Figura 7.90.a) así como en el borde la laguna temporaria innominada (Figuras 7.90.b-d) se observaron fuentes potenciales de aprovisionamiento de materias primas colorantes. Las muestras obtenidas se encuentran bajo análisis actualmente.

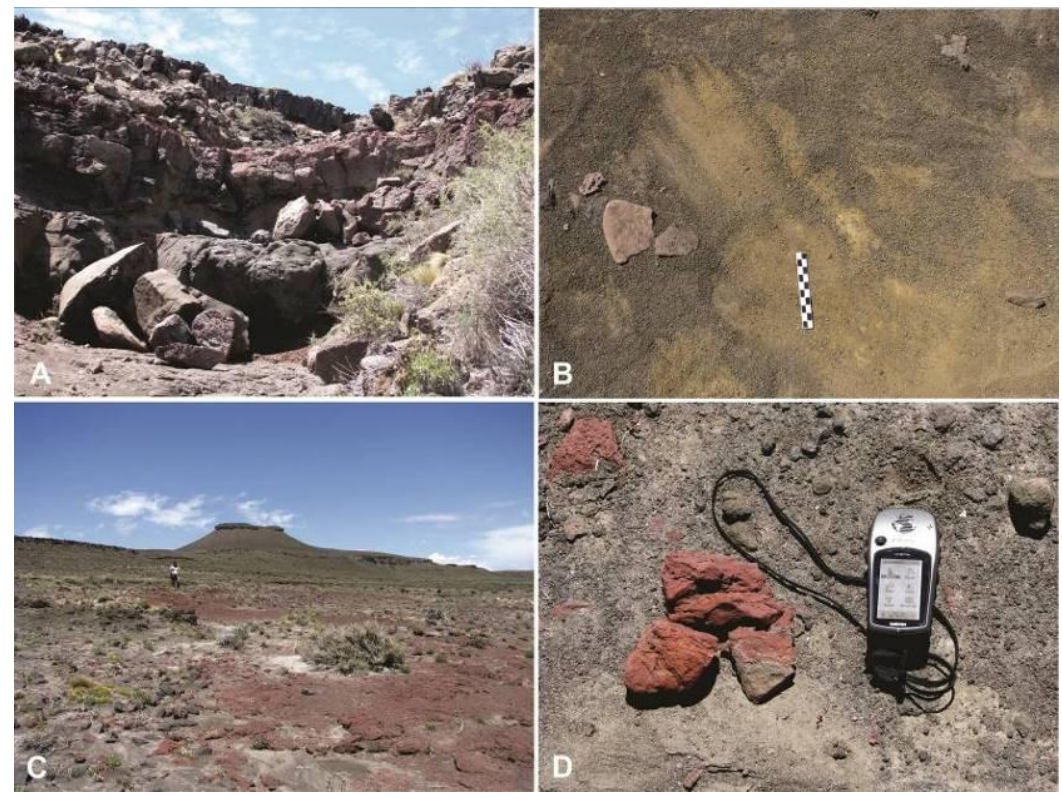

Figura 7.90. Potenciales fuentes de aprovisionamiento de materias primas colorantes en la Localidad Los Dos Amigos: a. "Cascada" ubicada al N de AW; b. Tierra de color que se puede encontrar en el piso de dicha cascada; c-d. Disposición de sustancias colorantes en el borde de la laguna innominada al $\mathrm{N}$ de AW.

El sitio Los Dos Amigos 5 (LDA5) fue reportado como fuente potencial de aprovisionamiento de materias primas colorantes en las primeras publicaciones del equipo (Miotti et al. 2004). Este sitio se encuentra al norte 
de la laguna de Las Vacas, y corresponde a una cárcava de escurrimiento superficial y temporario que ha corroído el pavimento basáltico, dejando al descubierto la disyunción entre este y las rocas sedimentarias subyacentes (Miotti et al. 2009c). Se recolectaron muestras y se tomaron las dimensiones del afloramiento: 7,50 m de largo, con un ancho que varía entre 0,90 y 2,0 m (Figura 7.91.a). Asimismo se observan clastos y guijarros diseminados sobre la superficie de la cárcava. Los colores observados son rosado (Figura 7.91.b), rojo y blanco; las muestras recolectadas se encuentran en análisis (difractometría de rayos $\mathrm{X}$ ).

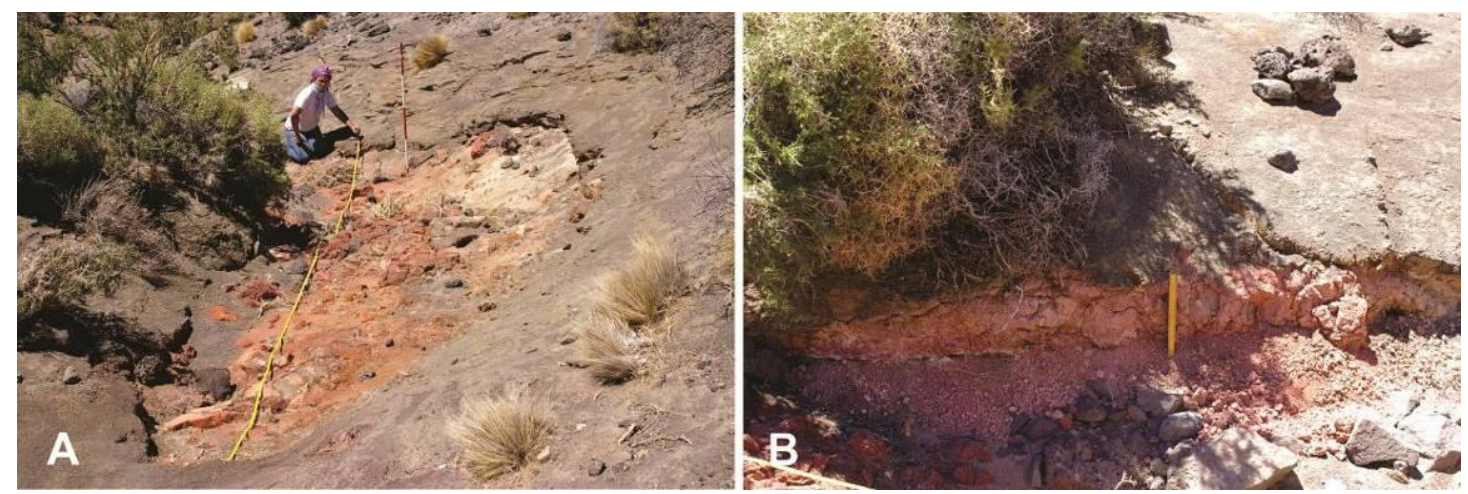

Figura 7.91. La Cárcava de LDA5: a. Disposición en superficie de potenciales materias primas colorantes; $b$. Detalle.

Estos afloramientos de materias primas colorantes (sumados a los que se presentan a continuación) remarcan la ubicuidad de las mismas en este sector de Somuncurá: donde se observe una disyunción entre la corona basáltica y las rocas sedimentarias subyacentes es altamente probable obtener sustancias colorantes (Remesal et al. 2001).

\section{7. h. LOCALIDAD ARQUEOLÓGICA TAPERA DE ISIDORO}

Las coordenadas geográficas de esta localidad son $41^{\circ} 43^{\prime} \mathrm{S}$ y $67^{\circ} 55^{\prime} \mathrm{W}$. Se encuentra a $20 \mathrm{~km}$ al ESE de El Caín (ver Figura 7.80). Se inserta dentro de lo que se ha definido como cuenca inferior del arroyo Talagapa (Miotti 2010b; Miotti et al. 2004, 2009c, 2011a; Terranova 2013), ya que durante las abundantes precipitaciones -nivales o pluviales- la laguna de Las Vacas 
aumenta su cauce, extendiéndose a las planicies adyacentes, formando una gran laguna o bien pequeñas lagunas temporarias.

Tapera de Isidoro se encuentra en el borde sudoccidental del área de inundación de laguna de Las Vacas. Allí se observan paredes de adobe que conformaban una antigua vivienda y estructuras de piedra que sirvieron para el resguardo de animales. Estas instalaciones son las que los pobladores locales reconocen como Tapera de Isidoro, y de donde deriva el nombre de la localidad arqueológica. Posiblemente el establecimiento de este puesto se deba a que este espacio se encuentra al resguardo de los vientos del SW que ofrece la Sierra de Tromen Niyeu y a la disponibilidad de agua por la presencia de una surgente.

\section{7. h. 1. Contextos arqueológicos}

A lo largo de los años, esta localidad ha brindado información relacionada con los primeros fechados radiocarbónicos procedentes de muestras estratigráficas (Terranova y Marchionni 2010), con datos isotópicos y radiocarbónicos de restos óseos humanos (Miotti 2010b), así como con artefactos y materiales arqueológicos recuperados en estratigrafía y en superficie (Miotti et al. 2004, 2009c, 2011a; Terranova 2013; Terranova y Marchionni 2010). Asimismo, ha permitido plantear posibles circuitos de movilidad entre el macizo somuncurense y la cordillera (Miotti 2010b; Miotti et al. 2009c).

Los sitios que integran la localidad son cinco: Tapera de Isidoro, Alero 2 de Los Cuatro Aleros, El Manantial, El Molle y Cueva de las Cañas (Figura 7.93.a). Resulta pertinente mencionar los hallazgos de El Molle y la vena de sustancias colorantes que aflora a lo largo de la sierra Tromen Niyeu.

El Molle es un sitio de superficie que se encuentra a $1,50 \mathrm{~km}$ al este de la Tapera de Isidoro (Figura 7.92.a). El conjunto está integrado por materiales líticos: raspadores, artefactos no formatizados y una mano de molienda con 
sustancia colorante en una de sus caras (Figura 7.92.b y 7.92.c), los cuales están asociados a panes de ocre (Figura 7.92.d) (Miotti et al. 2009c).

Por otro lado, en la ladera de la sierra de Tromen Niyeu se observan materias primas colorantes, desde Cueva de Las Cañas hacia el este, aflorando a lo largo de $800 \mathrm{~m}$ (Figura 7.92.a). Las materias primas de color rosado se encuentran en el punto de contacto entre la corona basáltica y las rocas sedimentarias subyacentes (Figura 7.92.e), mientras que por debajo las tonalidades sufren un degradado pasando por el rojo y el ocre (Figuras 7.92.f-g) que llega al color blanco, propio de la toba.

Si se considera la ubicación, el modo de presentación y su relación con sitios arqueológicos, se observa que las materias primas colorantes se encuentran en disyunciones, con variaciones en su coloración debidas al grado de termoalteración sufrido en las rocas sedimentarias por el emplazamiento de los basaltos suprayacentes y, generalmente, están asociadas a sitios arqueológicos. 

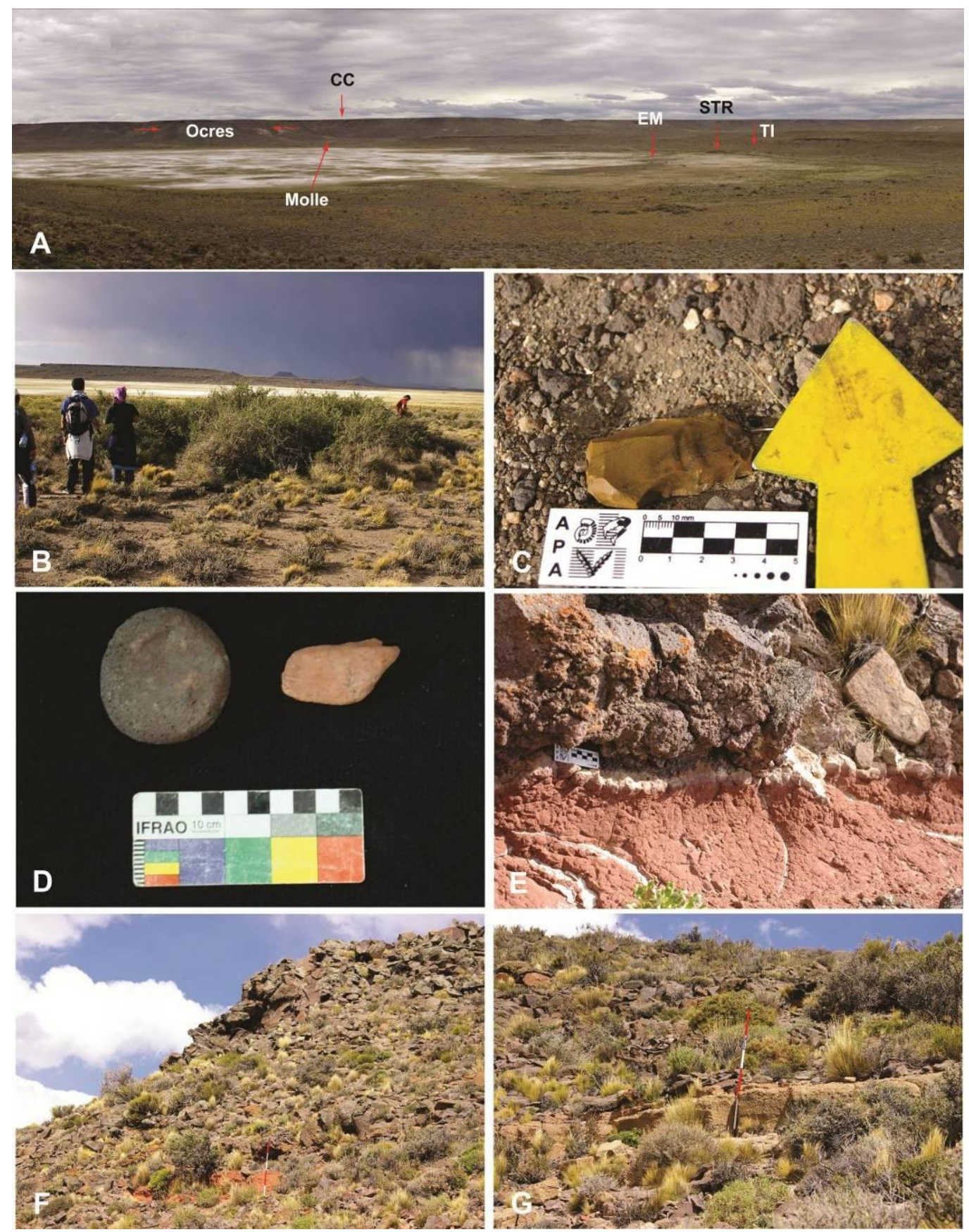

Figura 7.92.a. Vista de la localidad Tapera de Isidoro desde Los Cuatro Aleros; b.

Sitio El Molle; c. Material lítico recuperado en El Molle; d: Mano de moler y fragmento de ocre recuperado en el sitio; e-f: ocres aflorantes en la sierra de

Tromen Niyeu. Referencias: CC: Cueva de Las Cañas; STR: estructura de piedra; TI: Tapera de Isidoro; EM: El Manantial. 


\begin{tabular}{|c|c|c|c|c|c|c|c|}
\hline \multicolumn{2}{|c|}{ Variables } & LP & AAW & $\mathrm{CM}$ & PM1 & PP1 & PP2 \\
\hline Emplazamiento & $\begin{array}{l}\text { Pared } \\
\text { techo } \\
\text { bloques desprendidos }\end{array}$ & $\mathrm{X}$ & $\mathrm{X}$ & $\begin{array}{l}X \\
X\end{array}$ & $\begin{array}{l}\mathrm{X} \\
\mathrm{X}\end{array}$ & $\begin{array}{l}\mathrm{X} \\
\mathrm{X}\end{array}$ & $\mathrm{X}$ \\
\hline Posición & $\begin{array}{l}\mathrm{H} \\
\mathrm{V}\end{array}$ & $\mathrm{X}$ & $X$ & X & $\begin{array}{l}\mathrm{X} \\
\mathrm{X}\end{array}$ & $\begin{array}{l}\mathrm{X} \\
\mathrm{X}\end{array}$ & $X$ \\
\hline Orientación & $\begin{array}{l}\mathrm{N} \\
\mathrm{S} \\
\mathrm{E} \\
\mathrm{W}\end{array}$ & $\mathrm{X}$ & $\mathrm{X}$ & $X$ & $\begin{array}{l}\mathrm{X} \\
\mathrm{X} \\
\mathrm{X}\end{array}$ & $\begin{array}{l}\mathrm{X} \\
\mathrm{X} \\
\mathrm{X}\end{array}$ & $\mathrm{X}$ \\
\hline $\begin{array}{l}\text { Distancia al } \\
\text { suelo } \\
\text { en } \mathrm{m}\end{array}$ & $\begin{array}{l}>2 \\
2-1,51 \\
1,5-1 \\
<1\end{array}$ & $\begin{array}{l}\mathrm{X} \\
\mathrm{X}\end{array}$ & $\mathrm{X}$ & $\begin{array}{l}\mathrm{X} \\
\mathrm{X}\end{array}$ & $\mathrm{X}$ & $\begin{array}{l}\mathrm{X} \\
\mathrm{X} \\
\mathrm{X} \\
\mathrm{X}\end{array}$ & $\begin{array}{l}\mathrm{X} \\
\mathrm{X} \\
\mathrm{X} \\
\mathrm{X}\end{array}$ \\
\hline $\begin{array}{l}\text { Campo visual } \\
\text { máximo en } \mathrm{m}\end{array}$ & $\begin{array}{l}1 \\
3 \\
7 \\
15 \\
\end{array}$ & $\mathrm{X}$ & $\mathrm{X}$ & $X$ & $\mathrm{X}$ & $\mathrm{X}$ & $\mathrm{X}$ \\
\hline Iluminación & $\begin{array}{l}\text { luz tarde } \\
\text { luz mañana } \\
\text { penumbra } \\
\text { contraluz }\end{array}$ & $\begin{array}{l}\mathrm{X} \\
\mathrm{X}\end{array}$ & $\mathrm{X}$ & $\mathrm{X}$ & $\mathrm{X}$ & $\mathrm{X}$ & $\mathrm{X}$ \\
\hline Visibilidad & $\begin{array}{l}\text { 1) alta } \\
\text { 2) intermedia } \\
\text { 3) baja } \\
\text { 4) muy baja }\end{array}$ & $\mathrm{X}$ & $\mathrm{X}$ & $X$ & $\mathrm{X}$ & $\mathrm{X}$ & $\begin{array}{l}X \\
X\end{array}$ \\
\hline Motivos & $\begin{array}{l}\text { Puntiformes } \\
\text { Rectilíneos } \\
\text { Circulares llenos } \\
\text { Circulares lineales } \\
\text { Otros } \\
\text { Pintura ND }\end{array}$ & $\begin{array}{l}\mathrm{X} \\
\mathrm{X}\end{array}$ & $\mathrm{X}$ & $\mathrm{x}$ & $\mathrm{X}$ & $\begin{array}{l}\mathrm{X} \\
\mathrm{X} \\
\mathrm{X}\end{array}$ & $\begin{array}{l}\mathrm{X} \\
\mathrm{X} \\
\mathrm{X}\end{array}$ \\
\hline
\end{tabular}

Tabla 7.16. Emplazamiento y visibilidad de los sitios con arte rupestre del centrooeste de Somuncurá. Referencias. LP: La Porfía; AAW: Alero Amigo Oeste; CM: Cueva Martel; PM1: Peñón Martel 1; PP1: Peñón del Pueblo 1; PP2: Peñón del Pueblo 2.

\section{7. i. PEÑÓN DEL PUEBLO 1 y 2}

Los sitios están ubicados a $41^{\circ} 47^{\prime} \mathrm{S}$ y $68^{\circ} 7^{\prime} \mathrm{W}$, en la cuenca del arroyo Barril Niyeu, $14 \mathrm{~km}$ al SW de la localidad de El Caín (ver Figura 7.80). Este curso es uno de los tributarios de la laguna de Las Vacas, y presenta agua estacionalmente (Figura 7.93.a). Las formaciones que rodean el curso del arroyo corresponden al CVBN (Remesal et al. 2001, 2012). Este sector del macizo presenta lomadas, serranías y mesetas que conforman espacios reparados de los vientos, lo cual los torna más favorables para la ocupación.

En las inmediaciones del arroyo se pueden observar espacios verdes alimentados por la presencia de agua estancada en algunos sectores (2008, 
2011). La vegetación cercana al arroyo es similar a aquella registrada en otros sectores del macizo: arbustos achaparrados y en cojín (Figura 7.93.a).

Peñón del Pueblo 1 (PP1) y Peñón del Pueblo 2 (PP2) se encuentran en los espacios reparados ofrecidos por dos relictos de traquitas. PP1 corresponde a un alero (Figura 7.93.b) y PP2 es una pequeña cueva (Figura 7.93.c). Ambos sitios distan $250 \mathrm{~m}$ entre sí. La denominación de los mismos se debe a una pintada política documentada en PP1, la cual será tratada más adelante.

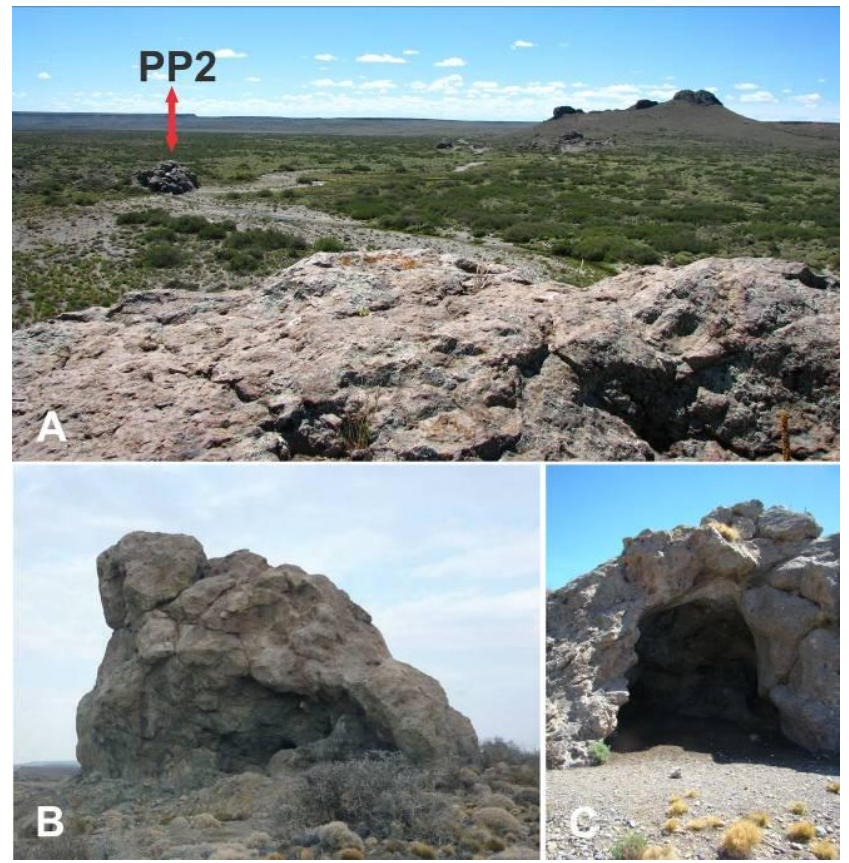

Figura 7.93. Peñón del Pueblo 1 y 2 (PP1 y PP2): a. Vista del arroyo Barril Niyeu y de Peñón del Pueblo 2 (PP2) desde el techo de Peñón del Pueblo 1; b. vista al Alero de PP1; c. cueva PP2.

Las manifestaciones documentadas corresponden a pinturas mayoritariamente de color rojo, aunque se observaron motivos de color naranja $u$ ocre. Del total de motivos relevado en ambos sitios $(n=63)$, el 59\% se encuentra en el sitio PP1 mientras que el 41\% restante está en PP2 (Figura 7.94). Se registraron motivos no figurativos y no determinados, habiendo una relación casi opuesta en ambos sitios: predominan los no figurativos en PP1 y los no determinado en PP2 (Figura 7.95.a). En los dos sitios prevalecen los motivos rectilíneos, seguidos en distintas proporciones por puntiformes, circulares lineales y circulares llenos (Figuras 7.95.b; Tabla 7.17). En líneas generales, el estado de conservación de los motivos es malo 
y algunos se encuentran muy desvaídos. El detalle de los motivos reconocidos en estos sitios se presenta en el Apéndice V.2.

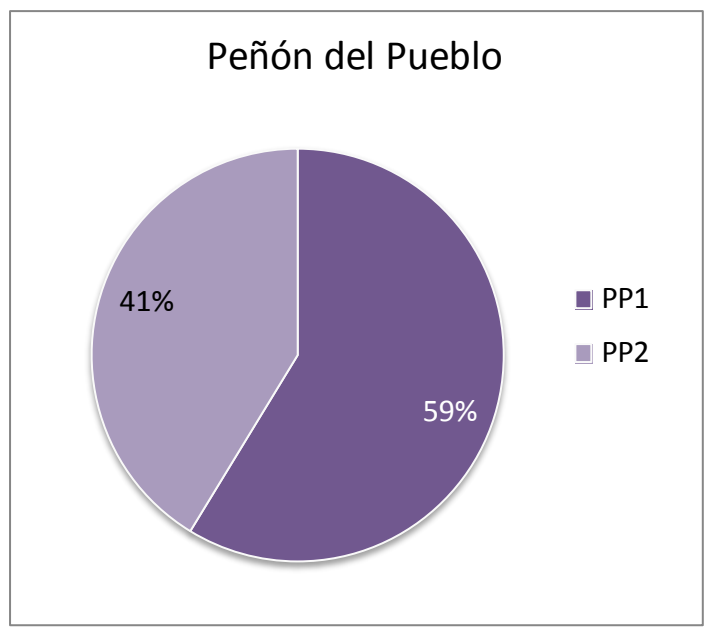

Figura 7.94. Proporciones de motivos por sitio.

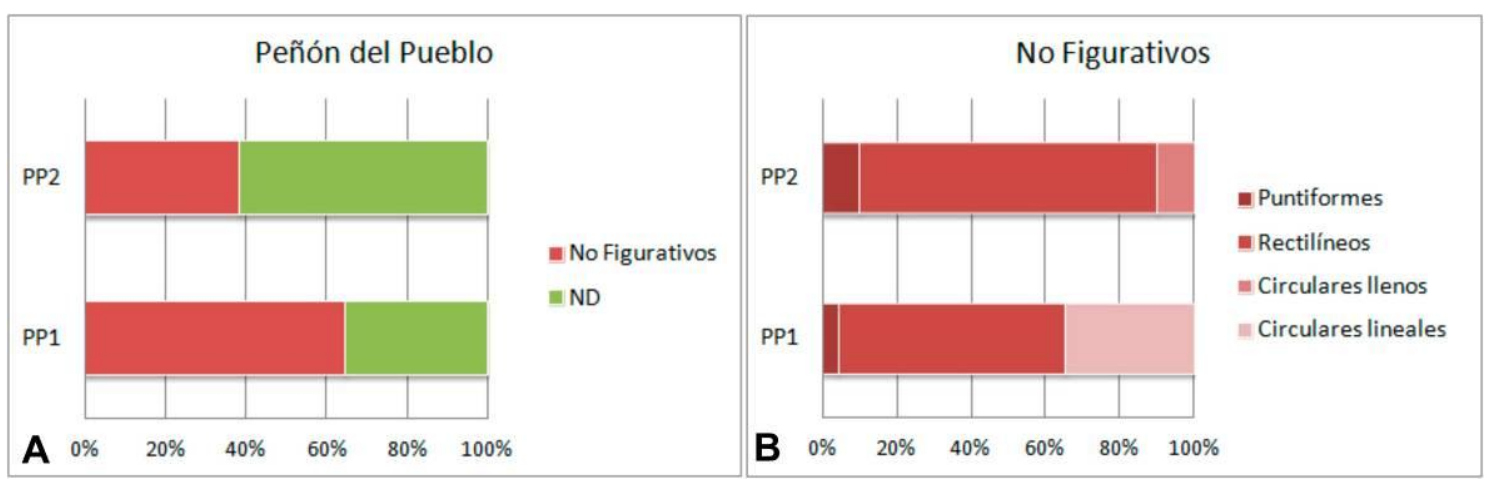

Figura 7.95. Proporciones de grupos y subgrupos de motivos en Peñón del Pueblo: a. Proporciones de grupos de motivos; b. Proporciones de subgrupos de motivos no figurativos. Referencias: ND: no determinados.

\begin{tabular}{|l|c|c|c|}
\cline { 2 - 3 } \multicolumn{1}{c|}{} & \multicolumn{2}{l|}{ Sitios } & \multicolumn{1}{c}{} \\
\hline Motivos & PP1 & PP2 & Subtotal \\
\hline Puntiformes & 1 & 1 & 2 \\
\hline Rectilíneos & 14 & 8 & 22 \\
\hline Circulares llenos & 0 & 1 & 1 \\
\hline Circulares lineales & 8 & 0 & 8 \\
\hline No Figurativos & 23 & 10 & 33 \\
\hline No Determinados & 14 & 16 & 30 \\
\hline \multicolumn{1}{|c|}{ Total } & 37 & 26 & 63 \\
\hline
\end{tabular}

Tabla 7.17. Grupos y subgrupos de motivos de Peñón del Pueblo. Referencias: PP1: Peñón del Pueblo 1; PP2: Peñón del Pueblo 2. 


\section{7. i. 1. Peñón del Pueblo 1}

Este sitio se encuentra en el relicto meridional. Corresponde al espacio reparado de un alero que abre hacia el este aunque la mayor superficie reparada se encuentra hacia el NE. Este espacio reparado es irregular, observándose en algunos puntos escalones y recovecos naturales. Se emplearon las paredes verticales para plasmar motivos pintados de rojo y un motivo en color ocre. Debido al tipo de soporte, el estado de conservación de los motivos es malo, observándose distintos grados de exfoliación.

El piso del alero está cubierto por gravas, sedimento limoso y una pequeña capa de excremento. Esta última se habría generado por la presencia de animales para guarecerse del sol, del viento o del agua. Asimismo, en superficie se han observado materiales actuales y artefactos líticos arqueológicos. Los primeros son el resultado de visitas por parte de las familias de la zona, que suelen usar el alero durante los fines de semana. Entre los segundos, se recuperaron una bola partida, dos puntas pedunculadas de tamaño pequeño, un ápice de punta de proyectil y varios desechos de talla.

En un trabajo previo (Blanco 2010) se planteó que en el alero podían reconocerse tres sectores con manifestaciones, ya que las superficies sobre las que se encuentran orientan al SE, al NNE y al este respectivamente, siendo los sectores 1, 2 y 3 . El sector 1 está conformado por el conjunto 1, el sector 2 por los conjuntos 2 a 5 , mientras que en el sector 3 por el conjunto 6 (Figura 7.96).

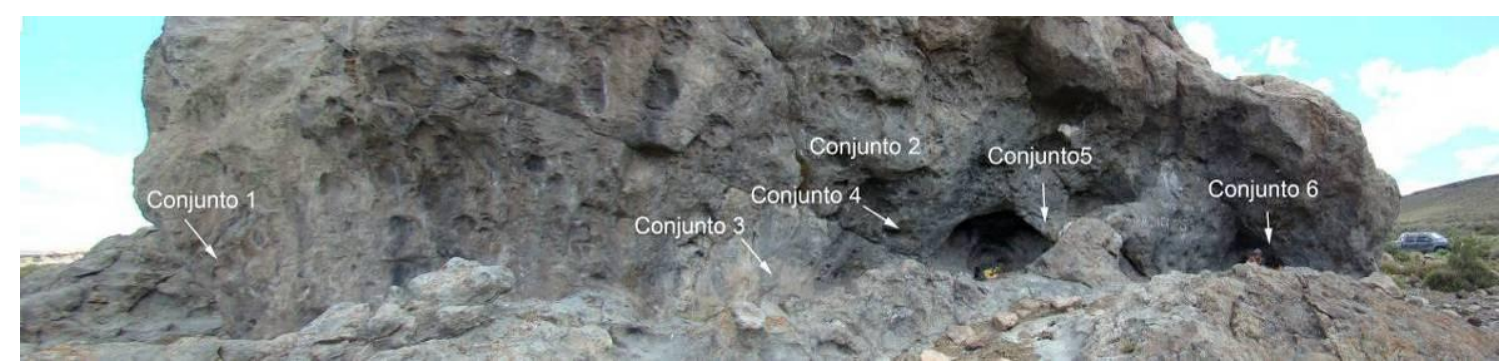

Figura 7.96. Panorámica de PP1, donde se indica la ubicación de los conjuntos. 


\section{7. i. 1. 1. Sector 1}

Conjunto 1. Los cuatro motivos que lo integran se encuentran sobre la superficie vertical de la pared SE, a alturas que oscilan entre 1,50 y $0,57 \mathrm{~m}$ respecto del suelo. Se trata de una semicircunferencia en color ocre (Figuras 7.97.a-b), un serpentiforme de puntos, un peiniforme y un motivo pintado no determinado. Los tres últimos presentan trazo muy pequeño y delicado, en color rojo.

\section{7. i. 1. 1. Sector 2}

Conjunto 2. Se encuentra sobre el techo/visera del alero, a alturas que oscilan entre 2,60-2,90 m respecto del suelo actual. Se trata de un negativo parcial de una circunferencia, un par de líneas oblicuas y una serie de líneas paralelas. Los dos primeros se emplazan sobre la superficie horizontal del techo mientras que el tercero se encuentra sobre una superficie vertical. Las líneas paralelas fueron consignadas como tales luego del tratamiento digital de la imagen (Figuras 7.97.c-d).

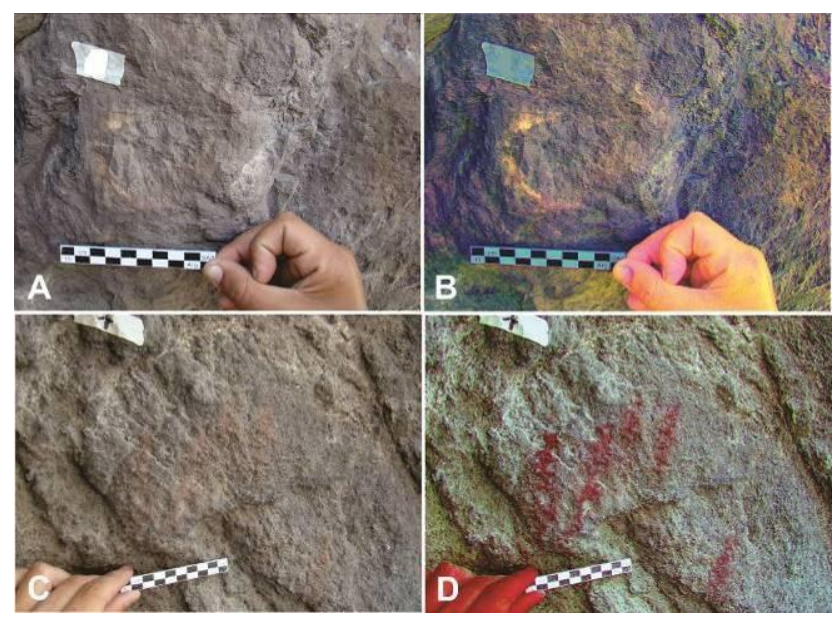

Figura 7.97. Motivos de los Conjuntos 1 y 2: a. Circunferencia en color ocre del Conjunto 1; b. imagen tratada digitalmente (D-Stretch ybk 15); c. serie de líneas paralelas del Conjunto 2; d. tratamiento digital de la imagen (D-Stretch yrd 15).

Conjunto 3. Se encuentra a alturas respecto del suelo que varían entre 2,30 y 1,65 m, hacia la izquierda de una oquedad que corta la pared. Este 
conjunto está conformado por ocho motivos: dos líneas rectas (una de ellas con trazo ancho), una serie de líneas paralelas (Figuras 7.98.a-b), una semicircunferencia (Figuras 7.98.c-d), dos circunferencias simples y dos motivos no determinados.

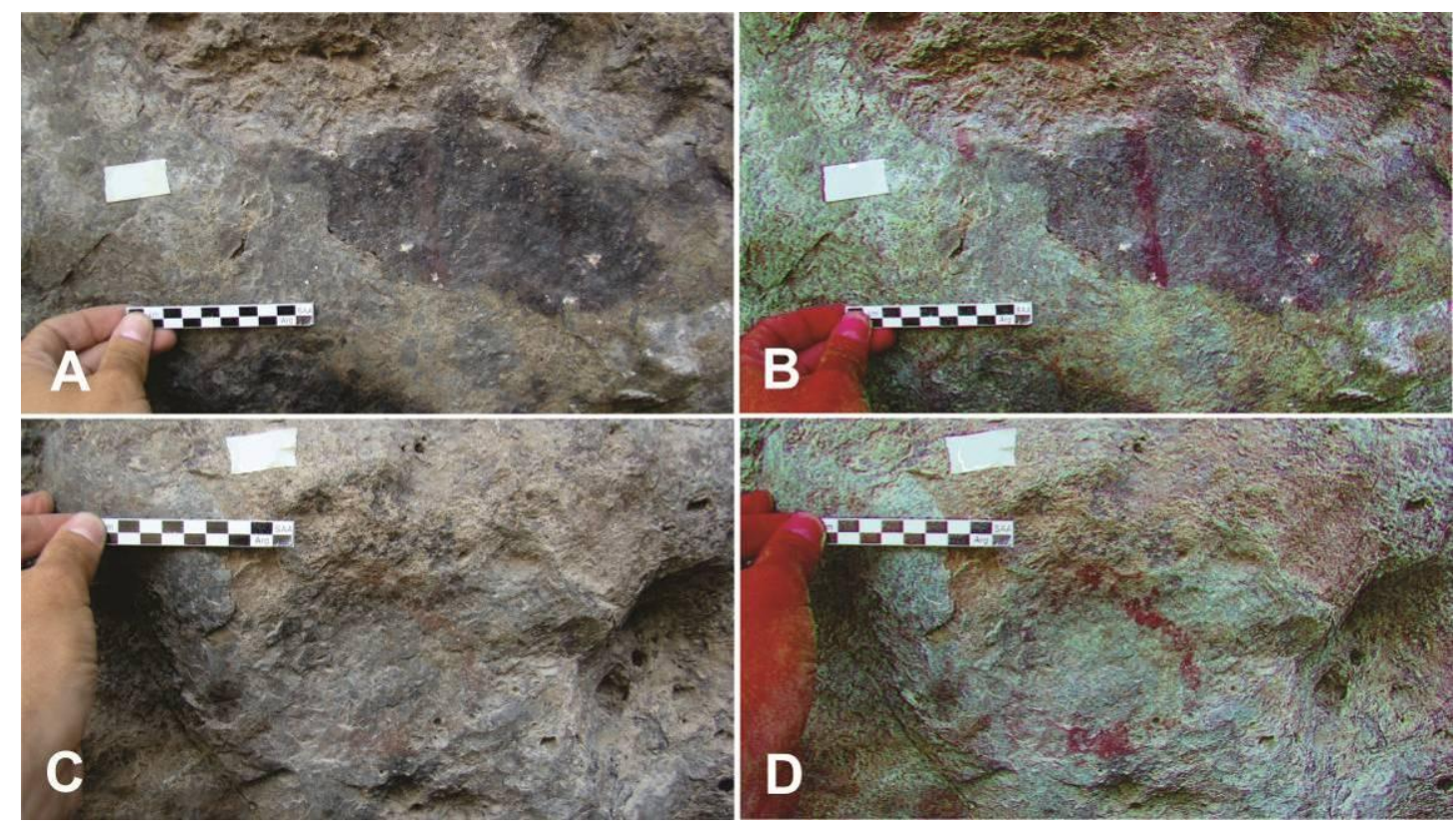

Figura 7.98. Conjunto 3: a. Serie de líneas paralelas; b. Tratamiento digital de la imagen (D-Stretch yrd 15); c. Semicircunferencia; d. Tratamiento digital de la imagen (D-Stretch yrd 15).

Conjunto 4. Por debajo de los anteriores, a alturas respecto del suelo que oscilan entre 0,52 y $1,20 \mathrm{~m}$, se observan seis motivos: una línea vertical simple, series de líneas paralelas verticales, una recta quebrada (Figuras 7.99.a-b) y tres motivos no determinados. Todos se encuentran en mal estado de conservación debido a las exfoliaciones y rozamientos que sufrió la superficie sobre la que se encuentran.

Conjunto 5. A la derecha de una gran oquedad del alero, sobre una superficie vertical, se registraron siete motivos a alturas respecto del suelo que varían entre 0,47 y $1,35 \mathrm{~m}$ : una circunferencia simple, cuatro hoyuelos naturales cubiertos de pintura; restos de pintura sobre el borde de un hoyuelo natural y restos de pintura considerados como motivo no determinado.

Conjunto 6. Sobre una superficie vertical, orientada al este, se documentaron nueve motivos entre 1,10 y $0,62 \mathrm{~m}$ respecto del suelo actual: 
dos líneas rectas simples con diferente orientación, tres series de líneas paralelas verticales (con diferente orientación), un par de líneas paralelas oblicuas, dos circunferencias simples alrededor de hoyuelo natural y un motivo no determinado. Al igual que los restantes conjuntos, la pintura presenta un grado avanzado de exfoliación (Figuras 7.99.c-d).

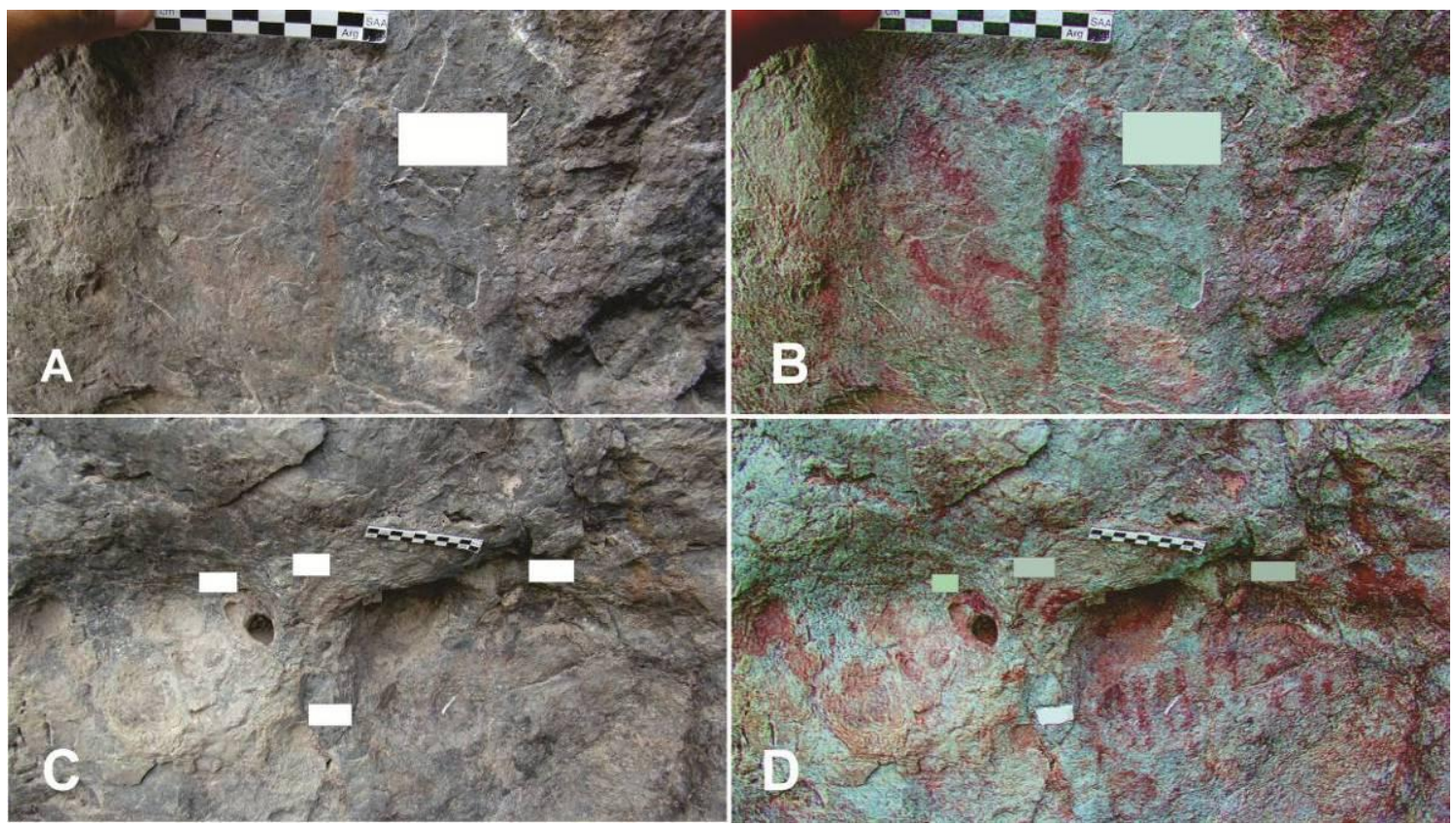

Figura 7.99. Conjuntos 4 y 6: a. Línea quebrada; b. Tratamiento digital de la imagen (D-Stretch yrd 15); c. Conjunto 6; d. Tratamiento digital de la imagen (DStretch yrd 15).

\section{7. i. 1. 3. Los grafitis de Peñón del Pueblo 1}

Las distintas inscripciones detectadas durante el relevamiento de 2008 se encuentran sobre superficies libres de pinturas rupestres. Corresponden a apodos en dos casos, uno de ellos como firma de la pintada política por la que reciben su denominación los sitios, y dos resultaron ininteligibles.

Grafiti I. Hacia la izquierda del conjunto 4, a 1,46 m del mismo, se encuentra la inscripción $N E G R O$, realizada con tiza blanca (Figura 7.100.a).

Grafiti II. Por encima del conjunto 3, en una superficie vertical se observan trazos en tiza blanca y una línea fina incisa que conforma un rayón (Figura 7.100.b). 
Grafiti III. Se trata de la pintada política por la que reciben su designación los sitios. La inscripción VOTE POR LOS RADICALES, LOLO se ubica entre los conjuntos 5 y 6 , sobre una superficie vertical orientada al norte. Está distribuida en tres líneas (Figura 7.100.c) con alturas que oscilan entre 1,16 y 1,85 m respecto del suelo actual. Fue realizada con pintura blanca, probablemente sintética.

Grafiti IV. Hacia la derecha de la inscripción anterior, a 1,75-1,80 m respecto del suelo, se observan unos trazos curvilíneos realizados con tiza.

Durante febrero 2011 el sitio fue re-visitado. En esa ocasión se registraron nuevos escritos. Sobre uno de los motivos del conjunto 4 se documentó el nombre NELSON, realizado con tiza. Mientras que en la superficie con la pintada política, por encima de "LOLO" se registraron dos nombres adicionales con el año de realización: Kevin Jeremías Ovalle, Sasha Ovalle, 2010; todos fueron realizados con borratinta (Figura 7.100.e). Parcialmente superpuesto al grafiti II, también escrito con borratinta, se lee Sasha (Figura 7.100.f).

Esta re-visita permitió, además, observar el avance en el deterioro de los motivos: la acción del agua ha afectado la superficie rocosa y, con ello, su conservación. Esto se ha evidenciado principalmente por la presencia de líquenes, de manchas de humedad y por pequeñas acumulaciones de concreciones de carbonatos. 


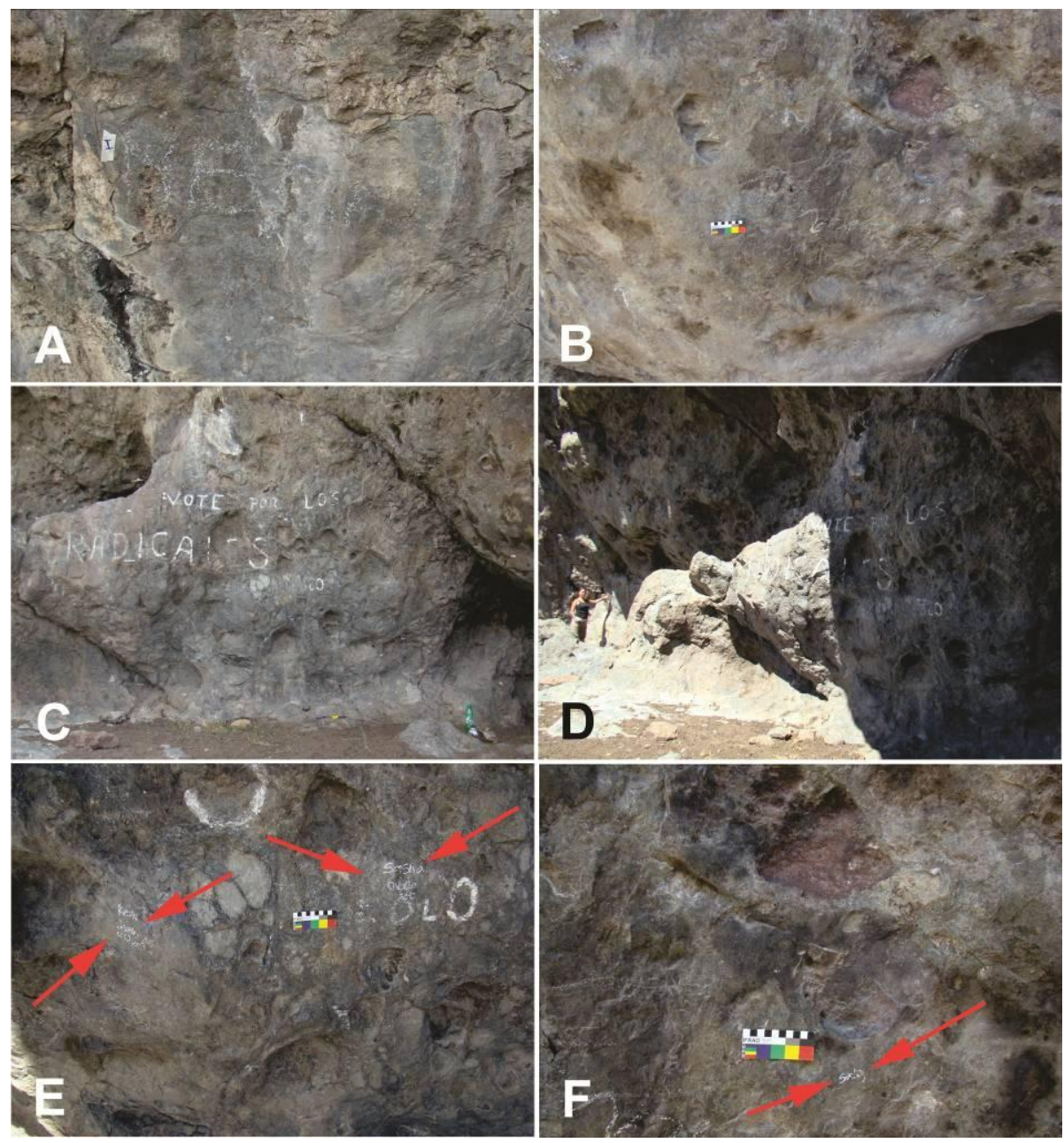

Figura 7.100. Grafitis de Peñón del Pueblo: a. Grafiti I; b. Grafiti II; c. Grafitis III y IV; d. Relación espacial entre los grafitis relevados en 2008; e. Grafitis registrados en 2011; f. Grafiti II e inscripción documentada en 2011.

\section{7. i. 2. Peñón del Pueblo 2}

Este sitio incluye las manifestaciones rupestres que se encuentran en las paredes interiores de la cueva (ver Figura 7.93.c), que está abre al este. Sus dimensiones son 4,50 $\mathrm{m}$ de boca por 9,30 $\mathrm{m}$ de profundidad. Se encuentra al norte de PP1, a $7 \mathrm{~m}$ del cauce del arroyo por lo que parte del sedimento en su superficie puede ser el resultado de las crecidas del arroyo y, además, a la acumulación de excremento producto del guarecimiento de animales. Durante el relevamiento de 2008 se observó una oveja muerta en estado avanzado de descomposición sobre la superficie del sedimento.

La cueva recibe sol por las mañanas, mientras que por las tardes el interior permanece en penumbras, esa condición hace que el interior sea 
fresco. Las filtraciones en el fondo de la cueva favorecen el crecimiento de pequeños helechos y se observaron pequeñas concreciones de carbonatos debido al escurrimiento de agua (Figura 7.101.a), mientras que en el ángulo formado por las paredes oeste y norte, y la mayor parte de ésta última, se observó una mezcla realizada con sedimento, estiércol y agua cubriendo la superficie (Figura 7.101.b).
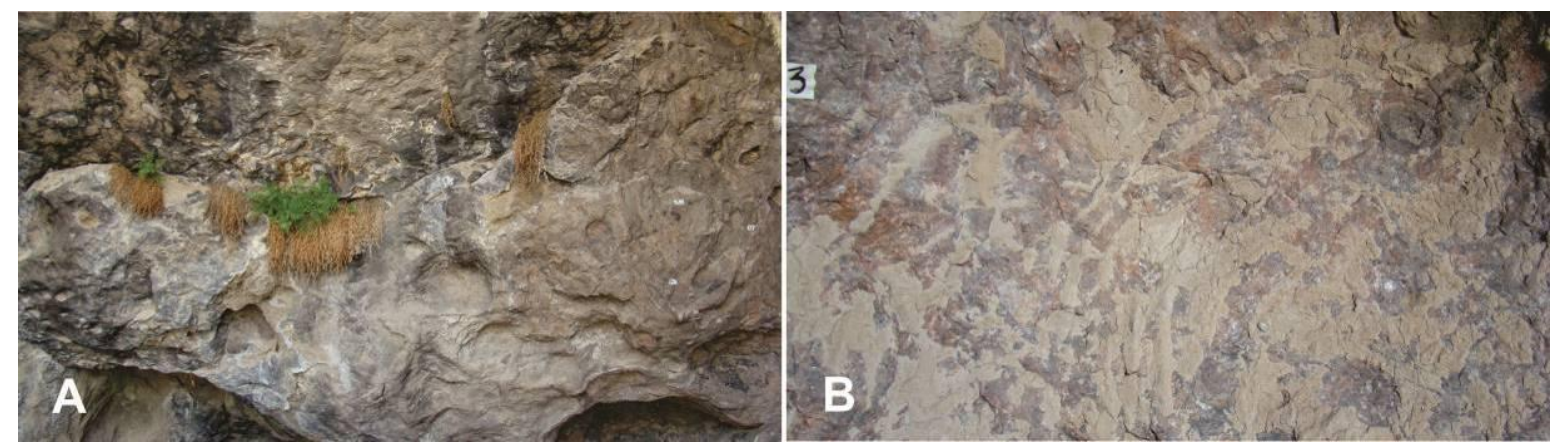

Figura 7.101. Condiciones interiores de PP2: a. Crecimiento de helechos y presencia de carbonatos en pared oeste; b. pared norte parcialmente cubierta con mezcla.

Respecto a la distribución de los motivos y conjuntos rupestres de PP2, los conjuntos 1 y 2 se encuentran en la pared sur; los motivos 3 , 4 y el conjunto 5 sobre la pared oeste mientras que los restantes se emplazan en la pared norte de la cueva.

\section{7. i. 2. 1. Pared Sur}

Conjunto 1. Los cuatro motivos que lo integran se encuentran entre 1,44 y 1,97 m respecto del suelo actual. Se trata de una serie de líneas paralelas (7.102.a), una línea recta de trazo ancho (Figura 7.102.b) y restos de pintura de color naranja. Con anterioridad, los dos primeros motivos fueron considerados como un peiniforme y un par de puntos respectivamente (Blanco 2010). El tratamiento digital de las imágenes permitió su correcta identificación ya que la pintura se observa desvaída. 
Conjunto 2. Está conformado por cinco motivos no determinados que se ubican entre 0,85 y $1,50 \mathrm{~m}$ respecto del suelo. Se trata de restos de pintura mal conservada y sin forma definida.
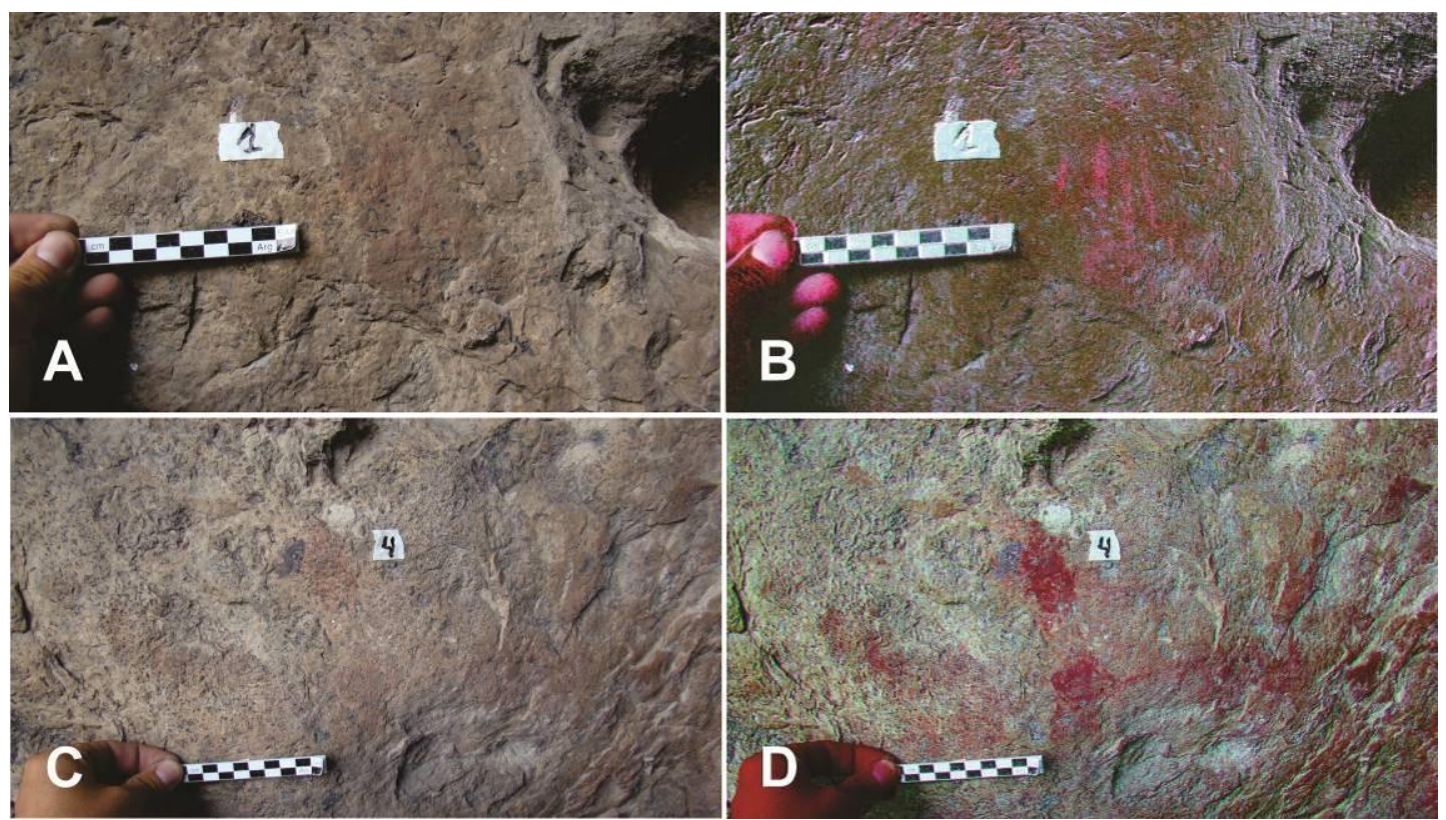

Figura 7.102. Motivos del Conjunto 1 de PP2: a. Serie de líneas paralelas verticales; b. Tratamiento digital de la imagen (D-Stretch yye 15); c. Línea vertical de trazo ancho; d. Tratamiento digital de la imagen (D-Stretch yrd 15).

\section{7. i. 2. 2. Pared Oeste}

Motivo 3. Serie de líneas paralelas verticales de color rojo, a 2,50 m respecto del suelo, en el interior de una concavidad del soporte.

Motivo 4. Restos de pintura de color naranja sin forma discernible a la derecha del motivo anterior.

Conjunto 5. Sobre una superficie vertical e irregular, a alturas que oscilan entre 1,90 y 2,48 m respecto del suelo actual se registraron seis motivos en color naranja. Corresponden a líneas paralelas verticales (Figuras 7.103.a-b), a restos de pintura alrededor de dos hoyuelos naturales y a tres motivos no determinados. Cerca del ángulo entre las paredes oeste y norte se encuentra uno de los motivos no determinados, el cual está parcialmente cubierto con una mezcla de sedimento y estiércol.

Motivo 6. Está compuesto por dos líneas paralelas verticales a 1,07 m respecto del suelo. 


\section{7. i. 2. 3. Pared Norte}

Conjunto 7. Conformado por tres motivos que se ubican entre 2,40 y 2,05 $\mathrm{m}$ respecto del suelo. Corresponden a una serie de líneas verticales paralelas, que aumentan su largo hacia el centro, y dos motivos no determinados pintados en rojo (Figuras 7.103.c-d). La superficie de estas pinturas está cubierta por una mezcla sedimentos, estiércol y agua.

Conjunto 8. Integrado por tres motivos ubicados entre 1,61 y 1,88 m respecto del suelo actual. Se trata de un círculo, un par líneas paralelas verticales y un motivo no determinado. Este último se encuentra cubierto por la mezcla que cubre mayoritariamente la pared.

Conjunto 9. Está conformado por dos motivos, que se localizan, respectivamente, a 1,55 y 1,61 m respecto del suelo actual. Se trata de un par de líneas verticales paralelas y una serie de líneas paralelas horizontales (Figuras 7.103.e-f).

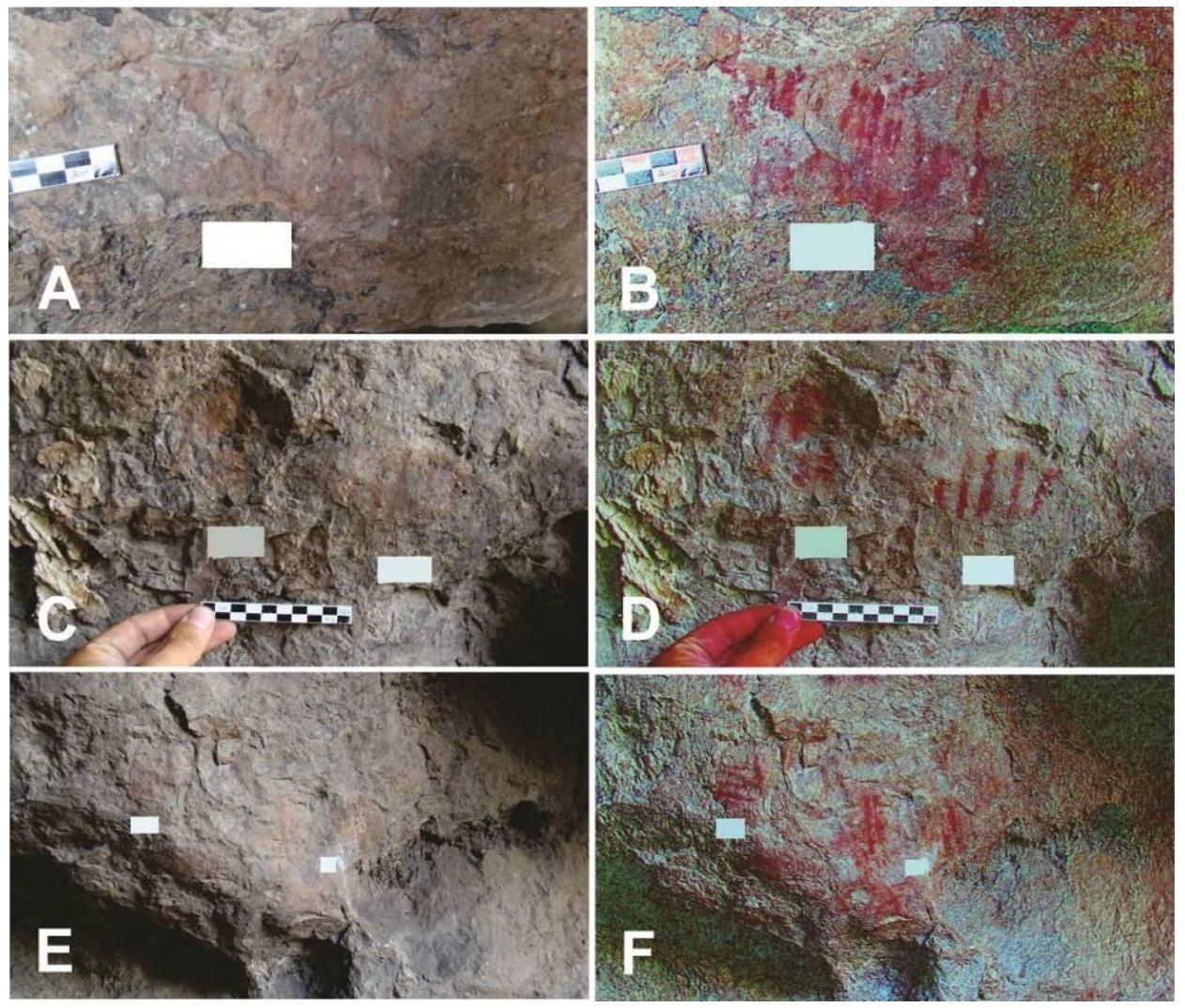

Figura 7.103. Conjuntos 5, 7 y 9 de PP2: a. Serie de líneas paralelas del conjunto 5; b. Tratamiento digital de la imagen (D-Stretch yrd 15); c. Serie de líneas paralelas del conjunto 7; d. Tratamiento digital de la imagen (D-Stretch yrd 15); e. Conjunto 9; f. Tratamiento digital de la imagen (D-Stretch yrd 15). 
El sitio PP2 carece de grafitis. La cobertura de buena parte de las paredes internas de la cueva con la mezcla de sedimento, estiércol y agua podría considerarse como parte de un ocultamiento del arte rupestre del sitio, ya que es posible observar restos de pintura por debajo de la mezcla, particularmente en los sectores de la cueva que presentan mayor densidad de motivos. Se propone que los ocupantes tardíos de la cueva tuvieron cierta intención en ocultar el arte pintado, por la presencia de estiércol de oveja en la mezcla. Si bien esta situación es diferente a la registrada en PP1, donde se documentaron grafitis ocupando paneles que carecen de motivos rupestres puede plantearse una resignificación actual de ambos espacios, mediante grafitis en PP1 y cobertura de paredes con mezcla en PP2, con la exclusión de los temas precedentes (en el sentido de Pastor 2012).

Durante la re-visita de 2011 se notó un crecimiento de los helechos que se encuentran en la pared $\mathrm{W}$, probablemente por las condiciones de mayor humedad en el interior de la cueva. Esto último también pudo favorecer el desarrollo de líquenes, no observados durante la primera visita. Asimismo, se advirtió que la mezcla usada como cobertura se ha ido desprendiendo, con lo que pudo observarse mejor la superficie de la pared, aunque sin poder definir los motivos.

\section{7. i. 3. Análisis}

$\mathrm{Al}$ considerar las condiciones de emplazamiento y visibilidad en Peñón del Pueblo 1 y 2 se observan diferencias y similitudes entre ambos (Tabla 7.16). Se emplearon superficies verticales en ambos sitios, en PP1 la superficie horizontal del techo (Conjunto 2). Esas superficies se encuentran a diferentes alturas respecto del suelo, superando los $2 \mathrm{~m}$ en algunos casos. En el caso de los motivos del conjunto 2 de PP1, una serie de líneas paralelas, un par de líneas verticales y un negativo parcial de una circunferencia ubicados a 2,60-2,90 m respecto del suelo, la línea oblicua podría haber sido realizada mediante el apoyo de un instrumento cargado 
con pintura que fue movido sobre la superficie (Figuras 7.104.a-b), en tanto que el negativo de circunferencia podría haber sido producto del pulverizado directo de pintura sobre el techo del alero, utilizando un esferoide (Figuras 7.104.c-d). En el primer ejemplo considerado, el acceso a esa porción del alero habría sido indirecto. En PP2, en los Conjuntos 5 y 7 el acceso a alturas superiores a $2 \mathrm{~m}$ habría ocurrido por el empleo de un escalón natural de la pared norte, el cual permite mantenerse de pie.

Respecto de la visibilidad de los motivos, ésta está estrechamente relacionada con las condiciones de conservación, el contraste entre el color de pintura utilizado y el soporte, y el grado de exfoliación que presentan las superficies en las que se encuentran los motivos. En este sentido, en PP1 y PP2 los motivos tienen baja visibilidad, siendo, además, muy baja para algunos conjuntos de PP2. La técnica de producción de los motivos es con exclusividad la pintura, de la cual se registraron dos modalidades: la pintura plana (Figura 7.104.a), que pudo haber sido aplicada con instrumentos (pincel o hisopo) de distinto tamaño, y el estarcido (Figura 7.104.c.).

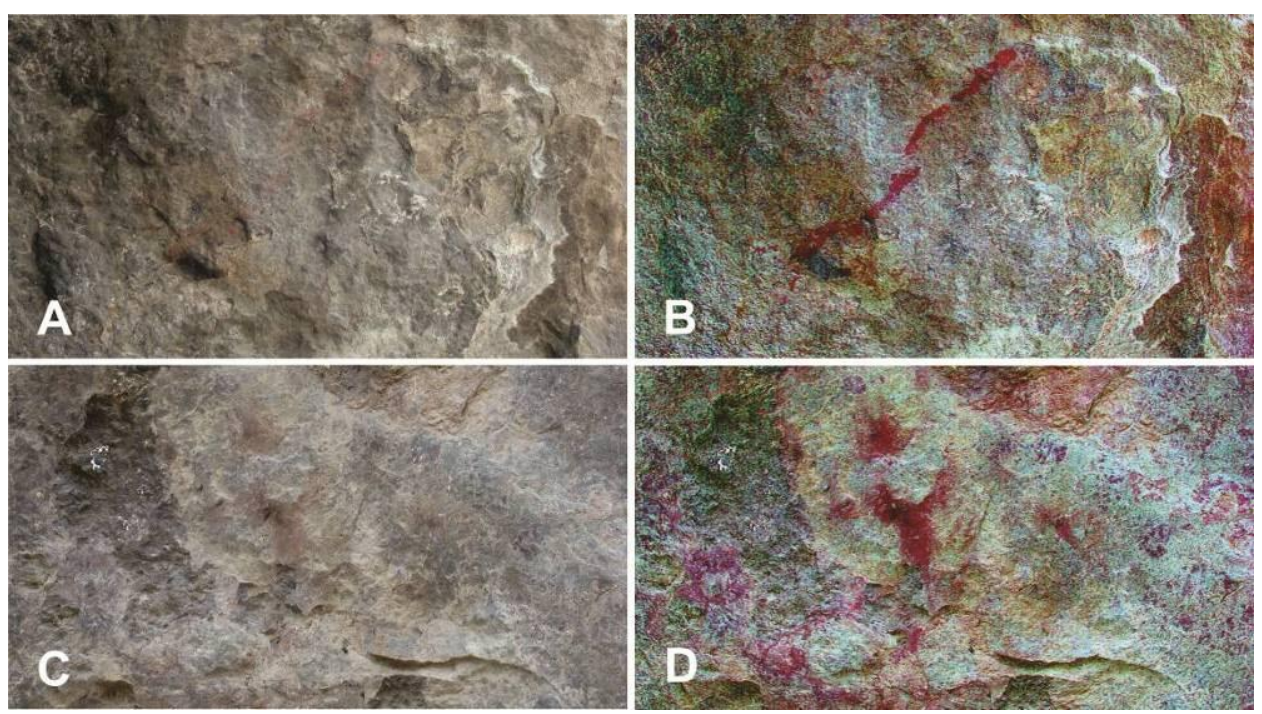

Figura 7.104. Técnicas de producción reconocidas en distintos motivos del Conjunto 6: a. línea oblicua; b. tratamiento digital de la imagen (D-Stretch yrd 15); c. negativo de circunferencia; $d$. tratamiento digital de la imagen (D-Stretch yrd $15)$.

Si bien en ambos sitios se documentaron motivos no figurativos y no determinados, presentan proporciones opuestas de dichos grupos. Todos los 
subgrupos no figurativos están presentes, siendo que PP1 presenta motivo circulares lineales y PP2 presenta motivos circulares llenos (Tabla 7.17).

De acuerdo con esta información, es posible considerar que estos sitios pertenecen a la Tendencia Abstracto Geométrica Simple (Gradin 1987), ya que presentan motivos puntiformes, curvilíneos y rectilíneos mayoritariamente en color rojo. En cuanto a la cronología del arte rupestre, no se obtuvieron fechados radiocarbónicos en ninguno de los dos sitios, por lo que remitiéndose al anclaje propuesto por Gradin (1987, 2003b) para dicha tendencia, podrían corresponder a 1.950 años AP.

\section{7. j. CAÑADÓN MARTEL}

Durante 2011, y como parte de las tareas de prospección en la cuenca alta del arroyo Talagapa, se relevó el cañadón Martel (Figuras 7.80 y 7.105.a). La información referida a los resultados de las transectas forma parte de la tesis doctoral de uno de los miembros del equipo (Terranova 2013). Las tareas de prospección fueron realizadas en grupos, abarcando el nivel de base y las zonas media y alta, con la expectativa de hallar arte rupestre en los paredones de este último sector (Figura 7.105.b). Para esta porción del macizo no existen antecedentes arqueológicos siendo estos trabajos los primeros vinculadas al estudio sistemático de la cuenca alta del Arroyo Talagapa.

El cañadón Martel tiene una extensión aproximada de $6,50 \mathrm{~km}$, con orientación SSW-NNE. Por él discurre un curso de agua temporario (Figura 7.105.c), y presenta además numerosas vertientes y manantiales, que se distinguen como manchones de vegetación. El cañadón se corresponde con la formación $C V B N$, caracterizada en este sector por traquitas con facies piroclásticas, basaltos y traquibasaltos (Remesal et al. 2001, 2012) (Figura 7.106.a). A lo largo de sus laderas se observan las distintas sucesiones de estos depósitos, que pueden presentar intercalaciones de tobas pumíceas. Las coladas basálticas pueden ser vesiculares o amigdaloides, o bien 
presentar disyunción grosera (Figura 7.106.b). En líneas generales, las rocas son de color marrón, con pátina rojiza (Figura 7.106.c).

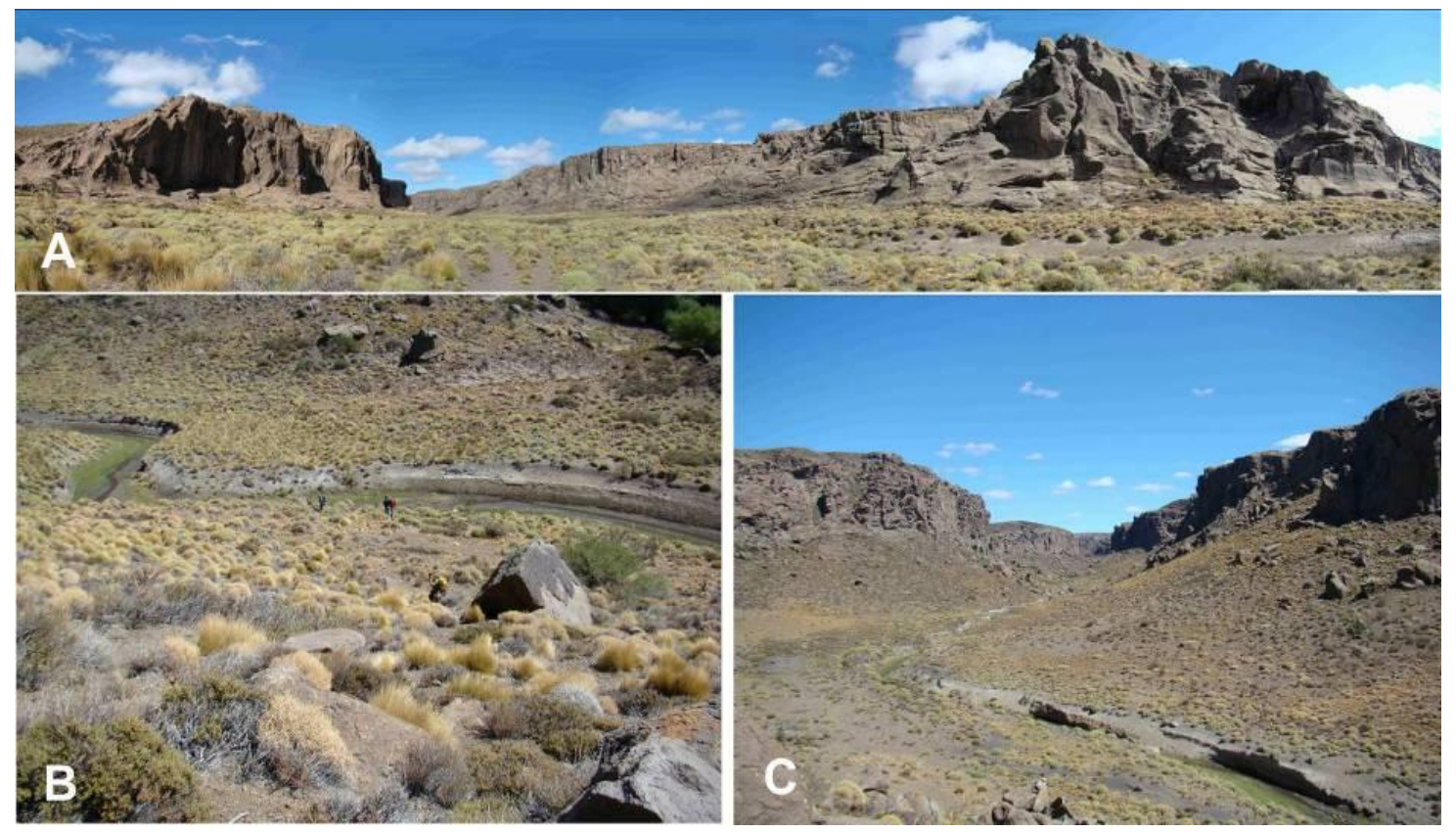

Figura 7.105. Cañadón Martel: a. Entrada; b. Grupos de prospección; c. Arroyo en la porción media del cañadón.
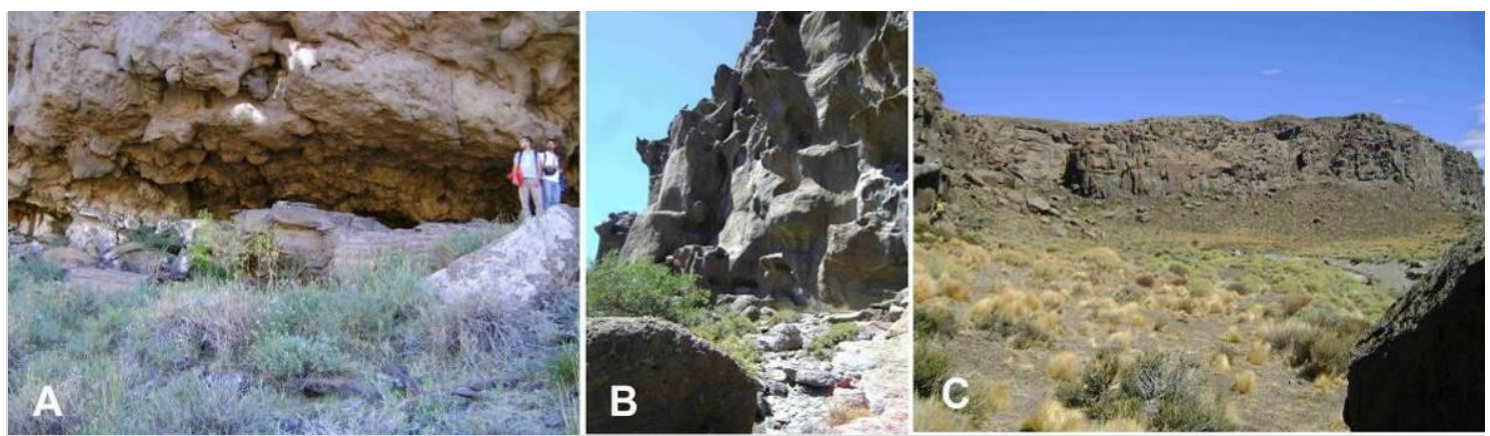

Figura 7.106. Rocas que conforman el cañadón Martel: a. Disyunción entre basaltos y traquitas en una de las laderas del cañadón; b. Bardas con disyunción grosera; c. Aspecto y color del basalto.

Dado que se trata de un cauce profundo, desde el arroyo o el pie de la corona basáltica no es posible tomar como referencia ningún punto alto de las inmediaciones. Sin embargo, desde la entrada al cañadón es posible considerar al Cerro Negro como punto de referencia, localizado en la cuenca media del arroyo Talagapa y altamente visible desde diferentes lugares.

En esta localidad se detectaron diferentes sitios, concentraciones y hallazgos de materiales arqueológicos así como dos sitios con arte rupestre y hallazgos en superficie de materias primas colorantes. 


\section{7. j. 1. Hallazgos arqueológicos}

A lo largo de los 3,30 km de la transecta realizada en el Cañadón Martel se localizaron dos sitios arqueológicos, dos concentraciones de materiales en superficie y nueve hallazgos aislados (Terranova 2013). Los dos sitios corresponden a Cueva Martel y a Meteoro, respectivamente.

En el interior de Cueva Martel se realizó un sondeo de $25 \mathrm{~cm}$ por $25 \mathrm{~cm}$, en el que se alcanzó $45 \mathrm{~cm}$ de profundidad hasta alcanzar la roca de caja. En los primeros veinte centímetros de profundidad del sondeo se recuperaron escasos materiales, mientras que en las recolecciones realizadas en el talud de la cueva se recuperaron artefactos formatizados (Terranova 2013).

Meteoro es un sitio de superficie que abarca aproximadamente $2.100 \mathrm{~m}^{2}$, ubicado a $1 \mathrm{~km}$ de la cueva. En este sitio se recuperaron diferentes clases de artefactos líticos, los cuales podrían haber ingresado formatizados al sitio. Por otro lado, al pie de la corona basáltica en el límite SE del sitio, así como en diferentes flancos del cañadón, se observaron venas silicificadas, de color y calidad variables para la talla (Terranova 2013).

\section{7. j. 2. El arte rupestre de Cueva Martel}

Las coordenadas geográficas del sitio son $41^{\circ} 56^{\prime \prime} \mathrm{S}$ y $68^{\circ} 6^{\prime} \mathrm{W}$. Corresponde a una oquedad en las rocas del CVBN. Tiene 21,60 m de boca por $13 \mathrm{~m}$ de profundidad, con su eje mayor en sentido N-S, coincidente con la orientación del cañadón en este tramo aunque abre hacia el SW (Figura 7.107.a). En el interior de la cueva se observaron dos áreas de combustión, una cacerola enlozada y un fragmento de chapa acanalada (Figura 7.107.b). En una de las áreas de combustión se realizó un pequeño sondeo (Terranova 2013) y se inspeccionaron las paredes en busca de manifestaciones rupestres. 

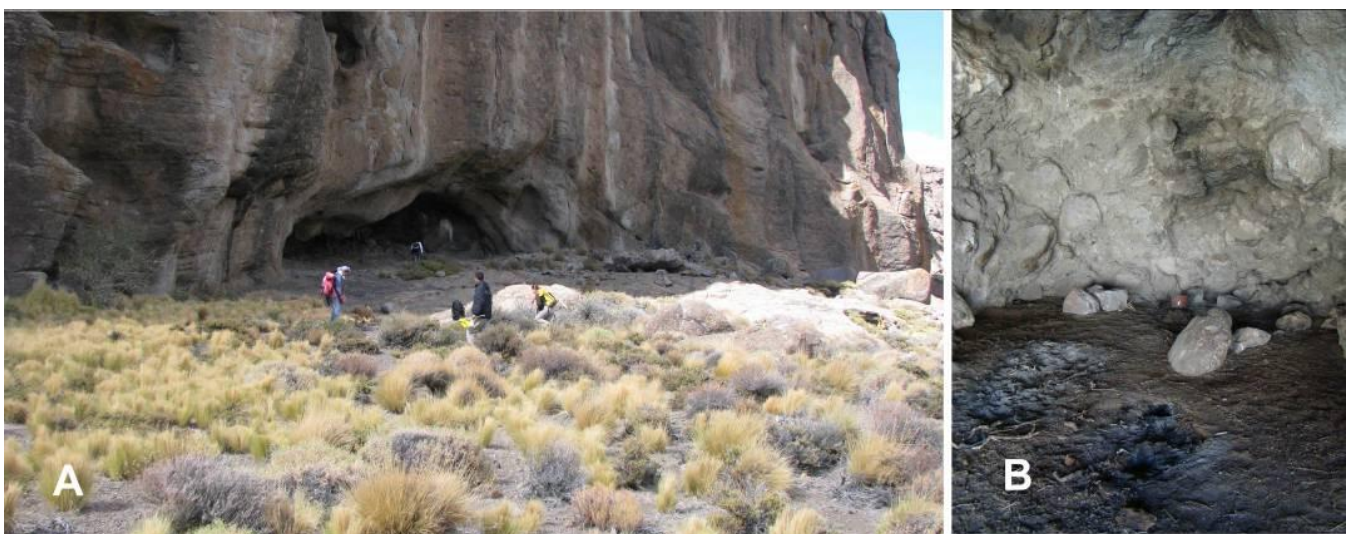

Figura 7.107. Cueva Martel: a. frente y talud de la cueva; b. Registro arqueológico en superficie en su interior.

En la cueva se registraron motivos rectilíneos y motivos pintados no determinados. En el sector norte de la entrada se observó un grafiti (Figura 7.108 y 7.109.a) que corresponde a la inscripción "MAR", efectuada con un instrumento filoso; es probable que la misma corresponda a las letras iniciales del apellido del puestero (Martel). En la porción meridional de la cueva se registraron dos motivos aislados y un conjunto. El Motivo 1 se encuentra al fondo de la cueva, en tanto que sobre la sobre la pared sur se detectaron restos muy desvaídos de pintura roja, fuertemente afectados por deyecciones de aves (Figura 7.108).

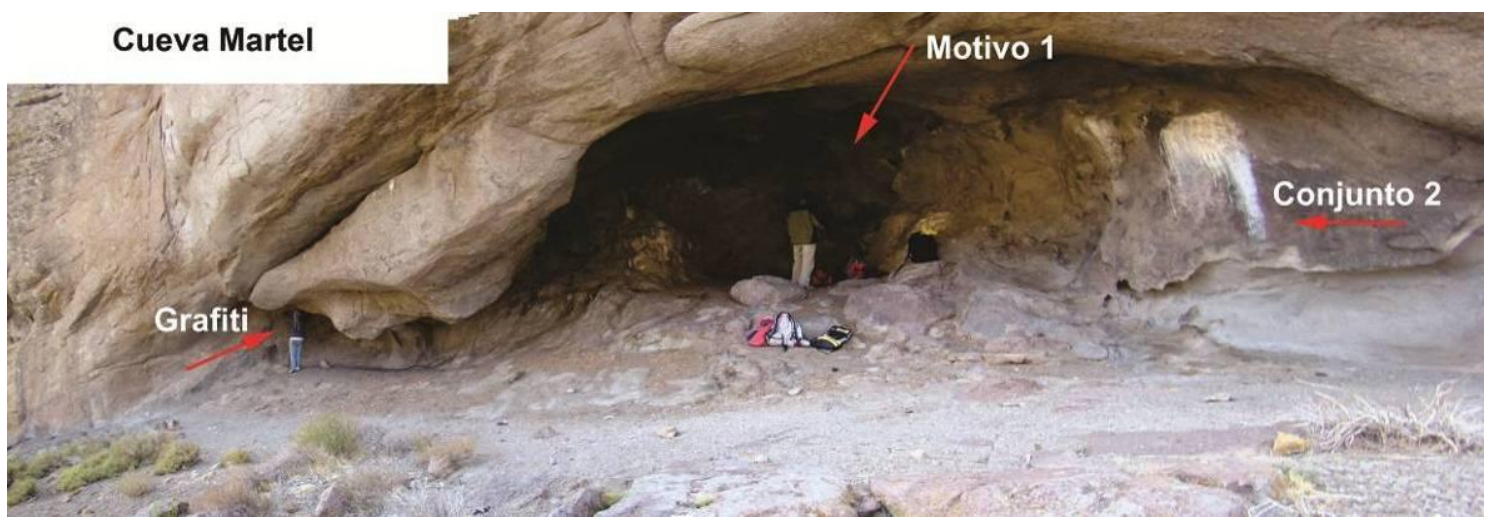

7.108. Localización del arte rupestre en Cueva Martel.

Motivo 1. Se encuentra al interior de una oquedad, a 2,50 $\mathrm{m}$ del suelo actual (Figura 7.109.b) y a la que se accede mediante diferentes escalones naturales de la roca de caja. La oquedad mide $0,85 \mathrm{~m}$ de ancho y tiene una altura variable entre 0,15 y $0,23 \mathrm{~m}$, en la que se observaron restos de pintura (Figura 7.109.c). Probablemente la pintura haya sido aplicada 
mediante estarcido o pulverizado directo con la boca debido a que la superficie se presenta cubierta totalmente y se observan gotas resultantes de pulverizado (Figura 7.109.d). En el interior de esta oquedad, además, se observaron restos de fecas de pilquín y sobre el borde inferior una percha de ave.

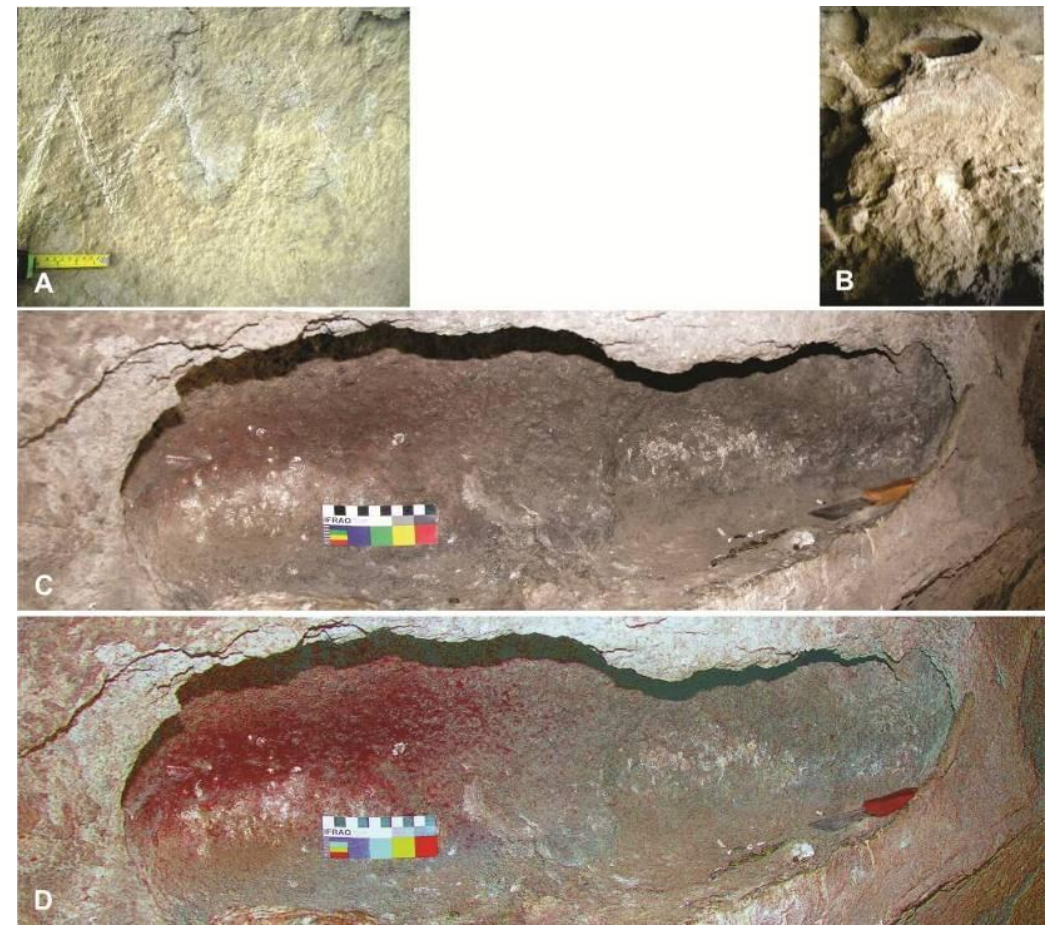

7.109. Grafiti y Motivo 1 de Cueva Martel: a. Grafiti de pared norte ("MAR"); b. Oquedad en la que se encuentra el motivo 1 sobre la pared sur; c. Motivo 1; d. Tratamiento digital de la imagen anterior (D-Stretch yrd 15) que permite observar el pulverizado de la pintura.

Conjunto 2. Se encuentra a $1,02 \mathrm{~m}$ de un escalón de la roca de caja y ocupa una superficie estimada de $52 \mathrm{~cm}$ de alto por $35 \mathrm{~cm}$ de ancho. El tratamiento digital de la imagen permitió discernir un motivo almenado y diferentes trazos rectilíneos en muy mal estado de conservación por la presencia de una gran mancha producto de defecaciones de ave (Figura 7.110). Todos los motivos están pintados en color rojo, cuyo trazo es menor a 1,5 cm de ancho. La percha ocupa la porción central del panel, cubriendo los motivos y alcanzando allí un ancho máximo de $0,30 \mathrm{~m}$ cuyo alto ronda 1,40 m.

Motivo 3. Se trata de restos de pintura rosa a $0,60 \mathrm{~m}$ del suelo actual, sin forma reconocible. 

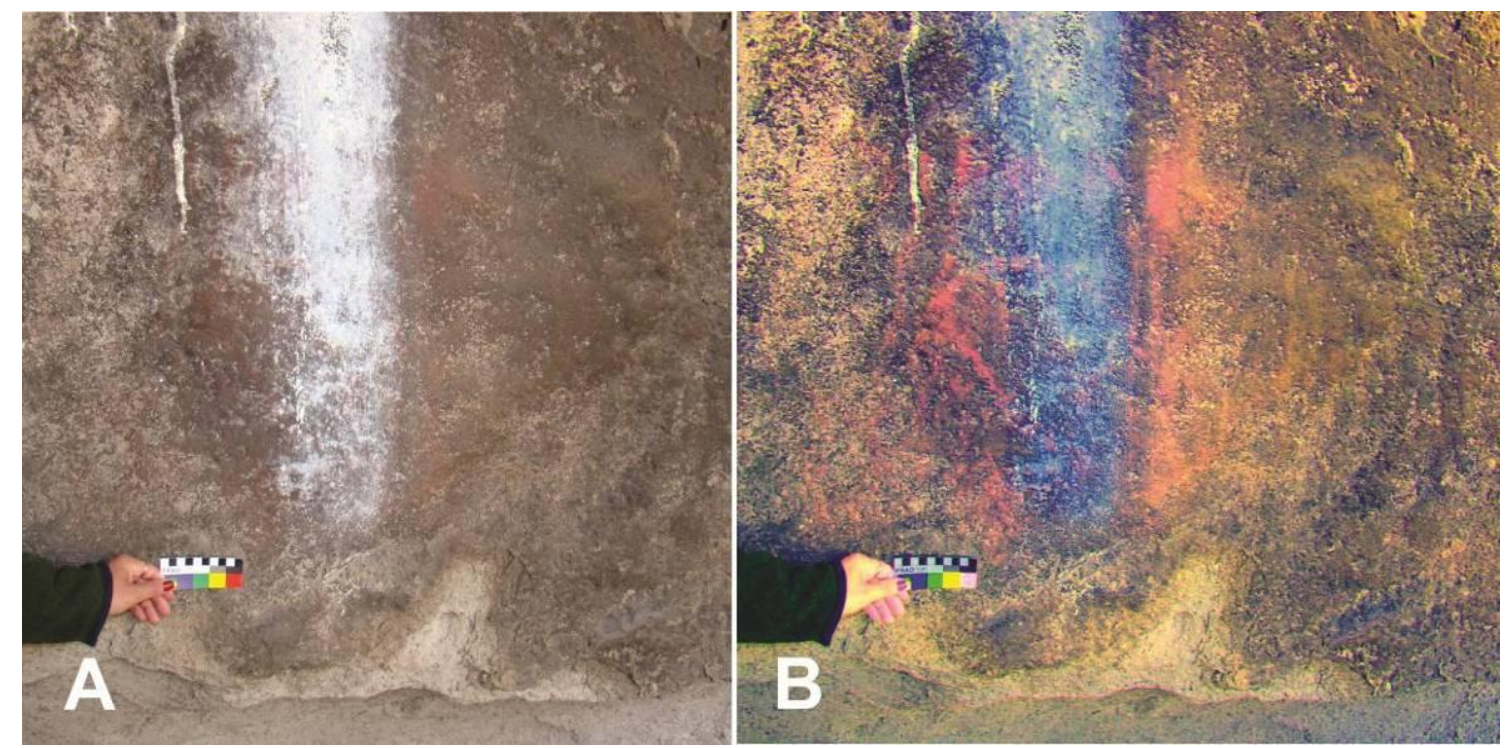

7.110. Conjunto 2 de Cueva Martel: a. Relevamiento fotográfico; b. Tratamiento digital de la imagen (D-Strecth ybk 15).

\section{6. j. 3. Pedrones Martel 1 y 2}

Las prospecciones realizadas en el cañadón permitieron la detección, geoposicionamiento y relevamiento de un sitio adicional con arte rupestre y una pequeña acumulación de materias primas colorantes. Alrededor de 1,30 $\mathrm{km}$ al sur de la cueva, en el borde del arroyo, se detectaron cinco pequeñas manchas de pintura en el sitio Pedrón Martel 1. Estos restos de pintura se encuentran al interior del espacio reparado de un bloque desprendido de la barda. Ese espacio abre hacia el E, y sus dimensiones son 1,75 m de ancho por $1,10 \mathrm{~m}$ de alto (Figura 7.111.a). La superficie interna es regular mientras que las superficies externas del bloque presentan líquenes y exfoliaciones, estas últimas debidas a la acumulación de agua en diferentes sectores y a la acción que ésta tiene sobre la roca. Los restos de pintura se encuentran a 0,40 m del suelo, ocupando una superficie de $20 \mathrm{~cm}$ de ancho por $10 \mathrm{~cm}$ de alto y son de color rosado (Figura 7.111.b). 

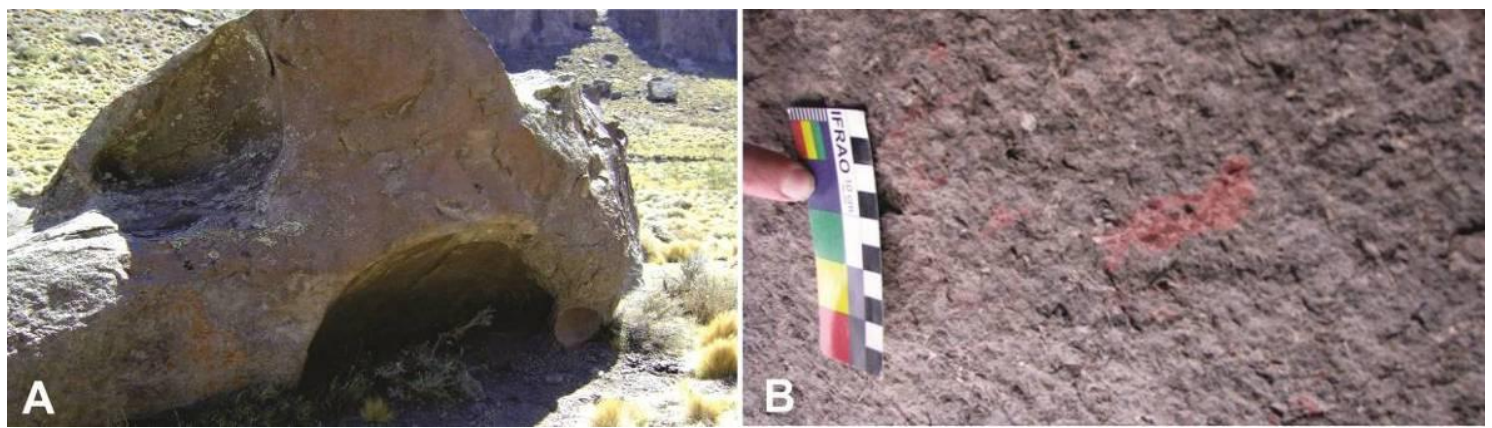

Figura 7.111. Pedrón Martel 1: a. Vista del pedrón y del espacio reparado interior desde la ladera del cañadón; b. Restos de pintura considerado como motivo no determinado en el interior.

La acumulación de materias primas colorantes fue registrada a $1,70 \mathrm{~km}$ de distancia de Cueva Martel y a 400 m de Pedrón Martel 1, debajo de un bloque con una pequeña oquedad que abre al E (Figura 7.112.a). Este bloque se denominó Pedrón Martel 2, debajo del cual y en superficie, se detectaron cinco fragmentos de materia colorante roja (Figura 7.112.b). Se infiere que los pigmentos fueron transportados al lugar por personas, ya que no se observa ninguna evidencia de escorrentía superficial que pueda haberlos acumulado allí de modo natural.

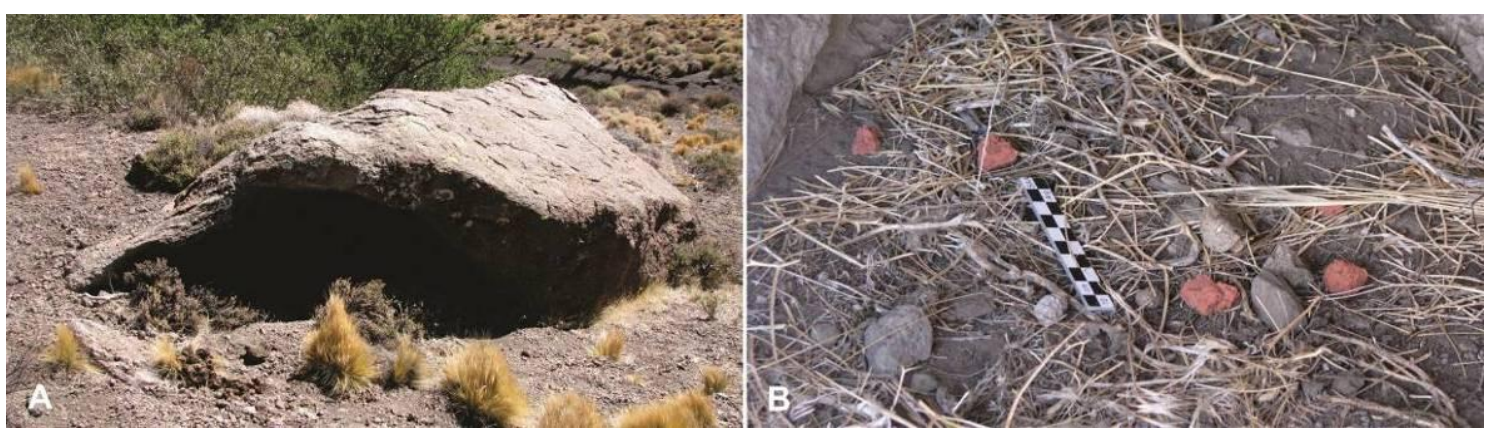

Figura 7.112. Pedrón Martel 2: a. vista del bloque; b. Materias primas colorantes encontradas en su interior.

\section{7. j. 4. Análisis}

El arte rupestre de Cañadón Martel está integrado por motivos pintados, que se encuentran al interior de espacios reparados. En el interior de Cueva Martel se emplearon superficies verticales mientras que en Peñón Martel 1 se emplazan en la superficie oblicua del fondo del espacio reparado que 
ofrece un bloque (ver Tabla 7.16). La altura de los motivos respecto del suelo es variable: más de $2 \mathrm{~m}$ para el Motivo 1 de Cueva Martel, y cercana o menor a $1 \mathrm{~m}$ en los restantes motivos de la cueva así como en Pedrón Martel 1. La visibilidad de los motivos es baja debido a su emplazamiento (Motivo 1 de Cueva Martel) y al estado de conservación (Conjunto 2): es necesario acercarse a las superficies para poder reconocerlos y/o distinguirlos. Respecto al diseño, se trata mayoritariamente de motivos no determinados, salvo el Conjunto 2 de cueva Martel que corresponde a motivos almenados y rectilíneos. Esta información permite pensar que se trata de motivos pintados de realización reciente, correspondiente a la Tendencia abstractogeométrica (Gradin 1987). El grafiti de Cueva Martel podría ser de factura actual si se lo contempla como una inscripción realizada por el parcelero actual del cañadón.

Si bien se prospectó la mitad del cañadón, resulta llamativo encontrar sólo dos sitios con arte rupestre a lo largo de $3,30 \mathrm{~km}$ a pesar de tener grandes superficies basálticas disponibles, libres de líquenes, que podrían haber sido empleadas en la producción de arte rupestre. Por otro lado, se registraron materias primas colorantes en Pedrón Martel 2, las cuales podrían haber sido empleadas para producción de pinturas. Quizás estas últimas pudieron haber sido aplicadas sobre superficies diferentes a los basaltos que conforman el cañadón.

\section{7. k. VACALAUQUÉN}

Este sitio se encuentra alrededor de $30 \mathrm{~km}$ al NW de El Caín (ver Figura 7.80), en la porción NE de un bajo, cuyas coordenadas geográficas son $41^{\circ} 23^{\prime}$ 38” s y $68^{\circ} 13$ '55” W. A comienzos de la década de 1970, durante la visita de Gradin (2003b), el bajo carecía de agua presentándose como un gran salitral, en tanto que durante la visita que realizó el equipo en 2006 la laguna presentaba agua (Figura 7.113.a). 
Si bien los sitios con arte rupestre de la localidad fueron presentados por Gradin, la revisita al sitio tuvo como objetivo el relevamiento fotográfico del arte, con el fin de complementar la información presentada por aquel autor. Los motivos rupestres se encuentran sobre las paredes del cañadón nororiental del bajo, donde se observaron varias surgentes y estructuras de piedra que sirven para encerrar parte del ganado (Figura 7.113.b). Por otro lado, sobre la margen derecha del cañadón, al pie del farallón se observó materia prima colorante disponible (Figura 7.114).

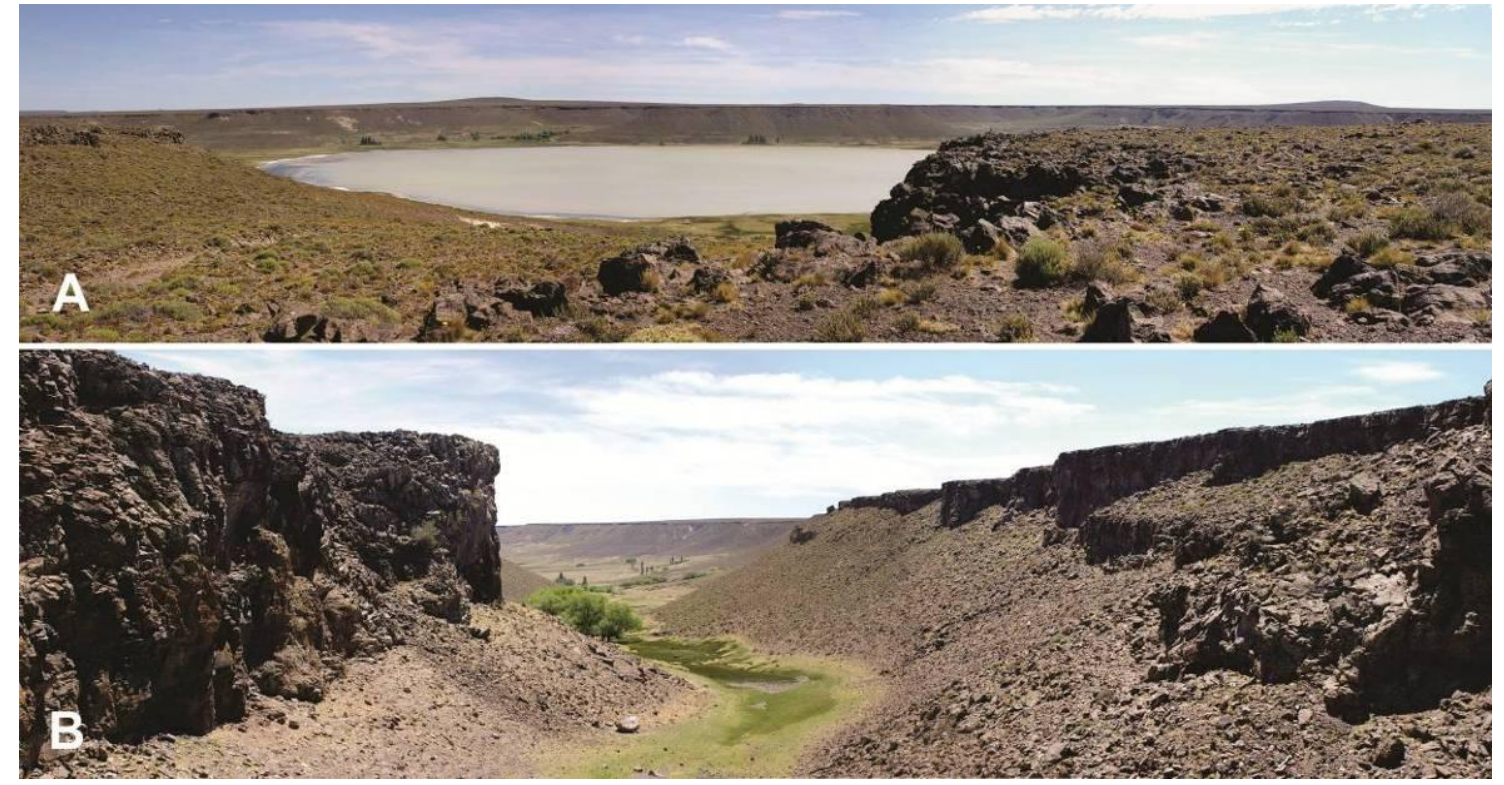

Figura 7.113. Vacalauquén: a. Laguna vista desde borde SE del bajo (2006); b. Cañadón nororiental donde se encuentran los sitios con arte rupestre, con numerosas surgentes de agua.

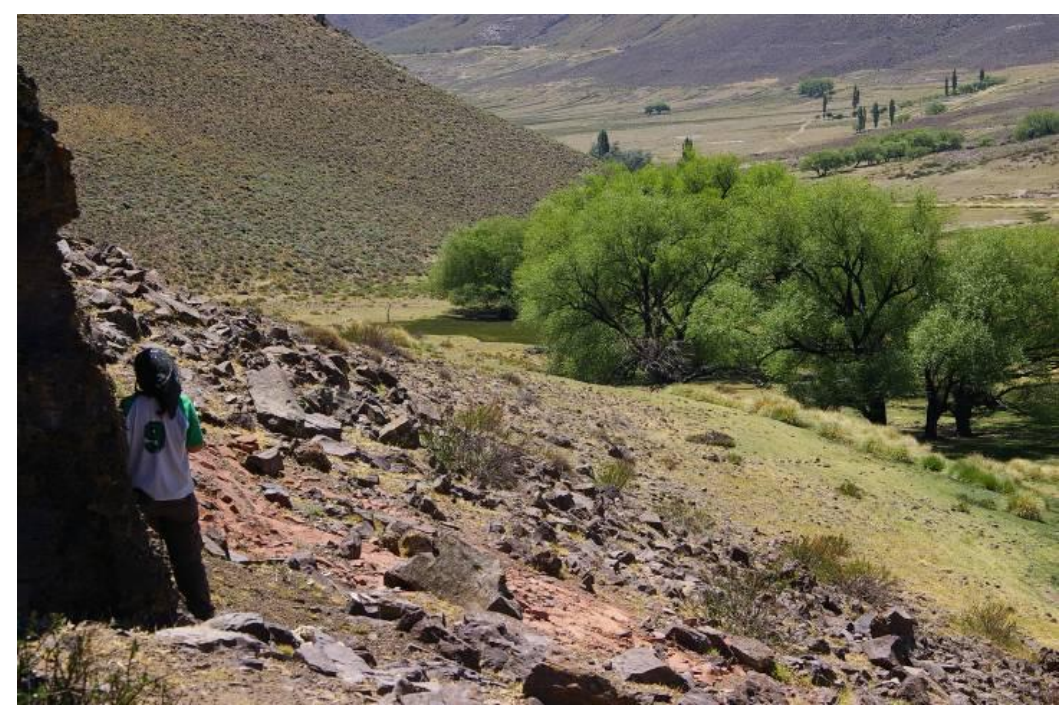

Figura 7.114. Materia prima colorante disponible cercana a los sitios con arte rupestre. 


\section{7. k. 1. El arte rupestre de Vacalauquén}

Los motivos se encuentran a alturas que oscilan entre 0,50 y $1,60 \mathrm{~m}$ respecto del suelo, sobre superficies basálticas pertenecientes a la formación Complejo Los Menucos. Tales superficies son relativamente regulares aunque algunas presentan craquelados y fracturas producto de la insolación directa y a los cambios de temperatura a los que están sometidas. En algunos casos, resulta difícil la visualización de los motivos ya que las pinturas tienden a confundirse con la coloración rojiza del soporte o por el alto grado de insolación que reciben en diferentes momentos del día (ver más adelante). Gradin (2003b) designa tres sitios (Vacalauquén I a III), dos de ellos ubicados sobre la margen derecha y el restante sobre la margen izquierda del cañadón.

La distribución de los motivos es heterogénea, con una concentración de los mismos en el sitio II (Figura 7.115). Se registraron motivos figurativos y no figurativos en todos los sitios, y motivos no determinados solamente en el sitio II (Figura 7.116.a; Tabla 7.18). Asimismo, dentro de los no figurativos predominan los rectilíneos -presentes en todos los sitios-, siendo que los circulares lineales o curvilíneos están presentes sólo en algunos de ellos (Figura 7.116.b; Tabla 7.18).

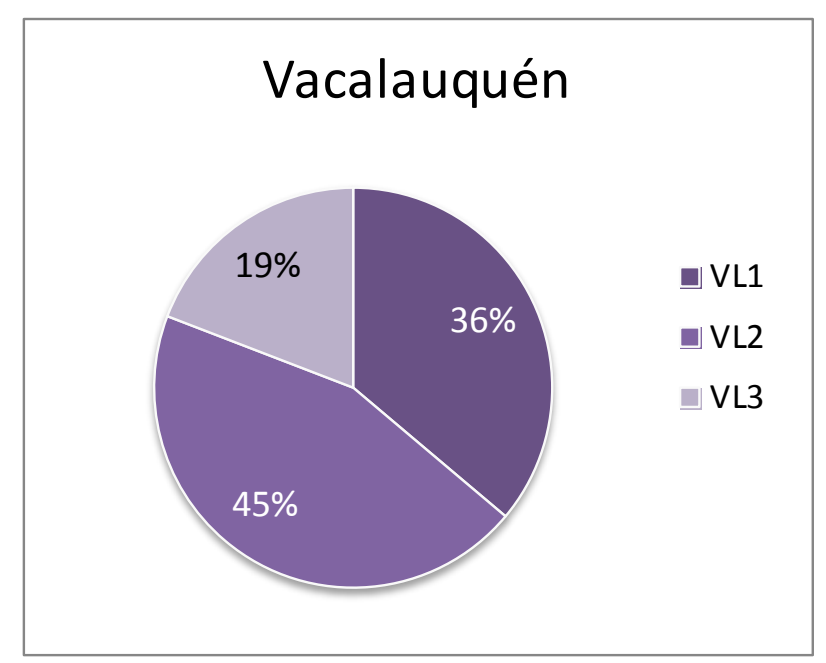

Figura 7.115. Distribución de motivos en los sitios de Vacalauquén. 


\begin{tabular}{|c|c|c|c|c|}
\hline Motivos & VL1 & VL2 & VL3 & Subtotal \\
\hline Rectilíneos & 11 & 15 & 8 & 34 \\
\hline Circulares lineales & 3 & 2 & 0 & 5 \\
\hline Curvilíneos & 0 & 1 & 0 & 1 \\
\hline No Figurativos & 14 & 18 & 8 & 40 \\
\hline Pisadas animales & 0 & 1 & 0 & 1 \\
\hline Figura animal & 2 & 0 & 0 & 2 \\
\hline Objetos & 1 & 1 & 1 & 3 \\
\hline Figurativos & 3 & 2 & 1 & 6 \\
\hline No Determinado & 0 & 1 & 0 & 1 \\
\hline Total & 17 & 21 & 9 & 47 \\
\hline
\end{tabular}

Tabla 7.18. Frecuencia de motivos para los sitios Vacalauquén (VL) 1 a 3, calculada a partir de la descripción realizada por Gradin (2003b).

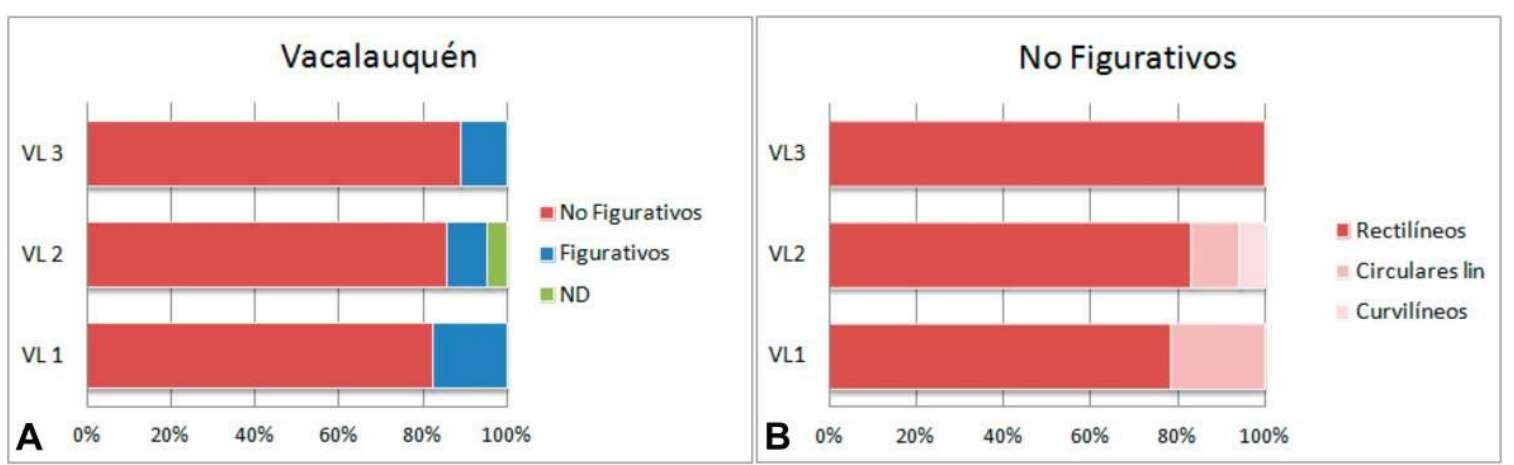

Figura 7.116. Proporciones de grupos y subgrupos de motivos en Vacalauquén: a. Por grupos de motivos; b. Motivos no figurativos. Referencias: ND: no determinado; Circulares lin: circulares lineales.

\section{7. k. 1. 2. Sitio $I$}

Se extiende a lo largo de aproximadamente $30 \mathrm{~m}$ de la margen izquierda del farallón (Figura 7.117), donde se observan tramos entre 3 y $14 \mathrm{~m}$ sin motivos. Gradin reconoció diecisiete motivos, entre los que menciona trazos almenados, figuras cuadrangulares, "en forma de U" de trazo rectilíneo, cruciformes y triángulos escalonados, series de líneas angulares paralelas entre los motivos no figurativos. Entre los figurativos, asimismo, mencionó dos siluetas de matuastos pintadas en color rojo con diferente disposición y "hachas en 8" (Gradin 2003b: 65). Las figuras animales no pudieron ser reubicadas por el equipo durante el relevamiento. 


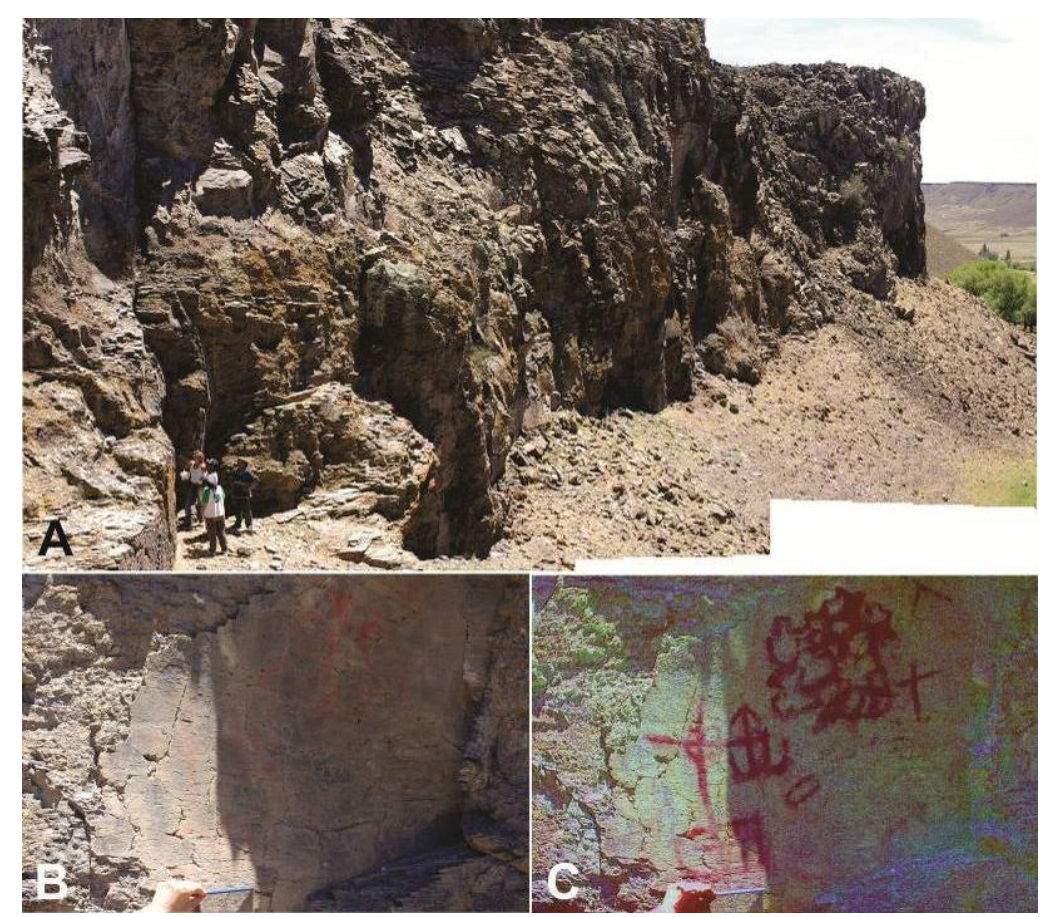

Figura 7.117. Sitio I de Vacalauquén: a. Extensión del sitio I; b. primer panel; c. imagen tratada digitalmente (D-Stretch yrd 15).

\section{7. k. 1. 2. Sitio II}

Se encuentra sobre la margen derecha del cañadón, su extensión aproximada es de $50 \mathrm{~m}$, en los que se observan tramos de soporte sin motivos que varían entre 3 y $15 \mathrm{~m}$. Gradin distinguió veintiún motivos, entre los más distintivos se pueden mencionar una circunferencia con negativo de estrella de 7 puntas y punto central en positivo (Figuras 7.118.a-b), rombos y rectángulos alineados horizontalmente (Figuras 7.118.c-d), trazos escalonados aislados, laberintos de trazos ortogonales (Figura 7.119), circunferencias agrupadas, grecas cruciformes y zig-zags. Entre los figurativos reconoció dígitos, un tridígito y placas rectangulares con trazos internos (Gradin 2003b: 65). En cuanto a la ejecución se reconocieron diferentes tonalidades de rojo, así como motivos en bicromías (Figura 7.119.c-d). 

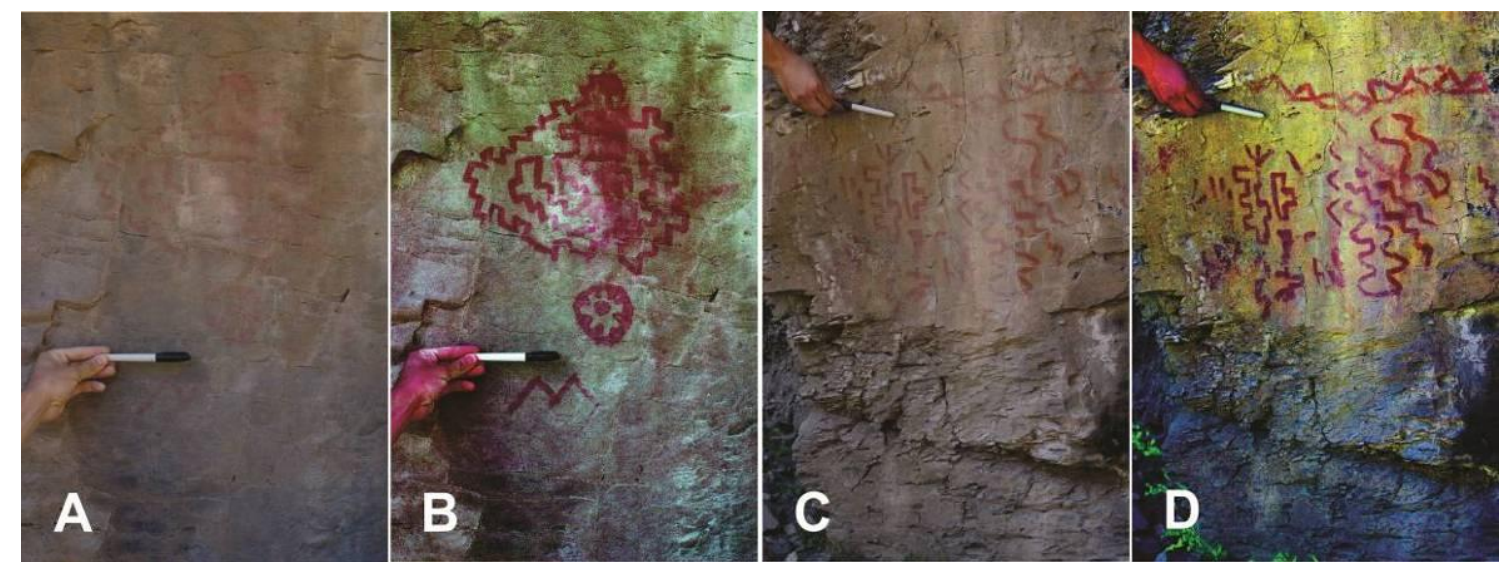

Figura 7.118. Sitio II: a. Laberinto de trazos almenados y escalonados, circunferencia con negativo de estrella de 7 puntas con punto en positivo interior y zig-zag; b. Tratamiento digital de la imagen (D-Stretch yrd 15); c. Triángulos alineados y unidos por el vértice, almenados, dígitos, tridígito; $d$. Tratamiento digital de la imagen (D-Stretch lds 15).

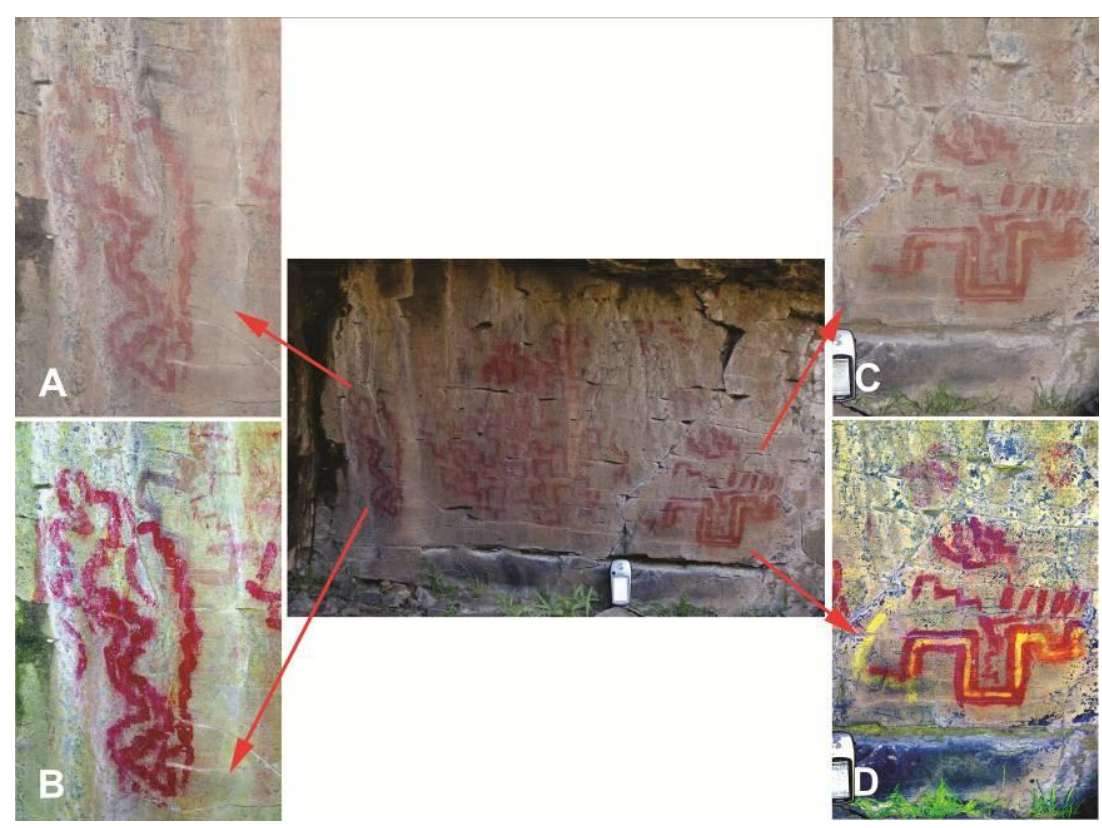

Figura 7.119. Alero del sitio II: a. Escalonados; b. Tratamiento digital de la imagen (D-Stretch yrd 15) donde pueden observarse superposiciones; c. Bicromía; d. Tratamiento digital (D-Stretch lds 15)

\section{7. k. 1. 3. Sitio III}

Se encuentra sobre la margen izquierda del cañadón, extendiéndose a lo largo de $50 \mathrm{~m}$ del farallón, en los que existen tramos de entre 2 y $15 \mathrm{~m}$ sin motivos. Gradin reconoció nueve motivos, entre los que se destacan las grecas laberintiformes, los motivos ornamentales compuestos por líneas 
quebradas, paralelas entre trazos ondulados verticales (Figura 7.120), y cruciformes escalonados (Gradin 2003b: 65-66).
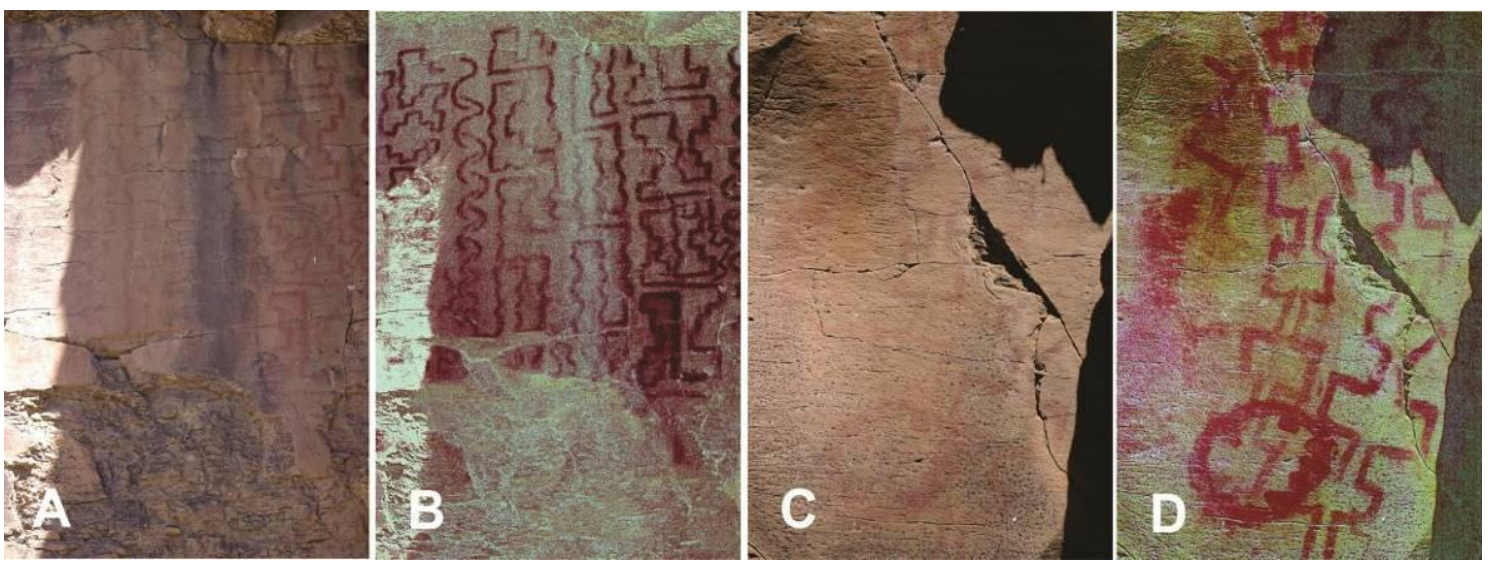

Figura 7.120. Sitio III: a. Panel del sitio I que se encuentra fuertemente craquelado; b. tratamiento digital de la imagen (D-Stretch yrd 15); c. detalle donde puede observarse la dificultad en discernir los motivos si estos reciben luz solar directa; d. Imagen tratada digitalmente (D-Stretch yrd 15): puede observarse una superposición.

\section{7. k. 1. 4. Análisis}

$\mathrm{El}$ arte rupestre de Vacalauquén está conformado por una amplia riqueza y variabilidad de motivos pintados. La información brindada por Gradin (2003b) permite considerar números mínimos $(n=1)$ por la mención de motivos; sin embargo, las frecuencias podrían aumentar si se realiza un relevamiento para cerrar el número de motivos presentes en los sitios. Por otro lado, la variabilidad en cuanto a los diseños observada en Vacalauquén es la mayor observada hasta el momento para el centro y el occidente de Somuncurá. Es decir que a diferencia de otros sectores, Vacalauquén concentra sitios, motivos y variabilidad en cuanto al diseño de los mismos.

Los motivos se encuentran sobre superficies verticales del farallón basáltico, tratándose en un sólo caso de un alero o espacio reparado (Alero del Sitio II). En aquellos casos en los que se emplearon superficies expuestas, la visibilidad de los motivos es baja debido a la exposición de la pintura a los diferentes agentes meteóricos que las afectaron a lo largo del tiempo. En algunos casos, ni siquiera el acercamiento a las superficies permite su neta distinción (ver Figuras 7.117.b y 7.120.c). La altura respecto 
del suelo a la que se encuentran los motivos es variable: entre 0,50 m y cercana a $1,60 \mathrm{~m}$.

Respecto al diseño, se trata mayoritariamente de motivos rectilíneos, a veces complejos en los que predominan los trazos almenados o escalonados y que pueden estar combinados con trazos curvilíneos (ver Figura 7.120.a-b). Si bien los motivos figurativos se corresponden principalmente con objetos (placas o hachas), los matuastos pintados en color rojo, documentados por Gradin en el Sitio II resultan llamativos, ya que no habían sido documentados en otros sitios del macizo somuncurense.

Entre las técnicas de producción pudo reconocerse la pintura plana para todos los motivos, la cual puede ser monocroma y bicroma. En el primer caso se trata mayoritariamente de motivos en diferentes tonalidades de rojo, mientras que entre los segundos se observó la combinación de rojo y amarillo (Figura 7.119.c-d). Asimismo, se registró la técnica digital para aplicación de pintura, utilizando la yema de los dedos (Figura 7.118.c-d). El tratamiento digital de las imágenes permitió reconocer que algunos motivos fueron realizados mediante el uso de artefactos, y también distinguir distintas superposiciones.

Se supone el uso de artefactos para la aplicación de la pintura, por los diferentes tamaños y colores reconocidos en los trazos. En el alero del sitio II (Figura 7.119) se observan trazos con características diferentes: uno muy fino $\mathrm{y}$ otros correspondientes a diferentes tonalidades de rojo -claro a borravino- de mayor tamaño (Figura 7.121.a). Esta información, junto con las superposiciones reconocidas, permite reconocer, por lo menos en ese panel, diferentes momentos de producción por el uso de artefactos y mezclas diferentes. Lamentablemente, el acceso al sitio tuvo su énfasis en el relevamiento fotográfico, efectuando observaciones de campo, pero no en el detalle que se realizan cuando se efectúa el relevamiento de un/os sitio/s.

Respecto a las superposiciones, Gradin (2003b: 64-65) las reconoció en el Sitio I. En posición inferior se observaron circunferencias de diferente tamaño con trazos interiores, mientras que los motivos en posición superior se corresponden con motivos rectilíneos, generalmente de trazo almenado 
(Figura 7.117.c). Por otro lado, el tratamiento digital de las imágenes tomadas en 2006 por el equipo de trabajo permitió reconocer superposiciones adicionales en el alero del Sitio II y en el Sitio III (Figura 7.121). La superposición detectada en el alero del Sitio II permitiría afirmar el uso de diferentes mezclas pigmentarias así como un uso relativamente diacrónico del sitio ya que las mezclas aparecen cubriéndose parcialmente entre sí, sin mezclarse (Figura 7.121.a). Por otro lado, en el Sitio III, la superposición detectada se corresponde con un escalonado en posición inferior, mientras que en posición superior se observa un circular lineal.

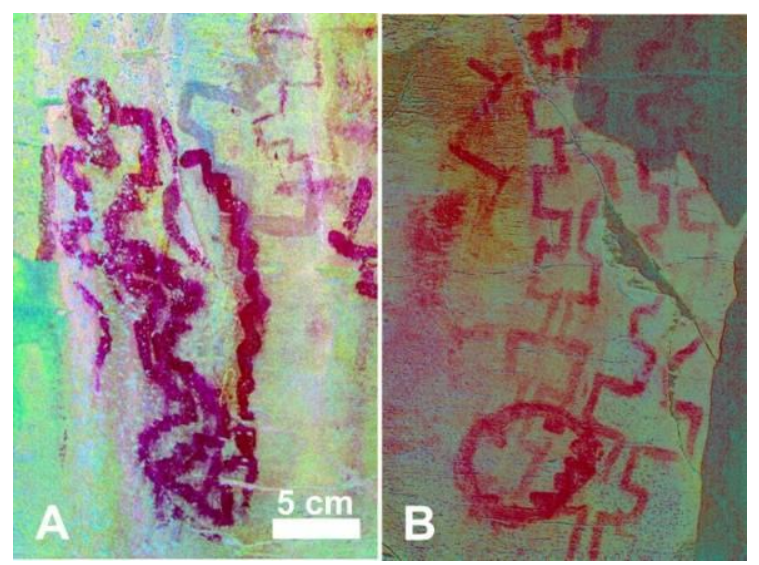

Figura 121. Uso de artefactos y superposiciones en Vacalauquén: a. alero del Sitio II, donde se observan diferentes trazos probablemente realizados por el uso de distintos artefactos y mezclas pigmentarias; b. Sitio III.

Las pinturas de Vacalauquén presentan las siguientes características: 1) en la realización de los motivos se incluye la utilización de hisopos, pinceles y las yemas de los dedos, que se distinguen por el ancho y tipo de trazo;

2) en cuanto a su diseño, si bien se detectó variabilidad, la mayor parte de los motivos son rectilíneos (72\%); seguidos por motivos figurativos $(12,8 \%)$ y en proporciones menores circulares lineales, circulares llenos y no determinados.

Entre los diseños rectilíneos, asimismo, se observa la mayor variabilidad registrada hasta el momento en Somuncurá, ya que si bien son abundantes los trazos ortogonales, estos adquieren complejidad al encontrarse combinados con motivos curvilíneos y/o circulares, o bien por formar grandes trazos laberínticos, típicos del "estilo de grecas"; 
3) la conservación de los motivos es regular a mala, en algunos casos se observa muy desvaída la pintura. Los motivos se encuentran sobre superficies que son afectadas por agentes atmosféricos (escurrimiento de agua, incidencia de la luz solar -ver Figura 7.120-). La mala conservación también se debe a la presencia de grafitis sobre las pinturas, que se observan escritos con lápiz o tizas, y algunos realizados mediante incisión.

4) si bien están presentes en todos los sitios, se detectaron escasas superposiciones. Estas se corresponden a circunferencias con trazos interiores por debajo de motivos almenados (Gradin 2003b), trazos almenados superpuestos o trazos almenados por debajo de un motivo circular lineal (ver Figura 7.121).

A partir del análisis de las superposiciones del alero del Sitio II, se desprende que el trazo ancho es previo al fino y que el color borravino es previo al rojo oscuro. Se desconoce el tiempo transcurrido entre la realización de los motivos que se encuentran superpuestos, aunque puede afirmarse que ese lapso temporal fue el suficiente para que la pintura se secara y se fijara al soporte. Por lo anterior, se puede hablar de redundancia en la utilización de ciertos paneles mediante el repintado, evidenciado por la presencia de distintas mezclas pigmentarias en un mismo conjunto. Por otro lado, la baja frecuencia de superposiciones permite apreciar la utilización de las superficies disponibles en este punto del cañadón indicando que negaron o suprimieron los motivos pre-existentes, por lo que podría considerarse la existencia de un código compartido entre los productores de los motivos rupestres pintados.

Por las particularidades que presentan las pinturas de Vacalauquén, Gradin propone que pueden corresponder al "estilo de grecas" de Menghin (1957), en el que se empleó el color rojo y, en algunos casos, el amarillo o blanco como colores complementarios. De igual manera, considera que dichas pinturas se pueden incluir en la Tendencia Abstracto Geométrica Compleja, la cual puede retrotraerse hasta $c a$. 1.250 años AP y que se extiende hasta momentos de contacto hispano-indígena (Gradin 2003b: 66$67)$. 


\section{1. EL ARTE RUPESTRE DEL CENTRO-OCCIDENTE DE SOMUNCURÁ}

Las manifestaciones rupestres de este sector son exclusivamente pinturas, entre las que abundan los motivos rectilíneos seguidos en frecuencia por los circulares lineales y los figurativos (Tabla 7.19). Los sitios se encuentran cercanos a fuentes de agua -temporarias o permanentes-, sobre superficies de origen volcánico y en espacios reparados (aleros, cuevas y/o al interior de cañadones).

En el centro-oeste de Somuncurá, Peñón del Pueblo 1 y 2 presentan la mayor concentración de motivos seguidos por Vacalauquén 1-3, siendo que los restantes sitios presentan entre uno y cinco motivos (Tabla 7.19; Figura 7.122). En la mayor parte de los sitios están presentes los motivos rectilíneos, siendo la excepción el Alero Amigo Oeste donde se registró un motivo rupestre que podría corresponder a una marca ganadera (Figura 7.89).

\begin{tabular}{|l|c|c|c|c|c|c|c|c|c|c|c|c|}
\hline \multicolumn{1}{|c|}{ Motivos } & LP & $\%$ & AAW & $\%$ & CM & $\%$ & $\begin{array}{c}\text { PP } \\
1-2\end{array}$ & $\%$ & $\begin{array}{c}\text { VL } \\
1-3\end{array}$ & Subtotal & $\%$ \\
\hline n & 5 & 100 & 1 & 100 & 4 & 100 & 63 & 100 & 47 & 100 & 120 & 100 \\
\hline Puntiformes & 0 & & - & - & - & - & 2 & 3,17 & - & - & 2 \\
\hline Rectilíneos & 3 & 60 & - & - & 2 & 50 & 22 & 34,92 & 34 & 72,34 & 61 \\
\hline Circulares llenos & - & - & - & - & - & - & 1 & 1,59 & - & - & 1 \\
\hline Circulares lineales & 1 & 20 & - & - & - & - & 8 & 12,70 & 5 & 10,64 & 14 \\
\hline Curvilíneos & - & - & - & - & - & - & - & - & 1 & 2,13 & 1 \\
\hline Figurativos & - & - & 1 & 100 & - & & - & & 6 & 12,76 & 7 \\
\hline No Determinados & 1 & 20 & - & - & 2 & 50 & 30 & 47,62 & 1 & 2,13 & 7,77 \\
\hline
\end{tabular}

Tabla 7.19. Frecuencias y proporciones de motivos reconocidos en los sitios.

Referencias: LP: La Porfía; AAW: Alero Amigo Oeste; CM: Cañadón Martel; PP:

Peñón del Pueblo; VL: Vacalauquén.

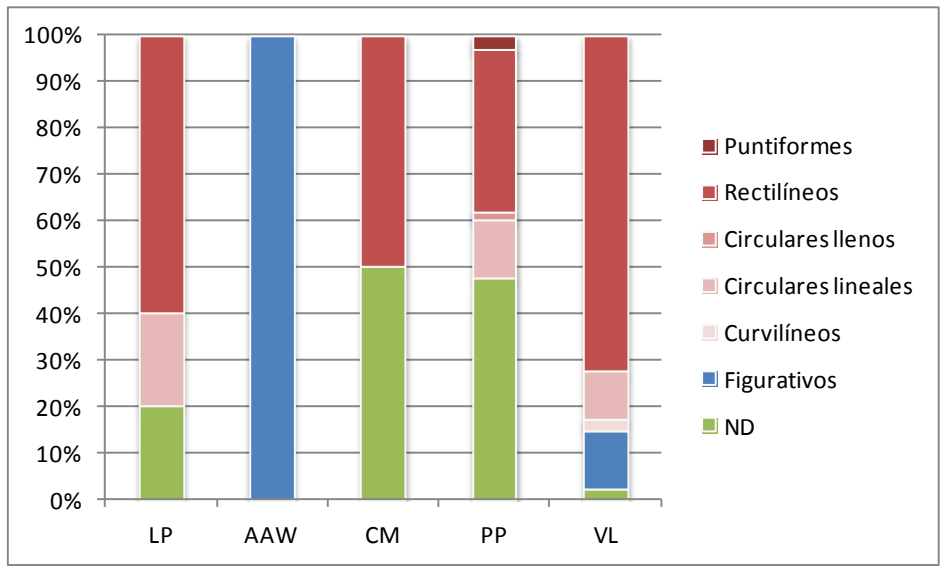

Figura 7.122. Proporciones acumuladas de subgrupos de motivos reconocidos en los sitios. Referencias: Referencias: LP: La Porfía; AAW: Alero Amigo Oeste; CM:

Cañadón Martel; PP: Peñón del Pueblo; VL: Vacalauquén. 
$\mathrm{Al}$ considerar en conjunto los atributos presentados en apartados previos, se pueden vislumbrar las diferencias y las similitudes entre los sitios del centro-occidente de Somuncurá (Tabla 7.20). Las superficies en las que se emplazan los motivos pueden estar siendo afectadas por la acción de líquenes o bien por procesos de exfoliación producidos por diferentes agentes atmosféricos (esto último relacionado principalmente con la formación rocosa en la que se encuentran). Estas condiciones son las que afectan, asimismo, el estado de conservación las pinturas. Todos los sitios presentan motivos por encima y por debajo de $1 \mathrm{~m}$, en tanto que en La Porfía, Cueva Martel y Peñón del Pueblo se registraron, además, motivos por encima de 2 m: a la mayoría de estos espacios altos se accede mediante escalones naturales en la roca. La visibilidad de los motivos es baja o muy baja debido al escaso contraste entre la pintura empleada y la coloración del soporte, lo que hace necesario acercarse para poder observarlos.

En las inmediaciones de los sitios con arte se encuentran actualmente disponibles materias primas colorantes (a excepción de Peñón del Pueblo 1 y 2). Cabe entonces preguntarse si las poblaciones del centro-occidente de Somuncurá no realizaron gran cantidad arte rupestre a pesar de tener materias primas colorantes -y de soportes- disponibles. Frente a esta situación se podrían pensar tres posibles explicaciones: a) sesgos en los muestreos; b) diferentes procesos atmosféricos y antrópicos afectaron la conservación de las pinturas; c) las materias primas colorantes no fueron empleadas para la realización de arte rupestre sino para otros fines.

Con respecto a la primera alternativa, los muestreos realizados fueron lo suficientemente amplios, cubriendo gran parte de la región, situación que reduce los sesgos de investigación; sin embargo, no puede ser dejado de lado de manera taxativa. La posibilidad de un sesgo tafonómico es más factible debido a las evidencias de procesos atmosféricos y biológicos que afectaron y afectan las superficies rocosas -escurrimiento de agua, insolación o presencia de líquenes- y que fueron detectadas en diferente medida en todos los sitios. Entre los procesos antrópicos se detectaron grafitis de diferente tipo, algunos realizados sobre los motivos rupestres (v.g., Vacalauquén). 
Teniendo en cuenta que los sitios se encuentran en sectores reparados, la posibilidad de conservación de pinturas en espacios más abiertos se reduce aún más. Por último, las materias colorantes pudieron haber sido empleadas para otros fines, como la preparación de cremas o de pintura corporal (Claraz 1988; Onelli 1998), para el laboreo de cueros o la preparación de quillangos (Miotti 1998; Prates 2009: 217-218). Sin embargo, este uso de los pigmentos para fines diferentes no resuelve el interrogante acerca de la ausencia de arte rupestre, sobre todo teniendo en cuenta que este tipo de evidencia abunda en la escala regional (Gradin et al. 2003), y que la profundidad temporal de las ocupaciones humanas en este sector de la meseta de Somuncurá se remontan a la transición Pleistoceno/Holoceno (Miotti 2010; Miotti y Terranova 2014; Terranova 2013). La evidencia indica que lo produjeron durante el Holoceno tardío, al aplicar la cronología propuesta para otras áreas al arte documentado en el macizo.

Dado que se observaron amplias superficies potencialmente utilizables y gran disponibilidad de materias primas colorantes, por el momento la frecuencia actual de sitios con arte rupestre podría deberse a la conjugación del sesgo tafonómico y sesgo de muestreo: nuevas prospecciones permitirían evaluar la de manera más exacta la incidencia de ambos respecto a este problema.

Los sitios con arte rupestre en este sector presentan baja frecuencia de motivos, entre los que resaltan Peñón del Pueblo 1 y 2 y Vacalaquén 1-3. En los primeros sitios los diseños son simples, con predominio de rectilíneos, mayoritariamente series de líneas paralelas, con un estado de conservación malo a regular por procesos de exfoliación que afectan al soporte. Por otro lado, en Vacalauquén 1-3 también predominan los motivos rectilíneos, aunque se diferencian de los anteriores por abundancia de diseños ortogonales, los cuales pueden alcanzar gran complejidad conformando verdaderos laberintos o "grecas", o pueden estar combinados con diseños circulares y curvilíneos. Si bien en Vacalauquén los motivos pueden estar fuertemente afectados por la insolación o el escurrimiento de agua, se observa actualmente una mayor riqueza y variabilidad de los diseños en 


\begin{tabular}{|c|c|c|c|c|c|}
\hline Atributos & LP & AAW & CM & PP & VL \\
\hline Fig vs. No fig. & $\begin{array}{l}\text { Predominio no figurativos, } \\
\text { sin figurativos }\end{array}$ & $\begin{array}{l}\text { El motivo registrado fue } \\
\text { categorizado como otro: } \\
\text { podría corresponder a } \\
\text { marca de ganado. No } \\
\text { figurativo }\end{array}$ & $\begin{array}{l}\text { Predominio de no figurativos, } \\
\text { sin figurativos }\end{array}$ & $\begin{array}{l}\text { Predominio de no } \\
\text { figurativos, sin figurativos }\end{array}$ & $\begin{array}{l}\text { Predominio de no figurativos. } \\
\text { Sólo } 12 \% \text { figurativos: } \\
\text { representan animales y a } \\
\text { artefactos. }\end{array}$ \\
\hline Diseño & $\begin{array}{l}\text { Abundancia de motivos } \\
\text { rectilíneos y circulares } \\
\text { lineales }\end{array}$ & - & $\begin{array}{l}\text { Motivos rectilíneos y ND en } \\
\text { cantidades similares }\end{array}$ & $\begin{array}{l}\text { Abundancia de motivos } \\
\text { ND; seguidos por } \\
\text { rectilíneos y circulares } \\
\text { lineales }\end{array}$ & $\begin{array}{l}\text { Predominio de motivos } \\
\text { rectilíneos (ortogonales), } \\
\text { abundancia de circulares } \\
\text { lineales. }\end{array}$ \\
\hline Técnica & \multicolumn{5}{|c|}{ Pintura } \\
\hline Superposiciones & - & - & & $\begin{array}{l}\text { Mezcla de sedimentos y } \\
\text { estiércol sobre motivos } \\
\text { pintados }\end{array}$ & $\begin{array}{l}\text { Grafitis sobre motivos } \\
\text { pintados }\end{array}$ \\
\hline Emplazamiento & $\begin{array}{l}\text { Sobre superficies } \\
\text { verticales, en el interior de } \\
\text { cañadón de poca extensión } \\
\text { con surgente en su interior }\end{array}$ & $\begin{array}{l}\text { En el techo de alero, sobre } \\
\text { geoforma positiva. Laguna } \\
\text { a } 1,50 \mathrm{~km}\end{array}$ & $\begin{array}{l}\text { Sobre superficies interiores de } \\
\text { espacios reparados en el } \\
\text { interior de cañadón por el que } \\
\text { fluye arroyo temporario }\end{array}$ & $\begin{array}{l}\text { En diferentes superficies } \\
\text { de dos espacios reparados } \\
\text { (alero y cueva), } \\
\text { inmediatos a arroyo } \\
\text { temporario }\end{array}$ & $\begin{array}{l}\text { Sobre superficies verticales al } \\
\text { interior de un cañadón, un } \\
\text { conjunto en alero. Cuenca } \\
\text { endorreica con laguna } \\
\text { temporaria }\end{array}$ \\
\hline Formación & Cerro Cortado & \multicolumn{3}{|c|}{ Complejo Volcánico Barril Niyeu } & Complejo Los Menucos \\
\hline Orientación & $\mathrm{NE}$ & $\mathrm{E}$ & W y al E & $\mathrm{E}^{*}$ & S, W y NW \\
\hline $\begin{array}{l}\text { Visibilidad de } \\
\text { los conjuntos }\end{array}$ & Baja y muy baja & Muy baja & Muy baja & Baja y muy baja & Baja y muy baja \\
\hline $\begin{array}{l}\text { Altura de los } \\
\text { motivos respecto } \\
\text { del suelo }\end{array}$ & $\geq$ a $1,5 \mathrm{~m}$ & $1,50 \mathrm{~m}$ & Variable: < a 1 y > a $2 \mathrm{~m}$ & Variable: < a 1 y > a $2 \mathrm{~m}$ & $\geq 0,40 \mathrm{y}<\mathrm{a} 1,60 \mathrm{~m}$ \\
\hline $\begin{array}{l}\text { Conservación de los } \\
\text { motivos }\end{array}$ & $\begin{array}{l}\text { Mala: escurrimiento de } \\
\text { agua en superficie y } \\
\text { presencia de líquenes }\end{array}$ & $\begin{array}{l}\text { Buena: no se observan } \\
\text { líquenes ni incidencia } \\
\text { directa del sol }\end{array}$ & $\begin{array}{l}\text { Mala a regular: en Cueva } \\
\text { Martel mala por presencia de } \\
\text { percha de ave. Peñón Martel } 1 \\
\text { regular, exfoliación del soporte } \\
\text { por acción del agua }\end{array}$ & $\begin{array}{l}\text { Mala a regular: se observa } \\
\text { la acción del agua, de } \\
\text { carbonatos, de perchas y } \\
\text { exfoliaciones del soporte. }\end{array}$ & $\begin{array}{l}\text { Mala a regular: incidencia } \\
\text { directa del sol y } \\
\text { escurrimiento de agua en } \\
\text { algunos paneles. }\end{array}$ \\
\hline
\end{tabular}

Tabla 7.20. Comparación de los sitios del centro-occidente de Somuncurá. * Para la mayoría de las superficies 
relación a los restantes sitios (Tabla 7.20). Esta situación, las evidencias de uso recurrente del cañadón y la importancia que tienen esos diseños en áreas aledañas (ver Capítulo 8), resaltaría la importancia Vacalauquén en la sector analizado.

\section{7. m. INTEGRACIÓN DE LA INFORMACIÓN}

En las inmediaciones a los sitios con arte, se realizaron diferentes hallazgos arqueológicos que permiten observar que, al igual que en otras partes de Patagonia, en Somuncurá el arte rupestre forma parte de un sistema comunicacional más amplio, asociado a otras actividades diferentes a la netamente de producción de motivos rupestres (Carden 2009a; Crivelli Montero 1988; Crivelli Montero et al. 1996; Curtoni 2011; Goñi 2010; Re 2011). Se documentaron estructuras de piedra -parapetos y corrales- y artefactos líticos en superficie hacia el noreste del macizo, coincidente con una topografía conformada por cuencas endorreicas y espacios mesetiformes intermedios, entre los que se destacan cerros y lomadas que sirven como punto de referencia. Por otro lado, hacia el centro-occidente del macizo, el paisaje está conformado por cañadones, bajos extensos y planicies aluviales, con acotados puntos de referencia. A pesar de estas diferencias en cuanto al espacio físico de los dos sectores considerado, entre los materiales asociados a los sitios con arte rupestre del centro-occidente del macizo se destacan las concentraciones de materiales líticos en superficie y las estructuras de piedra, denominadas actualmente como "corrales" (Tablas 7.15 y 7.20). Quizás sea esta recurrencia -agua, arte rupestre, estructuras de piedra, concentraciones de materiales líticos en superficie- la que esté señalando la manera en que las sociedades cazadoras-recolectoras que ocuparon Somuncurá le dieron significación a los espacios, transformándolos en paisajes pensados.

Respecto a la cronología del arte de Somuncurá, fue planteada a partir de asociaciones estilísticas con las regiones aledañas. Los motivos grabados de 
Laguna El Ganso y Bardas de Antonio podrían tener una antigüedad de $c a$. 2.800 años AP. Las manifestaciones de Laguna El Ganso y Bardas de Antonio, si bien no presentan amplia mayoría de pisadas animales grabadas, sí presentan motivos curvilíneos y circulares que han sido asignados como característicos de la Tendencia Representativo Esquemática. Por otro lado, las grecas grabadas de Laguna El Ganso remiten a una cronología más tardía, sirviendo como ejemplo para la implementación de dicha técnica a diseños que han sido considerados tardíos.

En el sector centro-occidental de Somuncurá, las manifestaciones rupestres fueron asignadas a la Tendencia Abstracto-Geométrica (Simple y Compleja). La TAGC aparecería hacia los 1.250 años AP y llegaría al momento del contacto hispano-indígena. Los fechados radiocarbónicos de las ocupaciones en Somuncurá avalarían esta asociación estilística (Belardi 1996; Stern et al. 2000; Miotti et al. 2014; Terranova y Marchionni 2010). En suma, el arte rupestre de Somuncurá es asignado al Holoceno tardío.

Los sitios presentados en este Capítulo se encuentran sobre diferentes superficies: en el caso de los sitios del noreste sobre bardas basálticas de la Formación Somun Curá que rodean a distintas cuencas lagunares (Parte 1), en tanto que en el centro-occidente del macizo los sitios con arte rupestre se encuentran sobre rocas volcánicas de diferentes complejos o formaciones (Parte 2).

Las diferencias y similitudes en cuanto al diseño de los motivos y las técnicas de producción serán analizadas en el Capítulo 8, considerando también sitios estudiados previamente por otros investigadores. Por el momento, y para los sitios presentados, se puede señalar que están ausentes los negativos y positivos de mano así como las figuras humanas, sea en forma pintada o grabada; el número de figuras animales es bajísimo y los rastros animales también se observan en baja frecuencia -en su mayoría grabados-; no hay representaciones de objetos mediante grabado. Por otro lado, entre los motivos no figurativos se registraron todos los grupos identificados, realizados por pintura o grabado, mientras que los escasos 
motivos pictograbados se relacionan particularmente con diseños circulares lineales.

Los sitios presentados en este Capítulo aportan información novedosa respecto al arte Patagónico: se relevaron motivos grabados y pictograbados, en donde se creía que sólo había pinturas. La integración de esta información con la obtenida de las revisiones bibliográficas para Somuncurá y para el arte nordpatagónico, así como su comparación con el arte documentado en el macizo del Deseado se realiza en el próximo Capítulo. 


\section{Capítulo 8}

\section{DISCUSIÓN}

En los apartados siguientes se evalúa la información analizada en capítulos anteriores, referida a la distribución espacial y temporal de los motivos documentados en las áreas en estudio incluyendo, además, la información de las regiones aledañas, las técnicas de producción y los diseños reconocidos. En primer término se contemplará el macizo del Deseado y luego el de Somuncurá.

\section{8. a. MACIZO DEL DESEADO}

A partir de un énfasis en lo tecnológico, se compara la distribución espacial y temporal del arte rupestre analizado y se discute con la información previa generada para el área de estudio (Carden 2008a, 2009a, 2013).

\section{8. a. 1. Distribución espacial de sitios y motivos}

Los sitios se distribuyen en tres sectores de las cuencas residuales del NE del macizo del Deseado (Figura 8.1, Tabla 8.1). Tomando como base el análisis efectuado por Carden (2009a: 260-261), se observa que se mantiene el patrón de distribución de los sitios con arte rupestre, que se concentran especialmente hacia el sur del área, en el sector de las cabeceras del zanjón Blanco (Figura 8.2.a). Esta distribución diferencial de sitios con arte rupestre se debería en parte a la mayor disponibilidad de cuevas y aleros en 
las cabeceras de las cuencas (sectores I, II y V; Carden 2008a). Si bien probablemente un sesgo en las prospecciones explique la presencia de un sólo sitio en la cuenca media de los zanjones Blanco y del Pescado (Figuras 8.1 y 8.2.a), es bajo el significado predictivo que puedan tener los resultados obtenidos para dichos sectores (III y VI). Teniendo esto presente, la siguiente discusión debería considerarse preliminar porque la información producida en los diferentes sectores es heterogénea debido a una mayor intensidad en las prospecciones en los extremos de los zanjones Blanco y Rojo.

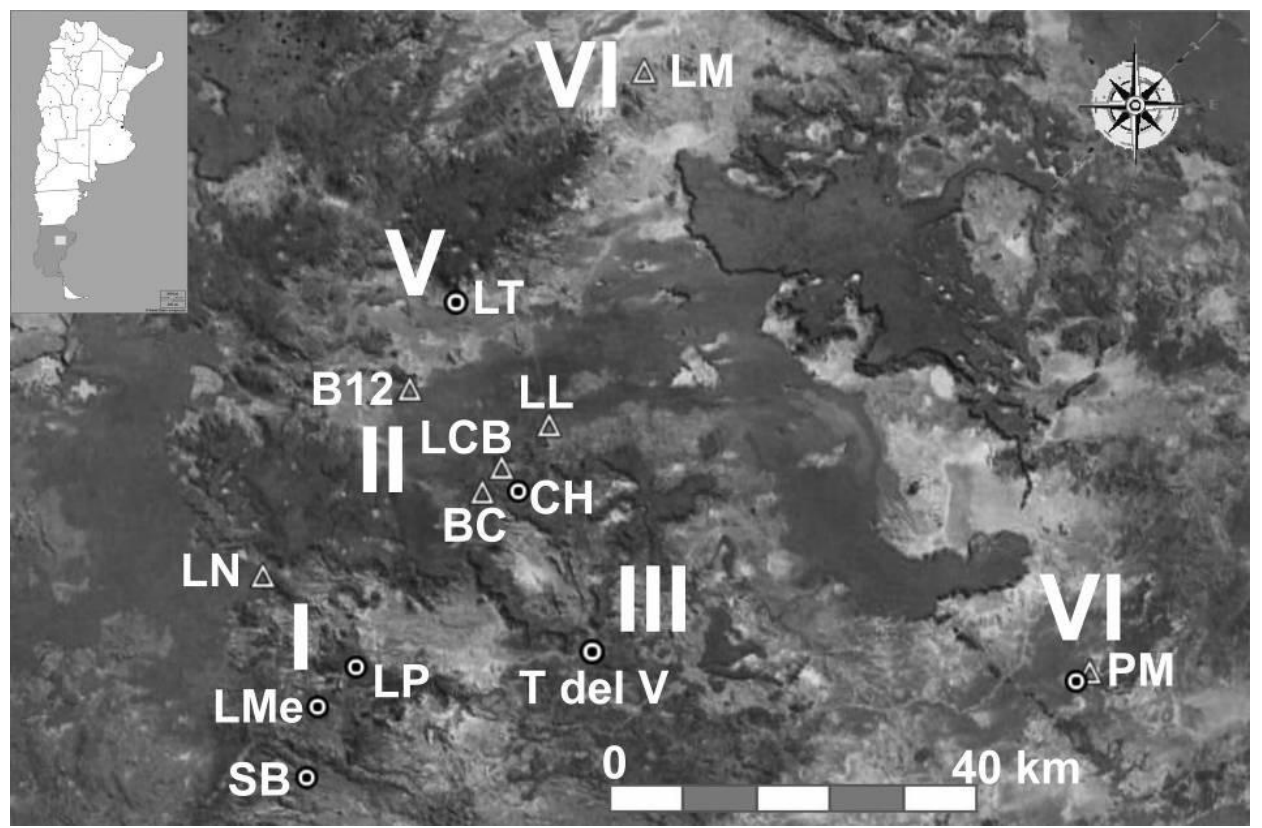

Figura 8.1. Ubicación de las localidades y los sitios tratados en esta tesis en los diferentes sectores del macizo del Deseado. Referencias: Sector I: cabecera sur del zanjón Blanco (SB: Sierras Blancas; LMe: Las Mercedes; LP: La Primavera; LN: Los Navarros); II: Cabecera norte del zanjón Blanco (B12: Bardas del Doce; BC: Bardas de Carlos; LCB: Laguna del Cerro Bonete; LL: La Leonera; CH: Cueva de La Hacienda); III: curso medio del zanjón Blanco (T del V: Tito del Valle); IV: curso inferior del zanjón Rojo (PM: Piedra Museo); V: cabecera del zanjón del Pescado (LT: Los Toldos); VI: curso medio del zanjón del Pescado (LM: La Marianita). Triángulos: sitios con grabados; círculos: sitios con pinturas.

En cuanto a la distribución de los motivos, en el área la mayor parte de los mismos se encuentran en el sector sur de las cabeceras del zanjón Blanco, lo cual coincide con la mayor cantidad de sitios registrados allí (Figura 8.2.b). Esta distribución modifica a la detectada por Carden (2009a), donde la mayor cantidad de motivos se encontraban en el curso inferior del 
zanjón Rojo, incluyendo los motivos de dos sitios en la localidad Piedra Museo. La nueva distribución se debe a la inclusión del sitio Los Navarros, el cual es incluido en esta investigación. Se destaca que los tres sitios documentados en esta tesis tienen una concentración alta de motivos ( $n=$ 422 motivos), mientras que en 32 sitios estudiados hasta el 2008 se documentaron 1332 motivos (Carden 2008a), ver detalle en Tabla 8.1.

\begin{tabular}{|c|c|c|c|c|c|}
\hline Cuenca & Sector & Localidad & Sitios & $\mathrm{n}$ motivos & $\%$ motivos \\
\hline \multirow{11}{*}{$\begin{array}{l}\text { Zanjón } \\
\text { Blanco }\end{array}$} & \multirow{5}{*}{ Cabecera Sur (I) } & La Primavera & 7 & 281 & 44,10 \\
\hline & & Los Ventisqueros & 2 & 17 & 2,70 \\
\hline & & Las Mercedes & 3 & 19 & 2,90 \\
\hline & & Sierras Blancas & 6 & 33 & 5,30 \\
\hline & & Los Navarros & 1 & 286 & 44,90 \\
\hline & & Subtotal & 19 & 636 & 100 \\
\hline & \multirow[t]{2}{*}{ Cabecera Norte (II) } & Aguada del Cuero & 5 & $369^{\#}$ & 92,70 \\
\hline & & Cerro del 12 & 1 & 29 & 7,30 \\
\hline & \multicolumn{2}{|r|}{ Subtotal } & 6 & 397 & 100 \\
\hline & Curso medio (III) & Bajo Pantano & 1 & 15 & 100 \\
\hline & \multicolumn{2}{|r|}{ Subtotal } & 1 & 15 & 100 \\
\hline \multirow{2}{*}{ Zanjón Rojo } & Curso inferior (IV) & Piedra Museo & 2 & 370 & 100 \\
\hline & \multicolumn{2}{|r|}{ Subtotal } & 2 & 370 & 100 \\
\hline \multirow{5}{*}{$\begin{array}{c}\text { Zanjón del } \\
\text { Pescado }\end{array}$} & Cabecera (V) & Los Toldos & 6 & 317 & 100 \\
\hline & \multicolumn{2}{|r|}{ Subtotal } & 6 & 317 & 100 \\
\hline & Curso medio (VI) & La Marianita & 1 & 18 & 100 \\
\hline & \multicolumn{2}{|r|}{ Subtotal } & 1 & 18 & 100 \\
\hline & \multicolumn{2}{|c|}{ Total } & 35 & 1754 & \\
\hline
\end{tabular}

Tabla 8.1. Distribución de sitios con arte rupestre en el NE del Macizo del Deseado (tomada y modificada de Carden 2008 a: Apéndice V, Tabla V.1). Sombreados en gris las localidades con los sitios presentados en esta tesis; \# incluye los datos del sitio Bardas de Carlos entre los restantes sitios con arte rupestre de la localidad.
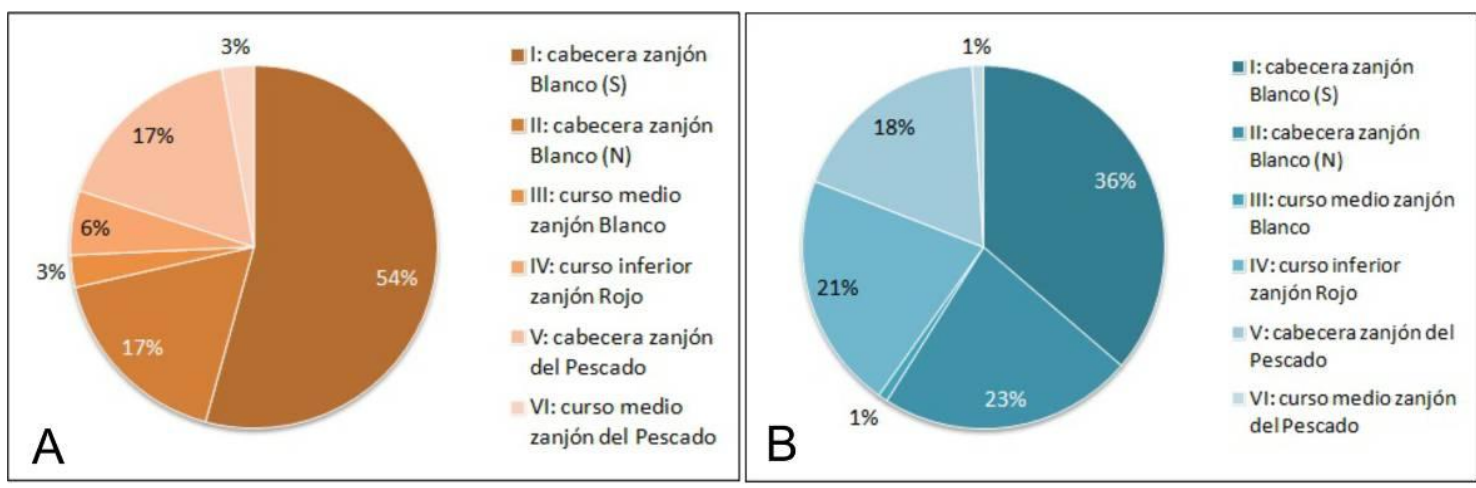

Figura 8.2. Distribución del arte rupestre en el noreste del macizo del Deseado: a. Distribución porcentual de sitios con arte; b. Distribución porcentual de motivos. En ambos casos, tomado y modificado de Carden (2009a). 


\section{8. a. 2. Distribución de técnicas}

Con respecto a la distribución de las técnicas, se observa un predominio de los motivos grabados con respecto a los pintados (Tabla 8.2; Figura 8.3.a). Los nuevos datos generados invierten, de este modo, a las proporciones detectadas por Carden (2009a). El hallazgo de los nuevos sitios con grabados también modifica la distribución de las técnicas en los diferentes sectores. De este modo, el sector I donde previamente sólo se habían registrado pinturas ahora muestra una mayor variabilidad debido a la presencia de grabados, y se agregan grabados en el sector VI (Figura 8.3.b). La integración de la información presentada en esta tesis permite aceptar parcialmente la propuesta para la distribución de técnicas efectuada por Carden (2009a), en la que se planteaba que donde predominan las pinturas se observan escasos grabados. La baja variabilidad de técnicas documentadas en los sectores medios de los zanjones (sector III y VI) podría estar relacionada con los problemas de muestreo planteados en el apartado anterior.

\begin{tabular}{|c|c|c|c|c|c|c|c|}
\hline Sector & Localidad & Sitios & $\begin{array}{c}\mathrm{n} \\
\text { pintura }\end{array}$ & $\begin{array}{c}\% \\
\text { pintura }\end{array}$ & $\begin{array}{c}\mathrm{n} \\
\text { grabados }\end{array}$ & $\begin{array}{c}\% \\
\text { grabados }\end{array}$ & Total \\
\hline \multirow{5}{*}{$\begin{array}{c}\text { Cabecera sur zanjón } \\
\text { Blanco (I) }\end{array}$} & La Primavera & 7 & 281 & 36,97 & - & - & 281 \\
\hline & Los Ventisqueros & 2 & 17 & 2,23 & - & - & 17 \\
\hline & Las Mercedes & 3 & 19 & 2,5 & - & - & 19 \\
\hline & Sierras Blancas & 6 & 33 & 4,34 & - & - & 33 \\
\hline & Los Navarros & 1 & - & - & 286 & 28,80 & 286 \\
\hline \multirow{2}{*}{$\begin{array}{c}\text { Cabecera norte zanjón } \\
\text { Blanco (II) }\end{array}$} & Aguada del Cuero & 5 & 23 & 3,02 & 346 & 34,74 & 369 \\
\hline & Cerro del 12 & 1 & - & - & 29 & 2,92 & 29 \\
\hline $\begin{array}{c}\text { Curso medio del zanjón } \\
\text { Blanco (III) }\end{array}$ & Bajo Pantano & 1 & 15 & 1,97 & - & - & 15 \\
\hline $\begin{array}{c}\text { Curso inferior del } \\
\text { zanjón Rojo (IV) }\end{array}$ & Piedra Museo & 2 & 55 & 7,23 & 315 & 31,72 & 370 \\
\hline $\begin{array}{l}\text { Cabecera zanjón del } \\
\text { Pescado (V) }\end{array}$ & Los Toldos & 6 & 317 & 41,71 & - & - & 317 \\
\hline $\begin{array}{c}\text { Curso medio zanjón del } \\
\text { Pescado (VI) }\end{array}$ & La Marianita & 1 & - & - & 18 & 1,81 & 18 \\
\hline \multicolumn{2}{|c|}{ Total } & 35 & 760 & 100 & 994 & 100 & 1754 \\
\hline
\end{tabular}

Tabla 8.2. Frecuencias y proporciones de técnicas de producción en el NE del macizo del Deseado. 


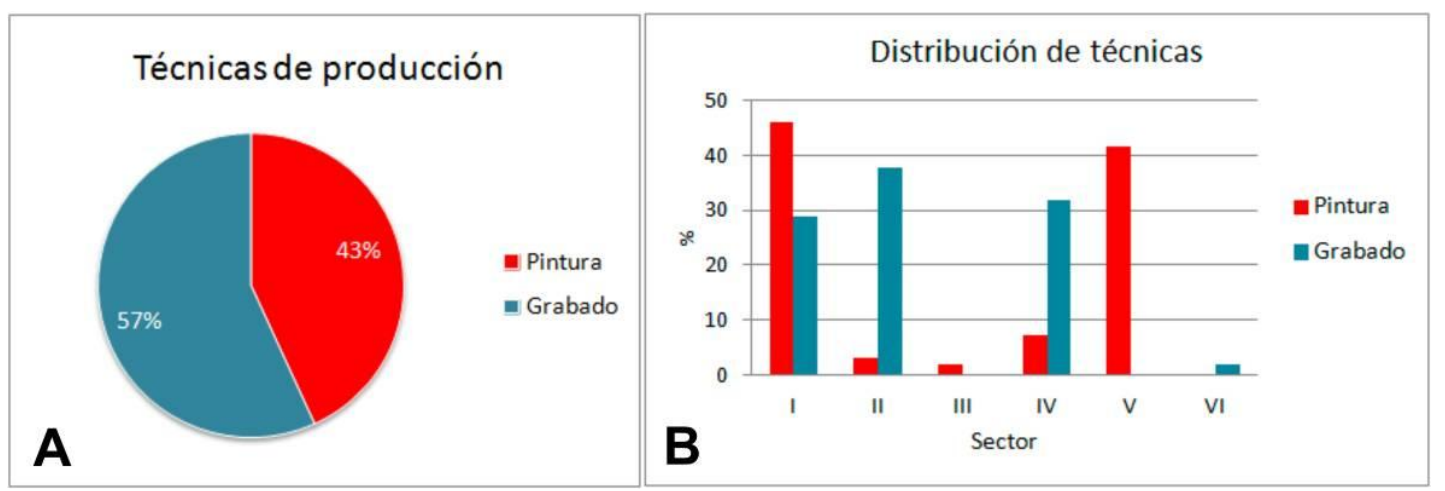

Figura 8.3. Distribución porcentual y espacial de técnicas de producción de arte rupestre reconocidas en el NE del macizo del Deseado: a. Proporción de técnicas de producción; b. distribución de técnicas por sectores. En estos gráficos se integra la información propuesta por Carden (2009a) y la presentada en el Capítulo 6 de esta tesis.

\section{8. a. 3. Distribución de diseños}

Se han reconocido las mismas categorías de motivos que en trabajos previos, con excepción de rastros y figuras humanas así como escenas de caza reconocidas exclusivamente en sitios con pinturas (Carden 2009a). Por otro lado, en esta tesis se han reconocido motivos no determinados (ver definición en el Capítulo 2 y ejemplos en el Capítulo 6). De igual manera, el tratamiento digital de las imágenes con $D$-Stretch, tratamiento que no había sido previamente aplicado al arte rupestre del área, permitió reconocer motivos que habían pasado desapercibidos.

En los sitios presentados en el Capítulo 6, entre los motivos no figurativos preponderan los motivos rectilíneos, seguidos por los circulares lineales y los curvilíneos (Tabla 8.3). Por otro lado, entre los motivos figurativos abundan los rastros animales. Ambas situaciones difieren con la propuesta efectuada por Carden (2009a), quien señala el predominio de los motivos figurativos (negativos de mano) mientras que entre los motivos no figurativos abundan los circulares lineales (Tabla 8.3). A pesar de esta situación, las proporciones acumuladas de los dos estudios indican que entre los motivos no figurativos predominan los motivos circulares lineales, los rectilíneos y los curvilíneos; mientras que los rastros humanos -negativos de manos- son preponderantes entre los figurativos (Tabla 8.3). 


\begin{tabular}{|l|c|c|c|c|c|c|}
\cline { 2 - 8 } \multicolumn{1}{c|}{} & \multicolumn{2}{c|}{ Blanco } & \multicolumn{2}{c|}{ Carden (2009a) } & \multicolumn{2}{c|}{ Total } \\
\hline Subgrupo de motivos & $\mathrm{n}$ & $\%$ & $\mathrm{n}$ & $\%$ & $\mathrm{n}$ & $\%$ \\
\hline Puntiformes & 19 & 4,50 & 47 & 3,40 & 66 & 3,72 \\
\hline Rectilíneos & 129 & 30,57 & 113 & 8,50 & 242 & 13,79 \\
\hline Circulares llenos & 1 & 0,24 & 37 & 2,85 & 38 & 2,17 \\
\hline Circulares lineales & 122 & 28,91 & 212 & 15,85 & 334 & 19,04 \\
\hline Curvilíneos & 86 & 20,38 & 124 & 9,40 & 210 & 11,97 \\
\hline No Figurativos & 357 & 84,60 & 533 & 40 & 890 & 50,69 \\
\hline Rastros humanos & - & - & 629 & 47,20 & 629 & 35,86 \\
\hline Rastros animales & 41 & 9,71 & 153 & 11,50 & 194 & 11,06 \\
\hline Figuras humanas & - & - & 5 & 0,38 & 5 & 0,28 \\
\hline Figuras animales & 2 & 0,47 & 11 & 0,82 & 13 & 0,74 \\
\hline Escenas de caza & - & - & 1 & 0,07 & 1 & 0,06 \\
\hline Figurativos & 43 & 10,19 & 799 & 60 & 842 & 48 \\
\hline No determinados & 22 & 5,21 & - & - & 22 & 1,28 \\
\hline \multicolumn{1}{|c|}{ Total } & 422 & 100 & 1332 & 100 & 1754 & 100 \\
\hline
\end{tabular}

Tabla 8.3. Frecuencias y proporciones de grupos y subgrupos de motivos reconocidos en esta tesis y por Carden (2009a).

\section{8. a. 4. Relación entre la distribución del diseño y la técnica}

A continuación, se integra la información disponible respecto a la relación entre diseño y técnica, la cual se desglosa en diferentes niveles considerando su distribución espacial en los distintos sectores de la cuenca. Existe una relación opuesta en cuanto a la técnica de producción de los motivos figurativos y no figurativos: los primeros son mayoritariamente pintados, mientras que los segundos son preponderantemente grabados (Figuras 8.4; Tabla 8.4).

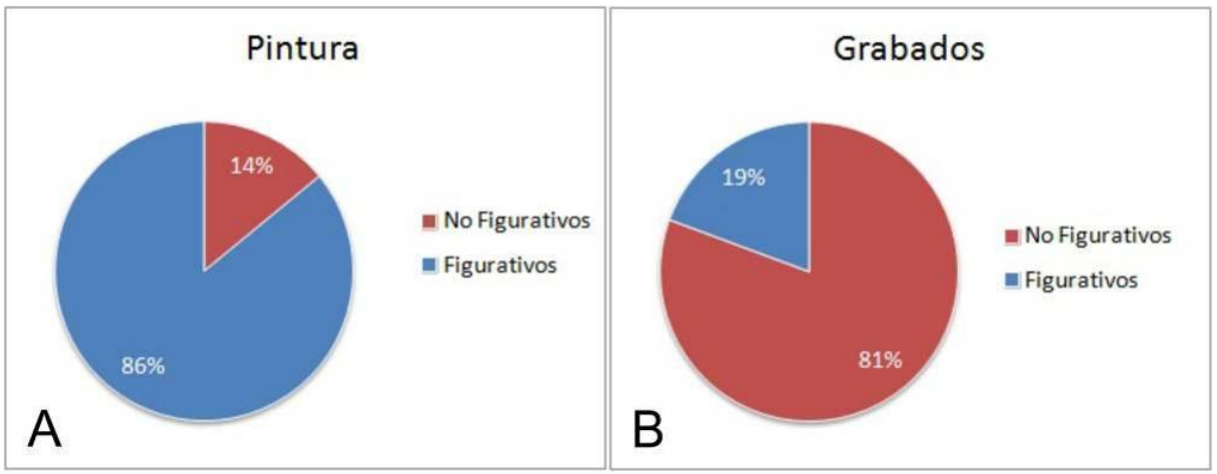

Figura 8.4. Proporciones de técnicas de producción para motivos figurativos y no figurativos: a. Pintura; b. Grabados. Cálculo realizado excluyendo los no determinados $(n=1.732)$. 
Respecto al diseño de los motivos, en el sector sur de la cabecera del zanjón Blanco (I) se reconoce ahora un aumento en la frecuencia de los motivos no figurativos, con una preponderancia de los motivos circulares lineales, mientras que los figurativos siguen siendo más frecuentes. Para la cabecera del zanjón del Pescado (V) se mantiene un predominio de motivos figurativos, particularmente de rastros humanos (Tabla 8.4; Figuras 8.5 y 8.6).

\begin{tabular}{|c|c|c|c|c|c|c|c|c|c|c|c|}
\hline \multirow{3}{*}{ Motivos/técnica } & \multicolumn{9}{|c|}{ Sector } & \multirow{2}{*}{\multicolumn{2}{|c|}{ Total }} \\
\hline & \multicolumn{2}{|c|}{$\mathrm{I}$} & \multicolumn{2}{|c|}{ II } & \multirow{2}{*}{$\begin{array}{c}\text { III } \\
\end{array}$} & \multicolumn{2}{|c|}{ IV } & \multirow{2}{*}{$\begin{array}{l}\mathrm{V} \\
\mathrm{P}\end{array}$} & \multirow{2}{*}{$\begin{array}{l}\mathrm{VI} \\
\mathrm{G}\end{array}$} & & \\
\hline & $\mathrm{P}$ & $\mathrm{G}$ & $\mathrm{P}$ & G & & $\mathrm{P}$ & $\mathrm{G}$ & & & $\mathrm{P}$ & $\mathrm{G}$ \\
\hline Puntiformes & 17 & 11 & 1 & 18 & - & 1 & 5 & 11 & 2 & 30 & 36 \\
\hline Rectilíneos & 9 & 70 & 5 & 90 & - & - & 59 & 4 & 5 & 18 & 224 \\
\hline Circular lleno & 9 & 1 & - & 4 & - & - & 24 & - & - & 9 & 29 \\
\hline Circulares lineales & 4 & 96 & 2 & 144 & - & - & 49 & 29 & 10 & 35 & 299 \\
\hline Curvilíneos & 6 & 62 & 2 & 84 & - & - & 49 & 7 & - & 15 & 195 \\
\hline No Figurativos & 45 & 240 & 10 & 340 & - & 1 & 186 & $\overline{51}$ & 17 & 107 & 783 \\
\hline Rastros humanos & 293 & - & 12 & - & 15 & 56 & 8 & 245 & - & 621 & 8 \\
\hline Rastros animales & 1 & 39 & 2 & 17 & - & - & 121 & 13 & 1 & 16 & 178 \\
\hline Figuras humanas & - & & - & - & - & - & - & 5 & - & 5 & - \\
\hline Figuras animales & 9 & 1 & - & 1 & - & - & - & 2 & - & 11 & 2 \\
\hline Escenas & 1 & - & - & - & - & - & - & - & - & 1 & - \\
\hline Figurativos & 302 & 40 & 14 & 18 & 15 & 56 & 129 & 266 & 1 & 654 & 188 \\
\hline Total & 593 & 280 & 24 & 358 & 15 & 57 & 339 & 318 & 18 & 761 & 971 \\
\hline
\end{tabular}

Tabla 8.4. Distribución de motivos y técnicas de producción en los diferentes sectores reconocidos. Referencias: P: pintura; G: grabado; $n=1.732$.

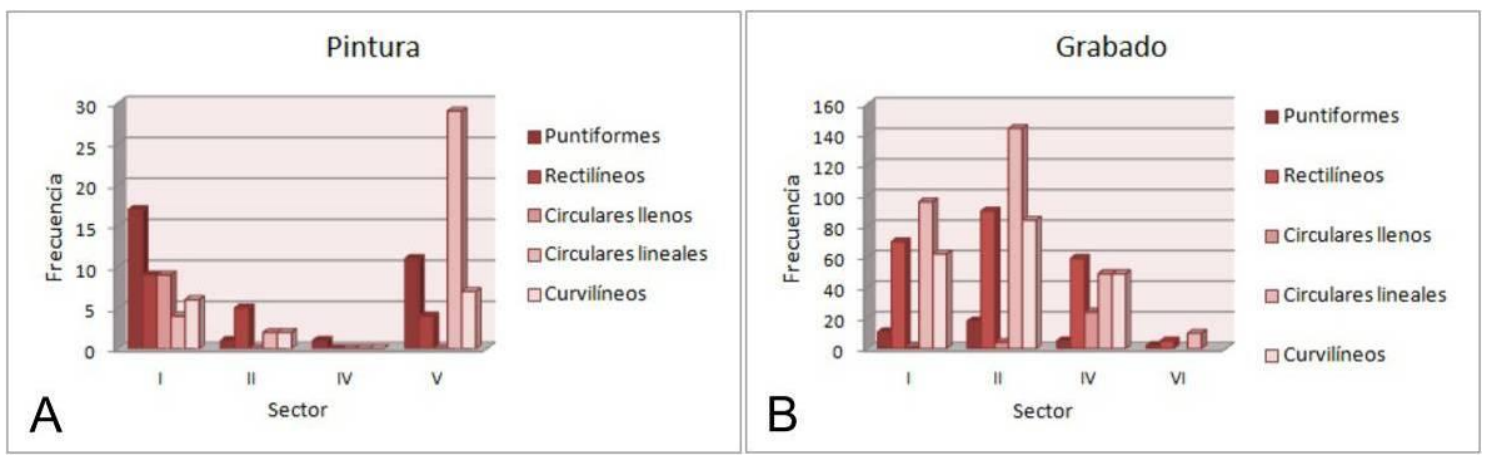

Figura 8.5. Distribución de técnicas y subgrupos de motivos no figurativos en los diferentes sectores reconocidos: a. Pintura; b. Grabado.

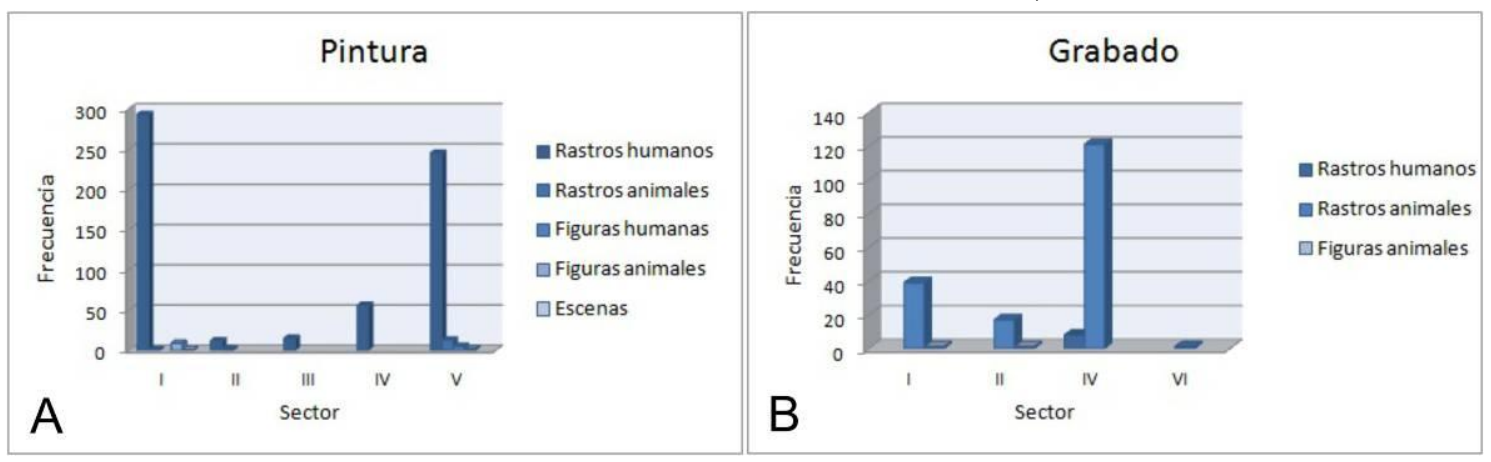

Figura 8.6. Distribución de técnicas y subgrupos de motivos figurativos en los diferentes sectores reconocidos: a. Pintura; b. Grabado. 


\section{8. a. 5. Evaluación de posibles condicionantes tecnológicos}

Para poder evaluar si los soportes rocosos funcionaron como condicionantes tecnológicos en la selección de las técnicas de producción y del diseño de los motivos rupestres deberían observarse, en soportes de litología similar, diseños y técnicas semejantes. Por el contrario, los soportes de litología diferente podrían presentar diseños semejantes realizados a partir de técnicas distintas. Por lo anterior, se integrará la información presentada en el apartado previo (diseño y técnica general -pintura o grabado-) con el análisis de los soportes empleados, para poder reconocer las similitudes y diferencias que pueden presentar. Luego, mediante la integración de la información previa y la resultante de la experimentación, se evalúan las técnicas reconocidas (particulares), se re-categorizan de ser necesario para poder realizar el análisis para los motivos figurativos y los circulares, ya que estos son los más representativos y abundantes del área.

\section{8. a. 5. 1. Soporte, técnica y diseño para grabados}

Entre los motivos grabados predominan los no figurativos, particularmente los motivos circulares lineales $(\mathrm{n}<250$; Tabla 8.4), mientras que entre los figurativos son abundantes los rastros animales. Estos motivos fueron registrados sobre tres tipos de soportes: toba, arenisca coquinoide y basalto. En los distintos sectores se registraron diversos subgrupos de motivos en soportes de variada litología (Tabla 8.5). Hasta el momento, solamente en el sector VI, en el sitio La Marianita, se han registrado motivos rectilíneos, circulares lineales y una pisada animal grabados sobre soporte tobáceo. Los grabados del sitio Angostura del Deseado -en el borde septentrional del macizo-, a orillas del río homónimo, se encuentran sobre un soporte de litología similar. Dicho sitio se emplaza sobre areniscas y entre los motivos grabados predominan los circulares lineales (Gradin 1979). Respecto a la dureza, un soporte de litología relativamente similar se 
corresponde con las areniscas coquinoides utilizadas en los sitios Alero El Galpón 2 (AEG-2) y Cueva Grande (CG) en el sector IV, que presentan grupos de motivos predominantes diferentes (Tabla 8.5). Por último, en los sitios con grabados emplazados sobre basalto la variabilidad de subgrupos observada se corresponde a motivos circulares lineales, curvilíneos, rectilíneos y pisadas, los cuales presentan distribuciones diferentes en los distintos sitios (Tabla 8.5).

Tal como se expresó en los Capítulos 2 y 5, las técnicas de grabado reconocidas en esta tesis refieren a la percusión, la incisión, la horadación, el raspado y la abrasión. La distinción entre percusión directa e indirecta resulta difícil a partir de la mera observación de los surcos grabados en los soportes (Bednarik 2007a). Estas consideraciones, sumadas a las presentadas en el Capítulo 4 sobre la información de los surcos, los artefactos potencialmente utilizados y los contextos del arte rupestre y que permitieron a los distintos autores reconocer las técnicas de grabado, fueron contempladas para realizar el análisis en este apartado.

En los tres tipos de soportes (toba, basalto y arenisca coquinoide) la percusión fue de uso generalizado, mientras que para soportes basálticos sólo en dos sitios se registraron casos de motivos incisos y raspados (Tabla 8.5). Adicionalmente a la percusión, sobre los soportes más blandos se observan motivos incisos (sobre toba) así como incisos, horadados y raspados, o producto de la combinación de técnicas (arenisca coquinoide; Tabla 8.5). 


\begin{tabular}{|c|c|c|c|c|c|c|c|c|}
\hline \multirow{4}{*}{ Sitio } & \multicolumn{8}{|c|}{ Sector } \\
\hline & \multirow{2}{*}{$\begin{array}{c}\mathrm{I} \\
\mathrm{LN}\end{array}$} & \multicolumn{4}{|c|}{ II } & \multicolumn{2}{|c|}{ IV } & \multirow{2}{*}{$\begin{array}{c}\text { VI } \\
\text { LM }\end{array}$} \\
\hline & & $\mathrm{LL}^{*}$ & $\mathrm{LCB}^{*}$ & $\mathrm{~B}$ de $\mathrm{C}$ & $\mathrm{B} 12^{*}$ & AEG-2* & $\mathrm{CG}^{*}$ & \\
\hline & Basalto & Basalto & Basalto & Basalto & Basalto & \multicolumn{2}{|c|}{ Arenisca coquinoide } & Toba \\
\hline Motivo/Técnica & $\mathrm{Pe}$ & Pind & $\begin{array}{c}\text { Pind; In } \\
\text { y R }\end{array}$ & $\mathrm{Pe}, \mathrm{In}$ & Pind & \multicolumn{2}{|c|}{$\begin{array}{l}\text { Pind, In, H, R y su } \\
\text { posible combinación }\end{array}$} & $\begin{array}{l}\text { Pe; } \\
\text { In }\end{array}$ \\
\hline Puntiformes & $\mathrm{X}$ & - & $\mathrm{X}$ & $\mathrm{X}$ & - & - & - & $\mathrm{X}$ \\
\hline Rectilíneos & $\mathrm{X}(2)$ & $\mathrm{X}(1)$ & $\mathrm{X}$ & $\mathrm{X}$ & $\mathrm{X}$ & $\mathrm{X}(2)$ & $\mathrm{X}(2)$ & $\mathrm{X}(1)$ \\
\hline $\begin{array}{l}\text { Circulares } \\
\text { llenos }\end{array}$ & $\mathrm{X}$ & - & & - & - & - & $\mathrm{X}$ & - \\
\hline $\begin{array}{l}\text { Circulares } \\
\text { lineales }\end{array}$ & $\mathrm{X}(1)$ & $\mathrm{X}$ & $\mathrm{X}(1)$ & $\mathrm{X}(1)$ & $\mathrm{X}(1)$ & $\mathrm{X}$ & $\mathrm{X}(1)$ & $\mathrm{X}(2)$ \\
\hline Curvilíneos & $\mathrm{X}$ & $\mathrm{X}(2)$ & $\mathrm{X}(2)$ & $\mathrm{X}(2)$ & $\mathrm{X}(2)$ & $\mathrm{X}$ & $\mathrm{X}$ & $\mathrm{X}$ \\
\hline $\begin{array}{l}\text { Pisadas } \\
\text { humanas }\end{array}$ & - & - & - & - & - & - & $\mathrm{X}$ & - \\
\hline $\begin{array}{l}\text { Pisadas } \\
\text { animales }\end{array}$ & $\mathrm{X}$ & $\mathrm{X}$ & $\mathrm{X}$ & $\mathrm{X}$ & - & $\mathrm{X}(1)$ & $\mathrm{X}$ & $\mathrm{X}$ \\
\hline $\begin{array}{l}\text { Figuras } \\
\text { animales }\end{array}$ & $\mathrm{X}$ & - & $\mathrm{X}$ & $\mathrm{X}$ & - & - & - & - \\
\hline
\end{tabular}

Tabla 8.5. Distribución de los subgrupos de motivos grabados más frecuentes en diferentes soportes. Referencias: LN: Los Navarros; LL: La Leonera; LCB: Laguna del Cerro Bonete; B de C: Bardas de Carlos; B12: Bardas del Doce; AEG-2: Alero El

Galpón 2; CG: Cueva Grande; LM: La Marianita. *: información extraída de Carden (2008a). Técnicas: Pe: Percusión; Pind: Percusión indirecta; In: Incisión; H:

Horadación; R: Raspado. X: presencia; -: ausencia. (1) y (2) indican orden y predominio de subgrupo de motivos.

Efectuar un análisis más detallado de la relación entre el diseño y la técnica implica una re-evaluación de las propuestas realizadas para estas últimas (Carden 2008a). La misma fue posible con el desarrollo de los estudios experimentales (Capítulo 5), en los que se emplearon bloques de arenisca coquinoide y basalto, útil para la discusión de las técnicas inferidas en los sitios AEG-2, CG y Laguna del Cerro Bonete (LCB).

Para el $80 \%$ de los motivos figurativos registrados en AEG-2 y CG se propuso alguna técnica de producción; el porcentaje restante corresponde a los motivos que actualmente están ausentes por depredación o intervención vandálica actual en los bloques. A partir de la observación macroscópica de los surcos grabados, se propuso que dichos motivos podrían haber sido realizados mediante percusión indirecta (picado), horadación, incisión, raspado o la combinación de dichas técnicas (mayor detalle en Carden 2008a: Apéndice IV). 
8. a. 5. 1. a. Re-evaluación de las técnicas de grabado en la localidad Piedra Museo

8. a. 5. 1. a.1. Rastros

Entre los rastros humanos, Carden reconoce que las manos grabadas podrían haber sido realizadas por percusión indirecta y raspado, mientras que los pies podrían haber sido producidos mediante la combinación de las mismas técnicas, incluida la horadación para la realización de los dedos (Carden 2008a: Apéndice IV). Dentro de la selección de motivos replicados experimentalmente no se incluyeron rastros humanos; sin embargo, los surcos resultantes de la percusión directa para realizar una pisada de ave (Capítulo 5: Figura 5.12) sugieren que dicha técnica es óptima para la producción de rastros humanos. La superficie grabada obtenida es homogénea, por lo que el raspado no habría sido necesario para la terminación del motivo, como previamente planteó Carden (2008a). Por otro lado, la propuesta efectuada por Carden para la realización de los dedos de los pies coincide con la morfología de los surcos grabados por horadación en la experimentación.

Entre los rastros animales se observa mayor variabilidad en cuanto a las técnicas reconocidas. Para las pisadas de ave del sitio AEG-2 se propusieron como técnicas la percusión indirecta, la incisión, la horadación - principalmente de nudillo - o la combinación de las mismas (Carden 2008a: Apéndice IV tablas IV.5-12). En líneas generales se coincide con aquella propuesta respecto a la técnica usada (Tabla 8.6) aunque algunos casos resultan diagnósticos para el reconocimiento de técnicas de producción diferentes. Por ejemplo, mientras que por observación macroscópica de los surcos se infirió que un tridígito había sido realizado por percusión indirecta y que habría sido el resultado de una sucesión de hoyuelos, a partir de la experimentación se obtuvo un motivo semejante mediante raspado (ver Capítulo 5: Figura 5.11). Por otro lado, aquellas pisadas de ave en las que se infirió el empleo de dos o más técnicas por presentar nudillo con hoyuelo, la 
experimentación ha planteado un problema de equifinalidad ya que si bien la horadación podría haberse empleado para la producción inicial del hoyuelo, la aplicación posterior de percusión habría permitido lograr mayor profundidad o ancho de surco enmascarando el empleo de la primera técnica (Figura 8.7).

Con respecto a las pisadas de ave reconocidas en CG, se reconocieron similitudes y diferencias con las propuestas efectuadas por Carden (2008a). En el bloque 2, esta autora infirió que 5 rastros de ave fueron realizados por incisión. La re-evaluación a partir de la experimentación permite considerar para dos tridígitos la posibilidad del empleo de la percusión combinada con la incisión (Tabla 8.6; Figura 8.7). La percusión se habría empleado para lograr un nudillo y el surco de un dedo medio (Figura 8.7.a). En el bloque 4 se propuso a la horadación como técnica utilizada para realizar el nudillo y los extremos de los dedos de un tridígito, aunque esta podría corresponderse con la percusión directa (Figura 8.7.d). En el bloque 12 se propuso que la horadación fue una técnica complementaria a la incisión para realizar los nudillos de cuatro tridígitos. Sin embargo, dichos nudillos pudieron haber sido realizados mediante la percusión (Tabla 8.6).

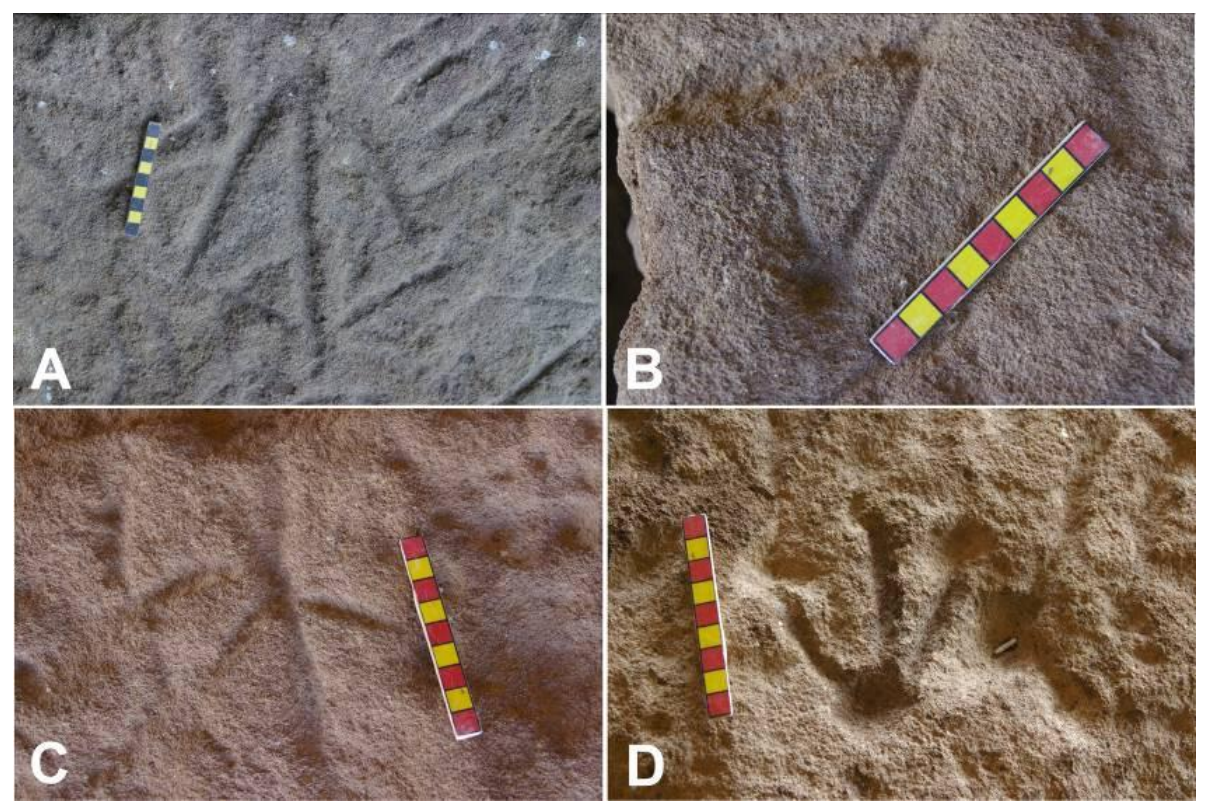

Figura 8.7. Rastros de aves realizados mediante percusión directa e incisión en los sitios de la localidad Piedra Museo: a. en el bloque de AEG-2; b-c. Bloque 2 de CG; d. Bloque 4 en CG. 
Para la producción de los rastros de felino se propuso la utilización de la horadación y la percusión indirecta, tanto en AEG-2 como en los bloques de CG. Sin embargo, es posible que la profundización y ensanchamiento del surco mediante percusión luego del empleo de la horadación para comenzar el hoyuelo haya enmascarado la utilización de la esta última técnica. Esta situación, sumada a la presencia de pintura blanca sobre los motivos de los bloques 2 y 4 de CG (Figura 8.8), que oculta la superficie de los surcos, genera una equifinalidad para identificar la técnica de producción. Dadas estas circunstancias, sin descartar el uso de la horadación y la percusión combinadas, se considera más factible que estos motivos hayan sido realizados por percusión, sin llegar a discernir si fue directa o indirecta (Figura 8.8).

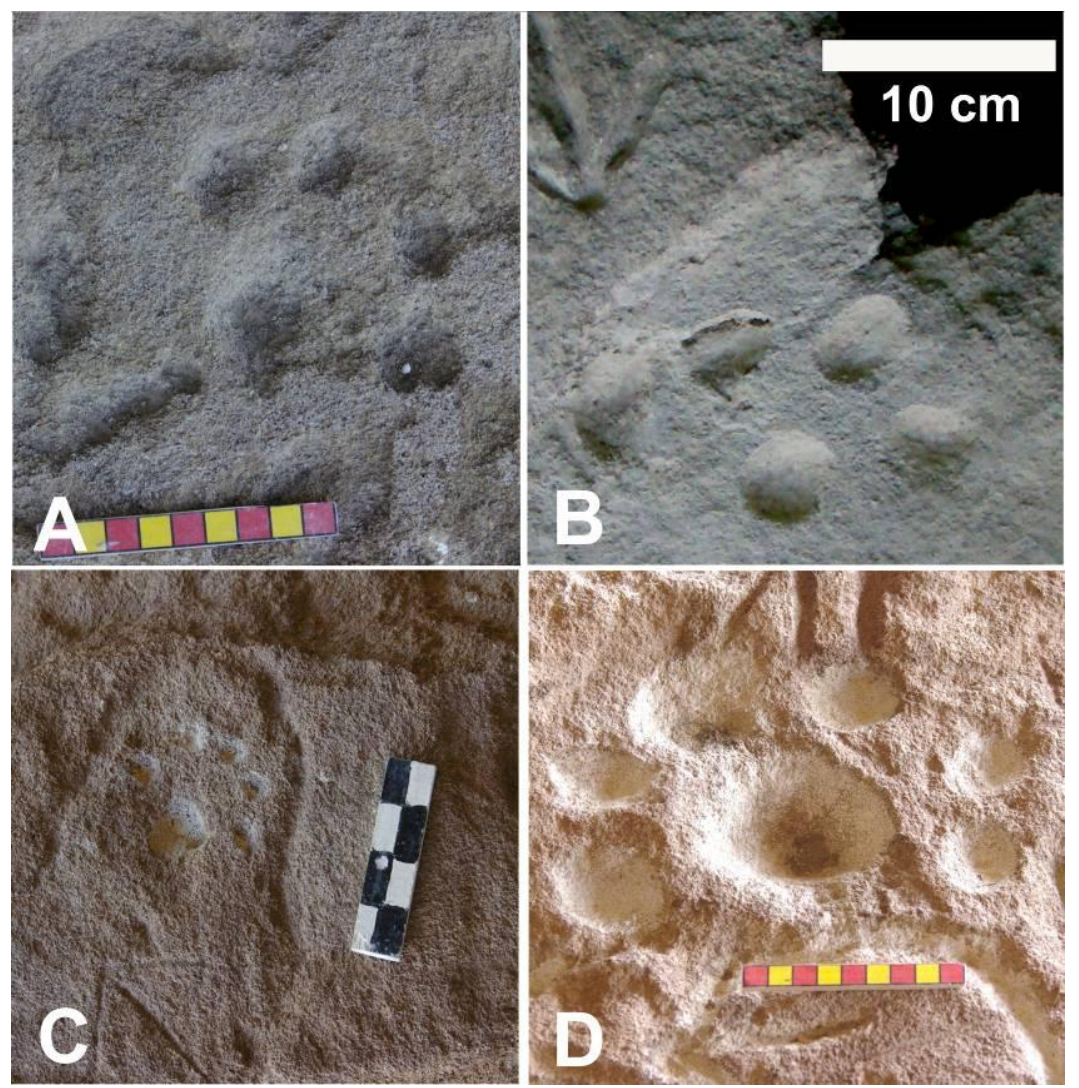

Figura 8.8. Pisadas de felino reconocidas en a. AEG-2; b. Motivo experimental; c. Bloque 2 en CG; $d$. Bloque 4 en CG.

Las pisadas de guanaco fueron registradas exclusivamente en el sitio AEG-2. Carden propuso que fueron realizadas por percusión indirecta, principalmente debido a su tamaño pequeño (alrededor de $5 \mathrm{~cm}$ de largo). La re-evaluación de los surcos grabados permite proponer que en la producción 
de estos motivos se podría haber empleado un percutor de punta acuminada, de tamaño pequeño, similar al utilizado en la producción de una de las pisadas de ave experimentales (Figura 8.9.a, ver también Figura 5.6). La experiencia señala nuevamente a la percusión directa como una posible técnica de ejecución de grabados en Piedra Museo (Tabla 8.6).

Con respecto a las pisadas de caballo, que también fueron registradas en AEG-2, se coincide con la propuesta de Carden respecto al uso de la percusión, aunque no se puede afirmar que dicha percusión haya sido indirecta (Figura 8.10.b). Al igual que en el caso de las pisadas de guanaco, podría haberse empleado un percutor de tamaño pequeño, de punta acuminada.

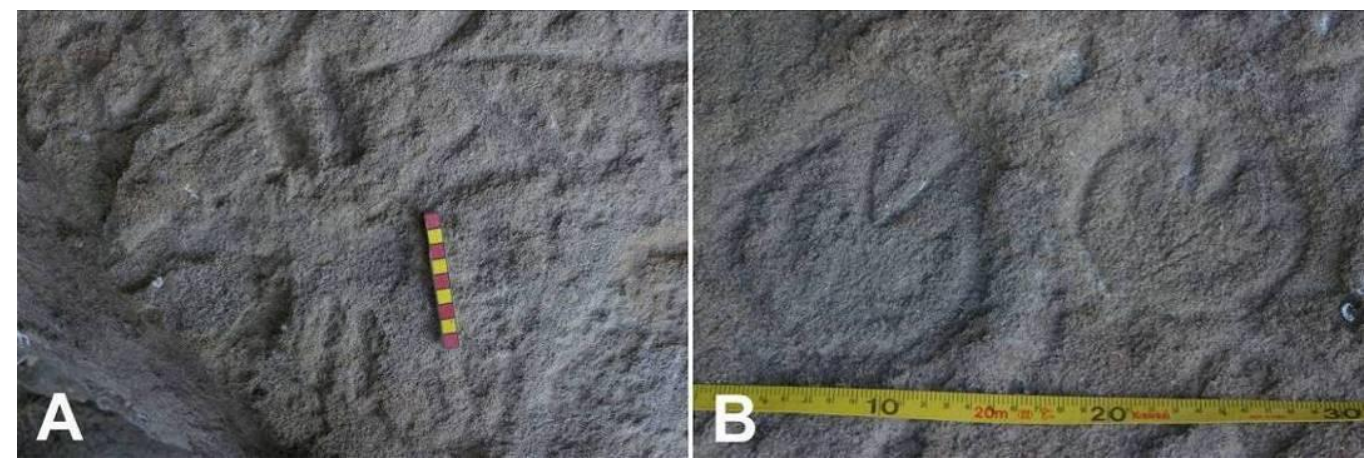

Figura 8.9. Motivos figurativos del sitio AEG-2: a. Pisadas de guanaco; b. pisadas de caballo.

\section{8. a. 5. 1. a. 2. Motivos circulares}

Estos motivos se registraron en AEG-2 y en los bloques de CG. Para la realización de estos diseños se propuso el empleo de la percusión indirecta y, para algunos casos específicos, la horadación o la combinación de ambas (Carden 2008a: Apéndice IV). Sin embargo, el nuevo reconocimiento de técnicas plantea que la mayor parte de las circunferencias fue realizada por percusión directa (Tabla 8.6; Figuras 8.10.a y 8.10.b). En algunos casos puede proponerse, además, el uso del raspado, donde se observa una sucesión de puntos grabados (Figura 8.10.c). Por último, los hoyuelos de contorno circular podrían corresponderse con el uso conjunto de horadación y percusión, tal como fuera propuesto previamente por Carden (2008a). En 
este sentido, la horadación habría permitido obtener un hoyuelo profundo, que luego, mediante la sucesión de golpes habría aumentado su diámetro (Figura 8.10.d).
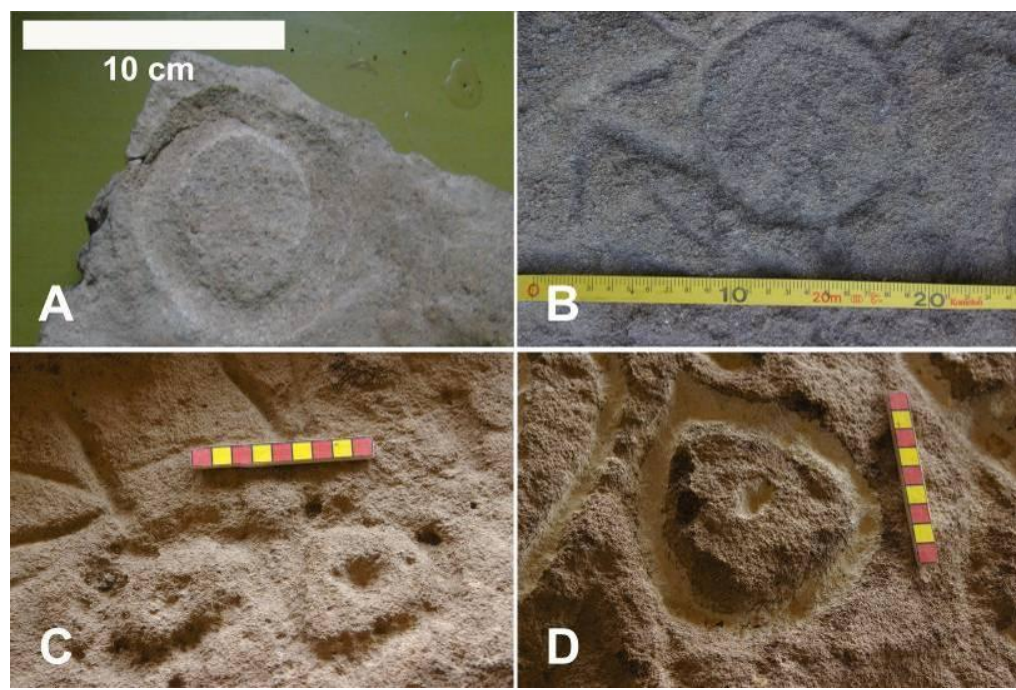

Figura 8.10. Motivos circulares: a. Motivo experimental (raspado y percusión directa); b. Circular de AEG-2; c. Circulares en bloque 3 de CG; d. Motivo circular con hoyuelo central bloque 4 de CG.

8. a. 5. 1. b. Re-evaluación de las técnicas de grabado en el sitio Laguna del Cerro Bonete

En cuanto a los grabados del sitio LCB, se coincide con Carden (2008a) en el empleo de la percusión como técnica de grabado. Sin embargo, y como se ha tratado previamente, no hay evidencia que indique el empleo de un intermediario, por lo que se considera que los grabados de LCB fueron realizados por percusión directa. Los surcos grabados de diferentes motivos son superficiales y similares a los obtenidos experimentalmente (Figuras 8.11.a y 8.11.b), mientras que los motivos curvilíneos más complejos presentan surco más profundos (Figura 8.11.c). Si bien esto último con anterioridad no se explicó como correspondiente a un gesto técnico diferente, se considera que podría deberse a una mayor inversión temporal en la percusión o al empleo de algún abrasivo intermediario durante el proceso de percusión. Las observaciones realizadas para las réplicas experimentales sobre basalto indicarían que la mayor profundidad y homogeneización del 
surco grabado se corresponde con la cantidad de tiempo trabajo y no tanto con el empleo de la percusión directa o indirecta (Capítulo 5). Por otro lado, la utilización de abrasivos sobre soportes duros para lograr "cazoletas" con surco profundo sobre soportes graníticos fue implementada en el centro de Chile (Camilo Valdivieso 2010; comunicación personal). Esta información permitirá pensar en el desarrollo de diseños experimentales que, además de considerar las variables aquí estudiadas, se les adicione el empleo de arena, ceniza o algún otro abrasivo para lograr una profundización de los surcos $\operatorname{grabados}^{1}$.

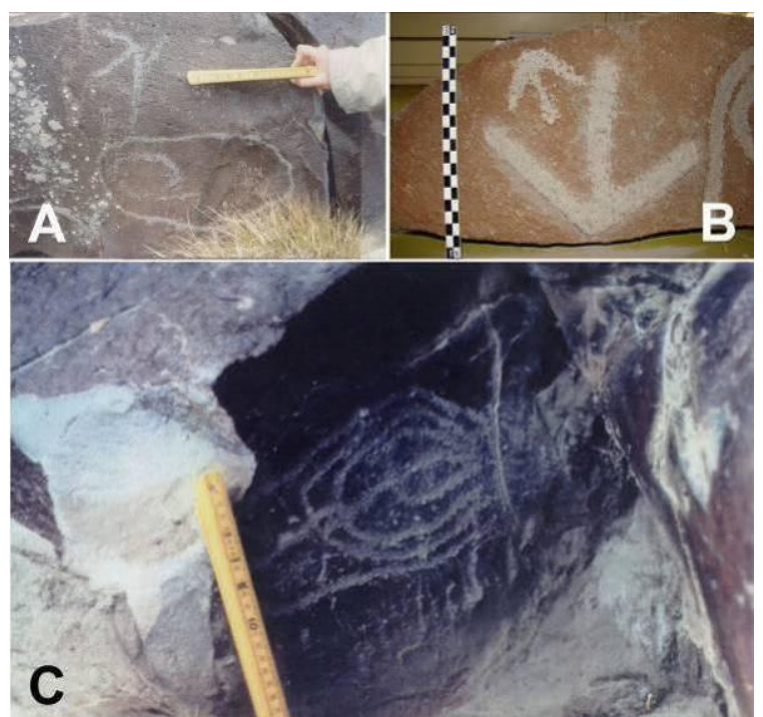

Figura 8.11. Motivos grabados sobre basalto: a. Surco de tridígito grabado en el sitio LCB; b. Motivos grabados experimentalmente que comportaron diferente inversión de tiempo: c. Motivo curvilíneo complejo de LCB con surco profundo.

8. a. 5. 1. c. Re-evaluación de técnicas para grabados

La re-evaluación de las técnicas de producción de grabados permite valorar los aportes de los estudios experimentales tanto para el análisis como para la interpretación de la producción del arte rupestre. Si bien la observación macroscópica de los surcos grabados en campo constituye el primer paso en la identificación de las técnicas de producción, el cruce de dicha información con aquella obtenida mediante réplicas experimentales

1 En el diseño experimental se empleó abrasión con arena sobre soporte coquinoide (Capítulo 5), y no se corresponde con percusión directa usando abrasivos. 
facilita su especificación. Por otro lado, la experimentación permite tener presente los potenciales artefactos empleados en la producción de diferentes motivos sobre distintos soportes. Las replicas fueron realizadas con guijarros naturales de diferente morfología, tamaño y peso que oficiaron de percutores (ver Capítulo 5). Trabajos similares fueron desarrollados por Álvarez y Fiore (1995), Méndez (2008), Vergara Murúa (2009) en soportes de distinta litología. Asimismo, artefactos no formatizados fueron empleados para la implementación de técnicas como la incisión, horadación y raspado, observándose micro-rastros de uso sobre los filos de dichos artefactos (Capítulo 5; ver también Álvarez y Fiore 1995; Álvarez et al. 2001; Blanco y Lynch 2011). En los antecedentes del arte rupestre del macizo del Deseado se ha mencionado el empleo de buriles, cinceles, y percutores-cinceles para la producción de grabados (ver Capítulo 4); sin embargo, no se cuenta con imágenes o figuras que describan tales artefactos. En este sentido, las tareas experimentales permitieron reconocer el empleo de artefactos diferentes a los esperados, tales como artefactos no formatizados y guijarros de diferente morfología (véase también Fiore 1996-98).

Los resultados de esta re-evaluación acerca de las técnicas de producción efectuada para los sitios AEG-2, CG y LCB, en conjunto con la presentación de las técnicas reconocidas para los motivos figurativos y los circulares lineales de cinco sitios adicionales (Bardas del Doce, La Leonera, La Marianita, Los Navarros y Bardas de Carlos), se resume en la Tabla 8.6. A pesar de los diferentes soportes y de los distintos diseños considerados, hay un amplio predominio de la percusión. El empleo de otras técnicas se corresponde con diseños que presentan trazos lineales (v.g., los tridígitos sobre arenisca coquinoide). Esta tendencia indica, por lo tanto, una homogeneización en el área de estudio en cuanto al empleo de las técnicas de grabado, donde predomina la percusión a pesar de los diferentes soportes y diseños. Entonces, el soporte sería un condicionante tecnológico: la microtopografía y la dureza del mismo se relacionan con la inversión del trabajo realizado. Sin embargo, los tridígitos sirven para graficar como el 


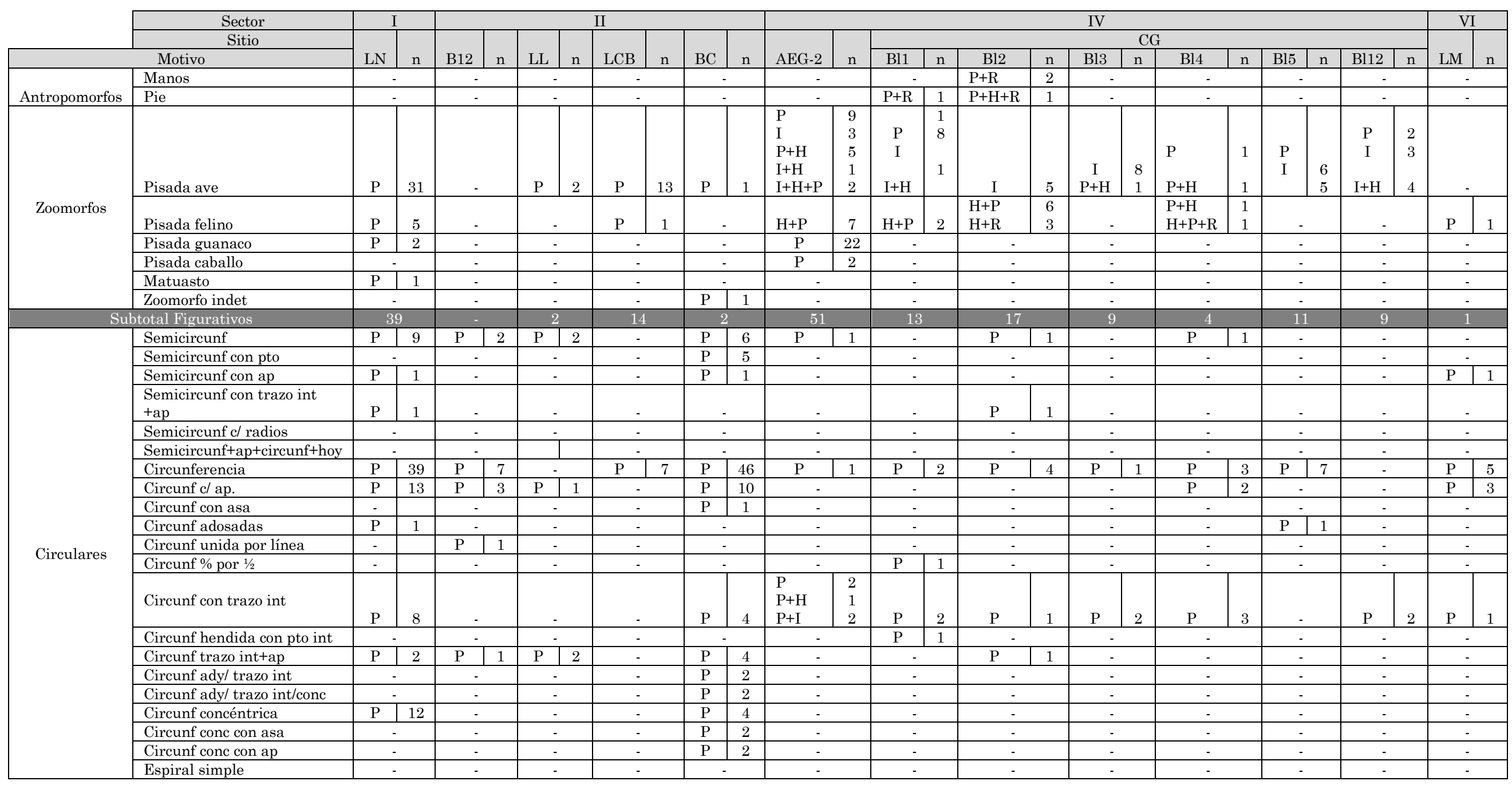

(Continúa) 


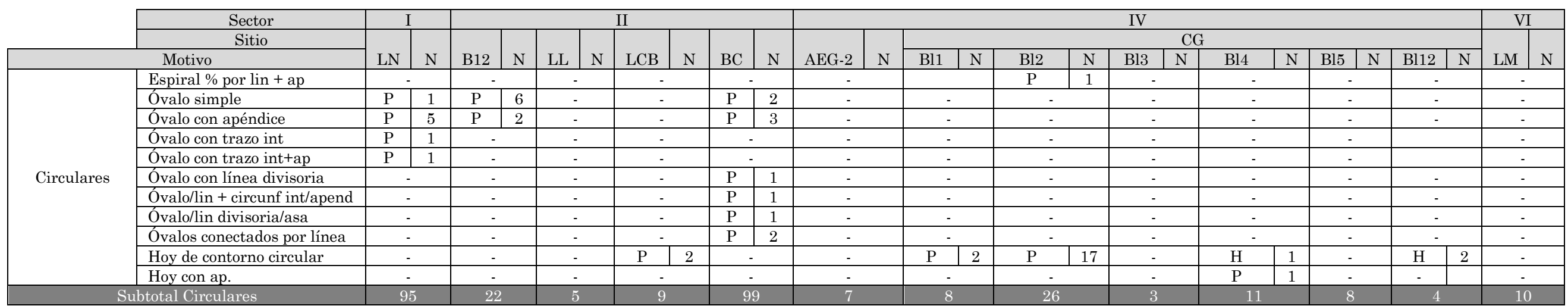

Tabla 8.6. Re-evaluación de las técnicas de producción de grabado reconocidas para motivos figurativos y los circulares en los sitios del

NE del macizo del Deseado.

REFERENCIAS. LN: Los Navarros; B12: Bardas del Doce; LCB: Laguna del Cerro Bonete; BC: Bardas de Carlos; AEG-2: Alero El Galpón 2; CG: Cueva Grande (Bl\#: Bloque \#); LM: La Marianita.

Motivos figurativos: zoomorfo indet: zoomorfo indeterminado. Motivos circulares: Semicircunf: semicircunferencia; Semicircunf con pto: semicircunferencia con punto; Semicircunf con ap.: semicircunferencia con apéndice; Semicircunf con trazo int +ap.: semicircunferencia con trazo interno y apéndice; semicircunf c/ radios: semicircunferencia con radios; Semicircunf+ap+ circunf+hoy: semicircunferencia con apéndice y circunferencia y hoyuelo; Circunf c/ ap.: circunferencia con apéndice; Circunf con asa: circunferencia con asa; Circunf adosadas: circunferencias adosadas; Circunf unida por línea: circunferencias unidas por líneas; Circunf \% por 1/2: circunferencia dividida por la mitad; Circunf con trazo int: circunferencia con trazo interior; Circunf hendida con pto int: circunferencia hendida con punto interior; Circunf trazo int+ap : circunferencia con trazo interior y apéndice; Circunf ady/ trazo int: circunferencias adyacentes con trazo interior; Circunf ady/ trazo int/conc; circunferencias adyacentes; con trazo interior concéntrica; Circunf concéntrica: circunferencias concéntricas; Circunf conc con asa: circunferencias concéntricas con asa; Circunf conc con ap: circunferencia concéntrica con apéndice; Espiral \% por lin + ap: espiral con apéndice dividido por línea; Óvalo con trazo int: óvalo con trazo interior; Óvalo con trazo int+ap: óvalo con apéndice y trazo interior; Óvalo/lin + circunf int/apend: óvalo dividido por línea más circunferencia interior con apéndice; Óvalo/lin divisoria/asa: óvalo con línea divisoria y asa; Hoy de contorno circular: hoyuelo de contorno circular; Hoy con ap.: hoyuelo con apéndice. 
diseño condiciona también la técnica de producción, ya que la misma depende de la morfología y el tamaño del motivo que se quiera lograr

La información procedente de las tareas experimentales así como la de los trabajos de campo permite evaluar si el emplazamiento jugó algún papel como condicionante tecnológico. El análisis realizado por Carden (2009a) permite observar que algunos motivos fueron producidos a escasa altura del suelo, destacando que los mismos tienen cierta complejidad en el diseño, tanto para motivos grabados (Figuras 8.11.a y 8.11.c) como para motivos pintados (ver más adelante). Esta situación indicaría la selección dentro de un sitio de un punto particular para desarrollar diseños complejos, los cuales demandarían más tiempo de elaboración no sólo por su diseño, sino también por la posición que debería haber adoptado el productor, la cual, transcurrido cierto tiempo, podría haberse tornado incómoda. Por otro lado, algunos sitios muestran una selección similar en cuanto al tipo de paisaje en el que se emplazan diseños semejantes.

En este sentido, Los Navarros corresponde a un paisaje similar al de LCB, AEG-2 y CG: el arte rupestre se encuentra en las inmediaciones de una fuente de agua (laguna temporaria), rodeada por un afloramiento rocoso y por un paisaje que podría corresponderse a posibles estaciones de caza. Los contextos arqueológicos de AEG-2 y AEP-1 indican la ocupación de estos aleros para tareas de procesamiento primario de presas cazadas desde el Pleistoceno final (Marchionni 2013; Miotti 1992, 1996; Miotti et al. 1999b). Por otro lado, los paisajes de Los Navarros (LN) y LCB coinciden con aquellos referidos por los cronistas para las cacerías colectivas de guanacos (Claraz 1988). En estos sitios se registraron grabados, entre los que predominan los motivos circulares, además se documentaron motivos rectilíneos y pisadas animales. Sin embargo, Bardas de Carlos (BC) y La Marianita (LM) son sitios con fuentes de agua relativamente cercanas, que se encuentran en espacios abiertos. Para poder relacionar estos últimos con sectores de cacería son necesarias mayores prospecciones en las áreas inmediatas a los sitios con arte rupestre y contrastar estas ideas con la evidencia arqueológica que se detecte. 
En cuanto a la asociación entre las técnicas de producción y la presencia de superposiciones, para los motivos grabados éstas últimas se observaron en La Leonera (LL), LCB, BC y LN. Tales superposiciones se corresponden con líneas incisas sobre otros motivos realizados por percusión (LL, LCB y $\mathrm{BC}$ ), aunque en el caso de LN se observa que los motivos superiores presentan mayor variabilidad de diseño (curvilíneos, rectilíneos, circulares lineales y pisadas de ave), pero se corresponden con una técnica de producción (percusión).

En BC algunas incisiones caóticas presentan pátina más oscura que los motivos subyacentes (ver Tabla 6.5). Esta situación resulta llamativa ya que la expectativa general para las superposiciones es que los motivos superiores presenten pátina similar o menos desarrollada que los inferiores. En este sitio, los motivos inferiores de las superposiciones corresponden a motivos realizados por percusión, de diseño circular lineal mayoritariamente, seguidos por motivos rectilíneos, y también se registraron sobre una pisada animal y motivos curvilíneos (ver Tabla 6.5). Estas superposiciones estarían indicando una posible diacronía en cuanto al empleo de las técnicas de grabado, primero percusión y luego incisión. Si bien se planteó en el Capítulo 6 que probablemente el/los artefacto/s empleado/s para la realización de las incisiones no lograron atravesar la pátina del soporte, razón por la cual los surcos incisos superiores presentan una coloración oscura en relación a los motivos inferiores, aún resta realizar trabajos experimentales adicionales para encontrar una posible explicación a esta situación. Quizás, y a modo de hipótesis, estas incisiones superpuestas sean de origen relativamente reciente y resultado de la acción de una re-apropiación del espacio grabado mediante la superposición de otros diseños no registrados con anterioridad (líneas caóticas incisas), sin llegar a negarlo completamente mediante su eliminación; sobre todo porque también se registraron casos de incisiones caóticas sin estar superpuestas a otros diseños. 
Las superposiciones registradas en el sitio LN son más numerosas que las de $\mathrm{BC}$, aunque alrededor del 50\% de las mismas se encuentra en un solo conjunto (ver Tabla 6.11). En la mayoría se observan motivos inferiores con pátina igual o más desarrollada que los motivos superiores, la única salvedad debería hacerse para las superposiciones 9 y 10 del Conjunto 6 donde los motivos motivo inferiores presentan pátinas menos desarrollada que los superiores. En cuanto a los motivos que integran estas superposiciones, se trata de motivos figurativos y no figurativos. Entre los primeros, solo se observaron tridígitos con pátina intermedia y oscura, que se encuentran en posición inferior o superior a motivos no figurativos. Entre estos últimos, la variabilidad observada es mayor, pudiendo encontrarse en posición inferior o superior y con los tres tipos de pátina reconocidos (ver Tabla 6.13). Estas superposiciones, conjuntamente con los distintos grados de pátina reconocidos en LN permiten proponer cronologías relativas en cuanto a la realización de los motivos. Los sectores 1 a 3 , 6 y 7 son los que presentan motivos con tres grados de pátina y en los que además se registraron superposiciones (ver Tabla 6.14), lo que permitiría plantear un uso diacrónico y reiterativo de tales sectores. Las superposiciones se corresponderían con diferentes maneras de relacionarse con el arte rupestre pre-existente que habrían tenido los productores. Esos vínculos implicarían la incorporación, la negación o la re-significación de las imágenes en sus propios discursos (Martel et al. 2012; Pastor 2012; Troncoso 2005).

\section{8. a. 5. 2. Soporte, técnica y diseño para pinturas}

Entre los motivos pintados predominan los figurativos, particularmente los negativos de mano ( $\mathrm{n}>610$; Tabla 8.7), mientras que entre los no figurativos son abundantes los circulares lineales. Estos motivos fueron registrados sobre cuatro tipos de soportes: conglomerado tobáceo, arenisca coquinoique, basaltos e ignimbritas, presentando variabilidad en cuanto a frecuencia y diseño en los diferentes sectores de la región en estudio (Tabla 
8.7). Asimismo, en estos soportes se observa el uso generalizado del estarcido como técnica de producción de negativos; solamente en dos localidades se registró el delineado para la realización de los negativos de mano. Adicionalmente, se documentaron motivos con tratamiento plano, en los que la pintura fue aplicada mediante técnica digital (Tabla 8.7).

Si bien las técnicas de producción para motivos pintados en el macizo del Deseado fueron consideradas en el Capítulo 4, y particularmente en el Capítulo 5 mediante la replicación experimental de una selección de motivos de la localidad La Primavera, aquí se realiza la re-evaluación respecto de los motivos figurativos, de los circulares y ortogonales documentados en trabajos previos (Carden 2008a, 2009a). Este abordaje se debe a que en las labores de campo realizadas para esta tesis no se documentaron motivos pintados. La inclusión de los motivos ortogonales permitirá más adelante la comparación con aquellos documentados en áreas aledañas y en el macizo de Somuncurá.

\begin{tabular}{|c|c|c|c|c|c|c|c|c|}
\hline \multirow{3}{*}{ Localidades } & \\
\hline & \multicolumn{4}{|c|}{$\mathrm{I}$} & \multicolumn{2}{|c|}{\begin{tabular}{l|l} 
II & \\
\end{tabular}} & \multirow{2}{*}{$\begin{array}{c}\text { IV } \\
\text { PM }\end{array}$} & \multirow{2}{*}{$\begin{array}{c}\mathrm{V} \\
\mathrm{LT}\end{array}$} \\
\hline & LP & LV & LM & SB & A del C & $\mathrm{BP}$ & & \\
\hline Soporte & \multicolumn{4}{|c|}{ Ignimbrita } & \multicolumn{2}{|c|}{$\begin{array}{c}\text { Conglomerado } \\
\text { tobáceo }\end{array}$} & $\begin{array}{l}\text { Arenisca } \\
\text { coquinoide }\end{array}$ & Ignimbrita \\
\hline $\begin{array}{ll} & \text { Técnica } \\
\text { Motivo } & \\
\end{array}$ & $\begin{array}{l}\text { E; PP; } \\
\text { dig }\end{array}$ & $\begin{array}{l}\mathrm{E} ; \\
\mathrm{PP}\end{array}$ & $\begin{array}{l}\mathrm{E} ; \\
\mathrm{PP}\end{array}$ & $\begin{array}{l}\text { E; PP; } \\
\text { dig }\end{array}$ & $\mathrm{E} ; \mathrm{PP}$ & $\mathrm{E}$ & E; delin & $\begin{array}{l}\text { E; PP; } \\
\text { delin }\end{array}$ \\
\hline Puntiformes & $\mathrm{X}$ & - & $\mathrm{X}(2)$ & $\mathrm{X}$ & $\mathrm{X}$ & - & $\mathrm{X}$ & $\mathrm{X}$ \\
\hline Rectilíneos & $\mathrm{X}(2)$ & - & - & $\mathrm{X}$ & $\mathrm{X}(2)$ & - & - & $\mathrm{X}$ \\
\hline Circulares llenos & $\mathrm{X}$ & - & - & $\mathrm{X}(2)$ & - & - & $\mathrm{X}$ & - \\
\hline $\begin{array}{l}\text { Circulares } \\
\text { lineales }\end{array}$ & $\mathrm{X}$ & $\mathrm{X}(2)$ & - & - & $\mathrm{X}$ & - & - & $\mathrm{X}(2)$ \\
\hline Curvilíneos & - & - & - & $\mathrm{X}$ & $\mathrm{X}$ & - & - & $\mathrm{X}$ \\
\hline $\begin{array}{l}\text { Pisadas } \\
\text { humanas }\end{array}$ & $\mathrm{X}(1)$ & $\mathrm{X}(1)$ & $\mathrm{X}(1)$ & $\mathrm{X}(1)$ & $\mathrm{X}(1)$ & $\mathrm{X}(1)$ & $\mathrm{X}(1)$ & $\mathrm{X}(1)$ \\
\hline $\begin{array}{l}\text { Pisadas } \\
\text { animales }\end{array}$ & $\mathrm{X}$ & - & - & - & $\mathrm{X}$ & - & - & $\mathrm{X}$ \\
\hline $\begin{array}{l}\text { Figuras } \\
\text { humanas }\end{array}$ & - & - & - & $\mathrm{X}$ & - & - & - & $\mathrm{X}$ \\
\hline $\begin{array}{l}\text { Figuras } \\
\text { animales }\end{array}$ & $\mathrm{X}$ & $\mathrm{X}$ & - & $\mathrm{X}$ & - & - & - & $\mathrm{X}$ \\
\hline Escena de caza & - & - & - & $\mathrm{X}$ & - & - & - & - \\
\hline
\end{tabular}

Tabla 8.7. Distribución de los subgrupos de motivos pintados más frecuentes en diferentes soportes. Referencias: LP: La Primavera; LV: Los Ventisqueros; LM: Las Mercedes; SB: Sierra Blanca; A del C: Aguada del Cuero; BP: Bajo Pantano; PM: Piedra Museo; LT: Los Toldos. Técnicas: E: estarcido; PP: pintura plana; dig: técnica digital. (1) y (2) indican orden y predominio de subgrupo de motivos. 
8. a. 5. 2. a. Evaluación de técnicas para motivos figurativos

8. a. 5. 2. a. 1. Rastros

Entre estos motivos se consideran los rastros humanos (manos y pies) y animales. Entre los rastros humanos se documentaron manos en negativo, en positivo y delineadas. Los rastros animales incluyen pisadas de ave, de felino y de guanaco. La observación de los trazos pintados en conjunto con los trabajos experimentales desarrollados permite proponer diferentes técnicas de producción. Asimismo, las replicaciones experimentales realizadas resultaron idóneas para reconocer algunos gestos técnicos relacionados con su producción (ver Capítulo 5).

\section{- Rastros humanos}

Como se señaló en el Capítulo 4, en el macizo del Deseado se documentaron manos en negativo (estarcidas) y delineadas entre los rastros humanos (Apéndice II.1.b), mayoritariamente sobre ignimbritas ( $\mathrm{n}>530$ ), registrándose alrededor de 50 negativos de manos sobre arenisca coquinoide, 27 sobre conglomerados tobáceos y un solo caso de este tipo de motivos sobre soporte basáltico (Carden 2008a, 2013).

La replicación experimental de manos negativas ha permitido ampliar el espectro de inferencias manejadas hasta ahora en los sitios de Patagonia que las presentan, ampliando el conocimiento referido a su proceso de producción. En este sentido, se retoman las consideraciones planteadas en el Capítulo 5, las cuales son ejemplificadas con motivos particulares documentados previamente (Carden 2008a, 2009a; Cardich et al. 1987).

1) La distancia así como la posición y relación entre el pintor y el modelo facilita, o dificulta, el acceso del primero al soporte para aplicar la pintura. De igual modo, la altura a la que se va a realizar el negativo por estarcido está en estrecha relación a la estatura del pintor, siendo necesaria cierta 
horizontalidad entre la boca y la mano, tanto para no tragar pintura como para acceder al soporte. En este sentido, es dable suponer el uso de algún medio de elevación de los pintores para aquellos negativos de mano ubicados en sectores como techos y paredes altas de cuevas.

En el Capítulo 5 se presentaron dos experiencias replicativas en las que participaron un modelo y una pintora, así como una modelo-pintora, intentando producir negativos de mano por estarcido a alturas similares a la estatura de la pintora (ver páginas 162-164). En sitios como Maripe, Los Toldos (LT) 2 y 6, y Tito del Valle se documentaron manos en sectores altos. En el caso de LT-6 el acceso a dichos sectores se realizó a través del uso de escalones naturales del soporte. Para Maripe y LT-2 podrían haberse empleado bloques rocosos aislados para elevar al modelo y/o pintor respecto del nivel del suelo, y de ese modo alcanzar cierto grado de horizontalidad entre la boca y la mano empleada como negativo.

2) Se puede inferir la participación de al menos dos actores a partir de la posición y del largo de la mano así como su altura respecto del suelo. En los sitios donde se documentaron negativos de mano de tamaño pequeño a alturas superiores a 1,30 m respecto del suelo actual (para mayor detalle ver Carden 2008a, 2013; Carden y Blanco 2013), es posible pensar en la participación de un niño como modelo y de un pintor. Este último pudo ser de mayor edad que aquel o bien un individuo adulto, y quien elevó al niño respecto del nivel del suelo.

Durante las tareas experimentales, cuatro casos en los que los niños no llegaban a colocar la mano sobre el soporte -ubicado entre 1,30 y 1,45 m respecto del suelo-, aquellos fueron levantados en brazos por la pintora, previamente a aplicar la pintura (ver Figura 5.24.b). Esta podría haber sido la situación en el caso de Cueva Maripe por ejemplo mientras que en el sitio Tito del Valle un negativo de tamaño pequeño ubicado a $2,30 \mathrm{~m}$ aproximadamente del suelo actual plantea un problema adicional, ya que a esa altura hay que adicionarle la altura de los sedimentos que se encuentran en el piso del alero. Esta situación le permitió a Carden (2009a) proponer que el niño fue elevado por algún adulto. Surge, entonces, la pregunta si 
durante la producción de este negativo (Figuras 8.12.a-b) intervinieron más de dos personas además de un niño como modelo y un adulto como pintor, ya que quizás habría sido necesaria también la elevación respecto del nivel del suelo no sólo del modelo sino también del pintor. Cabría preguntarse cuáles fueron los medios de elevación empleados por esos actores, si el niño fue subido sobre los hombros y participó un tercer individuo para aplicar pintura, o quizás fue el niño quien aplicó pintura sobre su propia mano. Por el momento, se puede afirmar que resulta imposible estarcir pintura con un niño sentado sobre los hombros, por lo que para mantener la condición de horizontalidad entre la boca del pintor y la mano del modelo, podría haber participado un cuarto actor que sostuviera al pintor. Los interrogantes están planteados, son necesarios entonces trabajos experimentales adicionales que permitan descartar las distintas opciones que pudieron implementarse en la producción de este caso específico.

3) Existen factores vinculados con los gestos técnicos que se relacionan con variaciones en el tamaño de las manos. Dichos factores fueron evaluados en el Capítulo 5 a partir de las diferencias entre el largo real de la mano y el de sus réplicas experimentales. Como ejemplo arqueológico podría citarse la mano negativa documentada en la localidad Sierras Blancas, la cual fue realizada por la misma persona: se trata de dos negativos superpuestos, realizados en color rojo -inferior- y rojo oscuro -superior- (Figuras 8.12.c-d). Esta situación indica la presencia de dos negativos diferentes producidos por el mismo individuo que, según se considere la pintura roja o la oscura, presenta variaciones en el ancho del negativo. Por otro lado, la superposición en sí misma informa respecto a un tiempo de espera relativo para que las mezclas empleadas se confundan parcialmente, ya que la misma fue detectada mediante el tratamiento digital de las imágenes (Figura 8.12.d). Cabría preguntarse si esta superposición se corresponde con el mantenimiento mediante repintado de este negativo de mano por parte del mismo individuo, en el cual la diferencia en las pinturas empleadas se relaciona con el uso de diferentes mezclas. Posiblemente el uso de distintas proporciones de componentes o, incluso, diferentes. 


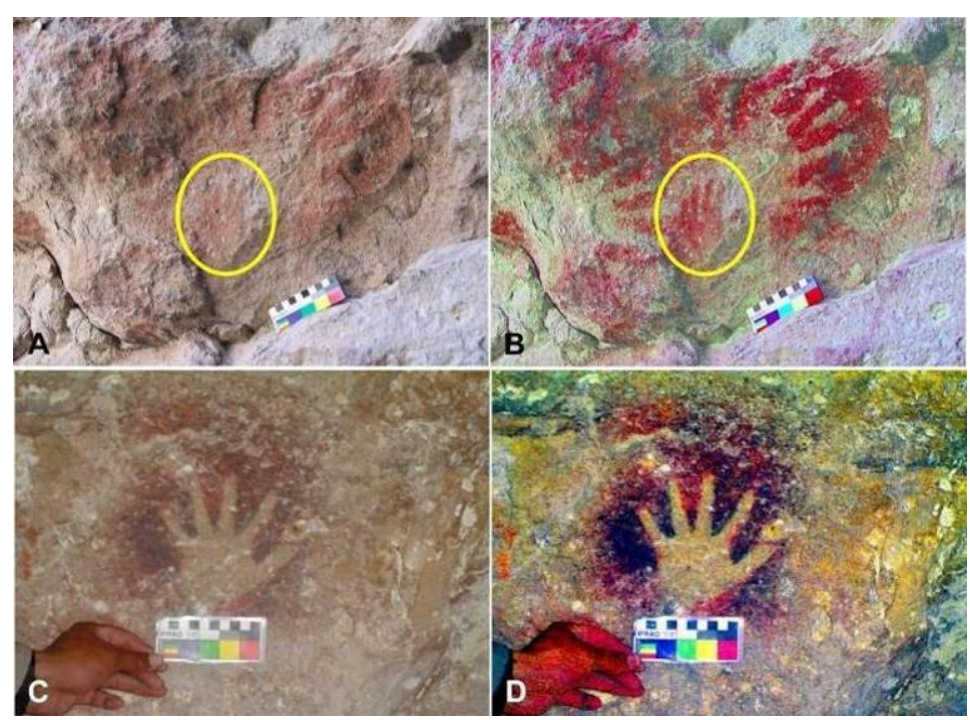

Figura 8.12. Manos negativas en Tito del Valle y Sierras Blancas: a. fotografía de los negativos a 2,30 $\mathrm{m}$ de altura respecto del suelo en Tito del Valle; b. imagen tratada digitalmente ( $D$-Stretch yrd 15$)$; c. negativo superpuesto en Sierras

Blancas; d. tratamiento digital de la imagen ( $D$-Stretch lds 15).

4) A partir de la comparación de motivos, en el registro arqueológico podría reconocerse el accionar de aprendices y el de sujetos con experiencia (Bleed 2011). En el caso de los negativos de mano podrían observarse, entonces, motivos con una cobertura homogénea de la superficie alrededor de la mano, en "forma de halo", los cuales corresponderían a sujetos con experiencia o habilidad para implementar la técnica del pulverizado directo, con un control motor de las respiraciones, pulverizaciones de pintura y movimientos corporales (Figuras 8.12.c y 8.13.a-c). Por otro lado, en el caso de que los negativos correspondan a ensayos o sujetos que están adquiriendo experiencia, podrían observarse alrededor de las manos superficies con una distribución de pintura heterogénea, en los que la definición de la mano empleada como plantilla es imprecisa (Figuras 8.13.d-e).

5) Los planteos efectuados en el Capítulo 5 permitirían reconocer negativos de manos realizados sobre manos izquierdas apoyando la palma y sobre manos derechas apoyando el dorso, principalmente la curvatura del pulgar. Asimismo, en algunos casos podría distinguirse el trabajo de un pintormodelo a partir de la posición, orientación y ángulos de abducción y aducción de la muñeca, siempre y cuando los negativos presenten antebrazo. 
Los ejemplos arqueológicos presentados en la Figura 8.13 permiten reconocer negativos realizados a partir de manos izquierdas y derechas en posición prona en Cueva Maripe, La Primavera 3, La Escuelita, Los Toldos 2 y 6, entre otros (Carden 2013; Magnin 2010). Hasta el momento no se documentaron negativos realizados a partir de manos izquierdas o derechas en posición supina. Quizás, esto se deba a que en el reconocimiento entre una y otra no se habían planteado los parámetros identificados en el Capítulo 5. Con una nueva observación y documentación fotográfica de este tipo de motivo, en la que se incluya la revisión de la altura respecto del suelo de cada uno y su tamaño, se podrán ahondar los planteamientos técnicos realizados.

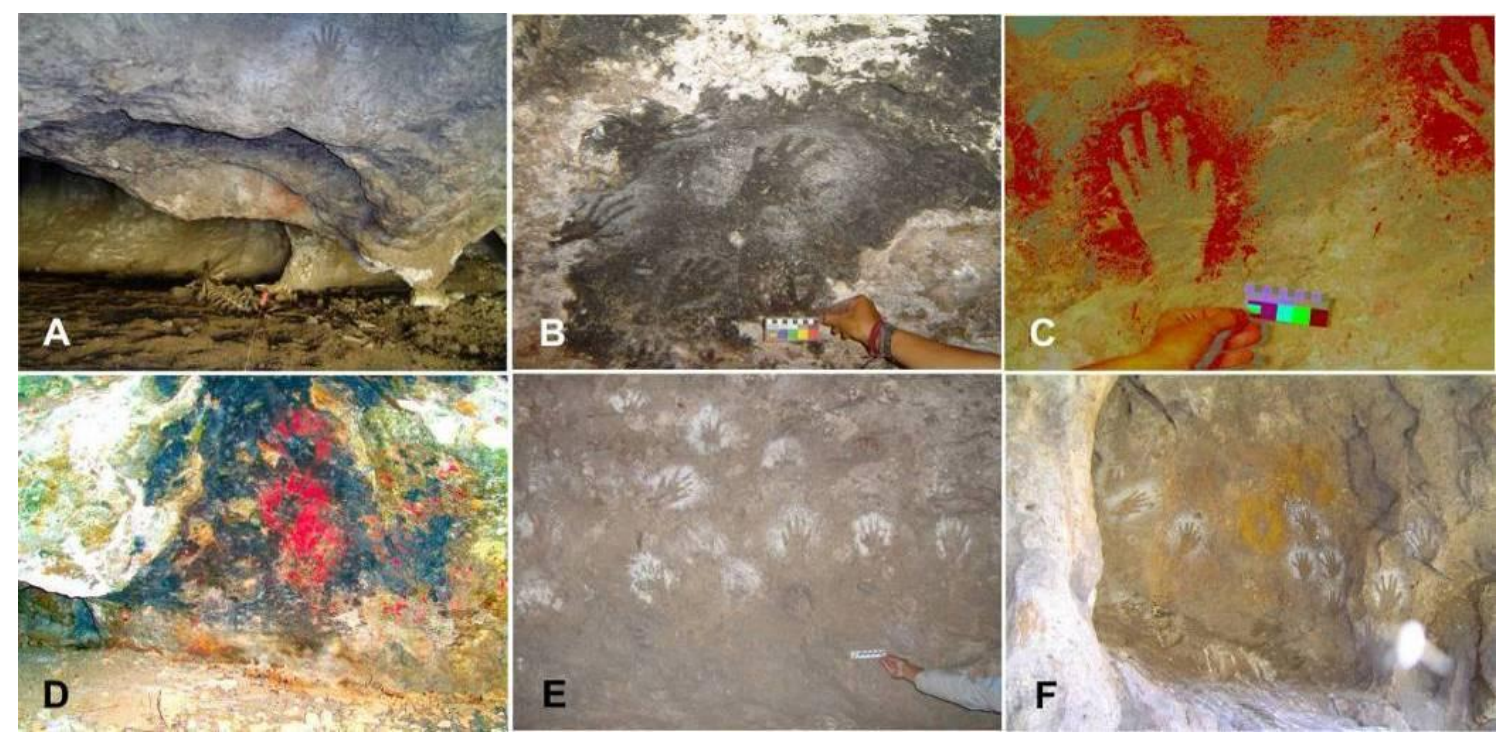

Figura 8.13. Manos negativas por estarcido: a-c. negativos realizados a partir de mano izquierda en posición prona en Cueva Maripe (c. imagen tratada digitalmente $D$-Stretch lre 15); d. negativos realizados a partir de mano derecha en posición prona LP-3 (imagen tratada digitalmente $D$-Stretch lab 15); e. negativos de manos izquierdas y derechas en posición prona en La Escuelita; f. negativos de mano izquierda en posición prona en LT-6.

En el sitio AEG-2 se documentaron manos delineadas y en las que se empleó la microtopografía existente para contornearlas (Carden 2008a). En el caso del negativo de mano delineado, la palma se apoyó sobre la roca, se delineó su contorno y se pintó la oquedad en la que se emplazó dándole forma circular (Figura 8.14.a). Por otro lado, hasta el momento y mediante el tratamiento digital de las imágenes, se ha detectado un sólo caso de mano 
en positivo en LT-2. Posiblemente, la mano fue contorneada con pintura -a excepción de la palma- cubriendo los dedos y luego aplicada sobre el soporte (Figura 8.14.b).

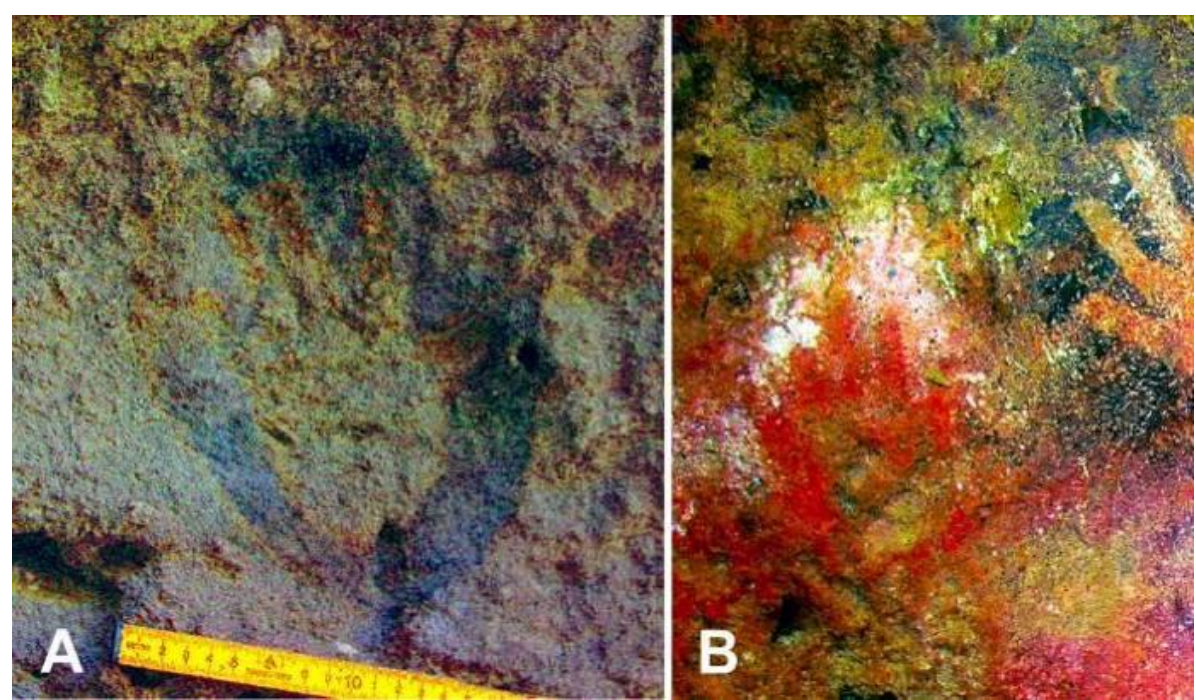

Figura 8.14. Técnicas adicionales reconocidas para la producción de manos: a. Fotografía tratada digitalmente de mano derecha delineada de AEG-2 ( $D$-Stretch lds 12.5); b. Mano en positivo en LT-2 (D-Stretch lab 15).

En esta porción del macizo del Deseado, los negativos de mano en su mayoría habrían sido realizados mediante el estarcido directo, aunque se observan algunos casos donde se emplearon otras técnicas (v.g., delineado o positivo). Es decir que los negativos de mano fueron realizados sobre soportes diferentes empleando técnicas similares de producción.

El análisis de la producción de rastros humanos (particularmente manos) permite obtener información adicional respecto a los productores (si fueron uno, dos o más participantes; sus posibles edades; sus potenciales habilidades -aprendiz versus sujeto experimentado-, etc.), las condiciones de producción (v.g., si se utilizaron características naturales del soporte para alcanzar sectores altos o se emplearon bloques que habrían servido para tal fin), el empleo de diferentes mezclas en el mantenimiento de ciertos motivos, etc. Es esta la información que permite proponer un contexto de uso de los mismos.

Respecto de los pies humanos, estos fueron documentados en negativo y en positivo en el sitio LT-2 (Figura 8.15). El negativo de pie se encuentra a 1,50 $\mathrm{m}$ sobre el nivel del suelo actual, sobre una superficie vertical de la 
pared rocosa (Carden 2008a; Figuras 8.15.a-b). Dicha altura permite preguntarse acerca de cómo se produjo dicho motivo. Al respecto podrían plantearse dos posibilidades:

a) en su producción intervinieron varias personas, como mínimo dos: un modelo y un pintor, aunque podrían haber participado más personas que sirvieron de apoyo y sostén para que el modelo adoptara la posición necesaria para colocar la planta del pie sobre el soporte.

Esta posibilidad surge a partir de observaciones realizadas en el taller "Análisis experimentales en arte rupestre: métodos y técnicas para la resolución de problemas arqueológicos". Dicho taller, ya citado con anterioridad, fue realizado en FCNyM-UNLP. Durante 2013 los alumnos, luego de la proyección de imágenes fotográficas, decidieron realizar un pie en positivo y otro en negativo (Figura 8.15.c). En esta ocasión, el bloque experimental se encontraba a $1 \mathrm{~m}$ respecto del suelo en posición vertical, mientras que la modelo estaba sentada en un banco de madera con las piernas flexionadas y fue sostenida por un tercer participante. El pintor se movió alrededor del modelo para aplicar la pintura, agachándose y, de este modo, alcanzó la horizontalidad necesaria para controlar la respiración, pulverizar la pintura y no tragarla;

b) la segunda posibilidad que puede plantearse se relaciona al empleo de algún escalón natural que permita al modelo acceder a la superficie en cuestión (v.g., bloque rocoso), mientras que el pintor permanece de pie y realiza los movimientos necesarios para aplicar la pintura y lograr el negativo.

Serán necesarias tareas experimentales adicionales en las que participen modelo y pintor, se emulen las condiciones de registro y se controlen adecuadamente las variables contempladas en los experimentos realizados hasta ahora, para poder confirmar la participación de uno, dos o más actores así como las posiciones adoptadas por cada uno a las diferentes alturas a las que fueron registrados estos motivos.

Por último, el pie en positivo fue detectado a partir del tratamiento digital de las imágenes del sitio LT-2 (Figura 8.15.d). Se trata de un motivo con 
tratamiento plano, mediante el cual se delinearon cuatro dedos. Posiblemente haya sido realizado mediante el empleo de algún artefacto o vellón embebido en pintura. Motivos de pie en positivo y en negativo fueron documentados en pocos sitios en el macizo del Deseado, los cuales serán tratados más adelante.

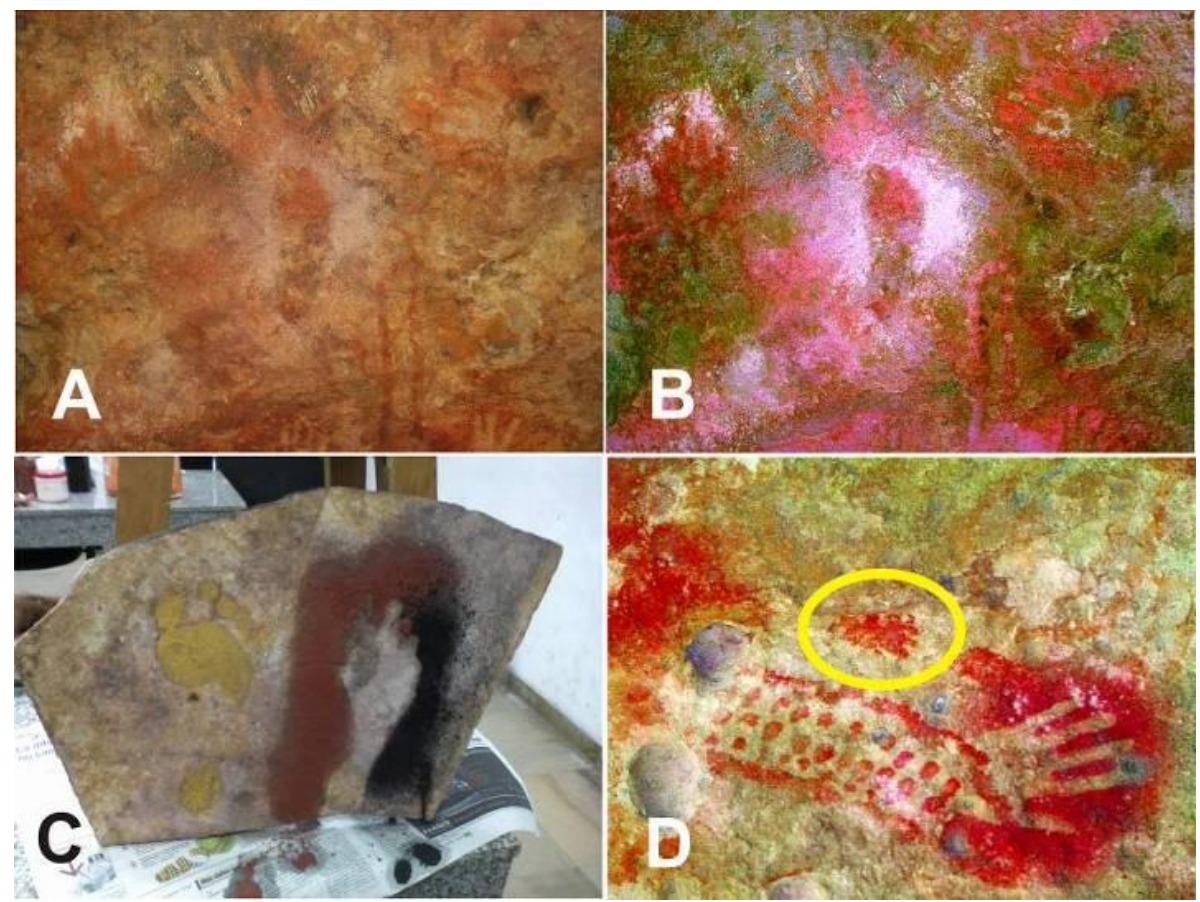

Figura 8.15. Pies humanos pintados: a. Pie en negativo en LT-2; b. imagen tratada digitalmente. Puede verse estarcido por debajo de talón ( $D$-Stretch yye15); c. pie experimental en positivo y en negativo; $d$. Pie en positivo en LT-2, imagen tratada digitalmente (D-Stretch yrd 15).

\section{- Rastros animales}

Los rastros animales pintados se documentaron en muy baja frecuencia, sobre ignimbritas y conglomerados tobáceos de diferentes localidades (Tabla 8.7). Estos motivos corresponden a una pisada de ungulado en negativo en Los Toldos, a pisadas de ave en positivo en Los Toldos y Aguada del Cuero, y a una pisada de felino en La Primavera (Figura 8.16).

El negativo de ungulado documentado en LT-2, la cual probablemente fue realizada sobre el miembro de un animal muerto. Esta extremidad fue apoyada contra el soporte rocoso y se le aplicó pintura roja alrededor (Figura 8.16.a). Las pisadas de ave en positivo se documentaron en LT-6 y en Cueva 
de la Hacienda $(\mathrm{CH})$, respectivamente (Figuras 8.16.b y 8.16.c). En ambos casos, es posible que la pintura haya sido aplicada mediante técnica digital. La pisada de felino documentada en LP-2 fue replicada experimentalmente mediante técnica digital y utilizando un artefacto, sin poder definirse por el momento el empleo de una u otra técnica (mayor detalle Capítulo 5).
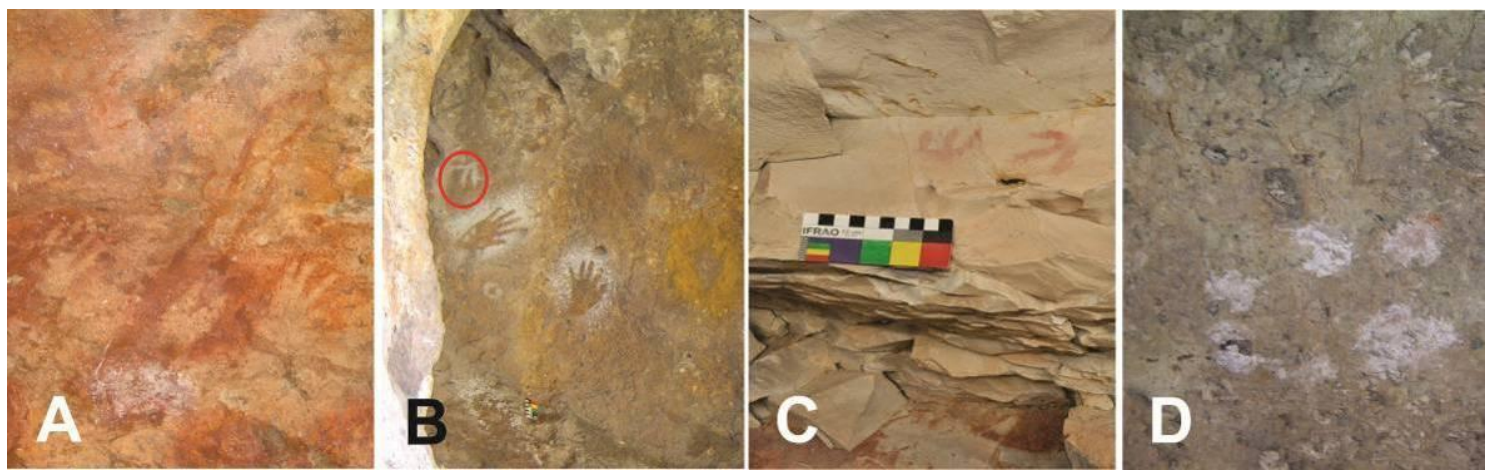

Figura 8.16. Rastros animales pintados: a. Negativo de pata de ungulado (LT-2); b. Tridígito en positivo (LT-6); c. Tridígitos de CH; d. pisada de felino (LP-2).

Los rastros animales, al igual que los rastros humanos, permiten observar la variabilidad técnica en su producción: negativo por estarcido y positivo mediante técnica digital y con el empleo de artefactos, el empleo de superficies disponibles para acceder a sectores altos de los aleros etc. De igual manera, presentan problemas de equifinalidad cuando la conservación de los motivos es mala.

\section{8. a. 5. 2. a. 2. Figuras humanas y animales}

Estos motivos también se encuentran en baja frecuencia en la región en estudio (Carden 2008a: Apéndice V). Las figuras humanas fueron documentadas en las localidades de Sierras Blancas y Los Toldos. En el sitio Cañadón de la Víbora 1 (CV-1), perteneciente a la primera localidad, probablemente se utilizó hisopo en su producción (Figura 8.17.a), mientras que los "danzantes" (sensu Menghin 1957) de LT-5 pudieron haber sido realizados mediante el uso de artefacto o vellón embebido en pintura (Figuras 8.17.b y 8.17.c). Las figuras humanas documentadas en LT-13 se encuentran altamente deterioradas por lo que es difícil proponer algún tipo de técnica de producción. 

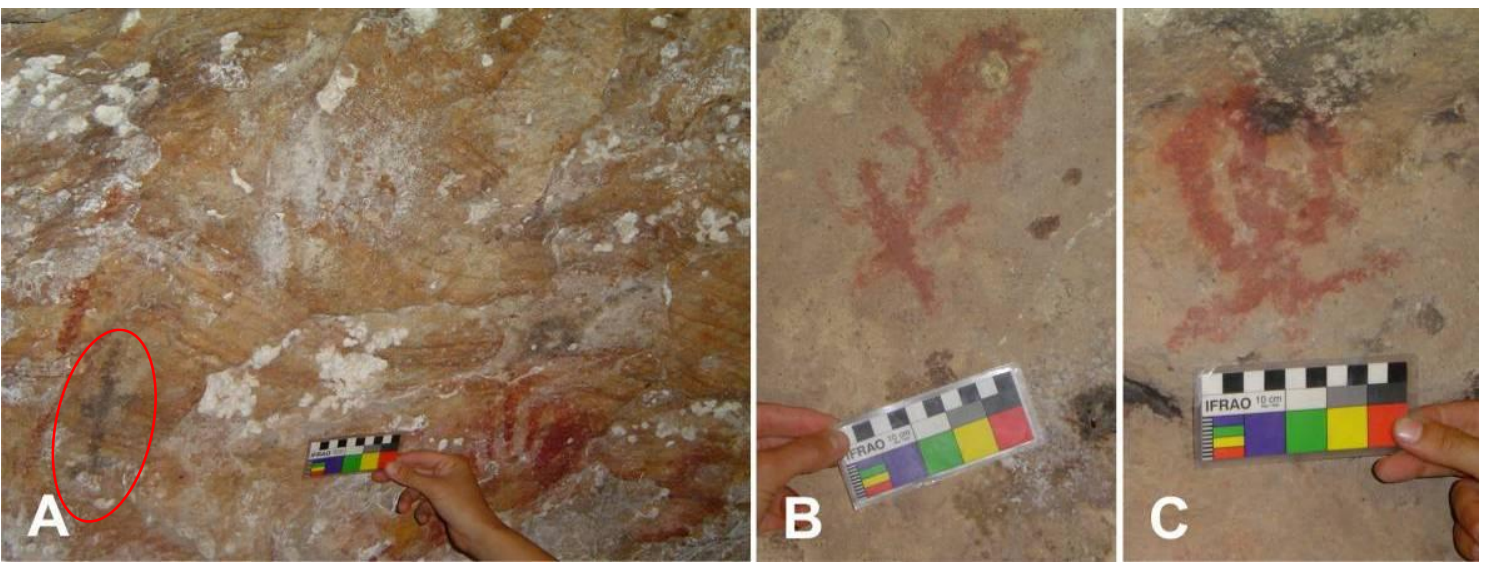

Figura 8.17. Figuras humanas pintadas: a. CV-1 en color negro; b y c. "danzantes" en LT-5.

Por otro lado, las figuras animales corresponden a zoomorfos en mal estado de conservación, resultando sumamente difícil proponer alguna técnica de producción (Figura 8.18.a). Se replicó experimentalmente uno de los zoomorfos documentados en el panel 7B de Maripe, que fue resultado del empleo de un vellón embebido en pintura (ver Figura 5.22). Es posible que esta técnica haya sido empleada en su producción, aunque deben realizarse réplicas adicionales para poder realizar una evaluación fehaciente (Figura 8.18.b). El zoomorfo de CV-1 podría haber sido realizado mediante técnica digital (Figura 8.18.c), en tanto que este tipo de motivo en LT-5 podría haber sido realizado mediante el empleo de algún artefacto o vellón de algún tipo de fibra (v.g., pelo de guanaco o humano, fibras vegetales, etc.) (Figura 8.18.d). 


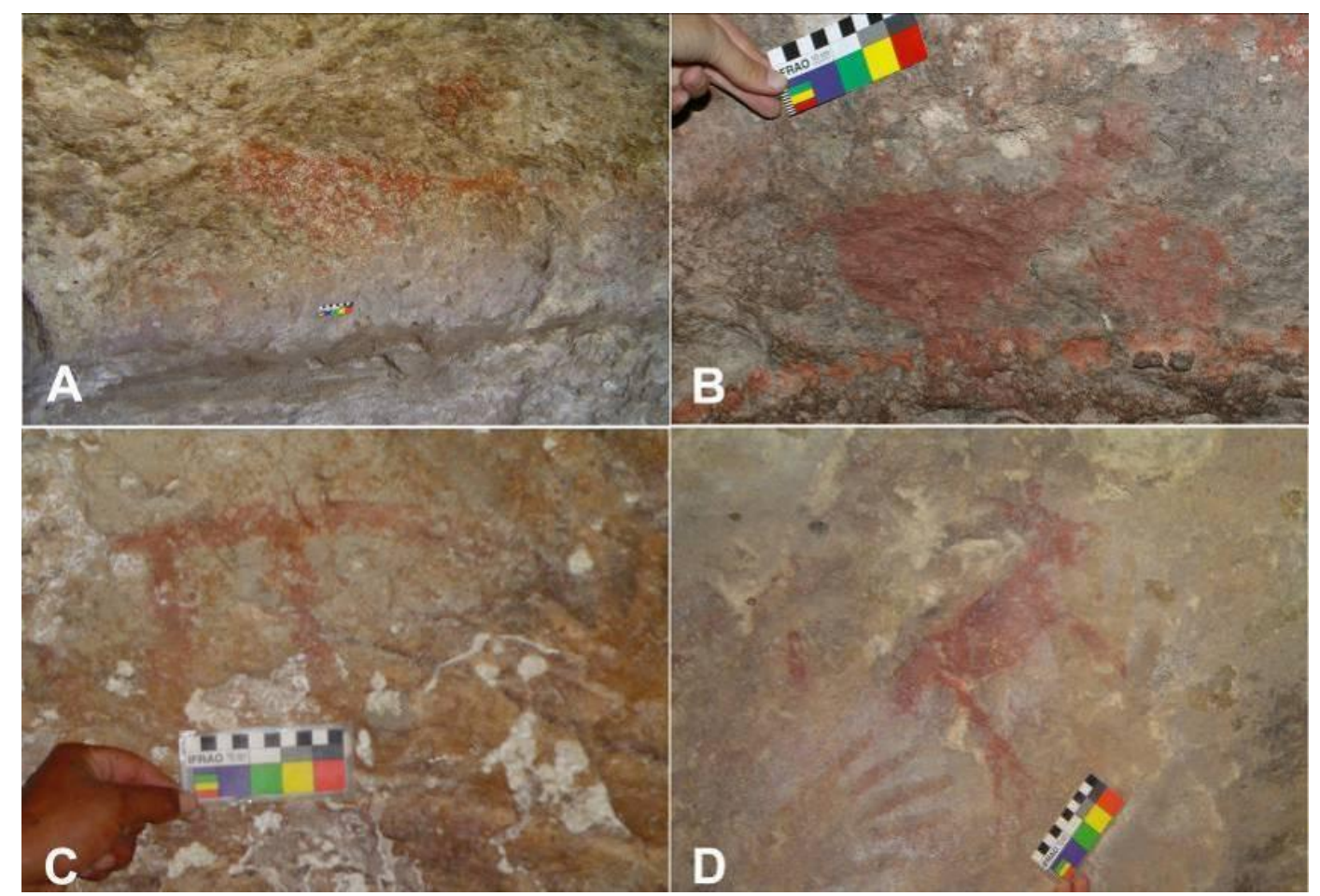

Figura 8.18. Figuras animales pintadas: a. LP-1; b. zoomorfo de MA; c. CV-1; d. LT-5.

8. a. 5. 2. b. Evaluación de técnicas para motivos circulares

Este tipo de diseño fue realizado en baja frecuencia en relación a los mismos motivos grabados $(n=44)$. Se documentaron en los sectores I, II y V, sobre ignimbrita y conglomerado tobáceo. En el primer sector corresponden a motivos documentados en las localidades de La Primavera, Los Ventisqueros y Sierras Blancas. En el sector II se documentaron dos motivos circulares con apéndices superiores en el sitio $\mathrm{CH}$, mientras que en el sector V se corresponden con espirales, circunferencias simples y concéntricas así como hoyuelos naturales delineados, los cuales fueron documentados en la localidad de Los Toldos (Carden 2008a: Apéndice V).

En el Capítulo 5 se explicitaron los criterios para reconocer entre la técnica digital y aquellas en las que se emplea un artefacto o un vellón embebido con pintura. Las pinturas resultantes de estarcido directo se corresponden con superficies de pintura variables, que hacia los bordes presentan gotas de diferente tamaño y de bordes relativamente heterogéneos. Las manchas documentadas en el sitio LP-2 fueron realizadas 
por estarcido de pintura, probablemente directo controlando las respiraciones con precisión (Figura 8.19.a). Asimismo, en el Capítulo 5, se replicó un motivo circular complejo polícromo documentado en el sitio LP5. Mediante la comparación entre ambos motivos -referente arqueológico y réplica experimental- se infirió que un hisopo podría haber sido empleado para la producción del motivo salvo para los trazos superiores blancos (ver páginas 142-143; Figura 5.21).

Respecto a los hoyuelos, aquellos documentados en LT-2 podrían haber sido delineados aplicando la pintura mediante la técnica digital o mediante un vellón de fibra animal o vegetal, embebido con pintura, ya que presentan un trazo ancho e irregular (Figura 8.19.b). Surge, entonces, un caso de equifinalidad ya que no se han recuperado artefactos ni vellones embebidos en pintura en contextos estratigráficos, a lo que se suma el mal estado de conservación de los motivos (Carden 2008a). Por otro lado, las espirales documentadas en LT-2 presentan trazo fino y continuo (Figura 8.19.c), por lo que podrían haber sido realizadas empleando un pincel o hisopo. Por último, dos motivos circulares lineales con apéndices (soles) fueron documentados a más de $2 \mathrm{~m}$ respecto del suelo en $\mathrm{CH}$ (Figura 8.19.d). Estos habrían sido realizados mediante técnica digital por la irregularidad del trazo, y para acceder al soporte habría sido necesario algún medio de elevación ya que la cueva carece de escalones naturales que faciliten dicho acceso. Durante el último relevamiento fotográfico de este sitio fue posible pensar una manera de acceder al soporte (Figura 8.20). 

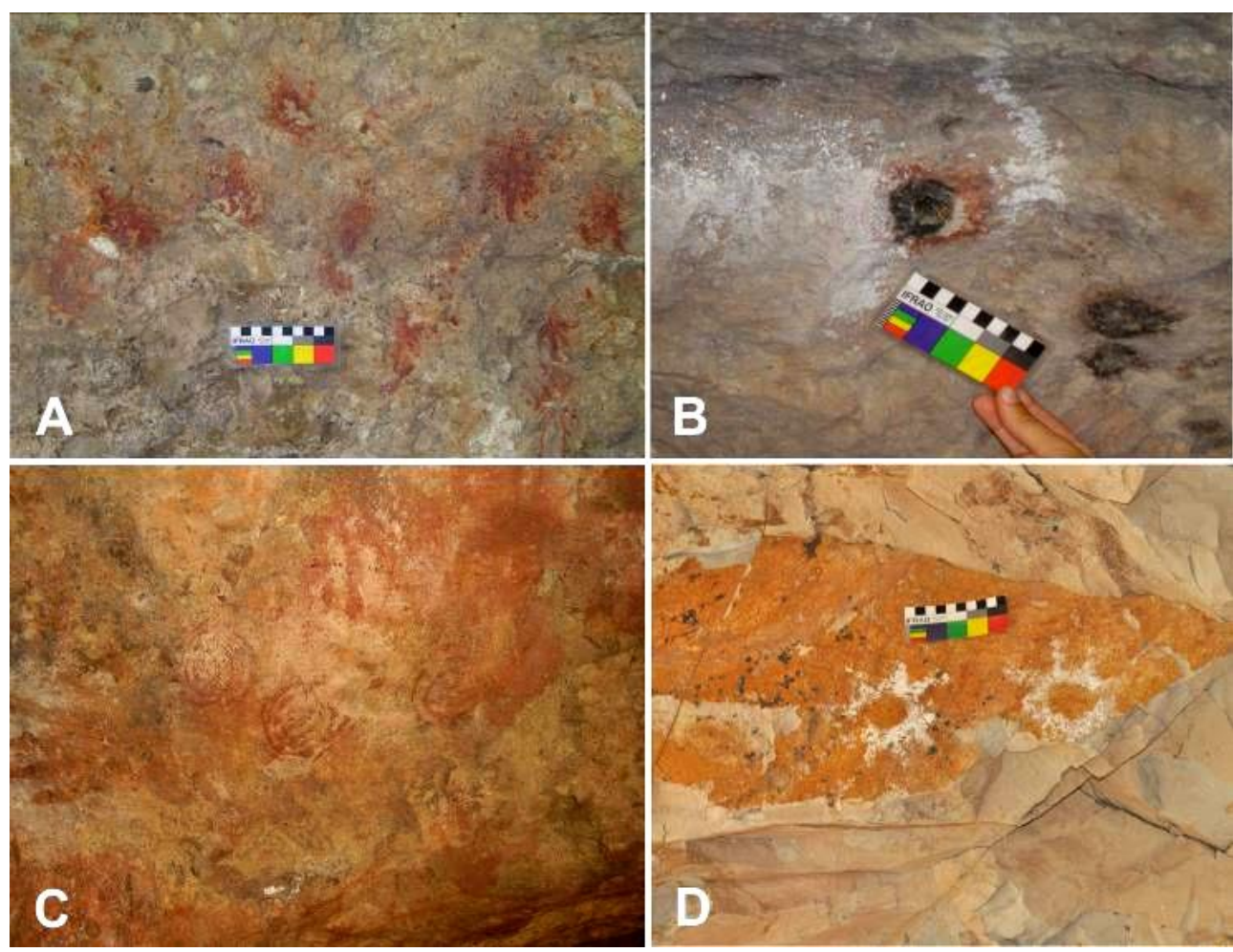

Figura 8.19. Motivos circulares pintados: a. manchas de pintura LP 2 por estarcido; b. Hoyuelo delineado en LT-2; c. espirales LT-2 con instrumento; d. circunferencias con apéndices en $\mathrm{CH}$ posiblemente por técnica digital.

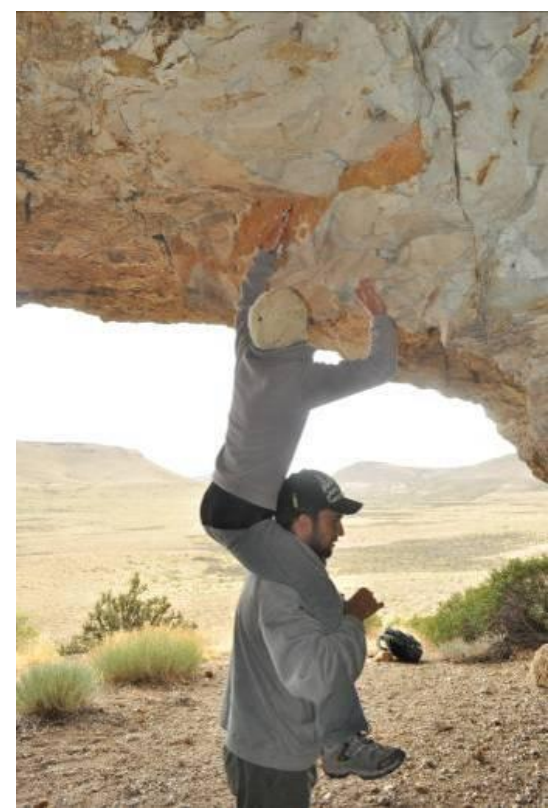

Figura 8.20. Una de las posibles maneras de acceder al soporte en $\mathrm{CH}$. En esta imagen se observa a dos integrantes del equipo colocando la escala para realizar la fotografía. 
8. a. 5. 2. c. Evaluación de motivos ortogonales

Sólo se registraron tres casos de este tipo de motivo, y corresponden a motivos cruciformes en Cañadón de la Víbora 4 (CV-4) y Cueva de la Hacienda (CH) (Carden 2008a) y un almenado en $\mathrm{CH}$, todos ellos realizados en diferentes tonalidades de color rojo. El cruciforme CV-4 y el almenado $\mathrm{CH}$ podrían haber sido realizados mediante la técnica digital (Figuras 8.21.a y 8.21.b) mientras que el cruciforme de $\mathrm{CH}$ podría haber sido hecho mediante el uso de un artefacto (Figura 8.21.c). La distinción fue realizada a partir de la morfología de los trazos y mediante el tratamiento digital de las imágenes.

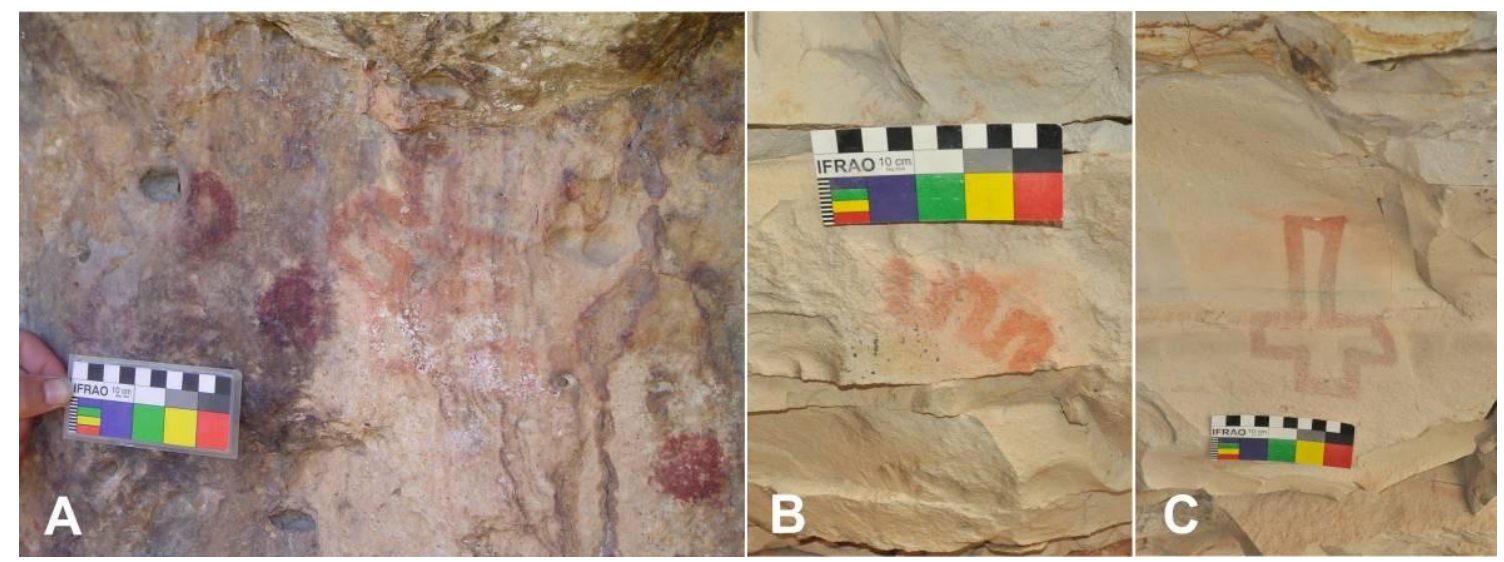

Figura 8.21. Motivos ortogonales pintados: a. Cruciforme de CV-4; b. Almenado; c. Cruciforme de Cueva de la Hacienda.

8. a. 5. 2. d. Evaluación de técnicas para pintura

Por el momento, para los grupos considerados se han reconocido principalmente tres técnicas de aplicación de pintura: el estarcido directo, la técnica digital y el uso de artefactos. Los rastros humanos y rastros animales en negativo comportan posiblemente el uso del estarcido directo en su producción, con una baja frecuencia de otras técnicas para motivos en positivo o el delineado. Los motivos de trazo fino posiblemente fueron realizados con algún tipo de artefacto, los cuales no han sido recuperados en estratigrafía en ninguno de los sitios excavados por el equipo. Por otro lado, en aquellos que presentan trazos anchos, dependiendo del grado de 
conservación, podría pensarse en el uso de algún artefacto o de vellones embebidos con pintura. Para los motivos pintados, las condiciones de emplazamiento o el tipo de soporte podrían haber condicionado la conservación de algunos motivos, los cuales podrían estar sub-representados debido a factores tafonómicos (Bednarik 2001).

8. a. 5. 2. e. Superposiciones

Para los motivos pintados, los rastros (humanos y animales) así como los motivos circulares se comportan de manera diferente en cuanto a su intervención en superposiciones. Las manos negativas se pueden encontrar en asociaciones sincrónicas o diacrónicas. Es decir, pueden estar superpuestas entre sí, por encima de motivos circulares, sobre fondos preparados, por debajo de motivos rectilíneos o puntiformes, y han sido estudiadas previamente (Carden 2008a, 2013). Por otro lado, el único pie humano en negativo registrado se encuentra sobre negativos de mano, motivos circulares lineales, curvilíneos y rectilíneos en diferentes colores (ver Figuras 8.15.a-b). Por otro lado, la pisada de guanaco en negativo se encuentra sobre un motivo curvilíneo y un negativo de mano (ver Figura 8.16.a).

Las pisadas de ave en positivo y los motivos ortogonales no intervienen en superposiciones así como tampoco participan los motivos zoomorfos y antropomorfos. A partir de esta información se plantea que además de ser el motivo pintado más abundante en el área de estudio, los negativos de mano fueron seleccionados para sobreponer a otros motivos.

\section{8. a. 6. Distribución temporal de los sitios con arte}

Si bien no se cuenta con fechados radiocarbónicos ni asociaciones contextuales estratigráficas (Aschero 1988) que permitan ubicar 
temporalmente los sitios tratados en esta tesis, se han utilizado, con cierto resguardo, las cronologías propuestas para sitios con grabados en la región en base a criterios estilísticos y técnicos, al análisis de las superposiciones y pátinas, así como a información contextual (Aschero 1997; Aschero et al. 2005; Belardi y Goñi 2006; Carden 2009a: 104; Durán 1983-85; Gradin y Aguerre 1983; Gradin et al. 1976; Menghin 1957; Re 2011). Al vincular dichos antecedentes con los materiales arqueológicos recuperados en superficie y los fechados obtenidos en el área, se plantea provisionalmente que los grabados se asocian a las ocupaciones tardías (ca. 3.000-2.250 años AP) (Miotti 2006, 2008; Miotti et al. 2005). Para las pinturas, se han recuperados materiales que permiten plantear los inicios de su producción durante el Holoceno temprano (Miotti et al. 2012a) y se continuaron produciendo a lo largo de todo el Holoceno (Carden 2009a; Fiore 2006).

Al considerar esta profundidad temporal, los sitios estudiados en esta tesis no aportan una temporalidad mayor a la reconocida previamente (Carden 2008a). Sin embargo, permiten plantear una mayor recurrencia ocupacional hacia el Holoceno tardío y la producción del arte hasta este momento, observándose un incremento en el número de los sitios con arte rupestre. Situación que concuerda con propuestas previas (Fiore 2006; Gradin 2001) y para áreas aledañas (Goñi 2010; Re 2011).

\section{8. a. 7. Distribución espacial de los sitios con arte}

Respecto a su distribución espacial, los motivos pintados se encuentran en espacios reparados, aleros o cuevas, que pueden estar en el interior de cañadones ubicados en diferentes sectores altitudinales (Carden 2013). Probablemente el emplazamiento de las pinturas al interior de espacios reparados se encuentre relacionado con su conservación, ya que en un sólo sitio emplazado en un espacio abierto se documentó un negativo de mano pintado en mal estado de conservación (Carden 2008a). Esta situación permitiría pensar al emplazamiento como un condicionante tecnológico ya 
que se seleccionarían espacios en los que las pinturas perduren, coincidente con lo propuesto por otros autores (Fiore 2006; Gradin 2001). Sin embargo, surge un problema de equifinalidad ya que si bien es plausible la selección de espacios reparados para mejorar la conservación de las pinturas, se desconoce si la motivación de los pintores, más allá del acto en sí mismo, era trascender a su propia comunidad. Por último, vale mencionar que la presencia de las pinturas documentadas en sectores reparados mayoritariamente, probablemente responda a un sesgo en las investigaciones, las cuales hicieron hincapié en dichos espacios por la presencia de sedimentos potencialmente excavables que sirvan para contextualizar al arte rupestre.

\section{8. a. 8. Relación entre soporte, técnicas y diseños en el macizo del}

\section{Deseado y áreas aledañas}

La información necesaria para plantear esta relación, tanto con otros sectores del macizo del Deseado como con áreas aledañas, fue desarrollada en el Capítulo 4.

En otros sectores del macizo del Deseado (área del Río Pinturas, cuenca del río Deseado, sector centro-meridional) se documentaron sitios emplazados en rocas de origen volcánico, algunos de los cuales presentan motivos pintados o grabados y se registraron en bajo número sitios con motivos pintados y grabados. Los motivos grabados se encuentran sobre rocas basálticas (en la localidad La Flecha), algunos sobre soportes más blandos -areniscas- (sitio Angostura del Deseado) y sobre rocas porfiríticas (aquellos documentados en la cuenca media del río Pinturas así como en las localidades de La Martita y El Verano). Respecto de los motivos pintados, el soporte utilizado en la mayoría de los casos corresponde a rocas porfiríticas (área del río Pinturas, La Reconquista, La María, El Ceibo, La Martita y El Verano) a excepción de las pinturas de $\mathrm{CH}$ y $\mathrm{CM}$ que se emplazan sobre conglomerados tobáceos así como AEG-2 y CG que se emplazan sobre 
areniscas coquinoides. LCB es el único sitio donde se documentó un motivo pintado sobre basalto (Apéndice II.1.b).

La relación entre la técnica y el diseño de los motivos será tratada en primer lugar para los grabados y luego para las pinturas. En el área del río Pinturas, para los grabados se empleó mayoritariamente la percusión como técnica de producción, y minoritariamente la incisión y el raspado (Aguerre y Gradin 2003; Aschero 2012b), tratándose de motivos circulares, pisadas animales y zoomorfos de cuerpo entero. En las localidades de La Martita y El Verano las técnicas reconocidas refieren a la percusión, empleada mayoritariamente para pisadas animales, circulares -llenos y lineales-, y algunos motivos rectilíneos en seis sitios de la localidad de El Verano, mientras que la incisión fue empleada en un sólo sitio para líneas paralelas y un reticulado (Durán 1983-85; mayor detalle en Apéndice II.1.c). El raspado fue empleado para redondear los bordes de un hoyuelo natural en el sitio Cañadón Viuda Quenzana 4 en la localidad La Martita (Gradin y Aguerre 1983). En La Flecha se registraron motivos grabados por percusión (puntiformes, circulares lineales y curvilíneos), por incisión (rectilíneos), pictograbados así como motivos conformados por trazos pintados y grabados (Gradin 2003d). Al integrar esta información con la presentada en los apartados previos, se puede observar que en el macizo del Deseado los motivos grabados fueron realizados sobre soporte de diferente litología, empleando mayoritariamente la técnica de percusión aunque se observaron motivos lineales incisos y, en bajísimas frecuencias, algunos motivos fueron realizados mediante el empleo de otras técnicas (raspado). Esto indicaría cierta homogeneidad en la técnica de grabado a nivel regional, empleada en diferentes soportes.

Los motivos pintados presentan mayor variabilidad en el diseño y en la técnica de aplicación de la pintura. Las manos son los motivos más abundantes. Estas fueron realizadas en negativo y en positivo. Si bien previamente se ha inferido que los negativos de mano podrían haber sido producidos mediante la aplicación indirecta de la pintura (Gradin 1983), durante las tareas experimentales, y mediante la implementación de la 
técnica de estarcido directo, se llegó a resultados similares a los arqueológicos (mayor detalle en Capítulos 4 y 5). Asimismo, se han documentado negativos realizados por delineado y motivos en positivo, estos últimos en muy baja frecuencia (Carden 2008a: Apéndice V). Para otros diseños, la pintura podría haber sido aplicada mediante la técnica digital ("dígitos"), mediante el empleo de artefactos o como resultado del impacto de objetos circulares recubiertos y embebidos con pintura sobre las superficies rocosas (Apéndice II.1.b). Las técnicas de aplicación de la pintura son similares y se encuentran sobre soportes también similares. En algunos casos (v.g., impactos de forma subcircular) el emplazamiento -altura respecto del suelo- habría condicionado la técnica a emplear.

En áreas aledañas al macizo, el soporte mayormente empleado tanto para grabar como para pintar corresponde a basalto. En el caso de los grabados se documentó como excepción un sitio sobre areniscas en la MNRSC y el sitio Cerro de los Indios, en tanto que algunos motivos pintados se emplazan sobre areniscas en el lago Cardiel (Apéndice II.2). Los sitios con grabados presentan variabilidad en cuanto a las técnicas empleadas, entre las que se incluyen la percusión, la incisión y el raspado, así como diferentes combinaciones de aquellas, para la realización de figuras y rastros humanos y animales, y motivos no figurativos (Apéndice II.2.c). Entre los motivos pintados predominan las manos negativas y se registraron manos positivas pintadas sobre basalto, aunque en Cerro de los Indios se documentó mayor variabilidad en cuanto a los diseños, entre los que se incluyen motivos circulares lineales, figuras humanas y animales (Apéndice II.2.b).

Al analizar esta situación se observa que los grabados se emplazan mayoritariamente sobre un mismo tipo de soporte (basalto), mientras que la variabilidad se ve reflejada en el diseño y a la técnica de producción. En las mesetas del oeste santacruceño las figuras animales presentan mayor variedad de diseños, con registros de guanacos, piches y matuastos, entre otras (Guichón 2012; Re 2011). Tales figuras han sido documentadas sobre el macizo del Deseado en muy baja frecuencia y poca variedad en cuanto a 
los diseños. Esta información permite plantear que los soportes no funcionaron como condicionantes para la producción de grabados.

Las pinturas presentan situación inversa: se emplazan mayoritariamente sobre soportes porfiríticos, con escasos registros sobre basaltos. Los negativos de manos y las figuras animales son los diseños predominantes. Esta situación es similar a la detectada en el sector NE del macizo del Deseado, por lo que la ausencia de pinturas sobre otros soportes podría estar relacionada con factores tafonómicos o bien de emplazamiento, ya que se encuentran al interior de espacios reparados.

La cronología documentada para el arte grabado y pintado a nivel regional se mantiene: las pinturas comenzaron a ser producidas durante la transición Pleistoceno/Holoceno y el Holoceno temprano, y perduraron hasta el Holoceno tardío (Aschero 1996; Aschero et al. 2005; Gradin et al. 1976, 1979; Miotti et al. 2012a) en tanto que la producción de grabados puede asociarse a ocupaciones del Holoceno tardío (Carden 2008a; Guichón 2012; Re 2011). En áreas aledañas al macizo del Deseado, también son escasos los sitios que presentan motivos pintados y grabados, y menos frecuentes los que presentan motivos pintados, grabados, pictograbados y conformados por pintura y grabado.

\section{8. b. MACIZO DE SOMUNCURÁ}

Se comparan doce sitios con arte rupestre ubicados dentro del macizo: seis en el sector NE, cinco en el centro y uno en el sector NW (Capítulo 7). Esta información se contrasta con la de los sitios con arte rupestre estudiados por otros investigadores, ubicados sobre el macizo de Somuncurá y en los alrededores. En las publicaciones donde solo se mencionó la presencia de determinados subgrupos de motivos sin informar cantidades precisas, se estimaron números mínimos para la comparación $(n=1$ en base a mención de presencia). Los sitios que se comparan con los estudiados en esta tesis se encuentran en los sectores II (Pailemán), III (borde Centro-oriental), V 
(borde Centro-occidental) y VI (NW) (Tabla 8.8; Figura 8.22). Como la información disponible para esta porción de Nordpatagonia es heterogénea, los resultados de este análisis son útiles para obtener un primer panorama de la distribución del arte rupestre, con particular referencia a las tendencias tecnológicas en el macizo somuncurense.

\section{8. b. 1. Distribución espacial de sitios y motivos}

Hasta el desarrollo de esta tesis, la información disponible indicaba el emplazamiento de arte rupestre en las zonas periféricas del macizo (borde septentrional, borde Centro-oriental, borde Centro-occidental), en tanto sobre el macizo se encontraban los sitios de Pintada de Corral Curá, de Vacalauquén y de Sierras de Apas (Belardi 1996; Casamiquela 1960; Gradin 2003b). Las labores de campo efectuadas, así como las tareas de campo realizadas por otros investigadores (Albornoz y Pereda 2010; Prates et al. 2011), permitieron observar que en Somuncurá el arte también se encuentra en el NE y en el centro del macizo, ampliando la variabilidad de los emplazamientos y del repertorio de motivos.

Los sitios con arte rupestre se concentran en el sector central y NE del macizo (Figura 8.22), en ambos casos abarcando proporciones mayores al $20 \%$ mientras que en los sectores restantes las proporciones abarcan entre 8 y 15\% cada uno (Tabla 8.8; Figura 8.23.a). Si bien la distribución de sitios con arte rupestre en el macizo es relativamente homogénea, no sucede lo mismo con la distribución porcentual de motivos. La mayor proporción se concentra en el sector NE (I), seguido por el sector central (IV), observándose bajas proporciones en los sectores restantes (Tabla 8.8; Figura 8.23.b). 


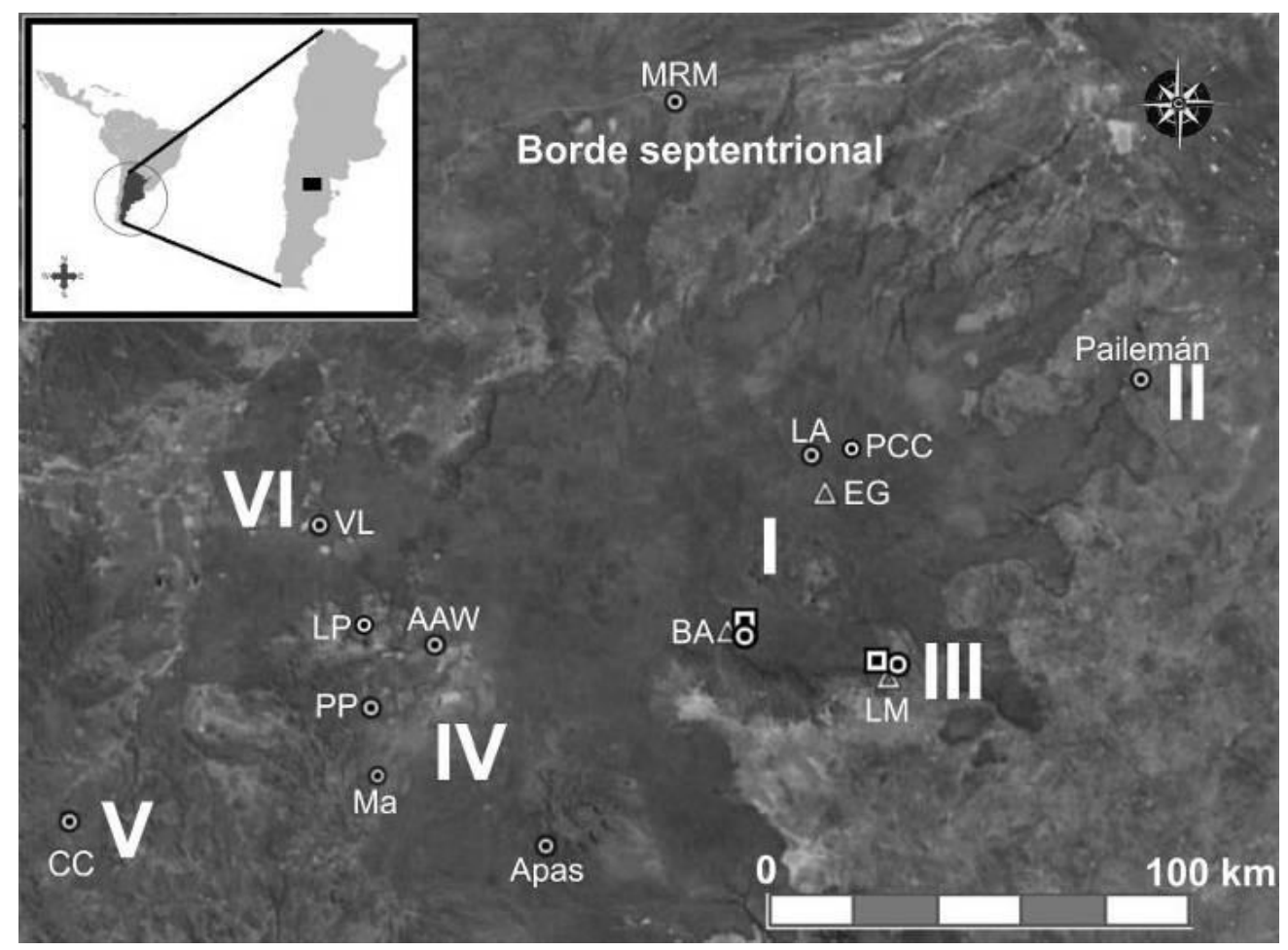

Figura 8.22. Sectores y sitios con arte rupestre del Macizo de Somuncurá y alrededores. Referencias: MRM: Manantial Ramos Mexía; LA: Laguna Azul; PCC: Pintada de Corral Curá; EG: Laguna El Ganso; BA: Bardas de Antonio; LM: Los Manantiales; CC: Cerro Castillo; Ma: Martel; PP: Peñón del Pueblo; AAW: Alero Amigo Oeste; LP: La Porfía; VL: Vacalauquén. Los números romanos indican los sectores: I: Noreste; II: Pailemán; III: borde Centro-oriental; IV: Centro; V: borde Centro-occidental; VI: Noroeste; circunferencias: pinturas; triángulos: grabados; cuadrados: pictograbados.

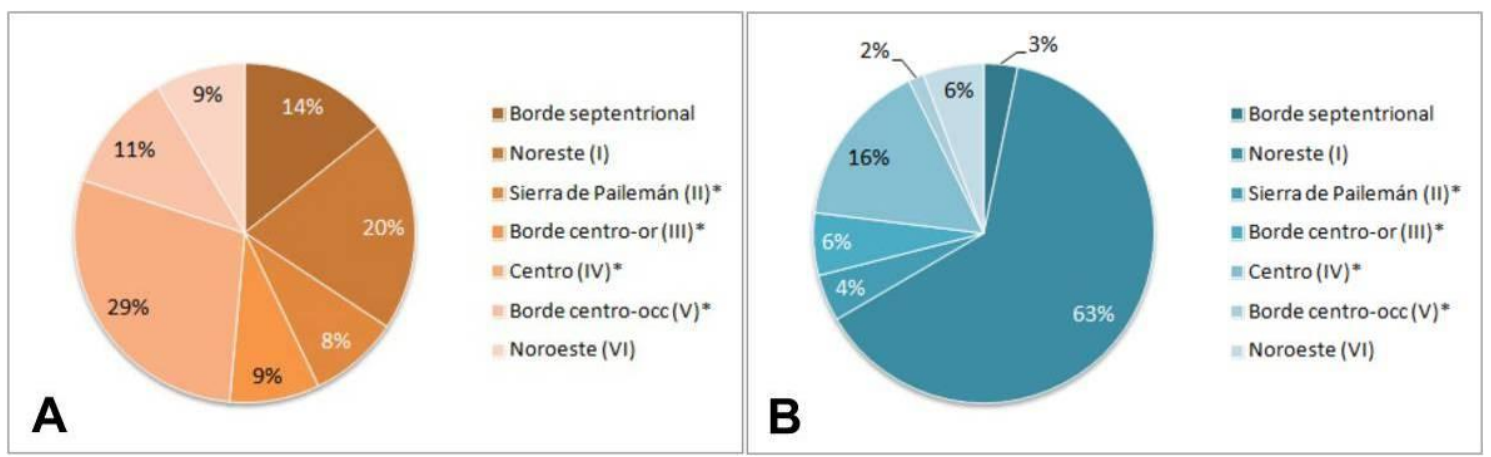

Figura 8.23. Distribución porcentual de sitios y motivos en el macizo de

Somuncurá: a. Distribución porcentual de sitios; b. Distribución porcentual de motivos. Referencias: Borde centro-or: borde centro oriental; borde centro-occ: borde centro occidental; *: frecuencia estimada. 


\begin{tabular}{|c|c|c|c|c|c|}
\hline Sector & Localidad & Sitios & $\mathrm{n}$ motivos & $\%$ motivos & Fuente \\
\hline $\begin{array}{c}\text { Borde } \\
\text { Septentrional }\end{array}$ & Manantial Ramos Mexía & 5 & $26^{*}$ & 100 & Gradin 2003b \\
\hline \multicolumn{2}{|r|}{ Subtotal } & 5 & $26^{*}$ & 100 & \multirow{5}{*}{ Gradin $2003 b$} \\
\hline \multirow{4}{*}{ Noreste (I) } & Pintada de Corral Curá & 1 & 7 & 1,36 & \\
\hline & Laguna Azul & 4 & 32 & 6,23 & \\
\hline & Laguna El Ganso & 1 & 92 & 17,90 & \\
\hline & Laguna La Maciega & 1 & 383 & 74,50 & \\
\hline \multicolumn{2}{|r|}{ Subtotal } & 7 & 514 & 100 & \multirow{3}{*}{$\begin{array}{c}\text { Gradin } 2003 \mathrm{~b} ; \\
\text { Prates et al. } \\
2011\end{array}$} \\
\hline \multirow{2}{*}{$\begin{array}{c}\text { Sierra de } \\
\text { Pailemán (II) }\end{array}$} & Cueva Galpón & 1 & $\mathrm{~s} / \mathrm{d}$ & - & \\
\hline & Rinconada Catriel & 2 & $36^{*}$ & 100 & \\
\hline \multicolumn{2}{|r|}{ Subtotal } & 3 & $36^{*}$ & 100 & \\
\hline $\begin{array}{c}\text { Borde Centro- } \\
\text { oriental (III) }\end{array}$ & Los Manantiales & 3 & $48^{*}$ & 100 & $\begin{array}{c}\text { Albornoz 2003; } \\
\text { Albornoz y } \\
\text { Pereda 2009 }\end{array}$ \\
\hline \multicolumn{2}{|r|}{ Subtotal } & 3 & $48^{*}$ & 100 & \\
\hline \multirow{5}{*}{ Centro (IV) } & La Porfía & 1 & 5 & 3,90 & \\
\hline & Alero Amigo Oeste & 1 & 1 & 0,78 & \\
\hline & Peñón del Pueblo & 2 & 63 & 49,21 & \\
\hline & Cañadón Martel & 2 & 5 & 3,90 & \\
\hline & Apas & 4 & $54^{*}$ & 42,19 & $\begin{array}{c}\text { Casamiquela } \\
1960 \\
\end{array}$ \\
\hline \multicolumn{2}{|r|}{ Subtotal } & 10 & $128^{*}$ & 100 & \\
\hline $\begin{array}{l}\text { Borde Centro- } \\
\text { occidental (V) }\end{array}$ & Cerro Castillo & 4 & $12^{*}$ & 100 & Belardi 1996 \\
\hline \multicolumn{2}{|r|}{ Subtotal } & 4 & $12^{*}$ & 100 & \\
\hline Noroeste (VI) & Vacalauquén & 3 & 47 & 100 & Gradin $2003 b$ \\
\hline \multirow{2}{*}{\multicolumn{2}{|c|}{ Subtotal }} & 3 & 47 & 100 & \\
\hline & & 35 & 811 & & \\
\hline
\end{tabular}

Tabla 8.8. Distribución de sitios y motivos en el macizo de Somuncurá. Referencias: sombreados en gris las localidades y sitios estudiados en esta tesis; *: estimación cuantitativa; s/d: sin datos.

\section{8. b. 2. Distribución de técnicas de producción de arte rupestre}

La información presentada en el Capítulo 7 permite afirmar que en Somuncurá se registraron motivos grabados, pintados y pictograbados, siendo predominante los primeros (Tabla 8.9; Figura 8.24.a). Esta situación difiere de lo registrado anteriormente (ver Capítulo 4), donde se proponía el empleo de pintura de manera casi exclusiva, con un caso excepcional de motivo pictograbado, principalmente para diseños curvilíneos (Belardi 1996; Gradin 2003b).

Al considerar la distribución espacial de las técnicas de producción se observa una concentración de los motivos grabados y pictograbados hacia el oriente del macizo, mientras que las pinturas se registraron en todos los sectores (Figura 8.24.b). 


\begin{tabular}{|c|c|c|c|c|c|c|c|c|}
\hline & \multicolumn{2}{|r|}{ Técnica } & \multicolumn{2}{|c|}{ Pintura } & \multicolumn{2}{|c|}{ Grabado } & \multicolumn{2}{|c|}{ Pictograbado } \\
\hline Sector & Localidad & Sitios & $\mathrm{n}$ & $\%$ & $\mathrm{n}$ & $\%$ & $\mathrm{n}$ & $\%$ \\
\hline $\begin{array}{c}\text { Borde } \\
\text { Septentrional }\end{array}$ & $\begin{array}{l}\text { Manantial Ramos } \\
\text { Mexía }\end{array}$ & 5 & $25^{*}$ & 7,83 & - & - & 1 & 6,66 \\
\hline \multirow{4}{*}{ Noreste (I) } & $\begin{array}{l}\text { Pintada de Corral } \\
\text { Curá }\end{array}$ & 1 & 7 & 2,11 & - & - & - & - \\
\hline & Laguna Azul & 4 & 32 & 9,64 & - & - & - & - \\
\hline & Laguna El Ganso & 1 & - & - & 92 & 19,78 & - & - \\
\hline & Laguna La Maciega & 1 & 24 & 7,23 & 356 & 76,56 & 3 & 20 \\
\hline \multirow{2}{*}{ Pailemán (II) } & Rinconada Catriel & 2 & $36^{*}$ & 10,84 & - & - & - & - \\
\hline & Cueva Galpón & 1 & $\mathrm{~s} / \mathrm{d}$ & - & - & - & - & - \\
\hline $\begin{array}{l}\text { Borde centro- } \\
\text { oriental (III) }\end{array}$ & Los Manantiales & 3 & $20^{*}$ & 6,02 & $17^{*}$ & 3,66 & $11^{*}$ & 73,33 \\
\hline \multirow{5}{*}{ Centro (IV) } & La Porfía & 1 & 5 & 1,51 & - & - & - & - \\
\hline & Alero Amigo Oeste & 1 & 1 & 0,30 & - & - & - & - \\
\hline & Peñón del Pueblo & 2 & 63 & 18,97 & - & - & - & - \\
\hline & Cañadón Martel & 2 & 5 & 1,51 & - & - & - & - \\
\hline & Apas & 4 & $54^{*}$ & 16,26 & - & - & - & - \\
\hline $\begin{array}{l}\text { Borde centro- } \\
\text { occidental (V) }\end{array}$ & Cerro Castillo & 4 & $12^{*}$ & 3,61 & - & - & - & - \\
\hline Noroeste (VI) & Vacalauquén & 3 & $47^{*}$ & 14,16 & - & - & - & - \\
\hline \multicolumn{2}{|r|}{ Total } & 35 & 331 & 100 & 465 & 100 & 15 & 100 \\
\hline
\end{tabular}

Tabla 8.9. Técnicas reconocidas en las diferentes localidades del macizo de Somuncurá. Referencias: s/d: sin datos cuantitativos; *: número estimado de motivos. Sombreado en gris, las localidades estudiadas en esta tesis.

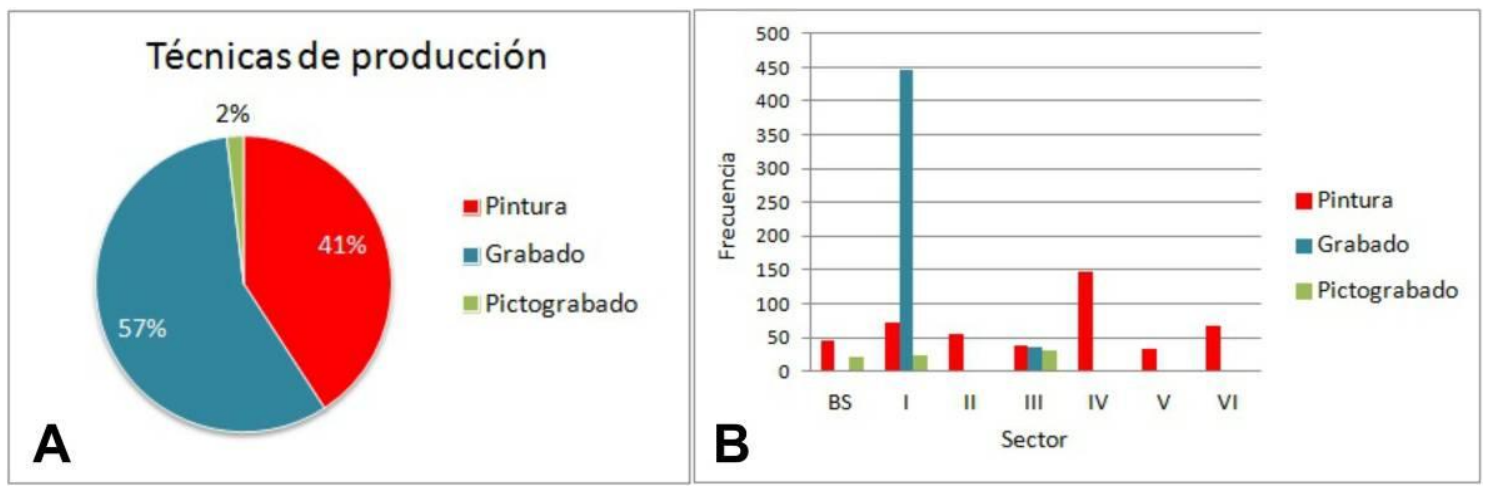

Figura 8.24. Técnicas de producción reconocidas en el macizo de Somuncurá y alrededores: a. proporción de técnicas de producción; b. distribución de técnicas por sectores. Referencias: Sector: BS: Borde Septentrional; I: Noreste; II: Pailemán; III: borde Centro-oriental; IV: Centro; V: borde Centro-occidental; VI: Noroeste. Los valores están sobre-representados para que aparezcan los pictograbados en el gráfico.

\section{8. b. 3. Distribución de diseños}

La clasificación de los motivos fue realizada siguiendo los criterios empleados para el macizo del Deseado, y fue detallada en los Capítulos 2 y 7. En Somuncurá predominan los motivos no figurativos, entre ellos los rectilíneos, los circulares lineales y los puntiformes. Por otro lado, entre los 
motivos figurativos se incluyen rastros y figuras animales así como objetos (Tabla 8.10). Esta situación coincide con lo documentado previamente en los sitios del macizo por otros autores (Albornoz 2003; Albornoz y Pereda 2010; Belardi 1996; Casamiquela 1960; Gradin 2003b). Sin embargo, la inclusión de los datos presentados en el Capítulo 7 permite plantear que, si bien las proporciones predominantes en relación a trabajos previos se mantienen (Tabla 8.10), se incluye mayor variabilidad en cuanto a diseños y a técnicas, ya que entre aquellos realizados mediante grabado se incluyen motivos que no habían sido documentados previamente (ver más adelante).

\begin{tabular}{|l|c|c|c|c|c|c|}
\cline { 2 - 7 } \multicolumn{1}{c|}{} & \multicolumn{2}{c|}{ Blanco } & \multicolumn{2}{c|}{ Otros autores } & \multicolumn{2}{c|}{ Total } \\
\hline Motivos & $\mathrm{n}$ & $\%$ & $\mathrm{n}$ & $\%$ & $\mathrm{n}$ & $\%$ \\
\hline Puntiformes & 77 & 13,25 & 18 & 7,83 & 95 & 11,76 \\
\hline Rectilíneos & 210 & 36,14 & 124 & 53,91 & 334 & 41,34 \\
\hline Circulares llenos & 8 & 1,38 & 2 & 0,87 & 10 & 1,23 \\
\hline Circulares lineales & 160 & 27,54 & 30 & 13,04 & 190 & 23,51 \\
\hline Curvilíneos & 40 & 6,88 & 10 & 4,35 & 50 & 6,19 \\
\hline No Figurativos & 495 & 85,20 & 184 & 80 & 679 & 84,03 \\
\hline Rastros animales & 22 & 3,79 & 11 & 4,78 & 33 & 4,08 \\
\hline Figuras animales & 1 & 0,17 & 2 & 0,87 & 3 & 0,37 \\
\hline Objetos & 1 & 0,17 & 7 & 3,04 & 8 & 0,99 \\
\hline Figurativos & 24 & 4,13 & 20 & 8,70 & 44 & 5,44 \\
\hline No Determinados & 61 & 10,50 & 12 & 5,22 & 73 & 8,66 \\
\hline Otro & 1 & 0,17 & 14 & 6,08 & 15 & 1,86 \\
\hline \multicolumn{1}{|c|}{ Total } & 581 & 100 & 230 & 100 & 811 & 100 \\
\hline
\end{tabular}

Tabla 8.10. Frecuencia y proporciones de grupos y subgrupos de motivos reconocidos en esta tesis y por otros autores.

\section{8. b. 4. Relación entre la distribución de diseños y técnicas}

La información disponible respecto a las técnicas de producción y diseños de los motivos ha sido integrada considerando su distribución espacial en los distintos sectores de Somuncurá. Tanto para los motivos pintados como para los grabados se observa un predominio (>90\%) de los no figurativos (Tabla 8.11; Figura 8.25). Lo mismo sucede entre los motivos pictograbados, entre los cuales el $74 \%$ corresponde a los no figurativos. 


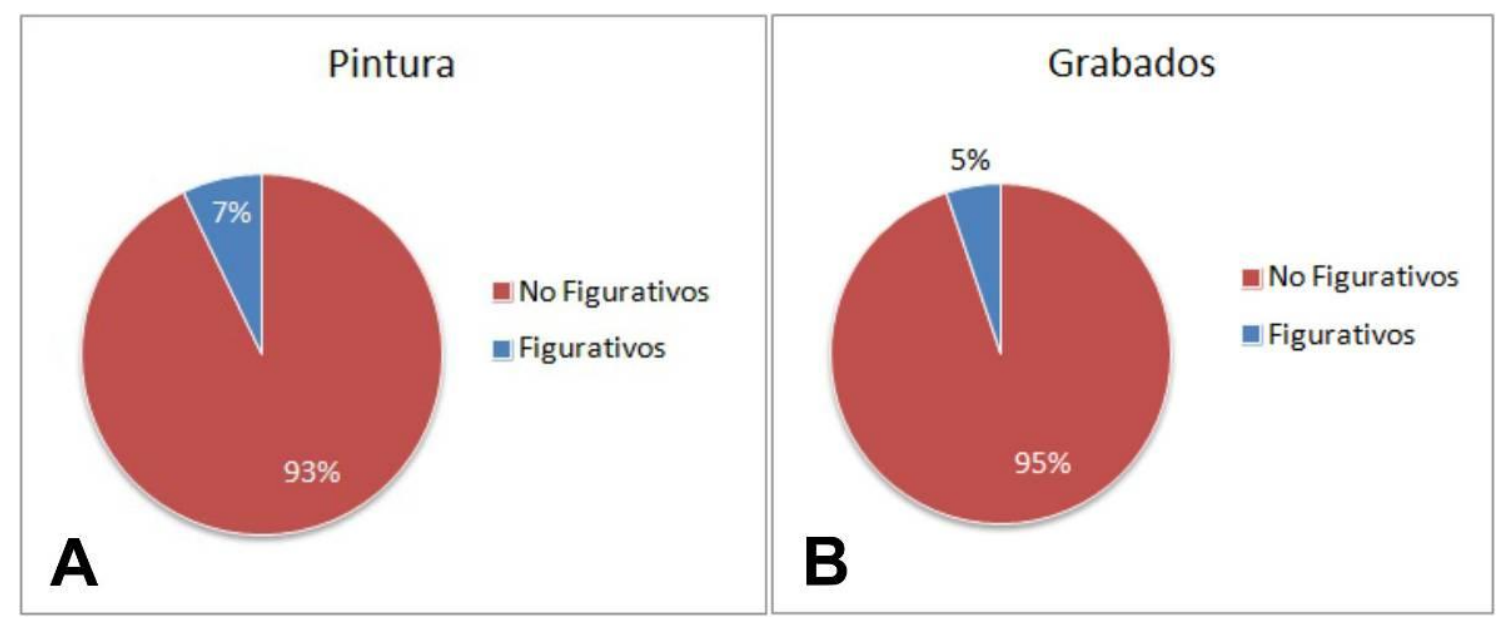

Figura 8.25. Proporciones de motivos por técnicas de producción: a. Pinturas; b. Grabados. $n=707$, cálculo realizado excluyendo los no determinados.

Respecto al diseño, los motivos pintados no figurativos fueron registrados en todos los sectores aunque se dispone de datos sub-representados para los sectores II, IV y V. A pesar de esta falencia en la información, se observa que son predominantes los rectilíneos (Tabla 8.11; Figura 8.26.a). Por otro lado, entre los grabados y pictograbados no figurativos preponderan los circulares lineales y los rectilíneos (Tabla 8.11; Figura 8.26.b). Entre los motivos figurativos pintados, los objetos y rastros animales son los más abundantes, aunque se registran en baja frecuencia, mientras que los motivos figurativos grabados fueron registrados en bajo número y se corresponden mayoritariamente a rastros animales (Tabla 8.11; Figura 8.27.a).

$\mathrm{Al}$ realizar un análisis más detallado de los motivos no figurativos, tanto para grabados como para pinturas abundan los motivos rectilíneos y los circulares lineales. Ambos subgrupos conjuntamente suman el 70\% entre los grabados mientras que entre las pinturas los motivos rectilíneos superan el $70 \%$ de los motivos registrados (Tabla 8.11). 


\begin{tabular}{|c|c|c|c|c|c|c|c|c|c|c|c|c|c|c|c|}
\hline & \multirow{2}{*}{\multicolumn{12}{|c|}{ Sector }} & \multirow{3}{*}{\multicolumn{3}{|c|}{ Total }} \\
\hline \multirow{3}{*}{ Motivos/Técnica } & & & & & & & & & & & & & & & \\
\hline & \multicolumn{2}{|c|}{ BS } & \multicolumn{3}{|c|}{$\mathrm{I}$} & II & \multicolumn{3}{|c|}{ III } & & \multirow{2}{*}{$\begin{array}{l}\mathrm{V} \\
\mathrm{P}\end{array}$} & \multirow{2}{*}{\begin{tabular}{|l} 
VI \\
$\mathrm{P}$
\end{tabular}} & & & \\
\hline & $\mathrm{P}$ & $\mathrm{P} / \mathrm{G}$ & $\mathrm{P}$ & $\mathrm{G}$ & $\mathrm{P} / \mathrm{G}$ & $\mathrm{P}$ & $\mathrm{P}$ & $\mathrm{G}$ & $\mathrm{P} / \mathrm{G}$ & & & & $\mathrm{P}$ & $\mathrm{G}$ & $\mathrm{P} / \mathrm{G}$ \\
\hline Puntiformes & & & 2 & 73 & & 5 & - & 2 & 2 & 7 & 4 & - & 18 & 75 & 2 \\
\hline Rectilíneos & 16 & - & 46 & 140 & & 29 & 12 & 5 & 3 & 45 & 4 & 34 & 186 & 145 & 3 \\
\hline Circulares llenos & - & - & - & 7 & - & 2 & - & - & - & 1 & - & - & 3 & 7 & - \\
\hline Circulares lineales & - & - & 2 & 146 & 3 & - & 5 & 5 & 4 & 20 & - & 5 & 32 & 151 & 7 \\
\hline Curvilíneos & - & 1 & 2 & 38 & - & - & - & 3 & 2 & 4 & - & 1 & 7 & 41 & 3 \\
\hline No Figurativos & 16 & 1 & 52 & 404 & 3 & 36 & 17 & 15 & 11 & 77 & 8 & 40 & 246 & 419 & 15 \\
\hline Rastros animales & - & - & - & 22 & - & - & 3 & & 2 & 5 & - & 1 & 9 & 22 & 2 \\
\hline Figuras animales & - & - & & 1 & - & - & - & - & - & - & - & 2 & 2 & 1 & - \\
\hline Objetos & 4 & - & 1 & - & - & - & - & - & - & - & - & 3 & 8 & - & - \\
\hline Figurativos & 4 & - & 1 & 23 & - & - & 3 & - & 2 & 5 & - & 6 & 19 & 23 & 2 \\
\hline Total & 20 & 1 & 53 & 427 & 3 & 36 & 20 & 15 & 13 & 82 & 8 & 46 & 265 & 442 & 17 \\
\hline
\end{tabular}

Tabla 8.11. Distribución espacial de técnicas y subgrupos de motivos en

Somuncurá. Referencias: BS: borde septentrional; I: NE; II: Pailemán; III: borde centro-oriental; IV: Centro; V: Borde centro-occidental; VI: NW. P: pintura; G: grabado; P/G: pictograbado. $n=724$. Sombreado en gris los sectores que incluyen sitios tratados en el Capítulo 7.

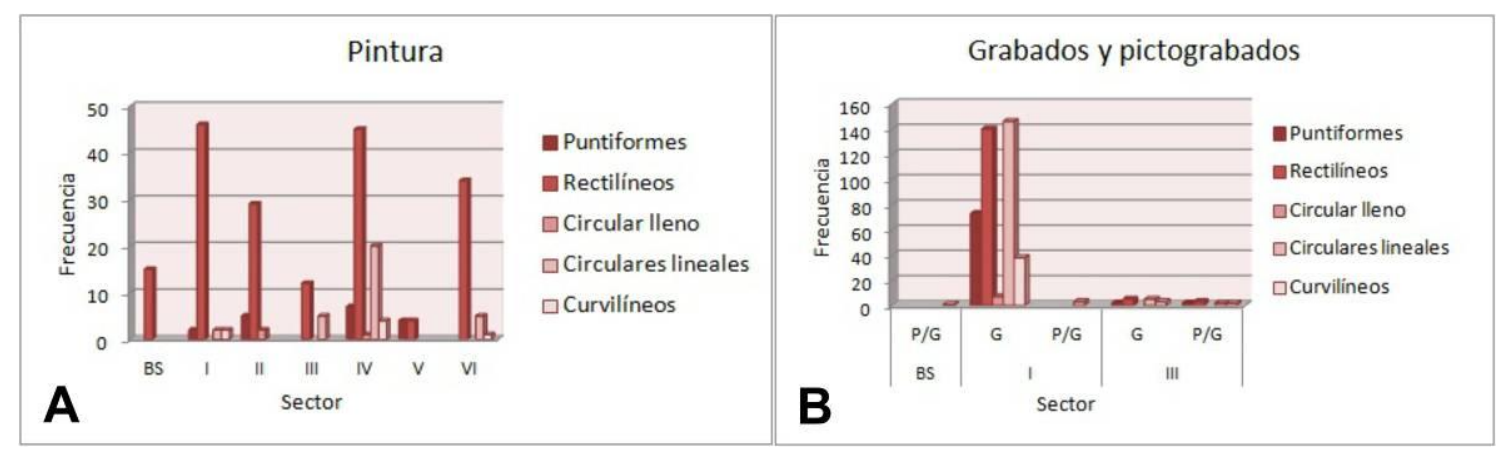

Figura 8.26. Distribución de motivos no figurativos en Somuncurá: a. pintados; b. grabados y pictograbados. Referencias: BS: borde septentrional; I: NW; II: NE; III: borde centro-oriental; IV: centro; V: borde centro-occidental; VI: NW; G: grabado; $\mathrm{P} / \mathrm{G}$ : pictograbado.

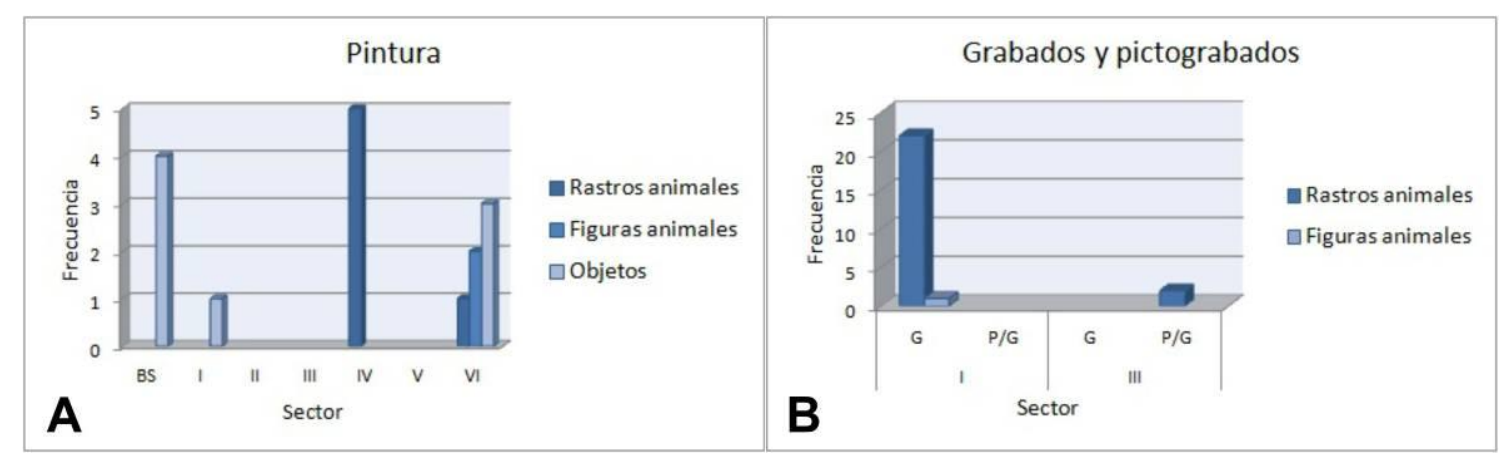

Figura 8.27. Distribución de motivos figurativos en Somuncurá: a. pintados; b. grabados y pictograbados. Referencias: BS: borde septentrional; I: NE; II:

Pailemán; III: borde Centro-oriental; IV: Centro; V: borde Centro-occidental; VI: NW; G: grabado; P/G: pictograbado 


\section{8. b. 5. Evaluación de posibles condicionantes tecnológicos}

Al igual que en el macizo del Deseado, se evalúa si los soportes rocosos funcionaron como condicionantes tecnológicos en la selección de las técnicas de producción y del diseño de los motivos rupestres. En este sentido, deberían observarse en soportes de litología similar, diseños y técnicas semejantes.

\section{8. b. 5. 1. Soporte, técnica y diseño para grabados}

Los grabados en el macizo de Somuncurá fueron documentados exclusivamente sobre soportes basálticos en los sitios Bardas de Antonio (BA) y Laguna El Ganso (LEG), ambos documentados para esta tesis, y en los sitios Los Manantiales 1 y 5 -LM1 y LM5- (Albornoz 2003; Albornoz y Pereda 2010; para mayor detalle ver Capítulos 4 y 7). Todos estos sitios se encuentran en el este del macizo. Los diseños considerados serán los mismos que aquellos analizados para el macizo del Deseado, entre los que se incluyen los motivos figurativos, los circulares lineales y los ortogonales.

\section{8. b. 5. 1. a. Motivos figurativos}

Este grupo de motivos está representado en baja frecuencia en el macizo de Somuncurá $(n=23)$ y, además, presenta baja variabilidad: corresponden a rastros animales (pisadas de felino o de ave), con un sólo motivo que podría ser asignado a un zoomorfo esquemático. Los rastros animales, en su mayoría, fueron realizados por percusión, a excepción de dos tridígitos en BA en los que no pudo determinarse la técnica de producción por el mal estado de conservación que presentaban (presencia de líquenes sobre surco grabado). El zoomorfo esquemático documentado en LEG fue realizado por 
percusión. El surco de este motivo es discontinuo, lo cual permitió plantear el empleo de un artefacto con extremo aguzado (ver Capítulo 7).

Resulta llamativa la ausencia de rastros o figuras humanas realizadas mediante grabado, situación que sí fuera documentada en áreas aledañas a Somuncurá (ver más adelante).

8. b. 5. 1. b. Motivos circulares

Este subgrupo de motivos fue documentado en todos los sitios con grabados sobre el macizo. Los motivos circulares presentan amplia variabilidad en cuanto a los diseños, tratándose de circunferencias simples, concéntricas, con o sin apéndices (simples, dobles, radiados, etc.) que en su mayoría fueron realizadas mediante percusión. Dentro de esta tendencia se registraron variaciones, como en LEG, donde se documentó una circunferencia realizada por percusión con trazos lineales internos hechos por incisión (ver Capítulo 7: Figura 7.31.e). En BA la mayoría de los motivos circulares fueron realizados mediante percusión, en tanto que mediante raspado, sólo o en combinación con la percusión, fueron producidos dos motivos. Las observaciones experimentales realizadas a partir de la replicación de distintos motivos sobre basalto (Capítulo 5), en conjunto con las observaciones realizadas en campo (Capítulo 7), permitirían pensar que los motivos con surco profundo realizados sobre basalto podrían haber sido realizados mediante la combinación de percusión y el uso de abrasivos.

A partir de la información brindada por Albornoz y Pereda (2010) se han podido reconocer diseños circulares grabados en LM1 y LM5. En el primer sitio no se infirió un tipo particular de técnica de producción, en tanto que para LM5 la técnica de producción inferida es el raspado. Sin embargo, a partir de las fotografías publicadas por Masera (1998: 479) y Gradin et al. (2003: Foto 16) se podría pensar en el empleo de la percusión, o de la percusión asociada al uso de abrasivos, por la profundidad alcanzada en algunos surcos. 
8. b. 5. 1. c. Motivos ortogonales

Este tipo de diseño fue documentado en LEG y en LM5. En el primer sitio se trata de tres motivos almenados para los cuales se infirió la percusión como técnica de producción (ver Figura 7.24). Si bien fuera de esta categoría, en este sitio algunos zigzags fueron realizados mediante incisión (ver Capítulo 7). En tanto que en LM5 estos diseños se corresponden a escalonados, que habrían sido producidos mediante raspado según lo señalado por Albornoz y Pereda (2010).

Para este tipo de diseño se propuso el empleo de dos técnicas de producción diferentes, la baja frecuencia en la que ha sido registrado, sin embargo, no permite proponer tendencias. El bajo número de diseños ortogonales grabados en Somuncurá contrasta con lo documentado en áreas aledañas (ver más adelante).

8. b. 5. 1. d. Evaluación de las técnicas de grabado

Las técnicas reconocidas para la producción de grabados son la percusión, la incisión y el raspado, siendo que la primera involucra la mayoría de los diseños, mientras que la incisión fue empleada en la producción de líneas caóticas y líneas quebradas (zig-zags). Por su parte, el raspado se empleó para lograr superficies que se superponen obliterando ciertos motivos (LEG) o para lograr profundidad en los surcos grabados por percusión (LM1 y LM5).

8. b. 5. 1. e. Superposiciones en grabados

Hasta el momento, se registraron superposiciones en el sitio LEG y en BA. En el primer caso se trata de incisiones caóticas sobre otros motivos efectuados por percusión. Asimismo, en este sitio se registró un caso de 
"supresión", el cual se corresponde con una superficie raspada debajo de la que se observa parcialmente una pisada de felino (ver Capítulo 7). A partir de esta superposición se propuso que pudo haber existido cierta intencionalidad en destruir $\mathrm{u}$ ocultar al motivo subyacente (Blanco et al. 2010a). En términos de Pastor (2012), este ejemplo señalaría la negación de un motivo pre-existente. En BA se registró una sola superposición, correspondiente a dos motivos grabados por percusión. Para los sitios LM1 y LM5 no se dispone de información referida a la presencia o ausencia de superposiciones entre grabados, por lo que la muestra está parcialmente sesgada respecto a este punto.

\section{8. b. 5. 2. Soporte, técnica y diseño para pinturas}

En las serranías colindantes a Somuncurá se emplearon soportes diferentes para emplazar pinturas, mientras que sobre el macizo se seleccionaron los soportes basálticos disponibles. En el sector II (Pailemán) se realizaron pinturas sobre soportes porfiríticos y en el sector V (Cerro Castillo) sobre rocas andesíticas (Belardi 1996; Gradin 2003b).

Los diseños son predominantemente no figurativos -rectilíneos-, de coloración rojiza, aunque también se realizaron motivos monocromos en otros colores, bícromos y polícromos, a veces combinando el rojo con amarillo, blanco y/o negro. Entre los colores distintos a los mencionados previamente, se documentaron motivos en azul o verde, estos últimos particularmente en las Sierras de Apas (Casamiquela 1960), lo cual relacionaría a estas sierras con áreas aledañas como Piedra Parada y los sitios con pinturas de colores similares ubicados sobre la cuenca del arroyo Maquinchao (Boschin 2009). 
8. b. 5. 2. a. Motivos figurativos

Esos motivos fueron documentados en baja frecuencia $(n=19)$, comprendiendo rastros y figuras animales así como objetos. En cuanto a su distribución, los rastros y las figuras animales pintados se encuentran en los sectores III, IV y VI mientras que aquellos correspondientes a objetos se encuentran en el borde septentrional y en los sectores I, III y VI. Entre los primeros se reconocieron pisadas de ave en Vacalauquén (VL) y en Sierras de Apas, pisadas de felino en Los Manantiales 12 (LM12) y las figuras de dos matuastos en VL.

Los objetos se corresponden a hachas "en 8", "pañuelos" y "placas" que fueron documentados en Manantial Ramos Mexía (MRM), Laguna Azul 2 (LA2), LM12 y VL (Albornoz y Pereda 2010; Casamiquela 1960; Gradin 2003b; Capítulo 7 de esta tesis). Dado que en la mayoría de los casos se cuenta con croquis de los relevamientos efectuados por otros autores, o de fotografías que muestran el bajo grado de conservación de las pinturas es difícil establecer algún tipo de técnica de producción (para detalles ver Apéndice II.3). Sin embargo, para LA2 se planteó que el hacha "en 8" podría haber sido realizada utilizando artefactos (hisopos o pinceles), ya que el trazo del motivo no supera los 1,50 cm (ver Capítulo 7).

\section{8. b. 5. 2. b. Motivos circulares}

Estos motivos fueron documentados en bajo número en todos los sectores considerados, siendo su frecuencia cercana a 30 (Tabla 8.11). Están presentes mayoritariamente en los sectores IV (Centro) y VI (Vacalauquén), hacia el oeste del macizo, y en el sector III (borde Centro-oriental).

Presentan amplia variabilidad de diseños, correspondiendo en ciertos casos a manchas de pinturas, algunas realizadas mediante su aplicación con algún tipo de artefacto mientras que otras pueden haber sido producidas por estarcido (v.g., Peñón del Pueblo 1, mayor detalle en Capítulo 7). En el sitio La Porfía, se infirió que las circunferencias con cruces internas fueron 
realizadas con algún artefacto por la forma y ancho del trazo (ver Figura 7.85). En las Sierras de Apas, a partir de la información brindada por Casamiquela (1960), se reconocieron diseños circulares de características monocromas (en rojo principalmente), con algunos casos de bicromías. Por último, diseños circulares en color rojo se documentaron en LM12 (Albornoz y Pereda 2010). Sin embargo, en estos últimos casos no existe información que corresponda a las técnicas de aplicación de la pintura.

8. b. 5. 2. c. Motivos ortogonales

Si bien la variabilidad observada en este grupo de motivos es mayor que la presentada para el resto de los motivos analizados, esta diferencia se sustenta en la mayor frecuencia de motivos rectilíneos pintados (Tabla 8.11). Fueron documentados en todos los sectores de Somuncurá, siendo de color rojo, negro, amarillo y/o blanco, en algunos casos conformando bi- o policromías (Figuras 8.28.a y 8.28.b; para referencias bibliográficas ver Apéndice II.3). En la amplia mayoría de los casos documentados en esta tesis el estado de conservación de los motivos es malo por lo que no se pudo reconocer una técnica de aplicación de la pintura (Capítulo 7).

Solamente para el sector VI, en Vacalauquén, y a partir de la revisita al sitio con una documentación fotográfica adicional, se propusieron técnicas de producción. Algunos motivos fueron realizados mediante la técnica digital ya que presentan trazo ancho y heterogéneo, observándose aún una porción del mismo sobrecargada de pintura (Figura 8.28.c), mientras que algunos escalonados podrían haber sido producidos mediante el uso de algún artefacto, principalmente por el ancho y la homogeneidad que presentan los trazos (Figura 8.28.d). El empleo de un/os artefacto/s de menores dimensiones se ofrece en la Figura 8.29.a, en la que el motivo presenta trazos menores a 0,50 cm de ancho (ver más adelante). 

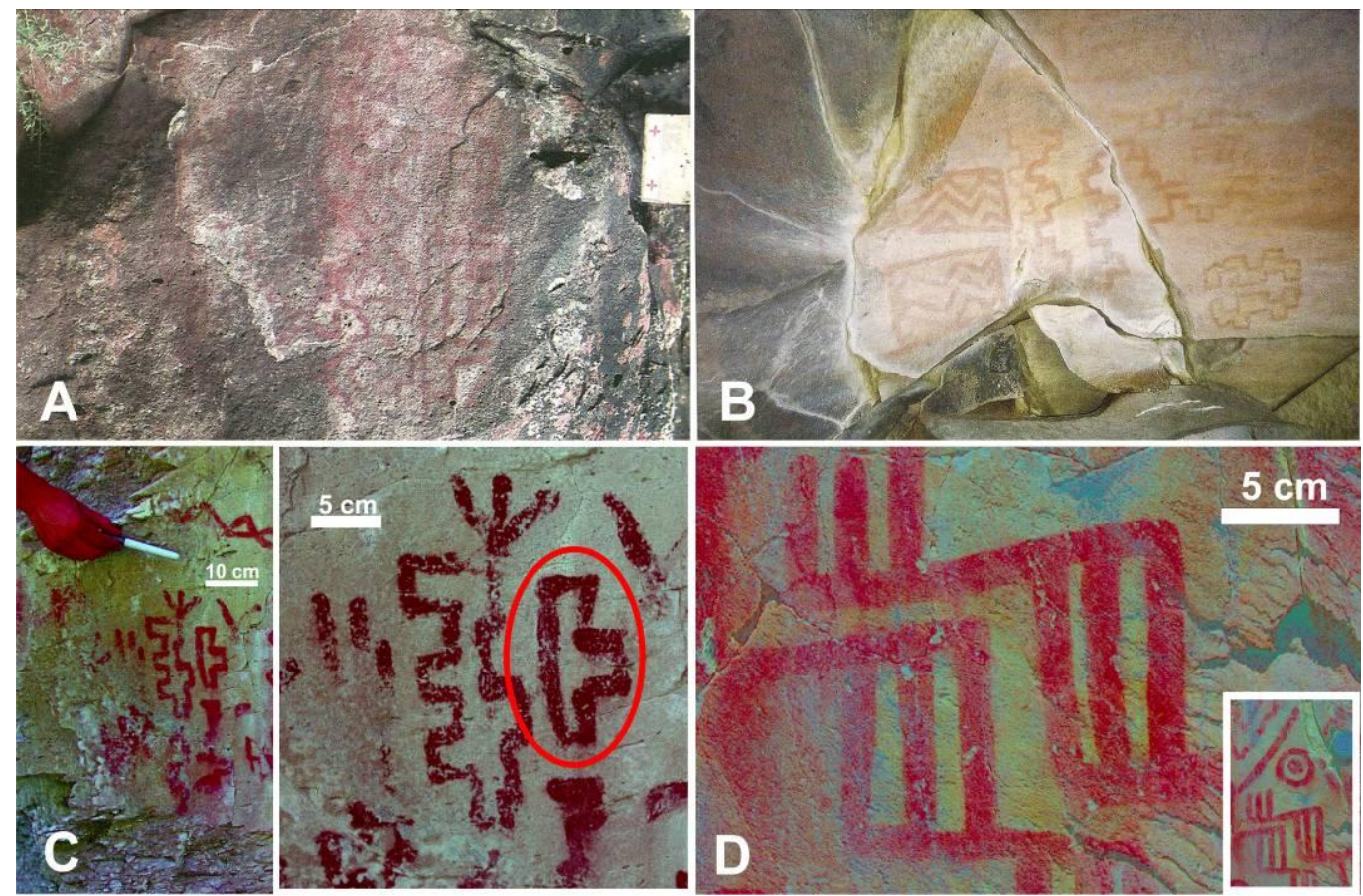

Figura 8.28. Motivos ortogonales: a. Manantial Ramos Mexía (Gradin et al. 2003: foto 3); b. Los Manantiales 1 (Masera 1998: 478); c. Técnica digital en Vacalauquén sitio II (imágenes tratadas digitalmente $D$-Stretch yrd 15 ; recuadro $D$-Stretch yre 15); d. Trazos escalonados en Vacalauquén sitio I (imágenes tratadas digitalmente $D$-Stretch yrd 15; recuadro D-Stretch lre 15).

8. b. 5. 2. d. Evaluación de las técnicas de pintura

Si bien el estado de conservación de los motivos no favorece en todos los casos en estudio la distinción de técnicas de producción, a partir del tratamiento digital de las fotografías se ha podido avanzar en su reconocimiento. En el macizo de Somuncurá, los motivos figurativos, los circulares y los ortogonales fueron realizados mediante la técnica digital o mediante el empleo de artefactos, sin haber podido plantear si en este último caso se correspondía al uso de un hisopo o un pincel. Asimismo, se documentaron motivos de tratamiento lineal o plano, y mono-, bi- o polícromos. Posiblemente, la revisita a los sitios estudiados por otros investigadores, la observación en campo con lupa de mano, el relevamiento fotográfico y el posterior tratamiento digital de las imágenes permita discernir si la propuesta efectuada es adecuada para todo el macizo. 
Hasta el momento solamente se han documentado superposiciones de motivos pintados en Vacalauquén. Algunas de ellas fueron mencionadas por Gradin (2003b) mientras que otras fueron detectadas a partir del tratamiento digital de las imágenes (Figuras 8.29.a y 8.29.b). El análisis de las mismas permitió proponer un uso diacrónico y recurrente del sitio, donde motivos con distinto trazo se superponen y, a su vez, presentan diferentes tonalidades de rojo (Figura 8.29.a; ver imagen sin tratar digitalmente en Figura 7.119). Probablemente esto se deba a la utilización de diferentes componentes en las mezclas pigmentarias.

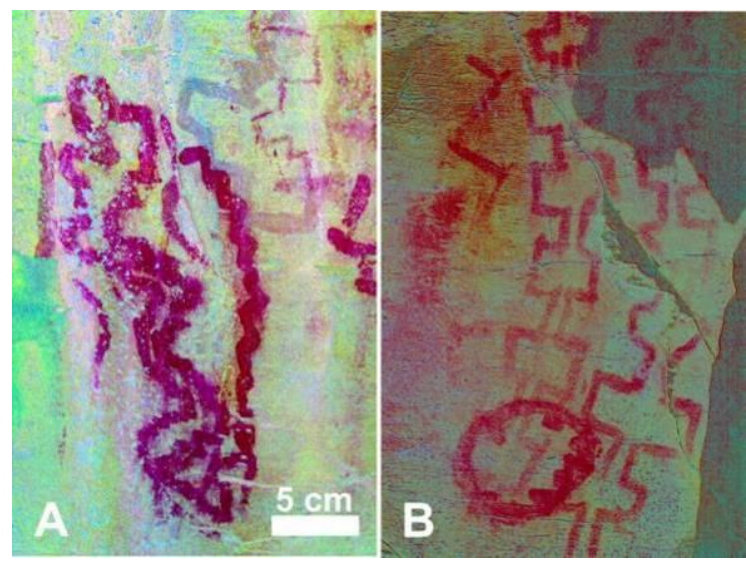

Figura 8.29. Motivos superpuestos en Vacalauquén: a. Superposiciones del Alero del sitio II donde se observan diferentes trazos ortogonales de distinto tamaño realizados con distintas mezclas pigmentarias; b. Superposiciones del sitio III

\section{8. b. 5. 3. Soporte, técnica y diseño para pictograbados}

Este tipo de técnica fue documentada en baja frecuencia $(n=17)$, sobre soportes basálticos en el borde septentrional del macizo y en los sectores que presentan grabados (I y III). Los sitios son Manantial Ramos Mexía (MRM), Bardas de Antonio (BA) y Los Manantiales 1 (LM1). En el primer sitio, ubicado en el borde septentrional del macizo, el motivo pictograbado se corresponde con un diseño curvilíneo (Gradin 2003b: Figura 3), por lo que queda por fuera de este análisis. 
8. b. 5. 3. a. Motivos figurativos

Este tipo de diseño fue documentado en LM1. Se trata de pisadas de ave para las cuales se infirió, a partir de la escasa profundidad de los surcos, el raspado como técnica de producción. Tales surcos grabados fueron sobrepintados en color rojo muy difuso, que por su mal estado de conservación no permitió reconocer un tipo particular de aplicación de la pintura (Albornoz y Pereda 2010).

8. b. 5. 3. b. Motivos circulares

Estos motivos fueron registrados en BA y en LM1 (Tabla 8.12). En BA se trata de circunferencias concéntricas realizadas por percusión, las cuales presentan trazos superficiales de pintura (ver Figura 7.73). En LM1 para los motivos con diseños circulares se reconoció al raspado como técnica de grabado y no se estableció una técnica para la pintura, aunque se reconoció la aplicación de pintura roja sobrepasando el surco grabado (Albornoz y Pereda 2010). Las circunferencias concéntricas corresponden al diseño que se repite en ambos sitios. Una visita a LM1 permitirá observar en detalle estos motivos y evaluar el estado de conservación de la pintura, para, de este modo, proponer alguna técnica de aplicación de la misma.

8. b. 5. 3. c. Evaluación de las técnicas de pictograbado

Si bien en baja frecuencia y solamente en dos sitios, los diseños pictograbados fueron realizados mediante técnicas similares a las registradas en los sitios con grabados (percusión y raspado), sin lograr reconocer aún un método de aplicación de la pintura. Los diseños realizados con esta técnica también repiten los de los motivos grabados (pisadas de ave y circulares lineales). 
La revisita a LM1 permitirá re-evaluar la utilización de los paneles en los que se encuentran estos motivos, ya que cabría preguntarse si los pictograbados se corresponden con una unidad de motivación y ejecución (sensu Gradin 1978) o si corresponden al re-uso de los paneles y de los motivos que los integran. Por el momento, inclinarse por una $\mathrm{u}$ otra alternativa conlleva a un problema de equifinalidad, ya que con los datos actuales procedentes de BA y LM1 no se puede establecer la sincronía de realización entre el grabado y la pintura o si corresponden a eventos sucesivos.

8. b. 6. Distribución temporal de los sitios con arte del macizo de Somuncurá

A partir de la revisión de los antecedentes -para Patagonia meridional y para Nordpatagonia- así como de su integración con los datos presentados a lo largo de la tesis, se puede plantear tentativamente una secuencia para el arte rupestre de Somuncurá. Resulta necesario aclarar que hasta no disponer de datos cronológicos locales, se utilizan las cronologías obtenidas en para el arte rupestre en áreas aledañas.

Las primeras manifestaciones rupestres pintadas se corresponderían con la Tendencia Abstracto Geométrica Simple (Gradin 1988), en la que se reconocen motivos puntiformes, circulares lineales y curvilíneos. Estos diseños fueron anclados cronológicamente en momentos tempranos de la ocupación en Patagonia meridional, ca. 5.000 años AP, incluso anteriores (Gradin 2001, 1987; Gradin et al. 1976, 1979). En Somuncurá, se correspondería al Holoceno tardío, ya que en se registraron ocupaciones entre los 3.000 y 2.000 años AP en sitios con arte rupestre (Belardi 1996; Prates 2011; Stern et al. 2000). De este modo, los sitios que presentan motivos correspondientes a la TAGS serían incluidos entre aquellos sitios con las primeras manifestaciones rupestres pintadas del macizo (Tabla $8.12)$. 
La cronología de los grabados ubica los inicios de su producción hacia los 2.800-2.500 años AP (Crivelli Montero 1988; Crivelli Montero et al. 1991, entre otros). A partir de la propuesta de Gradin (2001), podrían reconocerse tres momentos, caracterizados por diseños particulares (Tabla 8.12), los cuales pudieron reconocerse en los cuatro sitios con grabados en Somuncurá (Tabla 8.12 y Figura 8.30). Respecto de los motivos pictograbados, en Somuncurá estos se podrían ubicar cronológicamente hacia los 2.500 años AP, por la presencia de un sello arqueológico en Cueva Visconti (Ceballos y Peronja 1983). Por último, los motivos geométricos ornamentales, correspondientes a la Tendencia Abstracto Geométrica Compleja o "estilo de grecas", estos serían más tardíos y podrían llegado a momentos del contacto hispano indígena (Crivelli Montero 2006; Fernández 2006; Fernández et al. 2013; Fiore 2006; Onetto 1990; Podestá y Albornoz 2007; Podestá et al. 2008).

\begin{tabular}{|c|c|c|c|c|}
\hline Modalidad & Diseños & Cronología & Pintura & Grabado \\
\hline $\begin{array}{l}\text { TAGC o "estilo de } \\
\text { grecas" }\end{array}$ & $\begin{array}{l}\text { Geométrico } \\
\text { ornamental: trazos } \\
\text { ortogonales, que se } \\
\text { complejizan }\end{array}$ & 1.250 años $\mathrm{AP}$ & $\begin{array}{l}\text { VL; LP; MRM; } \\
\text { RC; PCC; CG; } \\
\text { C }^{\circ} \text { Castillo; LA }\end{array}$ & - \\
\hline $\begin{array}{l}\text { Abstracto- } \\
\text { Representativa o } \\
\text { "estilo de pisadas" }\end{array}$ & $\begin{array}{l}\text { Tres momentos: } \\
\text { 3) grabado fino - } \\
\text { reciente-: a) incisos } \\
\text { curvilíneos/ rectilineos } \\
\text { y } \\
\text { b) geométricos/ } \\
\text { ornamentales } \\
\text { 2) pisadas: } \\
\text { 1) antigua, trazos } \\
\text { curvilíneos; }\end{array}$ & Ca. 2800-2500 años AP & - & $\begin{array}{l}\text { 3a) LEG; } \\
\text { LM1 } \\
\text { 3b)LEG; } \\
\text { LM5 } \\
\text { 2) LEG, } \\
\text { BA } \\
\text { 1) LEG, } \\
\text { BA, LM1 } \\
\text { y LM5 }\end{array}$ \\
\hline TAGS & $\begin{array}{l}\text { Puntiformes y } \\
\text { geométricos } \\
\text { (circunferencias, } \\
\text { tridígitos, líneas } \\
\text { quebradas, espirales, } \\
\text { serpentiformes) }\end{array}$ & $\begin{array}{l}\text { Primeras ocupaciones } \\
\text { Contemporáneo o } \\
\text { anterior a los grabados } \\
\text { del estilo de pisadas }\end{array}$ & $\begin{array}{l}\text { VL; CG; LP; } \\
\text { PP; Apas; } \\
\text { LM12; } \\
\text { C }^{\circ} \text { Castillo }\end{array}$ & - \\
\hline
\end{tabular}

Tabla 8.12. Secuencia estilística del arte rupestre de Somuncurá. Las referencias para los sitios están en la figura 8.30. 


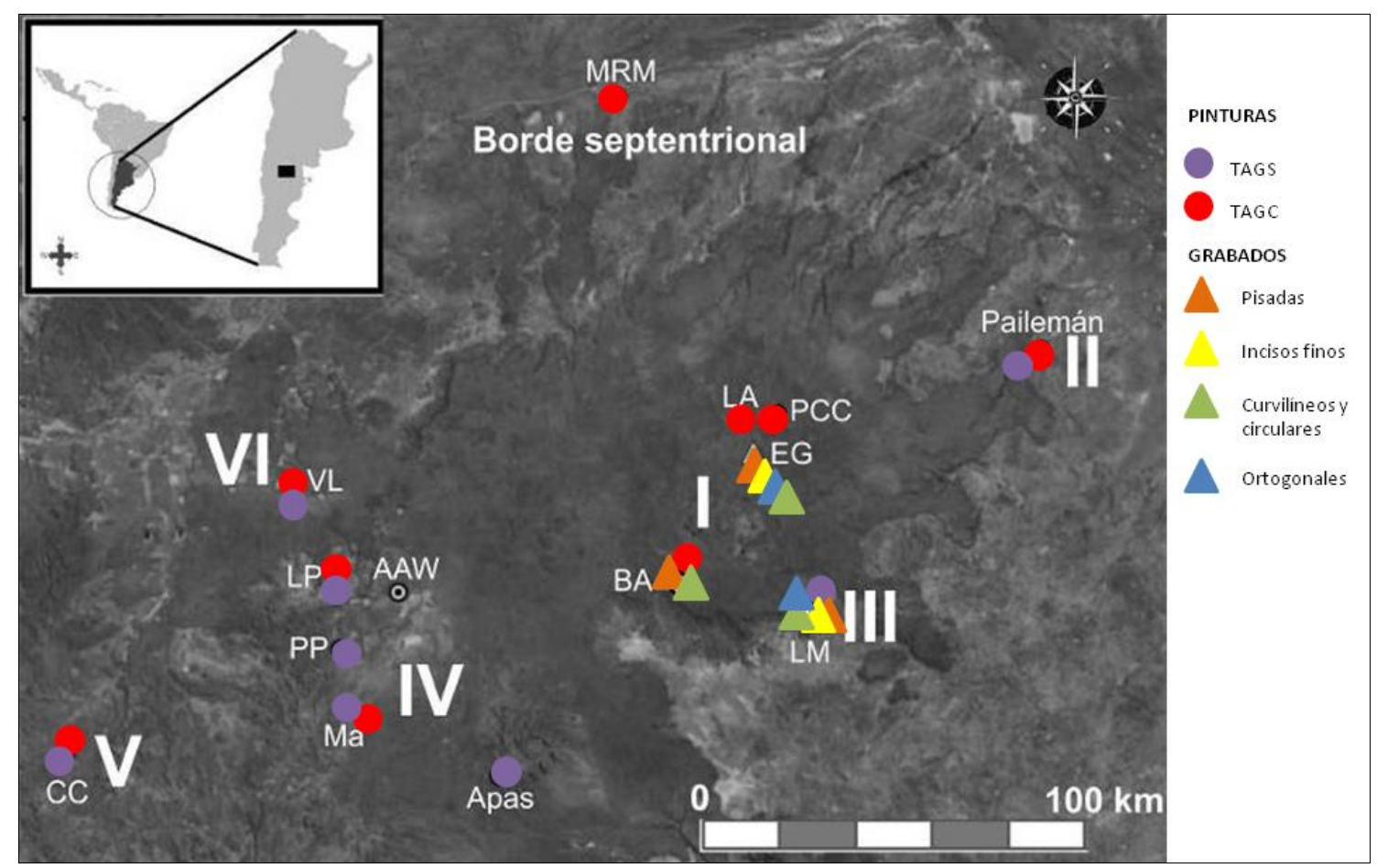

Figura 8.30. Distribución espacial de los sitios con arte rupestre según la secuencia cronológica propuesta en esta tesis. Referencias: MRM: Manantial Ramos Mexía;

LA: Laguna Azul; PCC: Pintada de Corral Curá; EG: Laguna El Ganso; BA: Bardas de Antonio; LM: Los Manantiales; CC: Cerro Castillo; Ma: Martel; PP: Peñón del Pueblo; AAW: Alero Amigo Oeste; LP: La Porfía; VL: Vacalauquén. Los números romanos indican los sectores: I: Noreste; II: Pailemán; III: borde Centro-oriental;

IV: Centro; V: borde Centro-occidental; VI: Noroeste

\section{8. b. 7. Distribución espacial de los sitios con arte del macizo de}

\section{Somuncura}

La información presentada en esta tesis agrega datos novedosos respecto a la técnica de grabado, la cual sólo había sido previamente registrada en el borde Centro-oriental del macizo (Albornoz y Pereda 2010). Se observó una mayor frecuencia de motivos grabados, los cuales se concentran en cuatro sitios en el oriente del macizo. Si bien el número de motivos pintados es más bajo que el de los grabados, las pinturas fueron documentadas en los todos sectores reconocidos, en una mayor cantidad de sitios (Figura 8.31). 


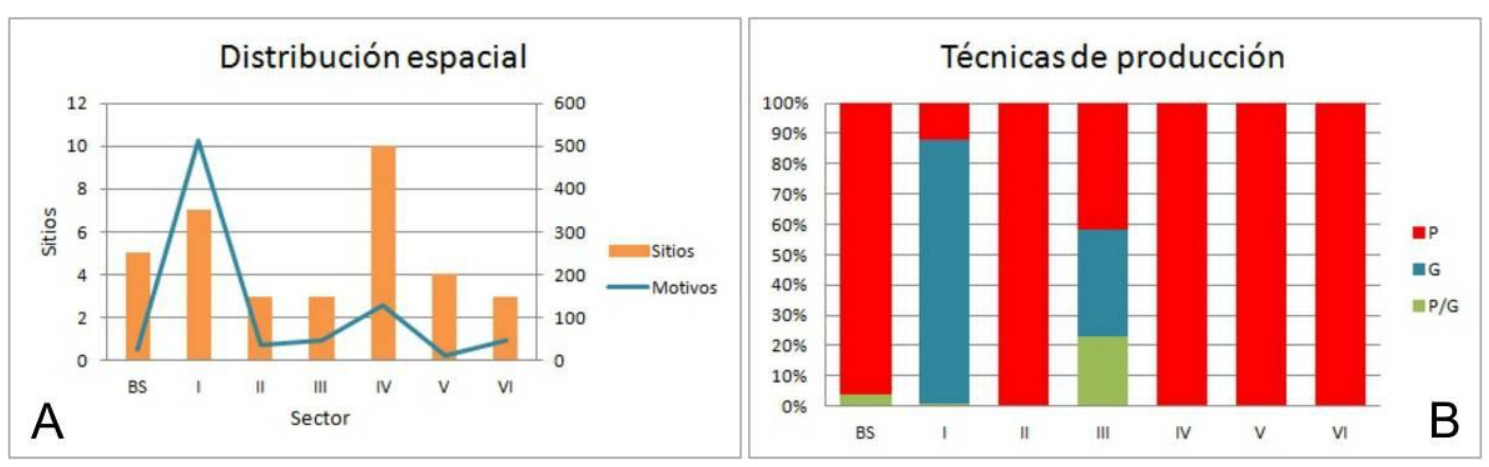

Figura 8.31. Distribución de sitios, motivos y técnicas de producción en los diferentes sectores estudiados en Somuncurá: a. Distribución espacial de sitios y motivos; b. Distribución porcentual de técnicas de producción. Referencias: BS: borde septentrional; I: NE; II: Pailemán; III: borde Centro-oriental; IV: Centro; V: borde Centro-occidental; VI: NW. Técnicas de producción: P: pintura; G: grabado;

P/G: pictograbado.

Esa distribución resulta más interesante al considerar un modelo previo respecto de la distribución espacial de técnicas. Gradin (2001: figura 1) planteó que la dispersión de la técnica de grabado cubría desde Neuquén hasta el sur del río Santa Cruz, estando ausente en el macizo somuncurense. La información presentada denota una ampliación hacia el este de los grabados (Figura 8.32), que incluyen diseños circulares, curvilíneos y de pisadas animales asignables al "estilo de pisadas". Asimismo, los datos aportados por Carden y Borella (2014) apoyarían esta idea, extendiendo la dispersión de los grabados hasta el litoral atlántico. En el modelo de Gradin la dispersión del arte geométrico ("estilo de grecas”) cubre el macizo somuncurense, por lo que el principal aporte de esta tesis a la propuesta de Gradin (2001) refiere al reconocimiento de la variabilidad en los diseños geométricos pintados, integrados por diseños simples correspondientes a los momentos iniciales del arte geométrico (v.g., en Sierras de Apas y en Peñón del Pueblo 1 y 2), y a momentos tardíos con diseños más complejos (i.e., Vacalauquén y La Porfía). 


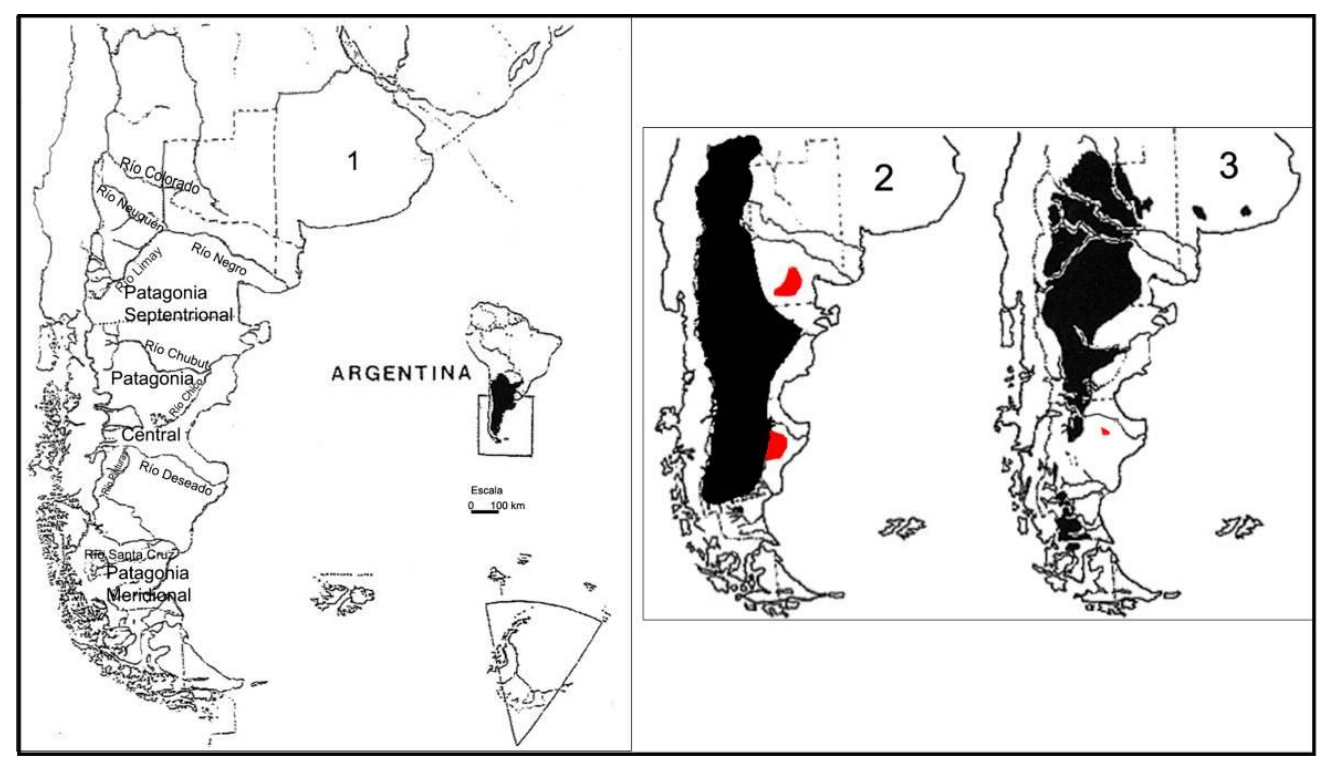

Figura 8.32. Dispersión de los grabados y los motivos geométricos en Patagonia según Gradin (2001: 841) y su modificación con los datos aportados en esta tesis, estos últimos señalados en color rojo. Referencias: 1) Mapa de localización dentro del territorio argentino del área patagónica analizada. 2) Dispersión aproximada de la técnica de grabado. 3) Dispersión del arte creativo o abstracto, primordialmente geométrico.

En Somuncurá, el emplazamiento los grabados se corresponde con paredones o bardas basálticas, en dos casos con fuentes de agua temporarias cercanas. En el caso de los grabados documentados en las cuencas lagunares, los diferentes grados de pátina estarían refiriendo a un uso recurrente de esos espacios a lo largo del tiempo, mientras que la ausencia de superposiciones estaría dando cuenta de un aprovechamiento intensivo y diferencial de los paneles, denotado a partir de la concentración de motivos en diferentes sectores de los sitios. En cambio, las pinturas se encuentran en espacios reparados, los cuales pueden corresponder con paredones o porciones reparadas de bardas -incluso aleros-, mayoritariamente basálticos. Podría proponerse, entonces, un uso más público de los grabados y las cuencas lagunas, ya que se utilizaron espacios abiertos para emplazar las imágenes, con sectores usados de manera intensiva y en relación a sitios ocupados a largo plazo mediante visitas recurrentes. Cabe la posibilidad de que estos hayan sido puntos de fusión social.

Los sitios con pinturas, en general, estarían mostrando usos menos frecuentes, ya que si bien son numerosos y están distribuidos de manera 
homogénea sobre el macizo (ver Figura 8.31.a), presentan baja frecuencia de motivos. Esta situación permitiría pensar en el accionar de grupos más pequeños (quizás unidades familiares), moviéndose entre diferentes puntos en ámbitos de cuencas, quienes compartían un código de comunicación por el uso recurrente de motivos similares (series de líneas paralelas y puntos) en espacios reparados que fueron ocupados durante períodos más breves.

Patrones similares han sido detectados por Recalde y Pastor (2011) con respecto a la distribución de las pinturas y grabados del valle de Guasapampa (Córdoba). Los autores observan un contraste entre la localización de las pinturas en el interior de abrigos y de los grabados en espacios abiertos con un campo visual más amplio, a partir de la cual infirieron contextos domésticos y públicos, en forma respectiva. La inserción de los grabados en la esfera de lo público habría estado vinculada con cambios socio-políticos que implicaron una mayor competencia intergrupal y el surgimiento de jerarquías. Ambas situaciones resaltan el rol del arte rupestre como un medio activo para el establecimiento, negociación y reproducción de vínculos sociales entre sus productores y observadores (Recalde y Pastor (2011).

En el macizo de Somuncurá aún falta resolver el escenario social y el marco cronológico de esa circulación diferente de imágenes pintadas y grabadas en las esferas domésticas y públicas. Por el momento, la tendencia indica la selección de espacios diferentes para la producción de imágenes a partir de técnicas distintas.

El grado de conservación de las pinturas es malo, sobre todo por la presencia de líquenes, de humedad o por la incidencia directa del sol sobre las superficies rocosas. En este sentido, es posible que la evaluación de la distribución de la pintura esté sesgada debido a que su conservación en espacios reparados es más factible. Queda pendiente un análisis más profundo de los agentes tafonómicos enunciados, y una evaluación de su incidencia concreta sobre las pinturas para conocer si su distribución en el interior de abrigos se debe a sus mayores chances de perdurar o a una selección deliberada de dichos espacios. 


\section{8. b. 8. Relación entre soporte, técnicas y diseños en áreas aledañas}

A continuación se retoma la información recopilada en el Capítulo 4 sobre las áreas aledañas -Piedra Parada, Pilcaniyeu y cuenca media y superior del río Limay (Apéndices II.4)-, para poder evaluar comparativamente las tendencias detectadas en el macizo de Somuncurá.

La información respecto del soporte empleado remite al uso de superficies de diferente litología, sobre las que se realizaron motivos pintados, grabados o pictograbados. Las técnicas de producción fueron reconocidas a partir de la observación macroscópica de los surcos y de los trazos de los motivos. La información referida a los grupos y subgrupos de motivos considerados previamente (figurativos, circulares lineales y ortogonales) se resume en la Tabla 8.13.

Se debe tener presente que el análisis realizado está parcialmente sesgado por la disponibilidad de información generada en cada área. La subrepresentación de motivos en el área de Piedra Parada se corresponde a la disponibilidad de datos cuantitativos para siete sitios con arte rupestre (Aschero et al. 1983; Onetto 1987, 1991), mientras que la sobrerepresentación en la frecuencia de motivos en el área de Pilcaniyeu $(n>3.500)$ se debe a las unidades analíticas empleadas por Boschin (2009), que son pocos claras ya que algunos motivos son segmentados arbitrariamente mientras que otros son interpretados utilizando información etnográfica sin establecer si corresponden a una unidad de motivación y/o ejecución (Gradin 1978).

A pesar de esta heterogeneidad en la información, se observa una mayor cantidad de sitios en Somuncurá en relación con las otras áreas mientras que la mayor concentración de motivos se encuentra en Pilcaniyeu (Figura 8.33.a). Respecto a las técnicas de producción, en Somuncurá, Piedra Parada y Pilcaniyeu se registraron pinturas, grabados y pictograbados, mientras que en la cuenca superior y media del río Limay se documentaron pinturas y grabados y tan sólo dos motivos pictograbados (Figura 8.33.b; Tabla 8.13). 


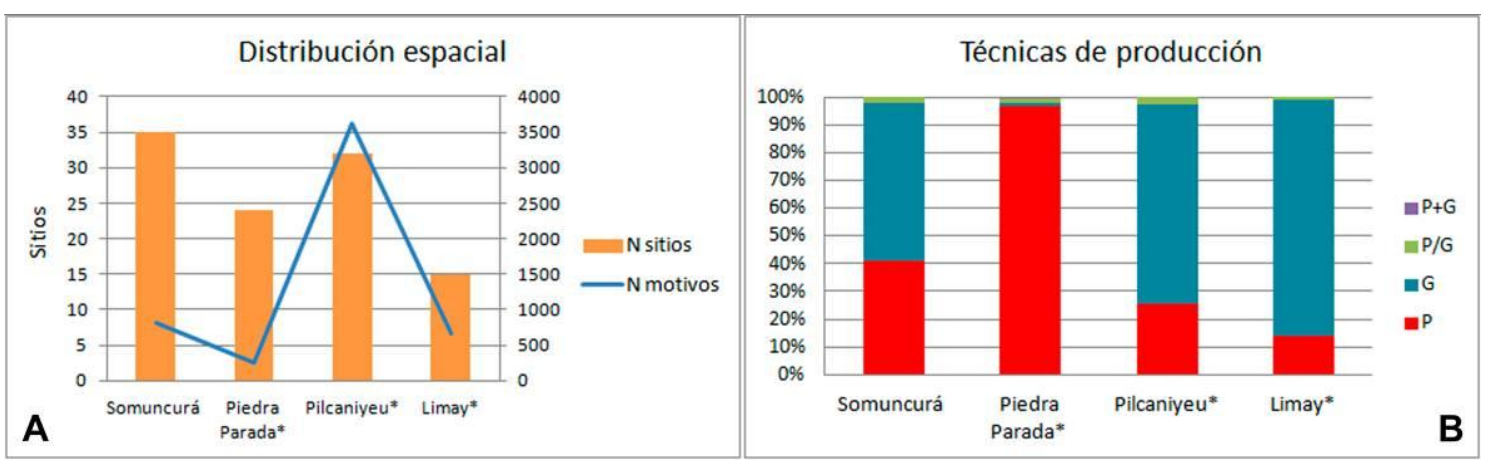

Figura 8.33. Distribución de sitios, motivos y técnicas de producción para

Somuncurá y áreas aledañas: a. Distribución espacial de sitios y motivos; b. Distribución porcentual de técnicas de producción. Referencias: el * indica la subrepresentación en la cantidad de motivos; Técnicas: P: pintura; G: grabado; P/G: pictograbado; $\mathrm{P}+\mathrm{G}$ : pintura y grabados asociados sin superponerse.

A partir de estas características pueden observarse similitudes y diferencias entre el macizo de Somuncurá y las áreas aledañas a nivel tecnológico, de emplazamiento y diseño de motivos.

Entre las similitudes:

1) Se emplearon todas las técnicas (pintura, el grabado y pictograbado) para la producción de arte rupestre. Incluso algunos sitios presentan motivos realizados mediante dos o tres técnicas.

2) Por lo general, los sitios con pinturas se encuentran en espacios reparados (Apéndice II.4.a). Tales sitios se encuentran cercanos a fuentes de agua y, en algunos casos, se los puede relacionar con zonas de tránsito (Gradin 2001; Onetto 1991). Probablemente esto se deba a los patrones de movilidad en el macizo de Somuncurá coincidieran con las zonas menos quebradas, como la amplia planicie entre las Sierras de Apas y de Talagapa, en el centro del macizo (Terranova 2013).

3) Los sitios con pinturas en la cuenca media y superior del río Limay se encuentran en espacios abiertos y paredones, alejados de lo que se estableció como lugares de asentamiento (Crivelli Montero 2006; Crivelli Montero et al. 1991). Esto coincide con los sitios con grecas de Somuncurá de diseños más complejos (La Porfía, Vacalauquén), pero no con los de diseños más simples que, como ya se explicó, predominan en espacios reparados. 


\begin{tabular}{|c|c|c|c|c|c|c|c|c|c|c|c|c|c|c|}
\hline & & & & \multicolumn{4}{|c|}{ TÉCNICAS } & \multicolumn{7}{|c|}{ MOTIVOS } \\
\hline \multirow{2}{*}{\multicolumn{2}{|c|}{ Área }} & \multirow{2}{*}{$\begin{array}{c}\text { Sitios } \\
n\end{array}$} & \multirow{2}{*}{$\begin{array}{c}\text { Motivos } \\
\mathrm{N}\end{array}$} & $\mathrm{P}$ & $\mathrm{G}$ & $\mathrm{P} / \mathrm{G}$ & $\mathrm{P}+\mathrm{G}$ & \multicolumn{5}{|c|}{ Figurativos } & \multicolumn{2}{|c|}{ No Figurativos } \\
\hline & & & & $\mathrm{n}$ & $\mathrm{N}$ & $\mathrm{n}$ & $\mathrm{n}$ & $\begin{array}{l}\text { Antropo- } \\
\text { morfos }\end{array}$ & $\begin{array}{c}\text { Rastros } \\
\text { Humanos }\end{array}$ & $\begin{array}{c}\text { Figuras } \\
\text { animales }\end{array}$ & $\begin{array}{c}\text { Rastros } \\
\text { animales }\end{array}$ & Objetos & $\begin{array}{c}\text { Circulares } \\
\text { lineales }\end{array}$ & Ortogonales \\
\hline \multicolumn{2}{|c|}{ Somuncurá } & 35 & 811 & 331 & 465 & 15 & & - & - & $\mathrm{PP} ; \mathrm{Pe}$ & $\mathrm{Pe}$ & $\mathrm{PL}$ & $\begin{array}{c}\text { PL; Neg; } \\
\text { Pe, R; P/G }\end{array}$ & $\mathrm{PL} ; \mathrm{Pe}$ \\
\hline \multicolumn{2}{|c|}{ Piedra Parada* } & 24 & 263 & 255 & 2 & 5 & 1 & - & Neg, PL & - & $\mathrm{PL} ; \mathrm{P} / \mathrm{G}$ & - & - & $\mathrm{PL}$ \\
\hline \multirow{4}{*}{ Pilcaniyeu } & $\begin{array}{c}\text { Arroyo } \\
\text { Pilcaniyeu* }\end{array}$ & 4 & 97 & 38 & 37 & 22 & - & - & $\begin{array}{l}\text { PL; Pind; } \\
\text { Pe+R; P/G }\end{array}$ & - & $\mathrm{PL}$ & $\mathrm{PL}$ & $\mathrm{P} / \mathrm{G}$ & PL; P/G \\
\hline & $\begin{array}{c}\text { Arroyo } \\
\text { Pichileufú* }\end{array}$ & 18 & 1748 & 345 & 1352 & 48 & 3 & PL; G & $\begin{array}{c}\text { PP; Pe; R. } \\
\text { G }\end{array}$ & - & $\begin{array}{c}\text { PL; Pe; In, } \\
\text { R y H; G } \\
\text { P/G; }\end{array}$ & $\begin{array}{c}\text { PL; I, R } \\
\text { y H }\end{array}$ & $\begin{array}{c}\text { PL; Pe; } \\
\text { P/G; P+G }\end{array}$ & $\mathrm{PL} ; \mathrm{P} / \mathrm{G}$ \\
\hline & Arroyo Comallo* & 5 & 1546 & 303 & 1215 & 28 & - & PL; In & $\mathrm{PL} ; \mathrm{P} / \mathrm{G}$ & - & PL; P/G; I & & $\mathrm{PL}$ & $\mathrm{PL}$ \\
\hline & $\begin{array}{c}\text { Arroyo } \\
\text { Maquinchao }\end{array}$ & 5 & 231 & 231 & - & - & - & PL & $\mathrm{PL}$ & - & PL & PL & PL & PL \\
\hline \multirow{5}{*}{$\begin{array}{c}\text { Cuenca } \\
\text { media y } \\
\text { superior } \\
\text { del Limay }\end{array}$} & $\begin{array}{c}\text { Piedra del } \\
\text { Águila* }\end{array}$ & 6 & 339 & 75 & 262 & 2 & - & $\mathrm{PL}$ & - & - & $\mathrm{PL}$ & $\mathrm{PL}$ & $\mathrm{PL}$ & PL; Neg; In \\
\hline & Quemquemtreu & 1 & 54 & - & 54 & - & - & $\mathrm{In}, \mathrm{Pe}$ & - & - & In & & In & In \\
\hline & $\begin{array}{l}\text { Paso Limay- } \\
\text { Paso Flores* }\end{array}$ & 4 & 30 & 7 & 23 & - & - & PL & - & - & PL; G & - & - & $\mathrm{PL}$ \\
\hline & Corralito & 2 & 174 & 5 & 169 & - & - & - & $\mathrm{R}$ & - & $\mathrm{R}$ & - & PL; R & $\mathrm{R} ;$ In \\
\hline & Alicurá & 2 & 62 & 4 & 53 & 5 & - & - & - & - & P/G; PL & - & PL & $\mathrm{PL}$ \\
\hline
\end{tabular}

Tabla 8.13. Distribución de sitios y motivos considerados en la comparación entre Somuncurá y áreas aledañas. Técnicas: P: pintura; G: grabado; P/G: pictograbado; P+G: pintura más grabado. Neg: negativo; PL: pintura lineal; PP: pintura plana o positiva. Grabado. Pe: percusión; In: incisión; R: Raspado; H: Horadación. P+G: Pintura y grabado sin superponerse conforman el mismo motivo.

$\mathrm{El}$ “*” indica que en esos sectores se cuenta con información cuantitativa para una cantidad inferior de sitios que la que señala el n de sitios 
Entre las diferencias, se resaltan:

1) Los sitios con grabados de la cuenca del Limay y buena parte de los del área de Pilcaniyeu se encuentran en cuevas o aleros (Boschin 2009; Crivelli Montero 2006), tendencia que difiere de aquella observada en Somuncurá, donde se encuentran en bardas rodeando lagunas.

2) En Piedra Parada y en la cuenca del arroyo Pichileufú se documentaron motivos resultantes de trazos pintados y surcos grabados sin superponerse. Se trata de asociaciones entre líneas incisas y grupos de puntos (Onetto1983b; Casamiquela 1960), los cuales también fueron registrados en Alero de las Manos Pintadas en el SW de Chubut (Gradin 1973; Gradin y Aschero 1978). Si bien corresponden a zonas distantes entre sí, la coincidencia en cuanto a técnica y tipo de diseño podría estar señalando patrones de movilidad y de códigos de comunicación en áreas más amplias.

3) Hasta el momento, trazos incisos superpuestos a otros grabados fueron documentados en un sitio en Somuncurá (Laguna El Ganso).

4) Los motivos antropomorfos y los rastros humanos -pintados o grabados(Pilcaniyeu y cuenca del río Limay) no fueron documentados en Somuncurá, mientras que solamente en este macizo se registraron figuras animales pintadas y grabadas-.

5) La variedad del repertorio de técnicas y motivos se acentúa hacia el oeste, entre el macizo de Somuncurá y el ingreso a las primeras estribaciones de la cordillera de los Andes, en el área de Pilcaniyeu. En este enclave se incluyen antropomorfos -pintados y grabados-, "cueros" pintados, grecas y laberintos de gran complejidad y abundancia. Esta variedad, además de remarcar la particularidad del sector podría estar indicando que este sector fue una zona de agregación social y de corredor entre la meseta y la cordillera (Miotti 2010b; Prates 2011, y Boschin 2009).

Los motivos ortogonales de tamaño pequeño ("miniaturas") fueron documentados en las áreas de Piedra Parada y Pilcaniyeu (Aschero 1983e; Boschin 2009). Los planteos realizados respecto de las "miniaturas" las relacionan estrechamente con el "estilo de grecas" aunque las remiten a momentos tardíos del mismo, a los siglos X a XV -entre 1.000 y 500 años AP- 
(Gradin 2003b; Menghin 1957). Las "miniaturas" documentadas en Piedra Parada presentan características peculiares, que permiten reconocer modalidades estilísticas locales en momentos tardíos, principalmente a partir de su frecuencia en los sitios, la angulosidad de los trazos y la colores con que fueron realizados (Aschero 1983e).

La presencia de motivos, emplazamientos y técnicas peculiares en las diferentes áreas analizadas permite plantear la existencia de modalidades estilísticas o "estilos" regionales hacia el Holoceno tardío final. En ese contexto, Somuncurá no parece estar mostrando particularidades

Este análisis permitió una profundización del conocimiento respecto a los procesos tecnológicos en torno a la producción del arte rupestre en Somuncurá y en las áreas aledañas. Sin embargo son necesarios estudios adicionales para seguir ahondando estas temáticas. La inclusión en la comparación de todos los subgrupos de motivos definidos en esta tesis (Capítulo 2), así como la introducción en el análisis de las zonas cordilleranas de Neuquén, Río Negro y Chubut (Comarca Andina del Paralelo $42^{\circ}$, Ambito lacustre boscoso del Nahuel Huapi) permitirán obtener un panorama aún más amplio sobre la distribución espacio-temporal del arte rupestre de Nordpatagonia.

La integración de la información presentada a lo largo de la tesis será presentada en el próximo Capítulo, donde se evalúan las hipótesis planteadas en el inicio de las investigaciones y se realiza la comparación entre los macizos del Deseado y de Somuncurá. 


\section{Capítulo 9}

\section{CONCLUSIONES}

La información tratada a lo largo de esta tesis, con un énfasis en la esfera tecnológica, permite iniciar la comparación del arte rupestre en los ámbitos mesetarios de dos macizos volcánicos: Somuncurá y del Deseado. Los ejes que se desarrollan aquí están relacionados con los objetivos y las hipótesis planteados en el Capítulo 1, que buscan reconocer, a partir de diferentes aspectos analíticos, los procesos de producción y uso del arte rupestre por parte de las sociedades cazadoras-recolectoras que habitaron ambas regiones, así como la relación de tales procesos con la apropiación y transformación social y simbólica del paisaje.

En este sentido, los objetivos generales apuntan a reconocer la variabilidad en la distribución de sitios y emplazamientos en los macizos del Deseado y de Somuncurá, así como los atributos de diseño y tecnológicos. En tanto que los objetivos específicos apuntan a profundizar el conocimiento de los procesos tecnológicos implicados en la producción de imágenes desde el registro arqueológico y desde la arqueología experimental en ambos macizos. En el marco de los objetivos específicos de la tesis se desarrollaron en laboratorio tareas experimentales, y de registro de afloramientos de pigmentos, arcillas y yeso durante las tareas de campo.

La implementación en laboratorio de diseños experimentales para la replicación de motivos grabados y pintados permitió evaluar variables relacionadas con la producción del arte rupestre. En este sentido, una de las hipótesis plantea que la variabilidad observada en las técnicas y los diseños de los 
motivos depende de las características del soporte utilizado. Experimentalmente se lograron motivos similares mediante técnicas diferentes en soportes de distinta litología (Capítulo 5). El cruce de esta información con aquella obtenida a partir del relevamiento de los sitios con arte en ambos macizos (Capítulos 6 y 7) permitió proponer que si bien la variabilidad de las técnicas de producción depende del tipo de soporte rocoso, también intervienen factores como la intencionalidad, los gestos técnicos empleados y los conocimientos previos del productor (Capítulo 8). Por otro lado, la hipótesis que plantea una relación entre la dureza de las materias primas de los artefactos usados para grabar y la dureza del soporte, también fue evaluada mediante datos arqueológicos y experimentales. En los contextos estratigráficos de los sitios con grabados estudiados en el macizo del Deseado no se han identificado artefactos potencialmente útiles para grabar, situación que coincide con la tendencia registrada previamente para Patagonia (Fiore 1996-98). Las experiencias replicativas realizadas permitieron plantear el uso potencial de guijarros con extremos acuminados, de mayor dureza que la de los soportes, para grabar directamente las superficies rocosas (Capítulos 5 y 8). En este sentido, la expectativa de la hipótesis fue cumplida experimentalmente, y plantea la necesidad de prestar atención a este tipo de materiales en el registro arqueológico.

Se detectaron afloramientos de pigmentos en el macizo del Deseado (Carden 2008a; Magnin 2010; Miotti 2008), algunos de los cuales han sido muestreados y analizados mediante difracción de rayos X (DRX) (Carden et al. 2011, 2014). Pequeñas fracciones de estas muestras se emplearon para la confección de las mezclas pigmentarias experimentales (Capítulo 5), y resultaron óptimas para pintar. Por otro lado, en el macizo de Somuncurá se detectaron numerosos afloramientos de pigmentos, detallados en el Capítulo 7, de los cuales se recolectaron muestras que están en proceso de análisis. Por el momento, estos datos permiten afirmar la disponibilidad de materias primas pigmentarias 
minerales en esta porción de Patagonia: queda aún pendiente la corroboración de su utilización para la producción de pinturas rupestres mediante análisis composicionales (ver agenda).

La información presentada en los Capítulos 3, 6 y 7 permite evaluar la hipótesis que sostiene que en ambientes geomorfológica y ambientalmente similares, como los macizos del Deseado y Somuncurá, sería esperable que la relación de los grupos humanos con los respectivos entornos fuese similar en cuanto a emplazamientos de los sitios y técnica de producción. Esto último se manifiesta en la selección de los enclaves para realizar el arte rupestre.

Los patrones de emplazamiento de los sitios con arte rupestre en ambos macizos son similares: cercanos a cursos de agua y a fuentes de materias primas, con recursos florísticos y faunísticos abundantes (Capítulos 6 y 7). La distribución geográfica de sitios con arte en Somuncurá se relaciona con algunas rutas de tránsito que cruzan la meseta en diversos sentidos (v.g., la ruta provincial $n^{\circ} 60$ para los sitios del sector NE, y las rutas provinciales $n^{\circ} 5$, 8 y 67 para los sitios del sector Central). Esta distribución de los sitios con arte rupestre, cercanos a rutas de tránsito, también ha sido propuesta para el macizo del Deseado a partir de la aplicación de SIG (Magnín 2013).

Respecto de la relación entre el emplazamiento y las técnicas de producción, podría plantearse que las pinturas se localizan al interior de espacios reparados, i.e., aleros o cuevas (Cueva de La Hacienda, Cueva Moreno, La Primavera 1-3, Cueva Maripe; Laguna Azul 1-4, sector 3 de Bardas de Antonio, Cueva Martel, Peñón del Pueblo 1 y 2, Alero Amigo Oeste) mientras que los grabados están en zonas abiertas -bardas o paredones-, por lo general asociados a cuencas endorreicas (Laguna del Cerro Bonete, Los Navarros, Laguna El Ganso y Bardas de Antonio en Somuncurá). Sin embargo, en ambos macizos se documentaron excepciones: en el Deseado en los sitios Laguna del Cerro Bonete, Cañadón de la Víbora 2 y 4 presentan pinturas en espacios abiertos, situación que también observa en Somuncurá en los sitios Pintada de Corral 
Curá, sectores 2 y 6 de Bardas de Antonio, La Porfía, y Vacalauquén. En ambos macizos se registraron escasos sitios con grabados al interior de espacios reparados (v.g., Alero El Puesto 1 y Cueva Grande -en el Deseado-, y en el sector 3 de Bardas de Antonio, en Somuncurá).

Dentro técnicas de producción más generales -pintura, grabado y pictograbado-, se observa mayor variabilidad en Somuncurá porque se documentaron motivos pictograbados. Este hecho coincide con la mayor presencia de esta técnica en Nordpatagonia en comparación con Patagonia meridional, donde solamente se registró en La Flecha (Gradin 2003c). Por otro lado, el macizo del Deseado presenta mayor variabilidad en cuanto a las técnicas de pinturas y de grabados, probablemente esta situación se deba a la mayor información disponible para este sector por el desarrollo de las investigaciones y a una tradición de producción del arte rupestre con mayor profundidad temporal (Tabla 9.1).

En ambos macizos se documentaron motivos pintados y grabados sobre diferentes superficies rocosas, siendo que los pictograbados están sobre superficies basálticas. Salvo para estos últimos, no se observa un patrón que relacione soporte y técnica.

Respecto de los diseños, en el macizo del Deseado los rastros humanos son ampliamente predominantes, principalmente bajo la forma de negativos de mano, mientras que en Somuncurá no se documentaron rastros o figuras humanas pintadas (Tabla 9.1). Las figuras animales fueron realizadas mediante grabado y pintura en las áreas que se comparan, en muy baja frecuencia. Los diseños no figurativos (circulares lineales y ortogonales) también fueron documentados en ambos macizos, realizados mediante pintura y grabado. En el macizo del Deseado los motivos circulares grabados están presentes en gran número mientras que los circulares pintados y los ortogonales están en bajas frecuencias (Tabla 9.1). Además, en Somuncurá los circulares lineales pintados son escasos y los grabados más numerosos, con 
exiguos casos realizados mediante pictograbado; los motivos ortogonales pintados son abundantes y mientras que los grabados son escasos (Tabla 9.1). A partir de esta información puede verse el repertorio de diseños en ambas regiones es diferente, situación que no cumple con la expectativa planteada para la hipótesis que proponía similitudes en ambas regiones en la distribución de motivos atribuibles a diferentes modalidades estilísticas. Esto último muestra que, a pesar de que ciertos espacios fueron usados de manera similar, cada sector tuvo su dinámica social propia, con temporalidades también diferentes.

La cronología para el arte rupestre en ambos macizos también es diferente (Tabla 9.1). Las pinturas del macizo del Deseado comenzaron a producirse durante la transición Pleistoceno/Holoceno y continuaron hasta el Holoceno tardío (Carden 2008a; Cardich et al. 1973; Gradin 1977; Gradin et al. 1976, 1979; Miotti et al. 2012a), en tanto que en Somuncurá las manifestaciones pictóricas pueden remitirse al Holoceno tardío (Capítulo 7; Fernández 2006; Fernández et al. 2013; Onetto 1987; Podestá y Albornoz 2007).

Los grabados en el macizo del Deseado se vincularon con el Holoceno tardío en base a la cronología de los sitios más cercanos y al tipo de cultura material asociada en los sitios (Carden 2008a; Miotti et al. 2005;), aunque también se planteó la posibilidad de que los grabados de Piedra Museo puedan ser más antiguos y que estén vinculados con ocupaciones del final del Holoceno medio (Carden 2008a; Miotti y Carden 2007). Edades correspondientes al Holoceno medio también se propusieron para algunos motivos grabados de las mesetas altas del Centro-oeste de Santa Cruz (Belardi y Goñi 2002; Guichón 2012; Re 2011). En Nordpatagonia los grabados remiten al Holoceno tardío por asociaciones cronológicas realizadas entre sitios (Capítulo 8).

Toda esa información permite observar diferentes momentos de producción del arte rupestre en los dos macizos, con registros de mayor profundidad temporal en el Deseado y más tardíos en Somuncurá (Tabla 9.1). Son 
necesarios estudios adicionales de los contextos arqueológicos para conocer la cronología de los grabados y las pinturas de Somuncurá mediante vías independientes a las consideraciones estilísticas regionales.

Por último, en el macizo del Deseado se observó una mayor variedad en cuanto a las modalidades estilísticas o "estilos" del arte rupestre (Tabla 9.1). Probablemente, esto se deba a una mayor profundidad temporal en las ocupaciones y de los estudios realizados, particularmente del arte, así como al desarrollo de estudios arqueológicos regionales desde hace más de 40 años. Los estudios sistemáticos en Somuncurá tienen alrededor de 12 años por lo que la diferencia puede ser parcialmente explicada en este último sentido. El desarrollo de nuevas prospecciones en este último sector permitirá corregir esta observación. 


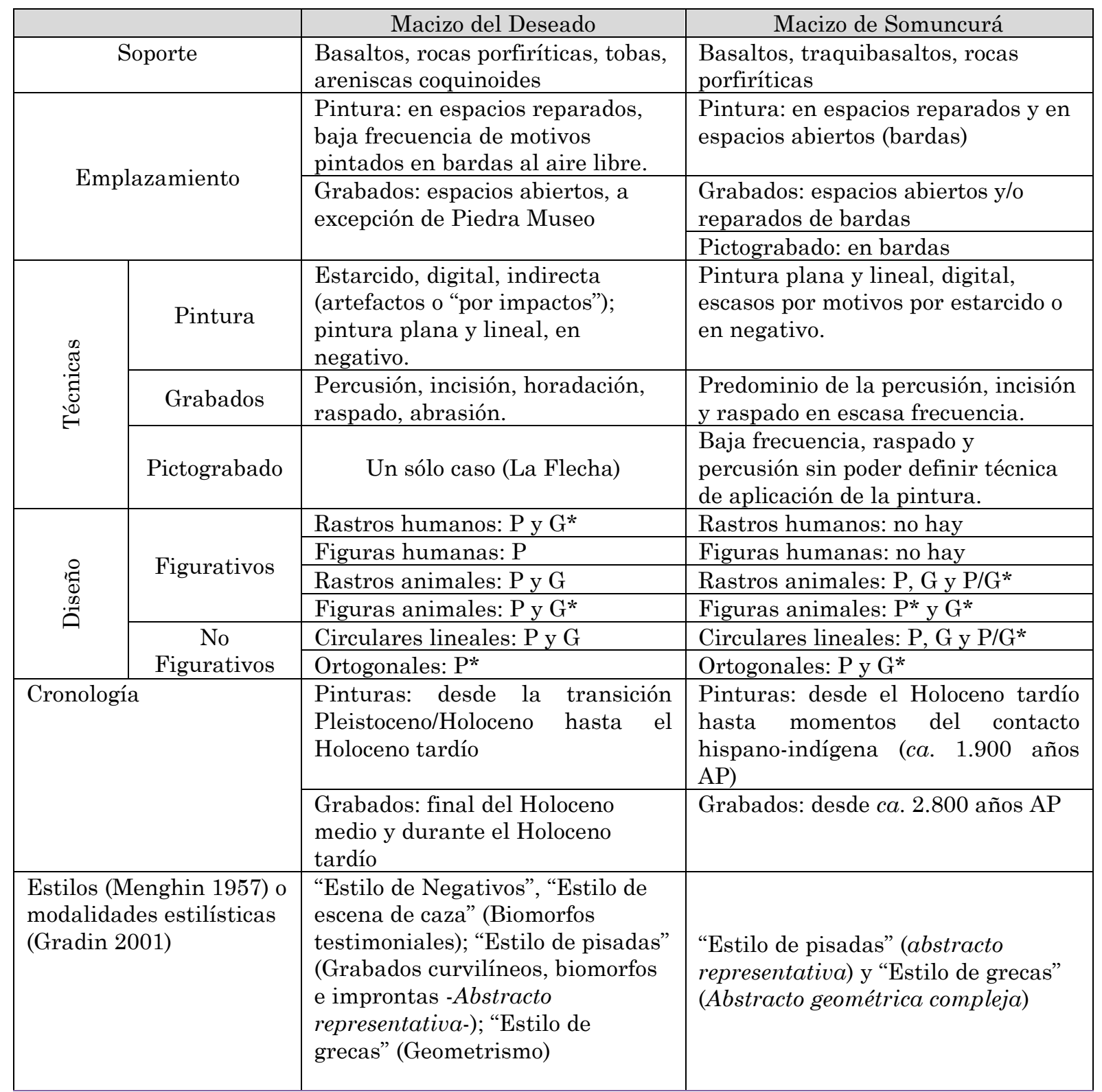

Tabla 9.1. Comparación entre macizos referida a aspectos de emplazamiento, tecnológicos, cronológicos y de diseño. Referencias: P: pintura; G: grabado; P/G:

pictograbado. *: en baja frecuencia.

Lo anterior permite vislumbrar ciertas tendencias:

1) El arte del Pleistoceno final y del Holoceno temprano es característico de Patagonia meridional, profusamente manifestado en el macizo del Deseado, en el sector NE del mismo presente mediante negativos de mano (Miotti et al. 2012); 
2) los grabados del "estilo de pisadas" podrían ser más antiguos en Patagonia meridional, de finales del Holoceno medio, mientras que en Nordpatagonia serían característicos del Holoceno tardío;

3) el estilo de "grecas" forma parte de la dinámica social propia de Nordpatagonia, y su expresión sólo llega muy puntualmente a Patagonia meridional (Carden 2008a; Gradin 1977, 1985), su expresión en Somuncurá es mayor que en el macizo del Deseado. Incluso es más notoria hacia los contrafuertes cordilleranos, quizás como resultado de un flujo de ideas y/o personas desde sectores septentrionales (Gradin 2003b);

4) los resultados de esta tesis aportan un panorama distribucional novedoso para los grabados de Nordpatagonia respecto de la propuesta de Gradin (2001: Figura 1). Esto señala circuitos de información y redes de interacción social de mayor cobertura espacial entre los grupos cazadores-recolectores que los produjeron (Aschero 1996). La localización más oriental de los grabados del macizo de Somuncurá (sitios LEG y BA) coincide con la de los grabados del macizo del Deseado (ver Carden 2008a). En este sentido, los nuevos datos obtenidos a partir del estudio de los sitios Los Navarros, Bardas de Carlos y La Marianita le otorgan relevancia a estas franjas longitudinales como escenarios de circulación de información a través de imágenes. Las similitudes en la ocupación de los espacios en ambos macizos se acentúan hacia finales del Holoceno medio y durante el Holoceno tardío (Miotti 2008, 2010b). Una situación similar se observa a partir de los patrones de movilidad que vincularían ambos macizos, los cuales se habrían enfatizado en momentos posteriores al contacto hispano-indígena, tal como lo dejan en evidencia las crónicas de fines de siglo XIX (Claraz 1988; Muster 2005; Onelli 1998). 


\section{AGENDA}

Se pretende profundizar distintos aspectos mediante actividades adicionales a las desarrolladas:

* excavación de sitios con arte rupestre para intentar contextualizar cronológicamente su produccion;

* ampliar la comparación de los diseños, incluyendo el análisis de todos los subgrupos de motivos definidos en el Capítulo 2 de esta tesis, ya que en detalle se presentaron los figurativos, los circulares lineales y los ortogonales;

* integrar la información del arte rupestre al SIG de sitios arqueológicos de Somuncurá para obtener un panorama más acabado de este macizo, vinculándolos con diferentes unidades del paisaje, lo cual permitirá profundizar la comparación con la información generada en el macizo del Deseado (Carden 2009a; Carden et al. 2009; Magnín 2010; Miotti et al. 2007b);

* ampliar la muestra de sustancias colorantes que puedan haber servido como materia prima para la confección de pinturas (yeso, arcillas, pigmentos) y realizar muestreos de motivos rupestres pintados en ambos macizos, para efectuar estudios arqueométricos adicionales (Chalmin et al. 2003; Iriarte et al. 2009; Pomiés et al. 1999; Sepúlveda et al. 2012, entre otros). Esta información será importante para comenzar a indagar su utilización en los soportes rocosos; * ampliar los diseños experimentales de replicación de motivos rupestres para poder incluir otros soportes rocosos, nuevos diseños artefactuales y materias primas (incluyendo materiales óseos), así como diseños de motivos diferentes. Estas actividades permitirán profundizar el conocimiento obtenido hasta el momento, y someter a prueba con nuevos datos las inferencias realizadas en esta tesis;

* ampliar las muestras de negativos de mano replicados experimentalmente para poder corroborar o modificar las aseveraciones realizadas respecto de los grupos etarios de los productores y de las inferencias respecto a los gestos técnicos (Carden y Blanco 2013). 
* incluir en el análisis del arte rupestre de Nordpatagonia a los sitios de las zonas cordilleranas de Neuquén, Río Negro y Chubut (la Comarca Andina del Paralelo $42^{\circ}$ y el ámbito lacustre boscoso del Nahuel Huapi), con lo que se lograría un reconocimiento pormenorizado de los patrones, similares y/o diferentes, a los aquí presentados.

La realización de estas actividades adicionales permitirá profundizar el estudio de los paisajes sociales de cazadores-recolectores en ambientes mesetarios, a partir de atributos de diseño y tecnológicos del arte rupestre. 


\section{Bibliografía}

Acevedo, A. y N. Franco

2012. Aplicación de DStretch-ImageJ a imágenes digitales del arte rupestre de Patagonia (Argentina). Comechingonia Virtual. Revista Electrónica de Arqueología VI(2): 152-175.

Acevedo, A.; M. Ocampo; D. Fiore y N. Franco

2010. El arte rupestre de los cañadones Yaten Guajen y El Lechuza, margen norte del río Santa Cruz: nuevos resultados y tendencias. En C. Aschero (Coord.), Resúmenes del VIII Simposio Internacional de Arte Rupestre, pp. 1-5. Instituto de Arqueología y Museo - Instituto Superior de Estudios Sociales - Secretaría de Ciencia y Técnica de la Universidad Nacional de Tucumán, San Miguel de Tucumán.

Aguerre, A. M.

1977. A propósito de un nuevo fechado radiocarbónico para la Cueva de las Manos, Alto río Pinturas, provincia de Santa Cruz. Relaciones de la Sociedad Argentina de Antropología XI: 129-142.

1987. Investigaciones arqueológicas en el "Área de La Martita”, Departamento Magallanes- Provincia de Santa Cruz. En Comunicaciones de las Primeras Jornadas de Arqueología de la Patagonia, pp. 11-16. Dirección de Cultura de la Provincia del Chubut, Rawson.

2000. Las Vidas de Pati. En la Toldería de Río Pinturas y Después.UBA- FFyL, Buenos. Aires

Aguerre, A. M. y C. Gradin

2003. La dinámica poblacional en el curso medio del río Pinturas. En A. Aguerre (Comp.), Arqueología y Paleoambiente en la Patagonia Santacruceña Argentina, pp. 153-204. Nuevo Offset, Buenos Aires.

Aguilera, E. Y.

2005. Identificación y distribución de diferentes superficies geomorfológicas de escaso relieve local por medio de sensores remotos en el área del Macizo Nordpatagónico, provincia de Río Negro. Tesis doctoral inédita de la Facultad de Ciencias Naturales y Museo, Universidad Nacional de La Plata, La Plata.

Aguilera, E. Y. y J. Rabassa

2010. Origin of the Northern Patagoninan Massif Regional Paleosurface, Geociências 29(4): 467-478. 
Alberti, B.

2011. Epílogo: acumulando historias desde un "terreno poco común”. En D. Hermo y L. Miotti (Eds.), Biografía de Paisajes y Seres. Visiones Desde la Arqueología Sudamericana, pp. 133-150. Encuentro Grupo Editor, Córdoba.

Albornoz, A. M.

2003. Estudios recientes en el arte rupestre de Río Negro (desde fines de 1970 hasta la actualidad). En C. J. Gradin, A. M. Aguerre y A. M. Albornoz (Eds.), Arqueología de Río Negro, pp. 79-96. Secretaría de Estado de Acción Social de Río Negro, Viedma.

Albornoz, A. M. y E. M. Cúneo

2000. Análisis comparativo de sitios con pictografías en ambientes lacustres boscosos de Patagonia Septentrional: Lagos Lacar y Nahuel Huapi (Provincias de Río Negro y Neuquén). En M. M. Podestá y M. de Hoyos (Eds.), Arte en las rocas. Arte rupestre, menhires y piedras de colores en Argentina, pp. 163-174. SAA- AINA, Buenos Aires.

Albornoz, A. M. e I. Pereda

2010. Interacción con particulares y su importancia en la preservación. Análisis de caso: Estancia Los Manantiales, meseta de Somuncurá, provincia de Río Negro. En F. Oliva, N. de Grandis y J. Rodríguez (Eds.), Arqueología Argentina en los Inicios de un Nuevo Siglo, Tomo 3: 15-27. Laborde Libros editor, Rosario.

Álvarez M. y D. Fiore

1993. La Arqueología como ciencia social: apuntes para un enfoque teóricometodológico. Boletín de Antropología Americana 27: 21-38.

1995. Recreando imágenes: diseño de experimentación acerca de las técnicas y los artefactos para realizar grabados de arte rupestre. Cuadernos del Instituto Nacional de Antropología y Pensamiento Latinoamericano 16: 215-239.

Álvarez, M.; D. Fiore; E. Favret y R. Castillo Guerra

1999. El uso de artefactos líticos para la ejecución de grabados rupestres: observación y análisis de los rastros de utilización mediante técnicas de microscopia óptica. En C. Diez (Ed.), Actas del XII Congreso Nacional de Arqueología Argentina, Tomo I: 327335. Universidad Nacional de La Plata, La Plata.

2001. The use of lithic artefacts for making rock art engravings: observation and analysis of use-wear traces in experimental tools through optical microscopy and SEM. Journal of Archaeological Science 28: 457-464.

Anschuetz K., R. Wilshusen y C. Scheick

2001. An archaeology of landscape: perspectives and directions. Journal of Archaeological Research 9(2): 157-211. 
Apel, J.

2000. Flint daggers and technological knowledge. Production and consumption during

LN I. En D. Olausson y H. Vandkilde (Eds.), Form, Function and Context. Material Culture Studies in Scandinavian Archaeology, pp. 135-154. Almqvist and Wiksell International, Lund.

Apel, J. y K. Knutsson (Eds.)

2006. Skilled Production and Social Reproduction. Aspects on Traditional Stoone-Tool

Technologies, Proceedings from an International Symposium held in Uppsala August 20-24, 2003. Societas Archaeologica Upsaliensis- SAU Stone Studies 2, Uppsala.

Aragón, E.; E. Aguilera, C. Cavarozzi y A. Ribot

2010. The North Patagonian altiplano and de Somun Curá basaltic Plateau. Geociências 29(4): 527-532.

Arias, P.; E. Crivelli Montero; M. Fernández y L. C. Teira Mayolini

2012. Grabados del Holoceno temprano en la Cueva Epullán Grande, Provincia del Neuquén, Argentina. Nuevas investigaciones. En J. Clottes (Dir.), L’art pléistocène dans le monde/ Pleistocene art of the world/ Arte pleistoceno en el mundo, Actes du Congrèss IFRAO, Tarascon-sur-Ariège, septembre 2010, Symposium "Art pléistocène dans les Amériques». $\mathrm{N}^{\circ}$ spécial de Préhistoire, Art et Sociétés, Bulletin de la Société Préhistorique Ariège-Pyrénées, LXV-LXVI, 2010-2011, CD: p. 793-806

Arrigoni, G.

1996. El arte rupestre del Cañadón sin Nombre: Cueva de los Felinos (Santa Cruz). En J. Gómez Otero (Ed.), Arqueología, Sólo Patagonia, pp. 131-141. CENPATCONICET, Puerto Madryn.

Arrigoni, G.; M. T. Boschin; J. A. Cordero; E. Crivelli Montero; M. Fernández y G. I. Massaferro

2010. Arqueología del sudoeste de la provincia de Río Negro. Nuevas investigaciones en las cuevas de Comallo. Rastros. Arqueología e Historia de la Cuenca del Río Limay 3: $1-11$.

Aschero, C.

1975. Ensayo para una clasificación morfológica de artefactos líticos (aplicado a estudios tipológico comparativos). Informe al CONICET. Buenos Aires

1981-82. Nuevos datos sobre la arqueología del Cerro Casa de Piedra. Relaciones de la Sociedad Argentina de Antropología XIV(2): 267-284.

1983a. El arte rupestre del sitio Piedra Parada 1. En C. Aschero, C. Pérez de Micou, M. Onetto, C. Bellelli, L. Nacuzzi y A. Fisher (Comps.), Arqueología del Chubut. El 
Valle de Piedra Parada, pp. 51-56. Dirección Provincial de Cultura- Gobierno de la Provincia del Chubut, Rawson.

1983b. El arte rupestre del sitio Campo Nassif 1. En C. Aschero, C. Pérez de Micou, M. Onetto, C. Bellelli, L. Nacuzzi y A. Fisher (Comps.), Arqueología del Chubut. El Valle de Piedra Parada, pp.71-76. Dirección Provincial de Cultura- Gobierno de la Provincia del Chubut, Rawson.

1983c. Sitio San Ramón 1. En C. Aschero, C. Pérez de Micou, M. Onetto, C. Bellelli, L. Nacuzzi y A. Fisher (Comps.), Arqueología del Chubut. El Valle de Piedra Parada, pp. 77-78. Dirección Provincial de Cultura- Gobierno de la Provincia del Chubut, Rawson.

1983d. Yacimiento Aguada del Potrillo. Sitios AP1 y AP5. En C. Aschero, C. Pérez de Micou, M. Onetto, C. Bellelli, L. Nacuzzi y A. Fisher (Comps.), Arqueología del Chubut. El Valle de Piedra Parada, pp. 85-88. Dirección Provincial de CulturaGobierno de la Provincia del Chubut, Rawson.

1983e. La secuencia de Piedra Parada a través de las campañas 1979-1981. Consideraciones finales. En C. Aschero, C. Pérez de Micou, M. Onetto, C. Bellelli, L. Nacuzzi y A. Fisher (Comps.), Arqueología del Chubut. El Valle de Piedra Parada, pp. 91-103. Dirección Provincial de Cultura- Gobierno de la Provincia del Chubut, Rawson.

1983-85. Pinturas rupestres en asentamientos cazadores-recolectores: dos casos de análisis aplicando difracción de rayos X. Cuadernos del Instituto Nacional de Antropología y Pensamiento Latinoamericano 10: 291-306.

1985. Nota sobre el uso de pigmentos minerales en el sitio CCP-5, provincia de Santa Cruz, Argentina. En C. Aldunate, J. Berenguer y V. Castro (Eds.), Estudios en Arte Rupestre, pp. 13-24. Museo Chileno de Arte Precolombino, Santiago de Chile.

1988. Pinturas rupestres, actividades y recursos naturales; un encuadre arqueológico. En L. Borrero y H. Yacobaccio (Eds.), Arqueología Contemporánea, pp. 109-145. Editorial Búsqueda, Buenos Aires.

1996. Adónde van esos guanacos? En J. Gómez Otero (Ed.), Arqueología, Sólo Patagonia, pp. 153-162. CENPAT-CONICET, Puerto Madryn.

1997. De cómo interactúan emplazamientos, conjuntos y temas. Revista del Museo de Historia de San Rafael XVI: 17-28.

2012a. Las escenas de caza en Cueva de las Manos: Una perspectiva regional (Santa Cruz, Argentina) En J. Clottes (dir.), L’art pléistocène dans le monde/ Pleistocene art of the world/ Arte pleistoceno en el mundo, Actes du Congrès IFRAO, Tarasconsur-Ariège, septembre 2010, Symposium «Art pléistocène dans les Amériques». N spécial de Préhistoire, Art et Sociétés, Bulletin de la Société Préhistorique AriègePyrénées, LXV-LXVI, 2010-2011, CD: pp. 807-823.

2012b. El arte rupestre de Alero Parado, Río Pinturas, Santa Cruz (Patagonia Argentina). Un aporte sobre técnicas de grabados rupestres en el ámbito NO de Santa Cruz. En M. Strecker (Ed.), Contribuciones al Estudio del Arte Rupestre 
Sudamericano $N^{\circ}$. Congreso Internacional Arqueología y Arte Rupestre. 25 años SIARB, pp. 95. La Paz.

Aschero, C. y S. Hocsman

2004. Viejas y nuevas categorías analíticas y niveles de clasificación en el análisis macroscópico de artefactos líticos tallados. Taller Morfología Macroscópica en la Clasificación de Artefactos Líticos: Innovaciones y Perspectivas. http://www.naya.org.ar/eventos/liticos_resumenes.htm

Aschero, C.; L. Nacuzzi y C. Pérez de Micou 1983a. Aspectos biogeográficos. En C. Aschero, C. Pérez de Micou, M. Onetto, C. Bellelli, L. Nacuzzi y A. Fisher (Comps.), Arqueología del Chubut. El Valle de Piedra Parada, pp. 25-28. Dirección Provincial de Cultura- Gobierno de la Provincia del Chubut, Rawson.

Aschero, C.; C. Pérez de Micou; M. Onetto; C. Bellelli; L. Nacuzzi y A. Fisher 1983b. Arqueología del Chubut. El Valle de Piedra Parada. Gobierno de la Provincia del Chubut-Dirección Provincial de Cultura, Rawson.

Aschero, C.; M. De Nigris; M. J. Figuerero Torres; A. G. Guráieb; G. L. Mengoni Goñalons y H. D. Yacobaccio

1999. Excavaciones recientes en Cerro de los Indios 1, Lago Posadas, Santa Cruz: nuevas perspectivas. En R. Goñi (Ed.), Soplando en el viento... Actas de las Terceras Jornadas de Arqueología de la Patagonia, pp. 269-286. Universidad del ComahueINAPL, Neuquén-Buenos Aires.

Aschero, C.; R. Goñi; M. T. Civalero; R. Molinari; S. Espinosa; A. G. Guráieb y C. Bellelli

2005. Holocenic Park: Arqueología del Parque Nacional Perito Moreno (PNPM). Anales de Parques Nacionales XVII: 71-119.

Aschero, C.; D. Bozzuto; M. T. Civalero; M. De Nigris; A. Di Vruno; V. Dolce; N. Fernández; L. González, P. Limbrunner

2009. El registro arqueológico de la costa norte del lago Pueyrredón- Cochrane (Santa Cruz, Argentina). En M. Salemme, F. Santiago, M. Álvarez, E. Piana, M. Vázquez y M. E. Mansur (Eds.), Arqueología de Patagonia: una Mirada Desde el Último Confín, pp. 919-926. Editorial Utopías, Ushuaia.

Attard Montalto, N.

2010. The characterization and provenancing of ancient ochres. Tesis doctoral inédita del Cranfield Health Translational Medicine, Universidad de Cranfield. Cranfield. 
Atkinson D.; P. Jackson, D. Sibley y N. Washburn

2005. Cultural Geography: A Critical Dictionary of Key Concepts. Taurus, Londres.

Bahn, P. y J. Vertut

1997. Blocks, rock shelters and caves. En P. Bahn y J. Vertut (Eds.), Journey Through the Ice Age, pp. 104-127. University of California Press, Berkeley y Los Ángeles.

Barbosa, C. y C. Gradin

1986-87. Estudio composicional por difracción de rayos $\mathrm{X}$ de los pigmentos provenientes de la excavación del Alero Cárdenas (provincia de Santa Cruz). Relaciones de la Sociedad de Antropología XVII(1): 143-17l.

Barbosa, C. y G. Rial

1985. Análisis mineralógico por difracción de rayos $\mathrm{X}$ de muestras de pintura de Cerro Casa de Piedra, sitio CCP-5, Provincia de Santa Cruz, Republica Argentina. En C. Aldunate; J. Berenguer y V. Castro (Eds.), Estudios en Arte Rupestre, pp. 21-24. Museo Chileno de Arte Precolombino, Santiago de Chile.

Bard, J. y C. Busby

1974. The manufacture of a petroglyph: a replicative experiment. Contribution of the University of California Archaeological Research Facility 20: 83-102.

Barton, C. M.; G. A. Clark y A. E. Cohen

1994. Art as information: explaining Upper Palaeolithic art in Western Europe. World Archaeology 26(2): 185-207.

Bate, F.

1981. Relación general entre teoría y método en Arqueología. Boletín de Antropología Americana 4: 7-54.

Bednarik, R.

2007a. Rock Art Science: an introduction. En R. Bednarik, Rock Art Science. The Scientific Study of Palaeoart, pp. 1-6. Aryan Books International, Nueva Delhi.

2007b. The technology of rock art. En R. Bednarik Rock Art Science. The Scientific Study of Palaeoart, pp. 37-54. Aryan Books International, Nueva Delhi.

2008. Children as Pleistocene artists. Rock Art Research 25(2): 173-182.

Belardi, J. B.

1996. Cuevas, aleros, distribuciones y poblamiento. En J. Gómez Otero (Ed.), Arqueología, Sólo Patagonia, pp. 43-48. CENPAT-CONICET, Puerto Madryn. 
2004. Más vueltas que una greca. En M. T. Civalero, P. Fernández y G. Guraieb (Comps.), Contra viento y marea. Arqueología de Patagonia, pp. 591-603. INAPLSAA, Buenos Aires.

Belardi, J. B. y R. Goñi

2002. Distribución espacial de motivos rupestres en la cuenca del lago Cardiel (Patagonia Argentina). Boletín de la SIARB 16: 29-38.

2006. Representaciones rupestres y convergencia poblacional durante momentos tardíos en Santa Cruz (Patagonia argentina). El caso de la meseta del Strobel. En D. Fiore y M. M. Podestá (Eds.), Tramas en la Piedra. Producción y Usos del Arte Rupestre, pp. 85-94. WAC- SAA- AAINA, Buenos Aires.

Belardi, J. B.; R. Goñi; T. Bourlot y A. Aragone

2003. Uso del espacio y paisajes arqueológicos en la cuenca del lago Cardiel (Provincia de Santa Cruz, Argentina). Magallania. Anales del Instituto de la Patagonia 31: 95-106.

Belardi, J.B.; A. Sunico y D. Puebla

2000. Análisis de pigmentos minerales y sus fuentes potenciales de aprovisionamiento en el Área del Lago Roca (Sector Chorrillo Malo), Provincia de Santa Cruz (Argentina). Anales del Instituto de la Patagonia 28: 291-304.

Bellelli, C.

1983. Sitio Campo Moncada 2. En C. Aschero, C. Pérez de Micou, M. Onetto, C. Bellelli, L. Nacuzzi y A. Fisher (Comps.), Arqueología del Chubut. El Valle de Piedra Parada, pp. 31-42. Dirección Provincial de Cultura- Gobierno de la Provincia del Chubut, Rawson.

1987. El Componente de las capas 3a, 3b y 4a de Campo Moncada 2 (CM2) -Provincia del Chubut- y sus relaciones con las industrias de Patagonia Central. En Comunicaciones de las Primeras Jornadas de Arqueología de la Patagonia, pp. 2732. Dirección Provincial de Cultura-Gobierno de la Provincia del Chubut, Rawson.

1994. Excavaciones en Campo Cerda 1 (Valle medio del río Chubut). Actas y Memorias del XI Congreso Nacional de Arqueología Argentina. Revista del Museo de Historia Natural de San Rafael XIV(I/IV): 285-287.

2000-02. Dataciones por AMS de artefactos realizados con técnicas cesteras en Campo Cerda 1 (Valle de Piedra Parada, Chubut). Cuadernos del Instituto Nacional de Antropología y Pensamiento Latinoamericano 19: 660-662.

2005. Tecnología y materias primas a la sombra de Don Segundo. Una cantera-taller en el valle de Piedra Parada. Intersecciones en Antropología 6: 75-92. 
Bellelli, C. y F. X. Pereyra

2002. Análisis geoquímicos de obsidiana. Distribuciones de fuentes y artefactos arqueológicos en el Noroeste del Chubut (Patagonia Argentina). Revista Werken 3: 99-118.

Bellelli, C.; M. Carballido Calatayud y P. Fernández

2007. El sitio Campo Cerda 1 en el contexto de la arqueología del Valle de Piedra Parada. Resúmenes Ampliados del XVI Congreso Nacional de Arqueología Argentina, Tomo III: 303-308. Universidad Nacional de Jujuy, San Salvador de Jujuy.

Blanco, R. V.

2010. Sitios Peñón del Pueblo 1 y 2: manifestaciones rupestres en la cuenca del arroyo Barril Niyeu (Río Negro). En C. Aschero (Coord.), Resúmenes del VIII Simposio Internacional de Arte Rupestre, pp. 246-250. Instituto de Arqueología y MuseoInstituto Superior de Estudios Sociales- Secretaría de Ciencia y Técnica de la Universidad Nacional de Tucumán, San Miguel de Tucumán.

Blanco, R. V. y V. Lynch

2011. Experimentos replicativos de grabados en piedra. Implicancias en el arte rupestre de la localidad arqueológica de Piedra Museo (Santa Cruz, Argentina). Boletín del Museo Chileno de Arte Precolombino 16(1): 9-21.

Blanco, R. V.; L. L. Miotti y N. Carden

2010a. Arte rupestre en la Meseta de Somuncurá (Río Negro). Revisitando las lagunas Azul y El Ganso. En R. Bárcena y H. Chiavazza (Eds.), Arqueología Argentina en el Bicentenario de la Revolución de Mayo, Actas del XVII Congreso Nacional de Arqueología Argentina, Tomo V: 1859-1864. UNCuyo- CONICET, Mendoza.

2010b. Arte rupestre en la Meseta de Somuncurá: Sitio Bardas de Antonio. Un nuevo aporte a la arqueología regional. En C. Aschero (Coord.), Resúmenes del VIII Simposio Internacional de Arte Rupestre, pp. 106-111. Instituto de Arqueología y Museo- Instituto Superior de Estudios Sociales- Secretaría de Ciencia y Técnica de la Universidad Nacional de Tucumán, San Miguel de Tucumán.

2013. El arte rupestre del nordeste de la meseta de Somuncurá: caracterización inicial e integración regional. Mundo de Antes 8, 30 págs. En prensa.

Bleed, P.

2011. Loosening our chaînes: cognitive insights for the archaeological application of sequence models. PaleoAnthropology 2011: 297-304. Special Issue: Reduction Sequence, Chaîne Opératoire, and Other Methods: The Epistemologies of Different Approaches to Lithic Analysis. 
Bórmida, M. y R. Casamiquela.

1958-59 Etnografía Gününa-Këna. Testimonio del último de los Tehuelches septentrionales. Runa IX (1-2): 153-193.

Boschin, M. T.

1986. Arqueología del Área Pilcaniyeu, Sudoeste de Río Negro, Argentina. Cuadernos del Instituto Nacional de Antropología y Pensamiento Latinoamericano 11: 99-119

2009. Tierra de hechiceros. Arte indigena de Patagonia Septentrional Argentina. Ediciones Universidad de Salamanca, Salamanca.

Boschin, M. T. y M. F. del Castillo Bernal

2005. El Yamnago: del registro histórico al registro arqueológico. Revista Española de Antropología Americana 36: 99-116.

Boschin, M. T. y L. Nacuzzi

1980. Investigaciones arqueológicas en el Abrigo Pilcaniyeu (Río Negro). Sapiens 4: 123129.

Boschin, M. T.; M. Maier y G. Massaferro

2011. Une lecture pluridisciplinaire des analyses chimiques et minéralogiques de peintures rupestres de la Patagonie argentine. L'anthropologie 115: 360-383.

Boschin, M. T.; M. Maier; M. F. del Castillo Bernal y S. Parera

2004. Análisis químico de pastas procedentes del nivel inferior de la Cueva Loncomán, Provincia de Rio Negro. Resúmenes del XV Congreso Nacional de Arqueología Argentina, pp. 409-410. Universidad Nacional de Río Cuarto, Río Cuarto.

Boschin, M. T.; A. Seldes; M. Maier; R. Casamiquela; R. Ledesma y G. Abad

2003. Análisis de las fracciones inorgánicas y orgánicas de pinturas rupestres y pastas de sitios arqueológicos de la Patagonia septentrional argentina. Zephyrus 55: 183198.

Bradley, R.

2000. An archaeology of Natural Places. Routledge, Londres - New York.

Bradley, R.; F. Criado y R. Fábregas.

1994. Rock art research as landscape archaeology: a pilot study in Galicia, north-west Spain. World Archaeology 25 (3): 374-390.

Browen Stahl, A. M.

2010. Material histories. En D. Hicks y M. Beaudry (Eds.), The Oxford Handbook of Material Culture Studies, pp. 150-172. Oxford University Press, Oxford. 
Bruch, C.

1902. La Piedra pintada del Arroyo Vaca Mala y las esculturas de la Cueva de Junín de los Andes (territorio de Neuquén). Revista del Museo de La Plata X: 173-176.

1904. La piedra pintada de El Manzanito (territorio del Río Negro). Revista del Museo de La Plata XI: 71-72.

Cabrera, A. L.

1971. Fitogeografía de la República Argentina. Boletín de la Serie Botánica 14 (1-2): 142.

Cabrera, A. y J. Yepes

1940. Mamíferos Sudamericanos. EDIAR Editores, Buenos Aires.

Cabrera, A. y A. Willink

1980. Biogeografía de América Latina. Serie de Biología. Monografía 13. Secretaría General de la OEA. Programa regional de Desarrollo Científico y Tecnológico. Washington D.C.

Carden, N.

2004. Valga la redundancia. Arte Rupestre e información en el Macizo del Deseado. En: M. T. Civalero, P. Fernández y G. Guráieb (Comps.), Contra viento y marea. Arqueología de Patagonia, pp. 613-623. INAPL - SAA, Buenos Aires.

2007. Paisajes rituales y laberintos: relaciones entre dos sitios con grabados rupestres en Piedra Museo, Argentina. Boletín del Museo Chileno de Arte Precolombino 12(1): 43-60.

2008a. Estudio del arte rupestre de la Meseta Central de Santa Cruz. El área de los zanjones Blanco y Rojo, al sur del río Deseado. Tesis doctoral inédita de la Facultad de Ciencias Naturales de la Universidad Nacional de La Plata, La Plata.

2008b. Territories among hunter gatherers and the ritual dimension of landscapes: the Central Patagonian Plateau, Argentina. Before Farming 2008/1 artículo 1: 1-19.

2009a. Imágenes a Través del Tiempo. Arte Rupestre y Construcción Social del Paisaje en la Meseta Central de Santa Cruz. SAA, Buenos Aires.

2009b. Prints in the rocks: a study of tracks representations from Piedra Museo locality. Rock Art Research 26(1): 29-42.

2013. Sobre diseños, lugares y prácticas sociales en el macizo del Deseado. En I. Gordillo y J. M. Vaquer (Eds.), La Espacialidad en Arqueología. Enfoques, métodos y aplicación, pp. 31-75 Ediciones Abya-Yala, Quito.

Carden, N. y R. V. Blanco

2013. Measurements and replications of hand stencils: a methodological approach for the estimation of the individuals' age and sex. En R. Bednarik, D. Fiore y M. Basile (Eds.), Paleoart and Materiality. The scientific study of rock art, pp. 30. En prensa. 
Carden, N. M. y M. F. Borella

2014. Primeros datos sobre arte rupestre costero en Patagonia. Los petroglifos de Punta Odriozola (Río Negro, Argentina). Ponencia presentada en las IX Jornadas de Arqueología de Patagonia, Coyhaique, Chile.

Carden, N.; L. Magnín y L. Miotti.

2009. Distribución de figuras animales y dinámica poblacional: un estudio comparativo en Patagonia (provincia de Santa Cruz, Argentina). En M. Sepúlveda, L. Briones y J. Chacama (Eds.), Crónicas sobre la piedra. Arte Rupestre de las Américas, pp. 153-173. Arica: Ediciones Universidad de Tarapacá.

Carden, N.; D.G. Poiré; R.V. Blanco; L.A. Magnín; C. Genazzini y P. García 2011. Análisis DRX en pigmentos de la localidad La Primavera (Santa Cruz, Argentina): hacia la contextualización espacio-temporal de la producción de arte rupestre. En A. F. Zangrando, R. Barberena, A. Gil y G. Neme (Comps.), Libro de resúmenes de las VIII Jornadas de Arqueología de la Patagonia, p. 22, Centro de Convenciones y Exposiciones Thesaurus, Museo de Historia Natural de San Rafael, Malargüe.

Carden, N.; R. V. Blanco; D. Poiré; C. Genazzini; L. Magnín y P. García

2014. Análisis de pigmentos del macizo del Deseado: hacia la contextualización espacio temporal de la producción de pinturas en Cueva Maripe (Santa Cruz, Argentina). Relaciones de la Sociedad Argentina de Antropología XXXIX (2), 33 pags, en prensa.

Cardich, A.

1977. Las culturas Pleistocénicas y post-pleistocénicas de Los Toldos y un bosquejo de la Prehistoria de Sudamérica. Obra del Centenario del Museo de la Plata II: 149172.

1979. A propósito de un motivo sobresaliente en las pinturas rupestres de "El Ceibo" (Provincia de Santa Cruz, Argentina). Relaciones de la Sociedad Argentina de Antropología XIII: 163-182.

1987. Arqueología de Los Toldos y El Ceibo (Provincia de Santa Cruz, Argentina). Investigaciones Paleoindias al sur de la línea ecuatorial. Estudios Atacameños 8: 98-117.

Cardich, A. y N. Flegenheimer

1978. Descripción y tipología de las industrias líticas más antiguas de Los Toldos. Relaciones de la Sociedad Argentina de Antropología XII: 225-242. 
Cardich, A. y L. Miotti

1983. Recursos faunísticos en la economía de los cazadores de Los Toldos (Santa Cruz, Argentina). Relaciones de la Sociedad Argentina de Antropología XV: 145- 157.

Cardich, A.; L. Cardich y A. Hajduk

1973. Secuencia arqueológica y cronología radiocarbónica de la Cueva 3 de Los Toldos (Santa Cruz, Argentina). Relaciones de la Sociedad Argentina de Antropología VII: 87-122.

Cardich; A.; E. Mansur, J. M. Franchomme; M. Giesso, M. y V. Durán 1981-82. Arqueología de las cuevas de El Ceibo, Provincia de Santa Cruz. Argentina. Relaciones de la Sociedad Argentina de Antropología XIV (2): 173-209.

Cardich, A.; R. S. Paunero y A. S. Castro

1993-94. Análisis de los conjuntos líticos de la cueva 2 de Los Toldos (Santa Cruz, Argentina), Anales del Instituto de la Patagonia. Serie Ciencias Humanas XXII: 149-173.

Carrasco, C.

2003. Los artefactos de molienda durante los períodos Intermedio Tardío y Tardío en San Pedro de Atacama y Loa Superior. Estudios Atacameños 25: 35-53.

Casamiquela, R.

1960. Sobre la Significación Mágica del Arte Rupestre Nordpatagónico. Cuadernos del Sur, Instituto de Humanidades de la Universidad Nacional del Sur, Bahía Blanca.

1968. Novedades interpretativas con relación a nuevos yacimientos con grabados rupestres del norte de la Patagonia. Actas y Memorias. XXXVII Congreso Internacional de Americanistas, Tomo III, pp. 375-394. Buenos Aires.

1980. El Arte Rupestre de la Patagonia. Siringa Libros, Neuquén.

Cattáneo, R.

2002. Una aproximación a la organización de la tecnología lítica entre los cazadoresrecolectores del Holoceno medio/Pleistoceno final en la Patagonia Austral (Argentina). Tesis doctoral inédita de la Facultad de Ciencias NaturalesUniversidad Nacional de La Plata, La Plata.

Ceballos, R. y A. Peronja

1983. Informe preliminar sobre el arte rupestre de la Cueva Visconti, provincia de Río Negro. Relaciones de la Sociedad Argentina de Antropología XV: 109-119 
Chalmin, E.; M. Menu y C. Vignaud

2003. Analysis of rock art painting and technology of Palaeolithic painters. Measurement Science and Technology 14: 1590-1597.

Childe, G.

1955. Man Makes Himself. The New American Library, New York.

Claraz, J.

1988. Diario de Viaje de Exploración al Chubut 1865-1866. Marymar, Buenos Aires.

Clottes J., M. Menu y P. Walter

1990a. La preparation des peintures magdaleniennes des cavernes ariegeoises. Bulletin de la SocietePrehistorique Francaise. 87(6): 170-192.

1990b. New light on Niaux paintings. Rock Art Research 7: 21-26

Corbella, H.

1984. Contribución al conocimiento geológico de la alta Sierra del Somuncurá. Macizo de Norpatagonia, provincia de Río Negro, República Argentina. Revista Asociación Geológica Argentina 29 (2): 155-170.

Criado Boado, F.

1991. Construcción social del espacio y reconstrucción arqueológica del paisaje. Boletín de Antropología Americana 24: 5-29

1999. Del Terreno al espacio: planteamientos y perspectivas para la arqueología del paisaje. CAPA 6: 1-58.

Crivelli Montero, E. A.

1987. La "Casa de Piedra de Ortega" y el problema del Patagoniense Septentrional. Comunicaciones Primeras Jornadas de Arqueología de la Patagonia, pp. 75-83. Dirección Provincial de Cultura- Gobierno de la Provincia del Chubut, Rawson.

1988. Tres sitios con arte rupestre de la banda rionegrina de Alicurá. Anales de la Sociedad Científica Argentina 218: 1-9.

2006. Frecuencia de creación de sitios con arte rupestre en la cuenca media y superior del río Limay (noroeste de Patagonia). En D. Fiore y M. M. Podestá (Eds.), Tramas en la Piedra. Productos y Usos del Arte Rupestre, pp. 63-83. WAC- SAA- AAINA- , Buenos Aires.

Crivelli Montero, E. A. y M. M. Fernández

1996. Paleoindian bedrock petroglyphs at Epullán Grande Cave, Northern Patagonia, Argentina. Rock Art Research 13(2): 124-28.

2003. Grabados en el piso de cuevas de la cuenca del río Limay (Patagonia Septentrional) Datos adicionales y discusión. Rupestre Digital 5: 40-47. 
Crivelli Montero, E. A.; M. Fernández y U. Pardiñas

1991. Diversidad estilística, cronológica y contextual en sitios con arte rupestre del Área de Piedra del Águila. En M. Podestá, M. I. Hernández Llosas y S. Renard de Coquet (Eds.), El Arte Rupestre en la Arqueología Contemporánea, pp. 113-122. Buenos Aires.

Crivelli Montero, E. A., U. F. J. Pardiñas, M. Fernández, M. Bogazzi, A. Chauvin, V. M. Fernández y M. J. Lezcano

1996. La Cueva Epullán Grande (provincia del Neuquén, Argentina). Informe de avance. Praehistoria 2: 185-265.

Croce, R.

1956. Formaciones características en las estructuras basales de la altiplanicie de Somuncurá (Río Negro). Revista Asociación Geológica Argentina 11(3): 158-201.

1963. El sistema del Somuncurá. Las Altas Sierras del Somuncurá y sus aledaños. Revista del Museo Argentino de Ciencias Naturales Bernardino Rivadavia, Ciencias Geológicas 6: 303-321.

Crumley, C; A. Deventer y J. Fletcher.

2001. New directions in Anthropology and Enviroment: Intersections. Altamira Press, New York.

Cueto, M. y A. Frank

2010. Prueba experimental del trabajo del hueso con herramientas líticas. Tratamiento térmico y manifestación de trazas de uso. Patagonia, Argentina. Boletín de Arqueología Experimental 8: 13-23.

Curtoni, R.

2011. Mapu-kó: el paisaje hecho agua. En D. Hermo y L. Miotti (Eds.), Biografía de Paisajes y Seres. Visiones Desde la Arqueología Sudamericana, pp. 99-110. Encuentro Grupo Editor, Córdoba.

Darvill, T.

2008. Pathways to a panoramic past: a brief history of European landscape archaeology.

En B. David y J. Thomas (Eds.), Handbook of Landscape Archaeology, pp. 60-76.

WAC- Research Handbooks in Archaeology- Left Coast Press, California.

David B. y J. Thomas

2008. Landscape Archaeology: Introduction. En B. David y J. Thomas (Eds.), Handbook of Landscape Archaeology, pp. 27-43. WAC- Research Handbooks in ArchaeologyLeft Coast Press, California. 
De Aparicio, F.

1933-35. Viaje preliminar de exploración en el territorio de Santa Cruz. Publicaciones Museo Antropológico y Etnográfico de la Facultad de Filosofía y Letras. Serie A III: 71-92.

Dobres, M.-A.

1999. Technology's links and chaînes: the processual unfolding of technique and technician. En M.-A. Dobres y C. R. Hoffman (Eds.), The Social Dynamics of Technology, pp. 124-146. Smithsonian Institution Press, Washington- Londres.

Dobres, M.-A. y C. Hoffman.

1994. Social agency and the dinamics of prehistoric technologies. Journal of Archaeological Methods and Theory 1(3): 211- 258.

Durán, V.

1983-85. El arte rupestre de los cazadores patagónicos en El Verano, área de Departamento de Magallanes, Provincia de Santa Cruz (II). Anales de Arqueología y Etnología 38-40: 43-75.

Eco, U.

2002. Cómo se Hace una Tesis. Técnicas y Procedimientos de Estudio, Investigación y Escritura. Gedisa Editorial, Madrid.

Falkenström, P.

2006. A matter of choice: social implications of raw material variability. En J. Apel y K. Knutsson (Eds.), Skilled Production and Social Reproduction. Aspects on Traditional Stone-Tool Technologies, Proceedings from an International Symposium held in Uppsala August 20-24, 2003, pp. 347-359. Societas Archaeologica Upsaliensis- SAU Stone Studies 2, Uppsala.

Fernández, M.

2003-05. Arte rupestre y ocupaciones prehistóricas en Rincón Chico 2/87. Cuadernos del Instituto Nacional de Antropología y Pensamiento Latinoamericano 20: 107-129.

2006. Cronología del Estilo de Grecas en la cuenca superior y media del río Limay. En

D. Fiore y M. M. Podestá (Eds.), Tramas en la Piedra. Productos y Usos del Arte Rupestre, pp. 73-83. WAC- SAA- AAINA, Buenos Aires.

Fernández, M. y E. Crivelli

2004. Excavaciones de rescate en Rincón Chico2/87, prov. del Neuquén. En M. T. Civalero, P. Fernández y A. Guráieb (Comps.), Contra Viento y Marea. Arqueología de Patagonia, pp. 701-714. INAPL- SAA, Buenos Aires. 
Fernández, P.; C. Bellelli; M. Carballido Calatayud y M. M. Podestá

2013. Tiempo de cazadores. Cronología de las ocupaciones humanas en el valle del río Manso Inferior. A. F. Zangrando, R. Barberena, A. Gil, G. Neme, M. Giardina,L. Luna, C. Otaola, S. Paulides, L. Salgán y A. Tivoli (Comps.), Tendencias Teóricometodológicas y Casos de Estudio en la Arqueología de la Patagonia, pp. 167-175. Museo de Historia Natural de San Rafael, San Rafael.

Ferraro, L. y R. Molinari

2006. Uso y valoración de las altas mesetassantacruceñas a partir del estudio del arte rupestre. Lago Strobel (Argentina). En D. Fiore y M. M. Podestá (Eds.), Tramas en la Piedra. Producción y Usos del Arte Rupestre, pp. 95-102. WAC- SAA- AAINA, Buenos Aires

2010. ¡Último momento! El arte de los cazadores recorre el lago Cardiel y se dirige al Strobel. En Oliva F.; N. de Grandis y J. Rodríguez (Eds.), Arqueología Argentina en los Inicios de un Nuevo Siglo, Tomo 3, pp. 523-534. Laborde Libros editor, Rosario.

Fiore, D.

1996. El arte rupestre como producto complejo de procesos ideológicos y económicos: una propuesta de análisis. Espacio, Tiempo y Forma 9: 239-259.

1996-98. Técnicas y artefactos para realizar grabados rupestres. Una investigación bibliográfica. Palimpsesto 5: 208-222.

1999. Cuestiones teórico-metodológicas e implicaciones arqueológicas en la identificación de artefactos utilizados en la producción de grabados rupestres. Hacia una arqueología del arte rupestre. Relaciones de la Sociedad Argentina de Antropología XXIV: 277-291.

2006. Poblamiento de imágenes: arte rupestre y colonización de la Patagonia. Variabilidad y ritmos de cambio en tiempo y espacio. En D. Fiore y M. M. Podestá (Eds.), Tramas en la Piedra. Producción y Usos del Arte Rupestre, pp. 43-61. WACSAA- AAINA, Buenos Aires.

2007. The economic side of rock art: concepts on the production of visual images. Rock Art Research 24(2): 149-160.

2009. La materialidad del arte. Modelos económicos, tecnológicos y cognitivos-visuales. En R. Barberena, K. Borrazo y L. A. Borrero (Eds.), Perspectivas Actuales en Arqueología Argentina, pp. 121-154. IMHICIHU, Buenos Aires.

2011. Materialidad visual y arqueología de la imagen. Perspectivas conceptuales y propuestas metodológicas desde el sur de Sudamérica. Boletín del Museo Chileno de Arte Precolombino 16(2): 101-119.

2012. Images made on stone: Argentina, 2005-2009. En P. G. Bahn, N. Franklin y M. Strecker (Eds.), Rock Art Studies: News of the World IV, pp. 364-385. Oxbow, Oxford. 
Fiore, D. y M. I. Hernández Llosas

2007. Miradas rupestres: tendencias en la investigación del arte parietal en Argentina. Relaciones de la Sociedad Argentina de Antropología XXXII: 217-242.

Fiore, D. y M. Ocampo

2009. Arte rupestre de la región margen Norte del Río Santa Cruz: una perspectiva distribucional. M. Salemme, F. Santiago, M. Álvarez, E. Piana, M. Vázquez y M. E. Mansur (Eds.), Arqueología de Patagonia: una Mirada Desde el Último Confín, pp. 499-513. Editorial Utopías, Ushuaia.

Fiore, D. y M. M. Podestá

2006. Introducción. Tramas conceptuales del arte rupestre. En D. Fiore y M. M. Podestá (Eds.), Tramas en la Piedra. Producción y usos del arte rupestre, pp. 13-32. WACSAA- AAINA, Buenos Aires.

Fiore, D.; A. Acevedo; N. Franco y M. Ocampo

2012. Cuantificando el arte rupestre. El uso de datos cuantitativos básicos en el análisis de repertorios rupestres y composiciones visuales. En M. Strecker (Comp.), Contribuciones al Estudio del Arte Rupestre Sudamericano 7. Congreso Internacional Arqueología y Arte Rupestre 25 años SIARB, pp. 28-29. SIARB, La Paz.

Fowler, C. and Cummings, V.

2003. Places of transformation: building monuments from water and stone in the Neolithic of the Irish Sea. Journal of the Royal Anthropological Institute 9: 1-21.

Franchomme, J. M.

1987. L'art Rupestre de Patagonie: quelques sites Prehistoriques du Plateau Central, Province de Santa Cruz, Argentine. Tesis doctoral inédita de la Universidad de París X. Nanterre.

Franco, N. V.

2008. La estructura tecnológica regional y la comprensión de la movilidad humana: tendencias para la cuenca del río Santa Cruz. En L. A. Borrero y N. V. Franco (Coords.), Arqueología del Extremo sur del Continente Americano. Resultados de Nuevos Proyectos, pp. 119-154. CONICET- IMHICIHU, Buenos Aires.

Franco, N.; P. Ambrústolo; A. Acevedo; N. Cirigliano y M. Vommaro

2013. Prospecciones en el sur del macizo del deseado (provincia de Santa Cruz, Argentina). Los casos de La Gruta y Viuda Quenzana. En A. F. Zangrando, R. Barberena, A. Gil, G. Neme, M. Giardina,L. Luna, C. Otaola, S. Paulides, L. Salgán y A. Tivoli (Comps.), Tendencias Teórico-metodológicas y Casos de Estudio en la 
Arqueología de la Patagonia, pp. 371-378. Museo de Historia Natural de San Rafael, San Rafael.

Franco, N.; M. Cardillo y C. Otaola

2007a. Resultados de los trabajos exploratorios realizados en la margen norte del río Santa Cruz (provincia de Santa Cruz, Argentina). En F. Morello, M. Martinic, A. Prieto y G. Bahamonde (Eds.), Arqueologia de Fuego-Patagonia. Levantando piedras, Desenterrando Huesos... y Develando Arcanos, pp. 541-553. Ediciones CEQUA, Punta Arenas.

Franco, N., M. Cardillo, C. Otaola, N. Arregui, E. Gaal

2007b. Tendencias preliminares en el registro arqueológico del curso medio y superior del arroyo El Lechuza, provincia de Santa Cruz, Argentina. Intersecciones en Antropología 8: 271-285.

Frank, A.

2011. Tratamiento térmico y manejo del fuego en sociedades cazadoras recolectoras de la Meseta Central de Santa Cruz. Tesis doctoral inédita de la Facultad de Ciencias Naturales y Museo- Universidad Nacional de La Plata, La Plata.

Gándara, M.

1990. Algunas notas sobre el análisis del conocimiento. Boletín de Antropología Americana 22: 5-20.

2006. La inferencia por analogía: más allá de la analogía etnográfica. Treballs $D^{\prime}$ Etnoarqueología 6: 13-23.

García, L. y C. Pérez de Micou

1980. Aproximación a un análisis funcional de parapetos pertenecientes al complejo Patagoniense en la meseta de Somuncurá, provincia de Río Negro. Sapiens 4: 139144.

García Roselló, J.

2009. Cadena operativa, forma, función y materias primas. Un Aporte a través de la producción cerámica del centro de Chile. Relaciones de la Sociedad Argentina de Antropología XXXIV: 123-148.

Gerónimo, A. y S. Hocsman

2011. Rock art at Cueva de Cristobal (Puna of Jujuy, Argentina): new evidence. INORA 60: 8-13. 
Giardina, M.; D. Hermo; L. Miotti y M. Vázquez

2000. Capítulo. 4.5. Resolución e integridad arqueológica del Componente inferior de Piedra Museo. En L. Miotti, R. Paunero, M. Salemme y R. Cattáneo (Comps.). Guía de Campo de la Visita a las Localidades Arqueológicas. Taller Internacional "La Colonización del Sur de América Durante la Transición Pleistoceno/Holoceno”, pp. 79-83. Servicoop, La Plata.

Gómez Otero, J. y C. Stern

2005. Circulación, intercambio y uso de obsidianas en la costa de la provincia del Chubut (Patagonia, Argentina) durante el Holoceno tardío. Intersecciones en Antropología 6: 93-108.

González Díaz, E. y E. Malagnino

1984. Geomorfología. En V. A. Ramos (Ed.), Geología y Recursos Naturales de la Provincia de Río Negro, $9^{\circ}$ Congreso Geológico Argentino, Relatorio 1(13): 347-364.

Goñi, R.

2010. Cambio climático y poblamiento humano durante el Holoceno tardío en Patagonia meridional. Una perspectiva arqueológica. Tesis doctoral inédita de la Facultad de Filosofía y Letras de la Universidad Nacional de Buenos Aires, Buenos Aires.

Goñi, R., J. B. Belardi, S. Espinosa y F. Savanti

2004. Más vale tarde que nunca: cronología de las ocupaciones cazadoras-recolectoras en la cuenca del lago Cardiel (Santa Cruz, Argentina). En M. T. Civalero, P. Fernández y A. Guráieb (Comps.), Contra Viento y Marea. Arqueología de Patagonia, pp. 237-248. INAPL- SAA, Buenos Aires.

Goñi, R.; J. B. Belardi; A. Re; A. Nuevo Delaunay; R. Molinari y L. Ferraro

2007. Los grabados de la meseta del Lago Strobel (Patagonia argentina) desde una perspectiva regional. En R. Hostnig, M. Strecker y J. Guffroy (Eds.), Actas del Primer Simposio Nacional de Arte Rupestre (Cuzco, noviembre de 2004), pp. 427438. IFEA- IRD- Embajada de la República Federal de Alemania, Lima.

Goñi, R. A; G. Cassiodoro; A. Re; F. Guichón; J. Flores Coni y J. Dellepiane.

2010. Arqueología de la meseta del lago Guitarra (Santa Cruz). En R. Bárcena y H. Chiavazza (Eds.), Arqueología Argentina en el Bicentenario de la Revolución de Mayo, XVII Congreso Nacional de Arqueología Argentina, Tomo V: 1923-1928. UNCuyo- CONICET, Mendoza

Gradin, C.

1959-60a. Petroglifos de la meseta del lago Strobel (provincia de Santa Cruz, Argentina). Acta Praehistorica III/IV: 123-143. 
1959-60b. Tres informaciones referentes a la Meseta del Lago Strobel. Acta Praehistorica III/IV: 144-149.

1962. Tres informaciones referentes a la meseta del Lago Strobel (Prov. De Santa Cruz, Argentina). Acta Praehistorica III-IV: 144-149.

1971. Parapetos habitacionales en la meseta de Somuncurá, Provincia de Río Negro. Relaciones de la Sociedad Argentina de Antropología V(2): 171-185.

1972. Noticia preliminar sobre el cañadón Supayniyeu. La industria lítica de paso Burgos. Provincia de Río Negro. Relaciones de la Sociedad Argentina de Antropología VI: 211-224.

1973. El alero de las Manos Pintadas (Las Pulgas, provincia de Chubut, Argentina). Bollettino del Centro Camuni di Studi Historici X: 169-207.

1976. Parapetos de piedra y grabados rupestres de la meseta del lago Buenos Aires. Actas y Memorias del IV Congreso Nacional de Arqueología Argentina, tomo III(1/4): 315-337. San Rafael, Mendoza.

1977. Pinturas rupestres del Alero Cárdenas, provincia de Santa Cruz. Relaciones de la Sociedad Argentina de Antropología XI: 143-158

1978. Algunos aspectos del análisis de las manifestaciones rupestres. Revista del Museo Provincial de Neuquén I: 120-137.

1979. Grabados de La Angostura del Deseado (provincia de Santa Cruz Argentina). En Actas del VII Congreso de Arqueología de Chile, Tomo II: 595-616, Santiago.

1980. Secuencias radiocarbónicas del sur de la Patagonia Argentina. Relaciones de la Sociedad Argentina de Antropología XIV: 177-194.

1981-82. Las pinturas de la Cueva Grande (Arroyo Feo). Area del Río Pinturas, provincia de Santa Cruz. Relaciones de la Sociedad Argentina de Antropología XIV(2): 241-265.

1983. El arte rupestre de la cuenca del río Pinturas, Provincia de Santa Cruz, República Argentina. Ars Praehistorica II: 87-149.

1984. Arqueología y arte rupestre de los cazadores prehistóricos de Patagonia. En Las culturas de América en la Época del Descubrimiento, Seminario Sobre la Situación de la Investigación de las Culturas Indigenas de Patagonia, pp. 37-58. Técnicas gráficas Forma, Madrid.

1985. Área de los cazadores meridionales (Pampa-Patagonia). En J. Schobinger y C. Gradin (Eds.), Arte Rupestre de la Argentina. Cazadores de la Patagonia y Agricultores Andinos. Ediciones Encuentro, Madrid.

1987. Tendencias estilísticas del arte rupestre de Patagonia Central y meridional. Primeras Comunicaciones de las Jornadas de Arqueología de Patagonia, pp. 139144. Publicación del Gobierno de la Provincia del Chubut, Rawson.

1988. Caracterización de las tendencias estilísticas del arte rupestre de la Patagonia (Provincias de Río Negro, Chubut y Santa Cruz, República Argentina). Contribuciones al Estudio del Arte Rupestre Sudamericano 2: 54-67. 
1996. Grabados y parapetos de la zona sur de la Meseta del Lago Buenos Aires (provincia de Santa Cruz). En J. Gómez Otero (Ed.), Arqueología. Sólo Patagonia, pp. 173-184. CENPAT- CONICET, Puerto Madryn.

1999. Sobre las tendencias del arte rupestre de Patagonia argentina. En Segundas Jornadas de Investigadores en Arqueología y Etnohistoria del Centro-oeste del País, pp. 85-99. Universidad de Río Cuarto, Río Cuarto.

2001. El arte rupestre de los cazadores de guanaco de la Patagonia. En E. Berberián y A. Nielsen (Eds.), Historia Argentina Prehispánica, Tomo 2: 839-874. Editorial Brujas, Córdoba.

2003a. El arte rupestre de Río Negro. En C. J. Gradin, A. M. Aguerre y A. M. Albornoz (Eds.), Arqueología de Río Negro, pp. 41-49. Secretaría de Estado de Acción Social de Río Negro, Viedma.

2003b. Nuevos sitios: el Bajo del Gualicho y Yamnago (Somuncurá) y otros con Arte Rupestre. En C. J. Gradin, A. M. Aguerre y A. M. Albornoz (Eds.), Arqueología de Río Negro, pp. 51-77. Secretaría de Estado de Acción Social de Río Negro, Viedma.

2003c. Grabados de Estancia "La Flecha", Gobernador Gregores- Provincia de Santa Cruz. En A. Aguerre (Comp.), Arqueología y Paleoambiente en la Patagonia Santacruceña Argentina, pp. 121-137. Nuevo Offset, Buenos Aires.

Gradin, C. y A. M. Aguerre

1983. El arte rupestre del "Área La Martita". Sección A del Departamento Magallanes, Provincia de Santa Cruz. Relaciones de la Sociedad Argentina de Antropología XV: 195-223.

1994. Contribución a la arqueología del Río Pinturas, Provincia de Santa Cruz. Colección "Estudios arqueológicos". Búsqueda de Ayllú, Concepción del Uruguay.

2003. Investigaciones arqueológicas en el Cañadón Santa Victoria. Meseta de El CuyRío Negro. En C. J. Gradin, A. M. Aguerre y A. M. Albornoz (Eds.), Arqueología de Río Negro, pp. 19-40. Secretaría de Estado de Acción Social de Río Negro, Viedma.

Gradin C. J., C. Aschero y A. M. Aguerre

1976. Investigaciones arqueológicas en la Cueva de las Manos, Estancia Alto Río Pinturas (Provincia de Santa Cruz). Relaciones de la Sociedad Argentina de Antropología X: 201-250.

1979. Arqueología del Área Río Pinturas. Relaciones de la Sociedad Argentina de Antropología XII: 183-227.

Groenen, M.

1988. Les représentations de mains négatives dans les grottes de Gargas et de Tibirán (Hautes-Pirinées) Approche méthodologique. Bulletin de la Société Royale Belge d'Anthropologie et de Préhistoire 9: 81-113. 
Guichón, F.

2012. Representaciones rupestres del sector norte de la meseta del Strobel: escalas espaciales y tendencias temporales. Tesis de licenciatura inédita de la Facultad de Ciencias Sociales de la Universidad Nacional del Centro de la Provincia de Buenos Aires, Olavarría.

Gunn, R. G.

2006. Hand sizes in rock art: interpreting the measurements of hand stencils and prints. Rock Art Research 23 (1): 97-112.

2007. Rock-art in the Tolmer sandstones, Northern Territory, Australia. Before Farming 2003/2 (7)

Hajduk , A.; P. Arias P.; A. M. Chauvin; A. M. Albornoz; A. Armendariz; M. Cueto; P. Fernández Sánchez; V. Fernández; S. Goye; M. Lezcano; J. Tapia y L. C. Teira

2007. Poblamiento temprano y arte rupestre en el área del lago Nahuel Huapi y cuenca del río Limay (pcias. De Río Negro y Neuquén, Argentina). En Resúmenes Ampliados del XVI Congreso Nacional de Arqueología Argentina, Tomo III: 393399. Universidad Nacional de Jujuy- Ediciones Pacarina, San Salvador de Jujuy.

Harman, J.

2008 (2005). Using Decorrelation Stretch to enhance Rock Art Images http://www.dstretch.com/AlgorithmDescription.html

2011. DStretch Help. http://www.dstretch.com/DStretchHelp.html

Harrington, H. J.

1962. Paleogeographic development of South America. Bulletin of the American Association of Petroleum Geologists 46(10): 1773-1814.

Hartley, R.

1992. Rock Art on the Northern Colorado Plateau: Variability in Content and Context. Brookfield, Avebury.

Hermo, D.

2008. Los cambios en la circulación de las materias primas líticas en ambientes mesetarios de Patagonia. Una aproximación para la construcción de los paisajes arqueológicos de las sociedades cazadoras-recolectoras. Tesis doctoral inédita de la Facultad de Ciencias Naturales- Universidad Nacional de La Plata, La Plata.

Hermo, D. y L. Magnín

2012. Blade and bifacial technology in Mid-Holocene occupations at Deseado Massif, Santa Cruz province, Argentina. Quaternary International 256: 71-77. 
Hermo, D. y E. Terranova

2012. Formal variability in fishtail points of the Amigo Oeste archaeological site, Somuncurá Plateau (Río Negro, Argentina). En L. Miotti, M. Salemme, N. Flegenheimer y T. Goebel (Eds.), Southbound: Late Pleistocene Peopling of Latin America, pp. 121-126. Center for the Study of the First Americans - A\&M Texas University, Texas.

Hermo, D.; E. Terranova; B. Mosquera y J. Frutos

2013a. Base regional de recursos líticos en la meseta de Somuncurá: primeros resultados en la cuenca del arroyo Talagapa (Río Negro, Argentina). En A. F. Zangrando, R. Barberena, A. Gil, G. Neme, M. Giardina,L. Luna, C. Otaola, S. Paulides, L. Salgán y A. Tivoli (Comps.), Tendencias Teórico-metodológicas y Casos de Estudio en la Arqueología de la Patagonia, pp. 109-118. Museo de Historia Natural de San Rafael, San Rafael.

Hermo, D.; E. Terranova; L. Marchionni; L. Magnín; B. Mosquera y L. Miotti

2013b. Piedras o litos discoidales en norpatagonia: evidencias en la meseta de Somuncurá (Río Negro, Argentina). Intersecciones en Antropología 14: 507-514.

Hernández Llosas, M. I.

1985. Diseño de una guía para el relevamiento y clasificación de datos de sitios arqueológicos con arte rupestre. En C. Aldunate, J. Berenguer y V. Castro (Eds.), Estudios en Arte Rupestre, pp. 25-36. Museo Chileno de Arte Precolombino, Santiago de Chile.

Hicks, D. y M. Beaudry

2010. The Oxford Handbook of Material Culture Studies. Oxford University Press, Oxford.

Hollenback, K. y M. B. Schiffer.

2010. Technology and material life. En D. Hicks y M. Beaudry (Eds.), The Oxford Handbook of Material Culture Studies, pp. 313-332. Oxford University Press, Oxford.

Howes, D.

2006. Scent, sound and synaesthesia: intersensoriality and material culture theory. En C. Tilley, W. Keane, S. Kuechler, M. Rowlands y P. Spyer (Eds.), The Handbook of Material Culture, pp. 161-172. SAGE Publications, Londres.

Ingold, T.

1990. Society, nature and the concept of technology. Archaeological Review of Cambridge 9(1): 5-17. 
1993. The temporality of landscape. World Archaeology 25(2): 152-174.

2000. Making culture and weaving the world. En P. M. Graves-Brown (Ed.), Matter, Materiality and Modern Culture, pp. 50-71. Routledge, Londres.

Iñiguez, A. M. y C. Gradin

1977. Análisis mineralógico por difracción de rayos $\mathrm{X}$ de muestras de pinturas de Cueva de las manos. Ea. Alto río Pinturas. Relaciones de la Sociedad Antropológica Argentina XI: 121-128.

Iriarte, E., A. Foyo, M. A. Sánchez, C. Tomillo y J. Setién

2009. The origin and geochemical characterization of red ochres from the Tito Bustillo and Monte Castillo Caves (northern Spain). Archaeometry 51 (2): 231-251

Kay, S. M.; M. Gorring y V. A. Ramos

2004. Magmatic sources, setting and causes of Eocene to Recent Patagonian plateau magmatism ( $36^{\circ} \mathrm{S}$ to $52^{\circ} \mathrm{S}$ latitude). Revista de la Asociación Geológica Argentina 59(4): 556-568.

Kay, S. M.; A. A. Ardolino; M. L. Gorring y V. A. Ramos

2007. The Somuncura large igneous province in Patagonia: interaction of a transient mantle thermal anomaly with a subducting slab. Journal of Petrology 48(1): 43-77.

Keyser, J. D.

2001. Relative dating methods. En D. S. Whitley (Ed.), Handbook of Rock Art Research, pp. 116-138. AltaMira Press, California.

2007. Direct evidence for the use of indirect percussion in petroglyph manufacture. INORA 49: 25-27.

Keyser, J. D. y G. Rabiega

1999. Petroglyph manufacture by indirect percussion: the potential occurrence of tools and debitage in datable context. Journal of California and Great Basin Anthropology 21(1): 124-136.

Knutsson, K.

2006. A genealogy of reflexivity: the skilled lithic craftman as "scientist". En J. Apel y K. Knutsson (Eds.), Skilled Production and Social Reproduction. Aspects on Traditional Stoone-Tool Technologies, Proceedings from an International Symposium held in Uppsala August 20-24, 2003, pp. 153-186. Societas Archaeologica Upsaliensis- SAU Stone Studies 2, Uppsala. 
Leanza, A. F.

1958. Geología Regional. La Argentina: Suma de Geografía 1 (3): 217-349. Ed. Peuser, Buenos Aires.

Ledesma, R.

2005. Contexto de producción de pinturas rupestres en El Divisadero (Cafayate, Salta, República Argentina). Andes. Antropología e Historia 16: 305-323.

Lemonnier, $\mathrm{P}$.

1992. Elements for an Anthropology of Technology. Anthropological Papers, Museum of Anthropology, University of Michigan, No. 88. Ann Arbor, Michigan.

Lenssen-Erz, T.

2004. The landscape setting of rock paint-ing sites. En C. Chippindale y G. Nash (Eds.), Pictures in Place. The Figured Landscapes of Rock-Art, pp. 131-150. Cambridge University Press, Cambridge.

León, R. J. C.; D. Bran; M. Collantes; J. M. Paruelo y A. Soriano

1998. Grandes unidades de vegetación de la Patagonia extra andina. Ecología Austral 8: $125-144$.

Leroi Gourhan, A.

1964. Le Geste et la Parole. PUF, París

1976. Sur les aspects socio-économiques de l'art paléolithique. L'autre et l'ailleurs. Hommages a Roger Bastide, S. 1. Berger-Levrault.

Lewis-Williams, J. D. y T. A. Dowson.

1989. Images of Power: Understanding Bushman Rock Art. Southern Book Publishers. Johannesburg.

Llamazares, A. M.

1980. El arte rupestre del Abrigo de Pilcaniyeu, Prov. de Río Negro. Relaciones de la Sociedad Argentina de Antropología XIV: 103-120.

1989. El estilo "Pisadas" en la Patagonia argentina. Análisis de su formulación y algunos datos sobre una posible modalidad septentrional. Boletín de la SIARB 3: 48-56.

Llambías, E., Caminos, R. y Rapela, C.

1984. Las plutonitas y vulcanitas del ciclo eruptivo gondwánico. En V. Ramos (Ed.), Geología y Recursos Naturales de Río Negro, $9^{\circ}$ Congreso Geológico Argentino, Relatorio 1(4): 85-117. Buenos Aires. 
Lorblanchet, M.

1991. Spitting images: replicating the spotted horses at Pech Merle. Archaeology 44: 2431.

Lumbreras, L.

1984. La Arqueología Como Ciencia Social. Colección Investigaciones Casa de las Américas. La Habana.

Magnín, L.

2010. Distribuciones arqueológicas en la meseta central de Santa Cruz: Implicancias para los estudios de uso del espacio y movilidad de sociedades cazadoras recolectoras. Tesis doctoral inédita de la Facultad de Ciencias NaturalesUniversidad Nacional de La Plata, La Plata.

2013. Análisis de visibilidad aplicado a estructuras rocosas en la localidad La Primavera, Santa Cruz. Revista Arqueología: 1-21.

https://sites.google.com/site/revistaarqueologia2/home/arqueologia-19

McDonald, J.

1995. Looking for a woman's touch; Indications of gender in sherlters sites in the Sydney Basin. En J. Balme y W. Beck (Eds.), Gendered Archaeology, The Second Australian Women in Archaeology Conference, pp. 92-96. ANH PublicationsRSPAS- The Australian National University, Canberra.

Maier, M. S.; D. de Faría; M. T. Boschin y S. D. Parera

2006. Characterization of reference lipids and their degradation products by Raman spectroscopy, nuclear magnetic resonance and gas chromatography-mass spectrometry. ARKIVOC 12: 311-318.

Maier, M.S.; D. de Faria; M. T. Boschin; S. D. Parera y M.F. del Castillo Bernal 2007. Combined use of vibrational spectroscopy and GC-MS methods in the characterization of archaeological pastes from Patagonia. Vibrational Spectroscopy 44: 182-186.

Manhire, A.

1998. The role of hand Prints in the rock art of the South-Western Cape. The South African Archaeological Bulletin 53(168): 98-108.

Marchione, P. C. y C. Bellelli

2013. El trabajo del cuero entre los cazadores-recolectores de la Patagonia centroseptentrional. Campo Moncada 2 (valle medio del río Chubut). Relaciones de la Sociedad Argentina de Antropología XXXVIII(1): 223-246. 
Marchionni, L.

2013. Comparación de las distintas historias tafonómicas en conjuntos zooarqueológicos provenientes de la Meseta Central de la provincia de Santa Cruz. Tesis doctoral inédita de la Facultad de Ciencias Naturales- Universidad Nacional de La Plata, La Plata.

Marchionni, L.; L. Miotti y B. Mosquera

2010. El uso de la fauna entre el Pleistoceno final y el Holoceno medio en la Patagonia extra-andina. En M. Gutiérrez, M. De Nigris, P. Fernández, M. Giardina, A. Gil, A. Izeta, G. Neme y H. Yacobacio (Eds.), Zooarqueología a Principios del Siglo XXI: Aportes Teórico, Metodológicos y Casos de Estudio, pp. 259-272. Ediciones del Espinillo, Buenos Aires.

Marchionni, L.; B. Mosquera y E. García Añino

2012. Analysis of zooarchaelogical and taphonomical variability from Maripe Cave Site, Santa Cruz Province, Argentinian Patagonia. Quaternary International 279: 12-21.

Mark, R. y E. Billo

2009. Applications of digital image processing to rock art documentation. En Global Rock Art. Anais do Congresso Internacional de Arte Rupestre IFRAO Fundhamentos IX (1), pp. 515- 520. Piauí (Brasil), Fundação Museu do Homen Americano. CD-Rom, Artigo 39

Maro, G. y M. Remesal

2012. El Volcanismo bimodal del Cerro Cornoa, Alta Sierra de Somun Curá, provincia de Río Negro. Revista Asociación Geológica Argentina 69(1): 142-151.

Martel, A.; S. Rodríguez y E. Del Bel

2012. Arte rupestre y espacios de memoria: las representaciones del sitio Confluencia (Antofagasta de la Sierra, Catamarca, Argentina). Revista de Antropología 25 (1er semestre): 121-162.

Massaferro, G.; G. Arrigoni, M. T. Boschin, M. Fernández, E. A. Crivelli y J. A. Cordero 2012. Indicadores de tecnología y etnodinamia: el análisis de pigmentos en el paraje arqueológico Comallo Arriba, provincia de Río Negro, Argentina. Boletín del Museo Chileno de Arte Precolombino 17(1): 117-127

Mauss, M.

1971. Sexta Parte: Técnicas y movimientos corporales. En Sociología y Antropología, pp. 337-358. Tecnos, Madrid. 
Maynard, L.

1977. Classification and terminology in Australian rock art. En P. Ucko (Ed.), Form in Indigenous Art, pp. 387-402. Australian Institute of Aboriginal Studies, Canberra.

Mazzoni, E.

2001. Distribución espacial y caracterización geomorfológica de "Bajos sin salida" de la

Patagonia Austral Extracordillerana. Anales del Instituto de la Patagonia. Serie Ciencias Naturales 29: 5-24.

Méndez, C.

2008. Cadenas operativas en la manufactura de arte rupestre: un estudio de caso en El Mauro, valle cordillerano del Norte Semiárido de Chile. Intersecciones en Antropología 9: 145-155.

Menghin, O.

1952. Las pinturas rupestres de la Patagonia. Runa V: 5-22.

1957. Estilos del arte rupestre de Patagonia. Acta Praehistorica I: 57-87.

Mengoni Goñalons, G. L. y M. Silveira

1976. Análisis e interpretación de los restos faunísticos de la cueva de las Manos, Estancia Alto Río Pinturas (Provincia de Santa Cruz). Relaciones de la Sociedad Argentina de Antropología X: 261-270.

Methol, E.

1967. Rasgos geomorfológicos de la meseta de Somuncurá, Río Negro. Consideraciones acerca de los orígenes de los "pequeños bajos sin salida". Revista Asociación Geológica Argentina 22(4): 295-311.

Miller, D. y C. Tilley

1996. Editorial. Journal of Material Culture 1(1): 5-14.

Miotti, L.

1991. Manifestaciones rupestres en Santa Cruz: la localidad arqueológica Piedra Museo. En M. M. Podestá, M. I. Hernández Llosas y S. F. Renard de Coquet (Eds.), El Arte Rupestre en la Arqueología Contemporánea, pp. 132-138. Buenos Aires.

1992. Paleoindian occupation at Piedra Museo Locality, Patagonian Region, Argentina. Current Research in the Pleistocene 9: 30-32.

1996. Piedra Museo (Santa Cruz), nuevos datos para la ocupación pleistocénica en Patagonia. En J. Gómez Otero (Ed.), Arqueología. Sólo Patagonia, pp. 27-38. CENPAT-CONICET, Puerto Madryn. 
1998. Zooarqueología de la Meseta Central y la Costa de la Provincia de Santa cruz. Un Enfoque de las Estrategias Adaptativas y Paleoambientales. Imprenta del Museo Municipal de Historia Natural de San Rafael, San Rafael.

2000. Localidad Arqueológica Piedra Museo, Introducción. En L. Miotti, R. Paunero, M. Salemme y R. Cattáneo (Comps.), Guía de Campo de la Visita a las Localidades Arqueológicas. Taller Internacional "La Colonización del Sur de América Durante la Transición Pleistoceno/Holoceno", pp. 55-56. Servicoop, La Plata.

2006. Paisajes domésticos y sagrados desde la arqueología de los cazadores-recolectores en el Macizo del Deseado, Provincia de Santa Cruz. Cazadores-Recolectores del Cono Sur. Revista de Arqueología 1: 11-40.

2008. Household and sacred landscapes among Holocene hunter-gatherers of Patagonia's Central Plateau. Before Farming, 2008/3: 5-44.

2010a. Cuevas y abrigos rocosos: nudos de las redes sociales entre los cazadoresrecolectores del Macizo del Deseado, Patagonia extra-andina. En J. C. Jiménez, C. Serrano, A. González y F. Aguilar (Eds.), III Simposio Internacional (2008) El Hombre Temprano en América, pp. 147-174. UNAM- Instituto de Investigaciones Antropológicas-INAH, México.

2010b. La señal arqueológica de colonización finipleistocénica y la continuidad ocupacional en la Meseta de Somuncurá, Provincia de Río Negro, Argentina. En R. Bárcena y H. Chiavazza (Eds.), Arqueología Argentina en el Bicentenario de la Revolución de Mayo, Actas del XVII Congreso Nacional de Arqueología Argentina, Tomo V: 1853-1859. FFyL (UNCuyo) y CONICET, Mendoza.

2012. El uso de los recursos faunísticos entre los cazadores-recolectores de Patagonia: tendencias espacio/temporales de las estrategias durante el Holoceno. Archaeofauna 21: 137-160.

Miotti, L. y N. Carden

2007. The relationships between rock art and archaeofaunas in the Central Patagonian Plateau. En M. Gutiérrez; L. Miotti; G. Barrientos; G. Mengoni Goñalons y M. Salemme (Eds.), Taphonomy and Archaeology in Argentina, pp. 203-218. BAR International Series, Londres.

Miotti, L. y R. Cattáneo

1997. Bifacial technology at 13,000 years ago in Southern Patagonia. Current Research in the Pleistocene 14: 65-68.

2003. Pleistocene/Holocene transition at Piedra Museo and surrounding region. En M. L. Miotti, M. Salemme y N. Flegenheimer (Eds.), Where the South Winds Blow: Ancient Evidence of Paleo South Americans, pp. 105-113. CSFA and Texas A\&M University Press, Texas. 
Miotti, L. y L. Marchionni

2009. Procesando huesos: entre la Etnografía y la Arqueología. En M. Salemme, F. Santiago, M. Álvarez, E. Piana, M. Vázquez y M. Mansur (Eds.), Arqueología de la Patagonia. Una Mirada Desde el Confín del Mundo, pp. 787-799. Editorial Utopía, Ushuaia.

Miotti, L. y M. Salemme

2003. When Patagonia was colonized: people, mobility at high latitudes during Pleistocene/Holocene transition. Quaternary International 109-110: 95-112.

2004. Poblamiento, movilidad y territorios entre las sociedades cazadoras recolectoras de Patagonia. Complutum 15: 177-206

2005. Hunting and butchering events at the Pleistocene/Holocene transition in Piedra Museo: An example of adaptation strategies of the first colonizers of Patagonia. En R. Bonnichsen, B. Leppers, D. Stanford y M. Waters (Eds.), Paleoamerican Origins: Beyond Clovis, pp. 209-220. Texas A\&M University Press, Texas.

Miotti, L. y E. Terranova

2010. Cerro Amigo Oeste, un nodo en la red de comunicación social finipleistocénica en Sudamérica. En D. Hermo y R. Blanco (Comps.), Libro de Resúmenes del V Simposio Internacional "El Hombre Temprano en América: a cien años del debate Ameghino- Hrdlicka (1910- 2010)”, pp. 136-137. Cooperativa gráfica El Río Suena, Buenos Aires.

2011. A overcrowded hill points in the terra incognita Patagonia: notes and reflections to discussion of the first human American Peopling. En XVI IUPPS World Congress/XVI SAB Congress. Session 10. Florianopolis

2014. A hill plenty of points in terra incognita from Patagonia: notes and reflections for discussing the way and tempo of the initial peopling. PaleoAmerica 1, 15 pags. En prensa.

Miotti, L.; R. V. Blanco y B. Mosquera

2007a. Exploraciones arqueológicas en la meseta de Somuncurá. Expectativas para el estudio del poblamiento de Nordpatagonia. Ponencia presentada en la Mesa de Patagonia del XVI Congreso Nacional de Arqueología Argentina. San Salvador de Jujuy.

Miotti, L.; N. Carden y M. J. Canosa

1999a. Paisajes arqueológicos de cazadores-recolectores, arte rupestre y lagunas. En C. Díez Marín (Ed.), Actas del XII Congreso Nacional de Arqueología Argentina, Tomo III: 54-63. Facultad de Ciencias Naturales y Museo, La Plata. 
Miotti, L.; N. Carden y L. Magnín

2007b. Tendencia central, dispersión y orientación en el paisaje regional. Estudios de distribución del arte rupestre en la meseta central de Santa Cruz, Argentina. En: F. Morello, M. Martinic, A. Prieto y G. Bahamonde (Eds.), Arqueología de FuegoPatagonia. Levantando Piedras, Desenterrando Huesos...y Develando Arcanos, pp. 601-612. Ediciones CEQUA, Punta Arenas

Miotti, L.; N. Carden y R. V. Blanco

2012a. Las manifestaciones artísticas de la transición Pleistoceno/Holoceno: la evidencia de la Meseta Central de Santa Cruz (Patagonia Argentina). En: J. Clottes (Dir.), L'art pléistocène dans le monde/ Pleistocene art of the world/ Arte pleistoceno en el mundo, Actes du Congrès IFRAO, Tarascon-sur-Ariège, septembre 2010, Symposium «Art pléistocène dans les Amériques». N spécial de Préhistoire, Art et Sociétés, Bulletin de la Société Préhistorique Ariège-Pyrénées 2010-2011, LXV-LXVI: 851-866.

Miotti, L.; D. Hermo y N. Carden

2009a. Piedra Museo, una ventana abierta hacia los cazadores-recolectores que colonizaron la Meseta Central de Santa Cruz durante finales de la era glacial. En Estado Actual de las Investigaciones Realizadas sobre Patrimonio Cultural en Santa Cruz, pp. 174-184. Dirección de Patrimonio Cultural- Subsecretaría de Cultura de la provincia de Santa Cruz, Río Gallegos.

Miotti, L.; M. Vázquez y D. Hermo

1999b. Piedra Museo un Yamnagoo Pleistocénico en la Colonización de la Meseta de Santa Cruz. El estudio de la arqueofauna. En R. Goñi (Ed.), Soplando en el Viento. Actas de las III Jornadas de Arqueología de Patagonia, pp.113-136. NeuquénBuenos Aires.

Miotti, L.; R. V. Blanco; E. Terranova; L. Marchionni

2008. Prospecciones arqueológicas en el este de Somuncurá y en la cuenca inferior del Arroyo Talagapa. Informe de campaña presentado ante CODEMA- Río Negro y Cultura- Río Negro.

Miotti, L.; R. V. Blanco; E. Terranova; L. Marchionni.

2009b. Informe de Campaña 2009, en el marco del proyecto "Investigación arqueológica cuando el espacio se convierte en territorio de sociedades cazadoras recolectoras en la meseta de Somuncurá”, presentado ante CODEMA- Río Negro y Cultura- Río Negro. 
Miotti, L.; R. Blanco, E. Terranova, D. Hermo y B. Mosquera

2009c. Paisajes y cazadores-recolectores. Localidades arqueológicas de Plan Luan y Cuenca Inferior del Arroyo Talagapa. En M. Salemme, F. Santiago, M. Álvarez, E. Piana, M. Vázquez y M. E. Mansur (Eds.), Arqueología de Patagonia. Una Mirada Desde el Último Confín, pp. 265-280. Editorial Utopías, Ushuaia.

Miotti, L.; R. Blanco; B. Mosquera D. Hermo; N. Carden y V. Lynch

2012b. Informe de campaña 2012 "Relevamiento y prospección en las localidades arqueológicas de Los Navarros, La Primavera y Agua del Cuero", Área Cultura Provincia de Santa Cruz. Manuscrito inédito.

Miotti, L.; R. V. Blanco; E. Terranova; L. Marchionni; D. Hermo y B. Mosquera 2014. La naturaleza de la observación: evidencias arqueológicas en Somuncurá (Río Negro). En G. Cassiodoro, A. Re y D. Rindel (Eds.), Integración de Diferentes Líneas de Evidencia en la Arqueología Argentina, pp. 73-91. Aspha Ediciones, Buenos Aires.

Miotti L.; D. Hermo, R. V. Blanco y E. Terranova

2011a. Puntas Cola de Pescado en el ecorrefugio de de la meseta de Somuncurá (provincia de Río Negro, Patagonia argentina). En J. C Jiménez López, C. Serrano Sánchez, A. González González y F. J. Aguilar Arellano (Eds.), IV Simposio Internacional "El Hombre Temprano en América", pp. 149-172. UNAM- Instituto de Investigaciones Antropológicas- INAH- Museo del Desierto, México.

Miotti,L; D. Hermo, E. Terranova y R. V. Blanco

2012c. Los edenes en el desierto, señales en la historia de la colonización de Patagonia. Libro de Resúmenes del VI Simposio Internacional del Hombre Temprano en América, pp. 24-25.Universidad Tecnológica de Pereira-INAH, Colombia.

Miotti, L.; D. Hermo, M. Salemme, L. Magnín y L. Marchionni

2009d. Cueva Maripe y su excavación. implicancias en los estudios regionales del Macizo del Deseado. En A. Austral y Tamagnini (Comps.), Problemática de Arqueología Contemporánea, Tomo III: 1031-1035. Universidad Nacional de Río Cuarto, Río Cuarto.

Miotti, L.; D. Hermo; L. Magnín; N. Carden; L. Marchionni; A. Alcaraz; B. Mosquera; E. Terranova y M. Salemme

2007c. Resolución arqueológica en la Cueva Maripe (Santa Cruz, Argentina). En F. Morello; M. Martinic; A. Prieto y G. Bahamonde (Eds.), Arqueología de FuegoPatagonia: Levantando Piedras, Desenterrando Huesos... y Develando Arcanos, pp. 555-568. Ediciones CEQUA, Punta Arenas. 
Miotti, L; L. Marchionni; R. V. Blanco; A. Alcaraz y L. Beckes.

2007d. Informe de campaña arqueológica 2007. Prospecciones en las localidades de La Marianita, La Primavera y Los Toldos. Informe de campaña inédito en posesión de los autores.

Miotti, L; L. Marchionni; B. Mosquera; D. Hermo y M. Fernández

2011b. Aportes metodológicos para el ajuste temporal de las ocupaciones humanas de la Cueva Maripe, Santa Cruz, Argentina. En A. F. Zangrando; R. Barberena; A. Gil y G. Neme (Comps.), Libro de Resúmenes de las VIII Jornadas de Arqueología de la Patagonia, p. 54. Centro de Convenciones y Exposiciones Thesaurus, Museo de Historia Natural de San Rafael, Malargüe.

Miotti, L.; M. Salemme, D. Hermo, L. Magnín y J. Rabassa

2004. Yamnagoo 137 años después: otro lenguaje para la misma región. En M. T. Civalero, P. Fernández y A. Guraieb (Comps.), Contra Viento y Marea, Arqueología de Patagonia, pp. 775-796. INAPL- SAA, Buenos Aires.

Miotti, L.; M. Salemme; D. Hermo; M. Vázquez; N. Carden; M. Giardina y L. Magnín 2005. Aguada del Cuero, un nuevo escalón en la arqueología de la Meseta Central de Santa Cruz. En E. Berberián (Ed.), Actas XIII Congreso Nacional de Arqueología Argentina, Tomo 4: 55-62. Universidad Nacional de Córdoba, Córdoba.

Miotti, L.; E. Terranova, R. Barberena, D. Hermo, M. Giesso y M. D. Glascock

2012d. Geochemical sourcing of obsidian Fishtail Points: studies for the Somuncurá Plateau (Río Negro, Argentina). En L. Miotti, M. Salemme, N. Flegenheimer y T. Goebel (Eds.), Southbound: Late Pleistocene Peopling of Latin America, pp. 127132. Center for the Study of the First Americans - A\&M Texas University, Texas.

Miotti, L.; E. Terranova; R. V. Blanco; L. Marchionni, B. Mosquera y D. Hermo

2011c. Informe "Prospecciones arqueológicas en la cuenca superior y media del Arroyo Talagapa (Somuncurá)”. Presentado ante CODEMA- Río Negro y Cultura- Río Negro.

Moreira, P.

2005. Geología y metalogénesis del distrito La Josefina, macizo del Deseado, provincia de Santa Cruz. Tesis Doctoral inédita de la Facultad de Ciencias Naturales y Museo- Universidad Nacional de La Plata, La Plata.

Moreira, P.; P. D. González; R. Fernández; H. Echeveste, I. Schalamuk y R. Etcheverry 2005. El basamento metamórfico de muy bajo a bajo grado de las estancias La Modesta y La Josefina, macizo del Deseado, provincia de Santa Cruz. Revista de la Asociación Geológica Argentina 60(1): 49-63. 
Moreira, P.; R. Fernandez; R. Etcheverry e I. A. Schalamuk

2010. Complejos de domos jurásicos ( 150 ma) La Josefina y Maria Esther, sector central del Macizo del Deseado, Patagonia. Revista de la Asociación Geológica Argentina 66 (3): 335-338.

Moreno, F. P.

S/f. Recuerdos de un viaje a Nahuel Huapi: 1) El llano de Yamnagóo. Vidita a los Guenaken. Una raza que muere. 27 páginas. Manuscrito Inédito de la Biblioteca del Museo Etnográfico, FFyL-UBA.

Musters, George C.

2005. Vida Entre los Patagones. Un Año de Excursiones por Tierras no Frecuentadas Desde el Estrecho de Magallanes hasta el Río Negro. Buenos Aires, Editorial El Elefante Blanco

Nacuzzi, L.

1987. Una hipótesis etnohistórica aplicada a sitios de la Patagonia central y septentrional. Comunicaciones de las Primeras Jornadas de la Patagonia, pp. 179184. Dirección Provincial de Cultura, Rawson.

Onelli, C.

1998. Trepando los Andes. El Elefante Blanco, Buenos Aires.

Onetto, M

1981-82. Arte rupestre de Campo Cretton, Piedra Parada, Chubut. Relaciones de la Sociedad Argentina de Antropología XIV(2): 159-172.

1983a. Sitio Campo Moncada 1. Arte Rupestre. En C. Aschero, C. Pérez de Micou, M. Onetto, C. Bellelli, L. Nacuzzi y A. Fisher (Comps.), Arqueología del Chubut. El Valle de Piedra Parada, pp. 29-30. Dirección Provincial de Cultura- Gobierno de la Provincia del Chubut, Rawson.

1983b. Sitio Piedra Parada 4. Arte rupestre. En C. Aschero, C. Pérez de Micou, M. Onetto, C. Bellelli, L. Nacuzzi y A. Fisher (Comps.), Arqueología del Chubut. El Valle de Piedra Parada, pp. pp. 57-60. Dirección Provincial de Cultura- Gobierno de la Provincia del Chubut, Rawson.

1983c. Sitio Campo Cretton 1. En C. Aschero, C. Pérez de Micou, M. Onetto, C. Bellelli, L. Nacuzzi y A. Fisher (Comps.), Arqueología del Chubut. El Valle de Piedra Parada, pp. 61-64. Dirección Provincial de Cultura- Gobierno de la Provincia del Chubut, Rawson.

1986-87. Nuevos resultados de las investigaciones en Campo Nassif 1. Valle de Piedra Parada. Provincia del Chubut. Relaciones de la Sociedad Argentina de Antropología XVII(1): 95-123. 
1987. El arte rupestre del valle de Piedra Parada, Provincia del Chubut. En Comunicaciones de las Primeras Jornadas de Arqueología de la Patagonia, pp. 195200. Dirección Provincial de Cultura, Rawson.

1990. Secuencia estilística del arte rupestre en el Valle de Piedra Parada, Provincia de Chubut, Argentina. Boletín de la SIARB 4: 55-63.

1991. Propuesta para la integración del arte rupestre dentro del sistema de comportamiento de los cazadores-recolectores del valle de Piedra Parada. Curso medio del río Chubut. En M. M. Podestá, M. I. Hernández Llosas y S. F. Renard de Coquet (Eds.), El Arte Rupestre en la Arqueología Contemporánea, pp. 123-150. Buenos Aires.

Ouzman, S.

2001. Seeing is deceiving: rock art and the non-visual. Word Archaeology 33(2): 237256.

Panza, J. L.

2001. Hoja Geológica 4769-IV Monumento Natural Bosques Petrificados, Provincia de Santa Cruz. Boletín del SEGEMAR 258. Instituto de Geología y Recursos Minerales, Buenos Aires.

Panza, J. L. y G. Marín

1998. Hoja Geológica 4969-I Gobernador Gregores, Provincia de Santa Cruz. Boletín del SEGEMAR 211. Instituto de Geología y Recursos Minerales, Buenos Aires.

Panza, J. L., C. Náñez y N. Malumián

1996. Afloramientos y foraminíferos eocenos en el Macizo del Deseado, provincia de Santa Cruz. Ameghiniana 33(2): 231.

Pastor, S.

2012. Arte Rupestre, paisaje y tensión social: Un caso de estudio en Córdoba, Argentina Revista Chilena de Antropología 26 (2do semestre): 7-32

Paunero R. S.

1992. Manos pintadas en negativo: Un ensayo de experimentación. Revista de Estudios Regionales - CEIDER 1: 47-67.

1994. Aproximación contextual, pinturas rupestres y experimentación. Actas y Memorias del XI Congreso Nacional de Arqueología Argentina. Revista del Museo de Historia Natural de San Rafael XIII: 98-100.

2000a. Relevamiento, arte rupestre y sectorización de la localidad La María. En L. Miotti, R. Paunero, M. Salemme y R. Cattáneo (Comps.), Guía de Campo de la Visita a las Localidades Arqueológicas. Taller Internacional "La Colonización del 
Sur de América Durante la Transición Pleistoceno/Holoceno”, pp. 104-108. Servicoop, La Plata.

2000b. Cueva de la Mesada de La María Quebrada. En L. Miotti, R. Paunero, M. Salemme y R. Cattáneo (Comps.), Guía de Campo de la Visita a las Localidades Arqueológicas. Taller Internacional "La Colonización del Sur de América Durante la Transición Pleistoceno/Holoceno”, pp. 109-113. Servicoop, La Plata.

2000c. Cañadón de La Mina: Sitio Casa del Minero 1. En L. Miotti, R. Paunero, M. Salemme y R. Cattáneo (Comps.), Guía de Campo de la Visita a las Localidades Arqueológicas. Taller Internacional "La Colonización del Sur de América Durante la Transición Pleistoceno/Holoceno”, pp. 118-120. Servicoop, La Plata.

2003a. The presence of a Pleistocene Colonizing Culture in La Maria archaeological locality, Casa del Minero 1. En L. Miotti, M. Salemme y N. Flegenheimer (Eds.), Where the South Winds Blow: Ancient Evidence of Paleo South Americans, pp. 127132. CSFA- Texas A\&M University Press, Arizona

2003b. The Cerro Tres Tetas (C3T) locality in the Central Plateau of Santa Cruz, Argentina. En L. Miotti, M. Salemme y N. Flegenheimer (Eds.), Where the South Winds Blow: Ancient Evidence of Paleo South Americans, pp. 133-140. CSFA and Texas A\&M University Press, Texas.

Paunero, R. S.; A. Frank; F. Skarbun; G. Rosales; G. Zapata; M. Cueto; M. F. Paunero; D. G. Martínez; R. López; N. Lunazzi y M. Del Giorgio

2005. Arte rupestre en Estancia La María, Meseta Central de Santa Cruz: sectorización y contextos arqueológicos. Relaciones de la Sociedad Argentina de Antropología XXX: 147-168.

Pérez de Micou, C.

1979-82. Sitio Piedra Parada 1 (PP1), Dpto. de Languiñeo, Pcia. Chubut (Argentina).

Cuadernos del Instituto Nacional de Antropología 9: 97-112.

1983. Sitio Piedra Parada 1. En C. Aschero, C. Pérez de Micou, M. Onetto, C. Bellelli, L. Nacuzzi y A. Fisher (Comps.), Arqueología del Chubut. El Valle de Piedra Parada, pp. 43-49. Dirección Provincial de Cultura- Gobierno de la Provincia del Chubut, Rawson.

1987. Aprovechamiento de la flora local en los sitios Campo Nassif 1 y Piedra Parada 1, Dpto. de Languiñeo, Chubut. Comunicaciones de las Primeras Jornadas de Arqueología de la Patagonia, pp. 231-241. Dirección Provincial de Cultura, Rawson. 2009. Tintes y plantas. Una clase con Agustina. En C. Pérez de Micou, M. Trivi y L. S. Burry (Eds.), Imágenes desde un alero. Investigaciones interdisciplinarias en Río Mayo, Chubut, pp.159-162. Buenos Aires.

Pérez de Micou, C. y A. Castro

2005. Recuperar un paisaje. Prospecciones en la estancia San Ramón, (Chubut, Argentina). Relaciones de la Sociedad Argentina de Antropología XXX: 263-275. 
Pérez de Micou, C.; C. Bellelli y C. Aschero

1992. Vestigios minerales y vegetales en la determinación del territorio de explotación de un sitio. En L. Lanata y L. A. Borrero (Eds.), Análisis Espacial en la Arqueología Patagónica, pp. 57-86. Ayllu, Buenos Aires.

Plautz de Frenchi, H.; H. Smekal y J. J. Yerio

1975. Grabados rupestres de Mata Molle- Valle de Collón Curá, provincia de Neuquén. Relaciones de la Sociedad Argentina de Antropología IX: 155-161.

Podestá, M. M. y A. M. Albornoz

2007. El arte rupestre del sitio Paredón Lanfré dentro del contexto arqueológico del valle del río Manso Inferior (pcia. de Río Negro). En Resúmenes Ampliados Actas del XVI Congreso Nacional de Arqueología Argentina, Tomo III: 429-434. Universidad Nacional de Jujuy- Ediciones Pacarina, San Salvador de Jujuy.

Podestá, M. M.; S. Paunero y D. Rolando

2005. El Arte Rupestre de Argentina Indigena. Patagonia. Academia Nacional de la Historia. Buenos Aires

Podestá, M. M., C. Bellelli, R. Labarca, A. M. Albornoz, A. Vasini y E. Tropea

2008. Arte rupestre en pasos cordilleranos del bosque andino patagónico (El Manso, Región de los Lagos y provincia de Río Negro, Chile-Argentina). Magallania 36(2): 143-153.

Pomiés, M. P., M. Menu and C. Vignaud

1999. Red Paleolithic pigments: natural hematite or heated goethite? Archaeometry 41: 185-192

Prates, L.

2009. El uso de recursos por los cazadores-recolectores posthispánicos de Patagonia continental y su importancia arqueológica. Relaciones de la Sociedad Argentina de Antropología XXXIV: 201-229.

Prates, L.; V. Di Prado, A. Serna y E. Mange

2011. Cueva Galpón. Un sitio con entierros humanos y representaciones rupestres en la Sierras de Pailemán (Este de Río Negro). En F. Zangrando, R. Barberena, A. Gil y G. Neme (Comps.), Libro de Resúmenes VIII Jornadas de Arqueología de Patagonia, pp. 66. Centro de Convenciones y Exposiciones Thesaurus - Museo de Historia Natural de San Rafael, San Rafael. 
Ramos, V. A.; A. C. Riccardi y E. O. Rolleri

2004. Límites naturales del norte de la Patagonia. Revista de la Asociación Geológica Argentina 59(4): 785-786.

Ravazzolli, I.

1982. Descripción geológica de la Hoja 40h Cerro Corona. Boletín del SEGEMAR 190. Buenos Aires.

Re, A.

2011. Representaciones rupestres en mesetas altas de la provincia de Santa Cruz. Circulación de información en espacios de uso estacional. Tesis doctoral inédita de la Facultad de Filosofía y Letras- Universidad Nacional de Buenos Aires, Buenos Aires.

2012. ¿Qué información podemos obtener de las superposiciones? El caso de los grabados de meseta del lago Strobel (Patagonia meridional). En M. Strecker (Ed.), Contribuciones al Estudio del Arte Rupestre Sudamericano $N^{o} 7$. Congreso Internacional Arqueología y Arte Rupestre. 25 años SIARB, pp. 30-31. La Paz.

Re, A.; R. Goñi y J. B. Belardi.

2009. Dinámica poblacional tardía en Patagonia meridional: su discusión y evaluación a través de la distribución de motivos rupestres En M. Sepúlveda; L. Briones y J. Chacama (Eds.), Crónicas Sobre la Piedra. Arte Rupestre de las Américas, pp. 293309. Ediciones de la Universidad de Tarapacá, Arica.

Re, A., R. Goñi, J. B. Belardi y F. Guichón

2009a. Evidencias de contacto en el arte rupestre de la Meseta del Strobel (Patagonia austral argentina). En Global Rock Art. Anais do Congresso Internacional de Arte Rupestre IFRAO Fundhamentos IX (1), pp. 1319- 1330. Piauí (Brasil), Fundação Museu do Homen Americano. CD-Rom, Artigo 97.

Re, A.; R. Goñi; J. B. Belardi y A. Nuevo Delaunay

2006-07. Variabilidad de representaciones rupestres en el sector sur de la meseta del Strobel (provincia de Santa Cruz). Cuadernos del Instituto Nacional de Antropología y Pensamiento Latinoamericano 21: 215- 225.

Re, A. y F. Guichón

2009. Densidad y distribución de representaciones rupestres en la meseta del Strobel (Provincia de Santa Cruz). En M. Salemme, F. Santiago, M. Álvarez, E. Piana, M. Vázquez y M. Mansur (Eds.), Arqueología de la Patagonia. Una Mirada Desde el Último Confín, pp. 527-540. Editorial Utopías, Ushuaia.

2013. Las representaciones rupestres de la Meseta del Lago Guitarra (Provincia de Santa Cruz). En A. F. Zangrando, R. Barberena, A. Gil, G. Neme, M. Giardina,L. 
Luna, C. Otaola, S. Paulides, L. Salgán y A. Tivoli (Comps.), Tendencias Teóricometodológicas y Casos de Estudio en la Arqueología de la Patagonia, pp. 495-504. Museo de Historia Natural de San Rafael, San Rafael.

Re, A.; F. Guichón y J. B. Belardi

2010b. Grabados en las mesetas de San Adolfo y del Cardiel Chico (provincia de Santa Cruz). En C. Aschero (Coord.), Resúmenes del VIII Simposio Internacional de Arte Rupestre, pp. 112-116. Instituto de Arqueología y Museo- Instituto Superior de Estudios Sociales- Secretaría de Ciencia y Técnica de la Universidad Nacional de Tucumán, San Miguel de Tucumán.

Re, A.; F. Guichón; I. Rapela y A. Nuevo Delaunay.

2010c. El cañadón en la meseta: análisis de las representaciones rupestres y de la tecnología lítica del Lobo - K22 (meseta del lago Strobel, Santa Cruz). En R. Bárcena y H. Chiavazza (Eds.), Arqueología Argentina en el Bicentenario de la Revolución de Mayo, XVII Congreso Nacional de Arqueología Argentina, Tomo V, pp. 1963-1968. UNCuyo- CONICET, Mendoza.

Re, A; A. Nuevo Delaunay y L. Ferraro

2005. Grabados en la Meseta del Lago Strobel (Santa Cruz, Argentina). Sitio Laguna del Faldeo Verde. Relaciones de la Sociedad Argentina de Antropología XXX: 245256.

Recalde, A. y S. Pastor

2012. Contextos "públicos" y "privados" para la ejecución del arte rupestre en el valle de Guasapampa (Córdoba, Argentina). Latin American Antiquity 23 (3): 327-245.

Reigadas, M.

2002. Fibras arqueológicas de origen animal. Análisis microscópico de muestras de Cerro Casa de Piedra-CCP 5 y 7. Relaciones de la Sociedad Argentina de Antropología XXX: 235-243.

2007. Cazadores del Holoceno y los recursos faunísticos: estudio de fibras animales de Cerro Casa de Piedra CCP5 y CCP7 (Santa Cruz). En F. Morello, M. Martinic, A. Prieto y G. Bahamonde (Eds.), Arqueología de Fuego Patagonia. Levantando Piedras, Desenterrando Huesos... y Develando Arcanos, pp. 89-94. Ediciones CEQUA, Punta Arenas.

Remesal, M.; F. Salani; M. Franchi y A. Ardolino

2001. Hoja Geológica 4169IV Maquinchao. Boletín del SEGEMAR 312. Instituto de Geología y Recursos Minerales, Buenos Aires. 
Remesal M.; M. E Cerredo y F. Salani

2011. Un modelo alternativo para la génesis de la Provincia Magmática Somún Curá, XVIII Congreso Geológico Argentino, pp. 364-365. Asociación Geológica Argentina, Buenos Aires.

Remesal, M.; F. Salani y M. E. Cerredo

2012. Petrología del complejo volcánico Barril Niyeu (Mioceno Inferior), Patagonia Argentina. Revista Mexicana de Ciencias Geológicas 29(2): 463-477.

Renfrew, C. y P. Bahn

2008. Archaeology: Theory, Method and Practice. Thames and Hudson Ltd, Londres.

Rial, G. y C. Barbosa

1983-85. Análisis mineralógico por DRX de muestras de pinturas del Cerro Casa de Piedra, sitio CCP5 (provincia de Santa Cruz, República argentina). Cuadernos del Instituto Nacional de Antropología y Pensamiento Latinoamericano 10: 307-311

Ribichich, M. A.

2002. El modelo clásico de la fitogeografía de Argentina: un análisis crítico. Interciencia 27(12): 669-675.

Rowe, M. W.

2001. Physical and chemical analysis. En D. Whitley (ed.), Handbook of Rock Art Research. Walnut Creek, Altamira Press

Ruiz, R.

2012. Geología y Mineralizaciones del sector sudoccidental del Macizo del Deseado, Santa Cruz. Tesis doctoral inédita de la Facultad de Ciencias Naturales y MuseoUniversidad Nacional de La Plata, La Plata.

Sanguinetti de Bórmida, A.

1996. Aproximaciones a la comprensión del área de investigación Piedra del Águila. Praehistoria 2: 309-311.

Sanguinetti de Bórmida, A.; A. Chauvin; D. Curzio; E. Crivelli Montero y M. Lezcano 2001. Arqueología de rescate en el alero La Marcelina 1, Provincia de Río Negro. Actas del III Congreso Argentino de Americanistas, pp. 351-72. Sociedad Argentina de Americanistas Buenos Aires. 
Santos Graneros, F.

2004. Escribiendo la historia en el paisaje: espacio, mitología y ritual entre la gente Yanesha. En A. Surrallés y P. García Hierro (Eds.), Tierra Adentro. Territorio Indigena y percepción del entorno, pp. 187-217. IWGIA, Lima

Scheinsohn, V.

2010. Down to the bone: tracking prehistoric bone technology in Southern Patagonia. En A. Legrand-Pineau, I. Sidera, N. Buc, E. David y V. Scheinsohn (Eds.), Ancient and Modern Bone Artefacts from America to Russia. Cultural, Technological and Functional Signature, pp. 295-302. BAR International Series, Oxford.

Scheinsohn, V.; C. Szumik, S. Leonardt y F. Rizzo

2009. Distribución especial del arte rupestre en el bosque y la estepa del Norte de Patagonia. En M. Salemme, F. Santiago, M. Álvarez, E. Piana, M. Vázquez y M.E. Mansur (Eds.), Arqueología de Patagonia. Una Mirada Desde el Último Confín, pp. 541-560. Editorial Utopías, Ushuaia.

2011. La localidad de Río Pico (Chubut) en el marco de los patrones distribucionales del arte rupestre en el Norte de Patagonia. En F. Zangrando, R. Barberena, A. Gil y G. Neme (Comps.), Libro de Resúmenes VIII Jornadas de Arqueología de Patagonia, pp. 73-74. Centro de Convenciones y Exposiciones Thesaurus - Museo de Historia Natural de San Rafael, San Rafael.

Schlanger, N.

2005. The chaîne opèrative. En C. Renfrew y P. Bahn (Eds.), Archaeology-Key Concepts, pp. 25-31. Routledge, London

Schiffer, M.

1972. Archaeological context and systemic context. American Antiquity 37(2): 156-165.

1992. Human behavior and artifacts. En M. B. Schiffer (Ed.), Technological Perspectives on Behavioral Change, pp. 1-21. The University of Arizona Press, Tucson and London.

Schobinger, J.

1956. El arte rupestre de la provincia del Neuquén. Anales de Arqueología y Etnología 12: $115-226$.

Sepúlveda, M.

2009. Aspectos tecnológicos en la pintura rupestre. Reflexiones elaboradas a partir de análisis físico-químicos aplicados al estudio de las pinturas de la localidad del río Salado (norte de Chile). En M. Sepúlveda, L. Briones y J. Chacama (Eds.), Crónicas Sobre la Piedra. Arte Rupestre de las Américas, pp. 119-128. Ediciones Universidad de Tarapacá, Arica. 
2011. Pinturas rupestres y tecnología del color en el extremo sur de Chile. Magallania 39(1): 193-210

Sepúlveda, M. y E. Laval

2010. Aplicación y aplicabilidad de métodos físico-químicos para el estudio de las pinturas rupestres. Ejemplo de estudio en la localidad del río Salado (II Región, norte de Chile). Actas del XVII Congreso Nacional de Arqueología Chilena 2006, Tomo II: 825-834. Valdivia.

Sepúlveda, M.; E. Laval; L. Cornejo y J. Acarapi

2012. Elemental characterisation of pre-hispanic rock art and arsenic in Northern Chile. Rock Art Research 29(1): 93-106.

Sepúlveda, M.; D. Valenzuela; L. Cornejo; H. Lienqueo y H. Rousselière

2013. Óxidos de manganeso en el extremo norte de Chile: abastecimiento, producción y movilidad del color negro durante el período Arcaico. Chungara 45(1): 143-159.

Silveira, M.

1979. Análisis e interpretación de los restos faunísticos de la Cueva Grande del Arroyo Feo (provincia de Santa Cruz). Relaciones de la Sociedad Argentina de Antropología XIII: 229-253.

Skarbun, F.

2009. La organización tecnológica en grupos cazadores recolectores desde las ocupaciones del Pleistoceno final al Holoceno tardio, en la Meseta Central de Santa Cruz. Tesis doctoral inédita de la Facultad de Ciencias Naturales- Universidad Nacional de La Plata. La Plata.

Snow, D. R.

2006. Sexual dimorphism in Upper Palaeolithic hand stencils. Antiquity 80: 390-404.

Stern, C.; J. Gómez Otero y J. B. Belardi

2000. Características químicas, fuentes potenciales y distribución de diferentes tipos de obsidianas en la costa e interior del centro-norte de la provincia del Chubut, Argentina. Anales del Instituto de la Patagonia (Serie Ciencias Sociales) 28: 275290.

Tehrani, J. J. y F. Riede

2008. Towards an archaeology of pedagogy: learning, teaching and the generation of material culture traditions. World Archaeology 40(3): 316-331. 
Terranova, E. D.

2009. Primeros resultados del sitio Cantera de Aneken en la meseta de Somuncurá.

Libro de Resúmenes de las VIII Jornadas de Jóvenes Investigadores en Ciencias Antropológicas del Instituto Nacional de Antropología y Pensamiento Latinoamericano, pp. 14. INAPL-UBA, Buenos Aires.

2012. Las vueltas de La Maciega. Arqueología de un pequeño bajo en la meseta de Somuncurá. En N. Kuperszmit, T. Lagos Mármol, L. Mucciolo y M. Sacchi (Comps.), Entre Pasados y Presentes III. Estudios Contemporáneos en Ciencias Antropológicas, pp. 847-859. Mnemosyne, Buenos Aires.

2013. Arqueología de la cuenca del arroyo Talagapa, Meseta de Somuncurá (provincia de Río Negro). Tesis doctoral inédita de la Facultad de Ciencias Naturales y MuseoUniversidad Nacional de La Plata, La Plata.

Terranova, E. y L. Marchionni

2010. Excavación del sitio Los Cuatro Aleros, localidad Tapera de Isidoro, meseta de Somuncurá, Río Negro. Primeros fechados para la ocupación humana en el área.En R. Bárcena y H. Chiavazza (Eds.), Arqueología Argentina en el Bicentenario de la Revolución de Mayo, Actas del XVII Congreso Nacional de Arqueología Argentina, Tomo V: 1993-1998. UNCuyo- CONICET, Mendoza.

Thomas, J.

2006. Phenomenology and material culture. En C. Tilley, W. Keane, S. Kuechler, M. Rowlands y P. Spyer (Eds.), The Handbook of Material Culture, pp. 60-73. SAGE Publications, Londres.

Tilley, C.

1994. A Phenomenology of Landscape. Places, Paths and Monuments. BERG, Oxford. 2008. Phenomenological Approaches to Landscape Archaeology. En B. David y J. Thomas (Eds.), Handbook of Landscape Archaeology, pp. 271-276. WAC- Research handbooks in archaeology- Left Coast Press, California.

Tilley, C.; W. Keane; S. Kuechler; M. Rowlands y P. Spyer 2008. Introduction. En C. Tilley, W. Keane, S. Kuechler, M. Rowlands y P. Spyer (Eds.), The Handbook of Material Culture, pp. 1-6. SAGE Publications, Londres.

Torres, M. A.

2000. Arte rupestre en la cordillera patagónica argentina. ArqueoWeb - Revista sobre Arqueología en Internet 2(1). http://pendientedemigracion.ucm.es/info/arqueoweb/pdf/2-1/marcelotorres.pdf 
Tostevin, M.

2011. Levels of theory and social practice in the reduction sequence and chaine opératoire methods of lithic analysis. PaleoAnthropology 2011: 351-375. Special Issue: Reduction Sequence, Chaîne Opératoire, and Other Methods: The Epistemologies of Different Approaches to Lithic Analysis. Learning From Lithics

Troncoso, A.

2005. Genealogía de un entorno rupestre en Chile central: un espacio, tres paisajes, tres sentidos. Boletín del Museo Chileno de Arte Precolombino 10(1): 35-53.

Vasini, A. y E. Tropea.

2009. Arte rupestre y ocupaciones del Holoceno tardío en la Patagonia andina (Comarca Andina del Paralelo $42^{\circ}$ y valle del río Manso inferior, Argentina). En Global Rock Art. Anais do Congresso Internacional de Arte Rupestre IFRAO Fundhamentos IX (1), pp. 535-554. Piauí (Brasil), Fundação Museu do Homen Americano. CD-Rom, Artigo 41.

Vergara Murúa, F.

2009. Postulados metodológicos para un acercamiento a las tecnologías de producción de grabados rupestres. Entre la corporalidad, el gesto y la técnica. En Global Rock Art. Anais do Congresso Internacional de Arte Rupestre IFRAO Fundhamentos IX (1), pp. 589-611. Piauí (Brasil), Fundação Museu do Homen Americano. CD-Rom, Artigo 97

Vicente Santos, F. J.

2011. Aproximación al estudio de las cadenas líticas operativas y sus sistemas de aprendizaje. El Futuro del Pasado 2: 13-28.

Vignati, M.

1944. Antigüedades en la región de los lagos Nahuel Huapi y Traful: IV. Hallazgos en cerro Leones. Notas del Museo de La Plata. Tomo 9, Antropología 26:103-117

1950. Estudios antropológicos en la Zona Militar de Comodoro Rivadavia. I Anales del Museo de La Plata, N.S., Sec. Antrop.1:7-18.

Vinci, M. C.

1998. El por qué del Área Natural Protegida "Reserva Natural Integral de la Meseta de Somuncurá”. En R. F. Masera (Coord.), La Meseta Patagónica del Somuncurá: un Horizonte en Movimiento, pp. 385-395. Secretaría de Acción Social de Río Negro, Viedma. 
Wainwright, I. N. M.; K. Helwig; M. M Podestá y C. Belelli

2000. Analysis of pigments from rock painting sites in Rio Negro and Chubut Provinces.

En M. M. Podestá y M. de Hoyos (Eds.), Arte en las Rocas. Arte rupestre, Menhires y

Piedras de Colores en la Argentina, pp. 203-206. SAA- AINA, Buenos Aires.

Waller, S. J.

2002. Rock Art Acoustics in the Past, Present and Future. En P. Whitehead, W. Whitehead y L. Loendorf (Eds.), International Rock Art Congress Proceedings, Vol. 2: 11-20. American Rock Art Research Association, Tucson.

2003. Conservation of rock art acoustics: "unexpected" echoes at petroglyph national monument. Rock Art Papers 41/16: 31-38.

Whitley, D.

2005. Introduction. En D. Whitley, Introduction to Rock Art Research, pp. 1-6. Left Coast Press, California.

Whittacker, J.; S. Koeman y R. Taylor

1999. Some experiments in petrogliphs technology. En P. Whitehead y L. Loendorf (Eds.), IRAC Proceedings Vol. 1: 155-168. ARARA, Ripon. 
Apéndices 
Apéndice I 
Apéndice I.1. Listado de los motivos documentados.

\section{Figurativos}

Antropomorfos:

figuras humanas;

rastros humanos: manos, pies

\section{Zoomorfos:}

Figuras animales: matuasto, zoomorfo indeterminado; rastros animales: pisada de ave, de felino, de guanaco

Objetos: Placa, hacha en " 8 "

\section{No Figurativos \\ Puntiformes \\ Punto}

Par de puntos

Línea recta de puntos (horizontal, oblicua o vertical)

Línea curva de puntos

Lineas de puntos paralelas (horizontales, oblicuas o verticales)

Triángulo de puntos

Conjunto de puntos

Conjunto de puntos alrededor de hoyuelo natural

Conjunto de puntos alrededor de hoyuelo natural asociado a línea recta

Círculo de puntos

Circunferencia de puntos

\section{Rectilíneos}

Linea recta (horizontal, oblicua o vertical)

Linea recta con apéndice:

Línea recta con apéndice "en forma de V";

Línea recta quebrada simple: "en forma de $V$ "; en forma de " $V$ invertida"; "en forma de $V$ " doble convergente; zig-zag;

Lineas rectas quebradas paralelas;

Línea recta quebrada combinada

Lineas rectas intersecadas en ángulo recto

Reticulado de líneas;

Incisiones caóticas;

Lineas rectas paralelas dobles (verticales, oblicuas u horizontales)

Dígitos: líneas paralelas verticales cortas y de trazo ancho.

Series de lineas rectas paralelas (horizontales, verticales, oblicuas)

Serie de lineas rectas paralelas combinadas

Lineas combinadas

Ortogonales: línea en ángulo recto; en forma de $T$; en forma de " $U$ " rectilínea; peiniforme; almenado; segmentado; enmarcado; greca; cruciforme; cruciforme escalonado; laberintiforme ornamental.

Figuras geométricas: triángulo escalonado; triángulo + línea recta horizontal; rombo; rombos unidos por vértice; rombos alineados; rombos y rectángulos alineados; triángulos unidos por el vértice (clepsidras); clepsidras unidas por líneas rectas; cuadrado; cuadrado con línea recta vertical en sector inferior; cuadrado con circunferencia y línea oblicua en su interior; Figura rectangular; trapezoide con lineas internas; figura poligonal;

\section{Circulares llenos}

Círculo lleno

Círculo con apéndices radiados

Círculo con apéndices radiados asociado a línea vertical

Circulares lineales

Semicircunferencia: en positivo y en negativo;

Semicircunferencia con apéndice (recto, curvo) 
Semicircunferencia punto central y apéndice

Circunferencia: circunferencia simple (en positivo y en negativo), circunferencia de trazo combinado (plano y puntiforme);

Circunferencia con apéndice

Circunferencia con múltiples apéndices

Circunferencia alrededor de hoyuelo natural

Circunferencia con trazo interior

Circunferencia con trazo interior y apéndice.

Circunferencias agrupadas

Circunferencias adosadas

Circunferencia concéntricas

Circunferencia concéntricas con apéndice

Circunferencias concéntricas alrededor de hoyuelo natural

Circunferencia concéntricas con trazos internos;

circunferencia concéntricas con trazos internos y apéndices

Óvalo

Óvalos con apéndice (recto, curvo, o doble)

Óvalo con trazos interiores

Espiral

Espiral con apéndices rectos

Espiral alrededor de hoyuelo natural

Circular combinado

Circular No Determinado

\section{Curvilíneos}

Linea curva (horizontal, oblicua o vertical)

Línea curva con apéndice

Línea curva intersecada con línea: línea curva intersecada con línea recta (horizontal u oblicua) o curva.

Línea curva asociada a circulares

Líneas curvas paralelas: líneas curvas paralelas (horizontales, verticales); líneas onduladas paralelas

Lineas curvas paralelas asociadas

en forma de "media U": simple o invertida

en forma de "media U" con apéndice: simple o invertida

"en forma de U": simple, sinuosa, invertida

"en forma de U" con apéndice (recto, curvo)

en forma de "U invertida" y cerrada

"En forma de U" concéntrica doble invertida

Escutiforme

Serpentiforme

Serpentiforme con apéndice

Laberinto con apéndices

Curvilíneos combinados 
Apéndice I.2. Protocolo para documentar las réplicas de los motivos grabados

PROTOCOLO EXPERIMENTAL ${ }^{\circ}$

REPLICACION N ${ }^{\circ}$

Fecha:

Lugar:

Experimentan:

\author{
MOTIVO ARQUEOLOGICO \\ LOCALIDAD \\ SITIO \\ PANEL
}

Características generales del motivo

Tipo de motivo: No Figurativo o Figurativo

(descripción en detalle)

Surco Ancho:

Profundidad

DIBUJO y FOTO

Tipo: "V", "U" o superficial.

Tamaño. Largo máximo:

Ancho máximo:

Técnica Inferida: Horadación, Raspado, Incisión, Percusión (Directa/indirecta), Combinada

Bloque Experimental $\mathrm{N}^{\circ}$ :

Tipo: basalto, arenisca, toba, ignimbrita

Microtopografía: hoyuelos, depresiones, fallas, etc. ¿se va a aprovechar para la confección del motivo? si / no ¿Por qué?

Pátina:

Color:

Posición del bloque: Horizontal, Vertical, Oblicua

Altura respecto del suelo:

ARTEFACTO

FOTO y DIBUJO

Materia Prima

características dimensionales: Ancho, largo, espesor

Tipo de artefacto: AF, ANF

Manufactura: percusión directa/indirecta,

$$
\text { ¿formatización? }
$$

Parte Activa: Filo, punta

Filo disponible:

Intensidad de uso: tiempo en minutos

Rastros Complementarios: microlascados adyacentes; arista con abrasión; marca u hoyuelos

de percusión, etc.

Sustancias adheridas: si / no Posición: 
TRABAJO

Preparación del soporte previa al trabajo: si/no ¿Por qué? ¿de qué tipo?

Dibujo previo: $\mathrm{Si} / \mathrm{no}$

Campo Manual: Adentro, afuera

Ejecutante: Nombre

¿por qué?

Lateralidad: Zurdo, diestro

Técnica de grabado usada: Horadación, Raspado, Incisión, Percusión (Directa/indirecta) Combinada

Establecer por escrito en que partes del motivo se empleó cada una.

Tipo de Acción: Presión, percusión

Dirección de la manufactura: horizontal, vertical, diagonal, circular

Sentido de la manufactura: número (ver listado abajo del todo)

Ángulo de trabajo:

Modo de prensión del artefacto:

Posición del filo respecto a la superficie: Paralelo, Perpendicular

Tiempo invertido: minutos

FOTOS de la posición del ejecutante

3: bidireccional horizontal

4: unidireccional arriba

5: unidireccional abajo

6: bidireccional vertical
9: unidireccional diagonal izquierdo arriba 10: unidireccional diagonal izquierdo abajo 11: bidireccional diagonal derecho 12: bidireccional diagonal izquierdo

Dibujo y foto de artefacto posterior al uso, para motivo replicado.

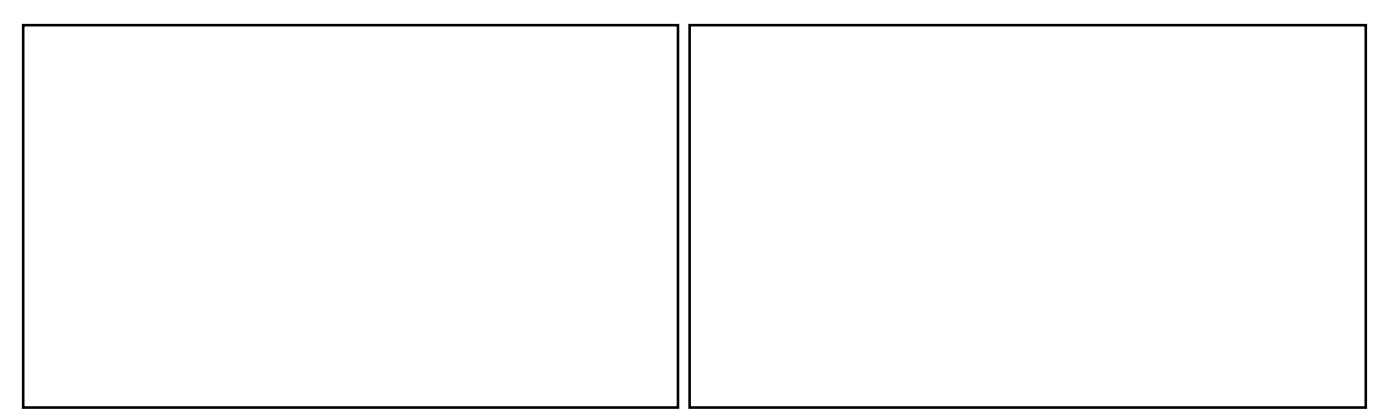


Apéndice I.3. Protocolo para replicar motivos pintados.

\section{PREPARACIÓN MEZCLA PINTURA}

Fecha:

Lugar:

\section{COMPONENTES}

\section{Pigmento}

Procedencia (GPS)

Formación:

Color:

Peso:

Molienda: Si/no

Artefacto de molienda: Tipo

Ligante

Agua: $\mathrm{ml}$.

Grasa: tipo: vacuna (de pella, de tuétano), de pollo; unto sin sal porcino, grasa de pollo, grasa de choique. Peso:

Procedimiento empleado en la obtención de la grasa: descripción

Huevo: clara, yema. Peso:

Aditivo

Yeso hemihidratado. Procedencia:

Peso:

MEZCLA PIGMENTARIA

Preparación Fecha:

Hora:

Pasos: orden en que se agregaron los componentes.

Tiempo de hidratación:

Utilización Fecha: Hora:

PROTOCOLO EXPERIMENTAL $n^{\circ}$

Fecha:

Lugar:

Productores:

MOTIVO ARQUEOLOGICO

Localidad

Sitio

Panel

Características generales

Tipo de motivo: No Figurativo, Figurativo

Trazo: continuo, discontinuo, ancho, fino.

Tamaño motivo: Largo máximo

REPLICACION $N^{\circ}$

Técnica Inferida: digital, estarcido directo, indirecta (uso de artefacto, posible artefacto utilizado)

SOPORTE

Bloque experimental $\mathrm{N}^{\circ}$

Roca: basalto, ignimbrita, toba

Color:

Pátina:

Medidas: largo*ancho*espesor (máximo)

Procedencia:

Microtopografía:

Altura respecto del suelo: en m Posición: Vertical, Oblicua.

Ángulo:

Señalar los elementos sobre los que se colocó el bloque. 
Técnica de replicación

Digital; estarcido directo (pulverizado); indirecta (con artefacto)

ARTEFACTO

FOTO y DIBUJO

Materia Prima:

Dimensiones: Ancho, largo, espesor en cm

Tipo de artefacto: hisopo, pincel, vellón de pelo

Manufactura:

Parte Activa:

Intensidad de uso: tiempo

Sustancias adheridas: Si/ no Posición

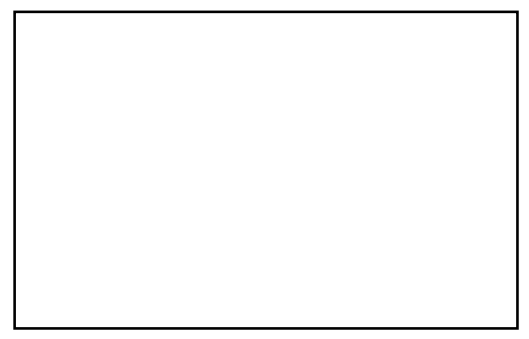

TRABAJO

Preparación del soporte previa al trabajo: ¿Por qué? ¿de qué tipo?

Dibujo previo: Si/no ¿por qué?

Campo Manual: adentro, afuera

Ejecutante:

Posición: de pie, sentado, agachado

Lateralidad: Zurdo, diestro

Técnica de pintura usada:

Establecer por escrito en que partes del motivo se empleó cada una.

Tipo de Acción: Presión, pulverización

Dirección de la manufactura: Horizontal, vertical, diagonal, circular

Ángulo de trabajo:

Modo de prensión del artefacto:

Tiempo invertido: en minutos

Cantidad de mezcla pigmentaria empleada:

FOTOS de la posición del ejecutante

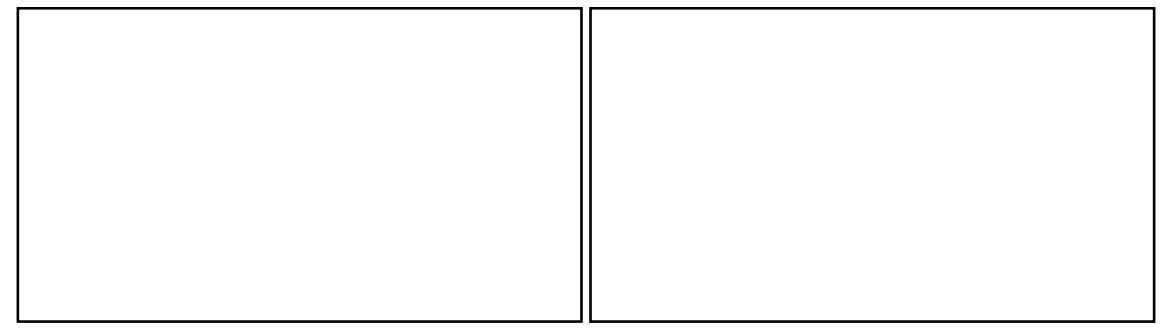


Apéndice II 
Apéndice II.1.a. Técnicas mencionadas para los diferentes sitios en el macizo del Deseado.

\begin{tabular}{|c|c|c|c|c|c|}
\hline Ubicación & Localidad/Área & Sitio & Tipo & Soporte & Fuente \\
\hline \multirow{11}{*}{$\begin{array}{l}\text { Macizo del Deseado } \\
\text { Norte }\end{array}$} & Los Toldos & Los Toldos $2,3,5,6$ y 15 & 1,2 & Ignimbrita & Carden 2008a \\
\hline & Piedra Museo & Alero El Galpón 2 y Cueva Grande & 2,4 & Arenisca coquinoide & De Aparicio 1933-35; Miotti 1991 Carden 2007, 2008a \\
\hline & Bajo Pantano & Tito del Valle & 2 & Conglomerado tobáceo & \\
\hline & \multirow[t]{2}{*}{ Aguada del Cuero } & Cueva Moreno y Cueva de la Hacienda & 1,2 & Conglomerados tobáceos & \multirow{8}{*}{ Carden 2008a, 2009a. } \\
\hline & & Lag. del Cerro Bonete y La Leonera & 3 & Basaltos & \\
\hline & Cerro del Doce & Bardas del Doce & 3 & Basaltos & \\
\hline & La Primavera & $\begin{array}{l}\text { La Primavera } 1 \text { a 5; Alero Lucifer; } \\
\text { Cueva Maripe }\end{array}$ & 1,2 & Ignimbritas, Toba & \\
\hline & Los Ventisqueros & Los Ventisqueros 1 y 2 & 2 & Ignimbritas & \\
\hline & Las Mercedes & Las Mercedes 1 a 3 & 1,2 & Ignimbritas & \\
\hline & Sierra Blanca & Sierra Blanca 1 y 2 & 2 & Toba & \\
\hline & Cañadón de la Víbora & Cañadón de la Víbora 1 a 4 & 1,2 & Ignimbrita & \\
\hline \multirow{15}{*}{ Macizo del Deseado Sur } & La María & La María (65 sitios) & $1,2,3$ & Ignimbrita & Paunero 2009, 2012; Paunero et al. 2005; \\
\hline & El Ceibo & El Ceibo 1 a 7 ; El Circo & 1,2 & Ignimbrita & Cardich 1987; Franchomme 1987; Miotti 1998 \\
\hline & \multirow[t]{8}{*}{ La Martita } & La Gruta & 1 & Roca porfirítica & \multirow{8}{*}{ Gradin y Aguerre 1983} \\
\hline & & Viuda Quenzana (12 sitios) & $1,2,3$ & Tobas porfiríticas & \\
\hline & & Segunda Angostura del Río Chico & 1 & Rocas porfiríticas & \\
\hline & & Cañadón Los Guanaquitos (1 a 3) & $1,2,3$ & Tobas porfiríticas & \\
\hline & & Cueva y Paredón La Martita (5 sitios) & 1,3 & $\mathrm{~s} / \mathrm{d}$ & \\
\hline & & Alero Quebrada Colorada & 2 & Tobas porfiríticas & \\
\hline & & Cueva Campo Corral & 1 & \multirow{4}{*}{ Rocas porfiríticas } & \\
\hline & & La Evelina 1 a 5 & $1,2,3$ & & \\
\hline & \multirow[t]{4}{*}{ El Verano } & El Verano 1 a 3 & 1 & & \multirow{4}{*}{ Durán 1983-85 } \\
\hline & & Alero El Lindero & 2 & & \\
\hline & & La Cantera 1 a 9 & 1,3 & s/d & \\
\hline & & Cueva Laguna Colorada & 1 & Roca porfirítica & \\
\hline & Ea. La Flecha & La Flecha & 3 & Basalto & Gradin $2003 \mathrm{c}$ \\
\hline \multirow[t]{7}{*}{ NW del macizo del Deseado } & Área del Río Pinturas & Cueva de las Manos (10 sitios) & $1,2,3$ & Rocas porfiríticas & \multirow{4}{*}{ Gradin 1983; Gradin et al. 1976, 1979} \\
\hline & & Arroyo Feo 1,2 y 3 & 1,2 & Toba & \\
\hline & & Cañadón Charcamata (5 sitios) & 1,2 & Toba & \\
\hline & & Alero Cárdenas (2 sitios) & 2,3 & Roca porfirítica & \\
\hline & & Alero Parado & 2 & Roca porfirítica & Aschero 2012b \\
\hline & & Cañadón La Magdalena (36 sitios) & 2,3 & Tobas & Aguerre y Gradin 2003 \\
\hline & Angostura del Deseado & Angostura del Deseado & 4 & Toba & Gradin 1979 \\
\hline
\end{tabular}

Tipo de sitio: 1. Cueva; 2. Alero; 3. Paredón o barda; 4. Bloques. 
Apéndice II.1.b. Motivos pintados del macizo del Deseado: procesos de trabajo inferidos y correlato material.

\begin{tabular}{|c|c|c|c|c|c|c|c|}
\hline & Localidad & Sitio & Tipo de motivo & $\begin{array}{c}\text { Proceso de trabajo } \\
\text { inferido }\end{array}$ & Correlato del proceso de trabajo & $\begin{array}{c}\text { Artefactos } \\
\text { relacionados }\end{array}$ & Autores \\
\hline \multirow{14}{*}{$\begin{array}{c}\text { Macizo del } \\
\text { Deseado Norte }\end{array}$} & \multirow{9}{*}{ Los Toldos } & \multirow{3}{*}{ Los Toldos 2} & $\begin{array}{l}\text { Negativo de puño } \\
\text { de mano }\end{array}$ & $\begin{array}{l}\text { Estarcido de } \\
\text { pintura }\end{array}$ & \multirow{3}{*}{ Gotas alrededor de motivo } & & \multirow{8}{*}{$\begin{array}{c}\text { Carden } \\
\text { 2008a; } \\
\text { Cardich } 1979 \\
\text { Miotti } 1998\end{array}$} \\
\hline & & & $\begin{array}{l}\text { Negativo de } \\
\text { pisada de guanaco }\end{array}$ & $\begin{array}{l}\text { Estarcido de } \\
\text { pintura }\end{array}$ & & - & \\
\hline & & & $\begin{array}{l}\text { Negativo de pie } \\
\text { humano }\end{array}$ & $\begin{array}{l}\text { Estarcido de } \\
\text { pintura }\end{array}$ & & & \\
\hline & & \multirow{4}{*}{ Los Toldos 3} & $\begin{array}{l}\text { Negativos de } \\
\text { mano sobre fondo } \\
\text { preparado }\end{array}$ & $\begin{array}{l}\text { Estarcido de } \\
\text { pintura }\end{array}$ & $\begin{array}{l}\text { Gotas alrededor de motivo. } \\
\text { Fondo de color homogéneo }\end{array}$ & & \\
\hline & & & & $\begin{array}{l}\text { Preparación de } \\
\text { pintura }\end{array}$ & $\begin{array}{l}\text { Porción de pintura roja y } \\
\text { fragmentos de roca de caja con } \\
\text { restos de motivos rupestres } \\
\text { (Capa 10) }\end{array}$ & & \\
\hline & & & - & $\begin{array}{l}\text { Preparación de } \\
\text { pintura }\end{array}$ & $\begin{array}{l}\text { Morteros para la preparación de } \\
\text { pigmentos y pinturas minerales } \\
\text { (Capa 10) }\end{array}$ & $\begin{array}{l}\text { Discoidales en } \\
\text { tobas volcánicas }\end{array}$ & \\
\hline & & & - & - & 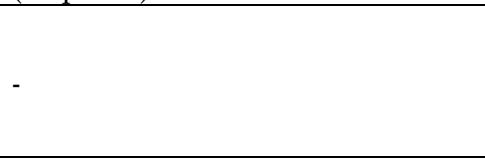 & $\begin{array}{c}\text { Diáfisis de hueso } \\
\text { de ave con bordes } \\
\text { pulidos y pintura } \\
\text { en su interior }\end{array}$ & \\
\hline & & Los Toldos 6 & $\begin{array}{l}\text { Hoyuelo natural } \\
\text { pintado en color } \\
\text { negro y delineado } \\
\text { en rojo }\end{array}$ & $\begin{array}{l}\text { Delineado con } \\
\text { instrumento? }\end{array}$ & Motivo & ( & \\
\hline & & Los Toldos 7 & e & $\begin{array}{l}\text { Preparación de } \\
\text { pintura }\end{array}$ & $\begin{array}{l}\text { Restos de pigmentos rojos } \\
\text { mayoritariamente y algunos } \\
\text { color ocre (Capa } 7 \text { y } 10 \text { ) }\end{array}$ & - & \multirow{6}{*}{$\begin{array}{c}\text { Carden } \\
2008 \mathrm{a}, 2009 \mathrm{~b}\end{array}$} \\
\hline & \multirow{5}{*}{$\begin{array}{l}\text { Piedra } \\
\text { Museo }\end{array}$} & AEG-2 & \multirow{3}{*}{ Negativo de mano } & Estarcido & Gotas alrededor de motivo & - & \\
\hline & & \multirow[b]{2}{*}{$\mathrm{CG}$} & & Fileteado/delineado & $\begin{array}{l}\text { Línea que remarca el contorno } \\
\text { de la mano }\end{array}$ & - & \\
\hline & & & & $\begin{array}{l}\text { Enmarcado de } \\
\text { negativo en } \\
\text { círculos u óvalos }\end{array}$ & $\begin{array}{l}\text { Mano y círculo u óvalo también } \\
\text { delineados }\end{array}$ & & \\
\hline & & \multirow{2}{*}{ AEP-1 } & - & $\begin{array}{l}\text { Preparación de } \\
\text { pinturas? }\end{array}$ & $\begin{array}{l}\text { Restos de pigmentos (Capas } 5 \text { y } \\
6 \text { ) }\end{array}$ & - & \\
\hline & & & - & 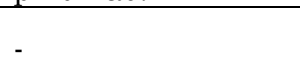 & $\begin{array}{l}\text { Laja con restos de pintura roja } \\
\text { (Capa } 6 \text {, Cuadrícula L) }\end{array}$ & - & \\
\hline
\end{tabular}




\begin{tabular}{|c|c|c|c|c|c|c|c|}
\hline & Localidad & Sitio & Tipo de motivo & $\begin{array}{l}\text { Proceso de trabajo } \\
\text { inferido }\end{array}$ & Correlato del proceso de trabajo & $\begin{array}{l}\text { Artefactos } \\
\text { relacionados }\end{array}$ & Autores \\
\hline \multirow{13}{*}{$\begin{array}{c}\text { Macizo del } \\
\text { Deseado Norte }\end{array}$} & $\begin{array}{l}\text { Piedra } \\
\text { Museo }\end{array}$ & AEG-2 & - & 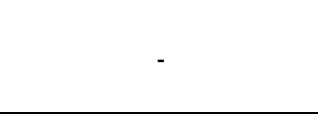 & $\begin{array}{l}\text { Lajas con restos de manos negativas } \\
\text { (Cuadrículas I y J) }\end{array}$ & 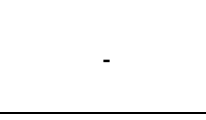 & $\begin{array}{l}\text { Carden } \\
2008 \mathrm{a}, \\
2009 \mathrm{~b}\end{array}$ \\
\hline & \multirow{4}{*}{$\begin{array}{l}\text { Aguada del } \\
\text { Cuero }\end{array}$} & \multirow{4}{*}{$\begin{array}{c}\text { Cueva de la } \\
\text { Hacienda }\end{array}$} & Cruciforme & Pintura plana & Línea de trazo relativamente ancho & \multirow{4}{*}{ - } & \multirow{6}{*}{$\begin{array}{l}\text { Carden } \\
2008 \mathrm{a}\end{array}$} \\
\hline & & & $\begin{array}{l}\text { Circulares con } \\
\text { apéndices radiados }\end{array}$ & $\begin{array}{l}\text { Elevación respecto } \\
\text { del suelo para } \\
\text { acceder al soporte y } \\
\text { realizar los motivos }\end{array}$ & $\begin{array}{l}\text { Altura respecto del suelo a la que se } \\
\text { encuentran los motivos }\end{array}$ & & \\
\hline & & & Negativo de mano & $\begin{array}{c}\text { Estarcido por debajo } \\
\text { de la muñeca } \\
\text { ¿agachado? }\end{array}$ & Motivo & & \\
\hline & & & Motivo ND pintado & Estarcido de pintura & Motivo & & \\
\hline & \multirow[t]{2}{*}{$\begin{array}{c}\text { Bajo } \\
\text { Pantano }\end{array}$} & \multirow[t]{2}{*}{$\begin{array}{l}\text { Tito del } \\
\text { Valle }\end{array}$} & $\begin{array}{l}\text { Negativos de mano } \\
\text { sobre fondo } \\
\text { preparado }\end{array}$ & $\begin{array}{l}\text { Estarcido de pintura } \\
\text { blanca para } \\
\text { negativo; fondo color } \\
\text { rosado }\end{array}$ & \multirow[t]{2}{*}{ Gotas alrededor de motivo } & \multirow[t]{2}{*}{-} & \\
\hline & & & $\begin{array}{l}\text { Restos de pintura } \\
\text { rosada }\end{array}$ & Estarcido & & & \\
\hline & \multirow{6}{*}{$\begin{array}{c}\text { La } \\
\text { Primavera }\end{array}$} & \multirow{3}{*}{ Maripe } & 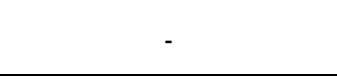 & $\begin{array}{l}\text { Preparación de } \\
\text { pinturas }\end{array}$ & Fragmentos de pigmentos en capa & \multirow{6}{*}{-} & \multirow{6}{*}{$\begin{array}{l}\text { Carden } \\
2008 \mathrm{a}\end{array}$} \\
\hline & & & $\begin{array}{l}\text { Negativos sobre fondo } \\
\text { preparado }\end{array}$ & Estarcido de pintura & $\begin{array}{l}\text { Gotas alrededor de motivo, fondo } \\
\text { preparado con pintura homogénea }\end{array}$ & & \\
\hline & & & $\begin{array}{c}\text { Hoyuelos naturales } \\
\text { pintados en color } \\
\text { naranja } \\
\end{array}$ & $\begin{array}{l}\text { Estarcido de } \\
\text { pinturas }\end{array}$ & Gotas en el interior del hoyuelo & & \\
\hline & & LP 2 & $\begin{array}{c}\text { Manchas de contorno } \\
\text { circular }\end{array}$ & Estarcido de pintura & Contorno irregular & & \\
\hline & & LP 5 & $\begin{array}{l}\text { Dígitos o arrastres de } \\
\text { dedos }\end{array}$ & $\begin{array}{c}\text { Aplicación de la } \\
\text { pintura con la yema } \\
\text { de los dedos }\end{array}$ & Trazos cortos de pintura superficial. & & \\
\hline & & $\begin{array}{l}\text { Maripe, LP } \\
\quad 1 \text { a } 5\end{array}$ & $\begin{array}{c}\text { Pintura plana } \\
\text { (puntiformes, líneas } \\
\text { rectas) }\end{array}$ & - & $\begin{array}{c}\text { Trazos de pintura de superficie } \\
\text { homogénea }\end{array}$ & & \\
\hline
\end{tabular}




\begin{tabular}{|c|c|c|c|c|c|c|c|}
\hline & Localidad & & Tipo de motivo & $\begin{array}{c}\text { Proceso de trabajo } \\
\text { inferido }\end{array}$ & Correlato del proceso de trabajo & $\begin{array}{l}\text { Artefactos } \\
\text { relacionados }\end{array}$ & Autores \\
\hline \multirow{4}{*}{ Norte } & \multirow{2}{*}{$\begin{array}{l}\text { Sierra } \\
\text { Blanca }\end{array}$} & \multirow{2}{*}{ SB 2} & Dígitos rojos y negros & $\begin{array}{c}\text { Aplicación de la } \\
\text { pintura con la yema } \\
\text { de los dedos }\end{array}$ & Trazos cortos de pintura superficial. & 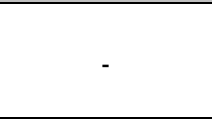 & \multirow{2}{*}{$\begin{array}{l}\text { Carden } \\
2008 \mathrm{a}\end{array}$} \\
\hline & & & $\begin{array}{l}\text { Motivo desvaído en } \\
\text { rojo de trazos cortos }\end{array}$ & $\begin{array}{c}\text { Aplicación de la } \\
\text { pintura mediante } \\
\text { arrastre de dedos }\end{array}$ & Motivo & & \\
\hline & \multirow{2}{*}{$\begin{array}{l}\text { Las } \\
\text { Mercedes }\end{array}$} & \multirow{2}{*}{ LM 1 a 3} & Negativos de mano & Estarcido de pintura & $\begin{array}{c}\text { Gotas de pintura alrededor del } \\
\text { motivo }\end{array}$ & - & \\
\hline & & & Pintura plana & - & $\begin{array}{c}\text { Trazos de pintura con superficie } \\
\text { homogénea }\end{array}$ & & $\begin{array}{l}\text { Carden } \\
2008 \mathrm{a} \\
\end{array}$ \\
\hline \multirow{12}{*}{ Sur } & \multirow{3}{*}{ La María } & \multirow{3}{*}{ LMB II } & Negativo & Estarcido directo & $\begin{array}{c}\text { Gotas de pintura alrededor del } \\
\text { motivo }\end{array}$ & \multirow[t]{2}{*}{-} & \multirow{3}{*}{$\begin{array}{l}\text { Paunero } \\
\quad(\mathrm{e} t \text { al. } \\
\text { 2005: } \\
\text { Figura 6) }\end{array}$} \\
\hline & & & Tricolor radial & Digital & Motivo & & \\
\hline & & & Abstracto bilateral & $\begin{array}{l}\text { Aplicación de pintura } \\
\text { con artefacto }\end{array}$ & Motivo & $\begin{array}{l}\text { Se infiere } \\
\text { pincel o } \\
\text { hisopo } \\
\end{array}$ & \\
\hline & El Ceibo & Cueva 7 & - & Pintura & $\begin{array}{l}\text { Porción de } 10 \mathrm{~cm} \text { de espesor de } \\
\text { arcilla roja que tiñe (Capa } 11)\end{array}$ & 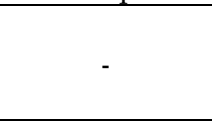 & $\begin{array}{l}\text { Cardich } \text { et } \\
\text { al. } 1981- \\
\quad 82\end{array}$ \\
\hline & \multirow{2}{*}{$\begin{array}{c}\text { La } \\
\text { Reconquista }\end{array}$} & \multirow{2}{*}{$\begin{array}{l}\text { Cueva de los } \\
\text { Felinos }\end{array}$} & Dígitos & $\begin{array}{c}\text { Pintura aplicada con } \\
\text { los dedos }\end{array}$ & Motivo & \multirow{2}{*}{-} & \multirow{2}{*}{$\begin{array}{l}\text { Arrigoni } \\
1996\end{array}$} \\
\hline & & & Felino & $\begin{array}{c}\text { Pintura plana } \\
\text { polícroma o bicroma }\end{array}$ & Motivo & & \\
\hline & \multirow{6}{*}{ La Martita } & \multirow{3}{*}{$\begin{array}{c}\text { Alero } \\
\text { Quebrada } \\
\text { Colorada }\end{array}$} & $\begin{array}{c}\text { Pie negativo con filete } \\
\text { negro } \\
\end{array}$ & $\begin{array}{l}\text { Fileteado: delineado } \\
\text { del contorno del pie }\end{array}$ & Motivo & & \multirow{6}{*}{$\begin{array}{c}\text { Franco et } \\
\text { al 2013; } \\
\text { Gradin y } \\
\text { Aguerre } \\
\text { 1983; }\end{array}$} \\
\hline & & & $\begin{array}{l}\text { Negativo pata de } \\
\text { ñandú }\end{array}$ & Estarcido & Motivo & - & \\
\hline & & & $\begin{array}{c}\text { Negativo objeto } \\
\text { circular }\end{array}$ & Estarcido & Motivo & & \\
\hline & & La Gruta & Negativos & $\begin{array}{c}\text { Filetado del contorno } \\
\text { de la mano }\end{array}$ & Motivo & - & \\
\hline & & La Evelina 1 & $\begin{array}{l}\text { Negativo mano } \\
\text { blanco rodeado por } \\
\text { circunferencia }\end{array}$ & $\begin{array}{l}\text { Delineado del } \\
\text { contorno }\end{array}$ & Motivo & \multirow[t]{2}{*}{-} & \\
\hline & & La Evelina 2 & Arrastre de dedos & $\begin{array}{l}\text { Aplicación de pintura } \\
\text { con los dedos }\end{array}$ & Motivo & & \\
\hline
\end{tabular}


Apéndice II.1.b (Continúa)

\begin{tabular}{|c|c|c|c|c|c|c|c|}
\hline & Localidad & & Tipo de motivo & $\begin{array}{l}\text { Proceso de trabajo } \\
\text { inferido }\end{array}$ & Correlato del proceso de trabajo & $\begin{array}{l}\text { Artefactos } \\
\text { relacionados }\end{array}$ & Autores \\
\hline \multirow{13}{*}{ Sur } & \multirow{13}{*}{ La Martita } & \multirow{2}{*}{$\begin{array}{c}\text { Viuda } \\
\text { Quenzana 1 }\end{array}$} & Negativo de mano & Salpicado de pintura & Motivo & \multirow[t]{2}{*}{ 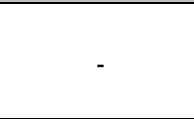 } & \multirow{13}{*}{$\begin{array}{c}\text { Gradin y } \\
\text { Aguerre } \\
1983\end{array}$} \\
\hline & & & $\begin{array}{l}\text { Triángulo con trazos } \\
\text { irregulares internos }\end{array}$ & $\begin{array}{l}\text { Aplicación de pintura } \\
\text { con los dedos }\end{array}$ & Motivo & & \\
\hline & & $\begin{array}{c}\text { Viuda } \\
\text { Quenzana 3 } \\
\end{array}$ & $\begin{array}{c}\text { Manos de tamaño } \\
\text { pequeño }\end{array}$ & Estarcido & Tamaño motivo, dos participantes? & - & \\
\hline & & \multirow{3}{*}{$\begin{array}{c}\text { Viuda } \\
\text { Quenzana } 4\end{array}$} & $\begin{array}{l}\text { Mano fileteada con } \\
\text { puntos negros en su } \\
\text { interior }\end{array}$ & Fileteado & Delineado de contorno & \multirow{3}{*}{-} & \\
\hline & & & Negativo pie & Fileteado & Delineado de contorno & & \\
\hline & & & $\begin{array}{c}\text { Mano negativa } \\
\text { contorneada por } \\
\text { puntos y manchas } \\
\text { rojas }\end{array}$ & Fileteado? & Motivo & & \\
\hline & & $\begin{array}{c}\text { Viuda } \\
\text { Quenzana 5 } \\
\end{array}$ & $\begin{array}{c}\text { Contorno de cavidad } \\
\text { delineado }\end{array}$ & Delineado & Motivo & - & \\
\hline & & \multirow{4}{*}{$\begin{array}{c}\text { Viuda } \\
\text { Quenzana } 9\end{array}$} & $\begin{array}{l}\text { Negativo negro de } \\
\text { tamaño pequeño }\end{array}$ & Estarcido & Participación de dos personas? & \multirow{4}{*}{-} & \\
\hline & & & $\begin{array}{c}\text { Negativos a mas de } 2 \\
\text { m respecto del suelo }\end{array}$ & Estarcido & $\begin{array}{l}\text { Medio de elevación: escalón en roca } \\
\text { soporte? }\end{array}$ & & \\
\hline & & & Dígitos rojos & $\begin{array}{l}\text { Aplicación de pintura } \\
\text { con los dedos }\end{array}$ & Motivo & & \\
\hline & & & $\begin{array}{l}\text { Negativo blanco sobre } \\
\text { fondo preparado }\end{array}$ & $\begin{array}{l}\text { Preparación de fondo } \\
\text { con pintura roja; } \\
\text { realización de } \\
\text { negativo }\end{array}$ & Motivo & & \\
\hline & & \multirow{2}{*}{$\begin{array}{c}\text { Guanaquitos } \\
1\end{array}$} & $\begin{array}{c}\text { Guanacos de } \\
\text { diferente tamaño } \\
\text { repintados }\end{array}$ & $\begin{array}{l}\text { Pintura sobre } \\
\text { pintura }\end{array}$ & Motivo & \multirow[b]{2}{*}{-} & \\
\hline & & & $\begin{array}{c}\text { Figura circular o } \\
\text { romboidal con trazos } \\
\text { de dedos en su } \\
\text { interior } \\
\end{array}$ & $\begin{array}{l}\text { Pintura directa } \\
\text { (técnica digital) }\end{array}$ & Arrastres y forma de dedos & & \\
\hline
\end{tabular}




\begin{tabular}{|c|c|c|c|c|c|c|c|}
\hline & Localidad & & Tipo de motivo & $\begin{array}{l}\text { Proceso de trabajo } \\
\text { inferido }\end{array}$ & Correlato del proceso de trabajo & $\begin{array}{l}\text { Artefactos } \\
\text { relacionados }\end{array}$ & Autores \\
\hline \multirow{15}{*}{ Sur } & \multirow{6}{*}{ La Martita } & \multirow{5}{*}{$\begin{array}{c}\text { Guanaquito } \\
\text { s } 1\end{array}$} & Roseta polícroma & $\begin{array}{l}\text { Hoyuelo natural } \\
\text { Cubier-to con } \\
\text { pintura blanca y } \\
\text { puntos rojos } \\
\text { alrededor }\end{array}$ & Motivo & \multirow[t]{5}{*}{ 2010 } & \multirow{7}{*}{$\begin{array}{l}\text { Gradin y } \\
\text { Aguerre } \\
1983\end{array}$} \\
\hline & & & Dígitos agrupados & $\begin{array}{l}\text { Pintura directa } \\
\text { (técnica digital) }\end{array}$ & Motivo & & \\
\hline & & & $\begin{array}{c}\text { Circunferencias } \\
\text { concéntricas blancas } \\
\text { con rojo }\end{array}$ & $\begin{array}{c}\text { Repintado del } \\
\text { espacio intermedio a } \\
\text { las circunferencias }\end{array}$ & Pintura roja sobre pintura blanca & & \\
\hline & & & $\begin{array}{c}\text { Mano Positiva } \\
\text { esquemática }\end{array}$ & $\begin{array}{c}\text { Mano dibujada } \\
\text { mediante arrastre }\end{array}$ & Motivo & & \\
\hline & & & $\begin{array}{c}\text { Dígitos formatizados } \\
\text { alineados } \\
\text { verticalmente } \\
\end{array}$ & Pintura directa & Motivo & & \\
\hline & & $\begin{array}{c}\text { Guanaquitos } \\
3 \\
\end{array}$ & $\begin{array}{c}\text { Hoyuelo central } \\
\text { cubierto con ocre }\end{array}$ & $\begin{array}{l}\text { Empleo de la } \\
\text { microtopografía }\end{array}$ & Motivo & & \\
\hline & \multirow{9}{*}{ El Verano } & \multirow{2}{*}{$\begin{array}{l}\text { El Verano } \\
\text { Cueva } 1\end{array}$} & & Pintura & $\begin{array}{c}\text { En estratigrafía fragmento de roca } \\
\text { con restos de pintura roja (Ca. } 8690 \\
\text { años AP) }\end{array}$ & - & \\
\hline & & & $\begin{array}{c}\text { Guanacos y } \\
\text { antropomorfos } \\
\text { blancos }\end{array}$ & $\begin{array}{c}\text { Pintura blanca sobre } \\
\text { fondo preparado por } \\
\text { abrasión }\end{array}$ & Motivo & - & \multirow{8}{*}{$\begin{array}{c}\text { Durán } \\
\text { 1983-85 }\end{array}$} \\
\hline & & $\begin{array}{l}\text { El Verano } \\
\text { Cueva } 2\end{array}$ & $\begin{array}{c}\text { Negativos y positivos } \\
\text { de mano }\end{array}$ & $\begin{array}{l}\text { Salpicado y pintura } \\
\text { plana }\end{array}$ & Motivo & - & \\
\hline & & $\begin{array}{l}\text { Alero El } \\
\text { Lindero }\end{array}$ & Roseta & Pintura plana roja & Motivo & & \\
\hline & & $\begin{array}{c}\text { La Cantera } \\
1 \\
\end{array}$ & Negativos & Salpicado de pintura & $\begin{array}{c}\text { Gotas de pintura alrededor del } \\
\text { motivo }\end{array}$ & & \\
\hline & & $\begin{array}{c}\text { La Cantera } \\
4 \\
\end{array}$ & $\begin{array}{l}\text { Pisada de felino y } \\
\text { guanaco esquemático }\end{array}$ & Pintura plana & Motivo & & \\
\hline & & $\begin{array}{c}\text { La Cantera } \\
5 \\
\end{array}$ & Negativo & Salpicado de Pintura & $\begin{array}{l}\text { Gotas de pintura alrededor del } \\
\text { motivo }\end{array}$ & & \\
\hline & & $\begin{array}{c}\text { La Cantera } \\
7 \\
\end{array}$ & $\begin{array}{l}\text { Negativo con puntos } \\
\text { negros en su interior }\end{array}$ & $\begin{array}{c}\text { Salpicado y pintura } \\
\text { plana }\end{array}$ & Motivo & & \\
\hline & & $\begin{array}{c}\text { La Cantera } \\
9 \\
\end{array}$ & Negativos & $\begin{array}{c}\text { Salpicado y } \\
\text { pincelado }\end{array}$ & $\begin{array}{l}\text { Fileteado (pincelado) de contorno de } \\
\text { mano }\end{array}$ & & \\
\hline
\end{tabular}

Apéndice II.1.b (Continuación) 


\begin{tabular}{|c|c|c|c|c|c|c|c|}
\hline & Localidad & & Tipo de motivo & $\begin{array}{l}\text { Proceso de trabajo } \\
\text { inferido }\end{array}$ & Correlato del proceso de trabajo & $\begin{array}{l}\text { Artefactos } \\
\text { relacionados }\end{array}$ & Autores \\
\hline \multirow{14}{*}{ NW } & \multirow[b]{2}{*}{ El Verano } & \multirow[b]{2}{*}{$\begin{array}{l}\text { Laguna } \\
\text { Colorada }\end{array}$} & Negativos & Salpicado & $\begin{array}{c}\text { Gotas de pintura alrededor del } \\
\text { motivo }\end{array}$ & & \multirow[b]{2}{*}{$\begin{array}{l}\text { Durán } \\
1983-85\end{array}$} \\
\hline & & & $\begin{array}{c}\text { Circunferencias, } \\
\text { líneas quebradas, } \\
\text { puntos }\end{array}$ & $\begin{array}{c}\text { Pintura plana } \\
\text { positiva }\end{array}$ & ( & & \\
\hline & \multicolumn{2}{|c|}{ La Flecha } & $\begin{array}{l}\text { Palotes pintados } \\
\text { entre trazos rectos } \\
\text { grabados }\end{array}$ & $\begin{array}{l}\text { Pintura para palotes; } \\
\text { Grabado para trazos } \\
\text { rectos }\end{array}$ & Motivo & & $\begin{array}{l}\text { Gradin } \\
2003 d\end{array}$ \\
\hline & \multirow{11}{*}{$\begin{array}{l}\text { Área Río } \\
\text { Pinturas }\end{array}$} & \multirow{6}{*}{$\begin{array}{l}\text { Cueva } \\
\text { Grande Sitio } \\
\text { IV }\end{array}$} & $\begin{array}{l}\text { Puntos pintados en el } \\
\text { techo }\end{array}$ & $\begin{array}{l}\text { Estampados por } \\
\text { impactos }\end{array}$ & Motivos (5 cm de diámetro) & & \multirow{11}{*}{$\begin{array}{c}\text { Gradin } \\
1984, \\
2001 \\
\text { Gradin et } \\
\text { al. } 1979\end{array}$} \\
\hline & & & $\begin{array}{l}\text { Negativo de mano, } \\
\text { pata de ñandú y } \\
\text { objetos de forma } \\
\text { circular }\end{array}$ & $\mathrm{s} / \mathrm{d}$ & Motivo & \multirow{5}{*}{ - } & \\
\hline & & & ( & $\begin{array}{l}\text { Preparación de } \\
\text { pintura }\end{array}$ & $\begin{array}{l}\text { Instrumento lítico con pintura ocre } \\
(\mathrm{Capa} 6)\end{array}$ & & \\
\hline & & & - & $\begin{array}{l}\text { Preparación de } \\
\text { pintura }\end{array}$ & Trozo de pigmentos color ocre & & \\
\hline & & & - & $\begin{array}{l}\text { Preparación de } \\
\text { pintura }\end{array}$ & $\begin{array}{l}\text { Restos de pintura roja en fragmento } \\
\text { de roca, esferoide, en lito natural, } \\
\text { restos óseos, en un tubo pequeño con } \\
\text { estrías de utilización y pintura en su } \\
\text { interior. (Capa 5) }\end{array}$ & & \\
\hline & & & - & $\begin{array}{l}\text { Preparación de } \\
\text { pintura }\end{array}$ & $\begin{array}{c}\text { Fragmentos de pigmento violáceo } \\
\text { (Capa 4) }\end{array}$ & & \\
\hline & & $\begin{array}{l}\text { Cueva de las } \\
\text { Manos }\end{array}$ & 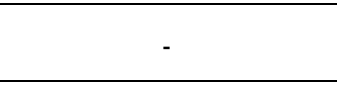 & & Fragmentos de pigmentos y yeso & - & \\
\hline & & \multirow{3}{*}{$\begin{array}{l}\text { Alero el } \\
\text { Buho }\end{array}$} & $\begin{array}{c}\text { Trazos alineados } \\
\text { cortos }\end{array}$ & Dígitos & Motivo & \multirow{3}{*}{ - } & \\
\hline & & & 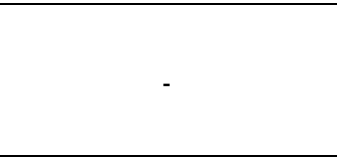 & $\begin{array}{l}\text { Preparación de } \\
\text { pintura }\end{array}$ & $\begin{array}{c}\text { Fragmentos de ocres en capa, } \\
\text { crayones (pigmento rojo amasado } \\
\text { con alguna sustancia grasa o } \\
\text { aceitosa) }\end{array}$ & & \\
\hline & & & ( & $\begin{array}{l}\text { Preparación de } \\
\text { pintura }\end{array}$ & $\begin{array}{c}\text { Restos de pigmentos minerales en } \\
\text { capa }\end{array}$ & & \\
\hline & & $\begin{array}{c}\text { Alero } \\
\text { Charcamata } \\
\text { (II) }\end{array}$ & $\begin{array}{l}\text { Círculo rojo con } \\
\text { pintura blanca } \\
\text { interna }\end{array}$ & $\begin{array}{l}\text { Combinación de } \\
\text { pinturas }\end{array}$ & Motivo & - & \\
\hline
\end{tabular}




\begin{tabular}{|c|c|c|c|c|c|c|}
\hline Localidad & & Tipo de motivo & $\begin{array}{l}\text { Proceso de trabajo } \\
\text { inferido }\end{array}$ & Correlato del proceso de trabajo & $\begin{array}{c}\text { Artefactos } \\
\text { relacionados }\end{array}$ & Autores \\
\hline & $\begin{array}{l}\text { Charcamata } \\
\text { III }\end{array}$ & $\begin{array}{l}\text { Figura redonda roja, } \\
\text { pintura plana con } \\
\text { reborde blanco }\end{array}$ & $\begin{array}{l}\text { Pintura plana roja, } \\
\text { delineado con blanco }\end{array}$ & Motivo & - & $\begin{array}{c}\text { Gradin } \\
1984\end{array}$ \\
\hline & \multirow{4}{*}{ Alero Hugo } & "Mariposita" blanca & Uso de pincel (i) & Trazo muy fino & \multirow{4}{*}{-} & \multirow{4}{*}{$\begin{array}{l}\text { Aguerre y } \\
\text { Gradin } \\
2003\end{array}$} \\
\hline & & $\begin{array}{l}\text { Arrastre de dedos y } \\
\text { puntos rojos } \\
\text { alineados } \\
\end{array}$ & $\begin{array}{l}\text { Aplicación de pintura } \\
\text { con yema de dedos }\end{array}$ & Motivo & & \\
\hline & & $\begin{array}{l}\text { Pie positivo rojo } \\
\text { fileteado con blanco }\end{array}$ & $\begin{array}{l}\text { Pintura estampada } \\
\text { con el pie, delineado } \\
\text { del contorno con otro } \\
\text { color } \\
\end{array}$ & Motivo & & \\
\hline & & - & $\begin{array}{l}\text { Preparación de } \\
\text { pintura }\end{array}$ & $\begin{array}{l}83 \text { muestras de color; Restos de } \\
\text { pintura adheridos a artefactos; } \\
\text { crayones. Artefacto con yeso }\end{array}$ & & \\
\hline & \multirow{6}{*}{$\begin{array}{c}\text { Cueva } \\
\text { Grande } \\
\text { Arroyo Feo }\end{array}$} & - & Aplicación de pintura & Vellones de pelo de guanaco teñidos & \multirow{5}{*}{-} & \multirow[b]{2}{*}{$\begin{array}{l}\text { Gradin } \\
1981-82\end{array}$} \\
\hline & & Dígitos; puntos & $\begin{array}{l}\text { Aplicación de pintura } \\
\text { con la yema de los } \\
\text { dedos }\end{array}$ & Motivo & & \\
\hline & & $\begin{array}{c}\text { Silueta estilizada de } \\
\text { un pie }\end{array}$ & Negativo? & Motivo & & \multirow{4}{*}{$\begin{array}{c}\text { Gradin } \\
1981-82\end{array}$} \\
\hline & & $\begin{array}{c}\text { Bastoniforme } \\
\text { (rectilíneo vertical) }\end{array}$ & $\begin{array}{l}\text { Aplicación pintura } \\
\text { negra y delineado en } \\
\text { rojo }\end{array}$ & Motivo & & \\
\hline & & $\begin{array}{l}\text { Bastoniforme con } \\
\text { puntos adosados }\end{array}$ & $\begin{array}{l}\text { Bastoniforme de } \\
\text { color violáceo con } \\
\text { puntos blancos } \\
\text { adosados de } 2 \mathrm{~mm} \\
\text { diámetro }\end{array}$ & Dos artefactos & & \\
\hline & & Zoomorfo delineado & $\begin{array}{c}\text { Pintura plana para } \\
\text { esquematizar cuerpo } \\
\text { en rojo, delineado en } \\
\text { blanco? } \\
\end{array}$ & Motivo & - & \\
\hline & $\begin{array}{l}\text { La } \\
\text { Madrugada }\end{array}$ & Negativos de mano & De diferente tamaño & $\begin{array}{l}\text { Participación de individuos de } \\
\text { diferentes edades. Pintor auxiliar } \\
\text { para manos pequeñas de niños de } \\
\text { corta edad }\end{array}$ & - & $\begin{array}{l}\text { Gradin } \\
1984\end{array}$ \\
\hline
\end{tabular}




\begin{tabular}{|c|c|c|c|c|c|c|}
\hline Localidad & Sitio & Tipo de motivo & $\begin{array}{l}\text { Proceso de trabajo } \\
\text { inferido }\end{array}$ & Correlato del proceso de trabajo & $\begin{array}{l}\text { Artefactos } \\
\text { relacionados }\end{array}$ & Autores \\
\hline \multirow{5}{*}{$\begin{array}{c}\text { Área del Río } \\
\text { Pinturas }\end{array}$} & \multirow[b]{2}{*}{$\begin{array}{c}\text { La } \\
\text { Madrugada }\end{array}$} & - & Pintura & $\begin{array}{c}\text { Fragmento de roca con negativos y } \\
\text { puntos en capa } 3\end{array}$ & \multirow[t]{2}{*}{ 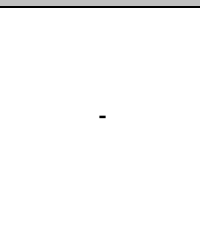 } & $\begin{array}{c}\text { Gradin } \\
1984 \\
\end{array}$ \\
\hline & & $\begin{array}{c}\text { Negativos, positivos } \\
\text { de mano y manos } \\
\text { fileteadas }\end{array}$ & $\begin{array}{l}\text { Salpicado; } \\
\text { estampado; } \\
\text { delineado con } \\
\text { pintura }\end{array}$ & Motivo & & $\begin{array}{l}\text { Gradin et } \\
\text { al } 1979\end{array}$ \\
\hline & \multirow{3}{*}{$\begin{array}{l}\text { Alero } \\
\text { Cárdenas }\end{array}$} & $\begin{array}{l}\text { Triángulos opuestos; } \\
\text { trazos cortos } \\
\text { encolumnados; manos } \\
\text { positivas } \\
\end{array}$ & $\begin{array}{c}\text { Trazos de cuerpo } \\
\text { lleno }\end{array}$ & Motivo & \multirow{3}{*}{-} & \multirow{3}{*}{$\begin{array}{c}\text { Gradin } \\
\text { 1984; } \\
\text { Barbosa y } \\
\text { Gracin } \\
\text { 1986-87 }\end{array}$} \\
\hline & & $\begin{array}{l}\text { Negativo de pie, } \\
\text { mano; de pata de } \\
\text { ñandú }\end{array}$ & Estarcido & Motivos y gotas de pintura alrededor & & \\
\hline & & $\begin{array}{c}\text { Preparación soporte y } \\
\text { de pinturas }\end{array}$ & - & - & & \\
\hline \multirow{6}{*}{$\begin{array}{c}\text { La } \\
\text { Magdalena }\end{array}$} & & $\begin{array}{l}\text { Negativos a } 2,20 \mathrm{~m} \\
\text { respecto del suelo }\end{array}$ & Estarcido & - & - & \multirow{6}{*}{$\begin{array}{l}\text { Aguerre y } \\
\text { Gradin } \\
2003\end{array}$} \\
\hline & & $\begin{array}{l}\text { Palotes o dígitos } \\
\text { verticales en rojo }\end{array}$ & $\begin{array}{l}\text { Aplicación de pintura } \\
\text { con la yema de los } \\
\text { dedos }\end{array}$ & Motivo & - & \\
\hline & & Trazos convergentes & $\begin{array}{l}\text { Arrastres de dedos } \\
\text { con pintura }\end{array}$ & Motivo & - & \\
\hline & & "Bolazos" & $\begin{array}{c}\text { Pintura roja } \\
\text { estampada }\end{array}$ & Motivo & - & \\
\hline & & Positivos de mano & $\begin{array}{c}\text { Pintura estampada } \\
\text { con la mano }\end{array}$ & Motivo & - & \\
\hline & & $\begin{array}{l}\text { Negativo de mano } \\
\text { rojo sobre fondo } \\
\text { preparado }\end{array}$ & $\begin{array}{c}\text { Estarcido de pintura } \\
\text { sobre fondo } \\
\text { preparado color } \\
\text { blanco } \\
\end{array}$ & Motivo & - & \\
\hline
\end{tabular}


Apéndice II.1.c. Motivos grabados, técnicas y artefactos inferidos en los diferentes sitios documentados en el macizo del Deseado.

\begin{tabular}{|c|c|c|c|c|c|c|c|}
\hline & Localidad & & Tipo de motivo & Proceso de trabajo inferido & $\begin{array}{c}\text { Correlato del proceso } \\
\text { de trabajo }\end{array}$ & $\begin{array}{l}\text { Artefactos } \\
\text { relacionados }\end{array}$ & Autores \\
\hline \multirow{13}{*}{ Norte } & \multirow{11}{*}{ Piedra Museo } & \multirow{4}{*}{$\begin{array}{l}\text { Alero El } \\
\text { Galpón } 2\end{array}$} & Circulares & Percusión indirecta & Surco & \multirow[t]{11}{*}{ 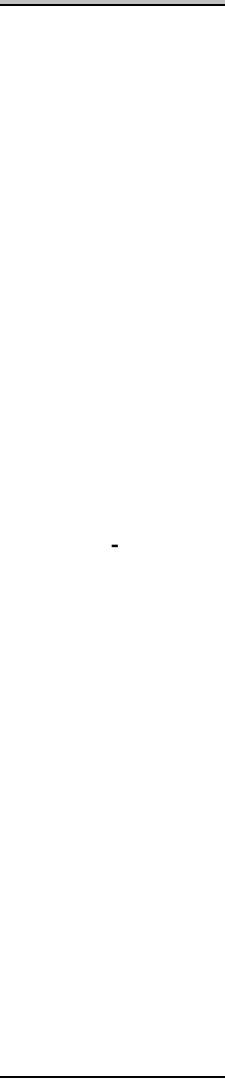 } & \multirow{11}{*}{$\begin{array}{c}\text { Carden } \\
\text { 2008a: } \\
\text { Apéndice } \\
\text { IV tablas } \\
5 \text { a } 12 ; \\
\text { Miotti } \\
1991\end{array}$} \\
\hline & & & & $\begin{array}{l}\text { Percusión indirecta y } \\
\text { horadación del vértice }\end{array}$ & Surco & & \\
\hline & & & Tridígitos & $\begin{array}{c}\text { Horadación (hoyuelos), } \\
\text { percusión indirecta e } \\
\text { incisión para líneas } \\
\text { convergentes. }\end{array}$ & $\begin{array}{c}\text { Percusión indirecta le } \\
\text { da ancho al surco, } \\
\text { incisión le da } \\
\text { profundidad }\end{array}$ & & \\
\hline & & & $\begin{array}{c}\text { Circular con punto y trazo } \\
\text { interior }\end{array}$ & $\begin{array}{l}\text { Percusión indirecta para } \\
\text { circunferencia e incisión } \\
\text { fina para trazo interior }\end{array}$ & surco & & \\
\hline & & \multirow{7}{*}{$\begin{array}{l}\text { Cueva } \\
\text { Grande }\end{array}$} & $\begin{array}{l}\text { Tridígitos pequeños, líneas } \\
\text { rectas simples }\end{array}$ & Incisión & \multirow{6}{*}{ Surco } & & \\
\hline & & & Roseta & $\begin{array}{l}\text { Horadación; Horadación + } \\
\text { Percusión indirecta }\end{array}$ & & & \\
\hline & & & Tridígitos & $\begin{array}{c}\text { Horadación + incisión; } \\
\text { Horadación + Percusión } \\
\text { indirecta; Percusión } \\
\text { indirecta }\end{array}$ & & & \\
\hline & & & Curvilíneos, circulares & Percusión indirecta & & & \\
\hline & & & Pisada de felino & $\begin{array}{c}\text { Horadación; Horadación + } \\
\text { Percusión indirecta; } \\
\text { Horadación + Percusión } \\
\text { indirecta + Raspado } \\
\end{array}$ & & & \\
\hline & & & Manos & $\begin{array}{c}\text { Percusión indirecta }+ \\
\text { raspado }\end{array}$ & & & \\
\hline & & & Pies & $\begin{array}{l}\text { Percusión indirecta } \\
\text { +raspado y horadación }\end{array}$ & $\begin{array}{c}\text { Dedos por horadación; } \\
\text { planta por picado y } \\
\text { raspado } \\
\end{array}$ & & \\
\hline & \multirow[t]{2}{*}{ Aguada del Cuero } & \multirow{2}{*}{$\begin{array}{c}\text { La } \\
\text { Leonera }\end{array}$} & $\begin{array}{c}\text { Semicircunferencia; } \\
\text { circunferencia con apéndice } \\
\text { y trazo interno; tridígitos }\end{array}$ & Percusión indirecta & Surco discontinuo & $\begin{array}{l}\text { Intermediario } \\
\text { sin correlato } \\
\text { material }\end{array}$ & \multirow{2}{*}{$\begin{array}{l}\text { Carden } \\
2008 \mathrm{a}\end{array}$} \\
\hline & & & Líneas simples & Incisión y Raspado & $\begin{array}{l}\text { Superpuestas a } \\
\text { motivos picados }\end{array}$ & 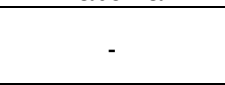 & \\
\hline
\end{tabular}

Apéndice II.1.c (Continúa) 


\begin{tabular}{|c|c|c|c|c|c|c|c|}
\hline & Localidad & Sitio & Tipo de motivo & Proceso de trabajo inferido & $\begin{array}{c}\text { Correlato del proceso } \\
\text { de trabajo }\end{array}$ & $\begin{array}{c}\text { Artefactos } \\
\text { relacionados }\end{array}$ & Autores \\
\hline \multirow{6}{*}{ Norte } & \multirow{4}{*}{ Aguada del Cuero } & \multirow{4}{*}{$\begin{array}{l}\text { Laguna } \\
\text { del Cerro } \\
\text { Bonete }\end{array}$} & ¿? & Percusión & Surco discontinuo & 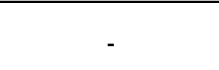 & \multirow{6}{*}{$\begin{array}{l}\text { Carden } \\
2008 \mathrm{a}\end{array}$} \\
\hline & & & $\begin{array}{l}\text { Tridígito; pisada de felino; } \\
\text { motivos complejos }\end{array}$ & Percusión indirecta & Trazos precisos & $\begin{array}{c}\text { Uso de } \\
\text { intermediario } \\
\text { sin correlato } \\
\text { material } \\
\end{array}$ & \\
\hline & & & ¿? & Incisión & Surco fino & - & \\
\hline & & & ¿? & Raspado & $\dot{i}$ & - & \\
\hline & \multirow{2}{*}{ Cerro del Doce } & \multirow{2}{*}{$\begin{array}{l}\text { Bardas } \\
\text { del } 12\end{array}$} & $\begin{array}{l}\text { Circunferencias unidas por } \\
\text { trazos rectos }\end{array}$ & Percusión indirecta & $\begin{array}{c}\text { Surco superficial, trazo } \\
\text { discontinuo }\end{array}$ & - & \\
\hline & & & $\begin{array}{l}\text { Óvalo con trazo interior y } \\
\text { apéndice }\end{array}$ & Percusión indirecta & 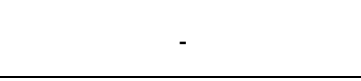 & - & \\
\hline \multirow{11}{*}{ Sur } & La Martita & $\begin{array}{c}\text { Viuda } \\
\text { Quenzana } \\
4\end{array}$ & $\begin{array}{c}\text { Hoyuelo natural con bordes } \\
\text { romos }\end{array}$ & Raspado & & & $\begin{array}{c}\text { Gradin y } \\
\text { Aguerre } \\
1984\end{array}$ \\
\hline & \multirow{7}{*}{ El Verano } & $\begin{array}{l}\text { Cueva } 2 \\
\text { El Verano }\end{array}$ & Pisadas y Abstractos & Percusión & $\begin{array}{c}\text { Surco en forma de } \mathrm{U} \\
\text { medianamente } \\
\text { profundo } \\
\end{array}$ & - & \multirow{7}{*}{$\begin{array}{c}\text { Durán } \\
1984-85\end{array}$} \\
\hline & & \multirow{2}{*}{$\begin{array}{c}\text { La } \\
\text { Cantera } 4\end{array}$} & Tridígito & Percusión & Surco en forma de $U$ & - & \\
\hline & & & $\begin{array}{c}\text { Reticulado y líneas } \\
\text { paralelas }\end{array}$ & Incisión & $\begin{array}{c}\text { Surco fino en forma de } \\
\text { V }\end{array}$ & - & \\
\hline & & $\begin{array}{c}\text { La } \\
\text { Cantera } 6\end{array}$ & $\begin{array}{c}\text { Circunferencia simple, } \\
\text { concéntricas, lineal con y } \\
\text { línea vertical }\end{array}$ & Percusión & Surco en U & - & \\
\hline & & $\begin{array}{c}\text { La } \\
\text { Cantera } 7\end{array}$ & $\begin{array}{c}\text { Tridígitos, puntos, } \\
\text { circunferecias, formas } \\
\text { abiertas y cerradas }\end{array}$ & Percusión & Surco en U & - & \\
\hline & & $\begin{array}{c}\text { La } \\
\text { Cantera } 9\end{array}$ & $\begin{array}{l}\text { Circunferencias, líneas } \\
\text { simples y paralelas }\end{array}$ & Percusión & Surco en forma de U & - & \\
\hline & & $\begin{array}{c}\text { Laguna } \\
\text { Colorada }\end{array}$ & $\begin{array}{l}\text { Tridígito, líneas rectas o } \\
\text { sinuosas; peiniforme }\end{array}$ & Percusión & Surco en forma de U & & \\
\hline & \multirow{3}{*}{\multicolumn{2}{|c|}{ La Flecha }} & Puntos & Picado & $i$ & - & \multirow{3}{*}{$\begin{array}{l}\text { Gradin } \\
2003 c\end{array}$} \\
\hline & & & Líneas paralelas & Incisión & $\begin{array}{l}\text { Surco de } 2 \mathrm{~cm} \text { ancho, } \\
\text { recto y fino }\end{array}$ & & \\
\hline & & & $\begin{array}{c}\text { Triángulos alineados y } \\
\text { cruces }\end{array}$ & Incisión & Surco & & \\
\hline
\end{tabular}




\begin{tabular}{|c|c|c|c|c|c|c|c|}
\hline & Localidad & Sitio & Tipo de motivo & Proceso de trabajo inferido & $\begin{array}{c}\text { Correlato del proceso } \\
\text { de trabajo }\end{array}$ & $\begin{array}{l}\text { Artefactos } \\
\text { relacionados }\end{array}$ & $\begin{array}{c}\text { Autores } \\
\\
\text { Gradin } \\
\text { 2003d }\end{array}$ \\
\hline \multirow{7}{*}{ Sur } & \multirow{7}{*}{\multicolumn{2}{|c|}{ La Flecha }} & $\begin{array}{c}\text { Línea con dos U invertidas } \\
\text { adosadas }\end{array}$ & Incisión?* & $\begin{array}{l}\text { Surco fino de entre } 2-3 \\
\mathrm{~mm}\end{array}$ & & \multirow{7}{*}{$\begin{array}{c} \\
\text { Gradin } \\
2003 d\end{array}$} \\
\hline & & & $\begin{array}{c}\text { Circunferencia doble } \\
\text { concéntrica }\end{array}$ & Percusión indirecta grueso & Motivo & & \\
\hline & & & $\begin{array}{l}\text { Peiniforme grabado con } \\
\text { pintura entre los trazos } \\
\text { verticales }\end{array}$ & Picado y pintura & Motivo & & \\
\hline & & & Peiniforme & Incisión & Motivo de surco fino & & \\
\hline & & & "U" invertida & Picado & Surco grabado fuerte & Punzón? & \\
\hline & & & $\begin{array}{c}\text { Escalonados y trazos } \\
\text { paralelos }\end{array}$ & Incisión & Motivo & 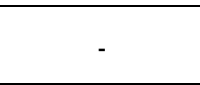 & \\
\hline & & & Grabados con puntos rojos & Pictograbado & Motivo & - & \\
\hline \multirow{7}{*}{ NW } & \multirow{4}{*}{$\mathrm{ARP}$} & $\begin{array}{l}\text { Alero } \\
\text { Parado }\end{array}$ & Grabados & Picado, Abrasión y Raspado & Surco motivos & $\begin{array}{c}\text { ¿Puntas } \\
\text { burilantes? }\end{array}$ & $\begin{array}{l}\text { Aschero } \\
2012\end{array}$ \\
\hline & & \multirow{3}{*}{$\begin{array}{c}\text { Alero } \\
\text { Rosamel }\end{array}$} & $\begin{array}{l}\text { Motivos grabados del bloque } \\
\text { del sector III (frente) }\end{array}$ & Picado & $\begin{array}{l}\text { Surco relativamente } \\
\text { profundo }\end{array}$ & & \multirow{3}{*}{$\begin{array}{c}\text { Aguerre } \\
\text { y Gradin } \\
2003 ; \\
\text { Gradin } \\
\text { et al. } \\
1979\end{array}$} \\
\hline & & & $\begin{array}{c}\text { Círculo del bloque del sector } \\
\text { III (cara posterior) }\end{array}$ & Raspado & $\begin{array}{c}\text { Surco de } 1,5 \mathrm{~cm} \text { de } \\
\text { profundidad }\end{array}$ & - & \\
\hline & & & $\begin{array}{c}\text { Trazos largos y sinuosos del } \\
\text { bloque del sector III (cara } \\
\text { posterior) }\end{array}$ & Picado $+?$ & $\begin{array}{c}\text { Surco variable, ancho } \\
\text { (Percusión indirecta) y } \\
\text { fino (i) }\end{array}$ & & \\
\hline & \multirow{3}{*}{$\begin{array}{l}\text { Angostura del } \\
\text { Deseado }\end{array}$} & \multirow{3}{*}{ Areniscas } & Percusión indirecta & & Surco profundo & - & \multirow{3}{*}{$\begin{array}{c}\text { Gradin } \\
1979\end{array}$} \\
\hline & & & 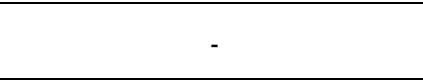 & - & $\begin{array}{l}\text { Realizados con cincel o } \\
\text { percutor }\end{array}$ & - & \\
\hline & & & - & $\begin{array}{l}\text { Percusión, incisión y } \\
\text { raspado }\end{array}$ & Surco & - & \\
\hline
\end{tabular}


Apéndice II.2.a. Identificación de técnicas en sitios de aéreas aledañas al macizo del Deseado.

\begin{tabular}{|c|c|c|c|c|c|}
\hline Ubicación & \multicolumn{2}{|c|}{ Localidad/Sitio } & Sitio & Soporte & Autor \\
\hline \multirow{10}{*}{ MNRSC } & \multicolumn{2}{|c|}{ Sitio El Rincón } & 3 & Areniscas & \multirow{10}{*}{$\begin{array}{c}\text { Acevedo et al. 2010; Fiore y Ocampo 2009; } \\
\text { Franco et al. 2007a }\end{array}$} \\
\hline & \multicolumn{2}{|c|}{ Cañadón El Lechuza y Moro } & 1,3 & Basalto & \\
\hline & \multicolumn{2}{|c|}{ Bajada del Dibujo } & $1,2,3$ & Basalto & \\
\hline & \multicolumn{2}{|c|}{ Yaten Guajen 1} & 3 & \multirow{6}{*}{ Basalto } & \\
\hline & \multirow{2}{*}{\multicolumn{2}{|c|}{$\begin{array}{l}\text { Yaten Guajen } 2 \\
\text { Yaten Guajen } 3\end{array}$}} & $1,2,3$ & & \\
\hline & & & $1,2,4$ & & \\
\hline & \multicolumn{2}{|c|}{$\begin{array}{l}\text { Yaten Guajen } 3 \\
\text { Yaten Guajen } 4\end{array}$} & $1,2,4$ & & \\
\hline & \multicolumn{2}{|c|}{ Yaten Guajen 5} & 1 & & \\
\hline & \multicolumn{2}{|c|}{ Yaten Guajen 6} & $1,2,3,4$ & & \\
\hline & \multicolumn{2}{|c|}{ Cañadón Mercerá } & 3 & Basalto & \\
\hline \multirow{6}{*}{$\begin{array}{c}\text { Mesetas del } \\
\text { oeste } \\
\text { santacruceño }\end{array}$} & \multirow[t]{2}{*}{ Lago Cardiel } & Cañadones & 2,3 & Areniscas & \multirow{2}{*}{ Belardi y Goñi 2002} \\
\hline & & Gerasín 1 y 2; Solís & 2,3 & Basalto & \\
\hline & \multicolumn{2}{|c|}{ MSA y Cch } & 3 & Basalto & Re 2011; Re et al 2010 \\
\hline & \multirow{2}{*}{\multicolumn{2}{|c|}{ MLS }} & 3 & Basalto & Re 2011, Guichón 2012 \\
\hline & & & 3 & Basalto & $\operatorname{Re} 2012$ \\
\hline & $\frac{\text { MLG } 1}{\text { MLBA }}$ & MLBA & 3 & Basalto & Gradin 1976, 1983, 1996 \\
\hline \multirow{11}{*}{$\begin{array}{c}\text { Área } \\
\text { pedemontana }\end{array}$} & \multirow[t]{5}{*}{ Lago Pueyrredón } & Cueva Milodón Norte 1 y 2 & 2 & $\mathrm{~s} / \mathrm{d}$ & \multirow{5}{*}{ Aschero et al. 2009} \\
\hline & & Alero Inclinado & 2 & & \\
\hline & & Alero Colgado & 2 & & \\
\hline & & Alero El Helecho & 2 & & \\
\hline & & Alero Bajo Laguna 2 & 2 & & \\
\hline & \multirow[t]{2}{*}{ Lago Posadas } & Lago Posadas Norte 1 y 2 & 2 & $\mathrm{~s} / \mathrm{d}$ & Aschero 1996a \\
\hline & & Cerro de los Indios 1 & 1 & $\begin{array}{c}\text { Roca } \\
\text { porfirítica }\end{array}$ & $\begin{array}{l}\text { Aschero 1996a; Aschero et al. 1999; Gradin et } \\
\text { al. } 1979\end{array}$ \\
\hline & \multirow[t]{3}{*}{ Lago Belgrano } & Alero Gorra de Vasco & 2 & $\mathrm{~s} / \mathrm{d}$ & \multirow{3}{*}{ Torres 2000} \\
\hline & & $\begin{array}{l}\text { Alero Destacamento } \\
\text { Guardaparque }\end{array}$ & 2 & & \\
\hline & & Alero Dirección Obligatoria & 2 & & \\
\hline & Lago Burmeister & Cerro Casa de Piedra 1-7 y 9 & $1,2,3$ & Ignimbrita & Aschero 1996 a; Aschero et al. 2005 \\
\hline
\end{tabular}

Referencias. Tipo de sitio: 1. Cueva, 2. Alero; 3. Paredones o barda; 4. Bloques. s/d: Sin datos. MNRSC: margen norte del río Santa Cruz;

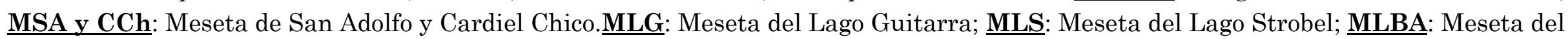
Lago Buenos Aires. Área pedemontana: incluye el área del Río Belgrano, Lago Pueyrredón-Posadas y el Parque Nacional Perito Moreno. 
Apéndice II.2.b. Motivos pintados, técnicas inferidas y materiales asociados en estratigrafía en áreas aledañas al Deseado

\begin{tabular}{|c|c|c|c|c|c|c|}
\hline Localidad & Sitio & Tipo de motivo & Proceso de trabajo inferido & $\begin{array}{l}\text { Correlato del proceso } \\
\text { de trabajo }\end{array}$ & $\begin{array}{l}\text { Artefactos } \\
\text { relacionados }\end{array}$ & Autores \\
\hline \multirow[b]{2}{*}{ MNRSC } & El Lechuza y Moro & Negativo de mano & Estarcido de pintura & - & - & \multirow{2}{*}{$\begin{array}{l}\text { Acevedo et al. 2010; } \\
\text { Fiore y Ocampo 2009; } \\
\text { Franco et al. 2007a }\end{array}$} \\
\hline & $\begin{array}{l}\text { Bajada El Dibujo } \\
\text { Yaten Guajen II }\end{array}$ & Manos positivas & Estampado de pintura & - & - & \\
\hline \multirow[b]{2}{*}{$\begin{array}{l}\text { Meseta del Lago } \\
\text { Strobel }\end{array}$} & Laguna de Los Negros & Negativo de mano & Salpicado de pintura & $\begin{array}{c}\text { Gotas de pintura alrededor de } \\
\text { motivo }\end{array}$ & - & Gradin $1959-60 \mathrm{a}$ \\
\hline & $\begin{array}{l}\text { Laguna Los Negros; Don } \\
\text { Edmundo; La Nativa }\end{array}$ & Negativo de mano & Estarcido indirecto & $\begin{array}{l}\text { Gotas de pintura alrededor de } \\
\text { motivo }\end{array}$ & - & Re 2011 \\
\hline \multirow{12}{*}{ Área Pedemontana } & CMN1 & - & Producción de pinturas & $\begin{array}{l}\text { Pigmentos preparados, vellones } \\
\text { y valvas con restos de pigmentos }\end{array}$ & - & Aschero et al. 2009 \\
\hline & Cerro de Los Indios 1 & - & Preparación de pintura & $\begin{array}{c}\text { Restos de pigmentos en } \\
\text { estratigrafía restos vegetales } \\
\text { teñidos con pintura roja; moleta } \\
\text { con restos de pintura }\end{array}$ & - & $\begin{array}{l}\text { Aschero et al. 1999; } \\
\text { Gradin et al. } 1979\end{array}$ \\
\hline & \multirow{3}{*}{ ADG y AGV } & $\begin{array}{c}\text { Zoomorfos, guanacos y } \\
\text { antropomorfo }\end{array}$ & $\begin{array}{l}\text { Aplicación con algún } \\
\text { artefacto o elemento }\end{array}$ & 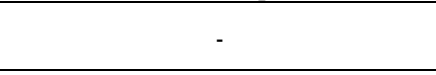 & \multirow{3}{*}{-} & \multirow{3}{*}{ Torres 2000} \\
\hline & & Trazos rectos paralelos & Digital & Motivo & & \\
\hline & & Negativos de mano & $\begin{array}{c}\text { Rociado bucal o uso de } \\
\text { hisopo o pincel }\end{array}$ & - & & \\
\hline & \multirow{5}{*}{ CCP5 } & Guanaco (M 56c y 44) & $\begin{array}{l}\text { Aplicación de pintura } \\
\text { sobre pared }\end{array}$ & $\begin{array}{l}\text { Chorreadura de pinturas (capas } \\
2 \text { y 4). Análisis DRX coinciden } \\
\text { muestra pared y capa }\end{array}$ & $\begin{array}{l}\text { Escápula de } \\
\text { guanaco con } \\
\text { restos de } \\
\text { pintura (Capa } \\
\text { 2); } \\
\end{array}$ & \multirow{6}{*}{$\begin{array}{l}\text { Aschero 1983-85; } \\
\text { Barbosa y Rial 1983-85; } \\
\text { Aschero et al. } 2005\end{array}$} \\
\hline & & - & Preparación de pintura & Fragmentos de pigmentos & & \\
\hline & & - & Aplicación de pintura & Vellones teñidos de rojo & - & \\
\hline & & - & $\begin{array}{l}\text { Alteración composición } \\
\text { mineralógica de } \\
\text { componentes pinturas }\end{array}$ & Pigmentos cercanos a fogones & - & \\
\hline & & $\begin{array}{c}\text { Alineación de trazos } \\
\text { cortos verticales } \\
\text { "dígitos" }\end{array}$ & $\begin{array}{l}\text { Aplicación de la pintura } \\
\text { con la yema de los dedos }\end{array}$ & - & - & \\
\hline & \multirow{2}{*}{$\mathrm{CCP} 7$} & Negativos & Estarcido & - & - & \\
\hline & & Guanacos & Pintura & - & Pincel & Scheinsohn 2010 \\
\hline
\end{tabular}

Referencias. MNRSC: Margen Norte del río Santa Cruz. CMN1: Cueva del Milodon Norte 1; ADG: Alero Destacamento Guardaparque; AGV: Alero Gorra de Vasco; CCP: Casa de Piedra 
Apéndice II.2.c. Motivos grabados, técnicas inferidas y correlatos materiales en áreas aledañas al macizo del Deseado.

\begin{tabular}{|c|c|c|c|c|c|c|}
\hline Localidad & Sitio & Tipo de motivo & Proceso de trabajo inferido & Correlato del proceso de trabajo & Artefactos relacionados & Autores \\
\hline \multirow{6}{*}{ MNRSC } & El Rincón & Pisadas; Abstractos & Piqueteado, incisión y raspado & \multirow[t]{6}{*}{ 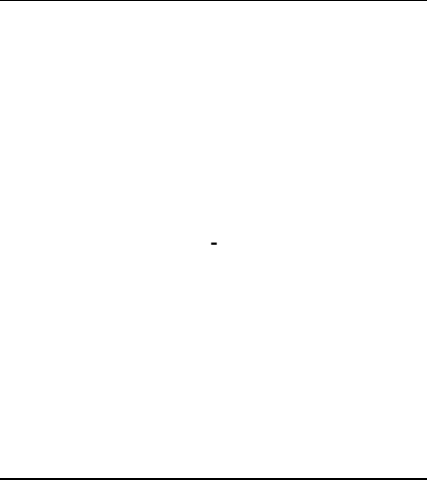 } & - & \multirow{6}{*}{$\begin{array}{l}\text { Acevedo et al. } \\
\text { 2010; Fiore y } \\
\text { Ocampo } 2009\end{array}$} \\
\hline & $\begin{array}{l}\text { El Lechuza y el } \\
\text { Moro }\end{array}$ & Rayados finos & Incisiones & & - & \\
\hline & El Dibujo & $\begin{array}{l}\text { Pisadas, geométricos } \\
\text { simples; zoomorfos } \\
\text { (guanacos) }\end{array}$ & Piqueteado, incisión y raspado & & - & \\
\hline & Yaten Guajen I & $\begin{array}{l}\text { Pisadas (humanas, de } \\
\text { felino y de ave), } \\
\text { Geométricos simples }\end{array}$ & Picado & & - & \\
\hline & Yaten Guajen II & Geométricos simples & Picado & & - & \\
\hline & Mercerá & $\begin{array}{l}\text { Pisadas (de guanaco, de } \\
\text { felino y de ave), } \\
\text { Geométricos simples; } \\
\text { mano }\end{array}$ & Picado & & - & \\
\hline Lago Cardiel & Gerasín 2 y Solís & $\begin{array}{l}\text { Pisada felino, guanaco, } \\
\text { tridígitos; círculos, } \\
\text { círculos concéntricos }\end{array}$ & Picado & - & - & $\begin{array}{l}\text { Belardi y Goñi } \\
2002\end{array}$ \\
\hline \multirow{7}{*}{$\begin{array}{l}\text { Meseta del Lago } \\
\text { Strobel }\end{array}$} & $\begin{array}{l}\text { Laguna del Faldeo } \\
\text { Verde }\end{array}$ & $\begin{array}{c}\text { Líneas sinuosas, figuras } \\
\text { geométricas, rastros y } \\
\text { miniaturas }\end{array}$ & Picado $^{1}$ & Surco superficial y ancho & Punzón & \multirow{7}{*}{$\begin{array}{l}\text { Guichón } 2012 ; \\
\text { Re } 2011 ; \operatorname{Re} \text { et } \\
\text { al } 2007 \text { ? }\end{array}$} \\
\hline & $\begin{array}{l}\text { Laguna del Faldeo } \\
\text { Verde; laguna de } \\
\text { Los Negros, Laguna } \\
\text { Sudeste; Laguna } \\
\text { del Puente }\end{array}$ & $\begin{array}{l}\text { Círculos yuxtapuestos, } \\
\text { espirales complicadas }\end{array}$ & Picado $^{1}$ & Surco superficial y ancho & punzón & \\
\hline & $\begin{array}{c}\text { Laguna del Faldeo } \\
\text { Verde }\end{array}$ & $\begin{array}{l}\text { Líneas sinuosas } \\
\text { combinadas }\end{array}$ & Incisión?** & Surco superficial y fino & buril & \\
\hline & $\begin{array}{c}\text { Laguna del Faldeo } \\
\text { Verde }\end{array}$ & Figura antropomorfa & Picado $^{1}$ & Surco punteado y mediano & punzón & \\
\hline & Laguna del Puente & Guanacos & $\begin{array}{l}\text { Raspado; Raspado-Inciso; } \\
\text { Picado }^{1} \text { y Picado }{ }^{1} \text {-Inciso } \\
\end{array}$ & - & - & \\
\hline & \multirow[t]{2}{*}{ Otros sitios } & Matuastos & Picado $^{1} ;$ Picado $^{1}$ + Incisión & Surco & . & \\
\hline & & Pisada felino & Picado $^{1}$ & & & \\
\hline
\end{tabular}

${ }^{1}$ La definición de la técnica de picado brindada por Re (2011) refiere a la percusión. Aclara pertinentemente que no se puede distinguir si la misma fue directa o indirecta mediante la mera observación macroscópica de los surcos grabados 


\begin{tabular}{|c|c|c|c|c|c|c|}
\hline Localidad & Sitio & Tipo de motivo & Proceso de trabajo inferido & Correlato del proceso de trabajo & Artefactos relacionados & Autores \\
\hline \multirow{5}{*}{$\begin{array}{l}\text { Meseta del Lago } \\
\quad \text { Strobel }\end{array}$} & \multirow{5}{*}{ Otros sitios } & Pies humanos & Picado; Picado + Raspado & \multirow[t]{5}{*}{ 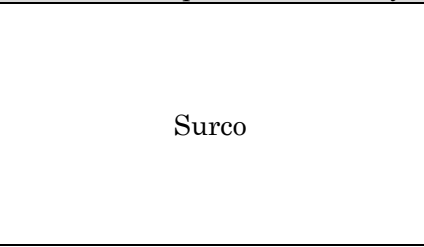 } & \multirow{5}{*}{-} & \multirow{5}{*}{$\begin{array}{l}\text { Guichón 2012; } \\
\quad \operatorname{Re} 2011\end{array}$} \\
\hline & & Tridígitos & $\begin{array}{c}\text { Picado}^{1} \text {; Incisión; Picado1+ } \\
\text { Incisión; Raspado; Picado+ } \\
\text { Raspado } \\
\end{array}$ & & & \\
\hline & & Manos & Picado; Picado + Incisión & & & \\
\hline & & Círculos & Picado & & & \\
\hline & & & Picado & & & \\
\hline \multirow{6}{*}{\multicolumn{2}{|c|}{ Lago Guitarra }} & Guanacos & $\begin{array}{l}\text { Picado; Picado + Incisión; } \\
\text { Raspado }\end{array}$ & \multirow{6}{*}{ Surco } & \multirow{6}{*}{-} & \multirow{6}{*}{$\begin{array}{l}\text { Guichón 2012; } \\
\text { Re 2011; Re et } \\
\text { al. 2009? }\end{array}$} \\
\hline & & Matuastos & Picado & & & \\
\hline & & Pisada felino & Picado; Incisión & & & \\
\hline & & Tridígitos & Picado & & & \\
\hline & & Pies humanos & Picado & & & \\
\hline & & Círculos & $\begin{array}{c}\text { Raspado + Incisión; Raspado; } \\
\text { Incisión }\end{array}$ & & & \\
\hline \multirow{6}{*}{\multicolumn{2}{|c|}{ Meseta San Adolfo y Lago Cardiel Chico }} & Guanacos & Picado; Picado + Incisión & & & \multirow{6}{*}{$\begin{array}{l}\text { Re } 2011 ; \text { Re y } \\
\text { Guichón } 2013 ?\end{array}$} \\
\hline & & Matuastos & Picado & & & \\
\hline & & Piche-zoomorfo & Picado & & & \\
\hline & & Pisada felino & Picado; Incisión & & & \\
\hline & & Tridígitos & Picado & & & \\
\hline & & Pies humanos & Picado; Incisión & & & \\
\hline \multirow{13}{*}{$\begin{array}{l}\text { Meseta del Lago } \\
\text { Buenos Aires }\end{array}$} & \multirow{4}{*}{$\begin{array}{l}\text { Puesto Filin } \\
\text { Sitio } 1\end{array}$} & Reticulado & Incisión & Surco fino & & \multirow{13}{*}{$\begin{array}{c}\text { Gradin } 1976, \\
1996\end{array}$} \\
\hline & & Curvilíneo & Picado & Surco irregular & & \\
\hline & & U invertida & Picado & Surco ancho y plano & & \\
\hline & & Circunferencia & Picado & Trazo discontinuo & - & \\
\hline & \multirow[b]{2}{*}{ Puesto Filin Sitio 2} & Filiforme & Incisión?* & Surco fino & - & \\
\hline & & $\begin{array}{c}\text { Circunferencias } \\
\text { concéntricas }\end{array}$ & Picado & Surco irregular & - & \\
\hline & Puesto Filin Sitio 3 & $\begin{array}{l}\text { Trazos rectos; tridígito; } \\
\text { líneas paralelas }\end{array}$ & Incisión & Surco fino & - & \\
\hline & \multirow{2}{*}{$\begin{array}{l}\text { Puesto Blanco Slick } \\
\text { Sitio } 3 \\
\end{array}$} & Curvilíneo & Picado & Surco superficial & - & \\
\hline & & Reticulado & Incisión & - & - & \\
\hline & \multirow{4}{*}{ Bardas Bajas } & Trazos & Picado & - & - & \\
\hline & & $\begin{array}{c}\text { Circunferencias } \\
\text { concéntricas }\end{array}$ & Raspado & Surco profundo & - & \\
\hline & & $\begin{array}{c}\text { Curvilíneos, tridígitos, } \\
\text { circunferencias con } \\
\text { apéndice }\end{array}$ & Picado & Surco ancho y superficial & - & \\
\hline & & $\begin{array}{l}\text { Reticulados irregulares y } \\
\text { tridígitos pequeños }\end{array}$ & Incisión & Surco fino & & \\
\hline
\end{tabular}




\begin{tabular}{|c|c|c|c|c|c|c|}
\hline Apéndice II.2 & ontinuación) & & & & & \\
\hline Localidad & Sitio & Tipo de motivo & Proceso de trabajo inferido & Correlato del proceso de trabajo & Artefactos relacionados & Autores \\
\hline $\begin{array}{l}\text { Meseta del Lago } \\
\text { Buenos Aires }\end{array}$ & Bardas Bajas & $\begin{array}{l}\text { Curvilíneos sinuosos; } \\
\text { circulares }\end{array}$ & Percusión & - & - & $\begin{array}{c}\text { Gradin } 1976, \\
1996\end{array}$ \\
\hline \multirow{3}{*}{$\begin{array}{l}\text { Sur Meseta Lago } \\
\text { Buenos Aires }\end{array}$} & Sitio 2 & $\begin{array}{c}\text { Curvilíneos sinuosos; } \\
\text { circulares con trazo } \\
\text { ecuatorial; siluetas de } \\
\text { matuastos }\end{array}$ & Percusión & \multirow{3}{*}{ - } & \multirow{4}{*}{ - } & \multirow{4}{*}{$\begin{array}{l}\text { Gradin et al. } \\
\quad 1979\end{array}$} \\
\hline & Sitio 11 & $\begin{array}{l}\text { Motivos curvilíneos; } \\
\text { tridígito y silueta de } \\
\text { matuastos }\end{array}$ & Percusión & & & \\
\hline & Sitio 14 & $\begin{array}{c}\text { Círculos pequeños o } \\
\text { aislados; serpentiforme }\end{array}$ & Percusión & & & \\
\hline Área Pedemontana & $\begin{array}{l}\text { Cerro de los Indios } \\
1\end{array}$ & - & - & Percutor-cincel sobre guijarro & & \\
\hline
\end{tabular}


Apéndice II.3.a. Sitios y tipos de motivos del macizo de Somuncurá.

\begin{tabular}{|c|c|c|c|c|c|c|c|c|c|c|c|c|c|}
\hline \multirow{2}{*}{\multicolumn{2}{|c|}{ Ubicación }} & \multirow[b]{2}{*}{ Sitio } & \multirow[b]{2}{*}{ Tipo } & \multirow[b]{2}{*}{ Soporte } & \multicolumn{8}{|c|}{ MOTIVOS } & \multirow[b]{2}{*}{ Fuentes } \\
\hline & & & & & Punt & Rect & $\begin{array}{l}\text { Circ } \\
\text { llen }\end{array}$ & $\begin{array}{l}\text { Circ } \\
\operatorname{lin}\end{array}$ & Curv & Comb & Fig & ND & \\
\hline \multicolumn{2}{|c|}{ Borde Septentrional } & $\begin{array}{c}\text { Manantial Ramos } \\
\text { Mexía }\end{array}$ & 3 & Basalto & - & $\mathrm{X}$ & - & - & - & - & - & $\mathrm{X}$ & Gradin $2003 b$ \\
\hline \multicolumn{2}{|c|}{ Noreste Somuncurá (I) } & $\begin{array}{c}\text { Pintada de Corral } \\
\text { Curá }\end{array}$ & 3 & Basalto & $\mathrm{X}$ & $\mathrm{X}$ & - & - & - & - & - & - & $\begin{array}{c}\text { Gradin1971, } \\
2003 \mathrm{a}\end{array}$ \\
\hline \multirow{2}{*}{\multicolumn{2}{|c|}{$\begin{array}{l}\text { Sierra de Pailemán } \\
\text { (II) }\end{array}$}} & Cueva Galpón & 1 & $\mathrm{n} / \mathrm{d}$ & $\mathrm{n} / \mathrm{d}$ & $\mathrm{n} / \mathrm{d}$ & $\mathrm{n} / \mathrm{d}$ & $\mathrm{n} / \mathrm{d}$ & $\mathrm{n} / \mathrm{d}$ & $\mathrm{n} / \mathrm{d}$ & $\mathrm{X}$ & $\mathrm{n} / \mathrm{d}$ & $\begin{array}{l}\text { Prates et al. } \\
2011 \\
\end{array}$ \\
\hline & & Rinconada Catriel & 3 & $\begin{array}{c}\text { Toba } \\
\text { porfirítica }\end{array}$ & $\mathrm{X}$ & $\mathrm{X}$ & - & - & - & - & - & - & Gradin $2003 a$ \\
\hline \multirow{3}{*}{\multicolumn{2}{|c|}{ Borde Centro-oriental (III) }} & Los Manantiales 1 & 3 & \multirow{3}{*}{ Basalto } & $\mathrm{X}$ & $\mathrm{X}$ & - & $\mathrm{X}$ & $\mathrm{X}$ & - & $\mathrm{X}$ & $\mathrm{X}$ & \multirow{3}{*}{$\begin{array}{c}\text { Albornoz } \\
\text { 2003; } \\
\text { Albornoz y } \\
\text { Pereda } 2010\end{array}$} \\
\hline & & Los Manantiales 5 & 3 & & $\mathrm{X}$ & $\mathrm{X}$ & - & $\mathrm{X}$ & $\mathrm{X}$ & - & - & - & \\
\hline & & $\begin{array}{c}\text { Los Manantiales } \\
12\end{array}$ & 1 & & - & $\mathrm{X}$ & - & $\mathrm{X}$ & - & - & $\mathrm{X}$ & $\mathrm{X}$ & \\
\hline \multirow{4}{*}{$\begin{array}{l}\text { Centro de } \\
\text { Somuncurá } \\
\text { (VI) }\end{array}$} & \multirow{4}{*}{$\begin{array}{l}\text { Sierra de } \\
\text { Apas }\end{array}$} & Cueva Llancafil & 1 & \multirow{4}{*}{ Basalto } & $\mathrm{X}$ & $\mathrm{X}$ & - & $\mathrm{X}$ & $\mathrm{X}$ & $\mathrm{X}$ & $\mathrm{X}$ & - & \multirow{4}{*}{$\begin{array}{c}\text { Casamiquela } \\
1960\end{array}$} \\
\hline & & Sandoval 1 & 3 & & $\mathrm{n} / \mathrm{d}$ & $\mathrm{n} / \mathrm{d}$ & $\mathrm{n} / \mathrm{d}$ & $\mathrm{n} / \mathrm{d}$ & $\mathrm{n} / \mathrm{d}$ & $\mathrm{n} / \mathrm{d}$ & $\mathrm{n} / \mathrm{d}$ & $\mathrm{n} / \mathrm{d}$ & \\
\hline & & Sandoval 2 & 3 & & $\mathrm{X}$ & $\mathrm{X}$ & - & - & - & - & - & - & \\
\hline & & Cide & 3 & & - & $\mathrm{X}$ & - & $\mathrm{X}$ & - & - & - & - & \\
\hline \multirow{4}{*}{\multicolumn{2}{|c|}{$\begin{array}{l}\text { Borde Centro-occidental } \\
\text { (V) }\end{array}$}} & Cueva La Rural & 1 & \multirow{4}{*}{ Andesita } & $\mathrm{X}$ & $\mathrm{X}$ & - & - & - & - & - & $\mathrm{X}$ & \multirow{4}{*}{ Belardi 1996} \\
\hline & & Alero La Rural & 2 & & $\mathrm{X}$ & $\mathrm{X}$ & - & - & - & - & - & $\mathrm{X}$ & \\
\hline & & $\begin{array}{c}\text { Cueva de Las } \\
\text { Grecas }\end{array}$ & 1 & & $\mathrm{X}$ & $\mathrm{X}$ & - & - & - & - & - & $\mathrm{X}$ & \\
\hline & & El Panel & 3 & & $\mathrm{X}$ & $\mathrm{X}$ & - & - & - & - & - & $\mathrm{X}$ & \\
\hline \multicolumn{2}{|c|}{ Noroeste (VI) } & Vacalauquén (1-3) & $2-3$ & Basalto & - & $\mathrm{X}$ & - & $\mathrm{X}$ & $\mathrm{X}$ & $\mathrm{X}$ & $\mathrm{X}$ & $\mathrm{X}$ & Gradin $2003 \mathrm{~b}$ \\
\hline
\end{tabular}

Referencias: Tipo de sitio. 1. Cueva; 2. Alero; 3. Paredón-barda.

Motivos: Punt: puntiformes; Rect: rectilíneos; Circ llen: circulares llenos; Circ lin: Circulares lineales; Curv: curvilíneo;

Comb: combinado; Fig: figurativo; ND: no determinado.

$\mathrm{X}$ : presencia; -: ausencia; $\mathrm{n} / \mathrm{d}$ : sin datos. 
Apéndice II.3.b. Motivos pintados, técnicas inferidas y materiales asociados en estratigrafía en Somuncurá

\begin{tabular}{|c|c|c|c|c|c|c|}
\hline Sitio & & Tipo de motivo & $\begin{array}{c}\text { Proceso de } \\
\text { trabajo inferido }\end{array}$ & $\begin{array}{c}\text { Correlato del proceso } \\
\text { de trabajo }\end{array}$ & $\begin{array}{l}\text { Artefactos } \\
\text { relacionados }\end{array}$ & Fuente \\
\hline \multirow{3}{*}{$\begin{array}{l}\text { Borde Centro- } \\
\text { oriental (III) }\end{array}$} & $\begin{array}{l}\text { Los Manantiales } \\
1\end{array}$ & Motivos rectilíneos & Pintura & Mono y Bicromías & 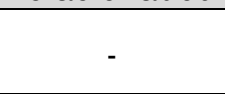 & \multirow{3}{*}{$\begin{array}{c}\text { Albornoz 2003; } \\
\text { Albornoz y Pereda } \\
2010\end{array}$} \\
\hline & \multirow{2}{*}{$\begin{array}{l}\text { Los Manantiales } \\
\qquad 12\end{array}$} & $\begin{array}{c}\text { Líneas verticales } \\
\text { cortas paralelas }\end{array}$ & $\begin{array}{c}\text { Arrastre de } \\
\text { dígitos }\end{array}$ & Trazo pintado & - & \\
\hline & & Motivos varios & Pintura & Monocromías & - & \\
\hline $\begin{array}{c}\text { Noroeste } \\
\text { Somuncurá (VI) }\end{array}$ & $\begin{array}{l}\text { Vacalauquén } \\
\text { (Sitio II) }\end{array}$ & $\begin{array}{l}\text { Líneas verticales } \\
\text { paralelas cortas }\end{array}$ & $\begin{array}{c}\text { Arrastre de } \\
\text { dígitos } \\
\end{array}$ & Motivo & - & Gradin 2003b \\
\hline
\end{tabular}

Apéndice II.3.c. Motivos grabados, técnicas inferidas y materiales asociados en estratigrafía en Somuncurá

\begin{tabular}{|c|c|c|c|c|c|c|}
\hline Sitio & & Tipo de motivo & $\begin{array}{l}\text { Proceso de } \\
\text { trabajo } \\
\text { inferido }\end{array}$ & $\begin{array}{l}\text { Correlato del proceso de } \\
\text { trabajo }\end{array}$ & $\begin{array}{l}\text { Artefactos } \\
\text { relacionados }\end{array}$ & Fuente \\
\hline $\begin{array}{c}\text { Borde } \\
\text { septentrional }\end{array}$ & $\begin{array}{c}\text { Manantial } \\
\text { Ramos Mexía }\end{array}$ & $\begin{array}{l}\text { Líneas curvas } \\
\text { paralelas unidas por } \\
\text { trazos rectos }\end{array}$ & $\begin{array}{l}\text { Pintura } \\
\text { sobre } \\
\text { grabado }\end{array}$ & $\begin{array}{l}\text { Surco profundo que presenta } \\
\text { restos de pintura roja }\end{array}$ & - & Gradin $2003 \mathrm{~b}$ \\
\hline \multirow{7}{*}{$\begin{array}{l}\text { Borde Centro- } \\
\text { oriental (III) }\end{array}$} & \multirow{6}{*}{$\begin{array}{c}\text { Los } \\
\text { Manantiales } 1\end{array}$} & $\begin{array}{l}\text { Reticulados de líneas } \\
\text { oblicuas }\end{array}$ & Incisión & $\begin{array}{l}\text { Surco fino superficial }(2 \mathrm{~mm} \\
\text { ancho x } 1 \mathrm{~mm} \text { profundidad }\end{array}$ & \multirow{7}{*}{-} & \multirow{7}{*}{$\begin{array}{c}\text { Albornoz 2003; } \\
\text { Albornoz y } \\
\text { Pereda } 2010\end{array}$} \\
\hline & & Curvilíneos & - & $\begin{array}{c}\text { Surco cóncavo profundo, ancho } \\
\text { o ancho medio }\end{array}$ & & \\
\hline & & Rectilíneos & Raspado & $\begin{array}{c}\text { surco profundo de ancho } \\
\text { variable }\end{array}$ & & \\
\hline & & Círculos llenos & Raspado & Surco ancho y superficial & & \\
\hline & & $\begin{array}{c}\text { Líneas rectas } \\
\text { intercaladas con líneas } \\
\text { de puntos }\end{array}$ & Raspado & $\begin{array}{l}\text { Surco profundo para líneas de } \\
\text { puntos y surco poco profundo } \\
\text { y ancho para líneas rectas }\end{array}$ & & \\
\hline & & $\begin{array}{l}\text { Rectilíneos, curvilíneos } \\
\text { y círculos planos }\end{array}$ & $\begin{array}{l}\text { Pintura } \\
\text { sobre } \\
\text { grabado }\end{array}$ & $\begin{array}{l}\text { El trazo pintado puede } \\
\text { sobrepasar al surco grabado }\end{array}$ & & \\
\hline & $\begin{array}{c}\text { Los } \\
\text { Manantiales } 5 \\
\end{array}$ & $\begin{array}{c}\text { Rectilíneos, curvilíneos } \\
\text { y circunferencias }\end{array}$ & Raspado & $\begin{array}{l}\text { Surco superficial de trazo } \\
\text { medio o muy ancho }\end{array}$ & & \\
\hline
\end{tabular}


Apéndice II.4.a. Sitios y tipos de motivos de áreas aledañas a Somuncurá

\begin{tabular}{|c|c|c|c|c|c|c|c|c|c|c|c|}
\hline \multirow[t]{2}{*}{ 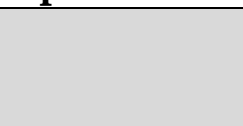 } & \multirow[t]{2}{*}{ Sitio } & \multirow[t]{2}{*}{ Tipo } & \multirow[t]{2}{*}{ Soporte } & \multicolumn{7}{|c|}{ Motivos } & \multirow[t]{2}{*}{ Fuente } \\
\hline & & & & Punt & Rect & $\begin{array}{l}\text { Circ } \\
\text { llen }\end{array}$ & Circ lin & Curvil & Fig & ND & \\
\hline \multirow{21}{*}{ Piedra Parada } & Barda Blanca 2 & $\mathrm{~s} / \mathrm{d}$ & \multirow[b]{2}{*}{ Toba } & $\mathrm{X}$ & $\mathrm{X}$ & & $\mathrm{X}$ & $\mathrm{X}$ & $\mathrm{X}$ & $\mathrm{s} / \mathrm{d}$ & \multirow{2}{*}{ Onetto 1987,1991} \\
\hline & Barda Blanca 3 & s/d & & $\mathrm{X}$ & $\mathrm{X}$ & - & - & - & - & - & \\
\hline & Campo Cerda 1 & $\mathrm{~s} / \mathrm{d}$ & Basalto & $\mathrm{s} / \mathrm{d}$ & $\mathrm{X}$ & s/d & $\mathrm{s} / \mathrm{d}$ & $\mathrm{s} / \mathrm{d}$ & $\mathrm{s} / \mathrm{d}$ & $\mathrm{s} / \mathrm{d}$ & Bellelli et al. 2007; \\
\hline & Campo Moncada 1 & 2 & Toba & - & $\mathrm{X}$ & - & $\mathrm{X}$ & - & $\mathrm{X}$ & $\mathrm{s} / \mathrm{d}$ & Bellelli 2002 \\
\hline & Campo Moncada 4-6 & $\mathrm{s} / \mathrm{d}$ & Toba & $\mathrm{X}$ & $\mathrm{X}$ & - & - & - & - & $\mathrm{X}$ & Onetto 1983a \\
\hline & Piedra Parada 1 & 2 & \multirow{2}{*}{ Toba } & $\mathrm{X}$ & $\mathrm{X}$ & - & $\mathrm{X}$ & $\mathrm{X}$ & $\mathrm{X}$ & - & Aschero 1983a; Onetto 1987 \\
\hline & Piedra Parada 4 & 3 & & $\mathrm{X}$ & $\mathrm{X}$ & - & $\mathrm{X}$ & $\mathrm{X}$ & - & $\mathrm{X}$ & Aschero 1983a; Pérez de Micou 1983a \\
\hline & Campo Cretton 1 & 3 & Toba & $\mathrm{X}$ & $\mathrm{X}$ & & $\mathrm{X}$ & $\mathrm{X}$ & $\mathrm{X}$ & $\mathrm{X}$ & Onetto $1981-82$ \\
\hline & Campo Nassif 1 & 2 & \multirow{2}{*}{ Arenisca } & $\mathrm{X}$ & $\mathrm{X}$ & & $\mathrm{X}$ & $\mathrm{X}$ & $\mathrm{X}$ & $\mathrm{X}$ & Onetto 1983c,1987; Nacuzzi 1983 \\
\hline & Campo Nassif 3 & $\mathrm{~s} / \mathrm{d}$ & & $\mathrm{X}$ & $\mathrm{X}$ & - & $\mathrm{X}$ & $\mathrm{X}$ & $\mathrm{X}$ & - & Aschero 1983b; Onetto 1987 \\
\hline & San Ramón 1 & 2 & \multirow{6}{*}{$\begin{array}{c}\text { Roca } \\
\text { porfirítica }\end{array}$} & $\mathrm{X}$ & $\mathrm{X}$ & & $\mathrm{X}$ & $\mathrm{X}$ & $\mathrm{X}$ & $\mathrm{X}$ & Aschero $1983 \mathrm{c}$ \\
\hline & San Ramón 2 & 2 & & $\mathrm{~s} / \mathrm{d}$ & $\mathrm{X}$ & s/d & $\mathrm{X}$ & $\mathrm{s} / \mathrm{d}$ & $\mathrm{X}$ & $\mathrm{s} / \mathrm{d}$ & Pérez de Micou y Castro 2005 \\
\hline & San Ramón 4 & 2 & & s/d & s/d & $\mathrm{s} / \mathrm{d}$ & $\mathrm{s} / \mathrm{d}$ & s/d & $\mathrm{s} / \mathrm{d}$ & $\mathrm{s} / \mathrm{d}$ & Pérez de Micou y Castro 2005 \\
\hline & San Ramón 5 & $\mathrm{~s} / \mathrm{d}$ & & $\mathrm{s} / \mathrm{d}$ & s/d & s/d & $\mathrm{s} / \mathrm{d}$ & $\mathrm{s} / \mathrm{d}$ & $\mathrm{s} / \mathrm{d}$ & $\mathrm{s} / \mathrm{d}$ & Onetto 1991 \\
\hline & San Ramón 6 & 4 & & $\mathrm{~s} / \mathrm{d}$ & $\mathrm{X}$ & $\mathrm{s} / \mathrm{d}$ & $\mathrm{s} / \mathrm{d}$ & s/d & $\mathrm{s} / \mathrm{d}$ & $\mathrm{s} / \mathrm{d}$ & Onetto 1990,1991 \\
\hline & San Ramón 7 & 2 & & $\mathrm{~s} / \mathrm{d}$ & $\mathrm{s} / \mathrm{d}$ & $\mathrm{s} / \mathrm{d}$ & $\mathrm{s} / \mathrm{d}$ & $\mathrm{s} / \mathrm{d}$ & $\mathrm{s} / \mathrm{d}$ & $\mathrm{s} / \mathrm{d}$ & \multirow[t]{2}{*}{ Pérez de Micou y Castro 2005} \\
\hline & Aguada del Potrillo 1 & 2 & s/d & - & $\mathrm{X}$ & - & - & - & - & $\mathrm{X}$ & \\
\hline & Alero Don Santiago & 2 & & $\mathrm{X}$ & $\mathrm{X}$ & - & - & - & $\mathrm{X}$ & - & Onetto 1987 \\
\hline & Campo Cosmen 1 & s/d & \multirow{3}{*}{$\mathrm{s} / \mathrm{d}$} & - & $\mathrm{X}$ & - & - & $\mathrm{X}$ & - & - & Onetto 1987 \\
\hline & Angostura Blanca & s/d & & $\mathrm{s} / \mathrm{d}$ & $\mathrm{X}$ & $\mathrm{s} / \mathrm{d}$ & $\mathrm{s} / \mathrm{d}$ & s/d & $\mathrm{s} / \mathrm{d}$ & $\mathrm{s} / \mathrm{d}$ & Onetto 1987 \\
\hline & Bajada del Tigre & s/d & & $\mathrm{s} / \mathrm{d}$ & $\mathrm{s} / \mathrm{d}$ & $\mathrm{s} / \mathrm{d}$ & $\mathrm{s} / \mathrm{d}$ & s/d & $\mathrm{X}$ & $\mathrm{s} / \mathrm{d}$ & Onetto 1990 \\
\hline \multirow{4}{*}{$\begin{array}{c}\text { Arroyo } \\
\text { Pilcaniyeu }\end{array}$} & Abrigo Pilcaniyeu & 2 & Toba & $\mathrm{X}$ & $\mathrm{X}$ & - & $\mathrm{X}$ & $\mathrm{X}$ & $\mathrm{X}$ & - & $\begin{array}{l}\text { Boschín 1986, Fernández 2006; } \\
\text { Llamazares } 1980\end{array}$ \\
\hline & Alero La Figura 1 & 2 & $\mathrm{~s} / \mathrm{d}$ & - & $\mathrm{X}$ & - & - & - & $\mathrm{X}$ & - & Nacuzzi 1987 \\
\hline & Cva Ceferino II* & $\mathrm{s} / \mathrm{d}$ & Toba & $\mathrm{s} / \mathrm{d}$ & s/d & s/d & $\mathrm{s} / \mathrm{d}$ & s/d & $\mathrm{s} / \mathrm{d}$ & $\mathrm{X}$ & Boschín 2009 \\
\hline & Cva Ceferino III & 1 & & - & $\mathrm{X}$ & - & - & - & $\mathrm{X}$ & - & Boschín 2009; Fiore 1999 \\
\hline \multirow{4}{*}{$\begin{array}{l}\text { Arroyo } \\
\text { Pichileufú }\end{array}$} & $\begin{array}{l}\text { Cueva } 1 \text { del río } \\
\text { Pichileufú }\end{array}$ & 1 & Toba & $\mathrm{X}$ & $\mathrm{X}$ & - & $\mathrm{X}$ & $\mathrm{X}$ & $\mathrm{X}$ & - & Boschín 1986, 2009 \\
\hline & Abrigo Pichileufú & 2 & & $\mathrm{X}$ & $\mathrm{X}$ & - & - & $\mathrm{X}$ & $\mathrm{X}$ & - & Boschín 2009 \\
\hline & $\begin{array}{l}\text { Paredones del río } \\
\text { Pichileufú }\end{array}$ & 3 & & $\mathrm{X}$ & $\mathrm{X}$ & - & - & $\mathrm{X}$ & $\mathrm{X}$ & - & \multirow[t]{2}{*}{ Boschín 1986} \\
\hline & Cueva Pulpulcurá I & $\mathrm{s} / \mathrm{d}$ & $\mathrm{s} / \mathrm{d}$ & $\mathrm{s} / \mathrm{d}$ & $\mathrm{s} / \mathrm{d}$ & $\mathrm{s} / \mathrm{d}$ & $\mathrm{s} / \mathrm{d}$ & $\mathrm{s} / \mathrm{d}$ & $\mathrm{s} / \mathrm{d}$ & $\mathrm{s} / \mathrm{d}$ & \\
\hline
\end{tabular}




\begin{tabular}{|c|c|c|c|c|c|c|c|c|c|c|c|}
\hline & \multirow[t]{2}{*}{ Sitio } & \multirow[t]{2}{*}{ Tipo } & \multirow[t]{2}{*}{ Soporte } & \multicolumn{7}{|c|}{ Motivos } & \multirow[t]{2}{*}{ Fuente } \\
\hline & & & & Punt & Rect & $\begin{array}{l}\text { Circ } \\
\text { llen }\end{array}$ & Circ lin & Curvil & Fig & ND & \\
\hline \multirow{15}{*}{$\begin{array}{c}\text { Arroyo } \\
\text { Pichileufú }\end{array}$} & Cueva Pulpulcurá I* & $\mathrm{s} / \mathrm{d}$ & $\mathrm{s} / \mathrm{d}$ & $\mathrm{s} / \mathrm{d}$ & $\mathrm{s} / \mathrm{d}$ & & & & & & \multirow{5}{*}{ Boschín 1986} \\
\hline & $\begin{array}{l}\text { Cueva I Julio Fernández } \\
*\end{array}$ & $\mathrm{~s} / \mathrm{d}$ & $\mathrm{s} / \mathrm{d}$ & $\mathrm{s} / \mathrm{d}$ & $\mathrm{s} / \mathrm{d}$ & $\mathrm{s} / \mathrm{d}$ & $\mathrm{s} / \mathrm{d}$ & $\mathrm{s} / \mathrm{d}$ & $\mathrm{s} / \mathrm{d}$ & $\mathrm{s} / \mathrm{d}$ & \\
\hline & Cueva Baudino* & $\mathrm{s} / \mathrm{d}$ & $\mathrm{s} / \mathrm{d}$ & $\mathrm{s} / \mathrm{d}$ & $\mathrm{s} / \mathrm{d}$ & $\mathrm{s} / \mathrm{d}$ & $\mathrm{s} / \mathrm{d}$ & $\mathrm{s} / \mathrm{d}$ & $\mathrm{s} / \mathrm{d}$ & $\mathrm{s} / \mathrm{d}$ & \\
\hline & $\begin{array}{l}\text { Abrigo I Angostura } \\
\text { Arriba* }\end{array}$ & $\mathrm{s} / \mathrm{d}$ & $\mathrm{s} / \mathrm{d}$ & $\mathrm{s} / \mathrm{d}$ & $\mathrm{s} / \mathrm{d}$ & $\mathrm{s} / \mathrm{d}$ & $\mathrm{s} / \mathrm{d}$ & $\mathrm{s} / \mathrm{d}$ & $\mathrm{s} / \mathrm{d}$ & $\mathrm{s} / \mathrm{d}$ & \\
\hline & $\begin{array}{l}\text { Abrigo II Angostura } \\
\text { Arriba* }\end{array}$ & $\mathrm{s} / \mathrm{d}$ & $\mathrm{s} / \mathrm{d}$ & $\mathrm{s} / \mathrm{d}$ & $\mathrm{s} / \mathrm{d}$ & $\mathrm{s} / \mathrm{d}$ & $\mathrm{s} / \mathrm{d}$ & $\mathrm{s} / \mathrm{d}$ & $\mathrm{s} / \mathrm{d}$ & $\mathrm{s} / \mathrm{d}$ & \\
\hline & Cueva Visconti & & Toba & - & $\mathrm{X}$ & - & - & - & $\mathrm{X}$ & - & Ceballos y Peronja 1983 \\
\hline & Cueva Alonso I & 2 & $\mathrm{~s} / \mathrm{d}$ & $\mathrm{X}$ & $\mathrm{X}$ & - & $\mathrm{X}$ & $\mathrm{X}$ & $\mathrm{X}$ & $\mathrm{X}$ & Boschín 1986 \\
\hline & Paredón Alonso & 3 & & $\mathrm{X}$ & $\mathrm{X}$ & - & $\mathrm{X}$ & $\mathrm{X}$ & $\mathrm{X}$ & - & Boschín 1986 \\
\hline & Cueva Alonso II & 1 & & $\mathrm{X}$ & $\mathrm{X}$ & - & - & $\mathrm{X}$ & $\mathrm{X}$ & - & Boschín 1986 \\
\hline & Cueva Sarita I & 1 & \multirow{4}{*}{ Toba } & $\mathrm{X}$ & $\mathrm{X}$ & - & $\mathrm{X}$ & $\mathrm{X}$ & $\mathrm{X}$ & - & Boschín 1986, 2009; Llamazares 1987 \\
\hline & Cueva Sarita II & 1 & & - & $\mathrm{X}$ & - & $\mathrm{X}$ & - & $\mathrm{X}$ & $\mathrm{X}$ & Boschín 1986, 2009; Fiore 1999 \\
\hline & Cueva Sarita III & 1 & & $\mathrm{X}$ & $\mathrm{X}$ & & $\mathrm{X}$ & $\mathrm{X}$ & $\mathrm{X}$ & & Boschín 1986 \\
\hline & Cueva Sarita IV & 1 & & $\mathrm{X}$ & $\mathrm{X}$ & - & - & $\mathrm{X}$ & $\mathrm{X}$ & - & Boschín 2009; Fiore 1999 \\
\hline & Peña I & 2 & Toba & $\mathrm{X}$ & $\mathrm{X}$ & - & - & $\mathrm{X}$ & $\mathrm{X}$ & & Boschín 2009 \\
\hline & Cuadro Leleque & 2 & $\mathrm{~s} / \mathrm{d}$ & $\mathrm{X}$ & $\mathrm{X}$ & & $\mathrm{X}$ & $\mathrm{X}$ & $\mathrm{X}$ & - & Boschín 2009 \\
\hline \multirow{5}{*}{ Arroyo Comallo } & Cueva Comallo I & 2 & $\mathrm{~s} / \mathrm{d}$ & $\mathrm{X}$ & $\mathrm{X}$ & - & $\mathrm{X}$ & $\mathrm{X}$ & $\mathrm{X}$ & $\mathrm{X}$ & Arrigoni et al. 2011; Boschín 1986, 2009 \\
\hline & Cueva Comallo II* & $\mathrm{s} / \mathrm{d}$ & & $\mathrm{s} / \mathrm{d}$ & $\mathrm{X}$ & $\mathrm{s} / \mathrm{d}$ & $\mathrm{s} / \mathrm{d}$ & $\mathrm{s} / \mathrm{d}$ & $\mathrm{s} / \mathrm{d}$ & $\mathrm{s} / \mathrm{d}$ & Boschín 1986 \\
\hline & Cueva Comallo IV* & $\mathrm{s} / \mathrm{d}$ & & $\mathrm{s} / \mathrm{d}$ & $\mathrm{X}$ & $\mathrm{s} / \mathrm{d}$ & $\mathrm{s} / \mathrm{d}$ & $\mathrm{s} / \mathrm{d}$ & $\mathrm{s} / \mathrm{d}$ & $\mathrm{s} / \mathrm{d}$ & Boschín 1986 \\
\hline & Cueva Loncomán & 2 & Toba & $\mathrm{X}$ & $\mathrm{X}$ & - & $\mathrm{X}$ & $\mathrm{X}$ & $\mathrm{X}$ & - & \multirow{7}{*}{ Boschín 2009} \\
\hline & $\begin{array}{l}\text { Paredón } \\
\text { Loncomán }\end{array}$ & 3 & Toba & $\mathrm{X}$ & $\mathrm{X}$ & - & $\mathrm{X}$ & $\mathrm{X}$ & $\mathrm{X}$ & - & \\
\hline \multirow{5}{*}{$\begin{array}{c}\text { Arroyo } \\
\text { Maquinchao }\end{array}$} & Calcatreo I & 2 & $\mathrm{~s} / \mathrm{d}$ & - & $\mathrm{X}$ & - & $\mathrm{X}$ & $\mathrm{X}$ & $\mathrm{X}$ & - & \\
\hline & Calcatreo II & 2 & & $\mathrm{X}$ & $\mathrm{X}$ & - & $\mathrm{X}$ & - & $\mathrm{X}$ & & \\
\hline & Santo Rosario & 2 & Basalto & $\mathrm{X}$ & $\mathrm{X}$ & - & $\mathrm{X}$ & $\mathrm{X}$ & $\mathrm{X}$ & - & \\
\hline & Angostura de Cides & 3 & Basalto & - & $\mathrm{X}$ & - & $\mathrm{X}$ & $\mathrm{X}$ & $\mathrm{X}$ & - & \\
\hline & Piedra Bonita de Beiroz & 3 & Basalto & - & $\mathrm{X}$ & - & $\mathrm{X}$ & $\mathrm{X}$ & $\mathrm{X}$ & $\mathrm{X}$ & \\
\hline
\end{tabular}

Apéndice II.4.a (Continuación) 


\begin{tabular}{|c|c|c|c|c|c|c|c|c|c|c|c|}
\hline & \multirow[t]{2}{*}{ Sitio } & \multirow[t]{2}{*}{ Tipo } & \multirow[t]{2}{*}{ Soporte } & \multicolumn{7}{|c|}{ Motivos } & \multirow[b]{2}{*}{ Fuente } \\
\hline & & & & Punt & Rect & $\begin{array}{l}\text { Circ } \\
\text { llen }\end{array}$ & $\begin{array}{l}\text { Circ } \\
\text { lin }\end{array}$ & Curvil & Fig & ND & \\
\hline \multirow{6}{*}{$\begin{array}{l}\text { Piédra del } \\
\text { Águila }\end{array}$} & Epullán Grande & 1 & Toba & $\mathrm{X}$ & $\mathrm{X}$ & - & $\mathrm{X}$ & - & $\mathrm{X}$ & - & \multirow{6}{*}{$\begin{array}{l}\text { Crivelli Montero 2006; Crivelli Montero } \\
\text { et al 1991, 1996, Crivelli y Fernández } \\
\text { 2003; Fernández } 2006\end{array}$} \\
\hline & Epullán Chica & 1 & \multirow{4}{*}{ Toba } & $\mathrm{X}$ & $\mathrm{X}$ & - & $\mathrm{X}$ & $\mathrm{X}$ & $\mathrm{X}$ & - & \\
\hline & Paredón Sur & 3 & & $\mathrm{~s} / \mathrm{d}$ & $\mathrm{X}$ & $\mathrm{s} / \mathrm{d}$ & $\mathrm{s} / \mathrm{d}$ & $\mathrm{s} / \mathrm{d}$ & $\mathrm{X}$ & $\mathrm{s} / \mathrm{d}$ & \\
\hline & La Oquedad & 2 & & $\mathrm{X}$ & $\mathrm{X}$ & - & - & - & $\mathrm{X}$ & - & \\
\hline & El Manantial & 3 & & $\mathrm{X}$ & $\mathrm{X}$ & - & - & $\mathrm{X}$ & $\mathrm{X}$ & - & \\
\hline & Rincón Chico 2/87 & 2,3 & $\begin{array}{l}\text { Volcánicas } \\
\text { intrusivas }\end{array}$ & - & $\mathrm{X}$ & - & $\mathrm{X}$ & - & $\mathrm{X}$ & $\mathrm{X}$ & \\
\hline Quemquemtreu & Mata Molle & 2 & Toba & $\mathrm{X}$ & $\mathrm{X}$ & & $\mathrm{X}$ & $\mathrm{X}$ & $\mathrm{X}$ & - & Plautz de Freschi et al. 1975; \\
\hline \multirow{4}{*}{$\begin{array}{l}\text { Paso Limay- } \\
\text { Paso Flores }\end{array}$} & El Monito & 3 & Ignimbrita & - & $\mathrm{X}$ & & - & - & $\mathrm{X}$ & $\mathrm{X}$ & $\begin{array}{l}\text { Crivelli Montero 2006; Crivelli et al. } \\
1991\end{array}$ \\
\hline & La Marcelina 1 & 2 & Toba & $\mathrm{X}$ & - & - & $\mathrm{X}$ & - & $\mathrm{X}$ & - & Boschín 2009 \\
\hline & Alero Carriqueo $\$$ & $\mathrm{~s} / \mathrm{d}$ & $\mathrm{s} / \mathrm{d}$ & $\mathrm{s} / \mathrm{d}$ & $\mathrm{s} / \mathrm{d}$ & s/d & $\mathrm{s} / \mathrm{d}$ & $\mathrm{s} / \mathrm{d}$ & $\mathrm{s} / \mathrm{d}$ & $\mathrm{s} / \mathrm{d}$ & Crivelli Montero 2006 \\
\hline & Barda Esteban\$ & $\mathrm{s} / \mathrm{d}$ & $\mathrm{s} / \mathrm{d}$ & $\mathrm{s} / \mathrm{d}$ & $\mathrm{s} / \mathrm{d}$ & $\mathrm{s} / \mathrm{d}$ & $\mathrm{s} / \mathrm{d}$ & $\mathrm{s} / \mathrm{d}$ & $\mathrm{s} / \mathrm{d}$ & $\mathrm{s} / \mathrm{d}$ & Crivelli Montero 2006 \\
\hline \multirow[t]{2}{*}{ Corralito } & $\begin{array}{l}\text { Casa de Piedra de } \\
\text { Curapil }\end{array}$ & 2 & Toba & - & $\mathrm{X}$ & - & - & - & - & - & Crivelli Montero 1988 \\
\hline & Casa de Piedra Ortega & 2,3 & Toba & $\mathrm{X}$ & $\mathrm{X}$ & - & $\mathrm{X}$ & $\mathrm{X}$ & $\mathrm{X}$ & - & Crivelli Montero 1988; 2006 \\
\hline \multirow{2}{*}{ Alicurá } & $\begin{array}{l}\text { Piedra Pintada El } \\
\text { Manzanito }\end{array}$ & 3 & Toba & - & $\mathrm{X}$ & $\mathrm{X}$ & $\mathrm{X}$ & - & $\mathrm{X}$ & $\mathrm{X}$ & Bruch 1904; Crivelli Montero 1988 \\
\hline & Vaca Mala\# & 3 & Toba & - & $\mathrm{X}$ & - & $\mathrm{X}$ & - & $\mathrm{X}$ & - & $\begin{array}{l}\text { Bruch 1902; Sanguinetti de Bórmida y } \\
\text { Curzio } 1985\end{array}$ \\
\hline
\end{tabular}

\section{Referencias:}

Tipo de sitio. 1 . cueva; 2. alero; 3. paredón-barda; 4. bloque separado de paredón o barda

Motivos: Punt: puntiformes; Rect: rectilíneos; Circ llen: circulares llenos; Circ lin: Circulares lineales; Curv: lineal curvilíneo; Fig: figurativo; ND: no determinado. X: Presencia; -: Ausencia; s/d: sin datos

* Sitio Ceferino II: Boschin (2009) da cuenta de la presencia de motivos pintados en muy mal estado de conservación. Los restantes sitios señalados con “*” son presentados en Boschin (1986). Ese trabajo es enumerativo y no descriptivo: sólo menciona la presencia de arte rupestre para los distintos sitios, correspondiendo a motivos pintados

\#. Vaca Mala (Bruch 1902) o Malal Huaca (en Boschín 2009, Crivelli Montero 2006, Fernández 2006).

\$. Alero Carriqueo y Barda Esteban presentan motivos grabados aunque no se cuenta con datos cuantitativos de los mismos (Crivelli Montero 2006). 
Apéndice II.4.b. Motivos pintados, técnicas inferidas y materiales asociados en estratigrafía en áreas aledañas a Somuncurá.

\begin{tabular}{|c|c|c|c|c|c|c|}
\hline & Sitio & Tipo de motivo & $\begin{array}{l}\text { Proceso de trabajo } \\
\text { inferido }\end{array}$ & $\begin{array}{c}\text { Correlato del proceso } \\
\text { de trabajo }\end{array}$ & Artefactos relacionados & Fuente \\
\hline \multirow{11}{*}{ Piedra Parada } & $\begin{array}{l}\text { Piedra Parada 1; } \\
\text { Campo Nassif } 3\end{array}$ & Negativo de Mano & 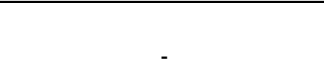 & Motivo & & \multirow{4}{*}{$\begin{array}{c}\text { Aschero 1983a, 1983b, } \\
\text { 1983c; Onetto 1983a; } \\
\text { 1983c; } 1987\end{array}$} \\
\hline & $\begin{array}{c}\text { Alero Don Santiago; } \\
\text { Campo Nassif 3; } \\
\text { Campo Cretton 1; } \\
\text { Campo Moncada 1; } \\
\text { Piedra Parada 1 }\end{array}$ & Pisada de felino & Pintura & Motivo & - & \\
\hline & $\begin{array}{c}\text { Bardas Blancas 2, } \\
\text { Campo Nassif } 1\end{array}$ & Positivo de mano & Estampado de pintura & Motivo & - & \\
\hline & $\begin{array}{c}\text { Campo Cretton 1; } \\
\text { Campo Moncada 1; } \\
\text { Piedra Parada 1 }\end{array}$ & Tridígito & pintura & Motivo & - & \\
\hline & Campo Cerda 1 & - & Pintura & $\begin{array}{c}\text { Roca plana con restos } \\
\text { de pintura roja; } \\
\text { guijarro manchado } \\
\text { con pintura } \\
\end{array}$ & - & Bellelli et al. 2007 \\
\hline & Piedra Parada 1 & Motivos puntiformes o lineales & - & - & Pincel o hisopo & Aschero 1983a \\
\hline & Piedra Parada 4 & Miniaturas & $\begin{array}{l}\text { Aplicación de pintura } \\
\text { con algún implemento* }\end{array}$ & Trazo fino & & Onetto $1983 b$ \\
\hline & \multirow{4}{*}{ Campo Nassif 1} & Positivo de mano & Pintura & $\begin{array}{c}\text { Estampado de mano } \\
\text { impregnada con } \\
\text { pintura }\end{array}$ & - & \multirow{4}{*}{$\begin{array}{l}\text { Aschero } 1983 \mathrm{~b} \\
\text { Onetto } 1986-87\end{array}$} \\
\hline & & Motivos ND & Salpicado & $\begin{array}{c}\text { Trazos gruesos, } \\
\text { salpicaduras y } \\
\text { manchas }\end{array}$ & - & \\
\hline & & Miniaturas & $\begin{array}{l}\text { Aplicación de pintura } \\
\text { con algún implemento* }\end{array}$ & Trazo menor a $2 \mathrm{~mm}$ & & \\
\hline & & - & Aplicación de pintura & - & $\begin{array}{l}\text { Hisopos teñidos, pig- } \\
\text { mentos y otros } \\
\text { elementos con trazos de } \\
\text { pintura. Tallo leñoso de } \\
2 \text { mm de espesor con } \\
\text { restos de pin-tura }\end{array}$ & \\
\hline
\end{tabular}




\begin{tabular}{|c|c|c|c|c|c|c|}
\hline \multicolumn{7}{|c|}{ Apéndice II.4.b (Continuación) } \\
\hline & Sitio & Tipo de motivo & $\begin{array}{c}\text { Proceso de trabajo } \\
\text { inferido }\end{array}$ & $\begin{array}{c}\text { Correlato del proceso } \\
\text { de trabajo }\end{array}$ & Artefactos relacionados & Fuente \\
\hline \multirow{6}{*}{ Piedra Parada } & \multirow[t]{3}{*}{ Campo Moncada 2} & \multirow[t]{3}{*}{$\mathrm{NO}$} & \multirow[t]{3}{*}{ Preparación de pintura } & \multirow[t]{3}{*}{-} & $\begin{array}{l}\text { Pigmentos preparados y } \\
\text { no preparados; yeso }\end{array}$ & \multirow{3}{*}{ Pérez de Micou et al. 1992} \\
\hline & & & & & $\begin{array}{c}\text { Artefactos teñidos con } \\
\text { pigmento preparado }\end{array}$ & \\
\hline & & & & & $\begin{array}{c}\text { Pigmentos en } \\
\text { estratigrafía }\end{array}$ & \\
\hline & \multirow[t]{3}{*}{$\begin{array}{c}\text { Aguada del Potrillo } \\
1\end{array}$} & Escalonados & - & $\begin{array}{c}\text { Trazo de } 2 \text { a } 5 \mathrm{~mm} \text { de } \\
\text { ancho }\end{array}$ & - & \multirow{3}{*}{ Aschero $1983 \mathrm{~d}$} \\
\hline & & Dígitos alineados & - & $\begin{array}{l}\text { Pintura aplicada con } \\
\text { yema de los dedos }\end{array}$ & & \\
\hline & & $\begin{array}{c}\text { Líneas almenadas opuestas } \\
\text { verticales y formas } \\
\text { bitriangulares }\end{array}$ & $\begin{array}{l}\text { Repintado o realizado } \\
\text { en diferentes momentos }\end{array}$ & $\begin{array}{c}\text { Diferente intensidad } \\
\text { en la pintura blanca } \\
\text { empleada }\end{array}$ & - & \\
\hline \multirow{8}{*}{$\begin{array}{c}\text { Arroyo } \\
\text { Pilcaniyeu }\end{array}$} & \multirow{5}{*}{ Abrigo Pilcaniyeu } & 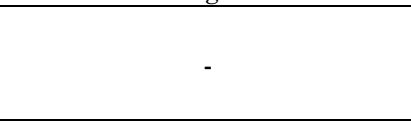 & $\begin{array}{l}\text { Preparación de } \\
\text { pintura }\end{array}$ & ( & $\begin{array}{l}\text { Hasta capa } 13 \text { apari- } \\
\text { ción de fragmentos } \\
\text { de pigmentos }\end{array}$ & Boschín y Nacuzzi 1980 \\
\hline & & Puntiformes & Pintura & $\begin{array}{l}\text { Tratamiento de } \\
\text { puntos }\end{array}$ & 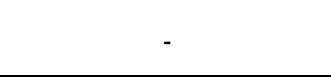 & \multirow{4}{*}{ Llamazares 1980} \\
\hline & & $\begin{array}{c}\text { Curvilíneos aislados; } \\
\text { hacha en ocho }\end{array}$ & & Plano monocroma & & \\
\hline & & $\begin{array}{c}\text { Trazos rectilíneos aislados, } \\
\text { trazos angulares } \\
\text { compuestos }\end{array}$ & & Lineal monocroma & & \\
\hline & & Enmarcados & & $\begin{array}{c}\text { Lineal polícroma y } \\
\text { plano lineal } \\
\text { polícroma }\end{array}$ & & \\
\hline & \multirow[b]{2}{*}{ Alero La Figura 1} & Motivos geométricos & Pintura & - & - & \multirow[t]{2}{*}{ Nacuzzi 1987} \\
\hline & & & - & $\begin{array}{l}\text { Preparación de } \\
\text { pinturas }\end{array}$ & $\begin{array}{l}\text { Pigmentos minerales } \\
\text { no preparados y } \\
\text { artefactos de } \\
\text { molienda (Nivel 7) } \\
\end{array}$ & \\
\hline & Cva Ceferino III & $\begin{array}{c}\text { Tridígitos, pies con puntos } \\
\text { interiores, rectilíneos, } \\
\text { almenados }\end{array}$ & Pintura & $\begin{array}{l}\text { Trazos de trata- } \\
\text { miento lineal y } \\
\text { plano }\end{array}$ & - & \multirow[t]{2}{*}{ Boschín 2009} \\
\hline $\begin{array}{l}\text { Arroyo } \\
\text { Pichileufú }\end{array}$ & Peña I & $\begin{array}{l}\text { Puntiformes, manos, pies, } \\
\text { escalonados, almenados, } \\
\text { curvilineos, círculos, } \\
\text { tridígitos, escaleriformes }\end{array}$ & Pintura & $\begin{array}{l}\text { Mono, bi- y poli- } \\
\text { cromías. Trata- } \\
\text { miento puntiforme, } \\
\text { lineal, plano y } \\
\text { combinado }\end{array}$ & - & \\
\hline
\end{tabular}




\begin{tabular}{|c|c|c|c|c|c|c|}
\hline \multicolumn{7}{|c|}{ Apéndice II.4.b (Continuación) } \\
\hline & Sitio & Tipo de motivo & $\begin{array}{l}\text { Proceso de trabajo } \\
\text { inferido }\end{array}$ & $\begin{array}{c}\text { Correlato del proceso } \\
\text { de trabajo }\end{array}$ & $\begin{array}{l}\text { Artefactos } \\
\text { relacionados }\end{array}$ & Fuente \\
\hline \multirow{8}{*}{$\begin{array}{l}\text { Arroyo } \\
\text { Pilcaniyeu }\end{array}$} & Cueva Alonso I & $\begin{array}{l}\text { Tridígitos, almenas, } \\
\text { puntiformes, } \\
\text { circunferencias, objetos }\end{array}$ & Pintura & $\begin{array}{c}\text { Mono, bi- y } \\
\text { policromías. } \\
\text { Tratamiento lineal, } \\
\text { plano y combinado }\end{array}$ & & \multirow{10}{*}{ Boschín 2009} \\
\hline & Cueva Alonso II & - & $\begin{array}{l}\text { Preparación de } \\
\text { pinturas }\end{array}$ & & $\begin{array}{c}\text { Restos vegetales } \\
\text { impregnados con } \\
\text { pintura roja; restos } \\
\text { óseos con residuos de } \\
\text { con pintura } \\
\end{array}$ & \\
\hline & Cueva Sarita I & NO & - & $\begin{array}{l}\text { Preparación de } \\
\text { pintura }\end{array}$ & $\begin{array}{c}\text { Fragmentos de } \\
\text { pastas colorantes; } \\
\text { cuenta con residuos } \\
\text { de pintura roja. }\end{array}$ & \\
\hline & Cueva Sarita II & Pintura & monocroma & - & 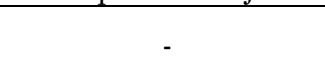 & \\
\hline & Cueva Sarita III & $\begin{array}{l}\text { Circunferencias, rombos, } \\
\text { líneas curvas, puntos }\end{array}$ & Pintura & Monocroma & Sin sedimento & \\
\hline & \multirow{2}{*}{ Cueva Sarita IV } & Cruciforme & Pintura & Líneal monocroma & - & \\
\hline & & 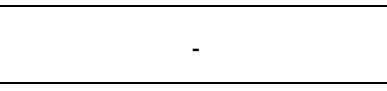 & $\begin{array}{c}\text { Preparación de } \\
\text { pintura }\end{array}$ & 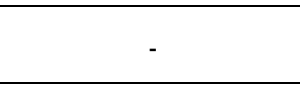 & Restos de pintura & \\
\hline & Cuadro Leleque & $\begin{array}{l}\text { Puntos, tridígitos, pies, } \\
\text { triángulos, curvilíneos, } \\
\text { escalonados, rectilíneos, } \\
\text { escaleriformes, } \\
\text { circunferencias, } \\
\text { antropomorfos }\end{array}$ & Pintura & $\begin{array}{l}\text { Mono y bicromías. } \\
\text { Tratamiento } \\
\text { puntiforme, lineal, } \\
\text { plano y combinado }\end{array}$ & & \\
\hline \multirow[t]{2}{*}{$\begin{array}{l}\text { Arroyo } \\
\text { Comallo }\end{array}$} & \multirow[t]{2}{*}{ Cueva Comallo I } & $\begin{array}{l}\text { Figuras almenadas, } \\
\text { circunferencia, } \\
\text { rectángulos, curvilíneos, } \\
\text { tridígitos, escaleriformes, } \\
\text { figuras humanas, } \\
\text { escalonados, puntos, } \\
\text { vulvas } \\
\end{array}$ & Pintura & $\begin{array}{l}\text { Mono, bi y } \\
\text { policromias }\end{array}$ & & \\
\hline & & 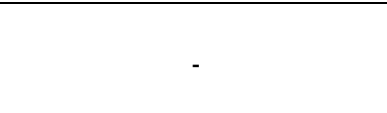 & $\begin{array}{l}\text { Preparación de } \\
\text { pinturas }\end{array}$ & $\begin{array}{c}\text { Pastas de color } \\
\text { rojo, ocre, naranja } \\
\text { y rosado }\end{array}$ & & \\
\hline
\end{tabular}




\begin{tabular}{|c|c|c|c|c|c|c|}
\hline & Sitio & Tipo de motivo & $\begin{array}{l}\text { Proceso de trabajo } \\
\text { inferido }\end{array}$ & $\begin{array}{c}\text { Correlato del proceso } \\
\text { de trabajo }\end{array}$ & $\begin{array}{l}\text { Artefactos } \\
\text { relacionados }\end{array}$ & Fuente \\
\hline \multirow{7}{*}{$\begin{array}{c}\text { Arroyo } \\
\text { Maquinchao }\end{array}$} & \multirow{2}{*}{ Calcatreo I } & $\begin{array}{l}\text { Curvilíneos, almenados, } \\
\text { escaleriformes, } \\
\text { antropomorfos, rectas, } \\
\text { trapecios }\end{array}$ & Pintura & $\begin{array}{c}\text { Monocromías y } \\
\text { bicromías. Trazo de } \\
\text { tratamiento lineal } \\
\text { y plano lineal }\end{array}$ & \multirow{2}{*}{ - } & \multirow{7}{*}{ Boschín 2009} \\
\hline & & 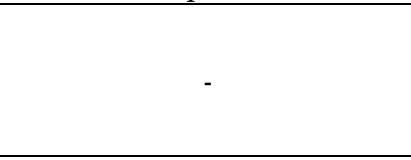 & $\begin{array}{c}\text { Altura sobre el suelo } \\
\text { a la que se } \\
\text { encuentran los } \\
\text { motivos }\end{array}$ & $\begin{array}{l}\text { Artesanos } \\
\text { trabajaron } \\
\text { sentados o } \\
\text { arrodillados } \\
\end{array}$ & & \\
\hline & Calcatreo II & $\begin{array}{c}\text { Triángulos, puntos, rectas, } \\
\text { líneas quebradascurvas, } \\
\text { antropomorfos, círculos, } \\
\text { rectángulos }\end{array}$ & Pintura & $\begin{array}{l}\text { Mono y bicromías. } \\
\text { Tratamiento } \\
\text { puntiforme, lineal, } \\
\text { plano y combinado }\end{array}$ & - & \\
\hline & \multirow{2}{*}{ Santo Rosario } & $\begin{array}{l}\text { Elipses, curvilíneos, } \\
\text { rectilíneos, pies, pisada } \\
\text { felino, puntos }\end{array}$ & Pintura & $\begin{array}{l}\text { Mono y bicromías. } \\
\text { Tratamiento } \\
\text { puntiforme, lineal, } \\
\text { plano y combinado }\end{array}$ & \multirow[b]{2}{*}{ - } & \\
\hline & & 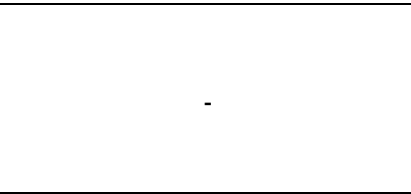 & $\begin{array}{l}\text { Preparación de } \\
\text { pinturas }\end{array}$ & $\begin{array}{l}\text { Pigmentos } \\
\text { minerales y } \\
\text { residuos de pintura } \\
\text { rojo, negro y } \\
\text { amarillo }\end{array}$ & & \\
\hline & $\begin{array}{l}\text { Angostura de } \\
\text { Cides }\end{array}$ & $\begin{array}{c}\text { Circunferencias, elipses, } \\
\text { curvilíneos, escaleriformes, } \\
\text { líneas quebradas, rectas, } \\
\text { laberintos }\end{array}$ & Pinturas & $\begin{array}{c}\text { Mono y } \\
\text { policromías.. } \\
\text { Tratamiento lineal, } \\
\text { plano-lineal } \\
\end{array}$ & - & \\
\hline & $\begin{array}{c}\text { Piedra Bonita de } \\
\text { Beiroz }\end{array}$ & $\begin{array}{c}\text { Hacha, curvilíneos, } \\
\text { almenados, escaleriformes, } \\
\text { laberintos, líneas } \\
\text { quebradas, líneas rectas, } \\
\text { pisadas de camélido }\end{array}$ & Pintura & $\begin{array}{l}\text { Mono y bicromías. } \\
\text { Tratamiento lineal, } \\
\text { plano y combinado }\end{array}$ & - & \\
\hline $\begin{array}{l}\text { Piedra del } \\
\text { Águila }\end{array}$ & Rincón Chico 2/87 & $\begin{array}{c}\text { Negativo de greca y negativo } \\
\text { de cruciforme }\end{array}$ & Pintura & - & - & $\begin{array}{l}\text { Crivelli et al. 1991; Crivelli } \\
\text { Montero y Fernández 2004; } \\
\text { Fernández 2003-2005 }\end{array}$ \\
\hline
\end{tabular}




\begin{tabular}{|c|c|c|c|c|c|c|}
\hline & Sitio & Tipo de motivo & $\begin{array}{l}\text { Proceso de trabajo } \\
\text { inferido }\end{array}$ & $\begin{array}{c}\text { Correlato del proceso } \\
\text { de trabajo }\end{array}$ & Artefactos relacionados & Fuente \\
\hline \multirow{3}{*}{$\begin{array}{l}\text { Piedra del } \\
\text { Águila }\end{array}$} & \multirow{3}{*}{ Rincón Chico 2/87 } & $\begin{array}{l}\text { Tridígito, antropomorfo, } \\
\text { rectilíneos, grecas, } \\
\text { cruciformes, circunferencias } \\
\text { concéntricas, simples, con } \\
\text { apéndice } \\
\end{array}$ & Pintura lineal & - & & \multirow{3}{*}{$\begin{array}{l}\text { Crivelli et al. 1991; Crivelli } \\
\text { Montero y Fernández } 2004 \\
\text { Fernández 2003-2005 }\end{array}$} \\
\hline & & ( & Preparación de pinturas & - & $\begin{array}{l}\text { Pigmentos en capa; } \\
\text { artefactos que } \\
\text { evidencian } \\
\text { procesamiento de } \\
\text { pigmentos } \\
\end{array}$ & \\
\hline & & $\begin{array}{c}\text { Motivos polícromos rojos y } \\
\text { amarillos }\end{array}$ & pintura & $\begin{array}{l}\text { Trazos amarillos más } \\
\text { finos que los rojos. }\end{array}$ & $\begin{array}{l}\text { Uso potencial de por lo } \\
\text { menos dos instrumentos }\end{array}$ & \\
\hline \multirow[t]{2}{*}{$\begin{array}{l}\text { Paso Limay- } \\
\text { Paso Flores }\end{array}$} & La Marcelina 1 & 2 & Preparación de pinturas & (1) & $\begin{array}{l}\text { Valva decorada con } \\
\text { restos de pintura; } \\
\text { residuos y una masa de } \\
\text { pintura }\end{array}$ & $\begin{array}{c}\text { Sanguinetti de Bórmida y } \\
\text { Curzio } 1985 \text { en Boschín } \\
2009\end{array}$ \\
\hline & El Monito & Antropomorfo, cruciforme & Pintura & $\begin{array}{l}\text { Tratamiento lineal } \\
\text { del trazo }\end{array}$ & 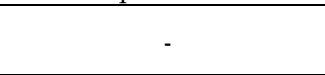 & Crivelli et al. 1991; \\
\hline Corralito & $\begin{array}{c}\text { Casa de Piedra de } \\
\text { Curapil }\end{array}$ & Greca, laberintiforme, cruz & Pintura roja & - & - & Crivelli Montero 1988 \\
\hline \multirow{3}{*}{ Alicurá } & $\begin{array}{l}\text { Piedra Pintada el } \\
\text { Manzanito }\end{array}$ & $\begin{array}{c}\text { Rosetas, cruces, } \\
\text { circunferencias, óvalos }\end{array}$ & Pintura & - & - & \\
\hline & \multirow[b]{2}{*}{ Vaca Mala } & Tridígito & Pintura & - & - & Bruch 1902 \\
\hline & & 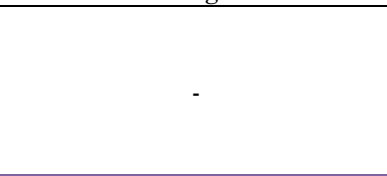 & Preparación de pintura & - & $\begin{array}{c}\text { Restos de pigmentos } \\
\text { similares a motivos } \\
\text { pintados en } \\
\text { estratigrafía (Capas } 3 y \\
\text { 4) }\end{array}$ & $\begin{array}{c}\text { Sanguinetti de Bórmida y } \\
\text { Curzio } 1985 \text { en Boschín } \\
2009\end{array}$ \\
\hline
\end{tabular}


Apéndice II.4.c. Motivos grabados, técnicas inferidas y materiales asociados en estratigrafía para áreas aledañas a Somuncurá.

\begin{tabular}{|c|c|c|c|c|c|c|}
\hline Área & Sitio & Tipo de motivo & $\begin{array}{c}\text { Proceso de } \\
\text { trabajo inferido }\end{array}$ & Correlato del proceso de trabajo & Artefactos relacionados & Fuente \\
\hline \multirow{8}{*}{ Piedra Parada } & $\begin{array}{l}\text { Bajada del } \\
\text { Tigre }\end{array}$ & Tridígitos, pisadas felino & grabado & Motivos & - & Onetto 1991 \\
\hline & \multirow{7}{*}{$\begin{array}{l}\text { Campo } \\
\text { Cretton } 1\end{array}$} & $\begin{array}{c}\text { Retículas Diago-nales; líneas } \\
\text { verti-cales alineadas } \\
\text { horizontalmente }\end{array}$ & Incisión & Surco inciso fino (en U) & & \multirow{7}{*}{$\begin{array}{l}\text { Onetto } 1981-82 \\
\quad 1983 \mathrm{c}, 1990\end{array}$} \\
\hline & & Serpentiforme & Picado+ Pintura & $\begin{array}{c}\text { Surco picado continuo (superficial y } \\
\text { profundo) }\end{array}$ & & \\
\hline & & Líneas rectas verticales & Picado & Surco continuo porfundo & & \\
\hline & & Serpentiforme & Incisión & Surco profundo y fino & & \\
\hline & & Retículas y rayado irregular & Incisión & Surco fino & & \\
\hline & & En Forma de V invertida & Incisión & Surco en V & & \\
\hline & & Óvalo & Picado & Surco continuo & & \\
\hline \multirow{7}{*}{$\begin{array}{c}\text { Arroyo } \\
\text { Pilcaniyeu }\end{array}$} & \multirow{7}{*}{$\begin{array}{c}\text { Abrigo } \\
\text { Pilcaniyeu }\end{array}$} & - & - & Grabado & Percutor cincel & \multirow{7}{*}{$\begin{array}{c}\text { Boschin y } \\
\text { Nacuzzi 1980; } \\
\text { Llamazares 1980 }\end{array}$} \\
\hline & & Pisadas humanas & $\begin{array}{l}\text { Picado y } \\
\text { raspado }\end{array}$ & - & 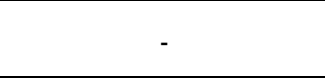 & \\
\hline & & Trazos rectilíneos & Incisión lineal & - & & \\
\hline & & $\begin{array}{c}\text { Hoyuelos natura-les } \\
\text { utilizados } \\
\end{array}$ & $\begin{array}{c}\text { Horadación } \\
\text { (+Pintura) }\end{array}$ & - & & \\
\hline & & $\begin{array}{c}\text { Pies humanos, pisada } \\
\text { felino, a-vestruz y guanaco }\end{array}$ & $\begin{array}{c}\text { Picado y } \\
\text { pintura }\end{array}$ & Surco plano, trazo plano & & \\
\hline & & Líneas curvas aisladas & $\begin{array}{l}\text { Incisión y } \\
\text { pintura }\end{array}$ & Surco y trazo lineal & & \\
\hline & & $\begin{array}{c}\text { Pies, figuras cur-vilíneas } \\
\text { aisladas y círculos } \\
\text { irradiados } \\
\end{array}$ & $\begin{array}{l}\text { Picado, } \\
\text { raspado y } \\
\text { pintura }\end{array}$ & $\begin{array}{c}\text { Surcos grabados plano y pintura } \\
\text { plana }\end{array}$ & & \\
\hline \multirow{3}{*}{$\begin{array}{l}\text { Arroyo } \\
\text { Pichileufú }\end{array}$} & \multirow{3}{*}{$\begin{array}{c}\text { Cueva } \\
\text { Pichileufú }\end{array}$} & - & Incisión & Trazos fino & - & \multirow{3}{*}{$\begin{array}{l}\text { Casamiquela } \\
1968\end{array}$} \\
\hline & & - & $\begin{array}{l}\text { Picado } \\
\text { (incisión } \\
\text { ancha) } \\
\end{array}$ & Surco profundo y ancho & & \\
\hline & & - & $\begin{array}{l}\text { Pintura sobre } \\
\text { grabado }\end{array}$ & $\begin{array}{l}\text { Surco profundo grabado con } \\
\text { restos de pintura amarilla o } \\
\text { blanca sobrepuesta }\end{array}$ & & \\
\hline
\end{tabular}




\begin{tabular}{|c|c|c|c|c|c|c|}
\hline Área & Sitio & Tipo de motivo & $\begin{array}{c}\text { Proceso de } \\
\text { trabajo inferido }\end{array}$ & Correlato del proceso de trabajo & Artefactos relacionados & Fuente \\
\hline \multirow{13}{*}{$\begin{array}{l}\text { Arroyo } \\
\text { Pichileufú }\end{array}$} & \multirow{4}{*}{$\begin{array}{l}\text { Cueva } \\
\text { Pichileufú }\end{array}$} & ( & 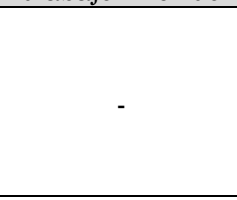 & $\begin{array}{l}\text { Trabajo individuo de pie x altura } \\
\text { a la que se encuentran los } \\
\text { motivos (excepto para aquellos } \\
\text { que se encuentran a menos de } 1 \\
\text { m del suelo) }\end{array}$ & \multirow{3}{*}{-} & \multirow{3}{*}{ Boschin 2009} \\
\hline & & $\begin{array}{c}\text { Pies humanos, tridígitos, } \\
\text { pisada de guanaco, pisada } \\
\text { de felino }\end{array}$ & $\mathrm{G}$ & $\begin{array}{l}\text { Surco grueso y profundo con } \\
\text { raspado superficial }\end{array}$ & & \\
\hline & & $\begin{array}{l}\text { Líneas curvas escalonado, } \\
\text { circunferencias }\end{array}$ & $\mathrm{P} / \mathrm{G}$ & $\begin{array}{c}\text { Pintura amarilla sobrepuesta a } \\
\text { surco grueso y profundo con } \\
\text { raspado superfi-cial } \\
\end{array}$ & & \\
\hline & & & $\begin{array}{l}\text { Preparación de } \\
\text { pintura }\end{array}$ & & $\begin{array}{l}\text { Pigmento amarillo en } \\
\text { sondeo }\end{array}$ & $\begin{array}{c}\text { Casamiquela } \\
1968 \text { en Boschín } \\
2009\end{array}$ \\
\hline & $\begin{array}{c}\text { Abrigo } \\
\text { Pichileufú }\end{array}$ & $\begin{array}{c}\text { Pisada guanaco, pies, } \\
\text { puntiformes, curvilíneos, } \\
\text { rec-tas } \\
\end{array}$ & G & $\begin{array}{l}\text { Surco areal y perimetral, de } \\
\text { trazo profundo y ancho }\end{array}$ & - & \multirow[b]{2}{*}{ Boschín 2009} \\
\hline & $\begin{array}{l}\text { Paredones } \\
\text { del río } \\
\text { Pichileufú }\end{array}$ & $\begin{array}{c}\text { Tridígitos, alme-nas, } \\
\text { escalonados, líneas } \\
\text { quebradas, rectas, puntifor- } \\
\text { mes } \\
\end{array}$ & G y $P / G$ & 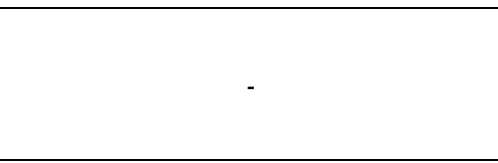 & - & \\
\hline & \multirow{6}{*}{$\begin{array}{l}\text { Cueva } \\
\text { Visconti }\end{array}$} & Pie humano & $\begin{array}{l}\text { Raspado; } \\
\text { Percusión }\end{array}$ & $\begin{array}{c}\text { Surco en bajo relieve plano líneal } \\
\text { y areal }\end{array}$ & & \multirow{6}{*}{$\begin{array}{c}\text { Ceballos y } \\
\text { Peronja } 1983\end{array}$} \\
\hline & & Mano & Percusión & $\begin{array}{c}\text { Surco en bajo relieve areal y en } \\
\text { alto relieve delineado }\end{array}$ & & \\
\hline & & Pisada felino & Percusión & Surco en bajo relieve plano & & \\
\hline & & Pisada de guana-co & Percusión & $\begin{array}{c}\text { Surco en bajo relieve areal y } \\
\text { plano }\end{array}$ & & \\
\hline & & Tridígito & Percusión & $\begin{array}{c}\text { Surco en bajo relieve lineal; } \\
\text { Surco en alto relieve delineado }\end{array}$ & & \\
\hline & & Figura lineal & $\mathrm{P} / \mathrm{G}$ & $\begin{array}{c}\text { Grabada con vestigios de pintura } \\
\text { por encima }\end{array}$ & & \\
\hline & La Figura 1 & - & $\mathrm{G} ; \mathrm{P} / \mathrm{G}$ & $\begin{array}{l}\text { Gran cantidad de residuos de } \\
\text { pintura; }\end{array}$ & $\begin{array}{l}\text { Fragmento de roca de } \\
\text { caja con restos de } \\
\text { pintura }(20 \mathrm{~cm} \mathrm{de} \\
\text { profundidad) }\end{array}$ & $\begin{array}{l}\text { Boschín 2009; } \\
\text { Nacuzzi } 1987\end{array}$ \\
\hline
\end{tabular}




\begin{tabular}{|c|c|c|c|c|c|c|}
\hline Área & Sitio & Tipo de motivo & $\begin{array}{c}\text { Proceso de } \\
\text { trabajo inferido }\end{array}$ & Correlato del proceso de trabajo & Artefactos relacionados & Fuente \\
\hline \multirow{10}{*}{$\begin{array}{l}\text { Arroyo } \\
\text { Pichileufú }\end{array}$} & \multirow[t]{2}{*}{$\begin{array}{l}\text { Cueva } \\
\text { Alonso II }\end{array}$} & $\begin{array}{c}\text { Antropomorfos, pies } \\
\text { humanos, pi-sada guanaco, } \\
\text { fe-lino y tridígitos, placa- } \\
\text { hacha }\end{array}$ & Grabado & De surco grueso y profundo; & & \multirow{13}{*}{ Boschin 2009} \\
\hline & & & $\begin{array}{l}\text { Pintura sobre } \\
\text { grabado }\end{array}$ & De surco grueso y profundo & & \\
\hline & \multirow{2}{*}{$\begin{array}{l}\text { Paredón } \\
\text { Alonso }\end{array}$} & $\begin{array}{l}\text { Pisadas felino, pisada } \\
\text { guanaco, tridígito. } \\
\text { artefactos }\end{array}$ & $\begin{array}{l}\text { Incisión, } \\
\text { raspado y } \\
\text { horadación }\end{array}$ & $\begin{array}{l}\text { De surco grueso y profundo con } \\
\text { trazos de pintura de diferente } \\
\text { tratamiento }\end{array}$ & \multirow[t]{2}{*}{-} & \\
\hline & & $\begin{array}{l}\text { Líneas rectas o quebradas; } \\
\text { líneas de puntos }\end{array}$ & $\begin{array}{c}\text { Pintura sobre } \\
\text { grabado }\end{array}$ & $\begin{array}{c}\text { Surco inciso con trazos de } \\
\text { pintura roja }\end{array}$ & & \\
\hline & \multirow{2}{*}{$\begin{array}{l}\text { Cueva Sarita } \\
\text { I }\end{array}$} & $\begin{array}{l}\text { Pisada de felino, de } \\
\text { guanaco, tridígitos }\end{array}$ & Picado & $\begin{array}{l}\text { Surco ancho de trazo grueso y } \\
\text { profundo }\end{array}$ & & \\
\hline & & Pisada de felino & Picado + Inciso & $\begin{array}{l}\text { Dedos realizados por picado, } \\
\text { sobre circulo inferior presenta } \\
\text { rayas o líneas }\end{array}$ & - & \\
\hline & $\begin{array}{c}\text { Cueva Sarita } \\
\text { II } \\
\end{array}$ & Tridígitos, pies humanos & Grabado & $\begin{array}{c}\text { Similar a las técnicas empleadas } \\
\text { Sarita } 1,3 \text { y } 4 \\
\end{array}$ & - & \\
\hline & Cueva Sarita & $\begin{array}{c}\text { Pisada felino, tri-dígitos, } \\
\text { pisada guanaco, } \\
\text { antropomorfo }\end{array}$ & Picado & Surco de trazo grueso y profundo & & \\
\hline & III & $\begin{array}{l}\text { Circunferencia simple, con } \\
\text { punto interior; con punto } \\
\text { interior y apéndice }\end{array}$ & $\begin{array}{l}\text { Grabado + } \\
\text { pintura }\end{array}$ & $\begin{array}{c}\text { Trazos grabados y pintados no } \\
\text { sobrepuesto }\end{array}$ & - & \\
\hline & $\begin{array}{l}\text { Cueva Sarita } \\
\text { IV }\end{array}$ & $\begin{array}{c}\text { Pisada guanaco, pisada } \\
\text { felino, tridígitos, pies } \\
\text { humanos } \\
\end{array}$ & Grabado & Surco de trazp grueso y profundo & & \\
\hline \multirow{3}{*}{$\begin{array}{l}\text { Arroyo } \\
\text { Comallo }\end{array}$} & \multirow{3}{*}{$\begin{array}{c}\text { Cueva } \\
\text { Loncomán }\end{array}$} & 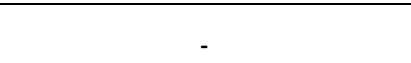 & Grabado & & & \\
\hline & & $\begin{array}{l}\text { Puntos, pies, tridígitos, } \\
\text { vulvas pisadas de guanaco, } \\
\text { líneas curvas }\end{array}$ & $\begin{array}{l}\text { Pintura sobre } \\
\text { grabado }\end{array}$ & - & & \\
\hline & & ( & $\begin{array}{l}\text { Preparación de } \\
\text { pinturas }\end{array}$ & - & $\begin{array}{l}\text { Restos de pintura de } \\
\text { diferentes colores } \\
\text { aunque no hay } \\
\text { pinturas en el sitio }\end{array}$ & \\
\hline
\end{tabular}

Apéndice II.4.c (Continuación) 


\begin{tabular}{|c|c|c|c|c|c|c|}
\hline Área & Sitio & Tipo de motivo & $\begin{array}{c}\text { Proceso de } \\
\text { trabajo inferido }\end{array}$ & Correlato del proceso de trabajo & Artefactos relacionados & Fuente \\
\hline \multirow{3}{*}{$\begin{array}{l}\text { Arroyo } \\
\text { Comallo }\end{array}$} & \multirow{3}{*}{$\begin{array}{l}\text { Paredón } \\
\text { Loncomán }\end{array}$} & $\begin{array}{l}\text { Pisada felino, tridígitos, } \\
\text { rostros antropomorfos }\end{array}$ & Incisión & $\begin{array}{l}\text { Surco homogéneo de trazo fino y } \\
\text { superficial }\end{array}$ & & \multirow{3}{*}{ Boschin 2009} \\
\hline & & 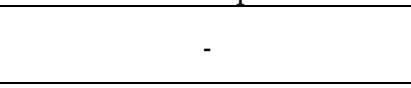 & Horadación & $\begin{array}{c}\text { Surco homogéneo de trazo } \\
\text { profundo y superficial }\end{array}$ & & \\
\hline & & - & $\begin{array}{l}\text { Incisión + } \\
\text { horadación }\end{array}$ & Combinación de los anteriores & & \\
\hline $\begin{array}{l}\text { Piedra del } \\
\text { Äguila }\end{array}$ & $\begin{array}{l}\text { Epullán } \\
\text { Grande }\end{array}$ & Líneas curvas basales & Incisión & - & - & $\begin{array}{c}\text { Crivelli Montero } \\
1988 \\
\end{array}$ \\
\hline \multirow{2}{*}{ Quemquemtreu } & \multirow{2}{*}{ Mata Molle } & Reticulado fino & Incisión & Surco fino & \multirow[b]{2}{*}{ - } & \multirow{2}{*}{$\begin{array}{l}\text { Plautz de Freschi et } \\
\text { al } 1975\end{array}$} \\
\hline & & Hoyuelos & - & Surco cónico, pequeño y superficial & & \\
\hline \multirow{3}{*}{ Corralito } & \multirow{3}{*}{$\begin{array}{l}\text { Casa de Piedra } \\
\text { de Ortega }\end{array}$} & $\begin{array}{c}\text { Tridígitos, rosetas, pies } \\
\text { humanos , pisadas guanaco, } \\
\text { circulares; puntos alineados }\end{array}$ & Raspado & Surco ancho & & \multirow{3}{*}{$\begin{array}{l}\text { Crivelli Montero } \\
1988\end{array}$} \\
\hline & & $\begin{array}{l}\text { Reticulados, formas } \\
\text { subrectangulares, trazos } \\
\text { lineales, zig-zags, geométricos } \\
\text { abstractos curvilíneos }\end{array}$ & Incisión & Surco fino & & \\
\hline & & $\begin{array}{c}\text { Hoyuelos naturales (aislados, } \\
\text { apareados, alineados) }\end{array}$ & Horadación & - & & \\
\hline
\end{tabular}


Apéndice III 
Apéndice III.1. Ficha de registro de ANF experimentales

\section{Ficha descriptiva para ANF}

\begin{tabular}{|c|c|c|c|c|c|c|c|c|c|c|c|c|c|c|c|c|c|c|c|c|c|c|c|c|c|c|c|c|c|c|}
\hline \multirow{2}{*}{\multicolumn{17}{|c|}{ Materia Prima }} & & & & & & & & \multicolumn{7}{|c|}{ Fecha: } \\
\hline & & & & & & & & & & & & & & & & & & & Taló & & & & lbo & & & & & & & \\
\hline & & & & & & & & & & & & & & & & & & & & & & & & & & & & & & \\
\hline & & & & & & & & & & & & & & & & & & & & & & & & & & & & & & \\
\hline & & & & & & & & & & & & & & & & & & & & & & & & & & & & & & \\
\hline & & & & & & & & & & & & & & & & & & & & & & & & & & & & & & \\
\hline
\end{tabular}


Apéndice III.2. Artefactos empleados durante las experiencias replicativas de motivos grabados

\begin{tabular}{|c|c|c|c|c|c|c|c|}
\hline & Artefacto & ID & $\begin{array}{l}\text { Medidas antes de } \\
\text { usar }(\mathrm{mm})\end{array}$ & $\begin{array}{l}\text { Medidas luego de } \\
\text { usar } \\
(\mathrm{mm})\end{array}$ & MP & Rastros Complementarios & Motivos Experimentales \\
\hline \multirow{10}{*}{ PM } & \multirow{7}{*}{$\mathrm{ANF}$} & E1 RVB 18 & $57,7 \times 26,6 \times 11,1$ & $56,3 \times 26,6 \times 11,1$ & Sílice & Redondeamiento de filo & \multirow{3}{*}{ Tridígito 1} \\
\hline & & E1 LM 5 & $52,1 \times 38,3 \times 10,3$ & $51,55 \times 36,3 \times 10,3$ & Sílice & Embotamiento de filo y Fractura & \\
\hline & & E1 LM 26 & $48,3 \times 27,0 \times 6,5$ & $48,0 \times 27,0 \times 6,5$ & Sílice & Redondeamiento de filo & \\
\hline & & E1 RVB 23 & $40,2 \times 51,1 \times 11,95$ & $34,4 \times 41,6 \times 10,2$ & Sílice & $\begin{array}{l}\text { Fractura de la punta luego de } 10 \text { minutos de } \\
\text { trabajo }\end{array}$ & \multirow{3}{*}{ Tridígito 2} \\
\hline & & E1 RVB 22 & $37,7 \times 47,6 \times 10,7$ & $37,6 \times 46,6 \times 10,7$ & Sílice & Fractura después de 15 minutos de uso. & \\
\hline & & E1 LM 21 & $31,6 \times 45,8 \times 7,4$ & $31,6 \times 44,8 \times 7,4$ & Sílice & Redondeamiento de filo & \\
\hline & & E1 LM 6 & $76,8 \times 28,8 \times 12,3$ & $67,9 \times 28,8 \times 12,3$ & Sílice & $\begin{array}{l}\text { Fractura de la punta después de } 10 \text { minutos } \\
\text { de trabajo, pero se continúa usando }\end{array}$ & \multirow{2}{*}{ Circunferencia simple } \\
\hline & Percutor & E1 RVB P1 & $72,4 \times 56,3 \times 44,7$ & $64,4 \times 56,3 \times 44,7$ & Sílice & Machacado en vértice de contacto & \\
\hline & Percutor & E1 RVB P3 & $62,35 \times 35,7 \times 21,1$ & $61,4 \times 35,7 \times 21,1$ & Cuarzo & Machado/abradido de vértice de contacto & Tridígito 3 \\
\hline & Percutor & E1 RVB P5 & $59 \times 43,5 \times 32,5$ & $58,5 \times 43,5 \times 32,5$ & Sílice & Machacado de vértice & Roseta \\
\hline \multirow[t]{2}{*}{ LCB } & Percutor & E1 RVB P1 & $72,4 \times 56,3 \times 44,7$ & $64,4 \times 56,3 \times 44,7$ & Sílice & Desprendimiento de microlascas & $\begin{array}{l}\text { Tridígito 1, Tridígito } 2 \text {, Conjunto de puntos, } \\
\text { Circular compuesto, Circunferencia doble con } \\
\text { apéndice }\end{array}$ \\
\hline & Percutor & E1 RVB P4 & $55,3 \times 39,2 \times 30,4$ & $55 \times 39,2 \times 30,4$ & Cuarzo & Machado en vértice de contacto & Tridígito 1, Tridígito 2 \\
\hline
\end{tabular}

Referencias: PM: Piedra Museo; LCB: Laguna Cerro Bonete; ANF: artefactos no formatizados; MP: Materia prima.

La numeración en los motivos experimentales condice la descripción efectuada en el Capítulo 5. 
Apéndice III.3. Proporciones de las mezclas pigmentarias usadas para realizar negativos de mano (n= 54).

\begin{tabular}{|c|c|c|c|c|c|c|c|c|c|c|c|c|}
\hline $\begin{array}{l}\text { Rango } \\
\text { Etario }\end{array}$ & Edad & Sexo & $\begin{array}{l}\text { Cant. de } \\
\text { réplicas }\end{array}$ & Pigmento & Cantidad & Yeso & Grasa & Agua & Soporte & Ángulo & Altura del bloque & Posición pintor \\
\hline \multirow[t]{5}{*}{$3-5$} & 3 & $\mathrm{M}$ & 1 & $2.5 \mathrm{Y} 8 / 2$ pale yellow & 15 & 4,5 & 3 & 21 & Ignimbrita & $79^{\circ}$ & 1,30 & PÑB \\
\hline & \multirow[t]{2}{*}{5} & \multirow[t]{2}{*}{$\mathrm{M}$} & \multirow[t]{2}{*}{2} & $10 \mathrm{R}$ 3/6 dark red & 5 & 1,5 & 1 & 2 & \multirow[t]{2}{*}{ Ignimbrita } & \multirow[t]{2}{*}{$78^{\circ}$} & \multirow[t]{2}{*}{1,30} & \multirow{2}{*}{ PÑB } \\
\hline & & & & 10YR 8/1 & 5 & 1.5 & 1 & 3 & & & & \\
\hline & 5 & $\mathrm{~F}$ & 1 & 10YR 8/1 & 5 & 1,5 & 1 & 3 & Ignimbrita & $68^{\circ}$ & 1,30 & PÑB \\
\hline & 5 & $\mathrm{~F}$ & 1 & 10YR 8/1 & 12 & 3,6 & 2,5 & 21 & Ignimbrita & $75^{\circ}$ & 1,30 & PÑB \\
\hline \multirow[t]{7}{*}{$8-11$} & 8 & $\mathrm{M}$ & 1 & $10 \mathrm{R} 3 / 6$ dark red & 11,25 & 3,35 & 2,25 & 15 & Ignimbrita & $79^{\circ}$ & 1,30 & PDM \\
\hline & 8 & $\mathrm{~F}$ & 1 & $2.5 \mathrm{Y} 7 / 8$ yellow & 5 & 1,5 & 1 & 9 & Ignimbrita & $68^{\circ}$ & 1,30 & $\mathrm{PDM}$ \\
\hline & 8 & $\mathrm{~F}$ & 1 & $10 \mathrm{R} 3 / 6$ dark red & 5 & 1,5 & 1 & 6 & Ignimbrita & $68^{\circ}$ & 1,30 & PDM \\
\hline & \multirow[t]{3}{*}{10} & \multirow[t]{3}{*}{$\mathrm{F}$} & \multirow[t]{3}{*}{3} & 10YR 8/1 & 10 & 3 & 2 & 24 & \multirow[t]{3}{*}{ Ignimbrita } & \multirow[t]{3}{*}{$78^{\circ}$} & \multirow[t]{3}{*}{1,30} & PIM \\
\hline & & & & $2.5 \mathrm{Y} 7 / 8$ yellow & 10 & 3 & 2 & 5 & & & & \multirow{2}{*}{$\mathrm{PDM}$} \\
\hline & & & & $10 \mathrm{R} 3 / 6$ dark red & 10 & 3 & 2 & 5 & & & & \\
\hline & 11 & $\mathrm{M}$ & 1 & $\mathrm{LD}^{\prime} 12$ & 16 & 4,8 & 3,2 & 33 & Ignimbrita & $79^{\circ}$ & 1,30 & PDM \\
\hline \multirow[t]{14}{*}{$\geq 13$} & 13 & $\mathrm{M}$ & 1 & 10YR 8/1 & 5 & 1,5 & 1 & 9 & Ignimbrita & $78^{\circ}$ & 1,30 & PDM \\
\hline & 15 & $\mathrm{M}$ & 1 & $10 \mathrm{R} 3 / 6$ dark red & 10 & 3 & 2 & 15 & Ignimbrita & $76^{\circ}$ & 1,30 & PDM \\
\hline & 17 & $\mathrm{M}$ & 1 & & & & & & Ignimbrita & $76^{\circ}$ & 1,30 & PDM \\
\hline & 23 & $\mathrm{~F}$ & 1 & 10YR 8/1 & 5 & 1,5 & 1 & 9 & Ignimbrita & $73^{\circ}$ & 1,30 & $\mathrm{PDM}$ \\
\hline & 23 & $\mathrm{~F}$ & 1 & $10 \mathrm{R} 3 / 6$ dark red & 12 & 3,6 & 2,5 & 12 & Ignimbrita & $75^{\circ}$ & 1,30 & Parado \\
\hline & 24 & $\mathrm{M}$ & 1 & 10YR 8/1 & 10 & 3 & 2 & 20 & Ignimbrita & 83 & 1,30 & PDM \\
\hline & \multirow[t]{8}{*}{29} & \multirow[t]{8}{*}{$\mathrm{F}$} & \multirow[t]{8}{*}{34} & 10R 5/8 red & 5 & 1,5 & 1 & 12 & \multirow[t]{5}{*}{ Ignimbrita } & \multirow{3}{*}{$83^{\circ}$} & \multirow{3}{*}{1} & \multirow{3}{*}{ Sentado } \\
\hline & & & & $2.5 \mathrm{Y} 7 / 8$ yellow & 5 & 1,5 & 1 & 10 & & & & \\
\hline & & & & $10 \mathrm{R} 3 / 6$ dark red & 5 & 1,5 & 1 & 10 & & & & \\
\hline & & & & $2.5 \mathrm{Y} 7 / 8$ yellow & 5 & 1,5 & 1 & 9 & & \multirow{2}{*}{$84^{\circ}$} & \multirow{2}{*}{1} & \multirow{2}{*}{ Sentado } \\
\hline & & & & $10 \mathrm{R} 3 / 6$ dark red & 5 & 1,5 & 1 & 10 & & & & \\
\hline & & & & $2.5 \mathrm{Y} 8 / 2$ pale yellow & 5 & 1,5 & 1 & 9 & \multirow[t]{2}{*}{ Arenisca coquinoide } & \multirow{2}{*}{$90^{\circ}$} & & \\
\hline & & & & 7.5 R 5/2 weak red & 5 & 1,5 & 1 & 9 & & & 1 & Arrodillado \\
\hline & & & & $10 \mathrm{YR} 8 / 1$ & 5 & 1,5 & 1 & 12 & Ignimbrita & $90^{\circ}$ & 1 & Arrodillado \\
\hline
\end{tabular}


Apéndice III.3 (Continuación)

\begin{tabular}{|c|c|c|c|c|c|c|c|c|c|c|c|c|}
\hline $\begin{array}{l}\text { Rango } \\
\text { Etario } \\
\end{array}$ & Edad & Sexo & $\begin{array}{l}\text { Cant. de } \\
\text { réplicas }\end{array}$ & Pigmento & Cantidad & Yeso & Grasa & Agua & Soporte & Ángulo & Altura del bloque & Posición pintor \\
\hline \multirow[t]{29}{*}{$\geq 13$} & \multirow[t]{24}{*}{29} & \multirow[t]{24}{*}{$\mathrm{F}$} & \multirow[t]{24}{*}{34} & \multirow[t]{2}{*}{ 10YR 8/1 } & 5 & 1,5 & 1 & 12 & \multirow{24}{*}{ Ignimbrita } & 90 & 1 & Arrodillado \\
\hline & & & & & 5 & 1,5 & 1 & 9 & & $80^{\circ}$ & 1,30 & \multirow{23}{*}{ Parado } \\
\hline & & & & \multirow[t]{2}{*}{ 10YR 8/1 } & 5 & 1,5 & 1 & 9 & & $84^{\circ}$ & 1,30 & \\
\hline & & & & & 5 & 1,5 & 1 & 9 & & \multirow[t]{2}{*}{$81^{\circ}$} & \multirow[t]{2}{*}{1,30} & \\
\hline & & & & \multirow[t]{2}{*}{10 R 3/6 dark red } & 5 & 1,5 & 1 & 12 & & & & \\
\hline & & & & & 5 & 1,5 & 1 & 12 & & \multirow{3}{*}{$78^{\circ}$} & \multirow{3}{*}{1,30} & \\
\hline & & & & \multirow[t]{2}{*}{10 R 3/6 dark red } & 5 & 1,5 & 1 & 7 & & & & \\
\hline & & & & & 6 & 1,8 & 1,20 & 7,5 & & & & \\
\hline & & & & $10 \mathrm{R} 3 / 6$ dark red & 5 & 1,5 & 1 & 12 & & \multirow[t]{2}{*}{$81^{\circ}$} & \multirow[t]{2}{*}{1,30} & \\
\hline & & & & $10 \mathrm{R} 3 / 6$ dark red & 6 & 1,8 & 1,20 & 7,5 & & & & \\
\hline & & & & $10 \mathrm{R} 3 / 6$ dark red & 6 & 1,8 & 1,20 & 9 & & 71 & 1,30 & \\
\hline & & & & $10 \mathrm{R} 3 / 6$ dark red & 6 & 1,8 & 1,20 & 9 & & $85^{\circ}$ & 1,30 & \\
\hline & & & & $10 \mathrm{R} 3 / 6$ dark red & 6 & 1,8 & 1,20 & 9 & & $90^{\circ}$ & 1,30 & \\
\hline & & & & $10 \mathrm{R} 3 / 6$ dark red & 6 & 1,8 & 1,20 & 9 & & $90^{\circ}$ & 1,30 & \\
\hline & & & & $10 \mathrm{R} 3 / 6$ dark red & 6 & 1,8 & 1,20 & 9 & & & & \\
\hline & & & & $10 \mathrm{R} 3 / 6$ dark red & 6 & 1,8 & 1,20 & 9 & & 90 & 1,30 & \\
\hline & & & & $10 \mathrm{R} \mathrm{3/6}$ dark red & 5 & 1,5 & 1 & 12 & & $83^{\circ}$ & 130 & \\
\hline & & & & $10 \mathrm{YR} 8 / 1$ & 6 & 1,8 & 1,20 & 7,5 & & 83 & 1,30 & \\
\hline & & & & $10 \mathrm{R} 3 / 6$ dark red & 6 & 1,8 & 1,20 & 7,5 & & $78^{\circ}$ & & \\
\hline & & & & $10 \mathrm{YR} 8 / 1$ & 6 & 1,8 & 1,20 & 12 & & 79 & 1,30 & \\
\hline & & & & $10 \mathrm{R} 3 / 6$ dark red & 6 & 1,8 & 1,20 & 7,5 & & $80^{\circ}$ & 1,30 & \\
\hline & & & & $10 \mathrm{YR} 8 / 1$ & 6 & 1,8 & 1,20 & 12 & & $81^{\circ}$ & 1,30 & \\
\hline & & & & $10 \mathrm{YR} 8 / 1$ & 6 & 1,8 & 1,20 & 12 & & $84^{\circ}$ & 130 & \\
\hline & & & & $10 \mathrm{YR} 8 / 1$ & 6 & 1,8 & 1,20 & 12 & & 84 & 1,00 & \\
\hline & 31 & $\mathrm{~F}$ & 1 & $10 \mathrm{R} 3 / 6$ dark red & 5 & 1,5 & 1 & 9 & Ignimbrita & 83 & 1,30 & $\mathrm{PDM}$ \\
\hline & 32 & $\mathrm{~F}$ & 1 & 10YR $8 / 1$ & 5 & 1,5 & 1 & 12 & Ignimbrita & 80 & 1,30 & $\mathrm{PDM}$ \\
\hline & 33 & $\mathrm{M}$ & 1 & $10 \mathrm{R} 3 / 6$ dark red & 5 & 1,5 & 1 & 10 & Ignimbrita & 80 & 1,30 & PDM \\
\hline & 34 & $\mathrm{M}$ & 1 & 10YR 8/1 & 5 & 1,5 & 1 & 15 & Ignimbrita & 78 & 1,30 & Al lado del modelo \\
\hline & 38 & $\mathrm{M}$ & 1 & 10YR 8/1 & 5 & 1,5 & 1 & 15 & Ignimbrita & 80 & 1,30 & $\mathrm{PDM}$ \\
\hline
\end{tabular}

Referencias: Cant. Réplicas: Cantidad de réplicas. PÑB: parado con niño en brazos a la izquierda; PDM: parado a la derecha del modelo; PIM: parado a la izquierda del modelo. 
| Apéndice III.4. Proporciones de las mezclas usadas en la replicación de negativos de manos_realizados apoyando el dorso de la extremidad derecha.

\begin{tabular}{|c|c|c|c|c|c|c|c|c|c|c|c|}
\hline Edad & Sexo & $\begin{array}{l}\text { Cant. de } \\
\text { réplicas }\end{array}$ & Pigmento & Cantidad & Yeso & Grasa & Agua & Soporte & Ángulo & Altura del bloque & Posición pintor \\
\hline \multirow[t]{4}{*}{29} & \multirow[t]{4}{*}{$\mathrm{F}$} & 1 & 10YR 8/1 & 15 & 4,5 & 3 & 21 & \multirow[t]{4}{*}{ Ignimbrita } & $79^{\circ}$ & 1,30 & \multirow{4}{*}{$\begin{array}{l}\text { Parado frente } \\
\text { al bloque }\end{array}$} \\
\hline & & 2 & 10R 5/8 & 5 & 1,5 & 1 & 2 & & \multirow[t]{2}{*}{$78^{\circ}$} & \multirow[t]{2}{*}{1,30} & \\
\hline & & 3 & $10 \mathrm{R} 3 / 6$ & 5 & 1.5 & 1 & 3 & & & & \\
\hline & & 4 & $2.5 \mathrm{Y} 7 / 8$ & 5 & 1,5 & 1 & $?$ & & $68^{\circ}$ & 1,30 & \\
\hline
\end{tabular}


Apéndice IV 
Apéndice IV.1. Motivos rupestres documentados en Bardas de Carlos.

Tabla IV.1.a. Distribución de motivos por sector.

\begin{tabular}{|c|c|c|c|c|c|c|c|}
\hline \multirow[b]{2}{*}{ Motivo } & \multicolumn{6}{|c|}{ Sector } & \multirow{2}{*}{ Total } \\
\hline & 1 & 2 & 3 & & 5 & & \\
\hline Punto & - & 1 & 3 & - & - & & 5 \\
\hline Conjunto de puntos & 1 & - & & - & - & & 1 \\
\hline PUNTIFORMES & 1 & 1 & 3 & - & - & 1 & 6 \\
\hline Línea recta vertical & 6 & - & 8 & - & - & & 16 \\
\hline Línea recta vertical intermitente & 4 & - & - & - & - & & 4 \\
\hline Línea recta oblicua & 2 & - & 4 & - & - & & 8 \\
\hline Línea recta horizontal & - & - & 1 & - & - & & 1 \\
\hline Zigzag & - & - & - & 1 & - & & 1 \\
\hline Serie de líneas rectas paralelas & 2 & - & - & - & - & & 2 \\
\hline L invertida & 1 & 1 & 1 &. & - & & 3 \\
\hline Línea vertical con apéndice perpendicular & 2 & - & - & - & - & & 2 \\
\hline Incisiones caóticas & 6 & - & 5 & - & 1 & & 15 \\
\hline Rombos unidos por vértice & - & - & 1 & - & - & & 1 \\
\hline RECTILÍNEOS & 23 & 1 & 20 & 1 & 1 & & 53 \\
\hline Semicircunferencia & - & 1 & 1 & - & - & & 2 \\
\hline Circunferencia & - & - & 2 & - & - & 1 & 3 \\
\hline Circunferencia con apéndice & 1 & 1 & 1 & - & - & - & 3 \\
\hline Circunferencia asociada a líneas rectas & - & 1 & - & - & - & - & 1 \\
\hline Circunferencia con apéndice recto +semicircunf conc & - & - & 1 & - & - & & 1 \\
\hline Circunferencia con apéndice y líneas curvas & - & - & 1 & - & - & & 1 \\
\hline Circunferencias adosadas + ap + con trazos inter & - & - & & - & - & 1 & 1 \\
\hline Óvalo & 1 & - & 1 & - & - & & 2 \\
\hline Óvalo con punto interior & 1 & - & & - & - & & 1 \\
\hline Óvalo con apéndice & - & - & & - & - & & 1 \\
\hline CIRCULARES LINEALES & 3 & 3 & 7 & - & - & & 16 \\
\hline Línea curva & 3 & 2 & 5 & - & - & & 10 \\
\hline Línea curva con apéndice & 1 & - & 1 & - & - & & 2 \\
\hline Serie de líneas curvas paralelas & 1 & - & - & - & - & & 1 \\
\hline Líneas curvas conectadas con apéndice lateral. & 1 & - & - & - & - & & 1 \\
\hline Línea sinuosa que termina en circulo plano & 1 & - & - & - & - & & 1 \\
\hline "Media U" invertida & - & - & 3 & - & - & & 3 \\
\hline "U” oblicua & - & - & 1 & - & - & - & 1 \\
\hline "U" invertida & - & - & 4 & - & - & - & 4 \\
\hline "U" adosadas & - & - & 1 & - & - & - & 1 \\
\hline Líneas curvas combinadas con puntiformes & - & - & 1 & - & & & 1 \\
\hline CURVILÍNEOS & 7 & 2 & 16 & - & & & 25 \\
\hline NO FIGURATIVOS & 34 & 7 & 46 & 1 & & 1 & 100 \\
\hline
\end{tabular}




\begin{tabular}{|c|c|c|c|c|c|c|c|}
\hline Continuación Tabla IV.1.a & \multicolumn{6}{|c|}{ Sector } & \\
\hline Motivo & 1 & 2 & 3 & 4 & 5 & 6 & Total \\
\hline Zoomorfo & - & 1 & & - & - & - & 1 \\
\hline Pisada de ave & - & - & 1 & - & - & - & 1 \\
\hline FIGURATIVO & - & 1 & 1 & - & - & - & 2 \\
\hline Superficie grabada & 4 & - & 6 & 1 & 1 & 4 & 16 \\
\hline NO DETERMINADOS & 4 & - & 6 & 1 & 1 & 4 & 16 \\
\hline TOTAL & 38 & 8 & 53 & 2 & 2 & 15 & 118 \\
\hline
\end{tabular}

Tablas IV.1.b. Categorías de motivos identificadas para los rectilíneos, los circulares lineales y los curvilíneos de Bardas de Carlos.

\begin{tabular}{|c|c|c|c|c|c|c|c|}
\hline & \multicolumn{6}{|c|}{ Sector } & \\
\hline Clase de motivos & 1 & 2 & 3 & 4 & 5 & 6 & Total \\
\hline Línea recta & 12 & - & 13 & - & - & 4 & 29 \\
\hline Línea recta con apéndice & 2 & - & - & - & - & & 2 \\
\hline Línea quebrada & 1 & 1 & 1 & 1 & - & - & 4 \\
\hline Líneas rectas paralelas & 2 & - & - & - & & - & 2 \\
\hline Caóticas & 6 & - & 5 & - & 1 & 3 & 15 \\
\hline Combinadas & - & - & 1 & - & - & - & 1 \\
\hline RECTILINEOS & 23 & 1 & 20 & 1 & 1 & 7 & 53 \\
\hline
\end{tabular}

Línea quebrada incluye "L"; "V"; zigzag

Combinada incluye rombos unidos por el vértice

\begin{tabular}{|l|c|c|c|c|c|c|c|}
\cline { 2 - 7 } \multicolumn{1}{c|}{} & \multicolumn{7}{c|}{ Sector } \\
\hline Clase de motivos & 1 & 2 & 3 & 4 & 5 & 6 & Total \\
\hline Semicircunferencia & - & 1 & 1 & - & - & - & 2 \\
\hline Circunferencia & - & 1 & 2 & - & - & 1 & 4 \\
\hline $\begin{array}{l}\text { Circunferencia con } \\
\text { apéndice }\end{array}$ & 1 & 1 & 3 & - & - & - & 5 \\
\hline Circunferencias adosadas & - & - & - & - & - & 1 & 1 \\
\hline Óvalo simple & 1 & - & 1 & - & - & - & 2 \\
\hline Óvalo con punto & 1 & - & - & - & - & - & 1 \\
\hline Óvalo con apéndice & - & - & - & - & - & 1 & 1 \\
\hline $\begin{array}{l}\text { CIRCULARES } \\
\text { LINEALES }\end{array}$ & 3 & 3 & 7 & - & - & 3 & 16 \\
\hline
\end{tabular}

Circunferencia incluye simple, + lineas rectas asociadas

Circunferencia con apéndice incluye simple; con apéndice + lineas rectas asociadas 


\begin{tabular}{|c|c|c|c|c|c|c|c|}
\hline & \multicolumn{6}{|c|}{ Sector } & \\
\hline Clase de motivos & 1 & 2 & 3 & 4 & 5 & 6 & Total \\
\hline Línea curva & 3 & 2 & 8 & - & - & - & 13 \\
\hline Línea curva con apéndice & 3 & - & 1 & - & - & - & 4 \\
\hline Líneas curvas paralelas & 1 & - & - & - & - & - & 1 \\
\hline En forma de "U” & - & - & 5 & - & - & - & 5 \\
\hline Combinados & - & - & 2 & - & - & - & 2 \\
\hline CURVILÍNEOS & 7 & 2 & 16 & - & - & - & 25 \\
\hline
\end{tabular}

Línea curva: simple y en forma de "media U"

Líneas curvas con apéndice: Curva + apéndice; líneas curvas conectadas por apéndice lateral 
Apéndice IV.2. Arte rupestre de los Navarros.

Tabla IV.2.a. Tipos de motivos registrados en Los Navarros.

\begin{tabular}{|c|c|c|c|c|c|c|c|c|c|c|}
\hline \multirow[b]{3}{*}{ Motivos } & \multirow{2}{*}{\multicolumn{9}{|c|}{ Sector }} & \multirow[b]{3}{*}{ Subtotal } \\
\hline & & & & & & & & & & \\
\hline & 1 & 2 & 3 & 4 & 5 & 6 & 7 & 8 & 9 & \\
\hline Punto & - & 3 & - & - & - & 2 & - & - & - & 5 \\
\hline Línea horizontal de puntos & 1 & - & - & - & - & - & - & - & - & 1 \\
\hline Línea vertical de puntos & 1 & - & - & - & - & - & - & - & - & 1 \\
\hline Línea oblicua de puntos & 1 & - & 1 & - & - & - & - & - & - & 2 \\
\hline Circunferencia de puntos & - & - & 1 & - & - & - & - & - & - & 1 \\
\hline Triángulo de puntiformes & - & - & - & - & - & 1 & - & - & - & 1 \\
\hline PUNTIFORMES & 3 & 3 & 2 & - & - & 3 & - & - & - & 11 \\
\hline Línea recta vertical & 16 & 3 & 3 & - & 1 & 4 & 1 & - & - & 28 \\
\hline Línea recta con apéndice & 3 & & 1 & & 1 & & & & & 5 \\
\hline Líneas rectas paralelas (2) & - & 1 & - & - & - & - & - & - & - & 1 \\
\hline Línea recta oblicua & 4 & 2 & 3 & - & - & - & 1 & - & - & $1-$ \\
\hline Líneas oblicuas paralelas (2) & - & 1 & - & - & - & - & - & - & - & 1 \\
\hline Línea recta horizontal & - & 2 & - & - & - & 1 & - & - & - & 3 \\
\hline $\begin{array}{l}\text { Línea horizontal intersecada con } \\
\text { recta }\end{array}$ & 1 & 2 & - & - & - & - & - & - & - & 3 \\
\hline línea recta quebrada & 1 & 1 & - & - & - & - & - & - & - & 2 \\
\hline $\begin{array}{l}\text { Líneas horizontales cortadas por } \\
\text { línea vertical oblicua }\end{array}$ & 1 & - & - & - & - & - & - & - & - & 1 \\
\hline Línea en ángulo recto & 3 & - & 1 & - & 1 & - & - & - & - & 5 \\
\hline "En forma de V" & 2 & - & 2 & - & - & - & 2 & - & - & 6 \\
\hline En forma de "V invertida" & - & 2 & - & - & - & - & - & - & - & 2 \\
\hline Fig rectangular con trazos int & 1 & - & - & - & 1 & - & - & - & - & 2 \\
\hline Combinado & 1 & - & - & - & - & - & - & - & - & 1 \\
\hline RECTILINEOS & 33 & 14 & $1-$ & - & 4 & 5 & 4 & - & - & 70 \\
\hline Círculo lleno & - & 1 & - & - & - & & - & - & - & \\
\hline CIRCULARES LLENOS & - & 1 & - & - & - & - & - & - & - & 1 \\
\hline Semicircunferencia & 4 & 3 & - & - & - & 1 & 1 & - & - & 9 \\
\hline $\begin{array}{l}\text { Semicircunferencia con punto central } \\
\text { y apéndices }\end{array}$ & - & - & - & - & - & 1 & - & - & - & 1 \\
\hline $\begin{array}{l}\text { Semicircunferencia con apéndice } \\
\text { curvo }\end{array}$ & - & - & - & - & - & 1 & - & - & - & 1 \\
\hline Circunferencia & 5 & 8 & 6 & 3 & 1 & 1- & 3 & 1 & 1 & 38 \\
\hline $\begin{array}{l}\text { Circunferencia alrededor de hoyuelo } \\
\text { natural }\end{array}$ & - & - & 1 & - & - & - & - & - & - & 1 \\
\hline Circunferencia con apéndice & 1 & 2 & 1 & - & 1 & 1 & - & - & - & 8 \\
\hline $\begin{array}{l}\text { Circunferencia con apéndice curvo } \\
\text { del que salen dos líneas rectas }\end{array}$ & - & - & 1 & - & - & - & - & - & - & 1 \\
\hline $\begin{array}{l}\text { Circunferencia con apéndice recto y } \\
\text { "U invertida" adosada }\end{array}$ & - & - & 1 & - & - & - & - & - & - & 1 \\
\hline $\begin{array}{l}\text { Circunferencia con apéndice que } \\
\text { remata en círculo plano (+ recta } \\
\text { corta) }\end{array}$ & 1 & - & - & - & - & - & - & & - & 1 \\
\hline Circunferencia con dos o + apéndices & - & - & 1 & - & - & 2 & - & - & - & 3 \\
\hline
\end{tabular}




\begin{tabular}{|c|c|c|c|c|c|c|c|c|c|c|}
\hline Continuación & & & & Sec & & & & & & \\
\hline Motivos & 1 & 2 & 3 & 4 & 5 & 6 & 7 & 8 & 9 & Subtotal \\
\hline $\begin{array}{l}\text { Circunferencia atravesada por línea } \\
\text { recta }\end{array}$ & - & - & - & - & 1 & - & - & - & - & 1 \\
\hline $\begin{array}{l}\text { Circunferencia con punto central + } \\
\text { punto adosado }\end{array}$ & - & - & - & - & - & 1 & - & - & - & 1 \\
\hline $\begin{array}{l}\text { Circunferencia con punto central y } \\
\text { dos pequeños apéndices rectilíneos }\end{array}$ & - & - & - & - & - & - & 1 & - & - & 1 \\
\hline $\begin{array}{l}\text { Circunferencia con líneas rectas en } \\
\text { su interior }\end{array}$ & 1 & - & - & - & - & 1 & - & - & - & 2 \\
\hline Circunferencia con tridígito interior & 1 & - & 1 & - & - & 1 & - & - & - & 3 \\
\hline $\begin{array}{l}\text { Circunferencia con trazos en su } \\
\text { interior }\end{array}$ & 1 & - & - & - & - & - & - & - & - & 1 \\
\hline $\begin{array}{l}\text { Circunferencia de trazo plano y } \\
\text { puntiforme }\end{array}$ & - & - & 1 & - & - & - & - & - & - & 1 \\
\hline $\begin{array}{l}\text { Circunferencias adosadas }(2)+3 \\
\text { puntiformes alrededor. }\end{array}$ & - & - & - & - & - & 1 & - & - & - & 1 \\
\hline Circunferencia concéntricas & 1 & 2 & 1 & - & 1 & 2 & - & - & - & 7 \\
\hline $\begin{array}{l}\text { Circunferencias concéntricas }+ \\
\text { circunferencia adosada }\end{array}$ & - & 1 & - & - & - & - & - & - & - & 1 \\
\hline $\begin{array}{l}\text { Circunferencias concéntricas } \\
\text { alrededor de punto central }\end{array}$ & - & - & 1 & - & - & 1 & - & - & - & 2 \\
\hline $\begin{array}{l}\text { Circunferencias concéntricas } \\
\text { rodeadas por semicircunferencia }\end{array}$ & - & 1 & - & - & - & - & 1 & - & - & 2 \\
\hline Óvalo & - & - & - & - & - & 1 & - & - & - & 1 \\
\hline Óvalo con trazo interior & - & - & 1 & - & - & - & - & - & - & 1 \\
\hline Óvalo con apéndice recto & 1 & - & - & - & - & 1 & - & - & - & 2 \\
\hline Óvalo con apéndice curvo & - & 1 & 1 & - & - & - & - & - & - & 2 \\
\hline Óvalo con dos apéndices & 1 & - & - & - & - & - & - & - & - & 1 \\
\hline $\begin{array}{l}\text { Óvalo alargado con trazos interiores } \\
\text { y apéndices rectos adosados }\end{array}$ & - & - & - & - & - & 1 & - & - & - & 1 \\
\hline Óvalo con línea recta en el medio & - & - & - & - & - & 1 & - & - & - & 1 \\
\hline CIRCULARES LINEALES & 17 & 18 & 19 & 3 & 4 & 27 & 6 & 1 & 1 & 96 \\
\hline Línea curva vertical & 3 & - & 4 & - & - & 1 & 1 & - & - & 9 \\
\hline Línea curva oblicua & 4 & - & - & - & - & - & - & - & - & 4 \\
\hline Línea curva horizontal & - & 1 & - & - & 1 & 1 & - & - & - & 3 \\
\hline Línea curva intersecada con línea & 1 & - & 1 & - & - & - & - & 1 & - & 1 \\
\hline $\begin{array}{l}\text { Líneas curvas horizontales asociadas } \\
\text { a circunferencia }\end{array}$ & - & - & 1 & - & - & - & - & - & - & 1 \\
\hline Líneas curvas verticales & 1 & - & - & - & - & - & - & - & - & 1 \\
\hline Líneas curvas intersecadas & 1 & - & - & - & - & - & - & - & - & 1 \\
\hline En forma de "media U” & 4 & - & - & - & - & - & 1 & - & - & 5 \\
\hline En forma de "media U" invertida & 3 & 1 & 1 & - & - & - & - & - & - & 5 \\
\hline $\begin{array}{l}\text { En forma de "media U" invertida con } \\
\text { apéndice }\end{array}$ & - & & 1 & - & - & - & - & - & - & 1 \\
\hline En forma de "U" & 2 & 2 & 2 & - & - & 1 & - & - & - & 7 \\
\hline En forma de "U" invertida & 5 & - & 1 & - & - & 1 & - & - & - & 7 \\
\hline En forma de "U" invertida+ apéndice & 3 & 1 & 1 & - & - & - & - & - & - & 5 \\
\hline
\end{tabular}




\begin{tabular}{|c|c|c|c|c|c|c|c|c|c|c|}
\hline Continuación & & & & $\mathrm{Sec}$ & & & & & & \\
\hline Motivos & 1 & 2 & 3 & 4 & 5 & 6 & 7 & 8 & 9 & Subtotal \\
\hline $\begin{array}{l}\text { En forma de "U invertida" } \\
\text { concéntrica }\end{array}$ & - & 2 & - & - & - & - & - & - & - & 2 \\
\hline Escutiforme & - & - & 1 & - & - & - & - & - & - & 1 \\
\hline Serpentiforme & 2 & 1 & 1 & - & - & - & 2 & - & - & 6 \\
\hline Laberinto con tres apéndices & - & 1 & - & - & - & - & - & - & - & 1 \\
\hline CURVILINEOS & 29 & 9 & 14 & - & 1 & 4 & 4 & 1 & - & 62 \\
\hline NO FIGURATIVOS & 82 & 45 & 45 & 3 & 9 & 39 & 14 & 2 & 1 & 240 \\
\hline Matuasto & 1 & - & - & - & - & - & - & - & - & 1 \\
\hline Tridígito & 16 & 6 & 3 & - & - & - & 5 & - & 1 & 31 \\
\hline Roseta & 3 & - & 1 & - & - & - & - & - & - & 4 \\
\hline Pisada de felino & 1 & - & - & - & - & - & - & - & - & 1 \\
\hline Pisada de guanaco & 2 & - & 1 & - & - & - & - & - & - & 3 \\
\hline FIGURATIVOS & 23 & 6 & 5 & - & - & - & 5 & - & 1 & 40 \\
\hline Superficie grabada no determinada & 1 & 3 & 1 & - & - & - & - & - & 1 & \\
\hline NO DETERMINADOS & 1 & 3 & 1 & - & - & - & - & - & 1 & 6 \\
\hline Total & 106 & 54 & 51 & 3 & 9 & 39 & 19 & 2 & 3 & 286 \\
\hline
\end{tabular}

Tabla IV.2.b. Categorías de motivos identificadas para los circulares lineales, los rectilíneos y los curvilíneos de Los Navarros

\begin{tabular}{|l|c|c|c|c|c|c|c|c|c|c|}
\cline { 2 - 10 } \multicolumn{1}{c|}{} & \multicolumn{9}{|c|}{ Sector } & \multicolumn{1}{c}{} \\
\hline Categoría & 1 & 2 & 3 & 4 & 5 & 6 & 7 & 8 & 9 & Total \\
\hline Semicircunferencia & 4 & 3 & - & - & - & 1 & 1 & - & - & 9 \\
\hline Semicircunferencia con apéndice & - & - & - & - & - & 2 & - & - & - & 2 \\
\hline Circunferencia & 5 & 7 & 8 & 3 & 1 & 10 & 3 & 1 & 1 & 39 \\
\hline Circunferencia con apéndice & 2 & 2 & 6 & - & 1 & 3 & - & - & - & 14 \\
\hline Circunferencia con trazos internos & 3 & - & 1 & - & 1 & 3 & - & - & - & 8 \\
\hline Circunferencia con apéndice y trazos internos & 1 & - & - & - & - & - & 1 & - & - & 2 \\
\hline Circunferencia concéntricas & 1 & 4 & 2 & - & 1 & 3 & 1 & - & - & 12 \\
\hline Circunferencias adosadas & - & - & - & - & - & 1 & - & - & - & 1 \\
\hline Óvalo & - & - & - & - & - & 1 & - & - & - & 1 \\
\hline Óvalo con apéndice & 2 & 1 & 1 & - & - & 1 & - & - & - & 5 \\
\hline Óvalo con trazo interno & - & - & 1 & - & - & 1 & - & - & - & 2 \\
\hline Ovalo con apéndices y trazos internos & - & - & - & - & - & 1 & - & - & - & 1 \\
\hline CIRCULARES LINEALES & 18 & 17 & 19 & 3 & 4 & 27 & 6 & 1 & 1 & 96 \\
\hline
\end{tabular}

Semicircunferencia: simple

Semicircunferencia con apéndice incluye: semicircunferencia con apéndice curvo; semicircunferencia con punto interior y dos apéndices. 
Circunferencia: simple; circunferencia de trazo puntiforme y plano; alrededor de hoyuelo natural.

Circunferencia con apéndice incluye aquellas con 1, 2 o más apéndices de diferente tipo (recto, curvo, serpentiforme);

Circunferencia con apéndice +elementos internos

Circunferencia con elementos interiores: circunferencia atravesada por línea recta; circunferencia con dos líneas rectas en su interior; Circunferencia con puntos y línea vertical en su interior; circunferencias con tridígito interno. Circunferencias adosadas: circunferencias adosadas; circunferencias adosadas rodeadas por puntos.

Circunferencia concéntricas: circunferencias concéntricas; circunferencia concéntrica doble con circunferencia simple adosada; circunferencias concéntricas alrededor de punto central; circunferencias concéntricas rodeadas por semicircunferencia.

Óvalo: simple.

Óvalo con trazo interno: con línea recta superior; óvalo con línea recta en el medio;

Óvalo con apéndice: recto; curvo o dos apéndices.

Óvalo con trazo interno y apéndices: óvalo alargado con línea vertical y líneas horizontales en su mitad superior +apéndices rectos adosados.

\begin{tabular}{|c|c|c|c|c|c|c|c|c|c|c|}
\hline & \multicolumn{9}{|c|}{ Sector } & \\
\hline Motivo & 1 & 2 & 3 & 4 & 5 & 6 & 7 & 8 & 9 & Subtotal \\
\hline Línea recta & 20 & 7 & 6 & - & 1 & 5 & 2 & - & & 41 \\
\hline Línea recta con apéndice & 3 & 1 & 1 & - & 1 & - & - & - & - & 6 \\
\hline Línea quebrada & 7 & 3 & 3 & - & 1 & - & 2 & - & - & 16 \\
\hline Líneas rectas paralelas & 2 & 3 & - & - & & - & - & - & & 5 \\
\hline Figura con elementos internos & 1 & - & - & - & 1 & - & - & - & & 2 \\
\hline RECTILÍNEOS & 33 & 14 & 10 & & 4 & 5 & 4 & - & & 70 \\
\hline
\end{tabular}

Línea recta: vertical, oblicua, horizontal;.

Con apéndice: perpendicular oblicuo; perpendicular; en V; recta horizontal con recta transversal;

Líneas quebradas: en forma de "V", en forma de "V" invertida; en ángulo recto; en zig-zag;

Líneas paralelas: rectas paralelas; oblicuas; líneas paralelas verticales atravesadas por línea recta horizontal; líneas horizontales + línea oblicua; Figura con elementos internos: Cuadrado con circunferencia y línea oblicua en su interior; Cuadrado con línea recta vertical en sector inferior; 


\begin{tabular}{|c|c|c|c|c|c|c|c|c|c|c|}
\hline \multirow[b]{2}{*}{ Motivo } & \multicolumn{9}{|c|}{ Sector } & \multirow[b]{2}{*}{ Total } \\
\hline & 1 & 2 & 3 & 4 & 5 & 6 & 7 & 8 & 9 & \\
\hline Línea curva & 14 & 2 & 5 & 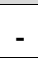 & 1 & 2 & 2 & - & 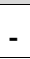 & 26 \\
\hline Línea curva con apéndice & - & - & 1 & - & - & - & - & - & - & 1 \\
\hline Líneas curvas paralelas & 1 & - & - & - & - & - & - & - & - & 1 \\
\hline En forma de "U” & 7 & 2 & 3 & - & - & 2 & - & - & - & 14 \\
\hline En forma de "U" con apéndice & 3 & 1 & 1 & - & - & - & - & - & & 5 \\
\hline En forma de "U" concéntrica & - & 2 & - & - & - & - & - & - & - & 2 \\
\hline Serpentiforme & 2 & 1 & 1 & - & - & - & 2 & - & - & 6 \\
\hline Figura & - & 1 & 1 & - & - & - & - & - & - & 2 \\
\hline Combinada & 2 & - & 2 & - & - & - & - & 1 & - & 5 \\
\hline CURVILÍNEOS & 29 & 9 & 14 & & 1 & 4 & 4 & 1 & & 62 \\
\hline
\end{tabular}

Línea curva: vertical, horizontal; oblicua; en forma de "media U"; "media U invertida";

En "forma de U": invertida, normal, sinuosa.

En "forma de U" con apéndice: recto, curvo

En forma de "U" concéntrica: en forma de "U invertida" concéntrica

Figuras: incluye laberintiforme con estela; escutiforme;

Combinada incluye lineas curvas asociada a circunferencia; linea curva intersecada con linea recta 


\section{Apéndice V}

